UNIVERSIDADE DE SÃO PAULO

ESCOLA POLITÉCNICA

UNIVERSIDADE DE COIMBRA

FACULDADE DE CIÊNCIAS E TECNOLOGIA

GABRIELA BANDEIRA DE MELO LINS DE ALBUQUERQUE

Análise numérico-experimental de vigas de concreto armado com restrições axial e rotacional em situação de incêndio 

GABRIELA BANDEIRA DE MELO LINS DE ALBUQUERQUE

\section{Análise numérico-experimental de vigas de concreto armado com restrições axial e rotacional em situação de incêndio}

Tese apresentada para a obtenção dos títulos de Doutora em Ciências e em Engenharia de Segurança ao Incêndio, no âmbito do Convênio Acadêmico Internacional para Realização de Doutorado em Regime de Cotutela celebrado pela Escola Politécnica da Universidade de São Paulo e pela Faculdade de Ciências e Tecnologia da Universidade de Coimbra.

Áreas de concentração:

Engenharia de Estruturas

Engenharia de Segurança ao Incêndio

Orientadores:

Prof. Dr. Sr. Valdir Pignatta e Silva (São Paulo)

Prof. Dr. João Paulo Correia Rodrigues (Coimbra) 
Este exemplar foi revisado e corrigido em relação à versão original, sob responsabilidade única do autor e com a anuência de seu orientador.

São Paulo, de de

Assinatura do autor:

Assinatura do orientador:

Albuquerque, Gabriela Bandeira de Melo Lins de

Análise numérico-experimental de vigas de concreto armado com restrições axial e rotacional em situação de incêndio / G. B. M. L. Albuquerque -versão corr. -- São Paulo, 2018.

$413 \mathrm{p}$.

Tese (Doutorado) - Escola Politécnica da Universidade de São Paulo. Departamento de Engenharia de Estruturas e Geotécnica.

1.concreto armado 2.vigas 3.incêndio 4.análise numérico-experimental 5.restrições axial e rotacional I.Universidade de São Paulo. Escola Politécnica. Departamento de Engenharia de Estruturas e Geotécnica II.t. 
Dedico esta tese, com amor, a meus pais George e fúlia,

$$
\text { e ao meu avô fúlio. }
$$





\section{AGRADECIMENTOS}

Ao meu orientador na Escola Politécnica da Universidade de São Paulo, Professor Valdir Pignatta e Silva, não só pelos conhecimentos e confiança transmitidos, mas, sobretudo, pelas palavras amigas e incentivadoras, responsáveis por me indicarem o caminho a seguir.

Ao meu orientador na Universidade de Coimbra (UC), Professor João Paulo Correia Rodrigues, pela atenção e construtivas sugestões, bem como por me ter mostrado a oportunidade de realizar o Doutorado em Regime de Cotutela em Portugal e de conceber a parte experimental desta tese.

À equipe da empresa DIANA FEA BV, em particular ao Maziar Partovi, à Denise Ferreira, à Chantal Frissen e ao Kesio Palacio, meus agradecimentos pela colaboração na parte numérica desta pesquisa ao longo dos cursos de que participei em Delft, na Holanda. Ao João Pereira, agradeço por ter-me recebido na Universidade do Minho, em Guimarães, e por auxiliar-me na introdução ao estudo do programa de computador DIANA.

Estendo a minha gratidão ao Luís Laím, pela amizade e auxílio durante o período em que estive na UC, e ao Augusto Silva e ao Rafael Campos, pelo companheirismo ao longo das atividades no Laboratório de Ensaio de Materiais e Estruturas.

Também sou grata à Coordenação de Aperfeiçoamento de Pessoal de Nível Superior (CAPES, Brasil), pela concessão de uma Bolsa de Estudos, e à Fundação para a Ciência e a Tecnologia (FCT, Portugal), que financiou os ensaios experimentais.

Aos meus queridos pais, George e Júlia, pelo incondicional apoio, incentivo, amor, paciência e dedicação em todos os momentos desta jornada. Ao meu avô, Júlio, pela ternura do seu olhar, que sempre me transmitiu grande exemplo de força e coragem. Às minhas irmãs, Geórgea e Gisela, e à minha sobrinha, Natasha, pelas demonstrações de carinho e motivação. 



\title{
RESUMO
}

\author{
ALBUQUERQUE, Gabriela Bandeira de Melo Lins de. Análise numérico-experimental de \\ vigas de concreto armado com restrições axial e rotacional em situação de incêndio. \\ 2018. 413 p. Tese. Doutorado em Engenharia de Estruturas - Escola Politécnica da \\ Universidade de São Paulo, Brasil. Doutoramento em Engenharia de Segurança ao Incêndio - \\ Universidade de Coimbra, Portugal.
}

As vigas de concreto armado sofrem deformações térmicas em situação de incêndio. Os comprimentos dos vãos se alongam resultando no deslocamento horizontal de seus respectivos apoios e elas passam a fletir de forma acentuada, o que gera a rotação nos mesmos. Se essas deformações forem impedidas pelas próprias condições de apoio da peça ou devido a elementos estruturais circundantes, por exemplo, esforços adicionais passarão a atuar nas vigas, modificando seu desempenho frente ao fogo. Estudos apontam que os efeitos desses esforços podem ser benéficos à resistência ao fogo (RF) das vigas aquecidas, contudo, nas poucas pesquisas voltadas à análise experimental dessa questão, as restrições foram admitidas apenas de forma isolada, i.e., ou as vigas estavam submetidas a restrições axiais ou a rotacionais. $\mathrm{O}$ efeito conjunto, mais representativo ao que ocorre na realidade, e a consideração de diferentes níveis de rigidezes impostos às deformações, foram avaliados em investigações numéricas sem dados experimentais apropriados para a validação dos resultados. Na presente Tese de Doutorado, avaliou-se experimentalmente o desempenho de vigas de concreto mediante a realização de ensaios de flexão em elementos em escala real e sob diferentes condições de apoio: sem restrições às deformações, com restrições apenas axiais e com restrições tanto axiais quanto rotacionais. Relativamente aos elementos restringidos, foram analisados dois níveis de rigidezes axial, 0,02 e 0,04EA/l, e rotacional, 1 e 2EI/l. Também houve ensaios de referência em vigas simplesmente apoiadas à temperatura ambiente para a verificação dos carregamentos e modos de ruptura. Os dados experimentais obtidos para diferentes esquemas estáticos de vigas motivaram a concepção de modelos numéricos que fossem representativos do comportamento dos mesmos. Com o auxílio do programa de computador DIANA, que tem base no método dos elementos finitos, foram criados modelos para as vigas ensaiadas à temperatura ambiente e ao fogo. Eles foram idealizados com a consideração de diversas propriedades características do comportamento não linear dos materiais e conduziram a boas correlações quando os seus resultados foram comparados aos obtidos em laboratório. A principal conclusão deste estudo numérico- 
experimental foi que a RF das vigas de concreto armado sempre aumentam quando admitido qualquer tipo de restrição (somente axial ou axial mais rotacional). Além disso, ao se fixar um valor para a restrição rotacional, as vigas com nível de restrição axial mais elevado apresentaram RF maiores do que aquelas com nível mais brando. O mesmo se verificou ao fixar a restrição axial e variar a rotacional. Vigas nos quais o efeito conjunto das restrições foi admitido conduziram a maiores RF do que aquelas apenas com restrição axial. Para a maior parte dos casos estudados, os aumentos das RF se mostraram significativos quando confrontados às vigas sem restrições. Assim, confirmou-se que os métodos simplificados normatizados que não consideram os efeitos provenientes das mesmas no dimensionamento para a situação de incêndio das vigas de concreto armado estão a favor da segurança. Os resultados numérico-experimentais aqui apresentados podem auxiliar na concepção de ferramentas alternativas para a consideração dos efeitos das restrições em projeto.

Palavras-chave: Concreto armado. Vigas. Incêndio. Análise experimental. Análise numérica. Restrição axial. Restrição rotacional. DIANA. 


\title{
ABSTRACT
}

\author{
ALBUQUERQUE, Gabriela Bandeira de Melo Lins de. Experimental and numerical \\ analysis of reinforced concrete beams with axial and rotational restraints in fire. 2018 . \\ 413 p. Thesis. PhD in Structural Engineering - Polytechnic School of the University of São \\ Paulo, Brazil. PhD in Fire Safety Engineering - University of Coimbra, Portugal.
}

Reinforced concrete beams are submitted to thermal deformations when exposed to fire. The lengths of the spans elongate, a fact that triggers the horizontal displacement of their supports, and they begin to bend sharply, resulting in their rotation. If these deformations are hindered by the support conditions of the element or by surrounding structural elements, for instance, additional efforts will act on the beams in order to modify their performance when facing the action of fire. Studies have pointed out that the effects of such efforts may be beneficial to the fire resistance of the beams; however, in the few researches focused on the experimental analysis of this issue, the restraints were admitted only in an isolated way, i.e., the beams were either submitted to axial or to rotational restraints. Their coupled effect, more representative of what occurs in reality, and the consideration of different stiffness levels imposed on the deformations, were evaluated in numerical investigations, without suitable experimental data for validating the results, though. In this $\mathrm{PhD}$ Thesis, the performance of concrete beams was evaluated experimentally by performing bending tests on full-scale elements under different support conditions: unrestrained, only with axial restraints and with both axial and rotational restraints. Regarding the restrained elements, two levels of axial and rotational stiffness were analyzed, 0.02 and $0.04 \mathrm{EA} / 1 ; 1$ and $2 \mathrm{EJ} / \mathrm{l}$. There were also reference tests on simply supported beams at ambient temperature to check the load-bearing capacities and failure modes. The experimental data obtained for different beam static schemes still motivated the conception of numerical models that would be representative of their behavior. With the aid of the DIANA software, which is based on the finite element and displacement methods, beam models to represent beams tested at ambient temperature and in fire conditions were created. These models were implemented considering several properties that characterize the nonlinear behavior of the materials and led to good correlations when their results were compared to those obtained in the laboratory. The main conclusion of this experimental and numerical study was that the fire resistance of RC beams always increases when any type of restraint (axial or axial plus rotational) is introduced. In addition, by fixing the rotational stiffness, the beams with higher axial stiffness level presented higher fire resistance than those with the 
lower level. The same was observed by fixing the axial stiffness and varying the rotational stiffness. Beams in which the combined effect of the restraints was admitted led to higher resistances than those with only axial restraint. For most of the studied situations, the increases of the resistances showed to be significant when confronted with the ones for unrestrained beams. Thus, it was confirmed that the standard simplified methods that allow the non-consideration of these effects during the fire design of the RC beams lead to conservative results. The numerical and experimental results presented herein may aid in the conception of alternative tools that allow applying restraint effects to design.

Keywords: Reinforced concrete. Beams. Fire. Experimental analysis. Numerical analysis. Axial restraint. Rotational restraint. DIANA. 


\section{LISTA DE SÍMBOLOS}

A - área da seção transversal da viga

$c_{1}$ - distância entre o eixo da armadura longitudinal inferior e a face do concreto exposta ao fogo ("a" nas normas europeias)

$\mathrm{c}_{\mathrm{a}, \theta \mathrm{a}}$ - calor específico do aço carbono estrutural à temperatura $\theta_{\mathrm{a}}$

$\mathrm{c}_{\mathrm{p}, \theta \mathrm{c}}-$ calor específico do concreto à temperatura $\theta_{\mathrm{c}}$

$\mathrm{d}$ - altura efetiva da viga

$\mathrm{dd}_{\mathrm{v}} / \mathrm{d}_{\mathrm{t}}$ - velocidade ou taxa de aumento do deslocamento vertical a meio vão da viga

$\mathrm{d}_{\mathrm{v}}$ - deslocamento vertical a meio vão da viga

$d_{v, S n}$ - deslocamento vertical na seção transversal $S_{n}$ da viga

$\mathrm{d}_{\mathrm{x}}$ - deslocamento horizontal produzido no nó da viga em resposta à força concentrada horizontal aplicada em sua extremidade

$\mathrm{E}_{\mathrm{cm}}$ - módulo de elasticidade secante do concreto

$\mathrm{E}_{\mathrm{cm}, 20^{\circ} \mathrm{C}}$ - módulo de elasticidade secante do concreto à temperatura de $20{ }^{\circ} \mathrm{C}$ (calculado em função de $\mathrm{f}_{\mathrm{cm}}$ e $\varepsilon_{\mathrm{c} 1,20^{\circ} \mathrm{C}}$ )

$\mathrm{E}_{\mathrm{cm}, \theta \mathrm{c}}$ - módulo de elasticidade secante do concreto à temperatura $\theta_{\mathrm{c}}$

$\mathrm{E}_{\mathrm{cw1}}$ - largura/abertura da fissura

$\mathrm{E}_{\mathrm{s}, \theta \mathrm{s}}-$ módulo de elasticidade do aço da armadura à temperatura $\theta_{\mathrm{s}}$

F - força concentrada horizontal aplicada na extremidade da viga

$\mathrm{f}_{\mathrm{ck}}$ - resistência característica à compressão do concreto

$\mathrm{f}_{\mathrm{cm}}$ - resistência média à compressão do concreto

$\mathrm{f}_{\mathrm{cm}, \theta \mathrm{c}}$ - resistência média à compressão do concreto à temperatura $\theta_{\mathrm{c}}$ 
$\mathrm{f}_{\mathrm{ctm}}$ - resistência média à tração simples do concreto

$\mathrm{f}_{\mathrm{ctm}, \theta \mathrm{c}}$ - resistência média à tração simples do concreto à temperatura $\theta_{\mathrm{c}}$

$\mathrm{f}_{\mathrm{sp}}$ - tensão correspondente ao limite de proporcionalidade do aço da armadura

$\mathrm{f}_{\mathrm{sp}, \theta \mathrm{s}}$ - tensão correspondente ao limite de proporcionalidade do aço da armadura à temperatura $\theta_{\mathrm{s}}$

$\mathrm{f}_{\mathrm{sy}}$ - resistência ao escoamento do aço da armadura

$\mathrm{f}_{\mathrm{sy}, \theta \mathrm{s}}$ - resistência ao escoamento do aço da armadura à temperatura $\theta_{\mathrm{s}}$

$\mathrm{f}_{\mathrm{yk}}$ - resistência característica à tração do aço da armadura

$\mathrm{G}_{\mathrm{c}}$ - energia de fratura à compressão do concreto

$\mathrm{G}_{\mathrm{fI}}$ - energia de fratura à tração do concreto no modo I

$\mathrm{g}_{\mathrm{k}}$ - força característica permanente

$\mathrm{h}$ - largura da banda de fissuração

$\mathrm{h}_{1}$ - coeficente de transferência de calor do fluido em movimento

$\mathrm{h}_{\mathrm{eq}}$ - coeficiente de transferência de calor equivalente ao conjunto concreto/camadas/fluido

I - momento de inércia

$\mathrm{k}_{\mathrm{a}}$ - rigidez axial

$\mathrm{k}_{\mathrm{c}, \theta \mathrm{c}}$ - fator de redução da resistência à compressão do concreto à temperatura $\theta_{\mathrm{c}}$

$\mathrm{k}_{\mathrm{ct}, \theta \mathrm{c}}$ - fator de redução da resistência à tração do concreto à temperatura $\theta_{\mathrm{c}}$

$\mathrm{k}_{\mathrm{E}, \theta c}$ - fator de redução do módulo de elasticidade secante do concreto à temperatura $\theta_{\mathrm{c}}$

$\mathrm{k}_{\mathrm{Es}, \theta \mathrm{s}}$ - fator de redução do módulo de elasticidade do aço da armadura à temperatura $\theta_{\mathrm{s}}$

$\mathrm{k}_{\mathrm{fsp}, \theta \mathrm{s}}$ - fator de redução da tensão correspondente ao limite de proporcionalidade do aço da armadura à temperatura $\theta_{\mathrm{s}}$

$\mathrm{k}_{\mathrm{fsy}, \theta \mathrm{s}}$ - fator de redução resistência ao escoamento do aço da armadura à temperatura $\theta_{\mathrm{s}}$

$\mathrm{k}_{\mathrm{i}}$ - espessura da camada i entre a superfície de concreto e o fluido

$\mathrm{k}_{\mathrm{r}}$ - rigidez rotacional 
1 - comprimento do vão da viga

$\mathrm{L}_{\mathrm{i}}$ - condutividade térmica da camada i entre a superfície de concreto e o fluido

M - momento fletor aplicado na extremidade da viga

n - número de camadas entre a superfície de concreto e o fluido

$\mathrm{N}_{\text {rest }}$ - força de restrição axial

$\mathrm{P}$ - força concentrada vertical aplicada à viga ensaiada

$\mathrm{P}_{\mathrm{d}}$ - valor de cálculo da força última da viga

$\mathrm{P}_{\mathrm{k}}$ - valor característico da força última da viga (analítico)

$\mathrm{q}_{\mathrm{k}}$ - força característica acidental

s - desvio padrão

$\mathrm{t}_{\mathrm{cr}, \mathrm{d}}$ - resistência ao fogo determinada pelo critério de ruptura em termos de deslocamentos (instante em que são verificados os critérios tanto de flecha máxima quanto de velocidade máxima de crescimento das flechas)

$\mathrm{t}_{\mathrm{cr}, \mathrm{r}}$ - resistência ao fogo determinada pelo critério de ruptura em termos de capacidade resistente (instante em que a força de restrição axial retorna a zero)

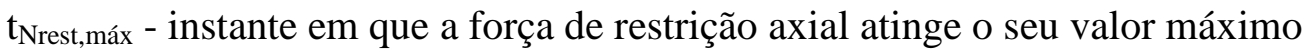

$\mathrm{u}$ - umidade do concreto

V - volume do elemento finito

$\varepsilon_{\text {res }}$ - emissividade resultante nas faces expostas ao fogo

$\varepsilon_{\mathrm{c}, \theta \mathrm{c}}$ - expansão térmica do concreto à temperatura $\theta_{\mathrm{c}}$

$\mathcal{E}_{\mathrm{c} 1}$ - deformação específica do concreto correspondente à tensão de compressão máxima

$\mathcal{E}_{\mathrm{c} 1,20{ }^{\circ} \mathrm{C}}$ - deformação específica do concreto à temperatura de $20{ }^{\circ} \mathrm{C}$, determinada conforme $\mathrm{o}$ Eurocode 2 parte 1-2 (2004)

$\mathcal{E}_{\mathrm{c} 1, \theta \mathrm{c}}$ - deformação específica do concreto à temperatura $\theta_{\mathrm{c}}$

$\varepsilon_{\text {cu1 }}$ - deformação específica última do concreto

$\varepsilon_{\mathrm{s}, \theta \mathrm{s}}$ - expansão térmica do aço à temperatura $\theta_{\mathrm{s}}$ 
$\varepsilon_{\mathrm{sp}}$ - deformação específica do aço da armadura correspondente ao limite de proporcionalidade

$\varepsilon_{\mathrm{st}}$ - deformação específica do aço da armadura correspondente à tensão que dá início ao trecho de decaimento do diagrama tensão vs deformação

$\varepsilon_{\mathrm{su}}$ - deformação última do aço da armadura

$\varepsilon_{\mathrm{sy}}$ - deformação específica do aço da armadura correspondente à resistência ao escoamento

$\mu$ - valor médio

$\alpha$ - rotação produzida no nó da viga em resposta ao momento fletor aplicado na extremidade

$\alpha_{c}$ - coeficiente de transferência de calor por convecção

$\alpha_{\mathrm{c}, \theta c}-$ coeficiente de expansão térmica do concreto à temperatura $\theta_{\mathrm{c}}$

$\alpha_{\mathrm{s}, \theta \mathrm{s}}$ - coeficiente de expansão térmica do aço da armadura à temperatura $\theta_{\mathrm{s}}$

$\gamma_{\mathrm{g}}$ - coeficiente de ponderação das forças permanentes

$\gamma_{\mathrm{q}}$ - coeficiente de ponderação das forças acidentais

$\theta_{\mathrm{a}}$ - temperatura do aço carbono estrutural

$\theta_{c}$ - temperatura do concreto

$\theta_{\text {co }}$ - temperatura inicial do concreto (admitida igual a $20^{\circ} \mathrm{C}$ )

$\theta_{\text {forno }}$ - temperatura do forno elétrico

$\theta_{\mathrm{m}}$ - temperatura da manta de lã de silicato alcalino

$\theta_{\mathrm{s}}$ - temperatura do aço da armadura

$\theta_{\text {so }}$ - temperatura inicial do aço da armadura (admitida igual a $20{ }^{\circ} \mathrm{C}$ )

$\theta_{\text {viga,Pn }}$ - temperatura da viga no ponto $\mathrm{P}_{\mathrm{n}}$ da seção transversal

$\lambda_{\mathrm{c}, \theta_{\mathrm{a}}}$ - condutividade térmica do aço carbono estrutural à temperatura $\theta_{\mathrm{a}}$

$\lambda_{\mathrm{c}, \theta \mathrm{c}}$ - condutividade térmica do concreto à temperatura $\theta_{\mathrm{c}}$

$\rho_{c}$ - massa específica do concreto

$\rho_{c}, \theta c-$ massa específica do concreto à temperatura $\theta_{c}$ 


\section{SUMÁRIO}

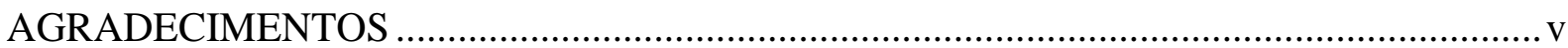

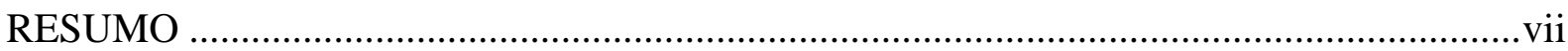

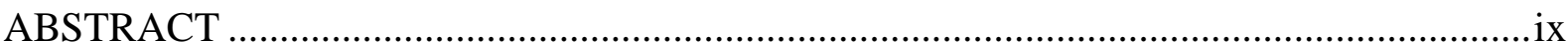

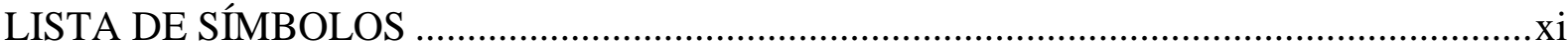

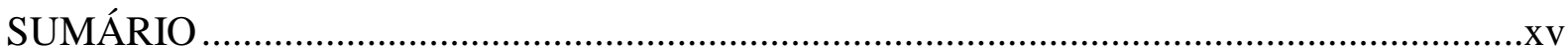

1 INTRODUÇÃO

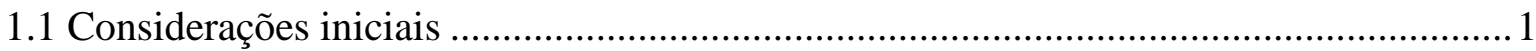

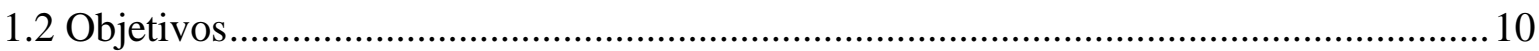

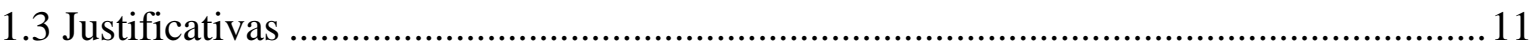

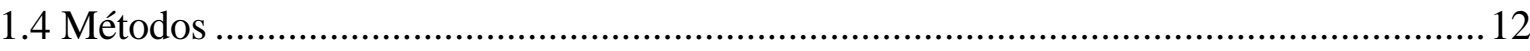

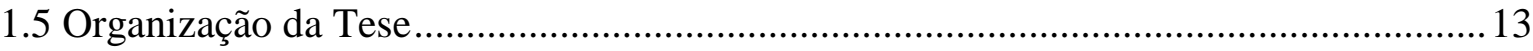

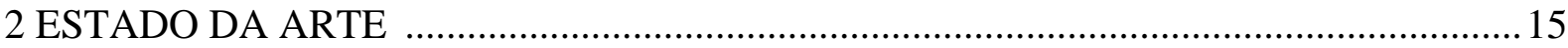

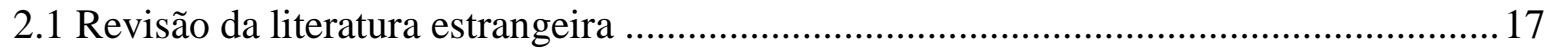

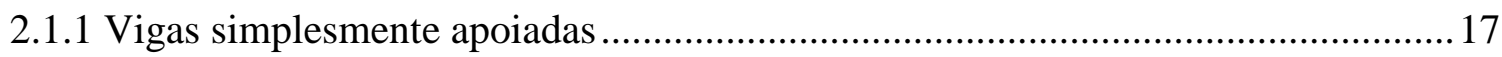

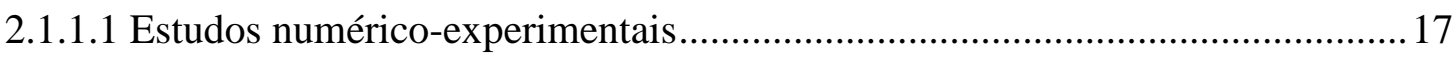

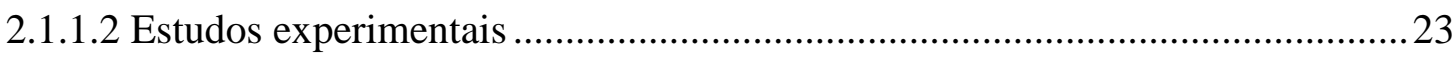

2.1.1.2.1 Influência do cobrimento na resistência ao fogo ......................................23

2.1.1.2.2 Análise da propagação de calor através de fissuras.................................25

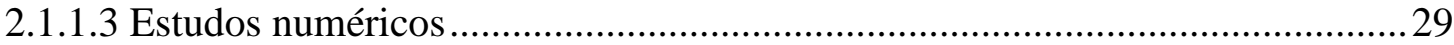

2.1.1.3.1 Influência do cobrimento e das dimensões da seção transversal...............29

2.1.1.3.2 Efeitos da evaporação da água nos campos térmicos ............................... 32 
2.1.1.3.3 Consideração da fluência dos materiais ................................................... 35

2.1.1.3.4 Perda de aderência concreto-aço .............................................................. 40

2.1.1.3.5 Comparação entre critérios de ruptura das vigas .................................... 48

2.1.1.3.6 Análises paramétricas com maior número de variáveis ............................50

2.1.1.3.7 Cálculo de momentos fletores resistentes em incêndio .......................... 51

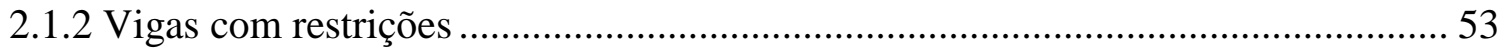

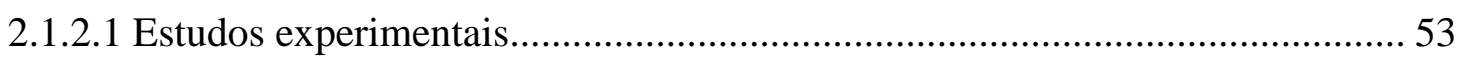

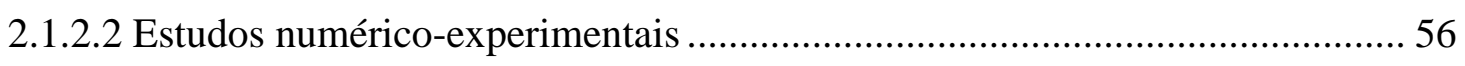

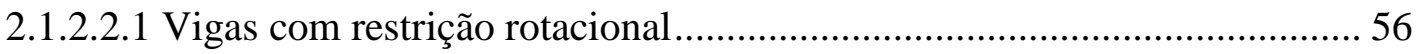

2.1.2.3.2 Vigas com restrições apenas axial ou axial mais rotacional .................... 61

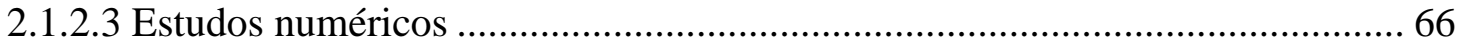

2.2 Literaturas brasileira e portuguesa (estudos numéricos) ........................................... 86

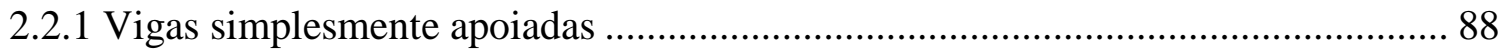

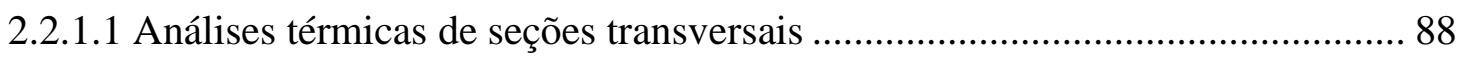

2.2.1.2 Cálculo de momentos fletores resistentes em incêndio .................................. 89

2.2.1.3 Métodos alternativos para dimensionamento................................................ 91

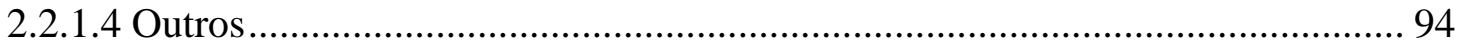

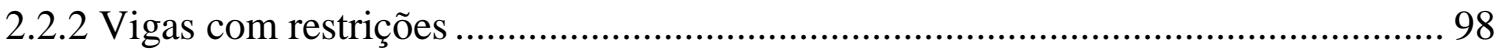

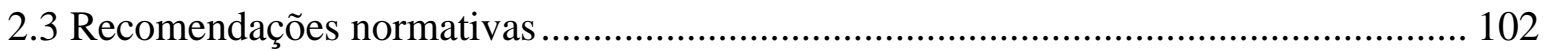

2.3.1 Eurocode 2 parte 1-2 (2004) e Anexo Nacional português (2010) ....................... 102

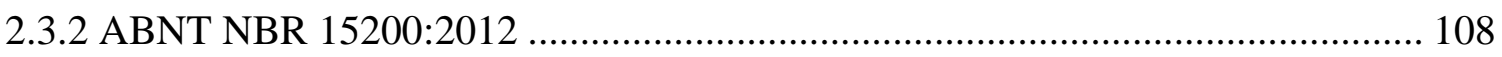

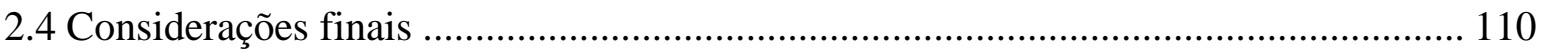

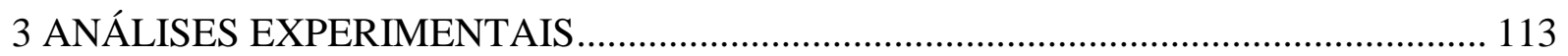

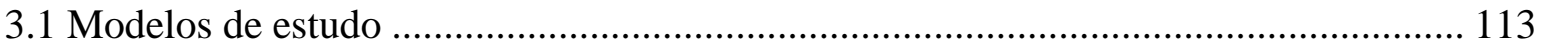

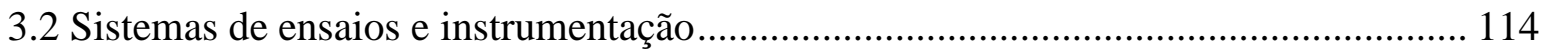

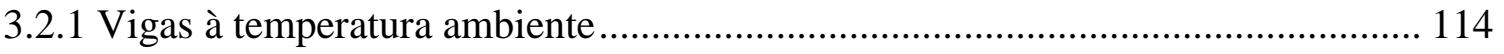

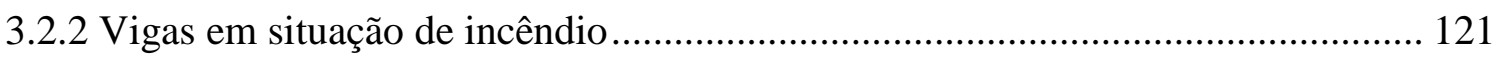




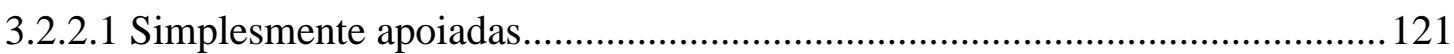

3.2.2.2 Com restrição axial.................................................................................... 127

3.2.2.3 Com restrições axial e rotacional..................................................................134

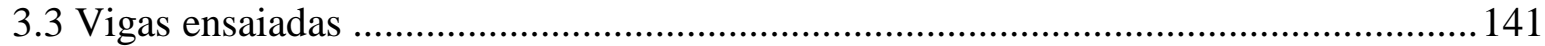

3.3.1 Dimensionamento e níveis de restrições ............................................................... 141

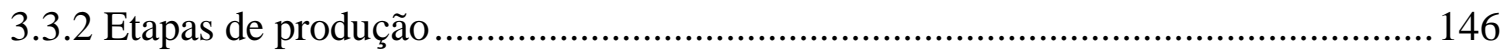

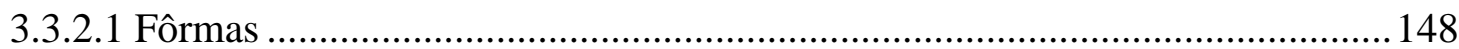

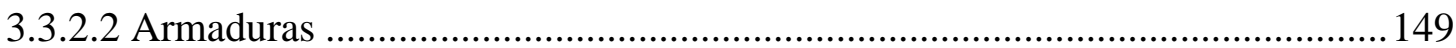

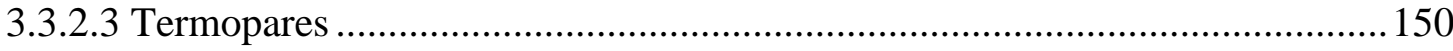

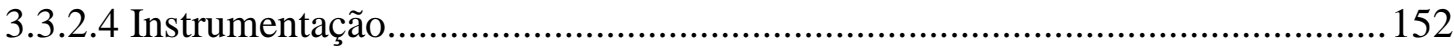

3.3.2.5 Montagem do conjunto fôrma-armadura .......................................................... 154

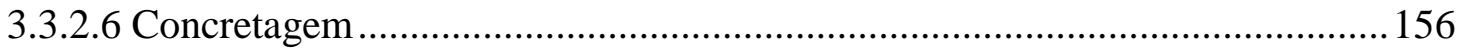

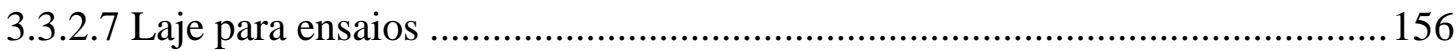

3.3.3 Ensaios de caracterização dos materiais ................................................................. 159

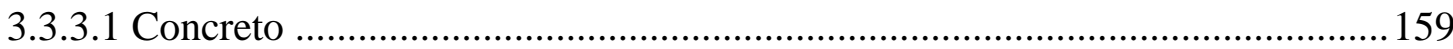

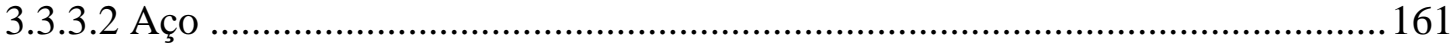

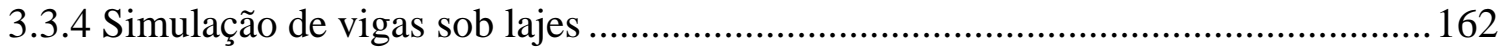

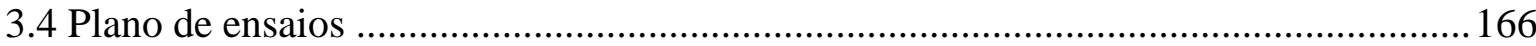

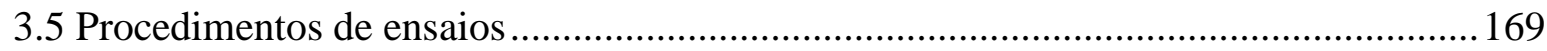

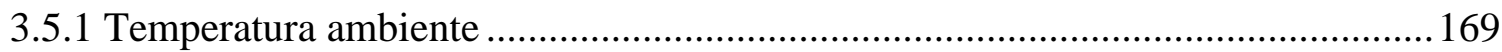

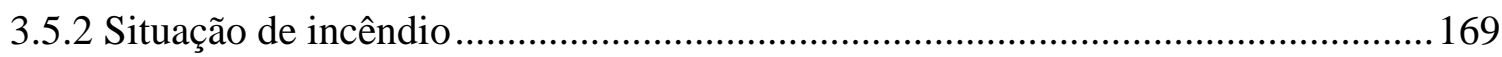

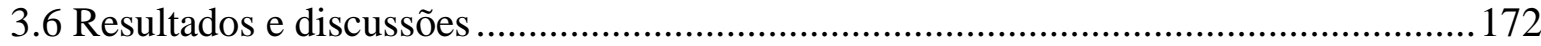

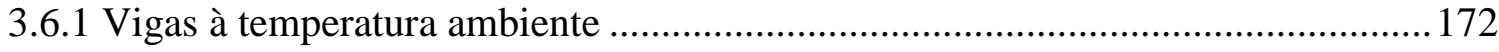

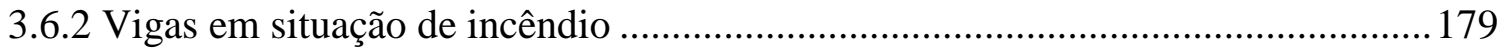

3.6.2.1 Distribuições de temperaturas .....................................................................179

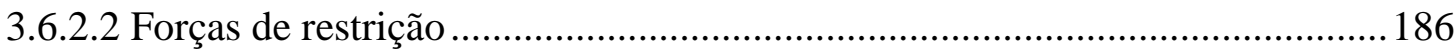

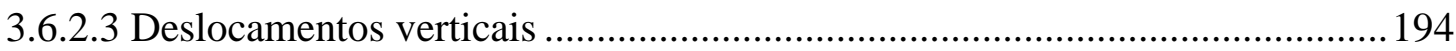

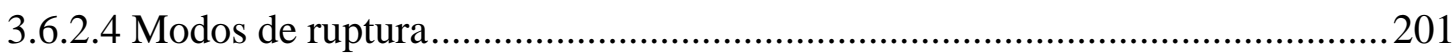

3.6.2.5 Resistências ao fogo .................................................................................. 207 


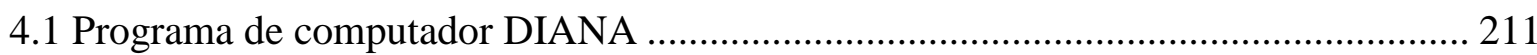

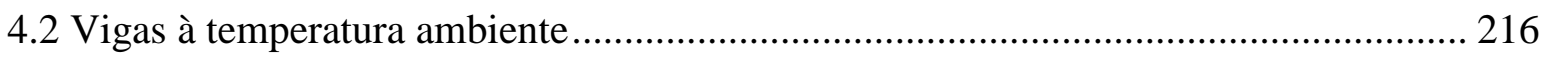

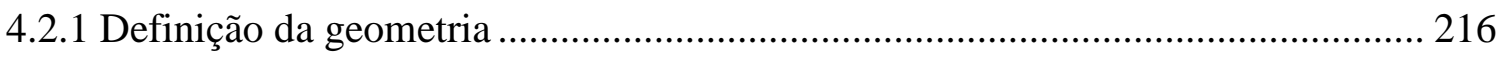

4.2.1.1 Modelagem dos elementos componentes.................................................. 216

4.2.1.2 Determinação das forças atuantes ................................................................. 218

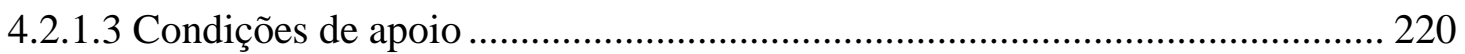

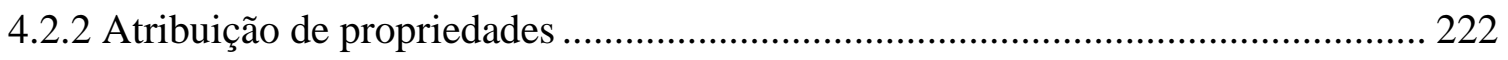

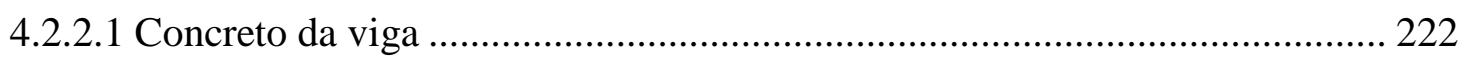

4.2.2.1.1 Modelo de fissuração distribuída ........................................................ 222

4.2.2.1.1.1 Orientação das fissuras.................................................................. 224

4.2.2.1.1.2 Largura da banda de fissuração..................................................... 226

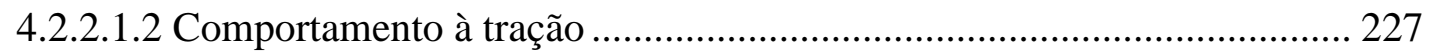

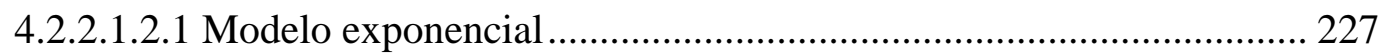

4.2.2.1.2.2 Resistência à tração ..................................................................... 230

4.2.2.1.2.3 Energia de fratura à tração no modo I.......................................... 231

4.2.2.1.3 Comportamento à compressão .......................................................... 232

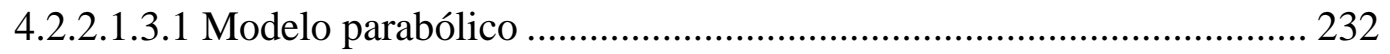

4.2.2.1.3.2 Resistência e energia de fratura à compressão............................... 235

4.2.2.1.4 Comportamento linear elástico ........................................................ 236

4.2.2.1.4.1 Coeficiente de Poisson e massa específica ................................... 236

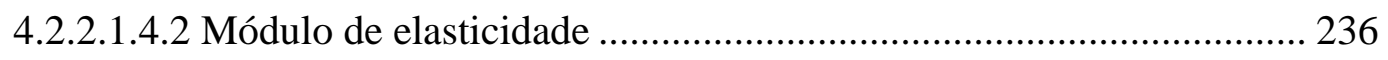

4.2.2.2 Aço dos blocos dos apoios e das chapas de distribuição das forças .............. 239

4.2.2.3 Aços das armaduras longitudinais e transversais ........................................... 239

4.2.2.3.1 Modelo elastoplástico com patamar de escoamento .............................. 240

4.2.2.3.2 Tensões de tração, deformações específicas e módulo de elasticidade .. 241

4.2.3 Determinação da malha de elementos finitos ...................................................... 243

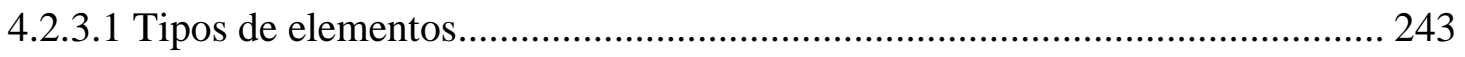

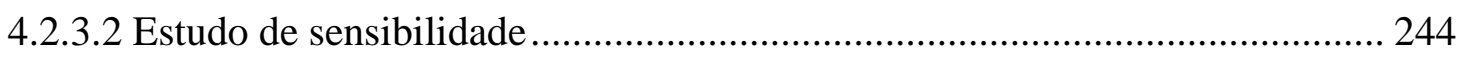




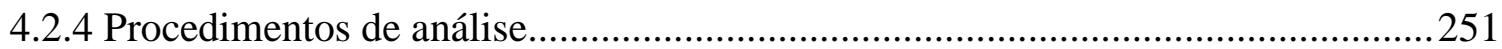

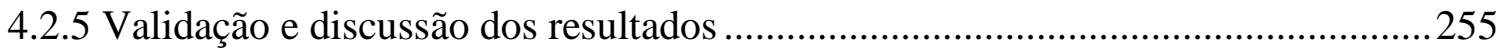

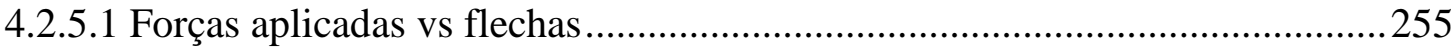

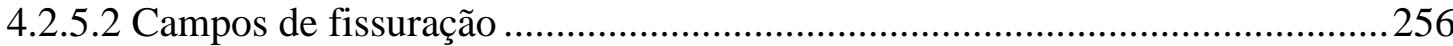

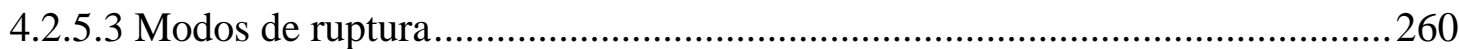

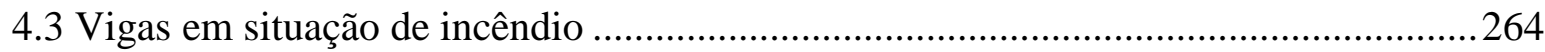

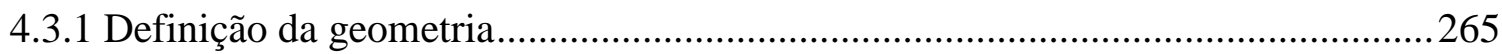

4.3.1.1 Pontos auxiliares para a medição de temperaturas ......................................265

4.3.1.2 Condições de contorno de origem térmica ....................................................2. 265

4.3.1.3 Determinação das forças atuantes.................................................................269

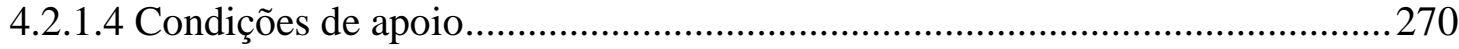

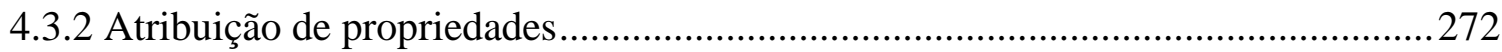

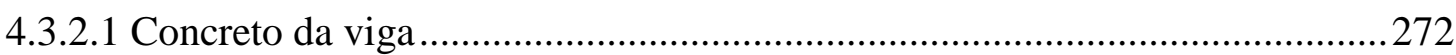

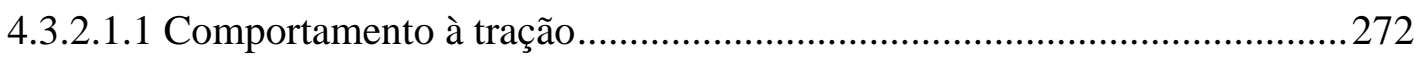

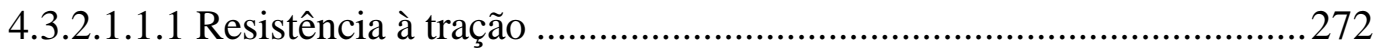

4.3.2.1.1.2 Energia de fratura à tração no modo I ..............................................2273

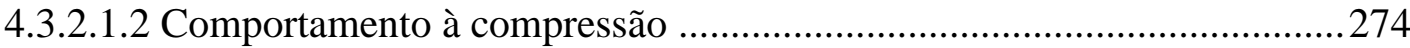

4.3.2.1.3 Comportamento linear elástico .............................................................. 275

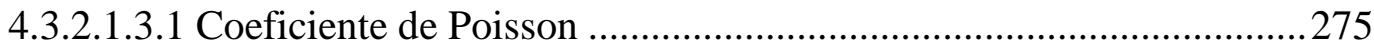

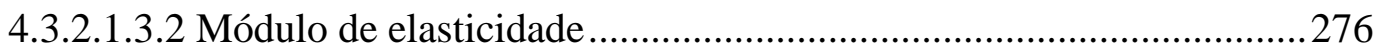

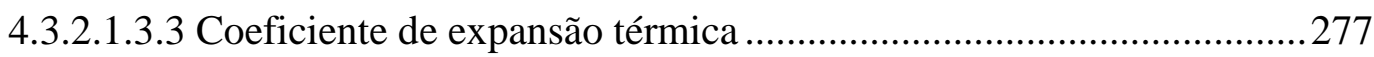

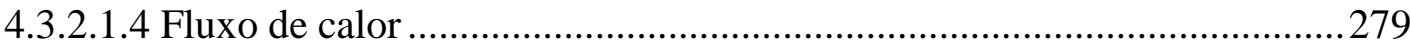

4.3.2.1.4.1 Condutividade térmica.....................................................................279

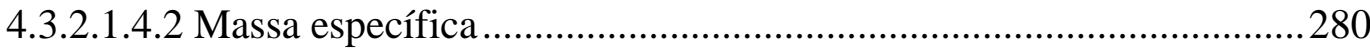

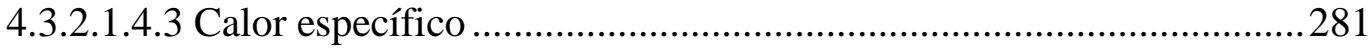

4.3.2.2 Aço dos blocos dos apoios e das chapas de distribuição das forças ...............2282

4.3.2.3 Aços das armaduras longitudinais e transversais ............................................2.283

4.3.2.3.1 Tensões de tração e módulo de elasticidade ............................................283

4.3.2.3.2 Coeficiente de expansão térmica ...........................................................28 
4.3.2.4 Fluxos de calor das interfaces diretamente aquecidas ou com isolamento .... 288

4.3.2.5 Restrições axial e rotacional das interfaces estruturais ................................ 291

4.3.3 Determinação da malha de elementos finitos ...................................................... 293

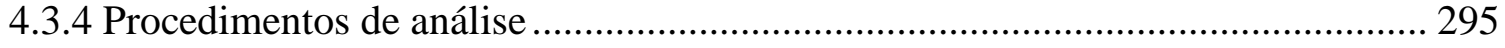

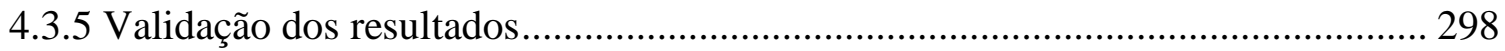

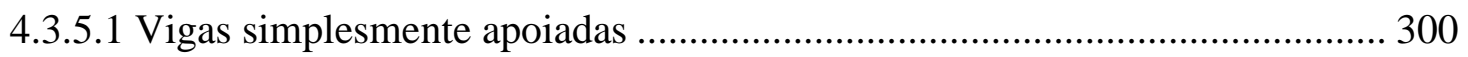

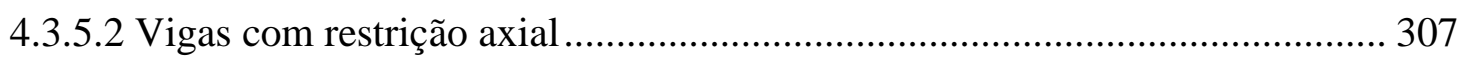

4.3.5.3 Vigas com restrições axial e rotacional..................................................... 310

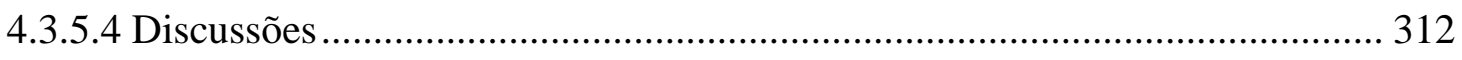

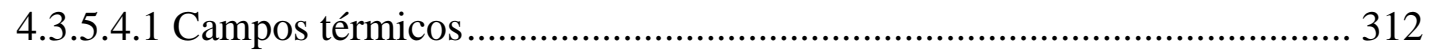

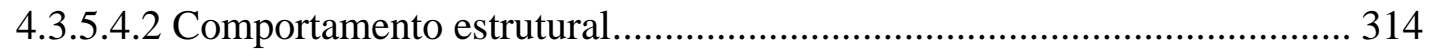

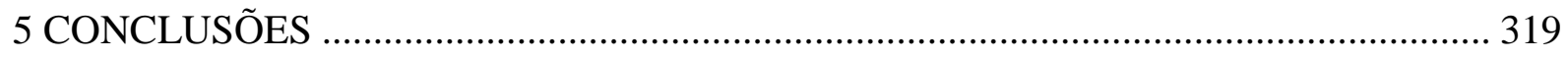

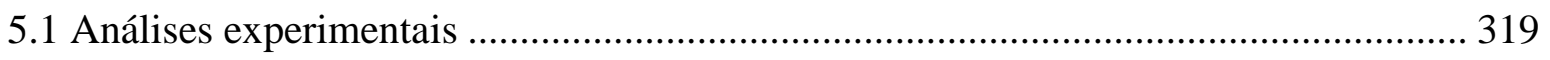

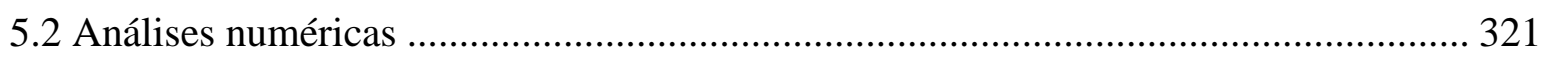

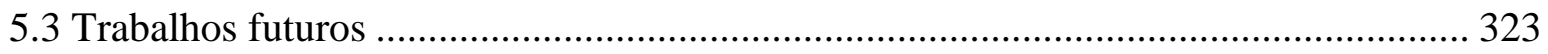

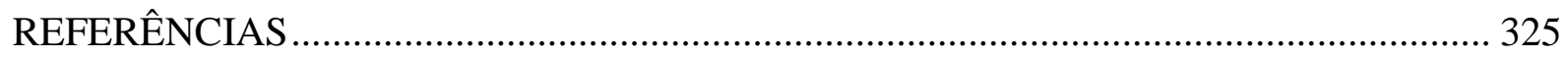

APÊNDICE A - PROJETO DE ELEMENTOS DO SISTEMA DE RESTRIÇÃO ............. 347

APÊNDICE B - ESQUEMAS DOS SISTEMAS DE ENSAIOS .................................... 355

APÊNDICE C - CRITÉRIOS DO PROJETO DE EDIFÍCIOS HIPOTÉTICOS ................. 361

APÊNDICE D - ESTUDO DA SIMULAÇÃO DE VIGAS SOB LAJES ............................ 363

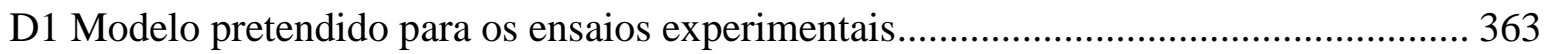

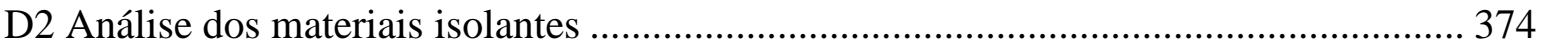




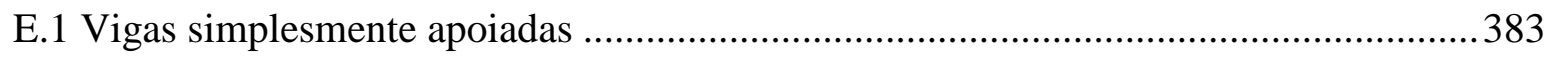

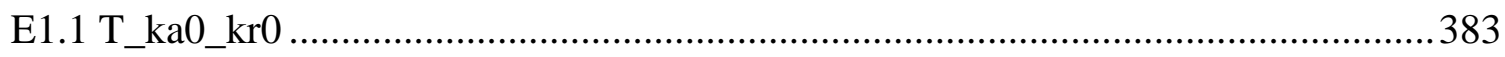

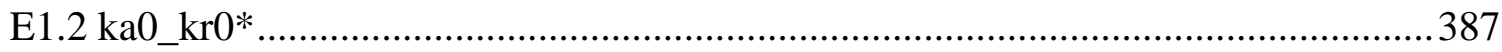

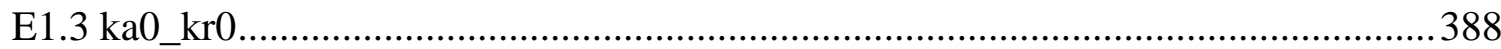

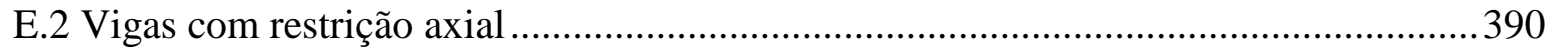

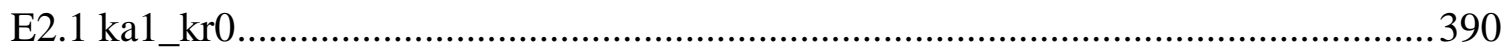

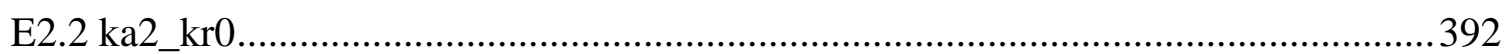

E.3 Vigas com restrições axial e rotacional................................................................ 395

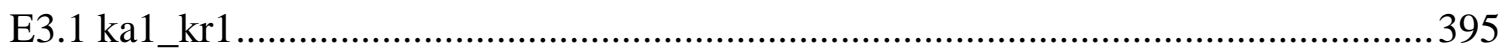

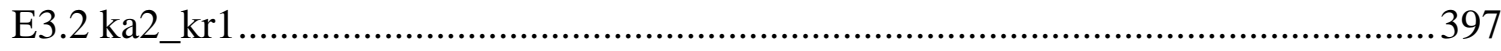

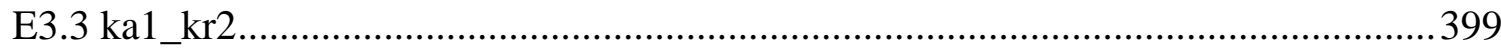

APÊNDICE F - FOTOS DOS ENSAIOS EXPERIMENTAIS DE VIGAS AO FOGO.......403

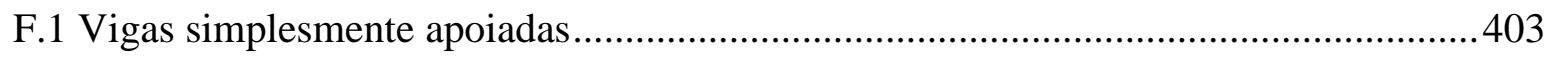

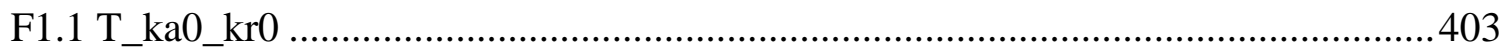

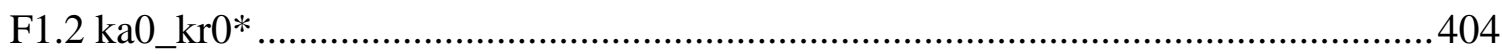

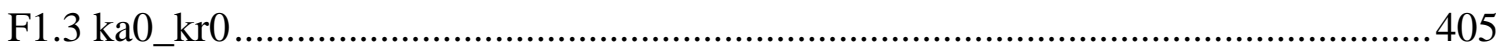

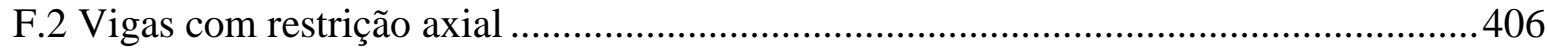

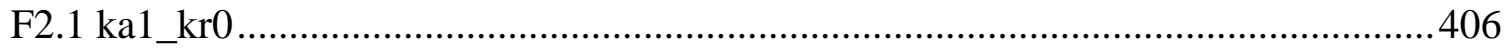

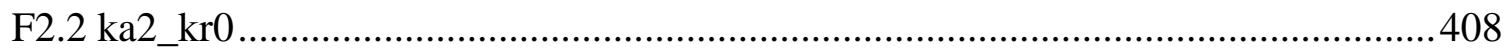

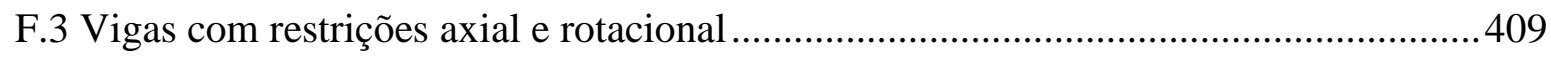

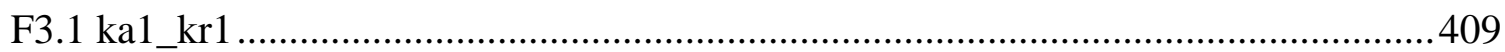

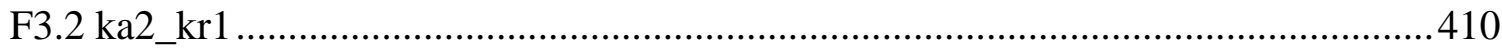

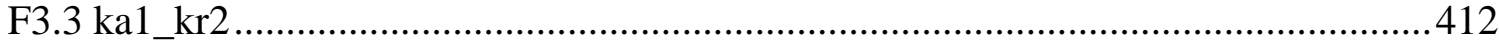





\section{INTRODUÇÃO}

\subsection{Considerações iniciais}

As vigas de concreto armado tendem a se deformar por flexão e a expandir o seu comprimento quando expostas ao fogo. Essas deformações de origem térmica resultam na rotação e no deslocamento horizontal dos seus apoios, respectivamente, se esses não forem fixos. Tais fenômenos são ilustrados na Figura 1.1 por meio de vigas simplesmente apoiadas, cujos apoios não apresentam quaisquer restrições à sua ocorrência, bem como não existem outras condições de contorno que os impeçam. Apenas para efeito didático e melhor entendimento, eles foram apresentados separadamente, contudo, é usual que ocorram de forma simultânea na prática. As vigas se encontram aquecidas por meio de uma fonte de calor disposta abaixo delas porque esse consiste no cenário de aquecimento comum a que são submetidas ao longo de incêndios que se alastram em edifícios. Uma vez que a tendência dos gases quentes é sempre de se mover em direção às camadas superiores do compartimento em chamas, as vigas dispostas no teto são atingidas por eles a partir de suas faces inferiores.
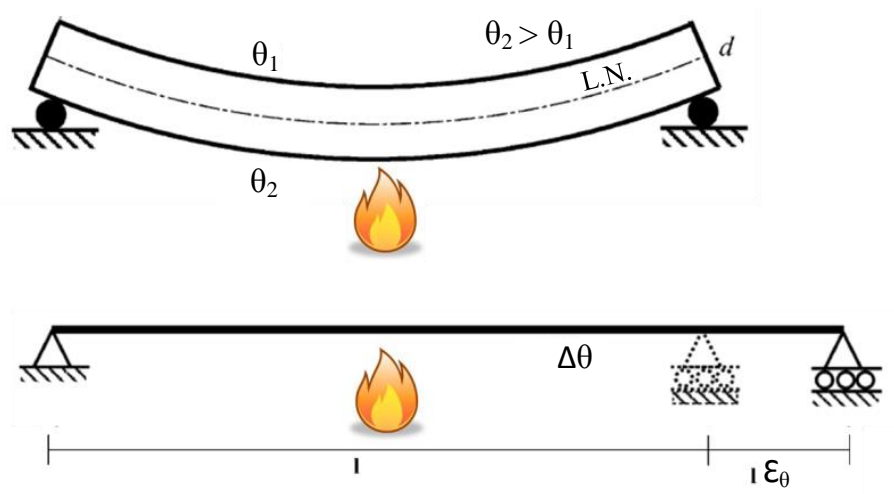

Figura 1.1 - Flexão seguida de rotação dos apoios e expansão do comprimento seguida de deslocamento do apoio em vigas submetidas a aumento de temperatura (USMANI et al., 2001; adaptado). 
Nessa condição de incêndio, as vigas de concreto desenvolvem um gradiente não linear de temperaturas ao longo da altura de sua seção transversal, como indica a Figura 1.2. O mesmo é resultante das diferenças entre as temperaturas que atuam nas faces superiores e inferiores das vigas, sendo que essas diferenças por sua vez podem ser atribuídas não apenas ao modelo de aquecimento (fogo por baixo), mas também à baixa condutividade térmica do concreto, que faz com que o calor que entra através da face inferior da peça seja transferido em taxas muito lentas para as regiões superiores da seção. Em uma viga idealmente sem carregamento gravitacional, a atuação desse gradiente é um fator determinante, junto com a diminuição do módulo de elasticidade do material, para a ocorrência da deformação por flexão, que foi apresentada anteriormente na Figura 1.1. O encurvamento é para baixo porque é justo nessa face que o elemento tende a experimentar maiores expansões. No caso hipotético de uma peça exposta ao fogo por meio de sua face superior, a flexão ocorreria gradualmente para cima.

Já a expansão do comprimento da viga, segundo caso de deformação de origem térmica ilustrado na Figura 1.1, ocorre pela dilatação térmica dos seus materiais constituintes (concreto e aço), sendo mais significativa na face inferior, novamente porque essa está diretamente exposta ao fogo. Tal fenômeno está ligado ao grau de agitação de suas partículas, que se encontram em posição de equilíbrio à temperatura ambiente, dispondo-se de forma regular, visto que existem forças de coesão intensas entre elas, características de corpos sólidos. Entretanto, com o aumento da temperatura, o grau de agitação também aumenta e fortes colisões tendem a formar um novo arranjo de partículas, agora dispostas irregularmente e separadas umas das outras, resultando no aumento das dimensões da estrutura.

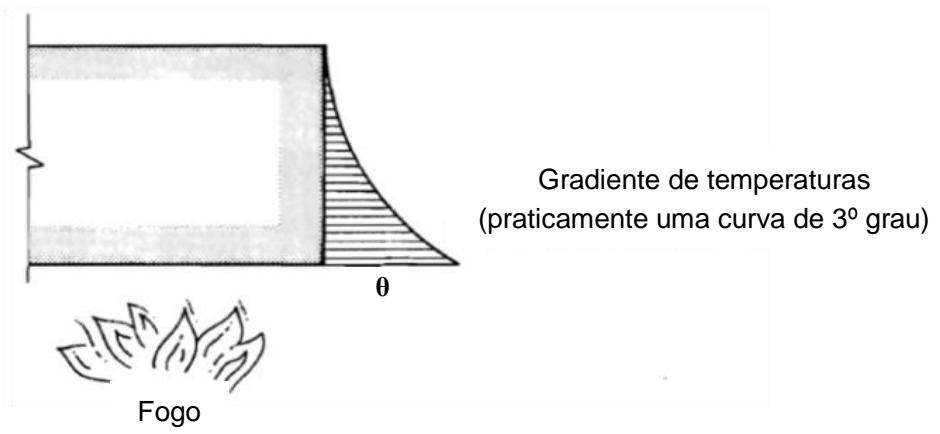

Figura 1.2 - Gradiente térmico não linear que se forma ao longo da altura de vigas de concreto armado em situação de incêndio (TASSIOS; CHRONOPOULOS, 1991; adaptado). 
As vigas presentes em estruturas reais certamente não possuem total liberdade para se deformarem como ilustrado na Figura 1.1, sendo mais correto admitir que existam impedimentos impostos a essas deformações (USMANI et al.; 2001). Esses impedimentos ou restrições podem ser resultantes dos seguintes fatores: próprias condições de apoio da viga (própria continuidade, por exemplo); condições de contorno/razões construtivas, i.e., devido a elementos estruturais circundantes como pilares ou vigas transversais, que possam estar localizados nas extremidades da viga de modo a restringir as suas deformações; rigidez imposta por elementos estruturais ainda frios, adjacentes às vigas localizadas no interior de um compartimento em chamas, pois uma vez não aquecidos eles mantêm a sua integridade e imprimem maior rigidez às vigas aquecidas, que por sua vez já se encontram em condição mais dúctil. As Figuras 1.3 a 1.5 ilustram alguns desses casos para os quais as restrições às deformações de origem térmica das vigas se fazem presentes.

Logo, é possível perceber que mesmo as vigas admitidas em projeto como simplesmente apoiadas na condição de temperatura ambiente podem acabar por experimentar os efeitos das restrições quando em situação de incêndio, não por suas condições de apoio, mas porventura devido a razões construtivas (COSTA, 2008). Porém, na presente Tese, o termo "simplesmente apoiada" será sempre adotado para designar as peças que não apresentam quaisquer impedimentos às deformações que ocorrem a temperaturas elevadas.

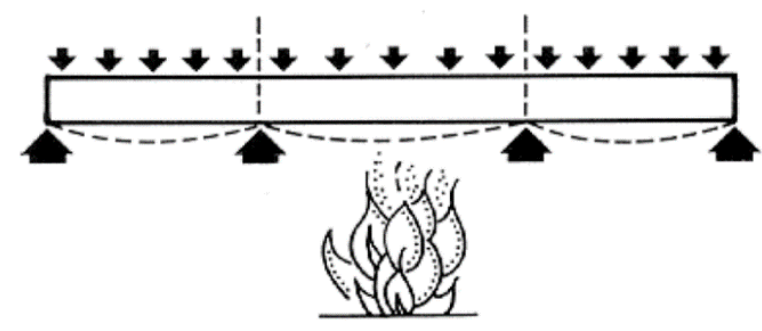

Figura 1.3 - Restrições às rotações dos apoios resultantes do próprio esquema estático das vigas contínuas (GOSSELIN, 1987).

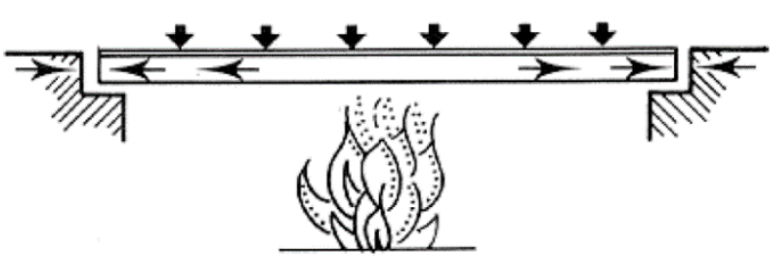

Figura 1.4 - Restrições à expansão do comprimento da viga resultantes das suas condições de contorno, que representam a ligação viga-pilar (GOSSELIN, 1987). 

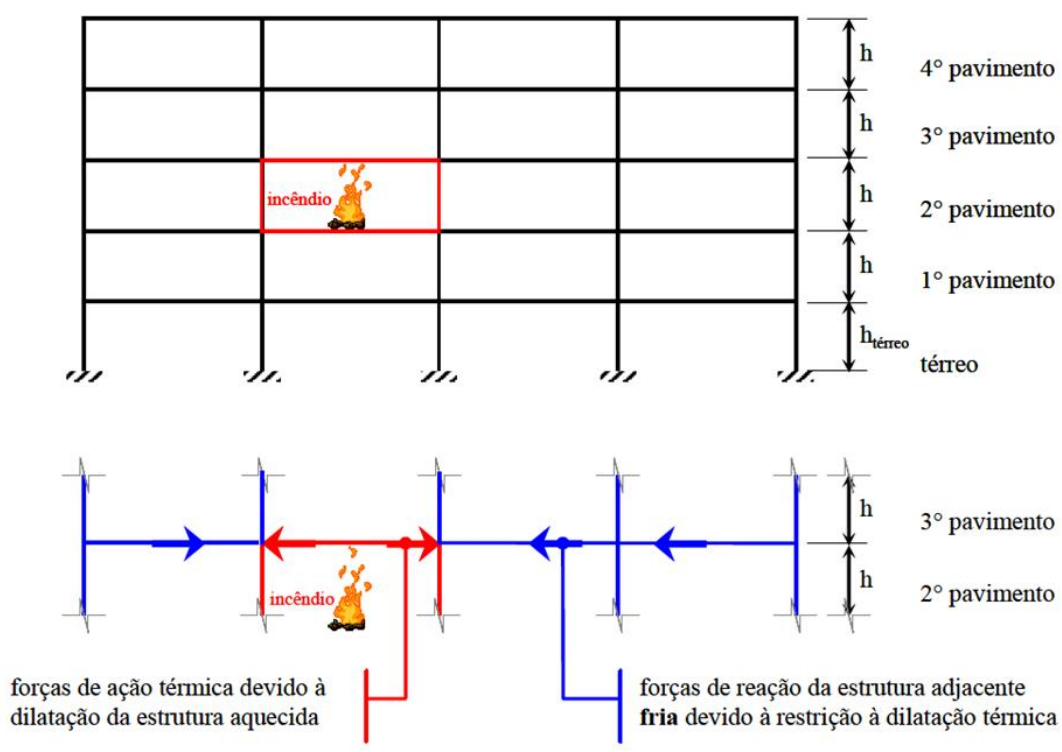

Figura 1.5 - Restrições à expansão do comprimento da viga localizada no interior de um compartimento em chamas, geradas pela rigidez imposta por elementos estruturais adjacentes não aquecidos (COSTA, 2008).

As restrições geram esforços adicionais nos elementos em que atuam. Há aproximadamente quarenta anos, as pesquisas começaram a apontar que os efeitos desses esforços podem ser benéficos ao comportamento das vigas de concreto armado expostas ao fogo, citando-se, por exemplo, as publicações CRSI (1980), Lin; Gustaferro e Abrams (1981) e Gustaferro e Lin (1986). Para explicar melhor de que forma os efeitos das restrições ajudam a melhorar a resposta ao fogo desses elementos estruturais, é válido abordar, a priori, aspectos do comportamento de vigas simplesmente apoiadas sob altas temperaturas, ou seja, daquelas que não são beneficiadas por esses efeitos, para que em seguida possam ser entendidas as diferenças em relação ao comportamento daquelas com restrições à expansão do comprimento e ao giro dos apoios.

Ao longo do incêndio, a região superior do concreto (bloco comprimido da seção transversal) de uma viga com qualquer tipo de esquema estático se mantém longe da ação direta da fonte de calor, posicionada abaixo do elemento, e permanece relativamente fria. Enquanto isso, a sua região inferior e, sobretudo, a armadura ali disposta ficam cada vez mais aquecidas mediante os gases quentes que sobem pelo processo de convecção. Isso faz com que a resistência ao fogo de uma viga simplesmente apoiada seja governada especialmente pela 
resistência da armadura positiva e o colapso da peça ocorrerá, de modo inevitável, quando o aço atingir temperaturas críticas da ordem de 500 a $550{ }^{\circ} \mathrm{C}$ (BUCHANAN; ABU, 2017; MARGARIDO, 1984). A Figura 1.6 ilustra os diagramas de momentos fletores solicitantes e resistentes de uma viga simplesmente apoiada em duas situações: logo no início do incêndio e após duas horas de exposição ao fogo. Como pode ser observado, os momentos solicitantes pouco se modificam, mas os resistentes são cada vez menores no decorrer do incêndio.
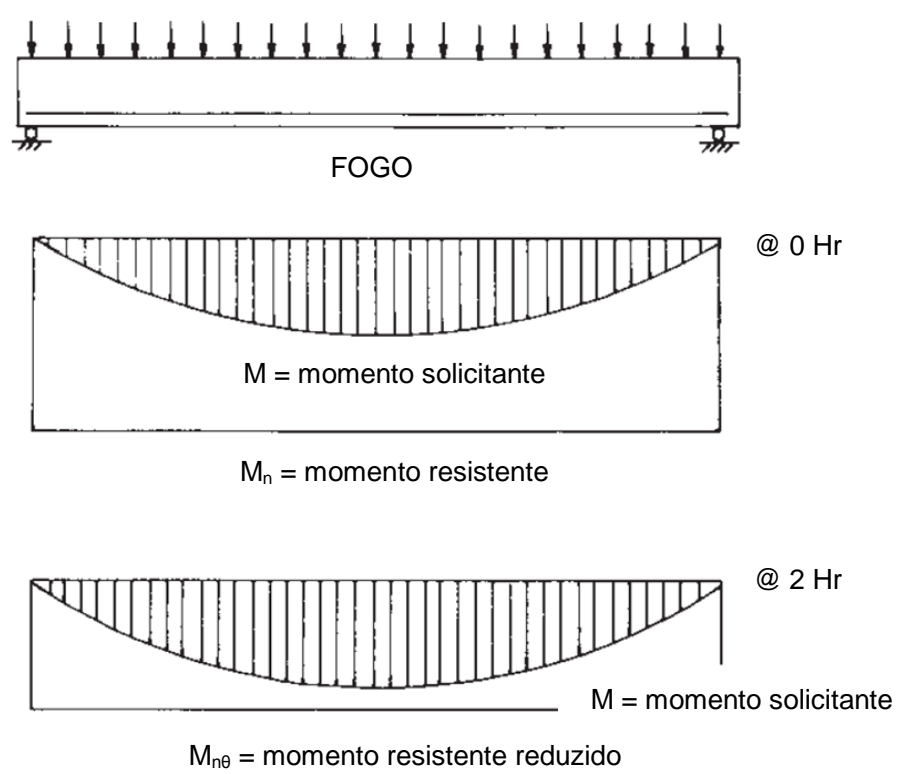

Figura 1.6 - Esquema estático e diagramas de momentos fletores solicitantes e resistentes antes e durante, respectivamente, a exposição ao fogo de uma viga simplesmente apoiada (GUSTAFERRO; MARTIN, 1977; adaptado).

Nas vigas com restrições às deformações de origem térmica, a perda de resistência das armaduras positivas pode ser compensada pelos efeitos dos esforços adicionais que são resultantes dessas restrições (BUCHANAN; ABU, 2017). Nas vigas contínuas, por exemplo, a flexão é impedida pelos seus próprios apoios, que desenvolvem momentos fletores solicitantes negativos, contrários ao encurvamento para baixo. Também conhecidos como momentos térmicos, eles representam, portanto, os esforços adicionais que surgem nas vigas com restrição do tipo rotacional. Esses momentos solicitantes se superpõem aos já existentes devido a carregamentos aplicados ao longo do vão, vide Figura 1.7. 
A elevação dos momentos negativos e a diminuição dos positivos são favoráveis ao comportamento desses elementos, haja vista que a armadura negativa, localizada na região superior da viga, possui resistência pouco prejudicada quando comparada à positiva, que se encontra na parte inferior e diretamente exposta às temperaturas elevadas. Ainda pela Figura 1.7, vê-se que enquanto os momentos resistentes positivos diminuem consideravelmente ao longo do incêndio, os negativos ainda conseguem se manter constantes por determinado período. Ressalta-se que certamente existe um limite para que essa redistribuição "natural" de momentos esteja a favor da segurança, uma vez que os apoios das vigas contínuas estarão aptos a suportar o aumento dos momentos negativos de acordo com sua capacidade de rotação. Portanto, ao contrário das vigas simplesmente apoiadas, cujo colapso da peça se dá pela formação de apenas uma rótula plástica a meio vão, as vigas restringidas rotacionalmente possuem uma reserva de segurança, resultante da redistribuição de momentos, de modo que o colapso não ocorrerá até que essas rótulas sejam formadas em três pontos ao longo do vão. A Figura 1.8 mostra a comparação dos mecanismos de ruptura característicos desses dois casos.

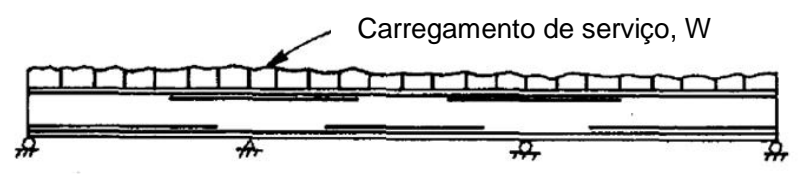

(a) Viga usual de concreto armado com três vãos

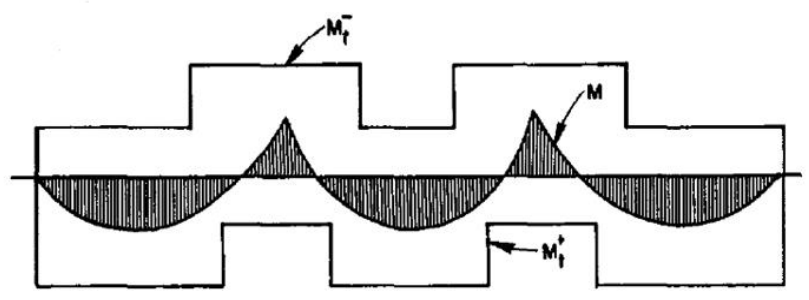

(b) Momentos resultantes do carregamento de serviço - Sem incêndio

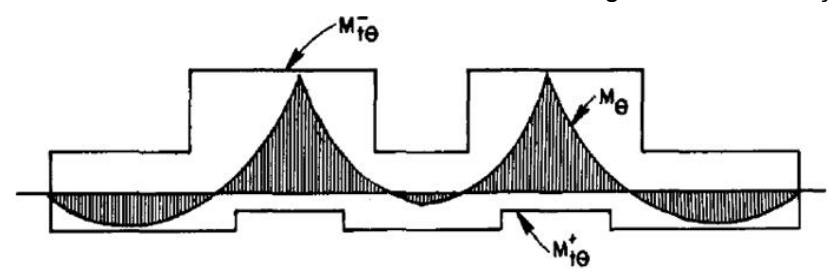

(c) Momentos redistribuídos - Devido ao incêndio

Figura 1.7 - Esquema estático (a) e diagramas de momentos fletores solicitantes $\left(\mathrm{M}\right.$ e $\left.\mathrm{M}_{\theta}\right)$ e resistentes $\left(\mathrm{M}_{\mathrm{t}}\right.$ e $\mathrm{M}_{\mathrm{t} \theta}$ ) antes (b) e durante (c) a exposição ao fogo de uma viga contínua (LIN; GUSTAFERRO, ABRAMS, 1981; adaptado). 
(a) VIGA SIMPLESMENTE APOIADA

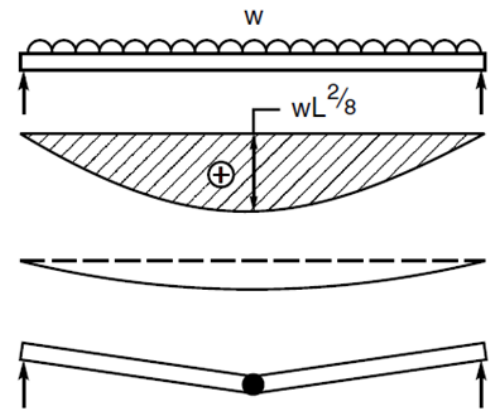

Carregamento e apoios

Diagrama de momentos fletores

Configuração deformada

Mecanismo de ruptura

(b) VIGA CONTÍNUA

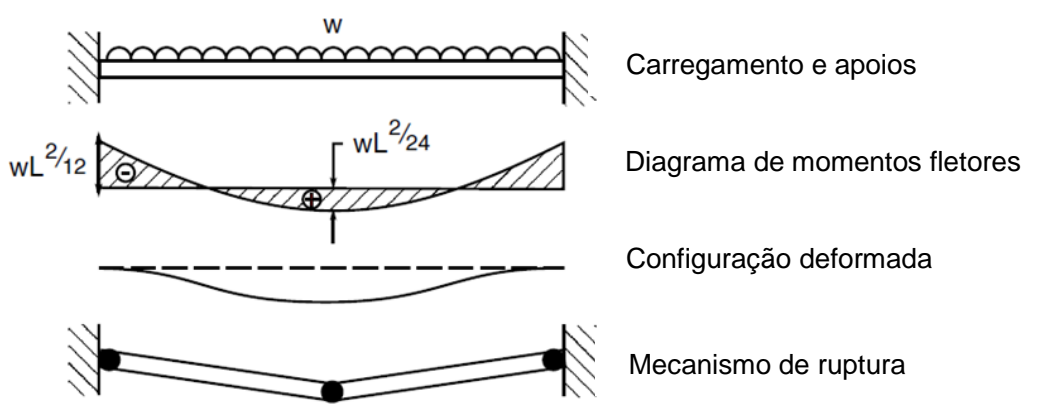

Figura 1.8 - Esquemas estáticos, diagramas de momentos solicitantes, configurações deformadas e mecanismos de ruptura de vigas simplesmente apoiadas (a) e contínuas (b) (BUCHANAN; ABU, 2017; adaptado).

Nas vigas em que a expansão do comprimento é restringida, forças de compressão irão atuar na peça, de forma a rebater à tentativa de alongamento, que "empurra" os apoios (esse fenômeno pode ser bem entendido pelas Figuras 1.4 e 1.5). Dependendo da localização dessas forças, da configuração deformada da viga (efeitos da não linearidade geométrica) e da fissuração do concreto (redistribuição de esforços), surgirão momentos que podem aumentar ou diminuir os momentos fletores solicitantes em situação de incêndio ou, em outras palavras, que podem ser benéficos ou não a resposta desses elementos estruturais frente ao fogo. Logo, os esforços adicionais que surgem em vigas com esse tipo de restrição compreendem forças de compressão e momentos.

A Figura 1.9 ilustra os diagramas de momentos fletores solicitantes de uma viga restringida axialmente. Carlson, Selvaggio e Gustaferro (1965) esclarecem que a localização vertical das forças de compressão depende das condições de apoio da viga, i.e., em função do aspecto 
construtivo elas podem ter uma linha de atuação bem definida e se manterem fixas ao longo da exposição ao fogo ou, nos casos em que isso não se verifica, a tendência é que elas atuem inicialmente próximas à face inferior do elemento, pois essa é a região submetida a maiores temperaturas e expansões. Para esclarecer a seguir os efeitos das restrições à expansão das vigas, à luz das informações fornecidas em Dwaikat e Kodur (2008) e Dwaikat (2009), supõese que a linha de atuação da força de compressão da referida figura é constante ao longo do incêndio. Entretanto, a título de informação, a Figura 1.10 mostra que a tendência das forças de compressão que não possuem linha de atuação bem definida é de subir durante o incêndio, por conta da uniformização do gradiente térmico e das expansões.

Nas Figuras 1.9-a e b, a linha tracejada indica a ligação dos pontos que são representativos da altura da linha neutra em cada uma das seções transversais ao longo do vão, com o símbolo “a" sendo escolhido para designar a distância entre a altura da linha neutra da seção a meio vão e a linha de atuação da força de restrição, sendo essa força denominada "P". Uma vez que a localização vertical da linha neutra se encontra acima da linha de atuação da força, como resultado da fissuração do concreto, será gerado um momento $\mathrm{P}$ x a negativo, contrário ao momento solicitante positivo que resulta da atuação das forças aplicadas em incêndio e dos efeitos do gradiente térmico. Esse efeito é denominado "arch action", traduzido para este texto como efeito arco. Em contrapartida, pelo fato das vigas fletirem gradualmente abaixo, as forças de restrição também irão gerar um momento positivo secundário, $\mathrm{P}$ x $\delta$, sendo " $\delta$ " a flecha da viga (deslocamento vertical a meio vão). O momento fletor solicitante líquido da peça será dado pela somatória de três momentos: os dois resultantes da atuação das forças de restrição, $\mathrm{P}$ x $(\mathrm{a}-\delta)$, e o resultante das forças aplicadas, $\mathrm{wL}^{2} / 8$.

Portanto, durante o período do incêndio em que o efeito arco for capaz de contrabalancear os demais momentos, as forças axiais irão atuar de forma benéfica ao desempenho da viga, prolongando a sua resistência ao fogo. É claro que da mesma forma que a redistribuição de momentos, há um limite para que os efeitos resultantes das forças de restrição, tanto as axiais quanto as excêntricas ou as de localização vertical variável ao longo do tempo, sejam capazes de agir de forma favorável ao desempenho das vigas. Em estágios mais avançados do 
aquecimento, é usual que o efeito arco já não seja preponderante em relação aos outros dois momentos ( $\mathrm{P} \times \delta$ e $\left.\mathrm{wL}^{2} / 8\right)$, pois as flechas se tornam mais excessivas e a linha neutra das seções ao longo do vão possui a tendência de se mover para baixo pelo aumento das forças de restrição com o tempo (Figura 1.10). A atuação dessas forças passam a requerer uma área maior da zona de concreto sob compressão, aumentando assim a altura do bloco comprido.

Portanto, é fato que os esforços adicionais gerados pelos impedimentos às deformações de origem térmica modificam o desempenho das vigas de concreto armado frente à ação do fogo, sendo imprescindível que a magnitude desses esforços e as influências que eles geram na resistência ao fogo desses elementos estruturais sejam objeto de investigação.

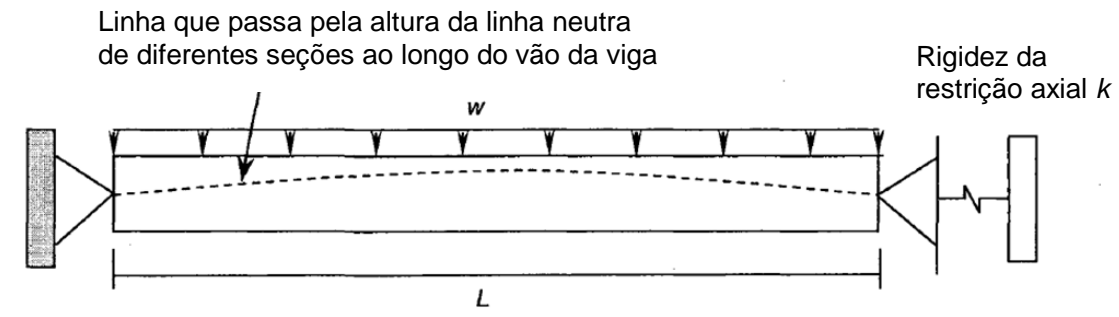

a) Vista frontal

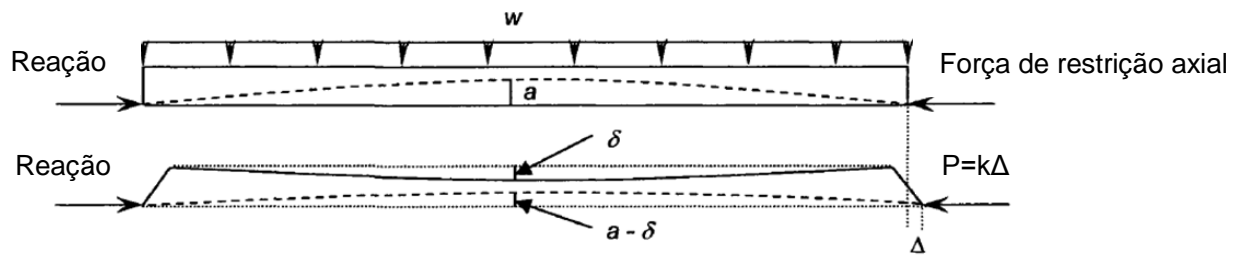

b) Ilustração do efeito arco

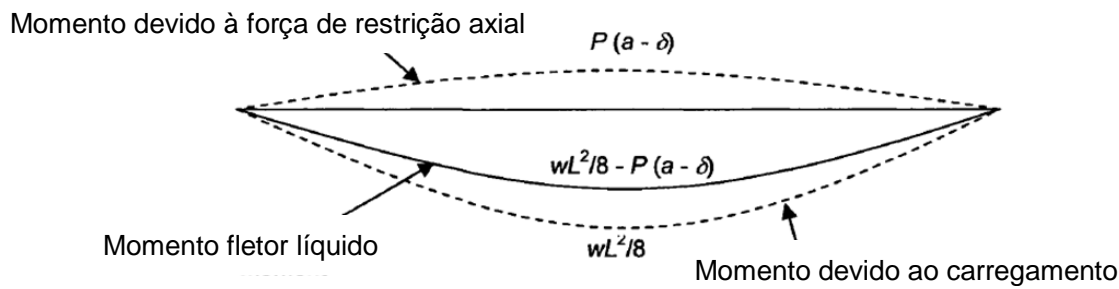

c) Diagrama de momento fletor

Figura 1.9 - Esquema estático (a), efeito arco (b) e diagramas de momentos fletores solicitantes durante a exposição ao fogo de uma viga com restrição axial (c) (DWAIKAT, 2009; adaptado). 


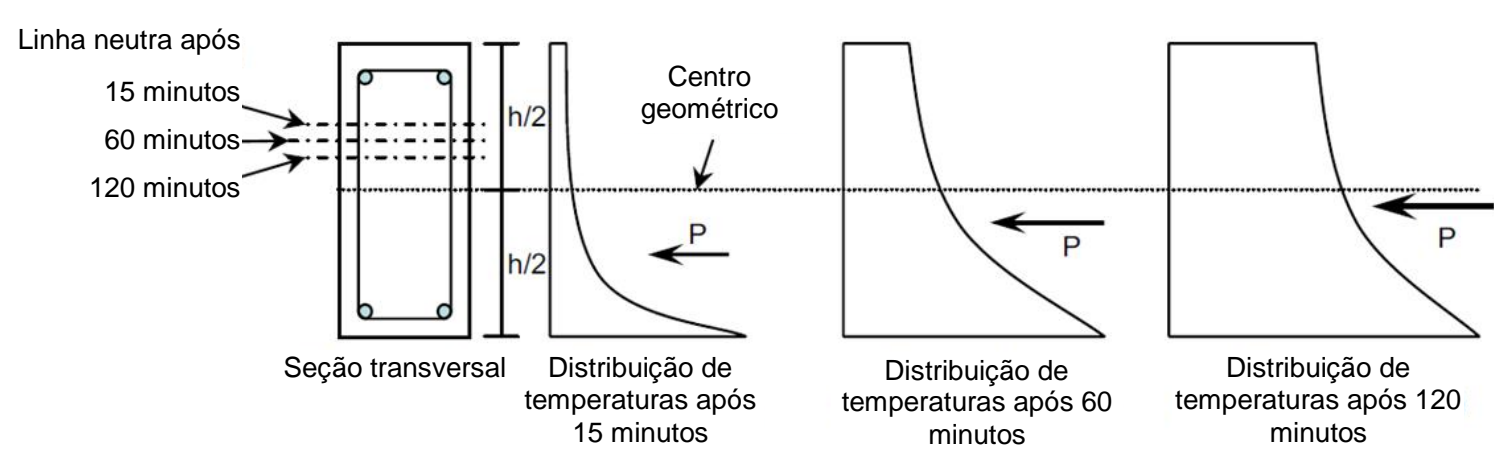

Figura 1.10 - Tendências da modificação durante o incêndio das alturas das linhas neutras e dos gradientes térmicos das seções transversais das vigas, bem como da posição vertical das forças de restrição que não possuem linha de atuação pré-definida (DWAIKAT; KODUR, 2008; adaptado).

\subsection{Objetivos}

Após o enunciado do tema proposto para investigação, serão descritos os objetivos da presente Tese de Doutorado. O geral consiste no estudo do comportamento de vigas de concreto armado com seções transversais retangulares em situação de incêndio. A seguir, os objetivos específicos.

- Executar análises experimentais de vigas com diferentes condições de restrição impostas pelos apoios às deformações de origem térmica, ou seja, ensaios de exposição ao fogo em vigas simplesmente apoiadas, em vigas com impedimentos às deformações axiais e, ainda, em vigas com impedimentos tanto às deformações axiais quanto rotacionais, uma vez que essa consiste na situação mais próxima ao que ocorre na prática;

- Relativamente aos ensaios experimentais de vigas restringidas, analisar níveis diferentes de restrições axial e rotacional, de modo a verificar a influência que as rigidezes mais altas ou mais baixas podem exercer na magnitude dos esforços adicionais e, por conseguinte, nos fenômenos resultantes das restrições; 
- Conceber análises numéricas com o propósito de obter modelos que sejam capazes de simular os resultados obtidos experimentalmente e que também permitam a avaliação das soluções mais adequadas para caracterizar o desempenho ao fogo das vigas de concreto armado por meios computacionais;

○ Com base nos resultados do estudo numérico-experimental, procurar parâmetros comportamentais para os diferentes tipos de vigas analisados e ponderar o quão significativos podem ser os efeitos das restrições no aumento da resistência ao fogo desses elementos, com o intuito de aferir o rigor dos atuais métodos de cálculo propostos pelas normas de dimensionamento em situação de incêndio.

\subsection{Justificativas}

Conforme esclarecido ao longo das considerações iniciais, há um consenso no meio acadêmico de que os efeitos das restrições podem ser benéficos à resistência ao fogo das vigas de concreto armado. Apesar das razões que conduzem a essa melhoria da resistência já se encontrarem bem definidas no que se refere a aspectos teóricos, o número de pesquisas nas quais foram conduzidos ensaios para verificar essa questão experimentalmente ainda é reduzido. Além disso, nos trabalhos encontrados, os efeitos das restrições foram estudados apenas de forma isolada, i.e., ou as vigas estavam submetidas a restrições axiais durante os ensaios ou a restrições somente rotacionais. Por isso, para esta Tese, também foram propostos testes de exposição ao fogo em vigas que apresentavam impedimentos às duas modalidades de deformações de origem térmica simultaneamente.

Além disso, traçou-se como objetivo analisar de forma experimental níveis diferentes de rigidezes impostas às deformações axiais e rotacionais das vigas porque não foram encontradas pesquisas em que essa questão tenha sido avaliada por meio de ensaios em laboratório. Foram encontrados alguns estudos numéricos, porém, os modelos computacionais foram usualmente validados somente a partir de resultados experimentais de ensaios em 
modelos de vigas mais simples (submetidas apenas a uma intensidade de restrição axial, por exemplo) e então foram extrapolados para a análise de diferentes rigidezes.

Essa questão também motivou a concepção de modelos numéricos capazes de simular o comportamento das vigas ensaiadas na campanha da presente pesquisa, pois agora estavam disponíveis resultados experimentais suficientes para certificar a coerência de modelos computacionais que fossem representativos não apenas de vigas de concreto armado simplesmente apoiadas expostas a temperaturas elevadas, mas também restringidas sob diferentes níveis de rigidezes impostos por determinada estrutura circundante.

\subsection{Métodos}

As análises experimentais pertinentes a esta Tese foram conduzidas no Laboratório de Ensaio de Materiais e Estruturas (LEME) do Departamento de Engenharia Civil da Universidade de Coimbra (UC). Como será apresentado com mais detalhes ao longo deste trabalho, foram montados diferentes sistemas de ensaios a partir dos quais se tornou possível analisar o comportamento ao fogo de vigas de concreto armado em escala real com diferentes tipos de restrição a deformações de origem térmica. Além dos ensaios ao fogo, um desses sistemas ainda foi utilizado para a realização de ensaios de referência, de vigas simplesmente apoiadas à temperatura ambiente. O LEME-UC disponibilizou vários equipamentos de instrumentação, como células de carga, transdutores e termopares, que foram capazes de aferir, por exemplo, as forças aplicadas nas vigas durante os ensaios, a magnitude das forças de restrição, os deslocamentos verticais das vigas e as temperaturas atuantes nas mesmas. Por intermédio de todos os resultados experimentais, foi possível estudar com detalhes as questões pretendidas.

Para a concepção dos modelos numéricos tridimensionais, propostos para reproduzir os resultados obtidos nos ensaios da melhor forma quanto possível, adotou-se o programa de computador Displacement Analyzer - DIANA (DIANA FEA, 2016a), que tem origem 
neerlandesa e adota como base os métodos dos deslocamentos e dos elementos finitos. $\mathrm{O}$ mesmo é bastante adequado para a análise de estruturas de concreto armado, uma vez que é capaz de considerar diversas propriedades que tangem ao comportamento não linear dos materiais, contando com a disponibilidade de uma vasta gama de modelos constitutivos, tipos de elementos finitos, critérios de análise, dentre outras ferramentas. Esse programa ainda possui um módulo térmico e é válido citar o ineditismo de seu uso no Brasil para a análise de vigas de concreto armado em situação de incêndio. Em Portugal, foi empregado anteriormente apenas em uma pesquisa, porém, não se avaliou o comportamento das vigas como um todo, haja vista que as análises se deram apenas ao nível da seção transversal. Na pesquisa de referências internacionais (fora do âmbito Brasil/Portugal), foi encontrado apenas um trabalho em que se adotou o DIANA para associar incêndio a vigas de concreto convencionais, contudo, foi em grande parte mais voltado a modelagem de vigas com fibras de reforço polimérico (FRP).

\subsection{Organização da Tese}

Além do capítulo 1, Introdução, em que se contextualizou e justificou o tema proposto para estudo e no qual foram apresentados os objetivos e os métodos adotados para o cumprimento dos mesmos, a presente Tese de Doutorado inclui mais quatro capítulos, que são brevemente descritos nos parágrafos a seguir.

O capítulo 2, Estado da arte, apresenta uma revisão de literaturas estrangeiras, brasileiras e portuguesas que discutem acerca do comportamento ao fogo de vigas de concreto armado cujos apoios restringem ou não as deformações de origem térmica. São expostos alguns comentários relevantes sobre cada uma dessas referências, que incluem artigos, Dissertações, Teses e livros. Nesse capítulo, os pontos de ineditismo da Tese são destacados. 
O capítulo 3, Análises experimentais, trata dos ensaios que foram desenvolvidos no LEMEUC. Discorrem-se informações sobre os sistemas de testes adotados, sobre as características e as etapas de produção das vigas de concreto armado, bem como detalhes do plano de ensaios e dos procedimentos estabelecidos para a condução dos mesmos. Finalmente, são apresentados os resultados provenientes dessas análises e discussões acerca de tais resultados tanto no que se refere aos ensaios de vigas à temperatura ambiente quanto expostas a temperaturas elevadas.

O capítulo 4, Análises numéricas, dedica-se à apresentação do programa de computador DIANA e ao esclarecimento das características e dados de entrada que foram estipulados para a concepção dos modelos computacionais. A priori, apresentam-se as considerações acerca do modelo de vigas à temperatura ambiente, pois esse serviu como base para a concepção dos modelos ao fogo, que são abordados em seguida. O capítulo ainda contempla as comparações entre os resultados numéricos e experimentais.

O capítulo 5, Conclusões, tece as considerações finais do trabalho. Discorre-se, por exemplo, sobre os principais resultados obtidos a partir das análises experimentais e acerca das modelagens numéricas. Ainda são apresentadas algumas propostas de trabalhos futuros que podem ser desenvolvidos à luz dos tópicos abordados nesta Tese.

Os Apêndices A a F são voltados à apresentação de informações e resultados adicionais da parte experimental desta investigação. 


\section{ESTADO DA ARTE}

Com base na bibliografia estrangeira pesquisada ${ }^{1}$, verificou-se que apesar de haver pesquisas sobre o comportamento de estruturas de concreto em situação de incêndio que remontam ao final do século XIX e meados do século XX, citam-se Freitag (1899) e Mörsch (1948), os estudos específicos sobre vigas começaram a ser publicados apenas na década de 1980 e vem se desenvolvendo até os dias atuais. De forma geral, esses estudos podem ser divididos em três grupos: numérico-experimentais, que consistem naqueles em que foram desenvolvidos modelos numéricos para a análise de vigas submetidas a temperaturas elevadas, sendo que esses modelos foram validados a partir dos resultados provenientes de testes de exposição ao fogo realizados pelos próprios autores dos respectivos trabalhos; numéricos, nos quais os modelos computacionais foram validados, na maior parte dos casos, mediante o uso de resultados experimentais obtidos por outros autores; e os estudos experimentais, fundamentados puramente em ensaios realizados em laboratório.

Em relação aos dois primeiros grupos - numérico-experimentais e numéricos -, houve um fator comum entre a maior parte dos trabalhos: embora desenvolvidos com base em métodos de cálculo distintos e apesar da tentativa constante de aperfeiçoar modelos precedentes, congregando propriedades dos materiais que são sensíveis à ação do calor e podem exercer influência na resposta ao fogo das vigas, os efeitos das restrições às deformações de origem térmica não foram considerados. Prova disso é que esses modelos foram validados mediante resultados oriundos de ensaios apenas em vigas simplesmente apoiadas. Mesmo nos trabalhos mais recentes, publicados nos últimos cinco anos, muitos autores ainda adotaram como base

\footnotetext{
${ }^{1}$ Neste texto, entende-se por "bibliografia estrangeira" os trabalhos publicados fora do Brasil e de Portugal, uma vez que a autora da presente Tese realizou Doutorado em Regime de Cotutela entre a Universidade de São Paulo (Brasil) e a Universidade de Coimbra (Portugal).
} 
de estudo modelos de vigas nos quais essas deformações estavam livres. Tal constatação também se aplicou às pesquisas puramente experimentais.

Sendo assim, à exceção da maioria, determinados autores analisaram vigas com apoios que restringiam deslocamentos horizontais ou rotações quando expostas ao fogo de forma numérica ou experimental. É válido ressaltar que muitos desses autores também analisaram vigas simplesmente apoiadas, porém, com o objetivo maior de comparar o comportamento dessas àquelas com restrições. Nos próximos itens, apresentar-se-ão mais detalhes, a priori, acerca dos trabalhos estrangeiros em que apenas as vigas simplesmente apoiadas foram objeto de estudo e, em seguida, daqueles nos quais também foram analisadas vigas com restrições.

Em seguida, apresentar-se-ão os levantamentos de pesquisas publicadas no Brasil e em Portugal acerca do assunto. Novamente, o conteúdo se divide com base nos trabalhos voltados ou apenas à análise de peças simplesmente apoiadas ou com restrições. Não foi necessário ainda subdividir com base na natureza do estudo, pois nesse caso foram encontrados apenas trabalhos numéricos. Ao final das revisões de literaturas, tanto estrangeiras quanto brasileiras e portuguesas, esclarecem-se os pontos de ineditismo desta Tese em relação a cada uma delas. Por fim, indicam-se as recomendações das normas europeia e brasileira, Eurocode 2 parte 1-2 (2004) e ABNT NBR 15200:2012, sobre os métodos para dimensionamento de vigas de concreto armado expostas ao fogo, com ênfase às informações fornecidas a respeito das restrições às deformações de origem térmica. 


\subsection{Revisão da literatura estrangeira}

\subsubsection{Vigas simplesmente apoiadas}

\subsubsection{Estudos numérico-experimentais}

Dotreppe e Franssen (1985) representam um dos primeiros trabalhos expressivos, publicados na década de 1980, a abordar o comportamento em incêndio de vigas. Os autores apresentaram um modelo numérico para a análise de estruturas de concreto armado e mistas (concreto e aço) expostas ao fogo. Com o objetivo de solucionar o problema termomecânico, que compreende a avaliação da distribuição de temperaturas e do comportamento estrutural, aplicaram o método dos elementos finitos, dividindo as estruturas em elementos de vigas com dois nós (cada um com três graus de liberdade), discretizaram a seção transversal com malha de elementos retangulares e utilizaram o procedimento de Newton-Raphson para ponderar o comportamento não linear do material.

A fim de validar o modelo desenvolvido, confrontaram resultados numéricos a experimentais. Para isso, utilizaram os dados do ensaio conduzido em uma viga de concreto armado simplesmente apoiada com seção retangular, submetida a duas forças concentradas e aquecida conforme o incêndio-padrão ISO 834 (o tipo de forno não foi especificado), vide Figura 2.1. Esse ensaio foi realizado alguns anos antes, na Universidade de Gante - Bélgica, pelo autor principal do artigo (DOTREPPE ${ }^{2}, 1980$ apud DOTREPPE; FRANSSEN, 1985). A precisão do modelo numérico foi comprovada por meio de resultados similares aos experimentais em

\footnotetext{
${ }^{2}$ DOTREPPE, J. C. Méthodes numériques pour la simulation du comportement au feu de structures en acier et en béton armé. 1980. Thèse (d'Agrégation de l'Enseignement Supérieur) - Université de Liège, Liège, 1980.
} 
termos de temperaturas na barra central da armadura longitudinal inferior e flechas, ambas em função do tempo de exposição ao fogo (Figura 2.2).
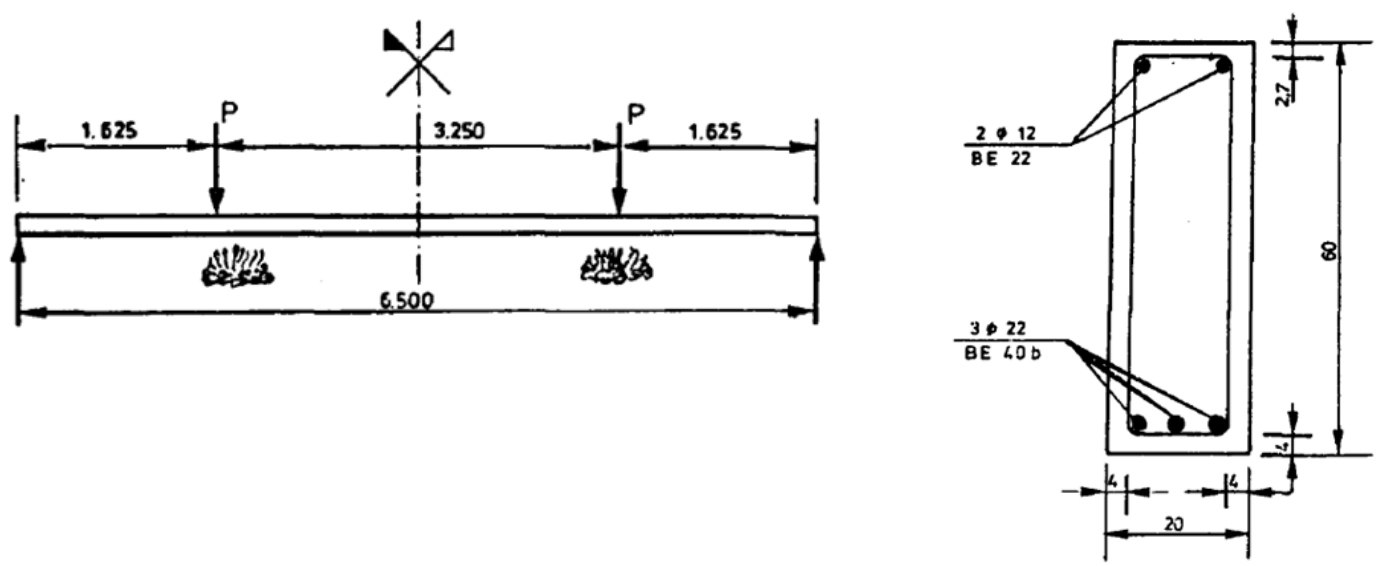

Figura 2.1 - Esquema estático e seção da viga simplesmente apoiada analisada por Dotreppe e Franssen (1985).
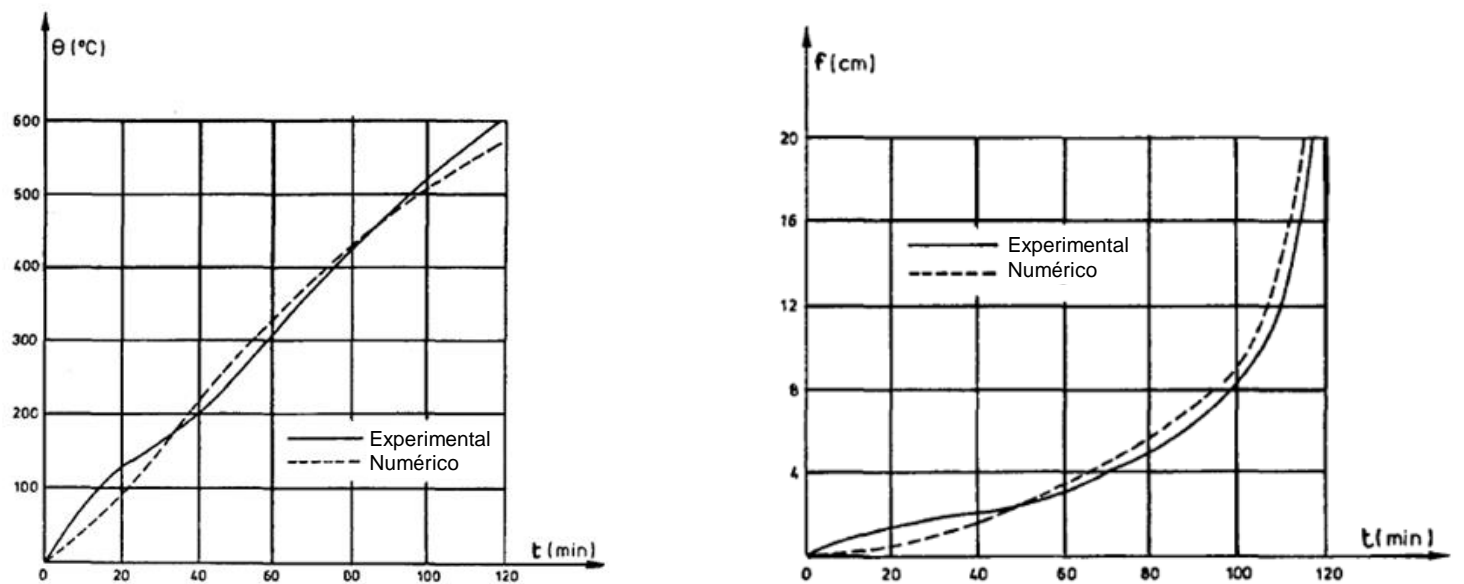

Figura 2.2 - Valores numéricos vs experimentais de temperaturas na barra central da armadura longitudinal inferior e de flechas, respectivamente (DOTREPPE; FRANSSEN, 1985; adaptado).

O escopo do trabalho de Dotreppe e Franssen (1985) foi mais voltado às considerações que devem ser tomadas em relação à análise numérica de tais elementos. Um exemplo se refere à verificação da necessidade de modelar ou não as armaduras longitudinais principais e adicionais, sendo as últimas aquelas que devem ser adotadas devido a razões construtivas, por exemplo, para vigas com alturas muito elevadas (Figura 2.3). Com base nas análises térmicas, os autores afirmaram que a influência tanto das armaduras longitudinais principais quanto das adicionais na distribuição de temperaturas da seção transversal é muito pequena, uma vez que 
a porcentagem de aço não é expressiva quando comparada a de concreto. Logo, para análises térmicas usuais de vigas de concreto armado, não há a necessidade de modelar armaduras. Contudo, para a análise estrutural, conforme esperado, devem ser consideradas as armaduras principais, enquanto a influência das adicionais não é significativa, não sendo preciso as levar em consideração no modelo. Isso se deve ao fato da área dessas armaduras ser pequena em relação às principais, que ficam situadas em regiões mais próximas às áreas expostas diretamente ao fogo e, por conseguinte, são aquecidas mais rapidamente. A necessidade da consideração dos estribos nas análises termestruturais não foi objeto de estudo nessa pesquisa.
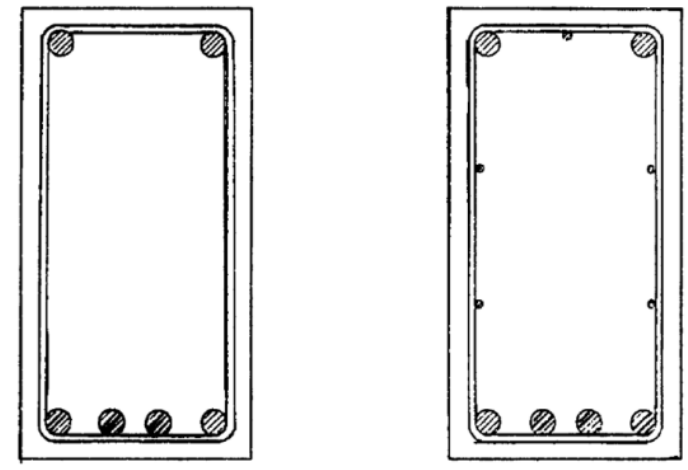

Figura 2.3 - Representação de seções com armaduras longitudinais principais e tanto com principais quanto adicionais, respectivamente (DOTREPPE; FRANSSEN, 1985).

Em uma pesquisa mais recente, Choi e Shin (2011) realizaram análises experimentais com o objetivo de avaliar a influência das resistências características à compressão do concreto $\left(\mathrm{f}_{\mathrm{ck}}\right)$ e dos cobrimentos das armaduras no comportamento estrutural de vigas de concreto armado frente ao fogo. Testaram quatro vigas, sendo que duas delas foram produzidas com concreto de resistência normal (igual a $21 \mathrm{MPa}$ ) e as demais com concreto de alta resistência (55 MPa). As espessuras dos cobrimentos analisados foram iguais a 40 e 50 milímetros. Todas as peças estavam na condição de simplesmente apoiadas e foram submetidas a ensaios de flexão a quatro pontos, com as duas forças concentradas de valor constante sendo aplicadas até ser atingido o critério de ruptura indicado pela norma ISO 834 (1999), no qual a finalização do ensaio é controlada com base nas flechas das vigas. $\mathrm{O}$ aquecimento foi proveniente de uma câmara de fogo, calibrado para seguir a curva proposta pela mesma norma. Na Figura 2.4 são mostrados os detalhes das vigas ensaiadas, bem como os três pontos ao longo das seções 
transversais, localizadas a meio vão, nos quais foram postos termopares para a medição das temperaturas. Na Figura 2.5, ilustram-se algumas vistas do sistema de ensaios, com as vigas posicionadas na câmara de fogo.
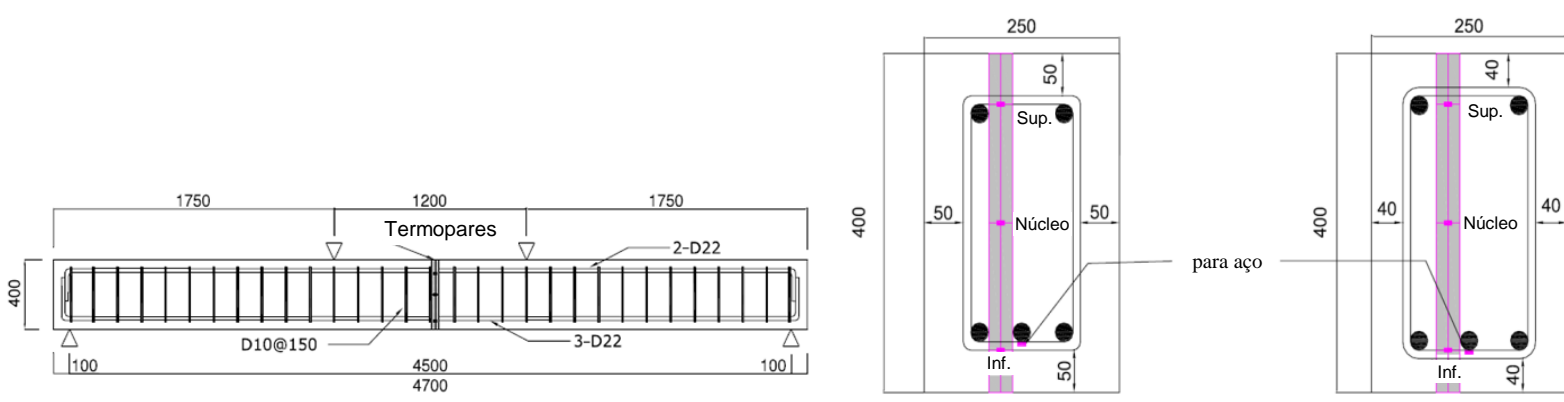

Figura 2.4 - Dimensões das vigas ensaiadas e posicionamento dos termopares nas seções transversais com diferentes cobrimentos (CHOI; SHIN, 2011; adaptado).

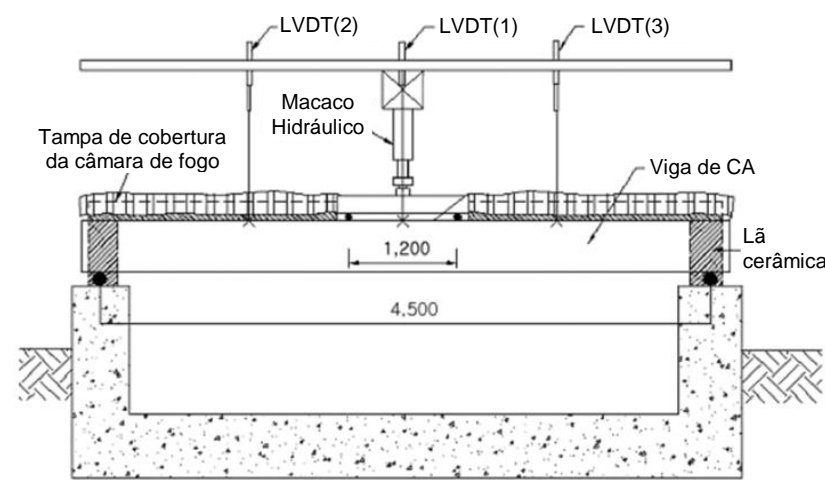

(a)

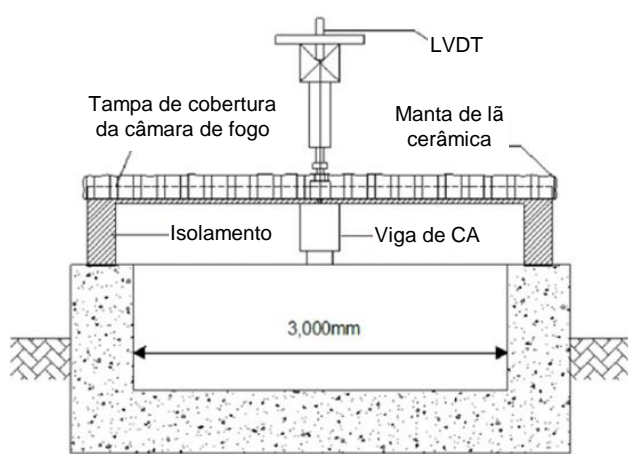

(b)

Figura 2.5 - Vistas em cortes (a) longitudinal e (b) transversal do sistema de ensaios com a viga de concreto armado posicionada na câmara de fogo (CHOI; SHIN, 2011; adaptado).

A primeira conclusão obtida por Choi e Shin (2011) foi que adotar um cobrimento maior ajuda a prolongar o tempo de resistência ao fogo de uma viga simplesmente apoiada produzida com concreto convencional, porém, essa estratégia pode ser ineficiente para vigas com concreto de alta resistência por conta do spalling, fenômeno ao qual costumam ser mais suscetíveis $^{3}$. [Ao longo do processo em que ocorre a evaporação da água presente na estrutura do concreto aquecido, o vapor exerce pressões internas nesse material, podendo ocasionar o desprendimento ou lascamento de suas camadas superficiais. Esse fenômeno é denominado

${ }^{3} \mathrm{O}$ spalling costuma ser mais expressivo em concretos de alta resistência devido à permeabilidade reduzida desse material, que faz gerar pressões de vapor maiores em seus poros (KHOURY, 2000). 
spalling, sendo ele também responsável pela redução da capacidade estrutural do elemento de concreto, devido à perda de sua área resistente e pela possível exposição da armadura ao calor]. $\mathrm{Na}$ Figura 2.6, mostra-se a aparência pós-ensaio de uma das vigas com concreto de alta resistência. A mesma foi submetida a um processo de cura térmica (a vapor) ao longo de um dia e depois foram estabelecidos mais seis meses de cura para que fosse ensaiada. No dia do ensaio, o teor de umidade estimado para essa peça foi igual a 0,0687. Na Figura 2.7 estão os esquemas das seções reduzidas de uma das vigas que sofreu o fenômeno de spalling.

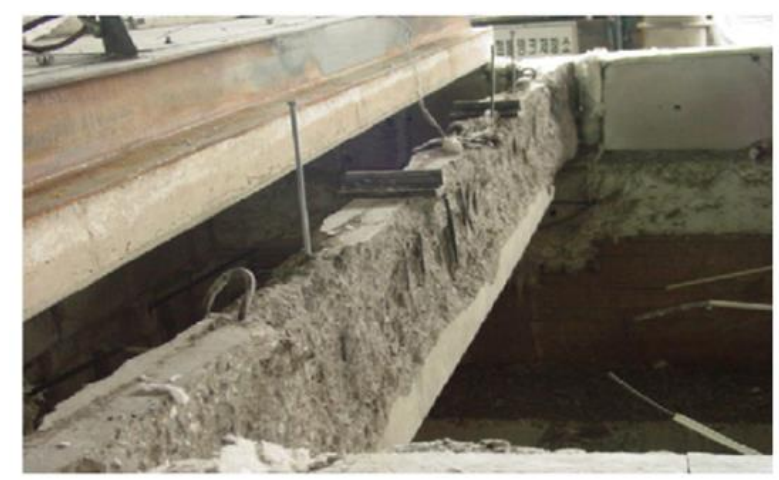

Figura 2.6 - Fenômeno de spalling em viga simplesmente apoiada constituída por concreto de alta resistência após ensaio de exposição a altas temperaturas (CHOI; SHIN, 2011).

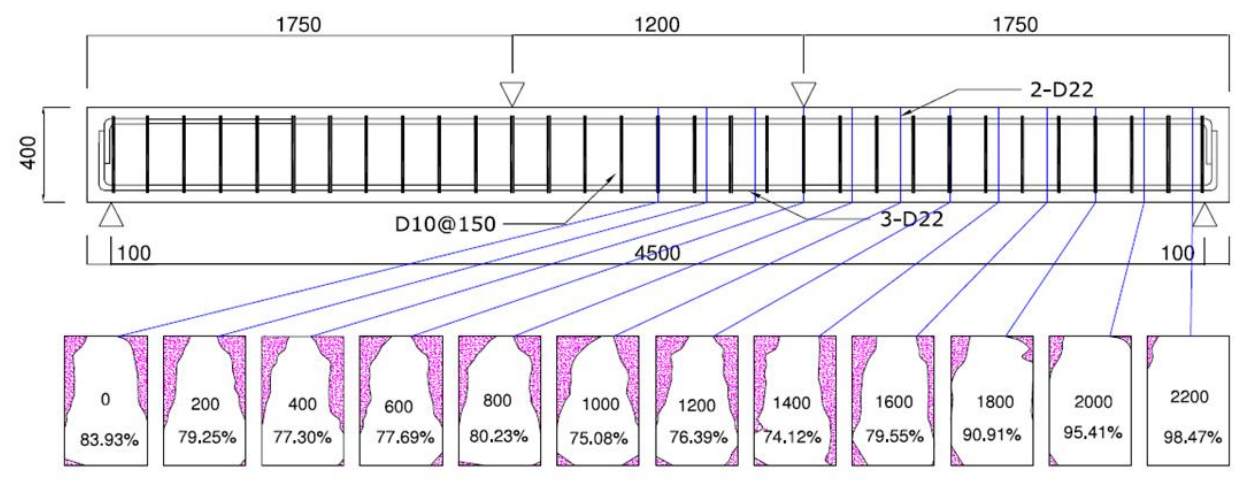

Figura 2.7 - Representação do spalling nas seções transversais de viga simplesmente apoiada constituída por concreto de alta resistência exposta ao fogo (CHOI; SHIN, 2011).

Também se verificou que as diferentes resistências do concreto não influenciaram de forma significativa os campos de temperaturas das vigas, uma vez que esses foram muito semelhantes para todas as peças ensaiadas, com exceção da parte superior das seções. Tal questão também está relacionada ao spalling, que ocorre de forma mais rápida e atinge camadas mais profundas nessa zona que se encontra extremamente solicitada por tensões de compressão, vide Figura 2.7. Os autores ainda pontuaram que as velocidades com que as flechas cresceram ao longo da exposição 
ao fogo foram muito similares para as vigas com concretos de resistências diferentes até o início do spalling, pois a partir do instante em que o fenômeno se tornou ativo, as flechas cresceram consideravelmente mais rápido nas vigas produzidas com concreto de alta resistência.

Por fim, Choi e Shin (2011) propuseram um modelo numérico simplificado, desenvolvido com base no método das diferenças finitas, para a análise térmica de vigas de concreto armado com a consideração dos efeitos do spalling. A partir da observação das seções transversais reduzidas dos ensaios, eles idealizaram apenas três tipos delas para que a modelagem se tornasse mais prática: primeiro uma seção original, i.e., não afetada pelo spalling; a segunda representativa de uma seção reduzida entre a primeira e a segunda manifestação do fenômeno; e a terceira uma seção reduzida após a segunda manifestação. Na Figura 2.8 essas seções estão ilustradas e na Figura 2.9 é possível constatar que aquelas traçadas numericamente apresentaram uma boa correlação às resultantes dos ensaios. Os campos de temperaturas numéricos e experimentais também apresentaram boa correlação. Em Choi; Shin e Kim (2013), os autores deram continuidade a essa pesquisa.

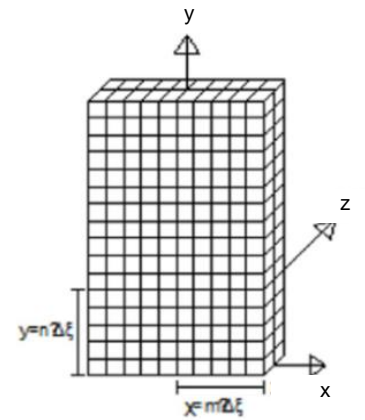

(a) $0<t<1^{a}$ manifestação de spalling

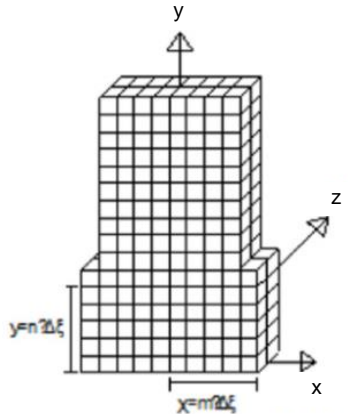

(b) $1^{\mathrm{a}}$ manifestação de spalling $<\mathrm{t}<2^{\mathrm{a}}$ manifestação de spalling

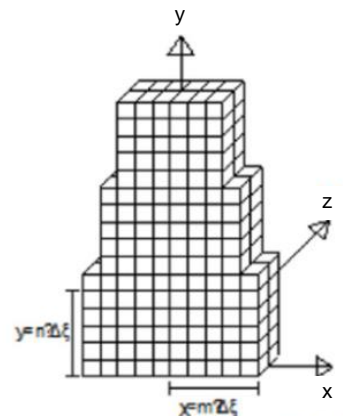

(c) $2^{\text {a }}$ manifestação de spalling $<$ t

Figura 2.8 - Seções adotadas no modelo numérico: (a) original; (b) entre a primeira e a segunda manifestação de spalling; (c) após a segunda manifestação (CHOI; SHIN, 2011; adaptado).
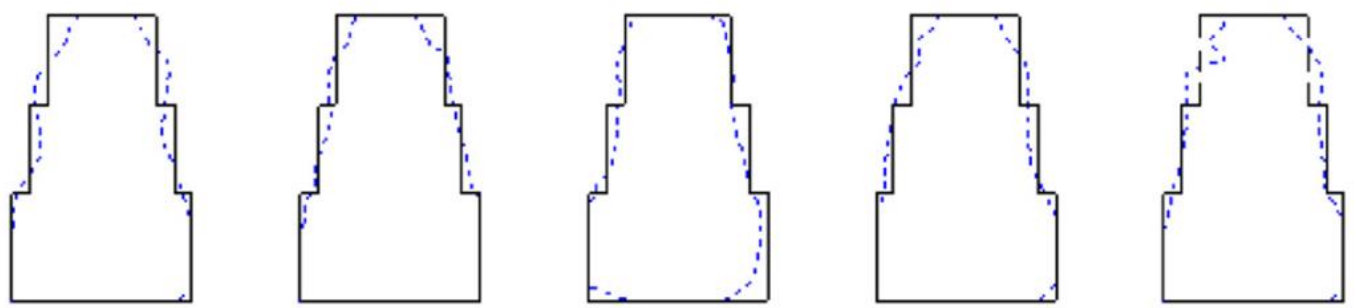

Figura 2.9 - Comparação das seções traçadas numericamente - linhas tracejadas - às obtidas nos ensaios de exposição ao fogo - linhas cheias - (CHOI; SHIN, 2011). 


\subsubsection{Estudos experimentais}

\subsection{Influência do cobrimento na resistência ao fogo}

Shi et al. (2004) também realizaram ensaios para analisar a influência dos cobrimentos das armaduras na resistência de vigas de concreto armado aquecidas, porém, ao contrário de Choi e Shin (2011), mencionados na seção prévia, todas foram produzidas com concreto de resistência convencional. Os autores efetuaram testes de exposição ao fogo em seis peças simplesmente apoiadas, com cobrimentos de 10 a 30 milímetros. Elas foram aquecidas em três faces (laterais e inferior) mediante um forno elétrico, nos quais as curvas de incêndio resultantes apresentaram temperaturas inferiores àquelas preconizadas pela ISO 834 (1999).

Dentre as vigas analisadas, testaram a primeira sob a atuação de duas forças concentradas apenas para obter a capacidade máxima à flexão em situação normal. Testaram a segunda, sem nenhum carregamento aplicado, para determinar a distribuição de temperaturas. As restantes foram testadas com o objetivo de avaliar, efetivamente, a influência do cobrimento da armadura no comportamento dessas peças. A Figura 2.10 ilustra características das vigas ensaiadas e o esquema estático adotado para as mesmas ao longo dos experimentos.

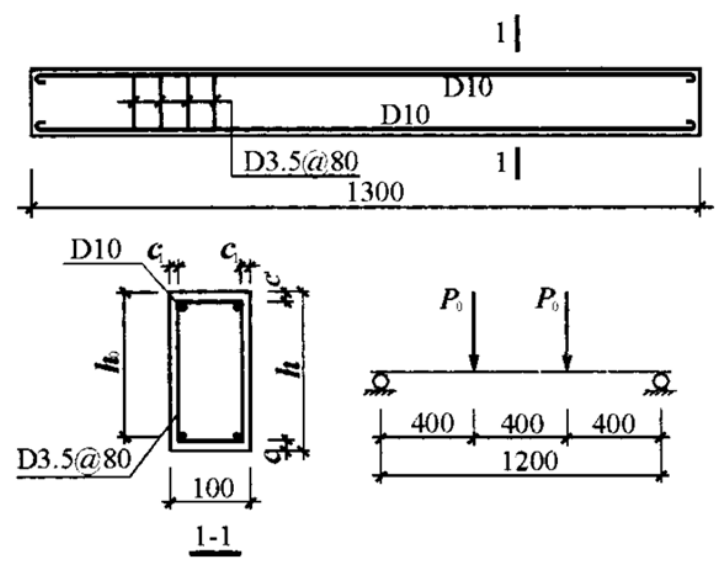

Figura 2.10 - Características das vigas ensaiadas ao fogo por Shi et al. (2004). 
$\mathrm{Na}$ análise dos resultados, Shi et al. (2004) observaram que apesar das seções transversais das vigas de concreto armado terem apresentado campos de temperaturas bastante desuniformes, houve uniformidade nos gradientes em sentido longitudinal, ou seja, os campos térmicos de diferentes seções localizadas ao longo dos vãos das vigas foram praticamente os mesmos (essas seções estão esquematizadas na Figura 2.11). Também verificaram que a espessura dos cobrimentos das armaduras inferiores praticamente não influenciou nas temperaturas das regiões superiores das seções transversais. Logo, as temperaturas de tais regiões dependem, sobretudo, do calor transferido através das faces laterais submetidas a aquecimento.

Da mesma forma que Choi e Shin (2011), os autores concluíram que o acréscimo do cobrimento contribui para a melhoria da resistência ao fogo das vigas produzidas com concreto convencional, porém, enfatizaram que deve haver um limite para esse aumento, não sendo prático adotar um valor excessivo. Ademais, a influência maior é exercida pelo cobrimento inferior, o lateral pouco afeta - desde que ele não seja menor do que o inferior -. Essas conclusões podem ser observadas por meio das curvas de flechas em função de temperaturas apresentadas na Figura 2.12.
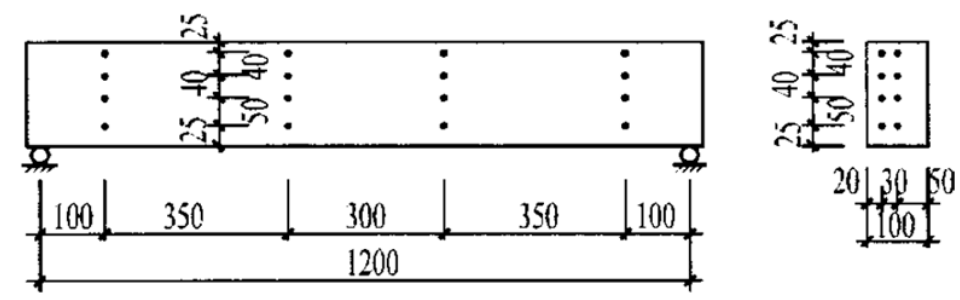

Figura 2.11 - Esquema das seções e pontos nos quais foram aferidas as temperaturas nas vigas (SHI et al., 2004).

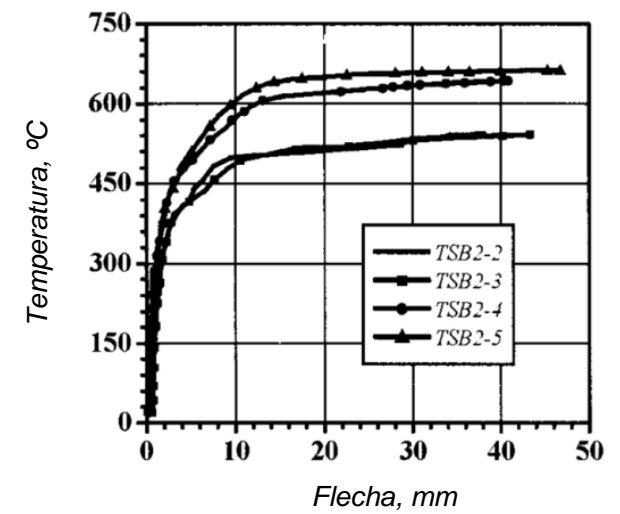

\begin{tabular}{cccccc}
\hline $\begin{array}{c}\text { Número } \\
\text { da } \\
\text { viga }\end{array}$ & $\begin{array}{c}\text { Largura da } \\
\text { seção } b \\
(\mathrm{~mm})\end{array}$ & $\begin{array}{c}\text { Altura da } \\
\text { seção } h \\
(\mathrm{~mm})\end{array}$ & $\begin{array}{c}\text { Cobrimento } \\
\text { superior } c^{\prime} \\
(\mathrm{mm})\end{array}$ & $\begin{array}{c}\text { Cobrimento } \\
\text { inferior } c \\
(\mathrm{~mm})\end{array}$ & $\begin{array}{c}\text { Cobrimento } \\
\text { lateral } c_{1} \\
(\mathrm{~mm})\end{array}$ \\
\hline TSB2-0 & 100 & 180 & 10 & 10 & 10 \\
TSB2-1 & 100 & 180 & 10 & 10 & 10 \\
TSB2-2 & 100 & 180 & 10 & 10 & 10 \\
TSB2-3 & 100 & 180 & 10 & 10 & 20 \\
TSB2-4 & 100 & 190 & 10 & 20 & 20 \\
TSB2-5 & 100 & 200 & 10 & 30 & 20 \\
\hline
\end{tabular}

Figura 2.12 - Relações temperatura vs flecha em vigas com diferentes cobrimentos (SHI et al., 2004; adaptado). 


\subsection{Análise da propagação de calor através de fissuras}

Ervine (2012) e Ba et al. (2016) investigaram de modo experimental se o calor propagado através das fissuras que se abrem nas zonas de tração das vigas de concreto armado exerce influência nos campos térmicos de suas seções transversais. Ervine (2012) conduziu ensaios de flexão a quatro pontos em determinadas vigas para que essas fossem submetidas a diferentes cenários de fissuração. Em seguida, a zona de tração das mesmas foi exposta a uma taxa de aquecimento constante, igual a $35 \mathrm{~kW} / \mathrm{m}^{2}$, durante uma hora. Por fim, o painel radiante utilizado para o aquecimento foi desligado, permitindo que as vigas arrefecessem naturalmente. Os campos térmicos de cada uma delas foram medidos por meio de termopares embutidos em seções ao longo dos vãos. O esquema do sistema adotado para as análises experimentais, bem como as características das vigas ensaiadas e do posicionamento dos termopares estão indicados na Figura 2.13.
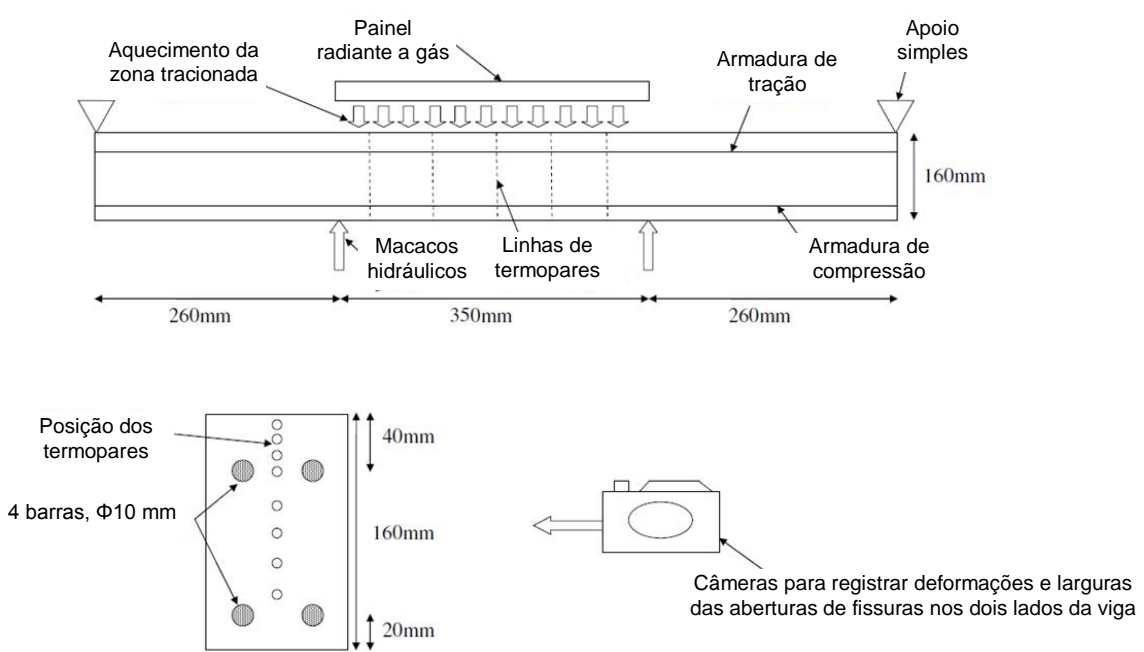

Figura 2.13 - Esquemas do sistema de ensaios e do posicionamento dos termopares na seção transversal das vigas ensaiadas por Ervine (2012; adaptado).

Na Figura 2.14, apresentam-se as comparações das temperaturas médias dos termopares das vigas sem fissuras (sem dano) àquelas submetidas ao que o autor denominou pequeno dano de fissuração, representativo de fissuras com aberturas médias de $1 \mathrm{~mm}$, e grande dano, com 
aberturas da ordem de $5 \pm 0,7 \mathrm{~mm}$. A partir delas, Ervine (2012) verificou que não houve aumento ou redução significativa da propagação de calor nas seções transversais fissuradas, considerando fissuras que chegaram a atingir até $10 \mathrm{~mm}$ nas faces aquecidas. Assim, o autor concluiu ser válida a hipótese de cálculo usualmente adotada nas análises numéricas de vigas de concreto armado aquecidas, em que as análises térmicas são realizadas antes e com resultados independentes das análises mecânicas, uma vez que ele não observou a necessidade de incorporar os efeitos das fissuras na determinação das temperaturas desses elementos.
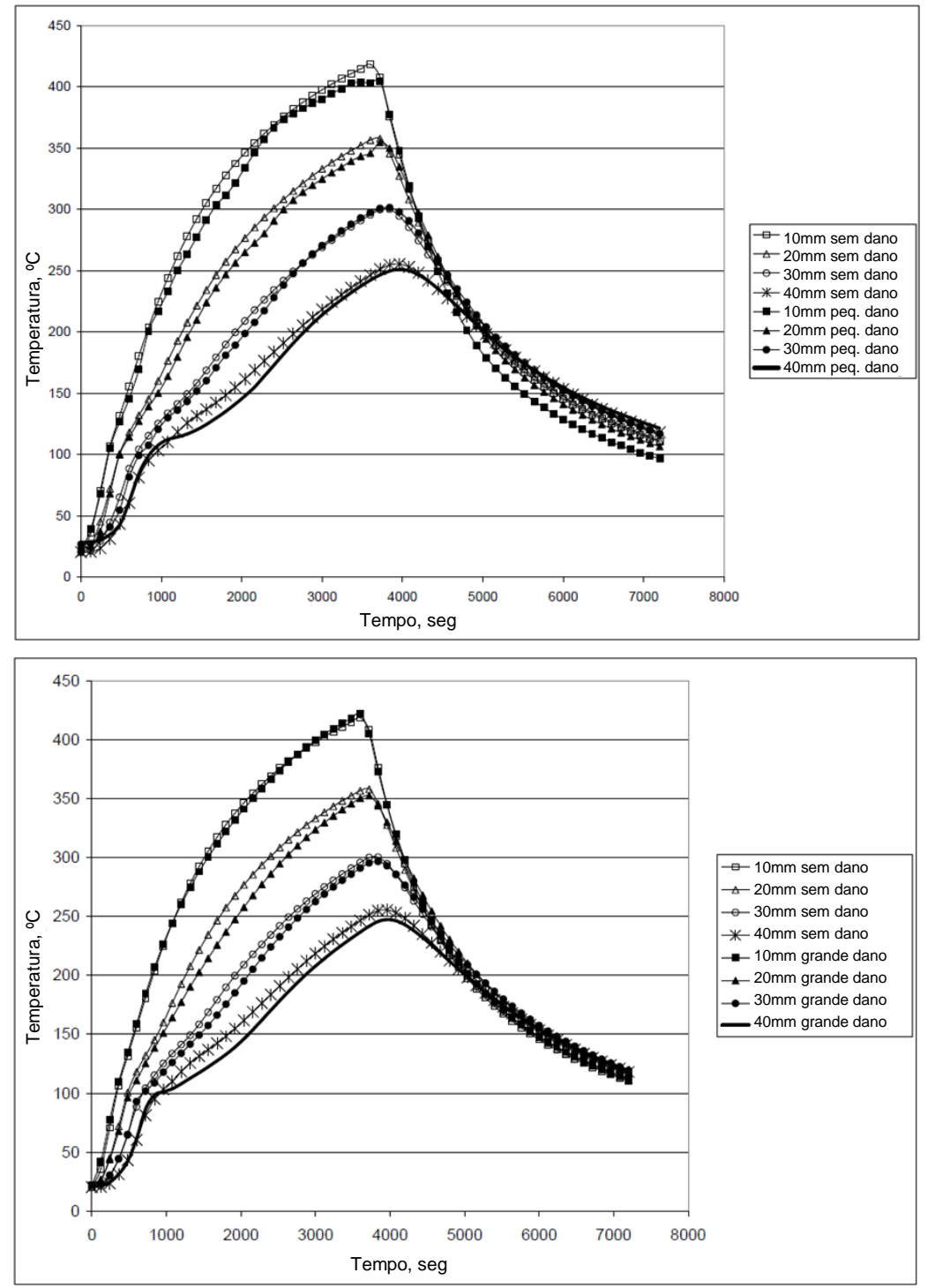

Figura 2.14 - Temperaturas médias aferidas a distâncias entre 10 e $40 \mathrm{~mm}$ da face aquecida de vigas não fissuradas e com pequeno e grande dano de fissuração, respectivamente (ERVINE; 2012; adaptado). 
Os ensaios realizados por Ba et al. (2016) foram similares ao de Ervine (2012), pois também aplicaram primeiramente diferentes forças nas vigas para que nelas fossem abertas fissuras de proporções distintas e, em seguida, realizaram os testes de exposição ao fogo (com pré-carga de abertura de fissuras mantida ao longo do aquecimento). Contudo, os ensaios foram de flexão a três pontos e o regime de aquecimento conforme a curva ISO 834 (1999) em três faces. O esquema do sistema de ensaios e as vigas adotadas, com o posicionamento dos termopares na seção transversal a meio vão, encontram-se ilustrados na Figura 2.15 e as fissuras resultantes em algumas das peças podem ser vistas na Figura 2.16.

A comparação das temperaturas obtidas em determinados pontos para as diferentes situações estão presentes na Figura 2.17. As denominações L1 a L7 são indicativas de vigas com aberturas de fissuras iniciais de 0,$05 ; 0,1 ; 0,15 ; 0,2 ; 0,25 ; 0,3$ e $0 \mathrm{~mm}$, respectivamente, enquanto o segundo número representa a posição do termopar analisado (5 ou 6).
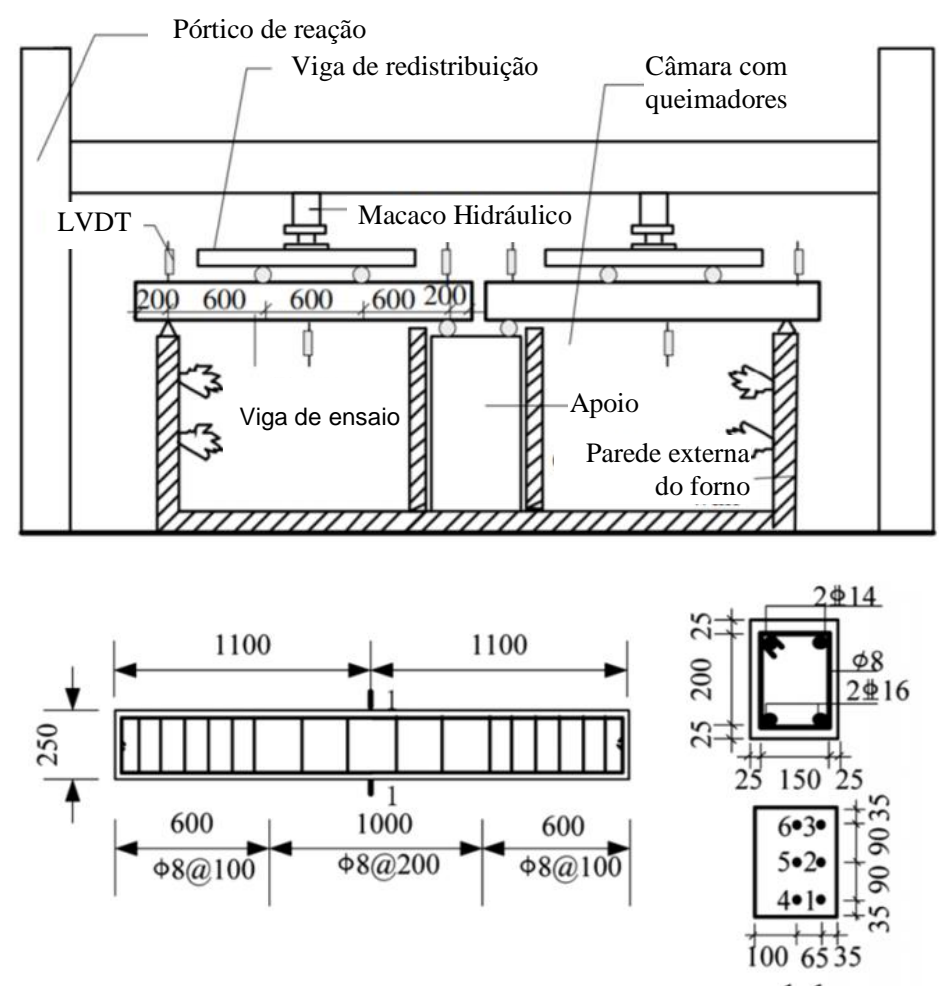

$1-1$

Figura 2.15 - Esquemas do sistema de ensaios e do posicionamento dos termopares na seção transversal das vigas ensaiadas por Ba et al. (2016; adaptado). 
L2
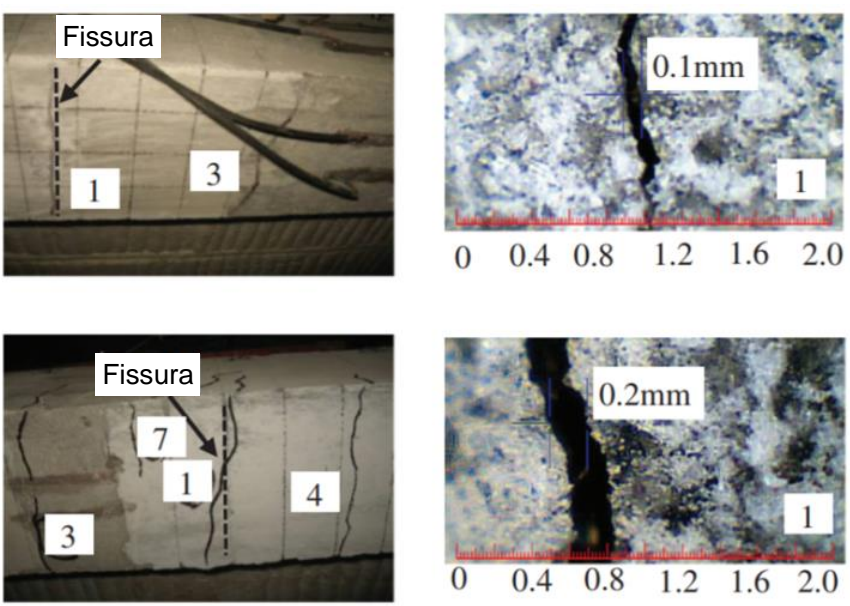

Figura 2.16 - Dimensões das aberturas de fissuras em vigas ensaiadas por Ba et al. (2016; adaptado).
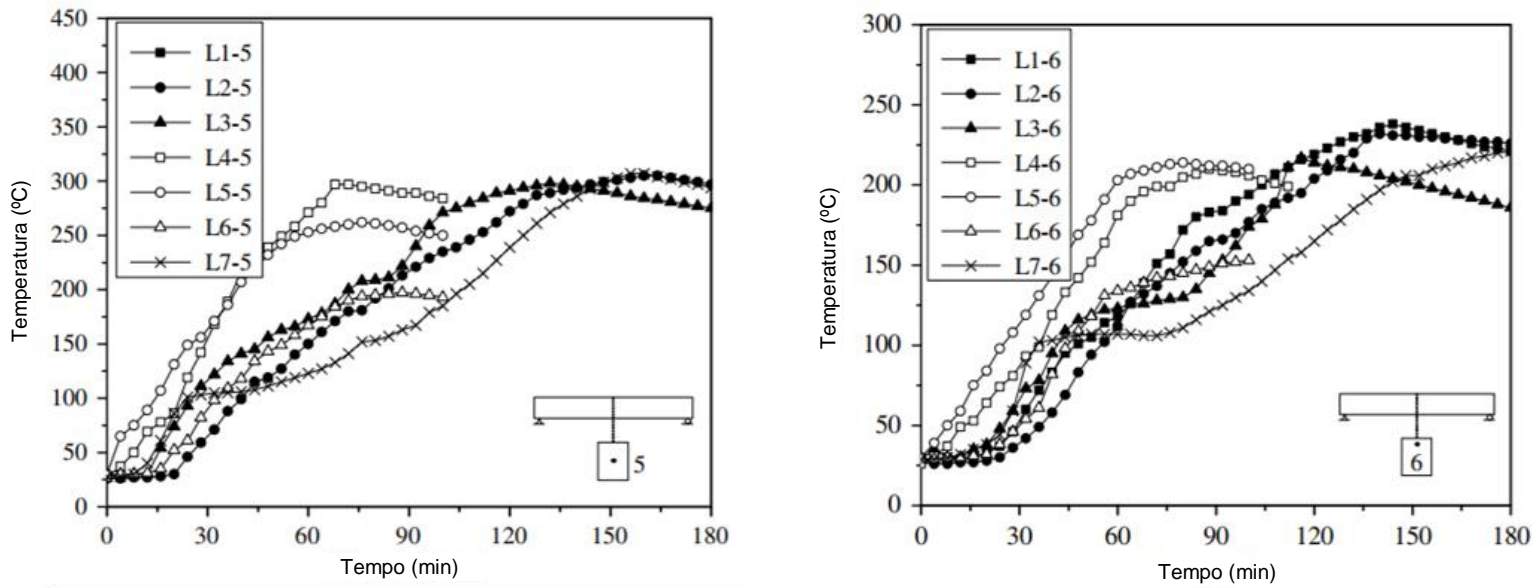

Figura 2.17 - Comparação das temperaturas aferidas nos termopares 5 e 6, respectivamente, em vigas com diferentes campos de fissuração (BA et al.; 2016; adaptado).

Ao contrário de Ervine (2012), Ba et al. (2016) observaram diferenças significativas nas temperaturas de vigas com diferentes campos de fissuras e um aumento na propagação de calor através dos concretos fissurados, colocando em prova a precisão do método adotado nas análises numéricas usuais, que havia sido defendido por Ervine (2012). Todavia, os próprios autores comentam que os estudos acerca desse tópico ainda são muito recentes, limitados e com conclusões contraditórias. Sendo assim, conclui-se que há a necessidade de mais pesquisas para que seja estabelecido um consenso sobre a influência das fissuras nos campos de temperaturas das vigas. 


\subsubsection{Estudos numéricos}

\subsection{Influência do cobrimento e das dimensões da seção transversal}

Enquanto Shi et al. (2004) e Choi e Shin (2011) analisaram de forma experimental a influência da espessura dos cobrimentos das barras de aço das armaduras na resistência ao fogo das vigas, Zha (2003) e Reddy et al. (2015) o fizeram por meio numérico. Esses autores também investigaram se as dimensões das seções transversais desses elementos exercem influência no desempenho dos mesmos quando em situação de incêndio.

No modelo numérico apresentado em Zha (2003), as análises térmicas foram efetuadas a partir do método simplificado de Hertz (HERTZ ${ }^{4}, 1981$ apud Zha, 2003) e as mecânicas por meio do DYNA3D (WHIRLEY; ENGELMANN, 1993), programa de computador que realiza análise não linear de estruturas expostas a temperaturas elevadas, em regime transiente, com a aplicação de elementos finitos tridimensionais. Esse modelo foi validado mediante a comparação dos resultados numéricos de momentos fletores resistentes obtidos para diferentes tempos de exposição ao fogo de uma viga simplesmente apoiada, com seção retangular e submetida a duas forças concentradas, aos resultados calculados com base nas prescrições de duas normas: BS 8110 parte 2 e Eurocode 2 parte 1-2 (as versões não foram especificadas pelo autor).

Para estudar os cobrimentos das armaduras e as dimensões das seções transversais, Zha (2003) modelou uma viga simplesmente apoiada, também com seção retangular, mas submetida à flexão simples, vide Figura 2.18. A peça foi exposta ao fogo em três faces. Igualmente a Shi et al. (2004) e Choi e Shin (2011), ele verificou um acréscimo no tempo de

\footnotetext{
${ }^{4}$ HERTZ, K. Sample temperature calculations of fire exposed concrete constructions. Lyngby: Technical University of Denmark, 1981. 53 p. (Institute of Building Design, Report n. 159).
} 
resistência ao fogo das vigas quando adotados cobrimentos mais espessos, uma vez que o aumento dos deslocamentos verticais das mesmas em função do tempo foi mais brando nesse caso (Figura 2.19-a). Ao analisar essa mesma relação para vigas com seções transversais de diferentes tamanhos, verificou que os deslocamentos verticais foram consideravelmente menores nas vigas com maiores dimensões (Figura 2.19-b). Assim, concluiu que o aumento das dimensões da seção transversal de uma viga de concreto armado contribui para o seu melhor desempenho frente à ação do fogo.

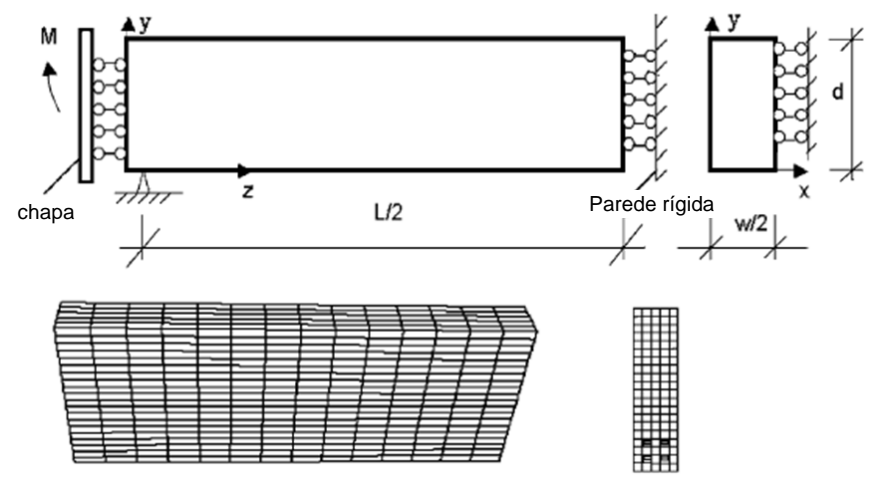

Figura 2.18 - Viga simplesmente apoiada submetida à flexão simples adotada para o estudo da influência do cobrimento e das dimensões das seções transversais na resistência ao fogo (ZHA, 2003; adaptado).
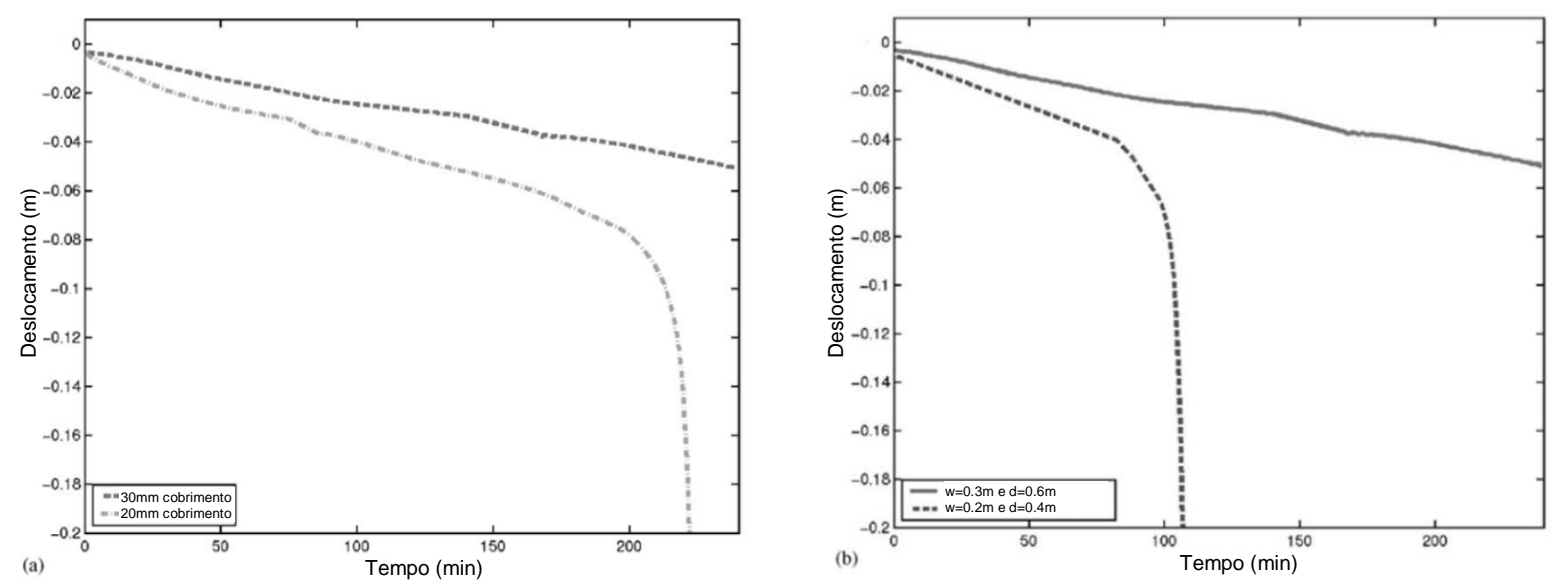

Figura 2.19 - Deslocamentos verticais das vigas em função do tempo de exposição ao fogo para (a) diferentes cobrimentos de armaduras e (b) tamanhos de seções transversais (ZHA, 2003; adaptado).

Reddy et al. (2015) realizaram o estudo desses parâmetros por intermédio do modelo computacional desenvolvido por Liu (2009), que conduz análises termestruturais com base no método das diferenças finitas e no cálculo das relações momento-curvatura das vigas para 
diferentes tempos de exposição ao fogo. Os autores modelaram vigas simplesmente apoiadas, com seções retangulares e aquecidas em três faces, e determinaram as resistências ao fogo das mesmas considerando os dois critérios de ruptura indicados pela ASTM E119 (versão de 1995): (1) carregamento solicitante da viga para a situação de incêndio excede o resistente; (2) temperatura da armadura inferior excede o valor crítico de $593{ }^{\circ} \mathrm{C}$. Na Figura 2.20, mostra-se a influência de diferentes larguras de seções transversais e cobrimentos das armaduras nas resistências determinadas à luz desses dois princípios.

Eles verificaram que ao se considerar o critério de ruptura que tem base na temperatura crítica do aço (critério 2, Figura 2.20-a), o aumento da largura da seção transversal pouco influencia no tempo de resistência ao fogo das vigas. Ao se considerar o critério de ruptura devido à perda de resistência da peça (critério 1, Figura 2.20-b), aumentar a largura da seção melhora de forma um pouco mais expressiva o desempenho ao fogo. Logo, ao final do trabalho, Reddy et al. (2015) apresentaram a mesma conclusão geral de Zha (2003) - vigas com seções transversais maiores apresentaram maiores tempos de resistência ao fogo -, mas, ao contrário do autor anteriormente citado, não ressaltaram que esse aumento fora significativo. Ainda a partir desses gráficos, é possível observar o já comentado ganho de resistência a partir do aumento da espessura dos cobrimentos.

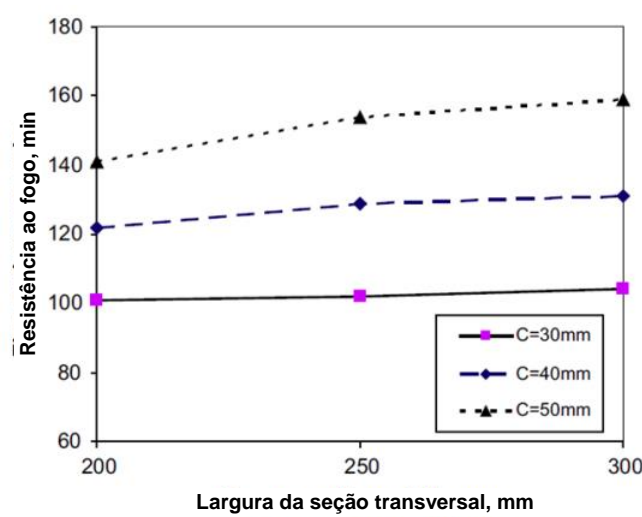

(a)

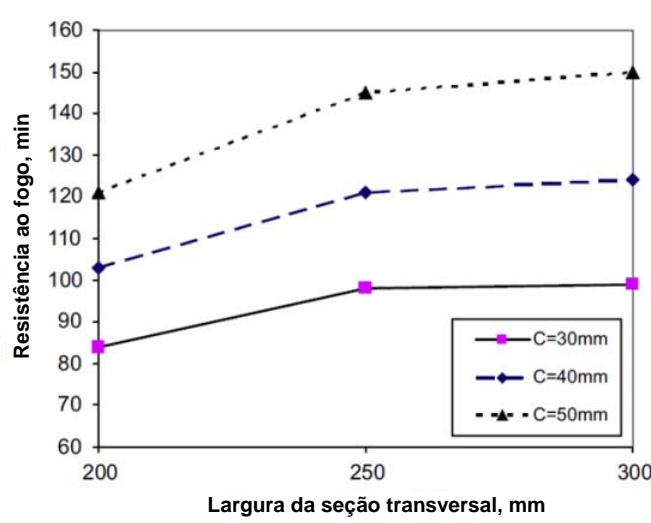

(b)

Figura 2.20 - Efeitos de diferentes larguras de seções e cobrimentos de armaduras nas resistências ao fogo de vigas calculadas pelos critérios de ruptura devido (a) à temperatura crítica do aço e (b) à perda de capacidade resistente (REDDY et al., 2015; adaptado). 


\subsection{Efeitos da evaporação da água nos campos térmicos}

Bratina e coautores (BRATINA et al., 2003; BRATINA; SAJE; PLANINC, 2007) verificaram parâmetros importantes que devem ser admitidos e outros que podem ser desconsiderados em modelos numéricos para a análise não linear de vigas de concreto armado em situação de incêndio. Em Bratina et al. (2003), apresentaram um modelo em que a determinação do campo de temperaturas nas seções transversais foi realizada via método dos elementos finitos, aplicando o programa de computador desenvolvido por Saje e Turk ${ }^{5}$ (1987) apud Bratina et al. (2003). O mesmo método foi utilizado para a análise mecânica e, segundo os autores, a nova proposta de elementos finitos, baseada na teoria de Reissner (1972) e adaptada de Planinc; Saje e Cas (2001), mostrou-se essencial para a precisão dos resultados obtidos nessa etapa. A fim de validar o modelo proposto, compararam os resultados numéricos aos experimentais obtidos por Gustaferro; Abrams e Salse ${ }^{6}$ (1971) apud Bratina et al. (2003), que realizaram um teste de exposição ao fogo, modelado conforme a curva-padrão ASTM E119, numa viga simplesmente apoiada com seção transversal $\mathrm{T}$ e submetida a um carregamento uniformemente distribuído (Figura 2.21).
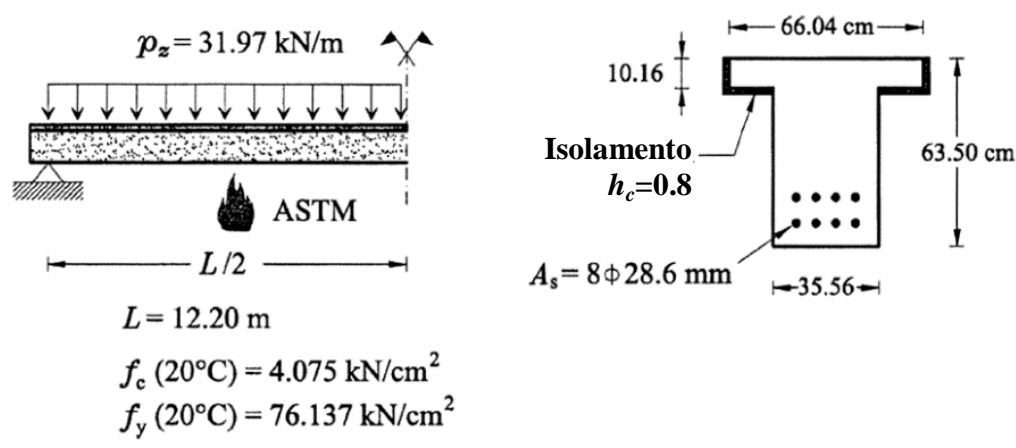

Figura 2.21 - Viga ensaiada por Gustaferro; Abrams e Salse (1971) e adotada por Bratina et al. (2003) para validação de modelo numérico (adaptado).

\footnotetext{
${ }^{5}$ SAJE, M.; TURK, G. HEATC. Computer programme for nonlinear transient heat conduction problems. Ljubljana: University of Ljubljana, 1987.

${ }^{6}$ GUSTAFERRO, A. H.; ABRAMS, M. S.; SALSE, E. A. B. Fire-resistance of prestressed concrete beams, study C: structural behaviour during fire tests. Skokie: Portland Cement Association, 1971. 28 p. (Research and Development Bulletin RD009.01B).
} 
Ao compararem as temperaturas obtidas de forma numérica e experimental para duas barras das armaduras, observaram valores consideravelmente díspares aos $100{ }^{\circ} \mathrm{C}$, vide Figura 2.22. Os resultados dos ensaios mostraram que ocorreu um atraso na curva de desenvolvimento das temperaturas e os autores justificaram que esse atraso estava relacionado à água que ainda deveria estar presente nas vigas. Apenas quando a água atingiu $100{ }^{\circ} \mathrm{C}$ se iniciou o seu processo de evaporação e não sendo possível que o vapor produzido ao longo desse processo escapasse imediatamente para fora do elemento, tal fenômeno acabou por retardar o aumento das temperaturas da própria estrutura de concreto armado.

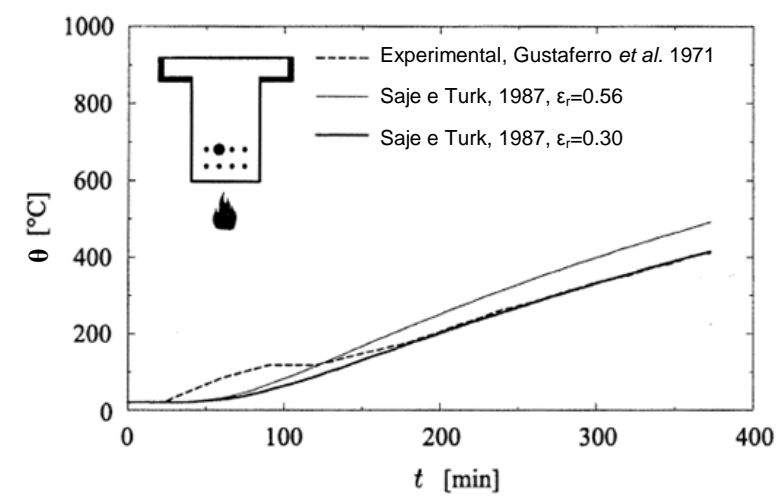

(a) Armadura menos exposta

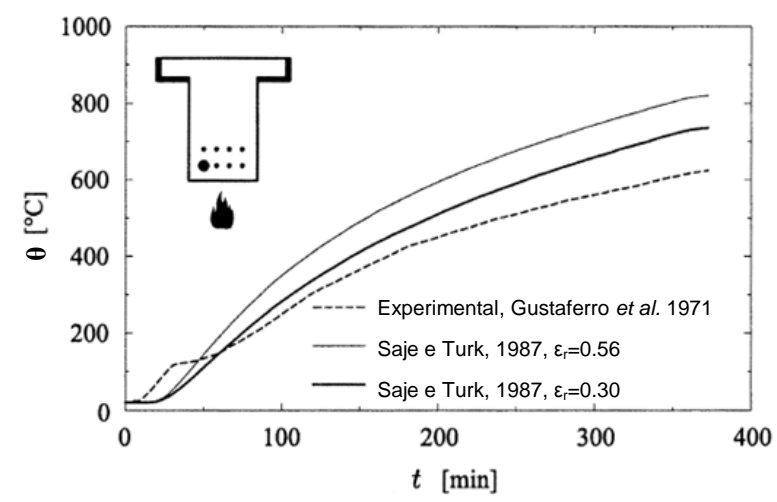

(b) Armadura mais exposta

Figura 2.22 - Comparação de temperaturas numéricas e experimentais das barras de aço das armaduras menos e mais expostas ao fogo, respectivamente (BRATINA et al.; 2003; adaptado).

O modelo numérico adotado por Bratina et al. (2003) não levava em conta os efeitos físicos da evaporação da água, por isso os resultados não conseguiram acompanhar esse trecho das curvas. Haja vista que análises mecânicas com resultados precisos estão intimamente ligadas a 
análises térmicas precisas, e considerando que os efeitos do calor latente de vaporização da água e transporte de vapor são marcantes nos campos térmicos de elementos de concreto, Bratina et al. (2003) concluíram a relevância de pesquisas que tratem de vincular análises de difusão de vapor a análises térmicas usuais.

É interessante citar que existe uma área de pesquisa totalmente voltada a esse tema. Segundo Burgh, Valipour e Foster (2013), foram Bažant e Thonguthai (1979) que desenvolveram o primeiro modelo numérico para análises hidrotérmicas de elementos estruturais de concreto [os elementos adotados como base para o estudo foram as paredes]. Nesse tipo de análise, as temperaturas são calculadas considerando que o concreto se comporta como um material poroso parcialmente saturado quando aquecido.

À luz do referido modelo, surgiram os "thermo-hydro-mechanical models - THM", considerados os mais avançados desse segmento, pelo fato de acoplarem as análises hidrotérmicas às mecânicas. Ainda de acordo com Burgh, Valipour e Foster (2013), o pesquisador Dariusz Gawin, da Universidade Técnica de Lodz - Polônia, concebeu junto de seus coautores um dos modelos THM mais difundidos entre os pesquisadores dessa área (GAWIN; MAJORANA; SCHREFLER, 1999 e GAWIN; PESAVENTO; SCHREFLER, 2011a, 2011b). O mesmo tem sido submetido a testes e aperfeiçoado há mais de quinze anos e ficou conhecido como "modelo de Pádua", pois foi desenvolvido na Universidade de Pádua Itália.

Elucida-se que Burgh, Valipour e Foster (2013) apresentaram um modelo numérico para análises hidrotérmicas do concreto, bem como Dwaikat e Kodur (2009a) e Cramer, Ostermann e Dinkler (2010). Já Capua e Mari (2007) e Davie, Pearce e Bicanic (2010) apresentaram modelos hidrotermomecânicos em artigos publicados em revistas, enquanto Kukla (2010) e Al Fadul (2017) o fizeram em Teses de Doutorado. Dentre os trabalhos encontrados, Capua e Mari (2007) e Al Fadul (2017) foram aqueles a aplicar os modelos concebidos em vigas de concreto armado simplesmente apoiadas. 


\subsection{Consideração da fluência dos materiais}

Bratina et al. (2003) também compararam as flechas das vigas obtidas a partir do programa, ora considerando o efeito da fluência do aço por intermédio de um modelo explícito apresentado em Williams-Leir (1983) para duas categorias diferentes do material e ora desconsiderando tal parâmetro. Na curva A do gráfico da Figura 2.23, a fluência do aço não foi admitida e a distribuição de temperaturas adotada para a viga foi a resultante da análise térmica efetuada numericamente. Todavia, para a obtenção de resultados mais precisos na análise mecânica, os autores admitiram as temperaturas nas armaduras iguais àquelas aferidas no ensaio para os demais casos de estudo (curvas B, C e D). A fluência do aço também foi desconsiderada na curva B. Já na curva $C$, eles inseriram parâmetros de baixa fluência, característicos do aço designado Au 50, enquanto na curva D os parâmetros foram de média fluência, tomados com base no aço X-60. Com base no gráfico mencionado, observaram a importância da consideração da fluência porque, caso contrário, os deslocamentos verticais das vigas simplesmente apoiadas serão subestimados, conforme indicam as curvas A e B.

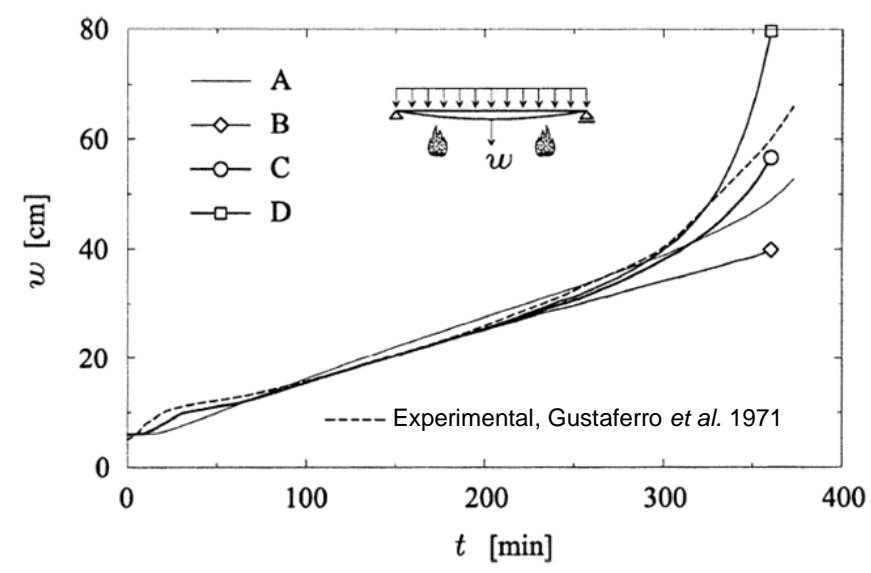

Figura 2.23 - Comparação de flechas numéricas e experimentais para estudo da fluência do aço realizado por Bratina et al. (2003; adaptado). 
Posteriormente, em Bratina; Saje e Planinc (2007), eles aperfeiçoaram o modelo numérico desenvolvido em Bratina et al. (2003). Além de já admitirem o modelo explícito de WilliamsLeir (1983) para a fluência do aço exposto a altas temperaturas, também congregaram o modelo explícito de Harmathy (1993) para o estudo da fluência do concreto, curvas de incêndio que possuíam fase de resfriamento e análises capazes de quantificar as contribuições das diferentes parcelas de deformação dos materiais na deformação total das vigas. Com o objetivo de validar essa ferramenta, confrontaram os seus resultados aos experimentais obtidos por Lin; Ellingwood e Piet (1988).

Conforme será discutido na próxima seção, esses autores ensaiaram vigas simplesmente apoiadas com um vão extremo em balanço e a configuração de forças aplicadas ao longo dos ensaios acabava por fazer essas peças serem características de vãos extremos de vigas contínuas. As mesmas foram submetidas a dois tipos de curvas de aquecimento: ASTM E119 (versão de 1976) e outra que admitia fase de resfriamento. Apesar disso, Bratina; Saje e Planinc (2007) se referiram a elas ao longo de todo o texto como vigas simplesmente apoiadas e, inclusive, como poderá ser visto logo a seguir, tomaram as suas conclusões apenas em relação a tal modelo estático. Por isso, essa pesquisa foi inserida na presente seção.

Ao compararem as flechas dessas vigas, para os dois casos de aquecimento, os autores concluíram que a fluência do concreto não interfere na resistência ao fogo de vigas simplesmente apoiadas. Também verificaram novamente que a consideração da fluência do aço acelera o colapso de vigas isostáticas expostas a curvas de incêndio-padrão, vide conclusão de Bratina et al. (2003), entretanto, concluíram que a relevância desse parâmetro é menor em vigas expostas a curvas com fase de resfriamento, por conta das temperaturas relativamente baixas das armaduras - por volta dos $400{ }^{\circ} \mathrm{C}-$. Segundo Williams-Leir (1983), a deformação por fluência do aço só começa a ser preponderante quando tal temperatura é atingida. A Figura 2.24 ilustra os diferentes parâmetros que podem ser obtidos mediante a aplicação do modelo desenvolvido por Bratina; Saje e Planinc (2007). 
(a) campo de temperaturas

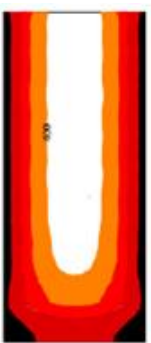

(d) deformações elásticas

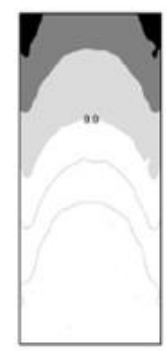

$D_{\sigma, c}[\%]$

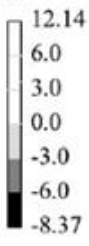

(g) deformações pela fluência no concreto

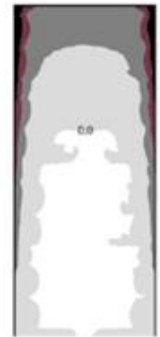

(b) deformações térmicas

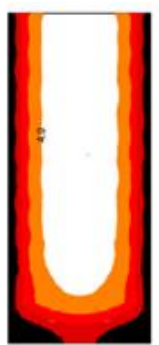

(e) deformações plásticas

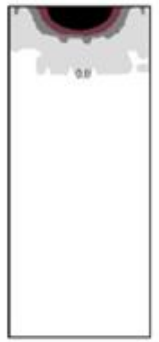

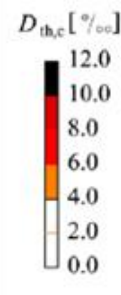

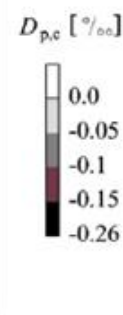

(c) deformações totais

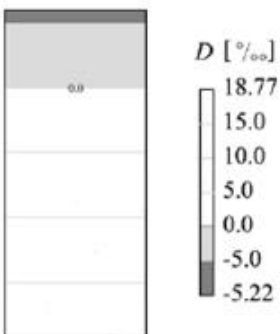

(f) tensões no concreto

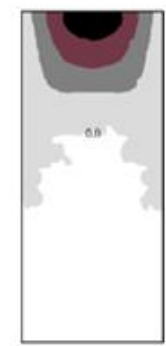

$\sigma_{\mathrm{e}}\left[\mathrm{kN} / \mathrm{cm}^{2}\right]$

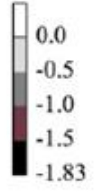

(h) deformações transientes no concreto

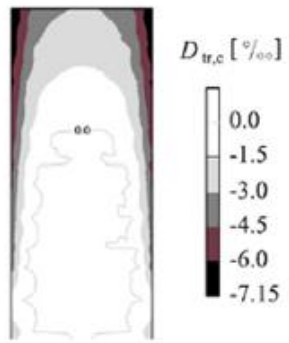

Figura 2.24 - Parâmetros obtidos ao longo da análise de viga simplesmente apoiada exposta à curva ASTM E119: (a) campo de temperaturas, (b) deformações térmicas, (c) deformações totais - geometric -, (d) deformações elásticas - mechanical -, (e) deformações plásticas, (f) tensões de compressão no concreto, (g) deformações devido à fluência e (h) deformações transientes (BRATINA; SAJE; PLANINC, 2007; adaptado).

No mesmo segmento de Bratina; Saje e Planinc (2007), Lu et al. (2015a) estudaram os efeitos da fluência do concreto a altas temperaturas no comportamento das vigas. Os autores fizeram uso do modelo numérico apresentado em Lu et al. (2015b), que tem base no método dos elementos finitos, para avaliar dois modos de consideração da fluência: o modelo do concreto (diagrama tensão vs deformação) proposto no Eurocode 2 parte 1-2 (2004), que admite a fluência do material de forma implícita, e o modelo explícito apresentado em Tao et al. (2012) e Tao; Yuan e Taerwe (2010, 2012). 
A primeira etapa para essa pesquisa consistiu na validação do modelo numérico, porém, houve uma particularidade, pois a mesma foi realizada mediante resultados experimentais provenientes de lajes simplesmente apoiadas, testadas por Minne e Vandamme ${ }^{7}$ (1979) apud Lu et al. (2015a). Em seguida, os autores modelaram vigas simplesmente apoiadas com seções retangulares de diferentes geometrias e taxas de armaduras e ainda submetidas a regimes de aquecimento variados (curva ISO 834 e curvas paramétricas do Eurocode 2 parte 1-2, que possuem fase de resfriamento, vide Figura 2.25). O foco principal da pesquisa consistia em analisar o quanto cada uma dessas variáveis influenciaria nos dois tipos de modelos adotados para a fluência do concreto.

Lu et al. (2015a) concluíram que as flechas de vigas simplesmente apoiadas resultantes de modelos implícitos e explícitos de fluência do concreto são similares independentemente do regime de aquecimento, conforme ilustra a Figura 2.26. Essa conclusão está em conformidade a Bratina; Saje e Planinc (2007), que ao estudarem outro modelo explícito, também verificaram que a fluência do concreto não é primordial para aferir a resistência ao fogo desses elementos. Na Figura 2.26, "M1" indica modelo implícito, "M2" explícito, "2hrs" caracteriza uma exposição de duas horas a incêndio-padrão, "60min" e "30min" caracterizam exposições a incêndios paramétricos com temperaturas crescentes até 60 e 30 min, respectivamente, seguidas das fases de resfriamento.

Os autores também verificaram que o aumento da taxa de armadura reduz os efeitos da fluência do concreto na resistência ao fogo das vigas; a largura da seção transversal não interfere nas flechas calculadas com os dois modelos de fluência, enquanto a altura as afeta moderadamente. Ao contrário de Bratina; Saje e Planinc (2007), que adotaram um modelo explícito para considerar a fluência do aço, Lu et al. (2015a) consideraram em todas as suas análises o modelo do Eurocode 2 parte 1-2 (2004), que a admite de forma implícita.

\footnotetext{
${ }^{7}$ MINNE, R.; VANDAMME, M. Fire resistance of reinforced concrete slabs. Ghent: Laboratory for Fuel Technology and Heat Transfer, Ghent University, 1979.
} 


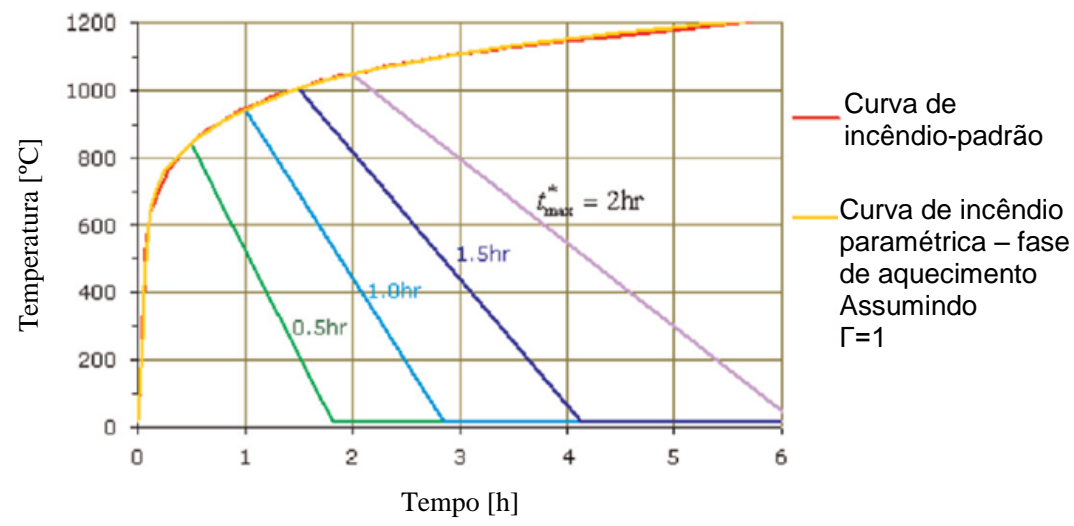

Figura 2.25 - Curvas de incêndio-padrão e paramétricas adotadas para análise de modelos implícitos e explícitos de fluência do concreto (LU et al.; 2015a; adaptado).

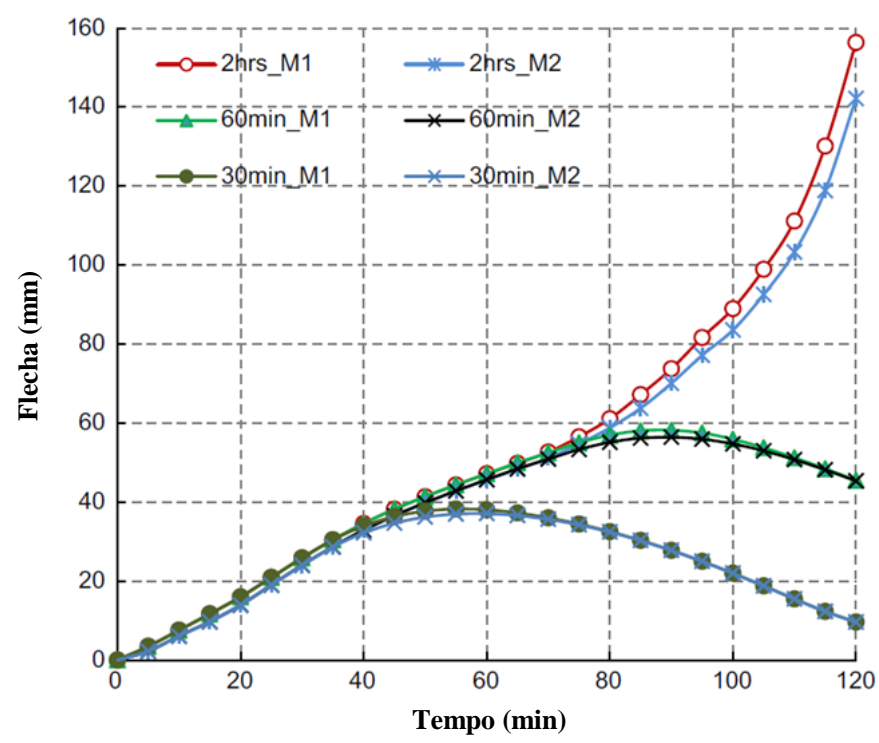

Figura 2.26 - Comparação de flechas obtidas pela consideração de diferentes modelos aquecimento e de fluência do concreto (LU et al.; 2015a; adaptado).

À luz dos trabalhos realizados por Poh e Bennetts (1995) e Lie e Irwin (1993), mais voltados para pilares, Kang e Hong (2004) apresentaram um modelo numérico para a análise de membros horizontais de concreto armado sob flexão em situação de incêndio e também adotaram um modelo explícito para a consideração da fluência do concreto a altas temperaturas. O modelo escolhido foi o proposto em Dias; Khoury e Sullivan (1987, 1990), que tem base no teorema de Dorn e aplica as relações de Arrenius para determinar a fluência do material em função do aumento de temperaturas. No entanto, o foco da pesquisa consistiu 
na apresentação dessa nova metodologia para a análise não linear das vigas e aspectos acerca da consideração de tal modelo de fluência não foram discutidos. As conclusões do trabalho foram apenas relacionadas à análise da precisão do método numérico proposto.

O método de Kang e Hong (2004) se dividiu em duas etapas de cálculo: análise da seção e solução do membro. Na primeira, os autores aplicaram o esquema de segmentação. Em cada uma dessas seções segmentadas, determinaram a distribuição de temperaturas, via método dos elementos finitos, e as deformações. Com base na teoria de Bernoulli-Navier para o cálculo de vigas, definiram as deformações devido às cargas aplicadas e, para a obtenção das deformações térmicas, assumiram deformações virtuais, a fim de que fossem satisfeitas as condições de equilíbrio. Para a obtenção do comportamento estrutural de todo o membro, aplicaram novamente a teoria de Bernoulli-Navier integrando ao longo do eixo longitudinal as curvaturas, também calculadas durante a análise da seção. Validaram o modelo por intermédio da comparação aos resultados experimentais provenientes da análise de uma viga simplesmente apoiada, obtidos por Lin; Gustaferro e Abrams (1981).

\subsection{Perda de aderência concreto-aço}

Enquanto as pesquisas de Bratina et al. (2003), Bratina; Saje e Planinc (2007) e Lu et al. (2015a) verificaram o comportamento ao fogo de vigas de concreto armado ao serem admitidos os efeitos da fluência dos materiais em função de altas temperaturas, Gao et al. (2013) e Kodur e Agrawal (2017) apresentaram estudos acerca da consideração da perda de aderência entre o concreto e o aço das armaduras nos modelos numéricos para a análise desses elementos. Segundo Gao et al. (2013), ao passo que as vigas são expostas ao sinistro, os materiais sofrem perdas significativas de resistência e de rigidez e o mesmo ocorre na ligação/aderência existente entre eles. Os autores ainda esclareceram que esse fenômeno só havia sido objeto de estudo, até então, em um modelo numérico sugerido por Huang (2010), 
enquanto nos demais era usual se admitir que as armaduras permaneciam perfeitamente ligadas ao concreto que as circundava ao longo da exposição a temperaturas elevadas.

Gao et al. (2013) propuseram um modelo numérico de elementos finitos tridimensionais, desenvolvido com o auxílio do programa de computador Abaqus (ABAQUS, 2008), e consideraram a perda de aderência nas análises ao incorporarem valores reduzidos de resistências de aderência no modelo de bond-slip à temperatura ambiente proposto no Model Code CEB-FIP 90 (1993). Essa hipótese foi adotada pelo fato de não terem sido encontradas relações já estabelecidas para caracterizar a deterioração da aderência em função do aumento de temperatura. As resistências de aderência à temperatura ambiente foram reduzidas com base em um limite superior e um inferior, traçados na tentativa de utilizar os resultados obtidos em uma pequena quantidade de ensaios de arrancamento a altas temperaturas encontrada na literatura estrangeira (pull-out tests), conforme ilustra Figura 2.27.

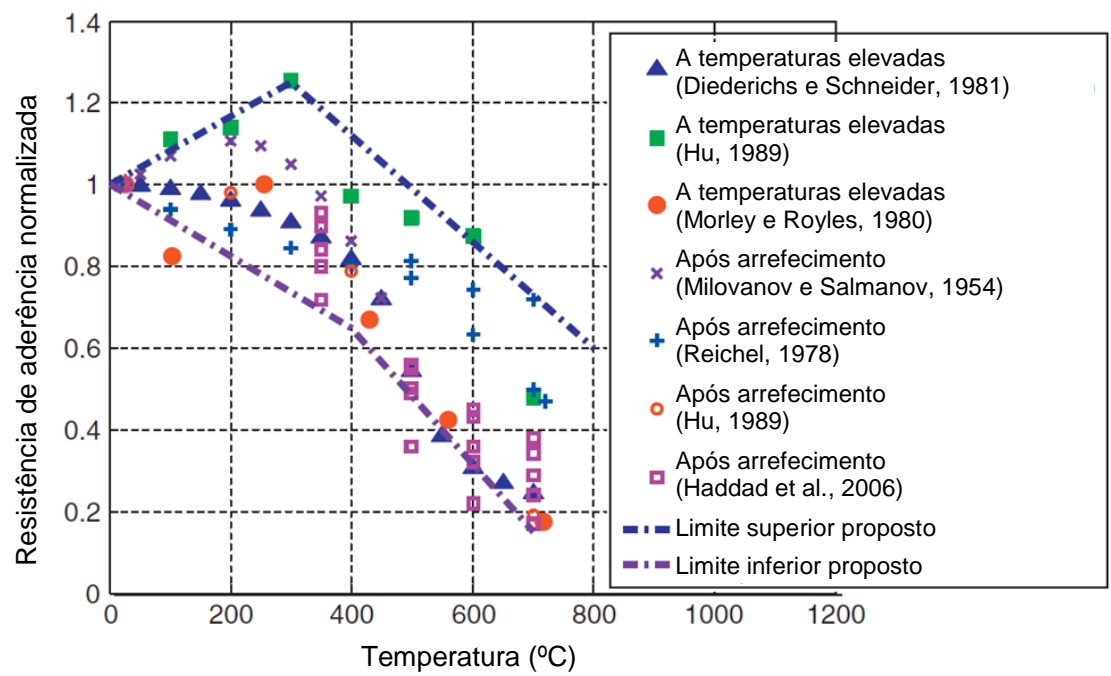

Figura 2.27 - Fatores de redução de resistências de aderência encontrados na literatura com representação dos limites superior e inferior propostos por Gao et al. (2013; adaptado).

Com o propósito de validar o modelo numérico e estudar a aderência, Gao et al. (2013) simularam o comportamento de três vigas simplesmente apoiadas que foram submetidas a 
análises experimentais por $\mathrm{Wu}$; Lie e $\mathrm{Hu}^{8}$ (1993) apud Gao et al. (2013), Lin; Gustaferro e Abrams (1981) e Dotreppe e Franssen (1985). Na Figura 2.28, ilustra-se o esquema apenas das vigas ensaiada por Wu; Lie e Hu (1993), já que as características das demais são apresentadas em outros trechos ao longo deste capítulo. O modelo de aderência discutido anteriormente foi implementado no programa por meio de elementos de mola incorporados nas interfaces entre os materiais e as vigas foram submetidas a aquecimentos condizentes às curvas de incêndio adotadas nos ensaios (ISO 834 e ASTM E119).
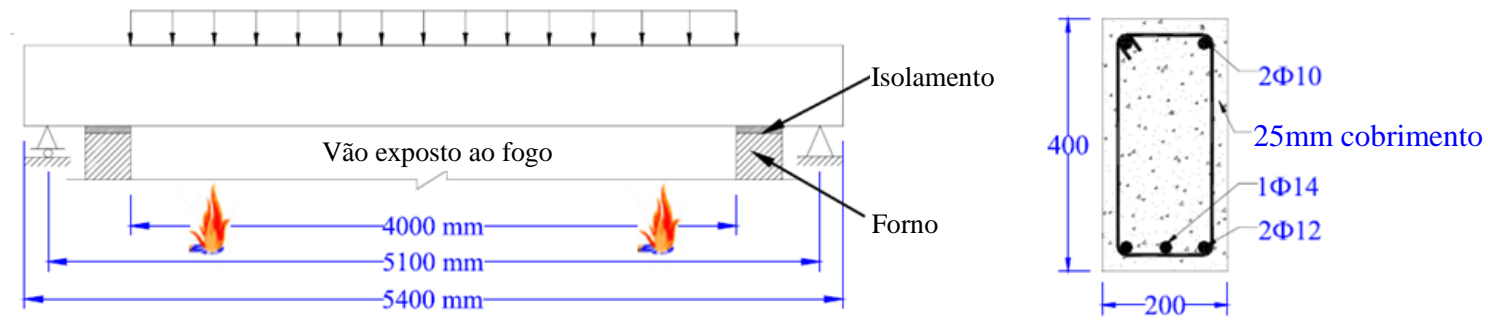

Figura 2.28 - Viga submetida a teste de exposição ao fogo por Wu; Lie e Hu (1993) (GAO et al., 2013; adaptado).

Ao compararem as flechas numéricas às experimentais, os autores verificaram, para os três casos, que os resultados mais próximos aos dos ensaios foram aqueles nos quais se consideraram os efeitos de aderência não perfeita entre o concreto e o aço de vigas expostas ao fogo, uma vez que as flechas resultantes da consideração de aderência perfeita apresentaram valores relativamente subestimados, como indicado nas Figuras 2.29 e 2.30. Porém, nas conclusões da pesquisa, eles comentaram que apesar da consideração dos efeitos do fogo na aderência entre os materiais conduzirem a resultados mais precisos de flechas, esses resultados não diferem de forma significativa daqueles em que se admite a aderência perfeita, de modo que esses efeitos podem ser desconsiderados quando o objetivo da análise consiste em aferir uma resposta global do comportamento das vigas em situação de incêndio. Vale citar que o modelo numérico apresentado em Gao et al. (2013) foi adotado posteriormente, em Gao; Dai e Teng (2017), para a realização de análises paramétricas que

\footnotetext{
${ }^{8}$ WU, H. J.; LIE, T. T.; HU, J.Y. Fire resistance of beam-slab specimens - experimental studies. Canada: Institute for Research in Construction, National Research Council Canada, 1993. (Internal Report n. 641).
} 
serviram de base ao desenvolvimento de equações capazes de aferir o tempo de resistência ao fogo de vigas simplesmente apoiadas.
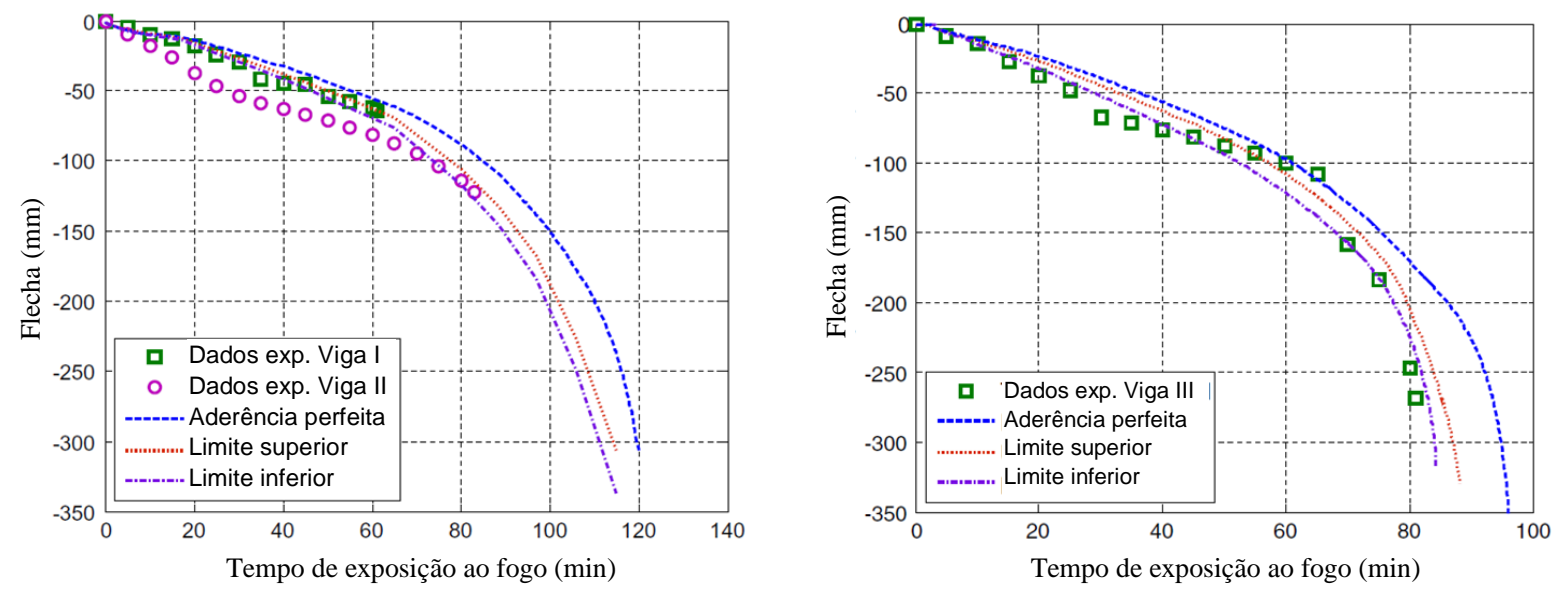

Figura 2.29 - Flechas experimentais vs numéricas para diferentes modelos de aderência entre o concreto e o aço em vigas submetidas a testes de exposição ao fogo por Wu; Lie e Hu (1993) (GAO et al., 2013; adaptado).

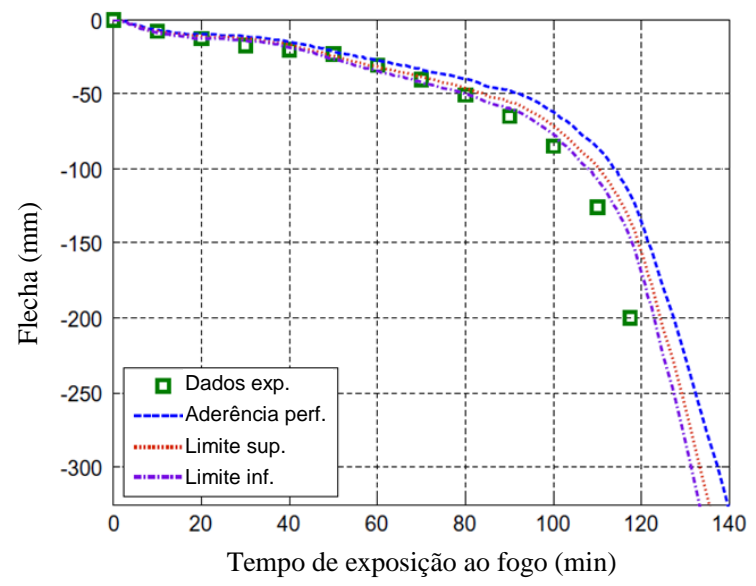

Figura 2.30 - Flechas experimentais vs numéricas para diferentes modelos de aderência entre o concreto e o aço em vigas submetidas a testes de exposição ao fogo por Lin; Gustaferro e Abrams (1993) e Dotreppe e Franssen (1985), respectivamente (GAO et al., 2013; adaptado).

Kodur e Agrawal (2017) também avaliaram a influência da perda de aderência entre os materiais no comportamento das vigas aquecidas pelo programa de computador Abaqus (ABAQUS, versão de 2012 do manual). Ainda de forma similar a Gao et al. (2013), utilizaram elementos de mola para considerar o decaimento da ligação na interface entre os materiais (Figura 2.31) e adotaram como base de estudo a viga simplesmente apoiada 
submetida a testes de exposição ao fogo por Wu; Lie e Hu (1993). Os autores adotaram para estudo os valores de resistência de aderência em função de temperaturas elevadas propostos por Huang (2010), Gao et al. (2013) e Aslani e Samali (2013), sendo que os últimos são redutores referentes a resistências de aderência residuais (pós-incêndio), vide Figura 2.32.

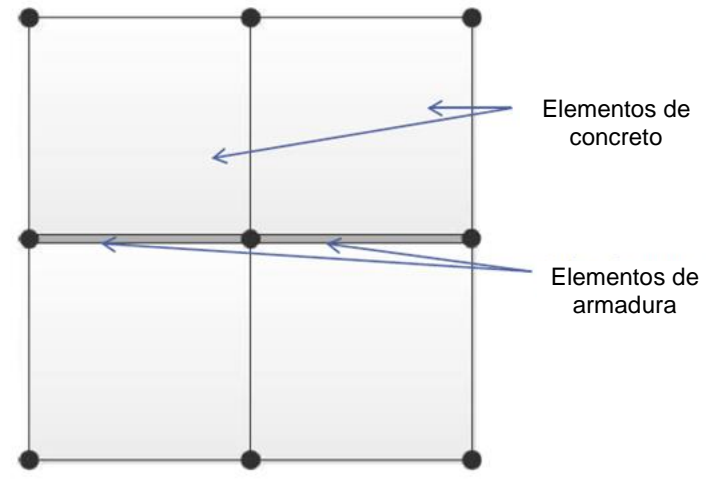

(a) Aderência perfeita

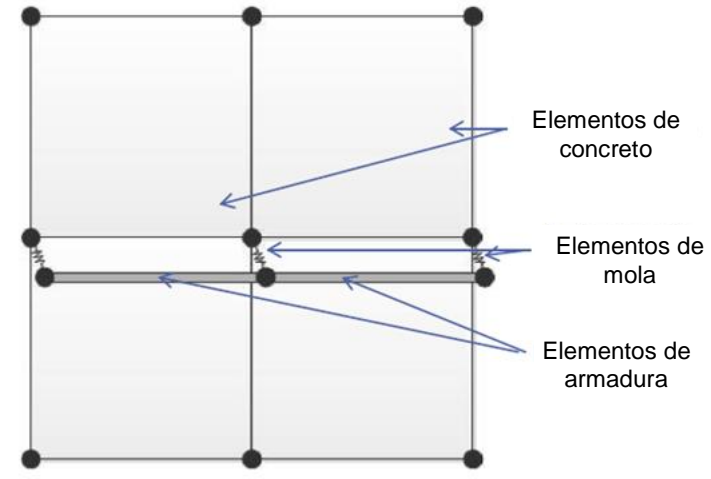

(b) Perda de aderência

Figura 2.31 - Esquema dos elementos de mola adotados para a consideração de perda de aderência na interface entre o concreto e o aço das armaduras (KODUR; AGRAWAL, 2017; adaptado).

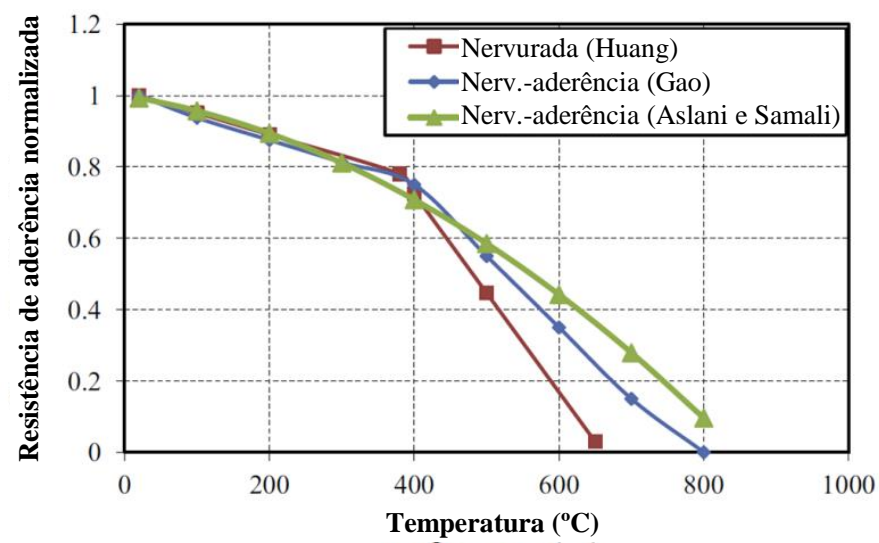

Figura 2.32 - Redutores de resistências de aderência adotados por Kodur e Agrawal (2017; adaptado).

Ao compararem as flechas numéricas aos resultados do ensaio e depois entre si, também verificaram que a consideração de aderência perfeita conduz a valores subestimados, porém, salientaram que tal fato foi verificado apenas em estágios mais avançados de exposição ao fogo, após as barras das armaduras terem atingido a temperatura de $400{ }^{\circ} \mathrm{C}$ (Figura 2.33). Haja vista que a maior diferença calculada entre as flechas foi $5 \%$, esse estudo se apresenta em conformidade ao de Gao et al. (2013), que igualmente ponderaram não haver diferenças 
significativas quando da consideração de modelos de aderência mais avançados na análise de vigas expostas ao fogo. Kodur e Agrawal (2017) também avaliaram esses efeitos em uma viga simplesmente apoiada produzida com concreto de alta resistência e verificaram que as diferenças são mais expressivas nesse caso, quando comparadas às produzidas com concretos de resistência convencional. Assim, os autores afirmaram ser de maior relevância a consideração da perda de aderência entre os materiais em vigas com concreto de alta resistência, justificando tal necessidade pelo fato desse tipo de concreto sofrer maiores reduções de resistência e módulo de elasticidade quando aquecido, o que também deve contribuir para a redução da aderência.
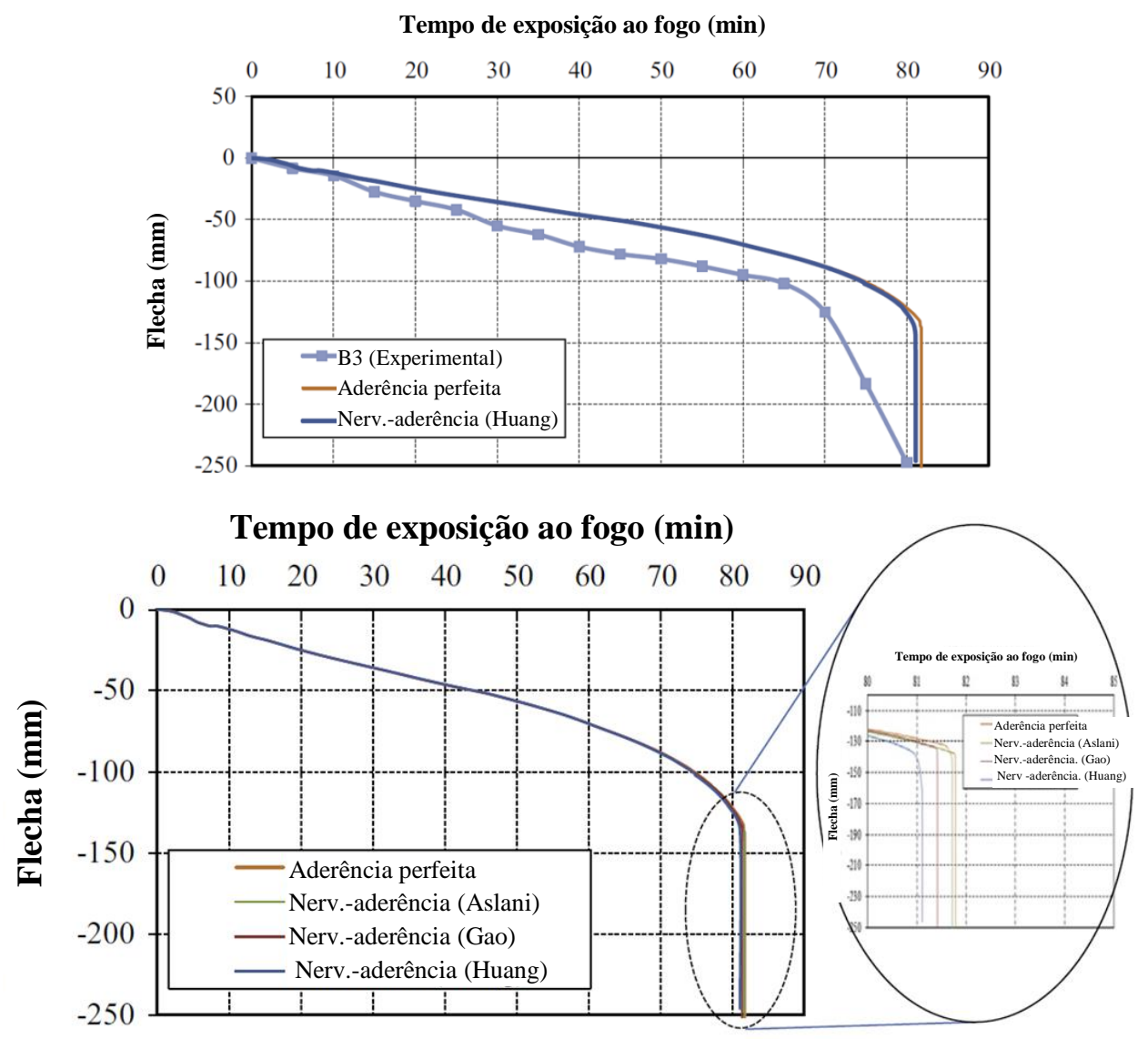

Figura 2.33 - Comparação de flechas experimentais e numéricas com diferentes modelos de perda de aderência entre os materiais (KODUR; AGRAWAL, 2017; adaptado).

Ainda em relação à linha de pesquisa que aborda a perda de aderência entre os materiais aquecidos, pode-se citar o trabalho de Liao e Huang (2015). Eles também estudaram os 
efeitos desse fenômeno nos deslocamentos verticais das vigas, da mesma forma que Gao et al. (2013) e Kodur e Agrawal (2017), mas avaliaram, sobretudo, a sua influência na simulação de aberturas de fissuras localizadas às quais as vigas podem ser submetidas quando expostas ao fogo. Os autores esclareceram que uma vez sob a ação do calor, as vigas tendem a sofrer grandes deformações, o que pode ocasionar a formação dessas extensas fissuras individuais, que já foram observadas em ensaios experimentais realizados em lajes, que também sofrem essas grandes deformações (BAILEY; TOH, 2007 e FOSTER et al., 2004). Logo, o principal objetivo da pesquisa consistiu em conceber uma ferramenta computacional capaz de prever tais fissuras.

As simulações numéricas foram divididas em duas etapas: análise térmica da seção das vigas, para a qual adotaram o programa desenvolvido por Huang, Platten e Roberts (1996), que realiza análises não lineares bidimensionais com base no método dos elementos finitos, e análise mecânica do elemento, na qual um modelo de elementos finitos extendido, denominado Extended Finite Element Model - XFEM (BELYTSCHKO; BLACK, 1999; MOES; DOLBOW; BELYTSCHKO, 1999), foi incorporado a elementos simples de concreto a fim de capturar a ocorrência das fissuras localizadas. Eles validaram esse modelo numérico mediante a comparação de temperaturas nas armaduras e flechas de quatro vigas que foram submetidas a ensaios por Lin; Ellingwood e Piet (1988).

Os autores ainda realizaram a modelagem de outra viga simplesmente apoiada com aquecimento ISO 834 (1999), ilustrada na Figura 2.34, a fim de traçar os campos de fissuras para diferentes modelos de aderência concreto-aço. Com base na Figura 2.35, afirmaram que o modelo concebido era capaz de representar a formação e a propagação de fissuras localizadas condizentes a diferentes situações: ou aderência perfeita entre materiais ou um caso mais crítico, no qual se admitiu perda de aderência entre concreto e barras de armaduras lisas. Liao e Huang (2015) concluíram que as características da aderência entre os materiais parecem influenciar de modo significativo na simulação das máximas aberturas de fissuras. 

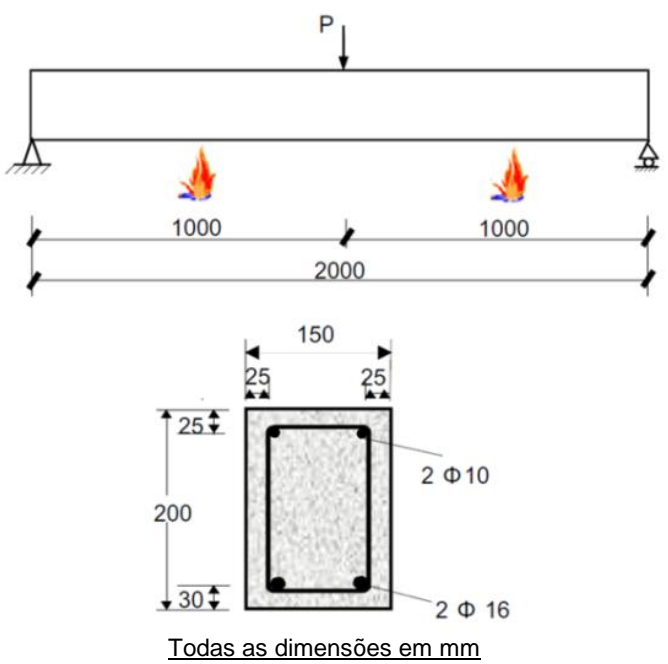

Figura 2.34 - Viga simplesmente apoiada modelada por Liao e Huang (2015) para a análise da abertura de fissuras localizadas (adaptado).

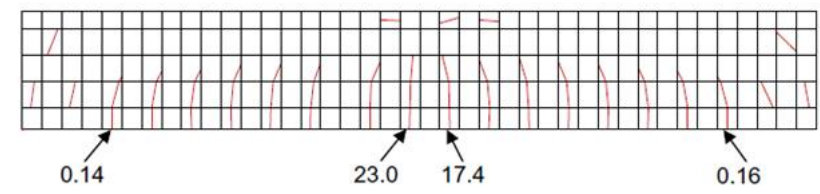

(a) Campo de fissuras previsto (aderência perfeita)

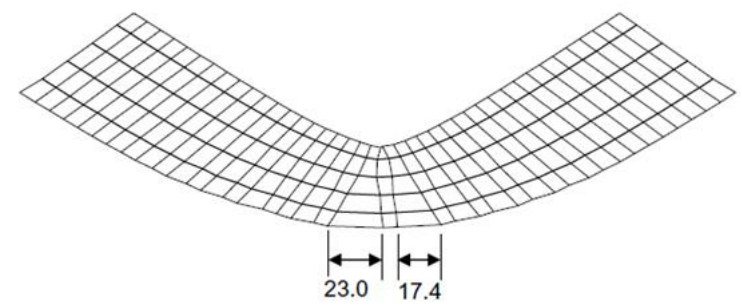

(b) Malha deformada prevista (aderência perfeita, deslocamento no eixo x ampliado 5 vezes).

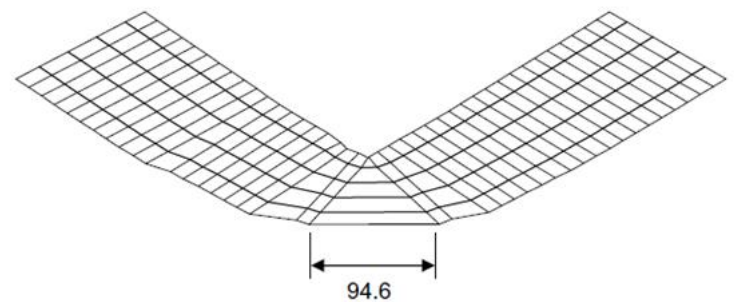

(c) Malha deformada prevista (aderência parcial com barras lisas, deslocamento no eixo $x$ ampliado 5 vezes).

Figura 2.35 - Campo de fissuras em viga simplesmente apoiada com consideração de aderência concreto-aço perfeita (a), malha deformada com aberturas de fissuras localizadas em viga com aderência concreto-aço perfeita (b) e com perda de aderência em armadura com barras lisas (c) (LIAO; HUANG, 2015; adaptado). 
Apesar de Liao e Huang (2015) terem adotado um método mais avançado para a determinação do campo de fissuras de vigas expostas ao fogo, os autores comentaram que muitos dos modelos numéricos previamente concebidos com base em modelos de fissuras distribuídas (smeared crack models) também são capazes de aferir satisfatoriamente a resposta global desses elementos, embora não consigam capturar essas possíveis fissuras localizadas no concreto aquecido. Os autores também pontuaram que a abertura de fissuras localizadas pode acarretar uma exposição maior das armaduras ao fogo, que por vezes podem até ficar diretamente expostas, de forma a reduzir drasticamente a capacidade resistente das vigas. Entretanto, eles não entraram nesse mérito no modelo numérico proposto, uma vez que as análises térmicas foram realizadas previamente às mecânicas, não examinando, portanto, o possível impacto que as fissuras poderiam causar nas distribuições de temperaturas das seções transversais. Porém, é válido recordar que foram encontrados na revisão de literaturas estrangeiras dois trabalhos experimentais a avaliar essa questão: Ervine (2012) e Ba et al. (2016), discutidos na seção prévia deste capítulo.

\subsection{Comparação entre critérios de ruptura das vigas}

Kodur e Dwaikat (2008a) apresentaram um modelo numérico, no formato de um programa de computador, para traçar o comportamento de vigas de concreto expostas ao fogo com base em três etapas: determinação da curva temperatura-tempo, representativa do tipo de incêndio, análise térmica e análise da capacidade resistente. Logo, a primeira etapa consistia em modelar o aquecimento que seria, posteriormente, empregado em três faces da seção transversal das vigas. Em seguida, dividia-se a viga em segmentos ao longo do vão, de modo que a seção média de cada um deles fosse representativa de seu comportamento. Para diferentes tempos de exposição ao fogo, a análise térmica era realizada para a avaliação do campo de temperaturas em cada segmento. $\mathrm{Na}$ análise da capacidade resistente, era possível 
traçar o comportamento da viga, desde sua fase linear-elástica até a fase de colapso, a partir do cálculo das relações momento-curvatura para cada segmento.

O programa de computador desenvolvido nesse trabalho aplicava um modelo de elementos finitos macroscópicos na segunda e terceira etapas e estipulava o momento fletor como a ação preponderante do carregamento, ou seja, esforços de cisalhamento e normais eram desconsiderados. O mesmo permitia considerar cenários reais de incêndio e carregamento, além dos efeitos do spalling em concretos de alta resistência, admitidos em conformidade à proposta simplificada de Kodur; Wang e Cheng (2004). No entanto, o diferencial mais interessante desse modelo computacional consistia na consideração de diferentes critérios de colapso/ruptura porque podem passar as vigas quando expostas a temperaturas elevadas.

Segundo Kodur e Dwaikat (2008a), os critérios que eram convencionalmente empregados para avaliar o tempo de resistência ao fogo desses elementos eram os propostos pela ASTM E119 (2000) que, conforme comentado anteriormente, admitem o colapso ou por perda de resistência (strength failure criteria) - ocorre quando o carregamento solicitante da viga para a situação de incêndio excede o resistente - ou pelo aspecto térmico (thermal failure criteria) - quando as temperaturas das barras da armadura excedem a temperatura crítica de $593{ }^{\circ} \mathrm{C}-$. Contudo, os autores destacaram que os critérios que têm base nos valores limites de flechas e velocidade de aumento das mesmas são primordiais para definir a resistência ao fogo das vigas, uma vez que a integridade dessas não pode ser garantida em um estado de deformações excessivas. Logo, esses dois critérios, indicados pela norma BS $476(1987)^{9}$, também foram incluídos no modelo numérico. Eles indicam a ruptura quando a máxima flecha excede, em qualquer tempo de exposição ao fogo, $l / 20$, em que "l" representa o vão da peça, e quando a taxa de aumento da flecha excede o limite dado pela expressão $l^{2} / 9000 d$, em que "d" consiste na altura efetiva da seção transversal.

\footnotetext{
${ }^{9}$ Os critérios de ruptura que têm base nas flechas também são propostos pela norma EN 1363-1 (1999).
} 
Para validar o modelo numérico e estudar os tempos de resistência ao fogo calculados a partir dos quatro critérios de ruptura, as autores adotaram três modelos de vigas simplesmente apoiadas: dois que foram submetidos a ensaios experimentais por Lin; Gustaferro e Abrams (1981) e Dotreppe e Franssen (1985) e um que eles próprios propuseram. Concluíram que o critério de ruptura estabelecido é determinante nos resultados do tempo de resistência ao fogo das vigas simplesmente apoiadas de concreto armado e, ainda, que os critérios fundamentados na resistência e na temperatura crítica das armaduras conduzem a valores contra a segurança em determinadas situações. Por conseguinte, os critérios que limitam as flechas são mais indicados para aferir a resposta ao fogo desses elementos estruturais. Segundo os autores, definir a resistência das vigas com base nesses critérios ajuda a facilitar a segurança dos bombeiros e dos demais ocupantes de um edifício em chamas, para que consigam realizar a fuga antes de colapsos estruturais.

\subsection{Análises paramétricas com maior número de variáveis}

Kodur e Dwaikat (2008b) fizeram uso do modelo numérico proposto em Kodur e Dwaikat (2008a) para analisar a influência de outros parâmetros, além dos critérios de ruptura, no comportamento ao fogo das vigas. Um deles foi o cenário de incêndio, estudado a partir de três modelos padronizados, citam-se as curvas ASTM E119 (versão de 2000), ASTM E1529 (1993), representativa de materiais à base de hidrocarbonetos, e a curva de incêndio externo (BUCHANAN, 2001), e dois modelos representativos de incêndios reais, i.e., que incorporavam a fase de resfriamento (Figura 2.36). Também analisaram a influência da espessura do cobrimento da armadura (admitindo valores de 30, 40 e $50 \mathrm{~mm}$ ), do tipo de agregado (calcário e silicoso), do comprimento do vão (4, 6 e $8 \mathrm{~m}$ ) e do nível de carregamento, que consiste na relação entre o carregamento aplicado em incêndio e a capacidade máxima da peça à temperatura normal, estipulando-se taxas de 30, 40, 50, 60 e $70 \%$. Esses parâmetros foram estudados a partir de vigas simplesmente apoiadas submetidas a 
carregamentos uniformemente distribuídos com seções retangulares e dimensões dos vãos iguais, exceto nas vigas em que essas dimensões foram avaliadas.

Eles observaram que o tipo de aquecimento exerce influência significativa no tempo de resistência ao fogo das vigas e, ainda, que as curvas de incêndio-padrão geralmente adotadas em projeto conduzem a resultados conservadores, mesmo quando comparados a resultados obtidos a partir da consideração de cenários mais severos de incêndio. A espessura do cobrimento das armaduras e o tipo de agregado também influenciam na resistência ao fogo, por isso os autores enfatizaram a importância de serem consideradas as propriedades térmicas condizentes a cada tipo de agregado nas análises numéricas. Os carregamentos aplicados são igualmente determinantes, logo, é imprescindível que a resistência ao fogo seja calculada com base em níveis e combinações realísticas dos mesmos. Ao contrário de todos esses parâmetros, as dimensões dos vãos não se mostraram relevantes na determinação da resistência ao fogo das vigas.

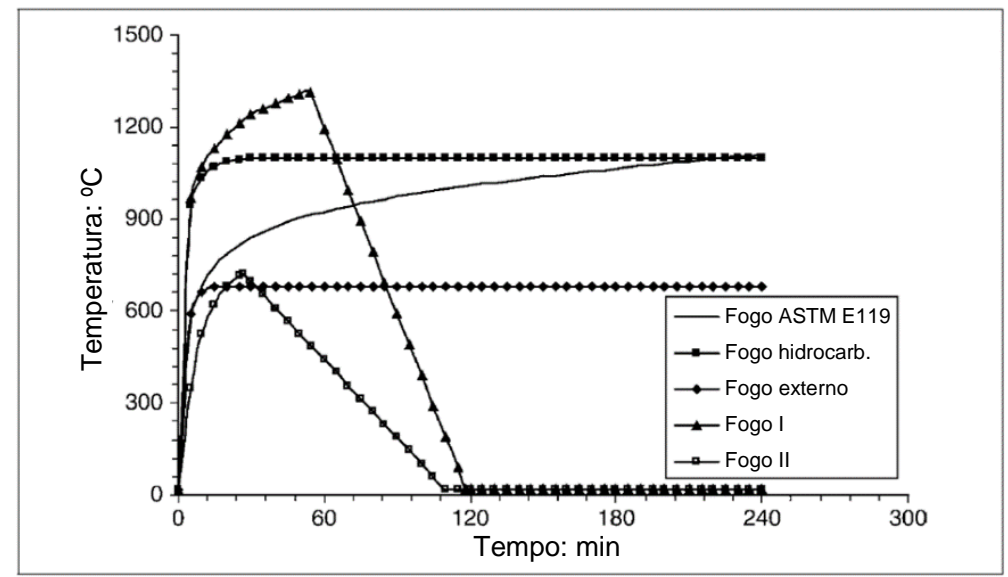

Figura 2.36 - Curvas de exposição ao fogo para estudo paramétrico (KODUR; DWAIKAT, 2008b; adaptado).

\subsection{Cálculo de momentos fletores resistentes em incêndio}

Rigberth (2000) apresentou uma pesquisa no qual comparou os momentos fletores resistentes de vigas de concreto armado aquecidas obtidos a partir de um programa de computador aos 
seguintes métodos propostos pelo Eurocode 2 parte 1-2 (versão de 1995): método da isoterma de $500{ }^{\circ} \mathrm{C}$ e método das zonas, sendo o último também conhecido como método de Hertz, pois foi idealizado pelo autor dinamarquês Kristian Hertz no trabalho Analyses of Prestressed Concrete Structures Exposed to Fire (HERTZ, 1985). Para a obtenção dos resultados numéricos, o autor empregou o Super Tempcalc (versão de 1999 do manual produzido pela FSD), no qual a análise térmica é efetuada via métodos dos elementos finitos e o momento é calculado unicamente por equilíbrio de forças (não há imposição das deformações específicas limites para ambos os materiais). As seções estudadas tinham geometrias I, T e retangular, além de diferentes arranjos de armaduras, e foram aquecidas em três faces conforme a curva ISO 834 de 1975 e uma curva de incêndio natural. A Figura 2.37 apresenta um exemplo de comparação entre os momentos resistentes de uma viga com seção $\mathrm{T}$ e armadura positiva obtidos para diferentes intervalos de exposição ao fogo e por diferentes métodos de cálculo.

Estas foram algumas das conclusões obtidas: os métodos propostos pela norma europeia conduzem a bons resultados, i.e., próximos aos obtidos com modelo computacional mais avançado, para as seções transversais com armaduras positivas; os dois métodos também conduzem a resultados satisfatórios para as seções com armaduras negativas, porém, apenas quando adotado aquecimento conforme a curva ISO 834, já que foram obtidos valores conservadores para exposição à curva de incêndio natural, especialmente em relação ao método da isoterma de $500{ }^{\circ} \mathrm{C}$.

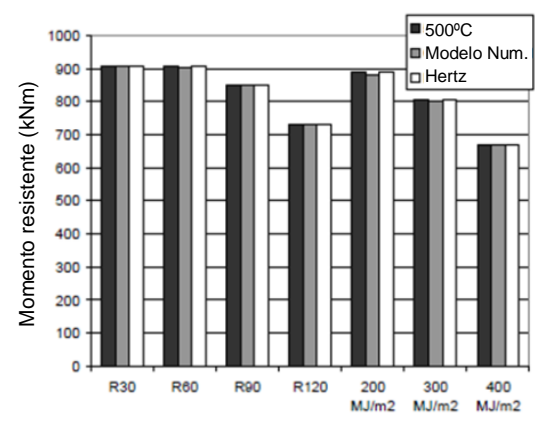

B.1 (Viga T)

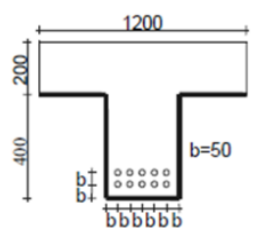

Concreto: $\mathrm{f}_{\mathrm{cc}}=29.6 \mathrm{MPa}$

Aço armaduras:

$\mathrm{f}_{\mathrm{y}}=370 \mathrm{MPa}, \Phi 25$

Figura 2.37 - Comparação entre os momentos fletores resistentes de uma viga obtidos a partir dos métodos do Eurocode 2 parte 1-2 e pelo programa de computador Super Tempcalc (RIGBERTH, 2000; adaptado). 


\subsubsection{Vigas com restrições}

\subsubsection{Estudos experimentais}

O trabalho mais antigo encontrado na pesquisa geral de literaturas estrangeiras sobre o comportamento de vigas de concreto armado em situação de incêndio foi, coincidentemente, o primeiro a abordar os efeitos das restrições na resposta ao fogo desses elementos. Logo no início da década de 1980, Lin; Gustaferro e Abrams (1981) já esclareceram que as vigas contínuas expostas a temperaturas elevadas são submetidas a uma redistribuição de momentos fletores solicitantes, do positivo para o negativo, e comentaram que essa redistribuição poderia ser favorável à capacidade resistente das mesmas.

Assim, os autores decidiram verificar experimentalmente essa hipótese realizando testes de exposição ao fogo, modelado conforme a curva-padrão americana ASTM E119, em onze vigas, sendo apenas uma simplesmente apoiada e as demais contínuas (seis representativas de vãos internos de vigas contínuas e quatro de vãos externos). Apenas em um caso de viga contínua foi utilizado concreto do tipo leve e, nos outros, concreto de densidade normal. $\mathrm{O}$ aquecimento foi resultante do forno para vigas pertencente à Portland Cement Association PCA, cujas características estão indicadas em Gustaferro; Abrams e Salse (1971) apud Lin; Gustaferro e Abrams (1981), trabalho citado anteriormente na nota de rodapé n. 6, e em Selavaggio e Carlson ${ }^{10}$ (1964) apud Lin; Gustaferro e Abrams (1981). Com seções transversais retangulares e submetidas a forças concentradas, vide Figura 2.38, as vigas de ensaio foram posicionadas sobre apoios de aço que não impediam a rotação e nem mesmo a expansão de seus comprimentos, ocasionados pela transferência de calor. Portanto, as

\footnotetext{
${ }^{10}$ SELVAGGIO, S. L.; CARLSON, C. C. Fire-resistance of prestressed concrete beams, study B: influence of aggregate and load intensity. Skokie: Portland Cement Association, 1964. (PCA Research Department Bulletin R171).
} 
restrições rotacionais porque passariam determinadas peças eram resultantes, apenas, da própria continuidade que seria imposta a elas.

A fim de prover diferentes esquemas estáticos ao mesmo modelo de viga, os autores modificavam o sistema de forças aplicadas a cada ensaio. Para simular a simplesmente apoiada, o trecho entre apoios era aquecido e submetido às forças denominadas $\mathrm{P}_{3}$, enquanto as forças $\mathrm{P}_{1}$ e $\mathrm{P}_{2}$, dos trechos em balanço mantidos a frio, não eram aplicadas. As vigas contínuas eram simuladas com as mesmas condições de aquecimento, porém, as forças concentradas $\mathrm{P}_{1}$ e $\mathrm{P}_{2}$ eram variadas, com o propósito de manter constantes os deslocamentos verticais dos balanços ao longo dos ensaios. Vãos internos de vigas contínuas, i.e., com continuidade em dois apoios, eram simulados pela aplicação tanto da força $\mathrm{P}_{1}$ quanto $\mathrm{P}_{2}$, enquanto os vãos extremos, contínuos em um apoio, eram simulados pela aplicação somente de $\mathrm{P}_{2}$.
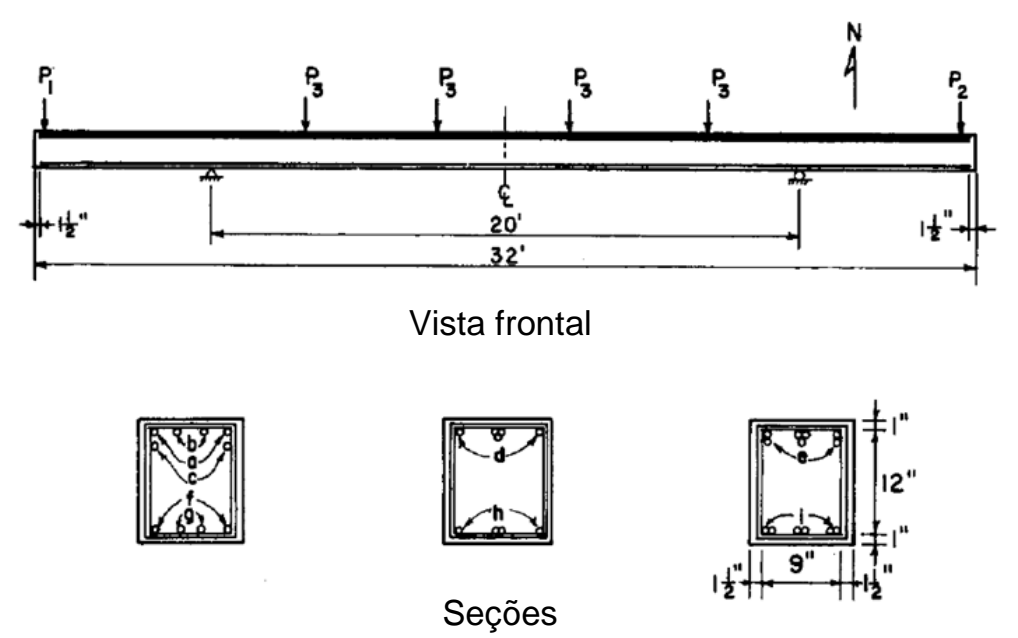

Figura 2.38 - Vista frontal do esquema estático e esquemas das seções transversais das vigas ensaiadas por Lin; Gustaferro e Abrams (1981; adaptado).

Para cada uma das vigas, Lin; Gustaferro e Abrams (1981) plotaram gráficos de forças aplicadas, flechas, temperaturas médias nas armaduras longitudinais inferiores, além dos diagramas de momentos fletores solicitantes e resistentes resultantes da fase inicial dos ensaios, nos quais apenas se aplicavam as forças, e relativamente a determinados tempos de exposição ao fogo (Figuras 2.39 e 2.40). Os resultados da pesquisa confirmaram a hipótese indicada inicialmente, ou seja, as vigas contínuas demonstraram maior resistência ao fogo 
quando comparadas às vigas simplesmente apoiadas, que não são contempladas pela redistribuição de momentos. Além disso, os autores verificaram que todas as vigas produzidas com concreto convencional romperam por flexão, sendo que nas vigas contínuas essa ruptura se mostrou eminente somente quando verificada a ocorrência de três rótulas plásticas. A viga com concreto leve rompeu por cisalhamento, mas foi verificado que a armadura para combater o esforço transverso era inadequada mesmo para a temperatura ambiente.

Dois dos autores principais do trabalho de Lin; Gustaferro e Abrams (1981) voltaram a abordar a redistribuição de momentos porque passam as vigas contínuas submetidas a incêndio em Gustaferro e Lin (1986). Em uma pesquisa de cunho teórico/analítico, eles complementaram esse tópico com a apresentação de precauções que devem ser tomadas, em projeto, para que essas peças consigam "acomodar" o acréscimo do momento solicitante negativo, como, por exemplo, aumentar o comprimento de ancoragem ao longo desse trecho.
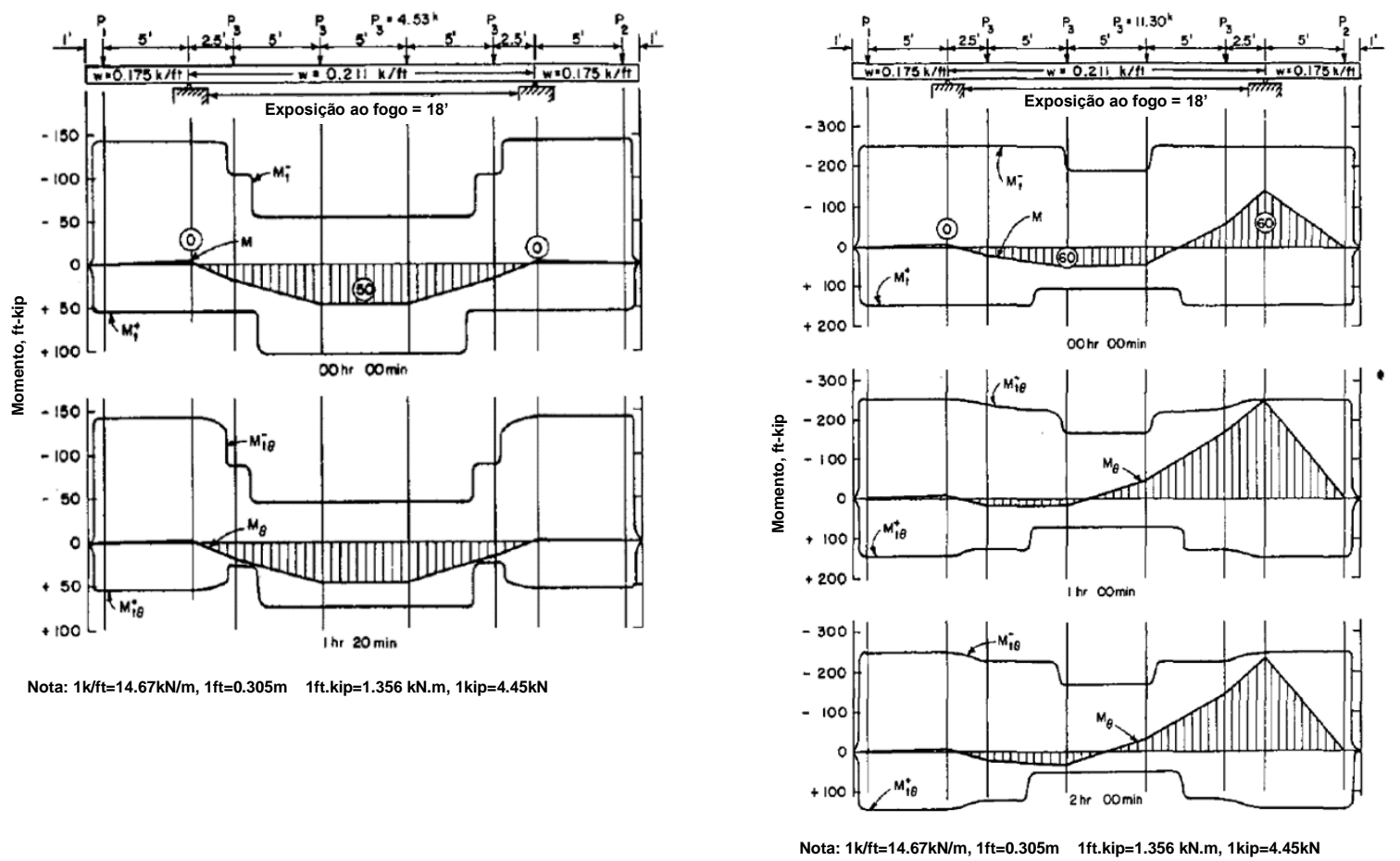

Figura 2.39 - Diagramas de momentos fletores solicitantes e resistentes traçados para vigas simplesmente apoiada e representativa de vão extremo de peça contínua em situação de incêndio, respectivamente (LIN; GUSTAFERRO; ABRAMS, 1981; adaptado). 

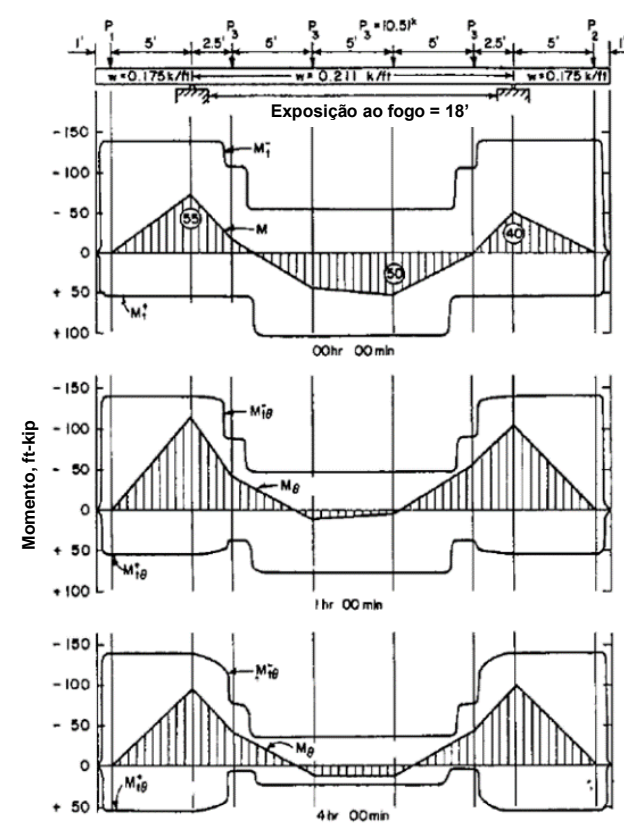

Nota: $1 \mathrm{k} / \mathrm{ft}=14.67 \mathrm{kN} / \mathrm{m}, 1 \mathrm{ft}=0.305 \mathrm{~m} \quad 1 \mathrm{ft} . \mathrm{kip}=1.356 \mathrm{kN} . \mathrm{m}, 1 \mathrm{kip}=4.45 \mathrm{kN}$

Figura 2.40 - Diagramas de momentos fletores solicitantes e resistentes traçados para viga representativa de vão interno de peça contínua em situação de incêndio (LIN; GUSTAFERRO; ABRAMS, 1981; adaptado).

\subsubsection{Estudos numérico-experimentais}

\subsection{Vigas com restrição rotacional}

Lin; Ellingwood e Piet (1988) ${ }^{11}$ desenvolveram um modelo numérico no qual, para a análise térmica, solucionaram a equação diferencial para fluxos bidimensionais de calor com base na aproximação de derivadas por diferenças finitas. Enquanto isso, para a análise estrutural, discretizaram as vigas em uma série de segmentos e, em seguida, computaram os esforços axiais e momentos resultantes para diferentes intervalos de exposição ao fogo. Esse modelo

\footnotetext{
${ }^{11}$ Essa pesquisa foi originalmente publicada pela Portland Cement Association - PCA em forma de "bulletin". Mais tarde, o Journal of Structural Engineering apresentou uma versão resumida em Ellingwood e Lin (1991).
} 
foi concebido por intermédio do proposto em Becker e Bresley (1974) e foi validado mediante a comparação a resultados experimentais. Os autores realizaram testes de exposição ao fogo em seis vigas de concreto armado que simulavam o vão extremo de uma viga contínua a partir do mesmo método de ensaio adotado em Lin; Gustaferro e Abrams (1981), logo, pela aplicação de forças concentradas no trecho entre apoios e na região em balanço (Figura 2.41).
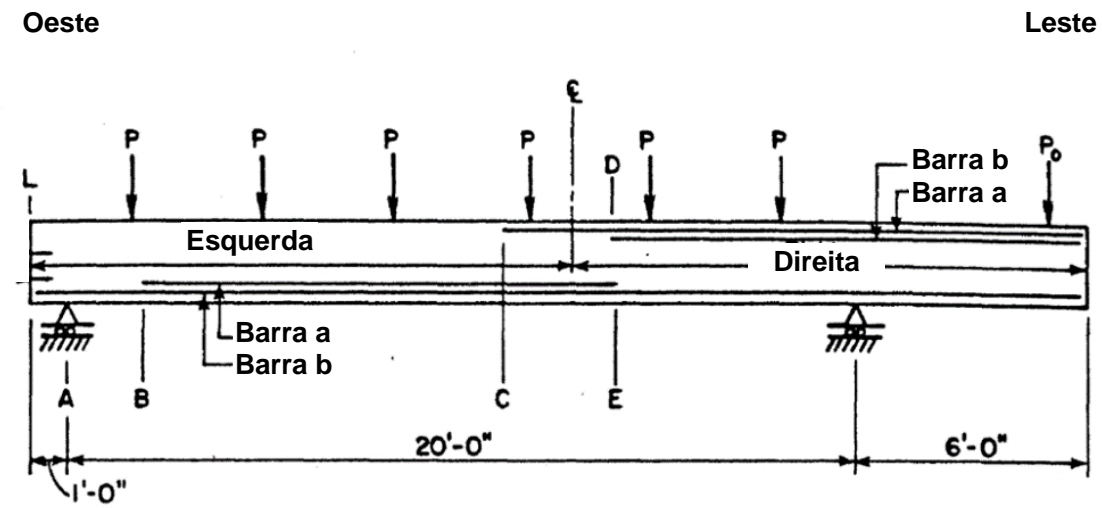

Figura 2.41 - Modelo das vigas, representativas de vãos extremos de peças contínuas, ensaiadas por Lin; Ellingwood e Piet (1988; adaptado).

As vigas ensaiadas possuíam diferentes seções transversais retangulares e foram fabricadas com concreto de massa específica normal. Quatro delas foram aquecidas conforme a curvapadrão ASTM E119, que representava um incêndio de longa duração e intensidade moderada, e as demais com base em uma curva temperatura-tempo na qual foram aplicados parâmetros de compartimentação e ventilação reais, a fim de representar um incêndio de curta duração e grande intensidade. A principal diferença entre eles era que o primeiro admitia apenas a fase de aquecimento do incêndio, enquanto o segundo incorporava a fase de resfriamento.

Além de obter dados para validar o modelo numérico proposto, o principal objetivo desses ensaios consistia em verificar o comportamento das vigas quanto à flexão e ao cisalhamento. A partir dos resultados, os autores observaram que todas apresentaram fissuras de cisalhamento localizadas próximas ao apoio contínuo em períodos relativamente iniciais dos testes de exposição ao fogo. As fissuras de flexão apareceram nas zonas de momento positivo e, apesar de terem surgido depois das fissuras de cisalhamento, elas rapidamente se 
estenderam pelas vigas ensaiadas (Figuras 2.42 e 2.43). Assim, todas as peças romperam por flexão e eles chegaram à mesma conclusão da campanha experimental realizada anteriormente em Lin; Gustaferro e Abrams (1981), de que o esforço de cisalhamento não representa um problema significativo na resistência ao fogo de vigas contínuas e que a ruptura por flexão consiste no caso mais usual de colapso desses elementos.

A pesquisa de Lin; Ellingwood e Piet (1988) também se tornou base para vários outros trabalhos, pois levou a mais uma conclusão importante: a resistência à flexão das vigas expostas ao fogo é função, principalmente, do histórico de temperaturas na armadura. Assim se justifica o fato de Zha (2003), Shi et al. (2004), Kodur e Dwaikat (2008b), Choi e Shin (2011) e Reddy et al. (2015), citados na seção prévia, terem percebido a necessidade de analisar a influência, nesse aspecto, da espessura do cobrimento das barras de aço.

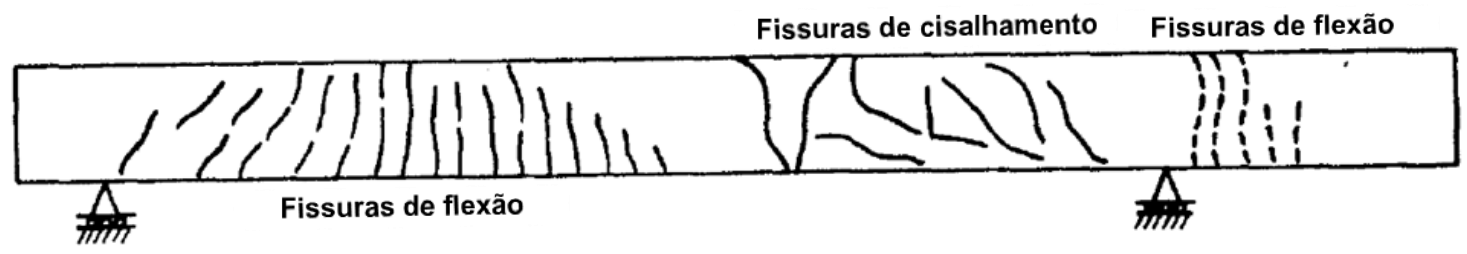

Figura 2.42 - Esquema das fissuras de flexão e de cisalhamento verificadas nas vigas submetidas a ensaios por Lin; Ellingwood e Piet (1988; adaptado).

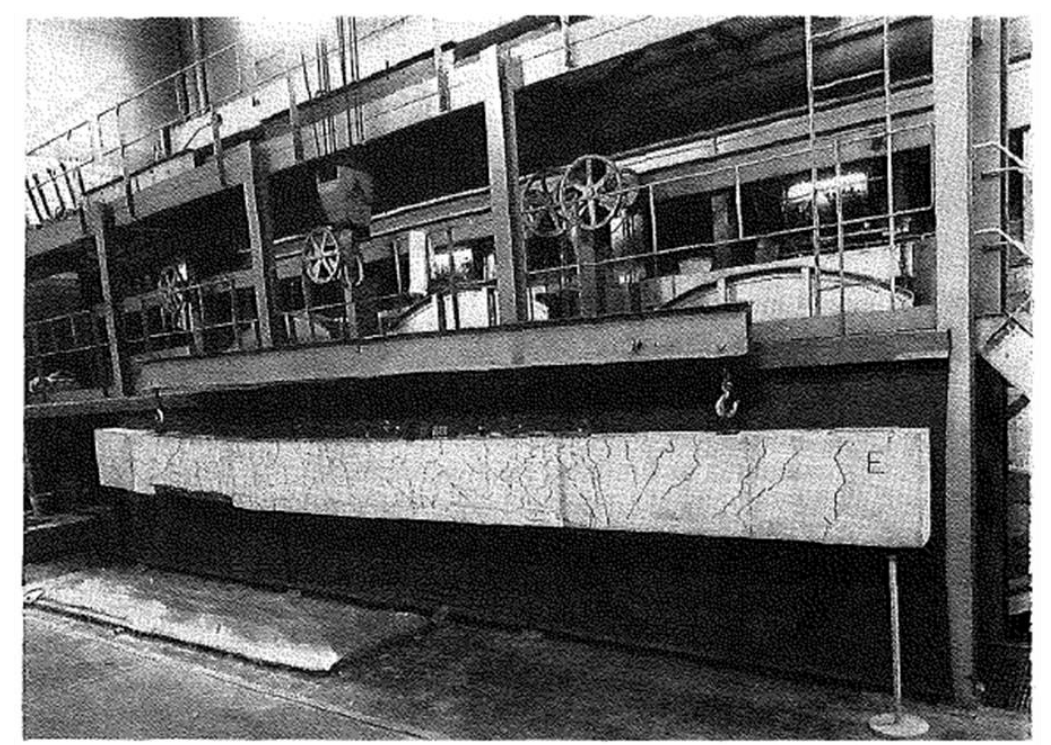

Figura 2.43 - Peça característica do vão extremo de uma viga contínua após teste de exposição a fogo modelado pela curva ASTM E119 (LIN; ELLINGWOOD; PIET, 1988). 
Guo e Shi (2011) conceberam um programa de computador com base no método dos elementos finitos para análises termestruturais de estruturas de concreto armado expostas ao fogo. A distribuição de temperaturas nas seções transversais foi calculada por meio do módulo denominado HTARC (Heat Transfer Analysis of Reinforced Concrete), enquanto o comportamento mecânico foi aferido pelo módulo NARCSLT (Nonlinear Analysis of Reinforced Concrete Structures under Loading and Elevated Temperatures). Para validar o programa, os autores utilizaram os resultados obtidos nos ensaios que realizaram em vigas simplesmente apoiadas, contínuas e também em pórticos. Em relação às vigas, compararam, por exemplo, as flechas obtidas numericamente às experimentais. Apesar de os métodos de cálculo adotados para a concepção do programa terem sido abordados com detalhes, não foram transmitidas muitas informações acerca da modelagem propriamente dita das vigas.

À semelhança de Lin; Gustaferro e Abrams (1981) e Lin; Ellingwood e Piet (1988), Guo e Shi (2011) realizaram ensaios de exposição ao fogo em vigas contínuas, contudo, essas possuíam dois vãos, conforme ilustra a Figura 2.44. Nas extremidades foram colocados apoios do tipo rolete e a meio vão uma rótula (Figura 2.45). Portanto, essas vigas não foram submetidas a restrições axiais, enquanto a flexão/giro foi restringida devido à continuidade imposta pelo apoio central. Os apoios de rolete adotados eram capazes de medir as reações verticais, de modo que se tornava possível traçar todo o comportamento das peças hiperestáticas em seguida.

Os autores produziram seis dessas vigas para verificar a influência de diferentes posicionamentos e valores de forças aplicadas, além de diferentes regimes de aquecimento dos vãos (ou dois ou apenas um vão diretamente aquecido). As mesmas foram submetidas à aplicação de forças iniciais na condição de temperatura ambiente e essas foram mantidas ao longo da exposição ao fogo (em três faces). A ação térmica foi procedente de um forno elétrico que produzia aquecimento a uma taxa de $20{ }^{\circ} \mathrm{C} / \mathrm{min}$, com temperatura máxima de $1000{ }^{\circ} \mathrm{C}$ a ser atingida. 
(a)

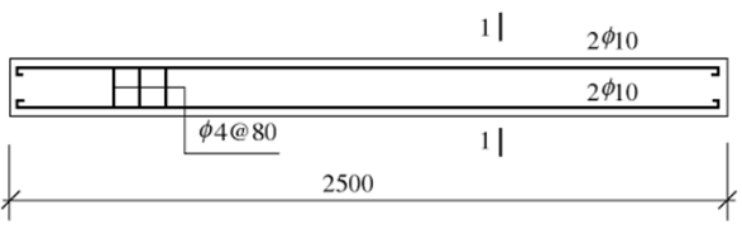

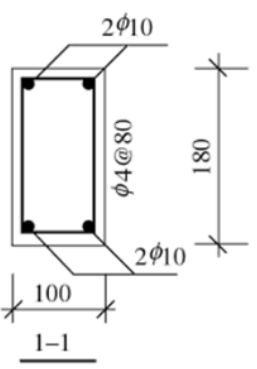

(b)

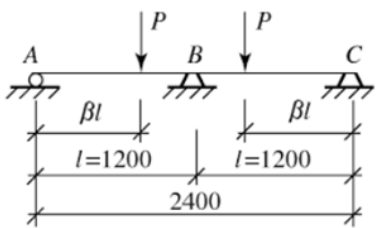

Figura 2.44 - Características das vigas (a) e esquema estático (b) atribuídos nos ensaios de exposição ao fogo realizados por Guo e Shi (2011).
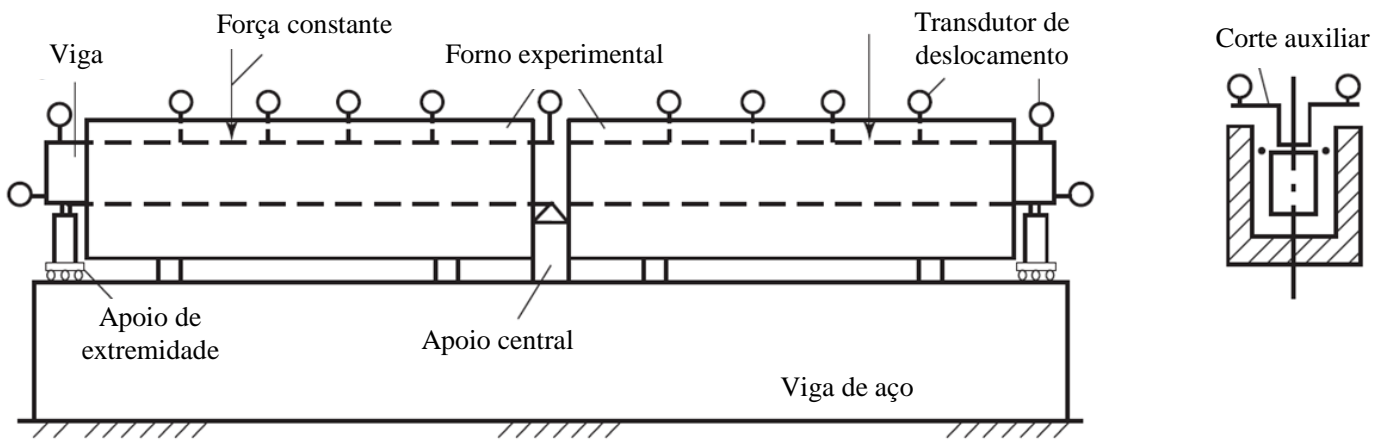

Figura 2.45 - Detalhes do leiaute de ensaios adotado por Guo e Shi (2011) para a análise de vigas contínuas de concreto armado expostas ao fogo (adaptado).

Guo e Shi (2011) também apresentaram informações acerca de redistribuição de esforços porque passaram as vigas contínuas ensaiadas, tal como feito em Lin; Gustaferro e Abrams (1981). Eles esclareceram que o processo de redistribuição pode ser dividido em três estágios, sendo os denominados "inicial" e "estável" aqueles em que os momentos fletores positivos dos vãos diminuem e os negativos do apoio central aumentam gradualmente, vide Figura 2.46-a. O estágio final consiste naquele em que ocorre o colapso da peça, após a formação das três rótulas plásticas, indicadas na Figura 2.46-b, que também surgiram nas vigas ensaiadas por Lin; Gustaferro e Abrams (1981). As primeiras rótulas a surgir são as localizadas nos trechos de momentos fletores solicitantes positivos, uma vez que a capacidade resistente à flexão das seções aí presentes é reduzida de forma mais rápida, pelo fato das armaduras estarem diretamente expostas ao fogo. Como esperado, verificou-se uma a redistribuição de esforços mais branda nas vigas contínuas nos quais apenas um vão foi diretamente aquecido. 
(a)

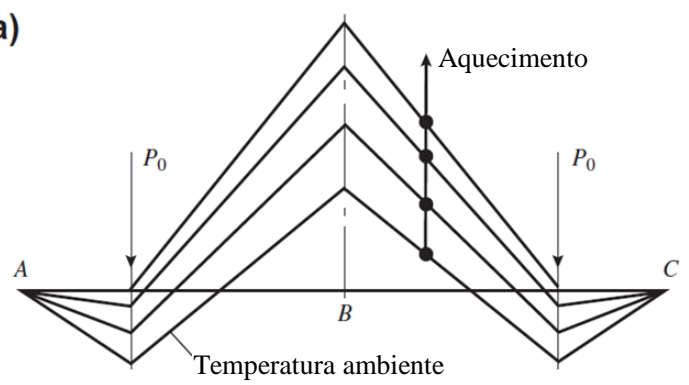

(b)

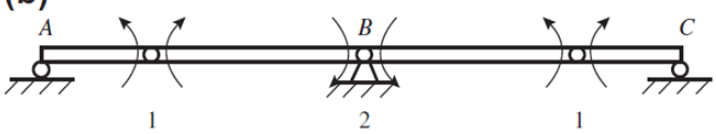

Figura 2.46 - Redistribuição de momentos fletores solicitantes (a) e rótulas plásticas (b) formadas nas vigas contínuas ensaiadas por Guo e Shi (2011; adaptado).

\subsection{Vigas com restrições apenas axial ou axial mais rotacional}

Dwaikat e Kodur (2008) aperfeiçoaram o modelo numérico desenvolvido em Kodur e Dwaikat (2008a), que até então era aplicável apenas a vigas simplesmente apoiadas, a fim de analisar os efeitos de restrição às deformações de origem térmica na resistência ao fogo das vigas de concreto armado. Nesse modelo, a restrição foi considerada por intermédio da força de compressão axial, resultante da tentativa de alongamento das peças.

Novamente, os cálculos se dividiram em três etapas, sendo que o diferencial esteve na análise da capacidade resistente, na qual essa força foi calculada em cada segmento de forma análoga a uma viga de concreto protendido. Em seguida, seu efeito foi aplicado nas relações momento-curvatura. Embora esse modelo permitisse considerar cenários reais de incêndio, carregamento, colapso e efeitos do spalling em concretos de alta resistência, os autores citaram brevemente a ponderação dos efeitos da fissuração do concreto, não deixando claro de que forma esse aspecto da não linearidade do material foi admitido. 
A validação dos resultados numéricos foi realizada mediante a comparação a resultados obtidos a partir do SAFIR (versão do manual não informada), programa de computador que realiza análise termomecânica de estruturas em situação de incêndio via método dos elementos finitos. Para isso, analisaram uma viga com restrição axial, submetida a um carregamento uniformemente distribuído e com seção transversal exposta à curva-padrão ASTM E119 de 2000 em três faces.

Nesse artigo, os autores justificaram que a escassez de dados na literatura sobre testes de exposição ao fogo em que as restrições às deformações térmicas foram consideradas foi o motivo pelo qual o método não havia sido validado a partir de resultados experimentais. Porém, já na Tese de Doutorado do autor principal da pesquisa (DWAIKAT, 2009), apresentou-se a validação também por meio dos resultados de ensaios realizados pelo próprio em vigas com restrições axiais, que serão comentados mais adiante.

A partir do modelo numérico validado, os autores realizaram um estudo paramétrico com o objetivo de analisar efetivamente a influência das restrições no comportamento ao fogo das vigas. Para isso, adotaram vigas submetidas a diferentes rigidezes na direção axial, modeladas a partir de elementos de mola (Figura 2.47-b), e também verificaram casos nos quais tanto as deformações do tipo axial quanto rotacional eram restringidas pelos apoios. Porém, como pode ser visto na Figura 2.47-c, não aplicaram molas para investigar a influência de diferentes rigidezes à rotação, ou seja, nesses apoios os giros estavam totalmente impedidos.
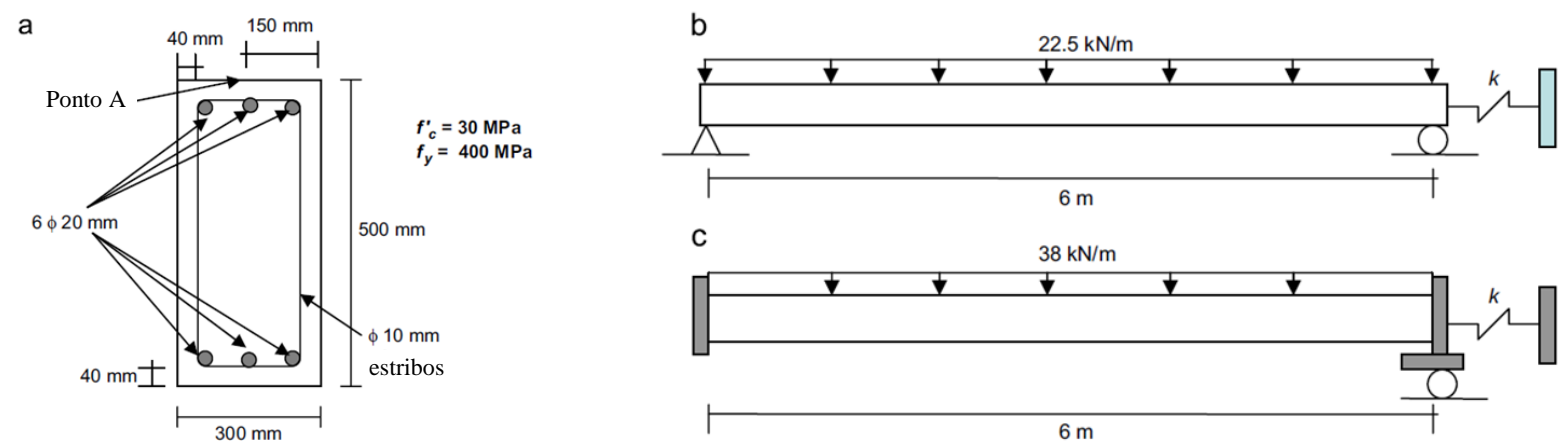

Figura 2.47 - Seção transversal (a) e modelos estáticos das vigas em que se analisou a influência de restrição axial (b) e restrições axial e rotacional (c) (DWAIKAT; KODUR, 2008; adaptado). 
As evoluções das forças axiais e das flechas em função do tempo encontradas para os dois modelos estáticos de vigas analisadas estão ilustrados nas Figuras 2.48 e 2.49. A principal conclusão obtida pelos autores foi que as restrições às deformações de origem térmica exercem influência significativa no desempenho ao fogo das vigas e, no geral, as resistências ao fogo desses elementos são maiores quando submetidos a tais restrições (ou apenas axiais ou axiais/rotacionais).
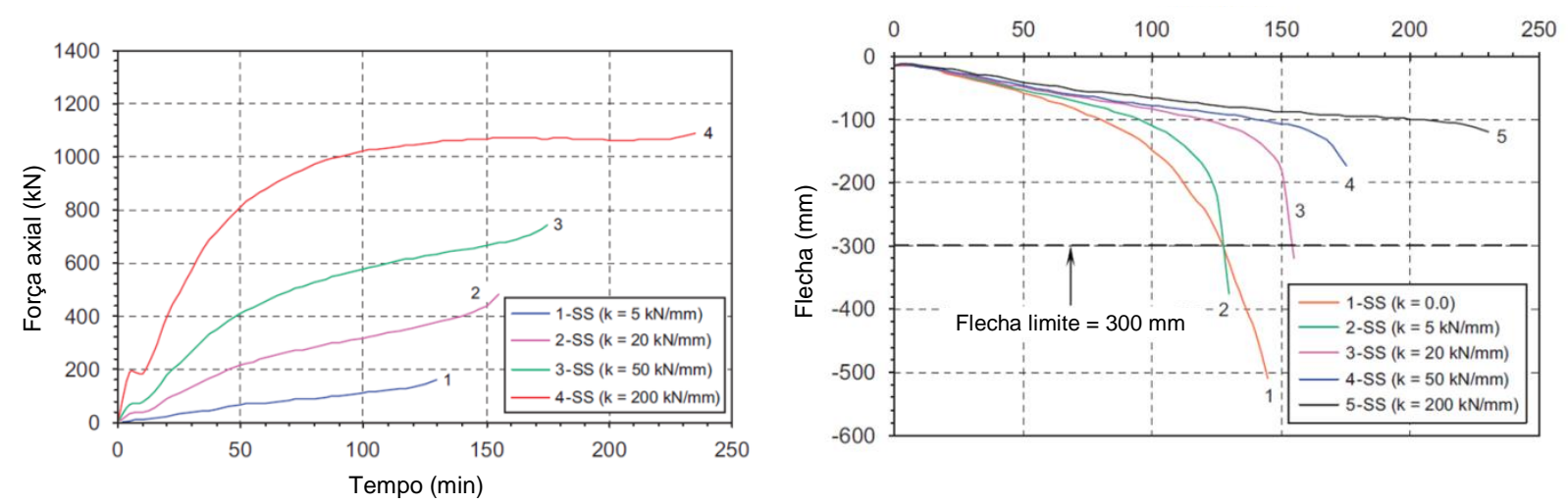

Figura 2.48 - Evolução das forças de restrição axiais e das flechas nas vigas com restrições apenas axiais modelo b da Figura 2.47 - (DWAIKAT; KODUR, 2008; adaptado).
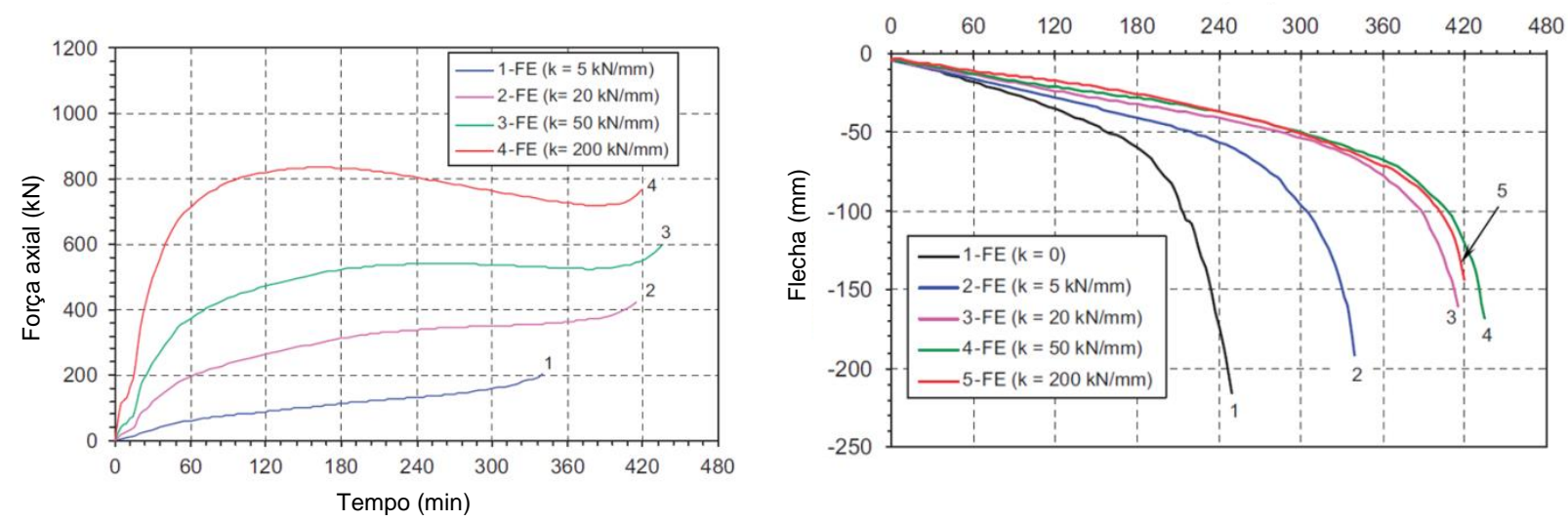

Figura 2.49 - Evolução das forças de restrição axiais e das flechas nas vigas com restrições axiais parciais e totalmente restringidas a rotações - modelo c da Figura 2.47 - (DWAIKAT; KODUR, 2008; adaptado).

Dwaikat e Kodur (2008) ainda esclareceram que a resistência ao fogo aumenta quanto maiores os níveis de restrição axial. Isso porque a rigidez mais alta nessa direção resulta em forças de compressão maiores, que por sua vez tornam mais significativos os efeitos gerados pelo que os autores denominam efeito arco. Esse fenômeno, abordado com detalhes nesta 
Tese ao longo do Capítulo 1 - Introdução, surge em decorrência do esforço gerado pelas forças de restrição, que ao comprimirem as vigas acabam por contrapor as flechas geradas pelas forças solicitantes em situação de incêndio. Por isso, quanto maiores as forças de restrição axiais, menores as flechas. Eles concluíram, por fim, que as restrições rotacionais reduzem sensivelmente as flechas das vigas, fato que pode ser atribuído à redistribuição que ocorre entre os momentos positivos e negativos.

Conforme mencionado anteriormente, os pesquisadores Monther Dwaikat e Venkatesh Kodur também realizaram testes de exposição ao fogo, que foram abordados nas referências Dwaikat e Kodur (2009b) e Dwaikat (2009). No laboratório da Universidade do Estado de Michigan Estados Unidos, ensaiaram seis vigas de concreto armado em que foram admitidas as seguintes variáveis: resistência do concreto (alta e normal), condições de apoio (simplesmente apoiada e submetida à restrição à deformação axial, com rigidez igual a $13 \mathrm{kN} / \mathrm{mm}$ ), cenário de incêndio (curva-padrão ASTM E119, 2008 e curvas reais de incêndios, com severidades de curta e longa duração) e nível de carregamento (taxas de 55 e 65\%). Todas as vigas foram produzidas em escala real, possuíam as mesmas dimensões de vãos e seções transversais retangulares e foram submetidas a duas forças concentradas (Figura 2.50).

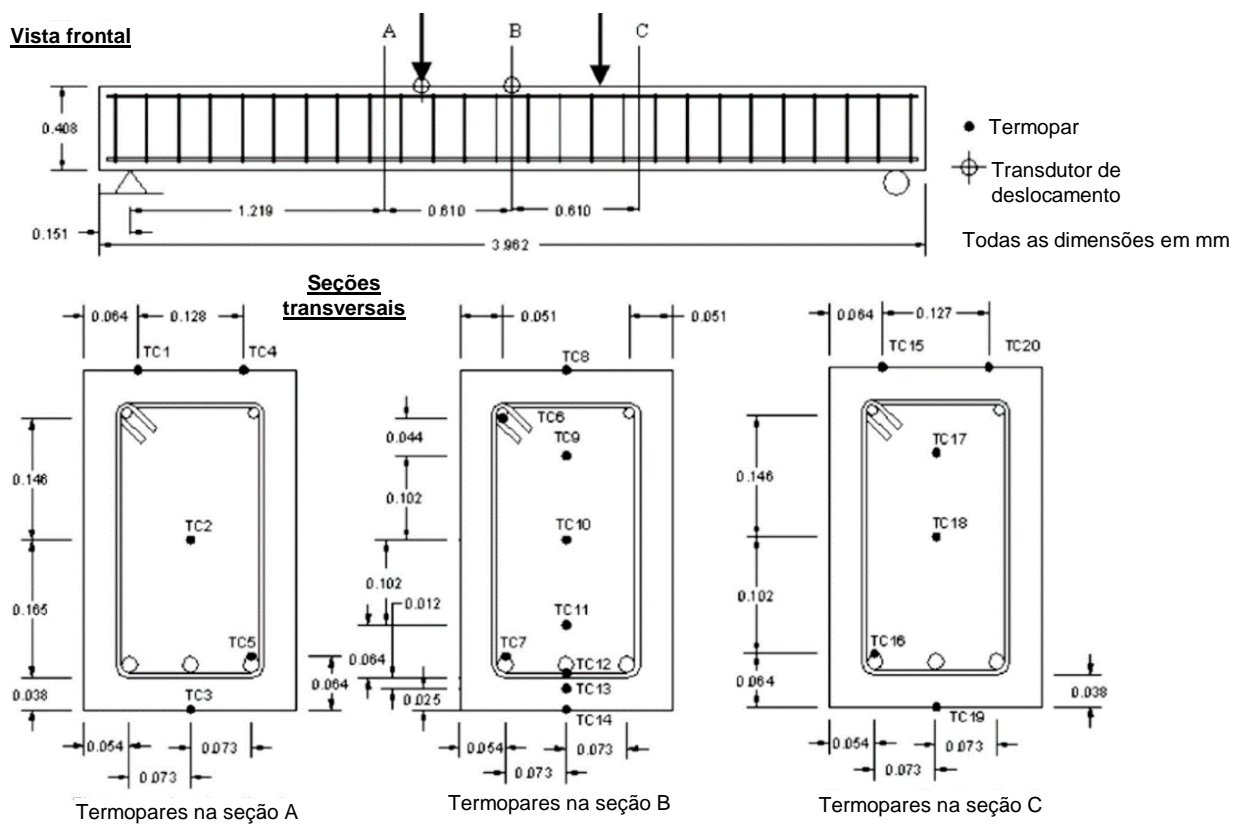

Figura 2.50 - Características das vigas ensaiadas ao fogo por Dwaikat e Kodur (2009b; adaptado). 
Apenas duas das seis vigas foram submetidas à restrição do tipo axial, sendo uma constituída por concreto de resistência convencional e a outra alta resistência. $\mathrm{O}$ aquecimento foi provido por um forno equipado com seis queimadores de gás natural, enquanto a restrição à viga foi imposta pela rigidez do pórtico que circundava o sistema de ensaios composto pelo forno e pela própria viga (Figura 2.51). Os efeitos das restrições rotacionais não foram considerados nesses ensaios, uma vez que o mecanismo de restrição adotado permitia a total rotação dos elementos estruturais em seus apoios.

Os autores voltaram a comprovar, agora de modo experimental, que as restrições à expansão longitudinal das vigas melhoram o desempenho dessas frente à ação do fogo. Também verificaram que o aumento da força de restrição axial se mostrou menor na viga produzida com concreto de alta resistência pelo fato dessa ter sofrido efeitos consideravelmente severos de spalling logo no início do ensaio. A degradação da viga por conta desse fenômeno fez com que a rigidez axial que estava sendo imposta a ela fosse reduzida e, por conseguinte, as forças axiais foram mais brandas quando comparadas às desenvolvidas na viga com concreto convencional, conforme ilustra a Figura 2.52. Aspectos pós-ensaio das vigas com concretos de diferentes resistências podem ser visualizados na Figura 2.53.

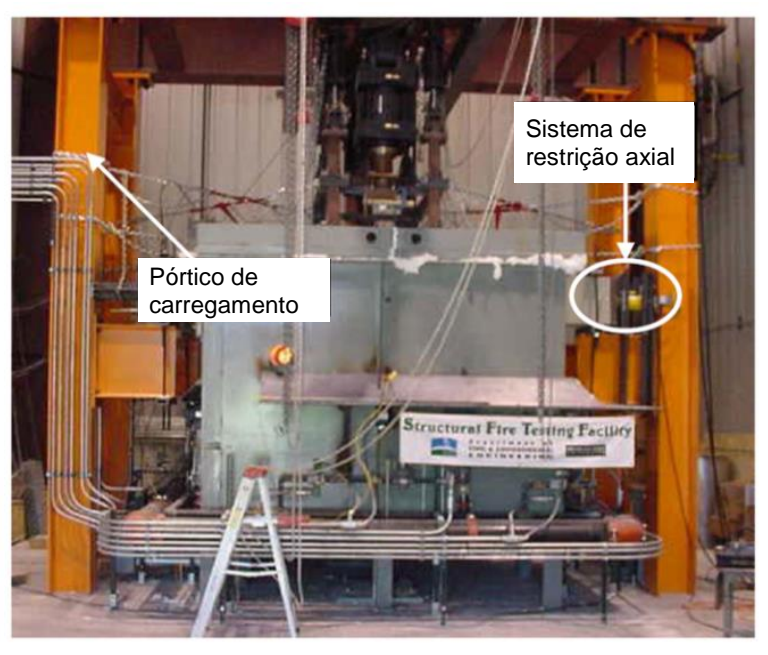

Figura 2.51 - Leiaute de ensaios adotado por Dwaikat e Kodur (2009b) para a análise de vigas de concreto armado aquecidas (adaptado).

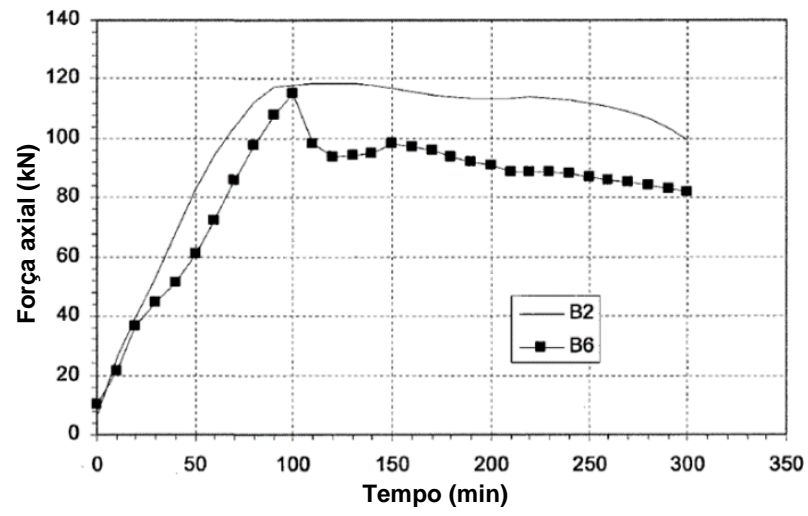

Figura 2.52 - Desenvolvimento de forças axiais em vigas produzidas com concreto de resistências normal (B2) e alta (B6) (DWAIKAT, 2009; adaptado). 


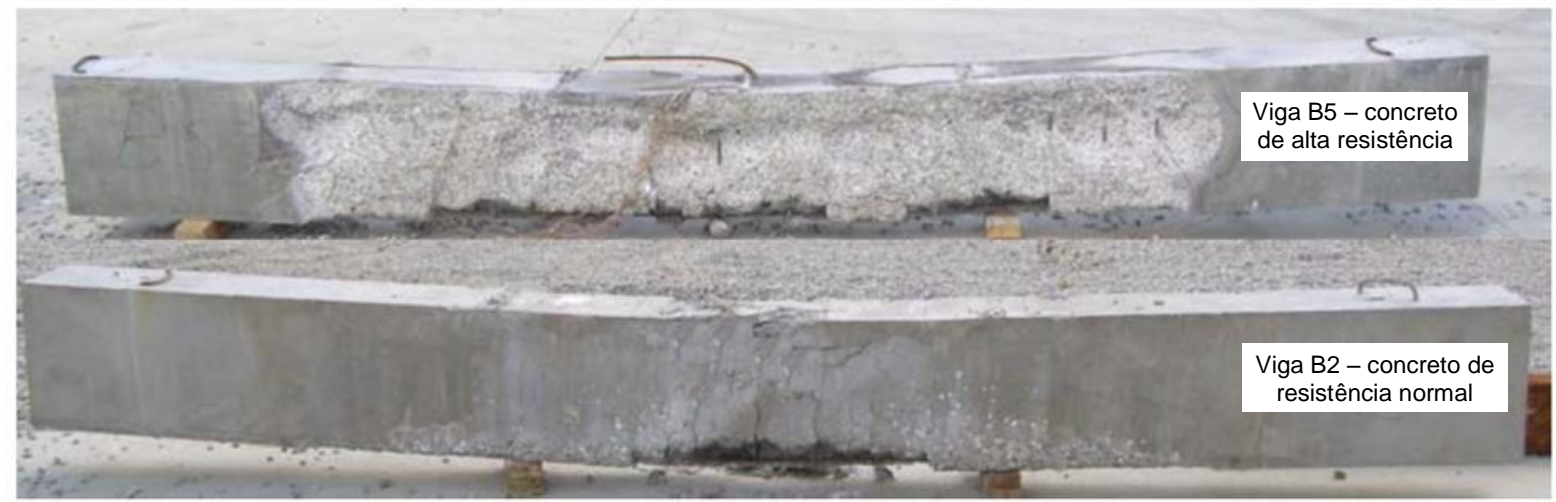

Figura 2.53 - Aspecto pós-incêndio de vigas de concreto com alta resistência, em que os efeitos de spalling foram marcantes, e com resistência normal (DWAIKAT; KODUR, 2009b; adaptado).

\subsubsection{Estudos numéricos}

Chythanya (2009) analisou e comparou o comportamento ao fogo de vigas com diferentes condições de apoio, haja vista que o tipo e intensidade das restrições dependem, entre outros, desse parâmetro. A autora modelou peças simplesmente apoiadas, biapoiadas, biengastadas e em balanço por intermédio do ALGOR (referência do manual não disponibilizada), programa de computador que utiliza o método dos elementos finitos em seus dois módulos: "transferência de calor em regime transiente" e "simulação mecânica". As vigas, representadas por modelos tridimensionais, foram submetidas a um aquecimento com duração de três horas, conforme a curva ASTM E119 de 2000, ao longo de três de suas superfícies (laterais e inferior), e a um carregamento uniformemente distribuído. O módulo térmico do programa foi validado pela comparação de seus resultados aos obtidos pelo modelo numérico apresentado em Kodur e Dwaikat (2008a).

A autora apresentou um trabalho numérico mais simples, haja vista que alguns parâmetros importantes não foram admitidos na sua pesquisa. Nas peças biapoiadas e biengastadas, por exemplo, representativas de modelos que apresentam impedimento às deformações de origem 
térmica tanto axiais quanto rotacionais, não foram aplicadas ou molas ou outro sistema para caracterizar as ligações semirrígidas entre vigas e pilares. Por conseguinte, os diferentes níveis de restrição aos deslocamentos horizontais e aos giros usualmente impostos pelos apoios encontrados na prática não foram avaliados. Ademais, Chythanya (2009) não fez nenhuma referência à consideração da fissuração do concreto nas análises via ALGOR, o módulo mecânico do programa não foi validado a partir da comparação a resultados provenientes de outra natureza e, apesar de terem sido analisadas tensões, deformações, flechas e outros deslocamentos para cada uma das vigas de estudo, não foram estabelecidos os critérios de ruptura. Logo, os tempos de resistência ao fogo relativos aos diferentes casos não foram calculados e comparados e, consequentemente, não foram verificados os efeitos das restrições no desempenho ao fogo das vigas. $\mathrm{O}$ desenvolvimento das forças de restrição axiais ao longo do tempo para determinados modelos também não foram apresentados.

Biondini e Nero (2006) apresentaram um modelo numérico para a análise não linear de estruturas de concreto armado aquecidas, fundamentado no método dos elementos finitos, no qual houve um diferencial na formulação adotada: os autores aplicaram uma classe especial de algoritmos evolutivos, denominados de autômatos celulares, com o objetivo de analisar os processos de transferência de calor por condução, convecção e radiação e, ainda, acoplar a análise térmica à mecânica. Eles confirmaram a precisão da análise térmica comparando os campos de temperaturas, para determinadas seções de concreto, a valores fornecidos pelos ábacos de isotermas do Eurocode 2 parte 1-2 (2004). Validaram a análise mecânica confrontando os resultados numéricos provenientes da análise de uma viga simplesmente apoiada, com seção retangular aquecida em três faces pela curva ASTM E119 e submetida a carregamento uniformemente distribuído, aos resultados experimentais de Hertz (1985) e a estimativas obtidas pelo método simplificado de Hertz, proposto pela norma europeia.

A partir do modelo numérico validado, os autores analisaram o comportamento estrutural de uma viga contínua que foi submetida a cinco diferentes cenários de incêndio, modelados conforme a curva ISO 834, vide Figuras 2.54 e 2.55. Igualmente à Chythanya (2009), não 
foram aplicadas molas axiais ou rotacionais para caracterizar ligações semirrígidas em determinados trechos da viga, totalmente engastada em suas extremidades.

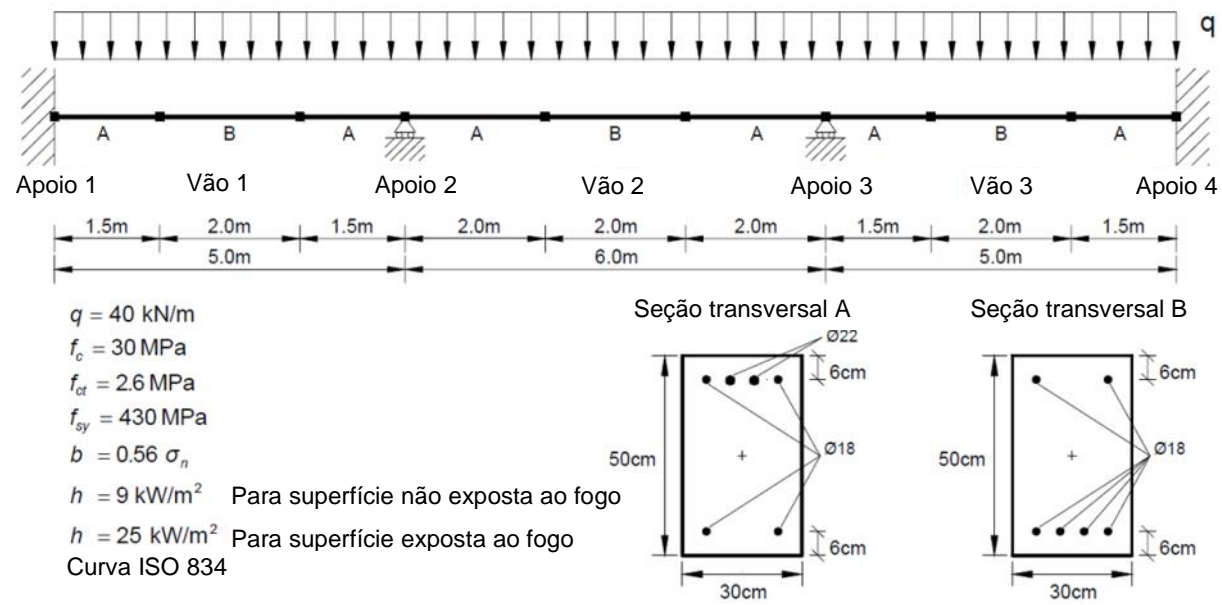

Figura 2.54 - Modelo de viga contínua analisado numericamente por Biondini e Nero (2006; adaptado).

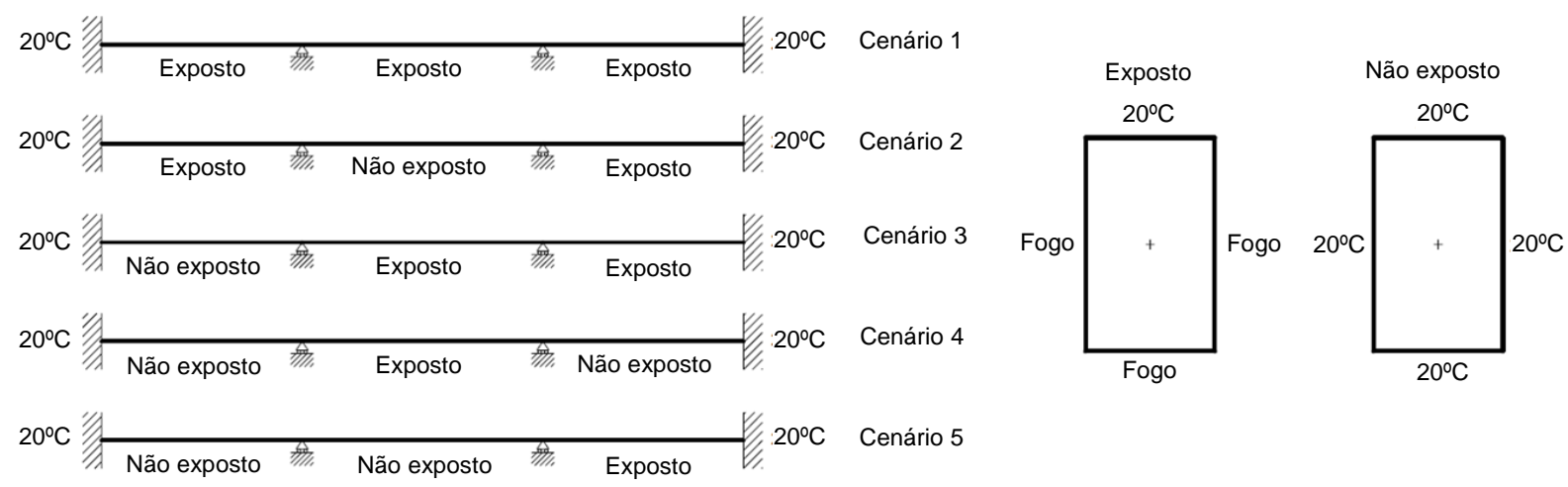

Figura 2.55 - Cenários de incêndio para análise de vigas contínuas (BIONDINI; NERO, 2006; adaptado).

Com base nos resultados, alguns deles indicados nas Figuras 2.56 a 2.58, os autores apresentaram as seguintes conclusões: as flechas em cada um dos vãos das vigas crescem de forma considerável ao longo do tempo de aquecimento e atingem valores máximos nos vãos diretamente expostos ao fogo; no início do incêndio, as forças axiais apresentam valores baixos, que são gerados exclusivamente pela deformação à flexão da viga, mas aumentam ao longo do tempo pelos efeitos oriundos da deformação longitudinal dos vãos; o valor máximo atingido pelas forças de restrição axiais está intimamente relacionado à quantidade de superfícies expostas ao fogo; os momentos fletores solicitantes são notavelmente 
redistribuídos, sobretudo nas zonas diretamente aquecidas; nessas zonas, os momentos negativos das extremidades tendem incialmente a aumentar e os positivos a meio vão a diminuir, contudo, após certo tempo de exposição ao fogo, essa tendência se reverte.
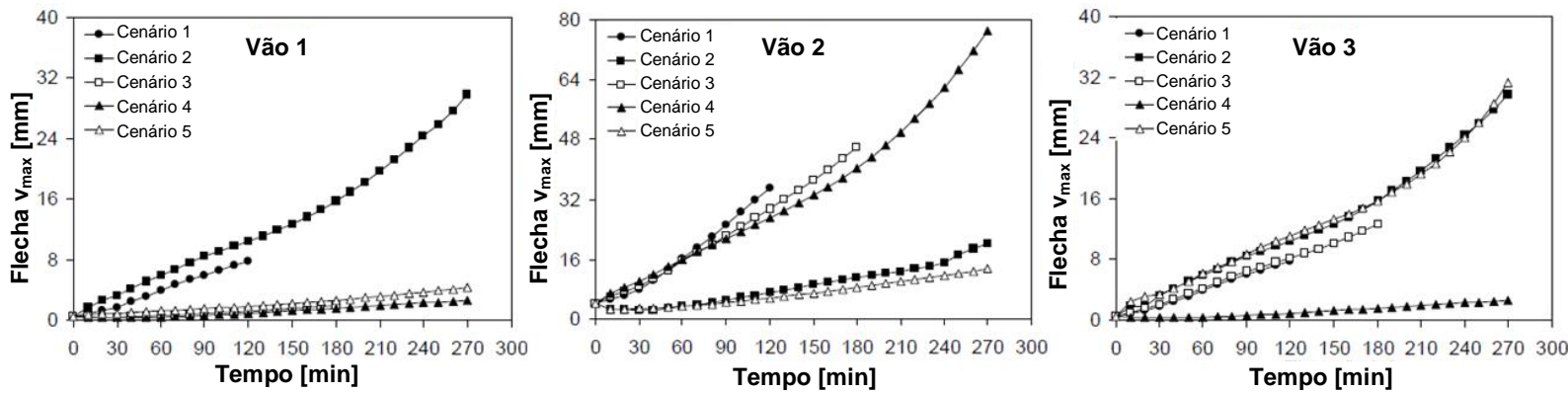

Figura 2.56 - Flechas resultantes dos diferentes cenários de incêndio para os vãos 1, 2 e 3 das vigas contínuas (BIONDINI; NERO, 2006; adaptado).

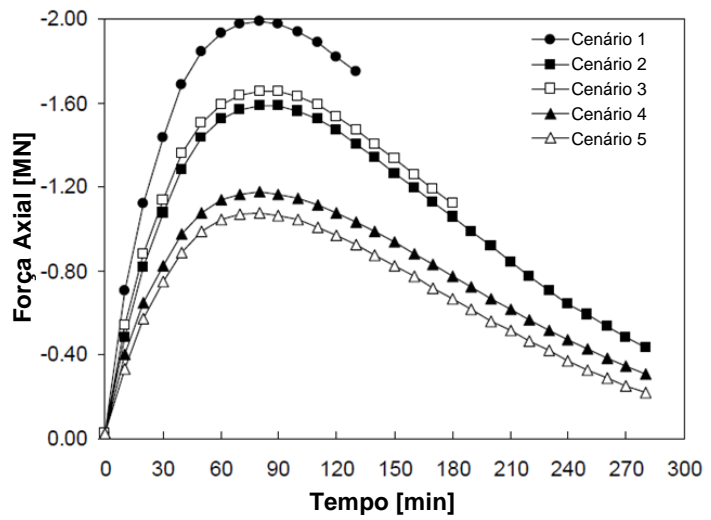

Figura 2.57 - Desenvolvimento de forças de restrição axiais para os diferentes cenários de incêndio adotados para as vigas contínuas (BIONDINI; NERO, 2006; adaptado).
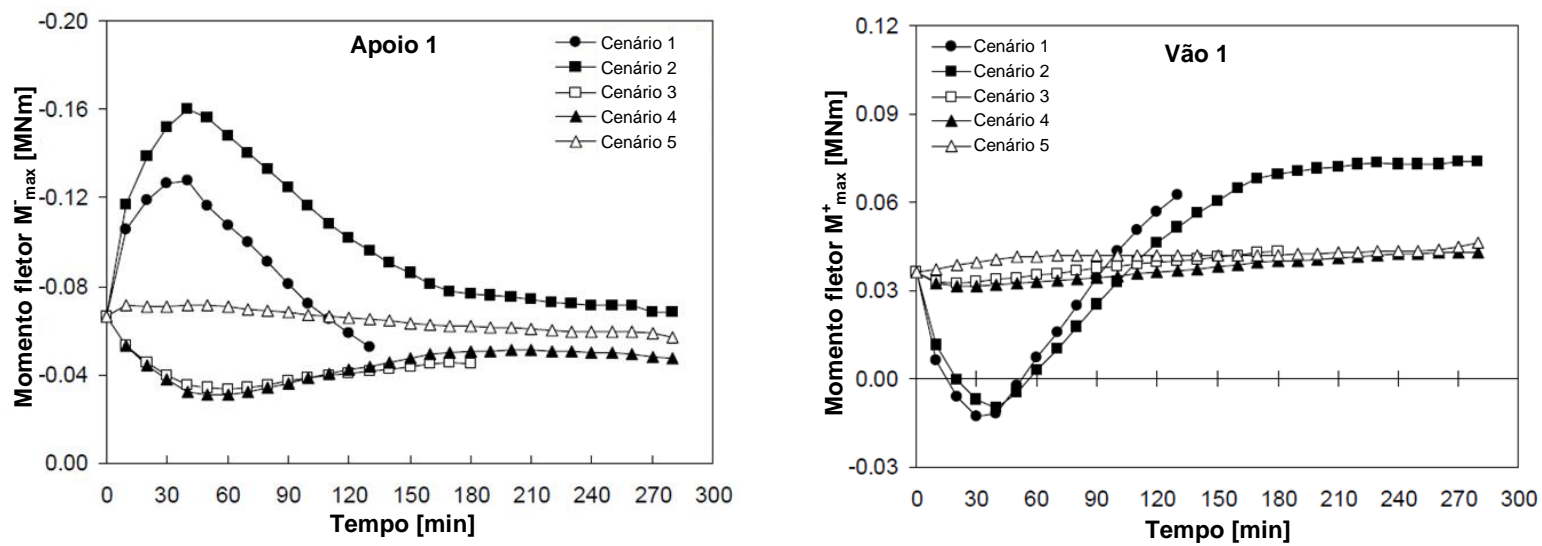

Figura 2.58 - Desenvolvimento dos momentos fletores solicitantes negativos do apoio 1 e positivos a meio vão 1 para os diferentes cenários de incêndio adotados em vigas contínuas (BIONDINI; NERO, 2006; adaptado). 
Biondini e Nero (2006) encerraram o trabalho alertando à questão de que o estudo do desempenho ao fogo de vigas hiperestáticas não deve ser realizado por meio de análises que consideram os danos causados a essas peças apenas ao nível da seção transversal. É necessário avaliar o comportamento dessas estruturas como um todo. Mais tarde, em Biondini e Nero (2011), eles complementaram a pesquisa ao aplicar o modelo numérico desenvolvido à análise de pórticos de concreto armado e vigas de concreto protendido.

Bernhart (2004) verificou a influência de diferentes condições de apoio na resistência ao fogo de vigas de concreto armado submetidas a carregamentos uniformemente distribuídos. Realizou essa análise numérica por meio do programa de computador SAFIR (FRANSSEN; KODUR; MASON, 2002) e aperfeiçoou a modelagem de peças biapoiadas e biengastadas ao aplicar molas para caracterizar restrições axiais parciais - o que não havia sido feito por Chythanya (2008) e Biondini e Nero (2006). Entretanto, a autora não considerou níveis parciais de restrição rotacional, i.e., ou o giro nos apoios estava livre ou totalmente impedido. Assim, os modelos estáticos ilustrados na Figura 2.59 seguiram a mesma linha daqueles adotados por Dwaikat e Kodur (2008).
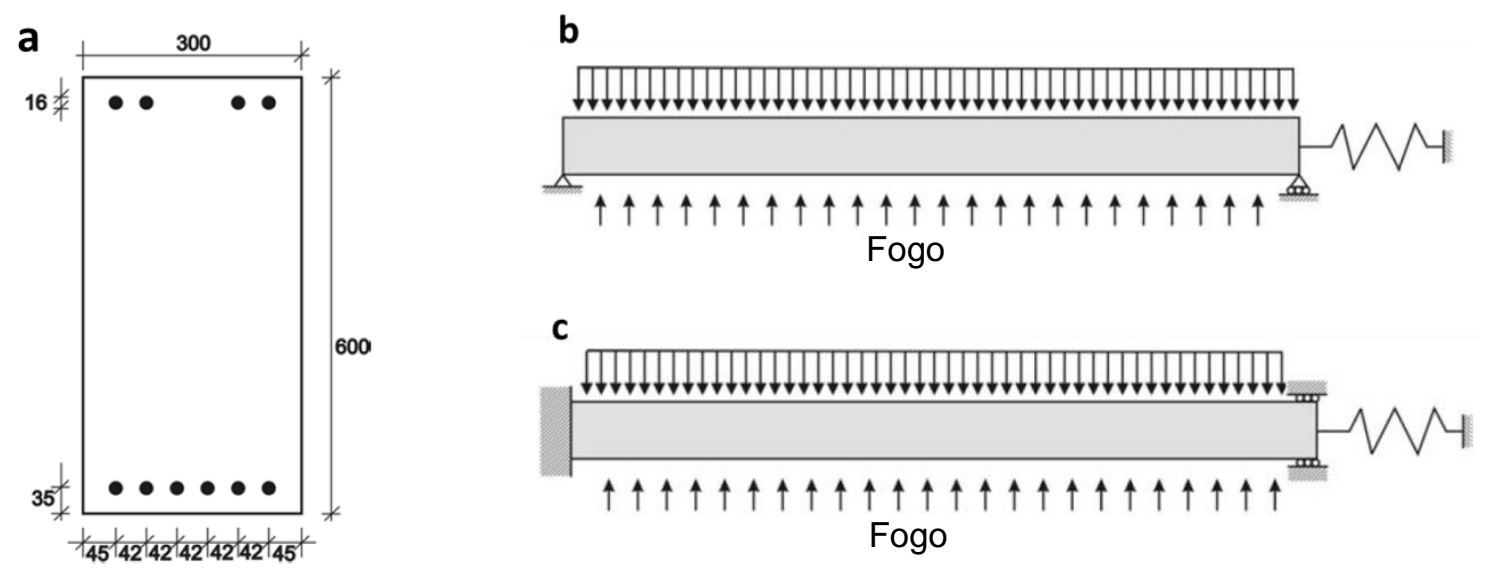

Figura 2.59 - Seção (a) e modelos estáticos das vigas em que se analisou a influência de restrição axial (b) e de restrições axial e rotacional (c) (BERNHART; 2004; adaptado).

Os desenvolvimentos das forças axiais, das flechas e dos momentos fletores solicitantes das vigas submetidas a restrições apenas do tipo axial estão apresentados na Figura 2.60. Além dos variados níveis de rigidez, consideraram-se casos limites: viga simplesmente apoiada e 
totalmente restringida axialmente (biapoiada). De forma similar à Dwaikat e Kodur (2008) na Figura 2.48, a autora verificou que maiores níveis de restrição axial geram forças de compressão mais elevadas, menores flechas e, ainda, que as vigas sujeitas a níveis superiores a 50\% apresentam decaimento da força de compressão após ter sido atingido o seu valor máximo. Também concluiu, portanto, que as forças provenientes da restrição axial são, na maior parte dos casos, favoráveis a resistência ao fogo das vigas, pois atuam como forças de protensão, aumentando a capacidade à flexão das mesmas. Mostraram-se beneficiadas por tal efeito as peças submetidas a níveis médios de rigidez, que são justamente aqueles impostos às vigas presentes em edifícios reais, e por isso essas foram escolhidas para traçar as conclusões. Já as vigas que foram sujeitas a rigidezes axiais muito elevadas acabaram por gerar, além de maiores forças axiais, flechas e momentos solicitantes que cresceram de forma mais rápida (vide curvas "500\%" e "apoio duplo-apoio duplo" dos gráficos).
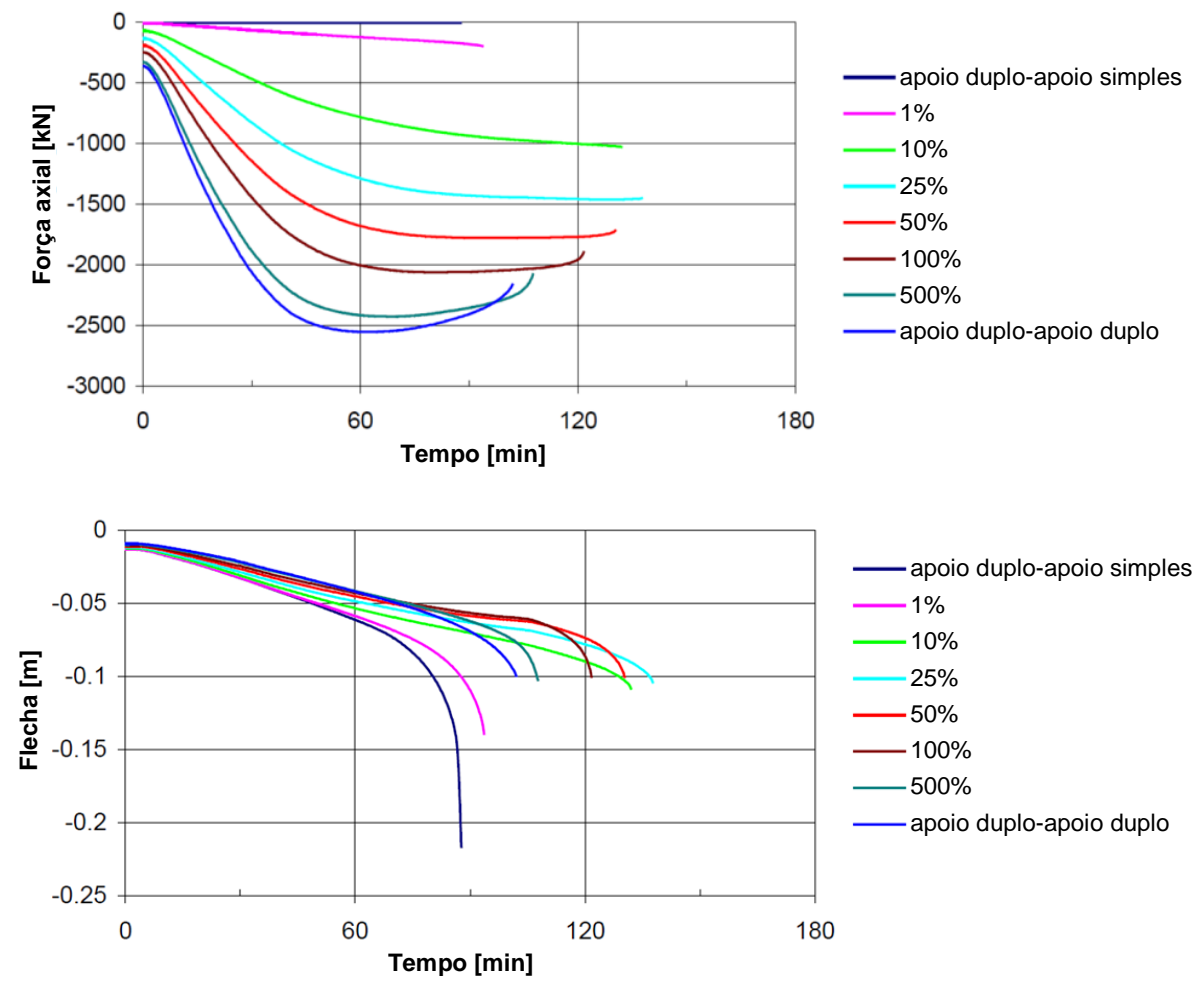

Figura 2.60 - Evolução de forças axiais, flechas e momentos fletores solicitantes nas vigas com restrições apenas axiais - modelo b da Figura 2.59 - (BERNHART, 2004; adaptado) (continua). 


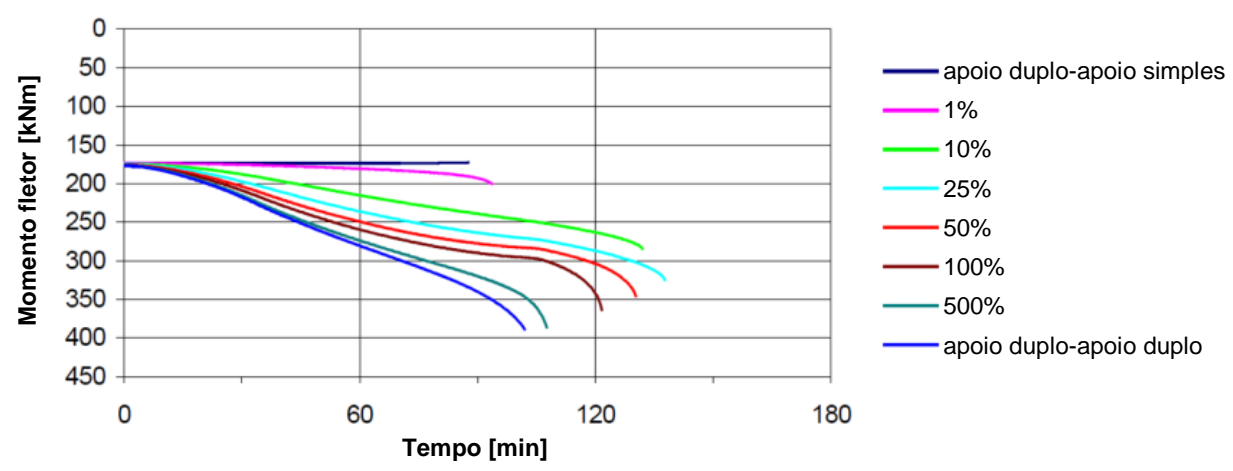

Figura 2.60 - Evolução de forças axiais, flechas e momentos fletores solicitantes nas vigas com restrições apenas axiais - modelo b da Figura 2.59 - (BERNHART, 2004; adaptado) (conclusão).

Na Figura 2.61, apresentam-se os desenvolvimentos das forças axiais, flechas e momentos fletores solicitantes positivos e negativos das vigas submetidas a restrições axiais parciais e totalmente restringidas ao giro. Também foram considerados casos limites, de viga totalmente livre para se expandir na direção longitudinal em um apoio (engaste-engaste deslizante) e totalmente restringida axial e rotacionalmente (biengastada). Porém, a autora tomou suas conclusões com base nos valores de rigidez axial mais encontrados na prática, da mesma forma que no caso anterior. Mais uma vez em consonância a Dwaikat e Kodur (2008), concluiu que a introdução de restrições rotacionais reduzem as flechas das vigas e aumentam as resistências ao fogo, por conta da redistribuição de momentos. Para essas situações, também verificou que maiores níveis de restrição na direção axial resultaram em forças de compressão mais elevadas.

Quanto aos diagramas traçados para os momentos fletores solicitantes, observou que para as vigas com nível de restrição axial superior a $10 \%$ os momentos negativos dos apoios inicialmente crescem bem rápido até que atingem um valor de pico e, em seguida, decrescem. Enquanto isso, os positivos diminuem e após certo limite aumentam. Essa mesma tendência foi verificada por Biondini e Nero (2006), na Figura 2.58, para vigas contínuas submetidas tanto a restrições axiais quanto rotacionais, igualmente às vigas de Bernhart (2004). Segundo a autora, os valores de pico dos momentos negativos são atingidos quando trechos das barras da armadura longitudinal inferior localizadas na região dos apoios alcançam seus respectivos limites à compressão. Desse ponto em diante, os momentos negativos então diminuem porque 
as capacidades resistentes à flexão das vigas nessas seções foram reduzidas. Após a fase mais acentuada de decaimento dos mesmos, a taxa de redução passa a ser mais lenta por conta das temperaturas das armaduras, que já ultrapassaram $700{ }^{\circ} \mathrm{C}$. A partir desse valor, a queda de resistência do aço é mais branda e, por conseguinte, acontece o mesmo com a redução da capacidade resistente à flexão da seção transversal. Nesse estágio, o aumento dos momentos positivos é mais rápido do que a diminuição dos negativos pelas forças axiais atuantes nos apoios, que passam a impor momentos positivos adicionais.
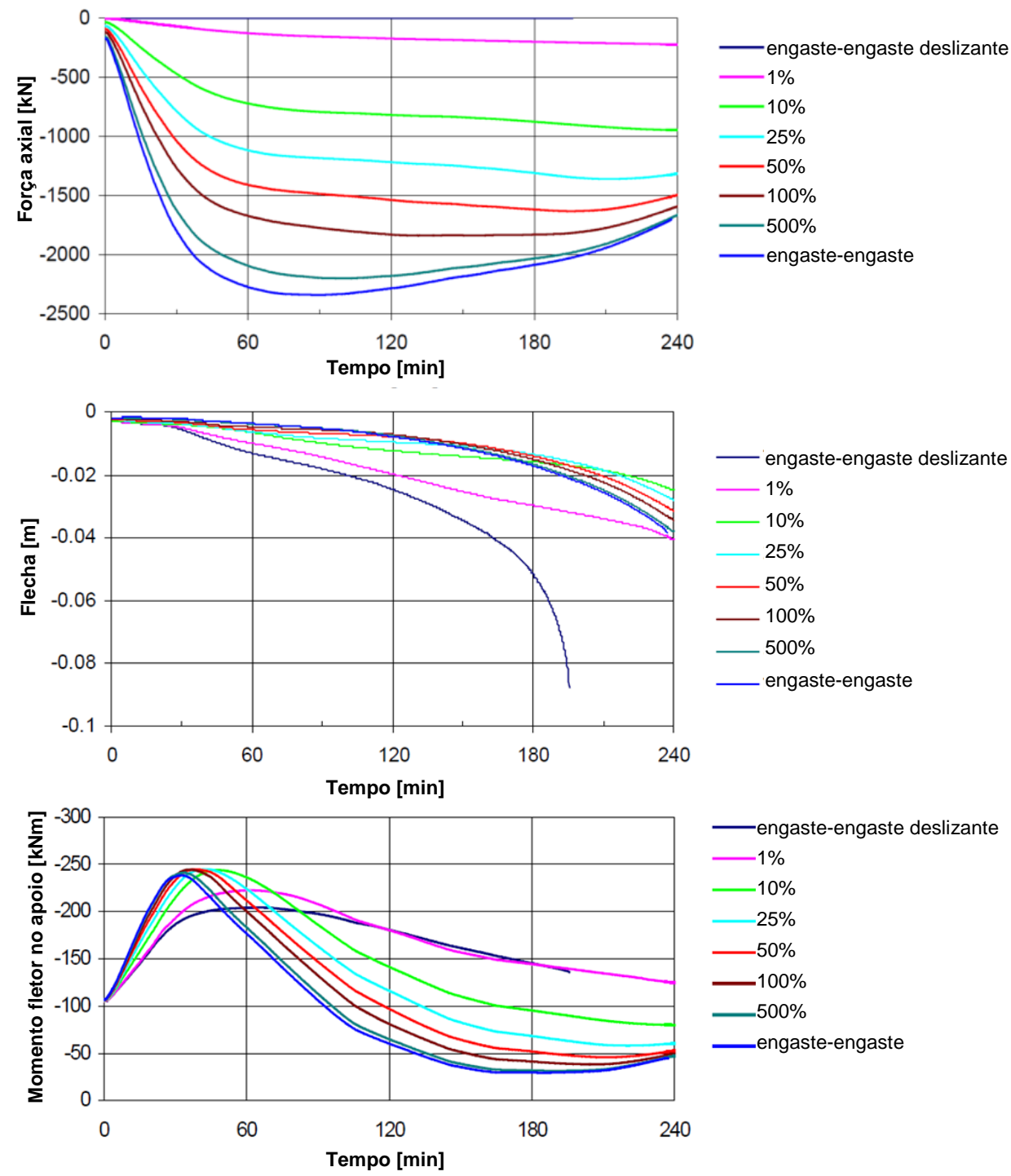

Figura 2.61 - Evolução de forças axiais, flechas, momentos negativos nos apoios e positivos a meio vão nas vigas com restrições axiais parciais e totalmente restringidas a rotações - modelo c da Figura 2.59 (BERNHART, 2004; adaptado) (continua). 


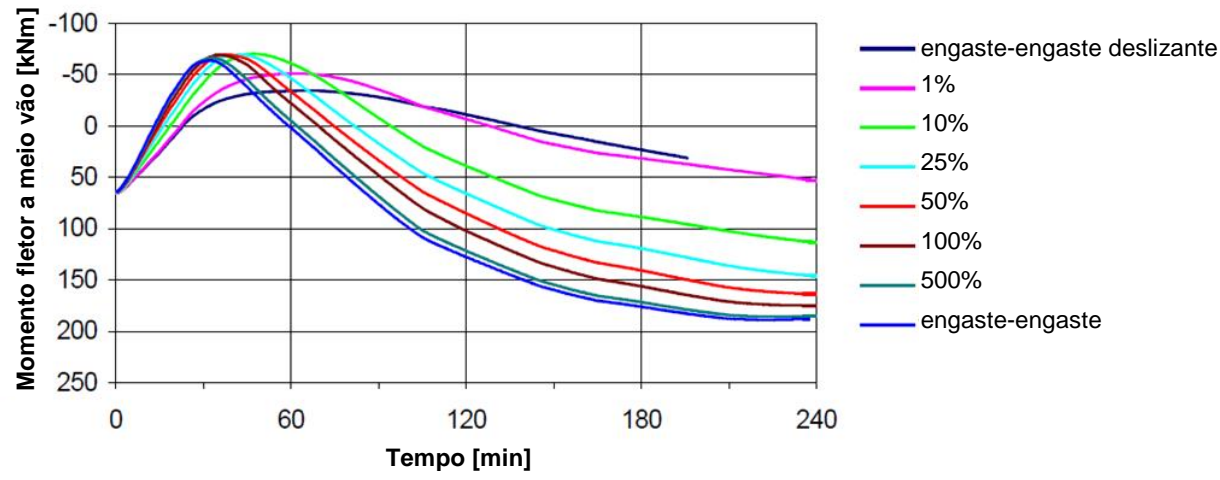

Figura 2.61 - Evolução de forças axiais, flechas, momentos negativos nos apoios e positivos a meio vão nas vigas com restrições axiais parciais e totalmente restringidas a rotações - modelo c da Figura 2.59 (BERNHART, 2004; adaptado) (conclusão).

Na pesquisa de Bernhart (2004), ainda foram analisados alguns modelos de vigas contínuas, com dois e três vãos. Para essa etapa, os efeitos de diferentes comprimentos das armaduras negativas situadas nos apoios foram estudados. Também foram avaliados casos de vigas contínuas (sem molas axiais) expostas a curvas de incêndio com fase de resfriamento. À exceção dessas, as seções transversais retangulares das vigas analisadas foram submetidas a aquecimento conforme incêndio-padrão ISO 834, em três faces.

O estudo apresentado por Bernhart (2004) se mostrou mais avançado quando comparado ao de Chythanya (2009) e Biondini e Nero (2006), devido à consideração das ligações viga-pilar semirrígidas na direção axial, e, ademais, pela verificação de momentos fletores solicitantes. Porém, da mesma forma que Dwaikat e Kodur (2008), não foram aplicadas molas para caracterizar diferentes rigidezes à rotação. Outro avanço em relação ao estudo puramente numérico de Chythanya (2009) consistiu na consideração da fissuração do concreto. Nas análises termomecânicas realizadas pelo SAFIR, essa pode ser considerada por meio dos modelos constitutivos do material que têm base na teoria da fissuração distribuída (smeared crack models). Assim, os efeitos da fissuração são "distribuídos" sobre os elementos de concreto, de forma que a rigidez e a resistência são reduzidas quando a tensão de tração excede certo limite (informação via rede) ${ }^{12}$. Apesar disso, as análises mecânicas não foram

\footnotetext{
${ }^{12}$ Informação fornecida por Thomas Gernay, Doutor em Ciências de Engenharia pela Université de Liège Bélgica, via e-mail, em 15 de fevereiro de 2013.
} 
validadas, uma vez que não houve comparação a outros resultados. A precisão do modelo foi aferida apenas para as análises térmicas, pela comparação dos campos de temperaturas das seções transversais obtidos via SAFIR aos calculados com base nos ábacos de isotermas propostos pelo Eurocode 2 parte 1-2 (2004).

Da mesma forma que Bernhart (2004) e Dwaikat e Kodur (2008), nas pesquisas de Riva e Franssen (2008) e Cvetkovska; Todorov e Lazarov (2013) foram analisadas as resistências ao fogo de vigas submetidas a carregamentos uniformemente distribuídos e modeladas com elementos de mola para caracterizar níveis parciais de restrição na direção axial. Ainda de forma similar aos referidos autores, consideraram alguns modelos com apoios totalmente restringidos ao giro, i.e., não adotaram níveis parciais de rigidez à rotação. A conclusão geral obtida nesses estudos também foi concordante: a introdução de restrições às deformações de origem térmica melhora o desempenho das vigas de concreto armado expostas ao fogo.

Riva e Franssen (2008) analisaram as vigas ilustradas na Figura 2.62 por meio do programa de computador Abaqus (ABAQUS, versão de 2006), adotando uma malha de elementos de fibras para discretização e admitindo nas análises os efeitos da fissuração do concreto. Deslocamentos verticais e axiais, forças de compressão axiais e de cisalhamento e momentos fletores solicitantes foram alguns dos parâmetros avaliados. Na Figura 2.63, ilustram-se as relações entre rigidez da mola axial e força de restrição/deslocamento na direção axial e entre rigidez da mola axial e flecha correspondentes aos modelos estudados. Em consonância às pesquisas anteriores, maiores rigidezes geram maiores forças axiais e menores flechas. Geram, ainda, menores deslocamentos na direção axial da viga (menor alongamento do vão).

Em uma das conclusões do trabalho, os autores comentaram que os métodos de dimensionamento de vigas que não admitem os efeitos das forças de restrição axiais conduzem a resultados bastante conservadores dos tempos de resistência ao fogo. Os autores verificaram essa questão mediante o uso do método tabular indicado pelo Eurocode 2 parte 12 (2004). Ainda propuseram um método simplificado para a análise não linear de vigas hiperestáticas de concreto em situação de incêndio, fundamentado em uma análise elastoplástica incremental, com o objetivo de serem estimadas suas flechas e capacidades de 
carga. Esse método inclui um procedimento para o cálculo aproximado da força de restrição axial das vigas. É importante mencionar que Riva e Franssen (2008) não confrontaram os resultados das suas análises termomecânicas àqueles provenientes de outras referências.

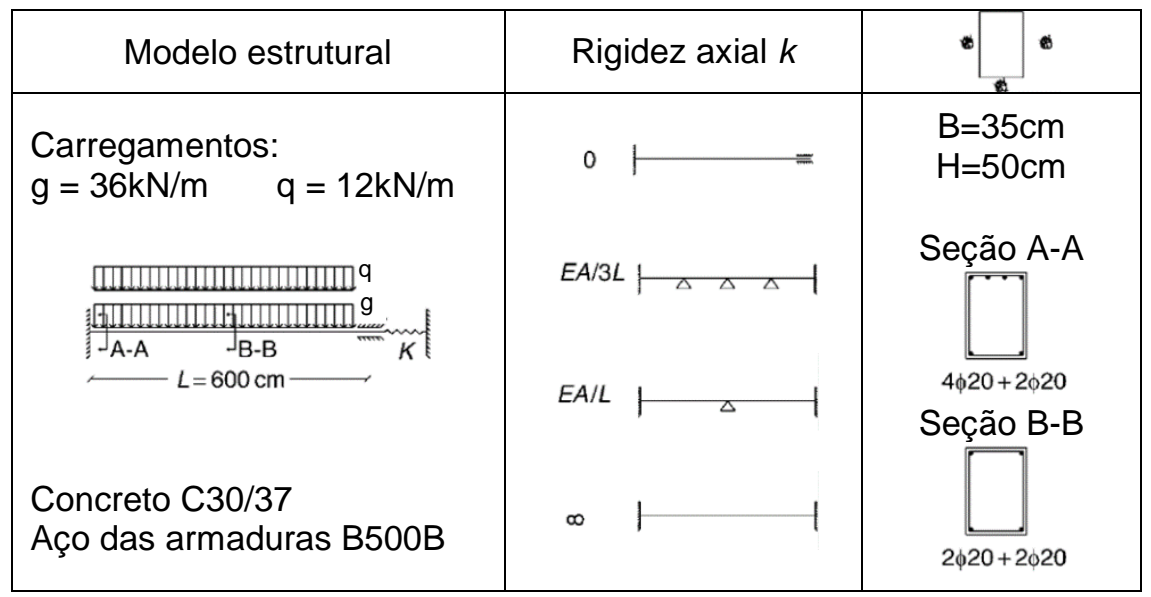

Figura 2.62 - Modelos de vigas com restrições axiais parciais e totalmente restringidas a rotações analisados por Riva e Franssen (2008; adaptado).
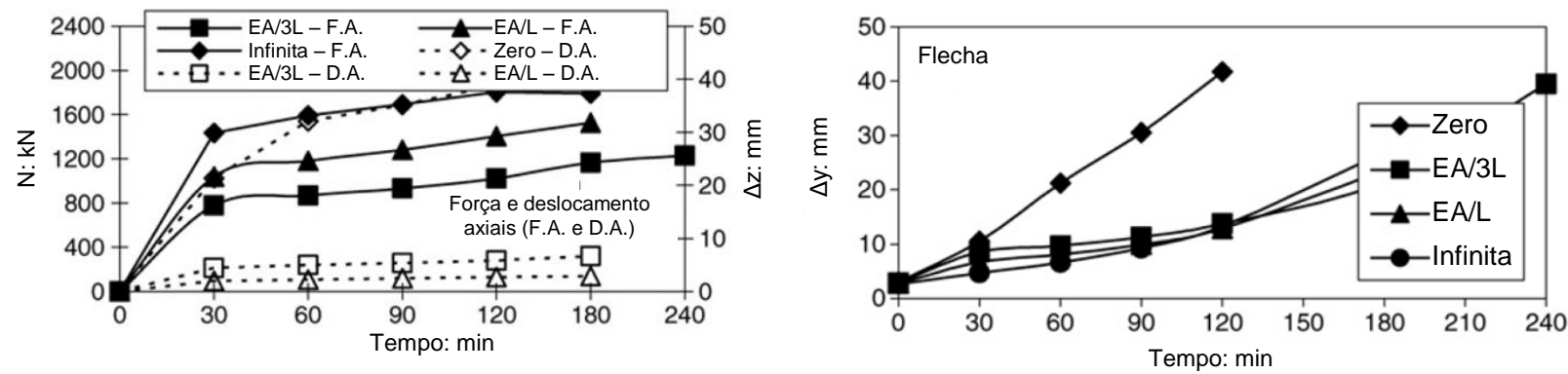

Figura 2.63 - Relações de diferentes rigidezes de molas axiais com as forças de restrição/deslocamentos axiais e as flechas, respectivamente, dos modelos de vigas analisados por Riva e Franssen (2008; adaptado).

As análises numéricas de Cvetkovska; Todorov e Lazarov (2013) foram conduzidas com o auxílio do programa de computador FIRE (CVETKOVSKA, 2002), no qual os módulos FIRE-T e FIRE-S, ambos fundamentados no método dos elementos finitos, realizam, respectivamente, análises térmicas não lineares em regime transiente e análises mecânicas não lineares, sendo as últimas a partir das relações tensão-deformação. O módulo FIRE-S foi proposto originalmente por Iding; Bresler e Nizamuddin (1977), sob a denominação FIRE-RC II. O mesmo foi adaptado pelos autores dessa pesquisa e leva em conta a degradação das seções transversais devido à fissuração ou esmagamento do concreto, efeitos da fluência dos 
materiais, mudanças de geometria devido à exposição ao fogo, dentre outros aspectos que podem ser pertinentes à análise não linear desses elementos.

Apesar de Cvetkovska; Todorov e Lazarov (2013) também não terem confrontado os resultados das suas análises termomecânicas aos provenientes de outras fontes, essa pesquisa apresentou uma particularidade interessante: os autores justificaram os níveis de restrição adotados nos modelos numéricos. Dwaikat e Kodur (2008) também haviam comentado que a rigidez axial igual a $200 \mathrm{kN} / \mathrm{mm}$ adotada por eles em determinado estudo de caso era decorrente de condições de contorno mais rígidas, que poderiam ser equivalentes a uma parede de cisalhamento como elemento circundante, e que o nível mais brando de $5 \mathrm{kN} / \mathrm{mm}$ era representativo de pilares menos rígidos localizados ao redor da viga. Apesar disso, os autores não apresentaram o cálculo desses valores, como feito nesse estudo mais recente.

A fim de simular situações mais condizentes à realidade, admitindo condições de contorno que fossem semelhantes a vigas presentes em edifícios correntes, Cvetkovska; Todorov e Lazarov (2013) modelaram alguns pórticos a partir do programa de computador SeismoStruc (SEISMOSOFT, 2011), vide Figuras 2.64 e 2.65. Para cada um deles, determinaram intervalos de rigidezes axiais e rotacionais para as quais estariam submetidas as vigas localizadas em diferentes posições. Esse método de analisar as vigas como elementos constituintes de pórticos para determinar os níveis de rigidezes a serem estudados também foi adotado na presente Tese, como será discutido no Capítulo 3 - Análises experimentais.

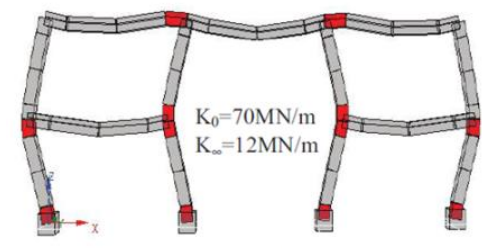

Caso 1

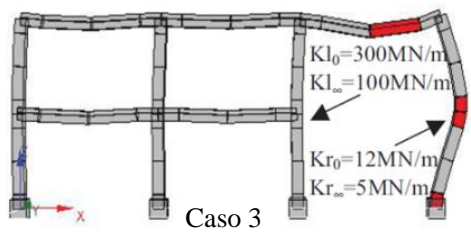

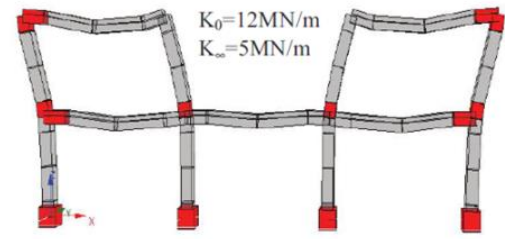

Caso 2

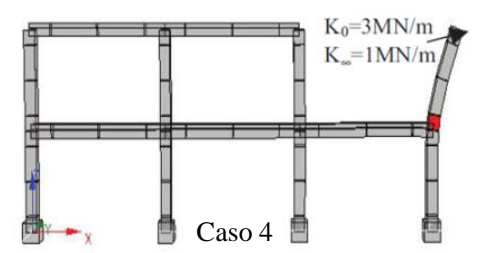

Figura 2.64 - Pórticos modelados por Cvetkovska; Todorov e Lazarov (2013) para o estudo de rigidezes axiais (adaptado). 


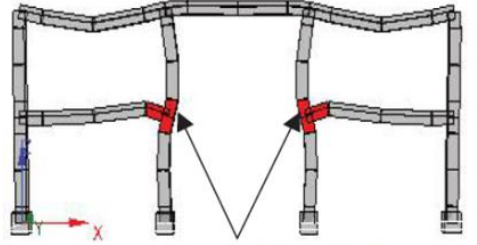

$\mathrm{K}_{\varphi, \mathrm{M}=0-200 \mathrm{kNm}}>165 \mathrm{MNm} / \mathrm{rad}$

$\mathrm{K}_{\varphi, \mathrm{M}=500 \mathrm{kNm}}=60 \mathrm{MNm} / \mathrm{rad}$

Caso 1

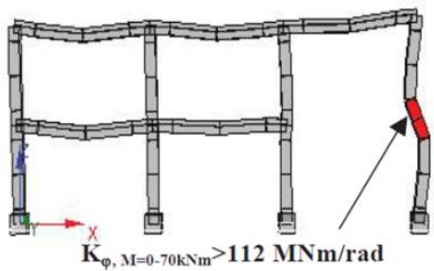

$\mathrm{K}_{\varphi, \mathrm{M}=300 \mathrm{kNm}}=23 \mathrm{MNm} / \mathrm{rad}$

Caso 3

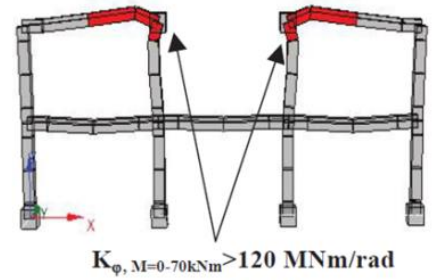

$\mathrm{K}_{\varphi, \mathrm{M}=200 \mathrm{kNm}}=20 \mathrm{MNm} / \mathrm{rad}$ Caso 2

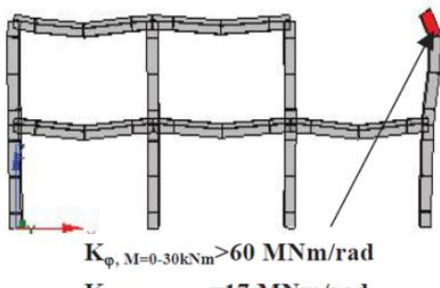

$\mathrm{K}_{\varphi}, \mathrm{M}=100 \mathrm{kNm}=17 \mathrm{MNm} / \mathrm{rad}$ Caso 4

Figura 2.65 - Pórticos modelados por Cvetkovska; Todorov e Lazarov (2013) para o estudo de rigidezes rotacionais (adaptado).

Pontua-se que apesar de os autores terem calculado valores de restrições rotacionais, essas não foram aplicadas às situações de estudo, apenas as do tipo axial. As vigas analisadas por Cvetkovska; Todorov e Lazarov (2013) se encontram ilustradas na Figura 2.66, enquanto o desenvolvimento das forças axiais e as relações entre rigidezes das molas axiais e forças de restrição nas Figuras 2.67 e 2.68. Novamente, maiores rigidezes axiais geraram maiores forças axiais.

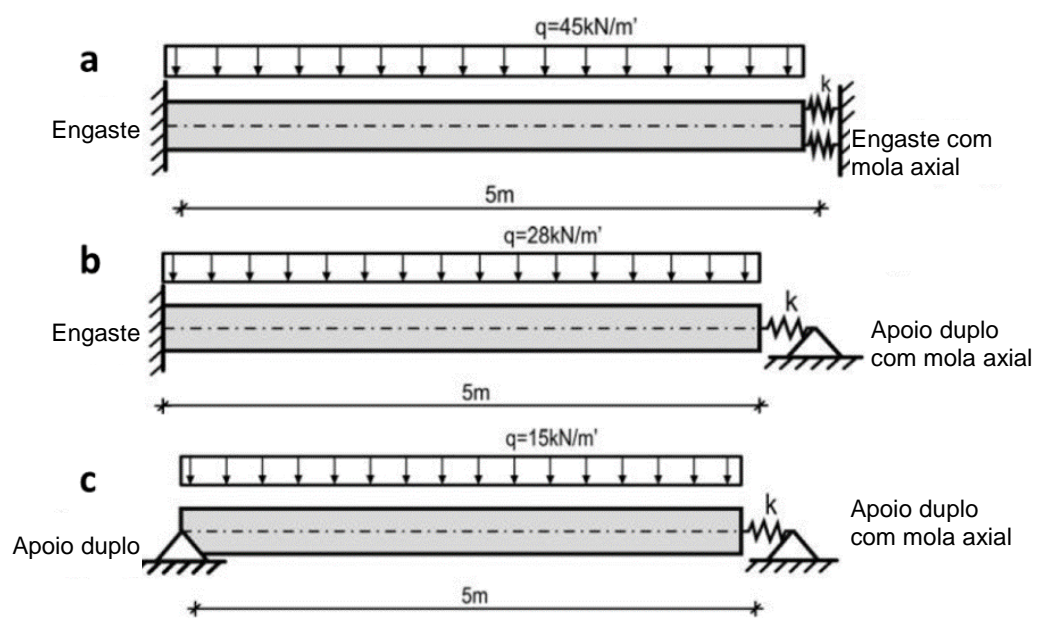

Figura 2.66 - Vigas analisadas por Cvetkovska; Todorov e Lazarov (2013): rotações totalmente impedidas em dois apoios e níveis parciais de restrição axial (a), rotação totalmente impedida em um apoio e níveis parciais de restrição axial (b) e rotações livres e apenas com níveis parciais de restrição axial (c) (adaptado). 

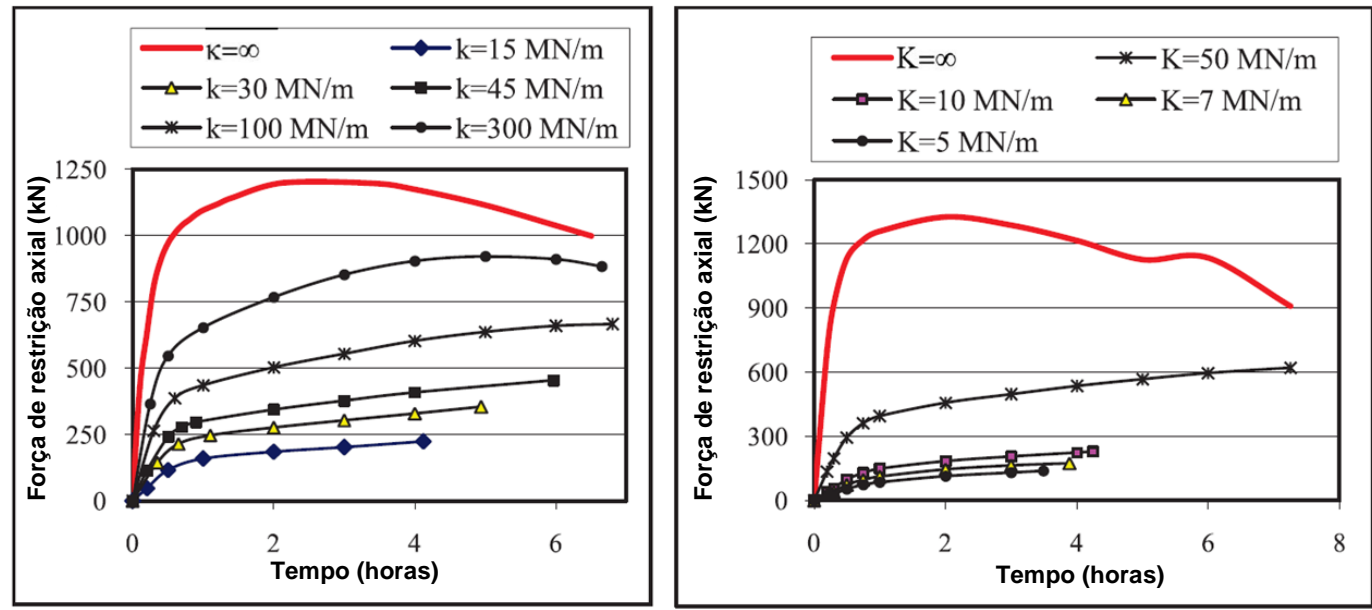

Figura 2.67 - Desenvolvimento de forças de restrição axiais para modelos de vigas a e b da Figura 2.66 (CVETKOVSKA; TODOROV; LAZAROV, 2013; adaptado).
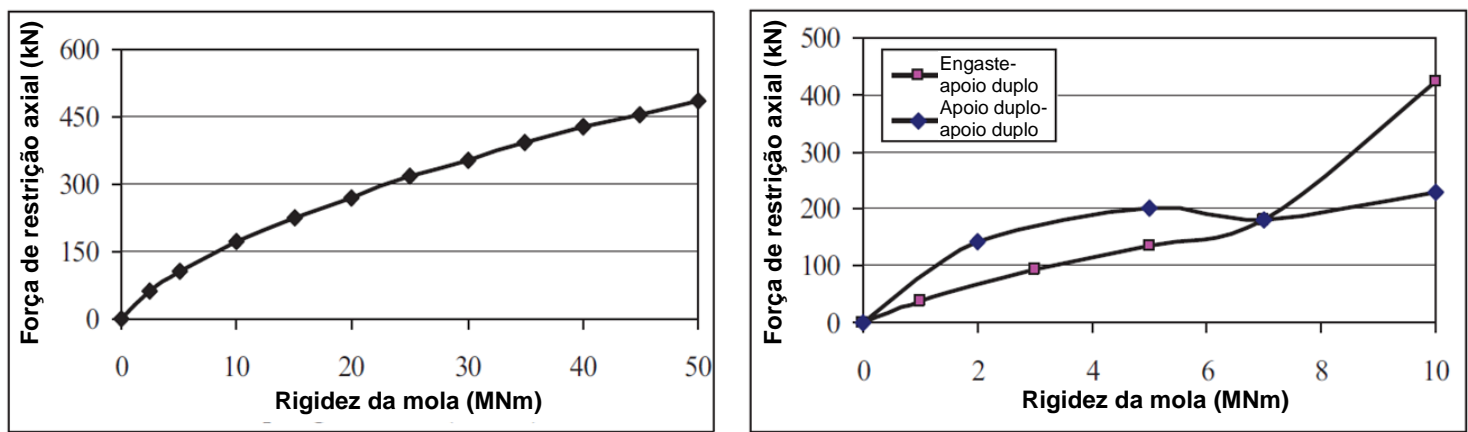

Figura 2.68 - Relação entre diferentes rigidezes de molas axiais e forças de restrição nos modelos de vigas a, b e c da Figura 2.66 (CVETKOVSKA; TODOROV; LAZAROV, 2013; adaptado).

Wu e Lu (2009) apresentaram um modelo de viga restringida diferente daqueles estudados até então pelos autores anteriormente citados. Eles analisaram peças em que foram impostos, por elementos de molas, níveis parciais tanto de restrições axiais quanto rotacionais, como indica o esquema da Figura 2.69. Com base nas referências de Ali e O'Connor (2001) e Yin e Wang (2004), os autores esclareceram que nas estruturas correntes, a restrição axial é imposta às vigas por meio de elementos circundantes a elas, como pilares e partes de pórticos. Esses elementos possuem rigidezes limitadas, de modo que considerar uma viga totalmente restringida na direção axial não retrata a realidade. Além disso, comentaram que os casos de vigas submetidas à restrição axial pura são raramente encontrados na prática. Portanto, na maior parte das situações reais, as restrições do tipo axial estão combinadas a restrições 
rotacionais. Assim, justificaram a importância da análise desse tipo de viga, nesse caso conduzida a partir de um programa de computador concebido por eles, que estipularam o método dos elementos finitos e a aproximação de derivadas por diferenças finitas como bases para a análise térmica e empregaram o princípio dos trabalhos virtuais para a solução da análise mecânica. A fissuração do concreto foi considerada. Os resultados de forças axiais e flechas em função do tempo de exposição ao fogo (ISO 834) para as peças nas quais foram admitidos seis níveis diferentes de restrição rotacional, enquanto a rigidez axial foi mantida igual a $0,05 \mathrm{~kb}$ ("kb" consiste na rigidez axial da viga à temperatura ambiente), estão ilustrados na Figura 2.70. Nos gráficos dessa figura, "kr" representa a rigidez rotacional da viga à temperatura ambiente.

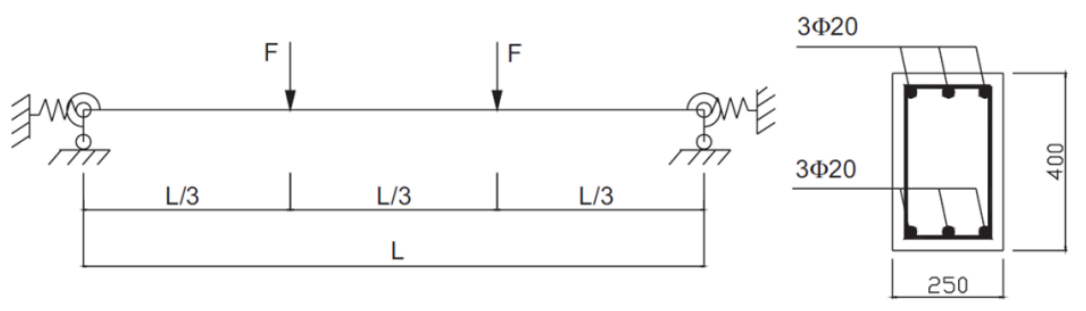

Figura 2.69 - Viga com níveis parciais de restrições axiais e rotacionais estudada por Wu e Lu (2009).

Wu e Lu (2009) concluíram que o efeito da restrição rotacional nos valores atingidos pelas forças axiais não é expressivo, haja vista a proximidade das curvas. Também verificaram que quanto maior o nível de restrição rotacional, menores as flechas das vigas. Isso se justifica por maiores restrições rotacionais gerarem maiores momentos negativos nos apoios, que acabam por reduzir os momentos positivos a meio vão e, consequentemente, os deslocamentos verticais. Logo, para rigidezes rotacionais mais elevadas, a redistribuição de momentos se torna mais efetiva. Antes dessas análises, o modelo numérico concebido por eles foi validado pelos dados experimentais de vigas submetidas a restrições tanto axiais quanto rotacionais presentes no pórtico em escala reduzida analisado por Guo e $\mathrm{Shi}^{13}$ (2003) apud Wu e Lu (2009), uma vez que se relatou a falta de testes de exposição ao fogo em peças com esse tipo de configuração.

\footnotetext{
${ }^{13}$ GUO, Z.; SHI, X. Behaviour of reinforced concrete at elevated temperature and its calculation. Beijing:
} Tsinghua University Press, 2003. 

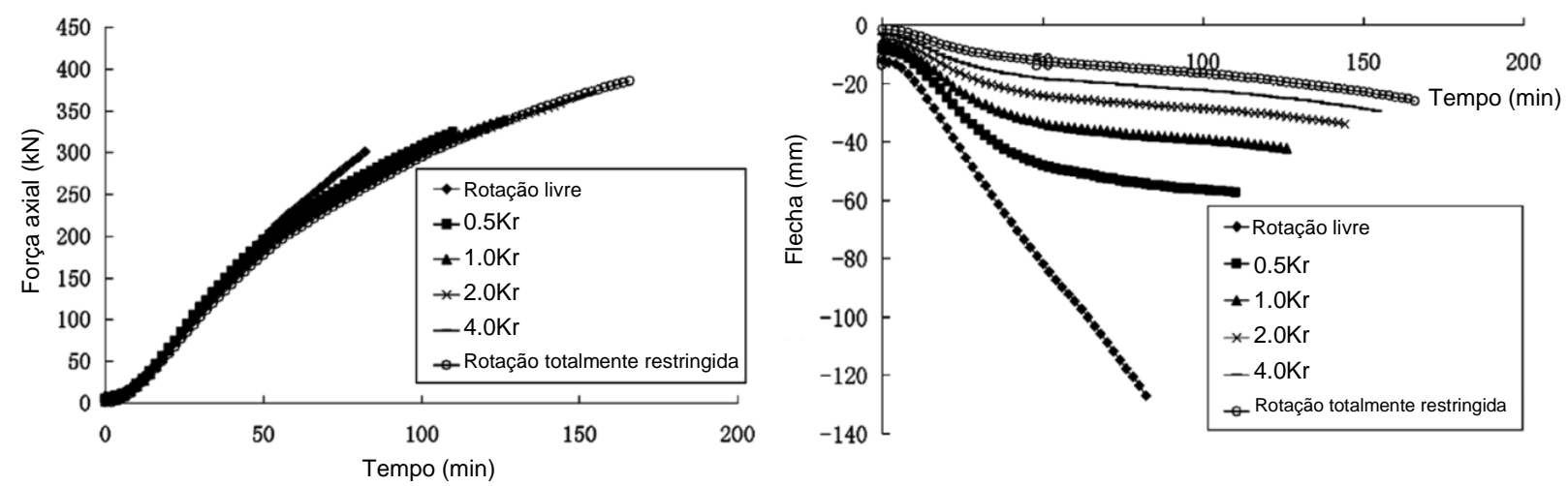

Figura 2.70 - Evoluções de forças axiais e flechas nas vigas analisadas por Wu e Lu (2009; adaptado).

Em um estudo mais recente, Albrifkani e Wang (2016) também analisaram um modelo de viga de concreto armado exposta ao fogo e submetida a níveis semirrígidos de restrições axiais e rotacionais em suas extremidades, porém, a investigação foi mais voltada à ação de catenária, que se desenvolve nas vigas apenas em estágios mais avançados do incêndio, no qual essas já apresentam valores de flechas muito elevados. De acordo com os autores, esse é um mecanismo extremamente importante para que as vigas resistam a colapsos progressivos e, para a sua análise, desenvolveram um método de simulação com elementos finitos explícitos dinâmicos. Essa consistiu na primeira pesquisa a adotar tal método para a análise de vigas de concreto armado restringidas em incêndio e, de acordo com os autores, o grande desafio para a sua implementação consiste na necessidade de se trabalhar com incrementos de tempo muito pequenos, enquanto as análises de incêndio possuem longa duração. Por isso, ao longo do texto, eles indicaram técnicas relacionadas a alguns parâmetros que podem ajudar na aplicação do método. Essas estão relacionadas aos já citados incrementos de tempo (mass scaling), além de fatores de carga (load factoring) e ferramentas que podem ser aplicadas para minimizar efeitos dinâmicos (material damping).

O modelo numérico proposto foi aplicado por intermédio do programa de computador Abaqus (ABAQUS, versão 2013) e sua precisão foi verificada em duas etapas: validação para o comportamento à temperatura ambiente - pela comparação aos resultados experimentais de Yu e Tan $(2013,2014)$, provenientes de ensaios em subconjuntos viga/pilar de pórticos - e validação para a situação de incêndio - comparação aos resultados experimentais de três vigas 
ensaiadas por Dwaikat e Kodur (2009b), sendo duas simplesmente apoiadas e uma com restrição axial -. No entanto, os autores informaram que essas vigas não foram ensaiadas até o instante do aquecimento em que se inicia a ação de catenária e, portanto, a validação do modelo não pôde ser completamente demonstrada. Após essa etapa, eles finalmente adotaram um modelo de viga para analisar o comportamento a altas flechas de vigas restringidas expostas ao fogo. As características da peça, que foi exposta a incêndio ISO 834 em três faces e restringida axial e rotacionalmente em seus apoios por meio de elementos conectores, estão indicadas na Figura 2.71.

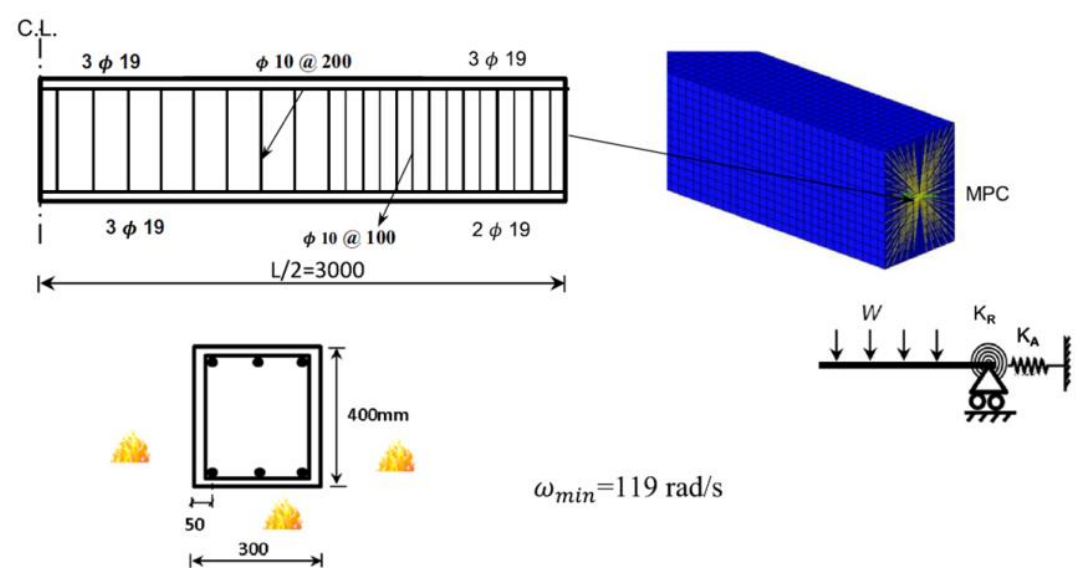

Figura 2.71 - Características da viga submetida a níveis parciais de restrições axiais e rotacionais por Albrifkani e Wang (2016).

Por conseguinte, eles traçaram um gráfico para mostrar o que ocorre nas vigas após a força axial retornar a zero, i.e., atingir o seu valor inicial, e após as flechas atingirem valores muito elevados (Figura 2.72). Albrifkani e Wang (2016) explicaram que as flechas iniciais das vigas são resultantes da sua deformação à flexão e, após as mesmas atingirem o seu limite a tal esforço, a taxa de aumento dos deslocamentos verticais passa a ser mais acelerada, até o instante no qual a ação de catenária é ativada. Esse estágio do comportamento da viga corresponde ao momento em que ocorre a transição da força de restrição, que até então era um esforço de compressão e passa a ser um esforço de tração. Em seguida, a viga entra num estágio de comportamento estável, uma vez que a taxa de aumento das flechas passa a ser praticamente constante e a carga aplicada ao elemento estrutural é resistida principalmente pelas forças de tração da ação de catenária. 


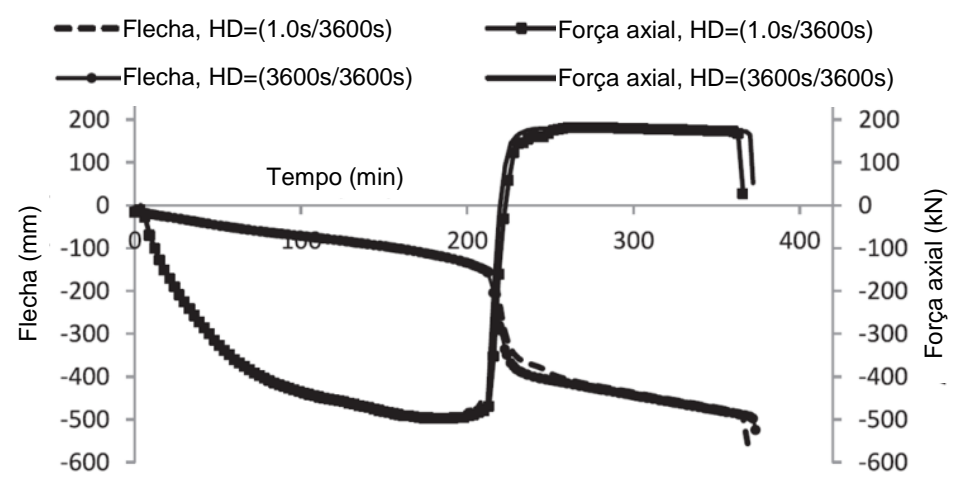

Figura 2.72 - Desenvolvimento de forças axiais e flechas em função do tempo em viga de concreto armado restringida analisada numericamente por Albrifkani e Wang (2016; adaptado).

Apesar de essa pesquisa ser extremamente interessante e ter adotado uma modelagem mais real para as vigas, uma vez consideradas restrições axiais e rotacionais diferentes de $100 \%$, as suas conclusões foram mais voltadas ao estudo da aplicação do modelo inédito desenvolvido por Albrifkani e Wang (2016) e não à análise propriamente dita do comportamento das vigas restringidas, sobretudo durante o período que antecede a ação de catenária. Esse estágio precedente é justamente o abordado no escopo desta Tese, pois segundo as normas voltadas a projeto, a resistência ao fogo das vigas já foi atingida quando da ocorrência de flechas exageradas e, além disso, esse é um comportamento extremo, difícil de ser acompanhado por meio de ensaios em laboratório. Na campanha experimental da presente Tese, por exemplo, não se atingiu esse estágio. Apenas em alguns ensaios, foi possível verificar o retorno da força axial a valores pequenos, contudo, em etapa anterior ao surgimento de grandes flechas.

Kodur e Pakala (2010) desenvolveram um método, com base no princípio da energia equivalente, para avaliar o tempo de resistência ao fogo de vigas submetidas a cenários reais de incêndio. Esse método estima um "tempo equivalente", mediante a comparação entre as energias transferidas durante esses tipos de cenários a outros padronizados. O cálculo é realizado da seguinte forma: parte-se do princípio que exposições ao fogo apresentarão a mesma severidade se transferirem a mesma quantidade de energia para a viga que está submetida ao sinistro. Depois disso, determina-se a quantidade total de energia transferida para essa peça a partir da curva de incêndio real. Essa quantidade é representada pela área abaixo da curva. Em seguida, avalia-se a área abaixo da curva de incêndio-padrão, em vários 
tempos, até o instante em que essa área seja igual à determinada anteriormente. Esse tempo, em que as energias provenientes dos dois cenários de incêndio se igualam, traduz o tempo equivalente de resistência ao fogo. Esses procedimentos podem ser mais bem entendidos por intermédio da Figura 2.73, em que as áreas A e B devem ser igualadas a fim de se encontrar um tempo equivalente na curva-padrão.

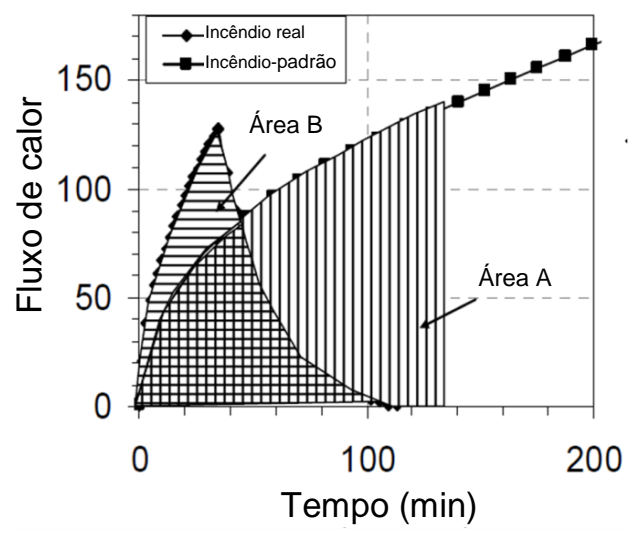

Figura 2.73 - Procedimentos de cálculo para a aplicação do método com base no princípio da energia equivalente (KODUR; PAKALA, 2010; adaptado).

Para a validação desse método, os autores analisaram setenta e duas vigas com diferentes condições de apoio (simplesmente apoiada, com restrição à deformação axial, com restrição à rotação nos apoios e com ambas as restrições às deformações térmicas) e curvas de exposição ao fogo (dezessete cenários de incêndios reais e um padronizado) por meio do programa de computador apresentado em Dwaikat e Kodur (2008). Além da comparação a resultados numéricos obtidos via método dos elementos finitos, empregaram fórmulas empíricas e outros métodos para o cálculo do tempo equivalente. Elucida-se que os autores apenas aplicaram o método desenvolvido por eles a diferentes modelos de vigas, inclusive com restrições, entretanto, não investigaram o comportamento ao fogo desses elementos. O objetivo maior, portanto, consistiu apenas em mostrar que o método da energia equivalente também era aplicável a vigas restringidas, uma vez que os tempos de resistência ao fogo dessas foram similares aos obtidos por outro modelo numérico.

Após a pesquisa dos estudos experimentais e numérico-experimentais pertinentes ao tema aqui proposto, é possível afirmar que, no âmbito internacional, ainda não houve a realização 
de ensaios similares aos que foram conduzidos na presente investigação, nos quais vigas de concreto armado, em escalas reais, foram submetidas não apenas a diferentes níveis de restrições a deformações axiais sob a ação de altas temperaturas, mas com restrições tanto axiais quanto rotacionais em um mesmo ensaio. Até então, tinham sido realizados ensaios em que apenas uma dessas modalidades de restrição estava presente. Lin; Gustaferro e Abrams (1981), Lin; Ellingwood e Piet (1988) e Guo e Shi (2011) testaram ao fogo vigas contínuas sem imposição de restrições axiais, ou seja, nesses modelos apenas as restrições rotacionais foram admitidas, pela continuidade dos elementos. Em contrapartida, Dwaikat e Kodur (2009b) ensaiaram vigas restringidas axialmente, mas com rotações totalmente livres. Mais informações sobre a campanha experimental desta Tese podem ser encontradas no Capítulo 3.

Com base nas pesquisas numérico-experimentais e puramente numéricas da literatura estrangeira, verificou-se que somente $\mathrm{Wu}$ e $\mathrm{Lu}$ (2009) analisaram modelos de vigas submetidos a níveis parciais tanto de restrição axial quanto rotacional, caracterizando ligações semirrígidas entre a viga e sua estrutura circundante - situação mais encontrada na realidade . Em contrapartida, Lin; Ellingwood e Piet (1988) e Guo e Shi (2011) modelaram vigas contínuas que, como dito anteriormente, apresentavam apenas impedimento ao giro; as deformações axiais estavam livres. Já Chythanya (2009) e Biondini e Nero (2006) adotaram vigas totalmente restringidas axial e rotacionalmente, i.e., consideraram níveis de rigidez iguais a 100\% nessas direções, hipótese que não condiz à realidade. Dwaikat e Kodur (2008), Bernhart (2004), Riva e Franssen (2008) e Cvetkovska; Todorov e Lazarov (2013) variaram os níveis das restrições axiais, contudo, para os modelos com restrições axial e rotacional, a segunda estava, mais uma vez, totalmente impedida.

Uma vez que nesta Tese foram modeladas numericamente as vigas provenientes da sua respectiva campanha experimental, a pesquisa de Wu e Lu (2009) é a que mais se aproxima do conteúdo da mesma como um todo. Logo, a fim de demarcar os pontos de ineditismo da parte numérica da presente pesquisa, realizar-se-ão a seguir algumas comparações ao referido trabalho. Wu e Lu (2009) estudaram o comportamento de vigas submetidas a diferentes níveis 
de restrição rotacional, porém, apenas para um valor de rigidez axial. Enquanto isso, esse tipo de combinação foi aqui avaliado levando em conta dois níveis diferentes de restrição axial.

O modelo numérico concebido pelos referidos autores foi validado pelos resultados experimentais das vigas provenientes de um pórtico de concreto armado produzido em escala reduzida e submetido a ensaios por Guo e Shi (2003) apud Wu e Lu (2009). Segundo os autores, a curva produzida pelo forno elétrico para o aquecimento do pórtico foi diferente da ISO 834, umas das mais utilizadas para o projeto de estruturas em situação de incêndio. Já nesta Tese, dados experimentais provenientes de ensaios em vigas de concreto armado produzidas em escalas reais e aquecidas por curvas muito próximas à ISO 834 foram adotados para validar as modelagens numéricas efetuadas no programa de computador DIANA (DIANA FEA, 2016a).

Por fim, ressalta-se que esta foi a primeira pesquisa a adotar o referido programa para esse tipo de análise, acerca de vigas de concreto armado com restrições a deformações de origem térmica. Como discutido no Capítulo 4 - Análises numéricas, o programa foi adotado anteriormente por Rafi; Nadjai e Ali (2008) para modelar vigas de concreto expostas ao fogo, contudo, essas não eram restringidas. Além disso, a maior parte das modelagens foi concebida para vigas com fibras de reforço polimérico (FRP), que representavam o foco principal da pesquisa, e não para vigas de concreto armado convencional, similar àquelas modeladas para a investigação desta Tese.

\subsection{Literaturas brasileira e portuguesa (estudos numéricos)}

O trabalho mais antigo encontrado na pesquisa de literaturas brasileiras sobre estruturas de concreto armado em situação de incêndio é da autoria de Molinari (1949). Em uma separata da Revista Politécnica, o autor apresentou as informações colhidas pelo Instituto de Pesquisas Tecnológicas (IPT) após a inspeção de um edifício que estava sendo construído para sede da 
Agência do Banco do Brasil, em São Paulo, tomado pelas chamas em 1947. Molinari (1949) chegou a apontar alguns danos causados em uma das vigas paredes do edifício em questão, porém, de forma muito breve.

Entre 1949 até o início da década de 1970, não foram publicados outros artigos relacionados ao tema. No entanto, após os incêndios ocorridos nos edifícios Andraus (em 1972), Joelma ${ }^{14}$ (1974) e Conjunto Nacional (1978), também na cidade de São Paulo, vários autores passaram a apresentar trabalhos nos quais esse assunto foi abordado ${ }^{15}$. Dentre eles, Petrucci (1972), Ferreira (1978), Almeida (1984) e Margarido (1987) delinearam, com mais destaque, comentários acerca de vigas de concreto armado expostas a altas temperaturas.

Todavia, foram estudos de cunho apenas teórico, pois não foram desenvolvidos modelos numéricos para a análise desses elementos e tampouco realizados testes de exposição ao fogo. No geral, as informações foram novamente mais voltadas aos danos causados nas vigas pela ação do calor e às técnicas que poderiam ser adotadas para a recuperação das mesmas. As pesquisas brasileiras mais avançadas começaram a surgir mais tarde, a partir dos anos 2000.

De acordo com um trecho retirado de uma publicação portuguesa, reproduzido a seguir, percebe-se que de forma similar ao que houve no Brasil, a ocorrência de um severo sinistro causado pela ação do fogo fez mudar o rumo da segurança contra incêndio no País. Enquanto os acidentes nos edifícios Andraus, Joelma e Conjunto Nacional repercutiram na atenção que passou a ser dada a esse tema no Brasil, a partir da década de 1970, o incêndio deflagrado nos Armazéns do Chiado, em Lisboa, consistiu no estopim para que tal questão também passasse a ser discutida em Portugal, ao fim da década de 1980. As primeiras pesquisas portuguesas específicas sobre vigas de concreto armado em situação de incêndio também começaram a

\footnotetext{
${ }^{14}$ No acervo da Biblioteca de Engenharia Civil da Escola Politécnica da Universidade de São Paulo, há o documento intitulado "Laudo Pericial do Incêndio no Edifício Joelma", elaborado pelo Instituto de Engenharia de São Paulo (1974), em que se apresentam informações colhidas após as vistorias técnicas realizadas em diferentes setores da estrutura sinistrada, bem como fotos não apenas da fachada, mas das áreas internas do edifício que foram danificadas pela ação do fogo.

${ }^{15}$ Informações adicionais sobre esses trabalhos brasileiros mais antigos podem ser encontradas em Albuquerque $(2012,2014)$.
} 
surgir nessa época. As mesmas já trataram de estudos numéricos, ou seja, não consistiram em comunicações apenas teóricas, tal como verificado nas publicações brasileiras iniciais.

Em Portugal, a partir de 1988 após o grande incêndio dos Armazéns do Chiado na baixa de Lisboa é que as Autoridades Nacionais despertaram para a necessidade de dotar o País de regulamentação adequada sobre segurança contra incêndio em edifícios. As temperaturas altas, os materiais existentes nas lojas, os gases inflamáveis e as explosões sucessivas, impediram o avanço dos bombeiros. Com o avanço do fogo, viu-se o desaparecimento dos estabelecimentos comerciais, alguns centenários, e as antigas construções pombalinas, deixando desalojadas dezenas de pessoas. Esforços foram insuficientes para evitar a destruição completa dos Armazéns do Chiado, assim como a sede do Valentim de Carvalho com o seu Arquivo Histórico, uma dependência a Eletricidade de Portugal e os edifícios Eduardo e Jerónimo Martins. (LOMBA, 2011, p. 3).

Nas próximas seções são discutidos os trabalhos brasileiros e portugueses que possuem relação ao tema desta Tese. Mais uma vez, esses se encontram divididos em duas partes principais: vigas simplesmente apoiadas e vigas com restrições. Adianta-se que não foram encontradas pesquisas ou puramente experimentais ou numérico-experimentais pertinentes ao assunto. As literaturas lusófonas do Brasil e de Portugal se concentraram apenas em estudos numéricos acerca do desempenho de vigas de concreto armado frente ao fogo.

\subsubsection{Vigas simplesmente apoiadas}

\subsubsection{Análises térmicas de seções transversais}

Em relação às publicações brasileiras, Figueiredo Júnior (2002) e Ribeiro (2004) propuseram modelos numéricos, denominados Caltemi e THERSYS, respectivamente, para conduzir análises térmicas de seções transversais de vigas de concreto expostas ao fogo. O Caltemi realiza tais análises com base no método dos elementos finitos e, com o objetivo de validação do modelo, Figueiredo Júnior (2002) estudou a seção de uma viga de concreto retangular 
exposta em três faces à versão de 1994 da curva ISO 834. O autor comparou os resultados às curvas isotérmicas do CEB (1982). Já o THERSYS realiza análises térmicas não lineares em regime transiente tanto de modelos bidimensionais quanto tridimensionais e Ribeiro (2004) verificou a precisão do mesmo confrontando o campo de temperaturas, encontrado pela análise da seção transversal de uma viga sob laje, a resultados obtidos a partir dos ábacos de isotermas propostos pela versão de 1996 do Eurocode 2 parte 1-2 e também por meio do programa de computador Caltemi. As faces laterais e inferior da viga e a face inferior da laje estavam submetidas ao aquecimento da curva ISO 834 (1999).

Quanto à literatura portuguesa, Albino (2012) apresentou uma pesquisa na qual o modelo desenvolvido por ele também era capaz de calcular os campos de temperaturas das seções com base no método dos elementos finitos. Denominado Fire Analysis System, foi concebido à luz de modelos pré-existentes, tais como o de Vila Real (1988). A fim de ilustrar a aplicação do mesmo e, ainda, com o propósito de sua validação, o autor adotou seções de vigas com as mesmas dimensões para as quais o Eurocode 2 parte 1-2 (2004) indica ábacos de isotermas.

\subsubsection{Cálculo de momentos fletores resistentes em incêndio}

No Brasil, Soares (2003), Castro (2005) e Miraval (2009) apresentaram métodos distintos para o cálculo dos momentos fletores resistentes de vigas de concreto armado aquecidas. Todos os autores analisaram seções retangulares submetidas em três faces a intervalos de 30, 60, 90 e 120 min de exposição ao fogo, modelado de acordo com a curva ISO 834 (1999). Eles admitiram casos tanto de momentos positivos quanto negativos, diferentes cobrimentos e configurações de armaduras. Nos três métodos indicados, calcularam esses momentos com base no equilíbrio de forças, aplicando os coeficientes de redução das resistências dos materiais a partir do campo de temperaturas, determinado de diferentes formas. 
Dois desses autores estipularam o uso de programas de computador, com base no método dos elementos finitos, para a análise térmica das seções. Castro (2005) aplicou o THERSYS e Miraval (2009) um programa de sua autoria, desenvolvido a partir do Scilab, Gmsh e openDX, que consistem em programas livres disponibilizados na internet e aplicados como plataforma para o cálculo numérico, a discretização das seções e a visualização dos resultados, respectivamente. Soares (2003) se trata, na verdade, de um estudo analítico, uma vez que foi proposta a utilização dos ábacos de curvas isotérmicas padronizados pela versão de 1995 do Eurocode 2 parte 1-2 para determinar as temperaturas das seções analisadas.

No ano seguinte ao incêndio nos Armazéns do Chiado, Ferreira (1989) desenvolveu a primeira pesquisa portuguesa de cunho numérico a abordar vigas de concreto armado em situação de incêndio. $\mathrm{O}$ autor concebeu um programa de computador, denominado UBMFIRE - Ultimate Bending Moment, que permitia calcular de forma automática o momento fletor resistente de seções transversais de vigas expostas a temperaturas elevadas. O campo térmico das seções era definido a partir de um programa auxiliar, o FIRES-T (BECKER; BIZRI; BRESLER, 1974). Ele aplicou o UBMFIRE a dez estudos de caso, em que foram consideradas seções submetidas a diferentes condições de contorno, com armaduras ou positivas ou negativas distribuídas ou em uma ou duas camadas, geometrias ou retangulares ou T, dentre outras variantes.

Nessa mesma linha de pesquisa de Ferreira (1989), encontraram-se outros quatro trabalhos portugueses. Fernandes (2008) igualmente apresentou um programa de computador, mas implementado a partir de uma rotina aplicada no DIANA (versão do manual não informada), sendo esse capaz de determinar o campo de temperaturas de seções transversais de vigas e, em seguida, o momento fletor resistente da seção exposta ao fogo a partir dos métodos simplificados da isoterma de $500{ }^{\circ} \mathrm{C}$ e das zonas, que são indicados pelo Eurocode 2 parte 1-2 (2004). Guimarães (2010) desenvolveu um modelo numérico denominado SiFiRe Verificação da Resistência ao Fogo de Estruturas de Betão, que também calculava o momento resistente da seção aquecida com base nos métodos simplificados propostos pela norma 
europeia. Esse programa ainda realizava o cálculo da resistência ao fogo a partir do método tabular, indicado pela mesma norma.

Enquanto isso, Soares (2008) desenvolveu um método simplificado de análise térmica das seções, denominado TS2, que uma vez conjugado ao programa de análise mecânica SimFirb (GONÇALVES, 2007), permitia calcular o momento resistente com base no equilíbrio de forças atuantes na seção aquecida. De forma análoga a Ferreira (1989), também foram consideradas por Fernandes (2008), Guimarães (2010) e Soares (2008) seções transversais com diferentes configurações para exemplificar a aplicação dos modelos numéricos propostos. Por fim, cita-se Alves (2012), que fez uso do programa SiFiRe, concebido por Guimarães (2010), para estudar diferentes seções de vigas para as quais foram calculadas as resistências ao fogo a partir dos métodos disponíveis no programa.

Nessas investigações, tanto de autores brasileiros quanto portugueses, as capacidades resistentes foram analisadas ao nível da seção transversal, sem considerar nos cálculos quaisquer efeitos gerados pelas restrições às deformações térmicas. Por isso, as mesmas foram inseridas na presente seção, que diz respeito a vigas simplesmente apoiadas, representativas de peças não restringidas.

\subsubsection{Métodos alternativos para dimensionamento}

Em alternativa ao método tabular, apresentado inicialmente na versão de 2004 da norma brasileira ABNT NBR 15200 para o dimensionamento de vigas de concreto armado expostas ao fogo, Costa (2008) propôs o método gráfico, que consistiu em uma ferramenta expedita para o dimensionamento. Esses gráficos do parâmetro $\mu$ em função do tempo de resistência ao fogo, em que $\mu$ representa a relação entre o momento fletor solicitante em situação de incêndio e o momento fletor resistente à temperatura ambiente, foram implementados a partir 
de análises termestruturais realizadas no programa de computador Super Tempcalc (FSD, versão de 2002 do manual).

A autora considerou seções transversais com larguras de 14 e $19 \mathrm{~cm}$ e alturas variáveis (entre 40 e $60 \mathrm{~cm}$ ), sob lajes de $5 \mathrm{~cm}$, submetidas a momentos tanto positivos quanto negativos e com diversas taxas de armaduras, dispostas em até três camadas com diferentes cobrimentos $(25,30,40$ e $50 \mathrm{~mm})$. A Figura 2.74 indica um dos gráficos construídos por ela. Elucida-se que apesar de nele se indicar o momento fletor resistente em situação de incêndio no parâmetro $\mu$, foi explicado ao longo do trabalho que para encontrar o tempo de resistência ao fogo do elemento estrutural, necessário para o dimensionamento, o referido momento deve ser substituído pelo momento solicitante em incêndio, como pontuado anteriormente.

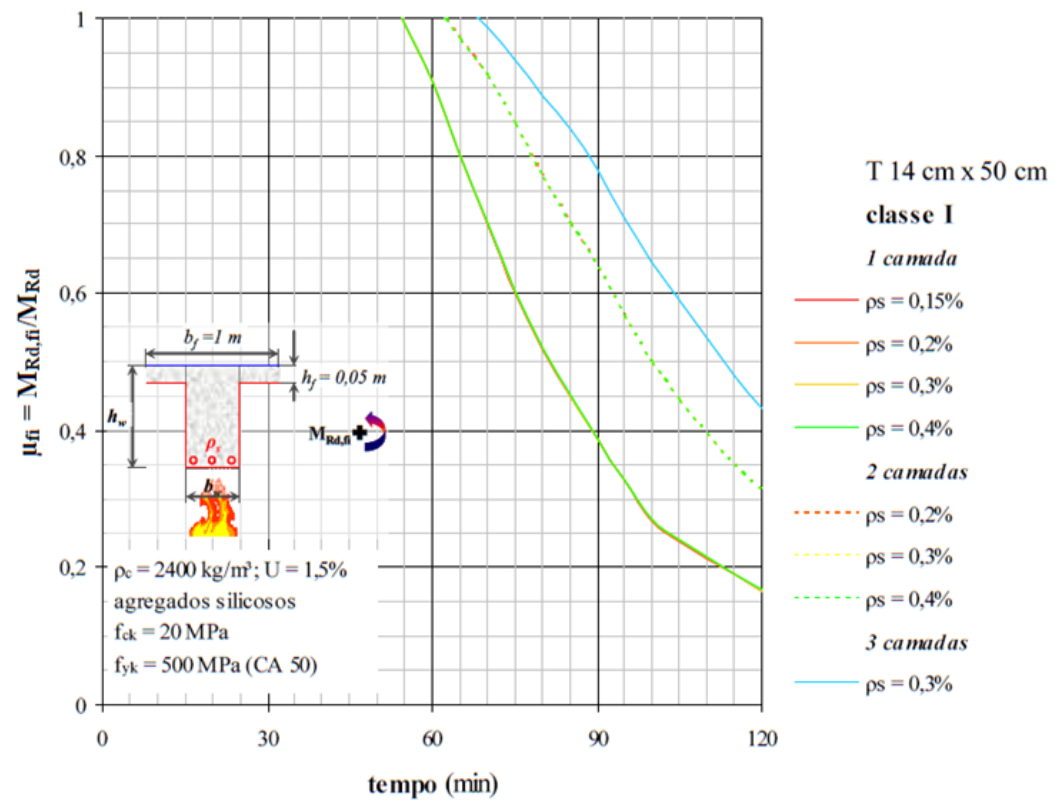

Figura 2.74 - Método gráfico para viga com seção transversal T de 14 x $50 \mathrm{~cm}$, momento positivo, cobrimento de $25 \mathrm{~mm}$ e armaduras em uma, duas e três camadas (COSTA, 2008).

Em sequência ao estudo de Costa (2008), a autora desta Tese incrementou em sua Dissertação de Mestrado - Albuquerque (2012) - a proposta do método gráfico, uma vez que ele foi concebido para um número superior de seções transversais. Além de peças com larguras de 14 e $19 \mathrm{~cm}$, também se consideraram as dimensões de 25, 30 e $35 \mathrm{~cm}$. Foram admitidas alturas variáveis (40 a $70 \mathrm{~cm}$ ), diferentes posições de momentos e diversas configurações de 
armaduras, i.e., combinações de barras com diâmetros e cobrimentos distintos, dispostas ou em uma ou duas camadas. Nesses gráficos, delineou-se ainda uma nova proposta: ao invés de taxas, apontaram-se diferentes configurações de armaduras, com o objetivo de facilitar o uso e elevar a praticidade dessa ferramenta, conforme ilustra um exemplo na Figura 2.75.

A partir dos diferentes dados de entrada para caracterizar as seções transversais, foram geradas mais de mil e quinhentas curvas de relação de momentos em função do tempo de aquecimento com o auxílio do Super Tempcalc (FSD, 2007). Essas curvas foram então compiladas em um total de cento e vinte gráficos. Todos eles também foram publicados em Albuquerque (2014), livro que apresenta a versão em língua inglesa dessa pesquisa, e Silva (2012), que consistiu no primeiro livro do espaço lbero-latino-americano a abordar, exclusivamente, o projeto de estruturas de concreto armado submetidas a incêndio. Já em Silva (2011) foram propostas novas alternativas para adaptar o método tabular aos costumes brasileiros de projeto. Essas informações foram posteriormente incorporadas à versão atualizada da ABNT NBR 15200:2012. Todos os trabalhos citados ao longo da presente seção foram realizados por brasileiros.

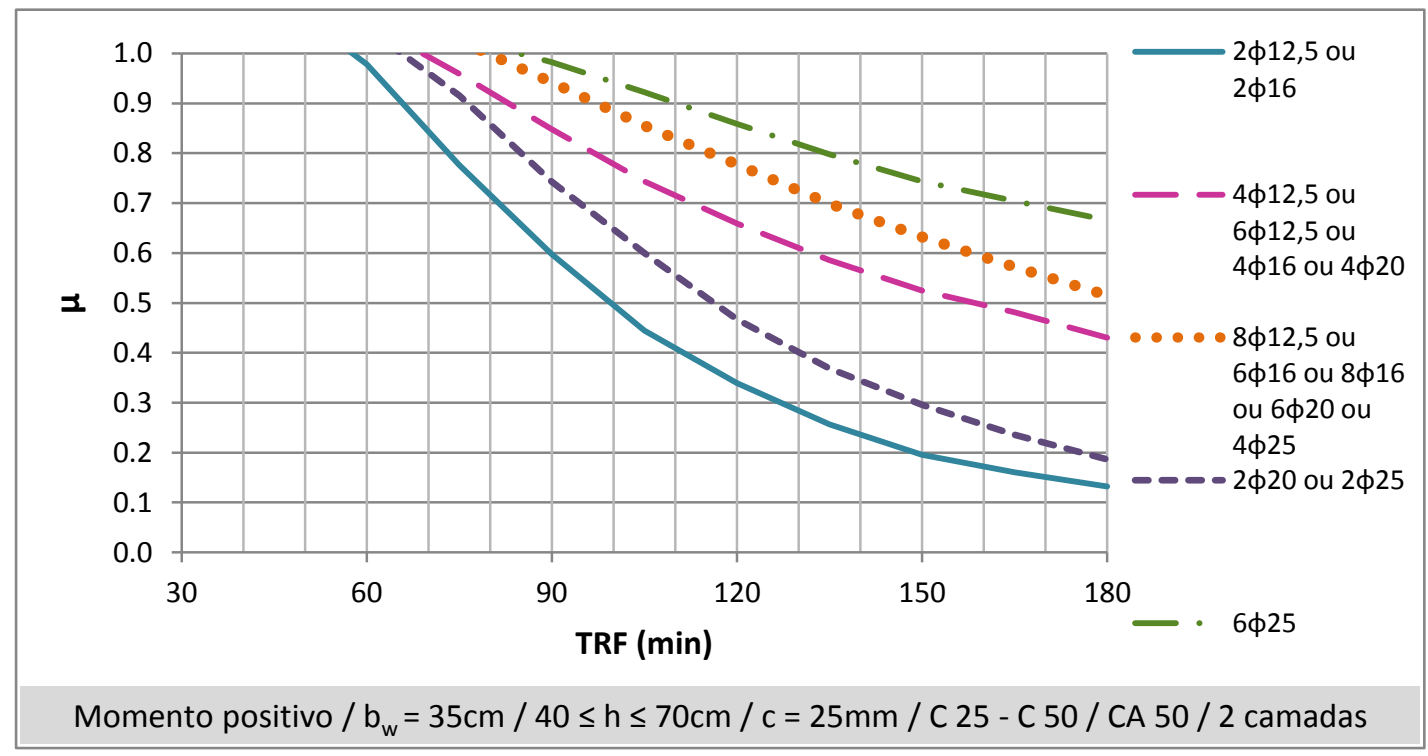

Figura 2.75 - Método gráfico para uma viga com seção transversal T de 35 x $40 \leq \mathrm{h} \geq 70 \mathrm{~cm}$, momento positivo, cobrimento de $25 \mathrm{~mm}$ e armaduras em duas camadas (ALBUQUERQUE, 2012). 


\subsubsection{Outros}

Caldas (2008) desenvolveu modelos numéricos tanto para a análise térmica quanto mecânica de estruturas de concreto armado em situação de incêndio. Dentre eles, aplicou o modelo fundamentado no método das diferenças finitas para a determinação da distribuição de temperaturas na seção transversal de uma viga sob laje. Essa seção foi igual à analisada por Ribeiro (2004). Portanto, o autor brasileiro validou o modelo térmico por intermédio de comparações a resultados obtidos com base no método dos elementos finitos e nas isotermas do Eurocode 2 parte 1-2 (2004).

A fim de simular o comportamento mecânico dessas estruturas, elaborou um elemento de viga tridimensional. A não linearidade do material foi considerada ao nível da seção, utilizando integração nos elementos que discretizavam a mesma e, para o tratamento da não linearidade geométrica, uma formulação corrotacional foi aplicada. As vigas escolhidas para a validação desse elemento corresponderam a duas, entre as seis, que foram submetidas a testes de exposição ao fogo por Lin; Ellingwood e Piet (1988), sendo uma delas aquecida conforme curva padronizada e a outra por curva real.

Ainda foram realizadas comparações a resultados obtidos em Cai; Burgess e Plank (2003), que avaliaram as mesmas vigas por meio do VULCAN (HUANG; BURGESS; PLANK, 2003), programa de computador que realiza análise termomecânica tridimensional, com base no método dos elementos finitos, de estruturas metálicas, mistas e de concreto, submetidas a temperaturas elevadas. Apesar de Caldas (2008) ter adotado vigas representativas de vãos extremos de vigas contínuas para validar o modelo numérico desenvolvido por ele, nada se comentou a respeito do comportamento ao fogo dessas, uma vez que o foco do trabalho, na realidade, estava mais voltado em apresentar a aplicabilidade desse modelo aos elementos estruturais em questão. 
Kirchhof (2010), também brasileira, realizou um estudo acerca da influência do teor de umidade no fenômeno de spalling explosivo em concretos de alta resistência expostos a temperaturas elevadas. A partir dos dados coletados na etapa experimental, na qual corpos de prova cilíndricos de concreto foram submetidos ao aquecimento de um forno elétrico, a autora propôs um modelo simplificado para a consideração de tal fenômeno em análises termomecânicas por meio do programa de computador VULCAN (HUANG; BURGESS; PLANK, 2003). A partir da aplicação desse modelo, ela apresentou a análise da resposta estrutural de uma viga de concreto armado simplesmente apoiada, considerando ou não os efeitos do spalling. Essa peça, submetida a um carregamento uniformemente distribuído e aquecida em três faces com base na curva ISO 834 de 1975, foi modelada com concreto de resistência à compressão igual a $70 \mathrm{MPa}$. A seção foi discretizada com malha de elementos finitos quadráticos e o vão com elementos do tipo viga-pilar.

Os resultados indicaram que a perda de seção transversal causada pelo spalling explosivo reduziu substancialmente o tempo de resistência ao fogo da viga simplesmente apoiada devido à aceleração dos danos e à redução da capacidade portante do elemento estrutural de concreto. Por meio da Figura 2.76, pode-se observar que o arrefecimento da seção da viga em análise, representada pela perda do cobrimento, conduz a um aumento brusco de temperatura especialmente na região das armaduras.

Desse modo, a autora concluiu que se faz necessária a consideração desse fenômeno em estruturas mais suscetíveis a sua ocorrência, ou seja, aquelas fabricadas com concretos de resistência superior a $40 \mathrm{MPa}$, que apresentam grau de saturação em torno ou superiores a 90\%. Apesar de Kirchhof (2010) ter escolhido uma viga para estudar o modelo simplificado proposto, o comportamento desses elementos não representou o foco principal do trabalho, tanto que os ensaios não foram realizados em vigas. O seu escopo foi voltado à avaliação propriamente dita dos danos causados pelo spalling em concretos de alta resistência, sendo a viga uma ferramenta para essa avaliação. 


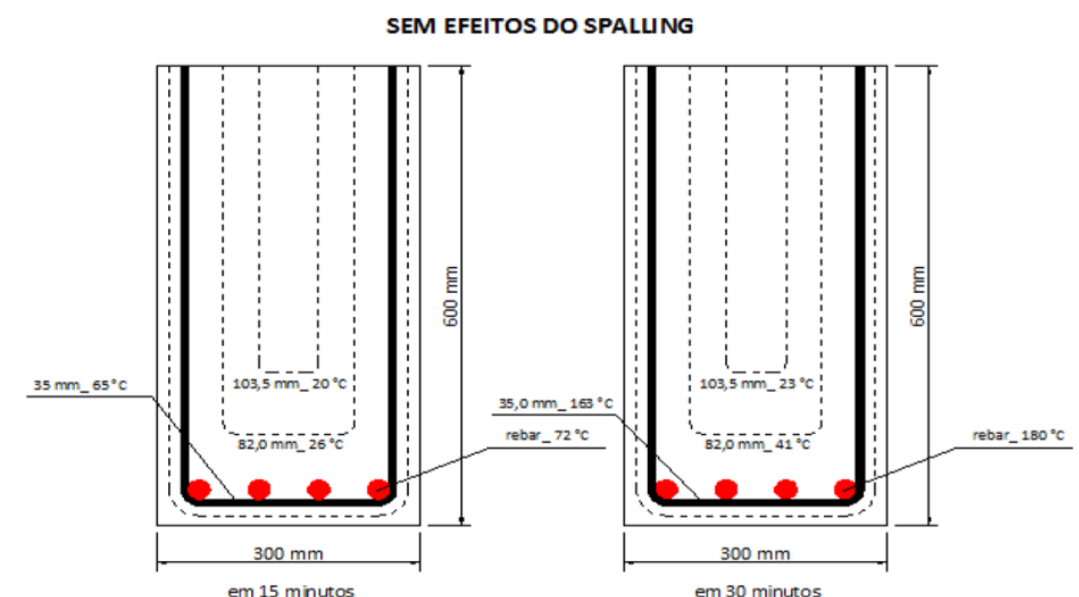

15 minutos

em 30 minutos
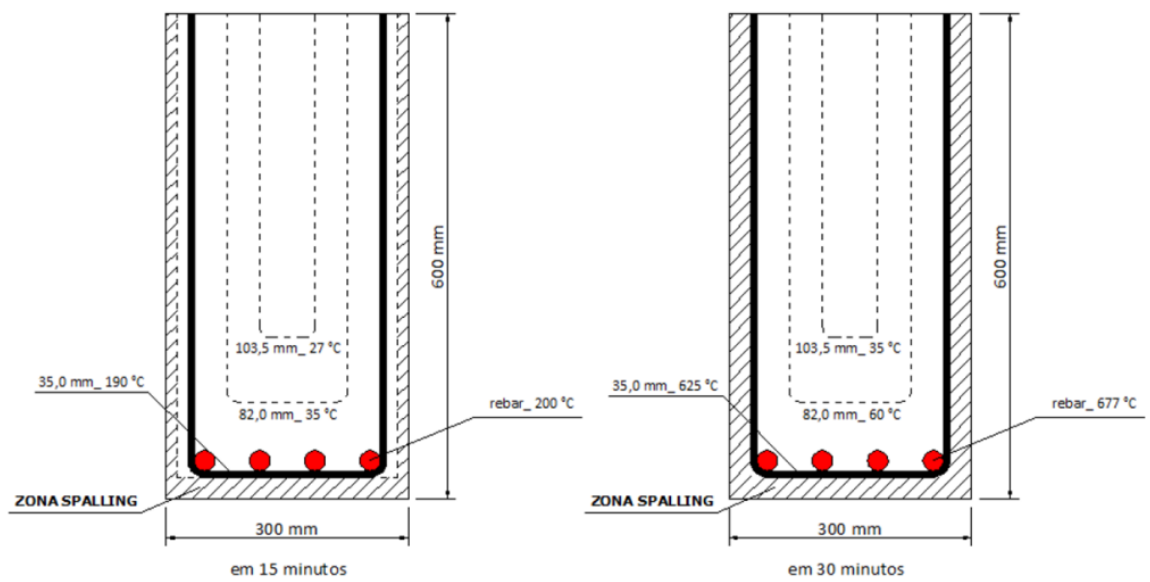

Figura 2.76 - Campo térmico da seção de viga simplesmente apoiada em diferentes profundidades e intervalos de tempo, desconsiderando-se e, sem seguida, admitindo-se os efeitos do spalling (KIRCHHOF, 2010).

O último trabalho a ser citado foi o de autoria de Gonçalves (2013). Em uma pesquisa de origem portuguesa, o autor desenvolveu um código computacional para verificar a resistência ao cisalhamento de vigas de concreto armado com base no método simplificado proposto pelo Eurocode 2 parte 1-2 (2004) ${ }^{18}$, que também faz uso dos já referidos métodos da isoterma de $500{ }^{\circ} \mathrm{C}$ e das zonas nessa verificação. Ele justificou essa investigação ao pontuar que apesar das rupturas por corte devido ao fogo serem raras [tal como visto na revisão de literaturas estrangeiras], são possíveis de acontecer. No código computacional em questão, a análise

\footnotetext{
${ }^{18}$ Mais informações acerca do método simplificado proposto pelo Eurocode 2 parte 1-2 (2004) para a verificação do cisalhamento em elementos de concreto armado expostos ao fogo podem ser encontradas em Faria; Xavier e Vila Real (2010) e em Albuquerque e Silva (2013a).
} 
térmica da seção transversal é determinada com o auxílio do programa de computador SAFIR, enquanto a rotina de cálculo para verificação ao cisalhamento é implementada na linguagem do programa MATLAB (versões dos manuais desses programas não foram indicadas).

O autor realizou exemplos de aplicação mediante dois modelos de vigas simplesmente apoiadas: uma em que a capacidade da seção foi condicionada pelo esgotamento da capacidade resistente dos estribos e outra em que a capacidade foi condicionada pelo esmagamento das bielas de compressão do concreto. A principal conclusão pontuada pelo autor foi que a escolha do método auxiliar para a verificação do cisalhamento (ou da isoterma de $500{ }^{\circ} \mathrm{C}$ ou das zonas) exerce pouca influência no resultado final dessa verificação, apesar do método das zonas se mostrar mais rigoroso.

Ao recapitular os estudos numéricos abordados nessa seção, verificou-se que as análises efetuadas pelos autores brasileiros Figueiredo Júnior (2002) e Ribeiro (2004) e pelo autor português Albino (2012) se ativeram apenas à determinação dos campos de temperaturas de seções transversais de vigas de concreto aquecidas. Enquanto isso, os brasileiros Soares (2003), Castro (2005) e Miraval (2009) e os portugueses Ferreira (1989), Fernandes (2008), Guimarães (2010), Soares (2008) e Alves (2012) verificaram a resposta ao fogo desses elementos ao nível da seção transversal, ao calcularem de diferentes formas os momentos fletores resistentes em função do tempo de aquecimento. Em sua pesquisa portuguesa, Gonçalves (2013) também efetuou análises apenas ao nível das seções transversais, mas para o cálculo da resistência ao cisalhamento das vigas.

Em contrapartida, os brasileiros Caldas (2008) e Kirchhof (2010) analisaram numericamente elementos de viga como um todo, i.e., não apenas ao nível da seção, porém, essas investigações estavam mais voltadas a certificar a aplicabilidade de um modelo numérico desenvolvido pelo próprio autor e a analisar os efeitos do fenômeno de spalling explosivo, respectivamente, do que ao estudo do comportamento propriamente dito das vigas. Os efeitos de restrições às deformações de origem térmica não foram analisados nos modelos adotados por eles. Costa (2008), Albuquerque $(2012,2014)$ e Silva (2012) apresentaram, novamente em pesquisas brasileiras, análises numéricas termestruturais que culminaram em um método 
alternativo para o dimensionamento de vigas expostas ao fogo, contudo, pelo fato de ter base em métodos simplificados de cálculo, os efeitos das restrições também não foram admitidos.

Logo, é possível constatar que, tanto no Brasil quanto em Portugal, ainda não foram apresentadas investigações mais profundas em relação ao desempenho a altas temperaturas de vigas simplesmente apoiadas. Conforme pode ser observado, as pesquisas brasileiras relacionadas ao tema se assemelham bastante às portuguesas e são mais voltadas à concepção de programas práticos para o cálculo da resistência ou à flexão ou ao cisalhamento dessas peças, tendo em conta, na maioria dos casos, análises apenas ao nível das seções transversais.

\subsubsection{Vigas com restrições}

Em uma pesquisa realizada no âmbito português, Gonçalves (2007) verificou o comportamento de vigas de concreto armado uniformemente carregadas, aquecidas em três faces conforme a versão de 1975 da ISO 834 e submetidas a diferentes modalidades de restrição mediante o programa de computador SAFIR (FRANSSEN, 2005; FRANSSEN; KODUR; MASON, 2002). A maior parte dos modelos estáticos estudados foi similar àqueles que já tinham sido avaliados na literatura estrangeira: vigas de um vão submetidas a restrições horizontais e rotacionais por meio de elementos de molas e considerando, em alguns deles, níveis parciais dessas rigidezes. Porém, nesses modelos de um vão, em nenhum dos casos se considerou simultaneamente restrições horizontal e rotacional parciais, i.e., quando se considerava, por exemplo, um nível parcial de restrição da direção horizontal, as rotacionais estavam 100\% impedidas, ao invés de também impedidas parcialmente. Os resultados apresentados para essas análises, em termos de flechas, forças de compressão, momentos solicitantes, critérios de ruptura, entre outros, seguiram a mesma linha de resultados daqueles apresentados ao longo da revisão da literatura estrangeira. Nessa pesquisa, denominaram-se "restrições horizontais" e não "axiais" pelo fato do autor também ter estipulado casos em que 
as forças de compressão não estavam localizadas no eixo das peças, mas ou na base da seção transversal ou a $1 / 4$ da altura em relação à base.

Em seguida, ele estudou alguns casos de vigas contínuas com dois e três vãos, nos quais foram consideradas restrições rotacionais parciais pelo efeito da continuidade dos apoios, e nessas ainda foram aplicadas molas para caracterizar níveis parciais de restrição na direção horizontal (iguais a 1 e 100\%, sendo o segundo representativo de uma viga equivalente à viga sob análise posta como elemento circundante na extremidade). Apesar de níveis parciais de ambas as restrições terem sido considerados em alguns desses modelos de vigas contínuas, a restrição horizontal foi admitida excêntrica em todos os casos, com posicionamento a $1 / 4$ da altura em relação à base da seção. Essa foi uma proposta diferente em relação às pesquisas anteriores, o que fez com que a sua Tese introduzisse, inclusive no âmbito estrangeiro, um modelo de viga ainda não analisado. Entretanto, fez com que os seus resultados não pudessem ser comparados aos encontrados por outros autores ou mesmo aos obtidos nesta investigação, nos quais as restrições horizontais foram centradas. Os resultados das análises mecânicas de Gonçalves (2007) não foram comparados a resultados provenientes de outras fontes (experimentais e numéricas).

Ainda em relação a essa pesquisa, vale citar que o autor desenvolveu o SimFIRb, modelo numérico que permite calcular o momento fletor resistente de seções transversais de vigas de concreto armado aquecidas, adotado no estudo de Soares (2008), citado anteriormente. Nesse modelo, o campo de temperaturas na seção é obtido com o auxílio do SAFIR e o momento é determinado com base no equilíbrio de forças atuantes na seção discretizada com malha de elementos finitos retangulares. Nos cálculos, verificam-se as deformações específicas limites tanto do concreto quanto do aço. Os resultados numéricos desse modelo foram validados por meio daqueles obtidos pelos métodos simplificados da isoterma de $500{ }^{\circ} \mathrm{C}$ e das zonas.

Xavier (2009), autor cuja nacionalidade também é portuguesa, apresentou uma investigação voltada à modelagem numérica de pórticos de concreto armado submetidos a aquecimento ISO 834 (1999) mediante o programa de computador SAFIR (FRANSSEN, 2005). Apesar de não ter sido uma pesquisa específica sobre vigas e ter englobado uma série de outras 
variantes, ele apresentou informações proveitosas ao escopo desta Tese em relação a esses elementos estruturais. Isso porque os níveis de restrições axiais e rotacionais que são aplicados nas vigas modeladas como elementos isolados - caso das vigas desta investigação e de todas as outras abordadas anteriormente - têm o objetivo de simular, justamente, o comportamento das mesmas como elementos constituintes de uma estrutura circundante, tal como feito por Xavier (2009).

Na Figura 2.77 se ilustra o esquema de um dos pórticos analisados pelo autor, em que os compartimentos I a VI foram submetidos ao fogo, e na Figura 2.78 estão as forças de restrição axiais resultantes em cada uma das vigas presentes nessa estrutura. Foi interessante certificar que os caminhos das forças de restrição axiais impostas às vigas pela presença dos pilares do pórtico apresentaram as mesmas tendências em relação às vigas nos quais não foram modelados os próprios pilares, mas sim aplicadas ou molas ou outro tipo de elemento/ferramenta para inserir níveis parciais de restrições axial e rotacional (vários gráficos de evolução de forças axiais foram mostrados antes neste capítulo, por exemplo, nas Figuras 2.52, 2.57, 2.60 e 2.61). Essa constatação certifica que a modelagem mais simplificada, sem a consideração de pilares propriamente ditos, também é aceitável e conduz a resultados coerentes.

Ainda em relação à Figura 2.78, pode-se observar que quanto mais próximas as vigas se encontram ao sistema de contravento presente na extremidade esquerda, maiores as forças de restrição nela atuantes. Ademais, as vigas presentes no segundo nível do pórtico (vigas 4, 5 e 6) se encontram mais restringidas que as do primeiro (vigas 1,2 e 3) porque as do nível mais baixo estão conectadas aos trechos de pilares 1 a 8 , completamente aquecidos pela ação do fogo, enquanto as do segundo piso estão ligadas aos trechos de pilares 9 a 12, cujas metades das alturas permanecem, aproximadamente, à temperatura ambiente. Portanto, nesse caso específico, as vigas do segundo nível estão mais restringidas que a do primeiro pelas condições de contorno adotadas na análise.

Ao final desta seção, enfatiza-se que Gonçalves (2007) foi o único autor a apresentar um trabalho numérico específico sobre vigas de concreto armado restringidas em situação de 
incêndio no que concerne à literatura proveniente de Portugal. $\mathrm{O}$ autor estudou determinados modelos em que foram impostos níveis parciais tanto de rigidezes horizontais quanto rotacionais, mas apenas com a linha de atuação das forças de compressão considerada excêntrica. No Brasil, não foram encontradas quaisquer estudos numéricos sobre os efeitos das restrições às deformações de origem térmica no comportamento de vigas aquecidas.
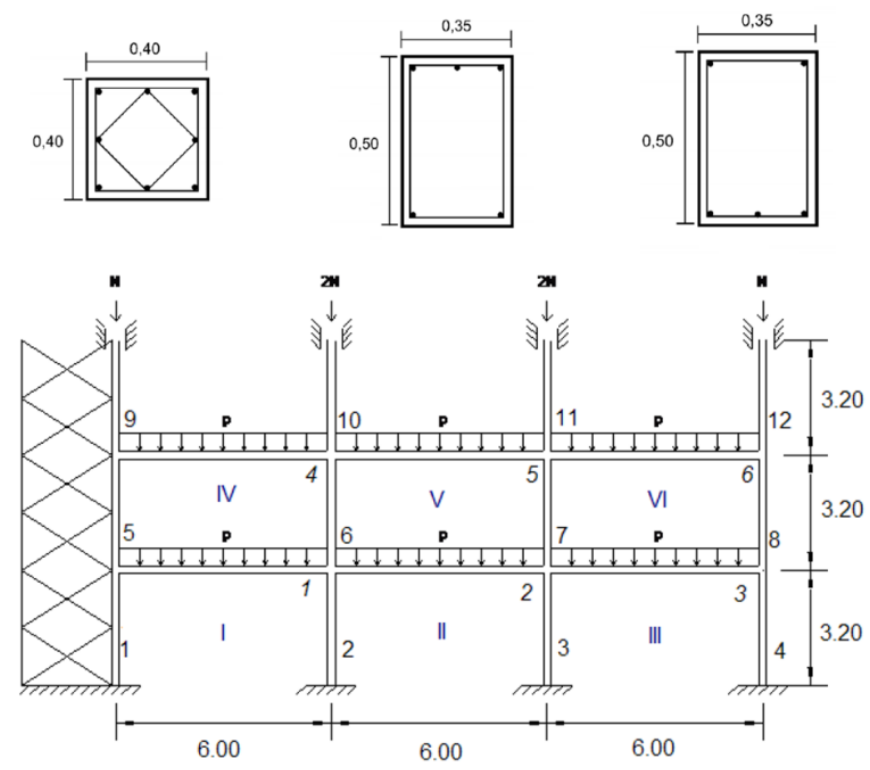

Figura 2.77 - Pórtico de concreto armado submetido a incêndio no estudo numérico de Xavier (2009).

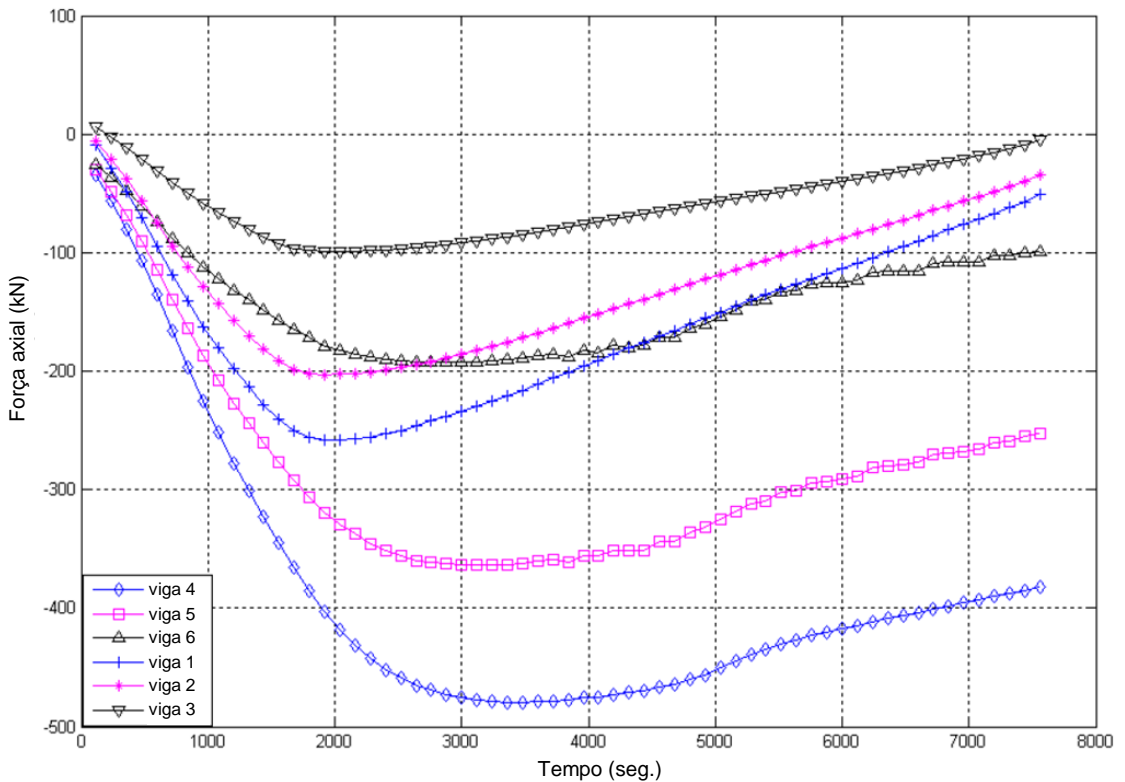

Figura 2.78 - Evolução das forças de restrição axial nas vigas presentes no pórtico analisado por Xavier (2009; adaptado). 


\subsection{Recomendações normativas}

A seguir serão apresentadas as informações presentes nas normas europeia e brasileira que tratam do projeto de estruturas de concreto em situação de incêndio no que diz respeito à consideração dos efeitos das restrições às deformações de origem térmica nos métodos para dimensionamento de vigas. Portanto, abordar-se-ão o Eurocode 2 parte 1-2 (2004), bem como o Anexo Nacional presente em sua versão portuguesa Eurocódigo 2 parte 1-2 (2010), e a ABNT NBR 15200:2012 pelo fato de serem as normas vigentes no âmbito em que a presente Tese foi desenvolvida e também pela norma europeia ter sido utilizada como referência para a maior parte das pesquisas encontradas na literatura estrangeira e, ainda, como base para a escrita da referida norma brasileira. Vale citar que a ABNT NBR 15200:2012 é o documento mais avançado da América Latina quanto ao projeto de estruturas de concreto em situação de incêndio, segundo levantamento realizado por Silva (2015).

\subsubsection{Eurocode 2 parte 1-2 (2004) e Anexo Nacional português (2010)}

O Eurocode 2 parte 1-2 (2004) estabelece que a verificação da resistência ao fogo de estruturas de concreto armado pode se realizada de três formas, indicadas adiante em ordem crescente de complexidade: avaliação por elementos, por partes da estrutura e global, sendo que na última a estrutura é analisada como um todo, por inteiro. Definido o nível/modelo para o qual a verificação será realizada - ou elemento, ou parte da estrutura ou estrutura completa - a norma indica quais os métodos disponíveis a cada um deles. Para a verificação do comportamento ao fogo de elementos expostos a curvas de incêndio-padrão, por exemplo, no qual se analisam vigas, pilares, lajes, entre outros, considerando-os elementos isolados, a norma europeia permite a aplicação de quatro métodos de cálculo: tabular, simplificado, 
avançado e experimental, sendo esses também descritos em escala crescente de complexidade. Já para análises por partes da estrutura, com exposição também ao incêndio-padrão, estão disponíveis apenas os métodos simplificados, avançados e experimentais, uma vez que o método tabular já não é aplicável para essa situação. Essas relações do nível/modelo estrutural de análise e dos modelos de incêndio com os métodos normatizados disponíveis para a verificação da resistência ao fogo estão indicadas na Figura 2.79.

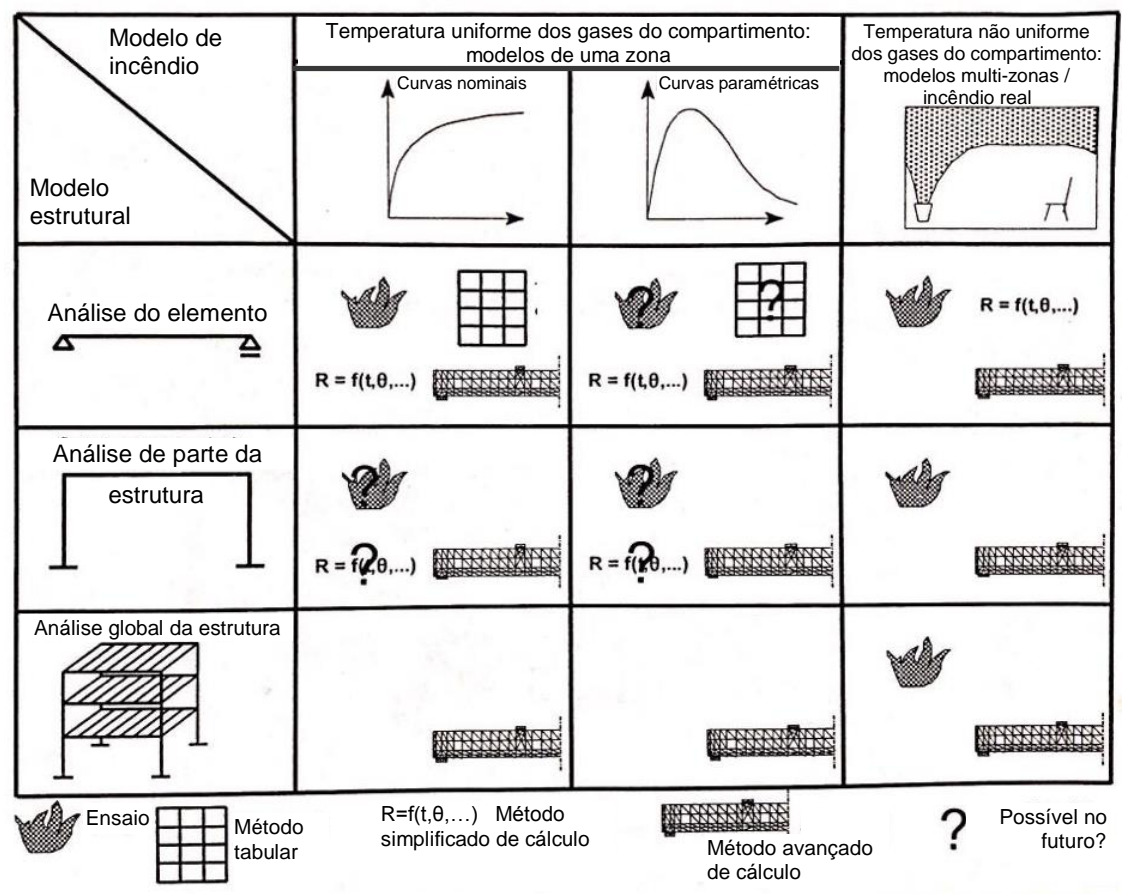

Figura 2.79 - Relação de níveis estruturais e modelos de incêndio aos métodos de avaliação da resistência ao fogo indicados no Eurocode 2 parte 1-2 (2004) (BOLETIM fib-CEB n 38, 2007; adaptado).

Além de informar os métodos aplicáveis a cada uma dessas análises, cujas diretrizes serão comentadas mais adiante, a norma europeia também apresenta algumas considerações sobre os parâmetros que devem ou não ser levados em conta quando do uso das mesmas. Relativamente à análise por elementos expostos ao fogo, comunica que se faz necessário que sejam admitidos apenas os efeitos dos esforços adicionais que surgem em decorrência das deformações térmicas resultantes dos gradientes de temperaturas atuantes ao longo da altura da seção transversal dos mesmos, enquanto os esforços adicionais provenientes dos efeitos das dilatações/deformações térmicas ou axiais ou no próprio plano podem ser desprezados. 
Uma vez que os esforços adicionais que decorrem das deformações térmicas consistem justamente nos esforços de restrição a tais deformações, entende-se que apenas os efeitos das restrições rotacionais precisam ser considerados na verificação ao fogo de elementos isolados de concreto armado, tais como as vigas. Contudo, o Eurocode 1 parte 1-2 (2002) afirma que não é necessário considerar esforços adicionais (entende-se axiais e rotacionais) quando as exigências de segurança ao incêndio se referem a elementos aquecidos conforme o incêndiopadrão. É possível que a norma admita, portanto, que associar a curva de incêndio-padrão a elevados tempos de resistência ao fogo, provavelmente aqueles provenientes do método tabular, já satisfaz a segurança do elemento.

De acordo com o Boletim fib-CEB n 38 (2007), os esforços de restrição (esforços adicionais) que podem ser desenvolvidos em resposta às deformações porque passam os elementos de concreto armado quando em situação de incêndio torna essencial a consideração de condições de contorno que sejam similares àquelas características do elemento como parte de uma estrutura completa. Caso contrário, como consequência a uma simplificação dessas condições de contorno [tal como feito pelas normas europeias, ao indicar que os efeitos das restrições podem ser completamente desconsiderados em elementos aquecidos pelo incêndio-padrão e apenas os efeitos das restrições rotacionais precisam ser admitidos em elementos aquecidos por curvas de incêndio mais avançadas], pode haver uma diferença significativa entre a resposta ao fogo obtida ou por métodos de cálculo ou ensaios experimentais e a resposta que ocorre na realidade de um elemento exposto a altas temperaturas.

Ainda segundo o Boletim fib-CEB n 38 (2007), um modo de superar esse impasse da análise de elementos isolados, que decorre da falta de condições de contorno ou de apoio condizentes a realidade, consiste em analisar partes da estrutura [i.e., elementos associados que acabam por formar estruturas aporticadas ou então pelo menos admitir condições de contorno que os caracterizem dessa forma]. Um trecho das diretrizes do Eurocode 2 parte 1-2 (2004) para a verificação da resistência ao fogo por partes da estrutura demostra a essência desse comentário. O mesmo está descrito a seguir, conforme tradução presente na versão portuguesa do documento. 
A parte da estrutura a analisar deverá ser especificada com base nas potenciais dilatações e deformações térmicas, de forma que a sua interação com as outras partes da estrutura possa ser estimada com condições de apoio e de fronteira independentes do tempo durante a situação de incêndio. $\mathrm{Na}$ parte da estrutura a analisar, devem se ter em conta o modo de colapso adequado em caso de exposição ao fogo, as propriedades dos materiais e a rigidez dos elementos que dependem da temperatura, e os efeitos das dilatações e das deformações térmicas (ações indiretas do fogo). Admite-se que as condições de fronteira nos apoios e nos limites da parte da estrutura, aplicáveis no instante $\mathrm{t}=0 \mathrm{~min}$, mantêm-se inalterados durante toda a exposição ao fogo. (EUROCÓDIGO 2 PARTE 1-2, 2010, p. 23).

Portanto, na análise de partes da estrutura, as deformações térmicas e os efeitos causados pelos impedimentos às mesmas devem ser considerados. É oportuno destacar que as vigas com restrições estudadas em algumas pesquisas encontradas na revisão de literaturas e mesmo as vigas avaliadas nesta Tese seguiram o modelo de análise imposto pelas diretrizes da norma europeia indicadas no trecho anterior, uma vez que a interação desses elementos com uma estrutura circundante foi considerada por meio de impedimentos às deformações axiais e rotacionais, tendo também sido atendidos os outros requisitos necessários para se concluir que as vigas foram analisadas como parte constituinte de uma estrutura e não com as características de um elemento isolado.

Conforme esperado, o modelo de verificação da resistência ao fogo mais complexo, que compreende a análise global de uma estrutura em situação de incêndio, também exige que sejam considerados os efeitos das restrições às deformações térmicas. No entanto, esse tipo de modelo é ainda pouco adotado, obviamente pelos altos custos que seriam gerados para uma análise experimental e também pela complexidade envolvida nas análises numéricas, realizadas a partir da aplicação das diretrizes dos métodos avançados. Como pode ser visto na Figura 2.79, os métodos experimentais e avançados são os únicos disponíveis para esse tipo de análise. Métodos tabulares e simplificados são impraticáveis nesse caso.

Sendo assim, conclui-se que a norma europeia recomenda que as restrições às deformações térmicas sejam consideradas na verificação/dimensionamento de estruturas de concreto armado em situação de incêndio, quer no nível do elemento, de parte da estrutura ou da estrutura como um todo (com algumas exceções no que diz respeito à análise de elementos 
isolados, conforme explicado anteriormente). Todavia, os métodos que são indicados pela referente norma para colocar em prática tais verificações não deixam claro de que forma as restrições podem ser consideradas nos cálculos.

Os métodos tabulares e simplificados são os únicos realmente detalhados na norma europeia, por serem mais práticos e simples. Quanto aos outros, apenas são apresentadas diretrizes para aplicação, uma vez que demandam programas de computador específicos ou a realização de ensaios em laboratório. No método tabular para a verificação de vigas aquecidas, por exemplo, o tempo de resistência é aferido com base na largura da seção transversal da peça e na distância entre o eixo da armadura longitudinal inferior e a face do concreto exposta ao fogo ("a" na norma europeia, "c $c_{1}$ " na brasileira). Apesar dos valores tabelados para vigas simplesmente apoiadas serem diferentes daqueles indicados para vigas contínuas, nos quais as restrições rotacionais são presentes devido à continuidade dos apoios, nada se comenta a respeito das deformações de origem térmica ao longo da apresentação do método.

Os métodos simplificados têm base em cálculos que levam em consideração seções transversais reduzidas, a fim de simular o decaimento da resistência do concreto exposto a altas temperaturas a partir da redução de sua área resistente. Dois métodos fundamentados em tal hipótese são propostos na norma europeia: o da isoterma de $500{ }^{\circ} \mathrm{C}$ e o das zonas (ou método das faixas ou de Hertz). As deformações térmicas e os efeitos das restrições impostas a elas não são admitidos nas diretrizes desses cálculos conduzidos ao nível da seção transversal das vigas. Apesar de ser possível incorporar o efeito de uma força de restrição axial na capacidade resistente da seção determinada pelo método da isoterma de $500{ }^{\circ} \mathrm{C}$, por exemplo, como demonstrado pelos pesquisadores Riva e Franssen $(2008)^{20}$, a própria norma não se pronuncia quanto a esse ou outros procedimentos que possam ser adotados para que os efeitos das restrições sejam admitidos nesses métodos simplificados.

\footnotetext{
${ }^{20}$ O procedimento de cálculo proposto por Riva e Franssen (2008) também está presente nas diretrizes do Model Code 2010 (2011).
} 
Segundo a norma europeia, os métodos avançados conduzem a análises mais realísticas do desempenho das estruturas de concreto armado frente ao fogo, uma vez que os cálculos se baseiam na modelagem do comportamento físico fundamental dos materiais. Considerando-se que esses são os métodos que podem ser aplicados, inclusive, para a análise global de uma estrutura em situação de incêndio, torna-se então imprescindível que vários requisitos sejam neles considerados, por exemplo: diferentes modos de colapso, tais como, aqueles ocasionados devido a esforços de cisalhamento, capacidade insuficiente de rotação nos apoios, spalling, perda de aderência, entre outros; alteração das propriedades mecânicas dos materiais em função do aumento de temperatura; efeitos de tensões e deformações de origem térmica; efeitos geométricos não lineares, quando relevantes; condições de contorno coerentes, de forma a evitar colapsos por perda de apoio necessário aos elementos.

Logo, as diretrizes dos métodos avançados citam, dentre várias necessidades, aquela relacionada à importância de serem considerados apoios/vínculos que não conduzam a colapsos prematuros dos elementos. Como já visto ao longo deste capítulo, as vigas simplesmente apoiadas de concreto armado possuem comportamento desfavorável frente ao fogo em comparação às vigas que possuem apoios a restringir deformações. Sendo assim, a norma manifesta nessas diretrizes, mesmo que de forma indireta ou nas entrelinhas, a relevância da consideração dos efeitos benéficos que podem ser atribuídos às restrições impostas pelos apoios, contudo, novamente, não são fornecidos detalhes sobre a forma como essas restrições devem ser consideradas quando da aplicação dos métodos avançados.

Em relação aos métodos experimentais, as informações sobre deformações de origem térmica ou restrições são ainda mais escassas. A norma apenas comunica que alternativamente aos métodos de cálculo, o projeto de resistência ao fogo pode se basear ou em resultados de ensaios ou de ensaios combinados com cálculos.

Sendo assim, não há métodos normatizados pelo Eurocode 2 parte 1-2 (2004) para a consideração dos efeitos das deformações de origem térmica no comportamento de vigas de concreto armado expostas ao fogo. O Anexo Nacional português, que estabelece as condições para implementação da referida norma em Portugal, acrescenta o seguinte: 
A segurança ao fogo da estrutura de um edifício depende da concepção, dimensionamento e pormenorização. Se a exigência da resistência ao fogo for elevada e se forem adotados métodos simplificados associados à abordagem prescritiva de verificação individualizada de cada elemento, é importante evitar que a solução estrutural adotada crie fortes restrições à deformação imposta pela ação do fogo. (EUROCÓDIGO 2 PARTE 1-2, 2010, p. 108).

Em outras palavras, o comentário presente no Anexo Nacional adverte para o fato de que os métodos simplificados e tabulares aplicados à análise de elementos isolados não devem ser adotados em casos de estruturas que possam apresentar esforços adicionais significativos resultantes de restrições a deformações térmicas, precisamente pelo fato de que essas análises realizadas ao nível do elemento e conjugadas a tais métodos, também conhecidos como métodos prescritivos para avaliação da resistência ao fogo, não contemplam tais efeitos. Esse foi o único comentário do Anexo Nacional relacionado ao tema. Logo, igualmente ao escopo presente no corpo do texto normativo, não foram apresentadas alternativas para a consideração desses efeitos no dimensionamento.

\subsubsection{ABNT NBR 15200:2012}

A ABNT NBR 15200:2012, norma brasileira referente ao projeto de estruturas de concreto em situação de incêndio, foi escrita com base nas informações presentes no Eurocode 2 parte 1-2 (2004). Então, de forma similar à norma europeia, a brasileira também permite que a verificação ao fogo de vigas de concreto armado seja realizada a partir de métodos tabulares, simplificados, avançados e experimentais.

$\mathrm{Na}$ norma europeia, as principais informações sobre a necessidade ou não de serem considerados os efeitos as restrições às deformações de origem térmica foram citadas ao longo da apresentação dos diferentes níveis que podem ser adotados para a verificação da resistência ao fogo de estruturas de concreto armado - por elementos isolados à análise global da estrutura -. Uma vez que a norma brasileira não apresenta comentários sobre essa distinção de 
níveis/modelos de avaliação, as considerações que se referem às deformações térmicas são citadas nas diretrizes dos diferentes métodos de cálculo - dos tabulares aos experimentais -

A abordagem do método tabular para o dimensionamento de vigas é muito similar à europeia, em que se apresentam valores tabelados para vigas simplesmente apoiadas e contínuas, entretanto, nada se comenta sobre deformações térmicas. Acrescenta-se que as larguras de $190 \mathrm{~mm}$ foram inseridas nas tabelas da norma brasileira no lugar das de $200 \mathrm{~mm}$, apresentadas no Eurocode 2 parte 1-2 (2004), por serem mais empregadas no País. Os valores de $\mathrm{c}_{1}$ para essas peças foram recalculados de acordo com a hipótese original adotada para a concepção do método, ou seja, evitando-se que a temperatura nas armaduras atingisse $500{ }^{\circ} \mathrm{C}$.

Ao contrário da norma europeia, que apresenta de forma detalhada os métodos simplificados de cálculo, a norma brasileira apresenta apenas diretrizes para a aplicação dos mesmos. Estabelece, por exemplo, que os esforços resistentes em situação de incêndio ou podem ser calculados com base nos valores determinados à temperatura ambiente, mas considerando resistências de cálculo médias reduzidas para os materiais expostos ao fogo, ou que podem ser calculados com base nos métodos que consideram seções de concreto reduzidas, i.e., os métodos da isoterma de $500{ }^{\circ} \mathrm{C}$ e das zonas ${ }^{21}$. Portanto, apenas permite o uso desses métodos, mas não apresenta os detalhes de aplicação. As deformações térmicas são primeiramente citadas na diretriz que aborda a determinação dos esforços solicitantes em situação de incêndio quando do uso de métodos simplificados de verificação. Segundo a norma brasileira, os esforços decorrentes de deformações impostas podem ser usualmente desprezados nessa determinação, pelo fato de serem esses muito reduzidos e pelas grandes deformações plásticas que ocorrem na presença de temperaturas elevadas.

\footnotetext{
${ }^{21}$ Em Albuquerque e Silva (2013b, 2013c) e Albuquerque; Silva e Rodrigues (2015) são descritas, de forma detalhada, as diretrizes de seis métodos de cálculo simplificados que podem ser adotados para a determinação do momento fletor resistente de seções transversais de vigas expostas ao fogo e, dentre esses métodos, estão aqueles propostos pelas normas brasileira e europeia. Também são apresentados exemplos de aplicação e comparações entre os resultados obtidos a partir de cada um deles.
} 
Entretanto, nas diretrizes para a aplicação de métodos avançados, já indica que os esforços solicitantes de cálculo devem ser acrescidos dos efeitos das deformações térmicas restringidas, desde que calculados por modelos não lineares capazes de considerar as profundas redistribuições de esforços que ocorrerem. Quanto às diretrizes dos métodos experimentais, novamente as deformações térmicas não são abordadas.

Logo, a ABNT NBR 15200:2012 exige, tal qual a norma europeia, que as restrições às deformações térmicas porque passam as vigas de concreto armado quando aquecidas sejam consideradas em determinadas situações, mas não apresenta pormenores ou um método para que sejam admitidas nos cálculos e, da mesma forma, não comenta sobre os efeitos benéficos que podem decorrer dessa consideração.

\subsection{Considerações finais}

Neste capítulo foram abordadas cerca de 60 literaturas que tratam do comportamento de vigas de concreto armado em situação de incêndio. Após a análise de cada uma delas, verificou-se que apenas 14 tiveram como objeto de estudo as vigas com restrições. Em relação à natureza desses trabalhos, há apenas 1 puramente experimental, 3 numérico-experimentais e 10 numéricos. Quanto à origem, a maior parte é estrangeira, com apenas 2 estudos portugueses (dos 10 numéricos) e nenhum brasileiro nessa lista. Sobre essas 14 literaturas, foram estabelecidas as seguintes considerações finais:

○ Apesar de existirem pesquisas experimentais, ainda não foram realizados ensaios em vigas produzidas em escala real e submetidas a restrições axial e rotacional simultaneamente;

- Nas análises experimentais de vigas com restrições ou axial ou rotacional, não foram analisados diferentes níveis parciais de restrições; 
○ Encontrou-se apenas um estudo numérico sobre vigas submetidas a restrições axial e rotacional simultaneamente e com diferentes níveis parciais de restrições, porém, não havia dados experimentais apropriados para a validação dos modelos, uma vez que foram utilizados resultados de ensaios em vigas reduzidas;

○ O programa de computador DIANA não foi adotado em nenhuma dessas literaturas.

Assim, foi possível confirmar o ineditismo da Tese, tanto âmbito estrangeiro quanto no âmbito Brasil/Portugal. Ao longo deste capítulo ainda foram analisadas as informações presentes no Eurocode 2 parte 1-2 (2004), no seu Anexo Nacional português e na norma brasileira ABNT NBR 15200:2012. A seguir são apresentadas as considerações finais acerca do conteúdo desses documentos.

- As normas europeia e brasileira permitem que o dimensionamento de vigas de concreto armado para a situação de incêndio seja realizado a partir de métodos tabulares, simplificados, avançados ou experimentais;

- As diretrizes indicadas para alguns desses métodos recomendam que os efeitos das restrições sejam considerados. Contudo, não indicam como fazê-lo. Além disso, essas normas não comentam sobre o efeito benéfico que pode decorrer dessa consideração;

○ Logo, nos Países que adotam esses documentos para a prática de projetos, ainda não existem métodos normatizados para admitir os efeitos das restrições no cálculo da resistência ao fogo das vigas. 



\section{ANÁLISES EXPERIMENTAIS}

\subsection{Modelos de estudo}

Neste capítulo serão abordadas as análises experimentais que foram realizadas no Laboratório de Ensaios de Materiais e Estruturas do Departamento de Engenharia Civil da Universidade de Coimbra (LEME-UC), em Portugal, e que se referem ao estudo de vigas de concreto armado em situação de incêndio com deformações de origem térmica restringidas. De forma detalhada, apresentar-se-ão informações que tratam desde os modelos de peças inicialmente estipuladas para análise até a discussão dos resultados obtidos.

No início do planejamento dos ensaios de temperaturas elevadas, o primeiro critério definido consistiu nos modelos de vigas que seriam analisados: peças simplesmente apoiadas, a fim de comparar os desempenhos dessas àquelas que apresentariam restrições; peças nas quais apenas a deformação axial seria impedida pelos apoios; e peças nas quais deformações axiais e rotacionais seriam impedidas pelos apoios, para que assim fosse realizada uma análise mais realística das vigas aquecidas, que na prática, segundo Wu e Lu (2009) e Ali e O’Connor (2001), podem possuir apoios ou condições de contorno que impedem tanto a variação do comprimento quanto a rotação (flexão da peça).

Além das análises em situação de incêndio, estipulou-se que também deveriam ser realizados ensaios de vigas simplesmente apoiadas à temperatura ambiente para comparar os carregamentos de ruptura determinados por meio experimental àqueles obtidos de forma analítica. Logo, com base nesses ensaios, seria possível certificar os valores das forças que deveriam ser aplicados posteriormente, nos ensaios a altas temperaturas. Ainda a partir dos 
ensaios à temperatura ambiente, poderiam ser verificados os campos de fissuração dessas vigas, a título de informações adicionais ${ }^{1}$.

\subsection{Sistemas de ensaios e instrumentação}

\subsubsection{Vigas à temperatura ambiente}

O programa experimental teve início com os ensaios de flexão a quatro pontos em vigas de concreto armado simplesmente apoiadas na condição de temperatura ambiente. Esses ensaios foram realizados com o auxílio de um sistema em que a montagem foi realizada nas dependências do LEME e do qual faziam parte os seguintes elementos: uma viga de concreto armado posicionada sobre dois apoios ( $\mathrm{n}^{\circ} 1$ na Figura 3.1); um apoio simples $\left(\mathrm{n}^{\circ} 2\right.$ nas Figuras 3.1 e 3.2), que permitia a rotação e o deslocamento na direção axial da viga; um apoio duplo ( $n^{\circ} 3$ nas Figuras 3.1 e 3.2), que permitia apenas a rotação; um macaco hidráulico para a aplicação do carregamento ( $\mathrm{n}^{\circ} 4$ nas Figuras 3.1, 3.3 e 3.4), sendo que esse macaco estava suspenso por um pórtico de reação com perfis de aço HEB 300 (n 5 nas Figuras 3.1, 3.3 e 3.4) e localizado sobre um sistema de redistribuição de forças ( ${ }^{\circ} 6$ nas Figuras 3.1 e 3.3$)^{2}$.

\footnotetext{
${ }^{1}$ Desde o planejamento da campanha experimental, já se havia estabelecido que os resultados dos ensaios seriam utilizados posteriormente para validar modelos numéricos que deveriam ser representativos do comportamento das vigas submetidas a testes em laboratório. A proposta consistia em conceber um modelo numérico para as análises à temperatura ambiente e depois o adaptar para as análises ao fogo. Logo, os campos de fissuras foram demarcados ao longo dos ensaios experimentais, bem como foram medidas as aberturas dessas fissuras, pois esses dados se mostravam relevantes à validação desses modelos. Adianta-se que as concretagens das vigas de ensaio foram realizadas em três etapas e os campos de fissuras também se mostravam úteis para certificar a similaridade entre as peças provenientes dessas três diferentes concretagens.

${ }^{2}$ As numerações atribuídas aos elementos dos sistemas de ensaios nas figuras se mantêm ao longo de todo este capítulo. $\mathrm{O} \mathrm{n}^{\circ} 1$, por exemplo, escolhido para indicar a viga de concreto armado ensaiada, estará presente em algumas das figuras das próximas seções como indicativo do mesmo elemento.
} 
O sistema de redistribuição de forças era composto por dois elementos de aço, um pilar HEA 160 e uma viga HEB 140, que foram preenchidos com argamassa refratária da $\mathrm{AXTON}^{3}$ para ajudar a manter a sua integridade nos ensaios que depois teriam a ação do fogo. Tal sistema era responsável por aplicar em dois pontos da viga de concreto o carregamento proveniente do macaco hidráulico. Assim, o pilar recebia a força resultante do macaco, transmitia essa força para a viga de aço e, por conseguinte, essa viga a redistribuía para a viga ensaiada. Nos dois pontos de aplicação, utilizaram-se chapas de aço para que essas forças fossem distribuídas ao longo de uma determinada área a fim de evitar rupturas localizadas por esmagamento do concreto, que podem ocorrer quando da aplicação de forças concentradas em um único ponto.

Os dois pontos de atuação das forças dividiam as vigas ensaiadas em três trechos de comprimentos iguais ( $1 \mathrm{~m}$, equivalente a um terço do vão) e faziam com que as mesmas apresentassem flexão pura no trecho central. O macaco hidráulico era do modelo RR 3014 da ENERPAC e, ao longo dos ensaios, foi controlado por uma central servo-hidráulica $\mathrm{W}+\mathrm{B}$ NSPA700/DIG2000 ( ${ }^{\circ} 7$ na Figura 3.1). A aquisição dos dados experimentais era realizada por intermédio de um data logger modelo TDS-530 da TML ( ${ }^{\circ} 8$ na Figura 3.1).

Os carregamentos aplicados às vigas de concreto ao longo de todos os ensaios, tanto à temperatura ambiente quanto em situação de incêndio, foram medidos por intermédio de uma célula de carga F204 da Novatech, com $250 \mathrm{kN}$ de capacidade, que foi acoplada ao mancal que ficava localizado entre o macaco hidráulico e o sistema de redistribuição de forças $\left(\mathrm{n}^{\circ} 9\right.$ nas Figuras 3.1, 3.3 e 3.4).

Os deslocamentos verticais do êmbolo (curso) do macaco hidráulico também foram monitorizados ao longo de todos os ensaios - temperatura ambiente e incêndio - por meio de um transdutor de deslocamento tipo cabo DP-1000E TML ( ${ }^{\circ} 10$ das Figuras 3.3 e 3.4 ) e também a partir de um transdutor de deslocamento tipo êmbolo SDP-200D da TML (Linear Variable Displacement Transformer - LVDT), n 11 das Figuras 3.3 e 3.4.

\footnotetext{
${ }^{3}$ De acordo com informações do fabricante, esse produto é constituído por apenas um componente e resiste a temperaturas de até $1200{ }^{\circ} \mathrm{C}$. Disponíveis em: <http://leroymerlin.pt/Site/Produtos/Construcao/Cimentos-areiase-brita/Argamassas/17526796.aspx >. Acesso em: 25 fev. 2016.
} 


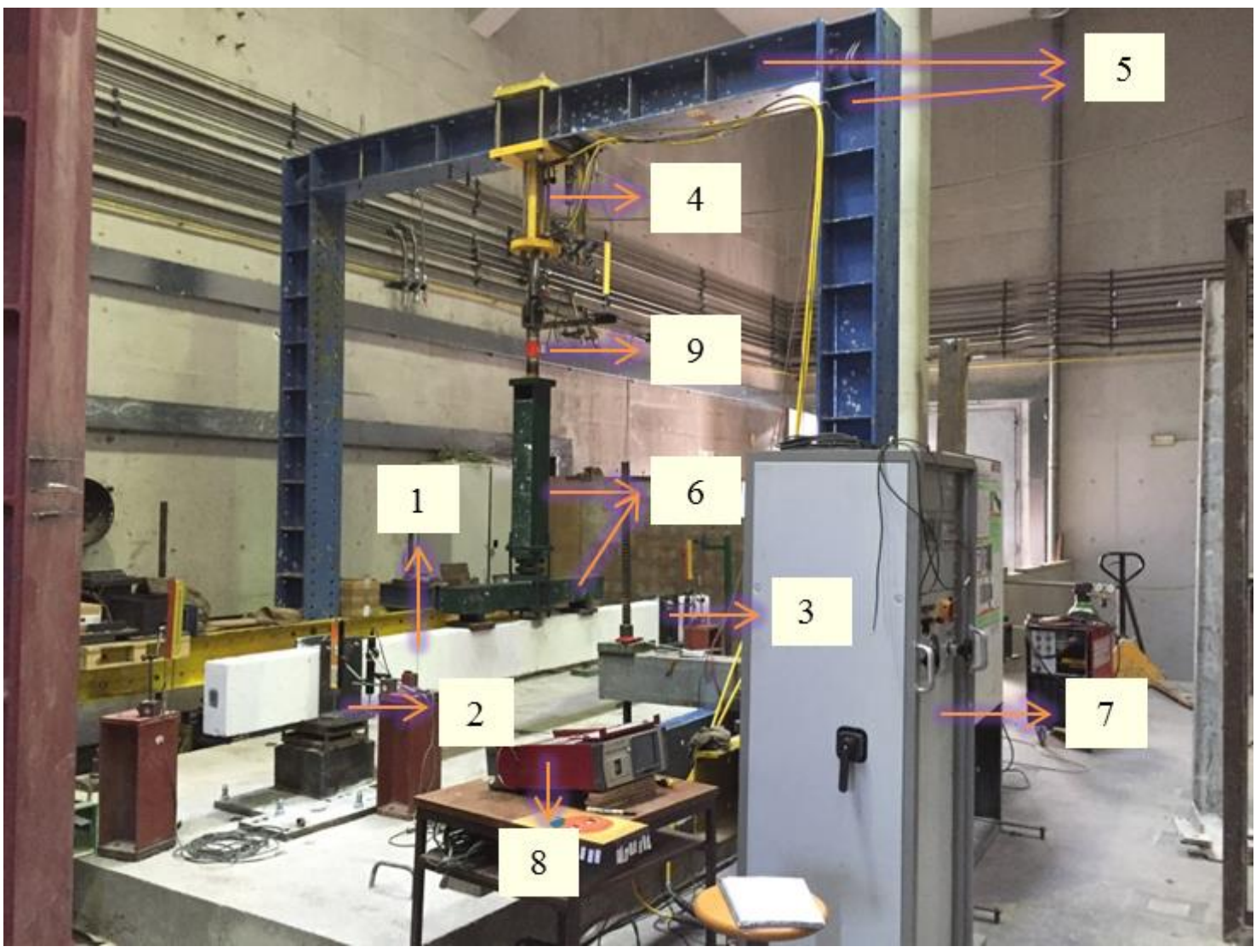

Legenda: 1. Viga de concreto armado ensaiada; 2. Apoio simples; 3. Apoio duplo; 4. Macaco hidráulico; 5. Pórtico de reação; 6. Sistema de redistribuição de forças; 7. Central servo-hidráulica; 8. Data logger; 9. Célula de carga para medição das forças aplicadas à viga de concreto.

Figura 3.1 - Vista geral do sistema para ensaios de vigas simplesmente apoiadas à temperatura ambiente.
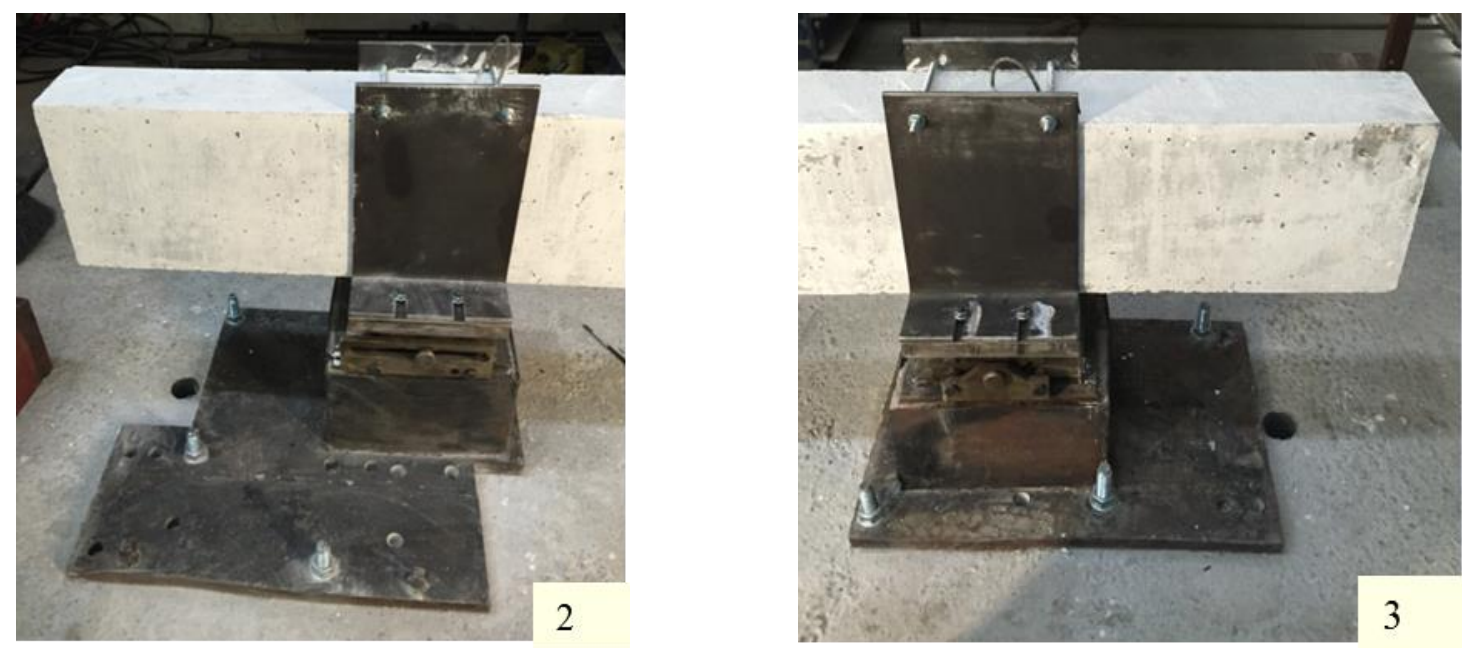

Legenda: 2. Apoio simples; 3. Apoio duplo.

Figura 3.2 - Detalhes dos apoios (continua). 

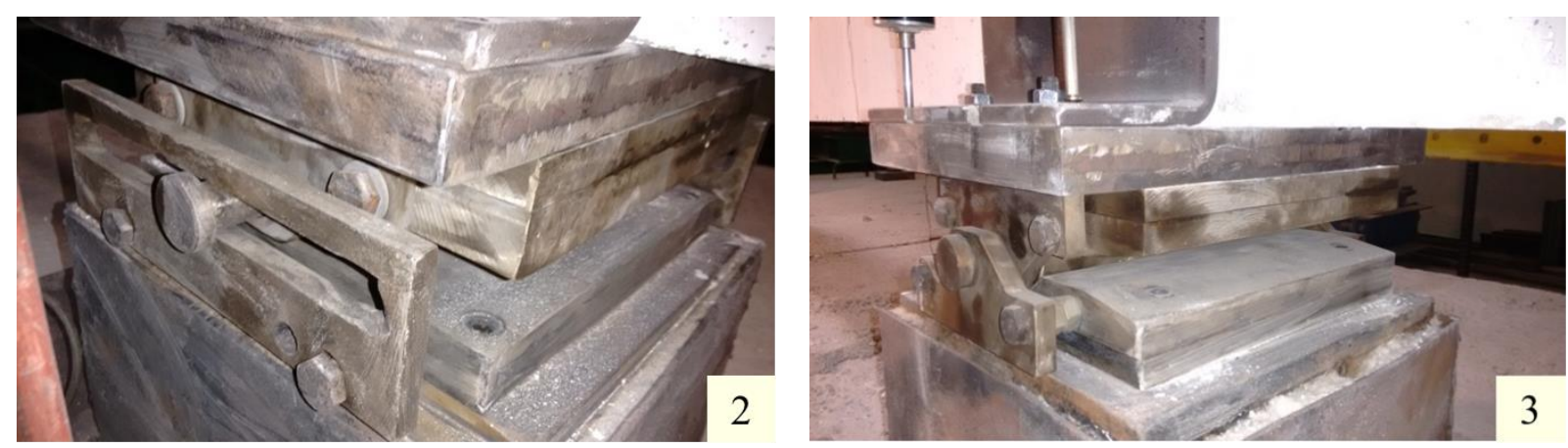

Legenda: 2. Apoio simples; 3. Apoio duplo.

Figura 3.2 - Detalhes dos apoios (conclusão).

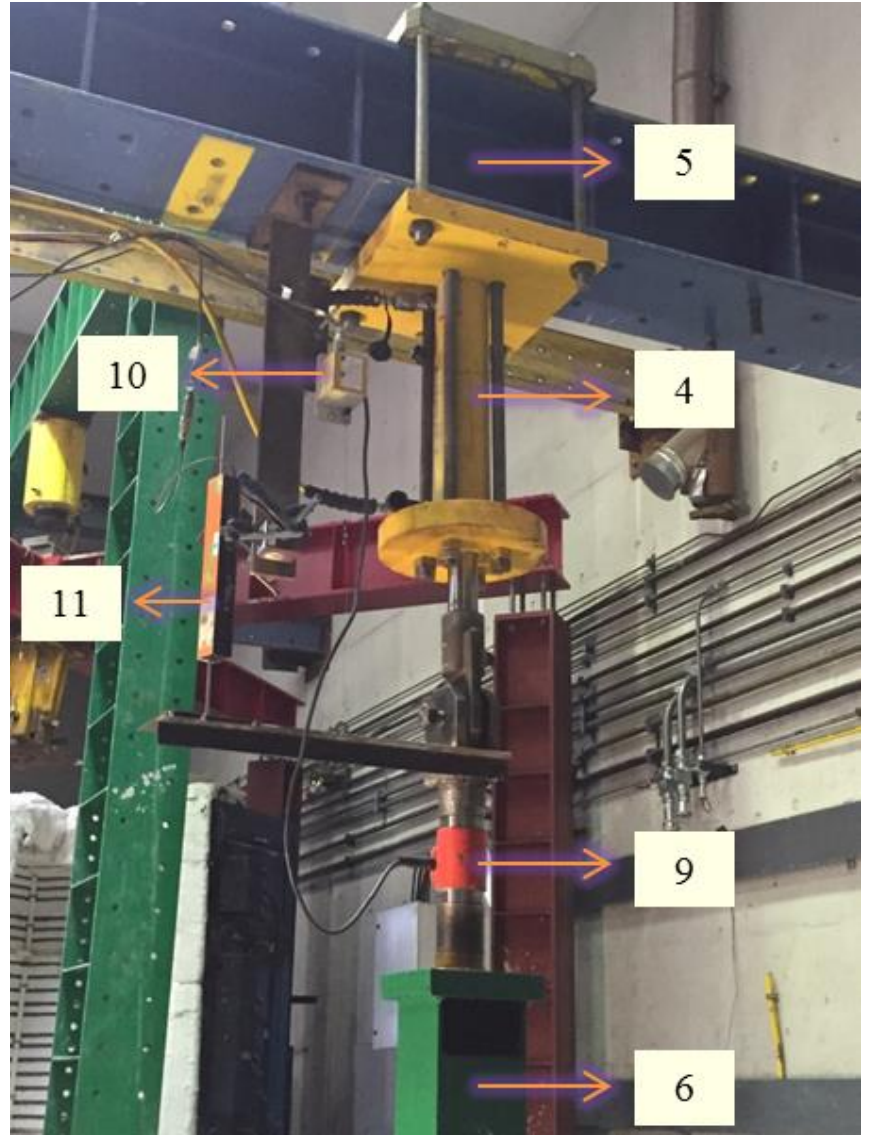

Legenda: 4. Macaco hidráulico; 5. Pórtico de reação; 6. Sistema de redistribuição de forças; 9. Célula de carga para medição das forças aplicadas à viga de concreto; 10 e 11. Transdutores de cabo e êmbolo, respectivamente, para medição dos deslocamentos do macaco.

Figura 3.3 - Posicionamento do macaco hidráulico sob o pórtico de reação e sobre o sistema de redistribuição de forças.

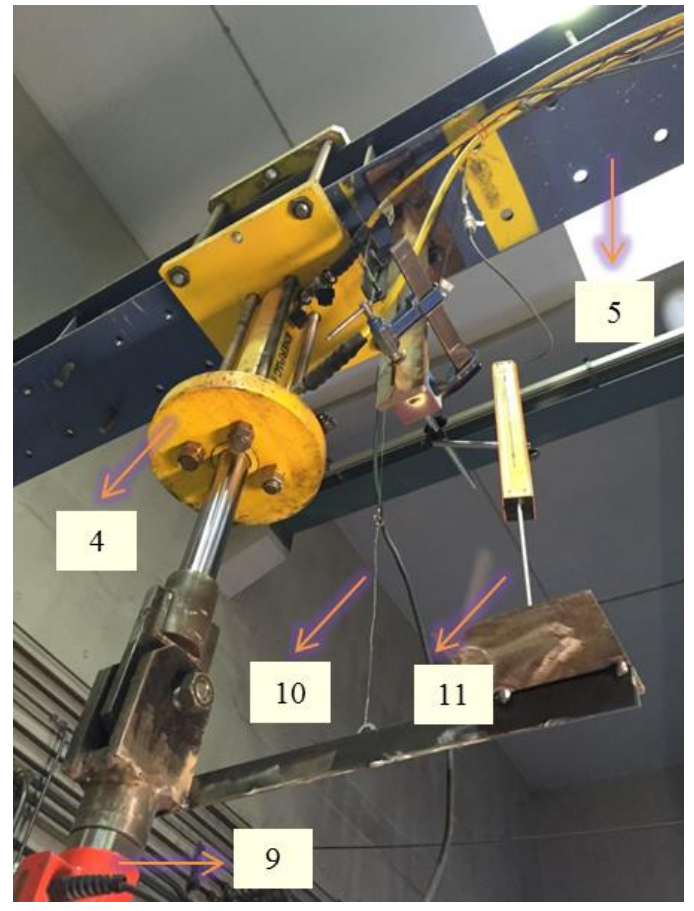

Legenda: 4. Macaco hidráulico; 5. Pórtico de reação; 9. Célula de carga para medição das forças aplicadas à viga de concreto; 10 e 11. Transdutores de cabo e êmbolo, respectivamente, para medição dos deslocamentos do macaco.

Figura 3.4 - Detalhes da instrumentação adotada para monitorizar os deslocamentos verticais do curso do macaco hidráulico e as forças aplicadas à viga de concreto durante os ensaios experimentais. 
Como ilustra a Figura 3.5, os deslocamentos verticais das vigas de concreto foram aferidos ao longo dos ensaios, também em ambos os casos - à temperatura ambiente e ao fogo -, pelos transdutores de deslocamento tipo cabo DP-1000E TML ( $\left.\mathrm{n}^{\circ} 12\right)$, que foram dispostos no piso inferior do LEME ( $\left.\mathrm{n}^{\circ} 13\right)$, logo abaixo daquele onde os ensaios foram conduzidos $\left(\mathrm{n}^{\circ} 14\right)$. Essa foi a alternativa encontrada para proteger os transdutores das altas temperaturas geradas no interior do forno nos ensaios seguintes. Esses deslocamentos foram analisados na direção de três seções das vigas: a $0,5 \mathrm{~m}$ dos apoios $\left(\mathrm{S}_{1}\right.$ e $\left.\mathrm{S}_{3}\right)$ e a meio vão $\left(\mathrm{S}_{2}\right)$. Nessas posições se amarravam fios de termopar (resistentes ao fogo) que eram conduzidos e conectados aos transdutores. Tais pontos de medição foram determinados com base no leiaute do espaço disponível para a realização dos ensaios, uma vez que nessas direções estavam locados alguns dos furos das lajes (do próprio piso superior do laboratório - $\mathrm{n}^{\circ} 14-\mathrm{e}$ da laje/plataforma sobre a qual os ensaios eram realizados $-\mathrm{n}^{\circ} 15-$ ), pelos quais os cabos poderiam ser conduzidos até o piso inferior. Mais detalhes são apresentados nas Figuras 3.6 a 3.8.

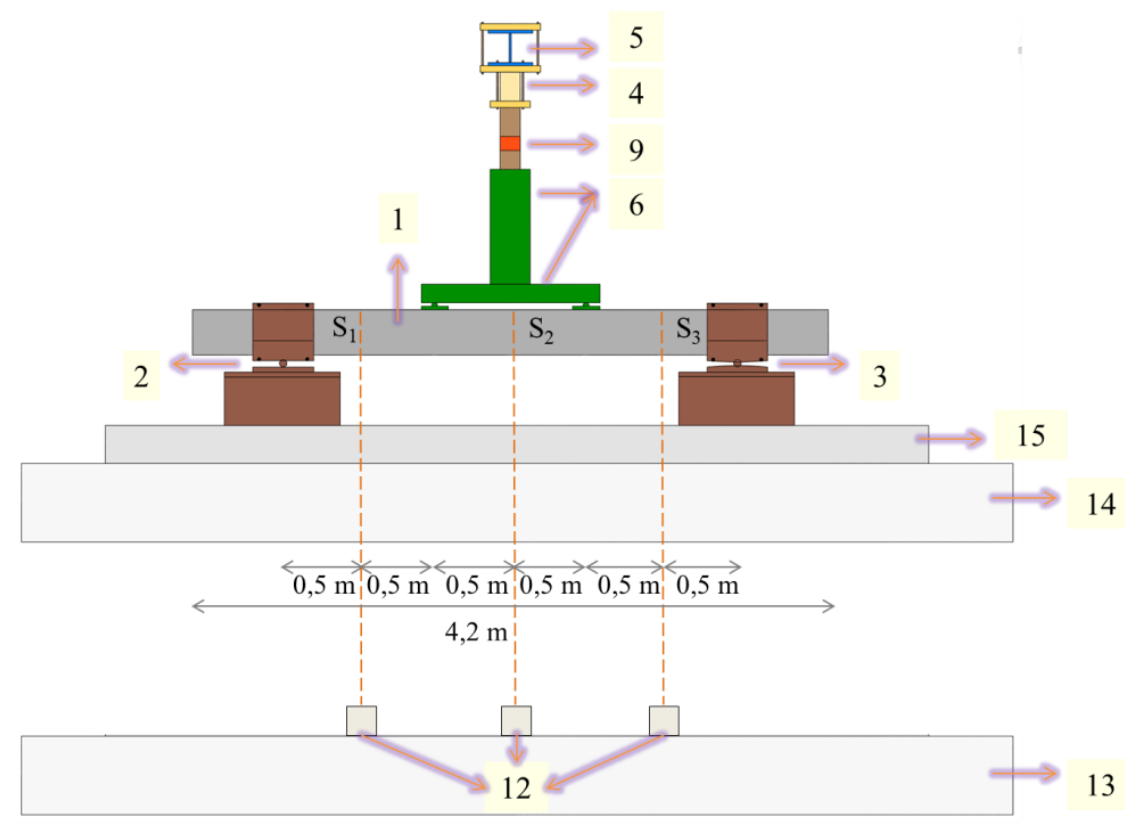

Legenda: 1. Viga de concreto ensaiada; 2. Apoio simples; 3. Apoio duplo; 4. Macaco hidráulico; 5. Pórtico de reação; 6. Sistema de redistribuição de forças; 9. Célula de carga para medição das forças aplicadas à viga de concreto; 12. Transdutores de cabo para medição dos deslocamentos da viga de concreto; 13. Piso inferior do LEME; 14. Piso superior do LEME; 15. Laje de ensaios; $\mathbf{S}_{\mathbf{1}} \mathbf{e} \mathbf{S}_{3}$. Seções $\mathrm{n}^{\circ} 1$ e 3 da viga de concreto, localizadas a $0,5 \mathrm{~m}$ dos apoios simples e duplo, respectivamente; $\mathbf{S}_{2 .}$ Seção $\mathrm{n}^{\circ} 2$ da viga de concreto, localizada a meio vão.

Figura 3.5 - Esquema do sistema para ensaios de vigas simplesmente apoiadas à temperatura ambiente com o detalhe do posicionamento dos transdutores de cabo para medição dos deslocamentos verticais da viga. 


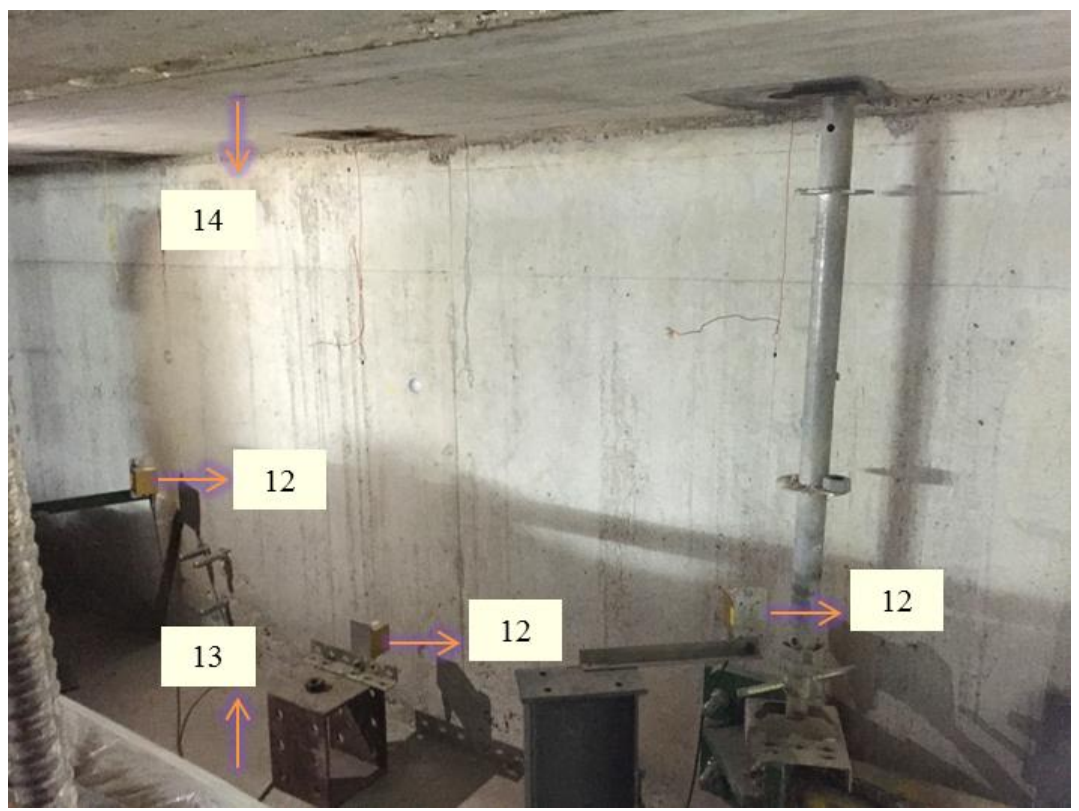

Legenda: 12. Transdutores de cabo para medição dos deslocamentos da viga de concreto; 13. Piso inferior do LEME; 14. Piso superior do LEME.

Figura 3.6 - Transdutores de cabo dispostos no piso inferior do LEME para a medição dos deslocamentos verticais da viga de concreto ensaiada.

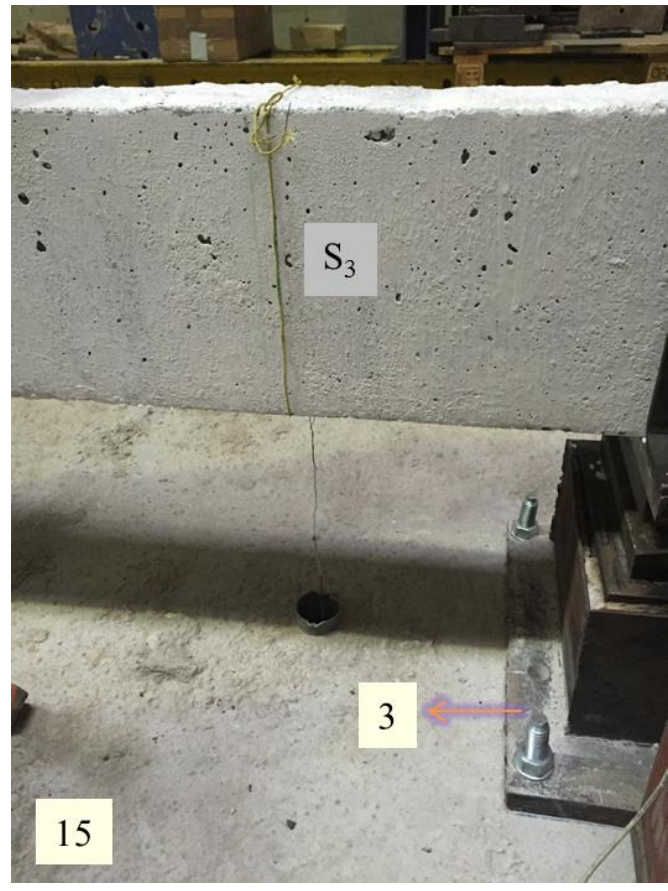

Legenda: 3. Apoio duplo; 15. Laje de ensaios; $\mathbf{S}_{\mathbf{3}}$. Seção $\mathrm{n}^{\circ} 3$ da viga, localizada a $0,5 \mathrm{~m}$ do apoio duplo.

Figura 3.7 - Detalhe do fio termopar amarrado à seção $\mathrm{S}_{3}$ e a passar pelo furo da laje de ensaios.

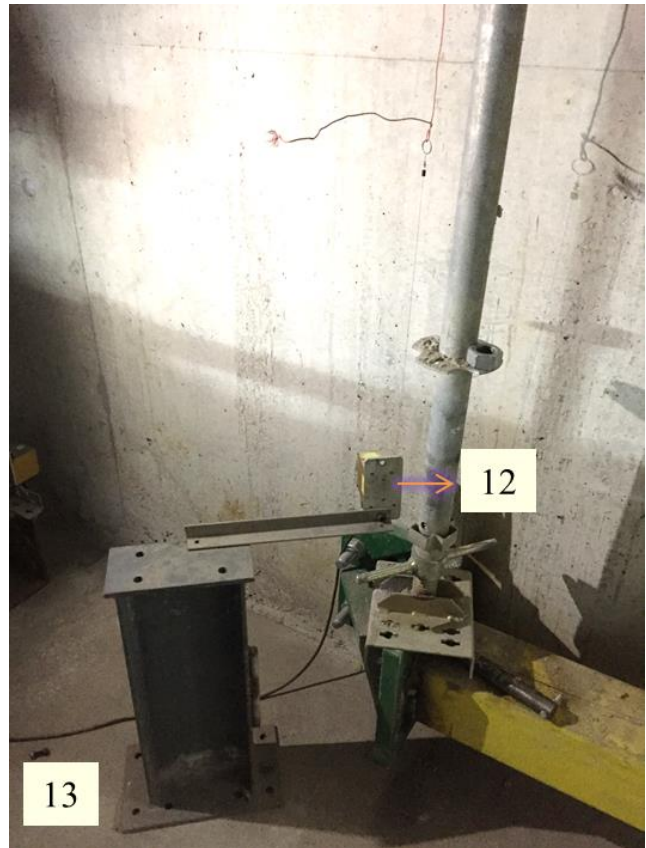

Legenda: 12. Transdutor de cabo para medição dos deslocamentos da viga de concreto; 13. Piso inferior do LEME.

Figura 3.8 - Detalhe do fio termopar amarrado ao cabo do transdutor, já no piso inferior do LEME. 
Apenas nos ensaios de vigas simplesmente apoiadas à temperatura ambiente, utilizaram-se transdutores de deslocamento tipo êmbolo SDP-200D ou eventualmente CDP-100 e CDP-50, ambos da TML, para a medição dos deslocamentos verticais dos apoios ( $\mathrm{n}^{\circ} 16$ da Figura 3.9) e de pontos nas extremidades das vigas de concreto ( $\mathrm{n}^{\circ} 17$ e 18 da mesma figura). Também apenas nesses ensaios, as deformações específicas do concreto foram aferidas na seção a meio vão a partir de extensômetros elétricos (strain gauges), modelo TML PL-60-11, que foram $\operatorname{colados}^{4}$ às faces lateral ( $\mathrm{n}^{\circ} 19$ da Figura 3.10), superior ( $\mathrm{n}^{\circ} 20$ da mesma figura) e inferior. Essas deformações ainda foram monitorizadas em regiões próximas às chapas de distribuição de forças, para analisar se ocorreriam rupturas localizadas por esmagamento $\left(n^{\circ} 21\right)$.

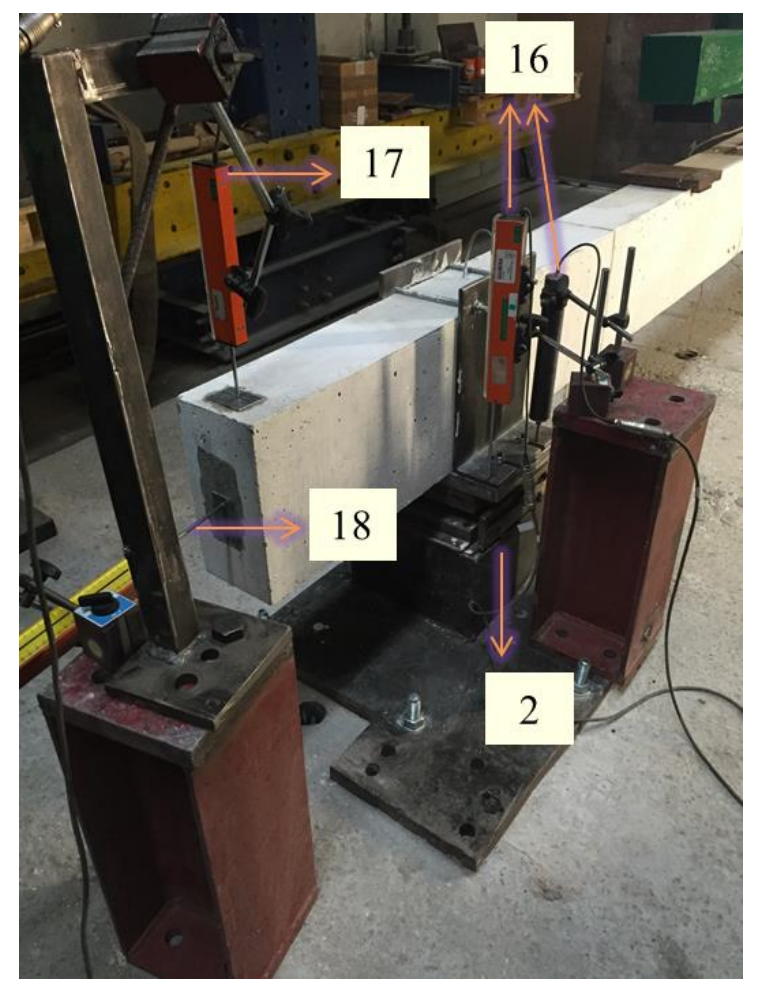

Legenda: 2. Apoio simples; 16. Transdutores de êmbolo para medição dos deslocamentos do apoio; 17 e 18. Transdutores de êmbolo para medição dos deslocamentos em pontos da extremidade da viga.

Figura 3.9 - Detalhes da instrumentação (LVDTs) adotada para aferir os deslocamentos de um dos apoios e de outros pontos da viga de concreto.
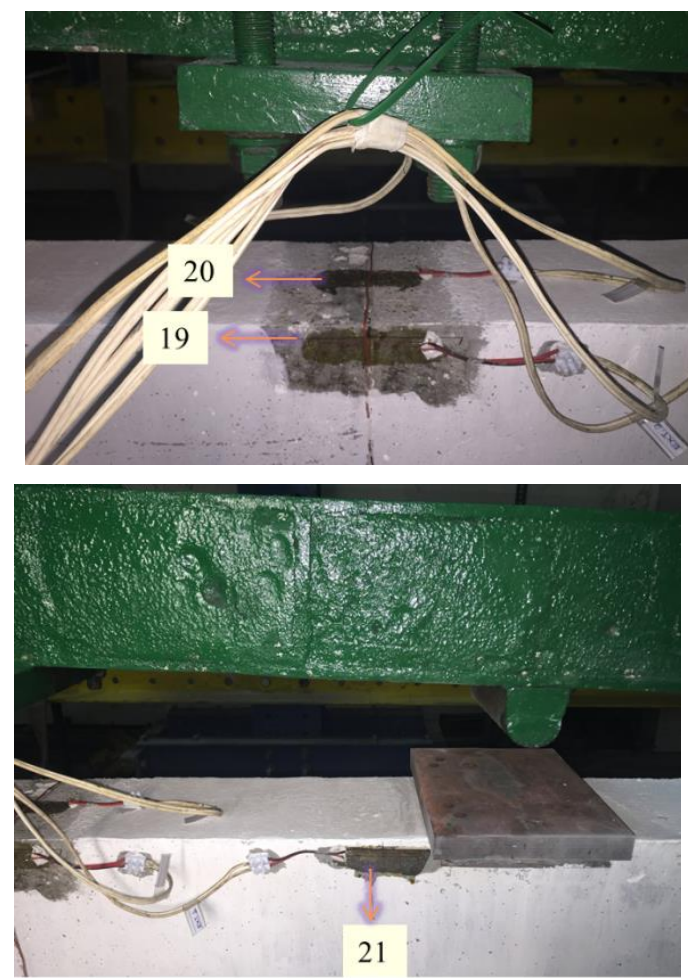

Legenda: 19 e 20. Extensômetros elétricos colados à face lateral e superior, respectivamente, da seção a meio vão da viga; 21. Extensômetro elétrico colado em região próxima à chapa de distribuição de forças.

Figura 3.10 - Extensômetros elétricos (strain gauges) colados na viga para monitorizar as deformações específicas do concreto.

\footnotetext{
${ }^{4}$ Utilizou-se a cola de mistura de dois componentes RP-2 da TML. Informações do fabricante estão disponíveis em: 〈http://www.tml.jp/e/product/strain_gauge/adhesives_list/\#a6 > . Acesso em: 04 nov. 2015.
} 


\subsubsection{Vigas em situação de incêndio}

\subsubsection{Simplesmente apoiadas}

Nos ensaios de vigas simplesmente apoiadas expostas a altas temperaturas, passou a fazer parte do sistema de ensaios apresentado na seção anterior um forno horizontal elétrico constituído por três módulos que eram posicionados sobre a viga para simular a situação de incêndio, vide $\mathrm{n}^{\circ} 22$ da Figura 3.11. Ressalta-se que nesse sistema, os apoios não apresentavam quaisquer impedimentos às deformações geradas na viga de concreto armado pela ação do calor.

Os apoios, que foram produzidos com aço S275 JR (designação portuguesa), eram sempre isolados com mantas de lã de silicato alcalino para que fossem preservados ao longo dos ensaios ao fogo $\left(n^{\circ} 2\right)$. O sistema de redistribuição de forças $\left(n^{\circ} 6\right)$, além de preenchido com argamassa refratária, também era protegido pelo mesmo tipo de material. A zona da laje sobre a qual eram realizados os ensaios $\left(n^{\circ} 15\right)$ era salvaguardada pelo uso de mantas de lã cerâmica. Esses detalhes também estão apresentados na Figura 3.11.

O forno elétrico foi produzido pela TermoLab e possuía dimensões internas de $4,5 \mathrm{~m}$ de comprimento e $1 \mathrm{~m}$ tanto de largura quanto de altura. Era capaz de atingir a temperatura máxima de $1200{ }^{\circ} \mathrm{C}$ e produzir diferentes regimes de exposição ao fogo. Nos ensaios realizados para a presente Tese, a sua taxa de aquecimento foi calibrada para seguir a curva de incêndio-padrão ISO 834 (1999). 

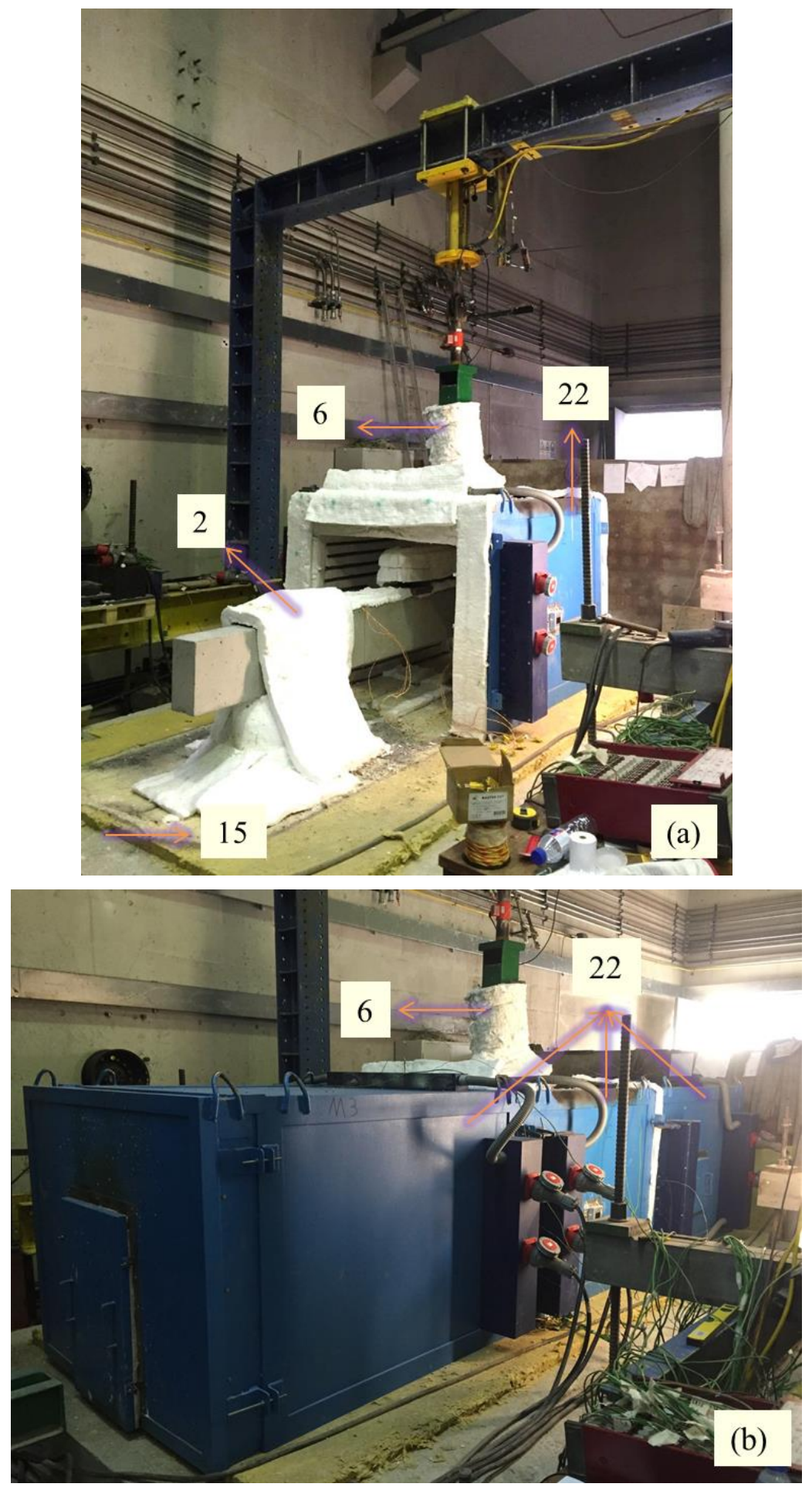

Legenda: 2. Apoio simples; 6. Sistema de redistribuição de forças; 15. Laje de ensaios; 22. Forno horizontal modular elétrico.

Figura 3.11 - Sistema para ensaios de vigas simplesmente apoiadas em situação de incêndio (a) com apenas um módulo e (b) com os três módulos do forno elétrico posicionados sobre a viga de concreto. 
Durante os ensaios experimentais, as temperaturas internas do forno foram monitorizadas por meio da utilização de termopares de sonda tipo $\mathrm{k}$, que foram posicionados em doze pontos localizados entre os três módulos (seis pontos em cada uma das duas seções que uniam os módulos). Como indicado na Figura 3.12, esses termopares foram colocados junto às paredes laterais do forno $\left(\mathrm{n}^{\circ} 23\right)$, em pontos coincidentes à base e ao topo da seção transversal da viga de concreto, e também no topo do forno $\left(n^{\circ} 24\right)$, em pontos coincidentes às faces laterais da seção. Assim, era possível certificar que as resistências elétricas localizadas nessas regiões estavam a simular à viga o aquecimento pretendido. Detalhes do posicionamento dos termopares entre os módulos do forno são apresentados na Figura 3.13, enquanto o interior do equipamento pode ser visualizado na Figura 3.14. Esse método para a medição das temperaturas internas foi adotado ao longo de todos os ensaios de vigas em situação de incêndio, ou seja, tanto para aqueles de vigas simplesmente apoiadas quanto com restrições.

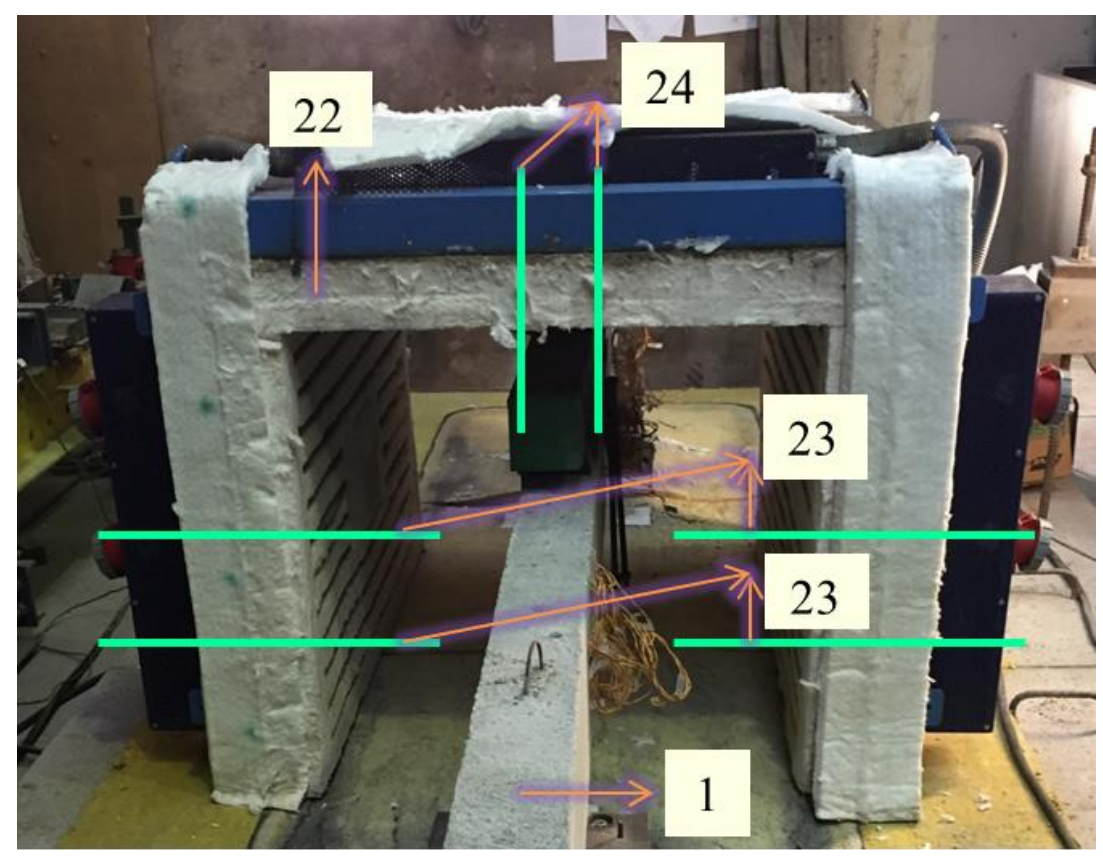

Legenda: 1. Viga de concreto armado ensaiada; 22. Forno horizontal modular elétrico; 23 e 24. Termopares de sonda posicionados junto às paredes laterais e ao topo do forno, respectivamente.

Figura 3.12 - Esquema do posicionamento dos termopares de sonda adotados para a medição das temperaturas internas produzidas pelo forno elétrico ao longo dos ensaios. 

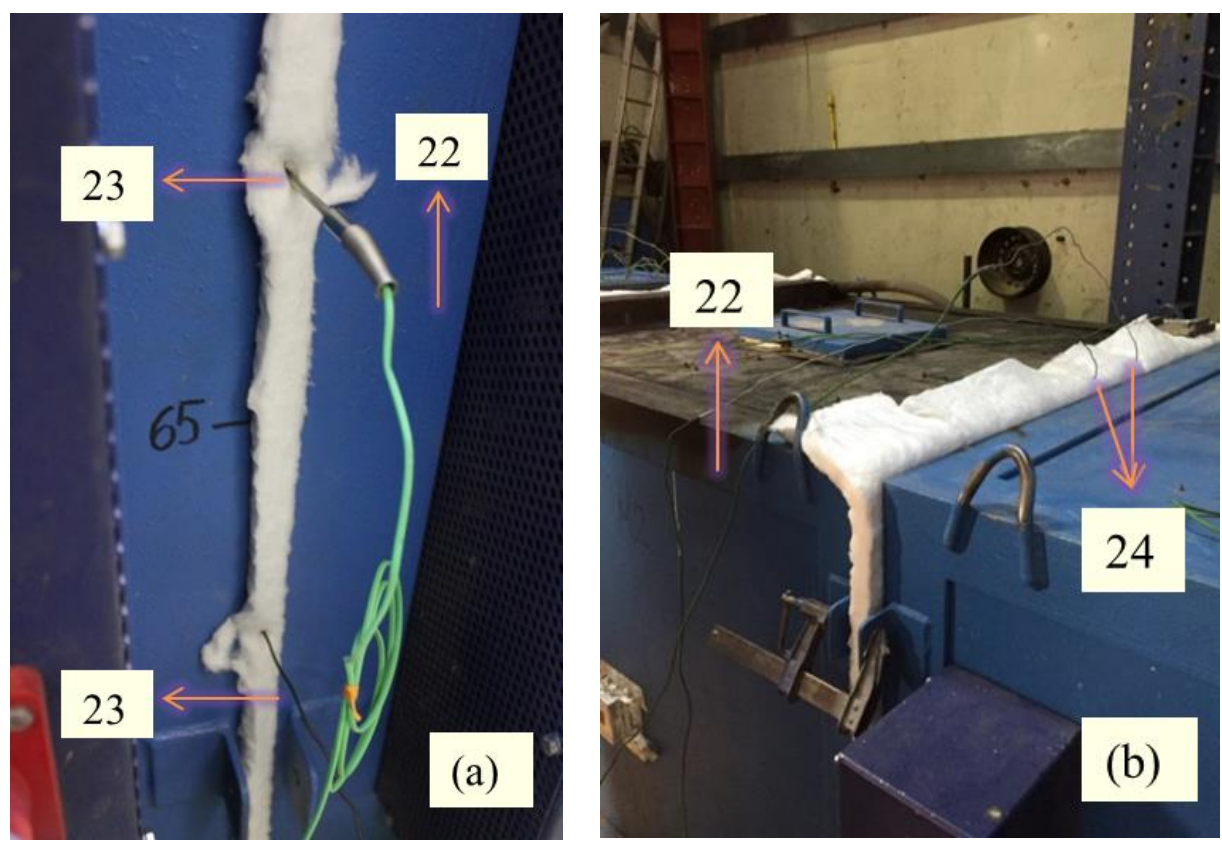

Legenda: 22. Forno horizontal modular elétrico; 23 e 24. Termopares de sonda posicionados junto às paredes laterais e ao topo do forno, respectivamente.

Figura 3.13 - Detalhes da instrumentação do forno, com termopares de sonda inseridos entre os módulos em (a) uma das faces laterais do equipamento e (b) em sua face superior.

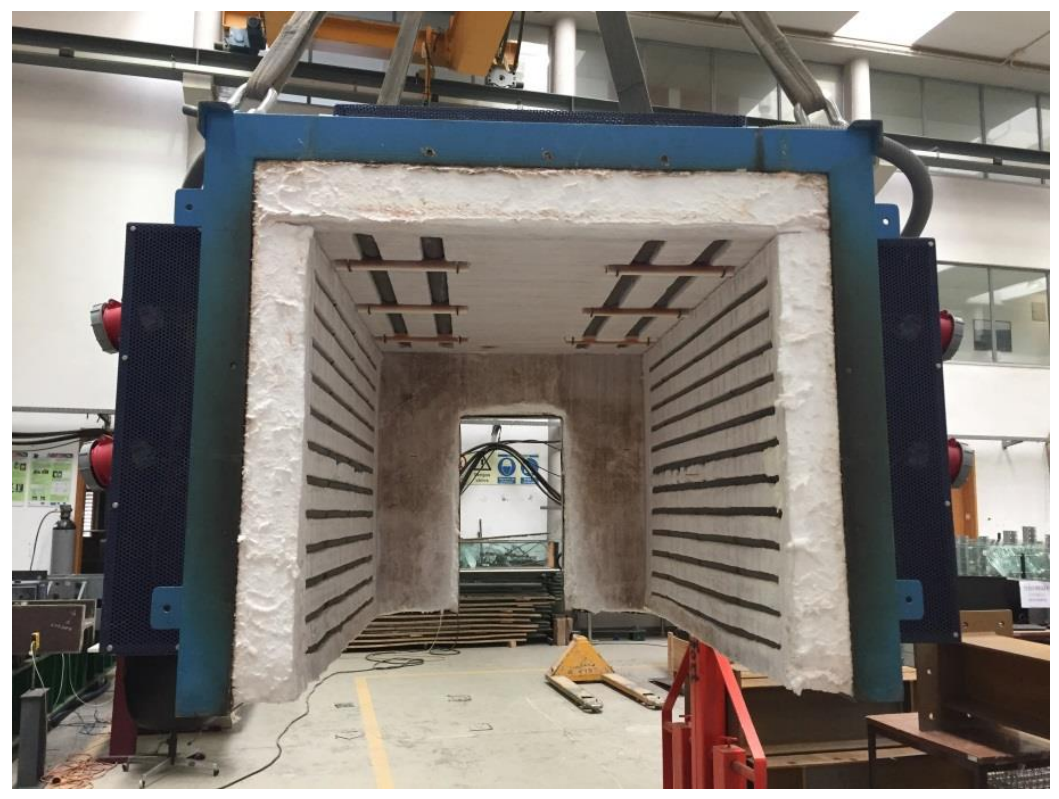

Figura 3.14 - Vista interior de um dos módulos do forno, com as resistências elétricas dispostas nas faces laterais e superior do equipamento. 
Os modelos de termopares tipo sonda foram utilizados porque conduziam a resultados mais satisfatórios para fornos elétricos. Apesar das normas ISO 834 (1999) e ASTM E119 (2000) apresentarem prescrições para a instrumentação de fornos indicando o uso de termopares tipo placa, tais prescrições possuem como base a utilização de fornos a gás, situação na qual esse modelo é mais indicado. Moreno Junior e Molina (2012) explicam que os termopares de placa são bem mais sensíveis à radiação do que os de sonda e, por isso, são mais representativos do fenômeno de aquecimento via chama, proveniente dos fornos a gás.

Os termopares de placa não são os mais eficientes para os fornos elétricos, conforme se pôde verificar em algumas análises prévias realizadas no LEME, justamente pelo fato da componente de radiação ser mais significativa nesse caso. Em contrapartida, os termopares tipo sonda são capazes de medir de forma mais coerente a temperatura do ar nos fornos elétricos porque ficam relativamente distantes das resistências, de modo que os seus resultados passam a ser pouco influenciados pela radiação.

Ainda nas normas citadas anteriormente - ISO 834 (1999) e ASTM E119 (2000) - e também na ISO 834 parte 6 (2000), específica para os ensaios de resistência ao fogo em vigas, apontam-se prescrições quanto ao posicionamento e a quantidade de termopares que devem ser utilizados para a medição das temperaturas do forno ${ }^{5}$. Contudo, essas prescrições não foram adotadas nos ensaios desta Tese porque não se mostraram aplicáveis às características e às dimensões do forno modular elétrico de projeto utilizado.

Além das temperaturas do forno, aferiram-se nos ensaios de vigas em situação de incêndio simplesmente apoiadas e com restrições - as evoluções das temperaturas internas desses elementos estruturais. Essas foram medidas a partir de fios termopar tipo k, que foram introduzidos em determinados pontos localizados nas mesmas três seções das vigas $\left(S_{1}\right.$ a $\left.S_{3}\right)$ para as quais os deslocamentos verticais foram medidos (Figura 3.5).

\footnotetext{
${ }^{5}$ Mais informações sobre essas prescrições podem ser encontradas na publicação de Moreno Junior e Molina (2012), que também indica as diretrizes da norma brasileira relacionada ao assunto, a ABNT NBR 5628:2001.
} 
Em apenas dois ensaios de vigas simplesmente apoiadas expostas a temperaturas elevadas, os termopares foram colocados nas posições indicadas na Figura 3.15 (a). Para a análise das temperaturas no concreto, estipularam-se os pontos localizados próximos às faces diretamente submetidas à ação do fogo e aqueles localizados na parte central, com o propósito de avaliar as temperaturas atingidas no núcleo da viga e na zona em que o concreto se encontrava sob compressão. Para a análise das temperaturas no aço, posicionaram-se dois termopares, sendo um deles em uma das barras da armadura inferior e outro na armadura superior. Ainda se adotou um termopar para aferir as temperaturas na interface concreto/manta ${ }^{6}$. Esses ensaios com vários termopares embutidos nas seções $S_{1}$ a $S_{3}$ foram realizados com o principal objetivo de analisar os campos térmicos das vigas de concreto armado de forma detalhada.

Para as outras vigas que foram ensaiadas ao fogo nesta campanha experimental, apenas quatro termopares foram inseridos em cada uma das seções, vide Figura 3.15 (b), haja vista que um número maior poderia influenciar nos resultados. Isso porque poderiam ser criados pontos de fragilidade nas peças, reduzindo suas respectivas capacidades resistentes. Além disso, os fios de termopar poderiam ocasionar a abertura de vazios para a saída de vapor, o que também poderia modificar o comportamento das vigas frente à situação de incêndio. Todavia, considerando que foram realizados dois ensaios exclusivamente para determinar os campos térmicos das vigas, esses três termopares se mostraram suficientes para a validação dos demais resultados.

Por fim, é válido citar que apenas uma peça foi analisada com três termopares a cada seção (Figura 3.15-c), pois nessa não havia a presença da manta na sua face superior. Esse foi um ensaio adicional, a fim de verificar como se comportavam as temperaturas do elemento sem a presença do material isolante.

\footnotetext{
${ }^{6}$ Conforme será discutido com detalhes na seção 3.3 Vigas ensaiadas, as mantas de lã de silicato alcalino foram adotadas como material isolante para a face superior das vigas de concreto armado.
} 

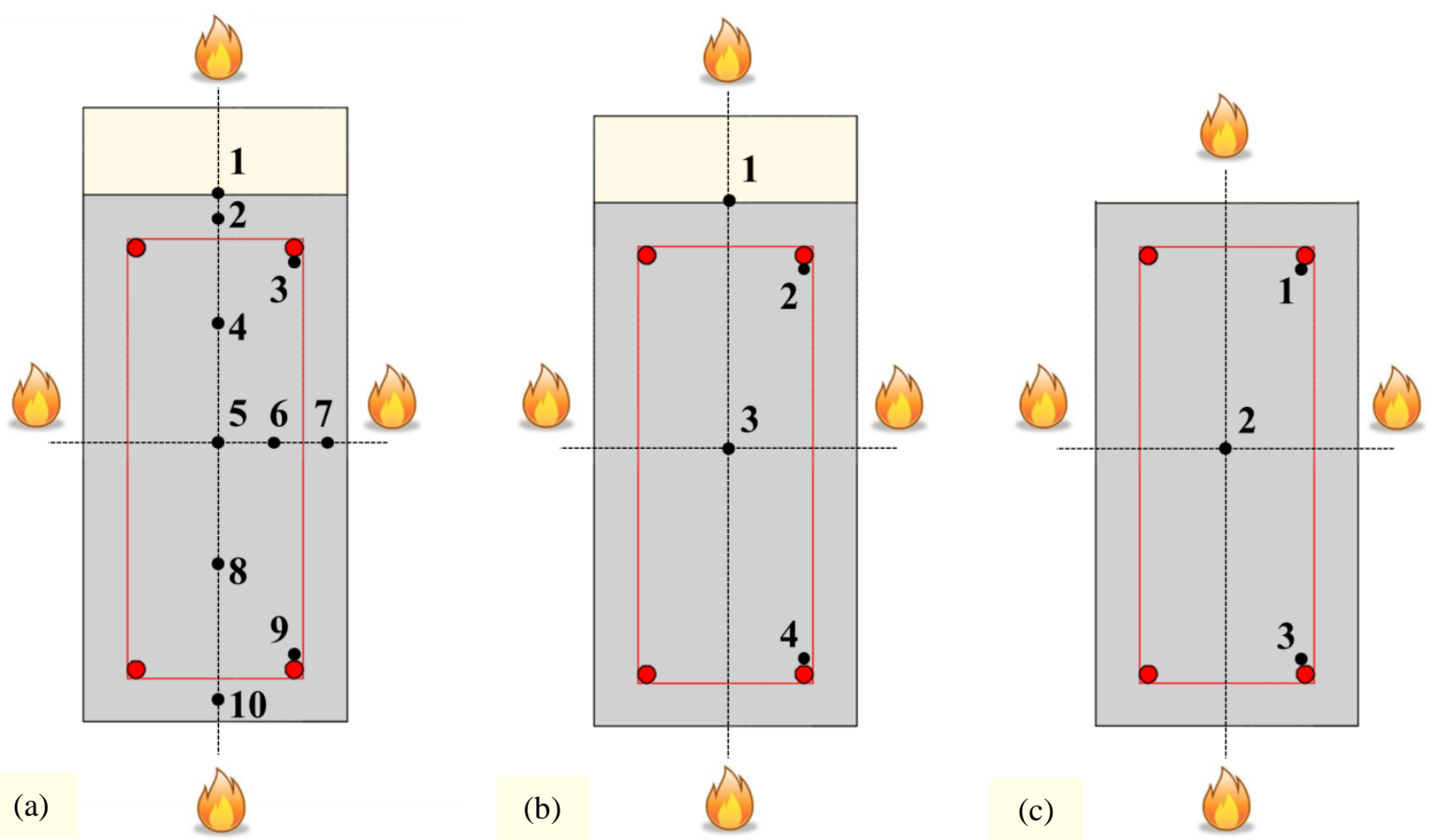

Figura 3.15 - Localização dos termopares nas seções $S_{1}$ a $S_{3}$ (a) de dois ensaios de vigas simplesmente apoiadas com material isolante na face superior (medição detalhada dos campos térmicos); (b) dos demais ensaios de vigas expostas ao fogo com material isolante na face superior (simplesmente apoiadas ou com restrições); (c) de um ensaio de viga simplesmente apoiada sem material isolante na face superior.

\subsubsection{Com restrição axial}

Para simular condições de contorno que restringissem o alongamento térmico do vão das vigas de concreto armado, duas vigas de aço simplesmente apoiadas foram acopladas ao sistema de ensaios anterior (o das vigas simplesmente apoiadas em situação de incêndio), como indicado a seguir, pelas Figuras 3.16 e 3.17. Essas vigas de restrição $\left(n^{\circ} 25\right.$ e 26$)$ foram posicionadas perpendicularmente à viga de concreto por meio de um conjunto de peças de aço que, bem conectadas entre si, funcionavam como complementos do elemento ensaiado.

$\mathrm{Na}$ extremidade próxima ao apoio simples, os complementos eram constituídos por chapas e barras roscadas de aço $\left(n^{\circ} 27\right)$ e na extremidade junto ao apoio duplo por chapas e um perfil 
HEB 220 de aço $\left(n^{\circ} 28\right)$. Esses elementos eram fixos à viga de concreto armado por meio de parafusos e chapas de aperto auxiliares. As barras roscadas indicadas no $\mathrm{n}^{\circ} 29$, uma vez bem apertadas com o auxílio de parafusos, tinham como objetivo principal eliminar possíveis folgas entre a viga de concreto e as vigas de aço que a restringiam axialmente. As primeiras peças que constituíam os conjuntos de complementos ( $n^{\circ} 30$ e 31 ), posicionadas em cada uma das extremidades da viga de concreto (logo após os apoios), eram nela encaixadas e a partir dali se prolongavam, por meio de outras peças, até o sistema de restrição. Na Figura 3.18, essas primeiras peças dos complementos são ilustradas por meio de esquemas. No Apêndice A são apresentados mais detalhes do projeto de alguns desses elementos que compunham o sistema de restrição.

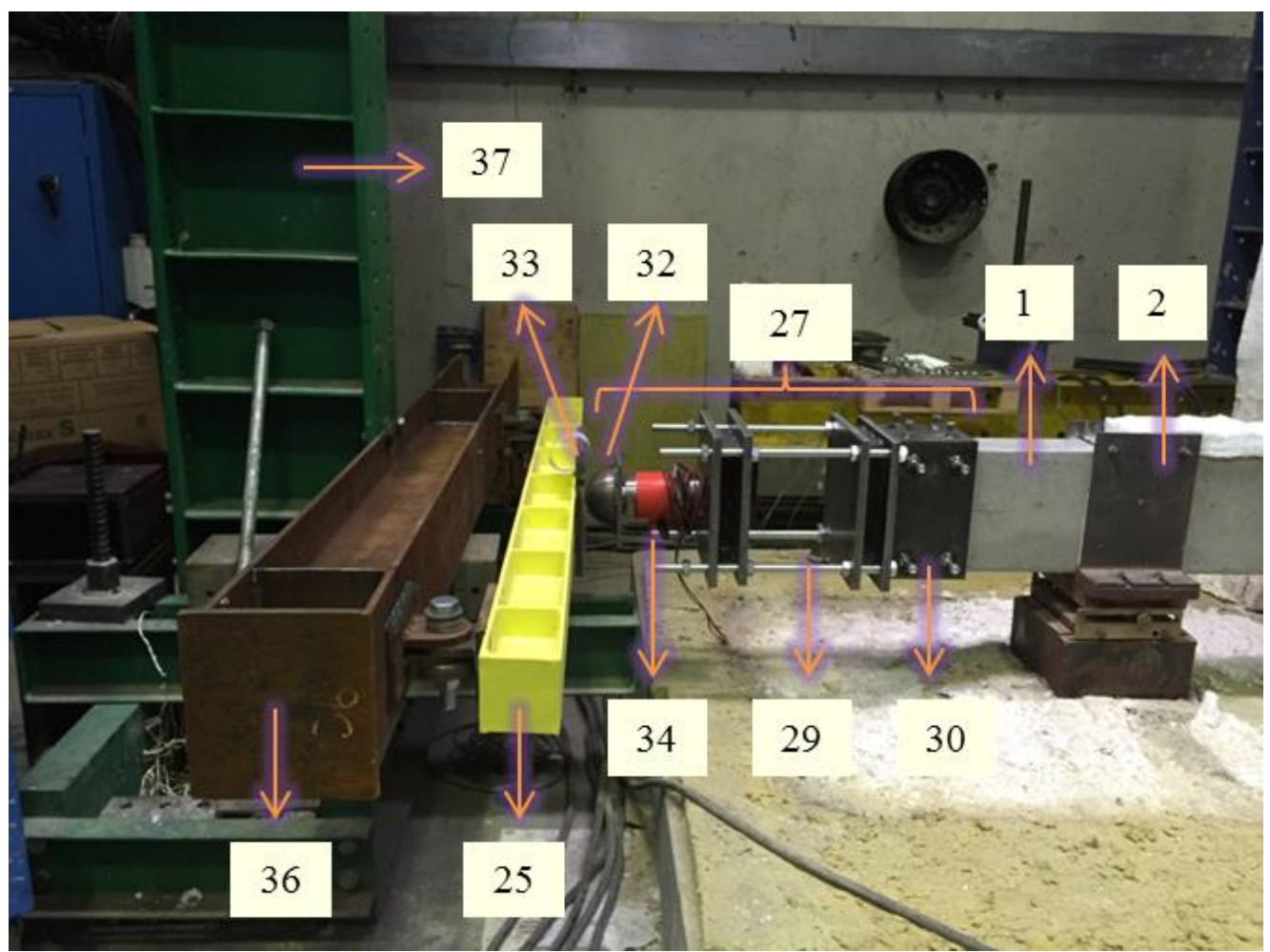

Legenda: 1. Viga de concreto ensaiada; 2. Apoio simples; 25. Viga de restrição para simulação de rigidez axial parcial; 27. Complementos da viga de concreto posicionados na extremidade próxima ao apoio simples; 29. Barras roscadas de aço; 30. Primeira peça dos complementos posicionados na extremidade próxima ao apoio simples; 32. Semi-esfera de aço posicionada junto aos complementos próximos ao apoio simples; 33. Chapa de aço soldada à viga de simulação de rigidez axial parcial; 34. Célula de carga para medição das forças de restrição axial; 36. Viga de conexão entre a viga de simulação de rigidez axial parcial e o pórtico de apoio ao sistema; 37. Pilar do pórtico de apoio ao sistema de restrição axial disposto na extremidade próxima ao apoio simples.

Figura 3.16 - Detalhes do sistema de restrição axial disposto na extremidade do apoio simples (rigidez parcial). 


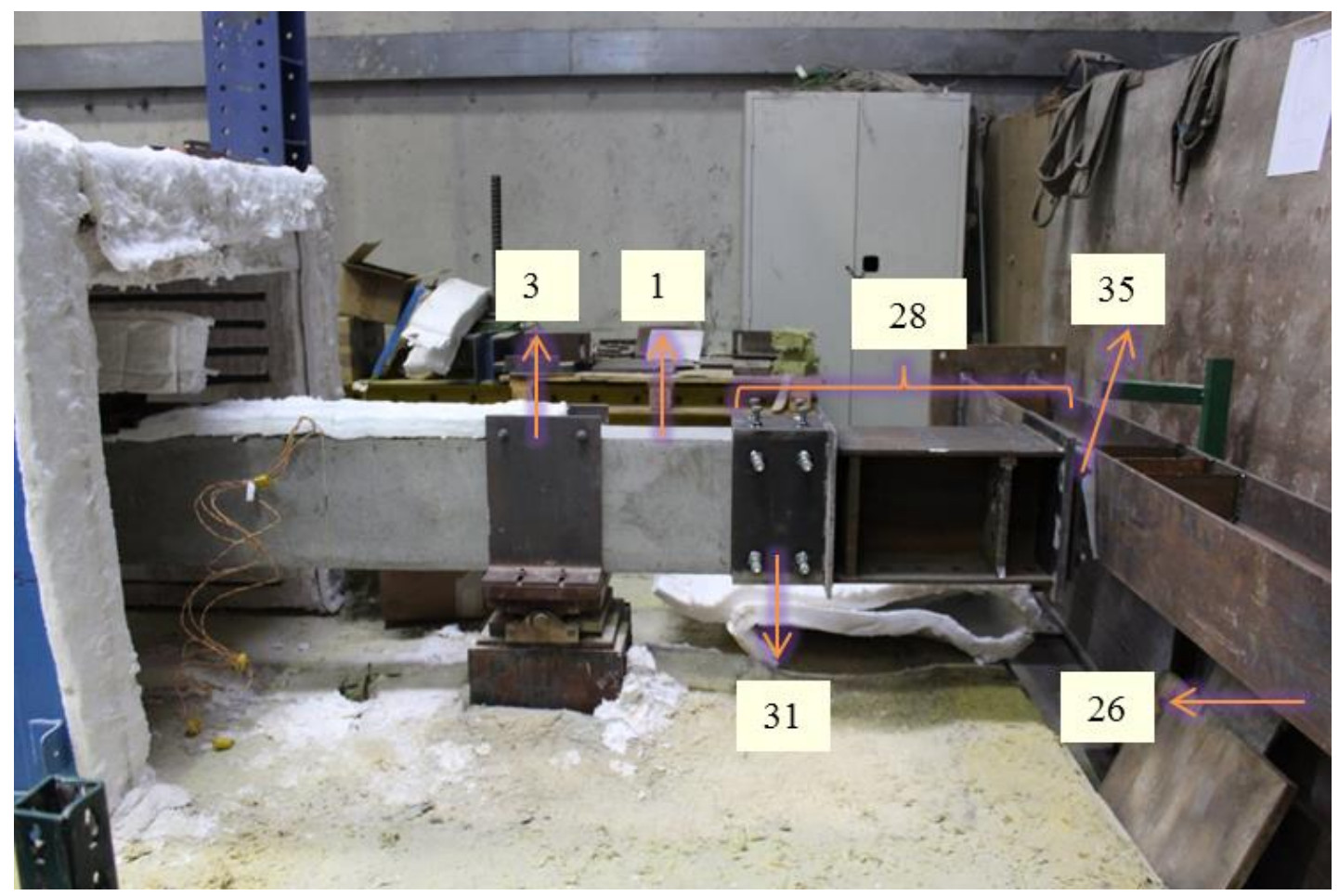

Legenda: 1. Viga de concreto ensaiada; 3. Apoio duplo; 26. Viga de restrição para simulação de rigidez axial "infinita"; 28. Complementos da viga de concreto posicionados na extremidade próxima ao apoio duplo; 31. Primeira peça dos complementos posicionados na extremidade próxima ao apoio duplo; 35. Semi-esfera de aço posicionada junto aos complementos próximos ao apoio duplo.

Figura 3.17 - Detalhes do sistema de restrição axial disposto na extremidade do apoio duplo (rigidez "infinita").

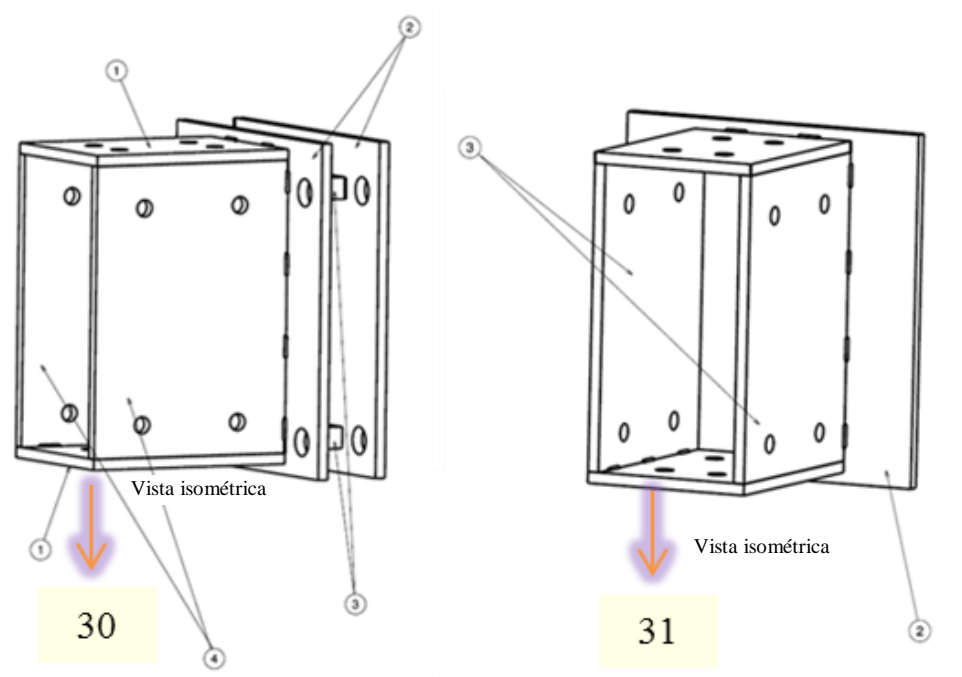

Legenda: 30 e 31. Primeiras peças dos complementos posicionados nas extremidades próximas aos apoios simples e duplo, respectivamente.

Figura 3.18 - Esquemas das peças dos complementos que foram encaixadas na viga de concreto em suas extremidades junto aos apoios simples (rigidez axial parcial) e duplo (rigidez axial "infinita"). 
Como o próprio nome os define, os complementos possuíam a função de prolongar o comprimento da viga de concreto sob análise e de conectar a mesma ao sistema de restrição. Logo, os complementos permitiam afastar as vigas de aço que simulavam a restrição axial, de modo que essas ficassem localizadas na parte de fora do forno. Assim, o equipamento poderia ser posicionado sobre a viga de concreto para aquecê-la, conforme ilustra o esquema geral da Figura 3.19. Pelo fato dos complementos resultarem num conjunto de peças de aço bastante rígido, todos (complementos e viga de concreto) se comportavam ou se deformavam de forma similar, por inteiro. Sendo assim, eles simulavam parte da viga de concreto ensaiada, representando um elemento estrutural mais longo.

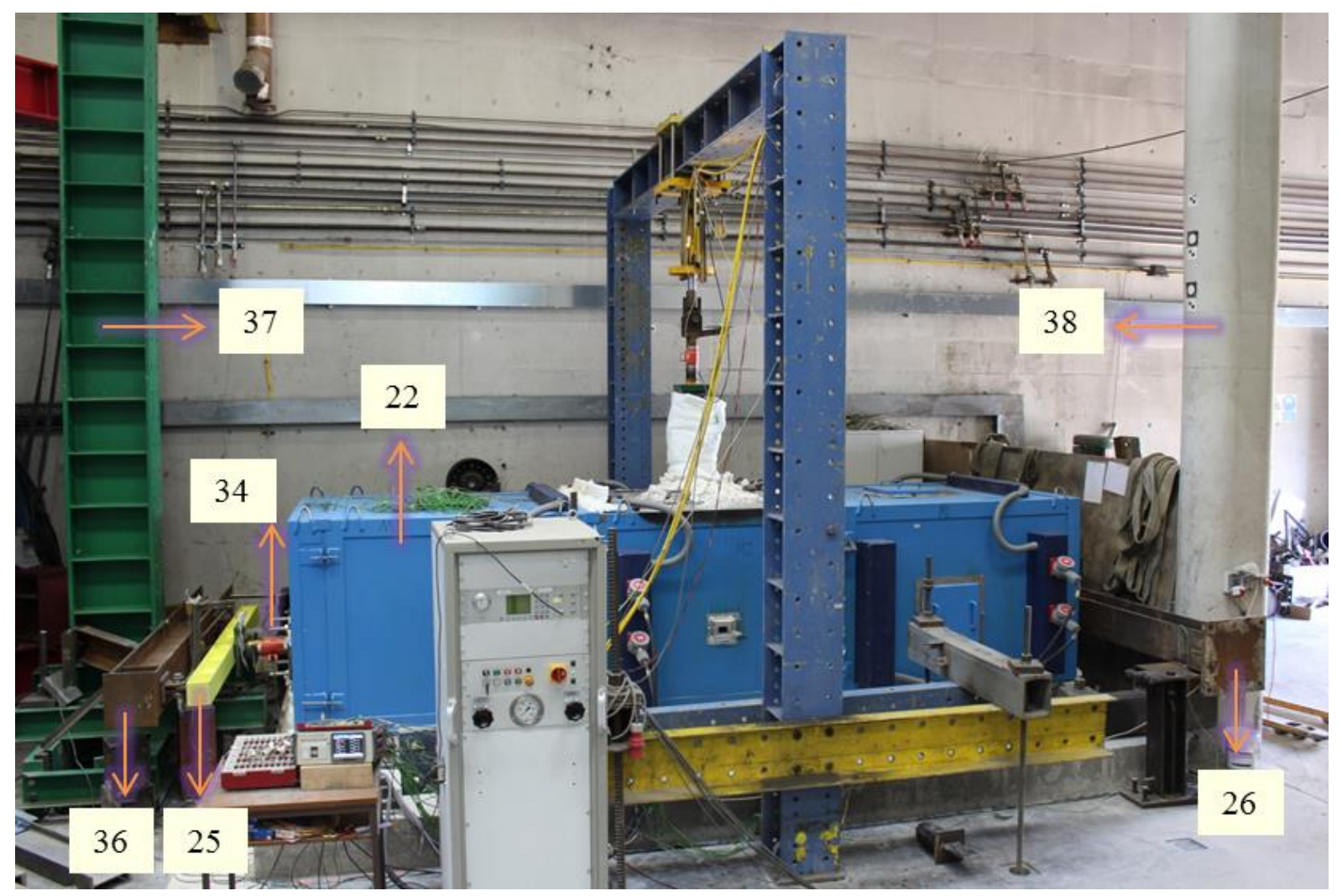

Legenda: 22. Forno horizontal modular elétrico; 25. Viga de restrição para simulação de rigidez axial parcial; 26. Viga de restrição para simulação de rigidez axial "infinita"; 34. Célula de carga para medição das forças de restrição axial; 36. Viga de conexão entre a viga de simulação de rigidez axial parcial e o pórtico de apoio ao sistema; 37. Pilar do pórtico de apoio ao sistema de restrição axial disposto na extremidade próxima ao apoio simples; 38. Pilar de apoio ao sistema de restrição axial disposto na extremidade próxima ao apoio duplo.

Figura 3.19 - Vista geral do sistema para ensaios de vigas com restrições axiais em situação de incêndio, com o detalhe dos elementos de restrição que ficavam dispostos na parte de fora do forno. 
Portanto, nesses ensaios com restrição axial, as vigas de concreto armado eram igualmente posicionadas sobre os apoios simples e duplo, contudo, na extremidade próxima ao apoio simples (lado esquerdo) havia agora uma viga de aço que simulava uma restrição parcial ao alongamento da viga de concreto, ou seja, era uma viga de aço com baixa rigidez à flexão ( ${ }^{\circ}$ 25), igual a 7 ou $14 \mathrm{kN} / \mathrm{mm}^{7}$, enquanto na outra extremidade, próxima ao apoio duplo (lado direito), havia uma viga de aço extremamente rígida ( $\left.\mathrm{n}^{\circ} 26\right)$, que impedia qualquer alongamento da viga de concreto, uma vez que essa tinha rigidez à flexão aproximadamente cinco vezes maior do que aquela de $14 \mathrm{kN} / \mathrm{mm}$ (máxima rigidez axial que pôde ser testada). Logo, esse sistema completo acabava por simular o modelo estático de uma viga biapoiada.

As rigidezes axiais de 7 ou $14 \mathrm{kN} / \mathrm{mm}$ foram simuladas por meio de vigas de aço com perfis HEB 120 e HEB 140, respectivamente, ambas com vãos de 1,8 m entre apoios. Para a rigidez axial "infinita", adotou-se uma viga de aço com seção HEB 240 com vão igual a 2,4 m. Todos esses perfis eram de aço classe $\mathrm{S} 355$.

Pela Figura 3.20, vê-se que o contato entre o conjunto de peças dos complementos da viga de concreto armado e a viga de aço que simulava a restrição axial parcial ( $\left.\mathrm{n}^{\circ} 25\right)$ se dava a partir de uma semiesfera de aço ( $\left.\mathrm{n}^{\circ} 32\right)$ que encostava em uma chapa também de aço $\left(\mathrm{n}^{\circ} 33\right)$ que fora soldada à essa viga de restrição axial. Entre a chapa e a semiesfera, colocava-se uma folha de papel Teflon ${ }^{\circledR}$ (PTFE) para minimizar os esforços que poderiam ser gerados devido ao atrito entre elas.

Posicionada logo atrás da esfera de aço estava uma célula de carga modelo F204 da Novatech ( $\left.\mathrm{n}^{\circ} 34\right)$, com $500 \mathrm{kN}$ de capacidade, que era responsável pela medição das forças de restrição axial geradas pela viga de concreto ao longo dos ensaios. O contato entre os complementos da viga ensaiada e a viga de aço que simulava a restrição "infinita" ( $\left.\mathrm{n}^{\circ} 26\right)$ se dava do mesmo modo: com uma semiesfera metálica $\left(n^{\circ} 35\right)$ e uma folha de papel Teflon ${ }^{\circledR}$ (PTFE).

\footnotetext{
${ }^{7} \mathrm{O}$ método adotado para a definição desses níveis de restrição às quais as vigas de concreto armado foram submetidas ao longo dos ensaios experimentais também será discutido mais em frente, na seção 3.3 Vigas ensaiadas.
} 

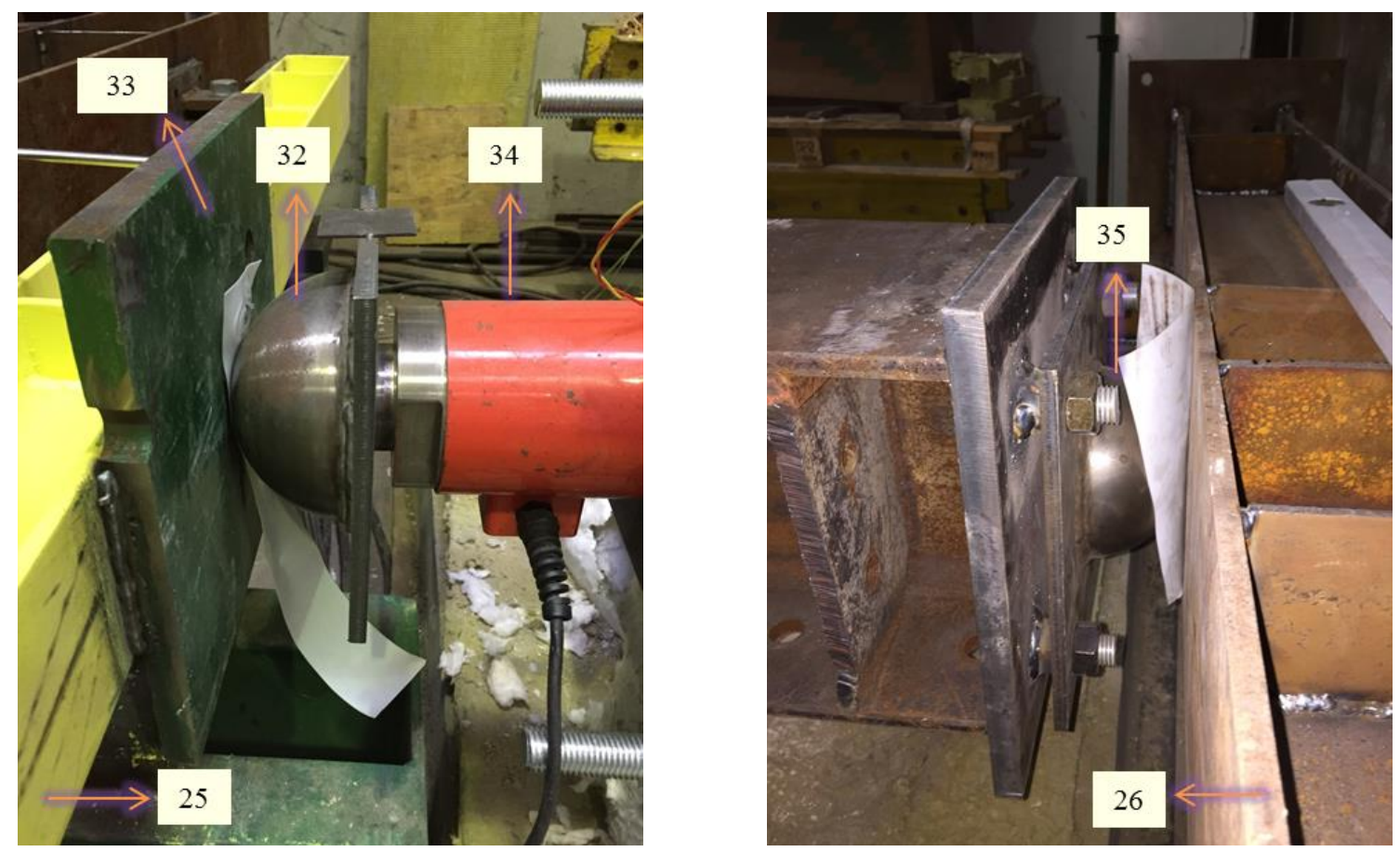

Legenda: 25. Viga de restrição para simulação de rigidez axial parcial; 26. Viga de restrição para simulação de rigidez axial "infinita"; 32. Semi-esfera de aço posicionada junto aos complementos próximos ao apoio simples; 33. Chapa de aço soldada à viga de simulação de rigidez axial parcial; 34. Célula de carga para medição das forças de restrição axial; 35. Semi-esfera de aço posicionada junto aos complementos próximos ao apoio duplo.

Figura 3.20 - Detalhes dos contatos entre os conjuntos de peças dos complementos da viga de concreto armado e as vigas de rigidez axial parcial e rigidez axial "infinita", respectivamente.

A viga de aço acoplada à viga que simulava a restrição axial parcial ( $n^{\circ} 36$ nas Figuras 3.16 e 3.19) tinha a função de conectar o sistema de restrição axial do lado do apoio simples a outro pórtico de reação do LEME ( ${ }^{\circ} 37$ nas Figuras 3.16 e 3.19), que funcionou como um pórtico de apoio ao sistema de restrição localizado nessa extremidade do lado esquerdo. Enquanto isso, a viga que simulava a restrição "infinita" estava encostada a um dos pilares do laboratório (n 38 na Figura 3.19), que serviu de apoio ao sistema de restrição da extremidade próxima ao apoio duplo (lado direito). Assim, garantia-se que todos os elementos constituintes desse sistema de ensaios se mantivessem sem folgas e bem fixos, i.e., que permanecessem em suas posições iniciais ao longo dos ensaios de exposição ao fogo e, sobretudo, que se mantivessem íntegros para desempenhar suas devidas funções.

Para que fosse possível posicionar os módulos do forno sobre a viga de concreto armado nesses ensaios nos quais foram analisadas as restrições axiais e existiam os complementos, 
retiraram-se as pequenas portas de suas laterais (uma delas pode ser vista na Figura 3.11-b) e, no lugar dessas, inseriram-se pedaços de mantas de lã de silicato alcalino, de modo a impedir que o calor passasse do interior do forno para o ambiente. As peças dos complementos que ficavam dentro do forno eram protegidas da ação do calor também por camadas desse material isolante, da mesma forma como se procedia com os apoios (Figura 3.11-a).

Além dos parâmetros igualmente aferidos nos ensaios de vigas simplesmente apoiadas em situação de incêndio, nos ensaios com restrições axiais ainda se utilizou um transdutor de cabo ( ${ }^{\circ} 39$ na Figura 3.21) para medir os deslocamentos horizontais a meio vão das vigas que simulavam as restrições axiais parciais de 7 ou $14 \mathrm{kN} / \mathrm{mm}$. Esses deslocamentos eram necessários para o cálculo das rigidezes axiais efetivamente impostas pela estrutura circundante à viga de concreto ao longo dos ensaios.

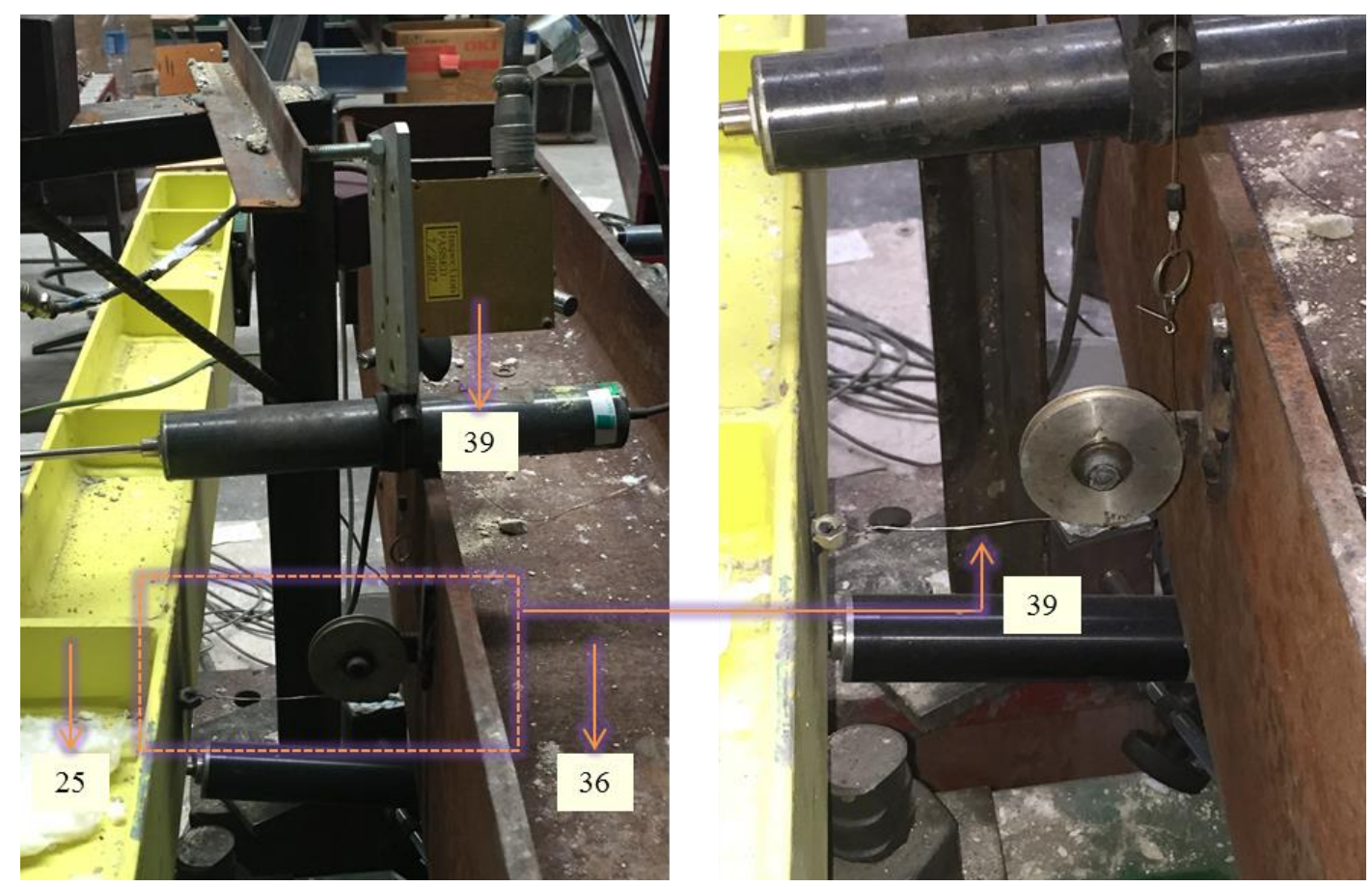

Legenda: 25. Viga de restrição para simulação de rigidez axial parcial; 36. Viga de conexão entre a viga de simulação de rigidez axial parcial e o pórtico de apoio ao sistema; 39. Transdutor de cabo para medição dos deslocamentos da viga de simulação de rigidez axial parcial.

Figura 3.21 - Detalhe da instrumentação adotada para aferir os deslocamentos horizontais a meio vão da viga que simulava restrição axial parcial para fins de cálculo da rigidez resultante ao longo dos ensaios. 


\subsubsection{Com restrições axial e rotacional}

Os últimos ensaios de exposição ao fogo foram realizados com o propósito de simular o comportamento de vigas submetidas simultaneamente a restrições axiais e rotacionais. Para simular essas condições de contorno, adicionou-se ao sistema de ensaios das vigas com restrição apenas axial mais duas vigas de aço ( ${ }^{\circ} 40$ nas Figuras 3.22 a 3.24), que foram responsáveis por prover rigidezes rotacionais aos apoios simples e duplo do sistema, a fim de impedir parcialmente as deformações térmicas rotacionais. Essas vigas foram posicionadas no piso inferior do LEME, logo abaixo daquele onde estava localizada a laje sobre a qual eram realizados os ensaios. $\mathrm{O}$ piso inferior já havia sido indicado anteriormente pelo $\mathrm{n}^{\circ} 13$ nas Figuras 3.5, 3.6 e 3.8 e consistia naquele onde também foram dispostos os transdutores de cabo adotados para medir os deslocamentos verticais das vigas de concreto.

As vigas usadas para simular as restrições rotacionais foram engastadas à parede do piso inferior, de forma que o esquema estático das mesmas fosse equivalente a peças em balanço. A referida parede era de concreto armado e bastante resistente (parede do próprio Laboratório, indicada pelo $\mathrm{n}^{\circ} 41$ nas Figuras 3.22 e 3.23). Essas vigas de aço foram fixadas à parede a partir de parafusos que eram bem apertados junto às cantoneiras de suporte $\left(n^{\circ} 42\right.$ nas Figuras 3.22 e 3.23) que foram soldadas a elas em uma de suas extremidades.

Como pode ser visto com detalhes nas Figuras 3.24 a 3.26, as vigas de restrição rotacional localizadas no piso inferior se conectavam à viga de concreto do piso logo acima por intermédio de barras lisas de aço $\left(\mathrm{n}^{\circ} 43\right)$ que passavam pela laje do próprio LEME $\left(\mathrm{n}^{\circ} 14\right)$ e depois pela laje dos ensaios $\left(n^{\circ} 15\right)$ através de furos que existiam nesses elementos. No piso superior, essas barras foram acopladas às peças dos complementos por meio de um mancal $\left(\mathrm{n}^{\circ} 44\right)$ que foi posto junto a um sistema de pino, formado por duas chapas e uma barra (essas chapas, $\mathrm{n}^{\circ} 45$, foram soldadas às peças $\mathrm{n}^{\circ} 30$ e 31 dos complementos). No piso inferior, também se utilizou um mancal para acoplar a outra extremidade da barra a esse sistema de 
encaixe. Dessa vez as chapas auxiliares foram soldadas na extremidade em balanço de cada uma das vigas de restrição rotacional. Nas Figuras 3.27 e 3.28 ainda se apresentam esquemas gerais adaptados de Laím e Rodrigues (2014) e Laím (2013) ${ }^{8}$ para ilustrar as barras que passavam através da laje do LEME, de modo a conectar o sistema de restrição rotacional à viga de concreto. No Apêndice B podem ser encontrados outros esquemas representativos dos sistemas de ensaios abordados neste texto.

As barras lisas de aço, que faziam a conexão entre a viga de concreto e as vigas de restrição rotacional, estavam localizadas a uma distância de $0,5 \mathrm{~m}$ dos apoios simples e duplo. Essa distância consistia em um valor fixo, novamente delimitado pelo leiaute de ensaios, uma vez que nesses pontos existiam os furos nas lajes pelos quais elas poderiam passar. Portanto, as barras transmitiam forças concentradas à viga de concreto, essas forças resultavam em um momento aplicado a cada um dos apoios e, por conseguinte, em restrições rotacionais que eram impostas à tentativa de giro das extremidades da viga de concreto.

As forças de restrição geradas nessas barras, devido às deformações térmicas da viga de concreto e por sua conexão ao sistema de restrição rotacional (vigas de aço engastadas), foram medidas ao longo dos ensaios por meio de células de carga modelo F202 da Novatech $\left(\mathrm{n}^{\circ} 46\right.$ nas Figuras 3.22 e 3.24), com $100 \mathrm{kN}$ de capacidade, posicionadas junto às barras. Os deslocamentos verticais resultantes das extremidades em balanço das vigas de restrição rotacional, nos pontos localizados na direção das barras, foram medidos por meio de transdutores tipo êmbolo ( $n^{\circ} 47$ na Figura 3.24). De forma análoga ao exposto na seção anterior para os ensaios de vigas restringidas axialmente, esses deslocamentos foram necessários para calcular as rigidezes rotacionais resultantes ao longo dos ensaios experimentais.

Para as referidas vigas de restrição, adotaram-se perfis HEB 300, com vãos em balanço iguais a $1 \mathrm{~m}$. Portanto, ambos possuíam rigidezes à flexão iguais e foram fabricados com aço classe S355. Dois níveis de rigidez rotacional foram reproduzidos experimentalmente com o uso

\footnotetext{
${ }^{8}$ Os sistemas adotados nos ensaios desta Tese foram similares aos apresentados em Laím e Rodrigues (2014) e Laím (2013) para a análise dos efeitos das restrições térmicas no comportamento de vigas de aço formadas a frio.
} 
desses perfis, um igual a $2500 \mathrm{kNm} / \mathrm{rad}$ e o outro igual a $5000 \mathrm{kNm} / \mathrm{rad}$, tendo sido o maior alcançado por meio de barras enrijecedoras que foram posicionadas a meio vão dos mesmos.
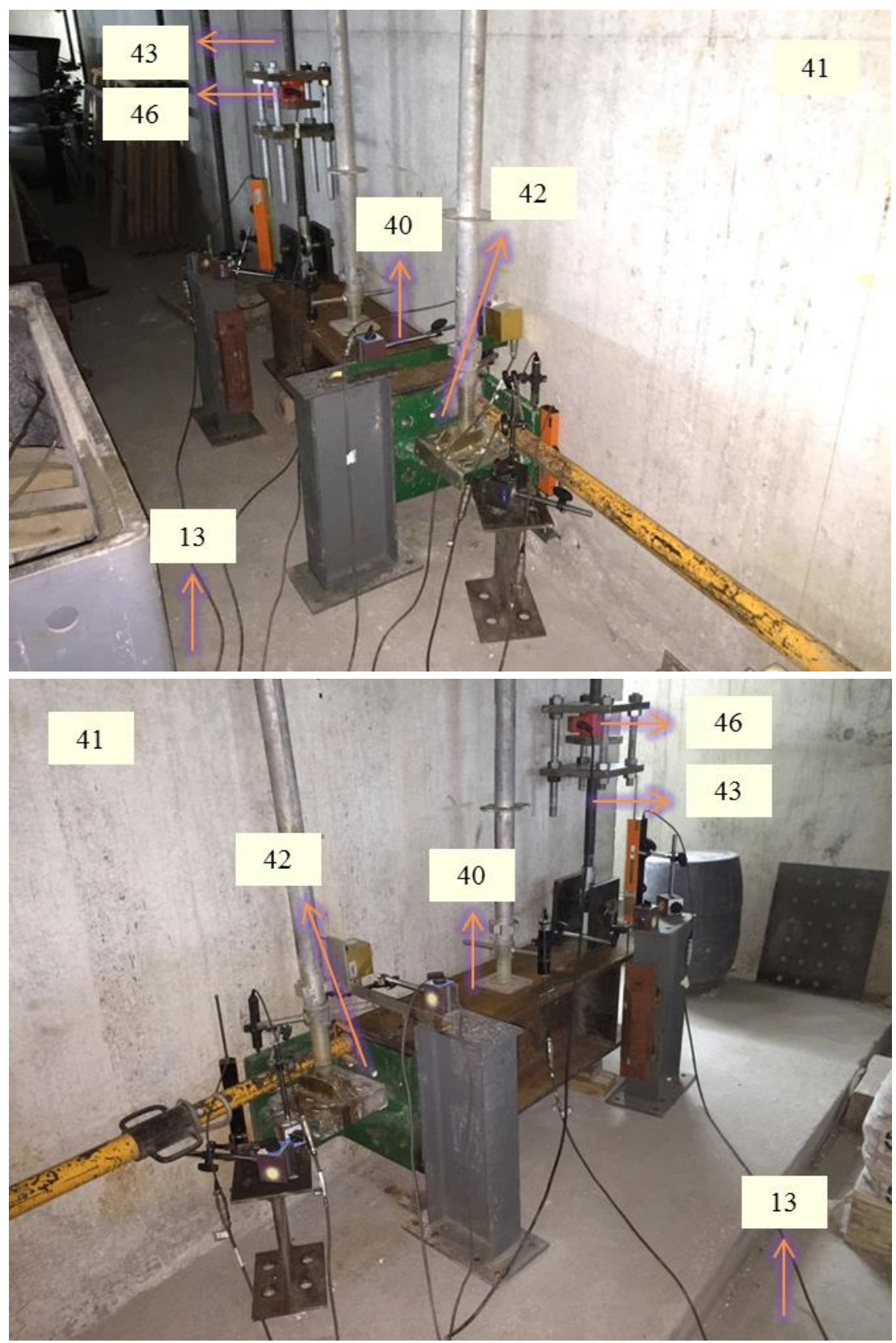

Legenda: 13. Piso inferior do LEME; 40. Viga de restrição para simulação de rigidez rotacional; 41. Parede do LEME; 42. Cantoneira de suporte à viga de rigidez rotacional; 43. Barra lisa de aço para conexão da viga de concreto armado ao sistema de restrição rotacional; 46. Célula de carga para medição das forças de restrição geradas na barra lisa de aço.

Figura 3.22 - Vigas de aço dispostas no piso inferior do LEME para a simulação das restrições rotacionais impostas à viga de concreto armado (nas direções próximas aos apoios simples e duplo, respectivamente). 


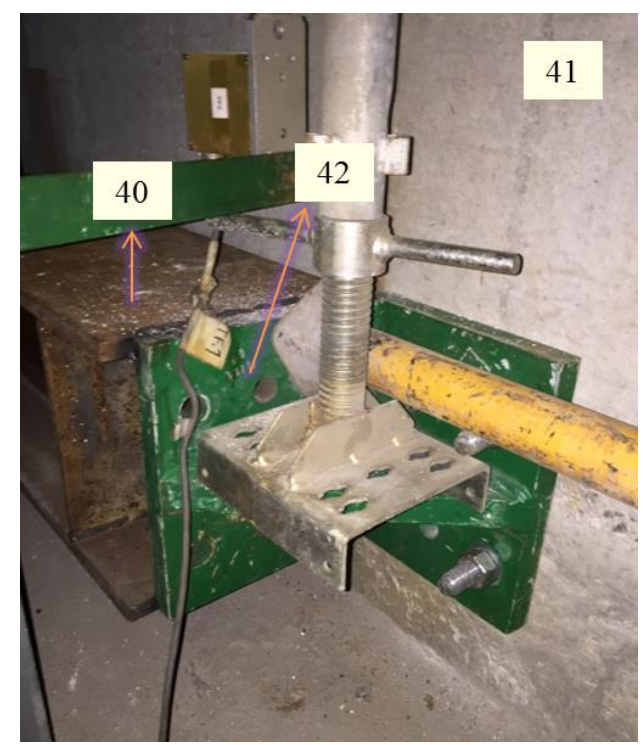

Legenda: 40. Viga de restrição para simulação de rigidez rotacional; 41. Parede do LEME; 42. Cantoneira de suporte à viga de simulação de rigidez rotacional.

Figura 3.23 - Detalhe da cantoneira de suporte soldada à viga de restrição rotacional e fixa à parede do LEME.
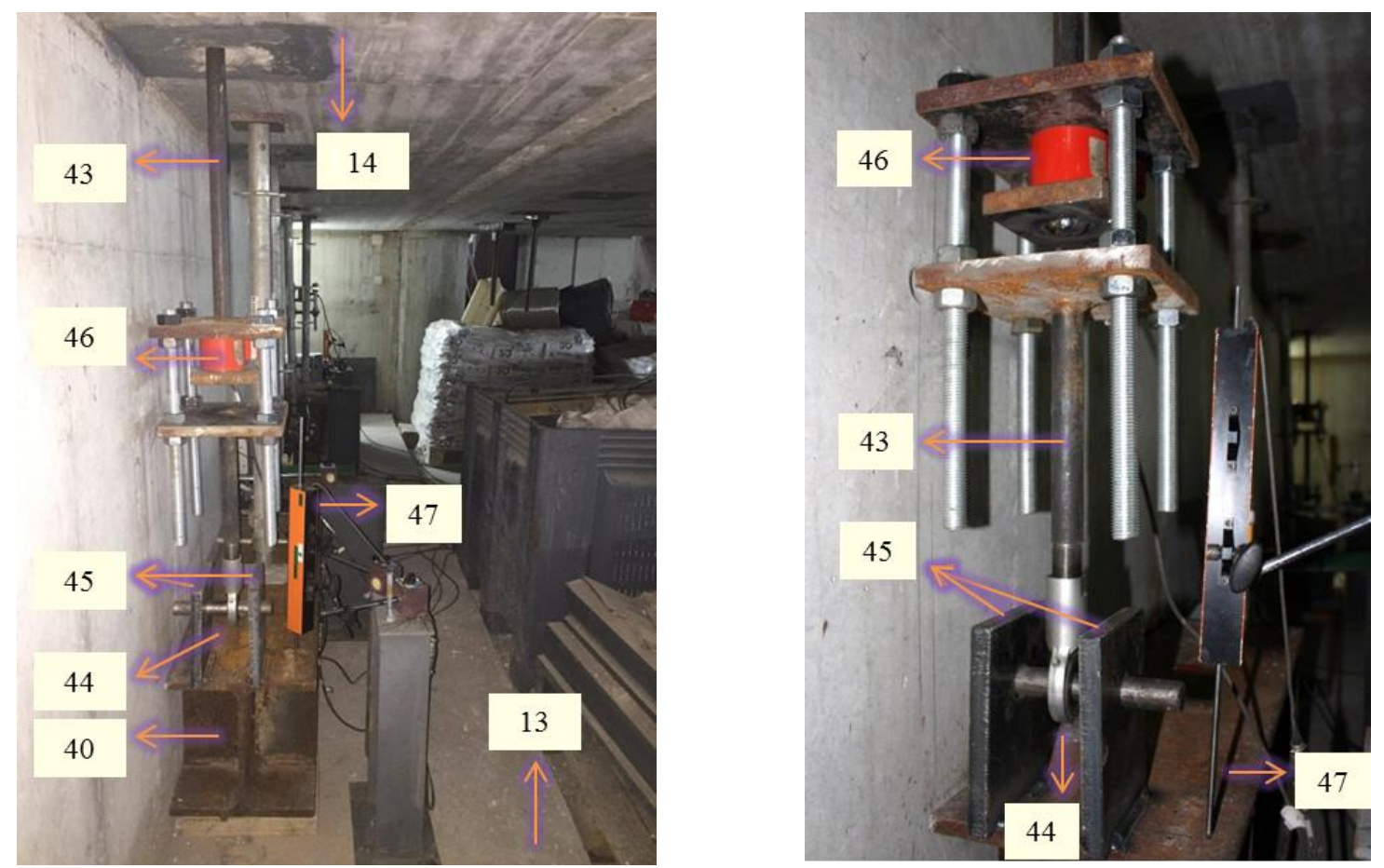

Legenda: 13. Piso inferior do LEME; 14. Piso superior do LEME; 40. Viga de restrição para simulação de rigidez rotacional; 43. Barra lisa de aço para conexão da viga de concreto armado ao sistema de restrição rotacional; 44. Mancal para conexão da extremidade da barra lisa de aço ao sistema de pino; 45. Chapas de aço constituintes do sistema de pino; 46. Célula de carga para medição das forças de restrição geradas na barra lisa de aço; 47. Transdutor de êmbolo para medição dos deslocamentos da viga de simulação de rigidez rotacional.

Figura 3.24 - Detalhes do sistema de restrição rotacional disposto no piso inferior do LEME. 

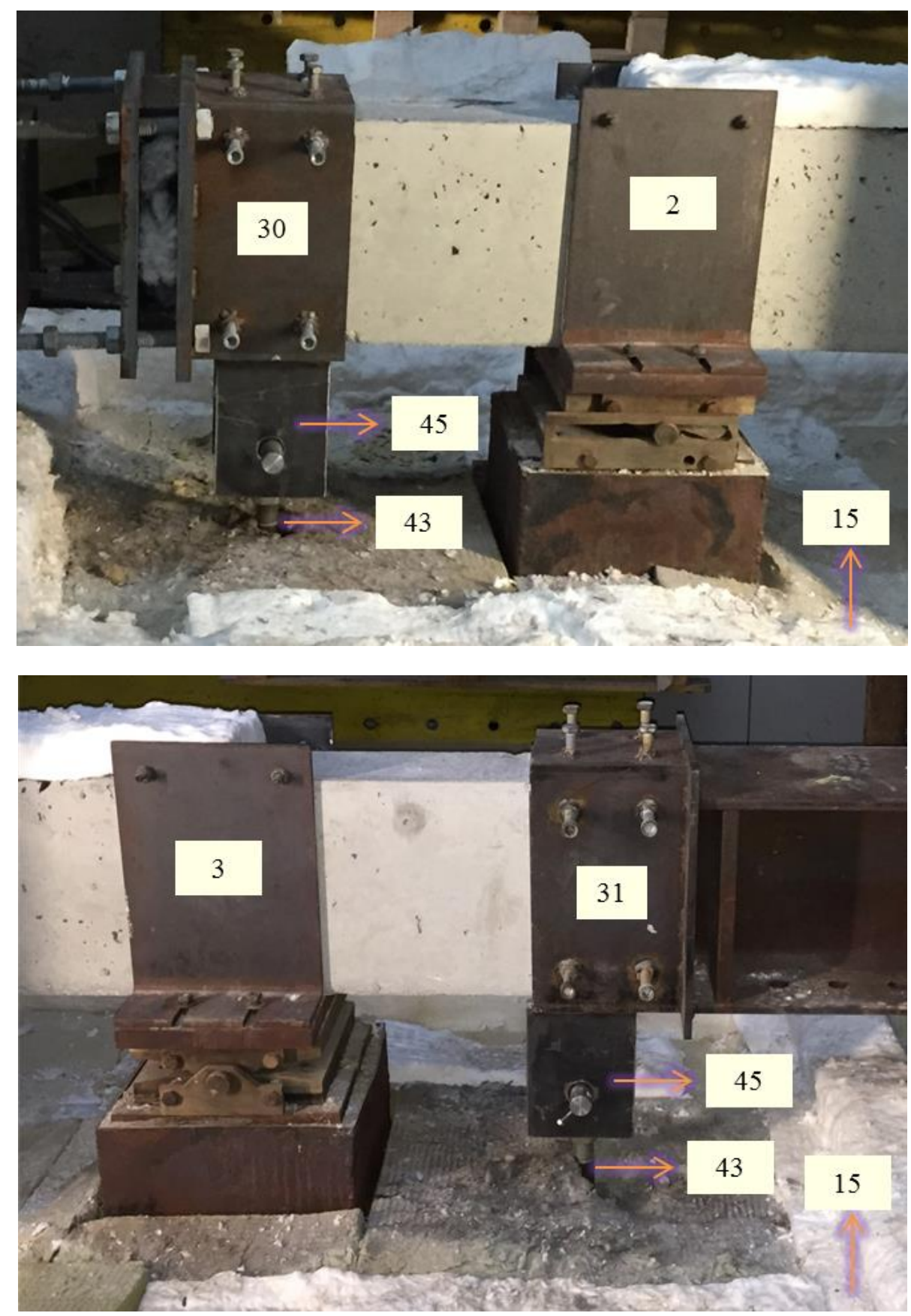

Legenda: 2. Apoio simples; 3. Apoio duplo; 15. Laje de ensaios; 30. Primeira peça dos complementos posicionados na extremidade próxima ao apoio simples; 31. Primeira peça dos complementos posicionados na extremidade próxima ao apoio duplo; 43. Barra lisa de aço para conexão da viga de concreto armado ao sistema de restrição rotacional; $\mathbf{4 5}$. Chapas de aço constituintes do sistema de pino.

Figura 3.25 - Elementos do sistema de restrição rotacional que chegam ao piso superior do LEME, junto às extremidades dos apoios simples e duplo, respectivamente. 

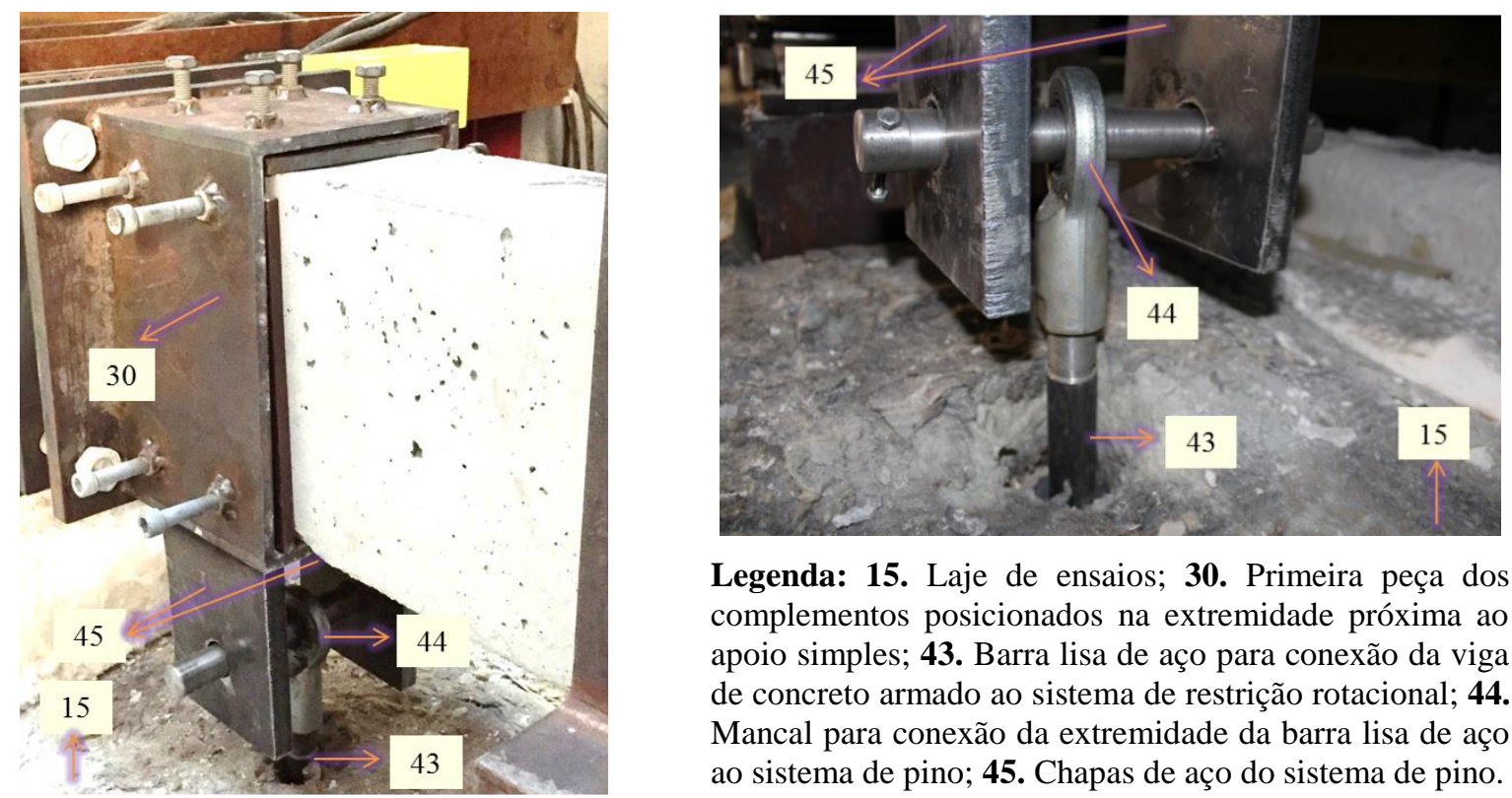

Legenda: 15. Laje de ensaios; 30. Primeira peça dos complementos posicionados na extremidade próxima ao apoio simples; 43. Barra lisa de aço para conexão da viga de concreto armado ao sistema de restrição rotacional; 44. Mancal para conexão da extremidade da barra lisa de aço ao sistema de pino; 45. Chapas de aço do sistema de pino.

Figura 3.26 - Detalhes das barras de aço que se conectavam aos complementos da viga de concreto, localizados no piso superior do LEME, a fim de fazer a ligação ao sistema de restrição rotacional, disposto no piso inferior.

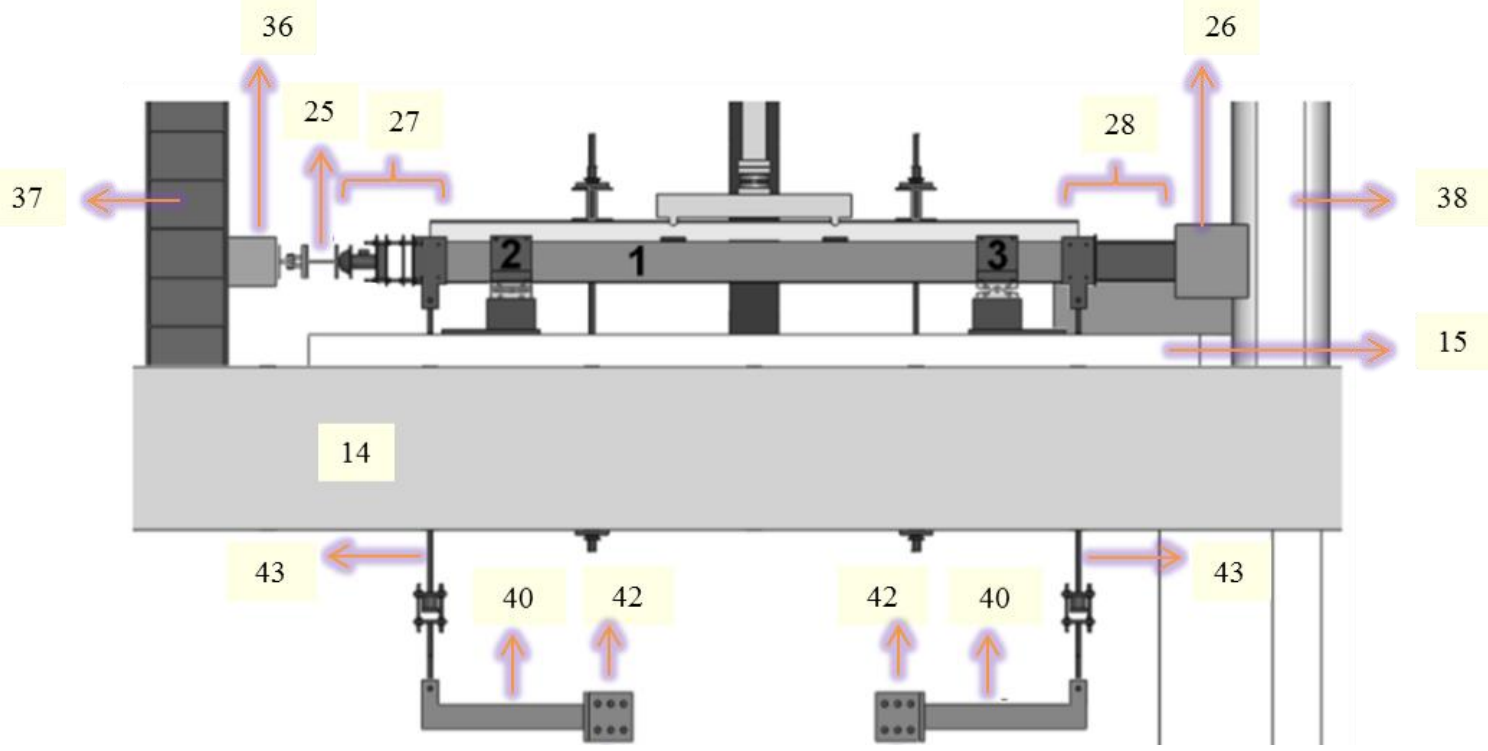

Legenda: 1. Viga de concreto ensaiada; 2. Apoio simples; 3. Apoio duplo; 14. Piso superior do LEME; 15. Laje de ensaios; 25. Viga de restrição para simulação de rigidez axial parcial; 26. Viga de restrição para simulação de rigidez axial "infinita"; 27 e 28. Complementos da viga de concreto posicionados nas extremidades próximas aos apoios simples e duplo, respectivamente; 36. Viga de conexão entre a viga de simulação de rigidez axial parcial e o pórtico de apoio ao sistema; 37. Pilar do pórtico de apoio ao sistema de restrição axial da extremidade do apoio simples; 38. Pilar de apoio ao sistema de restrição axial da extremidade do apoio duplo; 40. Viga de restrição para simulação de rigidez rotacional; 42. Cantoneira de suporte à viga de simulação de rigidez rotacional; 43. Barra lisa de aço para conexão da viga de concreto armado ao sistema de restrição rotacional.

Figura 3.27 - Esquema com vista frontal do sistema para ensaios de vigas com restrições axiais e rotacionais em situação de incêndio (LAÍM; RODRIGUES, 2014; adaptado). 


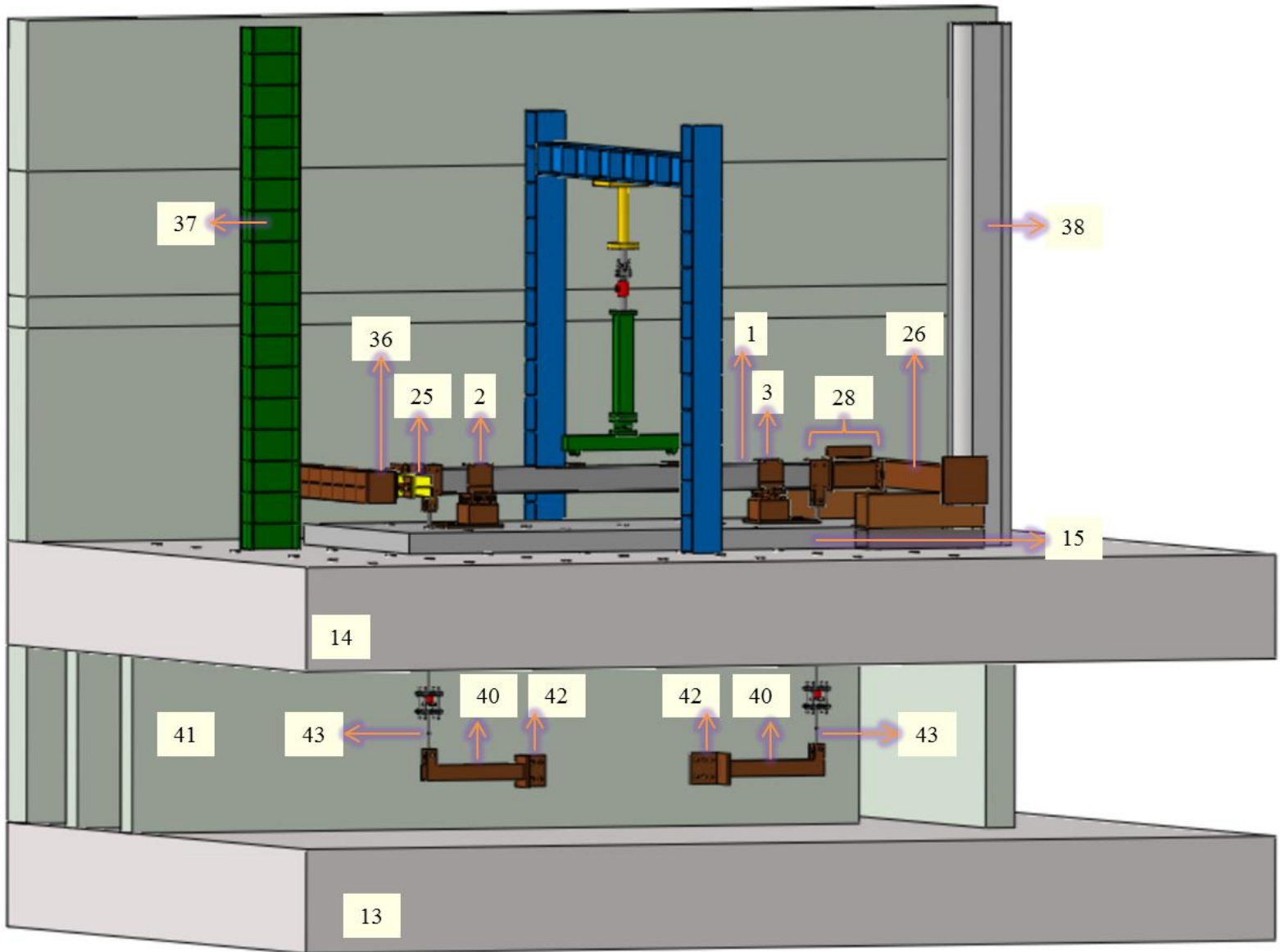

Legenda: 1. Viga de concreto ensaiada; 2. Apoio simples; 3. Apoio duplo; 13. Piso inferior do LEME; 14. Piso superior do LEME; 15. Laje de ensaios; 25. Viga de restrição para simulação de rigidez axial parcial; 26. Viga de restrição para simulação de rigidez axial "infinita"; 28. Complementos da viga de concreto posicionados na extremidade próxima ao apoio duplo; 36. Viga de conexão entre a viga de simulação de rigidez axial parcial e o pórtico de apoio ao sistema; 37. Pilar do pórtico de apoio ao sistema de restrição axial da extremidade do apoio simples; 38. Pilar de apoio ao sistema de restrição axial da extremidade do apoio duplo; 40. Viga de restrição para simulação de rigidez rotacional; 41. Parede do LEME; 42. Cantoneira de suporte à viga de rigidez rotacional; 43. Barra lisa de aço para conexão da viga de concreto armado ao sistema de restrição rotacional.

Figura 3.28 - Esquema com vista isométrica do sistema para ensaios de vigas com restrições axiais e rotacionais em situação de incêndio (LAÍM, 2013; adaptado). 


\subsection{Vigas ensaiadas}

\subsubsection{Dimensionamento e níveis de restrições}

Vários modelos hipotéticos de edifícios de concreto armado foram previamente analisados com o propósito de determinar as dimensões e as respectivas armaduras de vigas presentes nos mesmos, bem como os níveis de restrições axial e rotacional para as quais as vigas estavam submetidas como componentes desses edifícios. Subsequentemente, uma dessas vigas analisadas e algumas das rigidezes provenientes desses modelos foram escolhidas para representar as vigas de concreto armado ensaiadas e os níveis de restrição impostos a elas ao longo das análises experimentais, descritas na seção anterior. Esse método foi adotado a fim de que as vigas ensaiadas fossem representativas de elementos estruturais correntes, i.e., na condição de elementos constituintes de determinada edificação. Assim, as análises realizadas em laboratório seriam o mais próximas quanto possível da realidade.

Alguns fatores adicionais também determinaram os modelos de edifícios hipotéticos que foram analisados e, por conseguinte, a escolha das vigas que representaram as vigas ensaiadas e os níveis de restrição impostos. Em função das características do espaço disponível no LEME para a realização dos ensaios, por exemplo, as vigas de concreto deveriam ter uma distância entre apoios igual a $3 \mathrm{~m}$. Tal valor era fixo, uma vez condicionado pelos furos que existiam no piso ${ }^{9}$. Além disso, as vigas auxiliares responsáveis pela simulação das rigidezes tanto rotacionais quanto axiais deviam atender a determinadas dimensões máximas, sobretudo no que se relacionava aos comprimentos de vãos, fator também condicionado pelo espaço disponível. Tal fato ditava os níveis das restrições que poderiam ser aplicados.

\footnotetext{
${ }^{9}$ Esses eram os furos que permitiam conduzir as barras lisas de aço que conectavam a viga de concreto armado ensaiada às vigas auxiliares para simulação de rigidezes rotacionais, dispostas no pavimento inferior do Laboratório.
} 
O programa de computador CAD/TQS ${ }^{\circledR}$ Estudante v.17.1.72 ${ }^{10}$ (TQS INFORMÁTICA, 2012) foi adotado para auxiliar na modelação e no dimensionamento dos elementos estruturais presentes nos edifícios hipotéticos analisados. Já os níveis de rigidez axial e rotacional atuantes em determinados trechos de vigas desses edifícios foram calculados com o auxílio do Ftool - 2D Frame Analysis Tool ${ }^{11}$ (MARTHA, 2002), admitindo como dados de entrada as dimensões dos pilares e das vigas modelados via CAD/TQS ${ }^{\circledR}$.

Para lançar os modelos de edifícios no CAD/TQS ${ }^{\circledR}$, era necessário primeiramente realizar o pré-dimensionamento dos pilares, vigas e lajes que os compunham. A Figura 3.29 ilustra um dos casos estudados, sendo que as dimensões dos elementos estruturais indicadas nessa figura consistem nas dimensões finais, ou seja, que foram posteriormente verificadas e atenderam às prescrições tanto da norma europeia quanto da brasileira referentes ao projeto de estruturas de concreto armado (Eurocode 2 parte 1-1 (2004) e ABNT NBR 6118:2014 ${ }^{12}$, respectivamente). Para o caso da Figura 3.29 e todos os demais, admitiram-se sobrecargas representativas de escritórios $^{13}$. A viga constituinte desses edifícios que foi adotada para representar as vigas ensaiadas nas análises experimentais está ilustrada na Figura 3.30.

Todas as vigas ensaiadas foram produzidas com comprimentos iguais a 4,2 e não $3 \mathrm{~m}-$ distância entre apoios das vigas nos ensaios e adotada como base de cálculo nos modelos computacionais - porque nas situações em que os impedimentos às deformações térmicas foram analisados era preciso que as peças fossem um pouco mais longas para que pudessem

\footnotetext{
${ }^{10} \mathrm{O} \mathrm{CAD} / \mathrm{TQS}^{\circledR}$ compreende um conjunto de ferramentas computacionais capazes de calcular, dimensionar, detalhar e desenhar estruturas de concreto armado com base nas prescrições das normas brasileiras ou a partir de outros critérios que podem ser designados pelo seu utilizador.

${ }^{11}$ O Ftool consiste em um programa de computador que efetua análise linear de pórticos planos a partir dos métodos das forças e dos deslocamentos.

${ }^{12}$ Essas normas foram adotadas como base para a concepção dos edifícios hipotéticos. Realizaram-se algumas comparações entre as prescrições de ambas, por exemplo, no que indicavam para os valores de sobrecargas e para os coeficientes de ponderação pertinentes à determinação dos valores de cálculo das forças aplicadas. As eventuais diferenças não se mostraram significativas no resultado final do dimensionamento das estruturas, de modo que as dimensões e as armaduras adotadas para as vigas ensaiadas, bem como os níveis de restrições impostos, são condizentes aos critérios de projeto europeus e brasileiros.

13 Informações adicionais sobre os carregamentos considerados para dimensionar os edifícios hipotéticos são apresentadas no Apêndice C.
} 
ser encaixadas nos complementos, que por sua vez deveriam alcançar as extremidades das vigas de aço que simulavam as restrições axiais.

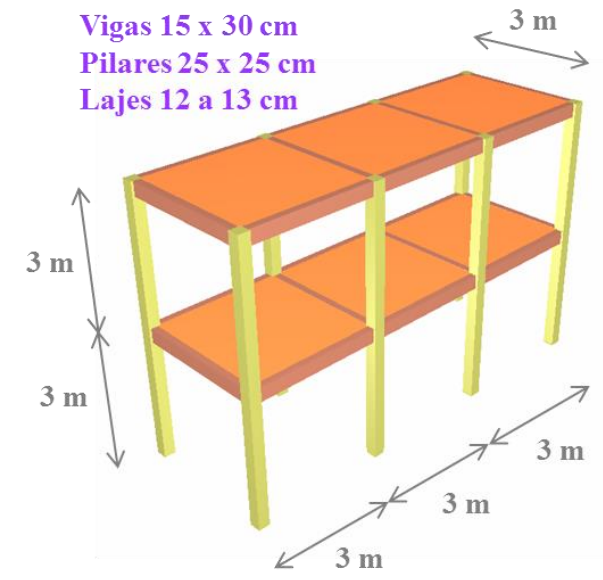

Figura 3.29 - Exemplo de um dos edifícios de concreto armado hipotéticos analisados para a determinação das vigas de ensaio e dos níveis de restrições impostos.
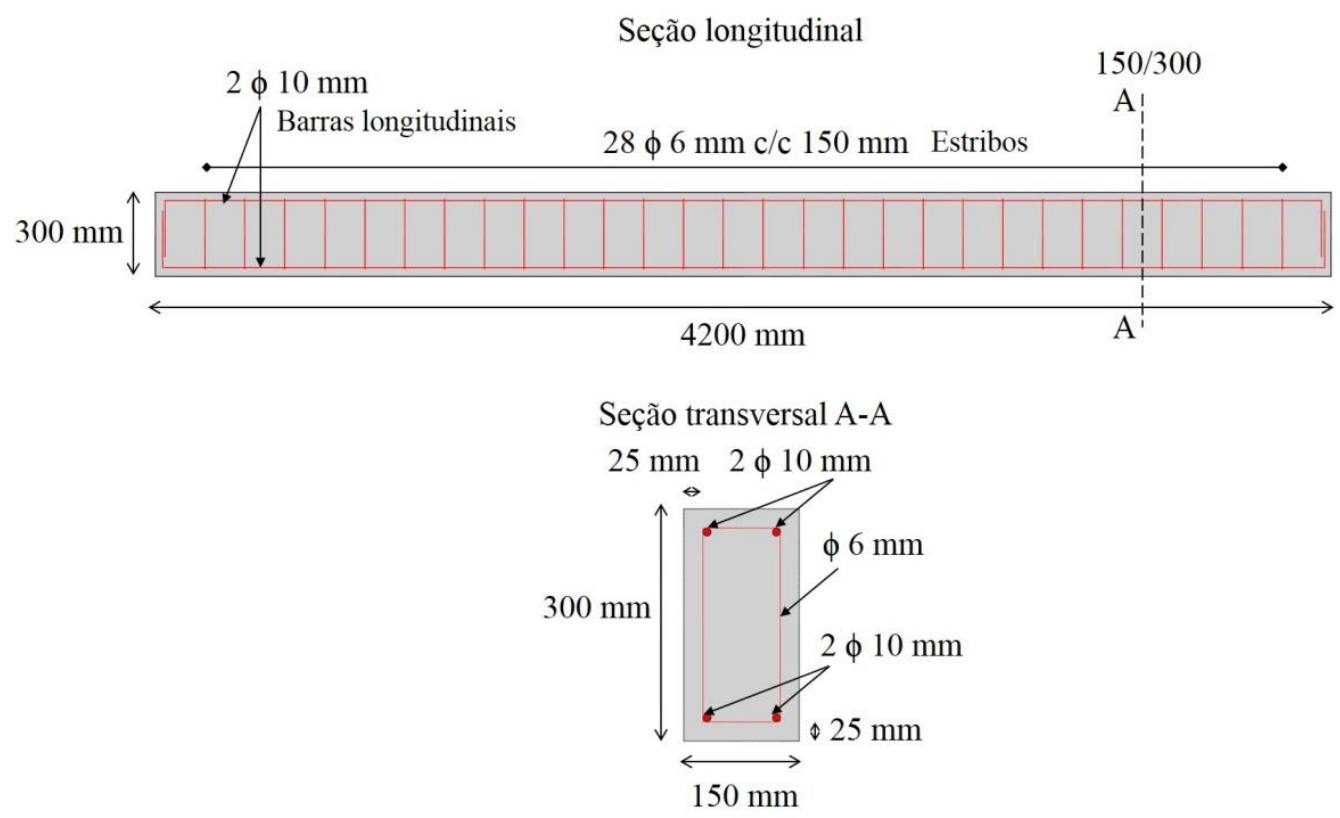

Figura 3.30 - Dimensões e armaduras das vigas adotadas nos ensaios da campanha experimental.

Uma vez que a campanha experimental desta Tese tinha como principal objetivo a comparação do comportamento ao fogo das vigas com diferentes esquemas estáticos, definiuse que seria mais coerente analisar elementos com as mesmas dimensões e armaduras em todos os ensaios, i.e., que diferissem entre si apenas em relação aos tipos de restrição aos 
quais seriam submetidos. No dimensionamento das vigas ensaiadas, estipularam-se cobrimentos de $2,5 \mathrm{~cm}$, concreto com $\mathrm{f}_{\mathrm{ck}}$ igual a $25 \mathrm{MPa}$ e aço com $\mathrm{f}_{\mathrm{yk}}$ igual a $500 \mathrm{MPa}$. Tanto as armaduras negativas (superiores) quanto as positivas (inferiores) foram estendidas ao longo de todo o vão, a fim de representar a armadura característica de trechos de vigas contínuas. Os estribos com diâmetro igual a $6 \mathrm{~mm}$ foram adotados em substituição aos de $5 \mathrm{~mm}$, mais empregados no Brasil, porém, não comercializados em Portugal (há apenas barras lisas com tal diâmetro).

Os dados de saída gerados pelo $\mathrm{CAD} / \mathrm{TQS}^{\circledR}$ e utilizados para a análise das rigidezes foram as dimensões das vigas e dos pilares de concreto armado. Esses elementos foram inseridos no Ftool de forma a modelar os edifícios de escritórios estudados como pórticos bidimensionais. Nesses modelos, calcularam-se as rigidezes axiais e rotacionais impostas pela estrutura circundante a trechos de vigas presentes em diferentes pavimentos e vãos. As lajes não foram admitidas no cálculo dos níveis das rigidezes porque tal consideração conduziria, por exemplo, a níveis mais elevados de restrição axial, que não seriam viáveis às condições das análises em laboratório. Além disso, não seriam consideradas lajes sobre as vigas ensaiadas.

Os níveis de restrição axial que foram adotados para simulação nos ensaios experimentais estão indicados nas Figuras 3.31 (a) e (b), sendo ambos representativos das vigas centrais do primeiro pavimento das estruturas. Como referido na seção anterior, esses valores foram iguais a 7 ou $14 \mathrm{kN} / \mathrm{mm}$. As restrições rotacionais resultantes desses modelos circundados por um número maior de elementos estruturais eram muito elevadas para serem praticadas no sistema de ensaios. Assim, adotou-se como base para os experimentos o nível de restrição rotacional equivalente à viga de cobertura do modelo de pórtico indicado na Figura 3.31 (c), igual a $2500 \mathrm{kNm} / \mathrm{rad}$. Portanto, os níveis de restrições adotados para os ensaios foram estimados a partir dos pórticos indicados nessas figuras, contudo, na prática, esses valores podem ser diferentes.

Ainda nessas ilustrações, indicam-se os procedimentos adotados para a determinação das rigidezes. Em cada um dos casos, retirou-se o trecho da viga sob análise, antes admitida no modelo como um elemento de barra com determinada seção transversal. Para o cálculo da 
rigidez axial, a barra retirada foi admitida como duas forças concentradas $(F)$ a serem aplicadas nos nós desse trecho e a produzirem deslocamentos horizontais $\left(\mathrm{d}_{\mathrm{x}}\right)$, cujos resultados são fornecidos pelo programa, vide Figuras 3.31 (a) e (b). A partir de tais valores, calculou-se a rigidez axial $\left(\mathrm{k}_{\mathrm{a}}\right)$ atuante nessa viga. De forma análoga, aplicaram-se nas extremidades da barra retirada momentos fletores (M) para que fossem produzidas rotações nos nós $(\alpha)$, tal como exposto na Figura 3.31 (c). A partir desses resultados, definiram-se as rigidezes rotacionais $\left(\mathrm{k}_{\mathrm{r}}\right)$. Esse método de cálculo também foi adotado na pesquisa de Cvetkovska; Todorov e Lazarov (2013), abordada no capítulo sobre o estado da arte.

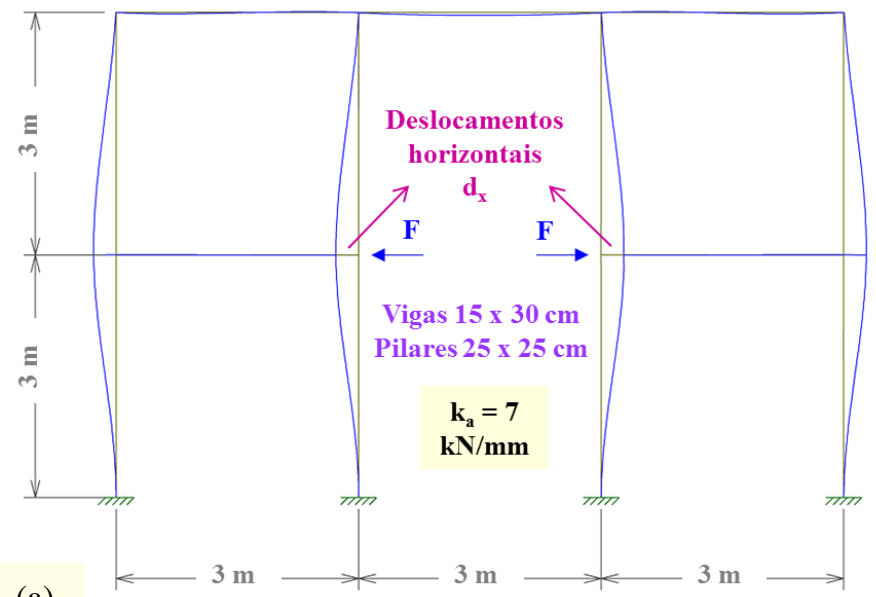

(a)

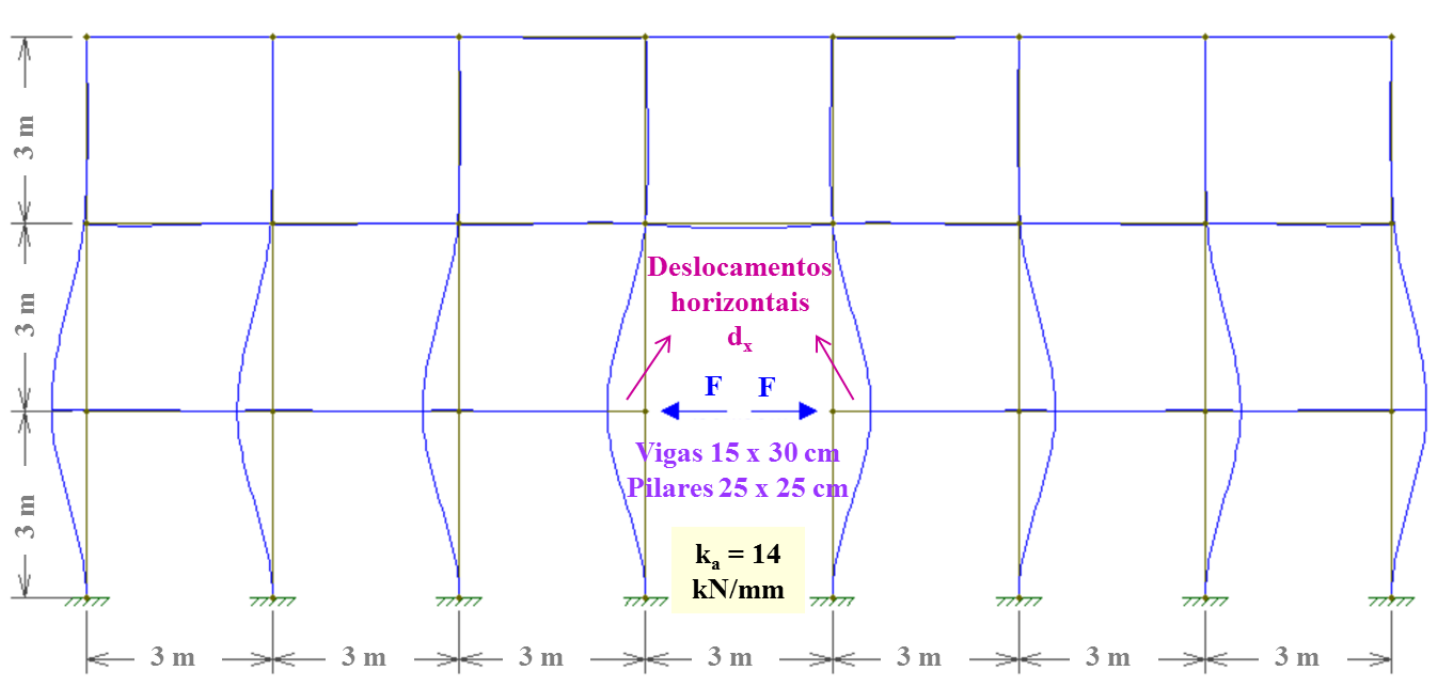

Figura 3.31 - Modelos de pórticos bidimensionais representativos (a e b) das rigidezes axiais e (c) rotacionais utilizadas como base para serem reproduzidas nos ensaios em Laboratório. 


\subsubsection{Etapas de produção}

Dezoito vigas de concreto armado foram produzidas para a presente investigação. O plano de concretagem foi dividido em três partes, com a produção de seis vigas em cada uma delas. Dessa forma, as questões de logística e espaço disponível no LEME não foram comprometidas, as fôrmas/cofragens para a produção desses elementos puderam ser reaproveitadas e, além disso, uma vez que o processo de instrumentação demandava maior tempo, havia vigas já em cura há um período maior para a realização dos primeiros ensaios.

Estipulou-se que o concreto seria fornecido por uma empresa especializada e que a cada concretagem também seriam produzidos corpos de prova cúbicos para a verificação da resistência à compressão à temperatura ambiente, nos seguintes intervalos: 7 e 28 dias de idade, primeiro e último dias de ensaios (para as seis vigas de cada grupo). Assim, as características do material poderiam ser monitoradas. Solicitou-se concreto com classe de resistência designada $\mathrm{C} 25 / 30$.

Nos ensaios ao fogo, procurou-se evitar ao máximo o spalling do concreto. Uma vez que o foco da pesquisa consistia no estudo do comportamento de vigas com deformações térmicas restringidas, esses efeitos poderiam acabar por comprometer os resultados. Segundo Khoury (2000), uma alternativa capaz de melhorar o desempenho tanto de concretos convencionais quanto de alta resistência frente a esse fenômeno consiste na utilização de agregados de tamanho pequeno e com baixa dilatação térmica, que aprimoram a compatibilidade térmica com a pasta de cimento. Por isso, solicitou-se que o concreto fosse produzido com o menor agregado graúdo fornecido pela empresa, com tamanho de $16 \mathrm{~mm}$.

Outra propriedade estipulada com o objetivo de reduzir a probabilidade de spalling consistiu na classe de fluidez. Solicitou-se S3, que consiste numa classe intermediária e que não agrega uma quantidade de água demasiada a mistura. Ainda sobre a composição do concreto, especificada na Tabela 3.1, utilizou-se cimento Portland de calcário tipo II/A-L (EN 197 
PARTE 1, 2000), agregados graúdos de origem calcária e areia lavada da zona de Pombal, Coimbra, Portugal. Tais componentes foram estabelecidos pela própria empresa que forneceu o material, pois eram os mais indicados para a classe de concreto solicitada. Já o plastificante MasterPozzolith 7002 da BASF foi utilizado para melhorar a trabalhabilidade do material, enquanto a cinza volante para um ligeiro aumento da sua resistência.

Também é oportuno citar que além de se ter estabelecido um processo de sazonamento para as vigas que seriam analisadas experimentalmente, esperando ao menos seis meses para a cura das mesmas, ainda foram produzidos corpos de prova cúbicos adicionais para a verificação do teor de umidade do material, antes da realização dos ensaios a temperaturas elevadas. Nesses ensaios de caracterização do material, realizados com base nas prescrições da norma EN 12390 parte 7 (2003), definiram-se os teores de umidade e as massas específicas do concreto endurecido $^{14}$. Ainda sobre o sazonamento, elucida-se que esse foi realizado não apenas com o intuito de prevenir o spalling, mas também de respeitar os costumes das obras de concreto.

Tabela 3.1 - Traço do concreto das vigas ensaiadas.

\begin{tabular}{cc}
\hline Material & $\begin{array}{c}\text { Quantidade } \\
\left(\mathrm{kg} / \mathrm{m}^{3}\right)\end{array}$ \\
\hline Cimento & 170 \\
\hline Cinza volante & 100 \\
\hline Brita 16 & 870 \\
\hline Areia grossa & 670 \\
\hline Areia fina & 330 \\
\hline Água & 166 \\
\hline Plastificante & 4,5 \\
\hline
\end{tabular}

Em relação ao fabrico das seis fôrmas que foram reutilizadas a cada concretagem, estipulouse o material aglomerado de madeira laminado a branco. Mais resistente do que as fôrmas de

\footnotetext{
${ }^{14}$ Esses parâmetros foram determinados experimentalmente para o controle dos efeitos do spalling e também para a obtenção de dados característicos dos materiais constituintes das vigas ensaiadas, que depois foram considerados na concepção de modelos numéricos representativos dos ensaios.
} 
madeira tradicionais, sua camada de melamina branca ainda garantiria menor aderência ao concreto no instante da retirada das placas que integravam as fôrmas. Para as armaduras, solicitaram-se barras de aço nervuradas com classe de resistência A500 (correspondente ao CA50, no Brasil) em dois diâmetros: $6 \mathrm{~mm}$ para os estribos e $10 \mathrm{~mm}$ para as armaduras longitudinais (positivas e negativas). Da mesma forma que o concreto, retiraram-se algumas amostras das armaduras longitudinais e transversais para que depois fossem submetidas a ensaios para a verificação da resistência característica à tração do aço, à temperatura ambiente $^{15}$. A seguir, apresentar-se-ão os detalhes acerca de cada etapa que constituiu a produção das vigas ensaiadas, realizada nas dependências do LEME pela autora desta Tese e com o auxílio dos técnicos do Laboratório em determinadas atividades.

\subsubsection{Fôrmas}

A produção das vigas de concreto armado teve início com a montagem das seis fôrmas a partir de placas de aglomerado de madeira laminado a branco, com espessuras iguais a 19 mm. As placas foram fabricadas e entregues ao LEME já cortadas nos tamanhos ideais e, em seguida, foram encaixadas umas às outras por meio de parafusos. Também para garantir que estariam bem fixas e resistentes no instante da concretagem, utilizaram-se ripas de pinho tratado em suas laterais e face superior. A montagem dessas fôrmas foi realizada de modo a serem pouco danificadas a cada uso e, por conseguinte, para cumprir o processo de reaproveitamento. Ao final das concretagens, as mesmas eram limpas para a remoção dos resquícios de concreto, que poderiam prejudicar o fabrico das próximas vigas. Para facilitar esse trabalho, após a montagem dessas peças, borrifava-se óleo descofrante nas suas placas, para reduzir a aderência concreto/fôrma. As informações aqui apresentadas estão compiladas na Figura 3.32.

\footnotetext{
${ }^{15}$ Apesar da resistência característica à tração do aço não ser de grande variação quando comparada aos valores de resistências características à compressão do concreto, também se mostraram relevantes como dados a serem posteriormente considerados nas análises numéricas.
} 

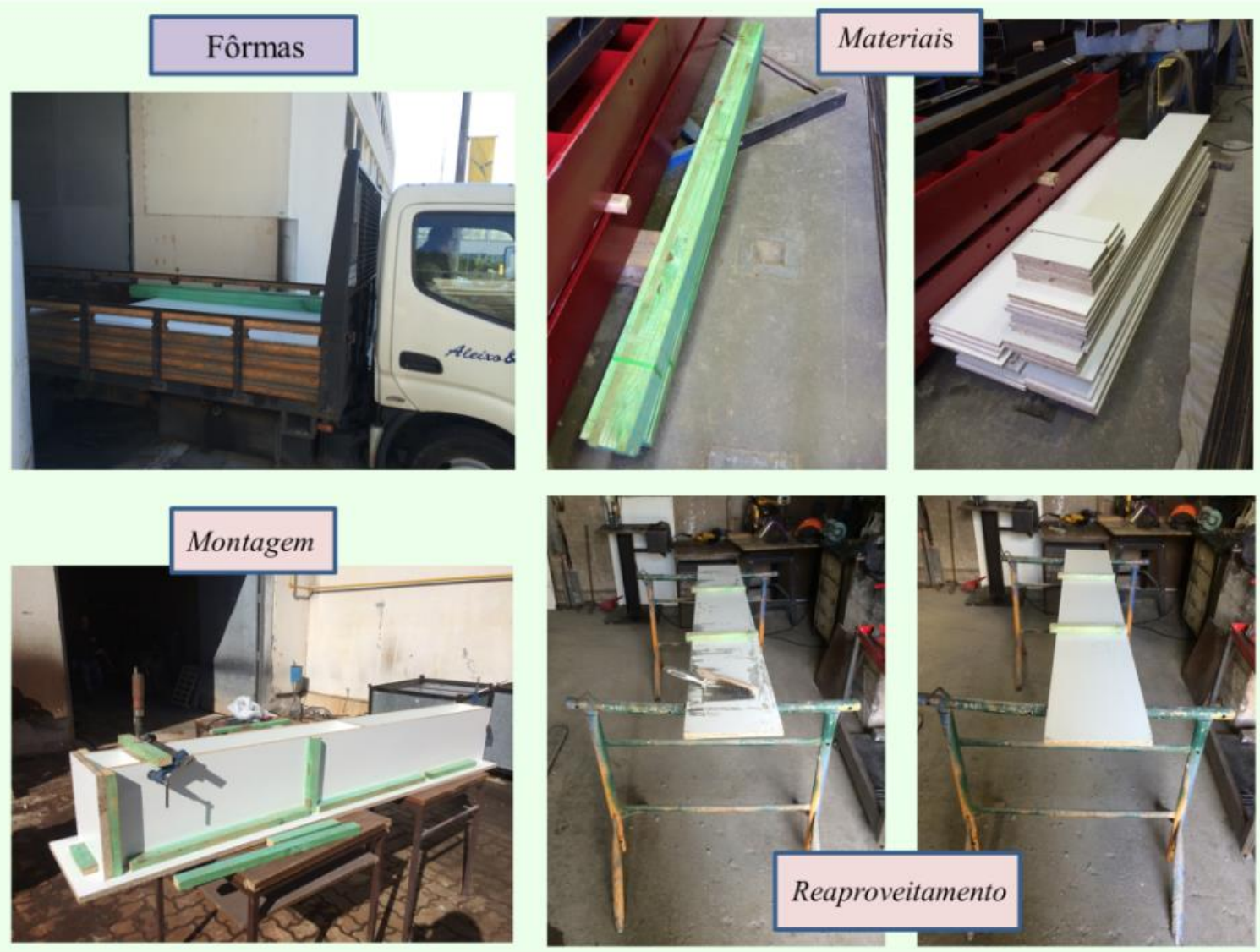

Figura 3.32 - Processos de montagem e reaproveitamento das fôrmas.

\subsubsection{Armaduras}

Em seguida, prepararam-se as armaduras necessárias para a produção das vigas. Inicialmente, as barras com $10 \mathrm{~mm}$ de diâmetro e comprimentos iguais a $12 \mathrm{~m}$ foram cortadas nos tamanhos corretos para a produção das armaduras longitudinais, que deveriam ter 4,15 $\mathrm{m}$ de comprimento e ancoragens retas de $20 \mathrm{~cm}$ (dobras D20). Depois, cortaram-se as barras com 6 $\mathrm{mm}$ de diâmetro para a dobragem dos estribos, que deveriam ter $25 \mathrm{~mm}$ de altura e $10 \mathrm{~mm}$ de largura (detalhes das armaduras das vigas ensaiadas foram ilustrados na Figura 3.30). As dobras das ancoragens das armaduras longitudinais, bem como dos estribos, foram efetuadas em uma máquina para dobra manual de armaduras, disponível no LEME. 
Posteriormente se iniciou o processo de montagem. Cada viga era produzida com quatro barras para as armaduras longitudinais (duas positivas e duas negativas). Nessas barras, demarcavam-se os pontos nos quais deveriam ser posicionados os 28 estribos $(\phi 6 \mathrm{~mm}$ a cada $15 \mathrm{~cm}$ ), fixos a elas por meio de arames recozidos. Relembra-se que foram feitas amostras das armaduras longitudinais e transversais, com comprimentos iguais a $1 \mathrm{~m}$, para os ensaios de resistência à tração do aço. A Figura 3.33 ilustra os detalhes da preparação das armaduras.
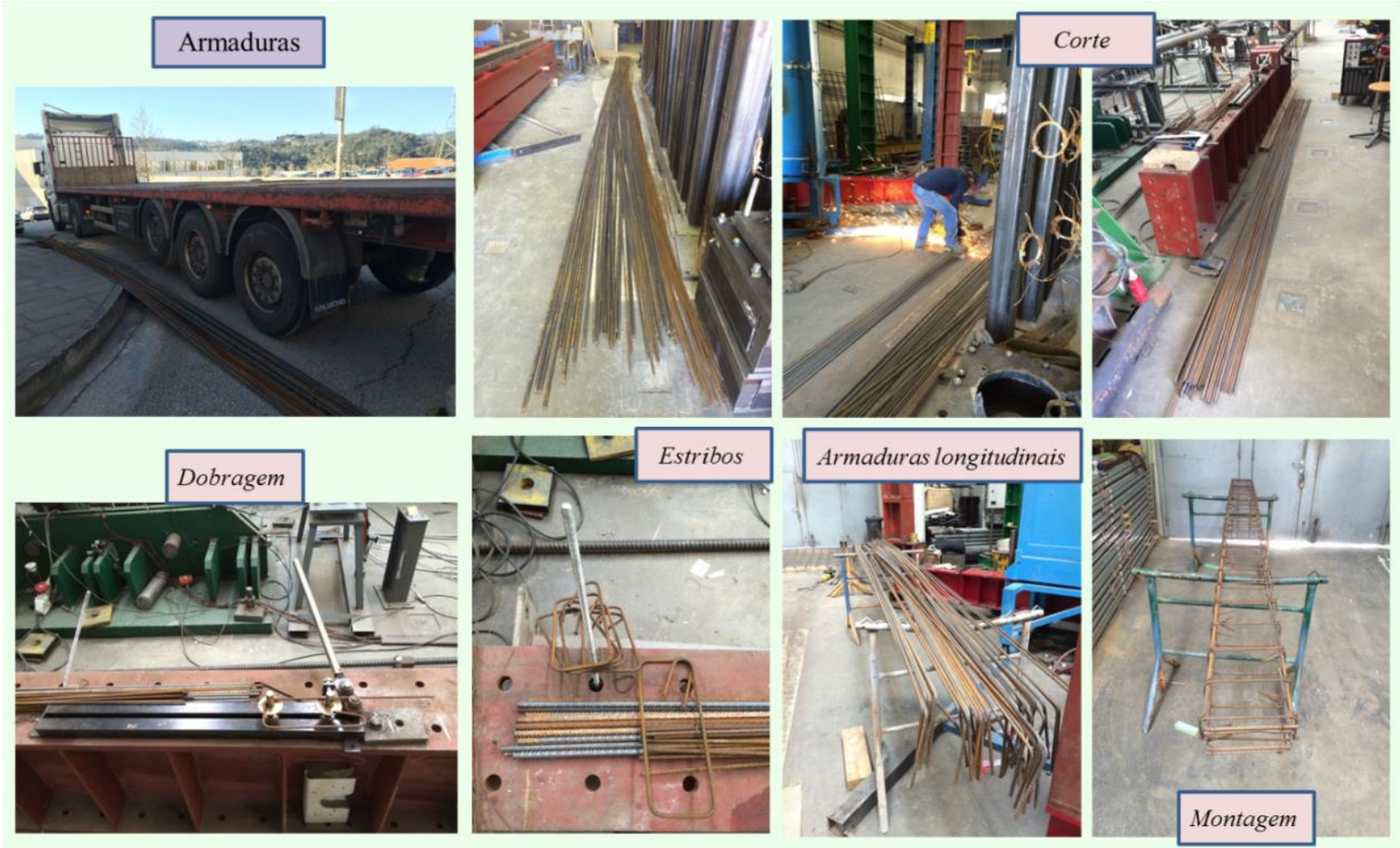

Figura 3.33 - Corte e dobragem das armaduras para produção das vigas.

\subsubsection{Termopares}

Outro passo realizado para a produção das vigas de concreto armado previstas para ensaios de resistência ao fogo consistiu na preparação dos fios de termopar, que deveriam ser inseridos para a verificação das temperaturas em pontos importantes do concreto e do aço. Primeiro, 
montou-se uma estrutura auxiliar para que todos os fios fossem cortados com comprimentos iguais a 1,85 m. Depois, separaram-se as quantidades de fios que seriam utilizados para a medição de temperaturas no aço e aqueles para o concreto. Os termopares para o aço não precisavam de nenhuma preparação prévia, uma vez que os mesmos poderiam ser diretamente soldados à armadura por meio de uma máquina de solda por descarga capacitiva, como será mostrado na seção a seguir, sobre a instrumentação das vigas.

Os termopares para o concreto, em contrapartida, necessitavam ser previamente adaptados para depois serem inseridos nas vigas. Inicialmente, os fios eram entrelaçados e, em seguida, inseridos numa máquina para a soldagem de termopares em mercúrio. Dessa forma, garantiase a junção desses fios (interiores aos revestimentos em cores amarela e vermelha). Na Figura 3.34, apresentam-se fotografias acerca da preparação dos termopares.
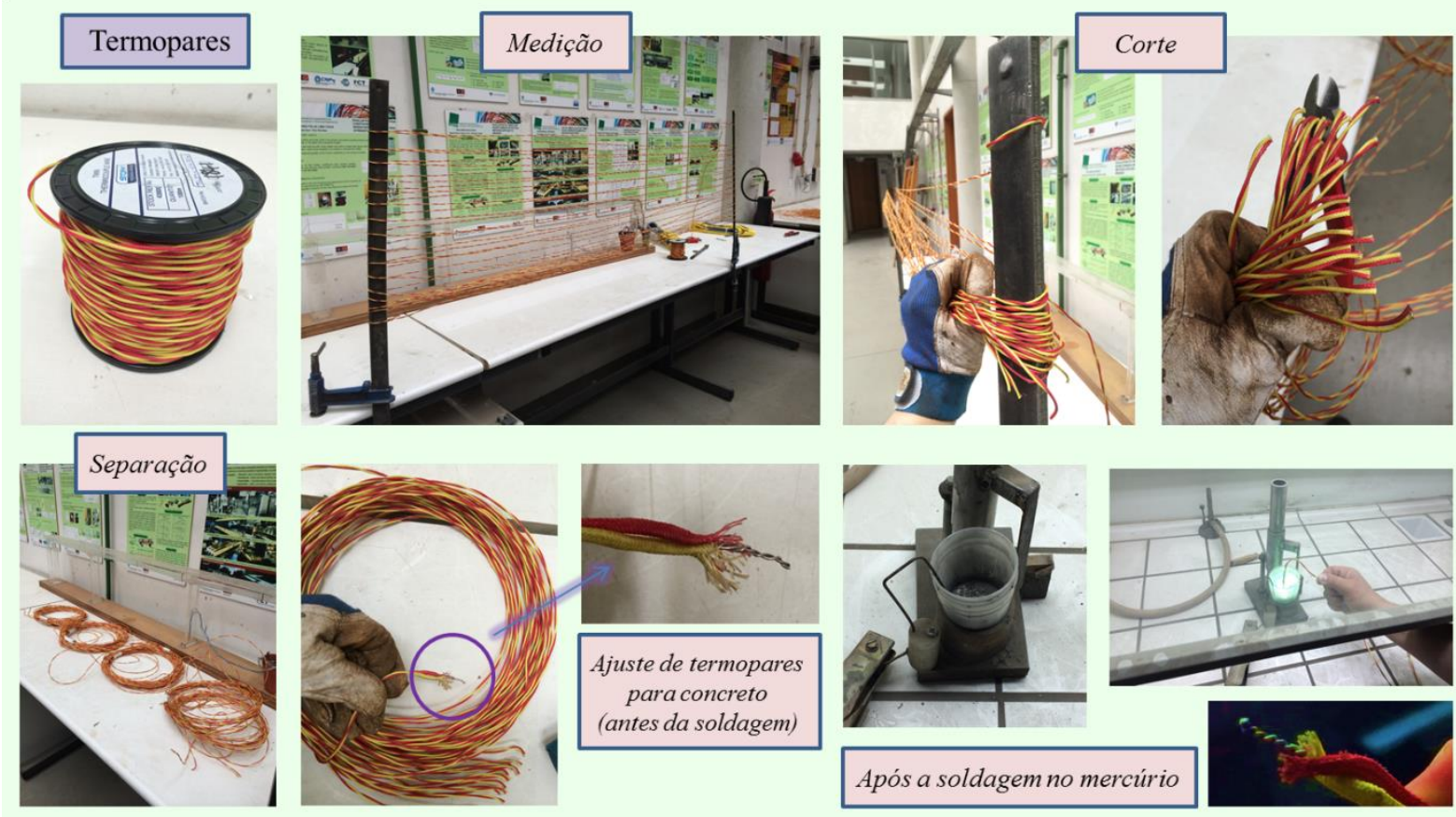

Figura 3.34 - Preparação dos termopares para a instrumentação das vigas de concreto armado. 


\subsubsection{Instrumentação}

Com a base das armaduras prontas e os termopares já preparados, iniciou-se o processo de instrumentação das vigas de concreto armado, que compreendia a colocação dos fios para a medição das temperaturas. Como primeiro passo, marcaram-se nas armaduras os três pontos nos quais deveriam ser colocados os termopares, representativos das seções $S_{1}$ e $S_{3}$, localizadas a 0,5 $\mathrm{m}$ dos apoios, e da seção $\mathrm{S}_{2}$, no meio do vão. Essas seções foram ilustradas anteriormente na Figura 3.5 e a posição dos termopares em cada uma delas na Figura 3.15.

Em seguida, criaram-se estruturas auxiliares para a introdução dos termopares estipulados para medir as temperaturas em pontos do concreto. Ao invés de arames recozidos, essas estruturas foram concebidas com a reutilização de fios de termopar retirados de seus revestimentos, pois conduziriam menos calor do que os arames novos e, além disso, por serem menos espessos, pouco alterariam a distribuição de temperaturas nas seções de concreto escolhidas para análise. A partir desses fios, que foram cortados, trançados com alicates e presos às armaduras, foi possível criar pontos para que os termopares fossem inseridos, fixos e ajustados, conforme estabelecido inicialmente.

Esses termopares foram testados com um multímetro para verificar se as soldas estavam bem executadas e se as temperaturas estavam sendo aferidas corretamente. Ao se aplicar uma chama, por meio de um isqueiro, na extremidade soldada dos termopares e ao conectar a outra extremidade dos fios ao multímetro, confirmava-se o funcionamento dos mesmos a partir da variação de temperaturas lida pelo equipamento.

Depois dos termopares para o concreto, utilizou-se a máquina de descarga capacitiva para soldar os termopares nos pontos escolhidos ao longo das armaduras longitudinais positivas (inferiores) e negativas (superiores). Os dois fios presentes na estrutura do termopar foram soldados bem próximos um ao outro, para garantir melhor leitura da temperatura equivalente. 
Antes da soldagem, retiraram-se, por meio de uma lima, as impurezas e ranhuras das superfícies nas quais seriam colocados os termopares, para que fossem mais bem fixados.

Finalmente, produziram-se etiquetas que foram fixas às extremidades dos termopares que ficariam na parte externa ao forno, para a demarcação de cada um dos fios, ou seja, para indicar os seguintes parâmetros: número da concretagem $\left(1^{\mathrm{a}}, 2^{\mathrm{a}}\right.$ ou $\left.3^{\mathrm{a}}\right)$, seção no qual estavam presentes $\left(S_{1}, S_{2}\right.$ ou $\left.S_{3}\right)$ e, ainda, em qual ponto da seção (1 a 10, para seções com maior quantidade de termopares, e 1 a 4 ou 1 a 3, para o menor número). Nas Figuras 3.35 e 3.36, os detalhes da instrumentação.

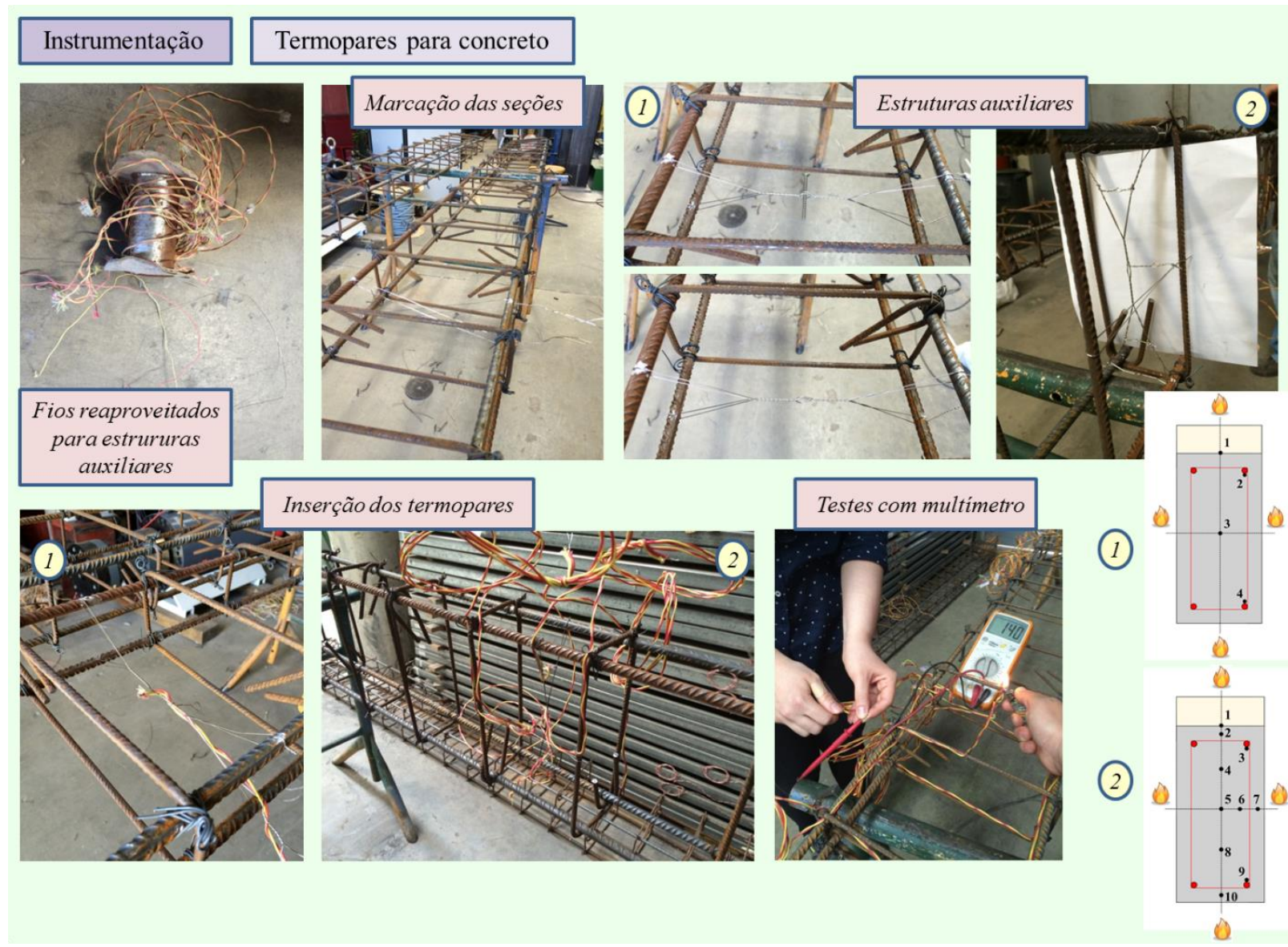

Figura 3.35 - Detalhes da instrumentação das vigas, com a inserção de fios de termopar para aferir as temperaturas em pontos do concreto. 


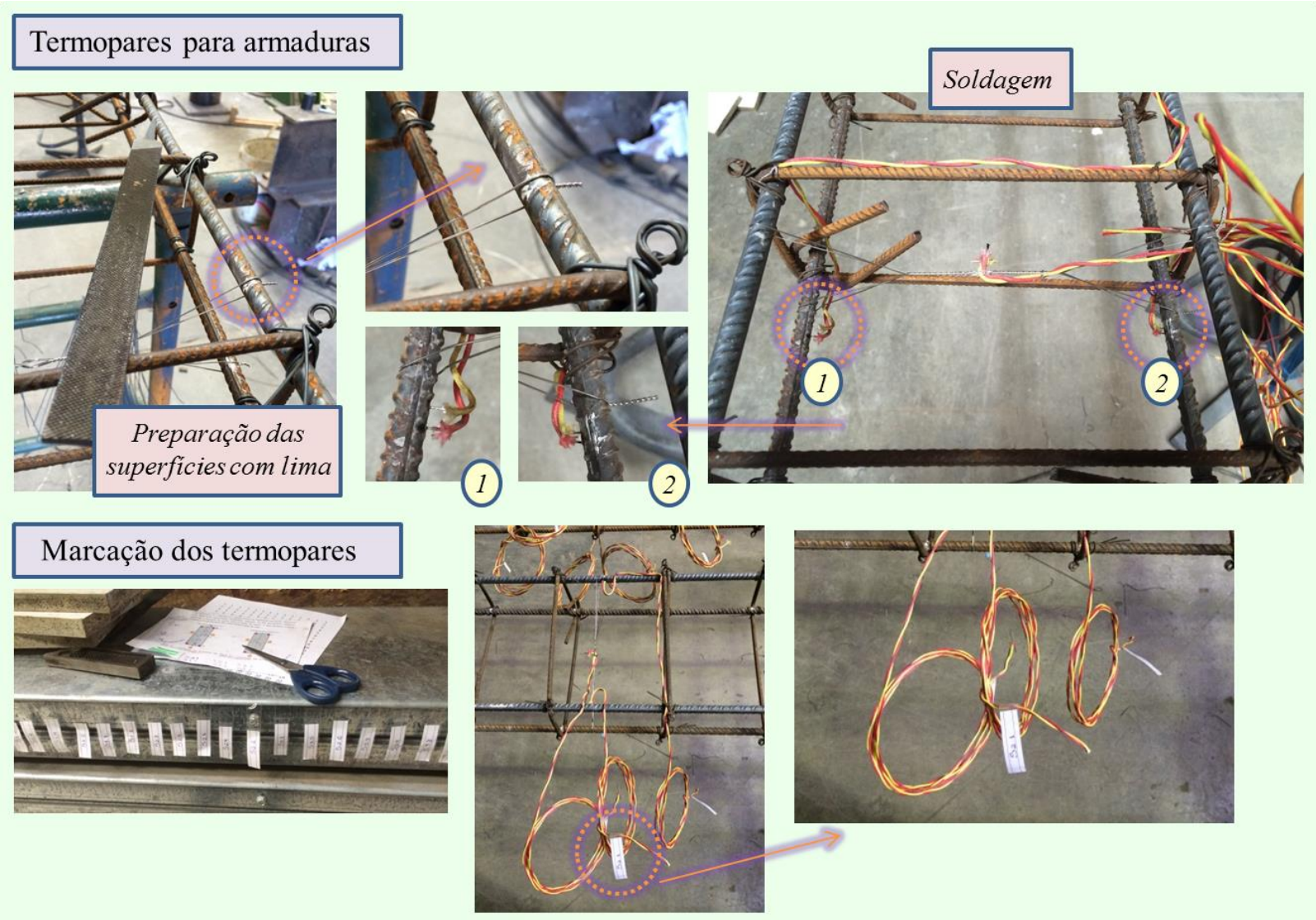

Figura 3.36 - Detalhes da instrumentação das vigas, com a inserção de termopares para aferir as temperaturas em pontos das armaduras, além da marcação dos fios.

\subsubsection{Montagem do conjunto fôrma-armadura}

Após a instrumentação dos termopares, foram fixos nas laterais e em uma das faces das vigas, na região dos estribos, alguns distanciadores em concreto, para garantir os cobrimentos das armaduras iguais a 2,5 cm. Em seguida, essas amostras foram inseridas nas fôrmas, onde se colocaram os demais distanciadores, agora na outra face, de modo que as armaduras ficassem bem fixas e alinhadas. Na parte inferior, também foram inseridos distanciadores em outro modelo, com uma forma mais conveniente para essa região da viga, para prover o cobrimento estipulado. Estruturas de ganchos também foram colocadas na região onde estariam 
localizados os apoios das vigas, para não comprometer os pontos de aplicação das forças ou aqueles em que seriam analisadas as temperaturas e os deslocamentos verticais. Esses ganchos foram produzidos, com armaduras de diâmetro igual a $6 \mathrm{~mm}$, para que pudessem funcionar como alças, necessárias para deslocar as amostras pelo LEME, com o auxílio de uma ponte rolante. Todos os fios de termopar foram organizados para um único lado da viga a fim de que, ao longo dos ensaios, fosse mais prática a condução dos mesmos para a parte de fora do forno até o data logger. Esses fios ainda foram fixos às faces exteriores das fôrmas para facilitar na hora da concretagem. Por fim, verificou-se, após a inserção e preparação das armaduras nas fôrmas, se todos os termopares continuavam posicionados corretamente. $\mathrm{Na}$ Figura 3.37, apresentam-se fotografias acerca da montagem dos conjuntos fôrma-armadura.

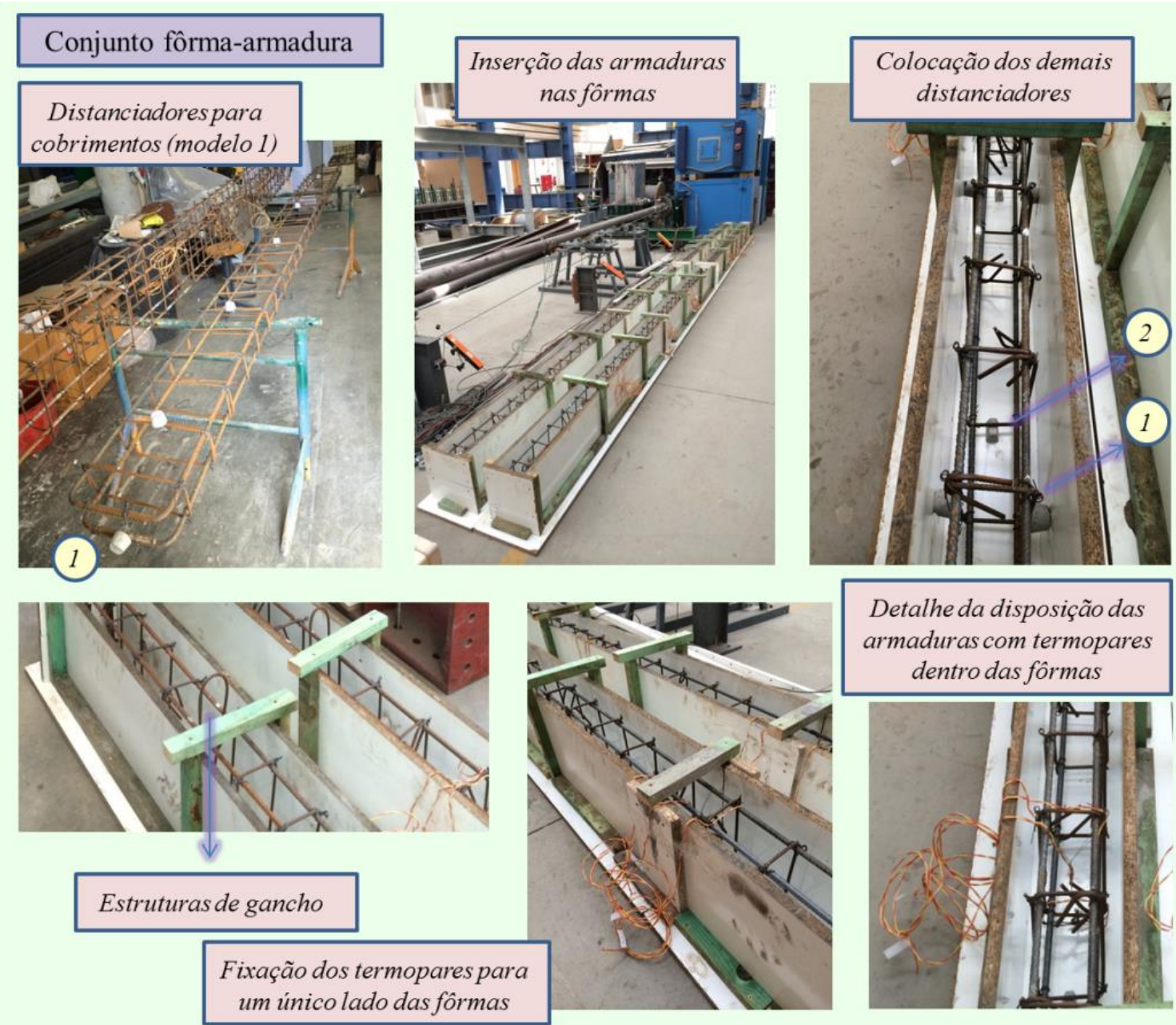

Figura 3.37 - Montagem das armaduras, já instrumentadas, nas fôrmas. 


\subsubsection{Concretagem}

$\mathrm{Na}$ concretagem das vigas, o vibrador foi utilizado de modo que não comprometesse a instrumentação dos termopares. Além da concretagem dessas, foram produzidas as amostras cúbicas de concreto, com arestas de $15 \mathrm{~cm}$. Para tal, utilizaram-se fôrmas padrão, disponíveis no Laboratório, que foram posicionadas sobre uma plataforma própria para a vibração do material inserido nesses cubos. Nessas fôrmas, também se borrifou óleo descofrante, para diminuir a aderência e facilitar a posterior retirada.

Quando já devidamente secas, as vigas concretadas para ensaios à temperatura ambiente foram submetidas a uma pintura com cal, a fim de facilitar a análise do grau de fissuração durante os ensaios, em que as fissuras foram demarcadas com outra cor para melhor visualização, a olho nu, da sua forma de propagação e, ainda, das suas respectivas aberturas e comprimentos. Esse não consiste num parâmetro verificado nas vigas submetidas ao fogo, considerando que ao final dos ensaios a temperaturas elevadas essas certamente estariam bastante danificadas e, por conseguinte, seria muito difícil a visualizar a propagação das fissuras. Os detalhes sobre a concretagem podem ser vistos na Figura 3.38.

\subsubsection{Laje para ensaios}

Além das vigas de ensaio, incluiu-se na segunda concretagem a produção da laje que foi utilizada para a realização das análises experimentais (apresentada anteriormente na Figura 3.5 , por exemplo, com o ${ }^{\circ} 15$ ). Pontua-se que esse elemento não possuía nenhuma finalidade estrutural nos ensaios propriamente ditos e funcionou apenas como uma plataforma de teste, para proteger e evitar o aquecimento da própria laje do LEME. O projeto foi executado de forma a prever os furos já existentes no piso do espaço, pelos quais seriam introduzidas as 
barras de conexão das vigas de concreto armado ao sistema de restrição rotacional e por onde passariam os fios a serem acoplados aos transdutores de deslocamentos verticais, dentre outras funções pertinentes ao leiaute de testes. Esses furos foram executados na laje por meio de tubos de PVC, fixos a armadura. A fim de facilitar a sua posterior locomoção pelo LEME, essa laje com dimensões significativas $(5,3 \times 2,8 \times 0,25 \mathrm{~m})$ foi projetada para ser concretada dividida em dois elementos iguais.
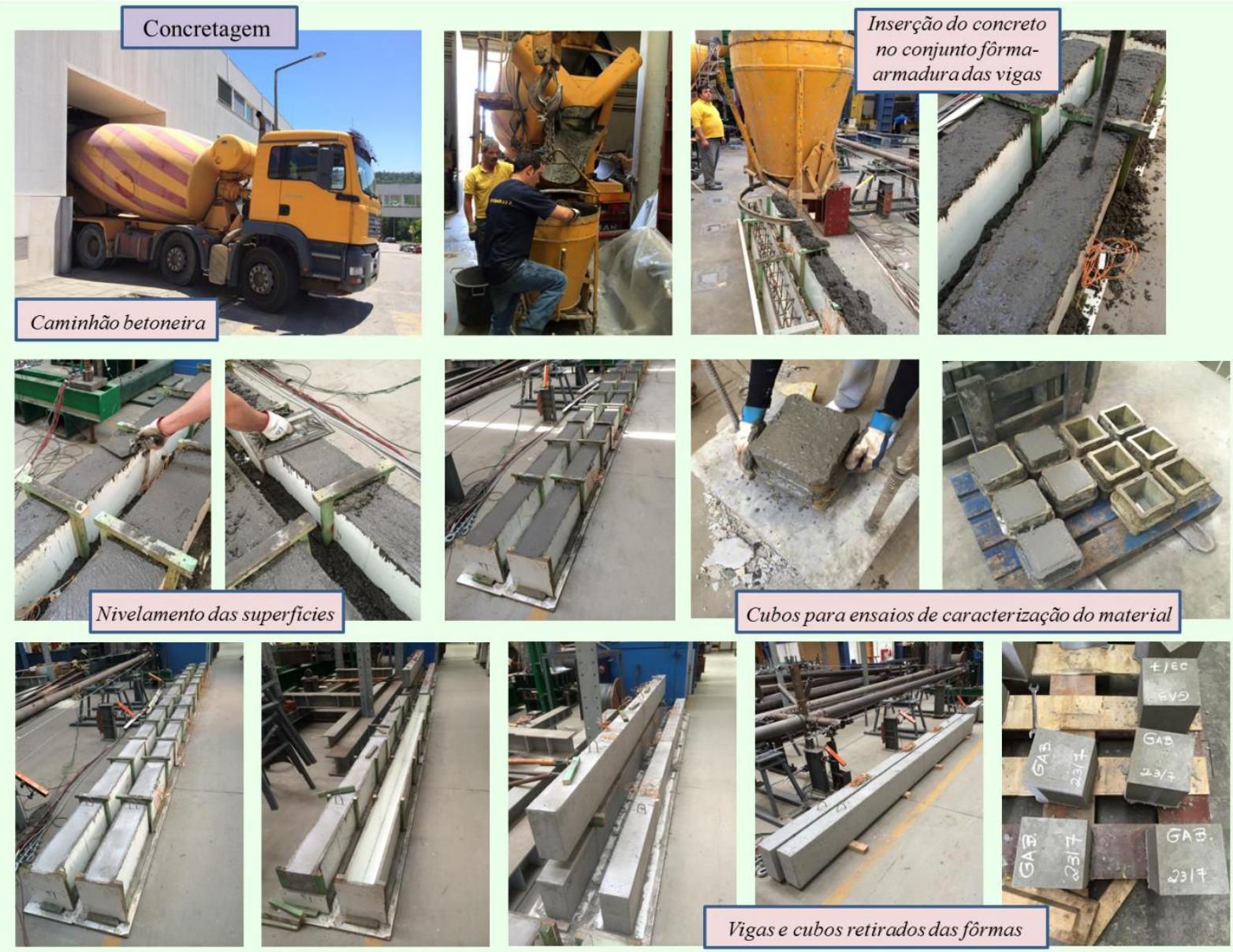

Figura 3.38 - Concretagem das vigas e de amostras cúbicas para ensaios de caracterização do material.

O concreto utilizado para a fabricação da laje foi o mesmo adotado para as vigas. Para as armaduras, também se estipulou barra nervurada do tipo A500, porém, com diâmetro igual a $16 \mathrm{~mm}$. Para a construção de uma laje com capacidade resistente suficiente para tal uso, optou-se pela disposição de armaduras em duas direções $(\phi 16 \mathrm{~mm}$ a cada $20 \mathrm{~cm}$ ) e pela 
aplicação de reforços nas regiões onde ficariam posicionados os apoios das vigas $(\phi 16 \mathrm{~mm}$ a cada $10 \mathrm{~cm}$ ). As fôrmas adotadas para a produção desse elemento foram compostas por placas de aço. Para monitorar as temperaturas a que essa laje estaria submetida ao longo dos ensaios de exposição ao fogo, previu-se, ainda, a introdução de alguns termopares tipo k embutidos em pontos críticos do concreto, ou seja, aqueles na região sob o forno, mais sujeitos à ação do calor. Para maior proteção a altas temperaturas, a face superior da laje ainda foi revestida com material isolante, como já se comentou ao longo deste capítulo. Na Figura 3.39, as imagens do processo de execução da referida laje.

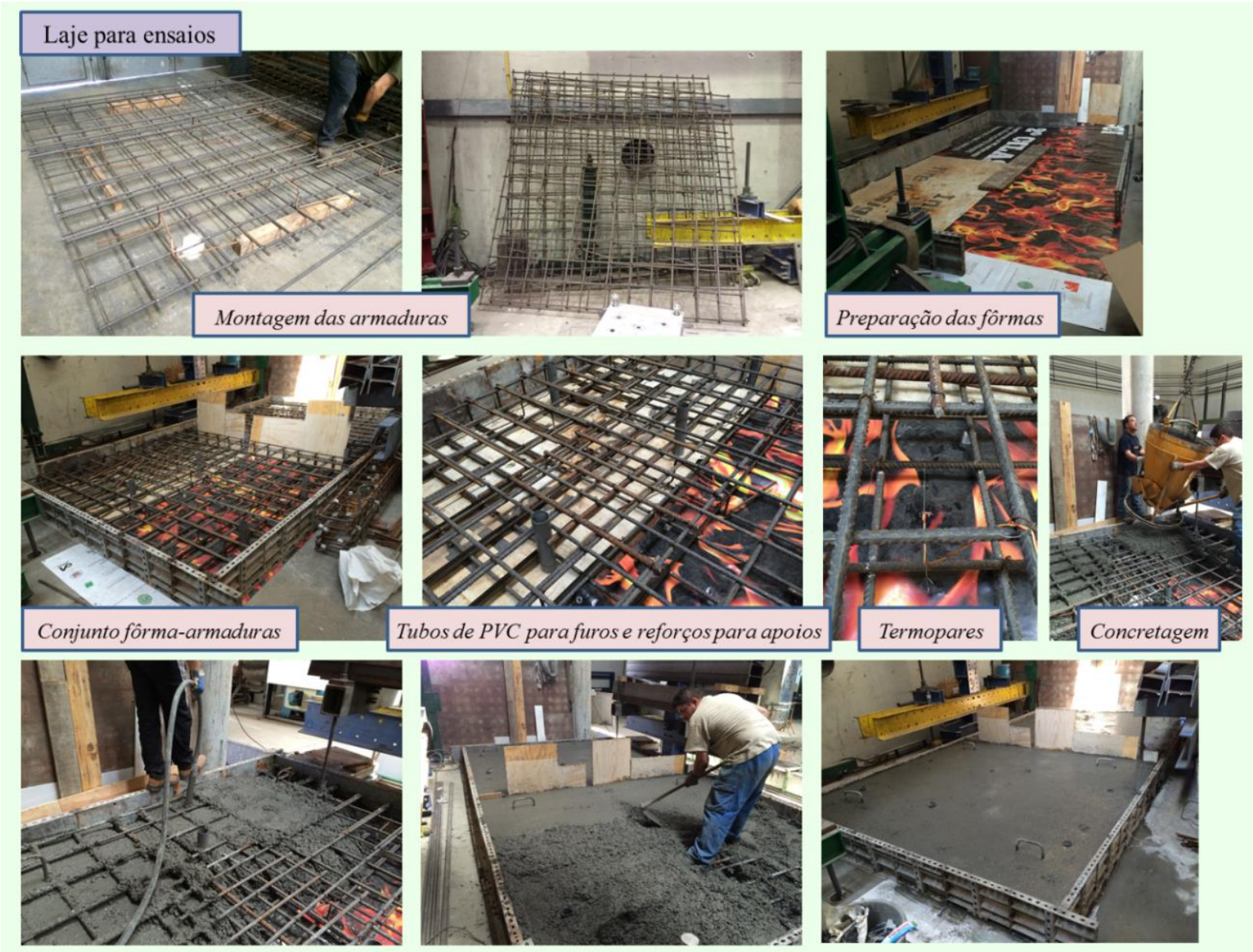

Figura 3.39 - Execução das armaduras e das fôrmas, instrumentação e concretagem da laje utilizada nos ensaios. 


\subsubsection{Ensaios de caracterização dos materiais}

\subsubsection{Concreto}

Algumas das amostras cúbicas de concreto retiradas ao longo da produção das vigas foram submetidas a ensaios experimentais para a determinação da resistência característica à compressão do material à temperatura ambiente, tendo sido esses realizados conforme as prescrições da norma EN 12390 parte 3 (2009). A Figura 3.40 contém algumas fotografias desses ensaios. Outras amostras cúbicas foram utilizadas para ensaios de verificação das massas específicas e teores de umidade, esses conduzidos com base na EN 12390 parte 7 (2000).
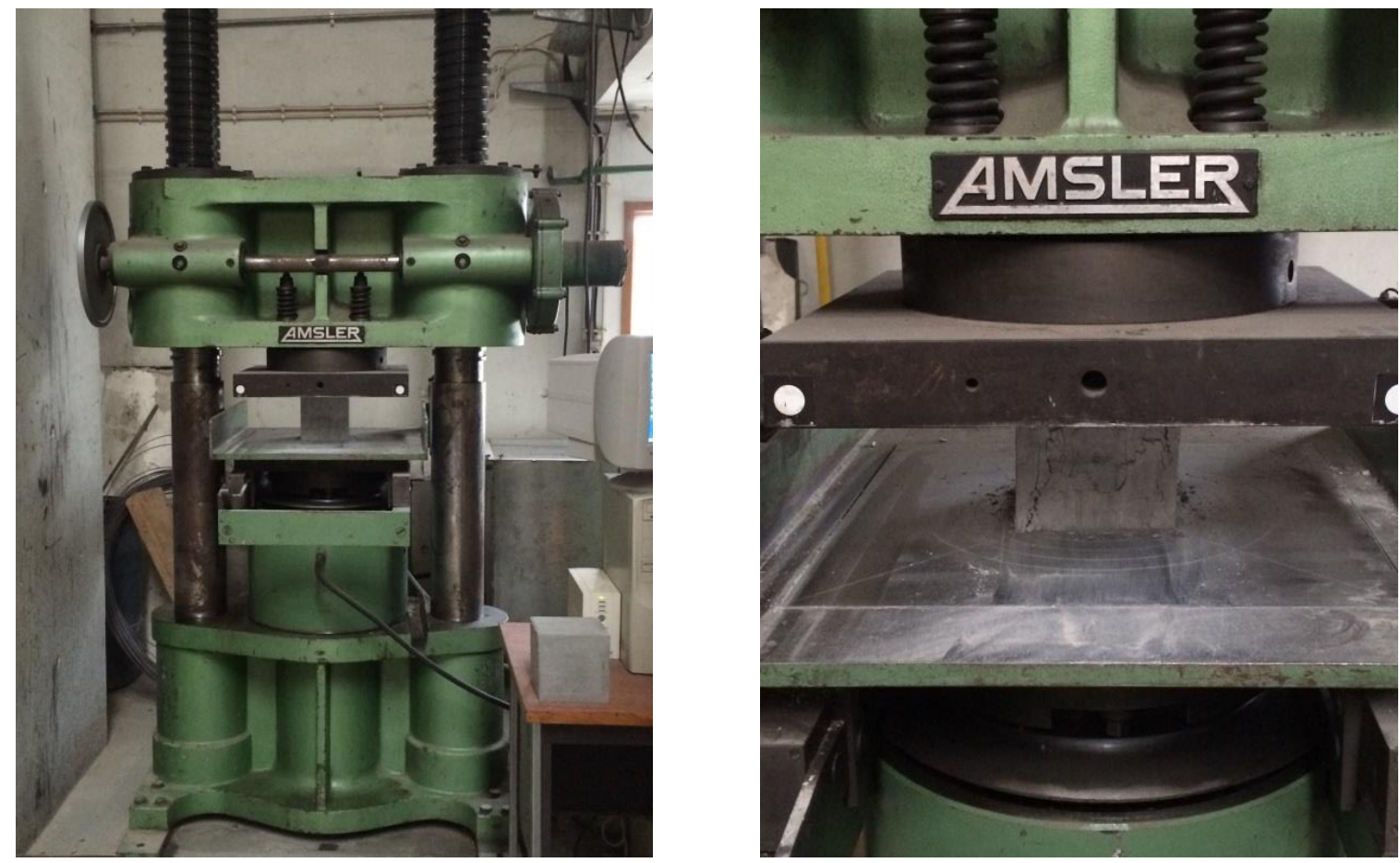

Figura 3.40 - Ensaios experimentais de resistência à compressão do concreto à temperatura ambiente. 
A seguir, na Tabela 3.2, apresentam-se as resistências médias características à compressão do concreto obtidas para diferentes idades do material. Para cada um dos casos, foram ensaiados três cubos de concreto. Os resultados dessa tabela já estão convertidos em resistências características de amostras cilíndricas, pois esse é o tipo de amostra no qual se fundamentam as classes de resistência do concreto apresentadas no Eurocode 2 parte 1-1 (2004). A partir da Tabela 3.1 dessa norma, verifica-se que os valores das resistências cilíndricas correspondem a aproximadamente $80 \%$ das cúbicas. Os valores das massas específicas e dos teores de umidade também foram obtidos pela média dos resultados dos ensaios realizados em três cubos de concreto (três para cada uma das concretagens) e estão indicados na Tabela 3.3.

Tabela 3.2 - Resistências características à compressão do concreto à temperatura ambiente.

\begin{tabular}{ccccc}
\hline \multirow{2}{*}{ Concretagem } & \multicolumn{3}{c}{ Resistência característica à compressão (MPa) / Idade do material } \\
\cline { 4 - 5 } & 7 dias & 28 dias & Primeiro dia de ensaio & Último dia de ensaio \\
\hline \multirow{2}{*}{$1^{\text {a }}$} & 16,51 & 20,18 & 221 dias & 361 dias \\
\cline { 4 - 5 } & & & 26,24 & 28,53 \\
$2^{2}$ & 22,16 & 28,61 & 181 dias & 322 dias \\
\cline { 4 - 5 } & & & 29,81 & 31,27 \\
\cline { 3 - 4 } $3^{\text {a }}$ & 19,15 & 25,85 & 124 dias & 265 dias \\
\cline { 3 - 4 } & & & 26,52 & 27,51 \\
\hline
\end{tabular}

Tabela 3.3 - Massas específicas e teores de umidade do concreto à temperatura ambiente.

\begin{tabular}{cccc}
\hline Concretagem & $\begin{array}{c}\text { Massa específica } \\
\left(\mathrm{kg} / \mathrm{m}^{3}\right)\end{array}$ & $\begin{array}{c}\text { Teor de umidade } \\
(\%)\end{array}$ & $\begin{array}{c}\text { Idade do material } \\
(\text { dias })\end{array}$ \\
\hline $1^{\text {a }}$ & 2297,95 & 1,66 & 271 \\
\hline $2^{\mathrm{a}}$ & 2308,46 & 1,65 & 266 \\
\hline $3^{\mathrm{a}}$ & 2290,48 & 1,69 & 216 \\
\hline
\end{tabular}




\subsubsection{Aço}

As amostras das barras das armaduras longitudinais $(\phi 10 \mathrm{~mm})$ e transversais $(\phi 6 \mathrm{~mm})$ foram submetidas a ensaios experimentais para a verificação da resistência característica à tração do aço à temperatura ambiente. Para a medição desse parâmetro, utilizaram-se extensômetros elétricos modelo TML YFLA-5, que foram colados às barras ${ }^{16}$, bem como um extensômetro mecânico. Os ensaios, ilustrados na Figura 3.41, foram realizados mediante as prescrições da norma ISO 6892 parte 1 (2009). As curvas resultantes dos ensaios estão indicadas na Figura 3.42 e os resultados obtidos a partir delas se encontram na Tabela 3.4.
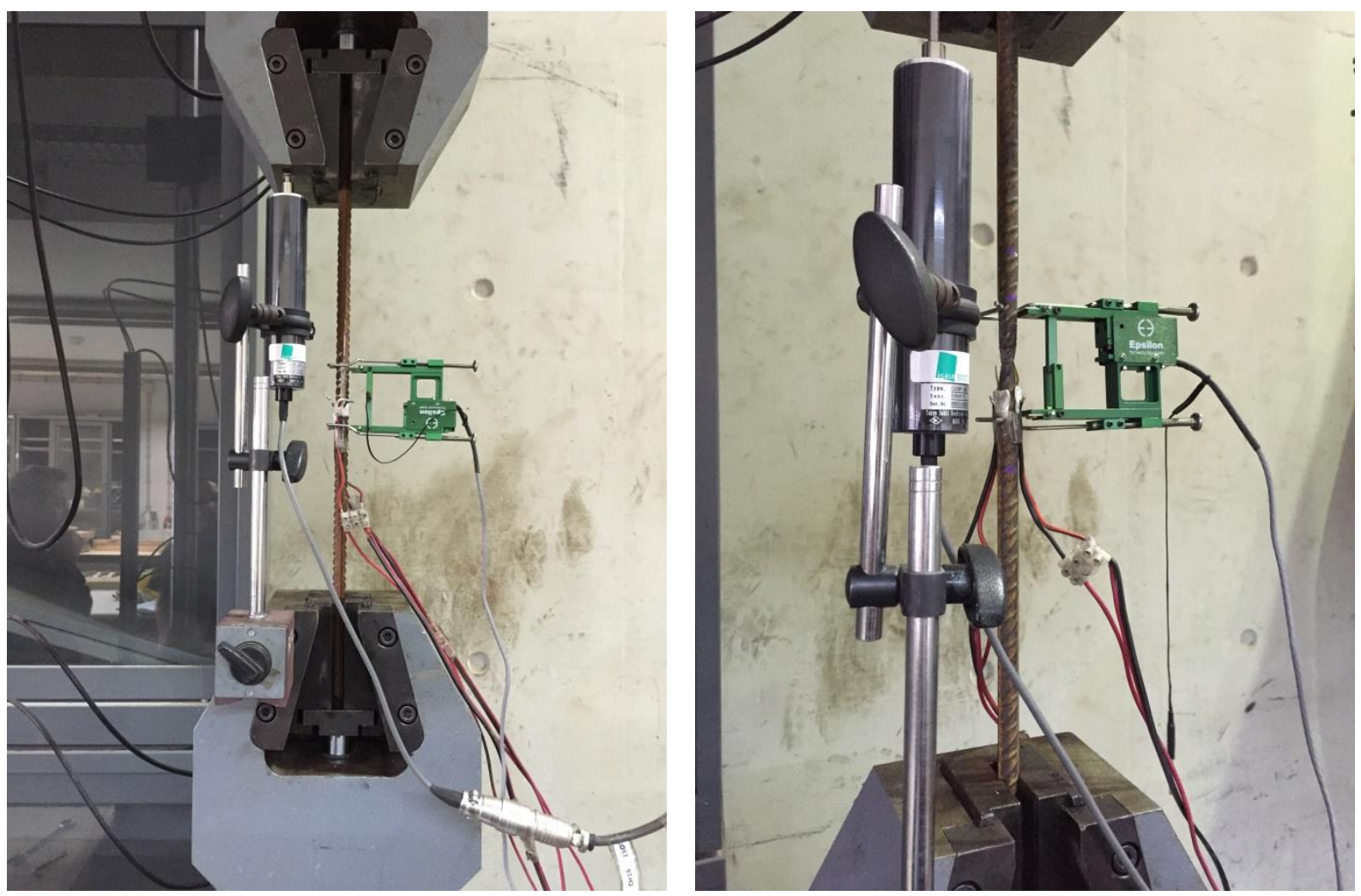

Figura 3.41 - Ensaios experimentais de resistência à tração das armaduras à temperatura ambiente.

16 Adotou-se a cola CN da TML. Informações adicionais do fabricante estão disponíveis em: 〈http://www.tml.jp/e/product/strain_gauge/adhesives_list/\#a1〉. Acesso em: 22 out. 2015. 


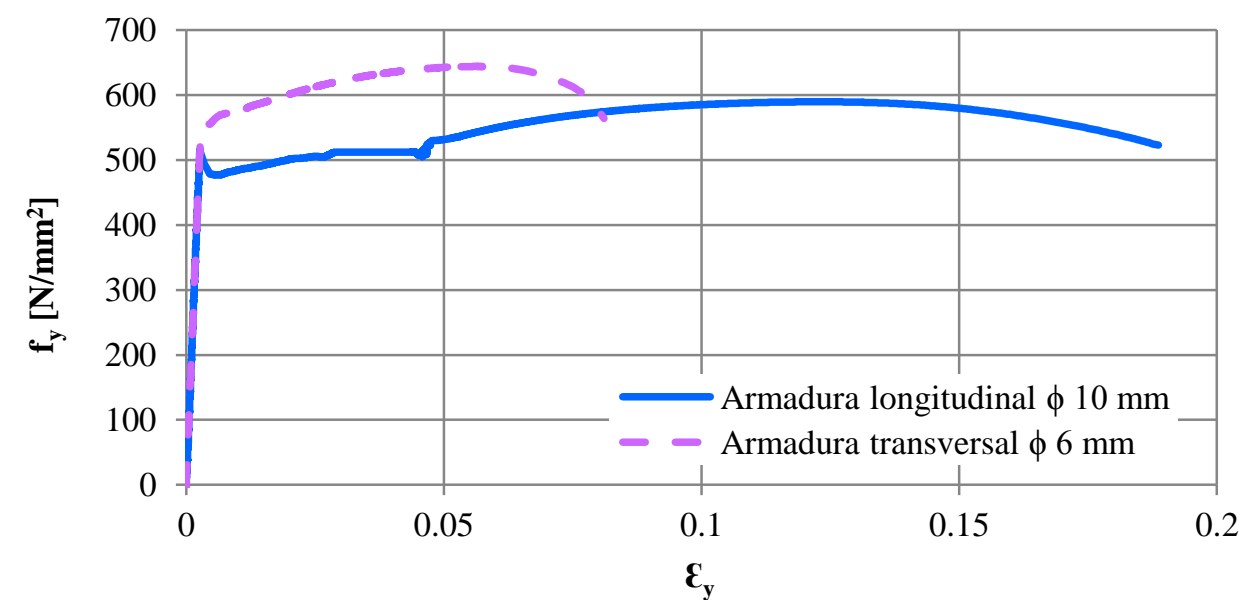

Figura 3.42 - Relações tensão vs deformação obtidas nos ensaios experimentais de tração das armaduras.

Tabela 3.4 - Resultados obtidos nos ensaios de tração das armaduras à temperatura ambiente.

\begin{tabular}{cccccc}
\hline Armadura & $\begin{array}{c}\text { Diâmetro } \\
\phi \\
(\mathrm{mm})\end{array}$ & $\begin{array}{c}\text { Tensão correspondente } \\
\text { ao limite de } \\
\text { proporcionalidade } \mathrm{f}_{\mathrm{sp}} \\
\left(\mathrm{N} / \mathrm{mm}^{2}\right)\end{array}$ & $\begin{array}{c}\text { Resistência ao } \\
\text { escoamento } \\
\left(\mathrm{N} / \mathrm{mm}^{2}\right)\end{array}$ & $\begin{array}{c}\text { Deformação } \\
\text { específica } \varepsilon_{\mathrm{sp}} \\
(\text { adimensional })\end{array}$ & $\begin{array}{c}\text { Módulo de } \\
\text { elasticidade } \\
\left(\mathrm{x} \mathrm{10} 0^{3} \mathrm{~N} / \mathrm{mm}^{2}\right)\end{array}$ \\
\hline Longitudinal & 10 & 515,39 & 589,67 & 0,00268 & 192,45 \\
\hline Transversal & 6 & 548,06 & 644,15 & 0,00277 & 198,14 \\
\hline
\end{tabular}

\subsubsection{Simulação de vigas sob lajes}

Nos ensaios de altas temperaturas, os módulos do forno horizontal elétrico seriam posicionados sobre a viga de concreto armado (Figuras 3.11 e 3.19), de forma que as quatro faces dessa peça ficariam submetidas a aquecimento. No entanto, em estruturas reais, as condições de contorno são diferentes, pois as vigas se encontram sob lajes, que proporcionam um determinado isolamento à face superior das mesmas. Logo, na simulação de fogo em apenas um andar da estrutura, é usual admitir que apenas as faces laterais e inferior das vigas ficam diretamente expostas às altas temperaturas. Essa hipótese de aquecimento apenas em três faces é frequentemente adotada nos trabalhos de cunho experimental nos quais são 
analisadas vigas de concreto armado em situação de incêndio (vários exemplos foram citados no capítulo anterior, Estado da Arte).

Nas análises experimentais executadas nesta pesquisa, a produção de vigas com seções tipo T, representativas de vigas sob lajes, era inviável. Primeiro porque elas seriam incompatíveis às peças de encaixe do leiaute de ensaios e, além disso, dependendo das espessuras e larguras adotadas, as lajes (ou as mesas dessas seções) alterariam outras variáveis do comportamento das vigas que seriam examinadas. Logo, em vista das seções retangulares das vigas de ensaio e das limitações impostas pelas características de aquecimento do forno (permitia apenas exposição ao fogo homogênea em quatro faces), a solução encontrada para simular vigas sob lajes consistiu na aplicação de materiais isolantes nas faces superiores dessas vigas, conforme esquema ilustrado na Figura 3.43.

Em busca do material adequado, foram analisadas placas de silicato de cálcio, tijolos refratários, mantas de fibra cerâmica e mantas de lã de silicato alcalino (Figura 3.44). Ainda em relação a cada um desses, foram estudados produtos com diferentes espessuras, propriedades térmicas e mecânicas, além da consideração de uma ou múltiplas camadas do material. Essa investigação foi conduzida com o auxílio de análises térmicas e é apresentada detalhadamente no Apêndice D desta Tese.

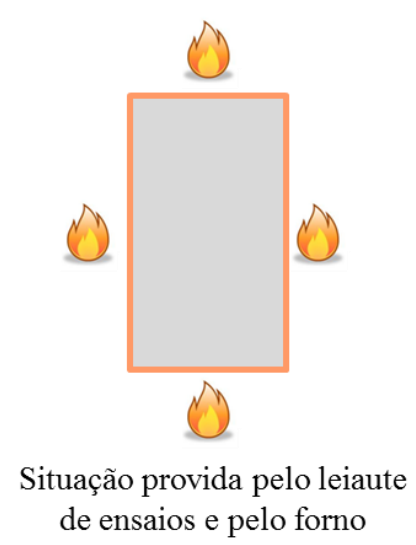

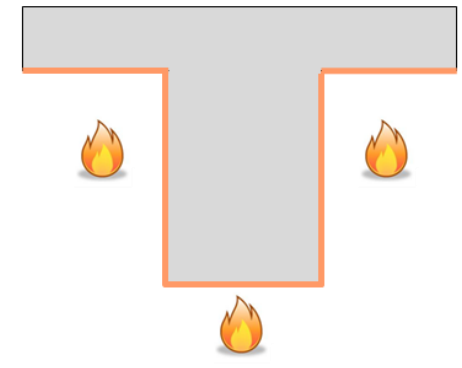

Situação pretendida

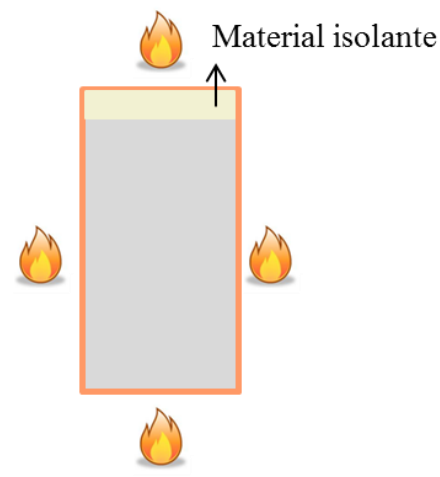

Solução adotada

Figura 3.43 - Esquemas das seções transversais e dos regimes de aquecimento que compuseram o estudo da simulação de vigas sob lajes. 


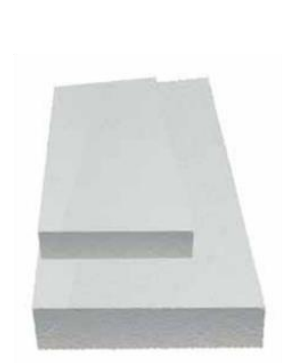

Placas de silicato de cálcio

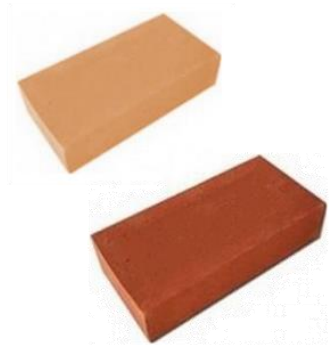

Tijolos refratários

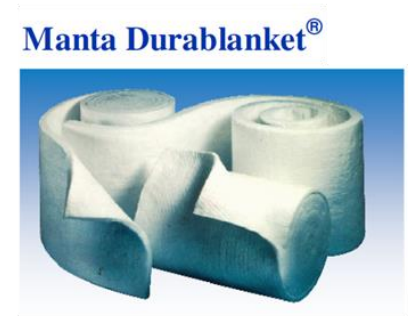

Mantas de fibra cerâmica

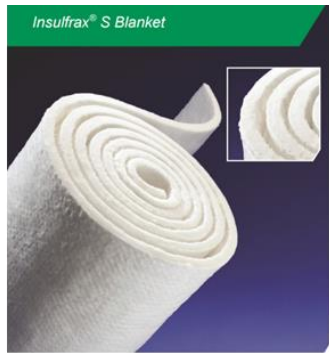

Mantas de lã de silicato alcalino

Figura 3.44 - Materiais isolantes adotados para estudo.

Dentre os materiais mencionados, as mantas de lã de silicato alcalino representaram a melhor opção por serem mais flexíveis, de modo que poderiam acompanhar as deformações por flexão que as vigas de concreto armado iriam sofrer, não comprometendo o isolamento. $\mathrm{O}$ fato de serem flexíveis também possibilitava a aplicação direta das forças provenientes do sistema de carregamento sobre as vigas de concreto, pois sobre as mantas seria mais fácil posicionar as chapas de distribuição das forças. Portanto, para os ensaios de exposição ao fogo, a face superior das vigas foi coberta com $\operatorname{mantas}^{17}$ denominadas Insulfrax ${ }^{\circledR} \mathrm{S}$ Blanket, cujas camadas possuíam espessura de $5 \mathrm{~cm}$ e com as propriedades térmicas indicadas na Tabela 3.5 (fornecidas pelo fabricante do produto).

Tabela 3.5 - Propriedades térmicas das mantas de lã de silicato alcalino.

\begin{tabular}{cccc}
\hline $\begin{array}{c}\text { Temperatura } \\
\left({ }^{\circ} \mathrm{C}\right)\end{array}$ & $\begin{array}{c}\text { Condutividade } \\
\text { térmica } \\
\left(\mathrm{W} / \mathrm{m}^{\circ} \mathrm{C}\right)\end{array}$ & $\begin{array}{c}\text { Massa específica } \\
\left(\mathrm{kg} / \mathrm{m}^{3}\right)\end{array}$ & $\begin{array}{c}\text { Calor específico } \\
\left(\mathrm{J} / \mathrm{kg}{ }^{\circ} \mathrm{C}\right)\end{array}$ \\
\hline 400 & 0,10 & & \\
\cline { 1 - 2 } 600 & 0,16 & 128 & 1172 \\
\hline 800 & 0,23 & & \\
\hline 1000 & 0,31 & & \\
\hline
\end{tabular}

\footnotetext{
${ }^{17}$ Essa estratégia de aplicar um material isolante na face superior de vigas de concreto armado com seções retangulares para simular vigas sob lajes com aquecimento em três faces também foi adotada nos ensaios experimentais de Dwaikat e Kodur (2009), abordados no capítulo anterior. Segundo informações apresentadas em Dwaikat (2009), eles utilizaram mantas de fibra cerâmica, também com espessura de $5 \mathrm{~cm}$.
} 
Para que as condições de isolamento pretendidas pudessem ser simuladas ao longo das análises experimentais, era essencial que não houvesse ar entre a superfície superior da viga de concreto armado e o material isolante. Caso contrário, o ar conduziria o fluxo de calor para essa superfície da viga. O material utilizado para realizar a aderência entre o concreto e o isolante também deveria ser resistente ao fogo e, na busca por produtos desse gênero, a massa refratária Soudal ${ }^{18}$ se mostrou a mais adequada. Esse material é produzido à base de silicato de sódio, resistente a temperaturas de até $1500{ }^{\circ} \mathrm{C}$. Na Figura 3.45, ilustram-se as etapas de aplicação da massa refratária e da manta na face superior das vigas. Ainda é possível visualizar o termopar que era posto para aferir as temperaturas na interface concreto/manta, já indicado anteriormente nas Figuras 3.15 (a) e (b), ponto 1.

\section{Material isolante Aplicação da massa refratária}
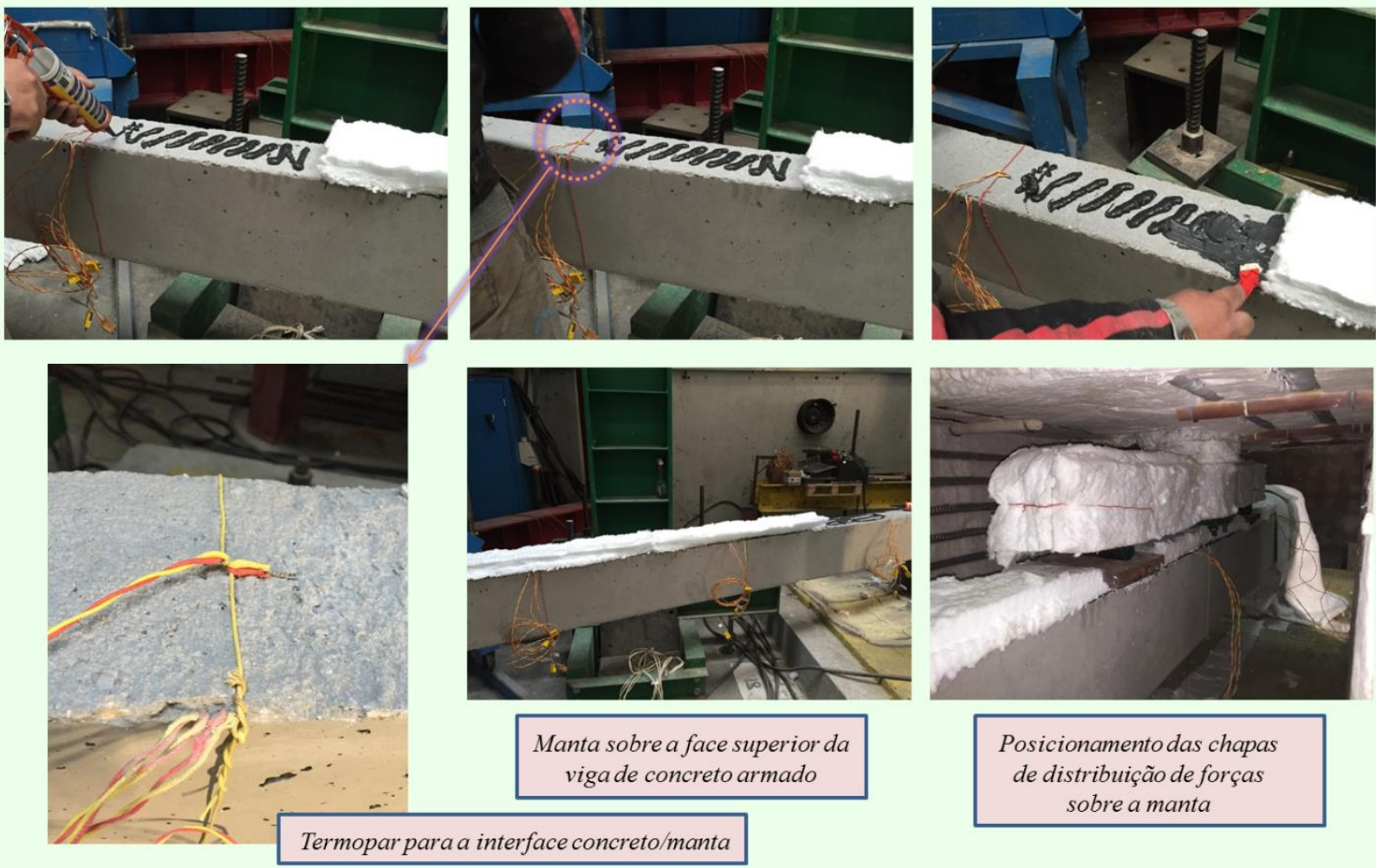

Figura 3.45 - Aplicação da massa refratária e da manta (material isolante) na face superior das vigas de concreto.

18 Outras informações sobre o produto disponíveis em <http://www.leroymerlin.pt/Site/Produtos/Pintura-edrogaria/Isolamento-e-impermeabilizacao/Silicones/17105774.aspx>. Acesso em: 01 dez. 2015. 


\subsection{Plano de ensaios}

O programa experimental foi composto por dezoito ensaios, sendo três à temperatura ambiente e os demais ao fogo. Em todos eles foram utilizadas vigas de concreto armado iguais, com as dimensões e armaduras apresentadas na Figura 3.30. As Tabelas 3.6 e 3.7 apresentam um resumo das análises conduzidas nas condições de temperatura ambiente e de incêndio, respectivamente.

Na Tabela 3.6, o ensaio A_ka0_kr0_1 representa um ensaio à temperatura ambiente (A) de viga simplesmente apoiada, ou seja, com restrição axial (ka) e restrição rotacional (kr) iguais a zero. O número posto ao final da referência (_1) indica que esse foi o primeiro ensaio de uma série de três ensaios iguais (A_ka0_kr0_1 a A_ka0_kr0_3). Como pode ser observado, estipulou-se um ensaio à temperatura ambiente para cada uma das vigas das diferentes concretagens.

Já na Tabela 3.7, o par de ensaios T_ka0_kr0 é indicativo daqueles que foram realizados com o objetivo principal de avaliar detalhadamente o campo térmico $(\mathrm{T})$ das vigas de concreto armado expostas ao fogo. As vigas desses ensaios foram as duas únicas instrumentadas com vários termopares nas seções transversais $S_{1}$ a $S_{3}$ (vide Figura 3.15-a). Novamente, vigas sem restrições (ka0 e kr0) e duas repetições de um mesmo tipo de ensaio (final_1 ou _2).

Os ensaios com referências ka0_kr0_1 e ka0_kr0_2 já são representativos daqueles de vigas simplesmente apoiadas ( $\mathrm{ka} 0$ e $\mathrm{kr} 0$ ) instrumentadas com um número menor de termopares nas seções (Figura 3.15-b). O ensaio ka0_kr0* foi assim demarcado, pois, dentre todos os ensaios de exposição ao fogo dessa campanha experimental, foi o único no qual não se aplicou manta na face superior da viga de concreto (Figura 3.15-c). Também consistiu em um caso de viga simplesmente apoiada. 
Os ensaios ka1_kr0 indicam aqueles nos quais as vigas foram submetidas a um nível mais baixo de restrição axial (ka1), igual a $7 \mathrm{kN} / \mathrm{mm}$, e para elas ainda não tinham sido impostas restrições rotacionais $(\mathrm{ka} 0)$. Analogamente, os ensaios ka2_kr0 representam aqueles com restrição axial mais elevada $(\mathrm{ka} 2)$, igual a $14 \mathrm{kN} / \mathrm{mm}$, e também sem restrição rotacional $(\mathrm{ka0})$.

A restrição de $7 \mathrm{kN} / \mathrm{mm}$ é equivalente a 0,02EA/1, em que "EA/1" representa a rigidez axial da viga de concreto à temperatura ambiente ("E" é o módulo de elasticidade, "A" a área da seção transversal e "l” o comprimento do vão). Já $14 \mathrm{kN} / \mathrm{mm}$ é equivalente a 0,4EA/l. Esses valores também estão indicados na Tabela 3.7.

As referências ka1_kr1 e ka2_kr1 representam os ensaios em que, além das restrições axiais (ka1 ou ka2), impuseram-se níveis mais baixos de restrição rotacional (kr1), iguais a 2500 kNm/rad. As referências ka1_kr2 são indicativas dos ensaios com níveis mais altos de restrição rotacional $(\mathrm{kr} 2)$, igual a $5000 \mathrm{kNm} / \mathrm{rad}$.

A restrição de $2500 \mathrm{kNm} / \mathrm{rad}$ é representativa de $1 \mathrm{EI} / \mathrm{l}$, onde "EI/l" representa a rigidez à flexão da viga de concreto à temperatura ambiente ("I" é o momento de inércia). Já a restrição rotacional de $5000 \mathrm{kNm} / \mathrm{rad}$ equivale a 2EI/l. Novamente, esses valores estão descritos na Tabela 3.7.

Tabela 3.6 - Plano de ensaios à temperatura ambiente.

\begin{tabular}{|c|c|c|c|c|}
\hline $\begin{array}{c}\text { Referência } \\
\text { do ensaio }\end{array}$ & $\begin{array}{c}\mathrm{k}_{\mathrm{a}} \\
(\mathrm{kN} / \mathrm{mm})\end{array}$ & $\begin{array}{c}\mathrm{k}_{\mathrm{r}} \\
(\mathrm{kNm} / \mathrm{rad})\end{array}$ & Concretagem & $\begin{array}{c}\text { Idade do } \\
\text { concreto } \\
\text { (dias) }\end{array}$ \\
\hline A_ka0_kr0_1 & & & $1^{\mathrm{a}}$ & $221^{*}$ \\
\hline A_ka0_kr0_2 & 0 & 0 & $2^{\mathrm{a}}$ & $181^{*}$ \\
\hline A_ka0_kr0_3 & & & $3^{a}$ & $124^{*}$ \\
\hline
\end{tabular}

*Indicam idades para as quais as resistências à compressão foram obtidas de forma experimental (indicadas na Tabela 3.2, coluna "Primeiro dia de ensaio"). 
Tabela 3.7 - Plano de ensaios em situação de incêndio.

\begin{tabular}{|c|c|c|c|c|}
\hline $\begin{array}{l}\text { Referência } \\
\text { do ensaio }\end{array}$ & $\begin{array}{c}\mathrm{k}_{\mathrm{a}} \\
(\mathrm{kN} / \mathrm{mm})\end{array}$ & $\begin{array}{c}\mathrm{k}_{\mathrm{r}} \\
(\mathrm{kNm} / \mathrm{rad})\end{array}$ & Concretagem & $\begin{array}{c}\text { Idade do } \\
\text { concreto } \\
\text { (dias) }\end{array}$ \\
\hline T_ka0_kr0_1 & \multirow{2}{*}{0} & \multirow{2}{*}{0} & $1^{\mathrm{a}}$ & $361^{*}$ \\
\hline T_ka0_kr0_2 & & & $1^{\mathrm{a}}$ & 350 \\
\hline $\mathrm{ka0} \_\mathrm{kr} 0 *$ & 0 & 0 & $1^{\mathrm{a}}$ & 357 \\
\hline ka0_kr0_1 & \multirow{2}{*}{0} & \multirow{2}{*}{0} & $1^{\mathrm{a}}$ & 238 \\
\hline ka0_kr0_2 & & & $1^{\mathrm{a}}$ & 277 \\
\hline ka1_kr0_1 & \multirow{2}{*}{$\begin{array}{c}7 \\
(0,02 \mathrm{EA} / \mathrm{l})\end{array}$} & \multirow{2}{*}{0} & $2^{a}$ & 304 \\
\hline ka1_kr0_2 & & & $2^{a}$ & 250 \\
\hline ka2_kr0_1 & \multirow{2}{*}{$\begin{array}{c}14 \\
(0,04 \mathrm{EA} / \mathrm{l})\end{array}$} & \multirow{2}{*}{0} & $3^{\mathrm{a}}$ & 197 \\
\hline ka2_kr0_2 & & & $3^{a}$ & 204 \\
\hline ka1_kr1_1 & \multirow{2}{*}{$\begin{array}{c}7 \\
(0,02 \mathrm{EA} / \mathrm{l})\end{array}$} & \multirow{2}{*}{$\begin{array}{c}2500 \\
(1 \mathrm{EI} / \mathrm{l})\end{array}$} & $2^{\mathrm{a}}$ & 299 \\
\hline ka1_kr1_2 & & & $2^{a}$ & 293 \\
\hline ka2_kr1_1 & \multirow{2}{*}{$\begin{array}{c}14 \\
(0,04 \mathrm{EA} / \mathrm{l})\end{array}$} & \multirow{2}{*}{$\begin{array}{c}2500 \\
(1 \mathrm{EI} / \mathrm{l})\end{array}$} & $3^{\mathrm{a}}$ & 215 \\
\hline ka2_kr1_2 & & & $3^{\mathrm{a}}$ & 222 \\
\hline ka1_kr2_1 & \multirow{2}{*}{$\begin{array}{c}7 \\
(0,02 \mathrm{EA} / \mathrm{l})\end{array}$} & \multirow{2}{*}{$\begin{array}{c}5000 \\
(2 \mathrm{EI} / \mathrm{l})\end{array}$} & $3^{\mathrm{a}}$ & $265^{*}$ \\
\hline ka1_kr2_2 & & & $2^{a}$ & $322^{*}$ \\
\hline
\end{tabular}

\footnotetext{
* Indicam idades para as quais as resistências à compressão foram obtidas de
} forma experimental (indicadas na Tabela 3.2, coluna "Último dia de ensaio"). 


\subsection{Procedimentos de ensaios}

\subsubsection{Temperatura ambiente}

Nos ensaios de flexão a quatro pontos das vigas simplesmente apoiadas à temperatura ambiente, as forças foram aplicadas por controle de deslocamentos, a uma taxa de 0,001 $\mathrm{mm} / \mathrm{s}$. Após a aparição da primeira fissura de flexão, os ensaios passavam a ser interrompidos eventualmente a cada $5 \mathrm{kN}$ de força total aplicada à viga, a fim de que a evolução das fissuras pudesse ser registrada. Assim, as fissuras eram demarcadas na viga ensaiada e também eram anotados os seus respectivos comprimentos ao longo da altura e as aberturas (essas verificadas por meio de uma régua medidora de fissuras, também conhecida como fissurômetro).

Dois desses ensaios foram levados até a ruína total (colapso real) das vigas de concreto armado para que o carregamento máximo e o modo de ruptura esperados pudessem ser efetivamente comprovados e para checar se o colapso final da viga poderia de alguma maneira danificar o forno nos ensaios subsequentes. Apenas um deles não foi conduzido até esse estágio, para salvaguardar duas células de carga que foram posicionadas junto às chapas de aço de distribuição de forças, porém a viga ensaiada já estava muito próxima da ruína total. Essas células, modelo CLC-20A TML com $200 \mathrm{kN}$ de capacidade, foram utilizadas somente em um ensaio para certificar que a força total proveniente do macaco hidráulico estava sendo igualmente distribuída nos dois pontos de aplicação.

\subsubsection{Situação de incêndio}

Nos ensaios em situação de incêndio, aplicava-se lentamente à viga de concreto armado, antes do forno ser acionado, uma força total inicial que correspondia a 50\% da carga última de 
projeto à temperatura ambiente. Após a aplicação dessa força é que se dava o início do aquecimento, de modo que tal força era mantida ao longo de todo o ensaio de exposição a temperaturas elevadas ${ }^{19}$. O forno elétrico programado para seguir a curva de incêndio-padrão ISO 834 (1999) realizava o aquecimento da viga de concreto até o instante em que eram atingidos os dois critérios estabelecidos para a finalização desses ensaios. Neste texto, tais critérios de finalização são denominados "critérios de ruptura". No entanto, é oportuno esclarecer que esses critérios não caracterizam, necessariamente e na maior parte dos casos, o instante do colapso/ruptura real das vigas ensaiadas, que consistiu no critério adotado para a finalização dos ensaios à temperatura ambiente. Logo, são critérios adotados por consenso da comunidade acadêmica para os ensaios de resistência ao fogo, em que se denomina "ruptura" a situação em que a viga ensaiada atinge os limites que serão descritos na presente seção.

O primeiro critério de ruptura consistiu no critério de deslocamentos ou de flechas máximas, definido de acordo com a norma EN 1363 parte 1 (1999) e, por simplificação, denominado ao longo desta Tese sob o título de "critério de deslocamentos". Essa norma estabelece que o ensaio deve ser finalizado quando atingidos dois valores limites: (1) o do deslocamento vertical a meio vão da viga ensaiada (flecha), vide Equação 3.1; (2) e o da velocidade de aumento desse deslocamento vertical, Equação 3.2, sendo que esse último precisa ser monitorado somente após ter sido atingido o deslocamento vertical apresentado na Equação 3.3. Tais valores limites são definidos com base na altura efetiva da seção e no comprimento do vão da viga. Considerando que as vigas de concreto armado ensaiadas tinham uma distância entre apoios igual a $3000 \mathrm{~mm}$ e altura efetiva de $264 \mathrm{~mm}$, admitia-se que elas tinham atingido a ruptura em termos de deslocamentos quando a flecha era maior que $85 \mathrm{~mm}$ e quando a taxa de aumento das flechas se mostrava superior a $3,78 \mathrm{~mm} / \mathrm{min}$, sendo que essa taxa passava a ser calculada quando a flecha tinha chegado aos $100 \mathrm{~mm}$.

\footnotetext{
19 Apenas nos ensaios T_ka0_kr0_1 e T_ka0_kr0_2 essa carga não foi mantida ao longo da etapa de aquecimento, pois uma vez que o objetivo desses consistia em analisar os campos térmicos das vigas de concreto armado, pretendia-se que eles tivessem maior duração. Porém, da mesma forma que os outros, a carga inicial foi aplicada para posicionar devidamente o sistema de redistribuição de forças e a manta na face superior da viga de concreto armado ensaiada e assim estabelecer condições de contorno similares às demais.
} 


$$
\begin{gathered}
d_{v}=\frac{l^{2}}{400 d} \therefore d_{v}=\frac{3000^{2}}{400 \times 264} \therefore d_{v}=85 \mathrm{~mm} \\
\frac{d d_{v}}{d t}=\frac{l^{2}}{9000 d} \therefore \frac{d d_{v}}{d t}=\frac{3000^{2}}{9000 \times 264} \therefore \frac{d d_{v}}{d t}=3,78 \mathrm{~mm} / \mathrm{min} \\
d_{v}=\frac{l}{30} \therefore d_{v}=\frac{3000}{30} \therefore d_{v}=100 \mathrm{~mm}
\end{gathered}
$$

onde:

$\mathrm{d}=$ altura efetiva da viga ensaiada $[\mathrm{mm}]$;

$\mathrm{dv}=$ deslocamento vertical a meio vão (flecha) da viga ensaiada [mm];

$\mathrm{ddv} / \mathrm{dt}=$ velocidade ou taxa de aumento do deslocamento vertical a meio vão da viga ensaiada $[\mathrm{mm} / \mathrm{min}]$

$1=$ comprimento do vão da viga ensaiada [mm].

O segundo critério de ruptura definido foi aquele em termos de capacidade resistente. Esse critério estabelece que a ruptura da viga de concreto armado ensaiada é atingida quando o valor da força de restrição axial retorna ao seu valor inicial, i.e., quando ela volta a ser igual a zero. Em outras palavras, admite que a viga ensaiada atinge a ruptura quando a deterioração das propriedades mecânicas dos seus materiais e da sua rigidez é tão elevada que ela não mais é capaz de resistir às forças aplicadas. O mesmo já foi abordado anteriormente em Albuquerque et al. (2016, 2017a, 2017b).

Como ainda poderá ser visto ao longo deste capítulo, na apresentação dos resultados, o critério de ruptura por deslocamentos foi na maioria dos casos atingido antes do critério de capacidade resistente das vigas ensaiadas. Para salvaguardar os equipamentos do LEME e, sobretudo, para garantir a segurança ao longo dos ensaios de exposição ao fogo, nem sempre foi possível conduzir os mesmos até ter sido verificado o critério de ruptura em termos de capacidade resistente.

Por fim, é válido citar que devido ao esquema estático das vigas de ensaio (flexão a quatro pontos), a carga última de projeto à temperatura ambiente é igual ao valor de cálculo da sua 
capacidade resistente à flexão (momento resistente). Essa capacidade resistente à temperatura ambiente foi calculada com base nas precrições do Eurocode 2 parte $1-1(2004)^{20}$, resultando em, aproximadamente, $17 \mathrm{kN} \mathrm{m}$. Sendo assim, ao longo dos ensaios ao fogo, aplicavam-se às vigas de concreto armado duas forças de $8,5 \mathrm{kN}$. A porcentagem de $50 \%$ foi estipulada para que os ensaios de exposição ao fogo tivessem curta duração, assim previnindo o desenvolvimento de temperaturas muito elevadas, que poderiam acabar por comprometer os equipamentos utilizados para a instrumentação. Além disso, Laím (2013) esclarece que os níveis de carregamento atuantes nos elementos estruturais presentes na maior parte dos edifícios submetidos a uma situação excepcional variam de 20 a 50\% do valor da carga última de projeto. Logo, supõe-se que $50 \%$ seja um nível a favor da segurança.

\subsection{Resultados e discussões}

\subsubsection{Vigas à temperatura ambiente}

Os ensaios de vigas simplesmente apoiadas à temperatura ambiente foram realizados com alguns objetivos específicos, delineados logo no início deste capítulo. Relativamente à campanha experimental, um desses objetivos estava voltado a verificar se as cargas últimas obtidas pelos ensaios seriam similares ao valor determinado de forma analítica, afinal, as forças que devem ser aplicadas nos ensaios ao fogo são usualmente determinadas com base

\footnotetext{
${ }^{20} \mathrm{O}$ momento resistente de cálculo à temperatura ambiente determinado com base na norma brasileira ABNT NBR 6118:2014 se mostrou bastante similar ao obtido pelas prescrições da norma europeia, também resultando em aproximadamente $17 \mathrm{kN} \mathrm{m}$, pois o coeficiente de ponderação da resistência do concreto é o único parâmetro que difere entre elas na definição do equilíbrio de esforços atuantes na seção transversal ( $\gamma_{c}$ é igual 1,4 no Brasil, enquanto na Europa é 1,5). Em valores exatos, o momento resultante da norma europeia foi igual a 17,16 kN m e o da brasileira $17,22 \mathrm{kN} \mathrm{m}$. Nos dois casos, em que os momentos foram calculados via equilíbrio de esforços, considerou-se a armadura dupla. Pelas posições das linhas neutras, foi possível certificar que as vigas se encontravam no domínio 2 , estado limite último com escoamento da armadura inferior.
} 
nesses métodos analíticos. Pontua-se que essa se trata de uma análise aproximada, pois nesse caso estão sendo comparados os valores de ruína, ou seja, de cargas últimas dos ensaios, à situação última teoricamente prevista. Como esclarecido na seção anterior, a carga última de cálculo à temperatura ambiente definida com base no Eurocode 2 parte 1-1 (2004) foi igual a 17 kN. Já o valor característico, esse sim a ser comparado com os ensaios, foi igual a $20 \mathrm{kN}$.

O gráfico da Figura 3.46 ilustra as forças totais aplicadas às vigas de concreto armado ensaiadas em função de suas flechas ${ }^{21}$. Por forças totais, entende-se a força aplicada pelo macaco hidráulico, igual à somatória das forças aplicadas em dois pontos da viga. Nesse caso, o valor analítico da força total característica seria igual a $40 \mathrm{kN}$ (também indicado no gráfico em questão, pelo símbolo $\mathrm{P}_{\mathrm{k}}$ ). Nos ensaios A_ka0_kr0_1 e A_ka0_kr0_2, as forças máximas foram iguais a $42 \mathrm{kN}$, enquanto no ensaio A_ka0_kr0_3 igual a 39,5 kN.

Com variações não superiores a 5\%, é possível afirmar que as forças últimas obtidas experimentalmente foram muito próximas aos valores previstos. Assim, confirma-se a precisão do método analítico adotado para a definição das forças que seriam aplicadas mais em frente, nos ensaios ao fogo. Apenas para informação, também se indica nessa figura o resultado da força total de cálculo determinada pelas prescrições do Eurocode 2 parte 1-1 (2004) e da ABNT NBR 6118:2014, representada pelo símbolo " $\mathrm{P}_{\mathrm{d}}$ (EC e NBR)". Como já mencionado neste texto, as duas conduziram a um resultado comum.

Além disso, verificou-se que as vigas provenientes das três concretagens apresentaram comportamentos similares nas relações de forças aplicadas em função de flechas, bem como nos valores de forças máximas resistidas. A confirmação da similaridade entre o comportamento dessas vigas consistiu em mais um dos objetivos que motivaram a realização dos ensaios à temperatura ambiente.

\footnotetext{
${ }^{21}$ As curvas da Figura 3.46 foram traçadas até os dados finais lidos pelo data logger, ou seja, até a ruptura real das vigas de concreto armado ensaiadas à temperatura ambiente, com exceção do ensaio A_ka0_kr0_2, que não foi conduzido até esse estágio, conforme será esclarecido mais adiante, ainda na presente seção.
} 


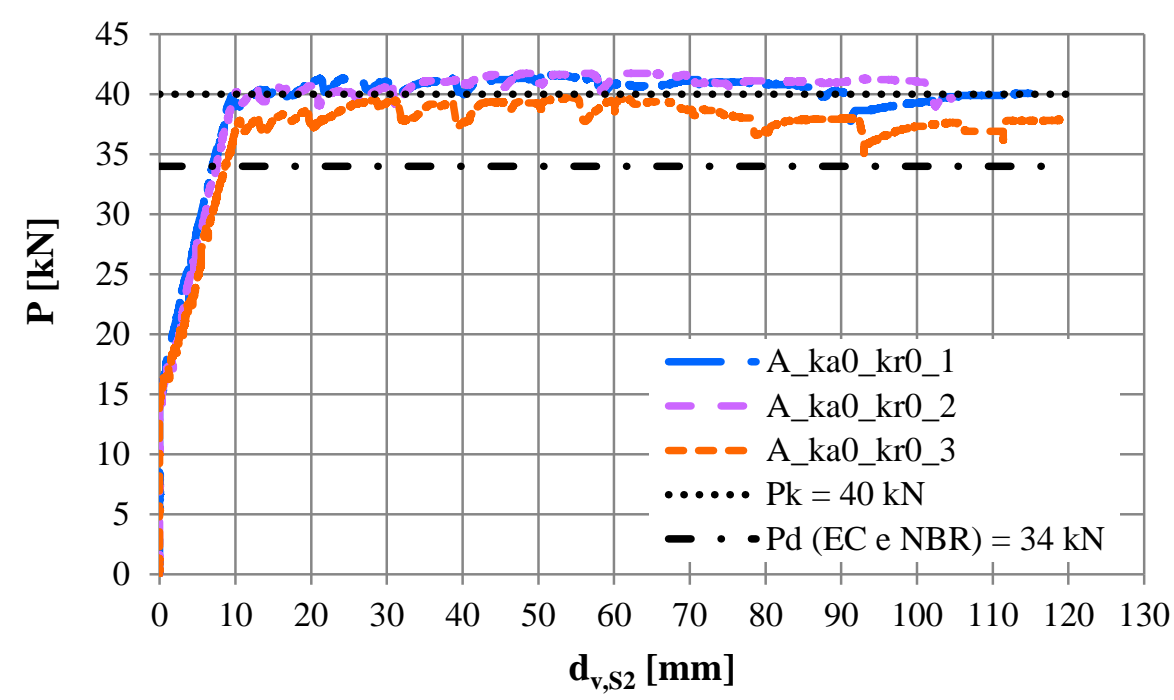

Figura 3.46 - Curvas experimentais de forças totais aplicadas em função das flechas (deslocamentos verticais na seção $S_{2}$ a meio vão) das vigas de concreto armado ensaiadas à temperatura ambiente, incluindo a indicação dos valores analíticos característico e de cálculo obtidos para as forças máximas.

A Figura 3.47 apresenta os campos de fissuração obtidos nos ensaios das vigas simplesmente apoiadas à temperatura ambiente ${ }^{22}$. Esses campos foram os últimos registrados em cada um dos ensaios, i.e., foram os correspondentes ao estágio final, pouco antes dos ensaios terem sido finalizados. A quantidade de fissuras, o posicionamento ao longo do vão e o comprimento ao longo da altura da seção se mostraram similares para as vigas características das concretagens 1 a 3 . As aberturas das fissuras correspondentes a determinadas forças totais aplicadas ao longo desses ensaios também foram próximas, vide Tabela 3.8.

O ensaio A_ka0_kr0_1 foi paralisado apenas quando as barras da armadura longitudinal inferior romperam e, de forma brusca, a viga de concreto armado atingiu o colapso e foi ao chão. Como indicado pela Figura 3.46, nesse instante a flecha da viga já estava próxima de $115 \mathrm{~mm}$. Novamente, assinala-se que o propósito de se ter levado a viga até o colapso real

\footnotetext{
${ }^{22}$ A Figura 3.47 mostra que as mantas de lã de silicato alcalino foram aplicadas em alguns dos ensaios à temperatura ambiente. Essa foi apenas uma estratégia para verificar como esse material se comportava frente às deformações da viga de concreto armado, a fim de prever o seu comportamento para os ensaios ao fogo. Mais adiante, na Figura 3.49, poderá ser visto que a manta se manteve bem colada à face superior do elemento, mesmo quando o colapso foi atingido. A aderência concreto/manta foi efetuada com o uso da massa refratária, mesmo produto estipulado para as análises ao fogo. Assim, comprovou-se que as mantas desempenhariam satisfatoriamente a função de material isolante para as quais foram adotadas.
} 
consistiu em verificar visualmente o seu modo de ruptura para que nos próximos ensaios, com o forno, o equipamento não corresse o risco de ser danificado. $O$ ensaio de referência A_ka0_kr0_3 também foi paralisado apenas quando as barras da armadura longitudinal inferior romperam e, de forma brusca, a peça atingiu o colapso. Nesse caso, a flecha já havia alcançado $120 \mathrm{~mm}$. As Figuras 3.48 e 3.49 ilustram alguns detalhes dos aspectos finais das vigas desses ensaios.

Já o ensaio A_ka0_kr0_2, por ter sido aproveitado para certificar a distribuição das forças que estavam sendo aplicadas pelo macaco hidráulico, não foi conduzido até o colapso real da viga, a fim de salvaguardar as células de carga adicionais. $O$ ensaio foi paralisado quando se chegou a aproximadamente 95\% da força máxima e as barras da armadura longitudinal inferior não chegaram a romper. Por tal motivo, essa foi a viga que apresentou a menor flecha máxima atingida, igual a $105 \mathrm{~mm}$.

Ao fim desses três ensaios, concluiu-se que todas as vigas simplesmente apoiadas ensaiadas à temperatura ambiente apresentaram o modo de ruptura por flexão, com seus estados limite sendo atingidos pela deformação última da armadura longitudinal tracionada, porém com o aviso prévio dado pelas fissuras de flexão e flechas excessivas. Logo, as vigas apresentaram um comportamento experimental que refletiu o estado limite de projeto adotado ao longo do dimensionamento dos mesmos.

Tabela 3.8 - Aberturas de fissuras registradas durante os ensaios de vigas à temperatura ambiente.

\begin{tabular}{ccccccccccccc}
\hline \multirow{2}{*}{$\begin{array}{c}\text { Referência } \\
\text { do ensaio }\end{array}$} & \multicolumn{7}{c}{ Forças aplicadas $(\mathrm{kN}) /$ Aberturas de fissuras em cada ensaio (mm) } \\
\cline { 2 - 11 } & 15 & 20 & 22 & 25 & 27 & 30 & 32 & 35 & 37 & 38 & 39 & 40 \\
\hline A_ka0_kr0_1 & 0,1 & 0,15 & - & 0,20 & - & 0,36 & - & 0,40 & - & - & - & 2,2 \\
\hline A_ka0_kr0_2 & - & - & 0,16 & - & 0,2 & - & 0,30 & - & 0,35 & - & - & 2,0 \\
\hline A_ka0_kr0_3 & 0,08 & 0,16 & - & 0,18 & - & 0,34 & - & 0,4 & - & 2,2 & 2,4 & - \\
\hline
\end{tabular}



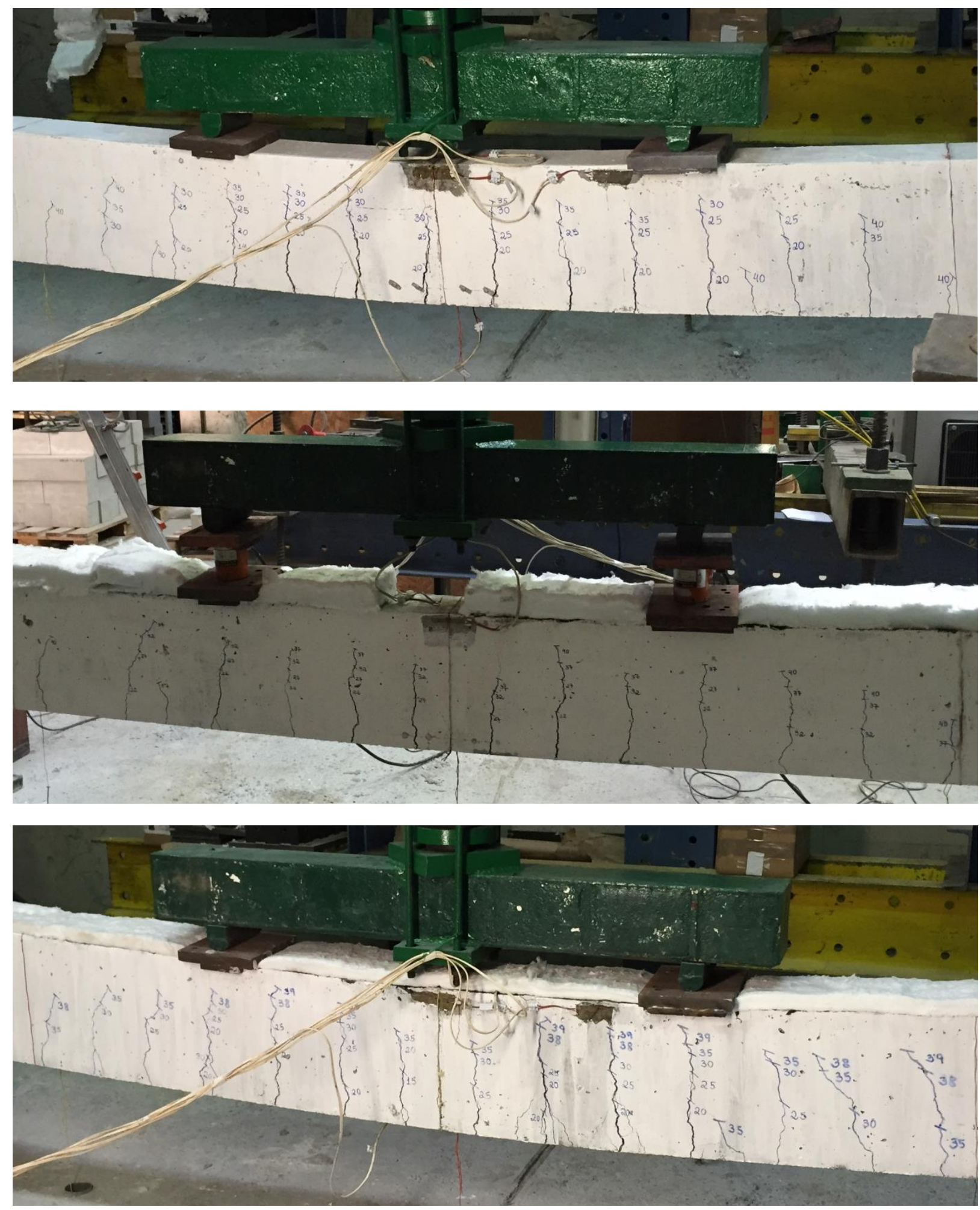

Figura 3.47 - Campos de fissuras registrados pouco antes da finalização dos ensaios de vigas simplesmente apoiadas à temperatura ambiente A_ka0_kr0_1, A_ka0_kr0_2 e A_ka0_kr0_3, respectivamente. 

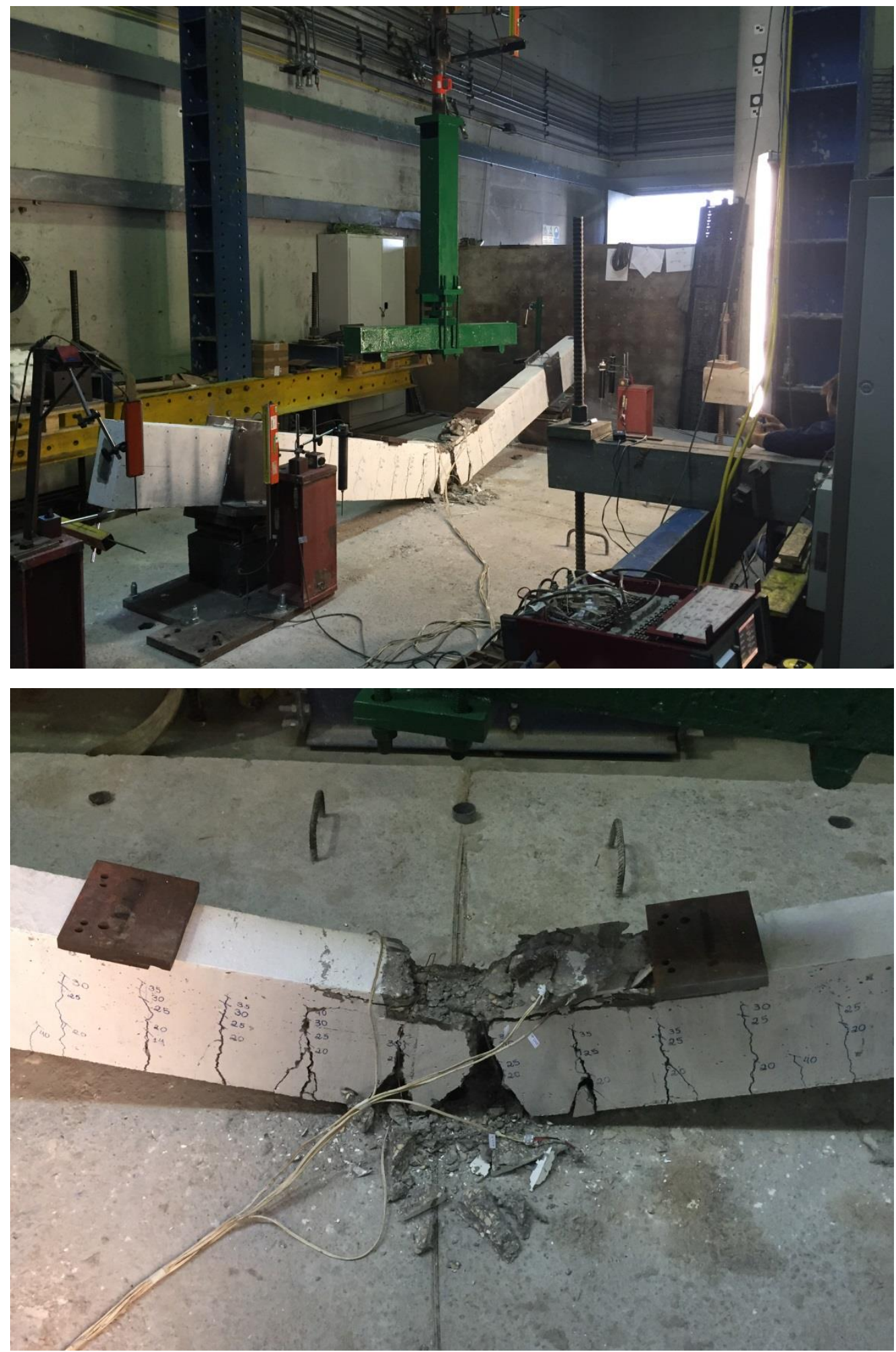

Figura 3.48 - Aspecto final da viga de concreto armado do ensaio A_ka0_kr0_1, com modo de ruptura à flexão. 

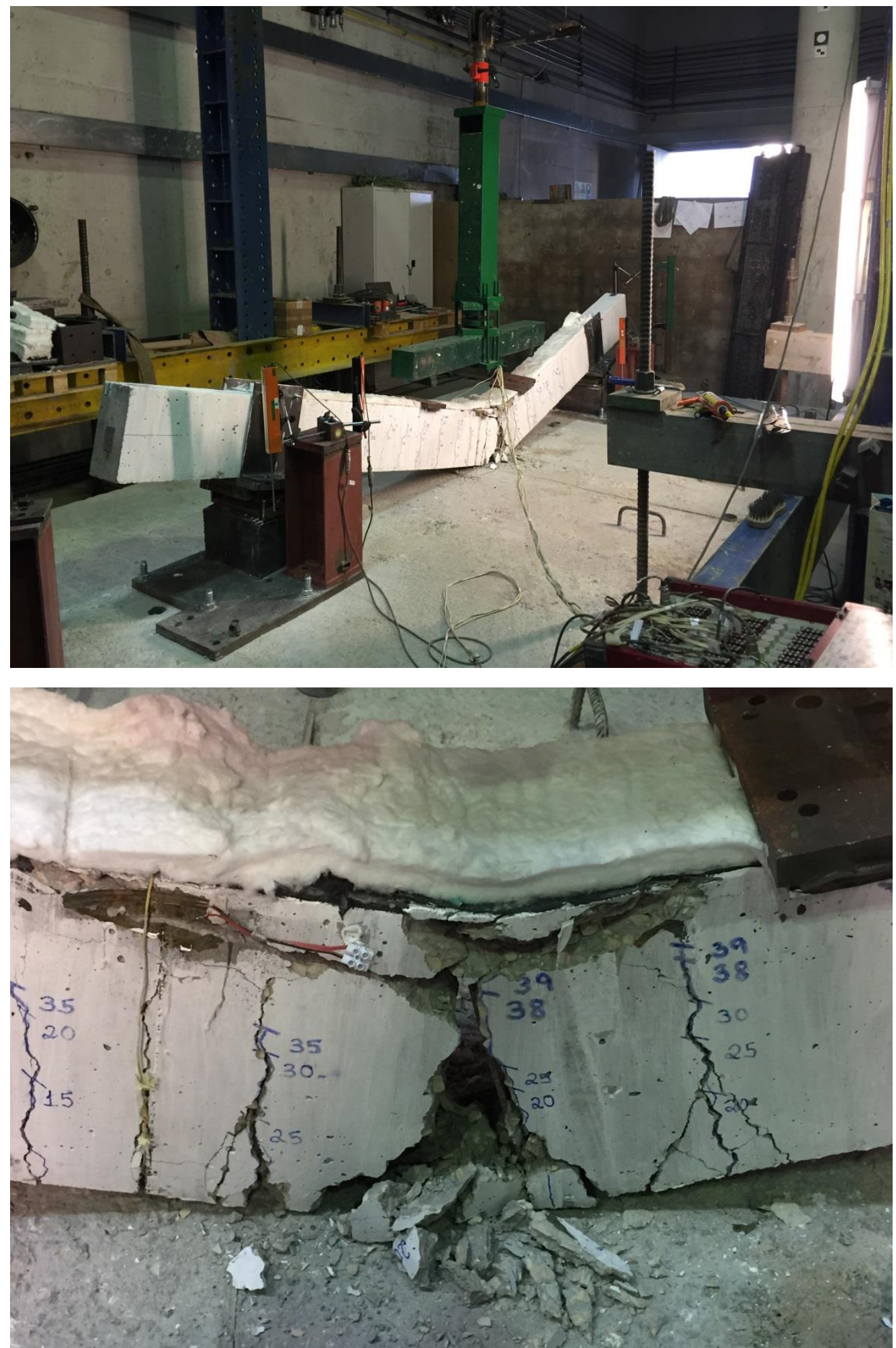

Figura 3.49 - Aspecto final da viga de concreto armado do ensaio A_ka0_kr0_3, com modo de ruptura à flexão. 


\subsubsection{Vigas em situação de incêndio}

\subsubsection{Distribuições de temperaturas}

A Figura 3.50 mostra as evoluções das temperaturas no forno dos ensaios realizados em vigas simplesmente apoiadas (gráficos a e b), com restrições axiais (c) e com restrições axiais e rotacionais (d). Para cada ensaio, a curva representativa do aquecimento foi obtida pela média das temperaturas resultantes dos termopares tipo sonda que foram posicionados ao longo do forno. As temperaturas apresentaram apenas um pequeno atraso nos primeiros minutos, quando comparadas àquelas preconizadas pela curva ISO 834 (1999), pois realmente costuma ser muito difícil reproduzir essa parte da curva com um forno elétrico. Porém, por volta dos 30 min da maior parte dos ensaios, as temperaturas do forno apresentaram uma boa correlação às temperaturas do incêndio-padrão. Ao se analisar a nuvem de pontos traçada no gráfico da Figura 3.50-e, vê-se que após 10 min de aquecimento, as curvas da maioria dos ensaios se mostram semelhantes entre si, com diferenças máximas entre elas da ordem de $100{ }^{\circ} \mathrm{C}$.

A partir desses gráficos, ainda é possível verificar que as curvas provenientes dos ensaios T_ka0_kr0_2 e ka2_kr1_2 foram as únicas que acabaram por se distanciar um pouco das curvas dos demais ensaios e também, em determinados intervalos de tempo, da curva pretendida. Essas exceções podem ser justificadas pelo fato de algumas resistências elétricas do forno terem sido danificadas ao longo desses ensaios, provavelmente porque o forno estava sendo muito solicitado durante os testes de longa duração dessa campanha experimental. Entretanto, de modo geral, pode-se afirmar que as curvas de aquecimento dos ensaios conseguiram seguir o regime pretendido e, além disso, que elas foram similares umas às outras, o que torna os resultados desses ensaios comparáveis. 

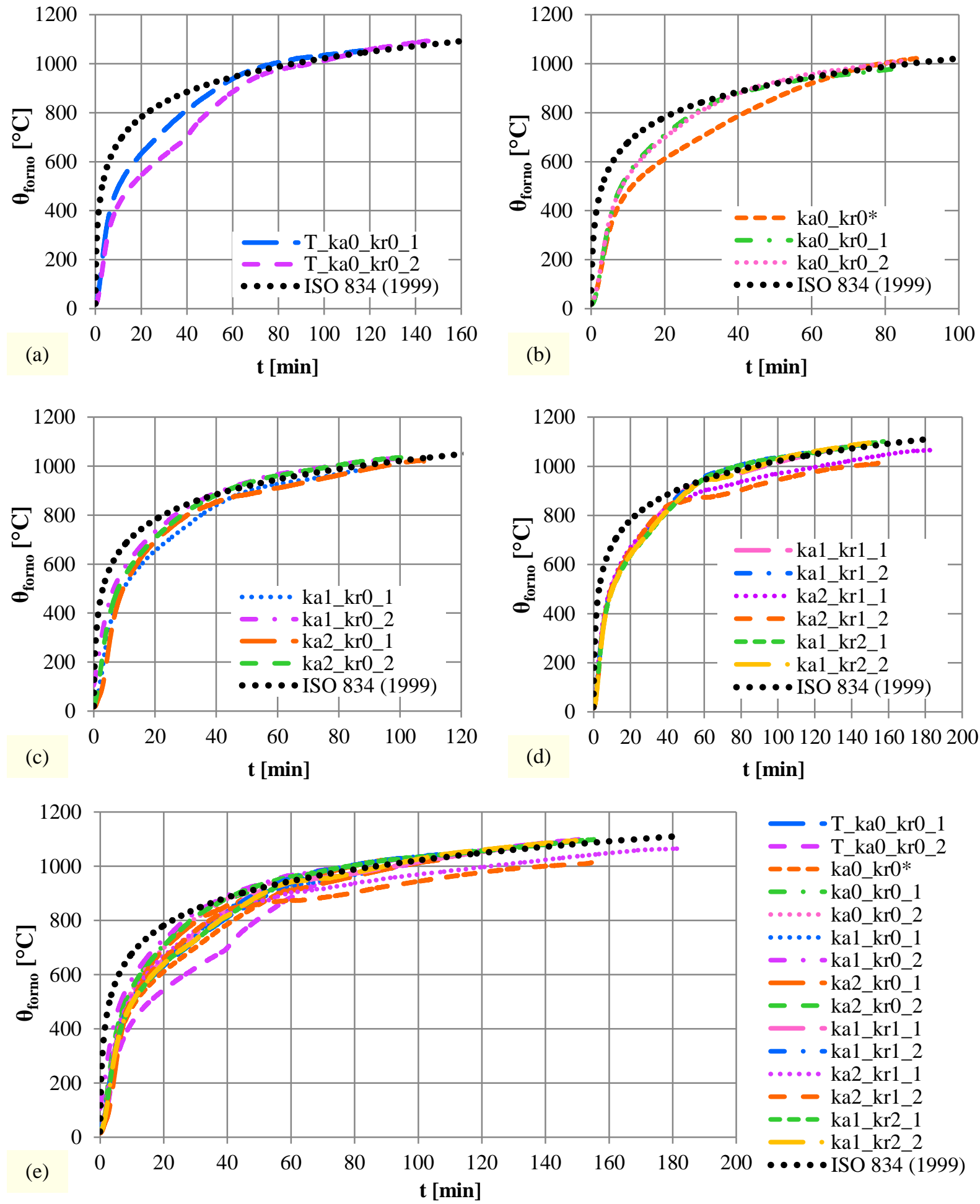

Figura 3.50 - Evolução das temperaturas internas do forno nos ensaios experimentais de (a e b) vigas simplesmente apoiadas, (c) com restrição axial e (d) com restrições axial e rotacional. Em (e) estão reunidas as curvas dos gráficos (a) a (d). 
Ao comparar as temperaturas das vigas aquecidas para um determinado ponto em relação às diferentes seções de um mesmo ensaio (exemplos na Figura 3.51), verificou-se, pela similaridade da maior parte dos resultados, a ocorrência de gradientes térmicos constantes ao longo dos vãos dos elementos estruturais. Ressalta-se que esses gradientes se mantiveram constantes ao longo de toda a duração dos ensaios e não apenas nos estágios iniciais. Ainda a partir dessa figura, observa-se que as temperaturas aferidas nos pontos das seções $S_{1}$ a $S_{3}$ foram parecidas para todos os esquemas estáticos estudados, i.e., vigas simplesmente apoiadas (gráfico a), com restrição apenas axial (b e c) e com restrições axial e rotacional (d). Logo, ao analisar esses ensaios de forma isolada, constatou-se que os gradientes térmicos das seções dispostas ao longo do vão são similares, independente do esquema estático da viga.
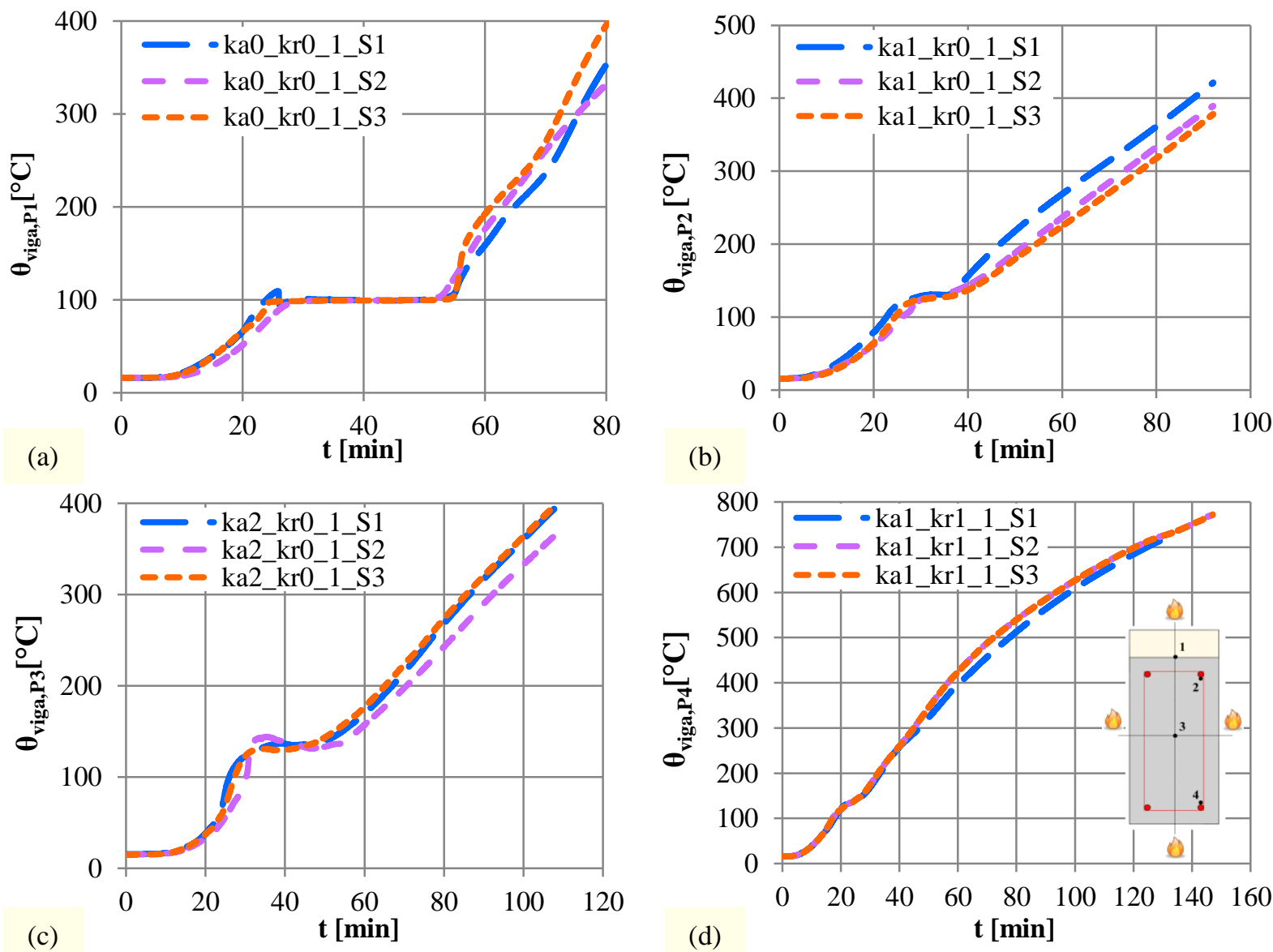

Figura 3.51 - Exemplos de comparação das evoluções de temperaturas das vigas para a primeira situação de estudo: apenas um ensaio, seções diferentes, pontos iguais. Em (a) vigas simplesmente apoiadas e temperaturas na interface concreto/manta $\left(\mathrm{P}_{1}\right)$, (b) e (c) com restrição axial, armadura superior e núcleo do concreto, $\mathrm{P}_{2}$ e $\mathrm{P}_{3}$, respectivamente e $(\mathrm{d})$ com restrições axial e rotacional, armadura inferior $\left(\mathrm{P}_{4}\right)$. 
Ao confrontar as temperaturas para um determinado ponto em relação a dois ensaios com esquemas estáticos iguais, vide Figura 3.52, as tendências das curvas foram novamente similares. Quanto aos valores das temperaturas, houve alguns casos em que as curvas se mostraram mais distantes, no entanto, não foram consideradas diferenças significativas porque para a maior parte das situações não superaram $100{ }^{\circ} \mathrm{C}$. Assim, ainda se tornou possível afirmar que os ensaios com esquemas estáticos iguais apresentaram resultados similares em termos de campos térmicos. Pelos gráficos (a) a (d) da referida figura, vê-se que essa questão foi verificada para os diferentes tipos de esquemas estáticos estudados.
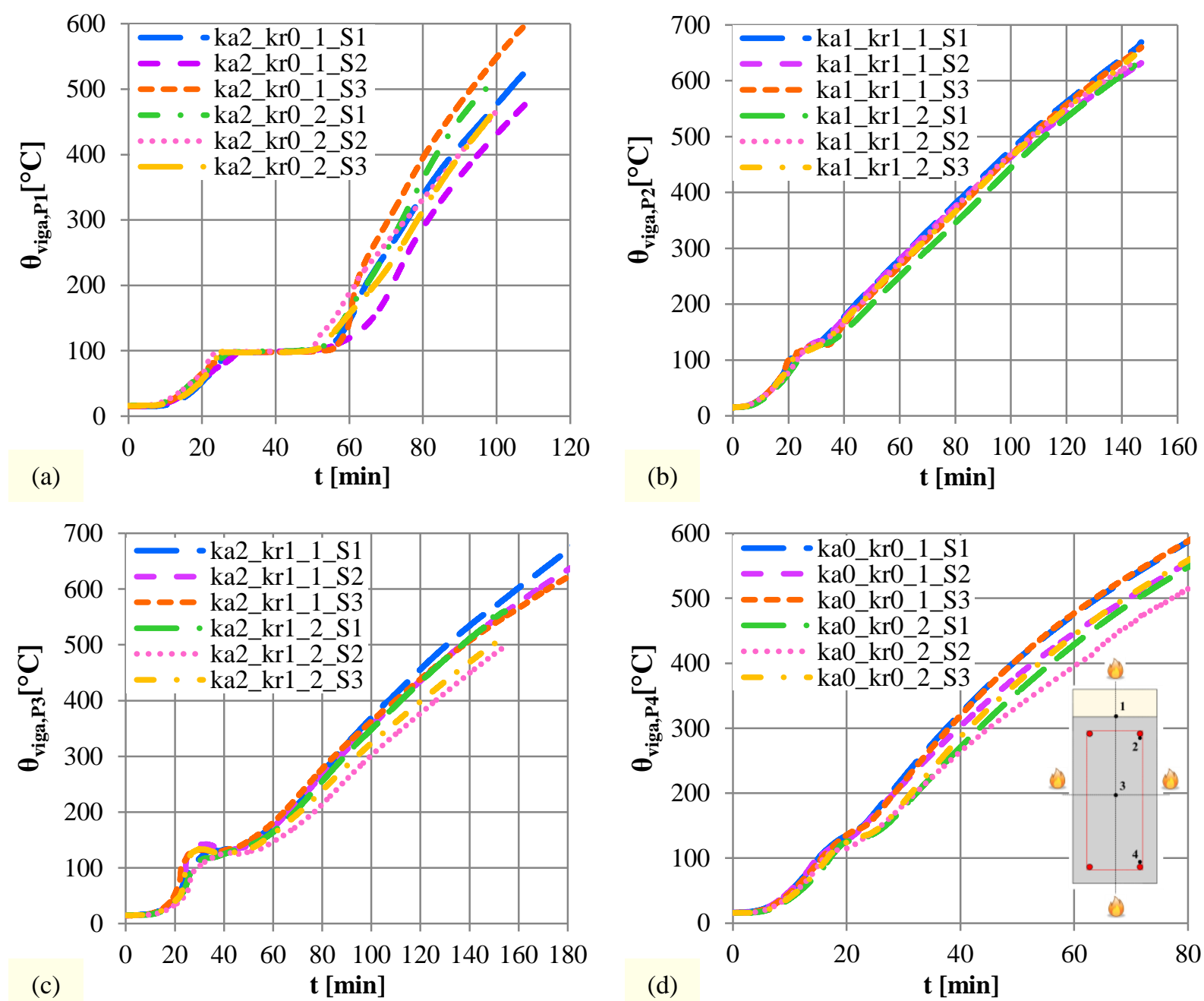

Figura 3.52 - Exemplos de comparação das evoluções de temperaturas das vigas para a segunda situação de estudo: dois ensaios com esquemas estáticos iguais, todas as seções, pontos iguais. Em (a) vigas com restrição axial e temperaturas na interface concreto/manta $\left(\mathrm{P}_{1}\right)$, (b) e (c) com restrições axial e rotacional, armadura superior e núcleo do concreto, $\mathrm{P}_{2}$ e $\mathrm{P}_{3}$, respectivamente, e (d) simplesmente apoiadas, armadura inferior $\left(\mathrm{P}_{4}\right)$. 
Visto a similaridade entre as temperaturas das diferentes seções transversais, que puderam ser constatadas pelas Figuras 3.51 e 3.52, foram escolhidas as temperaturas resultantes da seção a meio vão da viga ensaiada $\left(S_{2}\right)$ como base para a próxima situação de estudo. Ao comparar as temperaturas para um determinado ponto em relação a três ensaios com esquemas estáticos diferentes - viga simplesmente apoiada, com restrição apenas axial ou com restrições axial e rotacional - encontraram-se resultados que se mostraram próximos em termos de tendência (evolução) das curvas e também em termos de valores, com diferenças médias mais uma vez não superiores a $100{ }^{\circ} \mathrm{C}$. Na Figura 3.53 são apresentados alguns exemplos.
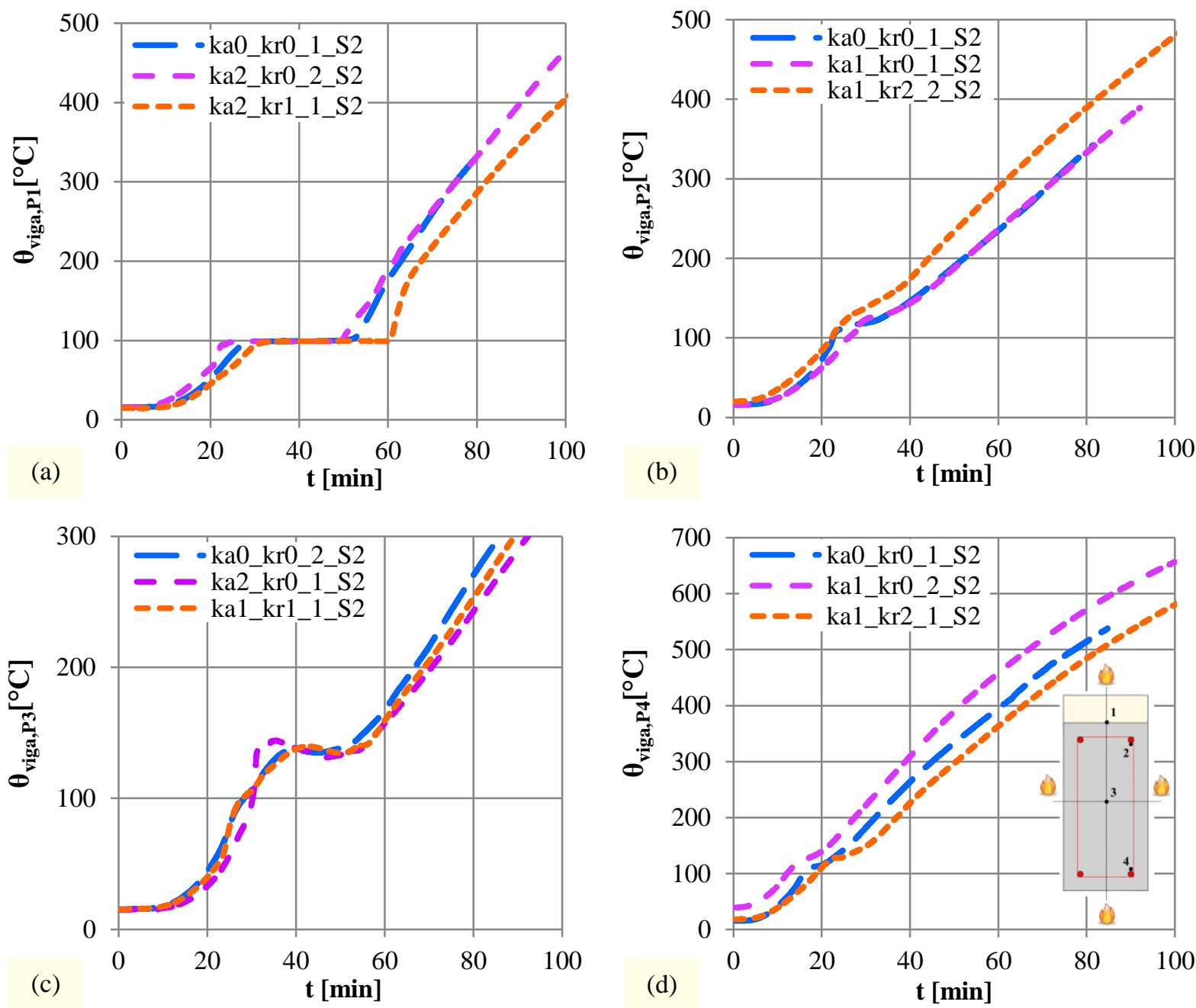

Figura 3.53 - Exemplos de comparação das evoluções de temperaturas das vigas para a terceira situação de estudo: três ensaios com esquemas estáticos diferentes, seções iguais, pontos iguais. Em (a) temperaturas na interface concreto/manta $\left(\mathrm{P}_{1}\right),(\mathrm{b})$ armadura superior $\left(\mathrm{P}_{2}\right),(\mathrm{c})$ núcleo do concreto $\left(\mathrm{P}_{3}\right)$ e $(\mathrm{d})$ armadura inferior $\left(\mathrm{P}_{4}\right)$. 
As diferenças de temperaturas mais significativas que foram verificadas em algumas das situações de estudo citadas anteriormente podem ser atribuídas a diferenças entre as homogeneidades de cada concreto, entre o estado de fissuração ou deformação das vigas, além da migração de vapor (fenômeno que ocorre com o aumento da temperatura). Um termopar localizado próximo de uma fissura, por exemplo, pode ter aquecido mais do que o termopar longe de uma fissura.

Porém, é válido pontuar mais uma vez que tais diferenças não se mostraram relevantes quando colocadas em questão as diversas curvas de temperaturas obtidas nos ensaios. Portanto, para as condições de apoio, carregamento e contorno considerados nos ensaios desta campanha experimental, concluiu-se que os gradientes térmicos atuantes tanto nas seções transversais das vigas quanto ao longo dos vãos independem do esquema estático desses elementos estruturais.

A questão dos campos de temperaturas terem sido similares em diferentes seções transversais dispostas ao longo do vão justifica a hipótese adotada por alguns pesquisadores em análises numéricas de vigas de concreto submetidas a condições de aquecimento uniformes, em que determinam o campo térmico apenas em relação a uma seção transversal (modelagem 2D) e depois admitem que todas as outras seções distribuídas pelo comprimento da peça possuem um campo igual a esse (modelagem 3D).

Já o fato das temperaturas serem independentes do esquema estático corrobora a outra hipótese usualmente adotada nessas análises, a da realização de análises térmicas antes das mecânicas (vários exemplos dessas pesquisas são citados no capítulo sobre o estado da arte).

Ainda por intermédio das Figuras 3.51 a 3.53 (gráfico "a" em todas elas), vê-se que as curvas representativas do ponto 1 - interface concreto/manta - apresentaram um atraso no crescimento das temperaturas, usualmente com duração de 40 min. Esse fenômeno ocorreu por conta movimentação da água presente no concreto, que uma vez aquecida nos ensaios de exposição a altas temperaturas acabava por se deslocar para a região superior da viga. Então, a 
água ficava retida na interface concreto/manta até que atingisse $100{ }^{\circ} \mathrm{C}$ e se evaporasse completamente.

As curvas representativas do ponto 3 - núcleo do concreto (centro geométrico), gráfico "c" nas Figuras 3.51 a 3.53 - também apresentaram atrasos na evolução das temperaturas. Porém, esses trechos indicaram picos de temperaturas superiores a $100{ }^{\circ} \mathrm{C}$ e se mantiveram atuantes por intervalos de tempo menores. Tal fenômeno se justifica pela evaporação da água que estava presente nessa região e os picos de temperaturas chegaram a alcançar valores superiores a $100{ }^{\circ} \mathrm{C}$ porque no interior do concreto as pressões podem ser superiores a $1 \mathrm{~atm}$ (BAZANT; THONGUTHAI, 1979).

Portanto, esse fenômeno também estava ligado à evaporação da água, porém, nada teve a ver com a presença da manta na face superior da viga ensaiada, foi mesmo uma questão inerente ao concreto. Isso foi comprovado ao se verificar a sua ocorrência em análises experimentais realizadas por outros pesquisadores, tal como Choi e Shin (2011), que aferiram temperaturas em pontos do concreto localizados no interior da seção de uma viga sem material isolante na face superior (Figura 3.54). Também houve comprovação a partir dos resultados da presente Tese, que mostraram novamente a ocorrência do fenômeno no ensaio realizado sem a aplicação da manta (Figura 3.55). Por fim, a Figura 3.56 confirma que a manta desempenhou as funções de isolamento previstas com base nas análises térmicas apresentadas no Apêndice D, já que as temperaturas da armadura superior foram efetivamente mais brandas.
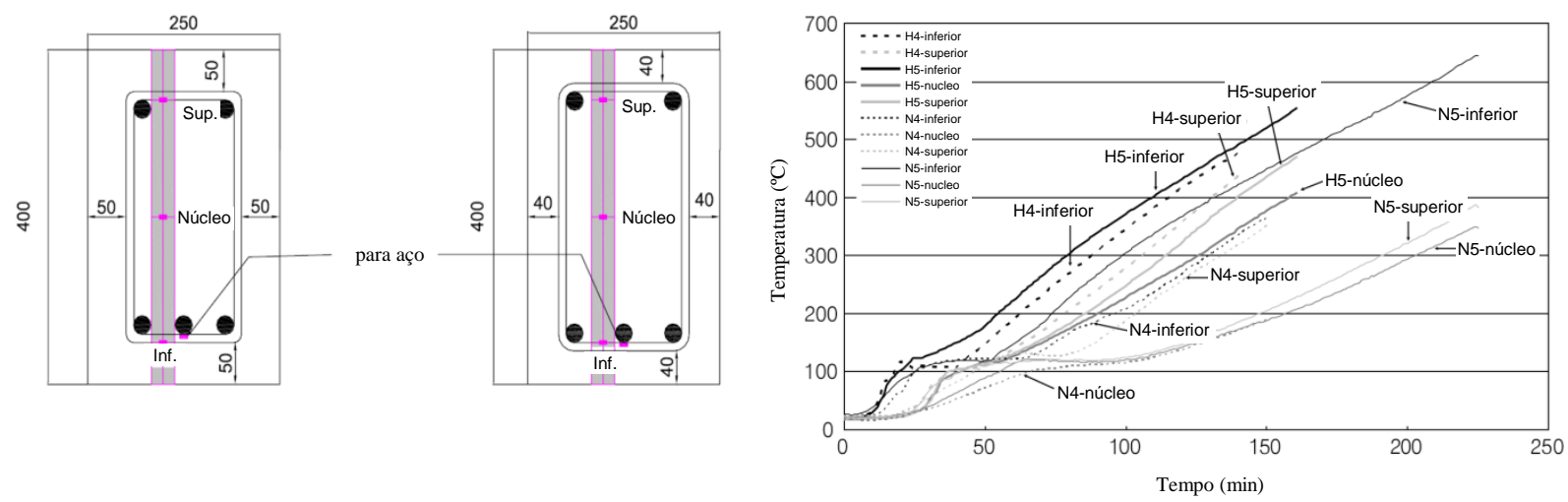

Figura 3.54 - Evoluções de temperaturas em pontos localizados nas regiões superior, do núcleo e inferior do concreto de vigas submetidas a ensaios de exposição ao fogo por Choi e Shin (2011; adaptado). 


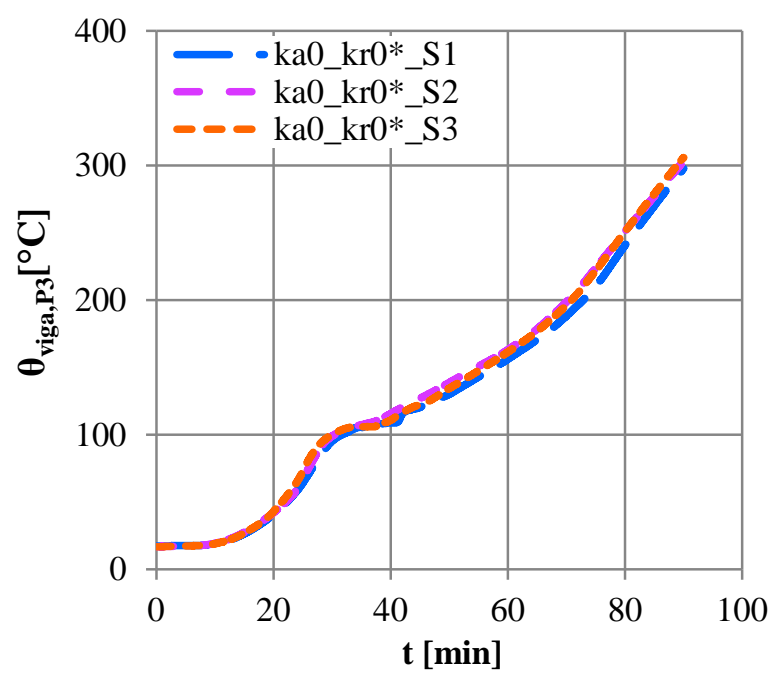

Figura 3.55 - Evoluções das temperaturas no núcleo do concreto de viga simplesmente apoiada submetida a ensaio sem a presença da manta na face superior.

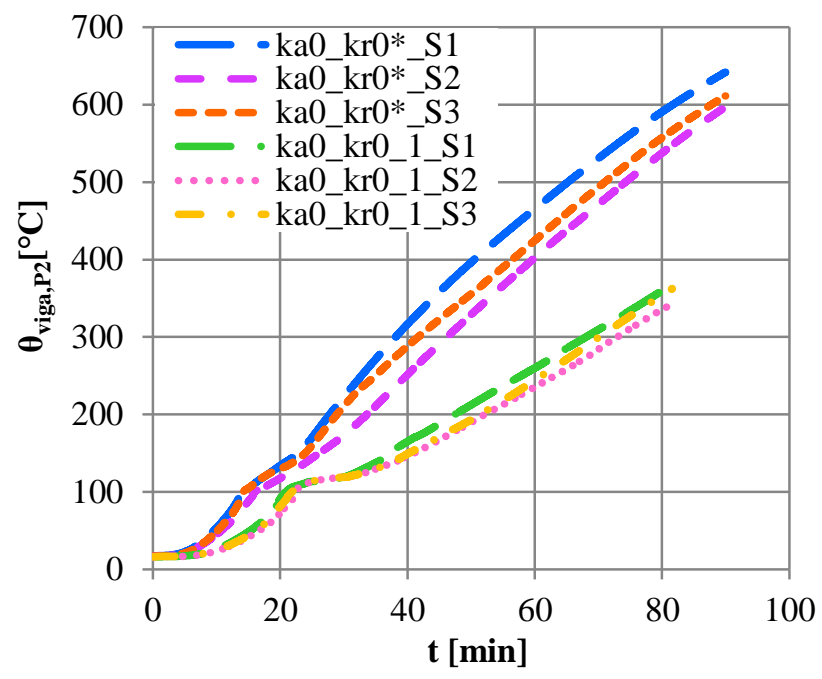

Figura 3.56 - Evoluções de temperaturas da armadura superior de vigas simplesmente apoiadas submetidas a ensaios com ou sem aplicação de manta na face superior.

\subsubsection{Forças de restrição}

Os gráficos das Figuras 3.57 e 3.58 ilustram a evolução das forças de restrição axiais em função do tempo para as vigas ensaiadas ao fogo sob diferentes condições de apoio (apenas com restrição axial ou com ambas, axial e rotacional). Os trechos finais de algumas curvas, em linhas tracejadas, consistem em linhas de tendência que foram traçadas por meio de uma função polinomial de $5^{\mathrm{a}}$ ordem para delimitar o instante em que a força de restrição axial retornava ao valor zero. Portanto, os trechos anteriores a esses, em linhas cheias, representam os valores das forças que puderam ser efetivamente medidos ao longo dos ensaios ${ }^{23}$. Isso precisou ser feito porque alguns testes tiveram que ser finalizados antes que as forças de restrição voltassem ao seu valor inicial, pois a longa duração dos mesmos estava conduzindo a um superaquecimento dos equipamentos de instrumentação, cujas temperaturas eram sempre monitorizadas.

\footnotetext{
${ }^{23}$ Dentre os pesquisadores que conduziram análises experimentais de vigas de concreto armado restringidas ao fogo, apenas Dwaikat e Kodur (2008) impuseram restrição do tipo axial (um nível foi estudado). No entanto, eles também não conseguiram checar experimentalmente o trecho de decaimento das curvas (gráfico apresentado na Figura 2.52 do capítulo anterior).
} 
Os pares de ensaios efetuados para cada uma das condições de apoio e níveis de restrições estudados (vide Tabela 3.7) apresentaram resultados com tendências similares na maior parte dos casos. Contudo, para realizar uma comparação mais coerente entre todos eles, reuniram-se na Figura 3.57 os resultados daqueles que apresentaram, dentre cada um dos pares de ensaios, forças de restrição axiais mais elevadas e durações de ensaio mais prolongadas (maiores resistências ao fogo pelo critério em termos de capacidade resistente). Na Figura 3.58, estão os ensaios com duração mais curta e valores de forças axiais menores.

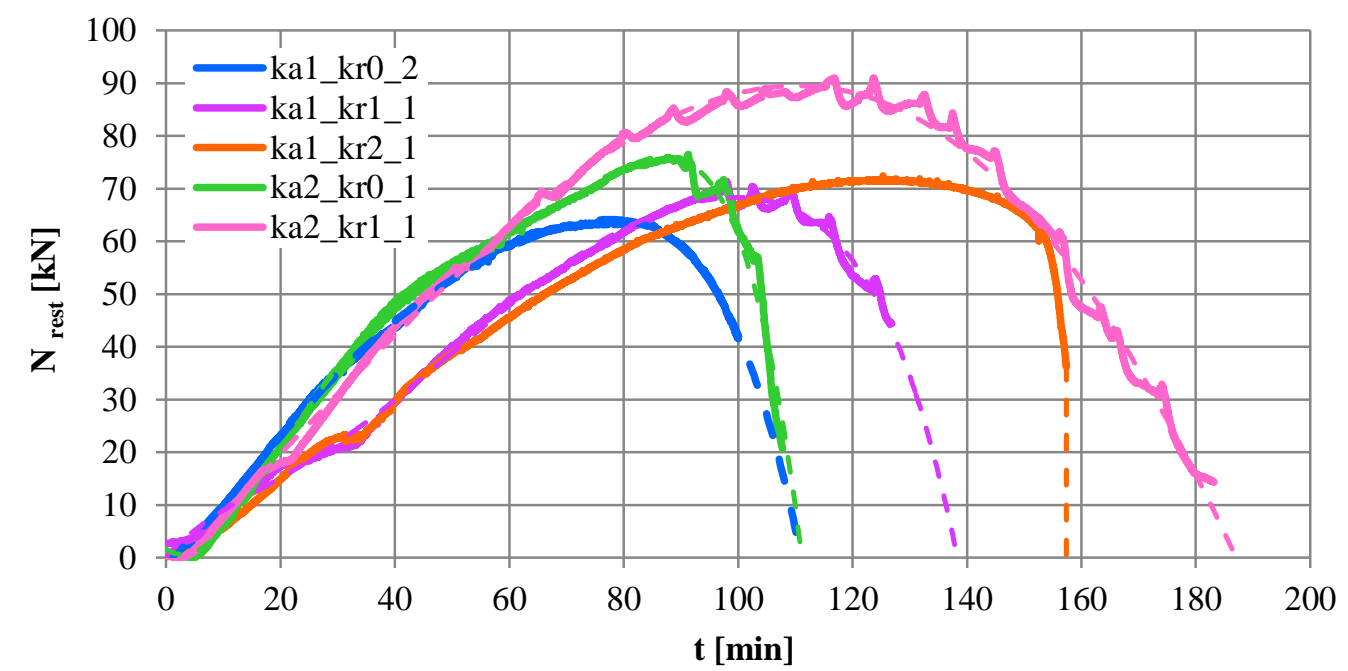

Figura 3.57 - Comparação das evoluções de forças de restrição axiais em função do tempo entre os ensaios que apresentaram forças axiais máximas e resistências ao fogo maiores.

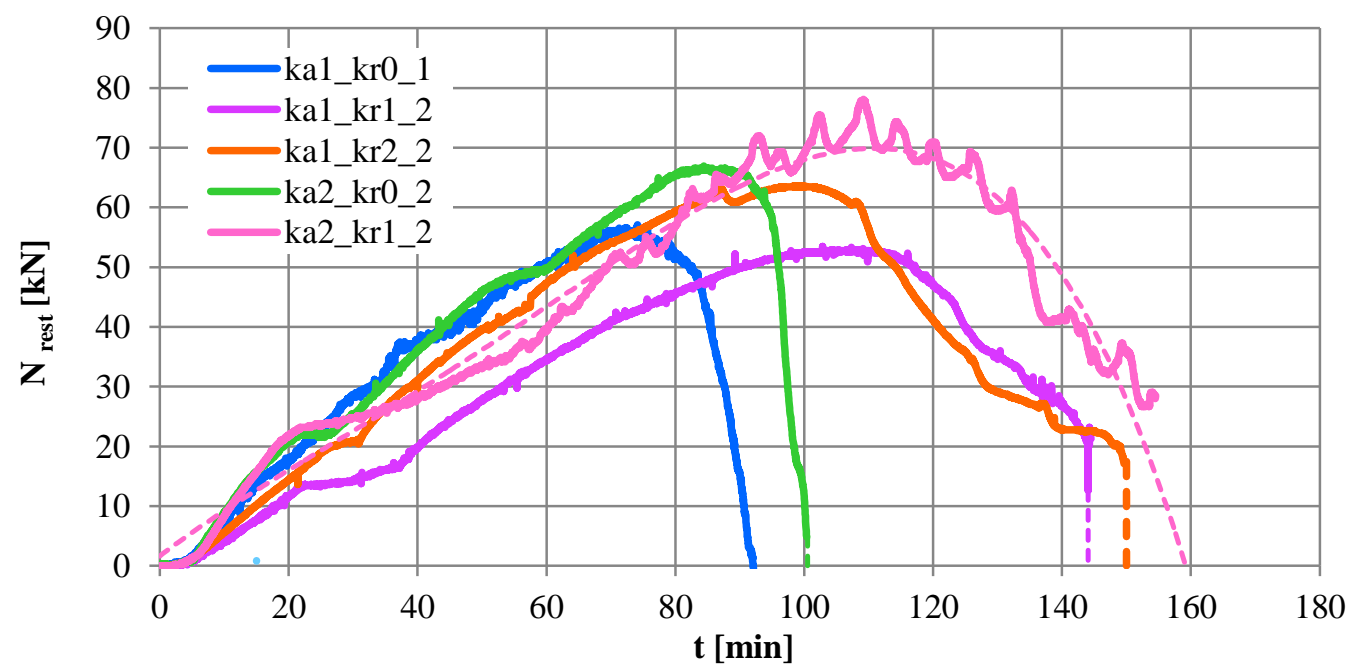

Figura 3.58 - Comparação das evoluções de forças de restrição axiais em função do tempo entre os ensaios que apresentaram forças axiais máximas e resistências ao fogo menores. 
Como previsto, os ensaios com nível de restrição axial mais baixo e sem restrição rotacional, ka1_kr0_1 e ka1_kr0_2, apresentaram valores menores de força axial máxima quando comparados aos ensaios com nível de restrição axial mais alto, mas também sem rotacional, ka2_kr0_1 e ka2_kr0_2. Portanto, quanto maior a rigidez da estrutura circundante, maior o nível de restrição imposto ao alongamento térmico da viga de concreto armado e, por conseguinte, maior a força de restrição axial gerada pela viga como reação ao impedimento da sua deformação. Essa tendência resultante dos ensaios experimentais também foi verificada anteriormente por Dwaikat e Kodur (2008), Bernhart (2004) e Wu e Lu (2009), contudo, apenas com base em estudos numéricos. No capítulo anterior foram apresentados os gráficos de forças axiais traçados por alguns deles (Figuras 2.48 e 2.59).

Além disso, verificou-se que para um mesmo nível de restrição axial, a introdução ou o aumento da restrição rotacional conduz a um aumento tanto da força de restrição axial máxima obtida quanto da resistência ao fogo da viga. Essa questão pode ser observada pela comparação dos seguintes conjuntos de curvas: ka1_kr0_2, ka1_kr1_1 e ka1_kr2_1; ka2_kr0_1 e ka2_kr1_1 (Figura 3.57); ka1_kr0_1 e ka1_kr2_2; ka2_kr0_2 e ka2_kr1_2 (Figura 3.58). É sabido que a consideração da restrição rotacional faz crescer o tempo de resistência ao fogo desses elementos. Lin; Gustaferro e Abrams (1981), Lin; Ellingwood e Piet (1988) e Guo e Shi (2011) constataram esse fato inclusive experimentalmente, ao submeter vigas contínuas a testes de exposição ao fogo.

Porém, em relação à força axial máxima atingida ser maior quando da introdução da restrição rotacional, é importante esclarecer o seguinte: ao introduzir a restrição rotacional, a viga passa a ser capaz de resistir ao fogo durante um período mais longo e, por conseguinte, essa viga acaba por gerar, também em um período mais avançado, uma força axial máxima maior. Portanto, entende-se que uma força maior é atingida porque a viga consegue ir mais em frente na resposta às temperaturas elevadas e não porque as restrições à rotação fazem surgir uma força de restrição adicional.

Isso pode ser mais bem entendido ao serem confrontadas as forças máximas obtidas em um determinado instante para as curvas que compõem um dos conjuntos de ensaios citados 
anteriormente. Por exemplo, pela Figura 3.57, a viga do ensaio ka1_kr0_2 atingiu força axial máxima de $63 \mathrm{kN}$ em $77 \mathrm{~min}$ de ensaio. Nesse instante, as forças axiais resultantes dos ensaios ka1_kr1_1 e ka1_kr2_1 eram muito próximas a tal valor, sendo iguais a 60 e 57 kN, respectivamente. A força máxima do ensaio ka1_kr1_1, igual a $67 \mathrm{kN}$, somente foi atingida mais tarde, aos 97 min de exposição ao fogo. Enquanto isso, a força máxima do ensaio ka1_kr2_1, igual a $71 \mathrm{kN}$, chegou a ser atingida apenas aos $120 \mathrm{~min}$.

Esse comportamento foi igualmente identificado por Wu e Lu (2009), porém, novamente com fundamentação apenas em modelos numéricos. Ao fixar um valor de restrição axial para determinada viga, os autores estudaram seis níveis diferentes de restrições rotacionais. No gráfico resultante de forças axiais em função do tempo traçado por eles, apresentado na Figura 2.70, as forças axiais maiores provenientes das vigas com restrições rotacionais mais elevadas também foram geradas apenas em estágios mais avançados de exposição ao fogo.

A curva do ensaio ka1_kr1_2, presente na Figura 3.58, não foi citada nas comparações dos ensaios com mesmo nível de restrição axial e restrições rotacionais diferentes porque foi a única que não seguiu de forma completa essa tendência verificada nas outras curvas. Isso porque apesar de ter conduzido a uma resistência ao fogo maior, da mesma forma que ocorreu com as outras quando introduzida a restrição rotacional, o valor máximo da força de restrição axial foi até menor do que aquele obtido no ensaio ainda sem esse tipo de restrição (ka1_kr0_1).

A viga do ensaio ka1_kr1_2 foi a única a apresentar modo de colapso por cisalhamento, com a ruptura de dois estribos posicionados próximos ao apoio simples. Por conta dessas rupturas, a peça deve ter perdido rigidez durante o ensaio e então acabou por não apresentar forças reativas condizentes ao nível de restrição axial a que foi submetida, fugindo à regra indicada pelas demais. $\mathrm{O}$ apoio simples, onde os estribos romperam, estava localizado justamente na extremidade em que as forças de restrição eram aferidas pela célula de carga.

Segundo Smith et al. (2011), existe uma conscientização crescente por parte dos projetistas de que as rupturas por esforços cortantes, geradas em função de expansões térmicas restringidas, 
por exemplo, podem governar o colapso de elementos estruturais de concreto aquecidos. Entretanto, dentre as 10 vigas restringidas ensaiadas nesta campanha experimental, apenas uma rompeu por características de cisalhamento. Logo, essa é uma questão que ainda deve ser mais bem estudada.

Além disso, constatou-se que para um mesmo nível de restrição rotacional, a força de restrição axial máxima e a resistência ao fogo aumentam à medida que se aumenta a restrição axial, vide comparação dos ensaios ka1_kr1_1 e ka2_kr1_1 (Figura 3.57) e ka1_kr1_2 e ka2_kr1_2 (Figura 3.58). A justificativa para essa questão está novamente no fato de que a imposição de uma rigidez mais elevada ao alongamento da viga gera forças de restrição axiais maiores e resistências ao fogo mais elevadas, ou seja, segue a regra verificada para vigas com imposição de restrições apenas axiais. A diferença é que o efeito conjunto das restrições, axial e rotacional, faz aumentar ainda mais a resistência ao fogo desses elementos. Mais uma vez, os resultados dos ensaios foram coerentes àqueles previstos por meio de modelos numéricos, tais como os concebidos por Dwaikat e Kodur (2008), Bernhart (2004), Riva e Franssen (2008) e Cvetkovska; Todorov e Lazarov (2013), que analisaram as forças axiais resultantes de vigas totalmente restringidas às rotações e com níveis parciais de restrição axial (Figuras $2.49,2.61,2.63$ e 2.67$)$.

Quanto ao desenvolvimento das curvas de forças de restrição axiais em função do tempo, pode-se observar que em todos os casos as forças começaram a surgir poucos minutos após o início da exposição ao fogo. Como dito anteriormente, elas eram resultantes da ação térmica que atuava sobre a viga de concreto armado e induzia a sua expansão. Ao passo que o alongamento do vão estava impedido por uma estrutura circundante mais rígida, surgiram forças reativas à compressão da viga ensaiada. Essas forças cresceram continuamente até terem atingido um valor de pico e, em seguida, passaram para a fase de decaimento.

Xavier (2009) esclarece que a taxa de crescimento da força de restrição axial é função da taxa de aquecimento imposta ao elemento estrutural [que no caso desses ensaios simulava a curva de incêndio-padrão ISO 834 (1999)] e que as forças passam a diminuir mesmo se as vigas estiverem submetidas a um regime de aquecimento com temperaturas sempre crescentes 
porque esse fenômeno está relacionado à degeneração das propriedades mecânicas dos seus materiais constituintes, que conduzem à redução da rigidez do elemento estrutural e, assim, da sua capacidade de resistir aos esforços pelos quais está sendo solicitado.

$\mathrm{O}$ autor comentou essa questão com base em forças de restrição axiais resultantes em vigas presentes em modelos numéricos de pórticos de concreto armado. Um dos gráficos apresentados por ele foi indicado na Figura 2.78 desta Tese. Haja vista a similaridade da evolução das forças traçadas por Xavier (2009) às obtidas experimentalmente nesta pesquisa, comprovou-se que foi possível simular nos ensaios a condição pretendida, que consistia em analisar o comportamento de vigas na condição de elementos constituintes de uma estrutura circundante similar às encontradas na realidade.

Também vale lembrar que os elementos que impõem as restrições axiais e comprimem a viga de concreto deixam de apresentar um efeito benéfico em estágios mais avançados da exposição ao fogo, quando a viga já apresenta flechas muito excessivas e linhas neutras das seções transversais localizadas abaixo do centro geométrico ${ }^{24}$. Nesse estágio, os momentos solicitantes gerados pela atuação das restrições axiais passam a atuar no mesmo sentido da flexão resultante da ação térmica e dos carregamentos impostos, ou seja, não mais produzem contra-flechas (mais informações sobre esse assunto no Capítulo 1 - Introdução).

Na Figura 3.59 são indicados gráficos nos quais as forças de restrição provenientes de um ensaio apenas com restrição axial (ka2_kr0_1) e outro com restrições axial e rotacional (ka1_kr2_1) foram traçadas em função das temperaturas obtidas na armadura superior, no núcleo do concreto e na armadura inferior. Eles foram adotados para a análise da degradação dos materiais expostos ao fogo na fase em que se inicia o decaimento das forças. Logo, foram traçados à luz da explicação fornecida por Xavier (2009).

\footnotetext{
${ }^{24}$ A linha neutra de qualquer seção ao longo da viga possui a tendência de se mover para baixo por conta do aumento das forças de restrição axiais com o tempo. A atuação dessas forças passa a requerer uma área maior da zona de concreto sob compressão, aumentando assim a altura do bloco comprido (DWAIKAT; KODUR, 2008).
} 

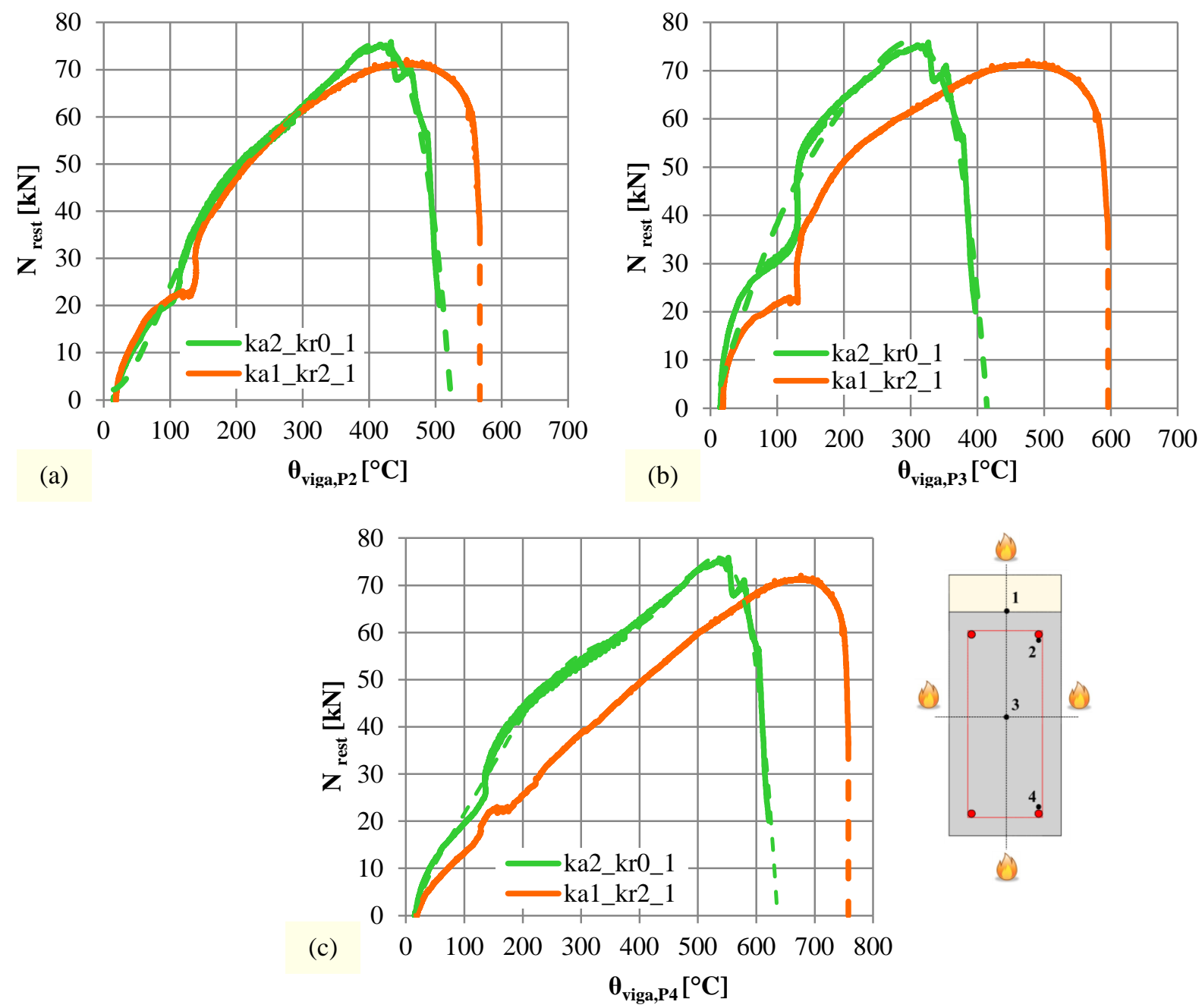

Figura 3.59 - Evoluções das forças de restrição axiais em função das temperaturas (a) na armadura longitudinal superior, (b) no núcleo do concreto e (c) na armadura inferior.

No que diz respeito ao ensaio ka2_kr0_1, no instante em que as forças de restrição passaram a decrescer, a temperatura da armadura inferior se encontrava a pouco mais de $550{ }^{\circ} \mathrm{C}$, sendo que o intervalo entre 500 e $550{ }^{\circ} \mathrm{C}$ é usualmente admitido como aquele no qual a temperatura crítica do aço é atingida. De acordo com o Eurocode 2 parte 1-2 (2004), a resistência à tração e o módulo de elasticidade das armaduras já teriam sido reduzidos a $60 \%$ dos valores à temperatura ambiente nesse estágio. $\mathrm{O}$ concreto, a aproximadamente $350^{\circ} \mathrm{C}$, também devia se encontrar bastante degradado, sobretudo em relação ao módulo de elasticidade (pela norma europeia, teria apenas $30 \%$ do seu valor inicial). Contudo, uma vez que é usual admitir que a ruptura de vigas de concreto armado seja dúctil, por excesso de deformação aço aquecido 
(RIGBERTH, 2000; COSTA, 2008), a temperatura crítica da armadura inferior parece ter governado o início do decaimento da força de restrição axial nesse caso. As armaduras superiores, em contrapartida, ainda não tinham atingido essa temperatura, mas no caso do modelo estático em questão, elas realmente não apresentariam contribuição à capacidade resistente da peça frente à ação do fogo.

Em contrapartida, a introdução da restrição rotacional no ensaio ka1_kr2_1 fez com que a viga ensaiada passasse a se comportar como uma viga hiperestática (contínua), sendo beneficiado pela redistribuição dos momentos fletores solicitantes. Logo, o decaimento da força de restrição axial não ocorreu logo no instante em que a armadura inferior atingiu a temperatura crítica, pois no início da queda essa já havia atingido os $700{ }^{\circ} \mathrm{C}$. Ao redistribuir os momentos positivos para os negativos, a viga apresentou o decaimento de sua capacidade resistente apenas quando as armaduras negativas também já tinham atingido a temperatura crítica. Além disso, a $500{ }^{\circ} \mathrm{C}$, sendo essa a temperatura do núcleo do concreto no início do decaimento das forças de restrição, restava a esse material apenas cerca de $10 \%$ do seu módulo de elasticidade (mais informações sobre os coeficientes de redução das propriedades dos materiais aquecidos são apresentadas no capítulo 4 desta Tese).

Ao fim desta seção são apresentados, na Figura 3.60, os gráficos com as evoluções das rigidezes axiais e rotacionais medidas ao longo de alguns ensaios, como exemplo. As oscilações existentes nos trechos iniciais de determinadas curvas ocorreram de forma aleatória, em alguns ensaios, e são justificadas por folgas que podem eventualmente existir na configuração inicial dos sistemas. Isso porque no começo dos ensaios algumas peças ainda podem se encontrar sob ajustes, acomodando-se aos demais elementos do sistema aos poucos. No entanto, vê-se que após esses trechos que se mostraram curtos, usualmente em torno de 20 min, as rigidezes apresentaram ao longo das análises experimentais valores médios muito próximos àqueles pretendidos: $7 \mathrm{kN} / \mathrm{mm}$ (ka1); $14 \mathrm{kN} / \mathrm{mm}(\mathrm{ka} 2) ; 2500 \mathrm{kNm} / \mathrm{rad}(\mathrm{kr} 1)$ e 5000 $\mathrm{kNm} / \mathrm{rad}(\mathrm{kr} 2)$. As curvas das rigidezes axiais foram traçadas com base nos resultados das forças de restrição medidas pela célula de carga com $500 \mathrm{kN}$ de capacidade $\left(\mathrm{n}^{\circ} 34\right.$ nas Figuras 3.19 e 3.20, por exemplo) e nos deslocamentos horizontais aferidos pelo transdutor de cabo 
indicado pelo $\mathrm{n}^{\circ} 39$ na Figura 3.21. Enquanto isso, as rigidezes rotacionais foram determinadas com base nas forças de restrição medidas pelas células de carga de $100 \mathrm{kN}$ de capacidade $\left(\mathrm{n}^{\circ} 46\right)$ e nos deslocamentos verticais aferidos pelo transdutor tipo êmbolo $\left(\mathrm{n}^{\circ} 47\right)$, ambos indicados na Figura 3.24.
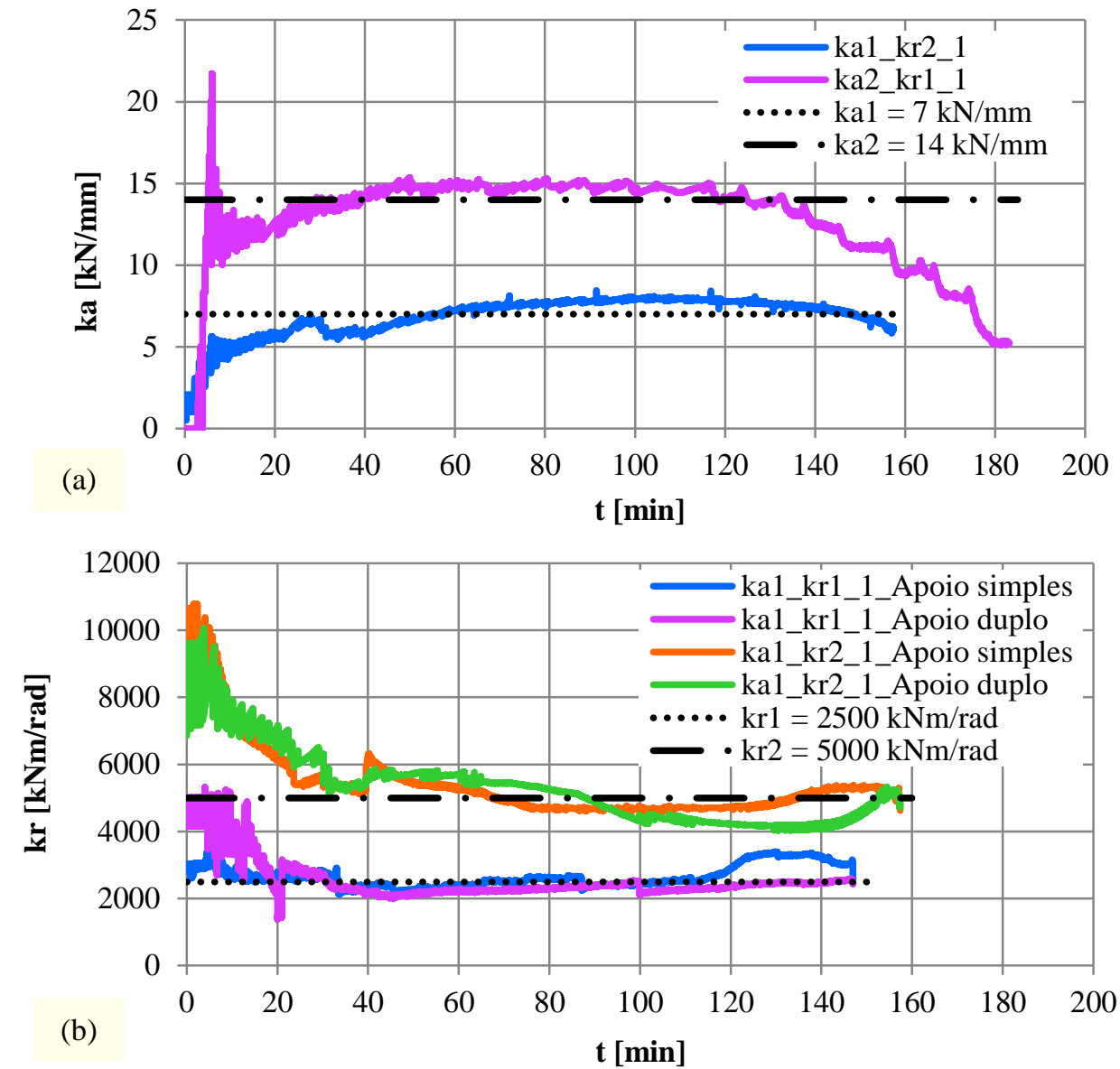

Figura 3.60 - Evolução das rigidezes (a) axiais e (b) rotacionais em função do tempo para determinados ensaios.

\subsubsection{Deslocamentos verticais}

Os gráficos das Figuras 3.61 e 3.62 apresentam as evoluções, em função do tempo, dos deslocamentos verticais a meio vão das vigas ensaiadas ao fogo na condição de simplesmente 
apoiadas ou com restrições (ou axial ou axial/rotacional). As curvas foram reunidas em cada gráfico com base no mesmo critério estabelecido para a comparação das forças de restrição axiais, i.e., na Figura 3.61 estão as representativas dos ensaios que tiveram crescimentos de deslocamentos verticais mais brandos e durações de ensaio mais prolongadas (maiores resistências ao fogo pelo critério de deslocamentos) e na Figura 3.62 as provenientes dos ensaios em que os deslocamentos verticais aumentaram de forma mais rápida e, por isso, foram mais curtos. Ao comparar a organização das curvas das Figuras 3.57, 3.58, 3.61 e 3.62, já se percebe que as vigas com maiores resistências ao fogo definidas com base no critério de capacidade resistente também tiveram maiores resistências em termos de deslocamentos.

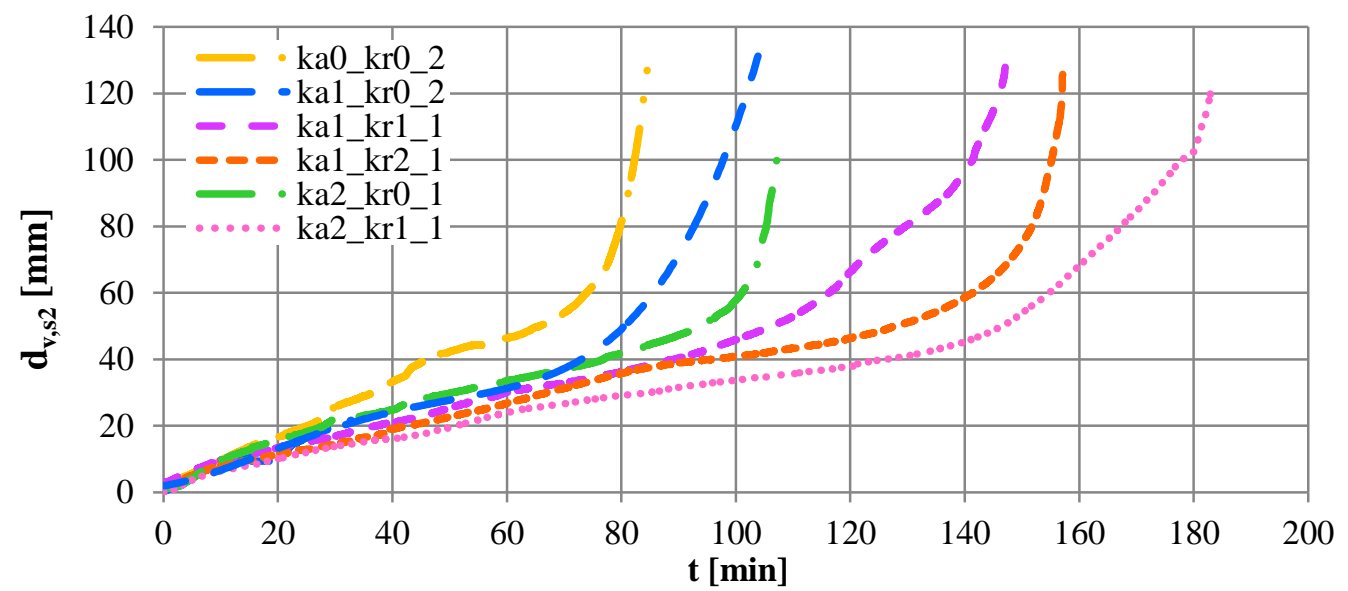

Figura 3.61 - Comparação das evoluções das flechas em função do tempo entre os ensaios que apresentaram crescimentos mais brandos desses deslocamentos e resistências ao fogo maiores.

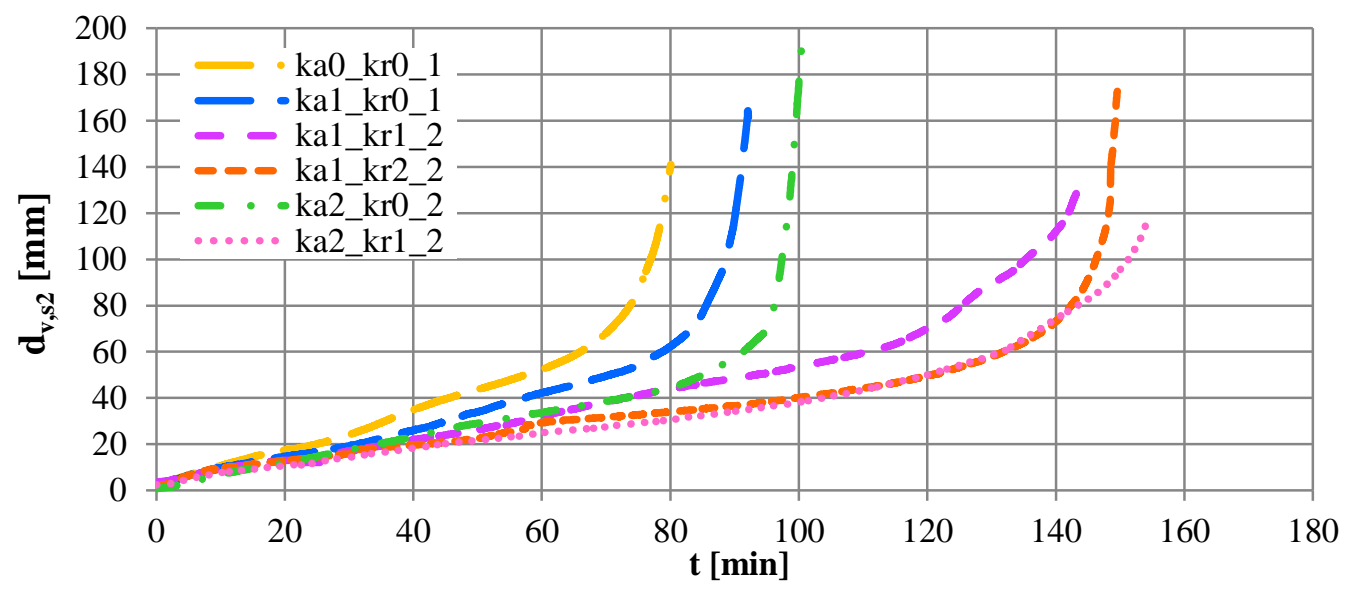

Figura 3.62 - Comparação das evoluções das flechas em função do tempo entre os ensaios que apresentaram crescimentos mais rápidos desses deslocamentos e resistências ao fogo menores. 
As vigas simplesmente apoiadas, ka0_kr0_1 e ka0_kr0_2, atingiram deslocamentos verticais maiores em tempos menores quando comparadas às demais vigas com restrições. Isso se deve ao fato das vigas simplesmente apoiadas não terem sido contempladas nem pelas contraflechas resultantes das forças de restrição axiais, que conseguem adiar o estágio em que as deformações se tornam excessivas, e nem mesmo pela redistribuição de momentos, resultante das restrições rotacionais, que alivia a solicitação da armadura positiva diretamente aquecida ao redistribuir os momentos positivos para os negativos dos apoios.

Esse resultado faz esclarecer que a introdução dos impedimentos às deformações de origem térmica (axiais e rotacionais) gera um aumento na resistência ao fogo das vigas de concreto armado. Tal resultado foi condizente às conclusões gerais obtidas por outros pesquisadores que realizaram ensaios experimentais em vigas de concreto submetidas a alguma modalidade de restrição quando em situação de incêndio (LIN; GUSTAFERRO; ABRAMS, 1981; LIN; ELLINGWOOD; PIET, 1988; GUO; SHI, 2011 e DWAIKAT; KODUR, 2008).

Portanto, além da resistência ao fogo, pode-se observar que a introdução de qualquer tipo de restrição também gera um aumento na rigidez da viga de concreto. Para alcançar uma flecha de $60 \mathrm{~mm}$, por exemplo, a viga simplesmente apoiada ka0_kr0_1 leva aproximadamente 62 minutos. Ao ser introduzido o nível mais baixo de restrição axial (k1_kr0_1), esse tempo já chega a aumentar quase 30\%. Para uma viga com restrições axial e rotacional (ka2_kr1_2), chega a ser $110 \%$ maior do que aquele verificado para a viga sem restrições.

Ao serem confrontados os resultados dos ensaios em que foram admitidas apenas restrições axiais, constatou-se que as vigas submetidas a um menor nível de restrição axial (ka1_kr0_1 e ka1_kr0_2) apresentaram maiores flechas em tempos mais curtos. Como esclarecido anteriormente, as vigas circundadas por estruturas menos rígidas são comprimidas em menor intensidade, ou seja, as forças de restrição axiais atuantes são mais brandas. Por esse motivo, o efeito benéfico das contra-flechas (efeito arco), que possuem como uma de suas varáveis a intensidade das forças de restrição, acabou por ser menos expressivo nesses ensaios. Essa tendência também foi verificada numericamente por Dwaikat e Kodur (2008) e Bernhart (2004), nos gráficos de flechas em função do tempo apresentados nas Figuras 2.48 e 2.60. 
Em contrapartida, ao serem comparados os comportamentos de vigas submetidas a um mesmo nível de restrição axial, mas diferentes restrições rotacionais, foi possível observar que as vigas com menores níveis de restrição rotacional (ka1_kr1_1 e ka1_kr1_2) se deformaram por flexão mais rapidamente. Quanto a essa questão, é válido citar mais uma vez que ao terem sido impostas restrições rotacionais ao sistema de ensaios, o esquema estático das vigas passou a ser representativo de peças contínuas. Nesse tipo de estrutura, a deformação por flexão porque passam as vigas aquecidas são parcialmente impedidas pelos apoios, que desenvolvem momentos negativos, contrários ao encurvamento para baixo. A atuação desses momentos solicitantes negativos faz reduzir os momentos positivos a meio vão, o que é favorável ao comportamento das vigas porque a armadura positiva tem sua resistência mais prejudicada pela ação do fogo quando comparada à negativa, que por se encontrar na parte superior da viga, está mais distante da ação direta da fonte de calor. Portanto, a redução dos momentos positivos a meio vão reduz a intensidade da taxa de crescimento das flechas.

No caso desses ensaios postos em questão, a imposição de restrições rotacionais menores nos apoios resultou em momentos negativos menores. Logo, a redistribuição de momentos foi mais branda, a região a meio vão foi mais solicitada e as flechas maiores ocorreram em tempos menores. Conforme esclarecido na seção anterior, Wu e Lu (2009) também estudaram essas situações, contudo, a partir de modelos numéricos. Os resultados das flechas obtidas por eles seguiu essa proposição vinda dos ensaios.

Em relação às vigas com níveis de restrição rotacional iguais, mas axiais diferentes, aquelas com menores restrições axiais (ka1_kr1_1 e ka1_kr1_2) apresentaram maiores flechas em tempos menores. Isso ocorreu como o esperado, pois no efeito conjunto das duas restrições, a contribuição da axial, nesses ensaios, foi menor. Esse resultado se assemelhou aos obtidos numericamente por Dwaikat e Kodur (2008), Bernhart (2004) e Riva e Franssen (2008), indicados nas Figuras 2.49, 2.61 e 2.63.

$\mathrm{O}$ efeito conjunto das restrições axiais e rotacionais se mostrou benéfico ao desempenho das vigas expostas ao fogo, pois ao comparar as flechas provenientes dos ensaios com restrição apenas axial àqueles com a imposição de ambas, vê-se que as flechas em que a rotacional não 
foi admitida apresentou valores maiores em tempos menores de exposição ao fogo. Tal fato foi verificado ao serem confrontadas, por exemplo, as flechas dos seguintes conjuntos de ensaios: ka1_kr0_2, ka1_kr1_1 e ka1_kr2_1; ka2_kr0_1 e ka2_kr1_1. Isso conduz à confirmação de que seria relevante haver uma conscientização dos projetistas sobre a necessidade de considerar esses efeitos gerados pelas restrições em projeto. Na prática, as vigas expostas ao fogo costumam experimentar restrições tanto axiais quanto rotacionais, de modo que o dimensionamento sem o efeito benéfico dessas pode levar a resultados muito conservadores.

Por fim, pode-se verificar que em todos os ensaios os deslocamentos verticais a meio vão das vigas cresceram de forma lenta até o instante em que atingiram pontos nos quais esses deslocamentos passaram a crescer abruptamente. Liao e Huang (2015) apresentaram um gráfico, ilustrado na Figura 3.63, para explicar cada um desses diferentes estágios porque passa a evolução das flechas de uma viga de concreto armado antes do seu colapso ser atingido. Os autores tomaram como base uma viga simplesmente apoiada (indicada na Figura 2.34 do capítulo anterior), bem como a curva vermelha da Figura 3.63 (aderência perfeita).

No estágio 1, as flechas se desenvolvem de forma lenta e são resultantes, sobretudo, da deformação à flexão gerada pelo efeito da ação térmica. Nesse estágio, a degradação das propriedades mecânicas dos materiais devido à exposição a altas temperaturas, no que se refere resistência e módulo de elasticidade, não costumam ser significativas. Durante o estágio 2, as flechas apresentam um segmento mais plano, que decorre do fato das armaduras longitudinais tracionadas permanecerem com temperaturas quase constantes por um determinado período. Esse atraso na evolução das temperaturas do aço é função do efeito da evaporação da água livre presente no interior do concreto.

No estágio 3, as temperaturas das armaduras e também as flechas voltam a crescer continuamente até a ocorrência do primeiro ponto inflexão da curva, para o qual as flechas passam a aumentar de forma mais acentuada. Nesse estágio, a taxa de aumento desses deslocamentos verticais já é resultante da alta degradação porque passam as resistências dos materiais expostos ao fogo e o referido ponto de inflexão ocorre pelo escoamento da armadura 
tracionada, que nesse instante já ultrapassa os $500^{\circ} \mathrm{C}$. Tal fenômeno marca o início do estágio 4, em que as flechas crescem de forma mais abrupta até a ocorrência da ruptura das armaduras localizadas a meio vão.

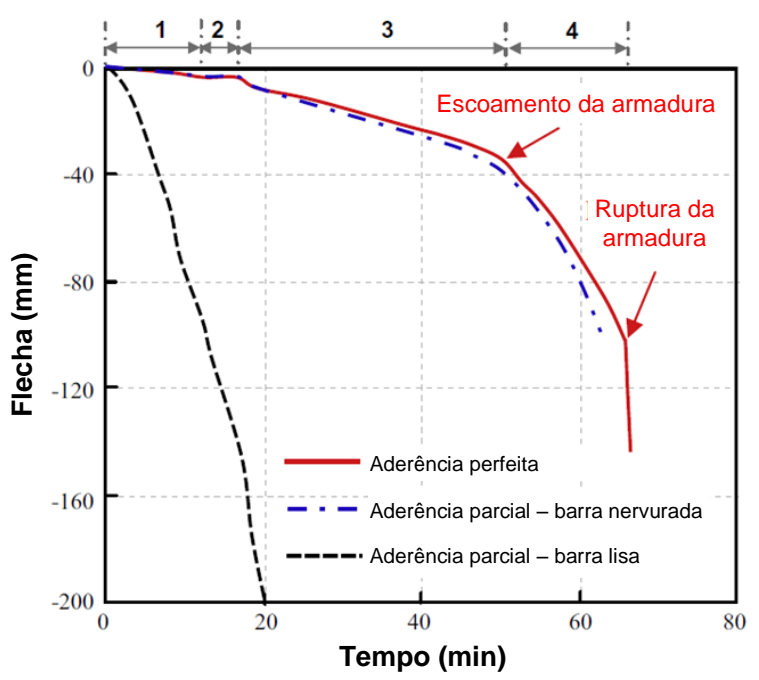

Figura 3.63 - Delimitação dos estágios de evolução das flechas de vigas de concreto armado expostas ao fogo (LIAO; HUANG, 2015; adaptado).

Na Figura 3.64 são apresentados gráficos em que as flechas provenientes de um ensaio de viga simplesmente apoiada (ka0_kr0_2), apenas com restrição axial (ka2_kr0_1) e outro com restrições axial e rotacional (ka1_kr2_1) foram traçadas em função das temperaturas obtidas na armadura superior, no núcleo do concreto e na armadura inferior. De forma semelhante ao que foi esclarecido por Liao e Huang (2015), o primeiro ponto de inflexão da curva representativa de viga simplesmente apoiada ocorreu quando a temperatura na armadura longitudinal inferior atingiu a temperatura de $500{ }^{\circ} \mathrm{C}$ e a viga então entrou no estágio 4 , de eminente colapso.

Buchanan e Abu (2017) complementaram essa questão ao afirmar que nas vigas simplesmente apoiadas a resistência ao fogo é realmente governada pela temperatura na armadura inferior, pois a região comprimida da seção é pouco afetada pelas altas temperaturas, mas que nas vigas restringidas axialmente os efeitos das forças de compressão podem compensar a perda de resistência do aço da armadura longitudinal inferior. Isso também pode ser verificado nos 
gráficos, em que as flechas das vigas com restrição axial só começaram a crescer de forma mais significativa um pouco mais a frente, quando as temperaturas da armadura inferior já estavam a quase $600{ }^{\circ} \mathrm{C}$.
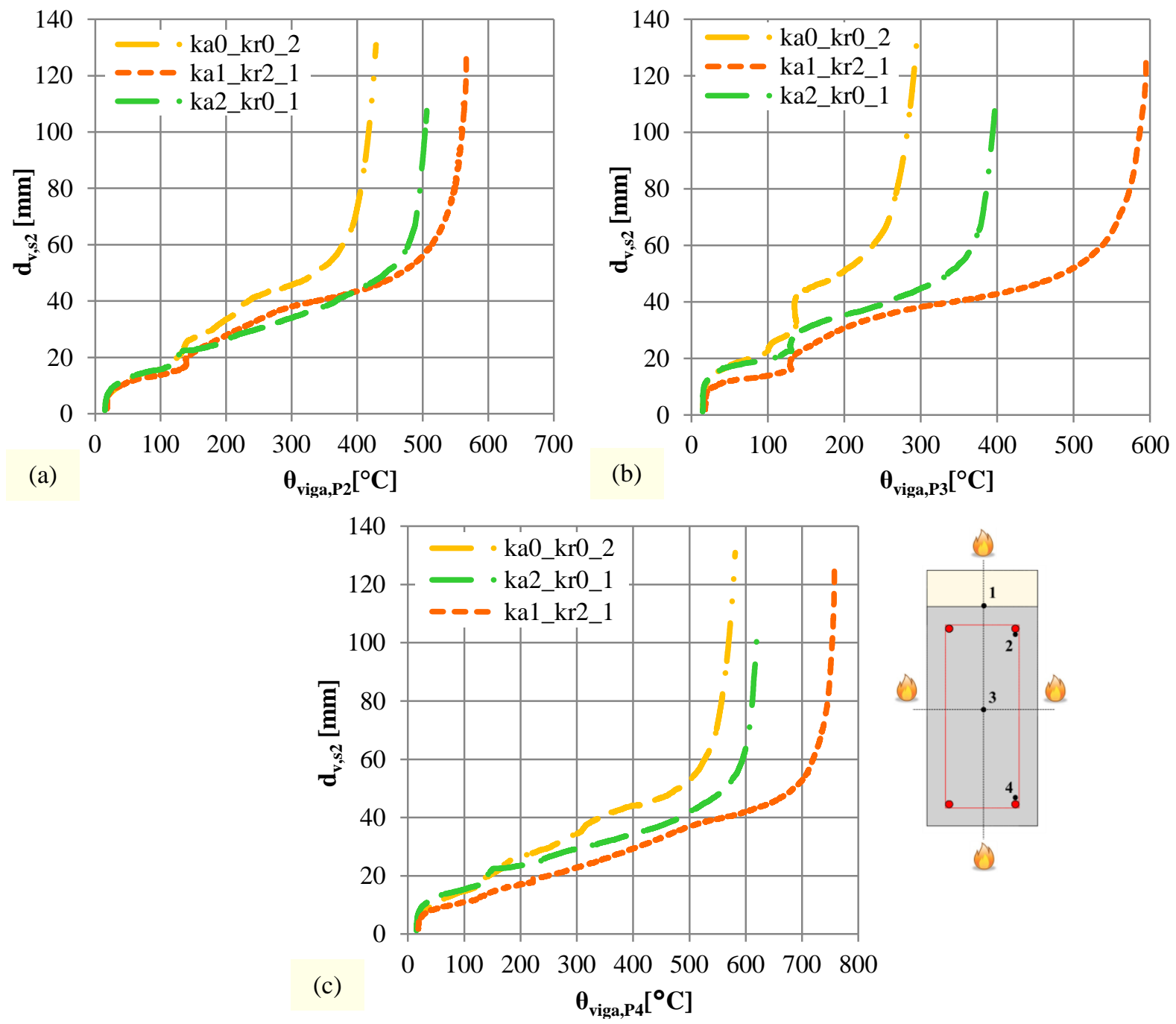

Figura 3.64 - Evoluções de flechas em função das temperaturas (a) na armadura longitudinal superior, (b) no núcleo do concreto e (c) na armadura inferior.

Quanto às vigas com restrições do tipo axial e rotacional, é possível observar pela curva das flechas em função da temperatura da armadura inferior que o primeiro ponto de inflexão ocorreu quando essa já chegava aos $700{ }^{\circ} \mathrm{C}$. No caso desse modelo estático, a compensação à perda de resistência da armadura positiva foi proveniente das armaduras negativas dos apoios, 
que se encontravam menos aquecidas e resistiam aos momentos adicionais impostos pela redistribuição. Já nas flechas traçadas em função das temperaturas na armadura inferior, o ponto de inflexão ocorre aos $500{ }^{\circ} \mathrm{C}$.

No Apêndice E são apresentados com mais detalhes os dados experimentais de temperaturas, deslocamentos verticais e eventualmente forças axiais obtidos ao longo de cada ensaio.

\subsubsection{Modos de ruptura}

Nesta seção serão discutidos os aspectos e as características pós-ensaios das vigas de concreto armado. Igualmente ao que foi estabelecido para o termo "critérios de ruptura", ao longo da seção sobre procedimentos de ensaios, aqui os "modos de ruptura" também não indicam, necessariamente, uma ruptura real da viga, mas sim o seu estado depois de terem sido atingidos os critérios adotados para finalização dos ensaios.

A configuração deformada (pós-ensaio) característica das vigas simplesmente apoiadas (ka0_kr0_1 e ka0_kr0_2) está ilustrada na Figura 3.65. Nesses ensaios, não se verificou a ruptura de barras das armaduras, contudo, foi possível observar a aparência "craquelada" das superfícies de concreto (Figura 3.66). Algumas fissuras de flexão também puderam ser vistas em tais peças após a realização desses ensaios (Figura 3.67). O mesmo se verificou após o ensaios de viga simplesmente apoiada sem manta ( $\mathrm{ka} 0 \_\mathrm{kr} 0 *$ ).

Nos ensaios com restrição axial e sem rotacional (ka1_kr0_1, ka1_kr0_2, ka2_kr0_1 e ka2_kr0_2) também não houve ruptura das armaduras. A Figura 3.68 ilustra a configuração deformada de uma dessas vigas. Em relação ao concreto, verificou-se apenas no ensaio ka1_kr0_2 o destacamento de dois pedaços do material à meia altura da seção transversal da viga, perto do apoio simples, provavelmente devido à compressão gerada pela força de restrição axial atuante naquela zona, conforme ilustra a Figura 3.69. 
À exceção dessa particularidade, as duas vigas ensaiadas com o nível de restrição axial mais baixo (ka1_kr0_1 e ka1_kr0_2) também apresentaram uma aparência final "craquelada" nas superfícies do concreto, de modo semelhante às simplesmente apoiadas. As fissuras de flexão foram mais marcantes no ensaio ka1_kr0_1, enquanto no ensaio ka1_kr0_2 não foram significativas.

Após os ensaios das vigas submetidas ao nível mais alto de restrição axial (ka2_kr0_1 e ka2_kr0_2), o forno não pôde ter sido aberto logo no dia seguinte para a verificação do aspecto final das mesmas. Por conta desse motivo, as vigas já apresentavam alguma esfoliação do concreto presente nas superfícies, deixando alguns agregados à mostra, mas não se identificaram fissuras (Figura 3.70).

Quanto aos ensaios nos quais foram impostos às vigas restrições tanto axiais quanto rotacionais, a aparência "craquelada" das superfícies de concreto e algumas fissuras de flexão também foram constatadas. Outro fenômeno em comum observado entre essas vigas consistiu em uma instabilidade lateral com torção, ilustrada na Figura 3.71, que se mostrou mais significativa nas vigas dos ensaios ka1_kr2_1 e ka1_kr2_2, logo, naquelas às quais foram impostos níveis mais elevados de restrição rotacional. É provável que essas vigas ao terem sofrido deformações de origem térmica sob o efeito de uma estrutura circundante muito mais rígida acabaram por se deformar na única direção em que não estavam restringidas, nesse caso o eixo horizontal. Todavia, o sistema de aplicação de forças, mesmo com a ocorrência desse fenômeno de instabilidade, continuou a acompanhar configuração deformada das vigas de concreto ao longo dos ensaios, impondo devidamente as forças a elas.

Haja vista que essas vigas passaram por deformações horizontais de magnitudes diferentes, os modos de ruptura desse grupo de ensaios foram um pouco diferentes dos demais. Para a viga do ensaio ka1_kr2_2, uma daquelas com restrição rotacional mais elevada, verificou-se a ruptura de armaduras longitudinais superiores tanto do lado do apoio simples quanto do fixo (Figura 3.72). Para algumas das vigas das séries de ensaios com restrições rotacionais mais brandas, ka1_kr1 e ka2_kr1, também foram verificadas rupturas das armaduras longitudinais superiores, porém, apenas em pontos localizados próximos ao apoio simples. Essas rupturas 
das armaduras superiores se relacionam tanto ao possível esgotamento da capacidade de rotação dos apoios, que não mais deviam estar aptos a suportar o aumento dos momentos negativos, quanto à torção das peças. No Apêndice F são apresentadas mais fotos do aspecto das vigas ao fim de cada ensaio.

Vale citar que a segurança à instabilidade lateral das vigas de concreto armado ensaiadas foi verificada para a condição de temperatura ambiente, com base nos critérios descritos nas normas europeia e brasileira, Eurocode 2 parte 1-1 (2004) e ABNT NBR 6118:2014, respectivamente. Porém, não foram encontrados métodos ou equações a partir dos quais essa verificação pudesse ser realizada para a situação de incêndio. Por ter sido um fenômeno observado nos ensaios experimentais, carece de mais estudos.

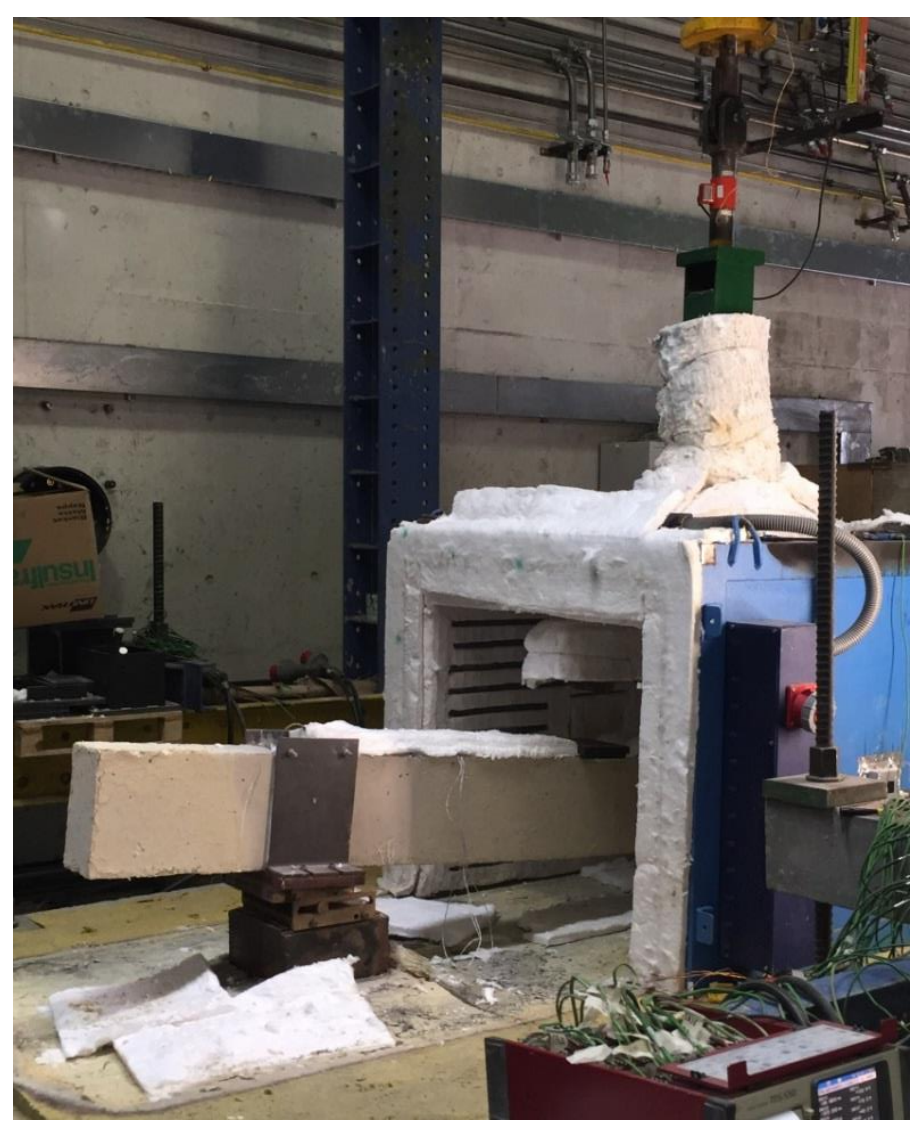

Figura 3.65 - Vista geral da configuração deformada da viga simplesmente apoiada do ensaio ka0_kr0_1. 

com restrições axial e rotacional em situação de incêndio
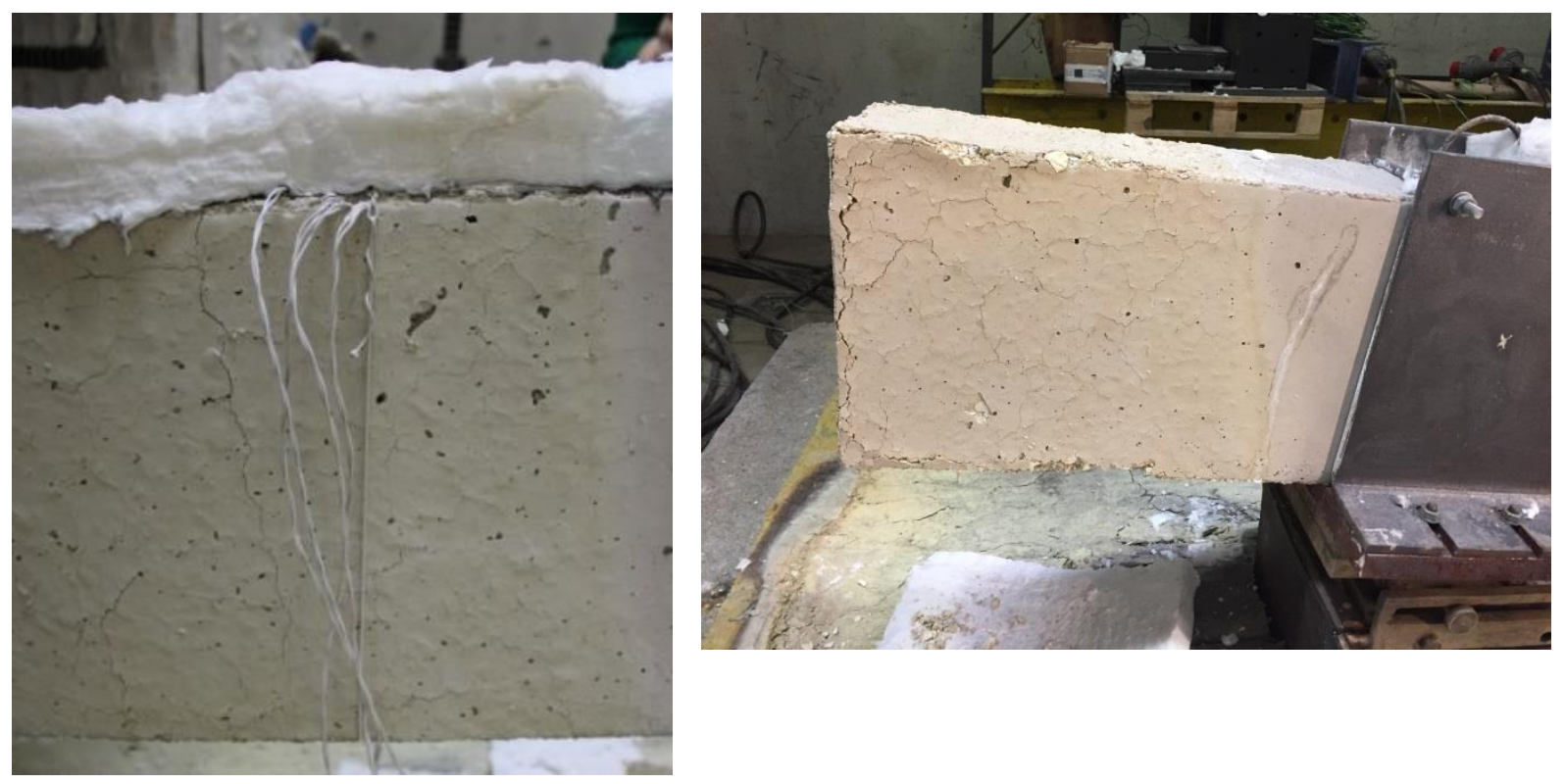

Figura 3.66 - Aparência "craquelada" das superfícies de concreto da viga simplesmente apoiada ka0_kr0_1.
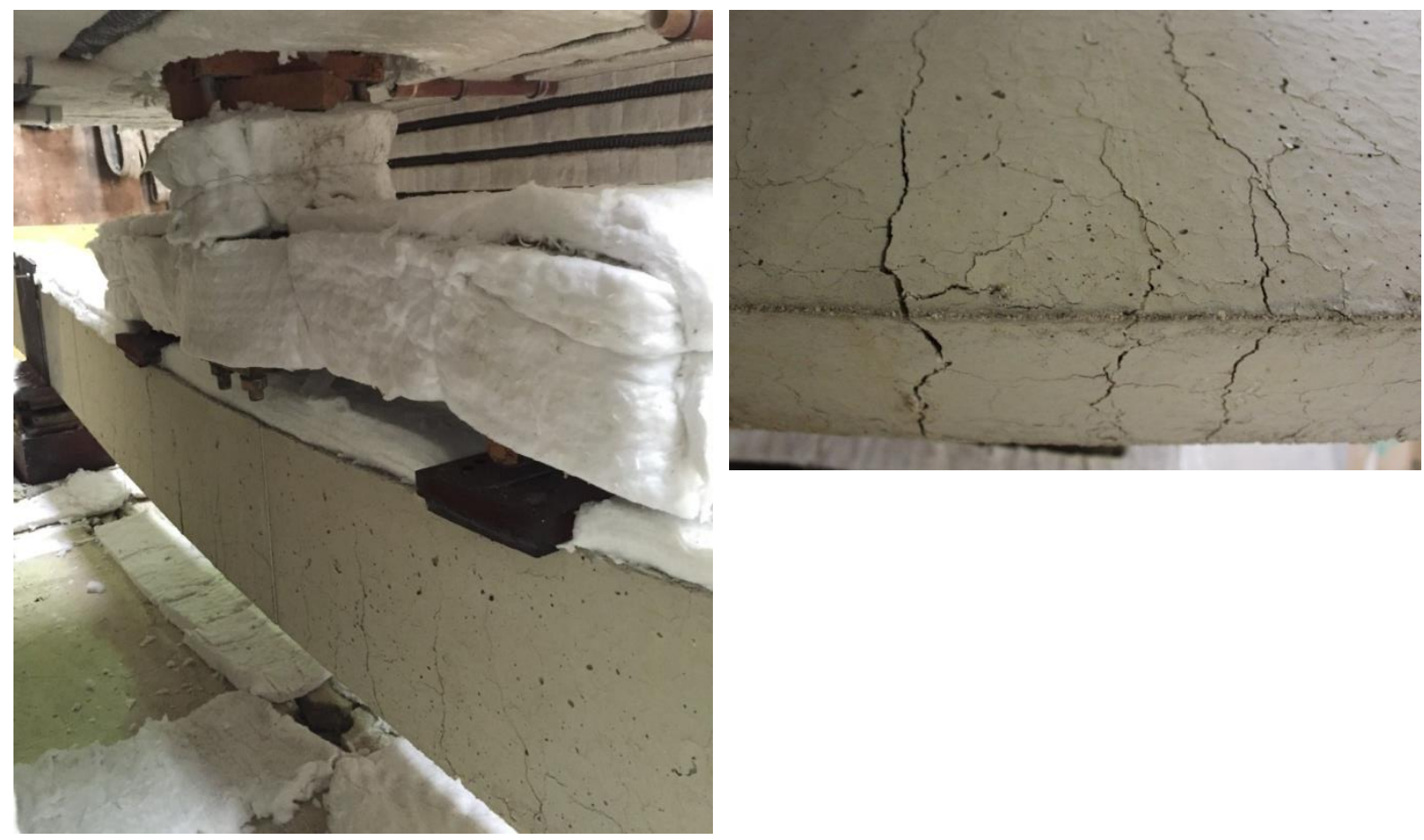

Figura 3.67 - Vista geral das fissuras de flexão e detalhe das aberturas das mesmas na face inferior da viga simplesmente apoiada do ensaio ka0_kr0_1. 


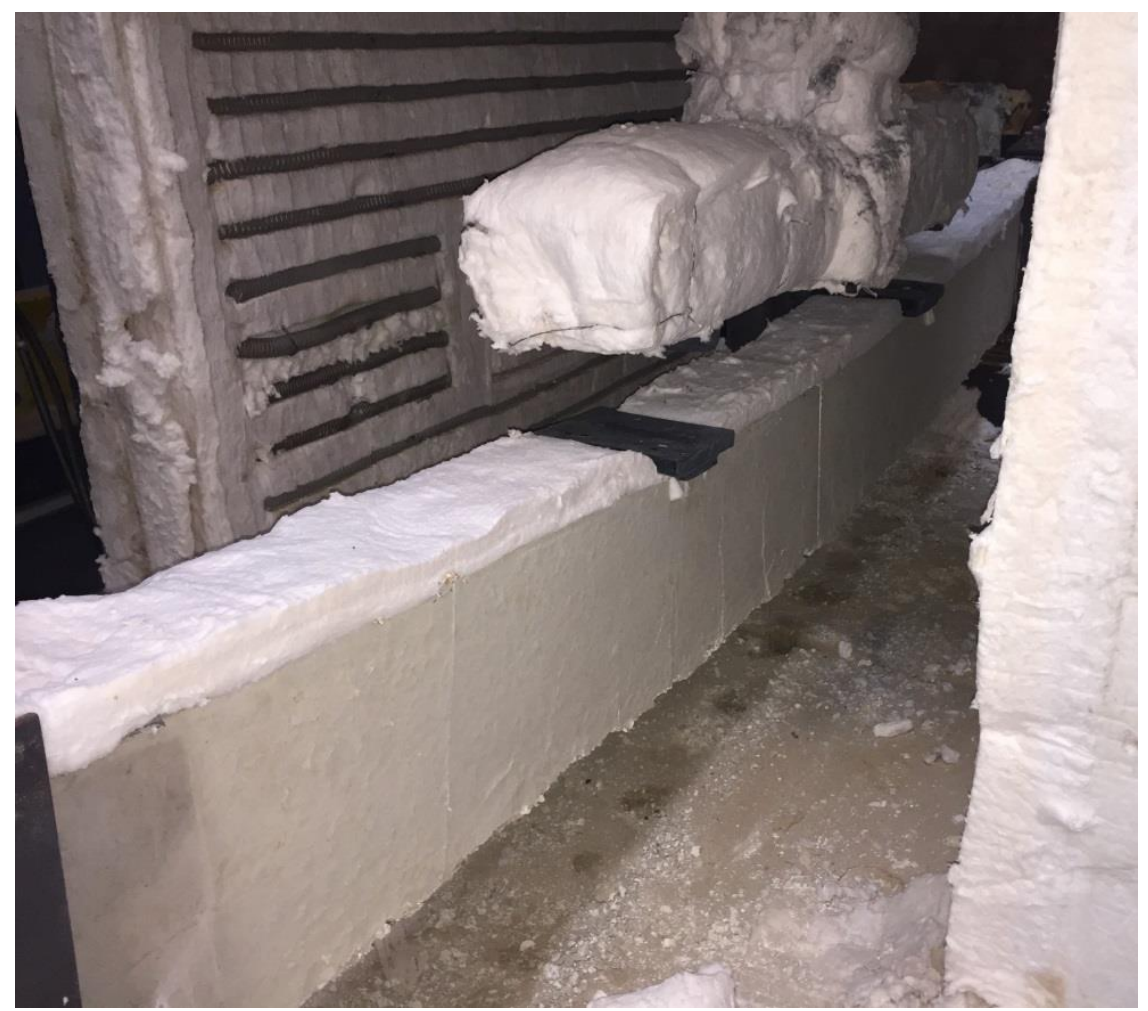

Figura 3.68 - Configuração deformada da viga com nível de restrição axial mais baixo do ensaio ka1_kr0_1.

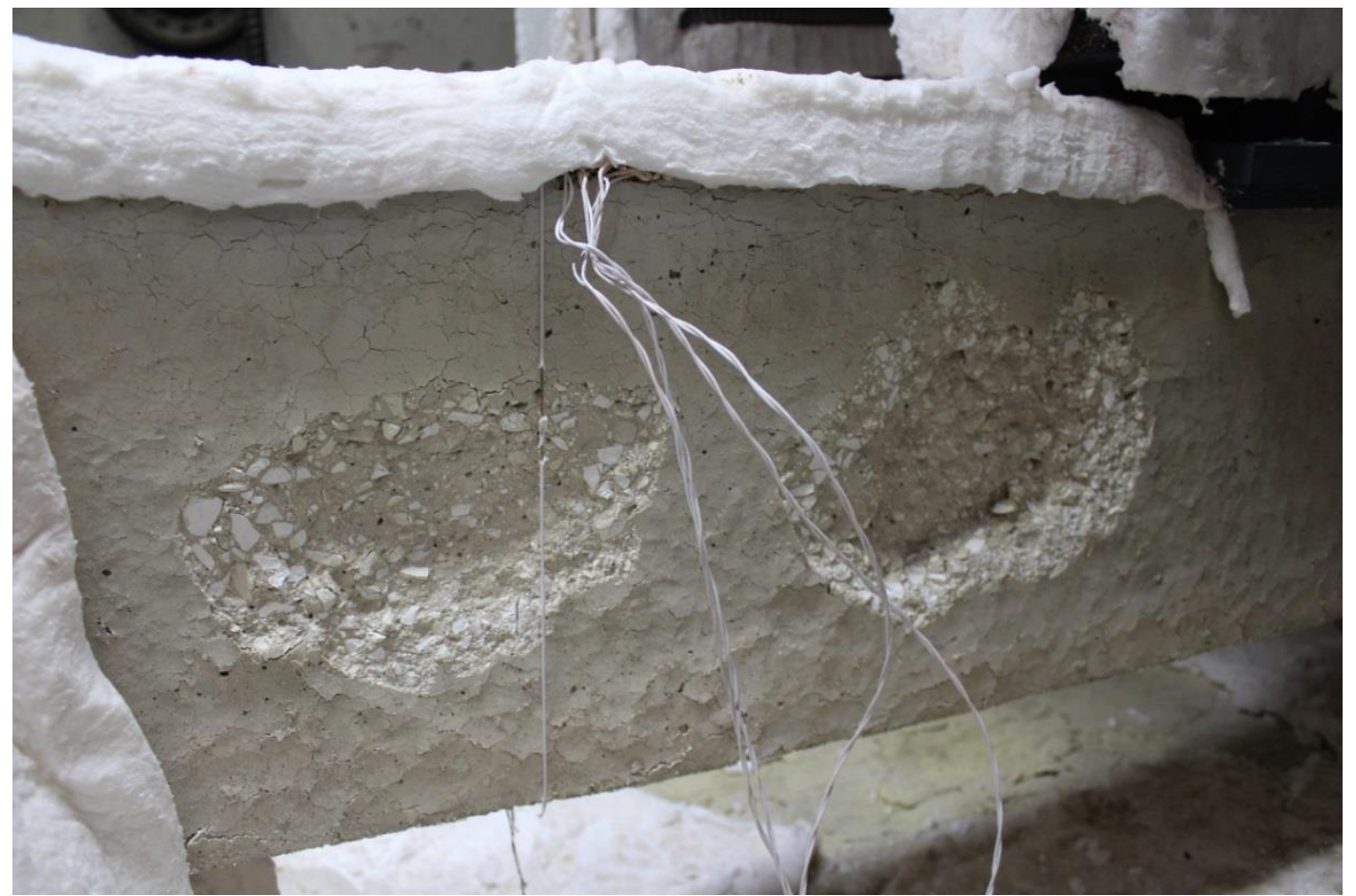

Figura 3.69 - Destacamento de pedaços de concreto na viga com restrição apenas axial do ensaio ka1_kr0_2. 


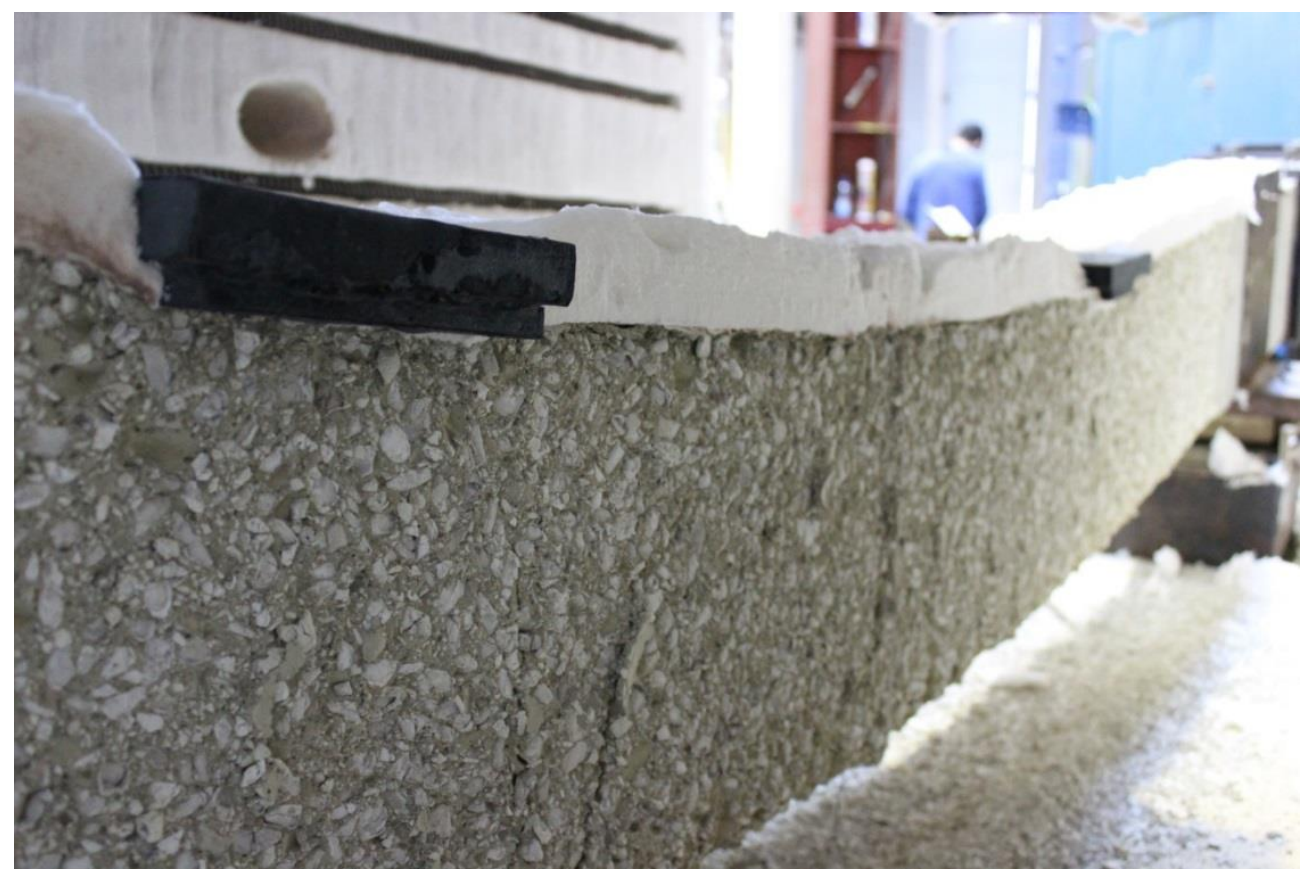

Figura 3.70 - Configuração deformada da viga com nível de restrição axial mais alto do ensaio ka2_kr0_2, com esfoliação do concreto presente nas superfícies.

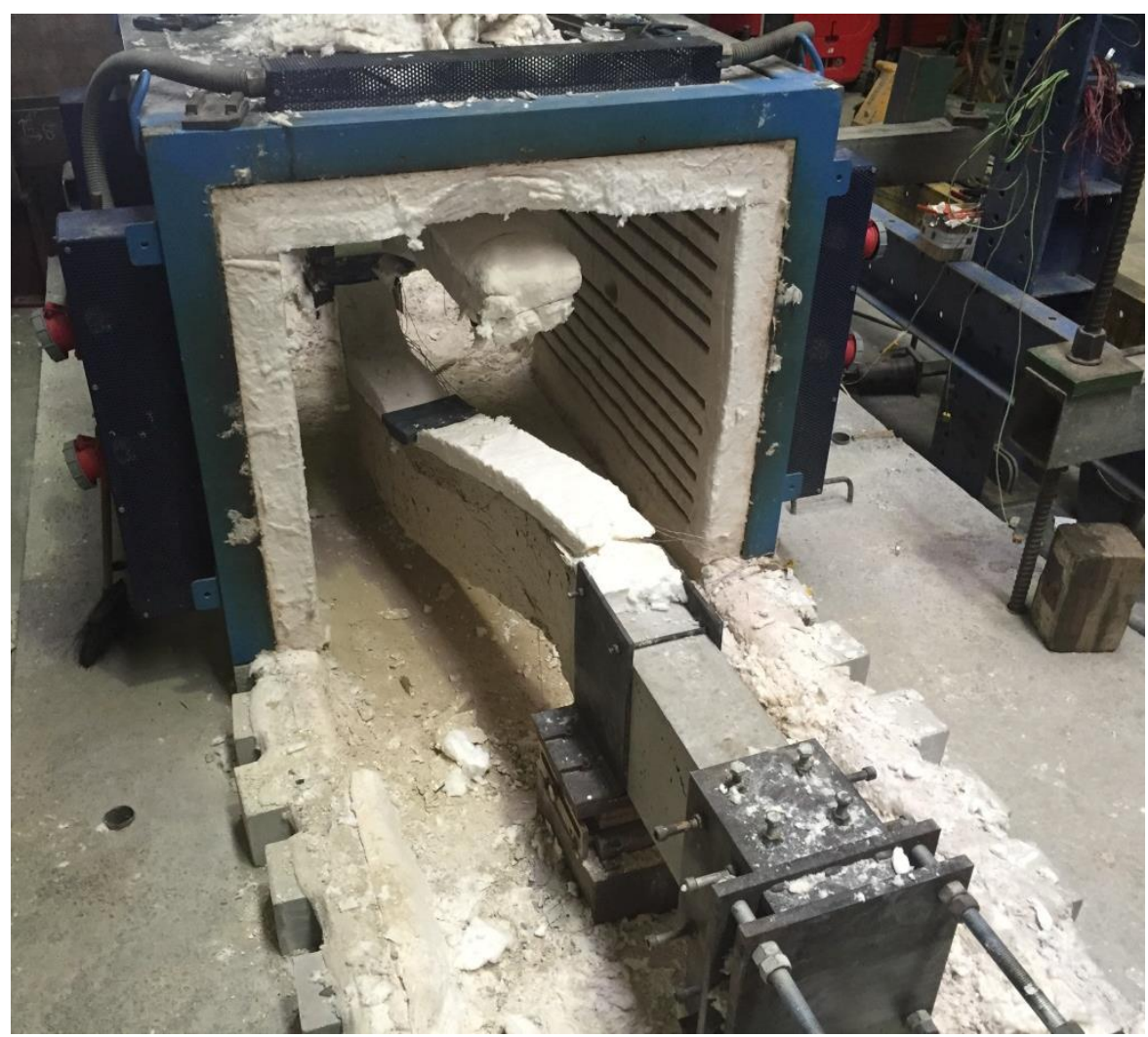

Figura 3.71 - Instabilidade lateral com torção da viga com restrições axial e rotacional do ensaio ka1_kr2_1. 


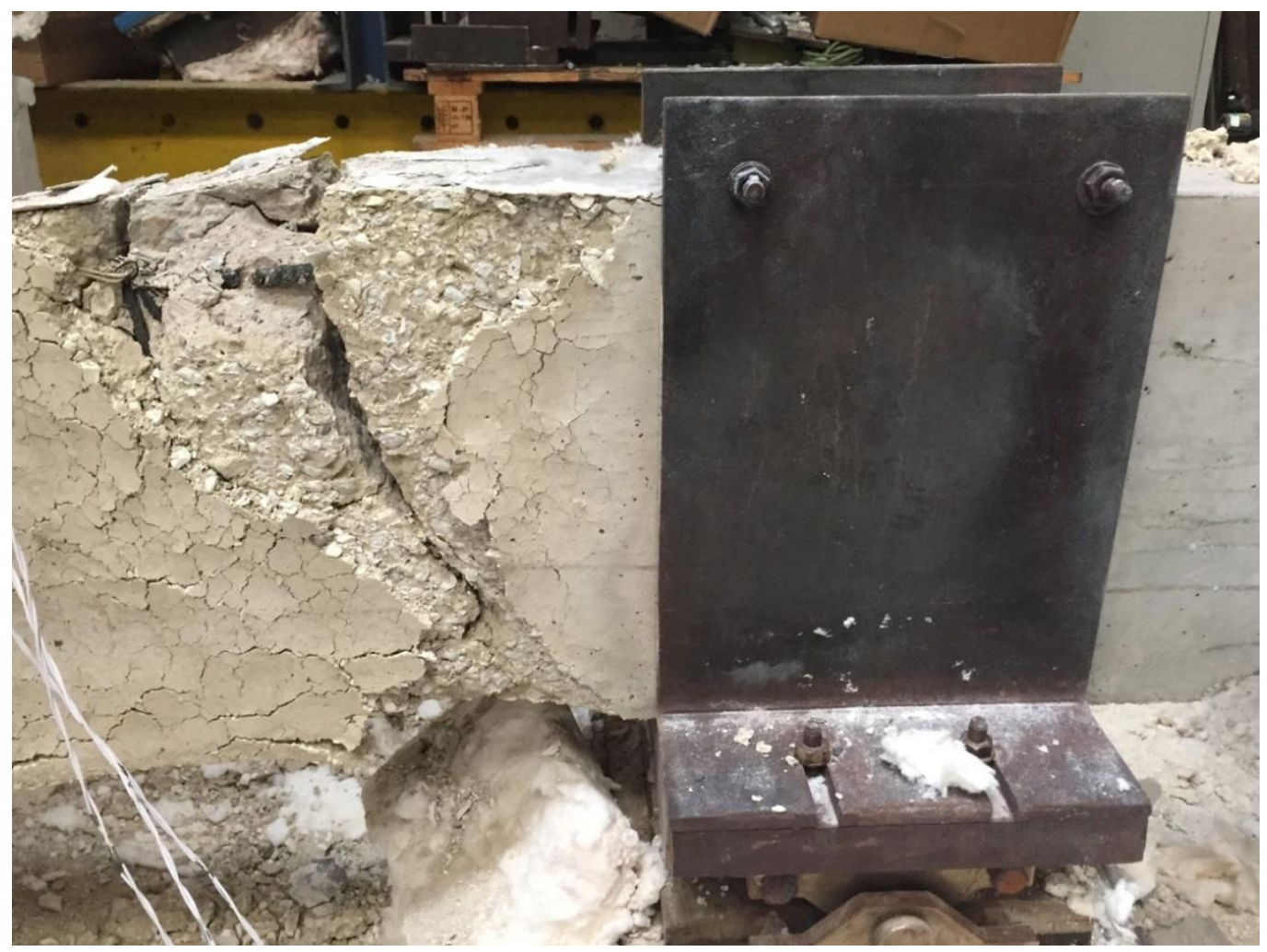

Figura 3.72 - Detalhe da ruptura de uma das armaduras superiores na região próxima ao apoio duplo (região dos momentos negativos) da viga do ensaio ka1_kr2_2.

\subsubsection{Resistências ao fogo}

A Tabela 3.9 apresenta os resultados de resistências ao fogo obtidos nos principais ensaios experimentais de vigas de concreto armado. Os símbolos presentes na mesma possuem os seguintes significados: " $\mathrm{t}_{\text {Nrest,máx }}$ indica o instante em que a força de restrição axial atingiu o seu valor máximo; " $\mathrm{t}_{\mathrm{cr}, \mathrm{r}}$ " representa a resistência ao fogo determinada pelo critério de ruptura em termos de capacidade resistente ou, em outras palavras, indica o instante em que a força de restrição axial retorna a zero; " $t_{\mathrm{cr}, \mathrm{d}}$ " representa a resistência ao fogo determinada pelo critério de ruptura em termos de deslocamentos, ou seja, compreende o instante em que são verificados os critérios tanto de flecha máxima quanto de velocidade máxima de crescimento das flechas (Equações 3.1 a 3.3); “ $\mu$ ” indica valor médio e "s" desvio padrão. 
Tabela 3.9 - Resistências ao fogo.

\begin{tabular}{|c|c|c|c|}
\hline \multirow{2}{*}{$\begin{array}{c}\text { Referência } \\
\text { do ensaio }\end{array}$} & \multicolumn{2}{|c|}{$\begin{array}{c}\text { Critério de ruptura em } \\
\text { termos de capacidade } \\
\text { resistente }\end{array}$} & \multirow{2}{*}{$\begin{array}{l}\text { Critério de ruptura em } \\
\text { termos de deslocamentos } \\
\mathrm{t}_{\mathrm{cr}, \mathrm{d}} \\
(\mathrm{min})\end{array}$} \\
\hline & $\begin{array}{l}\mathrm{t}_{\text {Nrest,máx }} \\
(\mathrm{min})\end{array}$ & $\begin{array}{c}\mathrm{t}_{\mathrm{cr}, \mathrm{r}} \\
(\mathrm{min})\end{array}$ & \\
\hline ka0_kr0_1 & - & - & 78 \\
\hline ka0_kr0_2 & - & - & 83 \\
\hline$\mu$ & - & - & 80,5 \\
\hline s & - & - & 2,5 \\
\hline ka1_kr0_1 & 74 & 93 & 89 \\
\hline ka1_kr0_2 & 77 & 110 & 101 \\
\hline$\mu$ & 75,5 & 101,5 & 95 \\
\hline $\mathrm{s}$ & 1,5 & 8,5 & 6 \\
\hline ka2_kr0_1 & 91 & 110 & 108 \\
\hline ka2_kr0_2 & 84 & 101 & 98 \\
\hline$\mu$ & 87,5 & 105,5 & 103 \\
\hline $\mathrm{s}$ & 3,5 & 4,5 & 5 \\
\hline ka1_kr1_1 & 97 & 138 & 142 \\
\hline ka1_kr1_2 & 107 & 144 & 142 \\
\hline$\mu$ & 102 & 141 & 142 \\
\hline $\mathrm{s}$ & 5 & 3 & 0 \\
\hline ka2_kr1_1 & 116 & 187 & 180 \\
\hline ka2_kr1_2 & 109 & 160 & 154 \\
\hline$\mu$ & 112,5 & 173,5 & 167 \\
\hline $\mathrm{s}$ & 3,5 & 13,5 & 13 \\
\hline ka1_kr2_1 & 120 & 157,5 & 156 \\
\hline ka1_kr2_2 & 100 & 150 & 147 \\
\hline$\mu$ & 110 & 154 & 151,5 \\
\hline $\mathrm{s}$ & 10 & 4 & 4,5 \\
\hline
\end{tabular}


Antes de tudo, pontua-se que houve uma concordância aceitável entre os valores de resistências obtidos para cada um dos pares de vigas que possuíam as mesmas condições de apoio, uma vez que os desvios padrão entre essas resistências foram inferiores ou igual a 10 na maioria dos casos, com exceção às vigas do conjunto de ensaios ka2_kr1. Uma razão para isso pode ter sido o fato de que essas vigas foram as que apresentaram maiores resistências ao fogo e justamente por terem sido expostas a temperaturas elevadas por períodos de tempo mais longos a heterogeneidade do concreto pode ter se sobressaído de forma diferente nesses ensaios. Apesar de o concreto ser usualmente tratado como um material homogêneo à temperatura ambiente, é sabido que sob a ação do fogo a sua heterogeneidade se aflora.

Nos ensaios onde foram aplicadas apenas restrições axiais, verificou-se que à medida que o nível dessa restrição era aumentado também aumentavam os tempos críticos em termos de deslocamentos e capacidade resistente, bem como o instante no qual se detectava a força axial máxima. Na comparação dos ensaios ka2_kr0 e ka0_kr0, encontrou-se um aumento de $28 \%$ no que concerne ao $t_{c r, d}$. Ao se fixar uma taxa de restrição axial e depois introduzir restrição rotacional, observou-se que os tempos críticos em termos de deslocamentos e de capacidade resistente, assim como o tempo no qual se atingia a força axial máxima, também aumentavam. Além disso, uma vez elevados os níveis de restrição rotacional, os tempos críticos aumentavam ainda mais. Comparando o ensaio ka1_kr0 ao ka1_kr2 foi detectado um aumento de $59 \%$ e ao confrontar os ensaios ka2_kr0 e ka2_kr1 o aumento foi igual 62\%, ambos em relação a $t_{c r, d}$.

Também foi constatado que ao se introduzir restrição rotacional em vigas com restrições axiais mais intensas, as elevações de $t_{c r, d}$ e $t_{c r, s}$ são mais significativas. No confronto dos ensaios ka1_kr0 e ka1_kr1, verificou-se um aumento de 39\%, enquanto na comparação dos ensaios ka2_kr0 a ka2_kr1 o aumento foi igual a 64\%, ambos em função de t trr,r. Além disso, ao se fixar um valor de restrição rotacional, o aumento dos níveis de restrição axial faz aumentar os tempos críticos em termos de deslocamentos e de capacidade resistente e, ainda, o tempo em que ocorre a força axial máxima. Comparando-se os ensaios ka1_kr1 e ka2_kr1, observou-se um aumento de $23 \%$ em $\mathrm{t}_{\mathrm{cr}, \mathrm{r}}$. 
Após essas conclusões específicas, é importante finalmente ressaltar a conclusão geral estabelecida quando finalizados os ensaios sob análise: as resistências ao fogo das vigas de concreto armado sempre aumentam quando introduzido qualquer tipo de restrição (somente axial ou axial mais rotacional). Por resistências ao fogo, compreendem-se os tempos críticos definidos com base nos critérios de ruptura, ou de capacidade resistente ou de deslocamentos. Pelos resultados experimentais chegou a ser encontrado, como exemplo, um aumento até superior a $100 \%$ quando comparados os ensaios ka0_kr0 e ka2_kr1. Essa constatação indica que se os efeitos das restrições às deformações de origem térmica não forem levados em consideração nos projetos em que possuem a oportunidade de ocorrer, os resultados do dimensionamento das vigas ao fogo podem ser extremamente conservadores.

Ainda é válido esclarecer que os ensaios experimentais desta investigação estão a favor da segurança em relação ao que normalmente ocorre em vigas de concreto armado, pois vigas com seções retangulares e com manta na face superior se encontram em condição mais crítica quando comparadas a vigas $\mathrm{T}$ (vigas sob lajes). Se as mesmas vigas que foram dimensionadas para a seção retangular fossem transformadas em seções $\mathrm{T}$, a laje aumentaria a resistência ao fogo independente das temperaturas do elemento estrutural, pois nesse caso a peça teria uma região comprimida maior. Logo, a viga sob laje em si, mesmo à temperatura ambiente, já possuiria uma capacidade resistente mais elevada. A laje também reduziria a ocorrência da instabilidade lateral com torção.

Além disso, no arranjo das armaduras conforme uma viga $\mathrm{T}$, as duas barras longitudinais superiores ficariam mais protegidas e se aqueceriam de forma mais lenta, uma vez que o calor passaria através da laje. Na seção retangular com a manta na face superior, o calor entra diretamente pelas faces laterais. Essa é uma questão relevante para as vigas com restrições axial e rotacional. Como visto ao longo deste capítulo, a resistência ao fogo das mesmas também depende das temperaturas das armaduras negativas. Novamente, destaca-se que os resultados dos ensaios estão a favor da segurança, pois essas vigas teriam resistências ao fogo ainda maiores se as armaduras negativas estivessem mais protegidas pela laje. 


\section{ANÁLISES NUMÉRICAS}

\subsection{Programa de computador DIANA}

O programa de computador DIANA (acrônimo para DIsplacement ANAlyzer) possui origem neerlandesa e avalia o comportamento de estruturas com base nos métodos dos deslocamentos e dos elementos finitos. A sua primeira versão foi criada em 1972 em Delft - Países Baixos, pela equipe do Departamento de Mecânica Computacional da TNO Building and Constructions Research Institute. O programa continua em desenvolvimento até os dias atuais, sendo que desde o ano de 2003 a organização agora intitulada DIANA FEA BV passou a coordenar a equipe responsável pela sua atualização e aprimoramento constantes, sendo essa constituída por engenheiros civis e geotécnicos, pesquisadores e desenvolvedores de software.

O programa pode ser aplicado a diversas áreas de análises voltadas às engenharias, tais como: barragens e diques, túneis e estruturas subterrâneas, análise geotécnica, petróleo e gás, engenharia sísmica, cura do concreto nas primeiras idades, alvenaria e construções históricas, bem como estruturas de concreto armado e análises de situação de incêndio. Ainda possui uma biblioteca com mais de duzentos e cinquenta tipos de elementos finitos, além de aproximadamente cento e cinquenta modelos de materiais disponíveis para a modelagem dessas estruturas. Permite a execução de análises estáticas ou dinâmicas (lineares ou não), de estabilidade, termestruturais, entre outras (DIANA FEA, 2016b).

A eficiência do DIANA é extremamente reconhecida no que tange a análise de estruturas em concreto armado, uma vez que permite considerar diversas variáveis características do comportamento não linear desse material compósito, tais como: fluência, retração, cura, fissuração e esmagamento do concreto, além da plastificação das armaduras e da aderência 
concreto/aço. Conforme mencionado anteriormente, o programa disponibiliza uma gama de elementos finitos para a discretização dessas estruturas, citam-se elementos de vigas, treliças, sólidos, placas, cascas, molas, interface/contato, contorno, fluxo e também permite a modelagem de armaduras embutidas no concreto (embedded reinforcements). O DIANA, inclusive, foi o primeiro programa de computador a considerar elementos finitos embutidos. As análises tridimensionais também são possíveis e dentre os modelos para a caracterização do concreto e do aço, há aqueles definidos com base nas diretrizes de normas internacionais, tais como os Eurocodes. A abordagem da fissuração do concreto pode ser conduzida por intermédio de modelos discretos com elementos de interface ou modelos de fissuras distribuídas com direções fixas ou rotacionais (DIANA FEA, 2016c).

Ainda segundo informações presentes em DIANA FEA (2016c), o programa tem sido utilizado para a investigação do comportamento de estruturas de concreto armado por diversas organizações/instituições de pesquisa ao redor do mundo desde a década de 1980. No Brasil, mais especificamente, a sua utilização para tal fim é usual. No âmbito de análises em estruturas de concreto à temperatura ambiente, podem ser citados os seguintes trabalhos científicos: Sampaio (2004), Souza (2004), Menin; Trautwein e Bittencourt (2009) e Pacheco; Lima e Lima (2013), para a modelagem de vigas de concreto convencionais; Gamino (2007), vigas com reforço; Trautwein (2006), lajes; Kataoka (2010), pilares; Oliveira (2013), blocos sobre cinco e seis estacas. A maior parte desses trabalhos foi realizada por pesquisadores da Escola Politécnica da Universidade de São Paulo, à exceção de Pacheco; Lima e Lima (2013), da Universidade Estadual de Feira de Santana, e Oliveira (2013), da Escola de Engenharia de São Carlos da Universidade de São Paulo.

O DIANA também já foi aplicado em Portugal para o estudo de tais estruturas. Azenha (2004, 2009) e Ferreira (2008) apresentaram análises voltadas ao comportamento do concreto nas primeiras idades, sendo que Ferreira (2008) o fez por meio da modelagem de uma viga préfabricada de concreto protendido; Pimentel (2004) analisou estruturas laminares, Silva (2008) estruturas reforçadas, Freitas (2012) tirantes e muros; Carvalho (2013) lajes. Todas essas pesquisas são provenientes da Universidade do Porto. Em Guimarães, na Universidade do 
Minho, houve também alguns pesquisadores que adotaram o programa para a modelagem de estruturas de concreto à temperatura ambiente: Palácio (2007) avaliou o comportamento de estruturas de superfície fina e Jacey (2016) lajes reforçadas.

Quanto às pesquisas acadêmicas estrangeiras, também podem ser apontados vários exemplos de aplicação do DIANA. Feenstra (1993) o adotou para a análise computacional de tensões biaxiais em concretos simples e armado; Rafi; Nadjai e Ali (2007), Mauludin (2009), Moltubakk (2014) e Qapo; Dirar e Jemaa (2016) modelaram vigas com reforços; Martin (2007), Alam e Amanate (2012) e Yang (2014) apresentaram estudos voltados à verificação do cisalhamento; Portal et al. (2013) estudou lajes; Deaton (2013) as ligações viga/pilar; e Johnson (2006) apresentou uma comparação das utilidades do DIANA para a análise de estruturas de concreto em relação a outros programas de computador comerciais como, por exemplo, Abaqus (ABAQUS, versão de 2006 do manual) e ADINA (ADINA, 2005).

O programa em questão também possui um módulo térmico a partir do qual se realizam análises de distribuição de temperaturas em regime transiente, considerando transferências de calor pelos processos de condução, convecção e radiação. Admite, ainda, o efeito das altas temperaturas na degradação das propriedades mecânicas dos materiais, nas deformações dos elementos e nos demais danos que podem ser ocasionados na estrutura. Tais efeitos são admitidos por intermédio da consideração dos resultados das análises térmicas nas análises mecânicas, conforme ilustra o esquema presente na Figura 4.1.

Ao serem introduzidas curvas de aquecimento como condições de contorno do modelo, o programa associa/converte automaticamente os elementos finitos convencionais da malha em elementos de fluxo, facilitando a compatibilização desse modelo às análises de exposição ao fogo. Também permite que as condições de contorno sejam modificadas durante as análises, bem como sejam removidos elementos danificados pela ação do fogo. Resistências, expansões térmicas, módulos de elasticidade e coeficientes de Poisson são apenas algumas das propriedades dos materiais para as quais podem ser admitidas dependências em função do tempo ou de temperaturas. Os efeitos do fogo também são considerados na fissuração, tanto para os modelos discretos quanto de fissuras distribuídas (DIANA FEA, 2016d). 


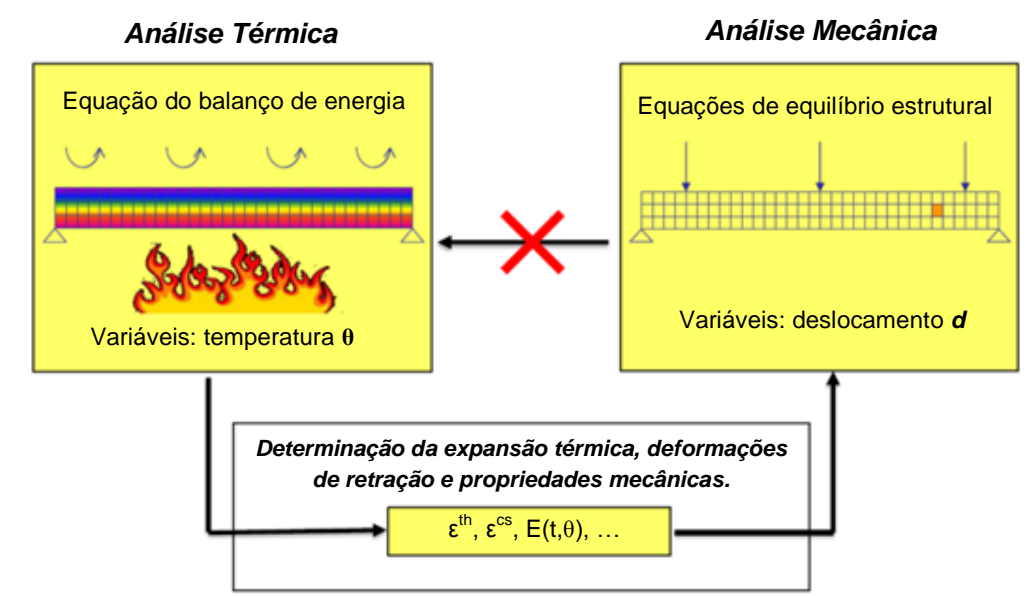

Figura 4.1 - Fluxograma das análises termestruturais (térmicas + mecânicas) realizadas pelo programa de computador DIANA (DIANA FEA, 2016e; adaptado).

No Brasil, essa será a primeira investigação a adotar o DIANA para o estudo de estruturas de concreto armado em situação de incêndio. Em Portugal, Fernandes (2008) desenvolveu uma rotina no programa para determinar campos térmicos e momentos fletores resistentes de seções transversais de vigas expostas ao fogo (vide Capítulo 2 - Estado da Arte), porém, consistiu em uma abordagem mais simples do problema, haja vista que o comportamento foi avaliado apenas no nível da seção, enquanto nesta Tese foram modeladas vigas tridimensionais, conforme será mostrado com mais detalhe ao longo do presente capítulo.

No âmbito internacional, o programa foi aplicado por Bacinskas et al. (2007) e Ali; Nadjai e Abu-Tair (2008) para analisar lajes de concreto armado submetidas ao fogo; por Doherty; Ali e Nadjai (2010), Huismann; Korzen e Schneider (2010) e Ali; Nadjai e Choi (2010) para o estudo de pilares e por Lilliu e Meda (2013); Bettini et al. (2014) para túneis. Na pesquisa realizada não foram encontrados trabalhos realmente voltados ao uso do DIANA para vigas de concreto armado convencionais expostas a temperaturas elevadas, que consiste no escopo desta Tese. Rafi; Nadjai e Ali (2008) apresentaram a modelagem de algumas vigas desse tipo, mas o foco da pesquisa consistia na análise do comportamento de vigas com fibras de reforço polimérico (FRP).

O módulo térmico aliado às avançadas modelagens de estruturas de concreto armado para condições normais (temperatura ambiente) ditou a escolha do DIANA para a presente 
pesquisa. Outra motivação para o seu uso consistiu no desafio de apresentar uma nova modelagem numérica para simular o comportamento de vigas de concreto armado simplesmente apoiadas e com restrições expostas ao fogo, uma vez que dentro das pesquisas voltadas ao tema, essa será a primeira a adotar o DIANA (mais informações novamente no Capítulo 2). Nos próximos itens, apresentar-se-ão detalhes da modelagem, bem como os resultados das análises e as respectivas comparações aos resultados experimentais. As informações serão delineadas com base na ordem de etapas que deve ser seguida para as análises numéricas a serem efetuadas no programa em questão, sendo essa ilustrada no fluxograma da Figura 4.2. Nesta Tese, adotou-se a versão DIANA 10.1 (DIANA FEA, 2016a) para todas as análises, que foram executadas em um computador com as seguintes configurações: processador Intel ${ }^{\circledR} \mathrm{Xeon}^{\circledR} \mathrm{CPU}$ E5-2630 v 4 @ 2,20 GHz (2 processadores); memória instalada (RAM) 64 GB; sistema operacional Windows 1064 bits.

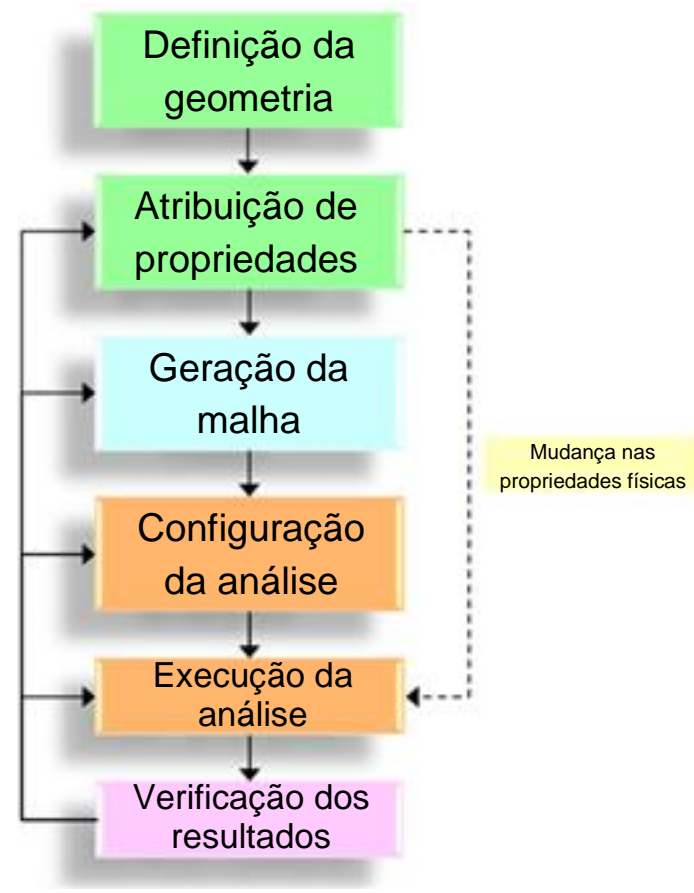

Figura 4.2 - Fluxograma com etapas a serem cumpridas para a realização de análises numéricas no programa de computador DIANA (DIANA FEA, 2016e; adaptado). 


\subsection{Vigas à temperatura ambiente}

\subsubsection{Definição da geometria}

\subsubsection{Modelagem dos elementos componentes}

O primeiro passo para a modelagem das vigas de concreto armado que foram adotadas nos ensaios à temperatura ambiente, apresentados no capítulo anterior, consistiu na definição da geometria da viga propriamente dita, dos blocos dos apoios e das chapas para distribuição das forças aplicadas. Todos esses elementos foram modelados por meio de sólidos tridimensionais no formato de blocos, conforme ilustra a Figura 4.3.

Esses blocos foram divididos em diferentes partes por conta de algumas razões. A primeira consistiu em delimitar regiões de interesse para a verificação de resultados, tais como, as seções da viga a meio vão e a meio metro de distância dos eixos dos apoios, onde mais tarde deveriam ser aferidos os deslocamentos verticais e as temperaturas (já com vistas a utilizar tal modelo da temperatura ambiente como base para em seguida simular aqueles com exposição ao fogo). A segunda consistiu em criar regiões, linhas ou pontos necessários para a modelagem. Os apoios foram divididos em dois blocos, por exemplo, para que em suas faces inferiores existisse uma linha média e, ainda, para que nela pudesse ser inserido um ponto central. Esses elementos posteriormente foram utilizados para delimitar as condições de restrição desses apoios. E, finalmente, para facilitar a geração de malhas uniformes, ou seja, para que não fossem obtidos pontos de descontinuidade dos elementos finitos presentes nas diferentes partes do modelo. 
Seguindo as dimensões dos elementos estruturais de concreto ensaiados, a viga foi modelada com um comprimento total de $4200 \mathrm{~mm}$, sendo a distância do vão entre eixos dos apoios igual a $3000 \mathrm{~mm}$, e a seção transversal com 150 x $300 \mathrm{~mm}$. Os blocos dos apoios tinham um comprimento total de $250 \mathrm{~mm}$ e seção de 150 x $40 \mathrm{~mm}$. Já as chapas para distribuir as forças aplicadas à viga tinham comprimento total de 150 mm e seção de 150 x 30 mm.

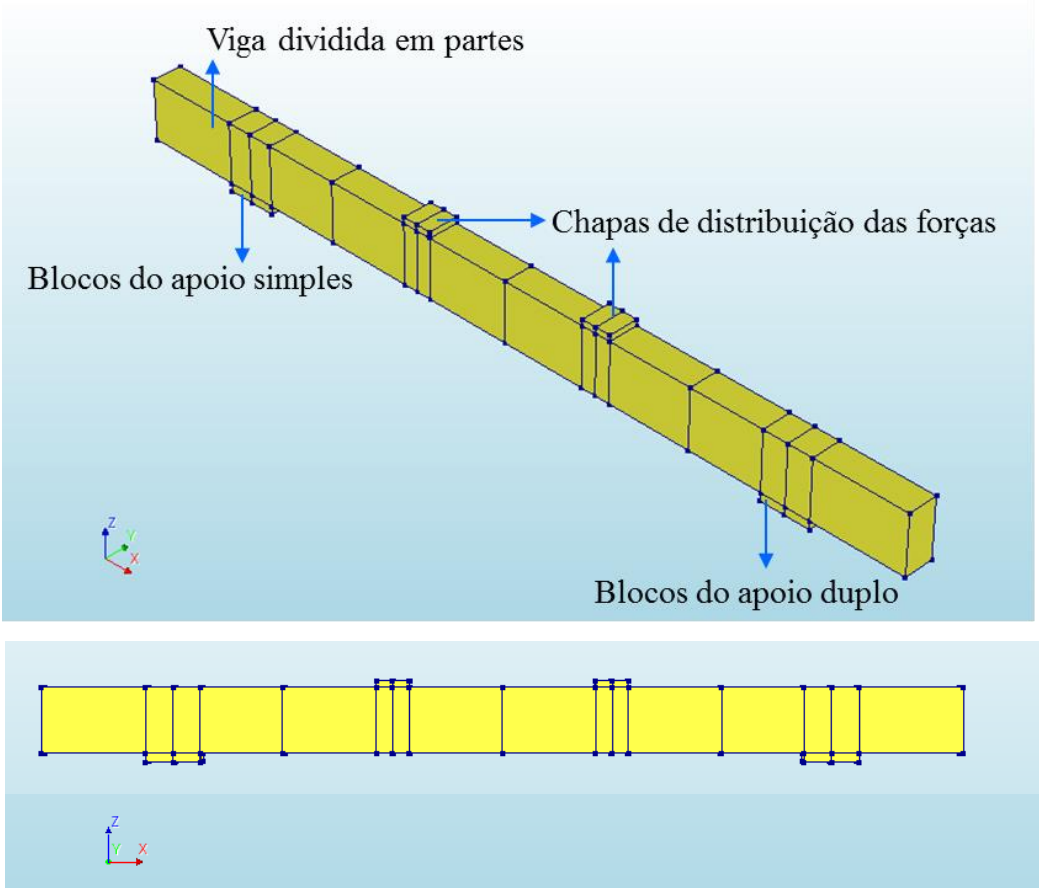

Figura 4.3 - Geometria da viga, dos blocos dos apoios e das chapas para distribuição de forças aplicadas (vistas isométrica e frontal, respectivamente).

O segundo passo consistiu na definição da geometria das armaduras. As longitudinais foram criadas por meio de linhas simples e posicionadas verticalmente nas alturas representativas dos eixos das respectivas seções transversais. Cada um dos 28 estribos constituintes da armadura transversal também foi criado a partir de quatro linhas simples, posicionadas com base na mesma proposição (eixos das barras). As dimensões seguiram o exposto no capítulo anterior. As Figuras 4.4 e 4.5 ilustram detalhes da modelagem desses elementos. 


\subsubsection{Determinação das forças atuantes}

Nos ensaios à temperatura ambiente realizados no Laboratório de Ensaio de Materiais e Estruturas da Universidade de Coimbra (LEME-UC), as deformações das vigas foram provenientes dos incrementos de carga aplicados continuamente a elas pelo macaco hidráulico e, em menor parcela, resultantes da atuação de seu peso próprio. A partir dos resultados experimentais, foi possível verificar que as mesmas resistiram a forças máximas totais de aproximadamente $40 \mathrm{kN}$. Com base nessa informação, aplicou-se no modelo numérico uma força total de $50 \mathrm{kN}$, sendo $25 \mathrm{kN}$ em cada uma das chapas de distribuição, pois já se sabia que esse era um valor próximo àquele atingido experimentalmente. Conforme será explicado mais adiante, na seção sobre procedimentos de análise, essa carga total foi aplicada aos poucos, por iterações, mediante passos de carga (load steps). Portanto, essa força era representativa daquela imposta pelo sistema de carregamento adotado.

Ainda nos ensaios, as chapas postas sob o conjunto pilar/viga de aço, que transferia o carregamento aplicado pelo macaco hidráulico até as vigas de concreto armado, tinham a função de distribuir as forças em uma determinada zona para prevenir a ocorrência de rupturas localizadas por compressão do concreto, que podem ocorrer devido a forças concentradas aplicadas diretamente sobre a viga. Por isso, no modelo numérico à temperatura ambiente, as forças de $25 \mathrm{kN}$ também foram distribuídas pelas áreas de $22500 \mathrm{~mm}^{2}$ (150 x $150 \mathrm{~mm}$ ) de cada uma das chapas e na direção - Z, como ilustrado na Figura 4.6.

Essa questão é abordada por Belletti et al. (2016) no documento técnico intitulado "Guidelines for nonlinear finite analysis of concrete structures"1. De acordo com os autores, tanto chapas de aplicação de carga quanto blocos de apoios podem ser inseridos no modelo

\footnotetext{
${ }^{1} \mathrm{O}$ documento técnico sob a autoria de Belletti et al. (2016) foi publicado pelo Ministério Holandês de Infraestrutura e Meio Ambiente e propõe um interessante guia para a execução de análises numéricas não lineares de estruturas de concreto armado com base no método dos elementos finitos. Recentemente, em Belletti et al. (2017), os autores apresentaram validações das diretrizes propostas nesse guia para a simulação de vigas.
} 
numérico desde que esse não tenha o objetivo de avaliar detalhadamente o comportamento dos pontos de aplicação de carga ou dos pontos de apoio e, ainda, desde que esses elementos sejam modelados de forma a não produzir eventuais concentrações de tensões. Para se evitar esse fenômeno nas chapas de aplicação de cargas, eles indicam justamente ou a opção que foi adotada nas análises desta Tese, de substituir forças concentradas por forças distribuídas ao longo da área da chapa porque assim a mesma se torna menos rígida, ou a opção de inserir elementos de interface que sejam capazes de reduzir as tensões e o atrito gerados entre a chapa e o concreto.

A outra força atribuída ao modelo foi a proveniente do seu peso próprio (força peso), que em seguida é calculada automaticamente pelo programa com base nas massas específicas dos materiais, que devem ser definidas para cada um dos elementos constituintes do modelo numérico, e também com base na direção e na aceleração da gravidade.

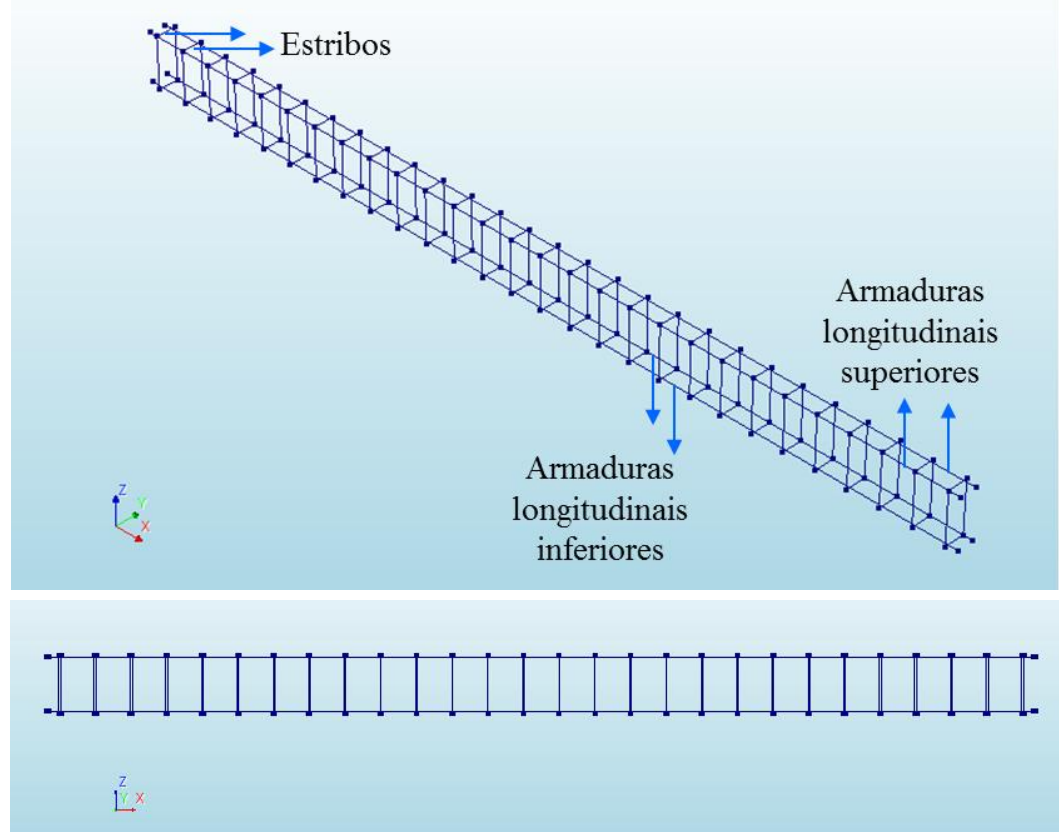

Figura 4.4 - Geometria das armaduras longitudinais e transversais (vistas isométrica e frontal, respectivamente). 


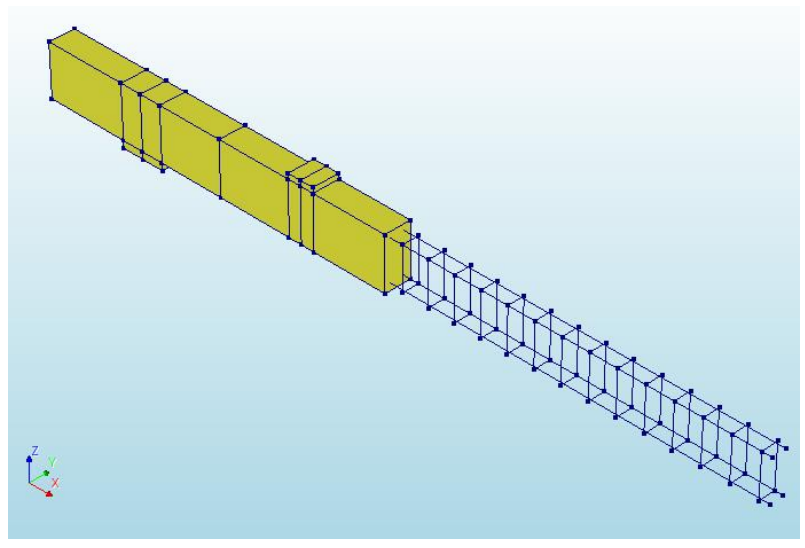

Figura 4.5 - Detalhe das armaduras longitudinais e transversais embutidas na geometria da viga.

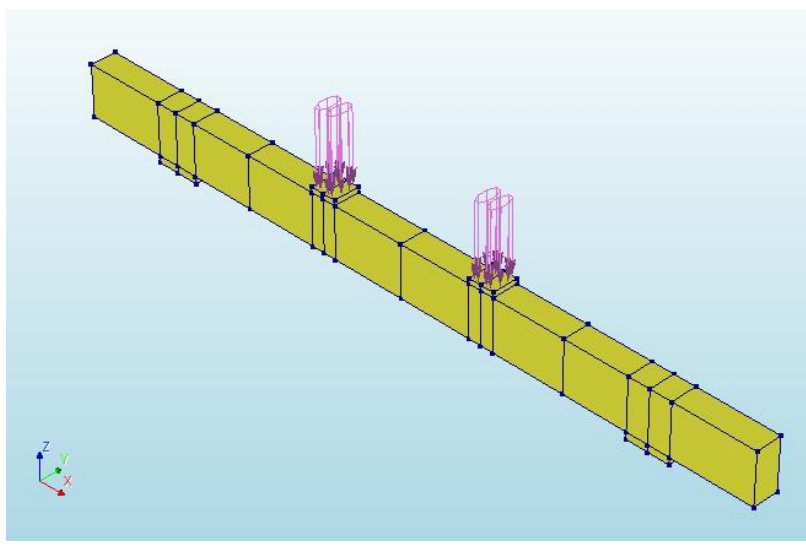

Figura 4.6 - Forças aplicadas à viga distribuídas nas superfícies das chapas de carga.

\subsubsection{Condições de apoio}

As vigas à temperatura ambiente precisavam ser simuladas com o esquema estático de peças simplesmente apoiadas, que consistiu na condição adotada nos seus ensaios. Para definir o apoio simples, que se encontrava localizado na extremidade esquerda da viga (conforme ilustra a Figura 4.3), foram admitidas como livres as rotações em todas as direções, bem como as translações na direção do eixo X (direção do deslocamento axial da peça). Enquanto isso, restringiram-se as translações na direção $\mathrm{Z}$ de todos os nós localizados na linha central da face inferior desse apoio, enquanto as translações na direção $\mathrm{Y}$ foram impedidas apenas no nó central da sua face inferior. Para o apoio duplo, localizado na extremidade direita, as rotações foram permitidas em todas as direções, enquanto as translações na direção $\mathrm{Z}$ de todos os nós localizados na linha central da face inferior desse apoio foram impedidas (igualmente ao apoio simples) e as translações nas direções $\mathrm{Y}$ e $\mathrm{X}$ foram impedidas no nó central da sua face inferior.

Essas condições de apoio, indicadas nas Figuras 4.7 e 4.8, foram adotadas porque conferiam o mínimo de restrição que poderia ser admitido para que não existissem movimentos de corpo rígido e para garantir a modelagem de uma estrutura isostática. Para os dois apoios, as 
translações na direção $\mathrm{Z}$ foram impedidas ao longo de toda a linha porque consistia no eixo onde a viga estava assentada. Contudo, nas direções Y e X, restringir as translações de todos os nós da linha poderia causar esforços que não existiram na prática (ao longo dos ensaios). Além disso, poderia dificultar a análise numérica por conta das já mencionadas concentrações de tensões que poderiam vir a ocorrer nesses blocos dos apoios.

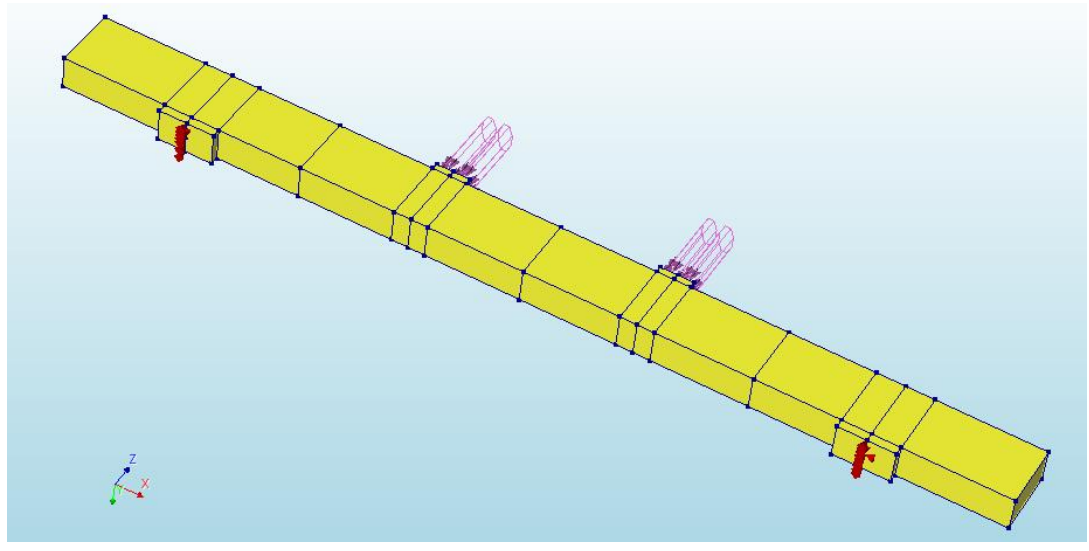

Figura 4.7 - Vista geral das condições de apoio adotadas no modelo numérico.
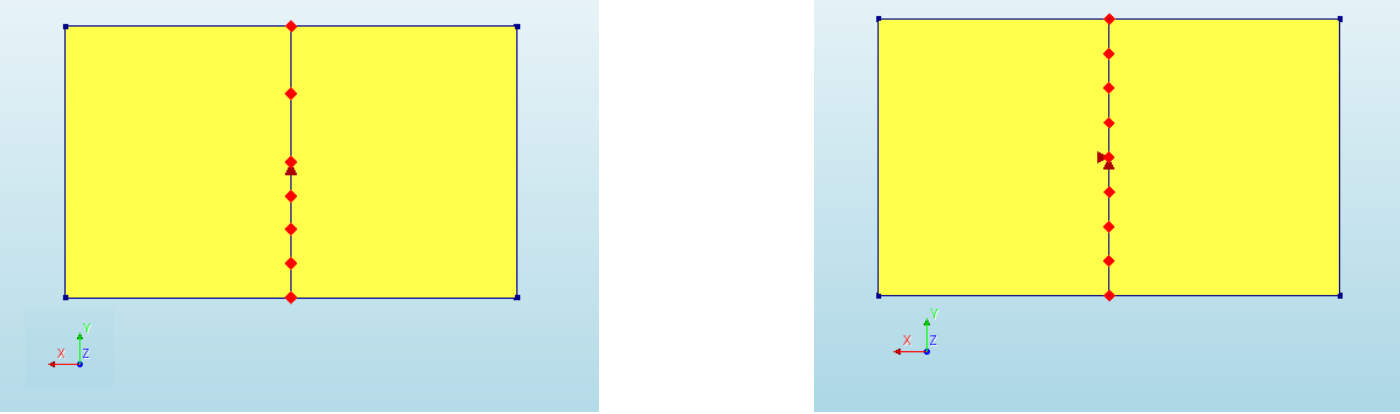

Figura 4.8 - Vistas das faces inferiores dos apoios simples e duplo, respectivamente, com a indicação das direções para as quais as translações foram restringidas.

Ainda sobre a geometria, optou-se por viga tridimensional, ao invés de bidimensional, porque o objetivo consistia em adaptar o modelo da temperatura ambiente para as análises ao fogo, nas quais a modelagem em três dimensões era a ideal para reproduzir os diferentes fluxos de temperatura ao longo de todo o elemento, de modo que fosse possível analisar os campos térmicos tanto nas seções transversais quanto ao longo do vão. Não se fez uso das condições simétricas de geometria e carregamento para modelar apenas metade da viga e então reduzir o 
esforço e o tempo das análises computacionais porque as restrições que seriam aplicadas em cada uma das extremidades da viga em alguns dos modelos ao fogo teriam valores diferentes, sendo necessário ter a peça completa para simular os esquemas estáticos dos ensaios.

\subsubsection{Atribuição de propriedades}

\subsubsection{Concreto da viga}

\subsection{Modelo de fissuração distribuída}

Para caracterizar o concreto da viga, estipulou-se o modelo de material denominado "total strain based crack model", que adota como base a abordagem de fissuração distribuída e pertence à classe "concreto e alvenaria" da biblioteca de materiais disponíveis no programa de computador DIANA. Esse modelo descreve o comportamento do concreto aos esforços de compressão e tração por meio de diagramas de tensões em função de deformações. Relativamente às análises numéricas realizadas nesta Tese, a consideração dos seus dados de entrada se dividiu em quatro etapas: (1) escolha de um modelo de fissuração distribuída específico; (2) e (3) caracterização do comportamento à compressão e à tração, respectivamente; (4) inserção das "propriedades lineares" do material - coeficiente de Poisson, massa específica e módulo de elasticidade -, assim denominadas no programa por serem inerentes ao comportamento ainda linear elástico do concreto. Esses dados serão abordados no presente texto na ordem em que foram citados.

O DIANA possui modelos de fissuração tanto distribuída quanto discreta, não sendo possível classificar um como mais avançado em relação ao outro, uma vez que o modelo adequado depende do contexto do problema a ser investigado, i.e., em algumas situações, aqueles que 
podem parecer mais simples são capazes de conduzir a bons resultados. O modelo de fissuração discreta, por exemplo, é mais recomendado para elementos de concreto que já apresentam fissuras iniciais ou poucas fissuras, porém marcantes, conforme as ilustradas na Figura 4.9. Uma vez aparentes na configuração inicial da peça, elas devem ser modeladas com elementos de interface, ou seja, para adotar esse modelo, é necessário saber onde a fissura está presente, como se indica na Figura 4.10. Logo, esse não seria o modelo ideal para as vigas analisadas porque as mesmas não possuíam fissuras em sua configuração inicial (précarregamento) e, para o seu uso, seria preciso estabelecer onde as fissuras apareceriam, o que seria muito difícil, pois essas eram generalizadas, espalhadas por várias regiões.
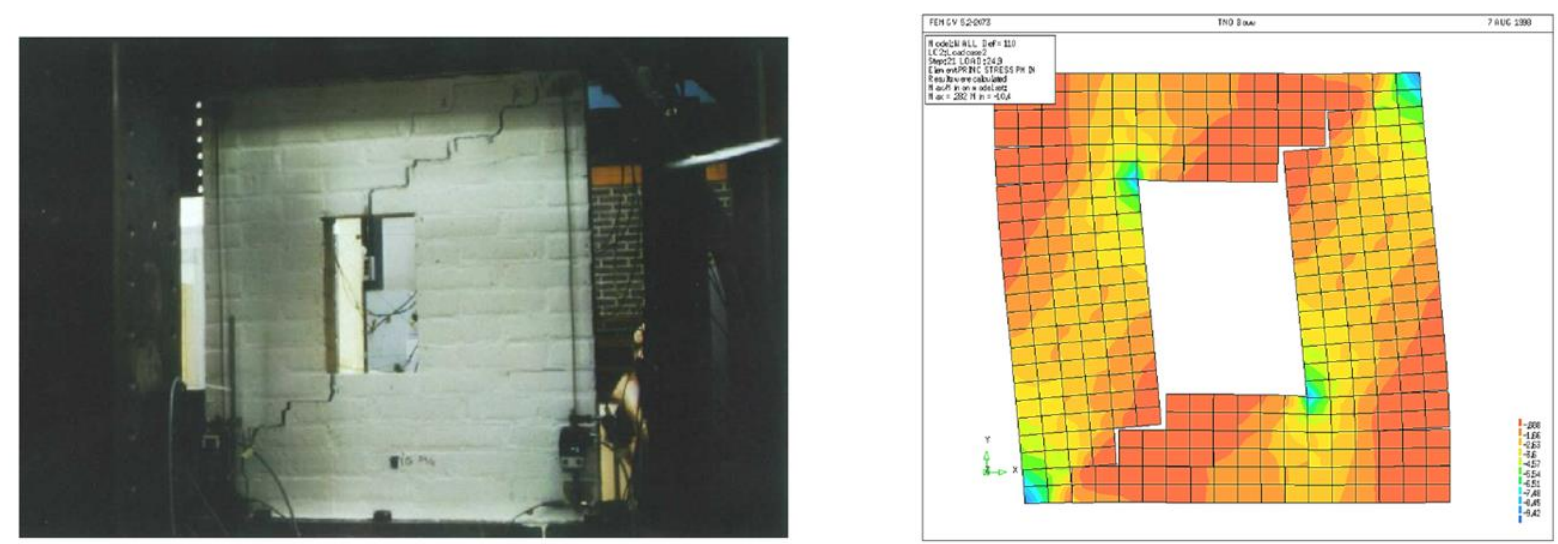

Figura 4.9 - Elemento de concreto com campo de fissuras para o qual o modelo numérico de fissuração discreta se mostra o mais adequado (DIANA FEA, 2016e).

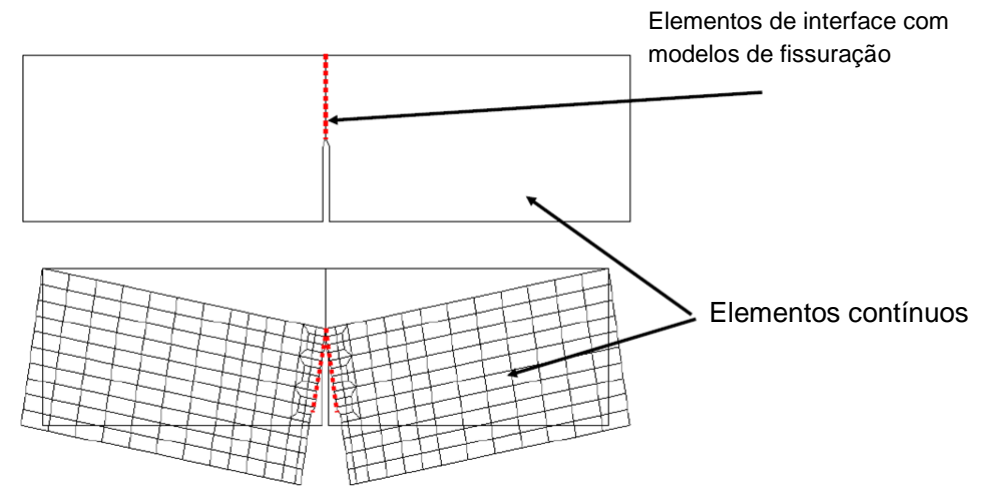

Figura 4.10 - Alguns dos procedimentos que devem ser adotados no modelo numérico com fissuras discretas: separação entre os bordos dos elementos finitos e consideração de elementos de interface (DIANA FEA, 2016e; adaptado).

Enquanto isso, nos modelos de fissuração distribuída, as fissuras são propagadas ao longo da peça a partir da imposição da carga aplicada, hipótese que mais se assemelha ao fenômeno de 
fissuração observado nos ensaios das vigas à temperatura ambiente. Ademais, como já citado ao longo do Capítulo 2 - Estado da arte, o modelo de fissuras distribuídas vem sendo satisfatoriamente adotado para as análises de estruturas de concreto armado expostas ao fogo, o que também ditou a sua escolha. Dentre alguns dos autores que fizeram esses tipos de análise pelo DIANA e o adotaram, citam-se Rafi; Nadjai e Ali (2008), Ali; Nadjai e Abu-Tair (2008) e Ali; Nadjai e Choi (2010). O conceito de fissuração distribuída foi proposto inicialmente por Rashid (1968) e se fundamenta na hipótese de que as aberturas das fissuras são distribuídas sobre os elementos finitos de concreto, tal como uma faixa de microfissuras, e de que podem ser representadas por meio das relações tensão vs deformação provenientes das mesmas (Figura 4.11).

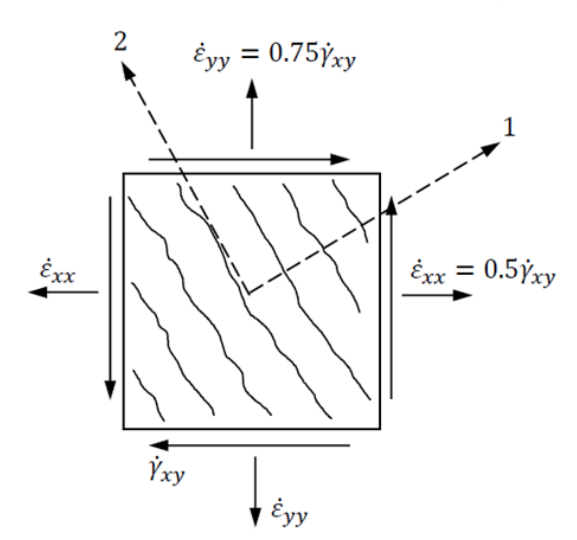

Figura 4.11 - Representação do conceito de fissuras distribuídas em um elemento finito (DIANA FEA, 2016e).

\subsection{ORIENTAÇÃO DAS FISSURAS}

O fator que distingue os modelos de fissuração distribuída pertencentes ao "total strain based crack model" disponível no DIANA se refere à hipótese adotada para representar a orientação da fissura (fixa, rotacional ou ambas, no qual se admite a orientação a mudar de rotacional para fixa). Pacheco, Lima e Lima (2013) esclareceram que, no modelo fixo, assume-se que no instante em que a tensão principal exceder um valor limite, uma fissura deverá surgir com uma direção fixa, o que irá resultar em um desalinhamento da direção das tensões principais com as deformações principais. Uma nova fissura irá aparecer apenas se a tensão principal 
formar um ângulo de $90^{\circ}$ com a fissura inicial. De acordo com Rots (1988), esse desalinhamento entre as fissuras e as direções principais proveniente do modelo fixo motivou Cope et al. (1980) a propor o modelo rotacional.

Nesse modelo, é assumido que uma fissura deverá se iniciar assim que a tensão limite de resistência à tração do material for atingida. Então, a fissura iniciada modificará a sua direção, acompanhando a direção do eixo da tensão principal e eliminando as deformações por cisalhamento. A variação contínua da direção da tensão principal induzirá a variação da direção da fissura, de modo que as direções principais das tensões e das deformações serão coincidentes durante todo o processo de fratura, ao contrário do modelo fixo (PACHECO; LIMA; LIMA, 2013; BITTENCOURT, 1999; ROTS, 1988). A Figura 4.12 esquematiza as hipóteses adotadas nos modelos rotacional e fixo, respectivamente.

Nesta Tese, adotou-se o modelo rotacional. Trata-se de um modelo robusto e bastante estável numericamente, o que se mostrou de grande valia para as análises da presente pesquisa, que envolveveriam tantas outras não linearidades, sobretudo quando da condiseração das altas temperaturas no modelo. Segundo DIANA FEA (2016a) e Scheibmeir (2012), esse modelo tem sido aplicado por um longo período para estruturas de concreto armado e tem se mostrado bastante adequado.

(a) Fissura rotacional

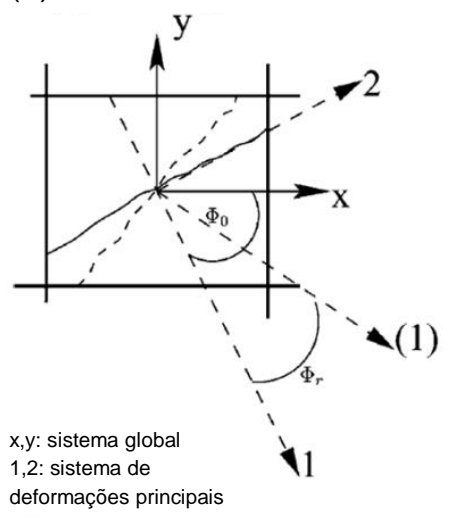

(b) Fissura fixa

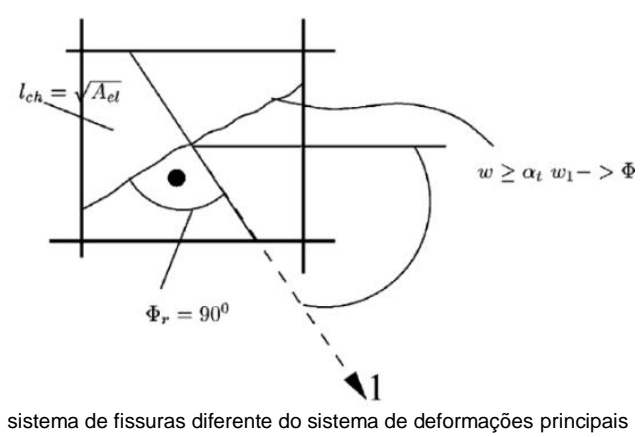

Figura 4.12 - Esquemas das hipóteses adotadas nos modelos de fissuras distribuídas (a) rotacional e (b) fixo (RABCZUK; AKKERMANN; EIBL, 2005; adaptado). 


\subsection{LARGURA DA BANDA DE FISSURAÇÃO}

A desvantagem dos modelos que têm base no conceito de fissuração distribuída reside no fato de que esses são sensíveis à dimensão da malha, uma vez que as fissuras são distribuídas sobre as áreas ou volumes dos elementos finitos. Sendo assim, o tamanho do elemento governa a energia de fratura dissipada. Porém, esse problema pode ser solucionado ao se considerar o parâmetro conhecido como largura da banda de fissuração (crack bandwidth). Ele é admitido no DIANA ao longo da caracterização do material e trabalha como um fator de escala, capaz de retirar a influência do tamanho do elemento na abertura das fissuras. Logo, uma vez considerado, o usuário não precisa de se preocupar se os elementos estão demasiado grandes ou pequenos para simular a fissuração (DIANA FEA, 2016e).

Umas das diretrizes de Belletti et al. (2016) recomenda que seja estipulado um procedimento de cálculo no qual a largura da banda de fissuração seja determinada de forma automática pelos programas de elementos finitos e, ainda, que esse procedimento deve ter base na área ou no volume do elemento finito. Sendo assim, adotou-se o modelo de Rots (1988), que consiste no default do DIANA. Esse modelo apresenta diferentes equações para o cálculo de tal parâmetro, sendo que a equação a ser adotada pelo programa depende dos seguintes itens: (1) do tipo de elemento finito utilizado na modelagem (bidimensional, sólido, viga ou treliça); (2) da dimensão do elemento finito (em termos de área, volume ou comprimento); (3) da função de interpolação do elemento finito (linear ou de ordem superior). Para discretizar a viga de concreto, estipularam-se elementos sólidos, logo, a largura da banda de fissuração (" $h$ ") calculada automaticamente seguiu o disposto na Equação 4.1, que depende do volume do elemento. Como será abordado mais em frente neste capítulo, esses elementos sólidos tinham lados iguais e com aproximadamente $40 \mathrm{~mm}$.

$$
h=\sqrt[3]{V} \therefore h=\sqrt[3]{(40)^{3} \therefore} h=40 \mathrm{~mm}
$$

Equação (4.1) 
onde:

$\mathrm{h}=$ largura da banda de fissuração $[\mathrm{mm}]$;

$\mathrm{V}=$ volume do elemento finito $\left[\mathrm{mm}^{3}\right]$.

D’Ávila (2003) informou que foram Bazant e Cedolin (1979, 1980, 1983) e Bazant e Oh (1983) que introduziram o conceito de largura de banda de fissuração nos modelos numéricos, com vistas a simular campos de fissuras em elementos de concreto, e que as propriedades do material fissurado nesses modelos são determinadas por outros dois parâmetros, além da largura de banda: a energia de fratura e a resistência à tração, que serão abordados logo a seguir. Fisicamente, esse conceito se refere à largura de uma banda de microfissuras uniformemente distribuídas, que é então representativa da zona que estará propensa ao processo de fissuração, tal como indica o esquema da Figura 4.13.

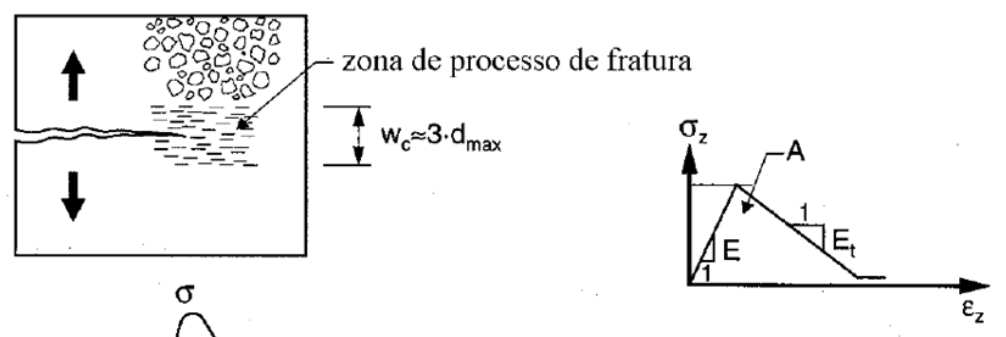

(a) energia de fraturamento

$G_{F}=A \cdot w_{c}$ (b)

Figura 4.13 - Representação da largura da banda de fissuração (neste caso, designada pelo símbolo “w”") de uma zona submetida a processo de fratura (BITTENCOURT, 1999).

\subsection{Comportamento à tração}

\subsection{MODELO EXPONENCIAL}

A baixa resistência do concreto aos esforços de tração é uma característica já conhecida desse material, por isso ele é associado ao aço, que o ajuda a resistir a tais esforços. Pacheco, Lima e Lima (2013) explicaram que essa resistência reduzida compreende a razão que leva o 
concreto a se encontrar usualmente submetido a um estado de fissuração: seja num estágio pré-carregamento, em que podem ser formadas microfissuras na interface pasta/agregado devido aos efeitos de retração, seja quando posto em situação de serviço, na qual a aplicação de cargas pode induzir a uma fissuração generalizada nas regiões em que as tensões superam a sua resistência à tração. Nesta Tese, o modelo exponencial ilustrado na Figura 4.14 foi adotado para simular o comportamento do concreto sob tração. Ele consiste em um dos modelos pré-definidos da biblioteca do DIANA que se fundamentam na Mecânica da Fratura, uma vez que as suas leis constitutivas são governadas, sobretudo, pela energia de fratura do material. A formulação completa pode ser encontrada em DIANA FEA (2016a).

Na região do ramo ascendente desse modelo, o concreto é considerado um material frágil, ainda íntegro (sem fissuras) e, portanto, com uma relação tensão vs deformação linear na direção das tensões de tração. O início da fissuração decorre do instante em que as tensões principais excedem o valor da resistência à tração do material (ponto de pico do diagrama) e, a partir daí, o mesmo passa a apresentar uma resposta não linear. De forma similar ao seu comportamento à compressão, o concreto tracionado também é capaz de resistir a esforços superiores a aqueles estabelecidos pelo seu máximo valor de resistência. Sendo assim, o material não se rompe quando a tensão de tração máxima é alcançada, mas ele passa a sofrer um decréscimo gradual dessas tensões com o aumento das deformações, sendo esse fenômeno conhecido como amolecimento do concreto (tension softening). É por esse motivo que o seu comportamento pós-pico passa a ser representado por um ramo com decaimento exponencial das tensões, sendo o amolecimento uma relação entre as tensões de tração, a zona de fratura do concreto e a largura da banda de fissuração (RAFI, 2010).

O concreto não apresenta o comportamento de um material frágil após o início da fissuração porque a aderência concreto/armadura possibilita a transmissão das tensões de tração do concreto para as armaduras e vice-versa, fazendo com que o concreto entre fissuras permaneça com uma significativa capacidade de absorver solicitações. Esse fenômeno é denominado colaboração à tração do concreto entre fissuras (tension stifenning), justamente porque acarreta uma resposta mais rígida do que aquela que seria vista num comportamento 
frágil (D’ÁVILA, 2003). Essas diferentes respostas aos esforços de tração são comparadas na Figura 4.15.

O modelo exponencial adotado engloba a modelagem tanto do fenômeno de amolecimento do concreto quanto os efeitos provenientes da sua colaboração à tração entre as aberturas de fissuras. D’Ávila (2003) comenta, à luz da pesquisa realizada por Feenstra e Borst (1995), a importância de serem adotados modelos que englobem esses dois fenômenos nas simulações numéricas do concreto fissurado, pois a rigidez de uma peça é sempre composta pela soma das contribuições das rigidezes das armaduras, do concreto simples (amolecimento) e do concreto entre fissuras. Vecchio e Collins (1986) analisaram esses fenômenos e ainda demonstraram experimentalmente, por meio de ensaios em trinta painéis de concreto armado, que uma curva de amolecimento exponencial é bastante coerente para simular o comportamento do concreto à tração, conforme ilustra a Figura 4.16.

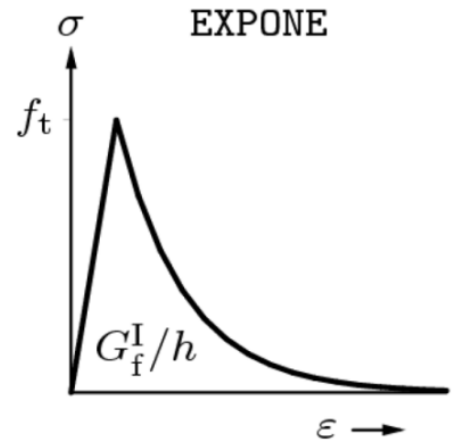

Figura 4.14 - Modelo exponencial adotado para caracterizar o comportamento do concreto aos esforços de tração (DIANA FEA, 2016a).

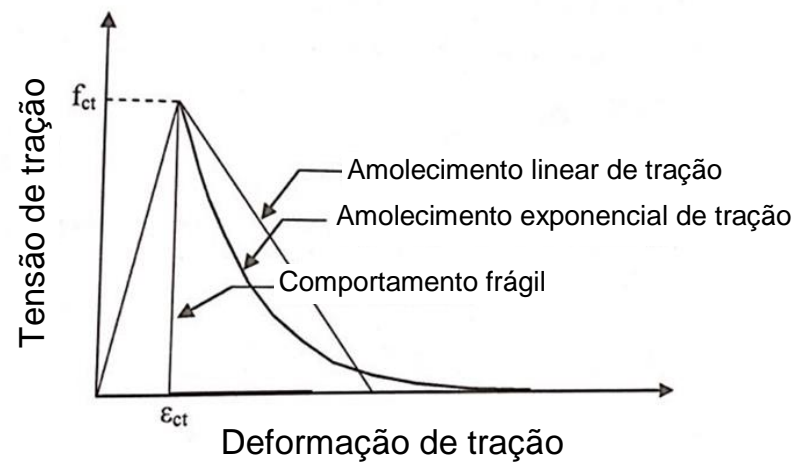

Figura 4.15 - Comparação entre modelos de tração representativos de materiais ou com comportamento frágil ou com amolecimento linear ou exponencial (RAFI, 2010; adaptado). 


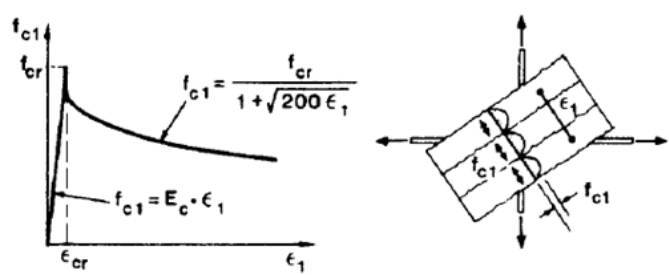

(a) Relação tensão-deformação média para concreto fissurado à tração

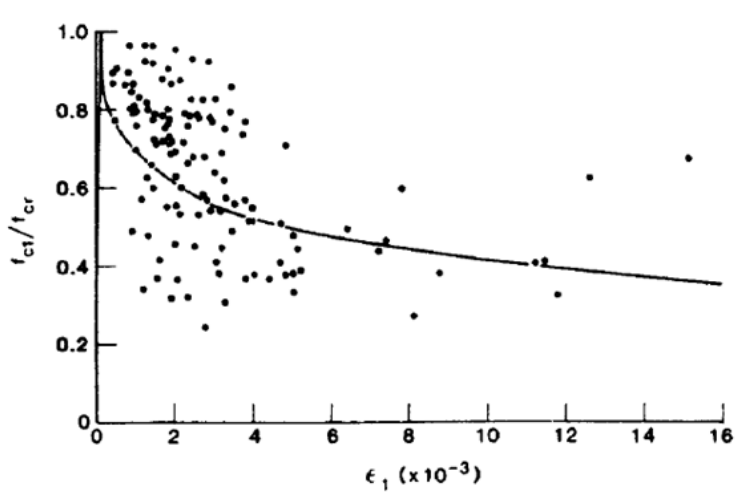

(b) Correlação de dados experimentais para concreto fissurado à tração

Figura 4.16 - Correlação entre um diagrama tensão vs deformação pré-definido com amolecimento exponencial do concreto e resultados obtidos experimentalmente (VECCHIO; COLLINS, 1986; adaptado).

\subsection{RESISTÊNCIA À TRAÇÃO}

A resistência média à tração do concreto inserida no DIANA como dado de entrada para definir a curva exponencial foi calculada a partir da Equação 4.2, proposta pelo Eurocode 2 parte 1-1 (2004). Logo, esse parâmetro foi definido analiticamente por intermédio da resistência característica à compressão do material $\left(\mathrm{f}_{\mathrm{ck}}\right)$, aqui admitida igual à resistência média à compressão $\left(\mathrm{f}_{\mathrm{cm}}\right)$, que foi medida de forma experimental no dia em que se efetuou o ensaio à temperatura ambiente da viga sob análise.

$$
\begin{gathered}
f_{c t m}=0,3 \times\left(f_{c m}\right)^{2 / 3} \\
f_{c t m}=0,3 \times(26,238)^{2 / 3} \therefore f_{c t m}=2,649 \mathrm{~N} / \mathrm{mm}^{2}
\end{gathered}
$$

onde:

$\mathrm{f}_{\mathrm{ctm}}=$ resistência média à tração simples do concreto $\left[\mathrm{N} / \mathrm{mm}^{2}\right]$;

$\mathrm{f}_{\mathrm{cm}}=$ resistência média à compressão do concreto $\left[\mathrm{N} / \mathrm{mm}^{2}\right]$. 


\subsection{ENERGIA DE FRATURA À TRAÇÃO NO MODO I}

A energia de fratura consiste na energia necessária para criar uma unidade de área de fissura e corresponde à área que se encontra sob a curva tensão vs abertura de fissura, vide Figura 4.14, que a representou pelo símbolo $\mathrm{G}_{\mathrm{fI}}$, indicativo da energia de fratura à tração do concreto no modo I. Esse modo é também conhecido como modo de abertura, pois é característico da deformação imposta apenas pela abertura de fissuras. Enquanto isso, o modo II de deformação de fissura compreende ou o deslizamento ou o corte e o modo III o rasgamento (Figura 4.17). A consideração dos modos II e III está associada a modelos numéricos que exigem graus mais avançados de sofisticação (BORGES, 2002; D’ÁVILA, 2003).

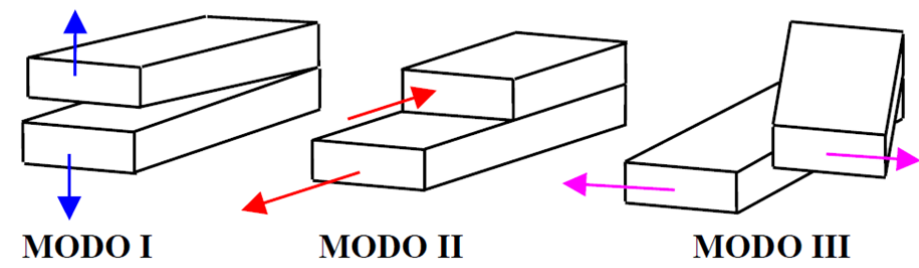

Figura 4.17 - Representação dos modos I a III de deformação de fissuras (D’ÁVILA, 2003).

Existem várias equações disponíveis na literatura para o cálculo de $\mathrm{G}_{\mathrm{fI}}$. Algumas são governadas, por exemplo, pelo tamanho do agregado máximo do concreto. Dentre essas, citase Wittmann (2002), que concebeu uma função para determinar esse parâmetro com base em resultados obtidos experimentalmente em Trunk e Wittmann (1998), como ilustra a Figura 4.18. Outras equações estabelecem como dado de entrada o valor médio da resistência à compressão do concreto, como aquela indicada tanto pelo Model Code 2010 (2011) quanto por Belletti et al. (2016).

Na falta de uma equação proposta ou pelo Eurocode 2 parte 1-1 (2004) ou pela ABNT NBR 6118 (2014), adotou-se a indicada pelo Model Code 2010 (2011), transcrita na Equação 4.3. O máximo agregado das vigas ensaiadas possuíam $16 \mathrm{~mm}$, o que não tornaria o resultado 
encontrado pelo gráfico de Trunk e Wittmann (1998) muito diferente daquele aqui adotado. Além disso, a energia de fratura em modo I igual a $0,1314 \mathrm{~N} / \mathrm{mm}$ se encontra dentro da faixa de valores de $\mathrm{G}_{\mathrm{fI}}$ citada por Neto (2015) no que se refere a vigas de concreto armado: entre 0,04 e $0,2 \mathrm{~N} / \mathrm{mm}$.

$$
\begin{gathered}
G_{f I}=73 \times\left(f_{c m}\right)^{0,18} \\
G_{f I}=73 \times(26,238)^{0,18} \therefore G_{f I}=131,441 \mathrm{~N} / \mathrm{m} \therefore G_{f I}=0,1314 \mathrm{~N} / \mathrm{mm}
\end{gathered}
$$

onde:

$\mathrm{G}_{\mathrm{fI}}=$ energia de fratura à tração do concreto no modo $\mathrm{I}[\mathrm{N} / \mathrm{mm}]$.

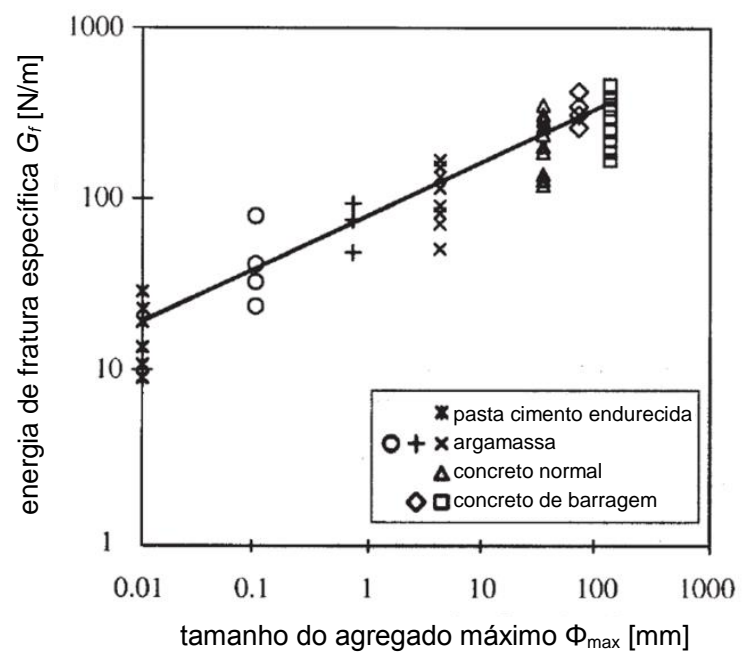

Figura 4.18 - Gráfico com resultados experimentais de energia de fratura em função do máximo diâmetro do agregado (TRUNK; WITTMANN, 1998; adaptado).

\subsection{Comportamento à compressão}

\subsection{MODELO PARABÓLICO}

O comportamento do concreto submetido a esforços de compressão foi simulado numericamente por intermédio do modelo parabólico ilustrado na Figura 4.19, também 
pertencente à biblioteca de modelos pré-definidos do DIANA. O mesmo foi concebido por Feenstra (1993), que propôs ao concreto sob compressão um comportamento linear elástico até o valor de, aproximadamente, $30 \%$ da sua resistência à compressão (trecho do diagrama entre 0 e $\alpha_{c} / 3$ ). Depois disso, a permanência dos esforços aplicados resulta em um decréscimo gradual da rigidez do concreto (trecho $\alpha_{c} / 3-\alpha_{c}$ ). Se as deformações continuarem após ter sido atingido o valor máximo da resistência à compressão (em $\left.\alpha_{c}\right)$, a curva apresentará um ramo descendente que é característico do amolecimento do material. Nesse modelo, assumeme que tal amolecimento pode ser representado a partir da energia de fratura para o concreto comprimido $\left(\mathrm{G}_{\mathrm{c}}\right)$, tomando como base, portanto, o mesmo critério de energia usualmente adotado para simular o amolecimento do material frente a esforços de tração. As equações constitutivas desse modelo também são indicadas em DIANA FEA (2016a).

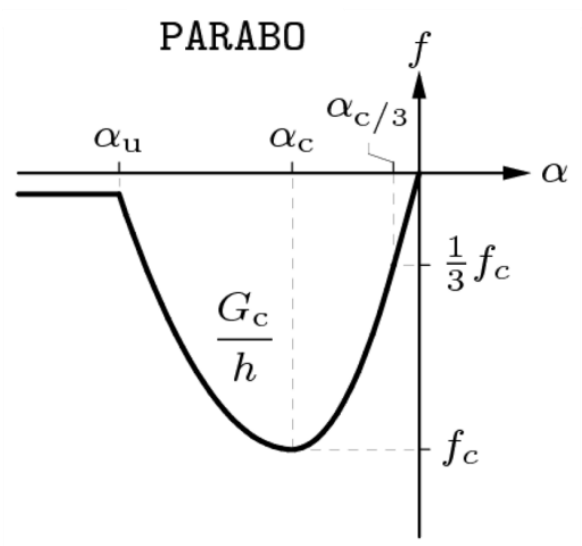

Figura 4.19 - Modelo parabólico adotado para caracterizar o comportamento do concreto aos esforços de compressão (DIANA FEA, 2016a).

O modelo parabólico foi adotado com base nas diretrizes de Belletti et al. (2016). Os autores recomendam que o comportamento à compressão do concreto seja definido com a imposição de um limite para a sua tensão à compressão e, ainda, com a consideração de modelos que apresentem uma curva tensão vs deformação parabólica para simular o amolecimento do material. Essa curva deve ter base na energia de fratura à compressão com o objetivo de reduzir a sensibilidade do tamanho da malha na localização das deformações resultantes dos esforços de compressão (por isso o valor da energia de fratura " $\mathrm{G}_{\mathrm{c}}$ " está relacionado à largura 
da banda de fissuração “h”, vide Figura 4.19). Haja vista que o modelo parabólico de Feenstra (1993) atende a todos esses requisitos, eles o apontam como o preferível.

Em contrapartida, Belletti et al. (2016) não aconselham o uso de modelos nos quais apenas se limitam as resistências à compressão do material ou suas deformações específicas, tais como os modelos elastoplástico e parábola-retângulo propostos no Eurocode 2 parte 1-1 (2004) para o dimensionamento de estruturas de concreto (ilustrados na Figura 4.20). Eles alegam que as análises numéricas conduzidas com esses modelos devem sempre ser procedidas de verificações para checar as deformações geradas pela compressão do material.
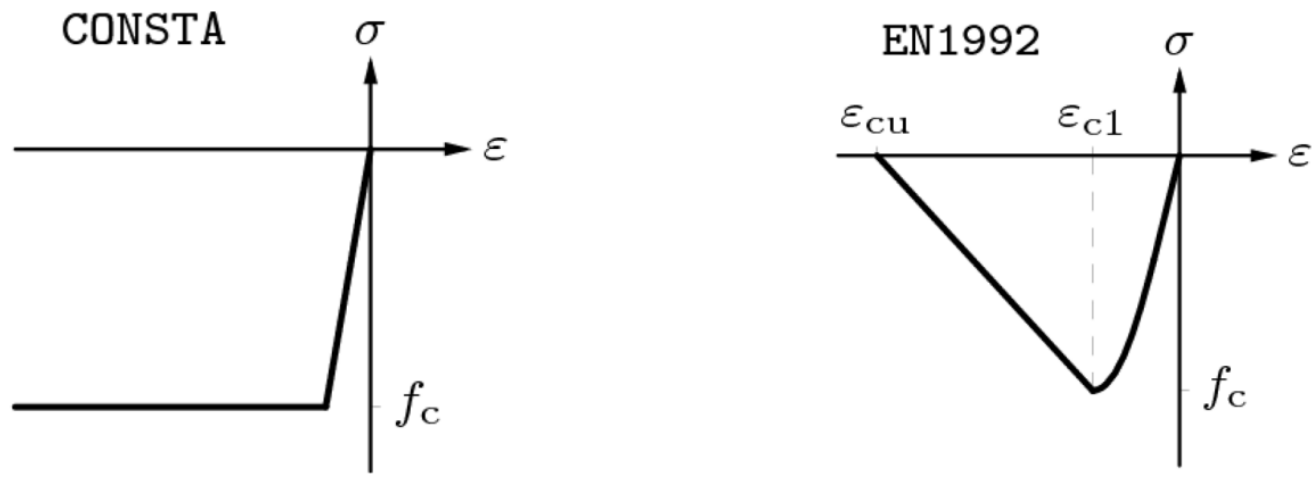

Figura 4.20 - Modelos do comportamento do concreto à compressão do tipo elastoplástico perfeito e parábolaretângulo, propostos pelo Eurocode 2 parte 1-2 (2004), respectivamente (DIANA FEA, 2016a).

É importante esclarecer que o DIANA disponibiliza o modelo parábola-retângulo da norma europeia. Ele foi testado em algumas das simulações numéricas realizadas nesta Tese, porém, não foi utilizado justamente pelo motivo exposto por Belletti et al. (2016). Uma vez adotado para simular o comportamento à compressão do concreto, a curva força aplicada vs flecha, traçada para validar o modelo de viga à temperatura ambiente, apresentou trechos de descontinuidade, que caracterizavam perdas da capacidade de carga. Ao investigar o comportamento da peça, verificou-se que essas quedas que ocorriam na curva eram resultantes justamente do esmagamento em alguns elementos de concreto localizados nas fibras superiores da viga (região mais solicitada à compressão). Alguns desses elementos tinham atingido o valor de 1,9274\%o, estipulado para a deformação específica correspondente à tensão de compressão máxima (denominada $\varepsilon_{\mathrm{c} 1}$ na norma europeia), e outros deles até 
superado a deformação específica última $\left(\varepsilon_{\mathrm{cu} 1}\right)$ de 3,5\%, sendo que esses valores foram estipulados com base na própria norma europeia, a partir da resistência média à compressão do concreto $\left(\mathrm{f}_{\mathrm{cm}}\right)$, parâmetro obtido experimentalmente para esse material.

Nos ensaios, o esmagamento do concreto chegou a ocorrer em zonas próximas das chapas de distribuição de forças, porém, apenas em estágios mais avançados, bem depois da carga máxima ter sido atingida. Enquanto isso, na viga modelada no DIANA com concreto à compressão conforme diagrama parábola-retângulo da norma europeia, o fenômeno de esmagamento ocorria mais cedo. Então, foram feitas algumas tentativas: a redução do tamanho dos elementos da malha "atrasavam" essas quedas, porém, elas não deixavam de ocorrer; o aumento dos valores de $\varepsilon_{\mathrm{c} 1}$ e $\varepsilon_{\mathrm{cu} 1}$ também não foi capaz de retardar o esmagamento, provavelmente pelo fato de terem sido rupturas muito localizadas, de modo que se tornava difícil prever o comportamento à compressão. Por esses motivos, confirmou-se que a proposta da norma, nesse caso, realmente não consistia na melhor opção, uma vez que o objetivo principal do presente estudo consistia em conceber um modelo numérico que representasse da melhor forma possível o comportamento da estrutura na realidade, ou seja, com resultados próximos aos experimentais. Os modelos de materiais indicados pelas normas, muitas vezes, podem ter base em valores conservadores, considerando que a função dos mesmos é a aplicação na prática dos projetos de estruturas.

\subsection{RESISTÊNCIA E ENERGIA DE FRATURA À COMPRESSÃO}

A resistência máxima à compressão do concreto estipulada como dado de entrada no DIANA para a definição do modelo parabólico foi a obtida pela média das resistências dos corpos de prova ensaiados na prensa do laboratório no dia da realização do ensaio de viga à temperatura ambiente escolhido para ser modelado no programa, conforme já comentado ao longo desse texto. Logo, $\mathrm{f}_{\mathrm{cm}}=26,238 \mathrm{~N} / \mathrm{mm}^{2}$. A energia de fratura à compressão foi calculada pela Equação 4.4, proposta pelo Model Code 2010 (2011). 


$$
\begin{gathered}
G_{c}=250 \times G_{f I} \\
G_{c}=250 \times 0,1314 \therefore G_{c}=32,85 \mathrm{~N} / \mathrm{mm}
\end{gathered}
$$

Equação (4.4)

onde:

$\mathrm{G}_{\mathrm{c}}=$ energia de fratura à compressão do concreto $[\mathrm{N} / \mathrm{mm}]$.

\subsection{Comportamento linear elástico}

\subsection{COEFICIENTE DE POISSON E MASSA ESPECÍFICA}

Nesta seção serão apresentadas as propriedades lineares do concreto, assim denominadas no programa de computador DIANA por caracterizarem a fase em que o material ainda apresenta comportamento linear elástico. O coeficiente de Poisson foi assumido igual a 0,2, seguindo a recomendação do Eurocode 2 parte 1-1 (2004). A massa específica adotada foi igual a $2297,953 \mathrm{~kg} / \mathrm{m}^{3}$, sendo esse valor a média dos resultados obtidos experimentalmente pelos ensaios em três amostras cúbicas de concreto proveniente da primeira concretagem.

\subsection{MÓDULO DE ELASTICIDADE}

O Eurocode 2 parte 1-1 (2004) indica a Equação 4.5 para o cálculo do módulo de elasticidade do concreto, definido na norma como o módulo secante entre a tensão de compressão no concreto igual a 0 e $0,4 \mathrm{f}_{\mathrm{cm}}$. Contudo, essa equação resulta em valores que são representativos de concretos com agregados de quartzito. Para adaptar esses valores a agregados calcários, a mesma esclarece que deve ser aplicada a eles uma redução de 10\%. A seguir, indica-se o valor estabelecido como dado de entrada para o módulo de elasticidade ou módulo de Young, 
sendo esse um dos parâmetros novamente calculados com base no valor de $f_{c m}$ obtido experimentalmente.

$$
\begin{gathered}
E_{c m}=\left[22 \times\left(\frac{f_{c m}}{10}\right)^{0,3}\right] \times 0,9 \therefore E_{c m}=\left[22 \times\left(\frac{26,238}{10}\right)^{0,3}\right] \times 0,9 \\
E_{c m}=26,446 \mathrm{GPa} \therefore E_{c m}=26,446 \times 10^{3} \mathrm{~N} / \mathrm{mm}^{2}
\end{gathered}
$$

onde:

$\mathrm{E}_{\mathrm{cm}}=$ módulo de elasticidade secante do concreto $\left[\mathrm{N} / \mathrm{mm}^{2}\right]$.

Outra opção para determinar o módulo secante consiste em traçar, efetivamente, o gráfico que apresenta as relações entre tensões e deformações do concreto. Com base nos valores fixos de $\mathrm{f}_{\mathrm{cm}}$ e $\varepsilon_{\mathrm{c} 1}$ e estipulando deformações ( $(\varepsilon)$ para $\mathrm{o}$ material, calculam-se as tensões correspondentes por meio da equação fornecida pelo Eurocode 2 parte 1-2 (2004), considerando a condição de temperatura ambiente. Encontrada a tensão aproximada de $0,4 \mathrm{f}_{\mathrm{cm}}$ e a deformação que corresponde a ela, é possível determinar o módulo pelo coeficiente angular da reta secante à curva do diagrama traçada da origem até esses pontos. Quando calculado por meio gráfico, o módulo de elasticidade do concreto foi igual a 20,228 x $10^{3}$ $\mathrm{N} / \mathrm{mm}^{2}$. Porém, após algumas análises, verificou-se que o valor advindo da Equação 4.5 se mostrou mais representativo dos resultados dos ensaios experimentais e, por isso, foi definido como dado de entrada para o modelo numérico.

Por fim, no que tange à caracterização do concreto, é válido pontuar que as propriedades apresentadas anteriormente também foram calculadas para o material proveniente da segunda concretagem realizada para a produção das vigas adotadas na campanha experimental desta investigação. Esses cálculos foram realizados de forma similar, considerando como base o valor médio da sua resistência à compressão $\left(f_{\mathrm{cm}}\right)$, obtida por meio de ensaios em amostras cúbicas de concreto. Isso foi feito para verificar se os resultados numéricos provenientes de vigas modeladas com as propriedades dos concretos das diferentes concretagens seriam similares, do mesmo modo que se verificou experimentalmente. 
Adotou-se para essa verificação o concreto da segunda concretagem, pois o seu valor de $f_{c m}$ foi o que se mostrou mais diferente das outras $\left(f_{\mathrm{cm}, 1 \mathrm{a} \text { conc }}=26,2378 \mathrm{MPa} ; \mathrm{f}_{\mathrm{cm}, 2 \mathrm{a} \text { conc }}=29,8087\right.$ $\left.\mathrm{MPa} ; \mathrm{f}_{\mathrm{cm}, 3 \mathrm{a} \text { conc }}=26,5231 \mathrm{MPa}\right)$. Pela Figura 4.21, certificou-se que as curvas de forças em função das flechas para os concretos das duas concretagens analisadas foram praticamente iguais. Esses modelos ainda apresentaram campos de fissuras e modo de colapso similares. Logo, optou-se por considerar a viga com o concreto da primeira concretagem como aquela representativa dos modelos à temperatura ambiente.

Também não se verificou a necessidade de modelar vigas com os dados de cada uma das concretagens nas análises seguintes, com a consideração de temperaturas elevadas, porque as massas específicas e os teores de umidade adotados para a determinação das propriedades térmicas do material também foram muito parecidos $\left(\mathrm{u}_{1 \mathrm{a} \text { conc }}=1,664 \%\right.$; $\mathrm{u}_{2 \mathrm{a} \text { conc }}=1,654 \%$; $\left.u_{3 a \text { conc }}=1,695 \% ; \rho_{1 \mathrm{a} \mathrm{conc}}=2297,95 \mathrm{~kg} / \mathrm{m}^{3} ; \rho_{2 \mathrm{aconc}}=2308,45 \mathrm{~kg} / \mathrm{m}^{3} ; \rho_{3 \mathrm{a} \mathrm{conc}}=2290,48 \mathrm{~kg} / \mathrm{m}^{3}\right)$. Além disso, os valores de $\mathrm{f}_{\mathrm{cm}}$ obtidos nos primeiros dias de ensaios das vigas com concretos de cada uma das concretagens pouco diferiram daqueles obtidos no último dia de ensaios, haja vista que as variações não foram superiores a $1,1 \%$. Portanto, as propriedades do concreto para a condição de temperatura ambiente de todas as vigas analisadas de forma numérica foram sempre admitidas conforme os cálculos apresentados nesta seção, ou seja, com base no valor de $\mathrm{f}_{\mathrm{cm}}$ obtido experimentalmente no primeiro dia de ensaio de uma viga da primeira concretagem, bem como com os valores também experimentais de massa específica e umidade da primeira concretagem.

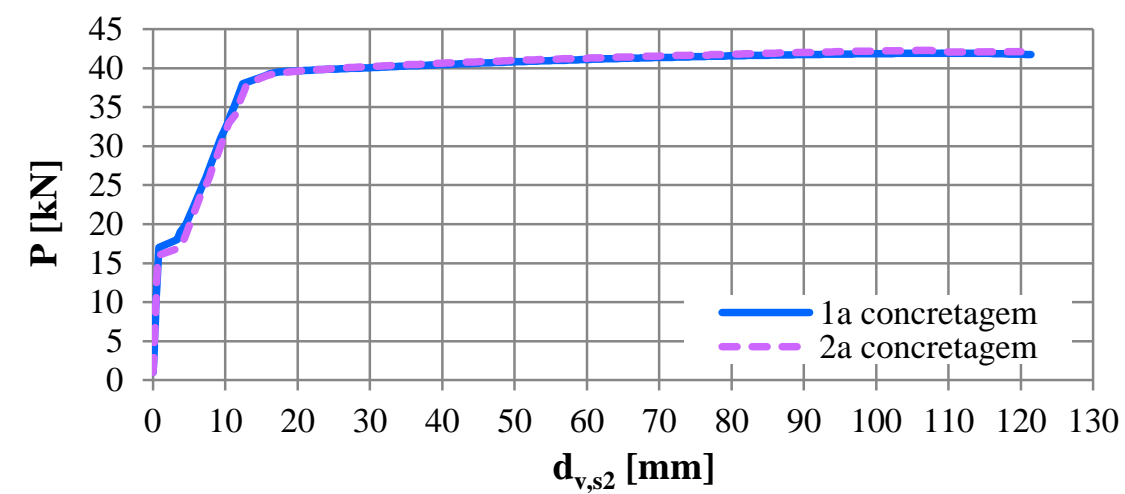

Figura 4.21 - Resultados numéricos de força aplicada em função da flecha (deslocamento vertical na seção S2, a meio vão) para concretos provenientes da $1^{\mathrm{a}}$ e $2^{\mathrm{a}}$ concretagens. 


\subsubsection{Aço dos blocos dos apoios e das chapas de distribuição das forças}

Os blocos dos apoios e as chapas de distribuição de forças utilizadas nos ensaios experimentais foram fabricados com aço S275 JR (designação europeia). Para representar esse material no DIANA, adotou-se o modelo denominado "linear elástico isotrópico", pertencente à classe aço da biblioteca de materiais do programa. Nesse modelo, bastavam ser introduzidas as suas propriedades lineares, o que se mostrou suficiente, já que esses blocos e chapas não possuíam função estrutural, mas sim funcionavam como elementos auxiliares, para transmitir condições de apoio ou para introduzir superfícies onde se poderiam distribuir forças. Tanto o coeficiente de Poisson, igual a 0,3, quanto o módulo de elasticidade, igual a $210 \times 10^{3} \mathrm{~N} / \mathrm{mm}^{2}$, foram adotados conforme as prescrições do Eurocode 3 parte 1-1 (2005). Estipulou-se a massa específica igual à zero para não tornar esses elementos muito rígidos às zonas que os circundam, nas quais deve ser evitada a questão da concentração de tensões, já abordada ao longo deste capítulo.

\subsubsection{Aços das armaduras longitudinais e transversais}

No DIANA, uma armadura é definida a partir da sua localização no modelo, das propriedades mecânicas do material que a constitui, das suas propriedades físicas (dimensão da seção transversal) e do método que deve ser adotado para a sua discretização. A localização é definida ao longo da etapa de geometria, enquanto os dois próximos itens fazem parte da atribuição de propriedades. Logo, nesta seção serão apresentadas as informações acerca dos parâmetros mecânicos e físicos do material, bem como do modelo constitutivo adotado para caracterizar o seu comportamento. O método de discretização estipulado para as armaduras será abordado mais adiante, junto às considerações sobre a malha de elementos finitos. 
A priori, elucida-se que tanto as armaduras longitudinais quanto as transversais foram definidas como embutidas (incorporadas) ao concreto. Esse é o procedimento mais recomendado para simular a contribuição da armadura na resposta global de uma estrutura ou de um elemento estrutural, tal como a viga de estudo. Em outras palavras, as armaduras embutidas são indicadas para modelos numéricos complexos, que já envolvem um grande número de variáveis, e, por isso, para os quais não se mostra viável modelar cada um dos seus componentes de forma muito detalhada. Em contrapartida, as armaduras discretas, também disponíveis no programa, são recomendadas para análises específicas, em que as armaduras representam o foco de estudo. Por exemplo, para modelar os pormenores do fenômeno da perda de aderência ou do escorregamento em barras isoladas. Ao contrário das armaduras embutidas, definidas na geometria do modelo a partir de linhas simples, as discretas precisam ser modeladas com elementos sólidos cilíndricos, sendo ainda necessário admitir elementos de interface para conectar as superfícies concreto/aço (DIANA FEA, 2016e).

\subsection{Modelo elastoplástico com patamar de escoamento}

O modelo de material escolhido para simular o comportamento das armaduras longitudinais e dos estribos foi o proposto pelo Eurocode 2 parte 1-2 (2004), pertencente à classe "Reinforcements and pile foundations" do programa. O diagrama que relaciona as tensões de tração em função das deformações específicas das armaduras proposto pela norma europeia se encontra ilustrado na Figura 4.22. Esse contempla, além da região elastoplástica, um patamar bem definido de escoamento do aço.

Com base nos artigos analisados ao longo da pesquisa do estado da arte, verificou-se que enquanto a fluência do concreto não consiste em um fenômeno determinante na resposta ao fogo das vigas de concreto armado, a fluência do aço deve ser considerada para que os valores das flechas não sejam subestimados (BRATINA et al., 2003; BRATINA; SAJE; PLANINC, 2007 e LU et al., 2015a). Ainda segundo os autores que apresentaram essas investigações a 
abordar a fluência dos materiais, os modelos constitutivos propostos pelo Eurocode 2 parte 12 (2004) consideram tal fenômeno de forma implícita, razão para o modelo da norma europeia indicado para o aço de armaduras ter sido adotado no modelo numérico desta Tese, sendo que esse mesmo modelo foi depois adaptado para as análises ao fogo.

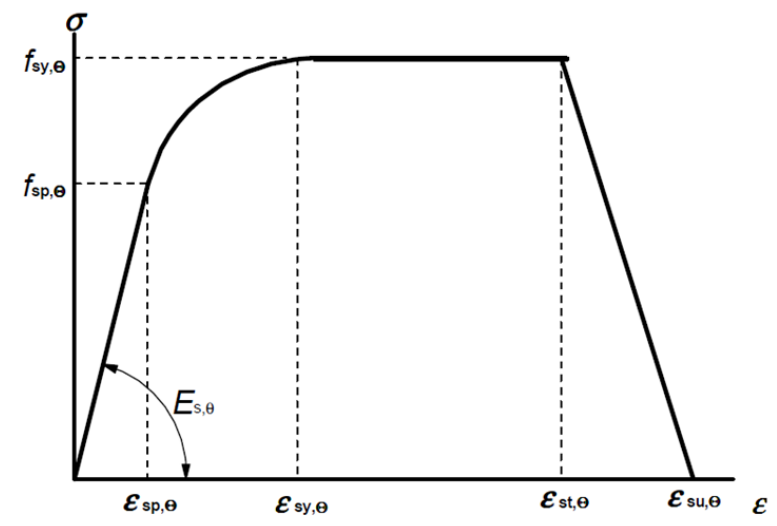

Figura 4.22 - Diagrama tensão vs deformação proposto pelo Eurocode 2 parte 1-2 (2004) para aço de armaduras.

\subsection{Tensões de tração, deformações específicas e módulo de elasticidade}

Para definir o modelo proposto pelo Eurocode 2 parte 1-2 (2004) no DIANA, é necessário que sejam inseridos como dados de entrada os valores à temperatura ambiente $\left(20^{\circ} \mathrm{C}\right)$ da tensão correspondente ao limite de proporcionalidade $\left(\mathrm{f}_{\mathrm{sp}}\right)$ e da resistência ao escoamento do aço $\left(\mathrm{f}_{\mathrm{sy}}\right)$, além das deformações específicas correspondentes à resistência ao escoamento $\left(\varepsilon_{\mathrm{sy}}\right)$, à tensão que dá início ao trecho de decaimento $\left(\varepsilon_{\mathrm{st}}\right)$ e, por fim, a deformação última $\left(\varepsilon_{\mathrm{su}}\right)$. Todos esses parâmetros estão indicados na Figura 4.22.

Realizaram-se ensaios de tração tanto em amostras das armaduras com diâmetro de $10 \mathrm{~mm}$ (longitudinais) quanto de $6 \mathrm{~mm}$ (estribos) utilizadas no fabrico das vigas de concreto armado ensaiadas. O aço que as constituía era do tipo A500 laminado a quente (designação portuguesa que corresponde, de forma similar, ao aço CA50 do Brasil). Sendo assim, os valores de $f_{s p}$ e $f_{s y}$ inseridos no DIANA para essas armaduras foram os resultantes dos diagramas tensão vs deformação obtidos experimentalmente, enquanto as deformações específicas foram adotadas 
de acordo com os valores sugeridos pela norma europeia, a fim de levar em conta a fluência do material. Também é necessário inserir no programa o módulo de elasticidade das armaduras $\left(\mathrm{E}_{\mathrm{s}}\right)$. Esse parâmetro foi calculado a partir da inclinação inicial da curva, tomando como base os resultados experimentais de $\mathrm{f}_{\mathrm{sp}}$ e $\varepsilon_{\mathrm{sp}}$.

Nas Figuras 4.23 e 4.24 são ilustradas as curvas obtidas nos ensaios superpostas pelos diagramas finais estipulados para caracterizar esses dois aços. Como pode ser visto, as curvas experimentais foram idealizadas e completadas para seguir o disposto pelo Eurocode 2 parte 1-2 (2004). Esses diagramas foram reproduzidos mediante as equações indicadas na norma europeia, a fim de ilustrar aqueles que seriam automaticamente definidos pelo programa de computador DIANA ao longo das análises. A Tabela 4.1 apresenta um resumo dos valores adotados como dados de entrada para a definição das armaduras longitudinais e dos estribos.

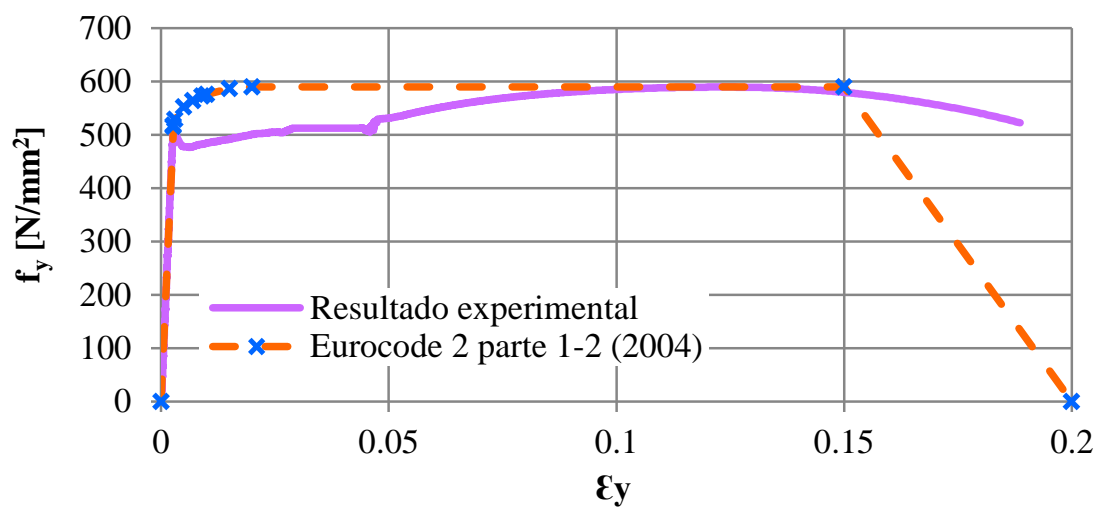

Figura 4.23 - Relação tensão vs deformação do aço com diâmetro $\phi 10 \mathrm{~mm}$ das armaduras longitudinais: comparação do resultado experimental ao diagrama idealizado com base no Eurocode 2 parte 1-2 (2004).

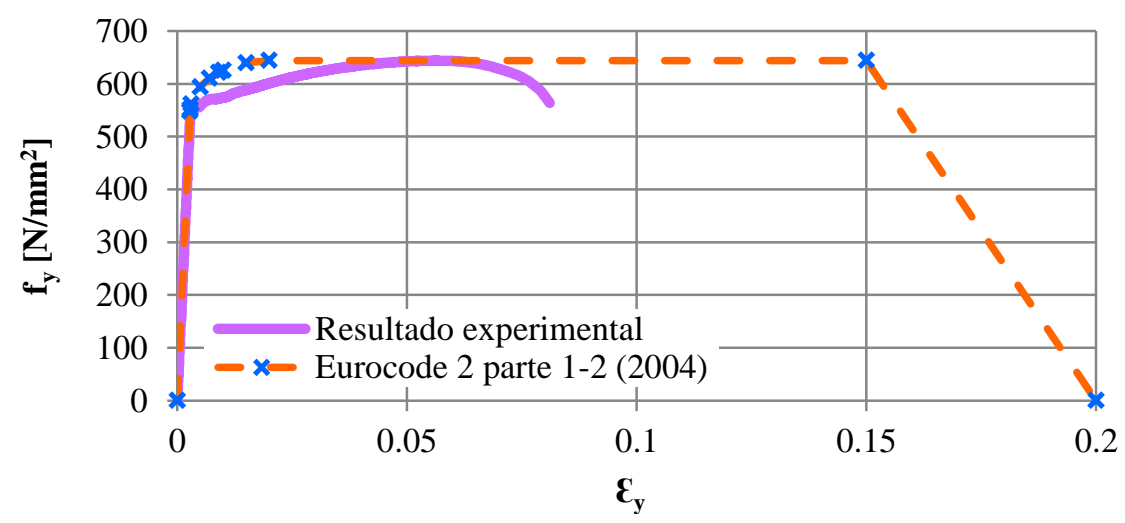

Figura 4.24 - Relação tensão vs deformação do aço com diâmetro $\phi 6 \mathrm{~mm}$ das armaduras transversais: comparação do resultado experimental ao diagrama idealizado com base no Eurocode 2 parte 1-2 (2004). 
Tabela 4.1 - Dados de entrada estipulados para a definição das armaduras longitudinais e transversais.

\begin{tabular}{|c|c|c|c|c|c|c|c|c|c|}
\hline \multirow[t]{2}{*}{ Armadura } & \multirow{2}{*}{$\begin{array}{c}\text { Diâmetro } \\
\phi \\
(\mathrm{mm})\end{array}$} & \multirow{2}{*}{$\begin{array}{c}\text { Área da seção } \\
\text { transversal } \\
\left(\mathrm{mm}^{2}\right)\end{array}$} & \multicolumn{2}{|c|}{$\begin{array}{l}\text { Tensões } \\
\left(\mathrm{N} / \mathrm{mm}^{2}\right)\end{array}$} & \multicolumn{4}{|c|}{$\begin{array}{l}\text { Deformações específicas } \\
\text { (adimensionais) }\end{array}$} & $\begin{array}{c}\text { Módulo de } \\
\text { elasticidade } \\
\left(\mathrm{x} 10^{3} \mathrm{~N} / \mathrm{mm}^{2}\right)\end{array}$ \\
\hline & & & $\mathrm{f}_{\mathrm{sp}}$ & $\mathrm{f}_{\mathrm{sy}}$ & $\varepsilon_{\mathrm{sp}}$ & $\varepsilon_{\mathrm{sy}}$ & $\varepsilon_{\mathrm{st}}$ & $\varepsilon_{\mathrm{su}}$ & $\mathrm{E}_{\mathrm{s}}$ \\
\hline Longitu & 10 & 78,5 & 515,387 & 589,669 & 0,002678 & 0,02 & 0,15 & 0,2 & 192,452 \\
\hline Transversal & 6 & 28,27 & 548,058 & 644,152 & 0,002766 & 0,02 & 0,15 & 0,2 & 198,141 \\
\hline
\end{tabular}

\subsubsection{Determinação da malha de elementos finitos}

\subsubsection{Tipos de elementos}

O modelo numérico tridimensional foi discretizado com elementos finitos denominados CHX60, cuja configuração se ilustra na Figura 4.25. Trata-se de um elemento sólido isoparamétrico do tipo "brick" com vinte nós e três graus de liberdade, que utiliza funções de interpolação quadráticas e integração de Gauss para determinar a matriz de rigidez do elemento. Pelo default, o DIANA aplica um esquema de integração de 3 x 3 x 3 pontos.

Esse consiste em um dos elementos de ordem superior recomendados pelo manual do programa (DIANA FEA, 2016a) para análises não lineares, enquanto o uso de elementos isoparamétricos com funções de interpolação lineares deve ser evitado nesse tipo de problema. Belletti et al. (2016) complementaram essa informação ao afirmar que os elementos de ordem quadrática também são os mais precisos para análises de estruturas de concreto, pois são capazes de descrever um número maior de modos de deformação, bem como modos de ruptura mais complexos (por exemplo, colapsos por cisalhamento). Os autores ainda informam que o modelo de elemento adotado nesta Tese é o mais indicado para a simulação de vigas de concreto em três dimensões. Ressalta-se que o CHX60 já foi adotado em outras 
investigações em que foram modelados elementos estruturais de concreto em $3 \mathrm{D}$, tais como em Rafi; Nadjai e Ali (2007), Ali; Nadjai e Abu-Tair (2008) e Ali; Nadjai e Choi (2010).

As armaduras foram incorporadas a essa malha de elementos finitos. Uma vez embutidas, elas foram modeladas como elementos de barras uniaxiais. Logo, não possuíam graus de liberdade próprios e as suas propriedades mecânicas, como resistência e rigidez, eram calculadas apenas na sua direção longitudinal. Para esses elementos, adotou-se um esquema de integração de $2 \mathrm{x}$ 2 x 2 pontos de Gauss. As tensões correspondentes a elas foram definidas a partir do campo de deslocamentos dos elementos estruturais que as circundavam, sendo esses denominados no manual do programa como "elementos mãe". Isso implicou na consideração de uma aderência perfeita entre as armaduras e o material constituinte dos elementos que as envolviam (o concreto). Sendo assim, manteve-se o default do programa, que admite armaduras embutidas perfeitamente incorporadas ao elemento principal.

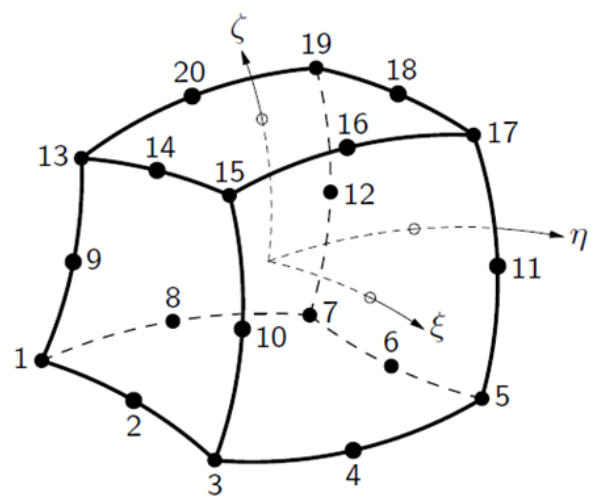

Figura 4.25 - Elemento finito sólido CHX60 (DIANA FEA, 2016a).

\subsubsection{Estudo de sensibilidade}

A precisão dos resultados obtidos a partir de análises fundamentadas no método dos elementos finitos está intimamente ligada a dois aspectos: (1) o uso de elementos apropriados para cada situação de estudo, devendo esses ser escolhidos com base na sua forma, grau de interpolação e esquema de integração; (2) correta discretização do modelo, definida a partir de 
um estudo comparativo de malhas com diferentes arranjos ou densidades (dimensões de elementos finitos). Nesta pesquisa, duas malhas foram analisadas para checar a influência do tamanho dos elementos na resposta do comportamento das vigas: uma mais grossa, constituída por elementos retangulares com lados de $40 \mathrm{~mm}$, aproximadamente; outra mais fina, com elementos retangulares de $20 \mathrm{~mm}$, conforme ilustra a Figura 4.26. A primeira malha possuía um número total de 2.880 elementos finitos e a segunda 25.875 elementos. As armaduras, por terem sido incorporadas a essa malha, também foram discretizadas em trechos com comprimentos aproximadamente iguais a 40 ou $20 \mathrm{~mm}$.

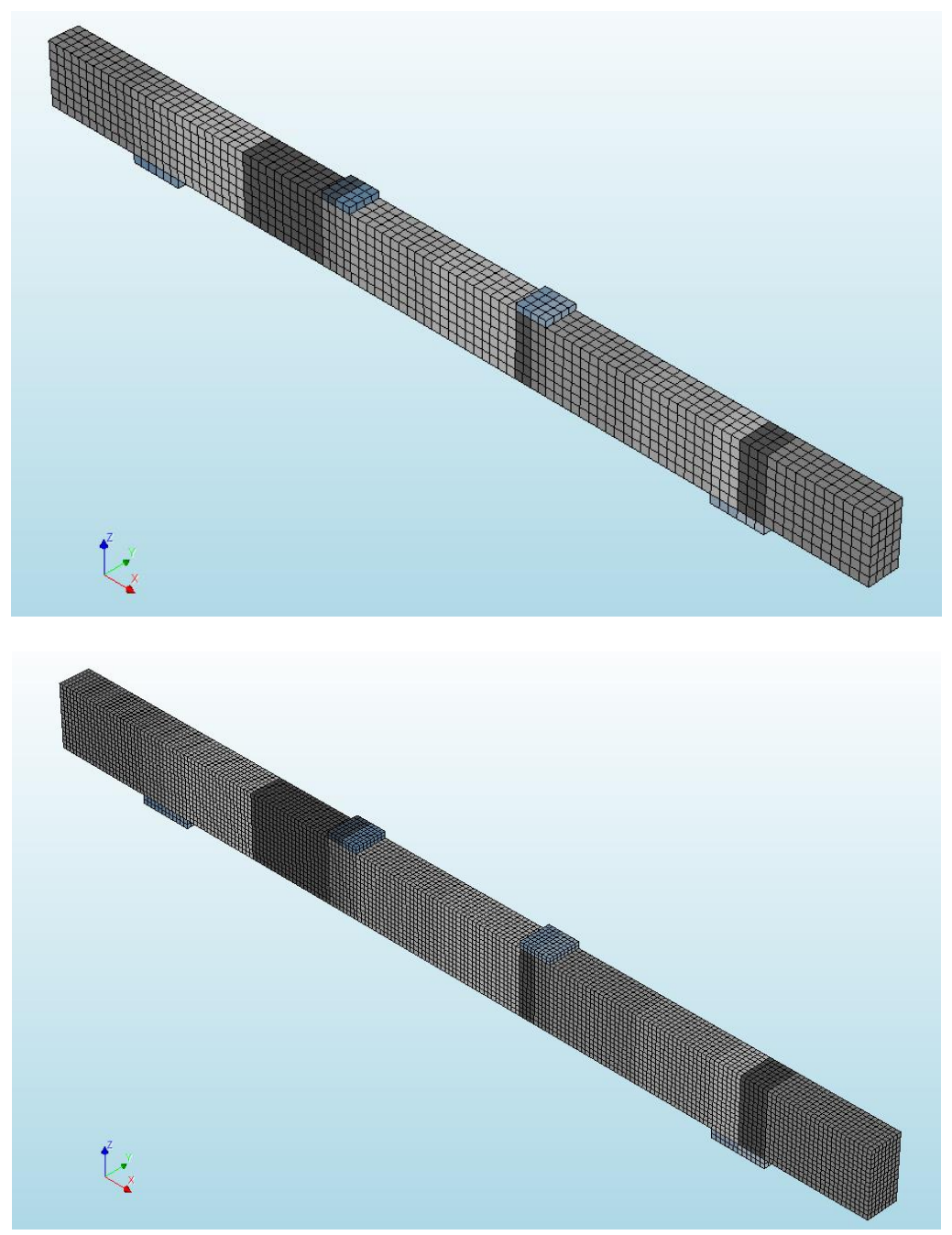

Figura 4.26 - Malhas adotadas para o estudo de sensibilidade: elementos finitos de 40x40 e 20x20 mm, respectivamente. 
Segundo Belletti et al. (2016), o menor tamanho de elemento finito a ser estudado deve ser definido com base em considerações práticas, levando-se em conta que o tempo de simulação computacional apresenta um crescimento quadrático em relação ao número de elementos presentes no modelo. Assim se justifica não terem sido apresentados os resultados de uma malha ainda mais fina, com elementos de 10 x $10 \mathrm{~mm}$. O esforço computacional exigido para a aplicação dessa malha se mostrou demasiado alto e, além disso, o tempo estimado para a obtenção de um resultado completo era inviável. Ademais, as posteriores análises ao fogo envolveriam ainda mais fenômenos de não linearidade, de modo a exigir tanto mais esforço computacional quanto tempo de simulação.

A Figura 4.27 ilustra o gráfico de forças aplicadas à viga em função dos deslocamentos verticais a meio vão obtidos a partir das malhas estudadas. As duas seguiram a mesma tendência no trecho da curva que identifica o comportamento ainda linear elástico do concreto. Ademais, apresentaram o primeiro ponto de descontinuidade, que é característico da primeira fissura de flexão mais expressiva que aparece na viga (da ordem de $10^{-1} \mathrm{~mm}$ ), para valores de carga muito próximos. No modelo com malha $40 \mathrm{~mm}$, essa primeira fissura expressiva abriu aos $18 \mathrm{kN}$ de carga aplicada e no modelo com malha de $20 \mathrm{~mm}$ se abriu logo em seguida, aos 19 kN. A Figura 4.28 apresenta essa região do gráfico mais detalhadamente.

Já no próximo trecho, após a abertura da primeira fissura até o ponto em que se inicia o patamar de carga resistida pela viga, sendo essa transição para a região do patamar proveniente do escoamento da armadura longitudinal inferior, a viga com malha de $40 \mathrm{~mm}$ apresentou menor rigidez, contudo, ainda bastante próxima da curva resultante da malha mais fina. Ambas também atingiram esse patamar devido ao escoamento da armadura, entrando na fase de estabilização da carga, de forma similar: a viga com malha de $40 \mathrm{~mm}$ o atingiu a partir de $39 \mathrm{kN}$ e a com malha de $20 \mathrm{~mm}$ a partir de $40 \mathrm{kN}$ (novamente, vide Figura 4.28).

O tamanho dos elementos finitos também não demonstrou impacto significativo na carga máxima resistida: $42 \mathrm{kN}$ na malha de $40 \mathrm{~mm}$ e $43 \mathrm{kN}$ na malha de $20 \mathrm{~mm}$. Já era esperada uma capacidade de carga um pouco menor no modelo com malha mais grossa, pois essa 
apresentou danos levemente mais acentuados no que se refere à fissuração e perda de rigidez para determinadas condições de carregamento.

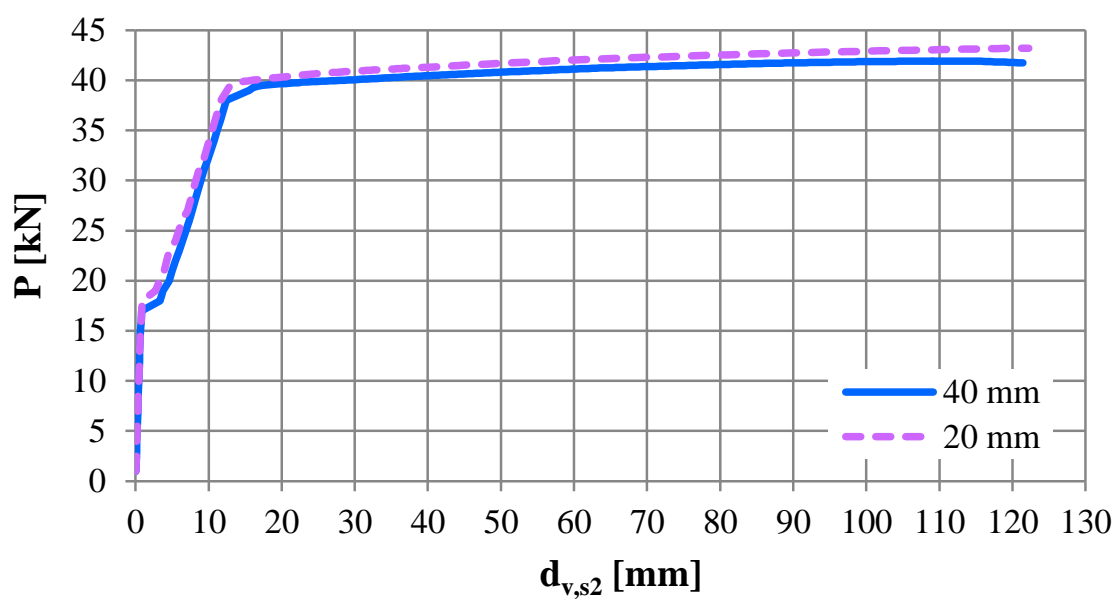

Figura 4.27 - Resultados numéricos de força aplicada em função da flecha (deslocamento vertical na seção $\mathrm{S}_{2}$ a meio vão) para diferentes malhas de elementos finitos (gráfico completo).

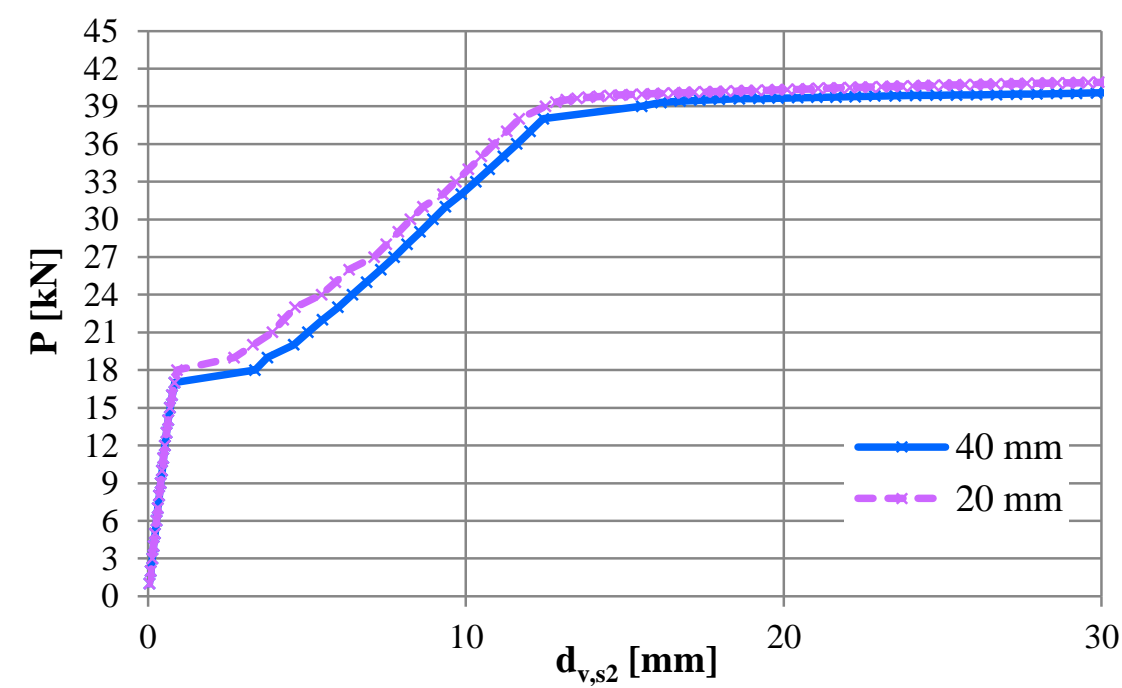

Figura 4.28 - Imagem ampliada dos trechos iniciais dos resultados numéricos de força aplicada em função da flecha (deslocamento vertical na seção $S_{2}$ a meio vão).

Os campos de fissuração e as aberturas de fissuras $\left(\mathrm{E}_{\mathrm{cw1}}\right)$ encontrados para as duas situações, em relação a alguns valores de força total aplicada, também foram bastante similares, como pode ser visto nas Figuras 4.29 a 4.34. As aberturas com valores negativos indicadas pelo programa de computador não possuem nenhum sentido físico, são apenas resíduos provenientes do método numérico adotado para calcular esse parâmetro. Portanto, esses 
valores podem ser aproximados a zero e representam regiões não fissuradas. Por fim, verificou-se o mesmo modo de ruptura - por flexão - para ambos os casos de estudo.
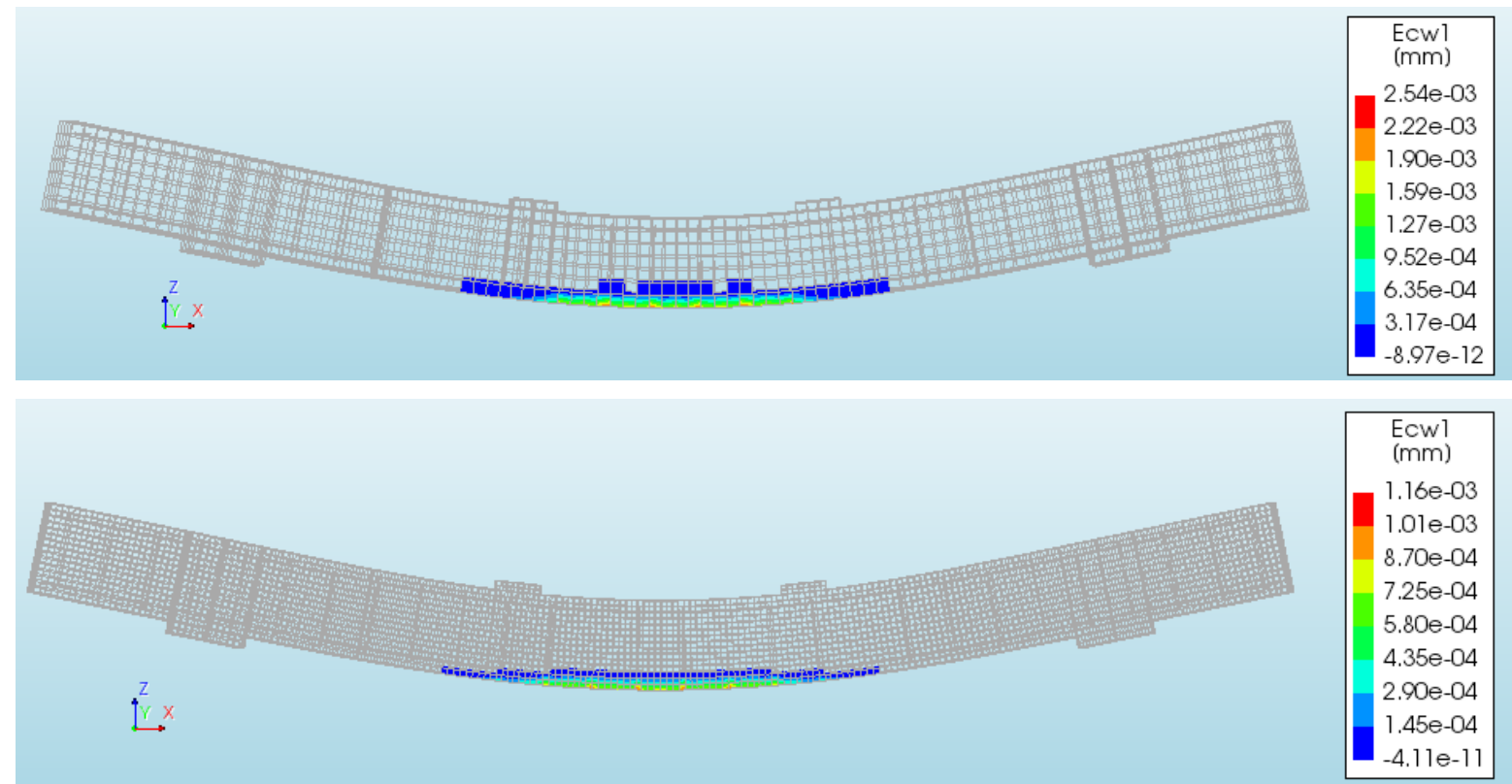

Figura 4.29 - Comparação dos campos de fissuras obtidos pelo DIANA para as malhas de 40 e $20 \mathrm{~mm}$, com a indicação das aberturas $\mathrm{E}_{\mathrm{cwl}}$, para a força total aplicada de $15 \mathrm{kN}$.

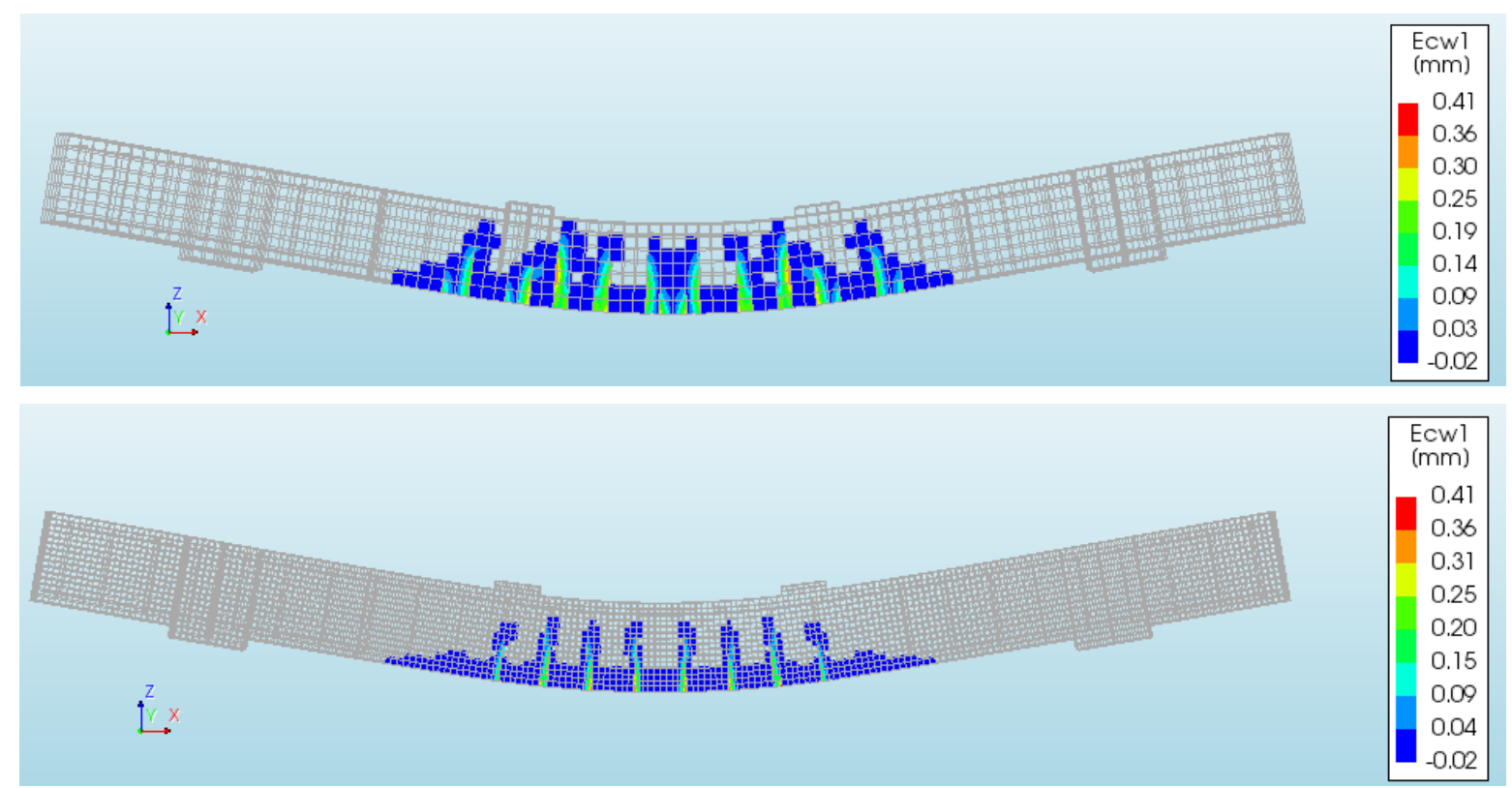

Figura 4.30 - Comparação dos campos de fissuras obtidos pelo DIANA para as malhas de 40 e $20 \mathrm{~mm}$, com a indicação das aberturas $\mathrm{E}_{\mathrm{cwl}}$, para a força total aplicada de $20 \mathrm{kN}$. 

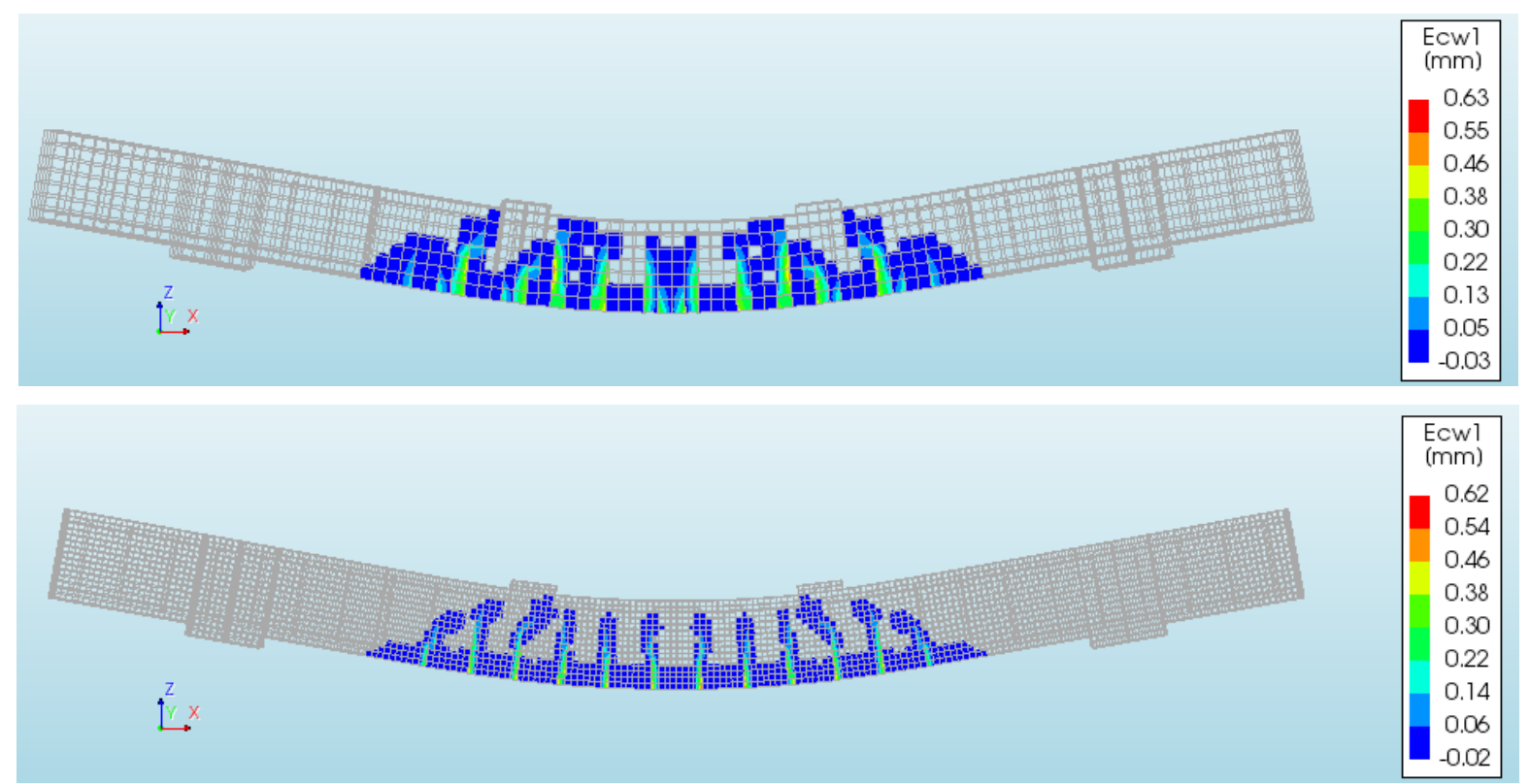

Figura 4.31 - Comparação dos campos de fissuras obtidos pelo DIANA para as malhas de 40 e $20 \mathrm{~mm}$, com a indicação das aberturas $\mathrm{E}_{\mathrm{cw} 1}$, para a força total aplicada de $25 \mathrm{kN}$.

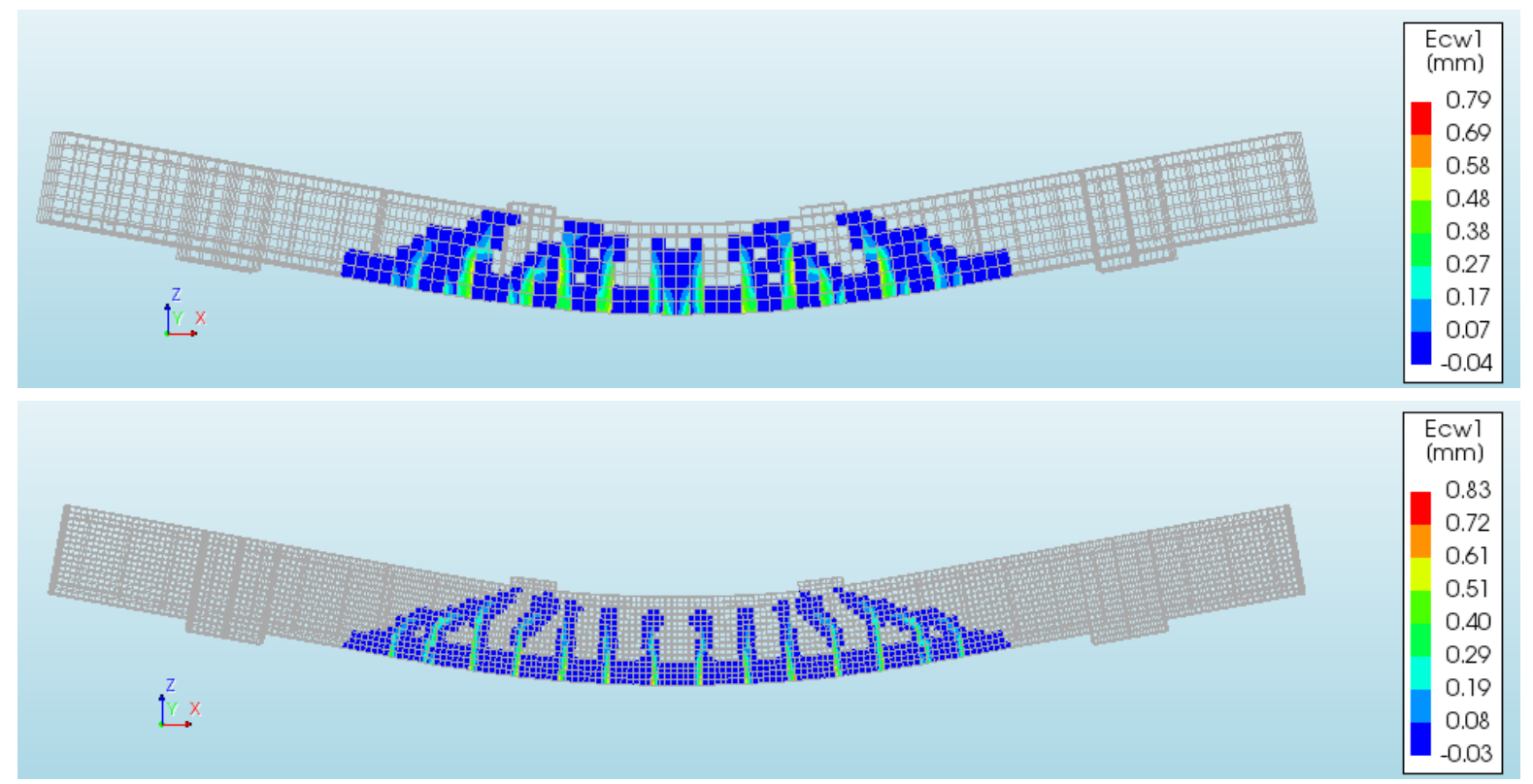

Figura 4.32 - Comparação dos campos de fissuras obtidos pelo DIANA para as malhas de 40 e $20 \mathrm{~mm}$, com a indicação das aberturas $\mathrm{E}_{\mathrm{cw} 1}$, para a força total aplicada de $30 \mathrm{kN}$. 

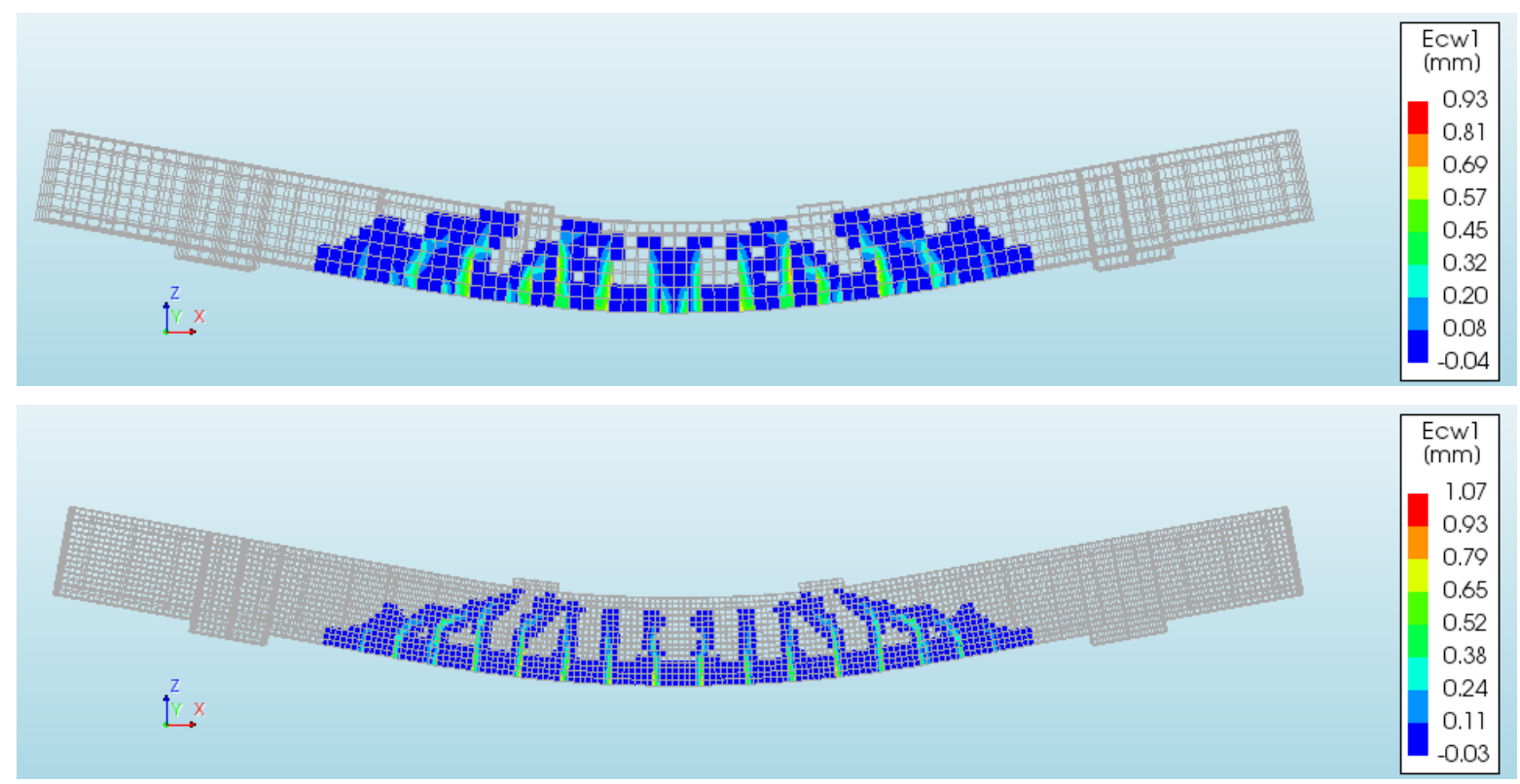

Figura 4.33 - Comparação dos campos de fissuras obtidos pelo DIANA para as malhas de 40 e $20 \mathrm{~mm}$, com a indicação das aberturas $\mathrm{E}_{\mathrm{cwl}}$, para a força total aplicada de $35 \mathrm{kN}$.

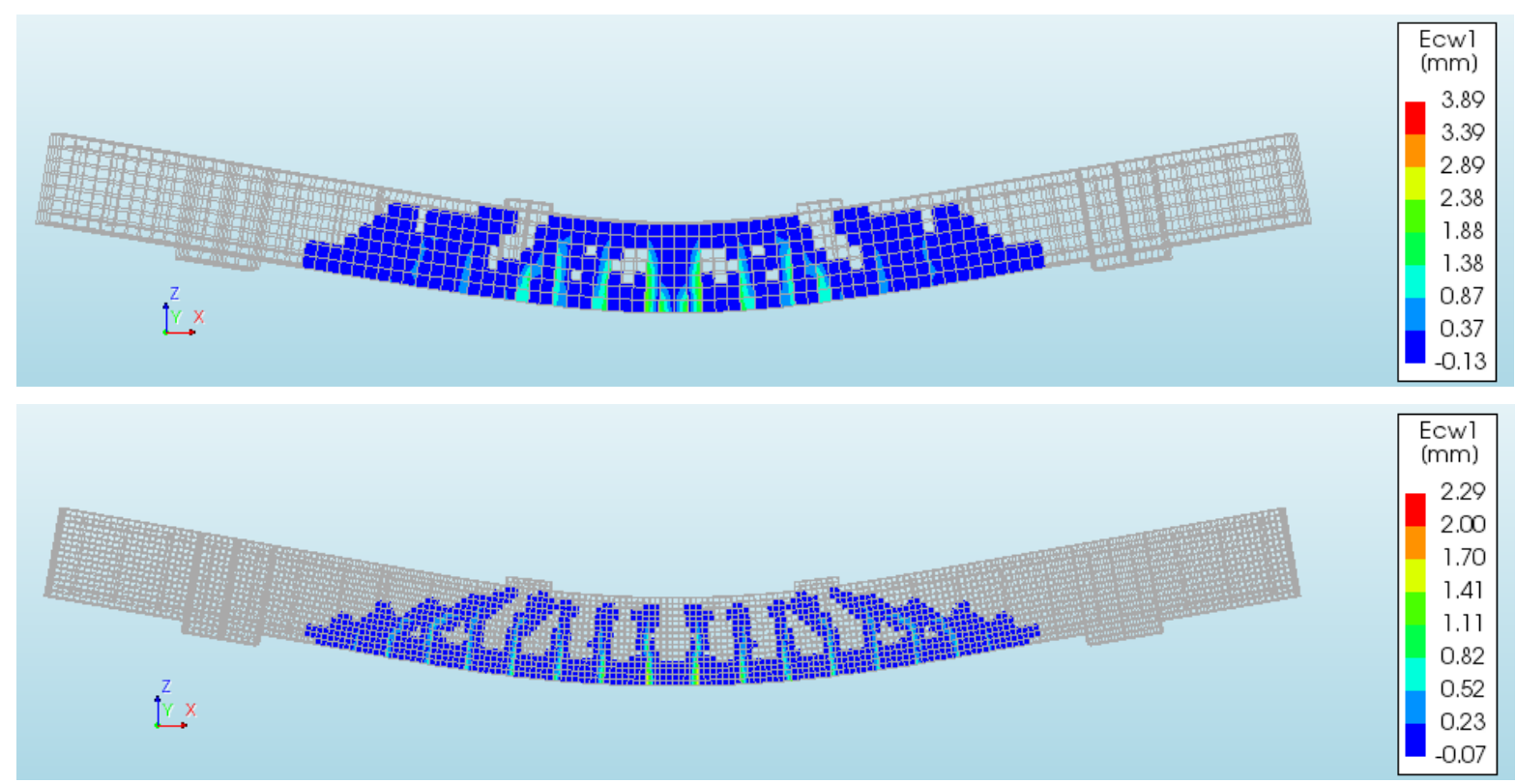

Figura 4.34 - Comparação dos campos de fissuras obtidos pelo DIANA para as malhas de 40 e $20 \mathrm{~mm}$, com a indicação das aberturas $\mathrm{E}_{\mathrm{cwl}}$, para a força total aplicada de $40 \mathrm{kN}$. 
Haja vista a similaridade entre as curvas força vs deslocamento, os danos por fissuração e o modo de colapso, optou-se por adotar a malha com elementos finitos de 40 x $40 \mathrm{~mm}$ em todos os modelos de vigas estudados nesta pesquisa, pois essa se mostrou estável e precisa frente aos resultados obtidos mediante o uso de uma malha extremamente mais refinada (quase nove vezes mais densa) e também mais prática no sentido de reduzir o esforço computacional e o tempo para a simulação das análises. Portanto, foi escolhida por apresentar um bom balanço precisão/eficiência e, certamente, por também ter apresentado em alguns testes campos de temperaturas praticamente iguais àqueles obtidos com a malha mais fina.

\subsubsection{Procedimentos de análise}

O comportamento da viga de concreto armado à temperatura ambiente foi avaliado com base em uma análise estrutural não linear. De acordo com Palacio (2013), a escolha correta do procedimento para incremento de carga, do método de solução iterativa e dos critérios de convergência é fundamental para manter a solução de análises desse tipo na trajetória de equilíbrio. Portanto, o sistema de equações não lineares provenientes dessas análises deve ser solucionado com base em um procedimento incremental-iterativo que possua a função de garantir a validade do resultado encontrado, uma vez que, ao contrário das análises lineares, existe a possibilidade de ser encontrada mais do que uma solução.

Nas análises conduzidas na presente pesquisa, as equações não lineares foram resolvidas iterativamente pelo método de Newton-Raphson Regular, no qual a matriz de rigidez tangente é derivada a cada uma das iterações. Moltubakk (2014) explica que apesar de esse método exigir um esforço computacional elevado, são a ele necessárias poucas iterações para que se alcance a convergência capaz de estabelecer a solução final. Além de Moltubakk (2014), os autores Rafi; Nadjai e Ali (2008), Mauludin (2009), Wu e Lu (2009), Gao et al. (2013) e Liao e Huang (2015) também aplicaram esse método em seus respectivos estudos, sendo todos eles 
voltados à modelagem de vigas de concreto armado, à temperatura ambiente ou em situação de incêndio. Na Figura 4.35, apresenta-se um esquema de aplicação do referido método.

O incremento de carga aplicado à viga foi realizado por controle de força, ou seja, adotaramse passos de carga ou parcelas de carga para que as forças fossem aplicadas aos poucos, por incrementos (Figura 4.36). Essa hipótese se mostrou consistente à adotada nos ensaios experimentais das vigas à temperatura ambiente, em que essas foram submetidas a deformações por intermédio do aumento contínuo de força/energia aplicada ao sistema a partir do macaco hidráulico.

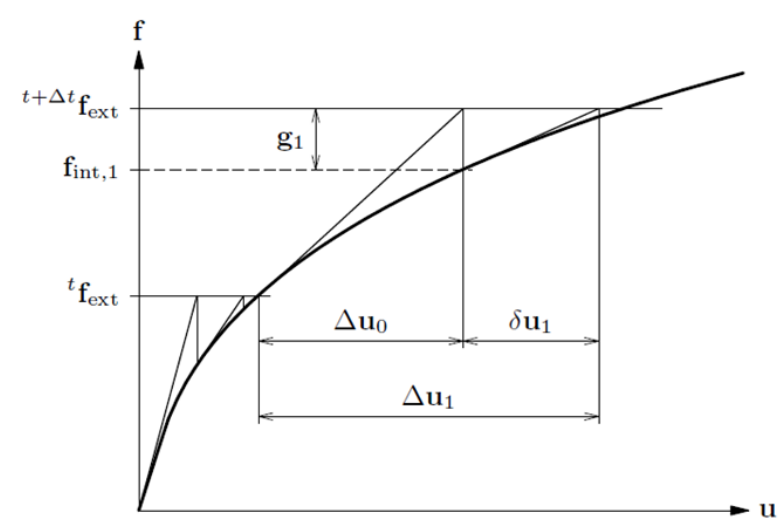

Figura 4.35 - Iteração pelo método Newton-Raphson Regular (DIANA FEA, 2016a).

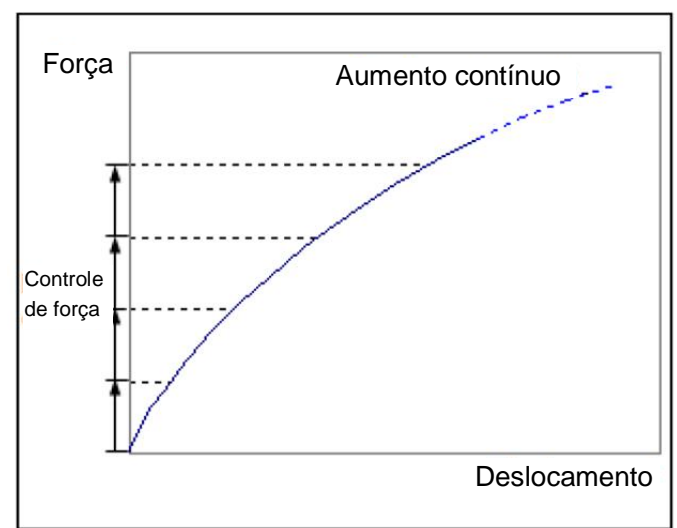

Figura 4.36 - Incremento de carga por controle de força (PALACIO, 2013; adaptado).

Adotaram-se nas análises numéricas três blocos de carga, que foram inseridos no comando referente a uma única análise estrutural não linear: o primeiro se referia a aplicação das forças resultantes do peso próprio do modelo, enquanto o segundo e o terceiro tratavam da aplicação das forças que foram uniformemente distribuídas sobre as duas chapas de aço. Em todos os blocos, os passos de carga foram definidos explicitamente.

O peso próprio foi aplicado de forma direta, i.e., apenas um passo foi o suficiente. Em seguida, no segundo bloco, aplicou-se cerca de $75 \%$ da força total de $50 \mathrm{kN}$ imposta ao modelo a partir de pequenos incrementos, de $1 \mathrm{kN}$, a fim de que se obtivesse convergência mesmo em pontos críticos da análise, como no início da fissuração do concreto. Finalmente, no terceiro bloco, pelo alto grau de fenômenos de não linearidade já envolvidos (concreto 
extremamente fissurado, por exemplo) e, por conseguinte, pela maior dificuldade imposta à convergência dos passos, aplicou-se a mesma configuração de passos de carga adotada no bloco anterior, porém, com a ativação do controle por comprimento de arco (arc-length control), representado na Figura 4.37.

Souza (2004) explica que para a obtenção de respostas satisfatórias em problemas estruturais com grandes não linearidades, caso das estruturas de concreto armado, é quase inevitável utilizar alguns recursos que são disponibilizados no DIANA para superar as dificuldades que normalmente surgem nas análises. Um desses recursos consiste no método de comprimento de arco, que resolve as deficiências do processo incremental e iterativo, possibilitando capturar o comportamento pós-pico da estrutura, pois permite a introdução de incrementos decrescentes no processo iterativo. Logo, são aplicados passos de carga bem pequenos, de forma que eles sejam capazes de satisfazer os critérios de convergência pré-estabelecidos.

Relativamente a esses critérios de convergência, eles podem ser formulados com base em normas de força, deslocamento ou energia, sendo que o critério energético engloba os outros dois, ou seja, de força e de deslocamento. Nesta investigação, adotou-se o critério de convergência apenas em termos de deslocamentos, admitindo-se uma tolerância igual a $5 \times 10^{-2}$, i.e., com a permissão de um erro máximo de $5 \%$ a cada passo.

O critério que tem base exclusivamente nos deslocamentos foi adotado para manter a coerência entre as análises à temperatura ambiente e as posteriores análises ao fogo, a fim de não comprometer a precisão dos seus resultados. Na simulação dos ensaios de vigas de concreto armado expostas a altas temperaturas, também existe um bloco de carga representativo das forças aplicadas na condição de temperatura ambiente, antes do acionamento do forno. Portanto, um dos blocos de carga que precede o da análise em regime transiente é similar ao adotado nas análises sem fogo, alterando-se apenas o valor da carga aplicada. Pelas análises numéricas realizadas nesta investigação, verificou-se que existe certa dificuldade em compatibilizar tanto forças quanto deslocamentos nas análises que envolvem cargas aplicadas e efeitos de altas temperaturas. Em incêndio, essas vigas sofrem grandes 
deslocamentos, mesmo a valores reduzidos de forças aplicadas, logo, esforçou-se pela convergência em termos desse parâmetro.

Essa dificuldade foi sem dúvida vivenciada por outros pesquisadores, haja vista que tal critério foi adotado em consonância às investigações de Rafi; Nadjai e Ali (2008), Gao et al. (2013), Wu e Lu (2009) e Bratina et al. (2003), que também realizaram análises termestruturais em vigas de concreto armado, não apenas pelo DIANA, mas com o programa de computador Abaqus, além de modelos computacionais desenvolvidos pelos próprios autores. A tolerância de 0,05 para as normas de deslocamentos também foi aplicada em Rafi; Nadjai e Ali (2008), Gao et al. (2013) e Wu e Lu (2009).

Para aumentar a taxa de convergência e estabilizar o seu comportamento, aplicou-se ainda um algoritmo para a procura de linhas (line search), que acelera a convergência do processo iterativo por intermédio do cálculo de um multiplicador ótimo para o campo dos deslocamentos incrementais, sendo bastante útil quando os processos ordinários de iteração são insuficientes (SOUZA, 2004). Esse recurso, cujo esquema de iteração se ilustra na Figura 4.38, também foi utilizado por outros autores que modelaram vigas de concreto tanto à temperatura ambiente quanto em incêndio, citam-se: Moltubakk (2014), Rafi; Nadjai e Ali (2007, 2008) e Gao et al. (2013). Mais informações sobre line search podem ser encontradas em Crisfield (1982) e Schweizerhof (1993).

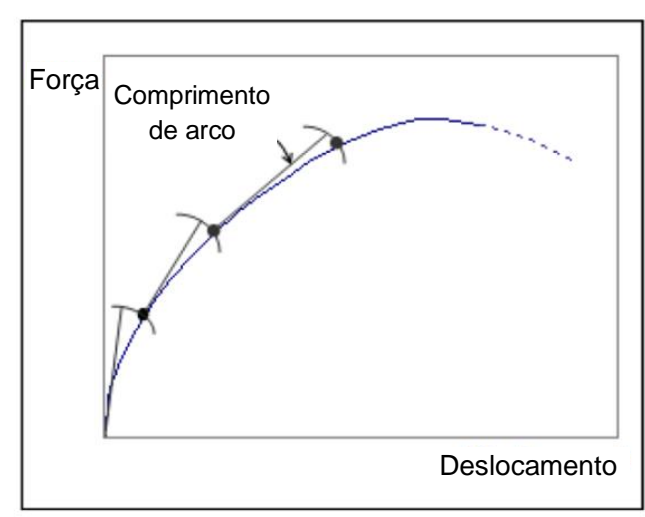

Figura 4.37 - Controle por comprimento de arco "arc-length control" (PALACIO, 2013; adaptado).

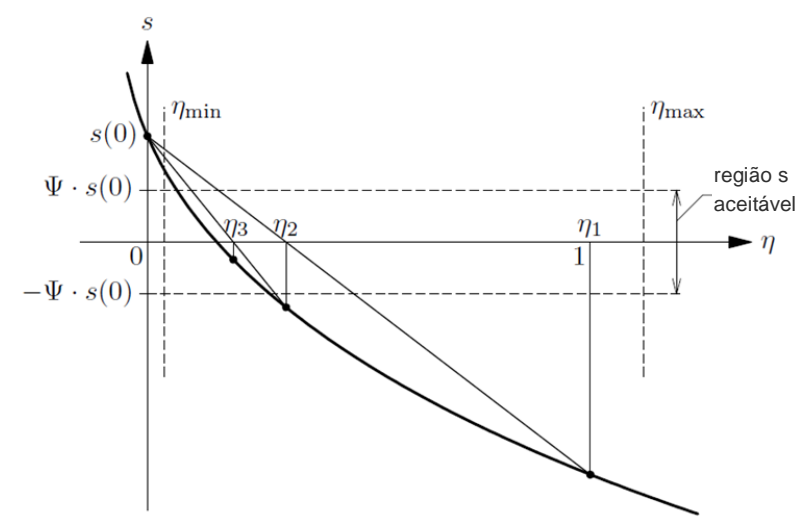

Figura 4.38 - Iteração para a procura de linhas "line search" (DIANA FEA, 2016a; adaptado). 


\subsubsection{Validação e discussão dos resultados}

\subsubsection{Forças aplicadas vs flechas}

O primeiro resultado do modelo numérico comparado aos de cunho experimental consistiu na curva que apresenta a relação entre as forças aplicadas à viga e as flechas. A curva denominada "DIANA" na Figura 4.39 foi traçada com base na somatória das reações verticais resultantes nos apoios da peça e nos deslocamentos verticais obtidos na direção do eixo - $\mathrm{Z}$ em relação ao nó localizado na parte inferior da seção a meio vão da viga $\left(\mathrm{S}_{2}\right)$ e na direção do centro geométrico da seção transversal $(Y=7,5 \mathrm{~cm})$, vide Figura 4.40. Dos deslocamentos verticais resultantes de cada incremento de carga foi subtraído aquele proveniente do peso próprio da viga, uma vez que esse não foi medido nos ensaios, em que os dados começaram a ser aferidos apenas a partir da aplicação de forças por intermédio do macaco hidráulico.

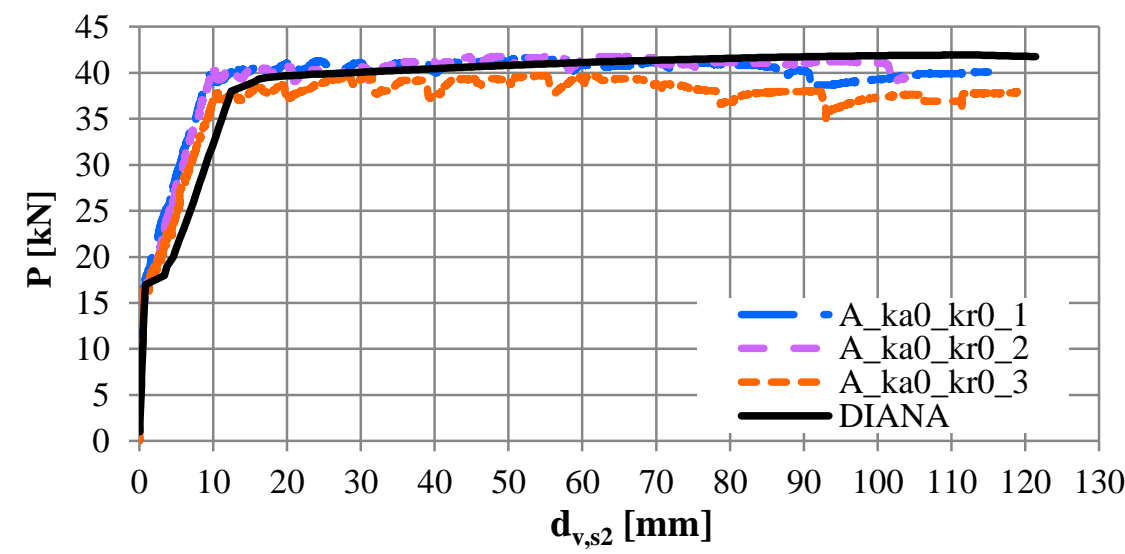

Figura 4.39 - Comparação das curvas experimentais e numérica de forças aplicadas em função das flechas.

Verificou-se uma boa correlação entre as curvas obtidas a partir dos ensaios experimentais e a curva resultante da análise no programa de computador DIANA. A fase inicial da curva numérica, característica do comportamento ainda linear elástico do concreto, bem como a rigidez do modelo após a abertura das fissuras, seguiram a mesma tendência dos ensaios. Em 
termos de forças máximas resistidas (ou carregamentos de ruptura), o resultado numérico de $42 \mathrm{kN}$ se igualou aos registrados nos ensaios referentes às duas primeiras concretagens (A_ka0_kr0_1 e A_ka0_kr0_2) e, ainda, foi bastante similar à da terceira (A_ka0_kr0_3), para a qual se registrou uma força máxima de $39,5 \mathrm{kN}$, aproximadamente.

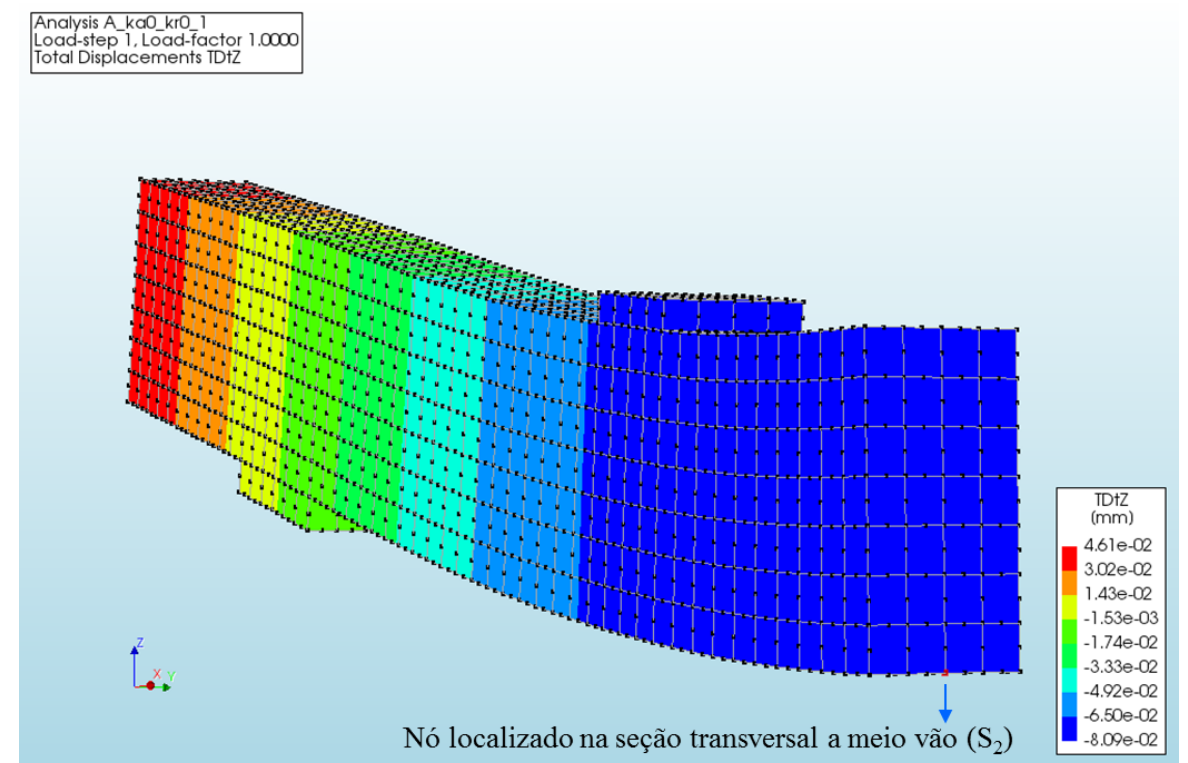

Figura 4.40 - Indicação do nó a partir do qual foram obtidas as flechas da viga.

\subsubsection{Campos de fissuração}

Nas Figuras 4.41 a 4.43 são apresentados os campos de fissuração obtidos para a viga modelada no DIANA, com a indicação das respectivas aberturas das fissuras $\left(\mathrm{E}_{\mathrm{cw} 1}\right)$, além da comparação aos campos traçados ao longo dos ensaios. Indicou-se apenas a metade do vão pela simetria não somente dos campos numéricos, mas também daqueles traçados experimentalmente. No geral, os campos de fissuras obtidos mediante o programa de computador e os ensaios, sendo ambos representativos de diferentes forças totais que foram aplicadas às vigas, apresentaram uma boa correlação. Como pode ser observado, o número de 
fissuras que se abriram ao longo do vão, o espaçamento entre elas e o prolongamento de cada uma ao longo da altura da seção transversal foram parecidos.

Quanto às aberturas de fissuras, essas se mostraram relativamente maiores no modelo numérico. Para uma carga total (P) igual a $20 \mathrm{kN}$, por exemplo, a máxima abertura medida experimentalmente $\left(E_{c w 1 m a ́ x, e x p}\right)$ foi igual a $0,15 \mathrm{~mm}$ enquanto a maior no modelo numérico ( $\left.E_{\text {cwlmáx,num }}\right)$ igual a $0,41 \mathrm{~mm}$. Já em $\mathrm{P}=25 \mathrm{kN}, \mathrm{E}_{\mathrm{cw1} \text { máx,exp }}=0,20 \mathrm{~mm}$ e $\mathrm{E}_{\text {cw1máx,num }}=0,63$ $\mathrm{mm} ; \mathrm{P}=30 \mathrm{kN}, \mathrm{E}_{\mathrm{cw} 1 \text { máx,exp }}=0,36 \mathrm{~mm}$ e $\mathrm{E}_{\mathrm{cw} 1 \text { máx,num }}=0,79 \mathrm{~mm} ; \mathrm{P}=35 \mathrm{kN}, \mathrm{E}_{\mathrm{cw} 1 \text { máx,exp }}=0,40$ $\mathrm{mm}$ e $\mathrm{E}_{\mathrm{cw} 1 \text { máx,num }}=0,93 \mathrm{~mm} ; \mathrm{P}=40 \mathrm{kN}, \mathrm{E}_{\mathrm{cw} 1 \text { máx,exp }}=2,2 \mathrm{~mm}$ e $\mathrm{E}_{\mathrm{cw} 1 \text { máx,num }}=3,89 \mathrm{~mm}$.

Contudo, todas as fissuras do modelo numérico foram representativas de fissuras de flexão, em consonância àquelas vistas ao longo dos ensaios. Esse é um dos fatores que caracterizam as rupturas por flexão e, portanto, contribui à conclusão de que o modelo numérico proposto apresentou um modo de ruptura coerente ao experimental. Mais evidências acerca dessa questão serão comentadas a seguir.

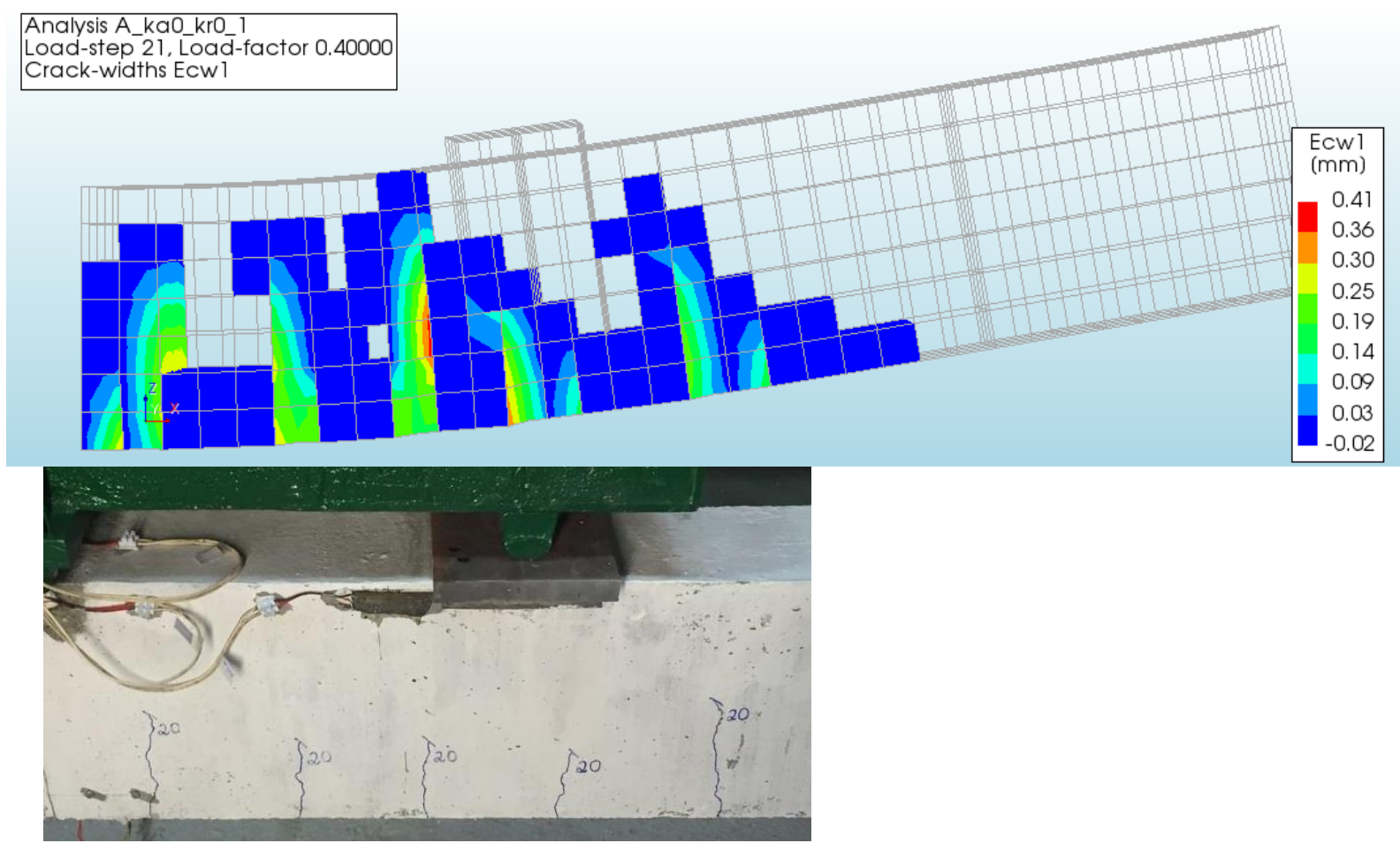

Figura 4.41 - Campo de fissuras obtido pelo DIANA, com a indicação das aberturas $\mathrm{E}_{\mathrm{cw} 1}$, comparado àquele traçado no ensaio experimental para a força total aplicada de $20 \mathrm{kN}$. 

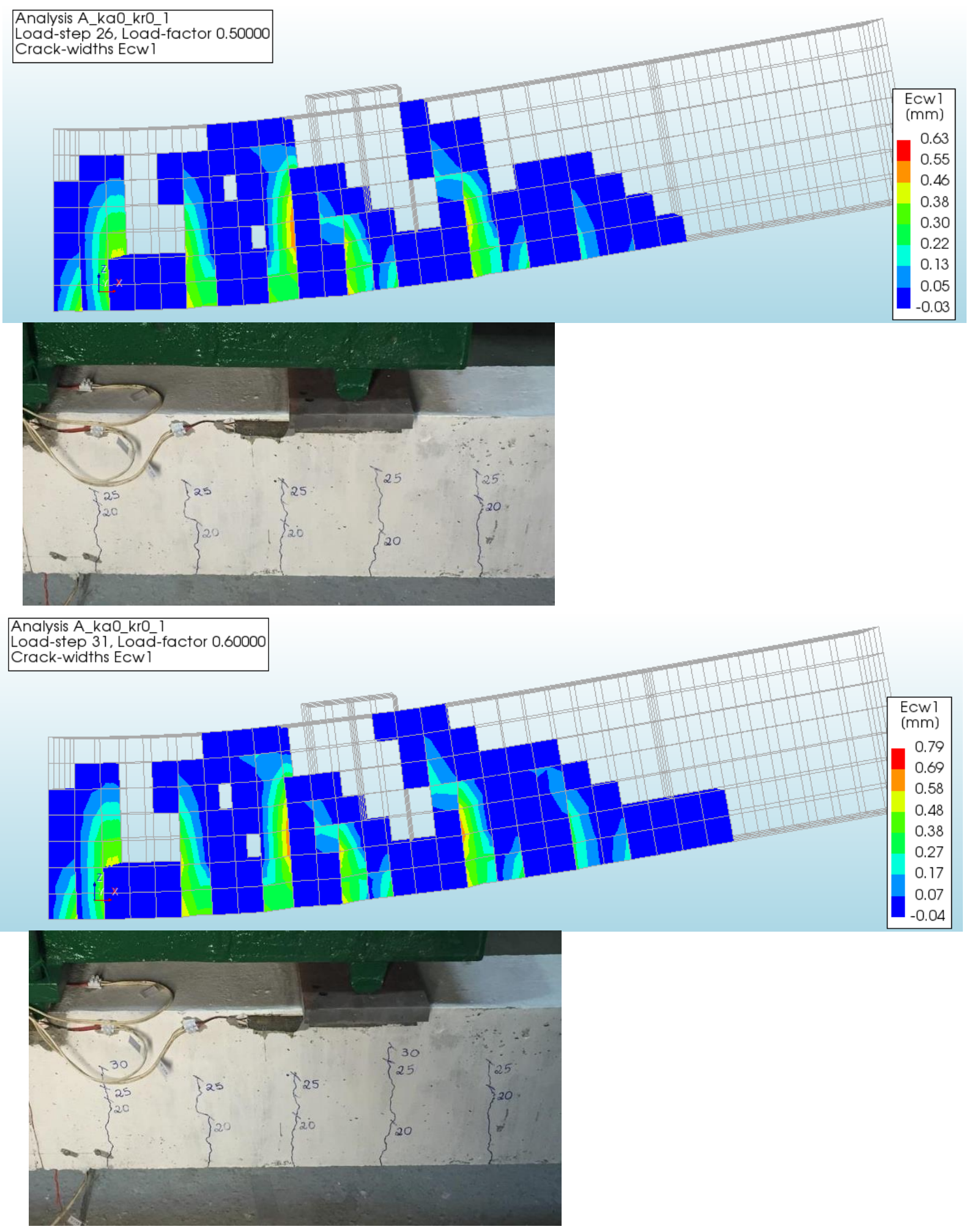

Figura 4.42 - Campos de fissuras obtidos pelo DIANA, com a indicação das aberturas $\mathrm{E}_{\mathrm{cwl}}$, comparados àqueles traçados no ensaio experimental para as forças totais aplicadas de 25 e $30 \mathrm{kN}$, respectivamente. 

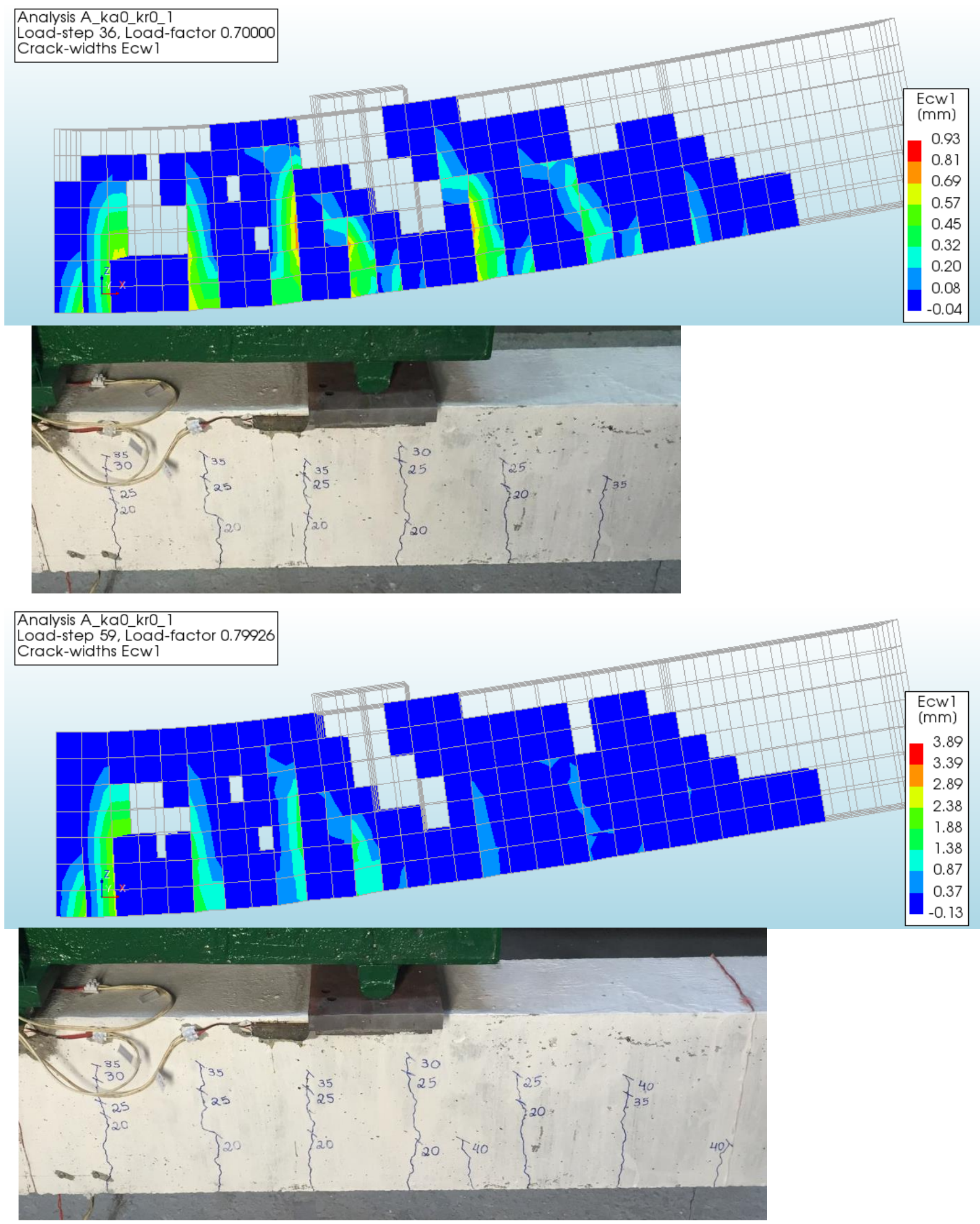

Figura 4.43 - Campos de fissuras obtidos pelo DIANA, com a indicação das aberturas $\mathrm{E}_{\mathrm{cwl}}$, comparados àqueles traçados no ensaio experimental para as forças totais aplicadas de 35 e $40 \mathrm{kN}$, respectivamente. 


\subsubsection{Modos de ruptura}

Todas as vigas que foram submetidas a ensaios experimentais de flexão a quatro pontos na condição de temperatura ambiente apresentaram excessivas aberturas de fissuras de flexão e aumento contínuo das flechas antes de atingirem o colapso total pela ruptura das barras das armaduras longitudinais inferiores, submetidas a esforços de tração. Portanto, todas apresentaram ruínas por flexão, com o aviso prévio dado pelas fissuras e flechas, correspondendo ao estado-limite de projeto para as quais foram dimensionadas.

O modo de ruptura por flexão também foi identificado na viga analisada a partir do programa de computador DIANA. Além das fissuras de flexão discutidas anteriormente, verificou-se o escoamento das armaduras longitudinais inferiores. Esse pôde ser identificado pelas deformações longitudinais superiores 0,02 , valor estipulado para a deformação correspondente à resistência ao escoamento do aço $\left(\varepsilon_{\mathrm{sy}}\right)$. A Figura 4.44 ilustra, como exemplo, as deformações longitudinais das armaduras para o passo de carga no qual foi atingida a força máxima, igual a $42 \mathrm{kN}$. Já a Figura 4.45 ilustra o aspecto final da viga deformada, relativamente ao último passo de carga convergido, com excessivas flechas (superiores a 120 mm) e iminente colapso nessa região a meio vão, de modo muito similar às deformações verificadas pouco antes do colapso total das vigas que foram submetidas a ensaios.

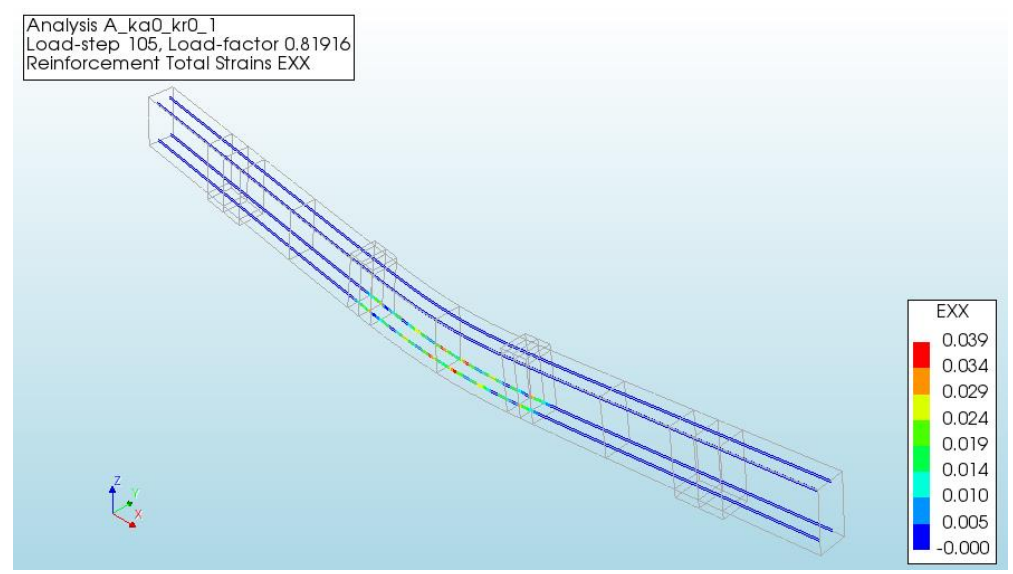

Figura 4.44 - Deformações EXX das armaduras longitudinais para a máxima força total aplicada, igual a $42 \mathrm{kN}$. 


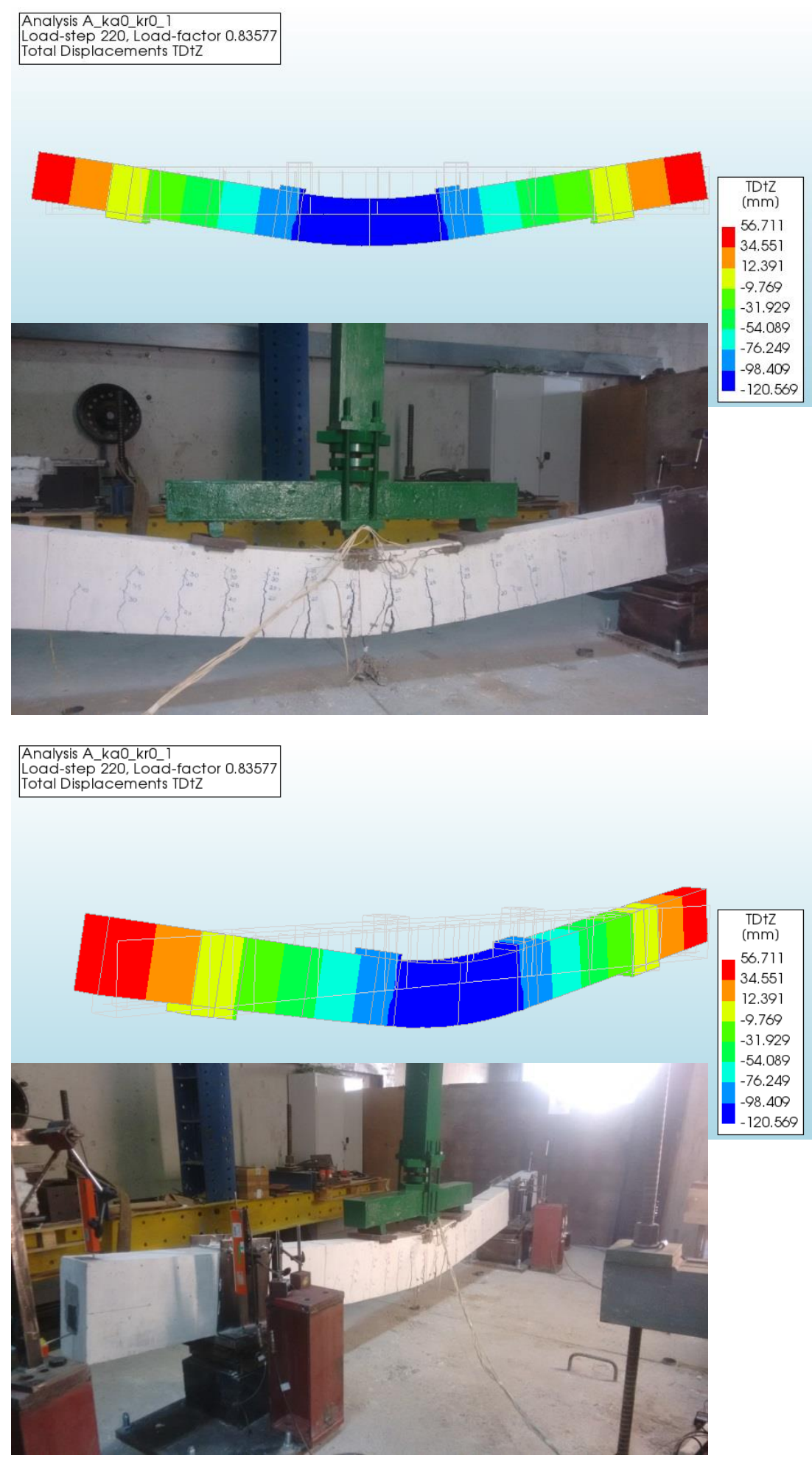

Figura 4.45 - Comparação numérico vs experimental das configurações deformadas das vigas para as máximas flechas atingidas. 
Pelas tensões e deformações dos estribos, certificou-se que esses ainda permaneciam em regime linear elástico tanto no passo de carga representativo da máxima força aplicada de 42 kN quanto no último passo de carga convergido, uma vez que essas armaduras não apresentaram escoamento (tensões superiores a 548,058 MPa e deformações superiores a 0,02), vide Figuras 4.46 e 4.47. Assim, descartou-se a hipótese de colapso por cisalhamento da peça, devido à ruptura da armadura transversal.

Ainda para a força última, não se verificou esmagamento do concreto, uma vez que as tensões de compressão ainda eram inferiores a 26,238 MPa. Esse fenômeno passou a ocorrer apenas em alguns elementos localizados na região central superior da viga, submetida a altos esforços de compressão, em estágios mais avançados da análise, com flechas já superiores a $100 \mathrm{~mm}$ (Figura 4.48). Esse fenômeno também foi verificado nos ensaios, porém, da mesma forma que no modelo numérico, a viga não atingiu colapso por conta desse esmagamento, continuando a desempenhar sua capacidade de carga.

Após a comparação dos resultados numéricos aos experimentais em termos de relações entre forças aplicadas em função de flechas, campos de fissuração e modo de ruptura, certificou-se a consistência do modelo que foi concebido no programa de computador DIANA para a simulação do comportamento de vigas de concreto armado à temperatura ambiente, de modo que poderia ser dado início às análises ao fogo o adotando como modelo base.

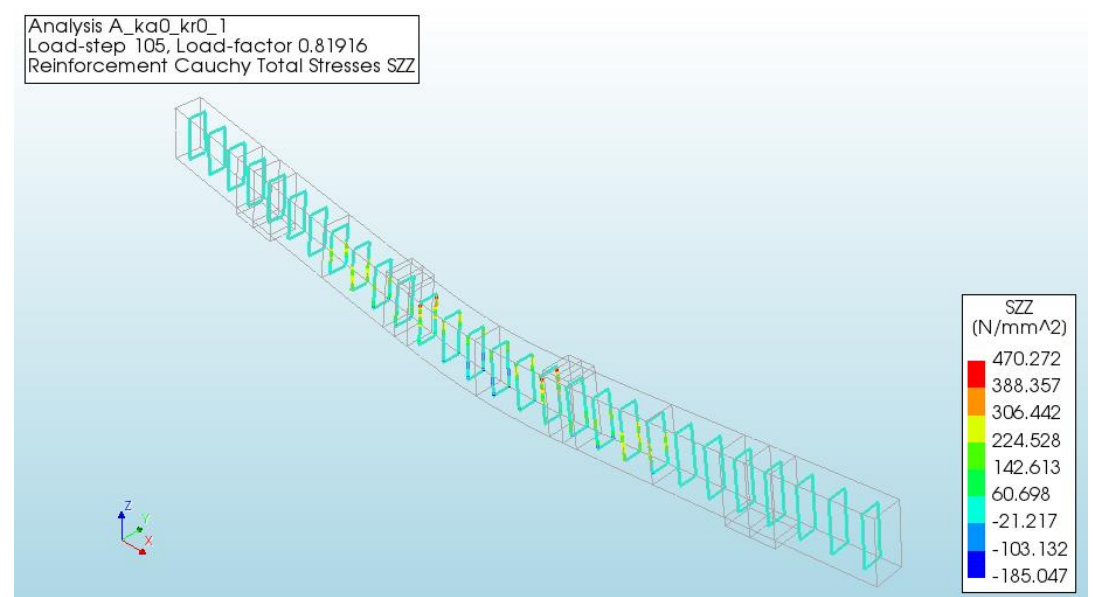

Figura 4.46 - Tensões SZZ e deformações EZZ das armaduras transversais, respectivamente, para a máxima força total aplicada, igual a $42 \mathrm{kN}$ (continua). 


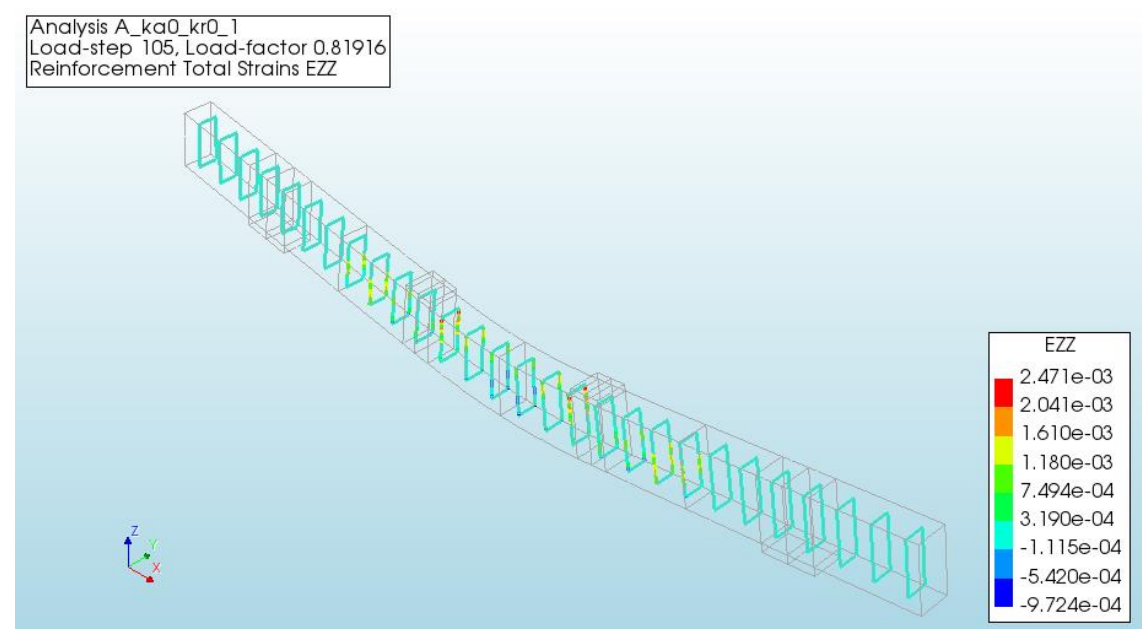

Figura 4.46 - Tensões SZZ e deformações EZZ das armaduras transversais, respectivamente, para a máxima força total aplicada, igual a $42 \mathrm{kN}$ (conclusão).

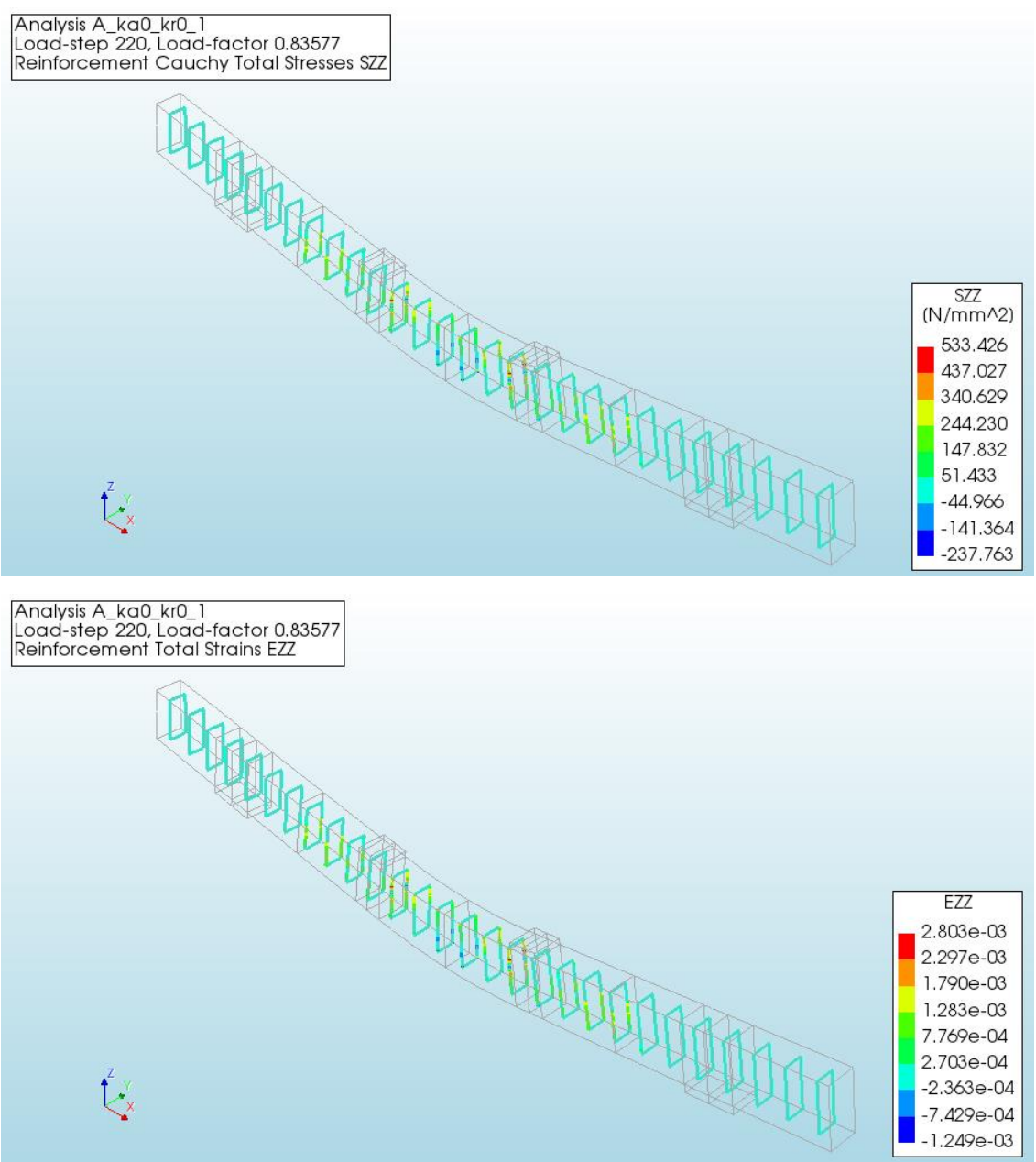

Figura 4.47 - Tensões SZZ e deformações EZZ das armaduras transversais, respectivamente, para o último passo de carga convergido. 


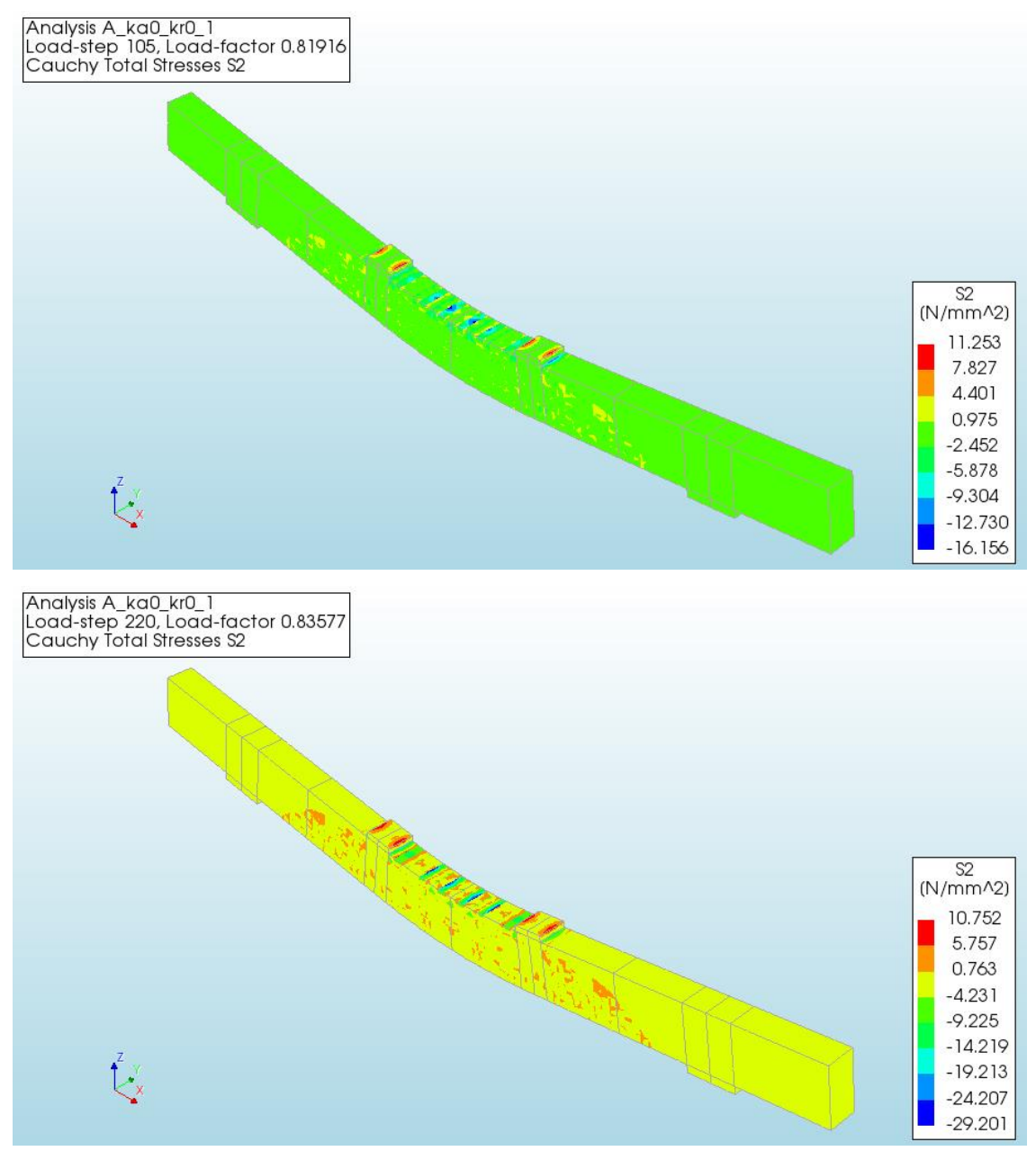

Figura 4.48 - Tensões principais S2 do concreto para a máxima força total aplicada, igual a $42 \mathrm{kN}$, e para o último passo de carga convergido, respectivamente.

\subsection{Vigas em situação de incêndio}

Nesta seção serão apresentados, a priori, os parâmetros que foram inseridos no modelo de viga simplesmente apoiada à temperatura ambiente para adaptá-lo às simulações dos ensaios experimentais conduzidos em vigas expostas a altas temperaturas com os seguintes esquemas estáticos: simplesmente apoiadas, com restrições axiais e com restrições tanto axiais quanto rotacionais. Logo, indicar-se-ão as eventuais modificações realizadas quanto à geometria, às propriedades dos materiais, à malha de elementos finitos e aos procedimentos de análise. 
Depois, poderão ser verificadas as comparações dos resultados numéricos aos experimentais no que diz respeito aos ensaios que foram simulados via programa de computador DIANA.

\subsubsection{Definição da geometria}

\subsubsection{Pontos auxiliares para a medição de temperaturas}

Com o propósito de adaptar o modelo de viga simplesmente apoiada à temperatura ambiente para as análises ao fogo, inseriram-se pontos auxiliares ao longo das seções transversais localizadas a meio metro de distância dos eixos dos apoios simples e duplo $\left(S_{1}\right.$ e $\left.S_{3}\right)$ e a meio vão $\left(S_{2}\right)$ para que pudessem ser obtidas as temperaturas resultantes das análises numéricas para os mesmos pontos em que essas foram aferidas experimentalmente (Figuras 4.49 e 4.50).

\subsubsection{Condições de contorno de origem térmica}

Para simular as condições de contorno resultantes do posicionamento dos módulos do forno elétrico sobre as vigas de concreto armado ao longo dos ensaios experimentais, todas as faces externas do conjunto formado pela viga, pelos blocos dos apoios e pelas chapas de aplicação de forças foram admitidas como expostas ao fogo no modelo numérico (Figura 4.51). No DIANA, os processos de transferência de calor atuantes nas faces aquecidas são considerados como carregamentos térmicos. Nesse modelo, definiu-se que tais faces estavam sujeitas a carregamentos dos tipos convecção e radiação. Depois de o modelo ser atingido por esses dois fluxos de calor, o programa de computador admite que o mesmo seja aquecido interiormente pelo processo de condução. 
$\mathrm{O}$ regime de aquecimento atribuído às faces expostas ao fogo foi estipulado conforme as curvas de temperaturas internas do forno em função do tempo provenientes de cada um dos ensaios experimentais que foram simulados no programa, sendo essas indicadas na Figura 4.52. Mais uma vez em relação a todo o modelo, admitiu-se uma temperatura inicial de $20{ }^{\circ} \mathrm{C}$, usualmente adotada para representar a temperatura ambiente. Apesar de algumas vigas ensaiadas terem apresentado pontos com temperaturas iniciais diferentes de $20{ }^{\circ} \mathrm{C}$, ainda assim a média dessas temperaturas foi próxima a tal valor.

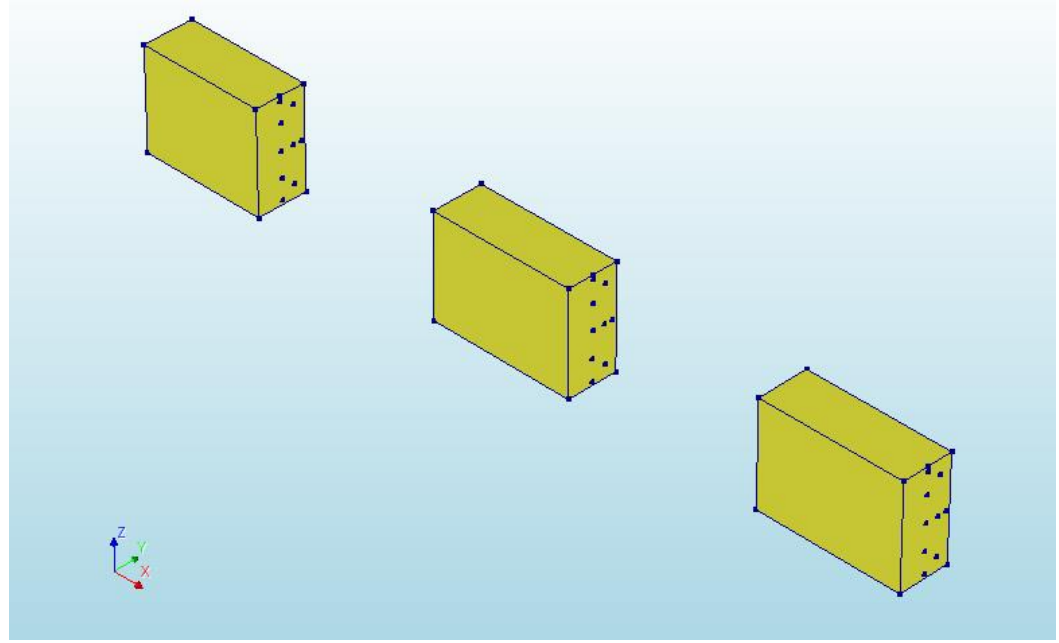

Figura 4.49 - Vista isométrica dos blocos da viga em que foram inseridos pontos auxiliares para a análise de temperaturas.

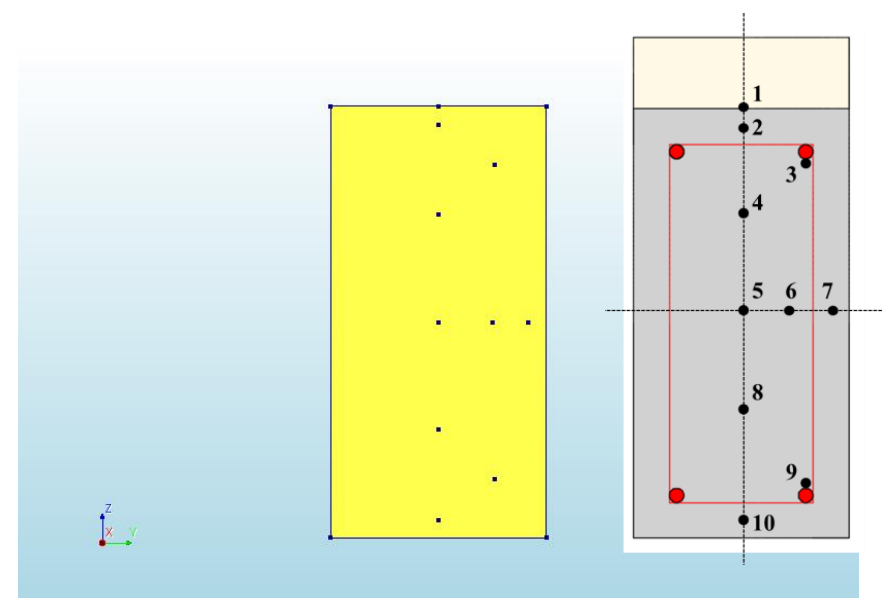

Figura 4.50 - Seção transversal do modelo numérico com pontos auxiliares considerados nas mesmas posições em que foram aferidas as temperaturas das vigas ao longo dos ensaios experimentais. 


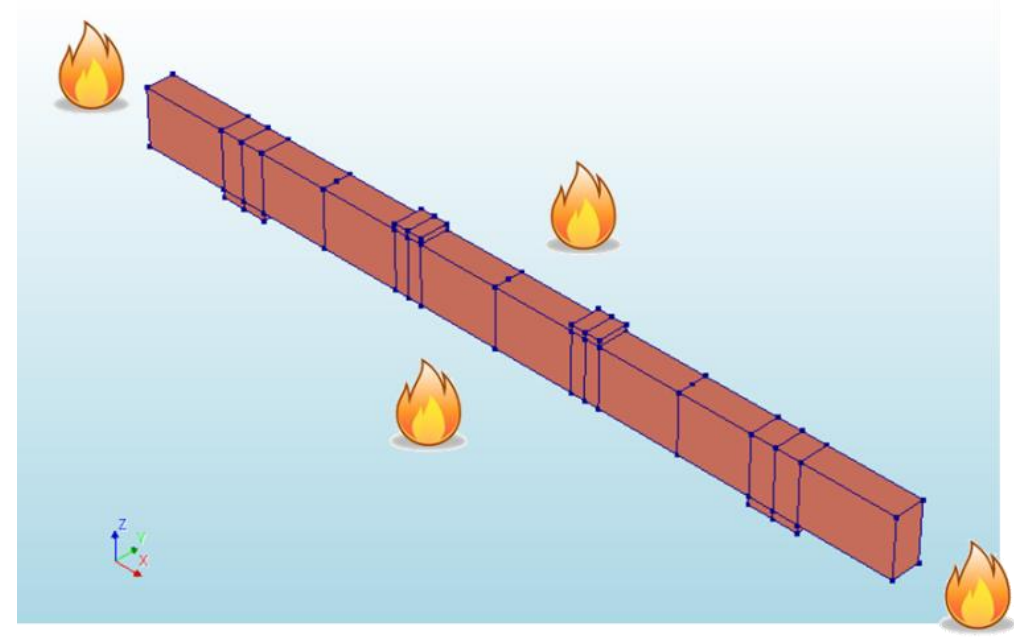

Figura 4.51 - Condições de contorno adotadas ao modelo: todas as faces expostas a temperaturas elevadas.

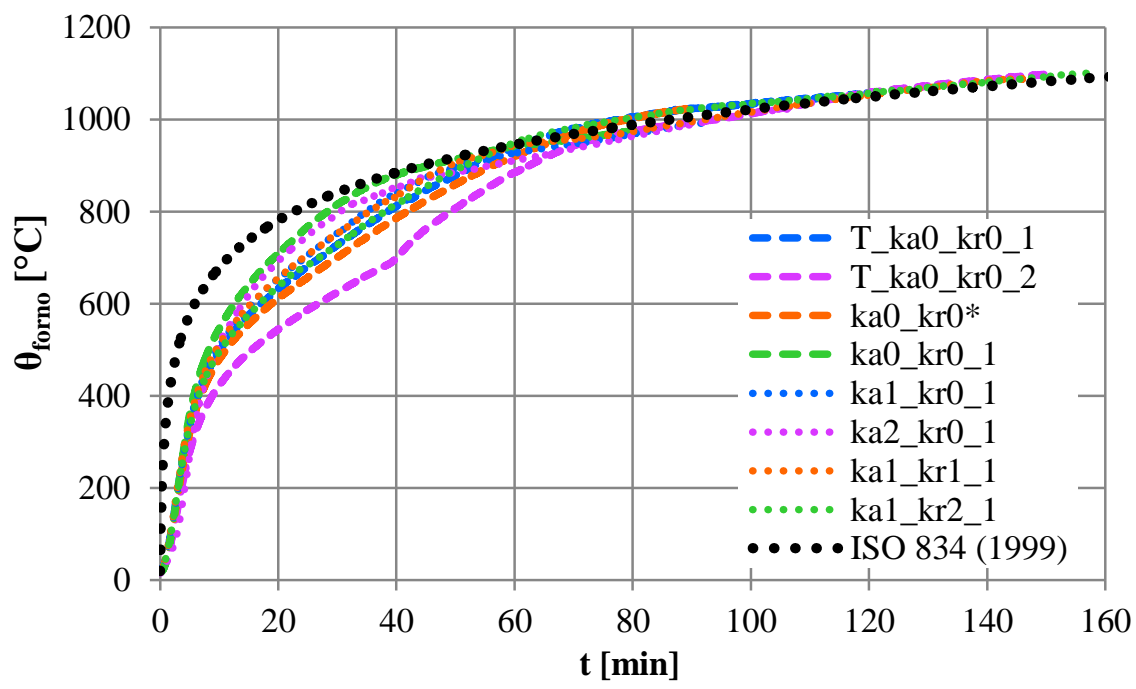

Figura 4.52 - Evoluções de temperaturas internas do forno, com eventual comparação à curva ISO 834 (1999), que foram admitidas como regime de aquecimento na simulação numérica dos diferentes ensaios experimentais.

Nos ensaios, algumas regiões estavam diretamente expostas ao aquecimento proveniente do forno enquanto outras estavam protegidas pela aplicação de uma ou mais camadas de um material isolante, as mantas de lã de silicato alcalino. Essas diferentes condições foram simuladas no DIANA a partir de interfaces de contorno (boundary interfaces), que são responsáveis por criar as superfícies que realizam a conexão/ligação existente entre o modelo e o seu entorno. Especificamente nesse caso, o conjunto viga - blocos - chapas representa o modelo, os gases quentes representam o entorno, o próprio ar a interface ou camada existente 
entre as superfícies diretamente expostas do modelo e o fogo, enquanto a manta representa a interface que caracteriza a ligação entre o modelo e o entorno para as regiões isoladas. Por isso, definiram-se as superfícies do modelo com interfaces do tipo "sem manta", "com manta/uma camada" ou "com manta/duas camadas".

Optou-se por não modelar a manta explicitamente, ou seja, como um elemento sólido na geometria, porque a mesma não apresentava nenhuma contribuição à resistência mecânica das vigas de ensaio. Por isso, a sua função de material isolante foi simulada por intermédio de interfaces às quais foram atribuídas propriedades térmicas que levavam em consideração o efeito da sua espessura (ou em uma ou em duas camadas). Assim, uma vez postas sobre determinadas faces do modelo, esses elementos seriam capazes de ali reduzir a condutividade.

As regiões com ou sem manta das vigas simplesmente apoiadas, ilustradas na Figura 4.53 e 4.54, foram estabelecidas de acordo com as condições dos ensaios. Nesses testes de exposição ao fogo, as faces superiores da viga eram protegidas com uma camada de manta para que representassem as condições de isolamento que seriam impostas por lajes. Já os blocos dos apoios e suas chapas constituintes eram protegidos com duas camadas de manta por se tratarem de elementos auxiliares, em aço, utilizados ao longo de todos os ensaios. Assim, as regiões da viga que se encontravam junto a esses apoios também acabavam isoladas mediante essas duas camadas de manta. As chapas de distribuição de forças também possuíam um determinado isolamento térmico, pois estavam localizadas sob a viga de aço, que fazia parte do conjunto de redistribuição de forças e estava protegida com uma camada de manta. Todas as demais regiões da viga permaneciam diretamente expostas ao regime de aquecimento. À exceção dos demais, houve apenas um ensaio de viga simplesmente apoiada em que a face superior do elemento estrutural de concreto armado não foi protegida por manta.

Os testes de exposição ao fogo com imposição de restrições seguiram em grande parte as condições de contorno daqueles em vigas simplesmente apoiadas. A única diferença estava relacionada aos blocos de extremidade das vigas, que também foram protegidos com duas camadas de manta porque junto deles estavam postos os elementos que constituíam o sistema 
de complementos em aço (Figura 4.55). Logo, não assumiram as interfaces do tipo "sem manta" no modelo numérico, como feito para aqueles das vigas simplesmente apoiadas.
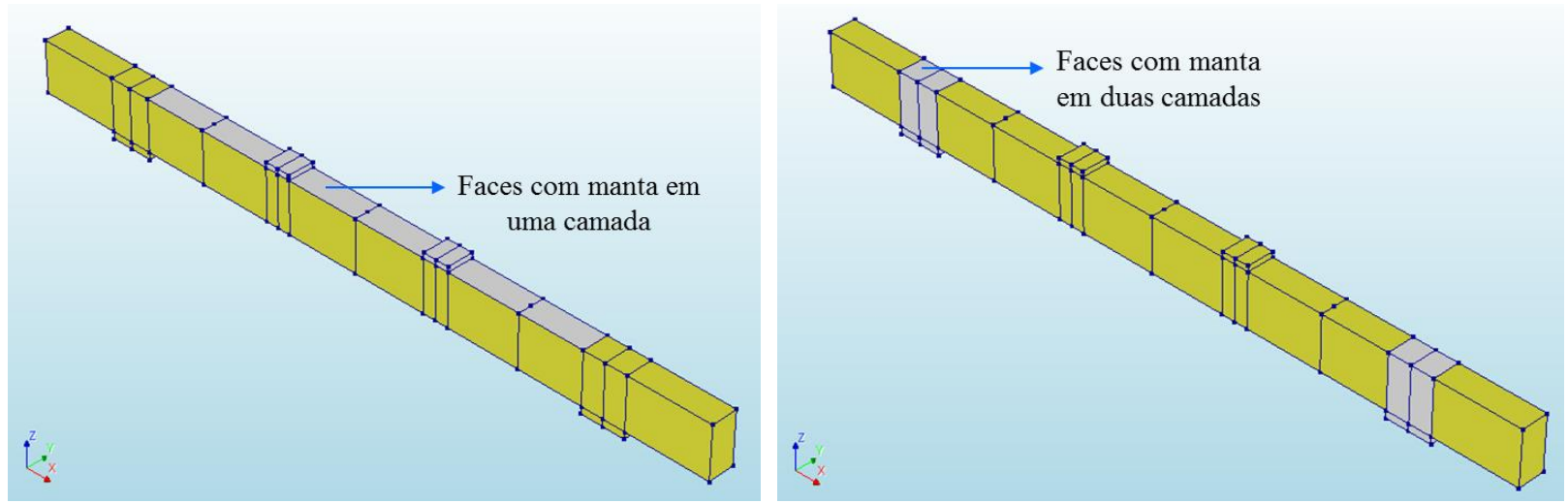

Figura 4.53 - Faces admitidas com manta de lã de silicato alcalino (em uma ou duas camadas), respectivamente, nos modelos de vigas simplesmente apoiadas expostas ao fogo.

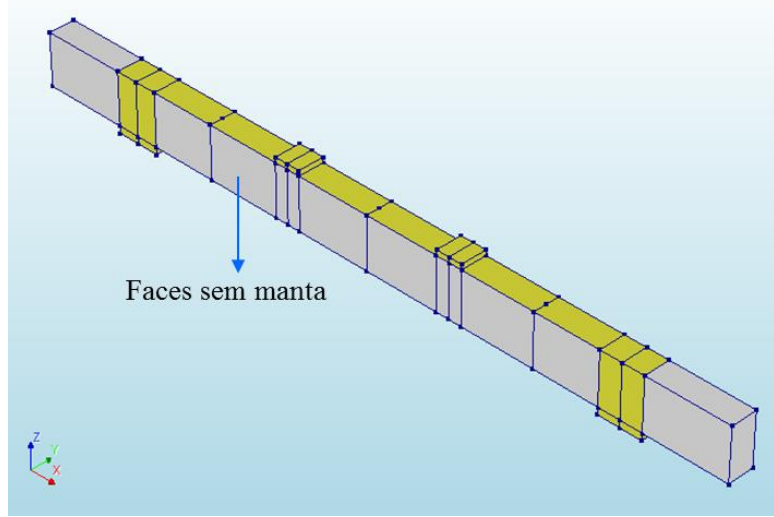

Figura 4.54 - Faces sem manta nos modelos de vigas simplesmente apoiadas expostas ao fogo.

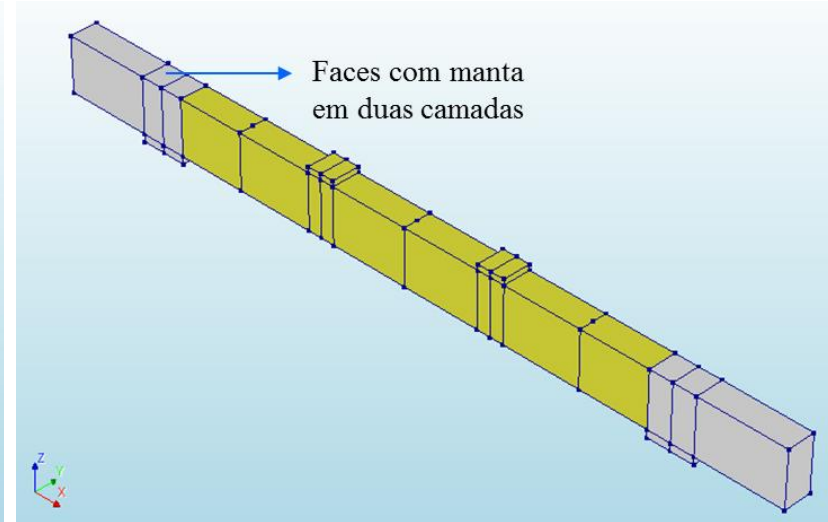

Figura 4.55 - Indicação do pormenor dos modelos de vigas com restrições: determinadas faces dos blocos das extremidades (localizados após os apoios) também com manta de lã de silicato alcalino em duas camadas.

\subsubsection{Determinação das forças atuantes}

Nos ensaios de vigas em situação de incêndio, aplicava-se lentamente a cada uma delas, antes de se acionar o forno, cerca de $50 \%$ do carregamento último calculado no projeto à temperatura ambiente (aproximadamente $17 \mathrm{kN}$ ), sendo esse o critério assumido para estabelecer o carregamento de serviço. Durante os ensaios de exposição ao fogo, mantinha-se esse 
carregamento, que era dividido nas duas forças distribuídas sobre as chapas. Logo, para as vigas aquecidas que foram modeladas no programa, não mais se considerou uma força total de $50 \mathrm{kN}$, como feito à temperatura ambiente, mas sim de $17 \mathrm{kN}$.

\subsubsection{Condições de apoio}

Nos modelos de vigas simplesmente apoiadas em situação de incêndio, mantiveram-se as condições de apoio especificadas na condição de temperatura ambiente. Nas análises de vigas restringidas, estipularam-se condições de apoio adicionais. As restrições apenas do tipo axial ou axial e rotacional aplicadas ao longo dos ensaios experimentais foram impostas às vigas aqui modeladas numericamente por intermédio de interfaces estruturais. Essas interfaces permitiam a introdução de condições de contorno mecânicas ao modelo porque a elas podiam ser atribuídas rigidezes que eram distribuídas em relação à área de suas respectivas faces. Sendo assim, uma vez posicionadas em contato com as faces extremas das vigas, eram capazes de transmitir tais rigidezes às peças simuladas no programa de computador.

Esse mecanismo de interfaces estruturais disponível no DIANA se mostrou bastante representativo daquele adotado nos ensaios em laboratório, em que o contato entre a viga de concreto armado, por meio de seu sistema de complementos, e as vigas de aço que simulavam as restrições axiais se dava mediante uma chapa e, ainda, pelo fato das restrições rotacionais terem sido transmitidas à viga de concreto por meio das forças provenientes de barras de aço, que ao puxarem determinadas seções dessa viga para baixo, aplicavam uma determinada rigidez que era distribuída ao longo da área dessas seções.

Para sustentar ou, em outras palavras, para servir de base à fixação dessas interfaces estruturais, foram criados, ao longo das faces extremas das vigas, apoios que restringiam as translações em todas as direções (X, Y e Z). As interfaces estruturais, quando acopladas a tais apoios, funcionavam como uma placa ou um anteparo, que estariam sempre fixos às faces extremas do modelo, acompanhando as suas deformações e, portanto, garantindo que os 
impedimentos às deformações de origem térmica fossem transmitidos à viga durante todo o tempo que duravam as análises.

Além disso, uma vez considerados apoios nessas regiões, ali foram transmitidas as reações da viga ao impedimento de suas deformações, imposto pelas rigidezes das interfaces estruturais. Pela somatória das reações em todos os nós que compunham a malha de discretização dessas faces, definiram-se as forças de compressão axiais resultantes do modelo numérico, para que fossem posteriormente comparadas àquelas obtidas nos ensaios. As informações apresentadas na presente seção estão compiladas nas Figuras 4.56 a 4.58, enquanto os valores das rigidezes aplicados a essas interfaces serão abordados na seção sobre atribuição de propriedades.

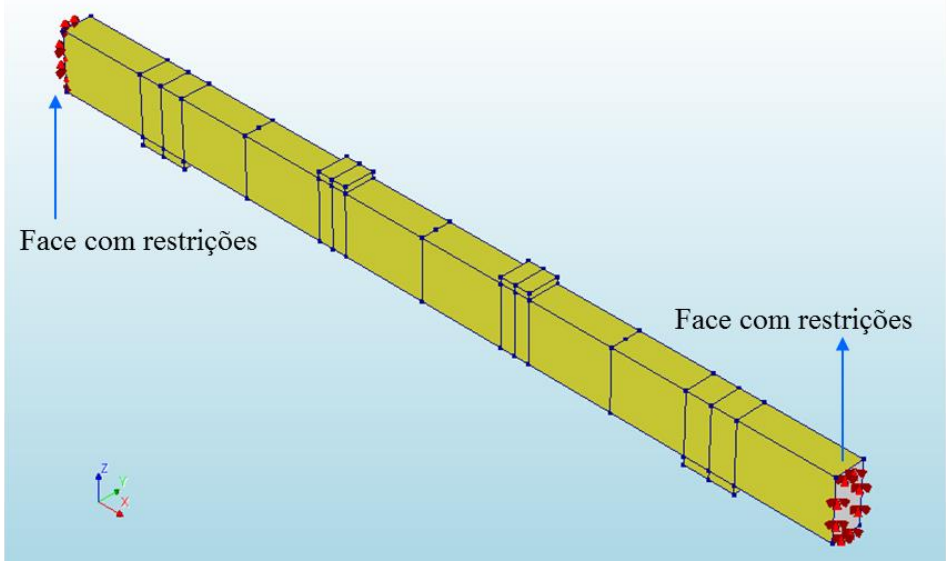

Figura 4.56 - Apoios e interfaces estruturais aplicadas às faces extremas da viga para a consideração dos efeitos das restrições axiais e rotacionais.

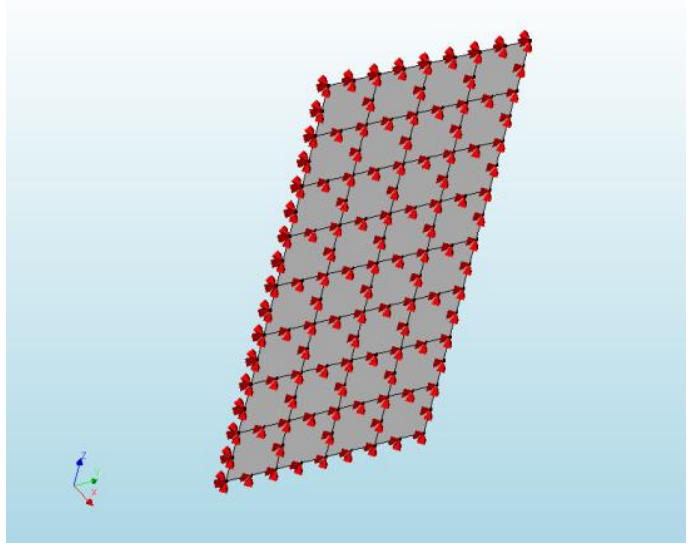

Figura 4.57 - Representação isolada de uma das interfaces estruturais acopladas ao seu sistema de apoio e discretizada com malha de elementos finitos.

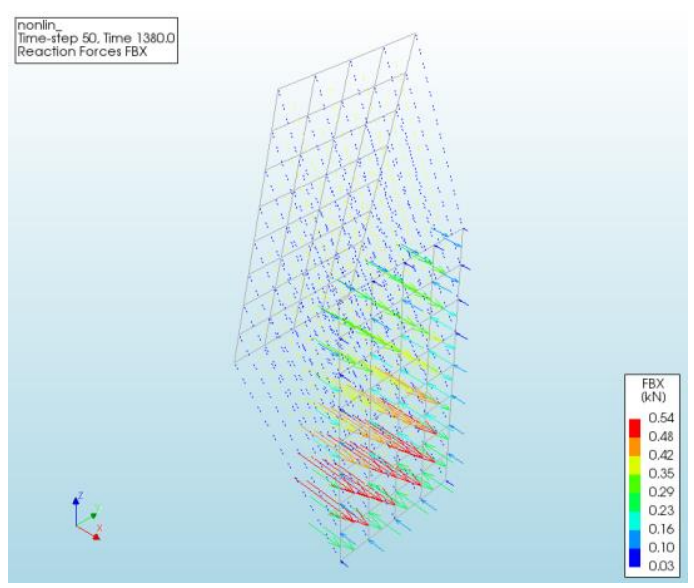

Figura 4.58 - Interface estrutural: representações da condição inicial e após certo tempo de análise e das reações atuantes sobre ela na direção X. 


\subsubsection{Atribuição de propriedades}

\subsubsection{Concreto da viga}

\subsection{Comportamento à tração}

\subsection{RESISTÊNCIA À TRAÇÃO}

Na modelagem do comportamento à tração do concreto, o programa de computador DIANA permite que tanto as propriedades referentes à resistência à tração quanto à energia de fratura no modo I sejam variadas em função das altas temperaturas. A resistência à tração do concreto para a situação de incêndio foi determinada com base na Equação 4.6, recomendada pelo Eurocode 2 parte 1-2 (2004), na qual são aplicados fatores de redução ao valor da resistência à temperatura ambiente. Esses fatores, que devem ser calculados pelas Equações 4.7 e 4.8, estão representados graficamente na Figura 4.59.

$$
\begin{array}{cc}
f_{c t m, \theta c}=k_{c t, \theta c} \times f_{c t m} & \text { Equação (4.6) } \\
20{ }^{\circ} \mathrm{C} \leq \theta_{c} \leq 100{ }^{\circ} \mathrm{C} \quad k_{c t, \theta c}=1 & \text { Equação (4.7) } \\
100{ }^{\circ} \mathrm{C}<\theta_{c} \leq 600{ }^{\circ} \mathrm{C} \quad k_{c t, \theta c}=1-\frac{\left(\theta_{c}-100\right)}{500} & \text { Equação (4.8) }
\end{array}
$$

onde:

$\mathrm{f}_{\mathrm{ctm}, \theta c}=$ resistência média à tração simples do concreto à temperatura $\theta_{\mathrm{c}}\left[\mathrm{N} / \mathrm{mm}^{2}\right]$;

$\mathrm{k}_{\mathrm{ct}, \theta \mathrm{c}}=$ fator de redução da resistência à tração do concreto à temperatura $\theta_{\mathrm{c}}$ [adimensional]; $\theta_{\mathrm{c}}=$ temperatura do concreto. 


\subsection{ENERGIA DE FRATURA À TRAÇÃO NO MODO I}

O Eurocode 2 parte 1-2 (2004) não apresenta uma equação para considerar a variação da energia de fratura à tração do concreto no modo $\mathrm{I}\left(\mathrm{G}_{\mathrm{fI}}\right)$ com a temperatura. $\mathrm{O}$ Eurocode 4 parte 1-2 (2005) e a norma AISC 360-10 (2010), que consistem em documentos voltados a estruturas de aço ou mistas aço-concreto, mas que apresentam algumas informações sobre propriedades do concreto aquecido, também não indicam uma variação. Já o Model Code 2010 (2011) apresenta uma equação que propõe reduzir $\mathrm{G}_{\mathrm{fI}}$ de acordo com o gráfico da Figura 4.60. Porém, o próprio código adverte que essa redução pode descrever o efeito do fogo em tal propriedade de forma mais marcante do que o observado em alguns casos. De fato, essa proposta não conduziu a análises numéricas satisfatórias no DIANA, que sempre acusava valores muito reduzidos para tal propriedade.

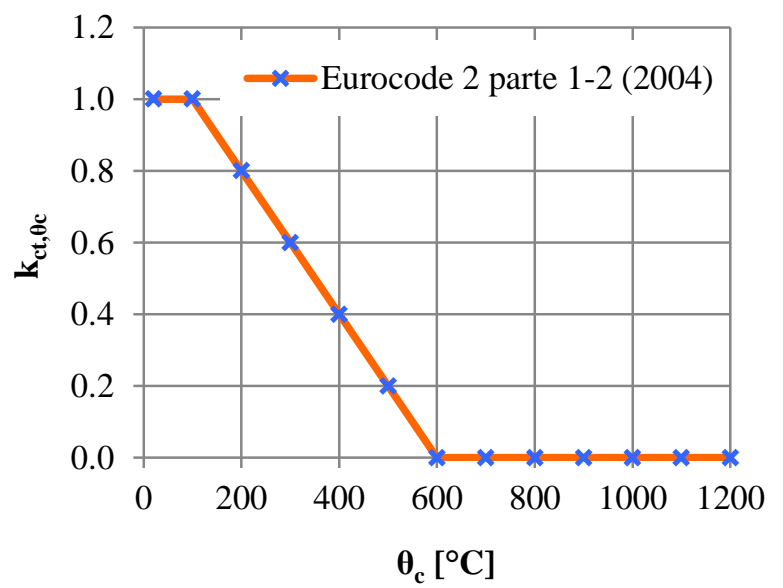

Figura 4.59 - Fatores de redução da resistência à tração do concreto.

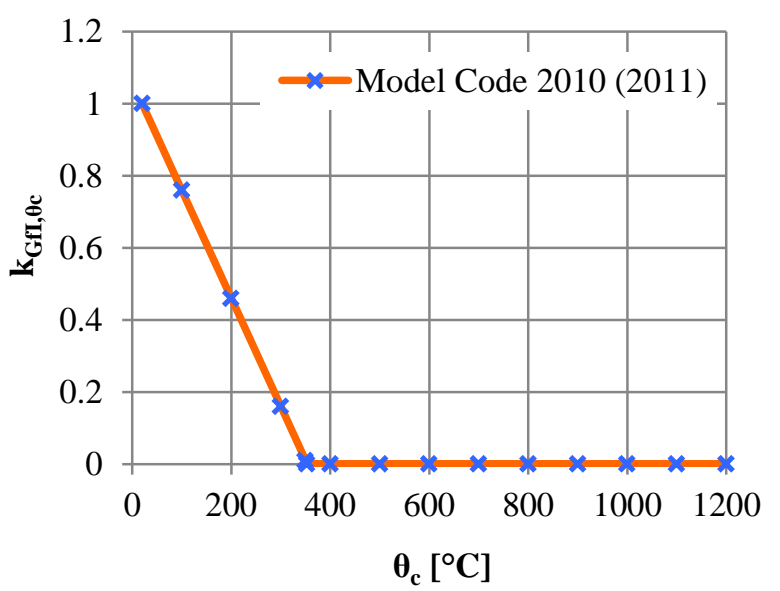

Figura 4.60 - Fatores de redução da energia de fratura à tração do concreto no modo I.

O Model Code 2010 (2011) ainda aponta que os dados experimentais disponíveis acerca da sensibilidade de $\mathrm{G}_{\mathrm{fI}}$ ao fogo apresentam uma faixa de dispersão considerável. Pelo gráfico apresentado em Gao et al. (2013), indicado na Figura 4.61, confirma-se essa questão e se percebe, além disso, que esses dados são escassos, pois a maior parte dos resultados foram coletados mediante ensaios de carga que não foram realizados durante o aquecimento dos 
corpos de prova, mas sim à temperatura ambiente, após o arrefecimento dos mesmos, caracterizando análises mais voltadas a propriedades residuais. Dentre os autores que avaliaram $\mathrm{G}_{\mathrm{fI}}$ via ensaios de aplicação de carga ao longo da exposição a altas temperaturas, Bazant e Prat (1988) aferiram os fatores de variação dessa propriedade apenas até $200{ }^{\circ} \mathrm{C}$, enquanto Zhang e Bicanic (2006) até $450{ }^{\circ} \mathrm{C}$.

Outros métodos de cálculo têm sido propostos para simular a energia de fratura à tração em incêndio, vide Carstense (2011) e Selden e Varma (2016), no entanto, é possível constatar que ainda não existe um consenso quanto a real variação de $\mathrm{G}_{\mathrm{fI}}$, sendo essa a justificativa dada, por exemplo, por Gao et al. (2013) e Rafi; Nadjai e Ali (2008) para terem considerado tal parâmetro constante com a temperatura. Nesta Tese, também se optou por considerar a energia de fratura à tração do concreto no modo I constante com a temperatura.

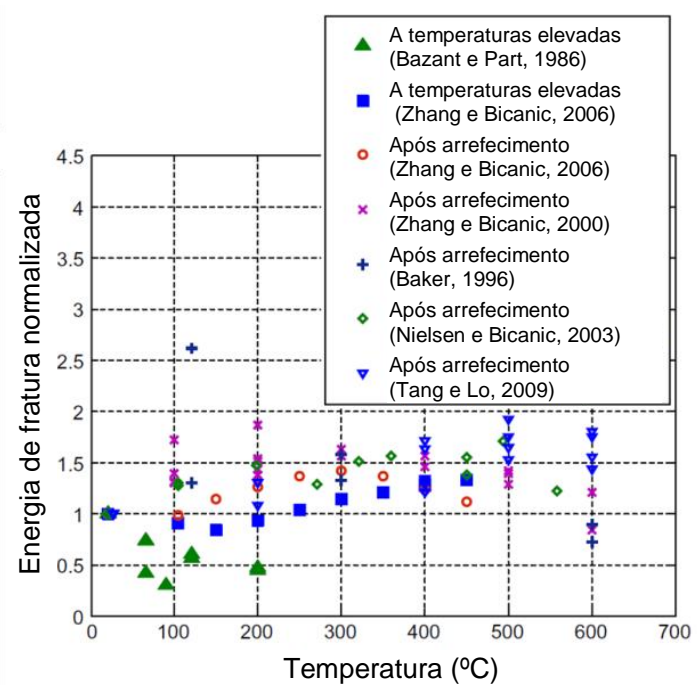

Figura 4.61 - Fatores experimentais de redução da energia de fratura $G_{f I}(G A O$ et al., 2013; adaptado).

\subsection{Comportamento à compressão}

A resistência à compressão do concreto em situação de incêndio foi calculada mediante a proposta do Eurocode 2 parte 1-2 (2004), aplicando-se na Equação 4.9 os fatores de redução 
característicos de concretos produzidos com agregados calcários. Esses fatores estão representados graficamente na Figura 4.62. O programa não apresenta a opção de considerar a energia de fratura à compressão do concreto $\left(\mathrm{G}_{\mathrm{c}}\right)$ variável com a temperatura. Sendo assim, manteve-se nas análises ao fogo o valor adotado para $\mathrm{G}_{\mathrm{c}}$ à temperatura ambiente.

$$
f_{c m, \theta c}=k_{c, \theta c} \times f_{c m}
$$

onde:

$\mathrm{f}_{\mathrm{cm}, \theta \mathrm{c}}=$ resistência média à compressão do concreto à temperatura $\theta_{\mathrm{c}}\left[\mathrm{N} / \mathrm{mm}^{2}\right]$;

$\mathrm{k}_{\mathrm{c}, \theta c}=$ fator de redução da resistência à compressão do concreto à temperatura $\theta_{\mathrm{c}}$ [adimensional].

\subsection{Comportamento linear elástico}

\subsection{COEFICIENTE DE POISSON}

O DIANA permite que o coeficiente de Poisson seja posto em função de temperaturas elevadas, mas essa propriedade foi considerada constante nas análises numéricas conduzidas nesta Tese. Apesar de terem sido encontradas algumas pesquisas que apresentaram dados experimentais ou métodos para admitir esse coeficiente na condição de incêndio, dentre elas as de Marechal (1972), Ehm (1986), Elghazouli e Izzuddin (2001) e Bahr et al. (2013), os próprios autores comentaram que as informações acerca desse tópico ainda são escassas. Além disso, não foram encontradas equações normativas para estabelecer a variação dessa propriedade frente à ação do fogo. 


\subsection{MÓDULO DE ELASTICIDADE}

A redução do valor característico do módulo de elasticidade secante do concreto foi adotada com base nas prescrições do Eurocode 4 parte 1-2 (2005), haja vista que o Eurocode 2 parte 1-2 (2004) não se pronuncia sobre o assunto ${ }^{2}$. Como indicado na Equação 4.10, essa variação foi determinada por meio de fatores que reduziam o valor estipulado para essa propriedade na condição de temperatura ambiente $\left(\mathrm{E}_{\mathrm{cm}}=26,446 \times 10^{3} \mathrm{~N} / \mathrm{mm}^{2}\right)$. De acordo com a norma europeia que apresenta as diretrizes para o projeto de estruturas mistas em situação de incêndio, esses fatores devem ser calculados pela Equação 4.11, considerando $\mathrm{E}_{\mathrm{cm}, 20^{\circ} \mathrm{C}}$ conforme a Equação 4.12. Admitindo-se as propriedades $\mathrm{k}_{\mathrm{c}, \theta \mathrm{c}}$ e $\varepsilon_{\mathrm{c} 1, \theta \mathrm{c}}$ indicadas pelo Eurocode 2 parte 1-2 (2004) para concretos produzidos com agregados calcários, determinaram-se os fatores $\mathrm{k}_{\mathrm{E}, \theta \mathrm{c}}$ representados graficamente na Figura 4.63. Logo, esses foram os fatores adotados nas análises numéricas da presente investigação para diminuir o módulo de elasticidade do concreto exposto a temperaturas elevadas. Mais detalhes sobre essa proposta de redução do Eurocode 4 parte 1-2 (2005) são apresentadas em Hager e Krzemień (2015).

$$
\begin{gathered}
E_{c m, \theta c}=k_{E, \theta c} \times E_{c m} \\
k_{E, \theta c}=\frac{\frac{f_{c m, \theta c}}{\varepsilon_{c 1, \theta c}}}{E_{c m, 20^{\circ} \mathrm{C}}} \therefore k_{E, \theta}=\frac{\frac{k_{c, \theta c} \times f_{c m}}{\varepsilon_{c 1, \theta c}}}{E_{c m, 20^{\circ} \mathrm{C}}} \\
E_{c m, 20^{\circ} \mathrm{C}}=\frac{f_{c m}}{\varepsilon_{c 1,20^{\circ} \mathrm{C}}}
\end{gathered}
$$

onde:

$\mathrm{E}_{\mathrm{cm}, \theta \mathrm{c}}=$ módulo de elasticidade secante do concreto à temperatura $\theta_{\mathrm{c}}\left[\mathrm{N} / \mathrm{mm}^{2}\right]$;

$\mathrm{E}_{\mathrm{cm}, 20^{\circ} \mathrm{C}}=$ módulo de elasticidade secante do concreto à temperatura de $20{ }^{\circ} \mathrm{C}$, calculado em função de $\mathrm{f}_{\mathrm{cm}}$ e $\varepsilon_{\mathrm{c} 1,20}{ }^{\circ} \mathrm{C}\left[\mathrm{N} / \mathrm{mm}^{2}\right]$;

\footnotetext{
${ }^{2}$ O Eurocode 2 parte 1-2 (2004) não apresenta uma variação do módulo de elasticidade no que tange a concretos de resistência convencional, indicando apenas uma proposta para concretos de resistência elevada, em que o valor à temperatura ambiente desse parâmetro pode ser reduzido pela multiplicação ao fator $\mathrm{k}_{\mathrm{c}, \theta \mathrm{c}}{ }^{2}$.
} 
$\mathrm{k}_{\mathrm{E}, \theta c}=$ fator de redução do módulo de elasticidade secante do concreto à temperatura $\theta_{\mathrm{c}}$ [adimensional];

$\varepsilon_{\mathrm{c} 1, \theta \mathrm{c}}=$ deformação específica do concreto à temperatura $\theta_{\mathrm{c}}$ [adimensional];

$\varepsilon_{\mathrm{c} 1,20{ }^{\circ} \mathrm{C}}=$ deformação específica do concreto à temperatura de $20^{\circ} \mathrm{C}$, determinada conforme $\mathrm{o}$ Eurocode 2 parte 1-2 (2004) [adimensional].

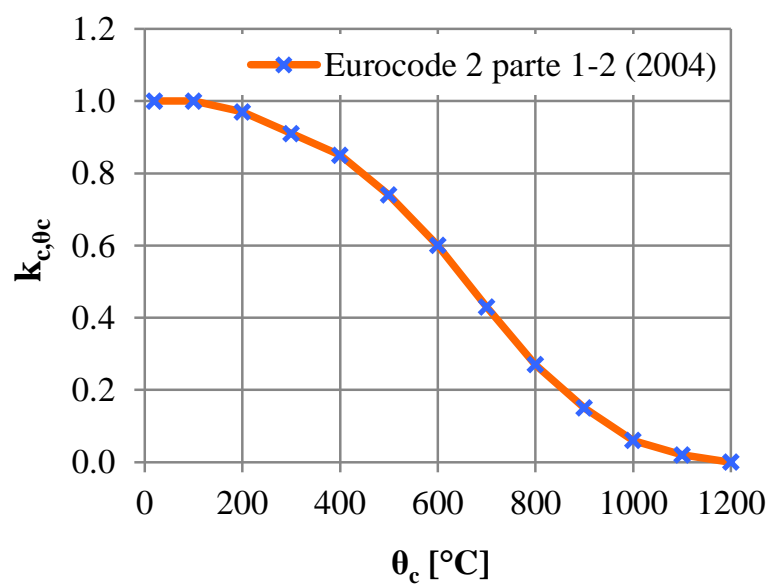

Figura 4.62 - Fatores de redução da resistência à compressão de concreto produzido com agregados calcários.

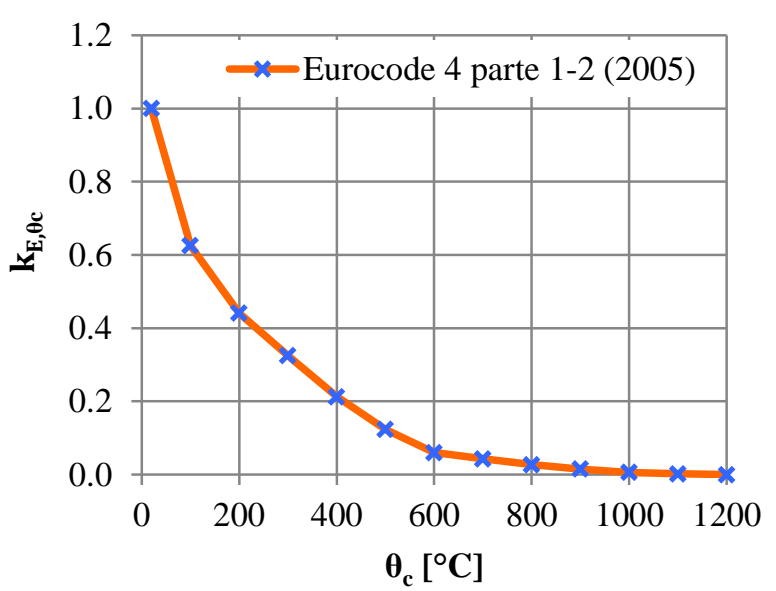

Figura 4.63 - Fatores de redução do módulo de elasticidade de concreto produzido com agregados calcários.

\subsection{COEFICIENTE DE EXPANSÃO TÉRMICA}

Nas análises ao fogo, o coeficiente de expansão térmica passou a ser considerado como uma das propriedades lineares do concreto. O Eurocode 2 parte 1-2 (2004) não disponibiliza uma fórmula direta para o seu cálculo, mas indica as Equações 4.13 e 4.14 para a determinação da expansão ou alongamento térmico de concretos produzidos com agregados calcários.

Os resultados obtidos por meio da Equação 4.13 foram introduzidos na Equação 4.15 para que então fossem determinados os coeficientes de expansão térmica para a situação de incêndio. Esse método de cálculo pôde ser aplicado somente até $805{ }^{\circ} \mathrm{C}$, pois em seguida a norma estabelece um valor constante para a expansão térmica, que uma vez aplicado à Equação 4.15 
resultava em um decaimento do coeficiente de expansão, o que não parecia ter sentido nesse caso. Se a expansão térmica do concreto se estabiliza após essa temperatura (Figura 4.64), o coeficiente de expansão térmica deveria seguir uma tendência similar.

$\mathrm{Na}$ análise das variações indicadas por outros poucos autores, verificou-se que ou o coeficiente de expansão se mostrava constante a partir de certa temperatura, conforme ilustra o gráfico de Ellingwood e Lin (1991) na Figura 4.65, ou era admitido sempre crescente, vide Rafi; Nadjai e Ali (2008) na Figura 4.66. Nesta investigação, optou-se por não fazer uma extrapolação de valores, mas sim em mantê-los constantes para as temperaturas superiores a $805^{\circ} \mathrm{C}$, tal como representado na Figura 4.67.

$$
\begin{array}{cl}
20{ }^{\circ} \mathrm{C} \leq \theta_{\mathrm{c}} \leq 805^{\circ} \mathrm{C} \quad \varepsilon_{c, \theta c}=-1,2 \times 10^{-4}+6 \times 10^{-6} \theta_{c}+1,4 \times 10^{-11} \theta_{c}{ }^{3} & \text { Equação (4.13) } \\
805^{\circ} \mathrm{C}<\theta_{c} \leq 1200{ }^{\circ} \mathrm{C} \quad \varepsilon_{c, \theta c}=12 \times 10^{-3} & \text { Equação (4.14) } \\
\alpha_{c, \theta c}=\frac{\varepsilon_{c, \theta c}}{\Delta_{\theta}} \therefore \alpha_{c, \theta c}=\frac{\varepsilon_{c, \theta c}}{\left(\theta_{c}-\theta_{c o}\right)} \therefore \alpha_{c, \theta c}=\frac{\varepsilon_{c, \theta c}}{\left(\theta_{c}-20\right)} & \text { Equação (4.15) }
\end{array}
$$

onde:

$\varepsilon_{\mathrm{c}, \theta \mathrm{c}}=$ expansão térmica do concreto à temperatura $\theta_{\mathrm{c}}[\mathrm{m} / \mathrm{m}]$;

$\alpha_{c, \theta c}=$ coeficiente de expansão térmica do concreto à temperatura $\theta_{\mathrm{c}}\left[{ }^{\circ} \mathrm{C}^{-1}\right]$;

$\theta_{\text {co }}=$ temperatura inicial do concreto, admitida igual a $20\left[{ }^{\circ} \mathrm{C}\right]$.

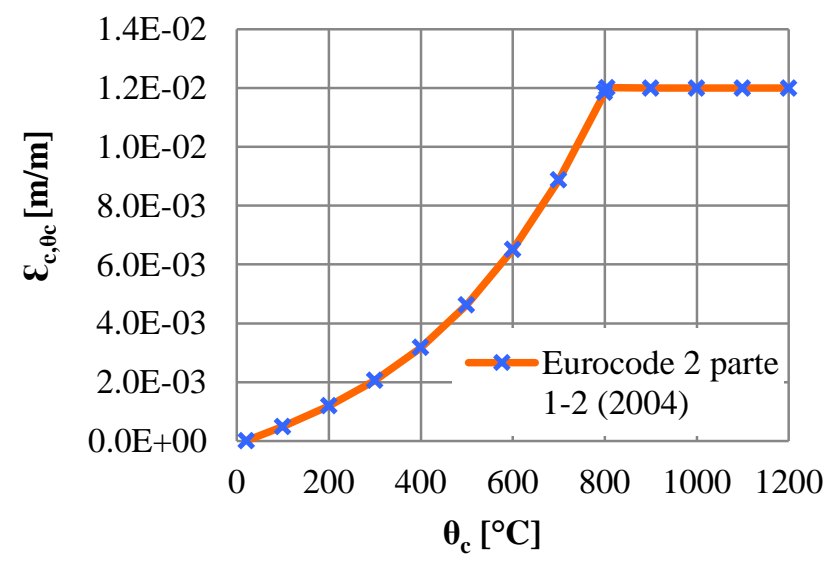

Figura 4.64 - Variação da expansão térmica (alongamento) de concreto produzido com agregados calcários.

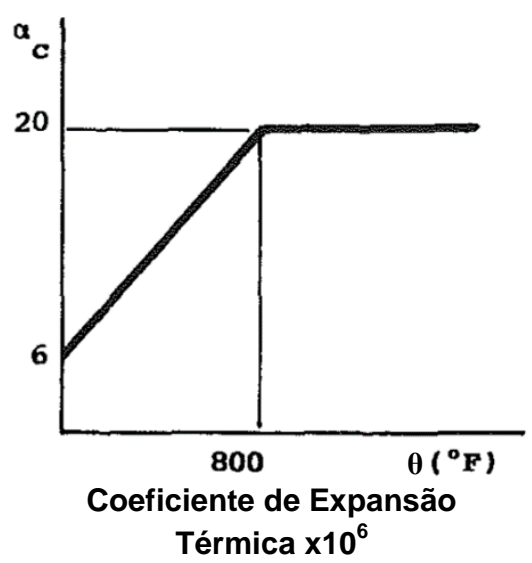

Figura 4.65 - Variação do coeficiente de expansão térmica do concreto apresentada por Ellingwood e Lin (1991; adaptado). 


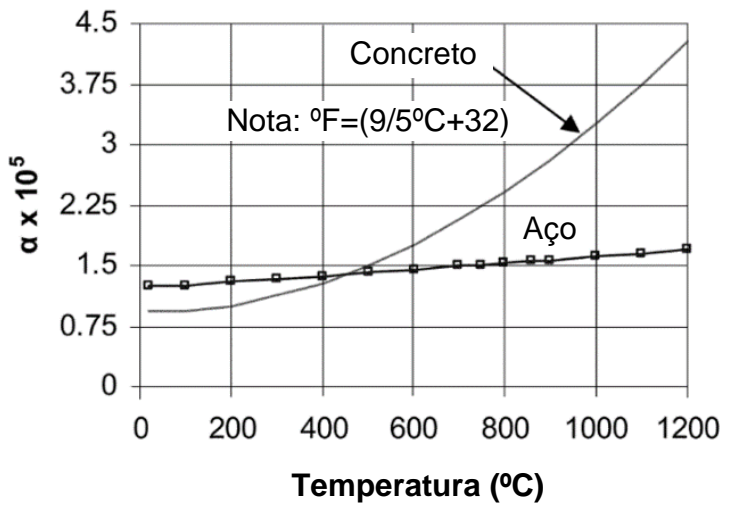

Figura 4.66 - Variação do coeficiente de expansão térmica de concreto produzido com agregados silicosos proposta por Rafi; Nadjai e Ali (2008; adaptado).

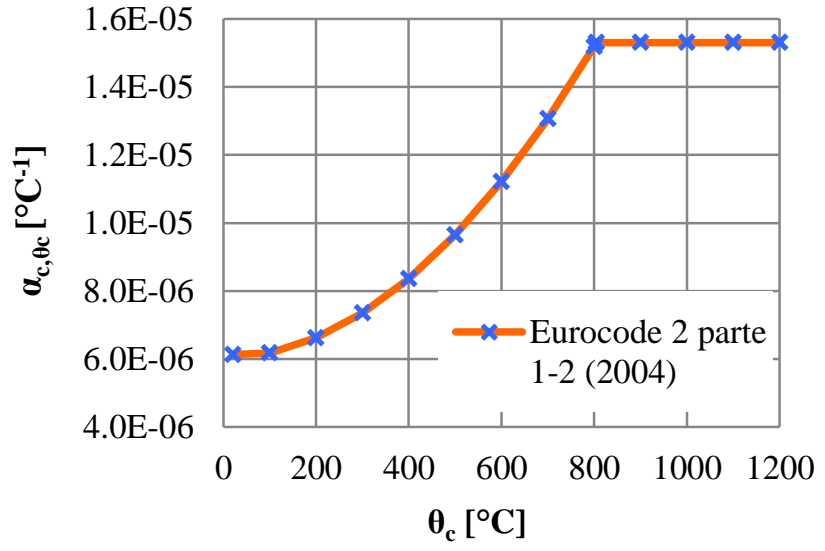

Figura 4.67 - Variação do coeficiente de expansão térmica de concreto produzido com agregados calcários.

\subsection{Fluxo de calor}

\subsection{CONDUTIVIDADE TÉRMICA}

As propriedades que devem ser inseridas nas análises ao fogo no DIANA para caracterizar o fluxo de calor em determinado material consistem na condutividade e na capacitância, sendo a segunda determinada pelo produto da massa específica e do calor específico, ambos em função de temperaturas elevadas. A condutividade térmica do concreto foi adotada de acordo com a curva do limite inferior proposta pelo Eurocode 2 parte 1-2 (2004) e expressa por meio da Equação 4.16, sendo essa mais representativa dos agregados calcários, que por serem mais isolantes apresentam comportamento próximo ao que ocorre nos concretos leves. Esse limite está representado graficamente na Figura 4.68.

$$
20{ }^{\circ} \mathrm{C} \leq \theta_{\mathrm{c}} \leq 1200{ }^{\circ} \mathrm{C} \quad \lambda_{c, \theta c}=1,36-0,136\left(\frac{\theta_{c}}{100}\right)+0,0057\left(\frac{\theta_{c}}{100}\right)^{2} \quad \text { Equação (4.16) }
$$

onde: 
$\lambda_{\mathrm{c}, \theta \mathrm{c}}=$ condutividade térmica do concreto à temperatura $\theta_{\mathrm{c}}\left[\mathrm{W} /\left(\mathrm{m}{ }^{\circ} \mathrm{C}\right)\right]$.

\subsection{MASSA ESPECÍFICA}

A variação da massa específica foi calculada conforme o Eurocode 2 parte 1-2 (2004), pelas Equações 4.17 a 4.20, admitindo-se o valor dessa propriedade à temperatura ambiente igual a $2297,953 \mathrm{~kg} / \mathrm{m}^{3}$, que fora obtido de forma experimental para caracterizar o material em estudo. Na Figura 4.69, indica-se a redução adotada para esse parâmetro no modelo numérico.

$$
\begin{array}{cll}
20{ }^{\circ} \mathrm{C} \leq \theta_{\mathrm{c}} \leq 115^{\circ} \mathrm{C} & \rho_{c, \theta c}=\rho_{c}\left(20^{\circ} \mathrm{C}\right) & \text { Equação (4.17) } \\
115^{\circ} \mathrm{C}<\theta_{\mathrm{c}} \leq 200^{\circ} \mathrm{C} & \rho_{c, \theta c}=\rho_{c}\left(20^{\circ} \mathrm{C}\right)\left(1-0,02 \frac{\left(\theta_{c}-115\right)}{85}\right) & \text { Equação (4.18) } \\
200{ }^{\circ} \mathrm{C}<\theta_{\mathrm{c}} \leq 400^{\circ} \mathrm{C} & \rho_{c, \theta c}=\rho_{c}\left(20^{\circ} \mathrm{C}\right)\left(0,98-0,03 \frac{\left(\theta_{c}-200\right)}{200}\right) & \text { Equação (4.19) } \\
400{ }^{\circ} \mathrm{C}<\theta_{\mathrm{c}} \leq 1200^{\circ} \mathrm{C} & \rho_{c, \theta c}=\rho_{c}\left(20^{\circ} \mathrm{C}\right)\left(0,95-0,07 \frac{\left(\theta_{c}-400\right)}{800}\right) & \text { Equação (4.20) }
\end{array}
$$

onde:

$\rho_{\mathrm{c}, \theta c}=$ massa específica do concreto à temperatura $\theta_{\mathrm{c}}\left[\mathrm{kg} / \mathrm{m}^{3}\right]$.

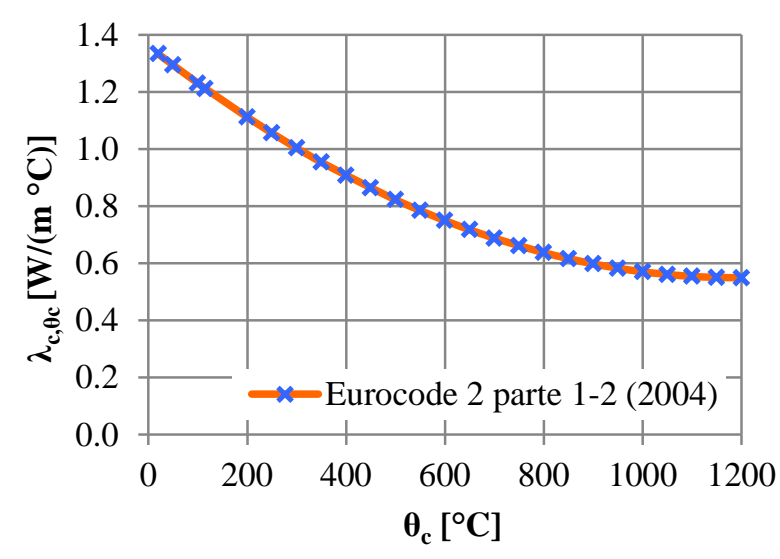

Figura 4.68 - Limite inferior da condutividade térmica de concreto submetido ao fogo.

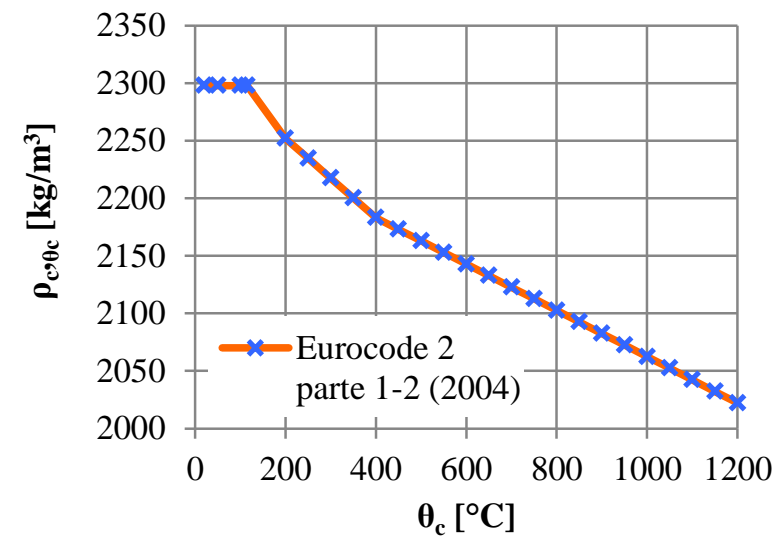

Figura 4.69 - Variação da massa específica do concreto com $\rho_{\mathrm{c}}\left(20{ }^{\circ} \mathrm{C}\right)=2297,953 \mathrm{~kg} / \mathrm{m}^{3}$. 


\subsection{CALOR ESPECÍFICO}

O calor específico também seguiu o disposto no Eurocode 2 parte 1-2 (2004), sendo definido a partir das Equações 4.21 a 4.24 .

$$
\begin{aligned}
20{ }^{\circ} \mathrm{C} \leq \theta_{c} \leq 100{ }^{\circ} \mathrm{C} & c_{p, \theta c}=900 \\
100{ }^{\circ} \mathrm{C}<\theta_{c} \leq 200{ }^{\circ} \mathrm{C} & c_{p, \theta c}=900+\left(\theta_{c}-100\right) \\
200{ }^{\circ} \mathrm{C}<\theta_{c} \leq 400{ }^{\circ} \mathrm{C} & c_{p, \theta c}=1000+\frac{\left(\theta_{c}-200\right)}{2} \\
400{ }^{\circ} \mathrm{C}<\theta_{\mathrm{c}} \leq 1200{ }^{\circ} \mathrm{C} & c_{p, \theta c}=1100
\end{aligned}
$$

onde:

$\mathrm{c}_{\mathrm{p}, \theta \mathrm{c}}=$ calor específico do concreto à temperatura $\theta_{\mathrm{c}}\left[\mathrm{J} /\left(\mathrm{kg}{ }^{\circ} \mathrm{C}\right)\right]$.

Essa propriedade é pouco influenciada pelo tipo de agregado, entretanto, a umidade consiste em um fator determinante ao calor específico do concreto, sobretudo em temperaturas abaixo de $200{ }^{\circ} \mathrm{C}$ (BERNHART, 2004). Desse modo, quando a umidade não for considerada explicitamente no método de cálculo, a função do calor específico para concretos com agregados calcários ou silicosos pode ser modelada por um valor constante situado entre 100 e $115^{\circ} \mathrm{C}$, com decréscimo linear entre 115 e $200{ }^{\circ} \mathrm{C}$, como indicado a seguir. Esses valores de pico, sugeridos pela norma europeia, correspondem à quantidade de energia térmica necessária para que a água livre da pasta de cimento seja evaporada. Logo, quanto maior a umidade, maior o calor específico do concreto, haja vista que é preciso mais calor para se aquecer a água.

○ Para umidade de $0 \%$ do peso do concreto: $\mathrm{c}_{\mathrm{p}, \mathrm{u}}=900 \mathrm{~J} /\left(\mathrm{kg}{ }^{\circ} \mathrm{C}\right)$;

○ Para umidade de $1,5 \%$ do peso do concreto: $\mathrm{c}_{\mathrm{p}, \mathrm{u}}=1470 \mathrm{~J} /\left(\mathrm{kg}{ }^{\circ} \mathrm{C}\right)$;

○ Para umidade de $3 \%$ do peso do concreto: $\mathrm{c}_{\mathrm{p}, \mathrm{u}}=2020 \mathrm{~J} /\left(\mathrm{kg}^{\circ} \mathrm{C}\right)$. 
Nas análises numéricas deste trabalho, o valor de pico do calor específico foi calculado mediante uma interpolação linear entre os dados indicados pela norma e a umidade obtida experimentalmente para caracterizar o concreto das vigas ensaiadas. Sendo assim, a partir de da umidade igual a $1,664 \%$ em peso referente ao material da primeira concretagem, encontrou-se $\mathrm{c}_{\mathrm{p}, \mathrm{u}}$ igual a $1530,1333 \mathrm{~J} /\left(\mathrm{kg}{ }^{\circ} \mathrm{C}\right)$. Na Figura 4.70 , ilustra-se por meio gráfico a variação adotada para o calor específico.

Mais informações teóricas acerca do efeito do fogo nas propriedades mecânicas e térmicas do concreto podem ser encontradas em Kodur (2014), Kodur e Harmathy (2002), Buchanan e Abu (2017), Purkiss e Li (2014), Boletim nº 38 da fib-CEB (2007) e Khoury (2000).

\subsubsection{Aço dos blocos dos apoios e das chapas de distribuição das forças}

Como já referido ao longo deste capítulo, os blocos dos apoios e as chapas de distribuição das forças não possuíam função estrutural, mas funcionavam como elementos auxiliares, tanto nos ensaios quanto na modelagem da viga. Por isso, não se verificou a necessidade de variar com a temperatura as propriedades mecânicas (módulo de elasticidade e coeficiente de Poisson) do aço que os constituía. Em contrapartida, a variação das suas propriedades térmicas foram admitidas como dados de entrada, a fim de que a eventual influência desses elementos no campo de temperaturas de determinadas regiões do modelo pudesse ser considerada. Essas propriedades foram calculadas com base nas prescrições do Eurocode 3 parte 1-2 (2005) no que diz respeito a aços carbono, classe a qual pertence o aço S275 JR de tais elementos. Assim, aplicaram-se as Equações 4.25 e 4.26 para o cálculo da condutividade térmica e as Equações 4.27 a 4.30 para a determinação do calor específico. As variações de ambos se encontram representadas graficamente nas Figuras 4.71 e 4.72. A capacitância foi calculada com a consideração de uma massa específica igual a $7850 \mathrm{~kg} / \mathrm{m}^{3}$, pois segundo a mesma norma essa propriedade pode ser admitida independente da sua temperatura. 


$$
\begin{aligned}
20{ }^{\circ} \mathrm{C} \leq \theta_{\mathrm{a}}<800{ }^{\circ} \mathrm{C} & \lambda_{c, \theta a}=54-3,33 \times 10^{-2} \theta_{a} \\
800{ }^{\circ} \mathrm{C} \leq \theta_{\mathrm{a}} \leq 1200{ }^{\circ} \mathrm{C} \quad \lambda_{c, \theta a} & =27,3
\end{aligned}
$$

onde:

$\lambda_{\mathrm{c}, \theta \mathrm{a}}=$ condutividade térmica do aço carbono estrutural à temperatura $\theta_{\mathrm{a}}\left[\mathrm{W} /\left(\mathrm{m}^{\circ} \mathrm{C}\right)\right]$;

$\theta_{\mathrm{a}}=$ temperatura do aço carbono estrutural $\left[{ }^{\circ} \mathrm{C}\right]$.

$$
\begin{aligned}
& \begin{aligned}
20{ }^{\circ} \mathrm{C} \leq \theta_{\mathrm{a}}<600{ }^{\circ} \mathrm{C} \quad \begin{array}{c}
c_{a, \theta a}=425+ \\
+, 73 \times 10^{-1} \theta_{a}-1,69 \times 10^{-3} \theta_{a}{ }^{2} \\
+2,22 \times 10^{-6} \theta_{a}{ }^{3}
\end{array} \\
600{ }^{\circ} \mathrm{C} \leq \theta_{\mathrm{a}} \leq 735^{\circ} \mathrm{C} \quad c_{a, \theta a}=666+\frac{13002}{738-\theta_{a}} \\
735^{\circ} \mathrm{C} \leq \theta_{\mathrm{a}} \leq 900^{\circ} \mathrm{C} \quad c_{a, \theta a}=545+\frac{17820}{\theta_{a}-731} \\
900{ }^{\circ} \mathrm{C} \leq \theta_{\mathrm{a}} \leq 1200{ }^{\circ} \mathrm{C} \quad c_{a, \theta a}=650
\end{aligned} \\
& \text { onde: } \\
& c_{\mathrm{a}, \theta \mathrm{a}}=\text { calor específico do aço carbono estrutural à temperatura } \theta_{\mathrm{a}}\left[\mathrm{J} /\left(\mathrm{kg}{ }^{\circ} \mathrm{C}\right)\right] .
\end{aligned}
$$

\subsubsection{Aços das armaduras longitudinais e transversais}

\subsection{Tensões de tração e módulo de elasticidade}

As propriedades mecânicas definidas à temperatura ambiente para as armaduras longitudinais e transversais - a tensão correspondente ao limite de proporcionalidade $\left(\mathrm{f}_{\mathrm{sp}}\right)$, a tensão máxima ou resistência ao escoamento do aço $\left(\mathrm{f}_{\mathrm{sy}}\right)$ e o módulo de elasticidade $\left(\mathrm{E}_{\mathrm{s}}\right)$ - foram variadas em função das altas temperaturas a partir das Equações 4.31 a 4.33, ou seja, mediante os 
coeficientes redutores indicados pelo Eurocode 2 parte 1-2 (2004) para aços laminados a quente, haja vista ser esse o processo de fabrico correspondente ao aço A500.

No programa de computador DIANA, uma vez estipulado o diagrama tensão vs deformação proposto pela norma europeia para modelar o comportamento ao fogo das armaduras e definido o processo de fabrico do aço, esses coeficientes, indicados nas Figuras 4.73 a 4.75 , são automaticamente aplicados às propriedades anteriormente citadas. Nas Figuras 4.76 e 4.77, apresentam-se as variações das curvas das tensões em função das deformações representativas dos aços das armaduras longitudinais e transversais. Essas curvas foram reproduzidas com base nas equações constitutivas normatizadas e nos valores correspondentes à temperatura ambiente para cada aço (vide Figuras 4.23 e 4.24 e Tabela 4.1), a fim de ilustrar os diagramas que são calculados automaticamente pelo programa durante as análises numéricas com consideração de temperaturas elevadas.

$$
\begin{gathered}
f_{s p, \theta s}=k_{s p, \theta s} \times f_{s p} \\
f_{s y, \theta s}=k_{s y, \theta s} \times f_{s y} \\
E_{s, \theta s}=k_{E s, \theta s} \times E_{s}
\end{gathered}
$$

onde:

$\mathrm{E}_{\mathrm{s}, \theta \mathrm{s}}=$ módulo de elasticidade do aço das armaduras à temperatura $\theta_{\mathrm{s}}\left[\mathrm{N} / \mathrm{mm}^{2}\right]$;

$\mathrm{f}_{\mathrm{sp}, \theta \mathrm{s}}=$ tensão correspondente ao limite de proporcionalidade do aço das armaduras à temperatura $\theta_{\mathrm{s}}\left[\mathrm{N} / \mathrm{mm}^{2}\right]$;

$\mathrm{f}_{\mathrm{sy}, \theta \mathrm{s}}=$ resistência ao escoamento do aço das armaduras à temperatura $\theta_{\mathrm{s}}\left[\mathrm{N} / \mathrm{mm}^{2}\right]$;

$\mathrm{k}_{\mathrm{Es}, \theta \mathrm{s}}=$ fator de redução do módulo de elasticidade do aço das armaduras à temperatura $\theta_{\mathrm{s}}$ [adimensional];

$\mathrm{k}_{\mathrm{fsp}, \theta \mathrm{s}}=$ fator de redução da tensão correspondente ao limite de proporcionalidade do aço das armaduras à temperatura $\theta_{\mathrm{s}}$ [adimensional].

$\mathrm{k}_{\mathrm{fsy}, \theta \mathrm{s}}=$ fator de redução resistência ao escoamento do aço das armaduras à temperatura $\theta_{\mathrm{s}}$ [adimensional];

$\theta_{\mathrm{s}}=$ temperatura do aço das armaduras $\left[{ }^{\circ} \mathrm{C}\right]$. 


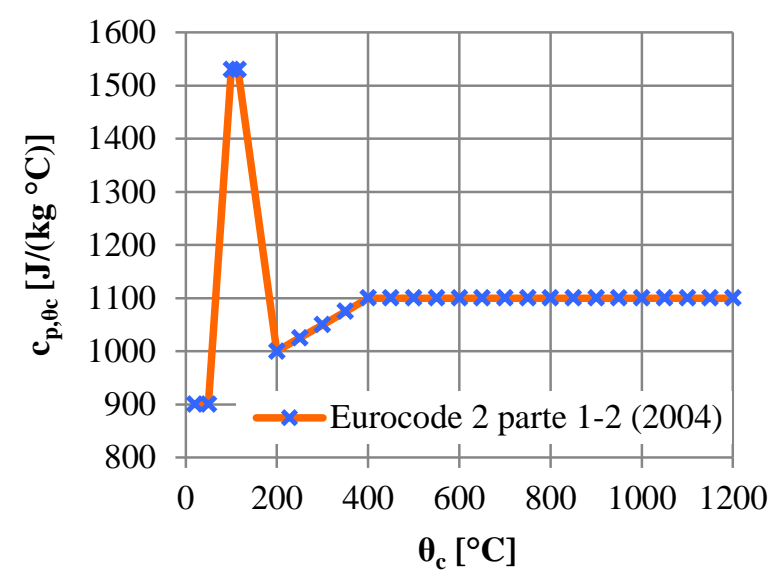

Figura 4.70 - Variação do calor específico do concreto com umidade de $1,664 \%$.

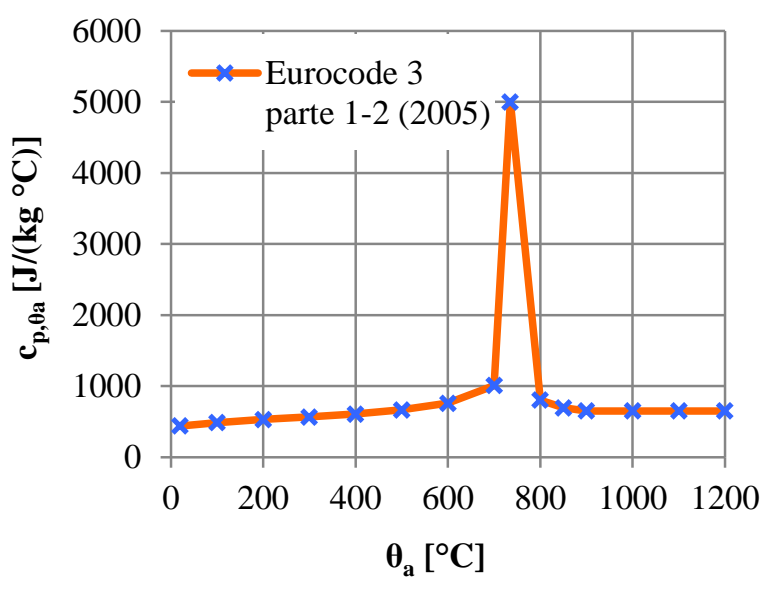

Figura 4.72 - Variação do calor específico do aço carbono estrutural.

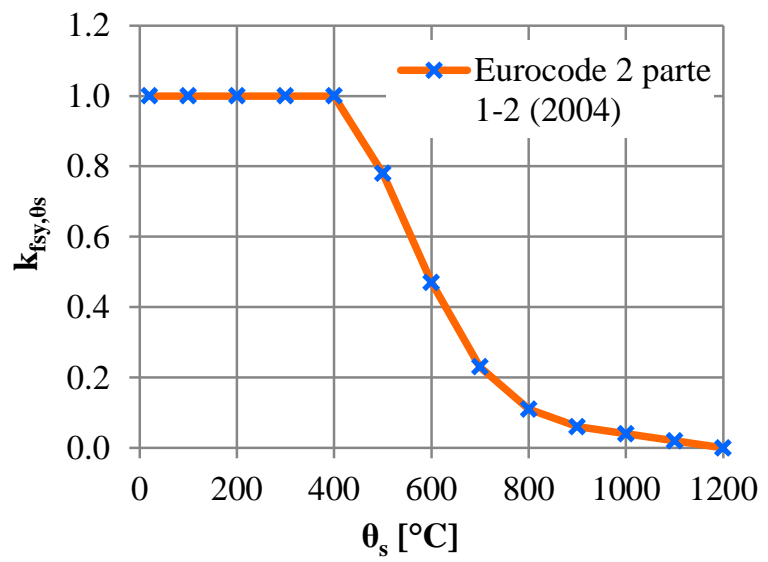

Figura 4.74 - Variação da resistência ao escoamento do aço das armaduras.

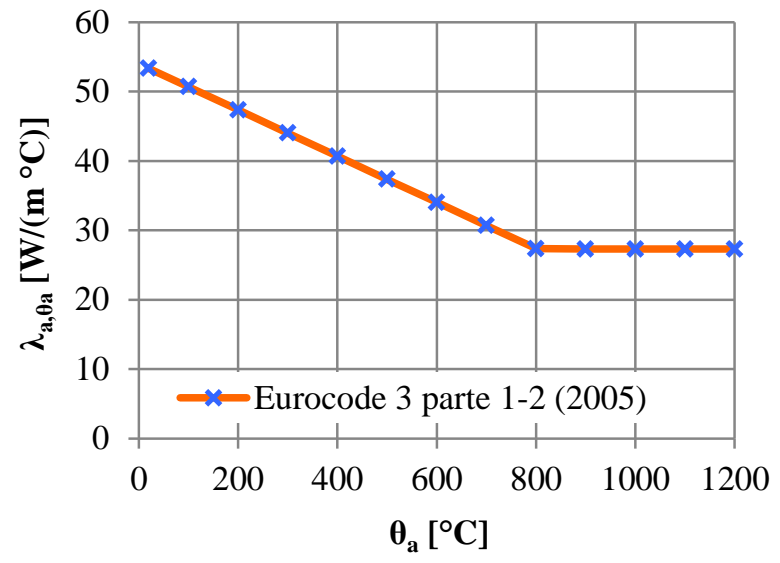

Figura 4.71 - Variação da condutividade térmica de aço carbono estrutural.

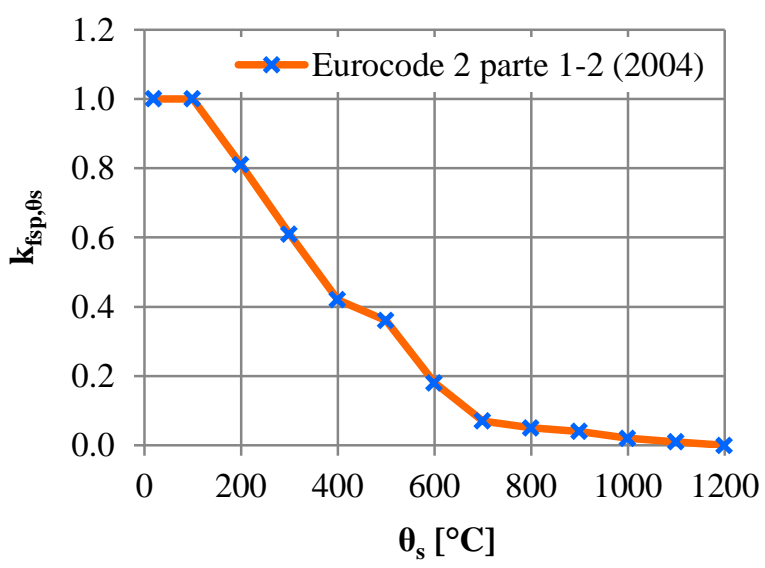

Figura 4.73 - Variação da tensão correspondente ao limite de proporcionalidade do aço das armaduras.

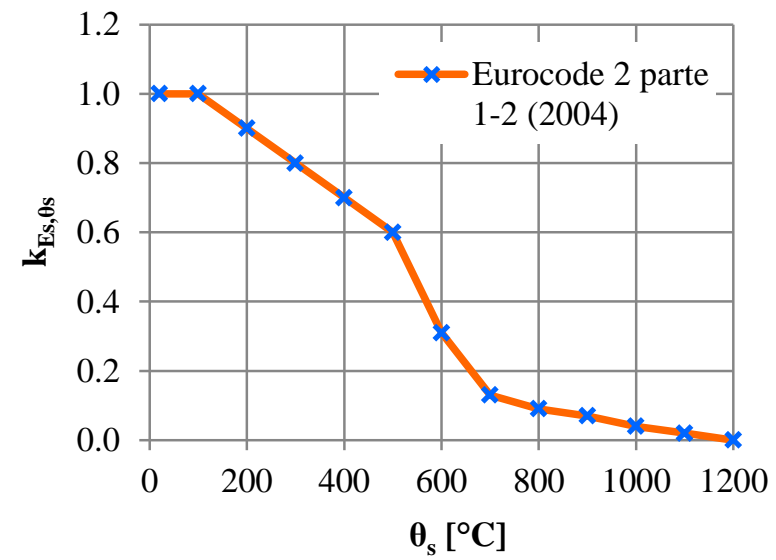

Figura 4.75 - Variação do módulo de elasticidade do aço das armaduras. 


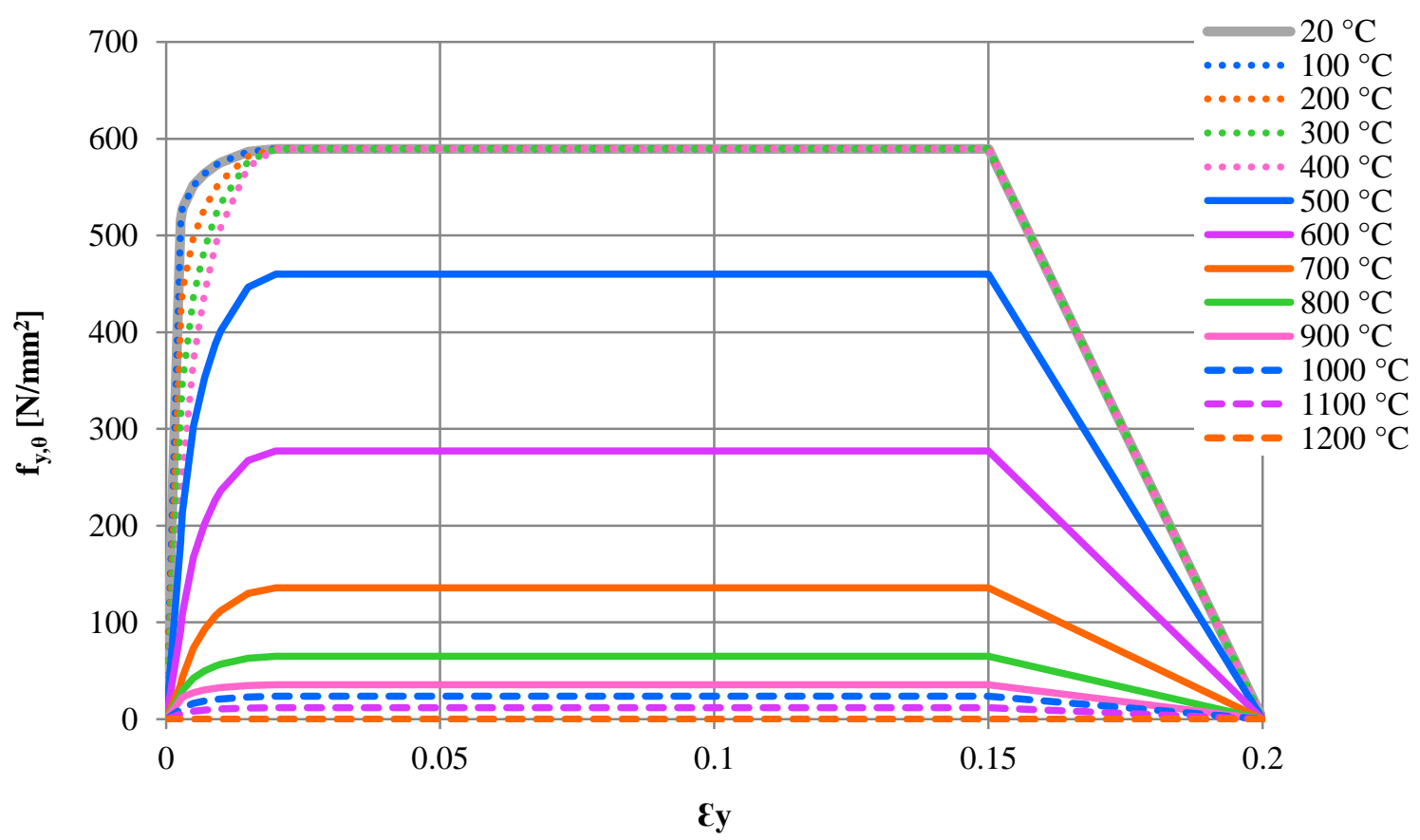

Figura 4.76 - Variações das curvas tensão vs deformação do aço com diâmetro $\phi 10$ mm das armaduras longitudinais, traçadas com coeficientes redutores propostos pelo Eurocode 2 parte 1-2 (2004).

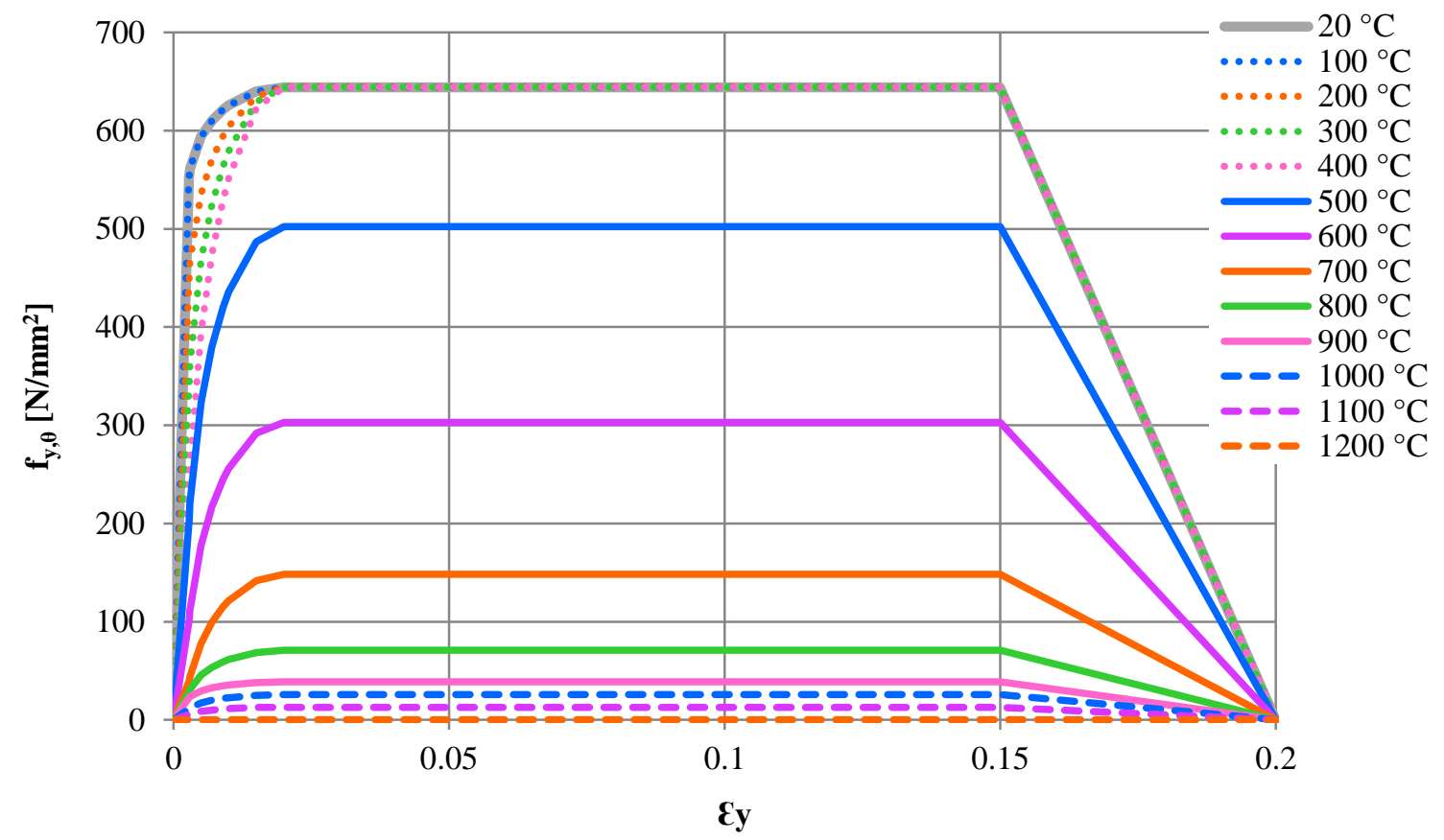

Figura 4.77 - Variações das curvas tensão vs deformação do aço com diâmetro $\phi 6$ mm das armaduras transversais, traçadas com coeficientes redutores propostos pelo Eurocode 2 parte 1-2 (2004). 


\subsection{Coeficiente de expansão térmica}

Ainda em relação aos dados de entrada para a caracterização das armaduras, inseriram-se os coeficientes de expansão térmica do aço. Da mesma forma que para o concreto, o Eurocode 2 parte 1-2 (2004) não disponibiliza uma fórmula direta para o cálculo de tais coeficientes, logo, esses foram novamente definidos com base nas Equações 4.34 a 4.36, que são indicadas pela norma para a determinação da expansão térmica do aço para concreto armado. Os resultados provenientes das mesmas foram inseridos na Equação 4.37 e, mais uma vez, admitiram-se coeficientes constantes a partir da temperatura para a qual eles passavam a apresentar valores decrescentes (nesse caso, após $750{ }^{\circ} \mathrm{C}$ ). Uma curva com a mesma tendência daquela adotada nesta investigação foi verificada em Ellingwood e Lin (1991).

A seguir, na Figura 4.78, indicam-se os valores de alongamento térmico que serviram de base para o cálculo dos coeficientes e, na Figura 4.79, a representação gráfica dos próprios coeficientes estipulados como dados de entrada no programa. Nessas análises, a introdução de propriedades térmicas para caracterizar os fluxos de calor atuantes nas armaduras embutidas não se mostrou necessária porque o DIANA admite que as temperaturas nesses elementos são iguais às equivalentes ao concreto.

$$
\begin{array}{clc}
20^{\circ} \mathrm{C} \leq \theta_{s} \leq 750{ }^{\circ} \mathrm{C} & \varepsilon_{s, \theta s}=-2,416 \times 10^{-4}+1,2 \times 10^{-5} \theta_{s}+0,4 \times 10^{-8} \theta_{s}{ }^{2} & \text { Equação (4.34) } \\
750{ }^{\circ} \mathrm{C}<\theta_{s} \leq 860{ }^{\circ} \mathrm{C} & \varepsilon_{s, \theta s}=11 \times 10^{-3} & \text { Equação (4.35) } \\
860{ }^{\circ} \mathrm{C}<\theta_{s} \leq 1200^{\circ} \mathrm{C} & \varepsilon_{s, \theta s}=-6,2 \times 10^{-3}+2 \times 10^{-5} \theta_{s} & \text { Equação (4.36) } \\
\alpha_{s, \theta s}=\frac{\varepsilon_{s, \theta s}}{\Delta_{\theta}} \therefore \alpha_{s, \theta s}=\frac{\varepsilon_{s, \theta s}}{\left(\theta_{s}-\theta_{s o}\right)} \therefore \alpha_{s, \theta s}=\frac{\varepsilon_{s, \theta s}}{\left(\theta_{s}-20\right)} & \text { Equação (4.37) }
\end{array}
$$

onde:

$\varepsilon_{\mathrm{s}, \theta \mathrm{s}}=$ expansão térmica do aço para armaduras à temperatura $\theta_{\mathrm{s}}[\mathrm{m} / \mathrm{m}]$;

$\alpha_{\mathrm{s}, \theta \mathrm{s}}=$ coeficiente de expansão térmica do aço para armaduras à temperatura $\theta_{\mathrm{s}}\left[{ }^{\circ} \mathrm{C}^{-1}\right]$;

$\theta_{\mathrm{so}}=$ temperatura inicial do aço das armaduras, admitida igual a $20\left[{ }^{\circ} \mathrm{C}\right]$. 
Informações adicionais sobre o comportamento do aço de armaduras e da variação de suas propriedades mecânicas frente à ação do fogo são apresentadas nas pesquisas de Wang; Wong e Kodur (2003), Hertz (2004), Topçu e Karakurt (2008), Elghazouli; Cashell e Izzuddin (2009), Kowalski e Kisieliński (2011) e Kowalski (2017).

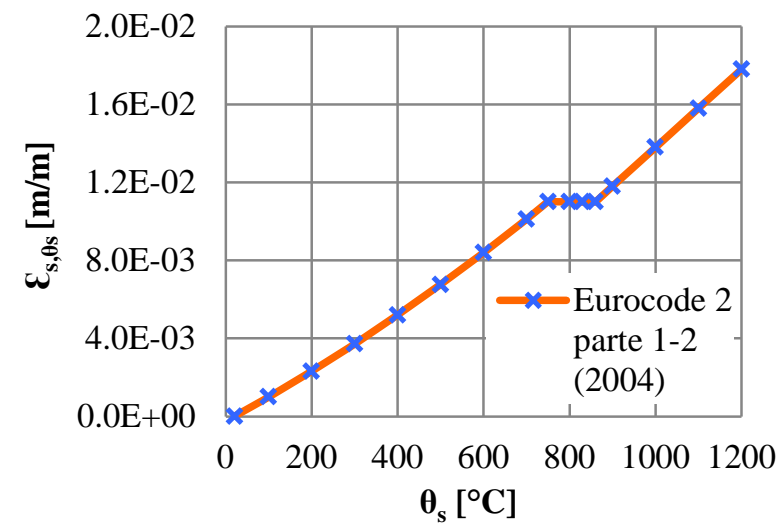

Figura 4.78 - Variação da expansão térmica (alongamento) de aço para concreto armado.

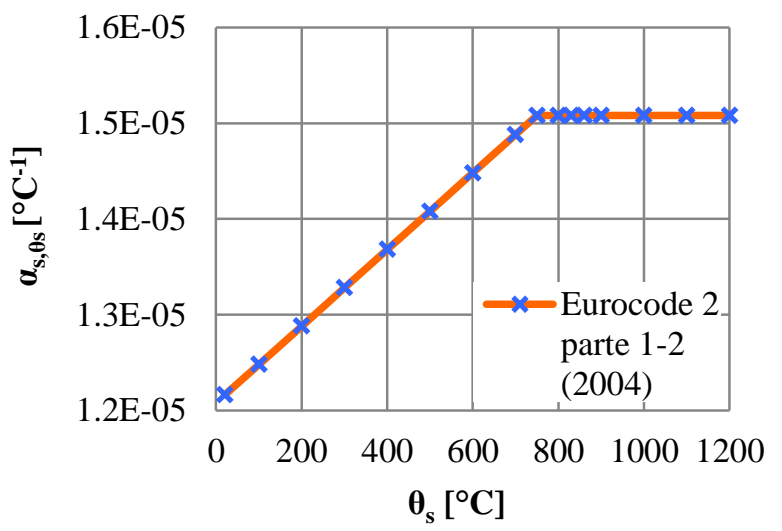

Figura 4.79 - Variação dos coeficientes de expansão térmica de aço para concreto armado.

\subsubsection{Fluxos de calor das interfaces diretamente aquecidas ou com isolamento}

Para caracterizar os fluxos de calor convectivos e radioativos dos elementos de interface designados sem manta, atribuíram-se as propriedades que de modo usual são adotadas para superfícies diretamente expostas ao fogo: coeficiente de transferência de calor por convecção $\left(\alpha_{c}\right)$ igual a $25 \mathrm{~W} /\left(\mathrm{m}^{2}{ }^{\circ} \mathrm{C}\right)$, haja vista que esse consiste no valor indicado pelo Eurocode 1 parte 1-2 (2002) para exposições conforme a curva de incêndio-padrão e o aquecimento do forno ao longo dos ensaios experimentais seguiu a tendência dessa curva; emissividade resultante $\left(\varepsilon_{\text {res }}\right)$ nas faces expostas ao fogo igual a 0,7, valor recomendado pelo Eurocode 2 parte 1-2 (2004) para superfícies de concreto.

Nas interfaces com manta, adotou-se um coeficiente de transferência de calor equivalente para simular no fluxo calorífico os efeitos advindos dessa camada de material isolante posta sobre as superfícies de concreto. Portanto, o uso desse coeficiente é capaz de simplificar a 
simulação numérica de camadas finas de materiais que existam entre o concreto e o seu entorno, tais como camadas de fôrmas (cofragens) ou isolantes térmicos, pois elimina a necessidade de que essas sejam modeladas explicitamente.

Esse método de cálculo foi proposto por Azenha (2004, 2009), com base nas seguintes hipóteses: considerando que os principais fluxos de calor que atuam nas superfícies de concreto são perpendiculares a elas e que as camadas desses materiais que envolvem o concreto usualmente possuem pequena espessura, é possível considerar o efeito do calor que se transfere por condução através dessas camadas até a supefície de concreto por meio de um coeficiente imposto a essa superfície. Então, o autor fez uma analogia dessas hipóteses a um circuito elétrico com resistências associadas em série, ilustrado na Figura 4.80, e propôs que o coeficiente de transferência de calor equivalente a esse circuito, ao qual ele chamou de "analogia resistência elétrica / resistência térmica", fosse calculado pela Equação 4.38.

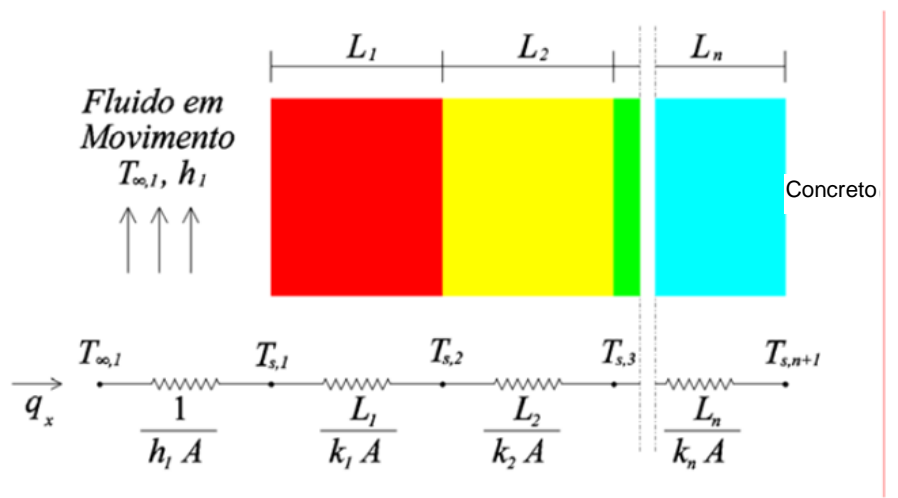

Figura 4.80 - Analogia resistência elétrica / resistência mecânica (AZENHA, 2004; adaptado).

$$
h_{e q}=\left[\frac{1}{h_{1}}+\sum_{i=1}^{n} \frac{L_{i}}{k_{i}}\right]^{-1}
$$

onde:

$\mathrm{h}_{\mathrm{eq}}=$ coeficiente de transferência de calor equivalente $\left[\mathrm{W} /\left(\mathrm{m}^{2}{ }^{\circ} \mathrm{C}\right)\right]$;

$\mathrm{h}_{1}=$ coeficente de transferência de calor do fluido em movimento $\left[\mathrm{W} /\left(\mathrm{m}^{2}{ }^{\circ} \mathrm{C}\right)\right]$;

$\mathrm{k}_{\mathrm{i}}=$ espessura da camada $\mathrm{i}[\mathrm{m}]$; 
$\mathrm{L}_{\mathrm{i}}=$ condutividade térmica da camada i entre a superfície de concreto e o fluido $\left[\mathrm{W} / \mathrm{m}{ }^{\circ} \mathrm{C}\right]$; $\mathrm{n}=$ número de camadas [adimensional] .

Considerando-se nessa equação o coeficiente de transferência de calor do fluido em movimento igual $25 \mathrm{~W} /\left(\mathrm{m}^{2}{ }^{\circ} \mathrm{C}\right)$, sendo esse o valor recomendado para os gases quentes que seguem a curva de incêndio-padrão, $n$ igual a 1 e $\mathrm{k}_{\mathrm{i}}$ igual a $0,05 \mathrm{~m}$, já que em algumas das faces isoladas foram aplicadas uma camada de manta com essa espessura, e as condutividades térmicas que foram fornecidas pelo fabricante da manta para determinadas temperaturas, obtiveram-se os valores de coeficientes de transferência de calor equivalentes indicados nas Equações 4.39 a 4.42 , que foram adotados como dados de entrada no DIANA para caracterizar os fluxos de calor das interfaces com manta em uma camada. Os mesmos estão representados graficamente na Figura 4.81 .

$$
\begin{gathered}
\theta_{\mathrm{m}}=400{ }^{\circ} \mathrm{C} \quad h_{e q}=\left[\frac{1}{25}+\frac{0,05}{0,1}\right]^{-1} \therefore h_{e q}=1,8518 \frac{\mathrm{W}}{\mathrm{m}^{2}{ }^{\circ} \mathrm{C}} \\
\theta_{\mathrm{m}}=600{ }^{\circ} \mathrm{C} \quad h_{e q}=\left[\frac{1}{25}+\frac{0,05}{0,16}\right]^{-1} \therefore h_{e q}=2,8369 \frac{\mathrm{W}}{\mathrm{m}^{2}{ }^{\circ} \mathrm{C}} \\
\theta_{\mathrm{m}}=800{ }^{\circ} \mathrm{C} \quad h_{e q}=\left[\frac{1}{25}+\frac{0,05}{0,23}\right]^{-1} \therefore h_{e q}=3,8851 \frac{\mathrm{W}}{\mathrm{m}^{2}{ }^{\circ} \mathrm{C}} \\
\theta_{\mathrm{m}}=1000{ }^{\circ} \mathrm{C} \quad h_{e q}=\left[\frac{1}{25}+\frac{0,05}{0,31}\right]^{-1} \therefore h_{e q}=4,9679 \frac{\mathrm{W}}{\mathrm{m}^{2}{ }^{\circ} \mathrm{C}}
\end{gathered}
$$

onde:

$\theta_{\mathrm{m}}=$ temperatura da manta de lã de silicato alcalino $\left[{ }^{\circ} \mathrm{C}\right]$.

Apenas substituindo $k_{i}$ por $0,1 \mathrm{~m}$ nas equações anteriores, encontraram-se os valores que se referem aos coeficientes de transferência de calor para as regiões isoladas com duas camadas de manta: $0,9615 \mathrm{~W} /\left(\mathrm{m}^{2}{ }^{\circ} \mathrm{C}\right)\left(\theta_{\mathrm{m}}=400{ }^{\circ} \mathrm{C}\right) ; 1,5037 \mathrm{~W} /\left(\mathrm{m}^{2}{ }^{\circ} \mathrm{C}\right)\left(\theta_{\mathrm{m}}=600{ }^{\circ} \mathrm{C}\right) ; 2,1062 \mathrm{~W} /\left(\mathrm{m}^{2}\right.$ $\left.{ }^{\circ} \mathrm{C}\right)\left(\theta_{\mathrm{m}}=800{ }^{\circ} \mathrm{C}\right) ; 2,7580 \mathrm{~W} /\left(\mathrm{m}^{2}{ }^{\circ} \mathrm{C}\right)\left(\theta_{\mathrm{m}}=1000{ }^{\circ} \mathrm{C}\right)$. Esses também estão representados na Figura 4.81 . 


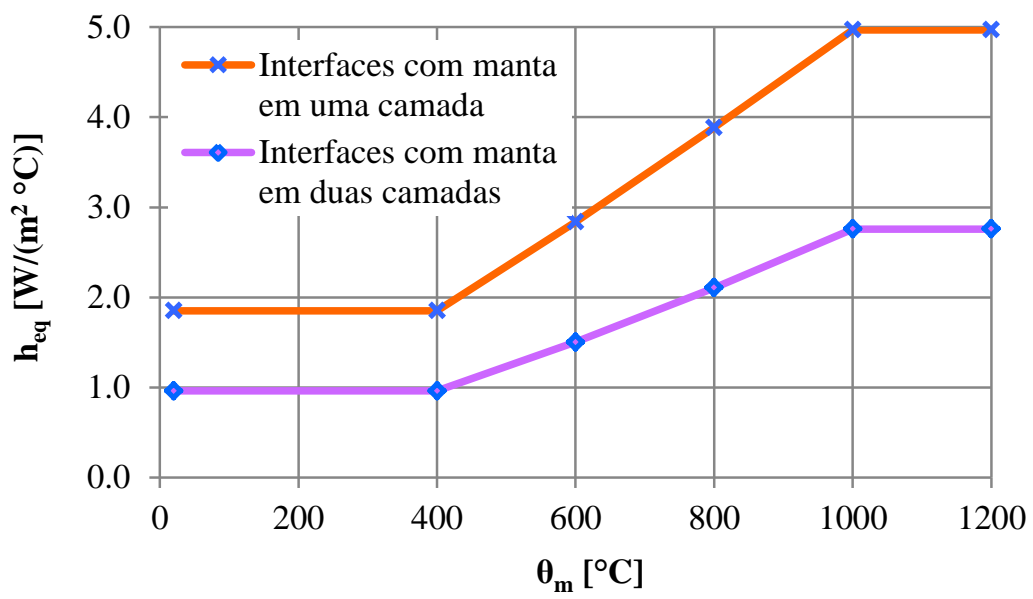

Figura 4.81 - Variação dos coeficientes de transferência de calor adotados para as interfaces com isolamento resultante da aplicação de mantas em uma ou em duas camadas.

\subsubsection{Restrições axial e rotacional das interfaces estruturais}

As interfaces estruturais foram adotadas para a aplicação das restrições às deformações de origem térmica nos modelos numéricos. Dentre os modelos de materiais disponíveis para a classe de elementos de interface do DIANA, foi escolhido um modelo linear elástico, que permitiu que a essas interfaces fossem atribuídas rigidezes uniformemente distribuídas ao longo de suas respectivas faces. Os ensaios de vigas de concreto armado ao fogo com restrições simulados numericamente no programa de computador foram os seguintes: ka1_kr0_1, viga com restrição axial igual a 7 kN/mm e restrição rotacional nula; ka2_kr0_1, viga com restrição axial igual a 14 kN/mm e restrição rotacional nula; ka1_kr1_1, viga com restrição axial igual a $7 \mathrm{kN} / \mathrm{mm}$ e restrição rotacional igual a $2,5 \times 10^{3} \mathrm{kNm} / \mathrm{rad}$; ka1_kr2_1, viga com restrição axial igual a $7 \mathrm{kN} / \mathrm{mm}$ e restrição rotacional igual a 5 x $10^{3} \mathrm{kNm} / \mathrm{rad}$.

Logo, simularam-se os dois casos de ensaios para os quais se considerou apenas restrição axial, sendo um com restrição menor e outro maior, e foram ainda simulados os dois casos de restrições rotacionais, uma mais baixa e outra mais elevada. Na modelagem numérica de cada um desses ensaios foram criadas duas interfaces, bem como dois materiais diferentes, para 
atribuir os níveis de restrições representativos dos ensaios, que diferiam do lado esquerdo (apoio simples) para o direito (apoio duplo).

Relativamente às restrições axiais admitidas nos ensaios, o lado esquerdo consistia naquele em que se considerava uma restrição parcial dos deslocamentos axiais (7 ou $14 \mathrm{kN} / \mathrm{mm}$ ) e o direito consistia no lado considerado como infinitamente rígido, pois ali se posicionava uma viga de aço muito mais robusta do que aquelas que simulavam os níveis de restrição parciais.

A fim de representar as restrições axiais atuantes nas extremidades esquerdas dos modelos numéricos, dividiram-se as rigidezes de 7 ou $14 \mathrm{kN} / \mathrm{mm}$ pela área da interface estrutural, que era igual à área da seção transversal da viga em estudo (150 x 300 mm). Assim, admitiram-se, em relação ao eixo $X$ (direção axial da peça), as rigidezes distribuídas iguais a 1,55 x $10^{-4}$ $\mathrm{kN} / \mathrm{mm}^{3}$ ou $3,11 \times 10^{-4} \mathrm{kN} / \mathrm{mm}^{3}$. A rigidez axial infinita foi considerada, aproximadamente, cinco vezes maior que a parcial mais elevada.

Quanto aos modelos que ainda deviam contar com restrições rotacionais, partiu-se do mesmo princípio adotado para a simulação das restrições axiais, ou seja, verificaram-se as rigidezes médias que atuaram na direção vertical das extremidades das vigas de concreto ao longo dos ensaios e que foram responsáveis por gerar os valores apresentados anteriormente para as restrições rotacionais impostas aos seus apoios. Essas rigidezes na direção vertical aplicadas às extremidades eram provenientes das forças transmitidas pelas barras de aço que vinham do sistema de restrição rotacional e dos respectivos deslocamentos verticais nessa direção.

Pelos resultados experimentais, verificou-se que a rigidez média igual à aproximadamente 10 $\mathrm{kN} / \mathrm{mm}$ foi a que imprimiu à região dos apoios a restrição rotacional de $2,5 \times 10^{3} \mathrm{kNm} / \mathrm{rad}$. Assim, esse valor foi distribuído, em relação ao eixo vertical $\mathrm{Z}$ do modelo, na área das interfaces esquerda e direita para simular as restrições rotacionais da viga representativa do ensaio ka1_kr1_1. Portanto, o dado de entrada considerado foi: $2,22 \times 10^{-4} \mathrm{kN} / \mathrm{mm}^{3}$. Em relação ao ensaio ka1_kr2_1, verificou-se que a rigidez média igual a $20 \mathrm{kN} / \mathrm{mm}$ gerou a restrição rotacional de $5 \times 10^{3} \mathrm{kNm} / \mathrm{rad}$. Ao distribuir essa rigidez pela área das interfaces, 
admitiu-se como dado de entrada o valor de $4,44 \times 10^{-4} \mathrm{kN} / \mathrm{mm}^{3}$ para simular as rotacionais esquerda e direita.

\subsubsection{Determinação da malha de elementos finitos}

Novos elementos finitos passaram a constituir a malha dos modelos numéricos após as adaptações realizadas para as análises ao fogo. Por conta dos pontos auxiliares que foram inseridos na geometria para a verificação de temperaturas em determinadas seções transversais da viga, foram estipulados para discretizar o modelo tridimensional não apenas os elementos tipo "brick" com vinte nós (CHX60), apresentado anteriormente na Figura 4.25, mas também os tetraédricos com dez nós (CTE30), os piramidais com treze nós (CPY39) e os prismáticos triangulares "wedge" (CTP45) com quinze nós, sendo esses indicados na Figura 4.82. Eles foram adotados porque possuíam o formato necessário para se encaixar nas regiões entre esses pontos auxiliares, contudo, são muito similares aos CHX60 utilizados no modelo à temperatura ambiente e também na maior parte do modelo ao fogo, uma vez que todos pertencem à mesma classe de elementos sólidos isoparamétricos e utilizam funções de interpolação quadráticas. Diferem, entre eles, os métodos e esquemas de integração: o CTE30 tem base em integração numérica com esquema de 4 pontos, o CPY39 integração quadrática com esquema de 13 pontos e o CTP45 integração numérica com esquemas de 4 pontos no domínio triangular e de 2 pontos na direção $\zeta$.
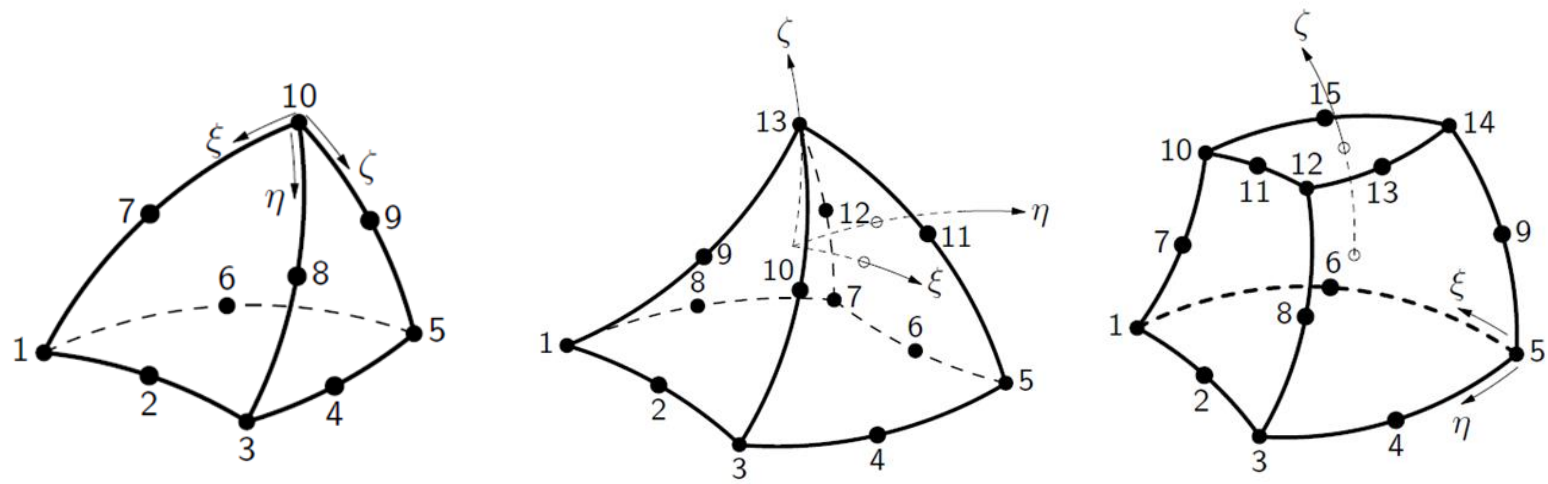

Figura 4.82 - Elementos finitos sólidos CTE30, CPY39 e CTP45, respectivamente (DIANA FEA, 2016e). 
Os elementos finitos denominados BQ4HT, ilustrados na Figura 4.83, também passaram a fazer parte da malha. Esses consistem em elementos de fluxo, indicados para análises que envolvam transferências de calor por convecção e radiação em superfícies de modelos que estejam em contato com o meio. Logo, tais elementos foram adotados para discretizar as faces externas do modelo numérico em questão, haja vista que todas foram consideradas como expostas ao fogo. O BQ4HT é um elemento isoparamétrico quadrilátero com quatro nós, que descreve as condições de contorno de origem térmica em modelos tridimensionais, que utiliza funções de interpolação lineares e integração de Gauss para determinar a matriz de rigidez e que aplica um esquema de integração de 2 x 2 pontos.

No que diz respeito às vigas em que foram consideradas interfaces estruturais para a imposição de restrições dos tipos axial ou axial/rotacional, também constituíram a malha os elementos de interface CQ48I, cujos esquemas de topologia e de representação dos deslocamentos atuantes sobre a interface se encontram ilustrados na Figura 4.84. Portanto, esses foram aplicados para a discretização das interfaces consideradas nas extremidades do modelo numérico. O elemento finito CQ48I é designado para caracterizar a interface estrutural presente entre dois planos na situação de um modelo numérico tridimensional. $\mathrm{O}$ mesmo se fundamenta em funções de interpolação quadráticas, em integração conforme fórmulas de Newton-Cotes e em um esquema de integração de 3 × 3 × 3 pontos. Nos modelos de vigas em situação de incêndio, aplicaram-se malhas com a mesma densidade definida à temperatura ambiente, i.e., elementos com lados de, aproximadamente, $40 \mathrm{~mm}$.

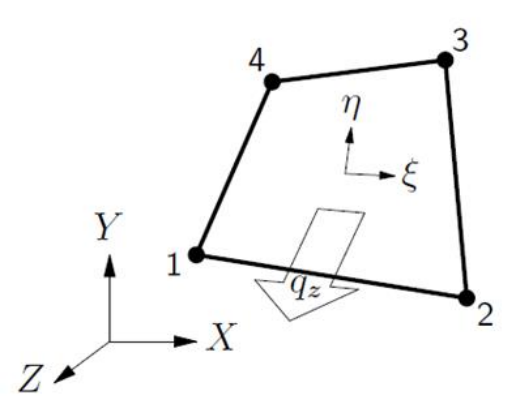

Figura 4.83 - Elemento finito de fluxo de calor BQ4HT (DIANA FEA, 2016e).

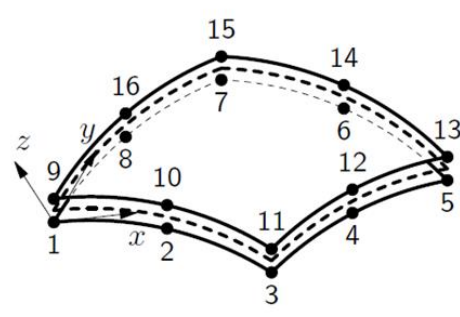

(a) topologia

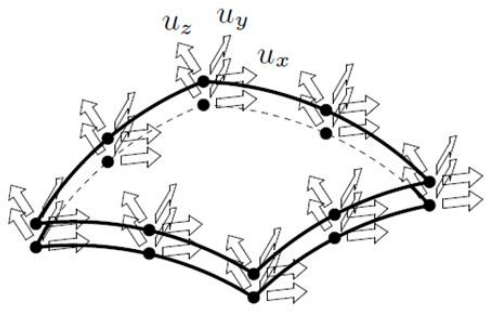

(b) deslocamentos
Figura 4.84 - Esquemas de topologia e deslocamentos do elemento finito de interface estrutural CQ48I (DIANA FEA, 2016e; adaptado). 


\subsubsection{Procedimentos de análise}

A resposta completa do comportamento ao fogo das vigas de concreto armado modeladas no programa de computador DIANA foi obtida pela conjugação de análises térmicas a análises estruturais. No módulo térmico, a equação do balanço de energia é solucionada para cada um dos passos/incrementos de tempo (time steps) pré-definidos, de modo que ao final da análise se dá como resultado o perfil de temperaturas em regime transiente do modelo numérico sob estudo. Essas temperaturas são posteriormente inseridas como dados de entrada nas análises estruturais, quando essas análises também são conduzidas em função do tempo, e, uma vez associadas às propriedades dos materiais que foram postas a variar com a ação térmica, o programa é então capaz de realizar a simulação dos danos causados ao desempenho do elemento estrutural quando esse se encontra em situação de incêndio.

As análises térmicas, acionadas pelo comando "transient heat transfer analysis" no DIANA, foram consideradas do tipo não lineares, pelo fato de terem sido admitidos os efeitos provenientes de radiação e, ainda, porque alguns parâmetros relacionados à condutividade e a coeficientes de transferência de calor por convecção foram postos em função de temperaturas. As equações não lineares foram solucionadas de modo iterativo por meio do método de Newton Raphson Regular. O tempo total das análises de exposição ao fogo foi fracionado em curtos passos de tempo, iguais a 1 min. Esses passos foram determinados de modo explícito e não apenas garantiram uma rápida convergência, mas também conduziram a resultados satisfatórios. O critério de convergência foi definido com base na norma de temperaturas, admitindo-se uma tolerância igual a $1 \times 10^{-6}$ e um número máximo de 5 iterações a cada passo, sendo esses os valores propostos pelo default do programa.

No que se refere às análises estruturais não lineares, é importante esclarecer que essas foram divididas em três blocos de carga: o primeiro era dedicado ao cálculo do peso próprio do modelo; o segundo à imposição das forças atuantes (aquelas que eram aplicadas nos ensaios 
experimentais antes do acionamento do forno e depois se mantinham constantes durante a exposição a altas temperaturas); o terceiro conduzia a análise termestrutural em regime transiente, i.e., acoplava os efeitos das temperaturas em função do tempo no modelo numérico que já se encontrava com as condições de carregamento devidamente aplicadas.

O primeiro e o segundo blocos de carga seguiram as condições de análise já apresentadas para o modelo à temperatura ambiente, ou seja, o peso próprio foi calculado em um passo de carga e a força total de $17 \mathrm{kN}$ imposta ao modelo foi aplicada a partir de pequenos passos de carga, iguais a $1 \mathrm{kN}$. O terceiro bloco foi colocado em função de passos de tempo e não passos de carga. Esses foram definidos da mesma forma que aqueles das análises térmicas: explicitamente e iguais a $1 \mathrm{~min}$.

A configuração da análise estrutural não linear, que englobava os três referidos blocos ou subanálises, foi estabelecida conforme os procedimentos comentados na seção sobre o modelo à temperatura ambiente: método Newton Raphson Regular para a resolução iterativa das equações não lineares, critérios de convergência estabelecidos com base na norma de deslocamentos, estipulando-se tolerância igual a $5 \times 10^{-2}$, e uso do algoritmo line search para o aumento da taxa de convergência.

Adicionalmente, levaram-se em consideração os efeitos advindos da não linearidade geométrica do modelo, sensivelmente importantes nas análises ao fogo. O método adotado foi o Total Lagrange, pois esse se mostrou ideal à análise de estruturas de concreto armado, uma vez que pode ser combinado a modelos que envolvam fenômenos de fissuração e armaduras do tipo embutidas, e, além disso, por ser indicado a estruturas que sejam submetidas a grandes deslocamentos e rotações, mas a pequenas deformações (DIANA FEA, 2016a).

É oportuno citar que a vinculação de análises térmicas a estruturais é uma prática entre os pesquisadores que já simularam numericamente o comportamento de estruturas de concreto armado em situação de incêndio. No estado da arte apresentado nesta Tese, foram dados vários exemplos de estudos em que tal procedimento foi adotado. $\mathrm{O}$ mesmo admite que os 
campos de temperaturas sejam aferidos com base em uma peça ainda não fissurada, uma vez que as análises térmicas são realizadas antes das estruturais.

Ainda pela pesquisa de referências realizada para a concepção do estado da arte, verificou-se que já houve autores a investigar de modo experimental se o calor propagado através das fissuras que surgem em vigas de concreto armado exerce influência nos campos térmicos de suas seções transversais ou, em outras palavras, a investigar se é mesmo coerente que os resultados das análises térmicas sejam independentes daqueles das análises mecânicas. Ervine (2012) chegou à conclusão de que não exerce influência significativa. Ba et al. (2016) levantou a questão de que essas fissuras poderiam sim influenciar na ação térmica, todavia, uma vez que o próprio autor julgou ainda não haver resultados suficientes para uma análise conclusiva acerca dessa questão, as análises numéricas desta Tese permaneceram a adotar o método de cálculo já consagrado nesse âmbito.

Por fim, ressalta-se que as temperaturas obtidas mediante as análises térmicas conduzidas no DIANA foram aquelas consideradas como dados de entrada dos modelos que simularam os ensaios experimentais de vigas aquecidas. Por conseguinte, ao contrário do que é feito de modo usual para simular o comportamento de elementos estruturais de aço que foram submetidos a ensaios de exposição ao fogo, as temperaturas obtidas experimentalmente pelos termopares, que foram embutidos nas seções transversais das vigas de concreto armado, não foram inseridas como dados de entrada nas presentes análises estruturais.

Isso porque os campos de temperaturas das seções de concreto são bastante desuniformes, logo, dividir essas seções em faixas ou regiões às quais poderiam ser aplicadas temperaturas iguais às aferidas pelos termopares, como se mostra possível nas seções de aço, não seria tão simples para as de concreto, e nem mesmo conduziria a campos tão representativos quanto aqueles determinados numericamente, com dados de temperaturas para todos os nós das seções. Dentre as investigações analisadas no estado da arte, apenas Albrifkani e Wang (2016) dividiram uma seção de concreto em faixas e introduziram em alguns pontos as temperaturas que foram obtidas a partir de ensaios. Todos os outros pesquisadores que conceberam 
modelos numéricos com vistas a simular ensaios experimentais, fizeram uso dos perfis de temperatura calculados pelo próprio programa de computador.

\subsubsection{Validação dos resultados}

As comparações realizadas entre os resultados obtidos por intermédio dos modelos numéricos concebidos no DIANA e aqueles que foram aferidos ao longo dos ensaios experimentais de vigas de concreto armado em situação de incêndio serão apresentadas ao longo desta seção. Em todos os casos foram analisados os campos térmicos das seções transversais, obtidos no programa de computador a partir das temperaturas dos nós indicativos dos termopares que foram utilizados ao longo dos experimentos.

Para alguns casos, ainda foram comparadas as respostas numéricas vs experimentais em termos de flechas, forças de restrição axiais e resistências ao fogo. Ao total, simularam-se oito testes de exposição ao fogo: quatro de vigas simplesmente apoiadas, dois de vigas apenas com restrição axial e dois em vigas com restrições axial e rotacional. A priori, todas as comparações serão apresentadas e os comentários acerca dessas serão apontados apenas no final, em uma seção sobre discussões.

Na Figura 4.85, ilustra-se um exemplo dos perfis de temperaturas resultantes das análises no programa, sendo esse o equivalente a um dos ensaios que foram simulados com restrições axiais e rotacionais. Indicam-se os perfis de temperatura encontrados tanto para o elemento tridimensional completo quanto no nível da seção transversal localizada no meio do vão (seção $S_{2}$ ), relativamente a 10, 50, 100 e $150 \mathrm{~min}$ de exposição ao fogo. Nas análises efetuadas no programa, as temperaturas obtidas tanto nas seções próximas aos apoios $\left(S_{1}\right.$ e $\left.S_{3}\right)$ quanto a meio vão $\left(S_{2}\right)$ foram sempre iguais. Logo, nos gráficos de temperaturas, enquanto se apresentam as curvas experimentais obtidas para cada seção, a curva designada "DIANA" é representativa das temperaturas em qualquer uma dessas seções transversais. 

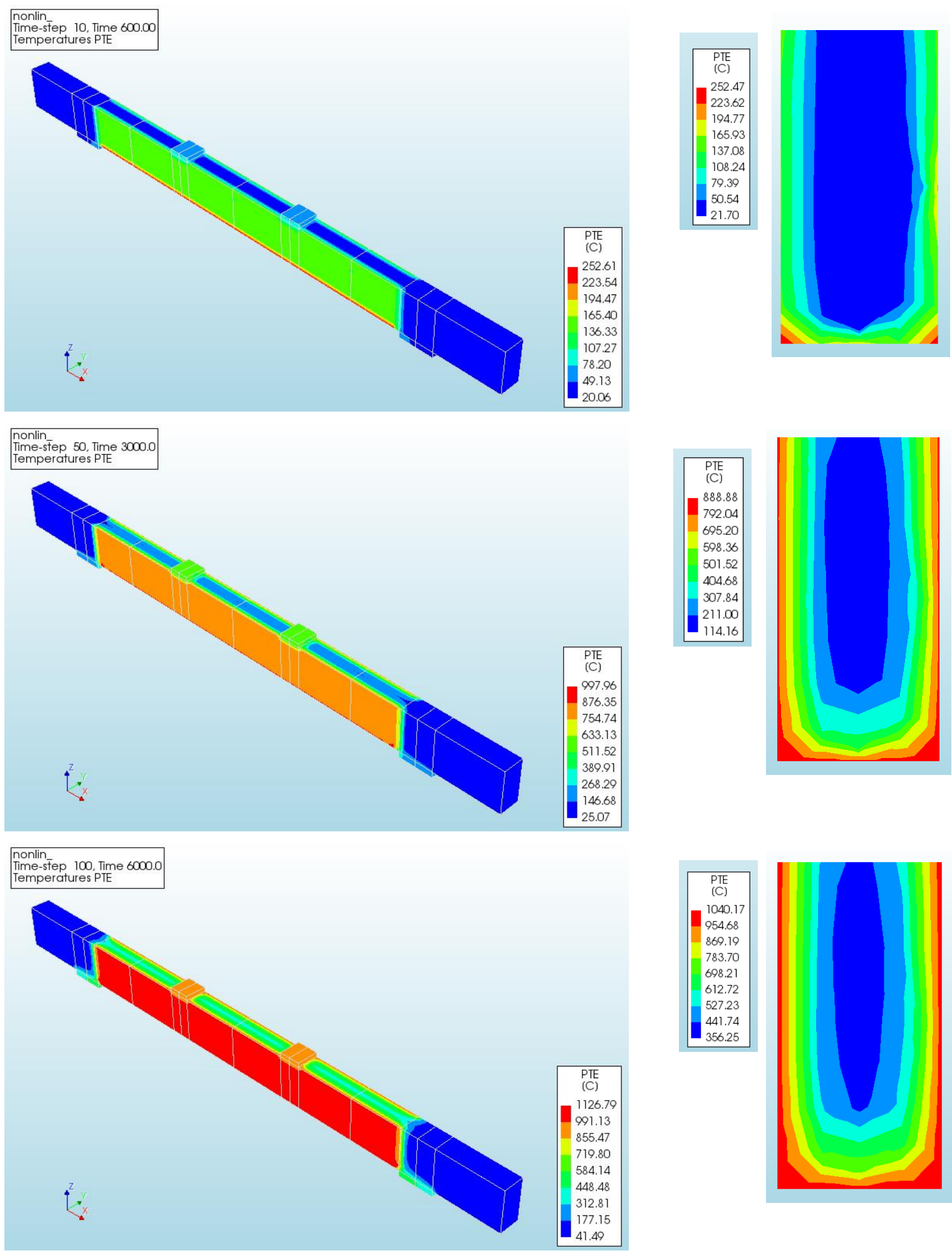

Figura 4.85 - Campos térmicos ao nível do elemento e da seção a meio vão $\left(\mathrm{S}_{2}\right)$ na simulação da viga do ensaio ka1_kr2_1 para os tempos de 10, 50, 100 e 150 minutos de exposição ao fogo, respectivamente (continua). 

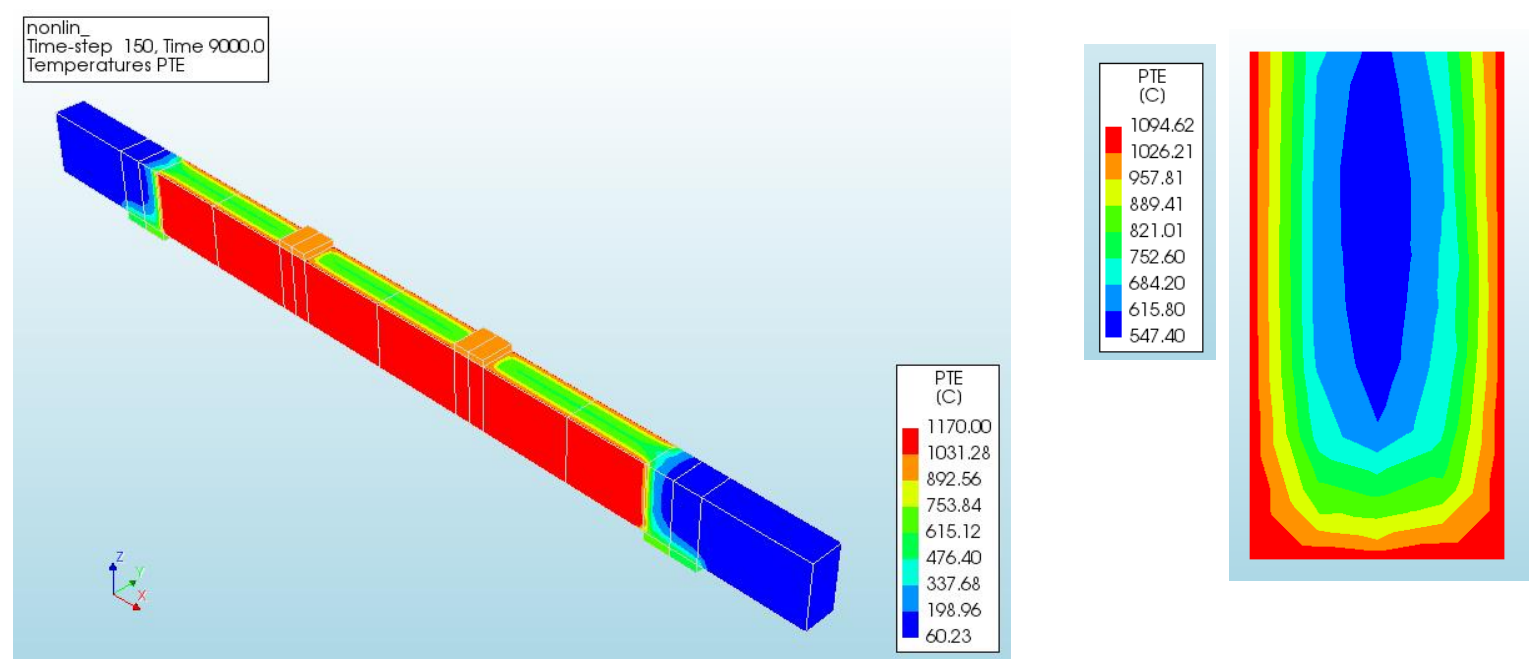

Figura 4.85 - Campos térmicos ao nível do elemento e da seção a meio vão $\left(S_{2}\right)$ na simulação da viga do ensaio ka1_kr2_1 para os tempos de 10,50, 100 e 150 minutos de exposição ao fogo, respectivamente (conclusão).

\subsubsection{Vigas simplesmente apoiadas}

O primeiro ensaio de viga simplesmente apoiada simulado no programa foi aquele em que excepcionalmente se considerou a face superior do elemento estrutural sem isolamento, i.e., sem a manta de lã de silicato alcalino. Apesar de esse ter sido efetuado em uma das vigas que possuíam apenas três termopares nas três seções transversais (Figura 4.86), foi aqui utilizado para se ter uma base de como caminhavam as evoluções de temperaturas em relação a um modelo mais simples, ou seja, sem a consideração da manta. As comparações dos resultados numéricos aos experimentais se encontram ilustradas nas Figuras 4.87 a 4.89.

O segundo ensaio simulado foi aquele em que se utilizou uma das vigas em que foram embutidos vários termopares (10 em cada seção transversal, conforme Figura 4.90), justamente com o propósito de aferir de forma mais detalhada os campos térmicos de vigas cujas faces superiores estavam protegidas com manta, haja vista que essa foi a condição de isolamento adotada em todos os demais ensaios conduzidos na campanha experimental da presente investigação. Os resultados se encontram ilustrados nas Figuras 4.91 a 4.100. 


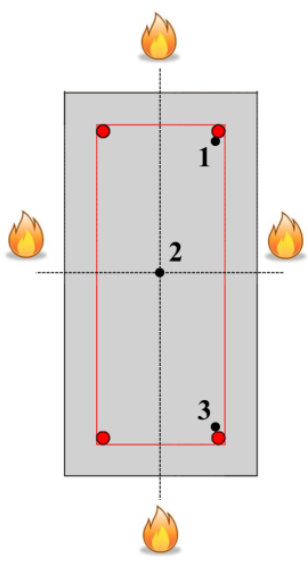

Figura 4.86 - Localização dos termopares nas seções de viga sem material isolante (ensaio $\mathrm{ka0} \_\mathrm{kr} 0 *$ ).

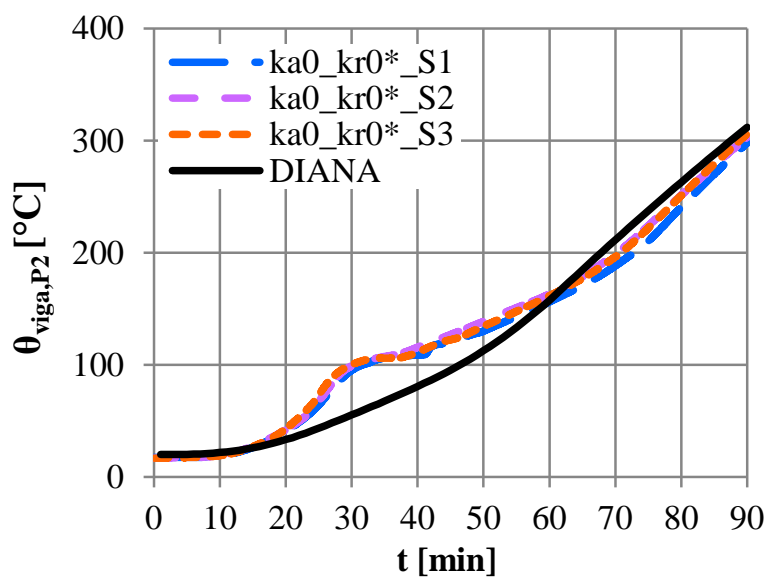

Figura 4.88 - Evolução de temperaturas no concreto (ponto 2) do ensaio ka0_kr0*.

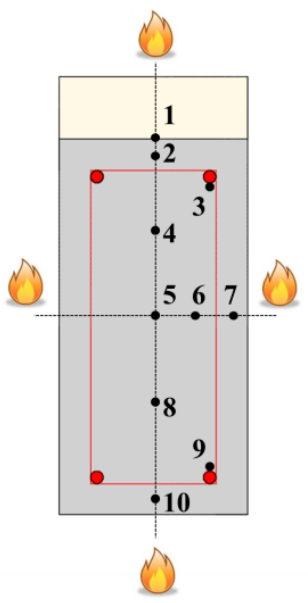

Figura 4.90 - Localização dos termopares nas seções de viga com material isolante (ensaios T_ka0_kr0).

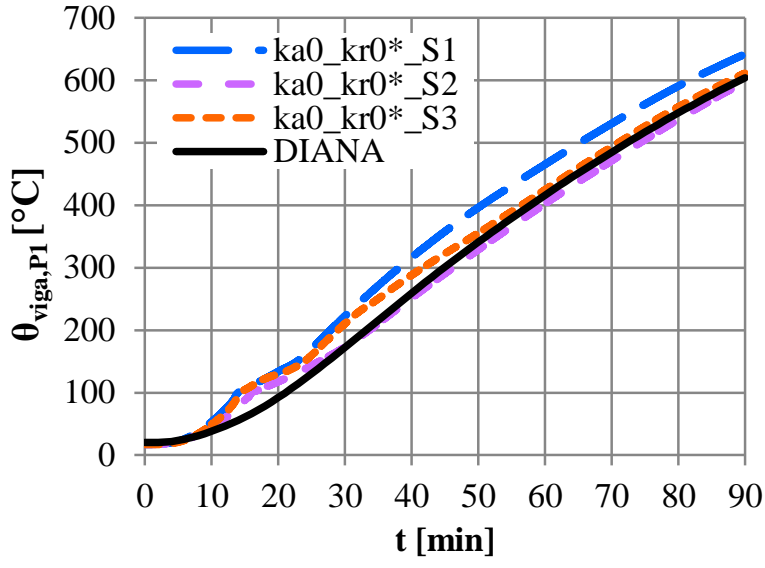

Figura 4.87 - Evolução de temperaturas na armadura longitudinal superior (ponto 1) do ensaio ka0_kr0*.

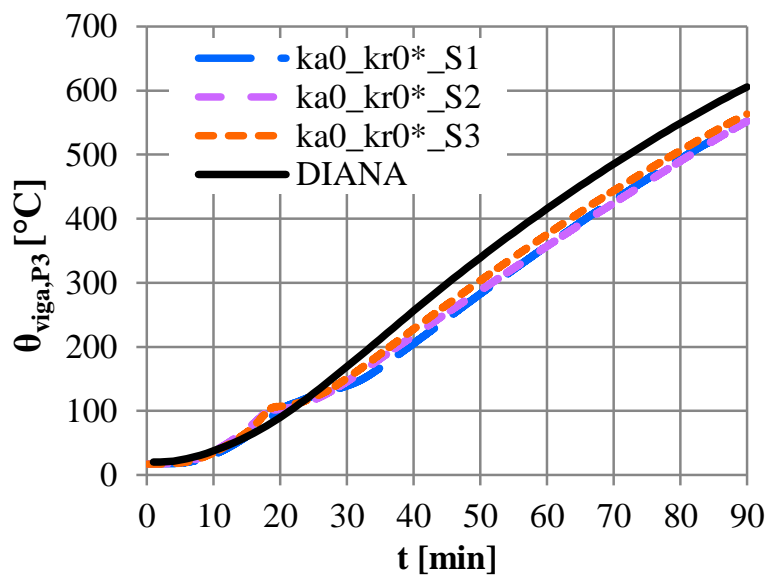

Figura 4.89 - Evolução de temperaturas na armadura longitudinal inferior (ponto 3 ) do ensaio $\mathrm{ka} 0 \_\mathrm{kr} 0$ *.

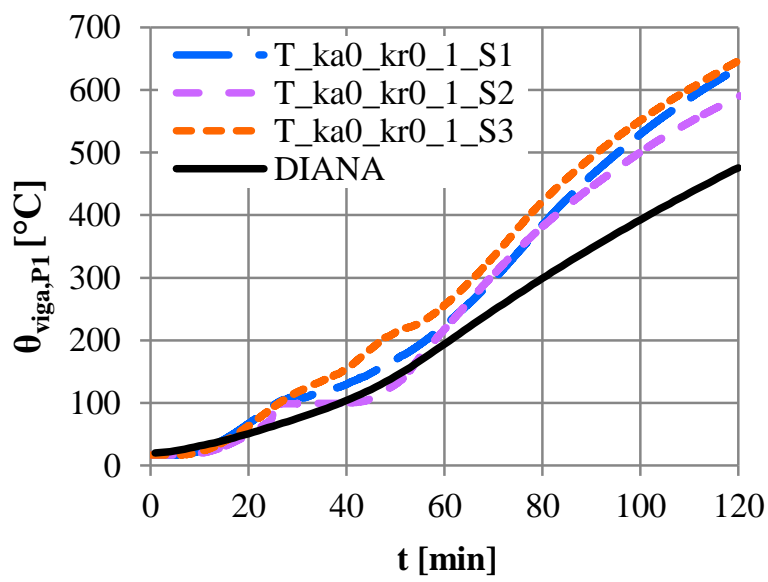

Figura 4.91 - Evolução de temperaturas na interface concreto/manta (ponto 1) do ensaio T_ka0_kr0_1. 


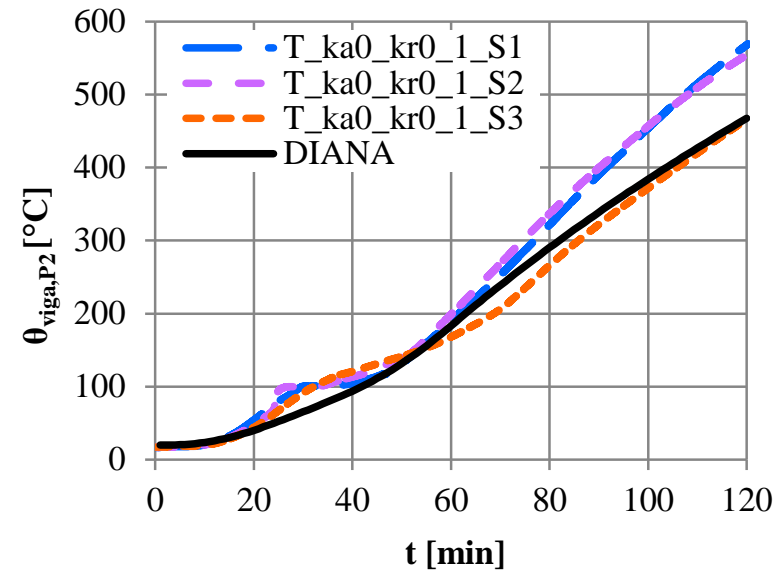

Figura 4.92 - Evolução de temperaturas no concreto (ponto 2) do ensaio T_ka0_kr0_1.

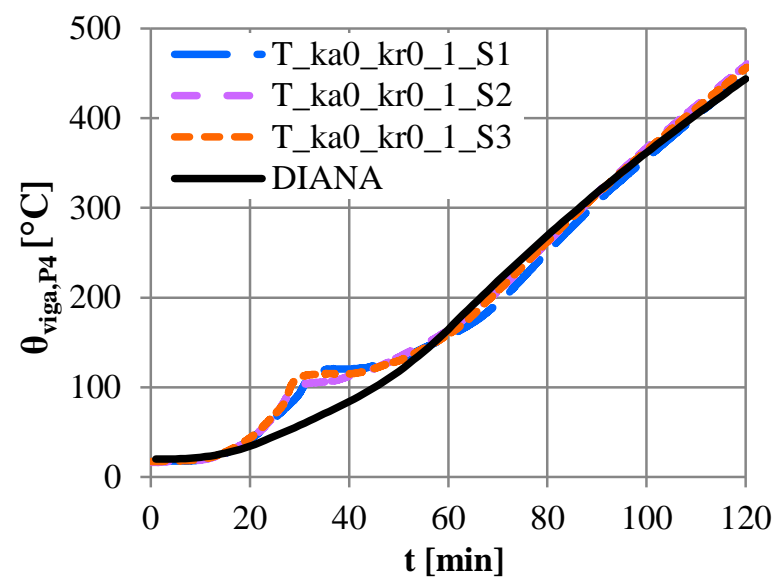

Figura 4.94 - Evolução de temperaturas no concreto (ponto 4) do ensaio T_ka0_kr0_1.

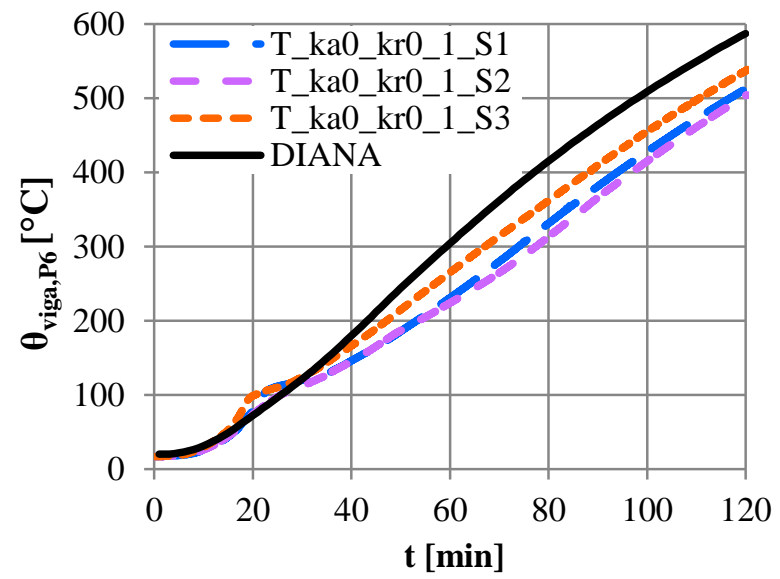

Figura 4.96 - Evolução de temperaturas no concreto (ponto 6) do ensaio T_ka0_kr0_1.

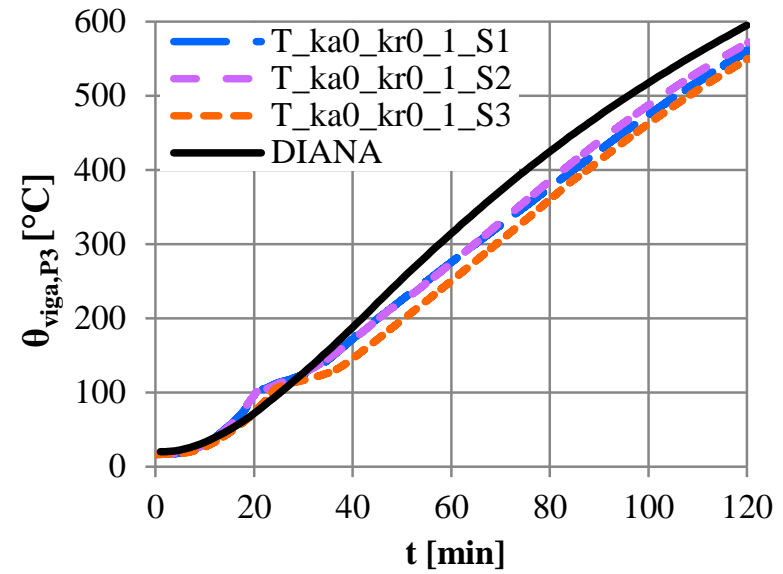

Figura 4.93 - Evolução de temperaturas na armadura longitudinal superior (ponto3) do ensaio T_ka0_kr0_1.

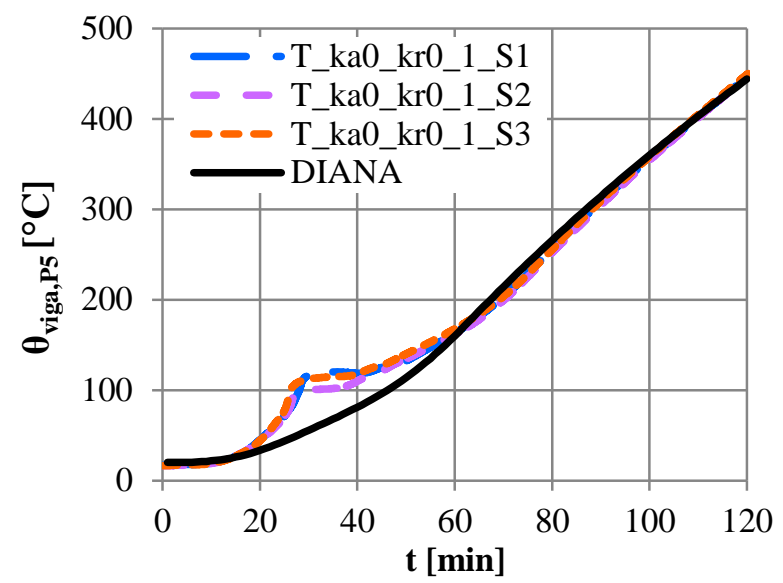

Figura 4.95 - Evolução de temperaturas no concreto (ponto 5) do ensaio T_ka0_kr0_1.

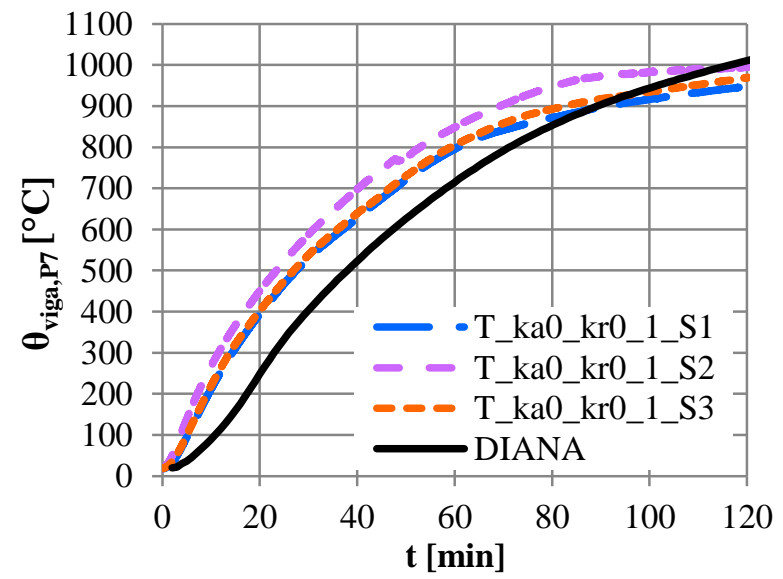

Figura 4.97 - Evolução de temperaturas no concreto (ponto 7) do ensaio T_ka0_kr0_1. 


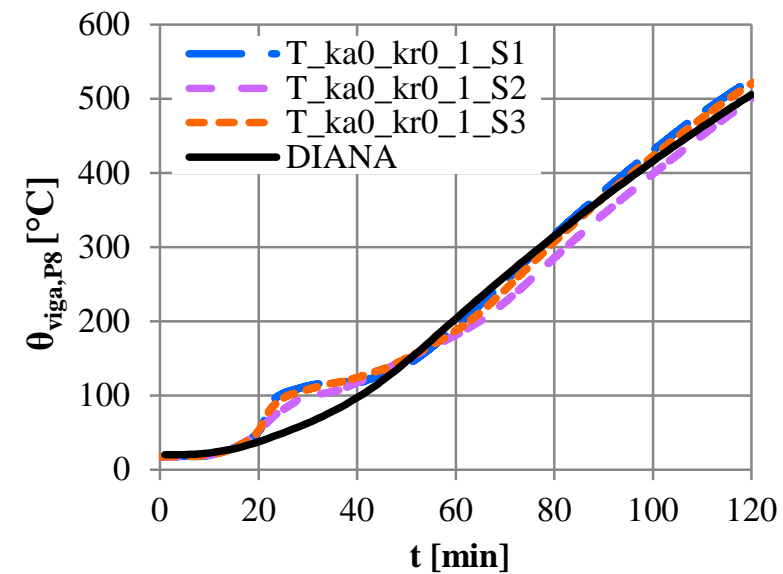

Figura 4.98 - Evolução de temperaturas no concreto (ponto 8) do ensaio T_ka0_kr0_1.

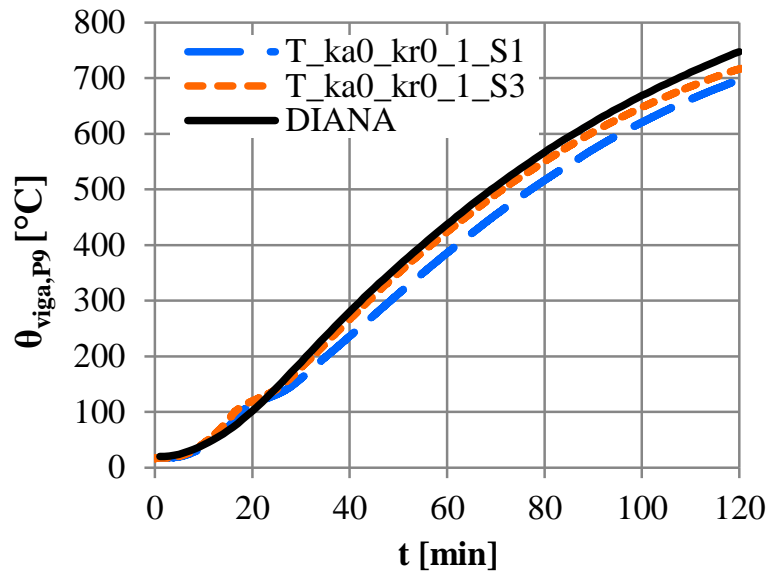

Figura 4.99 - Evolução de temperaturas na armadura longitudinal inferior (ponto 9) do ensaio T_ka0_kr0_1.

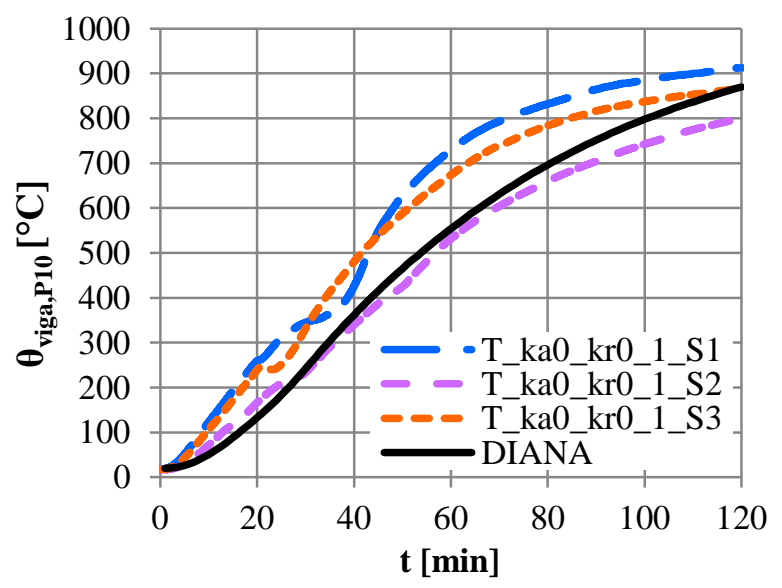

Figura 4.100 - Evolução de temperaturas no concreto (ponto 10) do ensaio T_ka0_kr0_1.

Em seguida, simulou-se numericamente o segundo ensaio realizado em laboratório para a verificação dos campos térmicos em vigas de concreto instrumentadas com vários termopares. Nesse caso, foi aproveitado o fato de que as flechas das vigas também foram medidas experimentalmente para aferir o comportamento mecânico do modelo em uma situação mais simples, pois, no referido ensaio, não foram impostos carregamentos constantes à viga durante a exposição a altas temperaturas. O único carregamento foi aquele aplicado antes de ser acionado o forno, a fim de que a manta fosse bem posicionada a uma viga com alguma deformação inicial, de forma parecida ao que foi feito nos outros ensaios. 
O artifício adotado para simular essas condições iniciais de carregamento no DIANA consistiu em aplicar uma força total igual a $17 \mathrm{kN}$ em função do tempo, de forma lenta e em pequenos incrementos, e depois retirar essa força do modelo progressivamente, até chegar a um valor nulo. Portanto, exclusivamente nesse modelo, a força foi aplicada em passos de tempo e não em passos de carga. Na curva de aquecimento do modelo, considerou-se um "atraso" para o início da ação do fogo, sendo esse equivalente ao intervalo de tempo que estava sendo utilizado para a aplicação desse artifício. Nas Figuras 4.101 a 4.110 são ilustradas as comparações em termos de campos térmicos e na Figura 4.111 a evolução das flechas. A posição dos termopares segue o disposto anteriormente na Figura 4.90.

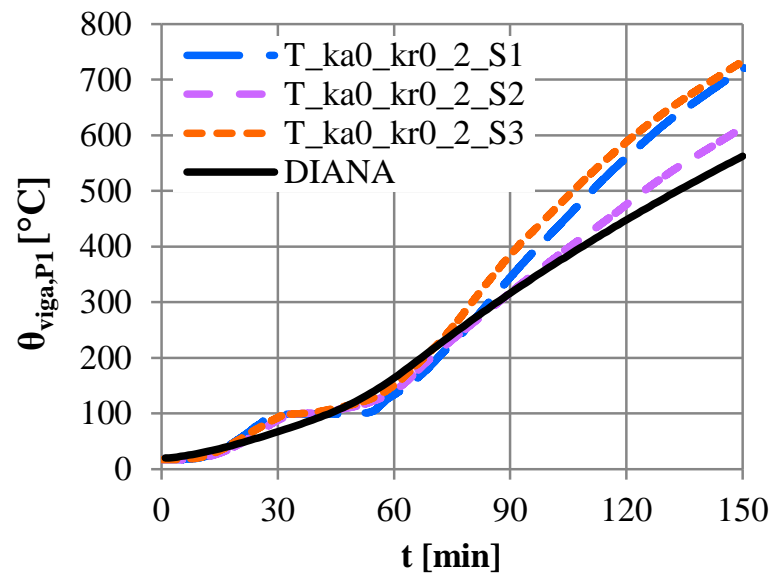

Figura 4.101 - Evolução de temperaturas na interface concreto/manta (ponto 1) do ensaio T_ka0_kr0_2.

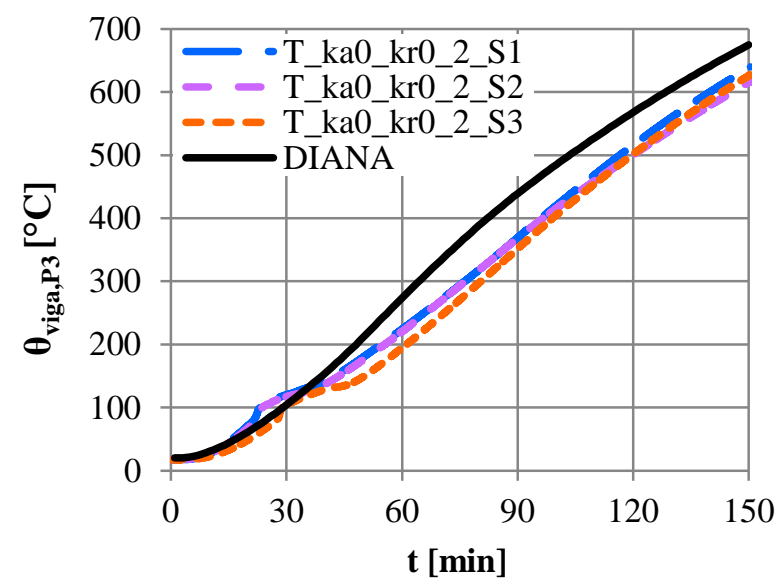

Figura 4.103 - Evolução de temperaturas na armadura longitudinal superior (ponto3) do ensaio T_ka0_kr0_2.

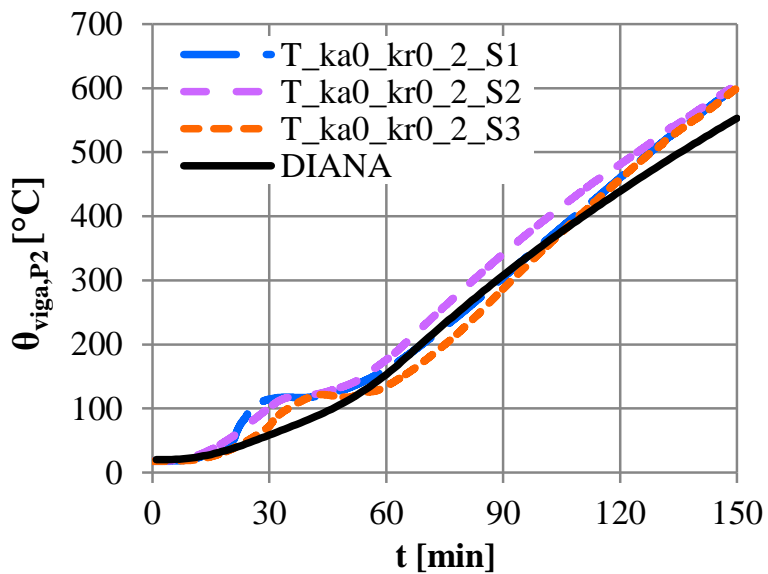

Figura 4.102 - Evolução de temperaturas no concreto (ponto 2) do ensaio T_ka0_kr0_2.

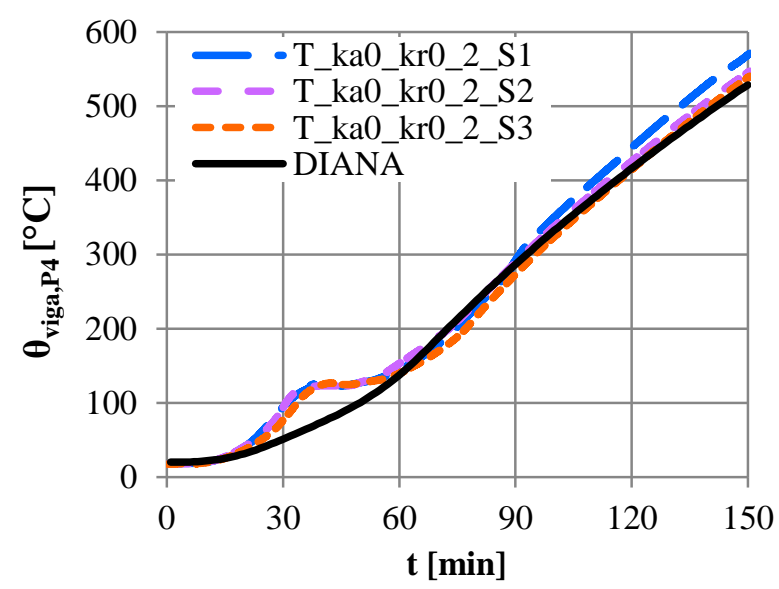

Figura 4.104 - Evolução de temperaturas no concreto (ponto 4) do ensaio T_ka0_kr0_2. 


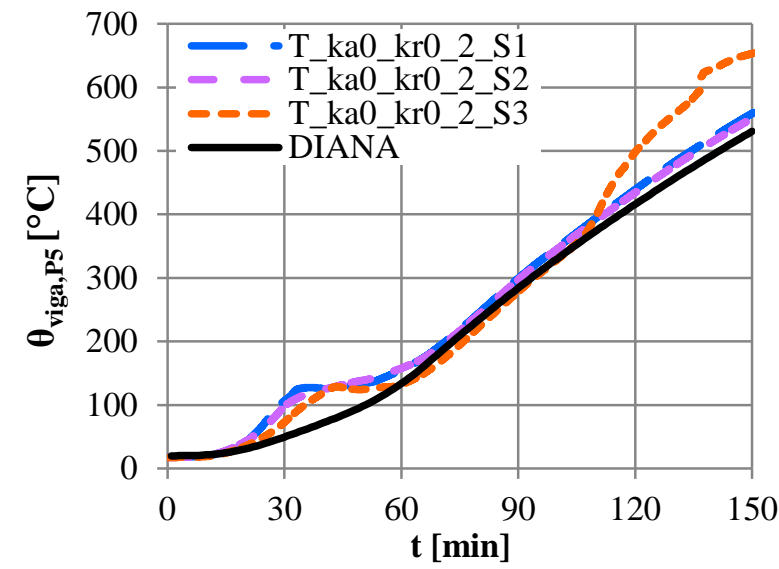

Figura 4.105 - Evolução de temperaturas no concreto (ponto 5) do ensaio T_ka0_kr0_2.

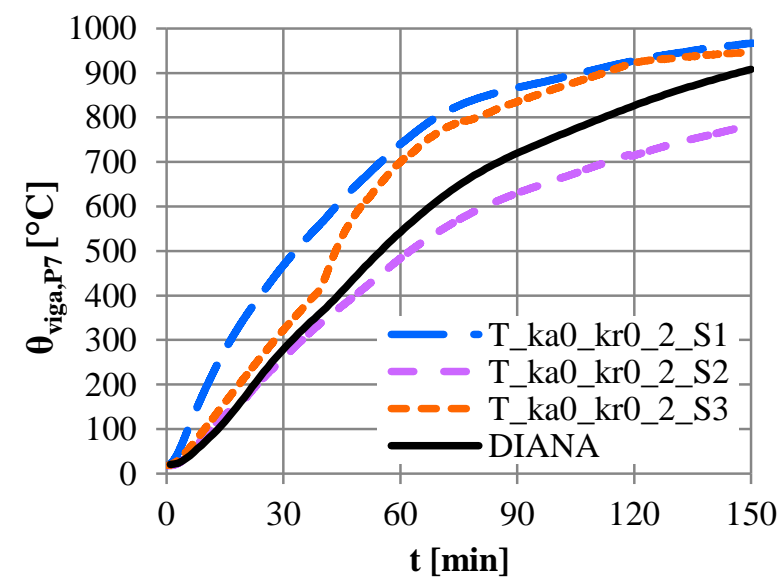

Figura 4.107 - Evolução de temperaturas no concreto (ponto 7) do ensaio T_ka0_kr0_2.

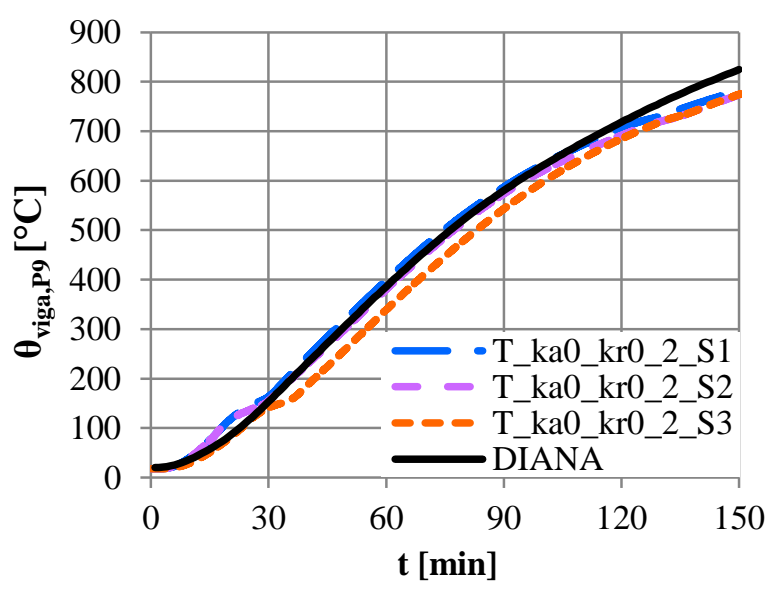

Figura 4.109 - Evolução de temperaturas na armadura longitudinal inferior (ponto 9) do ensaio T_ka0_kr0_2.

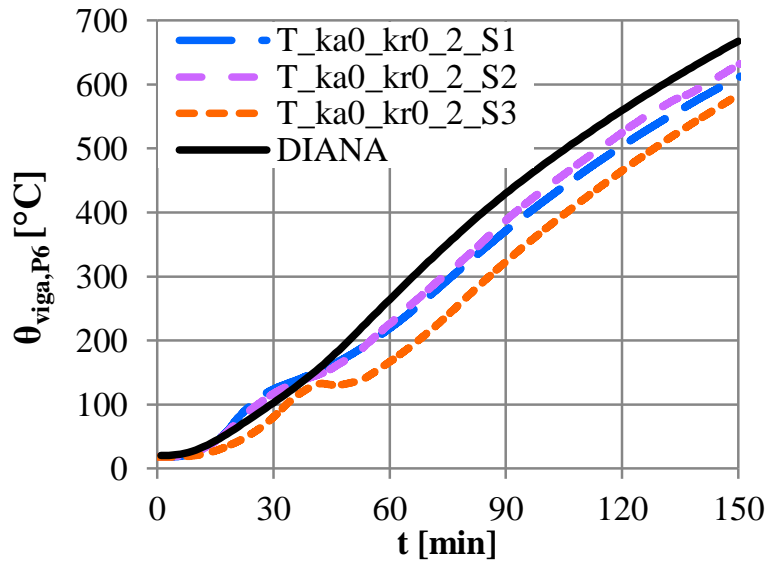

Figura 4.106 - Evolução de temperaturas no concreto (ponto 6) do ensaio T_ka0_kr0_2.

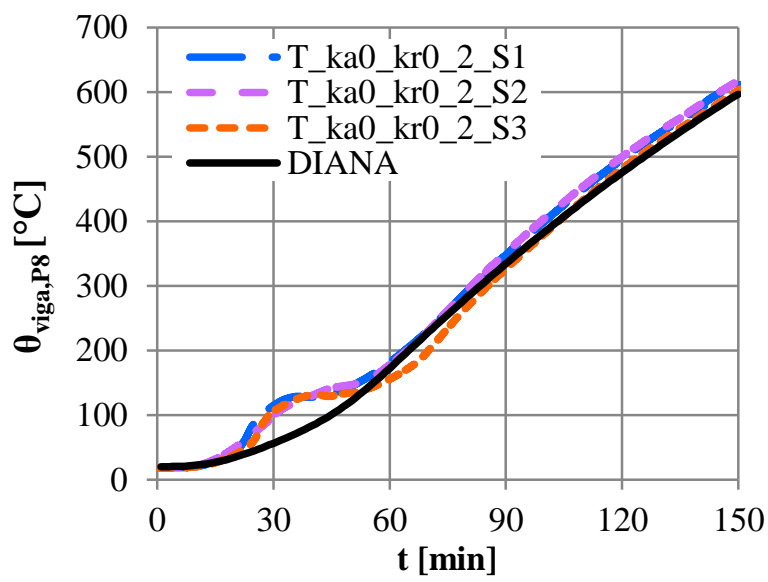

Figura 4.108 - Evolução de temperaturas no concreto (ponto 8) do ensaio T_ka0_kr0_2.

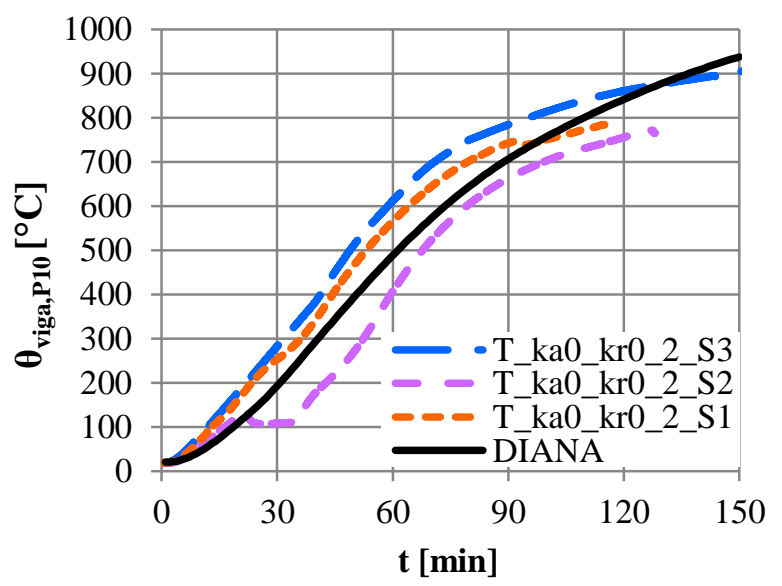

Figura 4.110 - Evolução de temperaturas no concreto (ponto 10) do ensaio T_ka0_kr0_2. 


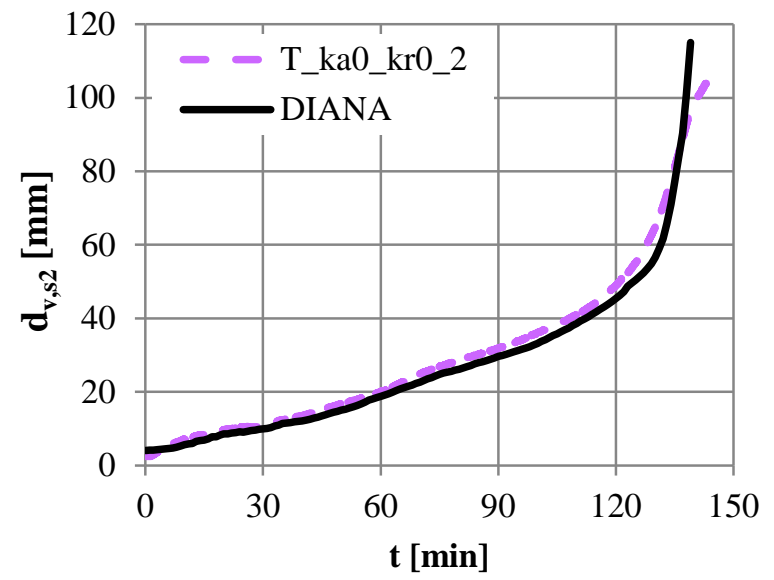

Figura 4.111 - Evolução das flechas (deslocamento vertical na seção $S_{2}$ ) do ensaio T_ka0_kr0_2.

O próximo modelo numérico é representativo de um dos ensaios experimentais realizados em vigas simplesmente apoiadas para analisar de forma completa o desempenho dessas frente à ação do fogo. Portanto, esse fez parte do conjunto de ensaios no qual foi aplicado o procedimento completo de análise de resistência estrutural ao fogo: exposição do elemento a altas temperaturas sob a influência de um carregamento constante. A posição dos termopares segue o esquema da Figura 4.112 e os resultados estão dispostos nas Figuras 4.113 a 4.117.

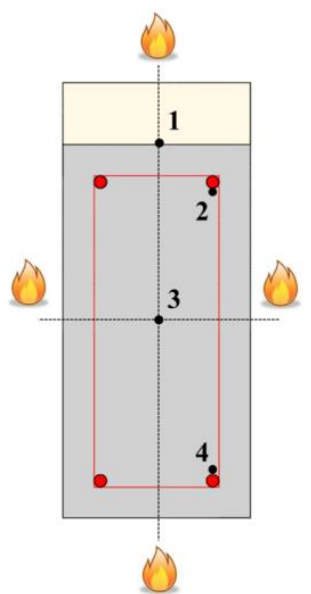

Figura 4.112 - Localização dos termopares nas seções de viga com material isolante (demais ensaios).

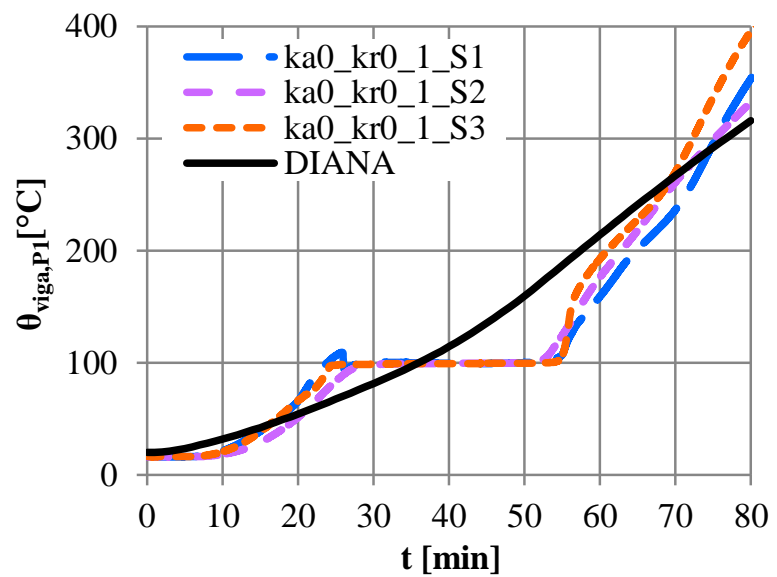

Figura 4.113 - Evolução de temperaturas na interface concreto/manta (ponto 1) do ensaio ka0_kr0_1. 


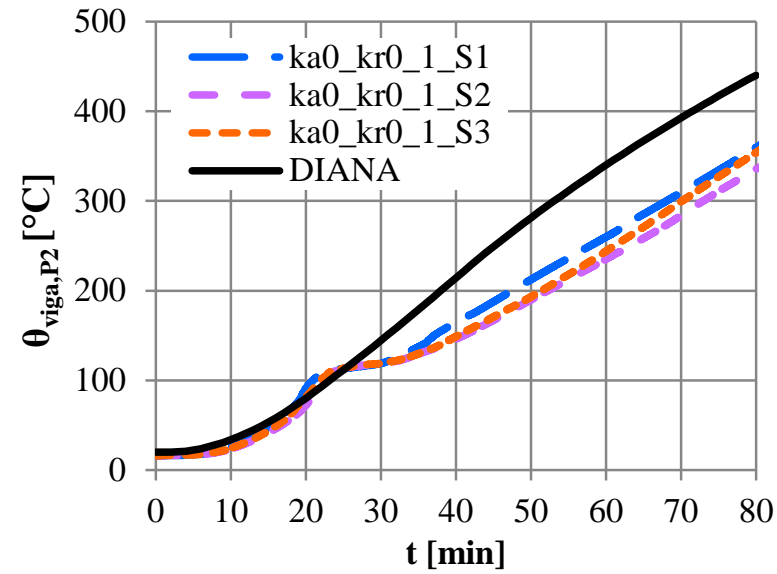

Figura 4.114 - Evolução de temperaturas na armadura longitudinal superior (ponto 2) do ensaio ka0_kr0_1.

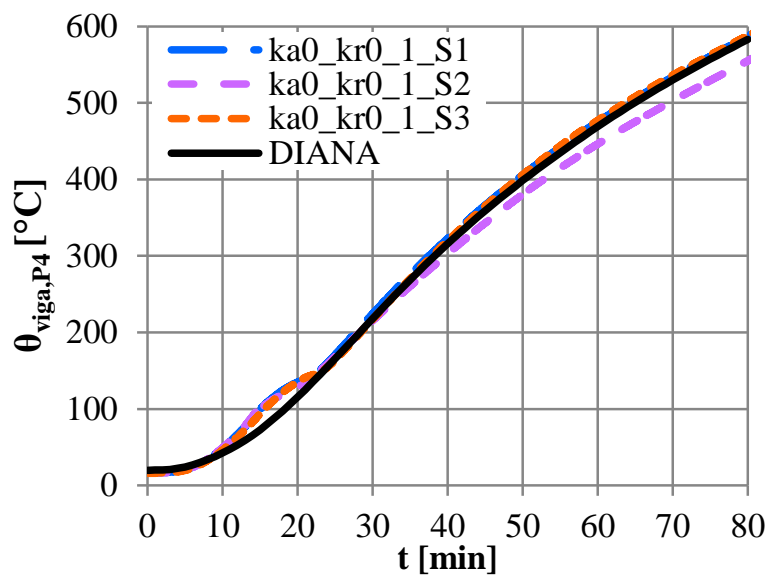

Figura 4.116 - Evolução de temperaturas na armadura longitudinal inferior (ponto 4) do ensaio ka0_kr0_1.

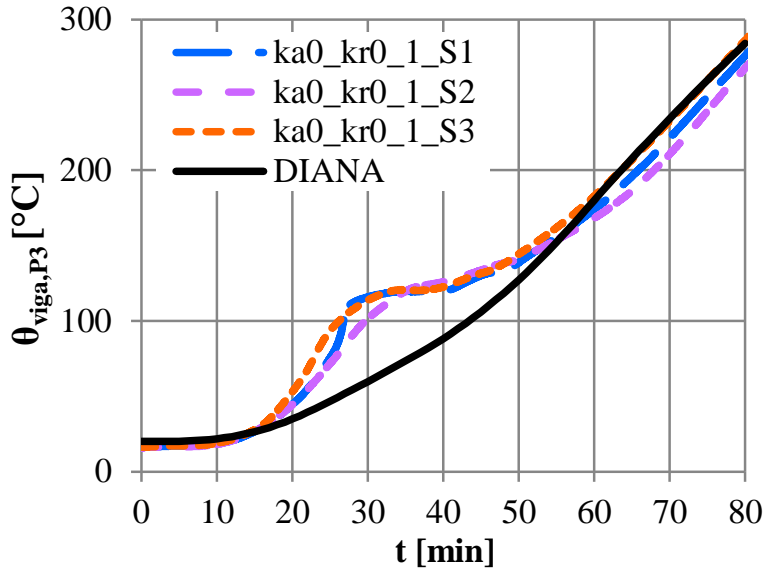

Figura 4.115 - Evolução de temperaturas no concreto (ponto 3) do ensaio ka0_kr0_1.

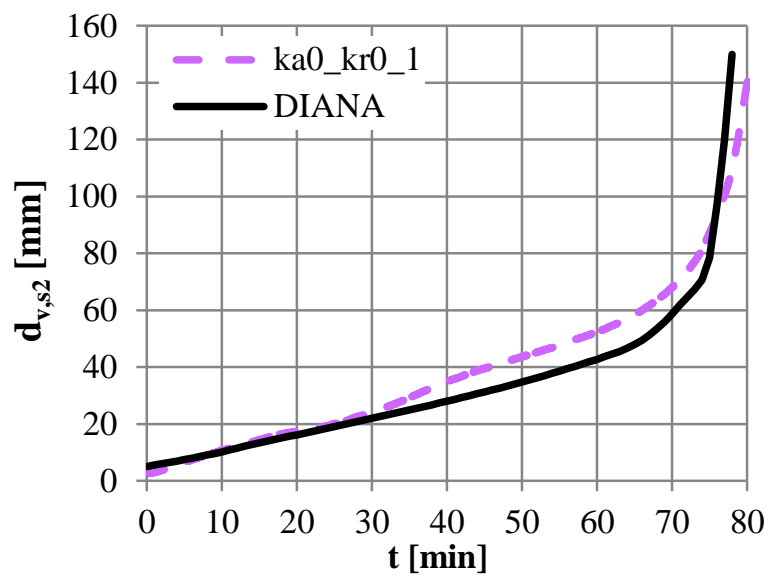

Figura 4.117 - Evolução das flechas (deslocamento vertical na seção $S_{2}$ ) do ensaio ka0_kr0_1.

\subsubsection{Vigas com restrição axial}

Primeiramente serão indicadas, nas Figuras 4.118 a 4.123, as comparações provenientes ao modelo numérico em que se considerou restrição axial parcial de $7 \mathrm{kN} / \mathrm{mm}$ (representativo do ensaio experimental ka1_kr0_1). Depois, nas Figuras 4.124 a 4.129, daquele com restrição axial de 14 kN/mm (representativo do ensaio ka2_kr0_1). Além de temperaturas e flechas, agora também são confrontadas as forças de restrição axiais obtidas por meio numérico e 
experimental. Esses ensaios e todos os demais que serão abordados adiante possuem posicionamento de termopares conforme o esquema ilustrado na Figura 4.112.

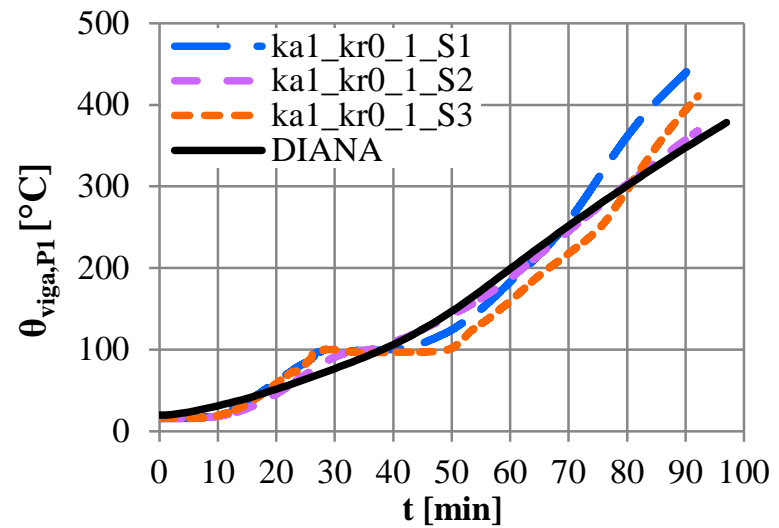

Figura 4.118 - Evolução de temperaturas na interface concreto/manta (ponto 1) do ensaio ka1_kr0_1.

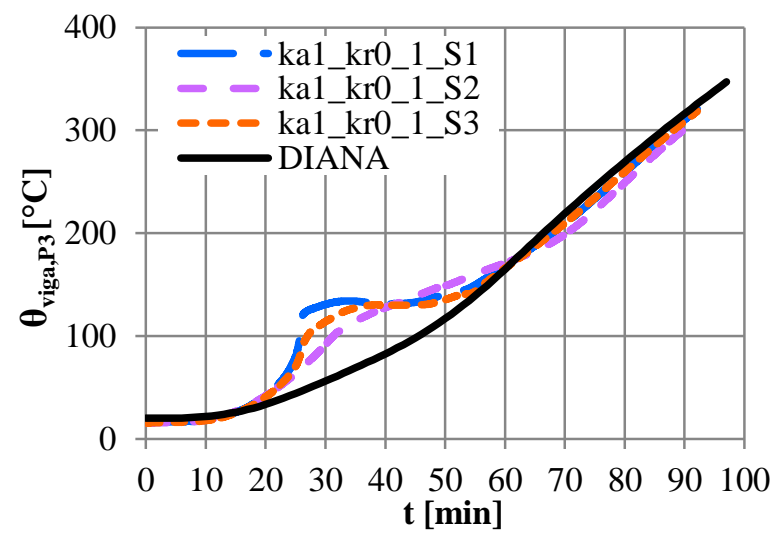

Figura 4.120 - Evolução de temperaturas no concreto (ponto 3) do ensaio ka1_kr0_1.

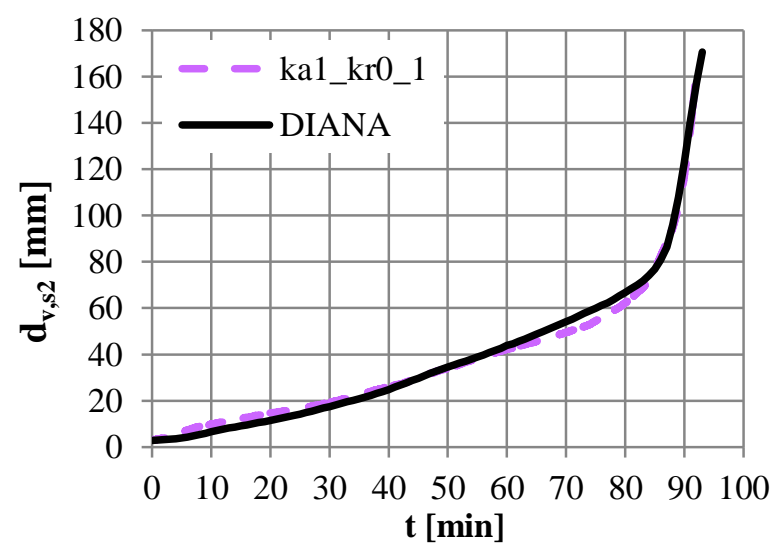

Figura 4.122 - Evolução das flechas (deslocamento vertical na seção $S_{2}$ ) do ensaio ka1_kr0_1.

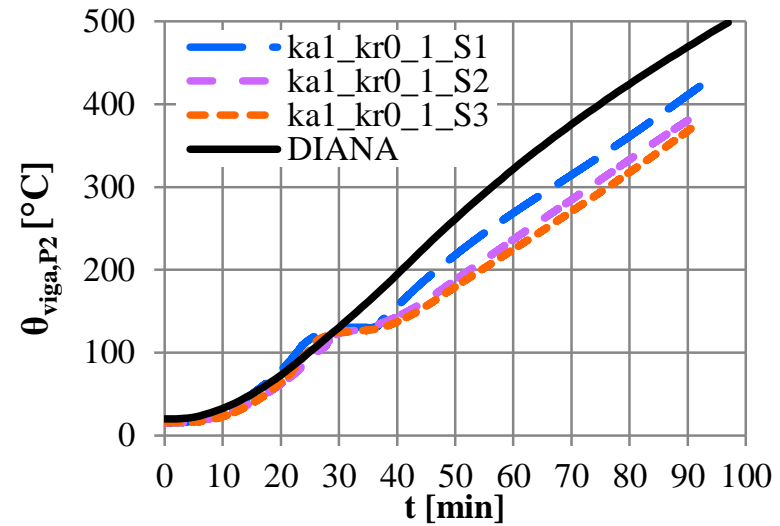

Figura 4.119 - Evolução de temperaturas na armadura longitudinal superior (ponto 2) do ensaio ka1_kr0_1.

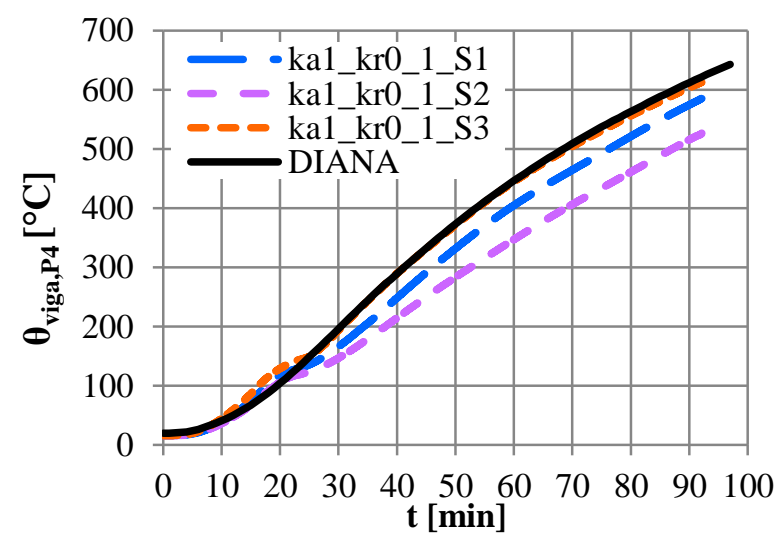

Figura 4.121 - Evolução de temperaturas na armadura longitudinal inferior (ponto 4) do ensaio ka1_kr0_1.

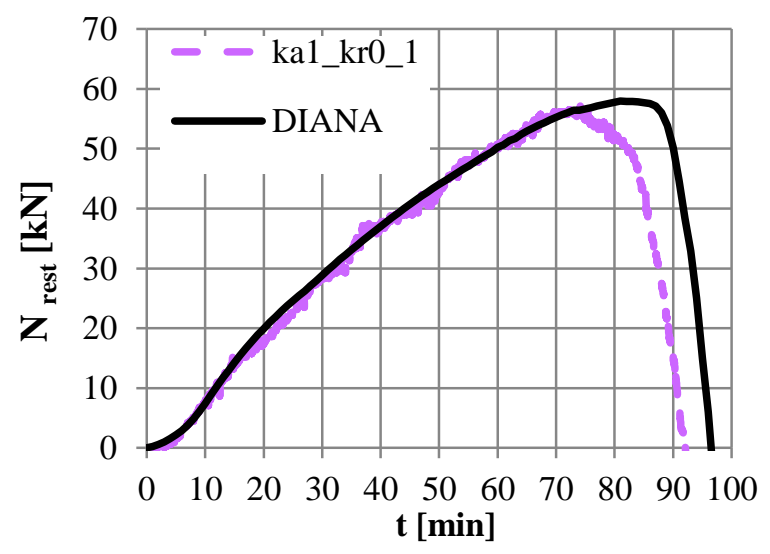

Figura 4.123 - Evolução das forças de restrição axiais do ensaio ka1_kr0_1. 


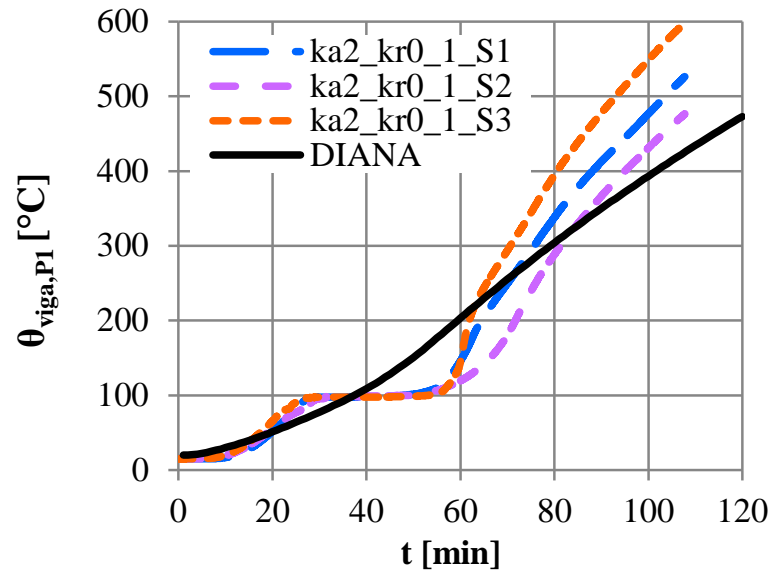

Figura 4.124 - Evolução de temperaturas na interface concreto/manta (ponto 1) do ensaio ka2_kr0_1.

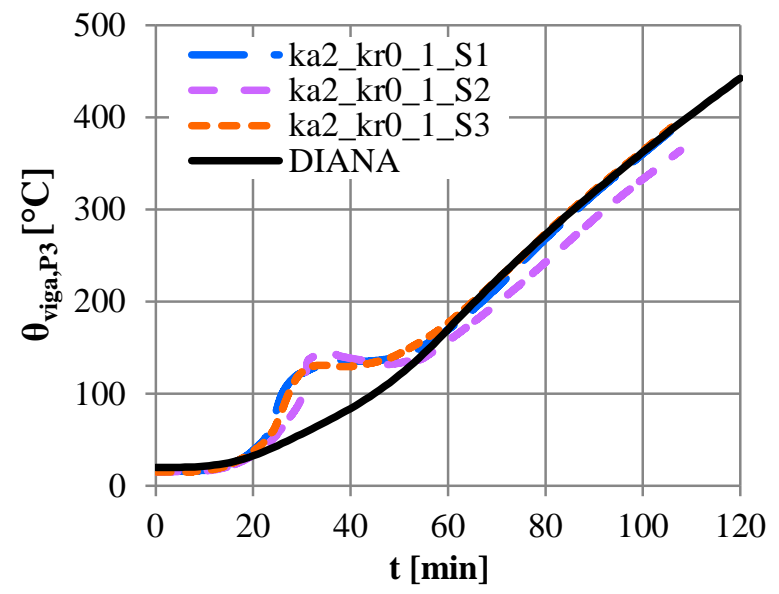

Figura 4.126 - Evolução de temperaturas no concreto (ponto 3) do ensaio ka2_kr0_1.

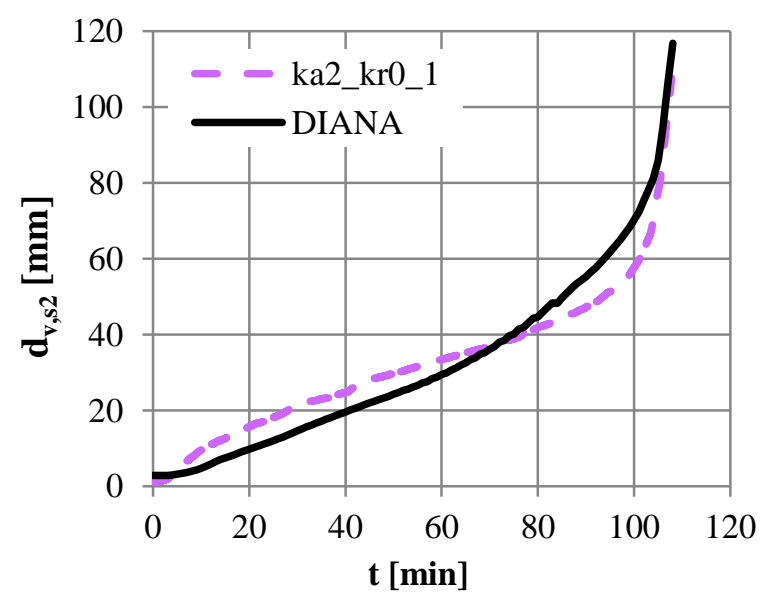

Figura 4.128 - Evolução das flechas (deslocamento vertical na seção $S_{2}$ ) do ensaio ka2_kr0_1.

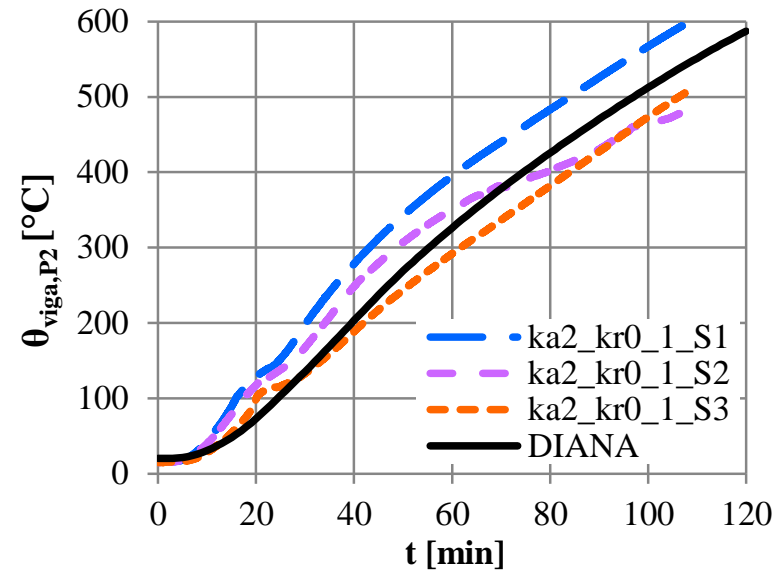

Figura 4.125 - Evolução de temperaturas na armadura longitudinal superior (ponto 2) do ensaio ka2_kr0_1.

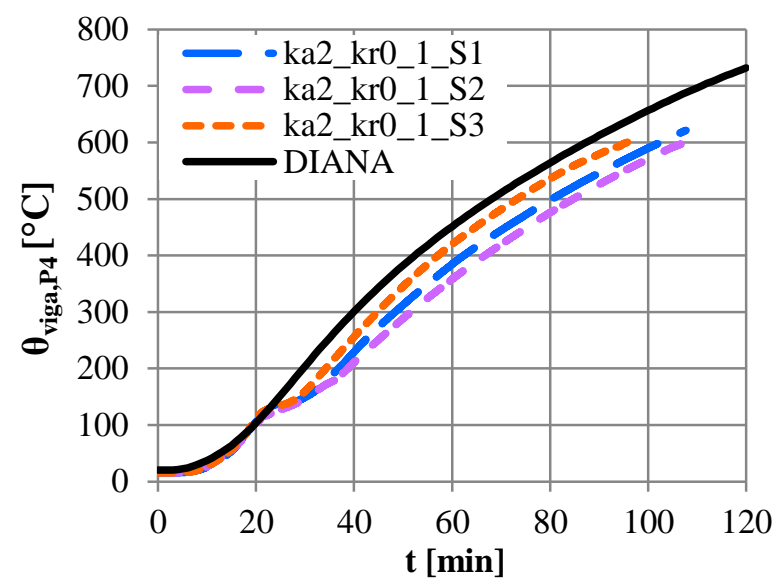

Figura 4.127 - Evolução de temperaturas na armadura longitudinal inferior (ponto 4) do ensaio ka2_kr0_1.

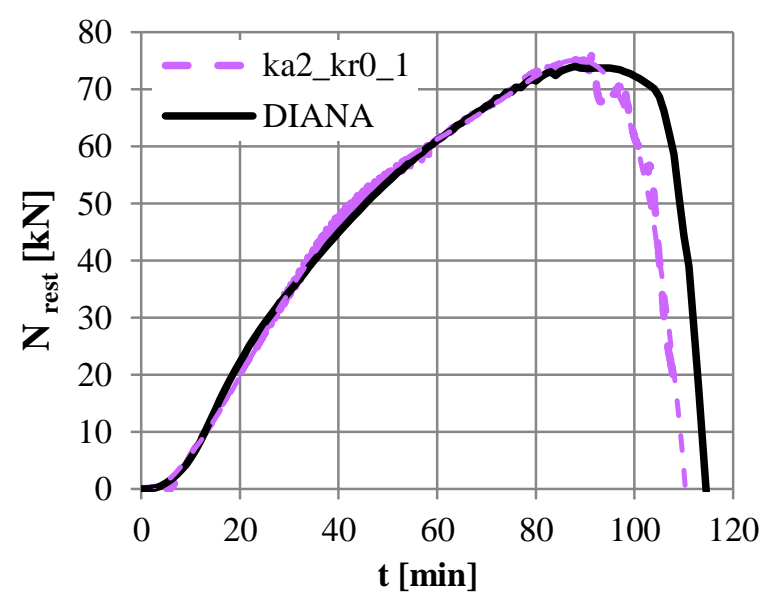

Figura 4.129 - Evolução das forças de restrição axiais do ensaio ka2_kr0_1. 


\subsubsection{Vigas com restrições axial e rotacional}

Por fim, as comparações numérico vs experimentais provenientes dos modelos representativos dos ensaios ka1_kr1_1 (Figuras 4.130 a 4.135) e ka1_kr2_1 (Figuras 4.136 a 4.141), em que além de restrições axiais parciais de $7 \mathrm{kN} / \mathrm{mm}$ também foram aplicadas restrições do tipo rotacional, sendo as designadas " $\mathrm{kr}_{2}$ " de nível mais intenso do que " $\mathrm{kr}_{1}$ ".

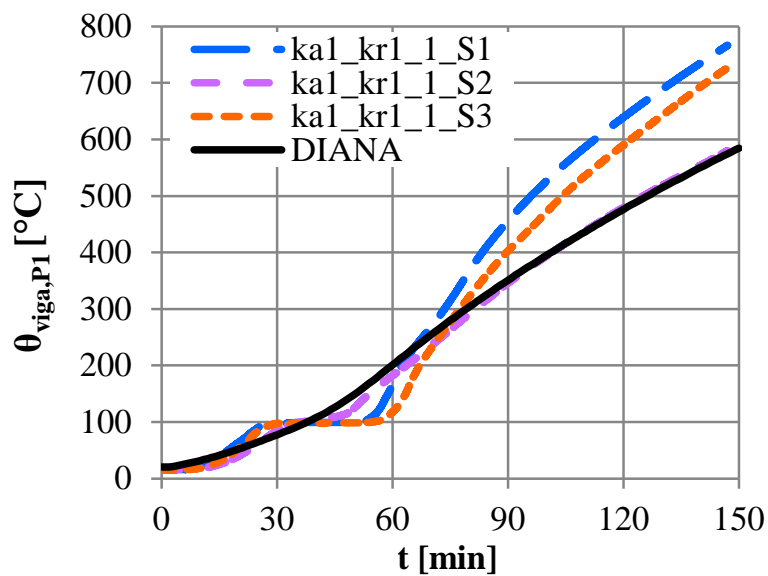

Figura 4.130 - Evolução de temperaturas na interface concreto/manta (ponto 1) do ensaio ka1_kr1_1.

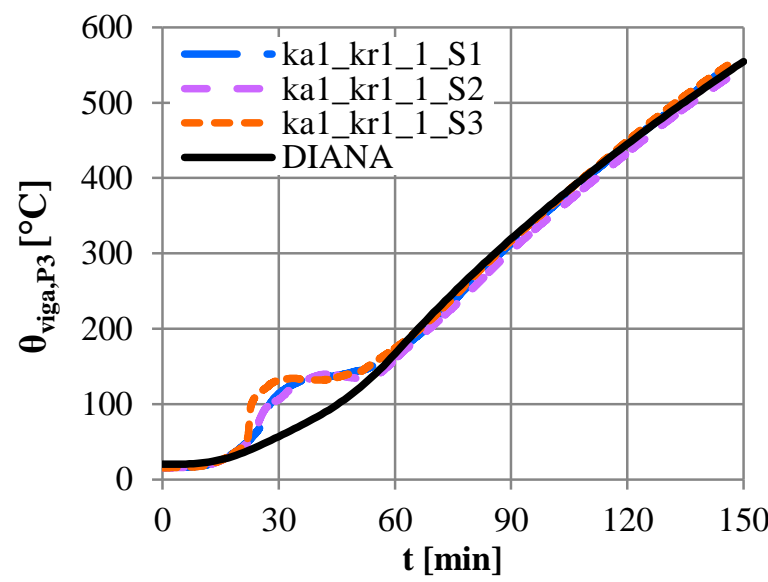

Figura 4.132 - Evolução de temperaturas no concreto (ponto 3) do ensaio ka1_kr1_1.

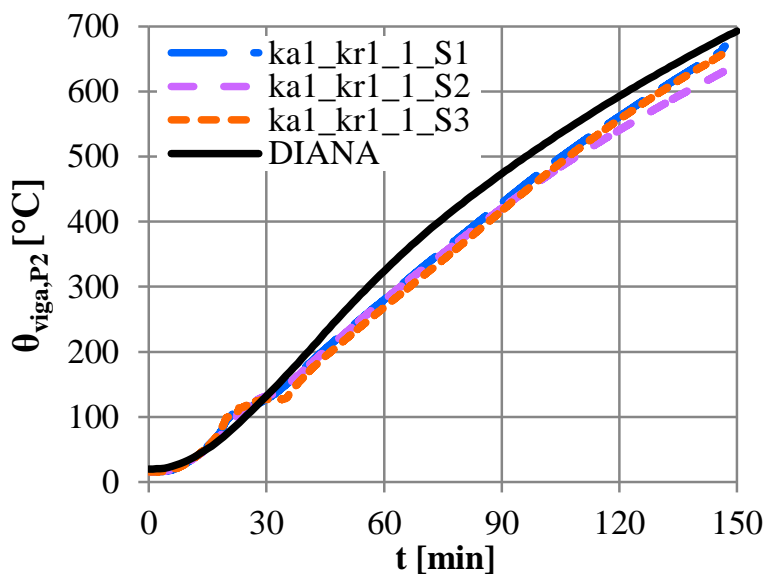

Figura 4.131 - Evolução de temperaturas na armadura longitudinal superior (ponto 2) do ensaio ka1_kr1_1.

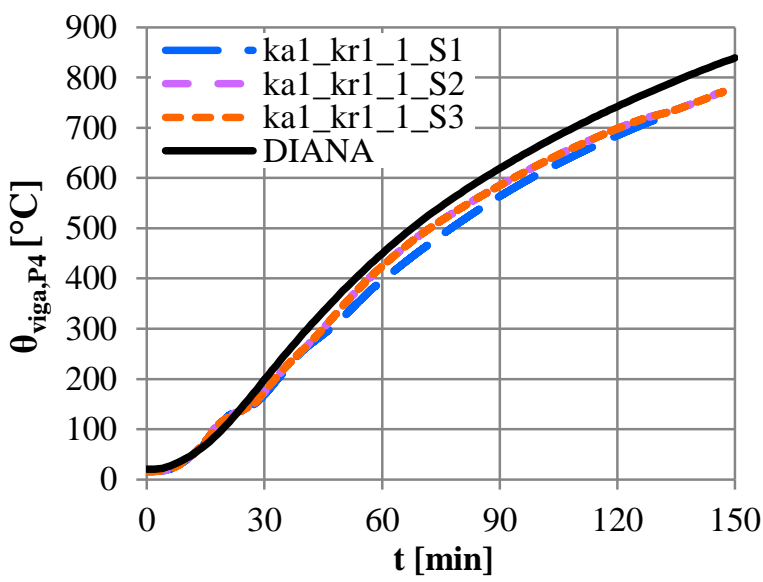

Figura 4.133 - Evolução de temperaturas na armadura longitudinal inferior (ponto 4) do ensaio ka1_kr1_1. 


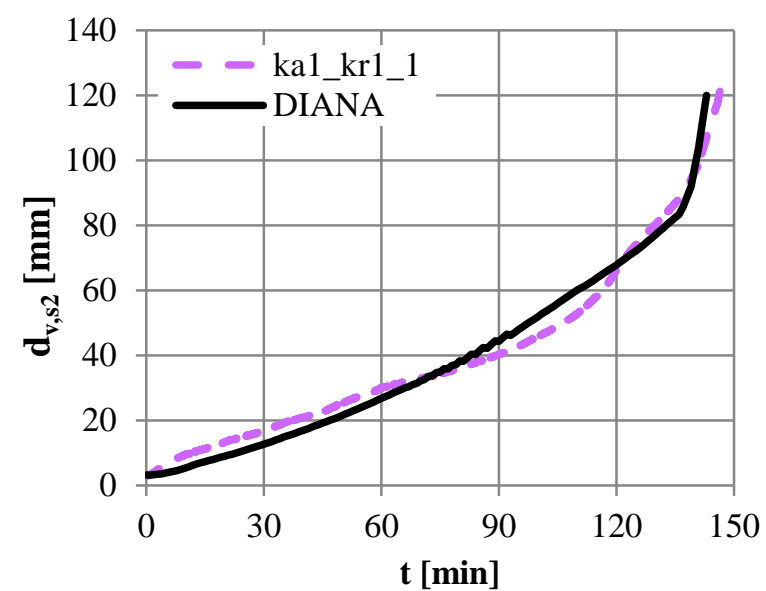

Figura 4.134 - Evolução das flechas (deslocamento vertical na seção $S_{2}$ ) do ensaio ka1_kr1_1.

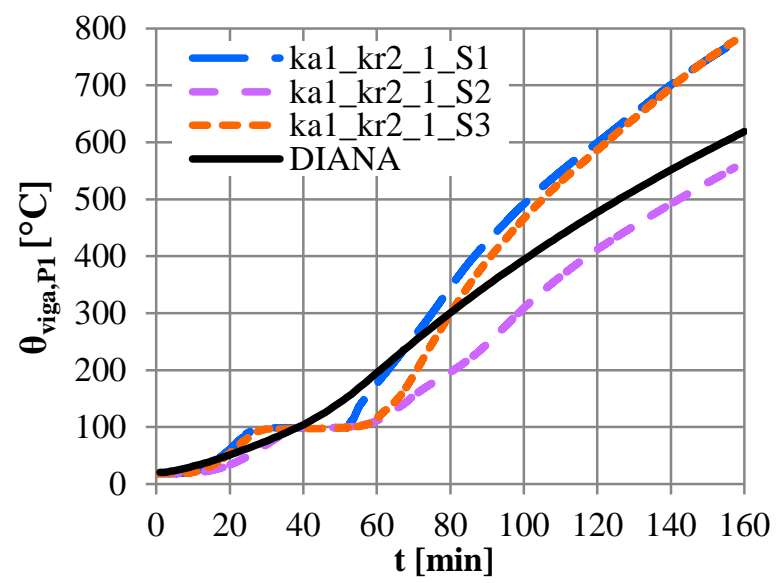

Figura 4.136 - Evolução de temperaturas na interface concreto/manta (ponto 1) do ensaio ka1_kr2_1.

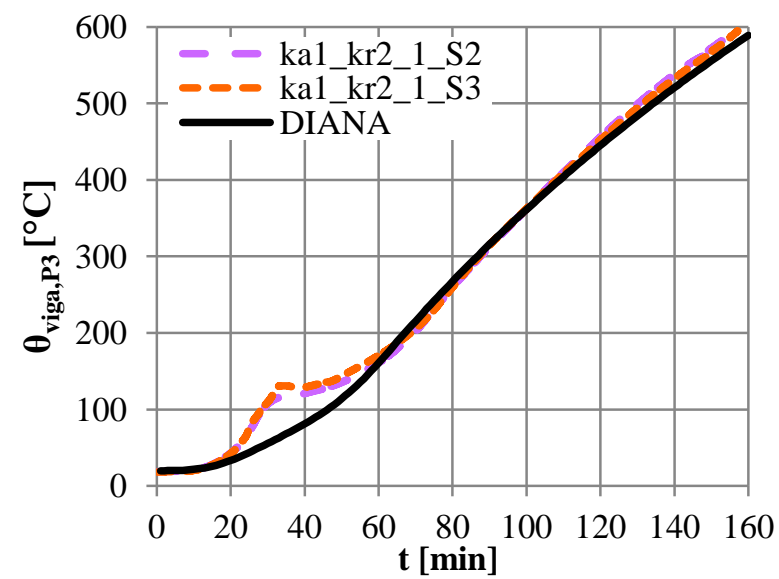

Figura 4.138 - Evolução de temperaturas no concreto (ponto 3) do ensaio ka1_kr2_1.

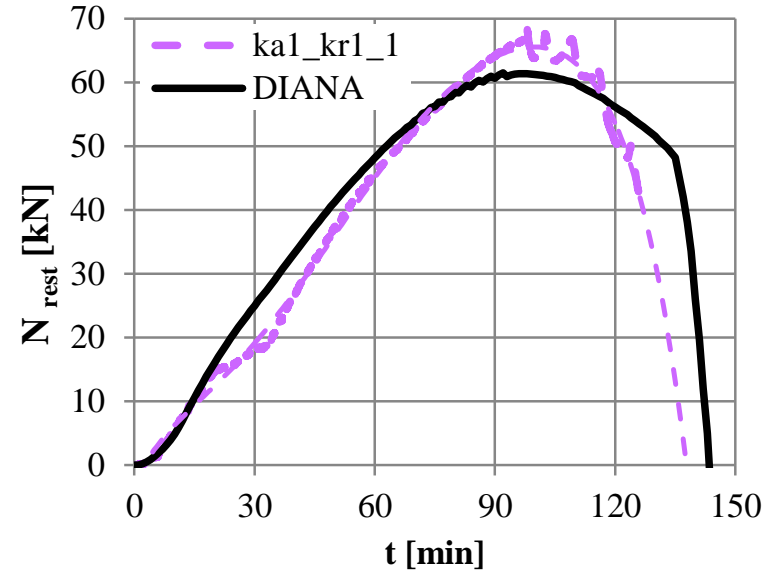

Figura 4.135 - Evolução das forças de restrição axiais do ensaio ka1_kr1_1.

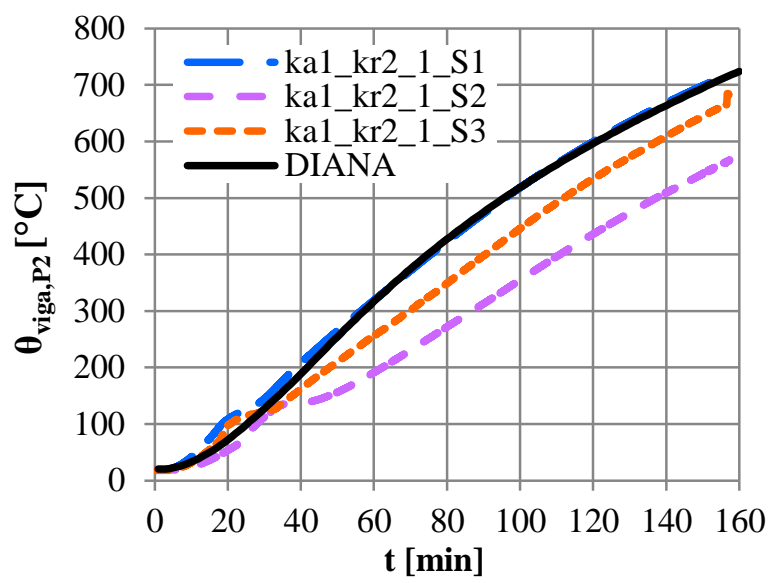

Figura 4.137 - Evolução de temperaturas na armadura longitudinal superior (ponto 2) do ensaio ka1_kr2_1.

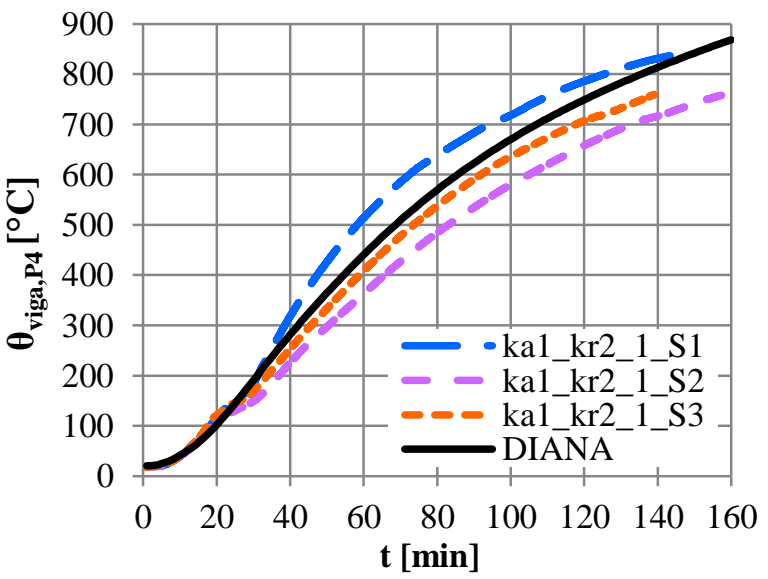

Figura 4.139 - Evolução de temperaturas na armadura longitudinal inferior (ponto 4) do ensaio ka1_kr2_1. 


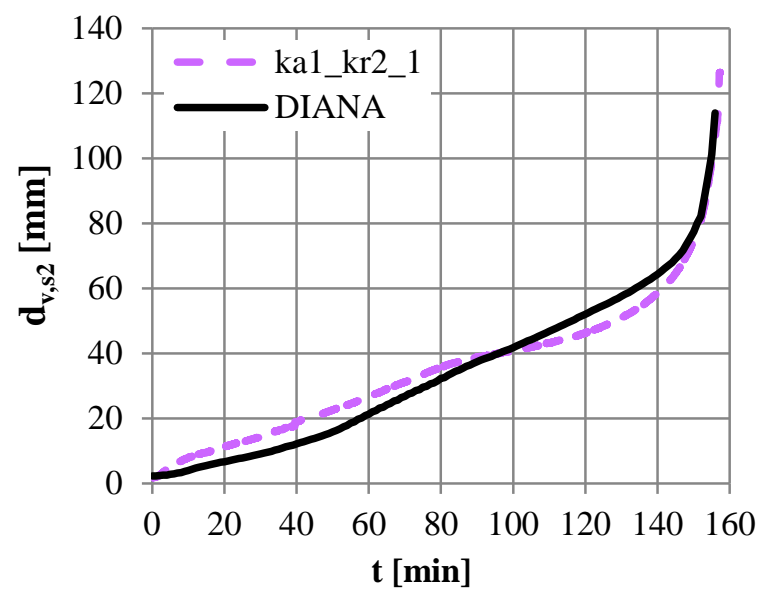

Figura 4.140 - Evolução das flechas (deslocamento vertical na seção $S_{2}$ ) do ensaio ka1_kr2_1.

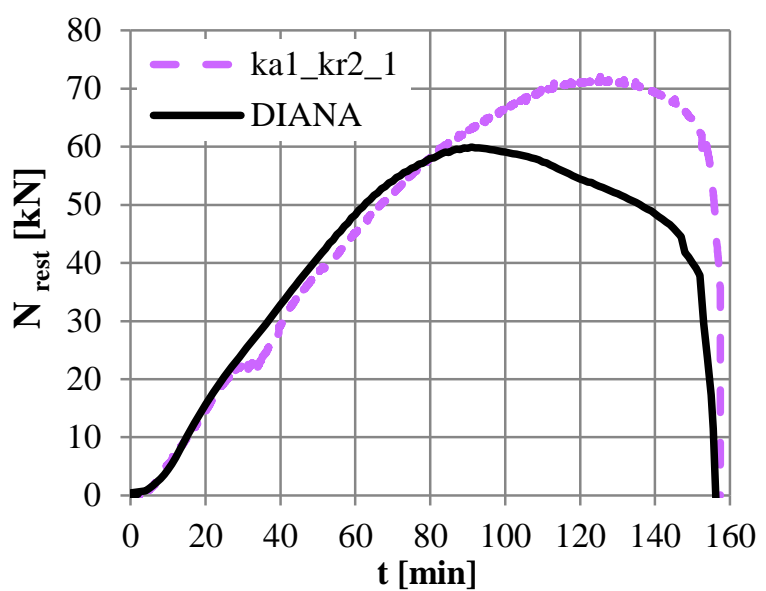

Figura 4.141 - Evolução das forças de restrição axiais do ensaio ka1_kr2_1.

\subsubsection{Discussões}

\subsection{Campos térmicos}

Nos modelos numéricos aqui concebidos, o teor de umidade do concreto não foi considerado explicitamente e, do mesmo modo, não se admitiram os efeitos advindos do fenômeno de vaporização da água presente na estrutura do material. A modelagem física desses parâmetros costuma ser bastante complexa, tanto que existe uma área de estudo totalmente voltada a esse tema (vide informações apresentadas no capítulo sobre o estado da arte da presente Tese).

A não consideração dos mesmos justifica o fato das curvas de temperaturas resultantes do DIANA para as interfaces concreto/manta não terem conseguido acompanhar os trechos em que ocorria um "atraso" na evolução das mesmas, que se mantinham constantes e iguais a $100{ }^{\circ} \mathrm{C}$, aproximadamente. Esse fenômeno verificado nos resultados experimentais ocorreu por conta da evaporação da água do concreto que ao subir para a face superior da viga ali ficava retida, entre o concreto e a manta, até que se evaporasse completamente. Sem a 
presença da água no modelo numérico, as curvas resultaram em temperaturas sempre crescentes em relação a esse ponto e interceptavam o patamar resultante dos ensaios.

Em contrapartida, os trechos das curvas numéricas que precediam esse patamar se mostraram sempre muito similares aos experimentais. Nos trechos que o procediam, as curvas do DIANA também se mostraram coerentes na maior parte dos casos, pois se encontravam ou dentro do intervalo de temperaturas delimitado pelas curvas experimentais ou, em outras situações, até se mostraram praticamente iguais a uma das curvas provenientes dos ensaios (vide resultados dos ensaios T_ka0_kr0_2 e ka1_kr1_1). Apenas na simulação dos ensaios ka0_kr0_1 e ka2_kr0_1, as diferenças se mostraram relativamente mais acentuadas, porém não passaram dos $50^{\circ} \mathrm{C}$ e, excepcionalmente na simulação do ensaio T_ka0_kr0_1, chegaram a atingir $100{ }^{\circ} \mathrm{C}$.

Apesar desses trechos divergentes entre curvas experimentais e numéricas para a interface concreto/manta, a evolução das temperaturas do ponto mais próximo a tal região não foi prejudicada. Como pode ser visto nos gráficos dos ensaios T_ka0_kr0_1 e _2, o ponto 2, localizado no concreto presente entre a interface e os estribos, apresentou respostas extremamente similares às experimentais.

A mesma justificativa - não consideração dos efeitos da água nas análises térmicas - se aplica à questão do DIANA não ter apanhado os trechos em que se apresentaram picos de temperaturas, também atuantes por determinados intervalos de tempo e da ordem de $100{ }^{\circ} \mathrm{C}$, relativamente aos pontos localizados no núcleo (centro geométrico) do concreto e em alguns outros próximos a ele (pontos 4 e 8 dos ensaios T_ka0_kr0_1 e_2). Esse fenômeno verificado nos ensaios estava intimamente ligado à evaporação da água que ocorria no interior do concreto. Porém, as diferenças entre as temperaturas numéricas e as experimentais nesses trechos não passaram, na maior parte dos casos, de $50{ }^{\circ} \mathrm{C}$ e, à parte desses trechos, as curvas resultantes do programa para esses pontos apresentaram boas correlações aos valores experimentais em todos os casos de estudo. 
No que diz respeito às temperaturas nas armaduras longitudinais superiores obtidas via DIANA, essas tiveram, no geral, resposta muito parecida àquelas medidas ao longo dos ensaios. Para os casos em que houve alguma diferença mais aparente entre curvas, essas ficaram na média de $60{ }^{\circ} \mathrm{C}$. Ressalta-se que as temperaturas nas armaduras longitudinais inferiores mostraram valores similares aos dos ensaios em todas as situações, sendo essa uma questão essencial para aferir o correto desempenho das vigas frente ao fogo porque o escoamento seguido da ruptura dessas barras comandam os pontos de inflexão das curvas das flechas (LIAO; HUANG, 2015).

Quanto às curvas dos demais pontos analisados em regiões concreto, muitas se mostraram entre aquelas resultantes dos ensaios e, mesmo para outras que apresentaram algumas diferenças eventualmente mais acentuadas, essas não influenciaram no comportamento global da estrutura, como será discutido mais adiante.

Sendo assim, concluiu-se que os campos térmicos obtidos pelas análises numéricas no DIANA foram capazes de simular de forma coerente aqueles provenientes dos ensaios experimentais. Logo, confirmou-se que as propriedades térmicas indicadas para os materiais constituintes do modelo pelas normas europeias são bastante representativas e que os coeficientes de transferência de calor equivalentes adotados para simular a contribuição das mantas no campo térmico apresentam soluções precisas.

\subsection{Comportamento estrutural}

No geral, as curvas numéricas de evolução das flechas apresentaram uma boa correlação aos resultados experimentais: as tendências foram sempre similares, bem como os valores encontrados para vários estágios de exposição ao fogo. Quanto a determinados trechos, sobretudo de instantes iniciais, que indicaram alguns valores subestimados para as flechas, pode-se atribuir o fato de que, no modelo numérico, as temperaturas na região do núcleo do concreto não apresentaram intervalos com picos de temperaturas. Logo, enquanto nos ensaios 
o núcleo estava mais aquecido e, por conseguinte, mais degradadas estavam as propriedades mecânicas do concreto, as flechas resultavam relativamente maiores. No modelo numérico, em contrapartida, as temperaturas do núcleo permaneceram mais baixas durante certo tempo e, sendo assim, o concreto estava ainda submetido a menores danos, sobretudo no que diz respeito ao módulo de elasticidade, parâmetro que influencia sensivelmente nas flechas.

Os pontos de inflexão dessas curvas, que estão intimamente ligados ao estado de degradação das propriedades do aço das armaduras longitudinais, ou foram muito similares àqueles vistos nos ensaios ou ocorreram um pouco antes, com a curva numérica acabando por interceptar a curva experimental. O segundo cenário não foi contra um comportamento já esperado pela questão de se ter adotado o diagrama tensão vs deformação para as armaduras conforme proposto pela norma europeia. Os valores de deformações específicas normatizados para o aço certamente possuem uma margem de segurança, pois são valores indicados para a prática de projetos.

A Tabela 4.2 indica comparações entre pontos relevantes das curvas de evolução das flechas obtidos experimental e numericamente, uma vez que tratam dos critérios que foram tomados a partir da norma EN 1363 parte 1 (1999) para o controle e finalização dos ensaios de resistência ao fogo. Como pode ser observado, os instantes em que as flechas atingiram os valores limites de 85 e $100 \mathrm{~mm}$ foram muito parecidos. Além disso, as resistências ao fogo aferidas com base no critério de ruptura em termos de deslocamentos verticais apresentaram um erro máximo de, aproximadamente, $1,3 \%$ em relação aos medidos via ensaios.

Quanto à evolução das curvas de forças de compressão para as vigas com restrição apenas do tipo axial, os valores de forças máximas encontradas pelo DIANA apresentaram boa correlação aos experimentais. Apesar dos instantes em que elas atingiram esse pico terem sido um pouco diferentes, aqueles em que elas retornaram ao valor igual a zero, sendo esse o procedimento para se estabelecer a resistência ao fogo com base no critério de ruptura em termos de capacidade resistente, foram coerentes, haja vista o erro máximo de 3,6\% indicado na Tabela 4.3. Para as vigas com restrições tanto axiais quanto rotacionais, apesar de os valores de forças máximas numéricas terem resultado menores que as obtidas por intermédio 
dos ensaios, os instantes em que elas ocorreram foram próximos. As resistências ao fogo também foram bastante representativas às dos ensaios, com um erro máximo de 2,2\% (valores indicados na mesma tabela).

Dessa forma, concluiu-se que as soluções adotadas nesta investigação para caracterizar as propriedades mecânicas dos materiais, admitidas variáveis ou não com a temperatura, e que as demais estratégias de modelagem foram capazes de simular de forma coerente o comportamento estrutural de vigas de concreto armado simplesmente apoiadas e com restrições a deformações de origem térmica que foram submetidas a ensaios de resistência ao fogo em laboratório. Portanto, esses modelos poderão ser eventualmente aplicados em trabalhos futuros que prevejam, por exemplo, estudos paramétricos relacionados a esses elementos estruturais.

Concluiu-se, ainda, que foi acertada a decisão de tomar preferencialmente como base as propriedades mecânicas e térmicas e até alguns modelos constitutivos indicados pelas normas europeias que foram citadas ao longo deste capítulo. À exceção de determinados modelos de caracterização do comportamento de materiais que se mostraram muito simplificados para as complexas análises numéricas em questão como, por exemplo, os modelos normatizados para representar as respostas à tração e à compressão do concreto, que não se fundamentavam nos preceitos da Mecânica de Fratura, as demais soluções adotadas conforme os Eurocodes conduziram a bons resultados.

As normas europeias foram escolhidas, ao invés das brasileiras, pelo fato das vigas de concreto armado ensaiadas terem sido fabricados em Portugal e, por conseguinte, com materiais provenientes do âmbito europeu. Uma vez que os modelos numéricos deveriam representar da melhor forma possível os ensaios laboratoriais, as normas europeias certamente seriam as mais indicadas. Entretanto, é oportuno destacar que as normas provenientes do Brasil se mostram muitas vezes similares a essas, sendo possível citar a própria norma brasileira de projeto de estruturas de concreto em situação de incêndio, a ABNT NBR 15200:2012, que foi concebida à luz das prescrições da norma europeia Eurocode 2 parte 1-2 (2004). 
Por fim, verificou-se que os modelos constitutivos adotados para caracterizar o comportamento dos materiais à temperatura ambiente também conduziram a resultados satisfatórios nas análises a altas temperaturas, pois os modelos escolhidos para as primeiras análises, sem fogo, foram sempre mantidos nos modelos em incêndio. As alterações nesses modelos constitutivos se davam apenas nos parâmetros que os compunham, eventualmente postos em função do aumento das temperaturas.

Tabela 4.2 - Comparações de resultados experimentais e numéricos relacionados às flechas das vigas.

\begin{tabular}{|c|c|c|c|c|c|c|c|}
\hline \multirow{2}{*}{ Ensaio } & \multicolumn{2}{|c|}{$\begin{array}{l}\text { Instante no qual } \mathrm{d}_{\mathrm{v}, \mathrm{S} 2} \\
\text { atingiu } 85 \mathrm{~mm}(\mathrm{~min})\end{array}$} & \multicolumn{2}{|c|}{$\begin{array}{l}\text { Instante no qual } \mathrm{d}_{\mathrm{v}, \mathrm{S} 2} \\
\text { atingiu } 100 \mathrm{~mm}(\mathrm{~min})\end{array}$} & \multicolumn{2}{|c|}{$\begin{array}{l}\text { Resistência ao fogo pelo } \\
\text { critério de ruptura } \mathrm{I}^{* * *}(\mathrm{~min})\end{array}$} & \multirow{2}{*}{ 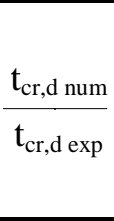 } \\
\hline & $\operatorname{Exp}^{*}$ & Num $^{* *}$ & Exp & Num & $\begin{array}{c}\text { Exp } \\
t_{c r, d \exp }\end{array}$ & $\begin{array}{l}\text { Num } \\
\mathrm{t}_{\mathrm{cr}, \mathrm{d} \text { num }}\end{array}$ & \\
\hline T_ka0_kr0_2 & 136 & 136,5 & 140,5 & 137,5 & - & - & - \\
\hline ka0_kr0_1 & 74 & 75 & 77 & 76 & 78 & 77 & 0,987 \\
\hline ka1_kr0_1 & 86 & 86,5 & 88 & 88 & 89 & 89 & 1,000 \\
\hline ka2_kr0_1 & 105 & 104,5 & 107 & 106,5 & 108 & 107,5 & 0,995 \\
\hline ka1_kr1_1 & 133 & 136,5 & 141 & 140,5 & 142 & 141,5 & 0,996 \\
\hline ka1_kr2_1 & 152 & 152,5 & 155 & 154,5 & 156 & 155,5 & 0,997 \\
\hline
\end{tabular}

* "Exp" representa os resultados experimentais; "** "Num” representa os resultados numéricos; *** Dá-se pelo instante no qual a taxa de aumento das flechas $\mathrm{d} / \mathrm{dt}\left(\mathrm{d}_{\mathrm{v}, \mathrm{S} 2}\right)$ excede $3,78 \mathrm{~mm} / \mathrm{min}$, sendo esse o critério de ruptura em termos de deslocamentos.

Tabela 4.3 - Comparações de resultados experimentais e numéricos relacionados às forças de restrição axiais.

\begin{tabular}{|c|c|c|c|c|c|c|c|}
\hline \multirow{2}{*}{ Ensaio } & \multicolumn{2}{|c|}{$\begin{array}{l}\mathrm{N}_{\text {rest }} \text { máxima } \\
{[\mathrm{kN}]}\end{array}$} & \multicolumn{2}{|c|}{$\begin{array}{l}\text { Instante no qual } \mathrm{N}_{\text {rest }} \\
\text { atingiu valor máximo (min) }\end{array}$} & \multicolumn{2}{|c|}{$\begin{array}{l}\text { Resistência ao fogo pelo } \\
\text { critério de ruptura } \mathrm{II}^{* * *} \text { (min) }\end{array}$} & \multirow{2}{*}{ 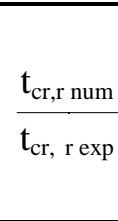 } \\
\hline & $\operatorname{Exp}^{*}$ & Num $^{* *}$ & Exp & Num & $\begin{array}{l}\text { Exp } \\
t_{c r, r \exp }\end{array}$ & 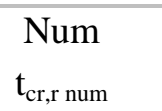 & \\
\hline ka1_kr0_1 & 57 & 58 & 74 & 81 & 93 & 96 & 1,032 \\
\hline ka2_kr0_1 & 76 & 74 & 91 & 88 & 110 & 114 & 1,036 \\
\hline ka1_kr1_1 & 67 & 61,5 & 97 & 92 & 138 & 141 & 1,022 \\
\hline ka1_kr2_1 & 71 & 60 & 120 & 91 & 157,5 & 155,5 & 0,987 \\
\hline
\end{tabular}

\footnotetext{
* "Exp" representa os resultados experimentais; "** "Num" representa os resultados numéricos; *** Dá-se pelo instante no qual a força de restrição axial $\mathrm{N}_{\text {rest }}$ retorna a zero, sendo esse o critério de ruptura em termos de capacidade resistente.
} 



\section{CONCLUSÕES}

$\mathrm{Na}$ presente Tese foi realizado um estudo numérico-experimental para a análise do comportamento de vigas de concreto armado em situação de incêndio. $\mathrm{O}$ foco principal consistiu em comparar o desempenho ao fogo de vigas sem restrições às deformações de origem térmica àquelas que experimentavam qualquer tipo de restrição (ou axial ou axial mais rotacional). A seguir, apresentar-se-ão as conclusões acerca da parte experimental desta investigação, em seguida da parte numérica e, por fim, os trabalhos futuros que podem ser realizados em face dos resultados aqui obtidos.

\subsection{Análises experimentais}

A campanha experimental desta Tese contou com a realização de três ensaios de flexão a quatro pontos de vigas de concreto armado simplesmente apoiadas à temperatura ambiente. Esses consistiram em ensaios de referência para as posteriores análises ao fogo e tinham como principais objetivos a determinação das forças máximas resistidas pelas vigas e a verificação do modo de ruptura das mesmas.

As vigas apresentaram um comportamento experimental conforme o esperado, uma vez que as forças últimas obtidas pelos ensaios foram similares ao valor determinado analiticamente $\mathrm{e}$ as rupturas ocorreram por flexão, com estados-limite atingidos pela deformação última da armadura longitudinal tracionada, entretanto com o aviso prévio das fissuras de flexão e flechas excessivas, refletindo o estado-limite de projeto para o qual foram dimensionadas. 
Depois foi realizada uma série de quinze ensaios de flexão a quatro pontos de vigas de concreto armado submetidas a altas temperaturas, nos quais foram admitidas como variáveis as condições de apoio: ensaios em vigas sem restrições às deformações de origem térmica (simplesmente apoiadas), com restrições às deformações axiais e com restrições tanto às deformações axiais quanto rotacionais. Em relação às vigas restringidas, foram estudados dois níveis parciais de rigidezes axial e rotacional, um mais elevado e outro mais baixo. A motivação para o desenvolvimento desses ensaios consistiu em analisar, sobretudo de forma quantitativa, a influência dos efeitos das restrições no comportamento das vigas de concreto armado em situação de incêndio e em obter valores para a validação de modelos numéricos.

A principal conclusão obtida por meio deles foi que as resistências ao fogo das vigas sempre aumentam quando considerado qualquer tipo de restrição (somente axial ou axial mais rotacional). Ao ser introduzido o nível mais baixo de restrição axial e ainda sem restrição rotacional, por exemplo, já chegou a ser verificado um aumento de $18 \%$ em relação à resistência média ao fogo das vigas simplesmente apoiadas. Novamente quanto aos ensaios apenas com restrição axial, concluiu-se que quanto maior o nível de restrição, maior a resistência ao fogo da viga. Ao se dobrar esse nível, encontrou-se um aumento de quase $10 \%$ na resistência, quando comparada à da viga com restrição axial mais baixa, e, portanto, um aumento de $28 \%$ relação à resistência das vigas simplesmente apoiadas.

A consideração dos efeitos resultantes das restrições rotacionais faz melhorar ainda mais o desempenho das vigas frente ao fogo. Para os níveis mais baixos tanto de restrição axial quanto rotacional, o acréscimo já se mostrou significativo, uma vez que a resistência ao fogo foi $76 \%$ maior que aquela obtida para as vigas simplesmente apoiadas. Enquanto isso, para o modelo que conduziu às maiores resistências ao fogo encontradas nessa série de quinze ensaios, no qual foi combinado o nível mais alto de restrição axial com o mais baixo de rotacional, o aumento chegou a ser superior a $100 \%$ em relação às simplesmente apoiadas. Pontua-se que a restrição rotacional seguiu a mesma regra da axial: maiores níveis de rigidez conduzem a resistências ao fogo maiores. Em um ensaio que foi possível fixar o nível de 
restrição axial e dobrar o nível da rotacional, a resistência ao fogo chegou a ser quase $10 \%$ maior quando comparado àquela com a rotacional mais baixa.

Uma vez que a consideração dos efeitos das restrições pode gerar um aumento significativo na resistência ao fogo das vigas de concreto armado, conclui-se que os métodos simplificados normatizados podem eventualmente conduzir a resultados de dimensionamento muito conservadores ao não admitir esses efeitos nas vigas que possam ter oportunidade de ser submetidas a eles em situação de incêndio. Contudo, um tópico que carece de estudo se refere a analisar os efeitos que as forças de restrição das vigas geram ao reagir nos pilares, que também devem ser dimensionados para resistir a esses esforços. Logo, os efeitos que melhoram a resistência ao fogo das vigas não necessariamente são benéficos aos pilares.

\subsection{Análises numéricas}

Nesta Tese ainda foram concebidos nove modelos numéricos tridimensionais para simular o comportamento das vigas de concreto armado que foram submetidas a ensaios em laboratório. Um deles foi desenvolvido para representar as vigas simplesmente apoiadas à temperatura ambiente e os demais para caracterizar aquelas ensaiadas ao fogo. Dentre os modelos com a consideração de incêndio, dois foram concebidos para o estudo específico das temperaturas das vigas com ou sem material isolante na face superior; dois para a análise não apenas do comportamento térmico, mas também mecânico de vigas simplesmente apoiadas (estudo de dois casos, com ou sem aplicação de forças sobre as vigas); dois para as vigas com restrição apenas axial (um dedicado a simular o nível mais elevado de restrição axial e o outro o nível mais baixo); finalmente, dois para vigas com restrições tanto axiais quanto rotacionais (da mesma forma que o anterior, uma para cada nível de restrição rotacional).

Haja vista a boa correlação entre os resultados numéricos e experimentais, concluiu-se que as análises fundamentadas no método dos elementos finitos conduzem a uma abordagem 
coerente do problema proposto para investigação em termos computacionais. No caso específico desta Tese, ainda foi possível apresentar uma nova ferramenta para a realização dessas análises, o programa de computador DIANA (DIANA FEA, 2016a). Ele ainda não tinha sido aplicado nas pesquisas mais semelhantes a esta, i.e., naquelas que foram realmente voltadas ao estudo das restrições no comportamento ao fogo das vigas de concreto armado.

Quanto aos aspectos concernentes à modelagem da viga à temperatura ambiente, verificou-se que apesar dos modelos constitutivos indicados pelas normas europeias pertinentes a projetos estruturais terem se mostrado coerentes para caracterizar o aço das armaduras, os modelos normatizados para a simulação do comportamento do concreto submetido a esforços ou de tração ou de compressão se mostraram muito simplificados. Para a obtenção de resultados mais próximos à realidade, o uso de modelos que levavam em conta os valores de energia de fratura do concreto se mostrou fundamental.

Os modelos de vigas ao fogo foram concebidos a partir do modelo à temperatura ambiente, não tendo sido necessário nessa adaptação modificar nenhum dos modelos constitutivos considerados para os materiais na condição normal (sem ação do fogo). Assim, concluiu-se que é possível fazer uso de muitas diretrizes indicadas para a modelagem de estruturas de concreto à temperatura ambiente para modelar as estruturas ao fogo, sendo a posterior consideração da degradação das propriedades mecânicas dos materiais, devido ao aumento das temperaturas, suficiente para adaptar esses modelos.

Relativamente às variações de propriedades mecânicas e térmicas dos materiais aquecidos, essas foram sempre admitidas com base nas diretrizes das normas europeias, de modo a confirmar que são bastante representativas da resposta do concreto e do aço expostos ao fogo. Por fim, verificou-se que se um material isolante não possui função estrutural no modelo numérico, considerá-lo de forma implícita, admitindo-o como um elemento de interface com um coeficiente de transferência de calor equivalente, conduz a resultados satisfatórios. 


\subsection{Trabalhos futuros}

Um dos trabalhos futuros que podem ser desenvolvidos com base nos resultados desta Tese consiste na comparação dos valores das forças de restrição encontradas ao longo dos ensaios experimentais àqueles calculados a partir do método proposto por Riva e Franssen (2008), que também está presente nas diretrizes do Model Code 2010 (2011) e que foi citado ao longo do Capítulo 2 - Estado da Arte.

Outra linha de investigação futura consiste na análise das porcentagens de redistribuição de momentos fletores solicitantes que são usualmente aplicadas, à luz das prescrições do Eurocode 2 parte 1-2 (2004), em projetos que envolvem o dimensionamento de vigas de concreto armado em situação de incêndio. Os resultados dos ensaios experimentais podem ser adotados para verificar o quanto os momentos negativos dos apoios crescem ao longo da exposição ao fogo, de modo a esclarecer se a porcentagem de redistribuição que ocorre na prática é mesmo condizente à adotada em projeto, onde é comum se admitir para o dimensionamento ao fogo a mesma porcentagem estabelecida para redistribuir os momentos à temperatura ambiente, apesar de nesse último caso se redistribuir dos negativos para os positivos.

Ainda por intermédio desta investigação pode ser conduzido um estudo paramétrico, mediante os modelos numéricos que foram calibrados pelos resultados experimentais dos ensaios. A partir desse estudo seriam analisados mais casos de vigas, diferentes daquelas submetidas a testes em laboratório, com o propósito de verificar a influência de cada variável no comportamento ao fogo das peças com ou sem deformações térmicas restringidas. Nele haveria a possibilidade de modificar, por exemplo: curvas de incêndio, níveis e configurações de carregamentos, comprimento e número de vãos (com a consideração de apoios intermédios), configurações de armaduras, dimensões e tipos de seções transversais (seções T, de vigas sob lajes, por exemplo), níveis de restrições axiais e rotacionais, além da localização vertical das forças de restrição. 
Os modelos e os resultados provenientes do estudo paramétrico, aliados aos resultados obtidos experimentalmente nesta Tese, também poderiam dar seguimento a uma linha de pesquisa que compreenderia a elaboração de uma ferramenta ou método simplificado, diferentes daqueles que já existem na literatura, para ser disponibilizado aos engenheiros com o intuito de facilitar a consideração dos efeitos das restrições às deformações de origem térmica na prática de projetos de vigas de concreto armado em situação de incêndio.

Os procedimentos adotados na presente investigação para realizar os ensaios experimentais em vigas de concreto armado com ou sem restrições expostas a temperaturas elevadas ainda poderiam ser adaptados para a análise de vigas de concreto ou com barras poliméricas ou reforçadas pelo uso de diferentes técnicas e de vigas produzidas com concreto de alta resistência mecânica. 


\section{REFERÊNCIAS}

ABAQUS. Finite Element Analysis. Pawtucket: Hibbert, Karlsson \& Sorenson, 2008.

ADINA. Theory and Modeling Guide: solids and structures. ADINA R \& D, 2005.

AL FADUL, M. Hydro-thermo-mechanical behavior of concrete at elevated temperatures. 2017. 170 p. $\mathrm{PhD}$ Thesis - College of Engineering and Computer Science, University of Central Florida, Orlando, 2017.

ALAM, A. K. M. J.; AMANAT, K. M. Finite element simulation on punching shear behavior of reinforced concrete slabs. International Scholarly Research Network - Civil Engineering, v. 2012, p. 1-9, 2012.

ALBINO, C. A. P. Análise térmica de seções de betão armado submetidas ao fogo. 2012. 73 p. + anexos. Dissertação (Mestrado) - Faculdade de Ciências e Tecnologia, Universidade de Coimbra, Coimbra, 2012.

ALBRIFKANI, S.; WANG, Y. C. Explicit modelling of large deflection behaviour of restrained reinforced concrete beams in fire. Engineering Structures, v. 121, p. 97-119, 2016.

ALBUQUERQUE, G. B. M. L. Dimensionamento de vigas de concreto armado em situação de incêndio. 2012. 245 p. Dissertação (Mestrado) - Escola Politécnica, Universidade de São Paulo, São Paulo, 2012.

ALBUQUERQUE, G. B. M. L. et al. Análise experimental da resistência ao fogo de vigas de concreto armado axialmente restringidas. In: CONGRESSO IBERO-LATINO-AMERICANO SOBRE SEGURANÇA CONTRA INCÊNDIO - CILASCI, 4., 2017b, Pernambuco. Anais... Olinda: Livro Rápido, 2017b. p. 44-64.

ALBUQUERQUE, G. B. M. L. et al. Análise experimental de vigas de concreto armado em situação de incêndio com deformações axiais restringidas. In: CONGRESSO BRASILEIRO DO CONCRETO, 58., 2016, Belo Horizonte. Anais... São Paulo: IBRACON, 2016. p. 1-16.

ALBUQUERQUE, G. B. M. L. et al. Experimental analysis of axially restrained reinforced concrete beams subjected to fire. In: INTERNATIONAL FIRE SAFETY SYMPOSIUM IFireSS, 2., 2017a, Naples. Proceedings... Naples: Doppiavoce, 2017a. p. 437-444. 
ALBUQUERQUE, G. B. M. L. Reinforced concrete beams fire design. Saarbrücken: LAMBERT Academic Publishing, 2014. 262 p.

ALBUQUERQUE, G. B. M. L.; SILVA, V. P. Análise numérica termestrutural de vigas de concreto armado em situação de incêndio. In: Congreso de Métodos Numéricos em Ingeniería - CMN, 2013c, Bilbao. Anais... Bilbao: CIMNE, 2013c. p. 1-20.

ALBUQUERQUE, G. B. M. L.; SILVA, V. P. Comparação entre métodos simplificados para a determinação do momento fletor resistente de vigas de concreto armado em situação de incêndio. In: CONGRESSO IBERO-LATINO-AMERICANO SOBRE SEGURANÇA CONTRA INCÊNDIO - CILASCI, 2., 2013b, Coimbra. Anais... Coimbra: ALBRASCI, 2013b. p. 281-289.

ALBUQUERQUE, G. B. M. L.; SILVA, V. P. Verificação ao cisalhamento em vigas de concreto armado em situação de incêndio. In: CONGRESSO BRASILEIRO DO CONCRETO, 55., 2013a, Gramado. Anais... São Paulo: IBRACON, 2013a. p. 1-16.

ALBUQUERQUE, G. B. M. L.; SILVA, V. P.; RODRIGUES, J. P. C. Thermo-structural analyses of RC beams in fire. In: INTERNATIONAL FIRE SAFETY SYMPOSIUM IFireSS, 1., 2015, Coimbra. Proceedings... Coimbra: ALBRASCI, 2015. p. 243-252.

ALI, F. A.; O'CONNOR, D. Structural performance of rotationally restrained steel columns in fire. Fire Safety Journal, v. 36, n. 7, p. 679-691, 2001.

ALI, F.; NADJAI, A.; ABU-TAIR, A. Experimental and numerical study on performance of concrete slabs subjected to severe fire. In: INTERNATIONAL SYMPOSIUM ON FIRE SAFETY SCIENCE, 9., 2008, Karlsruhe. Proceedings...Karlsruhe: International Association for Fire Safety Science, 2008. p. 1255-1266.

ALI, F.; NADJAI, A.; CHOI, S. Numerical and experimental investigation of the behavior of high strength concrete columns in fire. Engineering Structures, v. 32, n. 5, p. 1236-1243, 2010 .

ALMEIDA, D. F. As estruturas de concreto armado e o fogo: comportamento consequências - restauração. 1984. 143 p. Dissertação (Mestrado) - Escola Politécnica, Universidade de São Paulo, São Paulo, 1984.

ALVES, D. A. M. Métodos simplificados para avaliação da resistência ao fogo de vigas de betão armado - avaliação numérica com o modelo SiFiRe. 2012. 91 p. Dissertação (Mestrado) - Faculdade de Engenharia, Universidade do Porto, Porto, 2012.

AMERICAN INSTITUTE OF STEEL CONSTRUCTION. ANSI/AISC 360-10: Specification for structural steel buildings. Chicago, 2010. $552 \mathrm{p}$. 
AMERICAN SOCIETY FOR TESTING AND MATERIALS. ASTM E119-00a: Standard test methods for fire tests of building construction and materials. West Conshohocken, 2000. $21 \mathrm{p}$.

AMERICAN SOCIETY FOR TESTING AND MATERIALS. E1529-10: Standard test methods for determining effects of large hydrocarbon pool fires on structural members and assemblies. West Conshohocken, 1993. 24 p.

ASLANI, F.; SAMALI, B. Predicting the bond between concrete and reinforcing steel at elevated temperatures. Structural Engineering \& Mechanics, v. 48, n. 5, p. 643-660, 2013.

ASSOCIAÇÃO BRASILEIRA DE NORMAS TÉCNICAS. NBR 15200: Projeto de estruturas de concreto em situação de incêndio. Rio de Janeiro, 2012. 48 p.

ASSOCIAÇÃO BRASILEIRA DE NORMAS TÉCNICAS. NBR 5628: Componentes construtivos estruturais: determinação da resistência ao fogo. Rio de Janeiro, 2001. 6 p.

ASSOCIAÇÃO BRASILEIRA DE NORMAS TÉCNICAS. NBR 6118: Projeto de estruturas de concreto: procedimento. Rio de Janeiro, 2014. 238 p.

ASSOCIAÇÃO BRASILEIRA DE NORMAS TÉCNICAS. NBR 6120: Cargas para o cálculo de estruturas de edificações. Rio de Janeiro, 2000. 5 p.

AZENHA, M. A. D. Comportamento do betão nas primeiras idades: fenomenologia e análise termo-mecânica. 2004. 220 p. Dissertação (Mestrado) - Faculdade de Engenharia, Universidade do Porto, Porto, 2004.

AZENHA, M. A. D. Numerical simulation of the structural behaviour of concrete since its early ages. 2009. 375 p. PhD Thesis - Faculty of Engineering, University of Porto, Porto, 2009.

BA, G. et al. Influence of cracking on heat propagation in reinforced concrete structures. Journal of Structural Engineering, v. 142, n. 7, 2016.

BACINSKAS, D. et al. Computationally effective tool for mechanical simulation of reinforced concrete members subjected to fire. In: INTERNATIONAL CONFERENCE MODERN BUILDING MATERIALS, STRUCTURES AND TECHNIQUES, 9., 2007, Vilnius. Proceedings... Vilnius, 2007. p. 461-467.

BAHR, O. et al. Young's modulus and Poisson's ratio of concrete at high temperatures: experimental investigations. Materials and Design, v. 45, p. 421-429, 2013.

BAILEY, C. G.; TOH, W. S. Small-scale concrete slab tests at ambient and elevated temperatures. Engineering Structures, v. 29, n. 10, p. 2775-2791, 2007. 
BAZANT, Z. P.; CEDOLIN, L. Blunt crack band propagation in finite element analysis. Journal of the Engineering Mechanics Division, v. 105, p. 297-315, 1979.

BAZANT, Z. P.; CEDOLIN, L. Finite element modeling of crack band propagation. Journal of Structural Engineering, v. 109, n. 1, p. 69-92, 1983.

BAZANT, Z. P.; CEDOLIN, L. Fracture mechanics of reinforced concrete. Journal of the Engineering Mechanics Division, v. 106, p. 1287-1306, 1980.

BAZANT, Z. P.; OH, B. H. Crack band theory for fracture of concrete. Materials and Structures, v. 16, n. 3, p. 155-177, 1983.

BAZANT, Z. P.; PRAT, P. C. Effect of temperature and humidity on fracture energy of concrete. ACI Materials Journal, v. 84, p. 262-271, 1988.

BAZANT, Z. P.; THONGUTHAI, W. Pore pressure in heated concrete walls: theoretical prediction. Magazine of Concrete Research, v. 31, n. 107, p. 67-76, 1979.

BECKER, J. M.; BIZRI, H.; BRESLER, B. FIRES-T: a computer program for the fire response group. Berkeley: University of California, 1974. (Report n. UCB FRG 74-1).

BECKER, J. M.; BRESLER, B. FIRES-RC: a computer program for the fire response of structures - reinforced concrete frames. Berkeley: University of California, 1974. (Report n. UCB FRG 74-3).

BELLETTI, B. et al. Guidelines for nonlinear finite analysis of concrete structures. Utrecht: Rijkswaterstaat Centre for Infrastructure, 2016. 66 p. (Rijkswaterstaat Technical Document RTD: 1016-1:2016).

BELLETTI, B. et al. Validation of the guidelines for nonlinear finite analysis of concrete structures: part reinforced beams. Utrecht: Rijkswaterstaat Centre for Infrastructure, 2017. 105 p. (Rijkswaterstaat Technical Document RTD: 1016-3A:2017).

BELYTSCHKO, T.; BLACK, T. Elastic crack growth in finite elements with minimal remeshing. International Journal for Numerical Methods in Engineering, v. 45, n. 5, p. 601-620, 1999.

BERNHART, D. The effect of support conditions on the fire resistance of a reinforced concrete beam. 2004. 147 p. Thesis (Diplom-Bauingenieurin) - University of Karlsruhe, Karlsruhe, and University of Canterbury, Christchurch, 2004. (Fire Engineering Research Report n. 04/5).

BETTINI, N. et al. Fire analysis of reinforced concrete precast tunnel lining considering the spalling effect. In: INTERNATIONAL DIANA USERS MEETING, 9., 2014, Parma, Italy. Proceedings... Parma, 2014. 
BIONDINI, F.; NERO, A. Cellular finite beam element for nonlinear analysis of concrete structures under fire. Journal of Structural Engineering, v. 137, n. 5, p. 543-558, 2011.

BIONDINI, F.; NERO, A. Nonlinear analysis of concrete structures exposed to fire. In: FÉDÉRATION INTERNATIONALE DU BÉTON - INTERNATIONAL CONGRESS, 2 ., 2006, Naples. Proceedings... Naples: CEB-FIP, 2006. p. 1-12.

BITTENCOURT, T. N. Fraturamento do concreto estrutural: aspectos teóricos, computacionais e experimentais, e suas aplicações. 1999. 226 p. Tese (Livre Docência) Escola Politécnica, Universidade de São Paulo, São Paulo, 1999.

BORGES, J. U. A. Análise do comportamento de vigas de concreto de alto desempenho por meio da mecânica da fratura. 2002. 280 p. Tese (Doutorado) - Escola Politécnica, Universidade de São Paulo, São Paulo, 2002.

BRATINA, S. et al. Non-linear fire-resistance analysis of reinforced concrete beams. Structural Engineering and Mechanics, v. 16, n. 6, p. 695-712, 2003.

BRATINA, S.; SAJE, M.; PLANINC, I. The effects of different strain contributions on the response of RC beams in fire. Engineering Structures, v. 29, n. 3, p. 418-430, 2007.

BRITISH STANDARDS INSTITUTION. BS 8110-2: Structural use of concrete: code of practice for special circumstances - part 2. London, 1985. $68 \mathrm{p}$.

BRITISH STANDARDS INSTITUTION. BS 476-20: Fire tests on building materials and structures: method for determination of the fire resistance of elements of construction general principles. London, 1987. 48 p.

BUCHANAN, A. H. Structural design for fire safety. New York: Wiley, 2001. 421 p.

BUCHANAN, A. H.; ABU, A. K. Structural design for fire safety. New York: Wiley, 2017. $415 \mathrm{p}$.

BURGH, J. M.; VALIPOUR, H. R.; FOSTER, S. J. Fire induced spalling of reinforced or prestressed concrete: overview and initial numerical investigation. In: CONCRETE 2013 UNDERSTANDING CONCRETE, 2013, Gold Coast. Proceedings... Gold Coast: Concrete Institute of Australia, 2013.

CAI, J.; BURGESS, I.; PLANK, R. A generalised steel/reinforced concrete beam-column element model for fire conditions. Engineering Structures, v. 25, n. 6, p. 817-833, 2003.

CALDAS, R. B. Análise numérica de estruturas de aço, concreto e mistas em situação de incêndio. 2008. 226 p. Tese (Doutorado) - Escola de Engenharia, Universidade Federal de Minas Gerais, Belo Horizonte, 2008. 
CAPUA, D. D.; MARI, A. R. Nonlinear analysis of reinforced concrete cross-sections exposed to fire. Fire Safety Journal, v. 42, n. 2, p. 139-149, 2007.

CARLSON, C. C.; SELVAGiO, S. L.; GUSTAFERRO, A. H. A review of studies of the effects of restraint on the fire resistance of prestressed concrete. Skokie: Portland Cement Association, 1965. 11 p. (PCA Research Department Bulletin 206).

CARSTENSE, J. V. Material modelling of reinforced concrete at elevated temperatures. 2011. 98 p. Master's Thesis - Technical University of Denmark, Lyngby, 2011.

CARVALHO, J. F. Estudo da fendilhação em lajes restringidas, devida ao efeito conjunto da retração e das ações distribuídas no piso. 2013. 67 p. Dissertação (Mestrado) Faculdade de Engenharia, Universidade do Porto, Porto, 2013.

CASTRO, G. G. S. Um método geral de cálculo para verificação de estruturas de concreto em situação de incêndio. 2005. 97 p. Dissertação (Mestrado) - Escola de Engenharia, Universidade Federal de Minas Gerais, Belo Horizonte, 2005.

CHOI, E. G.; SHIN, Y. S. The structural behavior and simplified thermal analysis of normalstrength and high-strength concrete beams under fire. Engineering Structures, v. 33, n. 4, p. 1123-1132, 2011.

CHOI, E. G.; SHIN, Y. S.; KIM, H. S. Structural damage evaluation of reinforced concrete beams exposed to high temperatures. Journal of Fire Protection Engineering, v. 23, n. 2, p. 135-151, 2013.

CHYTHANYA, M. Finite element analysis on the effect of fire for specified duration, on a reinforced concrete beam with varied boundary conditions. 2009. 77 p. Master's Thesis - FAMU-FSU College of Engineering, Florida State University, Florida, 2008.

COMITÉ EURO-INTERNATIONAL DU BÉTON. CEB-FIP MC 2010: fib Model Code for concrete structures 2010. 2011.653 p.

COMITÉ EURO-INTERNATIONAL DU BÉTON. CEB-FIP MC 1990: Design code. London: Thomas Telford, 1993. 437 p.

COMITÉ EURO-INTERNATIONAL DU BÉTON. Design of concrete structures for fire resistance: preliminary draft of appendix to the CEB-FIP model code. Paris: CEB, 1982.

COMITÉ EUROPEU DE NORMALIZAÇÃO. NP EN 1992-1-2: Eurocódigo 2: projecto de estruturas de betão - parte 1.2: regras gerais - verificação da resistência ao fogo. Bruxelas: CEN, 2010. 109 p.

COMITÉ EUROPEU DE NORMALIZAÇÃO. NP EN 12390-7: Ensaios do betão endurecido - parte 7: massa volúmica do betão endurecido. Bruxelas: CEN, 2003. 12 p. 
CONCRETE REINFORCING STEEL INSTITUTE. Reinforced concrete fire resistance. Chicago: CRSI, 1980. 242 p.

COPE R. J. et al. Modelling of reinforced concrete behaviour for finite element analysis of bridge slabs. In: Numerical methods for nonlinear problems 1. Swansea: Pineridge Press, 1980. p. 457-470.

COSTA, C. N. Dimensionamento de elementos de concreto armado em situação de incêndio. 2008. 724 p. Tese (Doutorado) - Escola Politécnica, Universidade de São Paulo, São Paulo, 2008. 2 v.

CRAMER, F.; OSTERMANN, L.; DINKLER, D. A coupled transport and damage model for concrete at high temperatures. Proceedings in Applied Mathematics and Mechanics, v. 10, n. 1, p. 149-150, 2010.

CRISFIELD, M. A. Accelerated solution techniques and concrete cracking. Computer Methods in Applied Mechanics and Engineering, v. 33, n. 1-3, p. 585-607, 1982.

CVETKOVSKA, M. Nonlinear stress strain behaviour of $\mathbf{R C}$ elements and $\mathbf{R C}$ frames exposed to fire. 2002. PhD Thesis - Faculty of Civil Engineering, Ss. Cyril and Methodius University, Skopje, 2002.

CVETKOVSKA, M.; TODOROV, K.; LAZAROV, L. Axial restraint effects on fire resistance of statically indeterminate RC beams. Journal of Structural Fire Engineering, v. 4, n. 1, p. 47-58, 2013.

D’ÁVILA, V. M. R. Estudo sobre modelos de fissuração de peças de concreto armado via método dos elementos finitos. 2003. 259 p. Tese (Doutorado) - Escola de Engenharia, Universidade Federal do Rio Grande do Sul, Porto Alegre, 2003.

DAVIE, C.; PEARCE, C.; BICANIC, N. A fully generalised, coupled, multi-phase, hygrothermo-mechanical model for concrete. Materials and Structures, v. 43, n. 1, p. 13-33, 2010 .

DEATON, J. B. Nonlinear finite element analysis of reinforced concrete exterior beamcolumn joints with nonseismic detailing. 2013. 315 p. PhD Thesis - School of Civil and Environmental Engineering, Georgia Institute of Technology, Atlanta, 2012.

DIANA FEA. DIANA: finite element analysis. Delft: DIANA FEA BV, 2016b. 4 p.

DIANA FEA. DIANA: solutions for reinforced concrete. Delft: DIANA FEA BV, 2016c. 4 p.

DIANA FEA. DIANA: solutions for structural fire analysis. Delft: DIANA FEA BV, 2016d. $4 \mathrm{p}$. 
DIANA FEA. Nonlinear analysis of RC structures using DIANA. Delft: DIANA FEA BV, 2016e. DIANA Course material.

DIANA FEA. User's manual: release 10.1. Delft: DIANA FEA BV, 2016a. 13 v.

DIAS, W. P. S.; KHOURY, G. A.; SULLIVAN, P. J. E. An activation energy approach for the temperature dependence of basic creep of hardened cement paste. Magazine of Concrete Research, v. 39, n. 140, p. 141-147, 1987.

DIAS, W. P. S.; KHOURY, G. A.; SULLIVAN, P. J. E. The thermal and structural effects of elevated temperatures on the basic creep of hardened cement paste. Materials and Structures, v. 23, p. 418-425, 1990.

DOHERTY, P.; ALI, F.; NADJAI, A. Explosive spalling of concrete columns with steel and polypropylene fibres subjected to severe fire. In: SIF'10 INTERNATIONAL CONFERENCE ON STRUCTURES IN FIRE, 6., 2010, East Lansing. Proceedings... East Lansing: DEStech Publications, 2010. p. 165-172.

DOTREPPE, J. C.; FRANSSEN, J. M. The use of numerical models for the fire analysis of reinforced concrete and composite structures. Engineering Analysis, v. 2, n. 2, p. 67-74, 1985.

DWAIKAT, M. B. Flexural response of reinforced concrete beams exposed to fire. 2009. 369 p. PhD Dissertation - Michigan State University, East Lansing, 2009. 2 v.

DWAIKAT, M. B.; KODUR, V. K. R. A numerical approach for modeling the fire induced restraint effects in reinforced concrete beams. Fire Safety Journal, v. 43, n. 4, p. 291-307, 2008.

DWAIKAT, M. B.; KODUR, V. K. R. Hydrothermal model for predicting fire-induced spalling in concrete structural systems. Fire Safety Journal, v. 44, n. 3, p. 425-434, 2009a.

DWAIKAT, M. B.; KODUR, V. K. R. Response of restrained concrete beams under design fire exposure. Journal of Structural Engineering, v. 135, n. 11, p. 1408-1417, 2009b.

EHM, C. Versuche zur festigkeit und verformung von beton unter zweiaxialer beanspruchung und hohen temperature. 1986. 120 p. Dissertation - Institut für Baustoffe, Massivbau und Brandschutz, Technischen Universität Braunschweig, Braunschweig, 1986.

ELGHAZOULI, A. Y.; CASHELL, K. A.; IZZUDDIN, B. A. Experimental evaluation of the mechanical properties of steel reinforcement at elevated temperature. Fire Safety Journal, v. 44, p. 909-919, 2009. 
ELGHAZOULI, A. Y.; IZZUDDIN, B. A. Analytical assessment of the structural performance of composite floors subject to compartment fires. Fire Safety Journal, v. 36, p. 769-793, 2001.

ELLINGWOOD, B.; LIN, T. D. Flexure and shear behavior of concrete beams during fire. Journal of Structural Engineering, v. 117, n. 2, p. 440-458, 1991.

ERVINE, A. Damaged reinforced concrete structures in fire. 2012. 224 p. PhD Thesis Department of Civil Engineering, University of Edinburgh, Edinburgh, 2012.

EUROPEAN COMMITTEE FOR STANDARDIZATION. EN 1363-1: Fire resistance tests part 1: general requirements. Brussels, 1999. 49 p.

EUROPEAN COMMITTEE FOR STANDARDIZATION. EN 197-1: Cement - part 1: composition, specifications and conformity criteria for common cements. Brussels, 2000. $29 \mathrm{p}$.

EUROPEAN COMMITTEE FOR STANDARDIZATION. EN 1991-1-1: Eurocode 1: actions on structures - part 1.1: general actions - density, self-weight, imposed loads for buildings. Brussels, 2002. 44 p.

EUROPEAN COMMITTEE FOR STANDARDIZATION. EN 1991-1-2: Eurocode 1: actions on structures - part 1.2: general actions - actions on structures exposed to fire. Brussels, 2002. $59 \mathrm{p}$.

EUROPEAN COMMITTEE FOR STANDARDIZATION. EN 1992-1-1: Eurocode 2: design of concrete structures - part 1.1: general rules and rules for buildings. Brussels, 2004. 225 p.

EUROPEAN COMMITTEE FOR STANDARDIZATION. EN 1992-1-2: Eurocode 2: design of concrete structures - part 1.2: general rules - structural fire design. Brussels, 2004. 97 p.

EUROPEAN COMMITTEE FOR STANDARDIZATION. EN 1993-1-1: Eurocode 3: design of steel structures - part 1.1: general rules and rules for buildings. Brussels, 2005. 91 p.

EUROPEAN COMMITTEE FOR STANDARDIZATION. EN 1993-1-2: Eurocode 3: design of steel structures - part 1.2: general rules - structural fire design. Brussels, 2005. 78 p.

EUROPEAN COMMITTEE FOR STANDARDIZATION. EN 1994-1-2: Eurocode 4: design of composite steel and concrete structures - part 1.2: general rules - structural fire design. Brussels, 2005. 109 p.

FARIA, R.; XAVIER, H. F.; VILA REAL, P. Simplified procedure for shear failure assessment of RC framed structures exposed to fire. In: SIF'10 INTERNATIONAL CONFERENCE ON STRUCTURES IN FIRE, 6., 2010, East Lansing. Proceedings... East Lansing: DEStech Publications, 2010. p. 197-205. 
FÉDÉRATION INTERNATIONALE DU BÉTON (FIB). Fire design of concrete structures: materials, structures and modelling. Lausanne: International Federation for Structural Concrete, 2007. 97 p. (Bulletin. fib; 38).

FEENSTRA, P. H. Computational aspects of biaxial stress in plain and reinforced concrete. 1993. 151 p. PhD Thesis - Faculty of Civil Engineering and Geosciences, Delft University of Technology, Delft, 1993.

FEENSTRA, P. H.; BORST, R. Constitutive model for reinforced concrete. Journal of Engineering Mechanics, v. 121, n. 5, p. 587-595, 1995.

FERNANDES, M. C. V. Verificação da resistência ao fogo de estruturas de betão com base nos métodos simplificados do EC2 - parte 1-2. 2008. 102 p. + anexos. Dissertação (Mestrado) - Faculdade de Engenharia, Universidade do Porto, Porto, 2008.

FERREIRA, D. C. S. Identificação e modelação do comportamento de estruturas de betão nas primeiras idades. 2008. 180 p. Dissertação (Mestrado) - Faculdade de Engenharia, Universidade do Porto, Porto, 2008.

FERREIRA, J. P. S. Capacidade resistente de seções de betão armado sujeitas a incêndio. 1989. 43 p. + anexos. Dissertação (Mestrado) - Instituto Superior Técnico, Universidade Técnica de Lisboa, Lisboa, 1989.

FERREIRA, S. G. Ação do incêndio nas estruturas de concreto armado - consequências e recuperação. In: COLÓQUIO SOBRE PATOLOGIA DO CONCRETO E RECUPERAÇÃO DAS ESTRUTURAS, 1978, São Paulo. Anais... São Paulo: IBRACON, 1978. p. 19-39.

FIGUEIREDO JÚNIOR, F. P. Simulação via método dos elementos finitos da distribuição de temperatura em estruturas metálicas e mistas em caso de incêndio. 2002. 116 p. Dissertação (Mestrado) - Escola de Engenharia, Universidade Federal de Minas Gerais, Belo Horizonte, 2002.

FIRE SAFETY DESIGN (FSD). TCD 5.0 User's manual. Lund: Fire Safety Design AB, 2007. 129 p.

FOSTER, S. J. et al. Experimental behaviour of concrete floor slabs at large displacement. Engineering Structures, v. 26, n. 9, p. 1231-1247, 2004.

FRANSSEN, J. M. SAFIR: a thermal/structural program for modeling structures under fire. Engineering Journal, v. 42, n. 3, p. 143-158, 2005.

FRANSSEN, J. M.; KODUR, V. K. R.; MASON, J. Elements of theory for SAFIR 2002: a computer program for analysis of structures submitted to the fire. Liège: Department Mécanique des matériaux \& Structures - Université de Liège, 2002. 34 p. 
FREITAG, J. K. The fireproofing of steel structures. New York: John Wiley \& Sons, 1899. $319 \mathrm{p}$.

FREITAS, P. S. M. B. Avaliação do efeito das deformações auto-induzidas na fissuração de elementos em betão armado. 2012. 66 p. + anexos. Dissertação (Mestrado) - Faculdade de Engenharia, Universidade do Porto, Porto, 2012.

GAMINO, A. L. Modelagem física e computacional de estruturas de concreto reforçadas com CFRP. 2007. 259 p. Tese (Doutorado) - Escola Politécnica, Universidade de São Paulo, São Paulo, 2007.

GAO, W. Y. et al. Finite element modeling of reinforced concrete beams exposed to fire. Engineering Structures, v. 52, p. 488-501, 2013.

GAO, W. Y.; DAI, J. G.; TENG, J. G. Fire resistance of RC beams under design fire exposure. Magazine of Concrete Research, v. 69, n. 8, p. 402-423, 2017.

GAWIN, D.; MAJORANA, C. E.; SCHREFLER, B. A. Numerical analysis of hygro-thermal behaviour and damage of concrete at high temperature. Mechanics of cohesive-frictional materials, v.4, n. 1, p. 37-74, 1999.

GAWIN, D.; PESAVENTO, F.; SCHREFLER, B. A. What physical phenomena can be neglected when modelling concrete at high temperature? A comparative study. Part 1: Physical phenomena and mathematical model. International Journal of Solids and Structures, v.48, n. 13, p. 1927-1944, 2011a.

GAWIN, D.; PESAVENTO, F.; SCHREFLER, B. A. What physical phenomena can be neglected when modelling concrete at high temperature? A comparative study. Part 2: Comparison between models. International Journal of Solids and Structures, v.48, n. 13, p. 1945-1961, 2011b.

GMSH. A three-dimensional finite element mesh generator with built-in pre- and postprocessing facilities. Disponível em: 〈http://www.geuz.org/gmsh/>. Acesso em: 26 jun. 2012.

GONÇALVES, A. B. Simulação do comportamento ao corte de elementos de betão armado em situação de incêndio. 2013. 92 p. + anexos. Dissertação (Mestrado) - Faculdade de Engenharia, Universidade do Porto, Porto, 2013.

GONÇALVES, M. J. C. R. Comportamento ao fogo de elementos estruturais de betão: análise numérica e metodologia. 2007. 791 p. Tese (Doutorado) - Faculdade de Engenharia, Universidade do Porto, Porto, 2007.

GOSSELIN, G. C. Structural fire protection: predictive methods. In: BUILDING SCIENCE INSIGHT - DESIGNING FOR FIRE SAFETY: THE SCIENCE AND ITS APPLICATION TO BUILDING CODES, 87., 1987, Ottawa. Proceedings... Ottawa: IRC/NRCC, 1987. 
GUIMARÃES, N. B. T. Resistência ao fogo de estruturas de betão: modelação numérica dos métodos tabelados e simplificados e aplicação a um projecto. 2010.135 p. Dissertação (Mestrado) - Faculdade de Engenharia, Universidade do Porto, Porto, 2010.

GUO, Z.; SHI, X. Experiment and calculation of reinforced concrete at elevated temperatures. Waltham: Butterworth-Heinemann, 2011. $311 \mathrm{p}$.

GUSTAFERRO, A. H.; LIN, T. D. Rational design of reinforced concrete members for fire resistance. Fire Safety Journal, v. 11, n. 1-2, p. 85-98, 1986.

GUSTAFERRO, A. H.; MARTIN, L. D. PCI design for fire resistance of precast prestressed concrete. Chicago: Prestressed Concrete Institute, 1977. 85 p.

HAGER, I.; KRZEMIEŃ, K. An overview of concrete modulus of elasticity evolution with temperature and comments to European Code provisions. In: INTERNATIONAL FIRE SAFETY SYMPOSIUM - IFireSS, 1., 2015, Coimbra. Proceedings...Coimbra: ALBRASCI, 2015. p. 703-712.

HARMATHY, T. Z. Fire safety design \& concrete. London: Longman Scientific \& Technical, 1993. 412 p. (Concrete Design \& Construction Series).

HERTZ, K. Analyses of prestressed concrete structures exposed to fire. Lyngby: Technical University of Denmark, 1985. 152 p. (Institute of Building Design, Report n. 174).

HERTZ, K. D. Reinforcement data for fire safety design. Magazine of Concrete Research, v. 56, n. 8, p. 453-459, 2004.

HUANG, Z. Modelling the bond between concrete and reinforcing steel in a fire. Engineering Structures, v. 32, n. 11, p. 3660-3669, 2010.

HUANG, Z.; BURGESS, I. W.; PLANK, R. J. A non-linear beam-column element for 3D modelling of general cross-sections in fire. Sheffield: University of Sheffield, 2003. (Research Report n. DCSE/03/F/1).

HUANG, Z.; PLATTEN, A.; ROBERTS, J. Non-linear finite element model to predict temperature histories within reinforced concrete in fires. Building and Environment, v. 31, n. 2, p. 109-118, 1996.

HUISMANN, S.; KORZEN, M.; SCHNEIDER, U. A material model for the numerical simulation of high strength concrete columns subjected to fire loading. In: SIF'10 INTERNATIONAL CONFERENCE ON STRUCTURES IN FIRE, 6., 2010, East Lansing. Proceedings... East Lansing: DEStech Publications, 2010. p. 312-319. 
IDING, R.; BRESLER, B.; NIZAMUDDIN, Z. FIRES-RC II: a computer program for the fire response of structures-reinforced concrete frames. Berkeley: University of California, 1977. (Report n. UCG FRG 77-8).

INSTITUTO DE ENGENHARIA DE SÃO PAULO. Laudo pericial do incêndio do edifício Joelma. São Paulo, 1974.

INTERNATIONAL ORGANIZATION FOR STANDARDIZATION. ISO 6892-1: Metallic materials: tensile testing - part 1: method of test at room temperature. Geneva, 2009.65 p.

INTERNATIONAL ORGANIZATION FOR STANDARDIZATION. ISO 834-1: Fireresistance tests: elements of building construction - part 1: general requirements for fire resistance testing. Geneva, 1999. 25 p. (Revision of first edition ISO 834:1975).

INTERNATIONAL ORGANIZATION FOR STANDARDIZATION. ISO 834-6: Fireresistance tests: elements of building construction - part 6: specific requirements for beams. Geneva, 2000. 14 p.

JACEY, G. H. Numerical simulation of RC slabs strengthened with pre-stressed CFRP laminates. 2016. 77 p. Master's Thesis - School of Engineering, University of Minho, Guimarães, 2016.

JOHNSON, S. Comparison of nonlinear finite element modeling tools for structural concrete. 2006. 56 p. College of Engineering, University of Illinois, Urbana-Champaign, 2006. (CEE561 Project).

KANG, S. W.; HONG, S. G. Analytical method for the behaviour of a reinforced concrete flexural member at elevated temperatures. Fire and Materials, v. 28, n. 2-4, p. 227-235, 2004.

KATAOKA, L. T. Análise da deformabilidade por fluência e retração e sua utilização na monitoração de pilares de concreto. 2010. 228 p. Tese (Doutorado) - Escola Politécnica, Universidade de São Paulo, São Paulo, 2010.

KHOURY, G. A. Effect of fire on concrete and concrete structures. Progress in Structural Engineering and Materials, v. 2, n. 4, p. 429-447, 2000.

KIRCHHOF, L. D. Estudo teórico-experimental da influência do teor de umidade no fenômeno de spalling explosivo em concretos expostos a elevadas temperaturas. 2010. 237 p. Tese (Doutorado) - Escola de Engenharia, Universidade Federal do Rio Grande do Sul, Porto Alegre, 2010.

KODUR, V. K. R. Properties of concrete at elevated temperatures. ISRN Civil Engineering, v. 2014, p. 1-15, 2014. 
KODUR, V. K. R.; AGRAWAL, A. Effect of temperature induced bond degradation on fire response of reinforced concrete beams. Engineering Structures, v. 110, p. 98-109, 2017.

KODUR, V. K. R.; DWAIKAT, M. B. A numerical model for predicting the fire resistance of reinforced concrete beams. Cement \& Concrete Composites, v. 30, n. 5, p. 431-443, 2008a.

KODUR, V. K. R.; DWAIKAT, M. B. Flexural response of reinforced concrete beams exposed to fire. Structural Concrete, v. 9, n. 1, p. 45-54, $2008 \mathrm{~b}$.

KODUR, V. K. R.; HARMATHY, T. Z. Properties of building materials. In: SFPE Handbook of fire protection engineering. Quincy: National Fire Protection Association, 2002. p. 1-155-1-181.

KODUR, V. K. R.; PAKALA, P. Energy based time equivalent approach for evaluating fire resistance under design fire exposures. In: STRUCTURES CONGRESS, 2010, Orlando. Proceedings... Orlando: ASCE, 2010. p. 1287-1298.

KODUR, V. K. R.; WANG, T. C.; CHENG, F. P. Predicting the fire resistance behaviour of high strength concrete columns. Cement \& Concrete Composites, v. 26, n. 2, p. 141-153, 2004.

KOWALSKI, R. The use of Eurocode model of reinforcing steel behavior at high temperature for calculation of bars elongation in RC elements. Procedia Engineering, v. 193, p. 27-34, 2017.

KOWALSKI, R.; KISIELIŃSKI, R. On mechanical properties of reinforcing steel in RC beams subjected to high temperature. Architecture Civil Engineering Environment, n. 2, p. 49-56, 2011.

KUKLA, K. Concrete at high temperatures: hygro-thermo-mechanical degradation of concrete. 2010. 184 p. PhD Thesis - Faculty of Engineering, University of Glasgow, Glasgow, 2010 .

LAÍM, L. M. S. Experimental and numerical analysis on the structural behaviour of cold-formed steel beams subjected to fire. 2013. 165 p. + appendices. PhD Thesis - Faculty of Sciences and Technology, University of Coimbra, Coimbra, 2013.

LAÍM, L. M. S.; RODRIGUES, J. P. C. The effect of axial and rotational restraints on the performance of cold-formed steel beams subjected to fire. In: SIF'12 INTERNATIONAL CONFERENCE ON STRUCTURES IN FIRE, 8., 2014, Shanghai. Proceedings... Shanghai: Tongji University, 2014.

LIAO, F.; HUANG, Z. An extended finite element model for modelling localised fracture of reinforced concrete beams in fire. Computers \& Structures, v. 152, p. 11-26, 2015. 
LILLIU, G.; MEDA, A. Nonlinear phased analysis of reinforced concrete tunnels under fire exposure. Journal of Structural Fire Engineering, v. 3, n. 4, p. 131-142, 2013.

LIN, T. D.; ELLINGWOOD, B.; PIET, O. Flexural and shear behavior of reinforced concrete beams during fire tests. Skokie: Portland Cement Association, 1988. $81 \mathrm{p}$. (Research and Development Bulletin RD091T).

LIN, T. D.; GUSTAFERRO, A. H.; ABRAMS, M. S. Fire endurance of continuous reinforced concrete beams. Skokie: Portland Cement Association, 1981. 23 p. (Research and Development Bulletin RD072.01B).

LIU, L. Fire performance of high strength concrete materials and structural concrete. 2009. 229 p. PhD Thesis - Faculty of the College of Engineering and Computer Science, Florida Atlantic University, Boca Raton, 2009.

LOMBA, N. C. F. Resistência residual de vigas de betão armado após incêndio. 2011. 116 p. Dissertação (Mestrado), Universidade de Aveiro, Aveiro, 2011.

LU, L. et al. A simplified multi-iteration method for restrained beams under fire. Materials and Structures, v. 48, n. 1-2, p. 9-19, 2015 b.

LU, L. et al. Influencing factors for fire performance of simply supported RC beams with implicit and explicit transient creep strain material models. Fire Safety Journal, v. 73, p. 2936, $2015 \mathrm{a}$.

MARECHAL, J. C. Variations in the modulus of elasticity and Poisson's ratio with temperature. ACI Journal, v. 34, p. 495-504, 1972.

MARGARIDO, A. F. Ação do fogo sobre as estruturas de concreto. In: SIMPÓSIO NACIONAL DE ARQUITETURA E PROTEÇÃO CONTRA INCÊNDIOS, 1987, São Paulo. Anais... São Paulo: EPUSP, 1987. p. 147-167.

MARTHA, L. F. Ftool: um programa gráfico-interativo para ensino de comportamento de estruturas - versão educacional 2.11. Rio de Janeiro: Tecgraf/PUC-Rio, 2002. 33 p.

MARTIN, M. Nonlinear FE analysis of shear behaviour in reinforced concrete: modelling of shear panel tests. 2007. 223 p. Master's Thesis - Department of Civil and Environmental Engineering, Chalmers University of Technology, Göteborg, 2007.

MAULUDIN, L. M. Numerical modeling of reinforced concrete beams repaired with polymer modified mortar. 2009. 94 p. Master's Thesis, University of Padova, Padova, 2009.

MENIN, R. C. G.; TRAUTWEIN, L. M.; BITTENCOURT, T. N. Modelos de fissuração distribuída em vigas de concreto armado pelo método dos elementos finitos. Revista Ibracon de Estruturas e Materiais, v. 2, n. 2, p. 166-200, 2009. 
MIRAVAL, D. O. Análise não-linear de temperaturas para verificação da resistência de estruturas de concreto armado em situação de incêndio. 2009. 119 p. Dissertação (Mestrado) - Centro Tecnológico, Universidade Federal de Espírito Santo, Vitória, 2009.

MOES, N.; DOLBOW, J.; BELYTSCHKO, T. A finite element method for crack growth without remeshing. International Journal for Numerical Methods in Engineering, v. 46, n.1, p. 131-150, 1999.

MOLINARI, G. Efeitos de um incêndio da estrutura em concreto armado de um grande edifício, em construção. Separata da Revista Politécnica, São Paulo, n. 231, outubro 1949.

MOLTUBAKK, $\varnothing$. T. Nonlinear analysis of fibre reinforced concrete beams: Influence of fibre orientation and density. 2014. 121 p. Master's Thesis - Faculty of Engineering Science and Technology, Norwegian University of Science and Technology, Trondheim, 2014.

MORENO JUNIOR, A. L.; MOLINA, J. C. Considerações de interesse sobre a avaliação em laboratório de elementos estruturais em situação de incêndio: contribuições à revisão da NBR 5628:2001. Ambiente Construído, Porto Alegre, v. 12, n. 4, p. 37-53, 2012.

MÖRSCH, E. Teoría y práctica del hormigón armado. Barcelona: Editorial Gustavo Gili S. A., 1948. 476 p. Tomo 1. (Tradução COMPANY, M.).

NETO, C. P. S. Modelagem da fratura do concreto armado por meio de interfaces coesivas. 2015. 107 p. Dissertação (Mestrado) - Escola de Engenharia, Universidade Federal do Rio Grande do Sul, Porto Alegre, 2015.

OLIVEIRA, D. S. Análise do comportamento estrutural de blocos de concreto armado sobre cinco e seis estacas. 2013. 234 p. Dissertação (Mestrado) - Escola de Engenharia de São Carlos, Universidade de São Paulo, São Carlos, 2013.

OPENDX. The open source software projected based on ibm's visualization data explorer. Disponível em: <http://www.opendx.org/>. Acesso em: 26 jun. 2012.

PACHECO, T. M.; LIMA, J. M. F.; LIMA, P. R. L. Influência do modelo de fissuração na modelagem em elementos finitos de vigas de concreto armado. Ciência \& Engenharia, v. 22, n. 2, p. 57-63, 2013.

PALACIO, K. Advances on the design of thin surface structures in reinforced concrete. 2007. PhD Thesis - School of Engineering, University of Minho, Guimarães, 2007.

PALACIO, K. Practical recommendations for nonlinear structural analysis in DIANA. Delft: TNO DIANA BV, 2013. 8 p. 
PETRUCCI, E. G. R. A ação do fogo sobre as estruturas de concreto armado e protendido. In: COLÓQUIO SOBRE DURABILIDADE DO CONCRETO, 1972, São Paulo. Anais... São Paulo: IBRACON, 1972. p. 201 - 229.

PIERIN, I.; SILVA, V. P.; LA ROVERE, H. L. Análise térmica de estruturas bidimensionais em situação de incêndio. Revista Ibracon de Estruturas e Materiais, v. 8, n. 1, p. 25-48, 2015.

PIMENTEL, M. J. S. Modelação e análise de estruturas laminares de betão: possibilidades e desafios. 2004. 234 p. Dissertação (Mestrado) - Faculdade de Engenharia, Universidade do Porto, Porto, 2004.

PLANINC, I.; SAJE, M.; CAS, B. On the local stability condition in the planar beam finite element. Structural Engineering and Mechanics, v.12, n. 5, p. 507-526, 2001.

POH, K. W.; BENNETTS, I. D. Analysis of structural members under elevated temperature conditions. Journal of Structural Engineering, v. 121, n. 4, p. 664-675, 1995.

PORTAL, N. W. et al. Numerical modelling of textile reinforced concrete. In: INTERNATIONAL CONFERENCE ON FRACTURE MECHANICS OF CONCRETE AND CONCRETE STRUCTURES - FraMCoS, 8., 2013, Toledo. Proceedings... Toledo, 2013. p.1-12.

PURKISS, J. A.; LI, L. Y. Fire safety engineering design of structures. Boca Raton: Taylor \& Francis Group, 2014. 412 p.

QAPO, M.; DIRAR, S.; JEMAA, Y. Finite element parametric study of reinforced concrete beams shear-strengthened with embedded FRP bars. Composite Structures, v. 149, p. 93$105,2016$.

RABCZUK, T.; AKKERMANN, J.; EIBL, J. A numerical model for reinforced concrete structures. International Journal of Solids and Structures, v. 42, p. 1327-1354, 2005.

RAFI, M. M. Fire performance of FRP reinforced concrete beams. Saarbrücken: LAMBERT Academic Publishing, 2010. 287 p.

RAFI, M. M.; NADJAI, A.; ALI, F. Analytical modeling of concrete beams reinforced with carbon FRP bars. Journal of Composite Materials, v. 41, n. 22, p. 2675-2690, 2007.

RAFI, M. M.; NADJAI, A.; ALI, F. Finite element modeling of carbon fiber-reinforced polymer reinforced concrete beams under elevated temperatures. ACI Structural Journal, v. 38, n. 3, p. 701-710, 2008.

RASHID, Y. R. Ultimate strength analysis prestressed concrete pressure vessels. Nuclear Engineering and Design, v. 7, n. 4, p. 334-344, 1968. 
REDDY, D. V. et al. Size effect on fire resistance of structural concrete. Engineering Structures, v. 99, p. 468-478, 2015.

REISSNER, E. On one-dimensional finite-strain beam theory: the plane problem. Journal of Applied Mathematics and Physics (ZAMP), v. 23, n. 5, p. 795-804, 1972.

RIBEIRO, J. C. L. Simulação via método dos elementos finitos da distribuição tridimensional de temperatura em estruturas em situação de incêndio. 2004. 178 p. Dissertação (Mestrado) - Escola de Engenharia, Universidade Federal de Minas Gerais, Belo Horizonte, 2004.

RIGBERTH, J. Simplified design of fire exposed concrete beams and columns: an evaluation of Eurocode and Swedish building code against advanced computer models. Lund: Lund University, 2000. 88 p. (Report n. 5063).

RIVA, P.; FRANSSEN, J. M. Non-linear and plastic analysis of RC beams subjected to fire. Structural Concrete, v. 9, n. 1, p. 31-43, 2008.

ROTS, J. G. Computational modeling of concrete fracture. 1988. $132 \mathrm{p}$. PhD Thesis Faculty of Civil Engineering and Geosciences, Delft University of Technology, Delft, 1988.

SAMPAIO, C. D. C. Comparação entre a modelagem numérica e experimental da deformação por fluência em vigas de concreto armado. 2004. 146 p. Dissertação (Mestrado) - Escola Politécnica, Universidade de São Paulo, São Paulo, 2004.

SCHEIBMEIR, E. Nonlinear seismic analysis of a masonry arch bridge. 2012. 76 p. + annexes. Master's Thesis, Universitat Politècnica de Catalunya, Barcelona, 2012.

SCHWEIZERHOF, K. Consistent concept for line search algorithms in combination with arclength constraints. International Journal for Numerical Methods in Biomedical Engineering, v. 9, n. 9, p. 773-784, 1993.

SCILAB. Free open source software for numerical computation. Disponível em: <http://www.scilab.org/>. Acesso em: 26 jun. 2012.

SEISMOSOFT. SeismoStruct: a computer program for static and dynamic nonlinear analysis of framed structures - Version 5.2.2. 2011. Disponível em: 〈http://www.seismosoft.com>.

SELDEN, K. L.; VARMA, A. H. Composite beams under fire loading: numerical modeling of behavior. Journal of Structural Fire Engineering, v. 7, n. 2, p. 142-157, 2016.

SHI, X. et al. Influence of concrete cover on fire resistance of reinforced concrete flexural members. Journal of Structural Engineering, v. 130, n. 8, p. 1225-1232, 2004. 
SILVA, P. A. S. C. M. Comportamento de estruturas de betão reforçadas por colagem exterior de sistemas de CFRP. 2008. 556 p. Tese (Doutorado) - Faculdade de Engenharia, Universidade do Porto, Porto, 2008.

SILVA, V. P. Dimensionamento de vigas de concreto armado em situação de incêndio: aprimoramento de algumas recomendações do Eurocode. Revista Ibracon de Estruturas e Materiais, v. 4, n. 2, p. 277-303, 2011.

SILVA, V. P. Estruturas de aço em situação de incêndio. São Paulo: Zigurate, 2004. 249 p.

SILVA, V. P. Projeto de estruturas de concreto em situação de incêndio. São Paulo: Edgard Blücher, 2012. 237 p.

SILVA, V. P. Segurança das estruturas em situação de incêndio: uma visão da América Latina. Revista FLAMMAE, v. 1, p. 180-185, 2015.

SMITH, H. K. M. et al. Shear strength of concrete at elevated temperature. In: INTERNATIONAL CONFERENCE ON APPLICATIONS OF STRUCTURAL FIRE ENGINEERING, 2011, Prague. Proceedings... Prague: Czech Technical University, 2011. p.133-138.

SOARES, D. F. Análise da resistência ao fogo de vigas de betão com um método simplificado de cálculo. 2008. 49 p. + anexos. Dissertação (Mestrado) - Faculdade de Engenharia, Universidade do Porto, Porto, 2008.

SOARES, E. M. P. Verificação de peças usuais de concreto armado em situação de incêndio. 2003. 152 p. Dissertação (Mestrado) - Escola de Engenharia, Universidade Federal de Minas Gerais, Belo Horizonte, 2003.

SOUZA, R. A. Concreto estrutural: análise e dimensionamento de elementos com descontinuidades. 2004. 379 p. Tese (Doutorado) - Escola Politécnica, Universidade de São Paulo, São Paulo, 2004.

TAO, J. et al. Transient strain of self-compacting concrete loaded in compression heated to $700{ }^{\circ}$ C. Materials and Structures, v. 46, n. 1-2, p. 191-201, 2012.

TAO, J.; YUAN, Y.; TAERWE, L. Compressive strength of self-compacting concrete during high-temperature exposure. Journal of Materials in Civil Engineering, v. 2, n. 10, p. 10051011, 2010.

TAO, J.; YUAN, Y.; TAERWE, L. Thermal stress-strain of self-compacting concrete in compression. Fire and Materials, v. 37, n. 3, p. 187-199, 2013.

TASSIOS, T. P.; CHRONOPOULOS, M. P. Structural response of RC elements under fire. The Structural Engineer, v. 69, n. 15, p. 277-281, 1991. 
TOPÇU, I. B.; KARAKURT, C. Properties of reinforced concrete steel rebars exposed to high temperatures. Research Letters in Materials Science, v. 2008, p. 1-4, 2008.

TQS INFORMÁTICA. Dominando os sistemas CAD/TQS ${ }^{\circledR}$ : visão geral e exemplo completo. São Paulo, 2012. 447 p.

TRAUTWEIN, L. M. Punção em lajes cogumelo de concreto armado: análise experimental e numérica. 2006. 350 p. Tese (Doutorado) - Escola Politécnica, Universidade de São Paulo, São Paulo, 2006.

TRUNK, B.; WITTMANN, F. H. Experimental investigation into the size dependence of fracture mechanics parameters. In: INTERNATIONAL CONFERENCE OF FRACTURE MECHANICS OF CONCRETE STRUCTURES, 3., 1998, Gifu. Proceedings...Freiburg: Aedificatio Publishers, 1998. p. 1937-1948.

USMANI, A. S. et al. Fundamental principles of structural behaviour under thermal effects. Fire Safety Journal, v. 36, n. 8, p. 721-744, 2001.

VECCHIO, F. J.; COLLINS, M. P. The modified compression-field theory for reinforced concrete elements subjected to shear. ACI Journal, v. 83, n. 22, p. 219-231, 1986.

VILA REAL, P. J. M. M. F. Modelação por elementos finitos do comportamento térmico e termo-elástico de sólidos sujeitos a elevados gradientes térmicos. 1988. 174 p. Dissertação (Mestrado) - Faculdade de Engenharia, Universidade do Porto, Porto, 1988.

WANG, Y. C.; WONG, P. M. H.; KODUR, V. K. R. Mechanical properties of fibre reinforced polymer reinforcing bars at elevated temperatures. In: SFPE/ASCE SPECIALTY CONFERENCE: DESIGNING STRUCTURES FOR FIRE, 1., 2003, Baltimore. Proceedings... Baltimore: SFPE/ASCE, 2003. p. 183-192.

WHIRLEY, R. G.; ENGELMANN, B. E. DYNA3D: a non-linear, explicit, three-dimensional finite element code for solid and structural mechanics - User Manual. California: Lawrence Livermore National Laboratory, 1993. 354 p.

WILLIAMS-LEIR, G. Creep of structural steel in fire: analytical expressions. Fire and Materials, v. 7, n. 2, p. 73-78, 1983.

WITTMANN, F. H. Crack formation and fracture energy of normal and high strength concrete. Sadhana, v. 27, n. 4, p. 413-423, 2002.

WU, B.; LU, J. Z. A numerical study of the behaviour of restrained RC beams at elevated temperatures. Fire Safety Journal, v. 44, n. 4, p. 522-531, 2009. 
XAVIER, H. F. B. Analysis of reinforced concrete frames exposed to fire: based on advanced calculation methods. 2009. 140 p. Master's Thesis - Faculty of Engineering, University of Porto, Porto, 2009.

YANG, Y. Shear behaviour of reinforced concrete members without shear reinforcement: a new look at an old problem. 2014. 344 p. PhD Thesis - Faculty of Civil Engineering and Geosciences, Delft University of Technology, Delft, 2014.

YIN, Y.Z.; WANG, Y.C. A numerical study of large deflection behaviour of restrained steel beams at elevated temperatures. Journal of Constructional Steel Research, v. 60, n. 7, p. 1029-1047, 2004.

YU, J. T.; TAN, K. Special detailing techniques to improve structural resistance against progressive collapse. Journal of Structural Engineering, v. 140, n. 3, p. 233-250, 2014.

YU, J.; TAN, K. Structural behavior of RC beam-column subassemblages under a middle column removal scenario. Journal of Structural Engineering, v. 139, n. 2, p. 233-250, 2013.

ZHA, X. X. Three-dimensional non-linear analysis of reinforced concrete members in fire. Building and Environment, v. 38, n. 2, p. 297-307, 2003.

ZHANG, B.; BICANIC, N. Fracture energy of high-performance concrete at high temperatures up to $450{ }^{\circ} \mathrm{C}$ : the effects of heating temperatures and testing conditions (hot and cold). Magazine of Concrete Research, v. 58, n. 5, p. 277-288, 2006. 



\section{APÊNDICE A - PROJeTO de ELEMENTOS DO SISTEMA DE RESTRIÇÃO}

As vigas de aço adotadas para a simulação dos dois níveis de restrições axiais foram projetadas e solicitadas especialmente para os ensaios da campanha experimental desta Tese e, sendo assim, foram levados em consideração alguns cuidados adicionais quanto ao projeto das mesmas. Solicitou-se, por exemplo, que elas deveriam ser produzidas com aço S355, maior classe de resistência disponível na empresa que tratou da produção de tais perfis, e, além disso, que deveriam ser adicionados enrijecedores ao longo dos seus vãos.

Admitiu-se que essas seriam adaptações importantes por meio de um estudo prévio, no qual se verificaram as forças máximas que poderiam ser aplicadas nessas vigas auxiliares, conforme as prescrições do Eurocode 3 parte 1-1 (2005). Nas Figuras A.1 e A.2, apresentamse os projetos das vigas para os níveis de restrições axiais iguais a 7 e $14 \mathrm{kN} / \mathrm{mm}$, respectivamente. As localizações dos enrijecedores e dos furos nas faces inferiores e superiores foram estabelecidas de modo que não estivessem na região dos apoios, onde essas vigas seriam posteriormente parafusadas.

As chapas de aço e demais itens que compuseram o sistema de complementos das vigas de concreto armado, utilizado nos ensaios de vigas com restrições, foram estudados e projetados de forma que atendessem às dimensões determinadas para tais amostras. Esse sistema de complementos havia sido projetado anteriormente por Laím (2013), no entanto, pelo fato das vigas de concreto da presente pesquisa possuírem tamanhos maiores do que aquelas analisadas pelo autor, foi possível utilizar apenas alguns dos itens que já constituíam esse sistema e estavam presentes no LEME-UC. 
Na Figura A.3 são apresentadas as peças que foram solicitadas em uma metalúrgica para compor os complementos. Como pode ser observado, além das chapas de aço principais, que foram soldadas para formar o conjunto no qual as vigas de concreto deveriam ser encaixadas, também havia as chapas de aperto, que eram introduzidas nesse conjunto com o intuito de proteger a viga de concreto. Uma vez que eram adotados parafusos com porcas bem apertadas para que tal conjunto ficasse devidamente fixo à viga de concreto, essas chapas de aperto ou auxiliares eram colocadas junto às faces laterais e face superior dessa viga, de modo a impedir que ela fosse danificada.

As dimensões das chapas principais foram calculadas levando em consideração a altura e a largura das vigas de concreto, a presença das chapas de aperto e, além disso, pequenas folgas que deveriam facilitar o encaixe desses elementos. As demais peças e itens que formavam esses complementos e não estão detalhadas na figura em questão, foram aquelas que puderam ser reaproveitadas, citando, por exemplo, o perfil que conduzia esse conjunto soldado à viga que simulava a restrição axial "infinita".

A Figura A.4 apresenta o conjunto soldado que fazia parte dos complementos dispostos junto ao apoio simples (lado esquerdo), no qual foram simuladas as restrições axiais parciais de 7 ou $14 \mathrm{kN} / \mathrm{mm}$. Além das chapas de aço principais, chapas de aperto, porcas e parafusos, também foram solicitadas barras roscadas, utilizadas para conectar esse conjunto aos demais elementos do sistema, tal como o próximo conjunto apresentado na Figura A.5. Por fim, na Figura A.6, ilustram-se as chapas de aço para a montagem dos sistemas de pino, dispostos nos dois lados dos complementos. Todas as peças foram produzidas com aço S275 JR, haja vista que o material com essa classe de resistência se apresentou adequado em análises prévias. 
Perfil HEA 120 (S 355)

Vista frontal
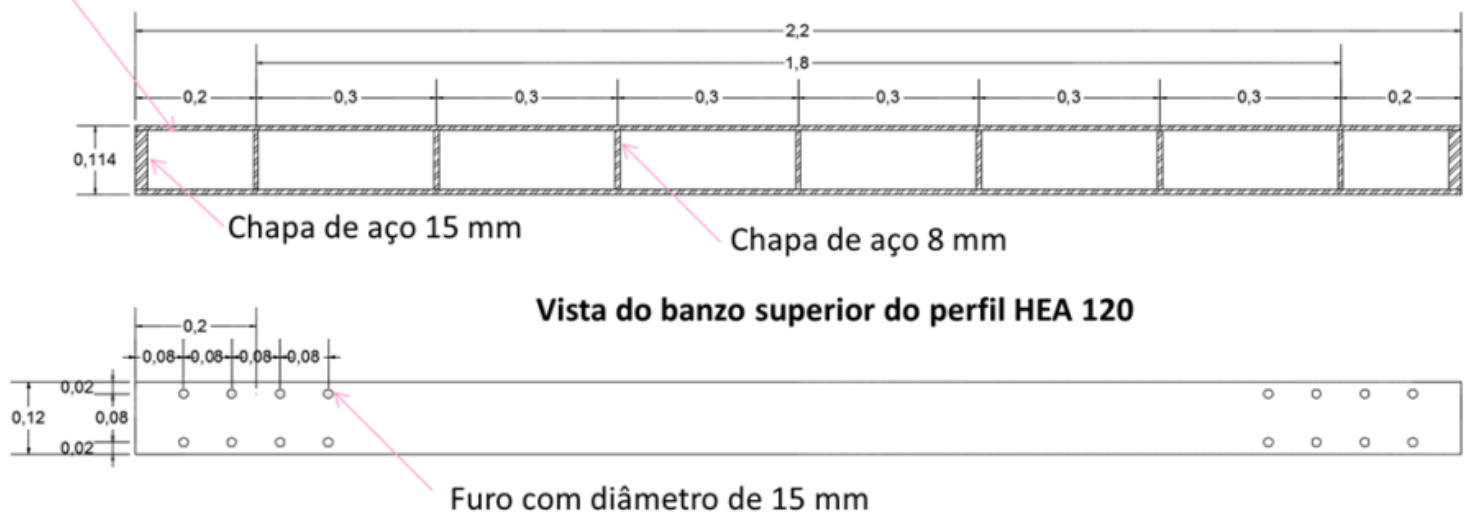

Detalhe da seção do perfil HEA 120

Dimensões da viga em metros.

Perfil HEA 120

Chapas de aço $8 \mathrm{~mm}$

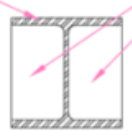

Figura A.1 - Projeto de viga de aço auxiliar para simulação de rigidez axial de 7 kN/mm.

Perfil HEA 140 (S 355)

Vista frontal

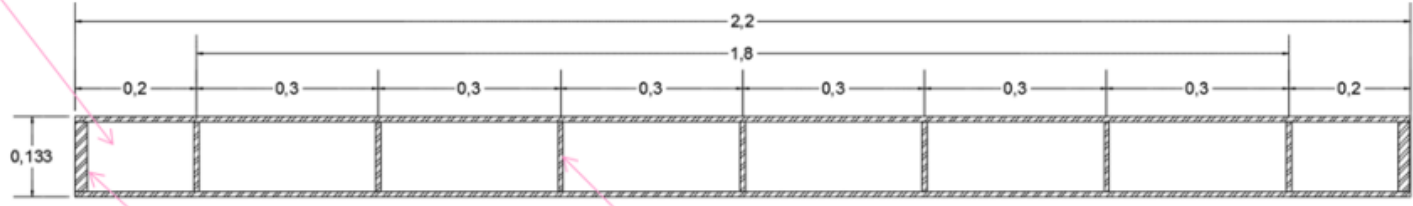

Chapa de aço $15 \mathrm{~mm}$

Chapa de aço $8 \mathrm{~mm}$

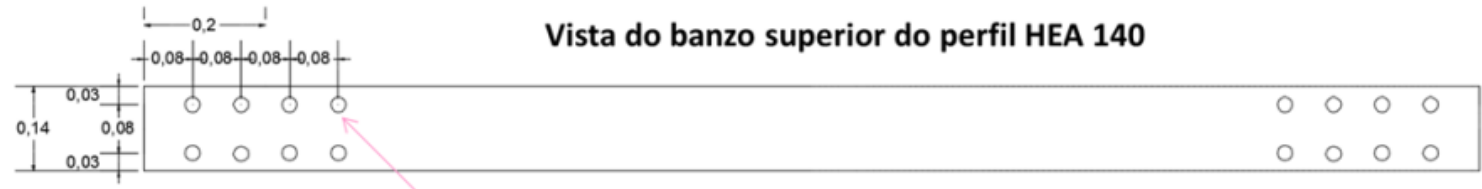

Furo com diâmetro de 26 mm

Detalhe da seção do perfil HEA 140

Dimensões da viga em metros.

Perfil HEA 140

Chapas de aço $8 \mathrm{~mm}$

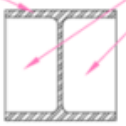

Figura A.2 - Projeto de viga de aço auxiliar para simulação de rigidez axial de 14 kN/mm. 


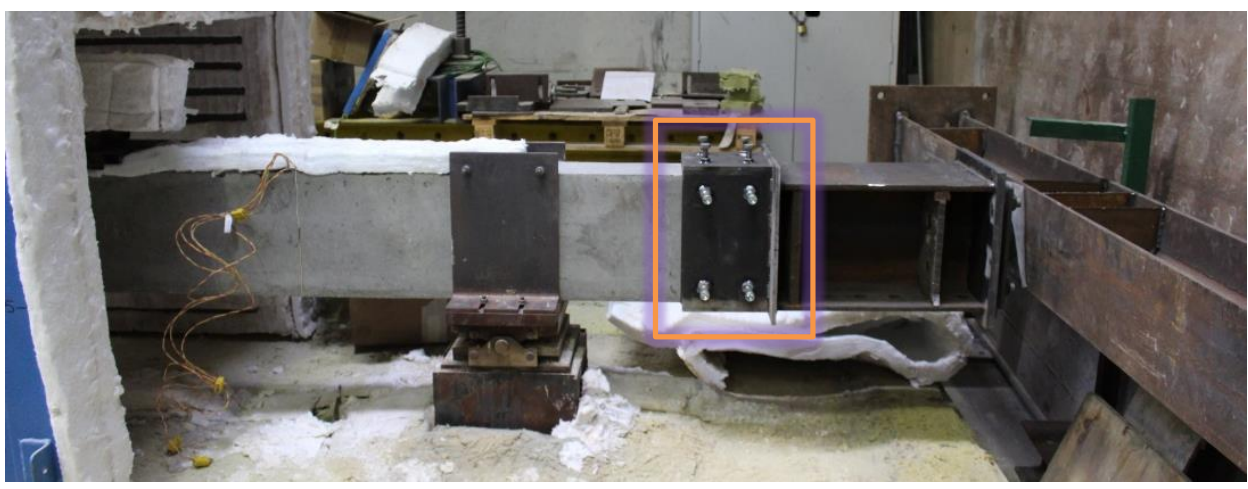

\begin{tabular}{|c|c|c|c|c|c|c|c|}
\hline \multicolumn{8}{|c|}{ Peças para sistema de complementos (lado direito - restrição axial "infinita") } \\
\hline \multirow{2}{*}{$\begin{array}{c}\text { Número da } \\
\text { peça }\end{array}$} & \multirow{2}{*}{ Designação } & \multicolumn{3}{|c|}{ Dimensões [mm] } & \multirow{2}{*}{ Quantidade } & \multirow{2}{*}{ Material } & \multirow{2}{*}{ Observações } \\
\hline & & Altura & Largura & Espessura & & & \\
\hline 1 & Chapa principal & 200 & 210 & 10 & 2 & S275JR & Ilustrada nos desenhos. \\
\hline 2 & Chapa principal & 360 & 340 & 10 & 1 & S275JR & Ilustrada nos desenhos. \\
\hline 3 & Chapa principal & 320 & 200 & 10 & 2 & S275JR & Ilustrada nos desenhos. \\
\hline 4 & Chapa de aperto & 290 & 200 & 10 & 2 & S275JR & Não ilustrada. Chapa individual, lisa, sem furos. \\
\hline 5 & Chapa de aperto & 200 & 185 & 10 & 1 & S275JR & Não ilustrada. Chapa individual, lisa, sem furos. \\
\hline 6 & Chapa principal & 360 & 340 & 20 & 1 & S275JR & Não ilustrada. Chapa individual, lisa, sem furos. \\
\hline
\end{tabular}

\begin{tabular}{|l|c|}
\hline \multicolumn{2}{|c|}{ Demais itens } \\
\hline Parafuso M14 Classe 8.8 + Porca & 12 unidades \\
\hline Parafuso M24 Classe 8.8 + Porca & 4 unidades \\
\hline
\end{tabular}
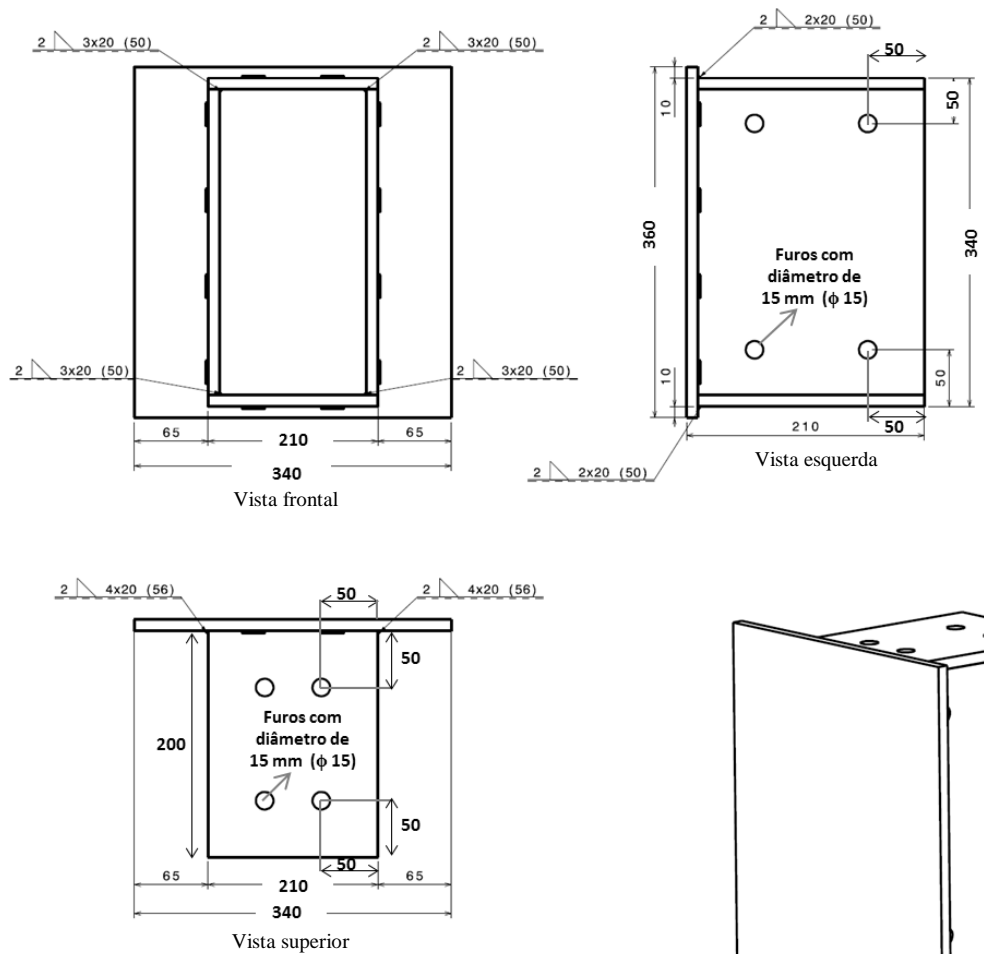

Observações:

Desenhos com dimensões em milimetros.

Todas as chapas devem ser soldadas por fora.
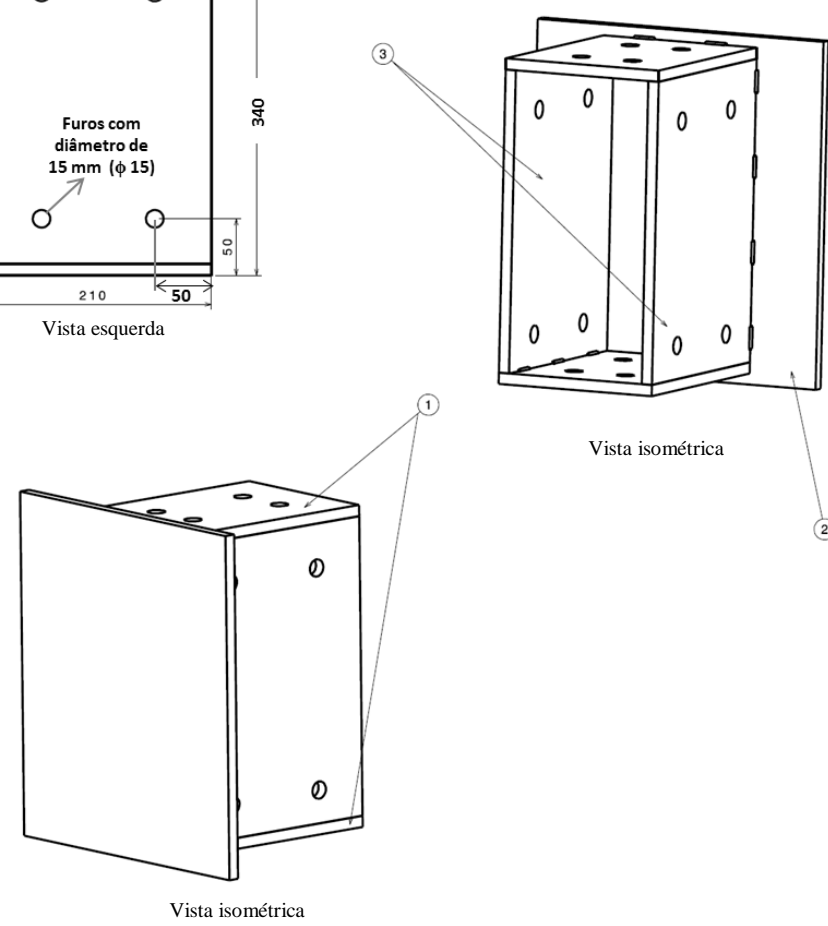

Vista isométrica

Figura A.3 - Conjunto de chapas de aço, parafusos e porcas para composição do sistema de complementos do lado direito da viga de ensaio (junto ao apoio duplo), no qual foi simulada restrição axial "infinita". 


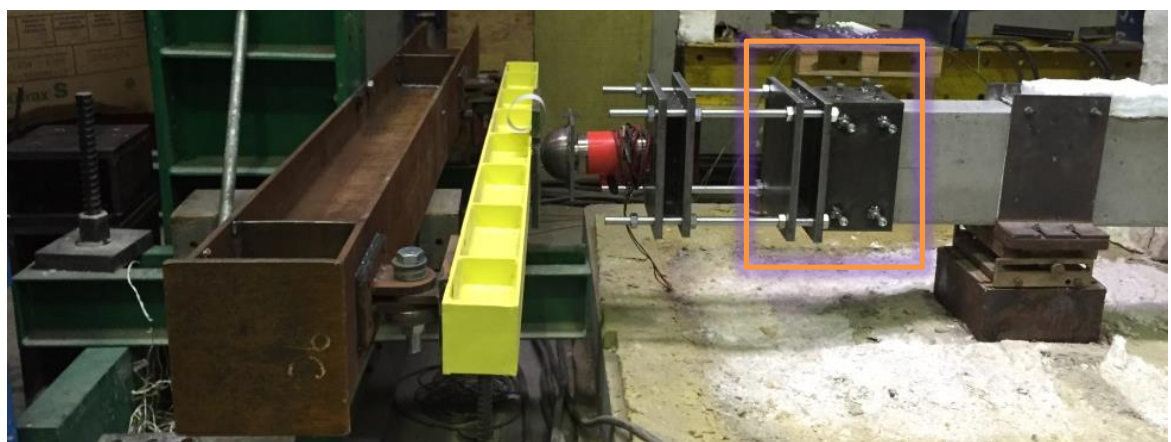

\begin{tabular}{|c|c|c|c|c|c|c|c|}
\hline \multicolumn{8}{|c|}{ Peças para sistema de complementos (lado esquerdo- restrição axial parcial) } \\
\cline { 3 - 7 } Número da peça & \multirow{2}{*}{ Designação } & Altura & Largura & Espessura & Quantidade & Material & Observações \\
\hline 1 & Chapa principal & 200 & 210 & 10 & 2 & S275JR & Ilustrada nos desenhos. \\
\hline 2 & Chapa principal & 360 & 340 & 20 & 2 & S275JR & Ilustrada nos desenhos. \\
\hline 3 & Chapa principal & 210 & 50 & 20 & 2 & S275JR & Ilustrada nos desenhos. \\
\hline 4 & Chapa principal & 320 & 200 & 10 & 2 & S275JR & Ilustrada nos desenhos. \\
\hline 5 & Chapa de aperto & 290 & 200 & 10 & 2 & S275JR & Não ilustrada. Chapa individual, lisa, sem furos. \\
\hline 6 & Chapa de aperto & 200 & 185 & 10 & 1 & S275JR & Não ilustrada. Chapa individual, lisa, sem furos. \\
\hline
\end{tabular}

\begin{tabular}{|l|c|}
\hline \multicolumn{2}{|c|}{ Demais itens } \\
\hline Parafuso M14 Classe 8.8 + Porca & 12 unidades \\
\hline Barra roscada circular com diâmetro $24 \mathrm{~mm}(\phi 24)$ e comprimento de $1 \mathrm{~m}$ & 4 unidades \\
\hline Porca para varão roscado circular com diâmetro $24 \mathrm{~mm}$ & 16 unidades \\
\hline
\end{tabular}
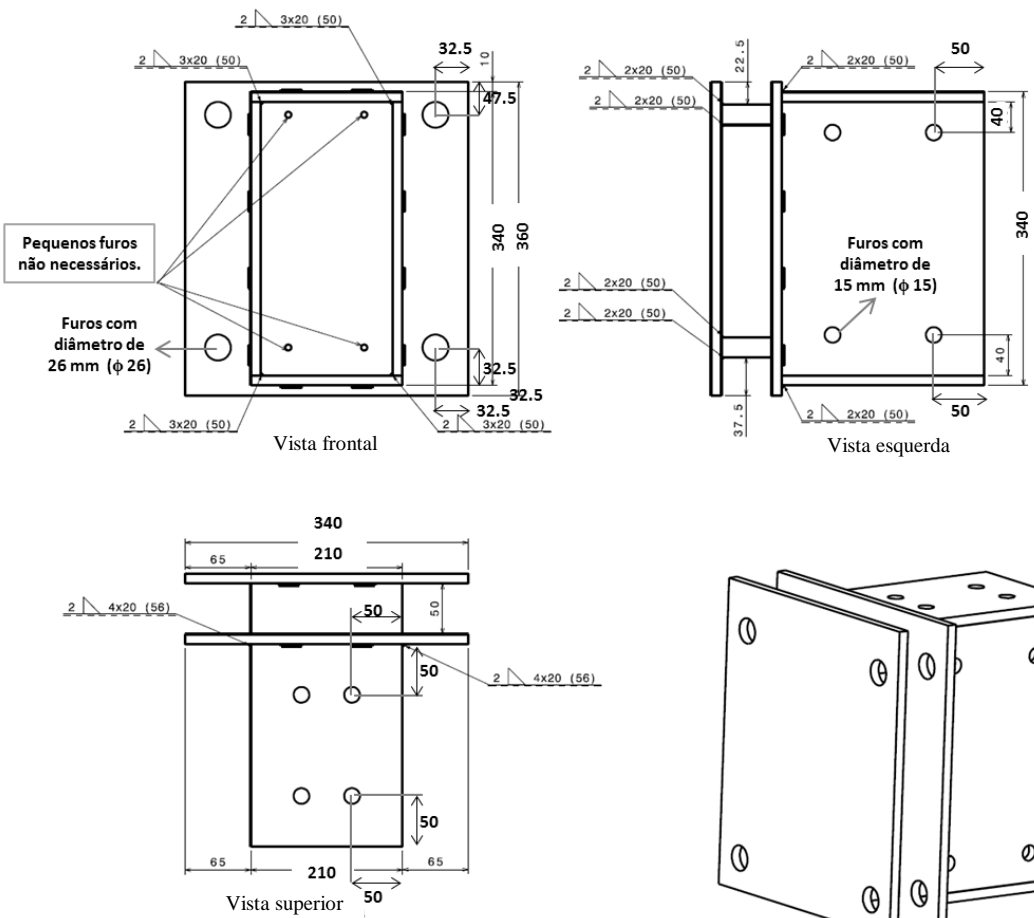

Observações:

Desenhos com dimensões em milimetros.

Todas as chapas devem ser soldadas por fora.
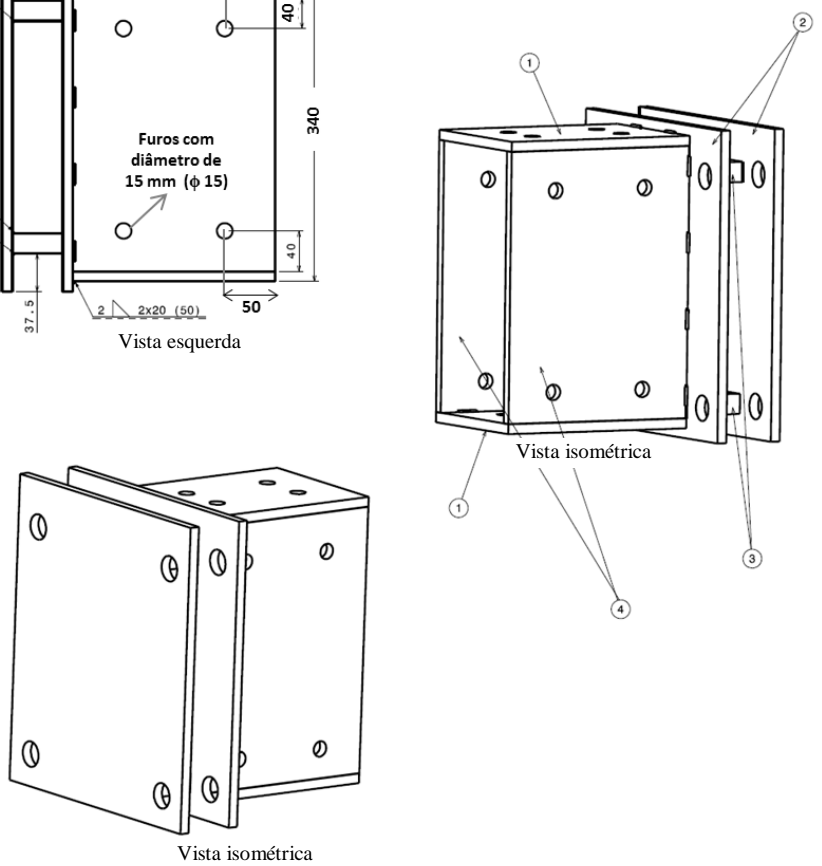

Figura A.4 - Primeiro conjunto de chapas de aço, parafusos, porcas e barras roscadas para composição do sistema de complementos do lado esquerdo da viga de ensaio (junto ao apoio simples), onde foram simuladas rigidezes axiais parciais de 7 ou $14 \mathrm{kN} / \mathrm{mm}$. 


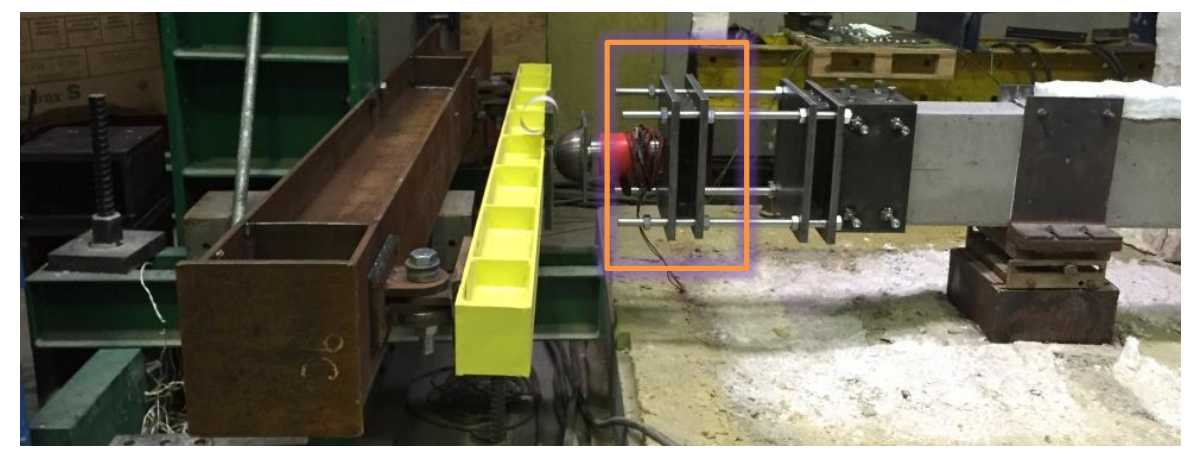

\begin{tabular}{|c|c|c|c|c|c|c|c|}
\hline \multicolumn{8}{|c|}{ Peças para sistema de complementos (lado esquerdo- restrição axial parcial) } \\
\cline { 3 - 7 } Número da peça & \multirow{2}{*}{ Designação } & \multicolumn{3}{|c|}{ Dimensões [mm] } & \multirow{2}{*}{ Quantidade } & \multirow{2}{*}{ Material } & \multirow{2}{*}{ Observações } \\
\cline { 3 - 7 } & Altura & Largura & Espessura & & & \\
\hline 2 & Chapa principal & 360 & 340 & 20 & 2 & S275JR & Ilustrada nos desenhos. \\
\hline 3 & Chapa principal & 260 & 50 & 10 & 1 & S275JR & Ilustrada nos desenhos. \\
\hline 4 & Chapa principal & 210 & 50 & 20 & 2 & S275JR & Ilustrada nos desenhos. \\
\hline
\end{tabular}

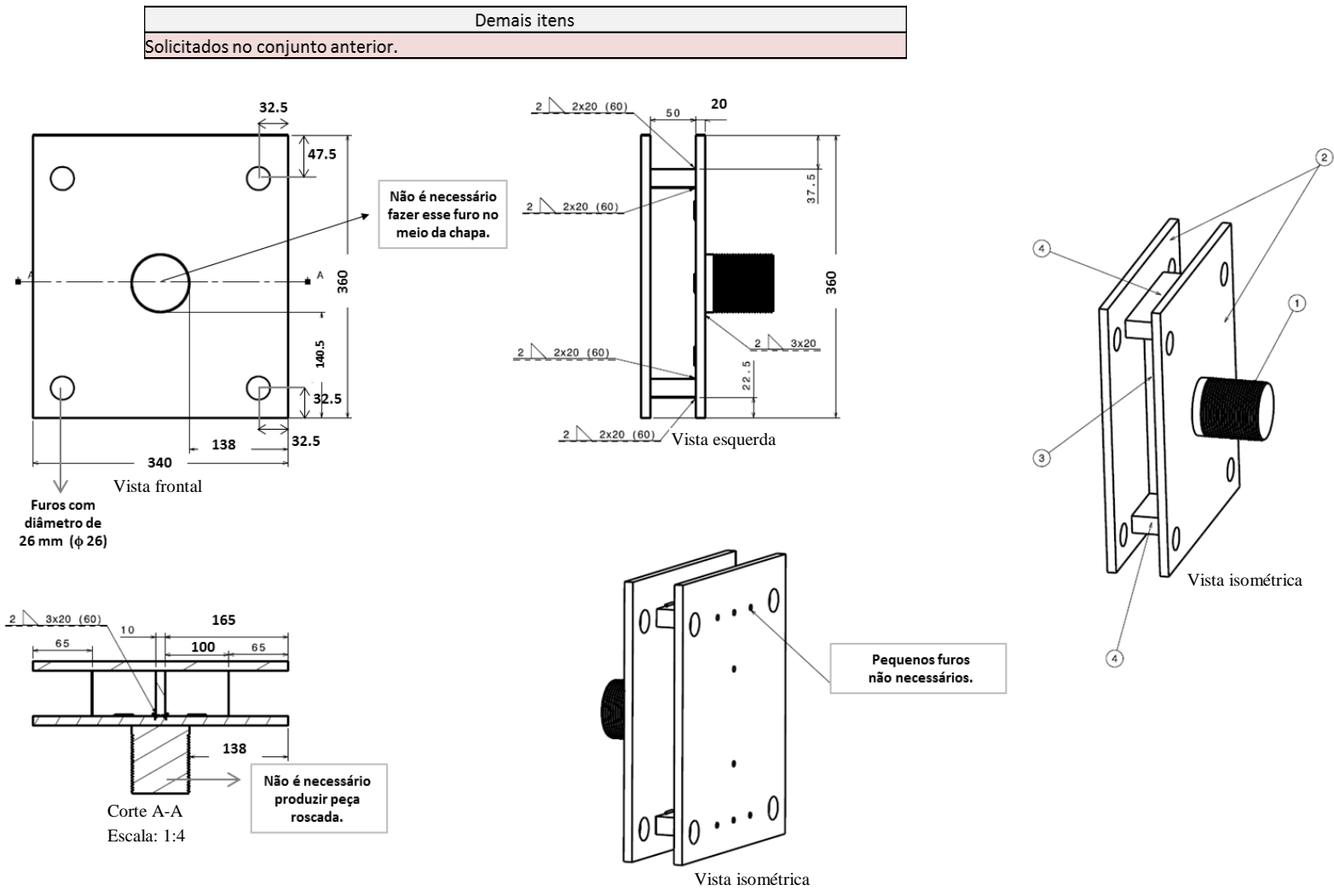

Observações:

Desenhos com dimensões em milimetros.

Todas as chapas devem ser soldadas por fora.

Figura A.5 - Segundo conjunto de chapas de aço, parafusos, porcas e barras roscadas para composição do sistema de complementos do lado esquerdo da viga de ensaio (junto ao apoio simples), onde foram simuladas rigidezes axiais parciais de 7 ou $14 \mathrm{kN} / \mathrm{mm}$. 
Análise numérico-experimental de vigas de concreto armado com restrições axial e rotacional em situação de incêndio
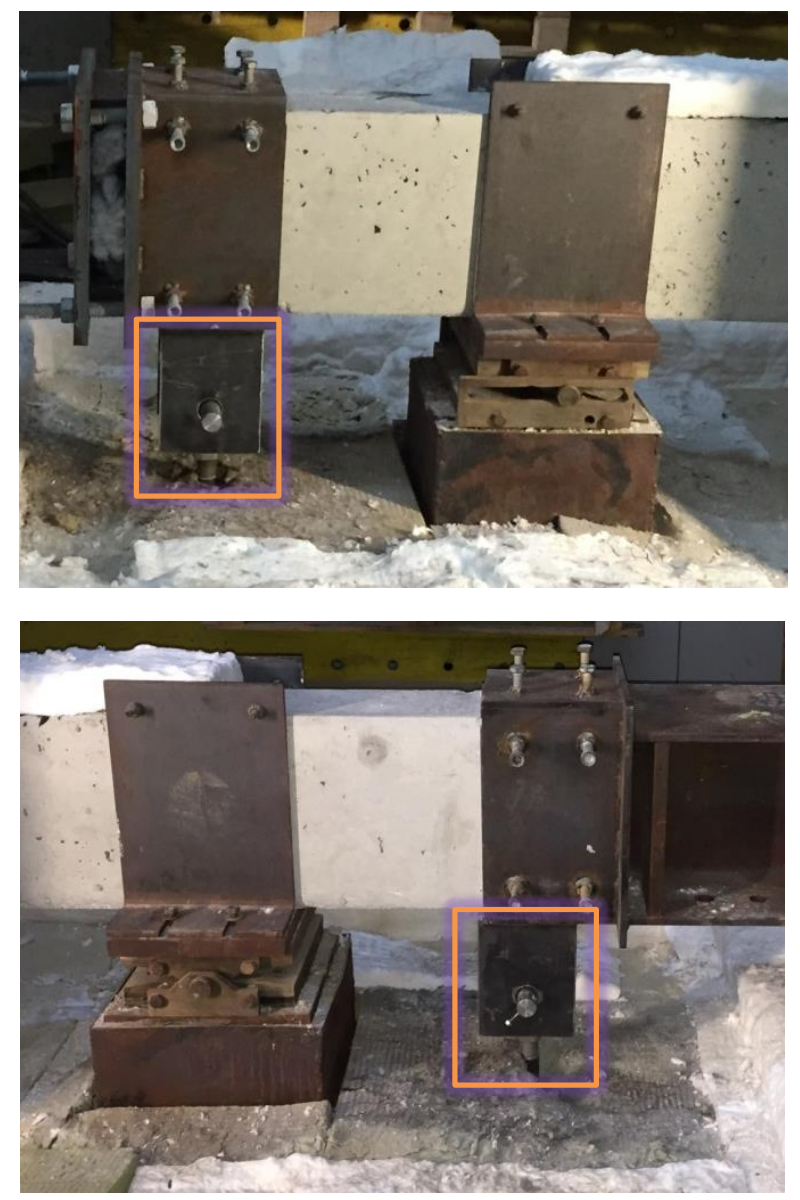

\begin{tabular}{|c|c|c|c|c|c|c|c|}
\hline \multicolumn{7}{|c|}{ Peças para sistemas de pino dos complementos (dois lados) } \\
\cline { 3 - 8 } Número da peça & \multirow{2}{*}{ Designação } & Altura & Largura & Espessura & Quantidade & Material & \multirow{2}{*}{ Observações } \\
\hline 1 & Chapa principal & 200 & 150 & 20 & 8 & S275JR & Ilustrada nos desenhos. \\
\hline
\end{tabular}

\begin{tabular}{|l|l|}
\hline \multicolumn{3}{|c|}{ Demais itens } \\
\hline Barra lisa circular com diâmetro $30 \mathrm{~mm}(\phi 30)$ e comprimento de $30 \mathrm{~cm}$ & 4 unidades \\
\hline
\end{tabular}

Figura A.6 - Chapas de aço para os sistemas de pino dos complementos, dispostas nos dois lados. 



\section{APÊNDICE B - ESQUEMAS DOS SISTEMAS DE ENSAIOS}

Nas Figuras B.1 a B.4 são apresentados esquemas gerais com a indicação dos principais elementos que constituíam os sistemas de ensaios abordados ao longo do Capítulo 3 Análises Experimentais. A numeração adotada para designar os elementos segue a que foi indicada no referido capítulo. Nessas figuras ainda estão representados pelo $\mathrm{n}^{\circ} 48$ os elementos de fixação/apoio do pórtico de reação e pelo $n^{\circ} 49$ os apoios da viga de aço que simulava a rigidez axial "infinita". A primeira vista apresentada nas Figuras B.1 a B.3 é sempre a mais completa, com a ilustração da maioria dos elementos que faziam parte do sistema de ensaios mais complexo, o de vigas de concreto armado submetidas a restrições axiais e rotacionais em incêndio. Nas demais vistas, alguns elementos são excluídos, progressivamente, para melhor visualização.

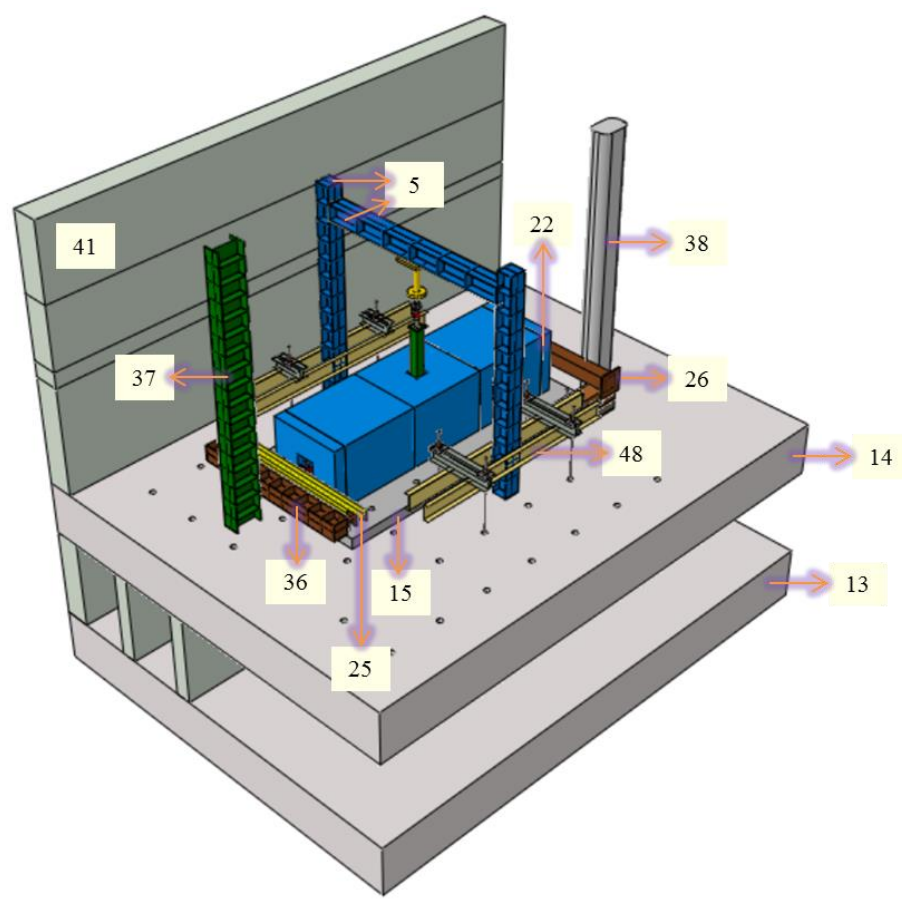

Legenda: 5. Pórtico de reação; 13. Piso inferior do LEME; 14. Piso superior do LEME; 15. Laje de ensaios; 22. Forno horizontal modular elétrico; 25. Viga de restrição para simulação de rigidez axial parcial; 26. Viga de restrição para simulação de rigidez axial "infinita"; 36. Viga de conexão entre a viga de simulação de rigidez axial parcial e o pórtico de apoio ao sistema; 37. Pilar do pórtico de apoio ao sistema de restrição axial disposto na extremidade próxima ao apoio simples; 38. Pilar de apoio ao sistema de restrição axial disposto na extremidade próxima ao apoio duplo; 41. Parede do LEME; 48. Elementos de fixação/apoio do pórtico de reação.

Figura B.1 - Esquemas com vistas isométricas do sistema para ensaios de vigas com restrições axiais e rotacionais em situação de incêndio (LAÍM, 2013; adaptado) (continua). 


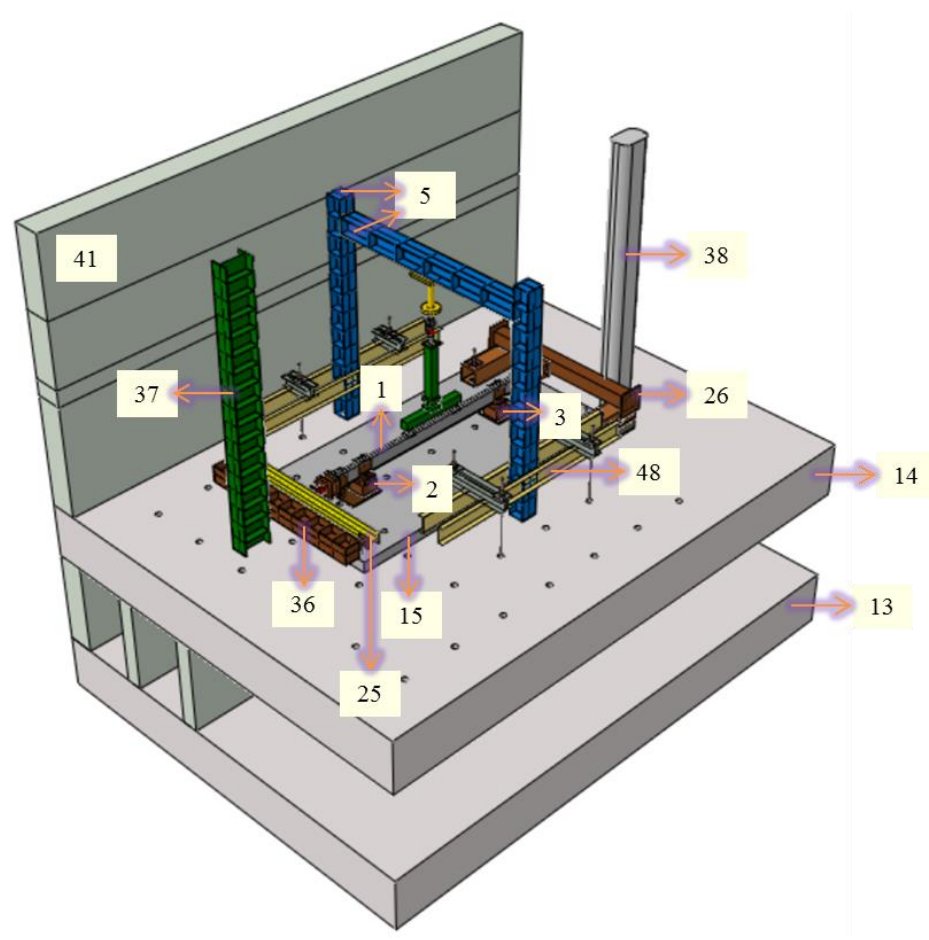

Legenda: 1. Viga de concreto ensaiada; 2. Apoio simples; 3. Apoio duplo; 4. Macaco hidráulico; 5. Pórtico de reação; 6. Sistema de redistribuição de forças; 9. Célula de carga para medição das forças aplicadas à viga de concreto; 13. Piso inferior do LEME; 14. Piso superior do LEME; 15. Laje de ensaios; 25. Viga de restrição para simulação de rigidez axial parcial; 26. Viga de restrição para simulação de rigidez axial "infinita"; 36. Viga de conexão entre a viga de simulação de rigidez axial parcial e o pórtico de apoio ao sistema; 37. Pilar do pórtico de apoio ao sistema de restrição axial disposto na extremidade próxima ao apoio simples; 38. Pilar de apoio ao sistema de restrição axial disposto na extremidade próxima ao apoio duplo; 40. Viga de restrição para simulação de rigidez rotacional; 41. Parede do LEME; 42. Cantoneira de suporte à viga de simulação de rigidez rotacional; 48. Elementos de fixação/apoio do pórtico de reação; 49. Apoios da viga de aço de simulação de rigidez axial "infinita".

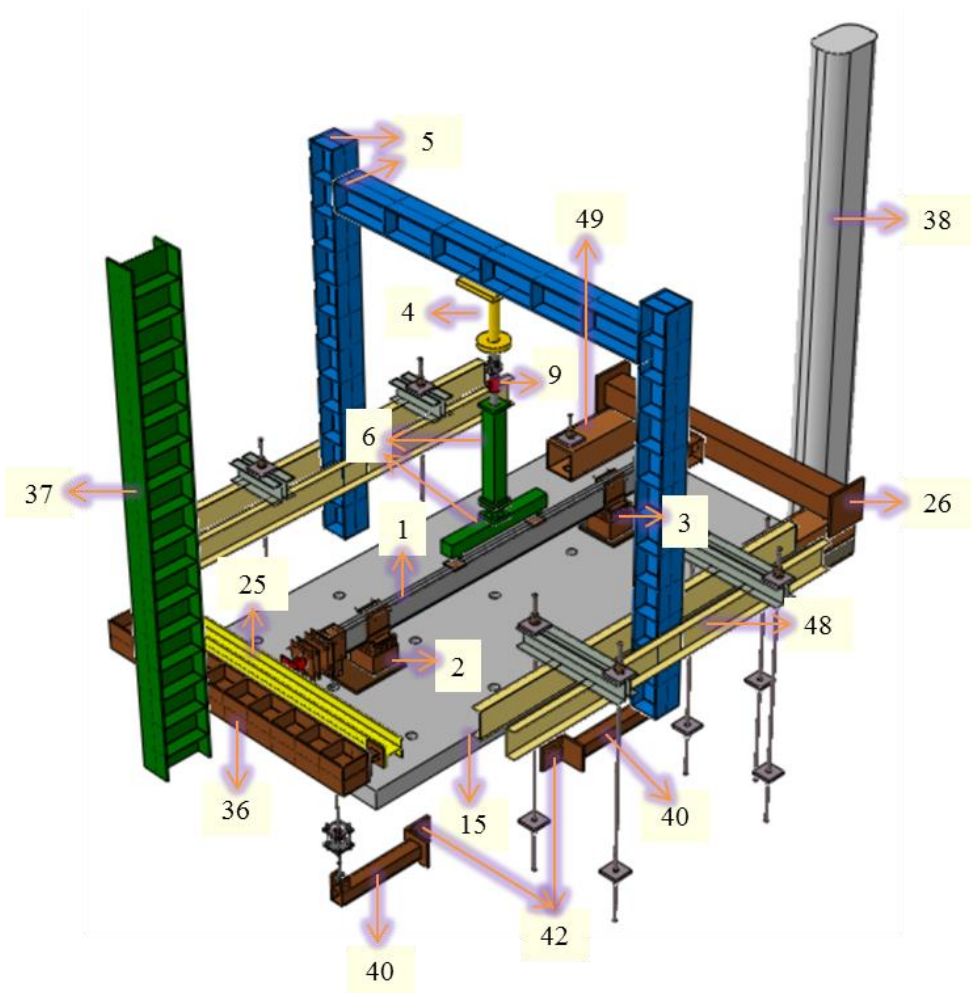

Figura B.1 - Esquemas com vistas isométricas do sistema para ensaios de vigas com restrições axiais e rotacionais em situação de incêndio (LAÍM, 2013; adaptado) (continua). 


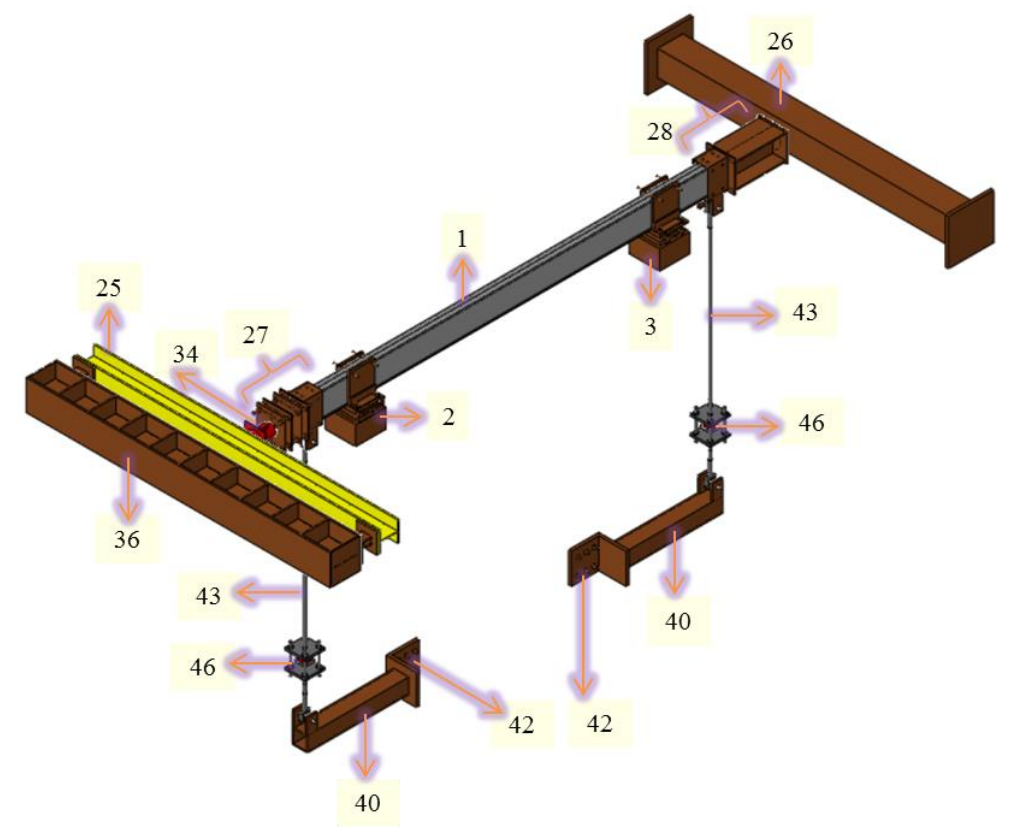

Legenda: 1. Viga de concreto ensaiada; 2. Apoio simples; 3. Apoio duplo; 25. Viga de restrição para simulação de rigidez axial parcial; 26. Viga de restrição para simulação de rigidez axial "infinita"; 27 e 28. Complementos da viga de concreto posicionados nas extremidades próximas aos apoios simples e duplo, respectivamente; 34. Célula de carga para medição das forças de restrição axial; 36. Viga de conexão entre a viga de simulação de rigidez axial parcial e o pórtico de apoio ao sistema; 40. Viga de restrição para simulação de rigidez rotacional; 42. Cantoneira de suporte à viga de simulação de rigidez rotacional; 43. Barra lisa de aço para conexão da viga de concreto armado ao sistema de restrição rotacional; 46. Célula de carga para medição das forças de restrição geradas na barra lisa de aço.

Figura B.1 - Esquemas com vistas isométricas do sistema para ensaios de vigas com restrições axiais e rotacionais em situação de incêndio (LAÍM, 2013; adaptado) (conclusão).

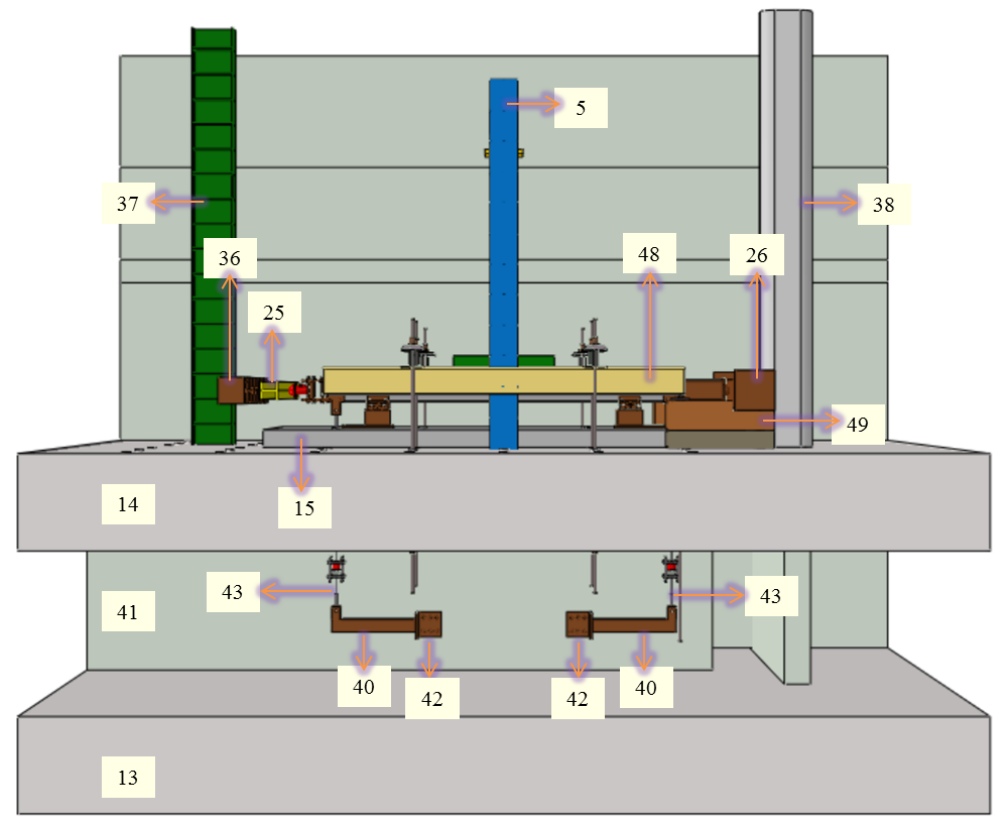

Legenda: 5. Pórtico de reação; 13. Piso inferior do LEME; 14. Piso superior do LEME; 15. Laje de ensaios; 25. Viga de restrição para simulação de rigidez axial parcial; 26. Viga de restrição para simulação de rigidez axial "infinita"; 36. Viga de conexão entre a viga de simulação de rigidez axial parcial e o pórtico de apoio ao sistema; 37. Pilar do pórtico de apoio ao sistema de restrição axial da extremidade do apoio simples; 38. Pilar de apoio ao sistema de restrição axial da extremidade do apoio duplo; 40. Viga de restrição para simulação de rigidez rotacional; 41. Parede do LEME; 42. Cantoneira de suporte à viga de rigidez rotacional; 43. Barra lisa de aço para conexão da viga de concreto armado ao sistema de restrição rotacional; 48. Elementos de fixação/apoio do pórtico de reação; 49. Apoios da viga de aço de simulação de rigidez axial "infinita".

Figura B.2 - Esquemas com vistas frontais do sistema para ensaios de vigas com restrições axiais e rotacionais em situação de incêndio (LAÍM, 2013; adaptado) (continua). 

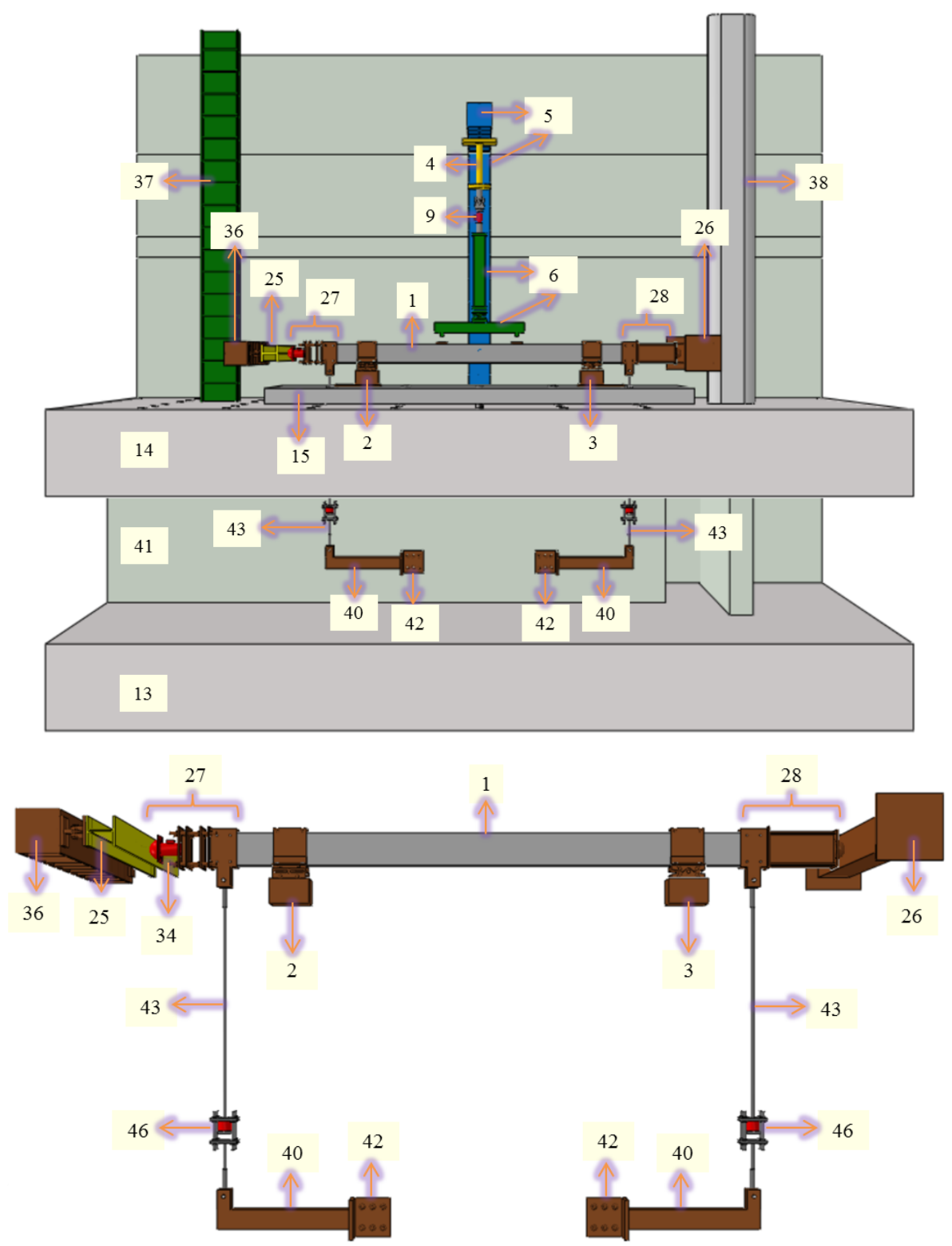

Legenda: 1. Viga de concreto ensaiada; 2. Apoio simples; 3. Apoio duplo; 4. Macaco hidráulico; 5. Pórtico de reação; 6. Sistema de redistribuição de forças; 9. Célula de carga para medição das forças aplicadas à viga de concreto; 13. Piso inferior do LEME; 14. Piso superior do LEME; 15. Laje de ensaios; 25. Viga de restrição para simulação de rigidez axial parcial; 26. Viga de restrição para simulação de rigidez axial "infinita"; 27 e 28. Complementos da viga de concreto posicionados nas extremidades próximas aos apoios simples e duplo, respectivamente; 34. Célula de carga para medição das forças de restrição axial; 36. Viga de conexão entre a viga de simulação de rigidez axial parcial e o pórtico de apoio ao sistema; 37. Pilar do pórtico de apoio ao sistema de restrição axial da extremidade do apoio simples; 38. Pilar de apoio ao sistema de restrição axial da extremidade do apoio duplo; 40. Viga de restrição para simulação de rigidez rotacional; 41. Parede do LEME; 42. Cantoneira de suporte à viga de rigidez rotacional; 43. Barra lisa de aço para conexão da viga de concreto armado ao sistema de restrição rotacional; 46. Célula de carga para medição das forças de restrição geradas na barra lisa de aço.

Figura B.2 - Esquemas com vistas frontais do sistema para ensaios de vigas com restrições axiais e rotacionais em situação de incêndio (LAÍM, 2013; adaptado) (conclusão). 

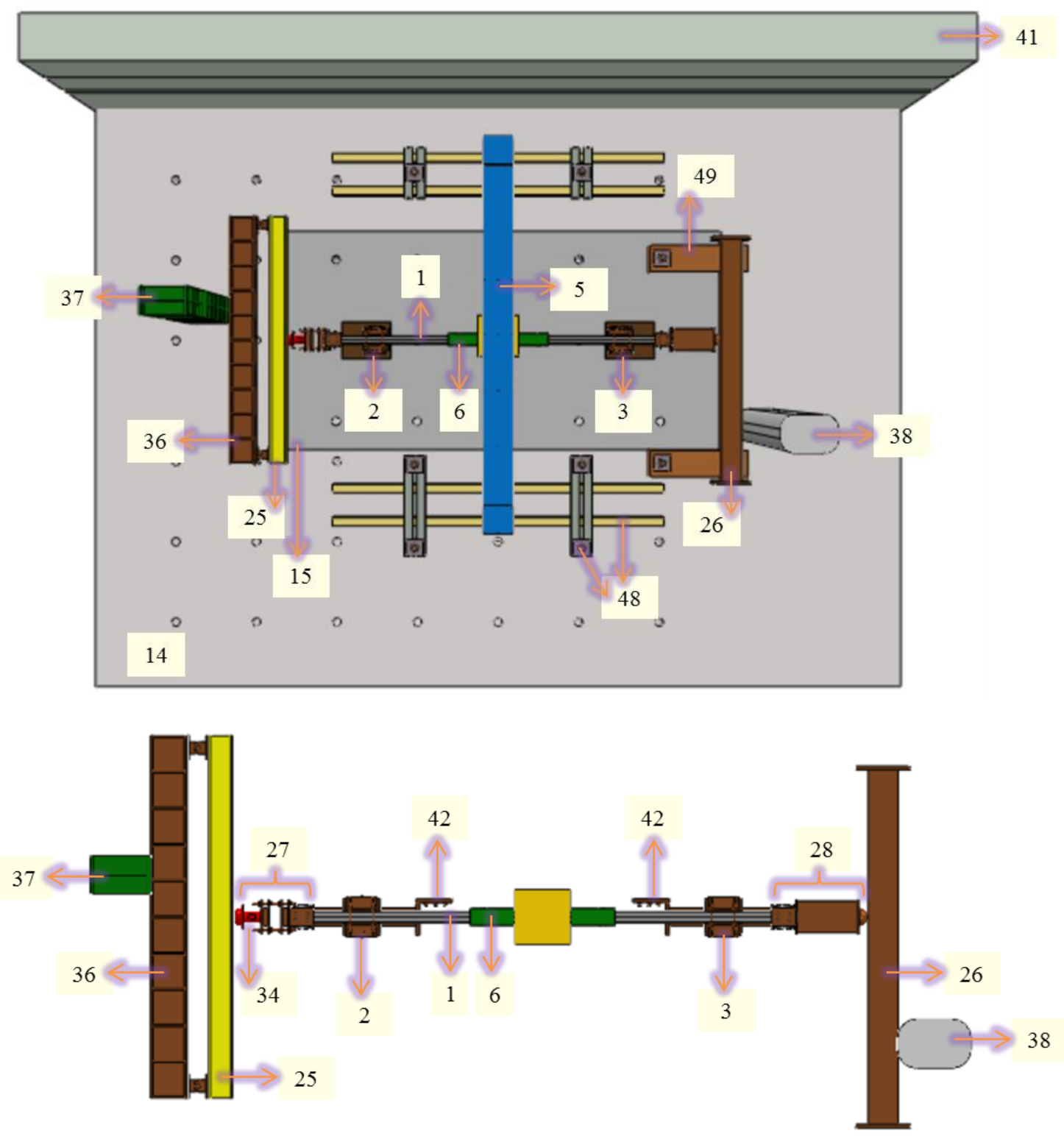

Legenda: 1. Viga de concreto ensaiada; 2. Apoio simples; 3. Apoio duplo; 5. Pórtico de reação; 6. Sistema de redistribuição de forças; 14. Piso superior do LEME; 15. Laje de ensaios; 25. Viga de restrição para simulação de rigidez axial parcial; 26. Viga de restrição para simulação de rigidez axial "infinita"; 27 e 28. Complementos da viga de concreto posicionados nas extremidades próximas aos apoios simples e duplo, respectivamente; 34. Célula de carga para medição das forças de restrição axial; 36. Viga de conexão entre a viga de simulação de rigidez axial parcial e o pórtico de apoio ao sistema; 37. Pilar do pórtico de apoio ao sistema de restrição axial da extremidade do apoio simples; 38. Pilar de apoio ao sistema de restrição axial da extremidade do apoio duplo; 41. Parede do LEME; 42. Cantoneira de suporte à viga de rigidez rotacional; 48. Elementos de fixação/apoio do pórtico de reação; 49. Apoios da viga de aço de simulação de rigidez axial "infinita".

Figura B.3 - Esquemas com vistas superiores do sistema para ensaios de vigas com restrições axiais e rotacionais em situação de incêndio (LAÍM, 2013; adaptado). 


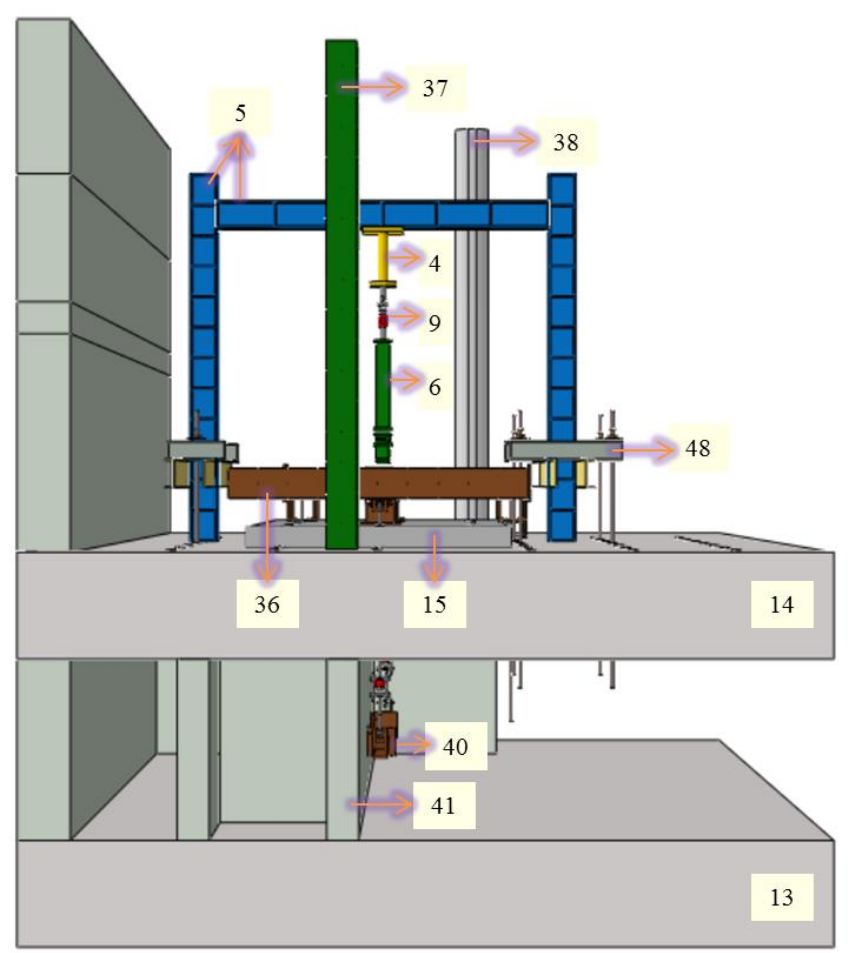

Legenda: 4. Macaco hidráulico; 5. Pórtico de reação; 6. Sistema de redistribuição de forças; 9. Célula de carga para medição das forças aplicadas à viga de concreto; 13. Piso inferior do LEME; 14. Piso superior do LEME; 15. Laje de ensaios; 26. Viga de restrição para simulação de rigidez axial "infinita"; 36. Viga de conexão entre a viga de simulação de rigidez axial parcial e o pórtico de apoio ao sistema; 37. Pilar do pórtico de apoio ao sistema de restrição axial da extremidade do apoio simples; 38. Pilar de apoio ao sistema de restrição axial da extremidade do apoio duplo; 40. Viga de restrição para simulação de rigidez rotacional; 41. Parede do LEME; 48. Elementos de fixação/apoio do pórtico de reação.

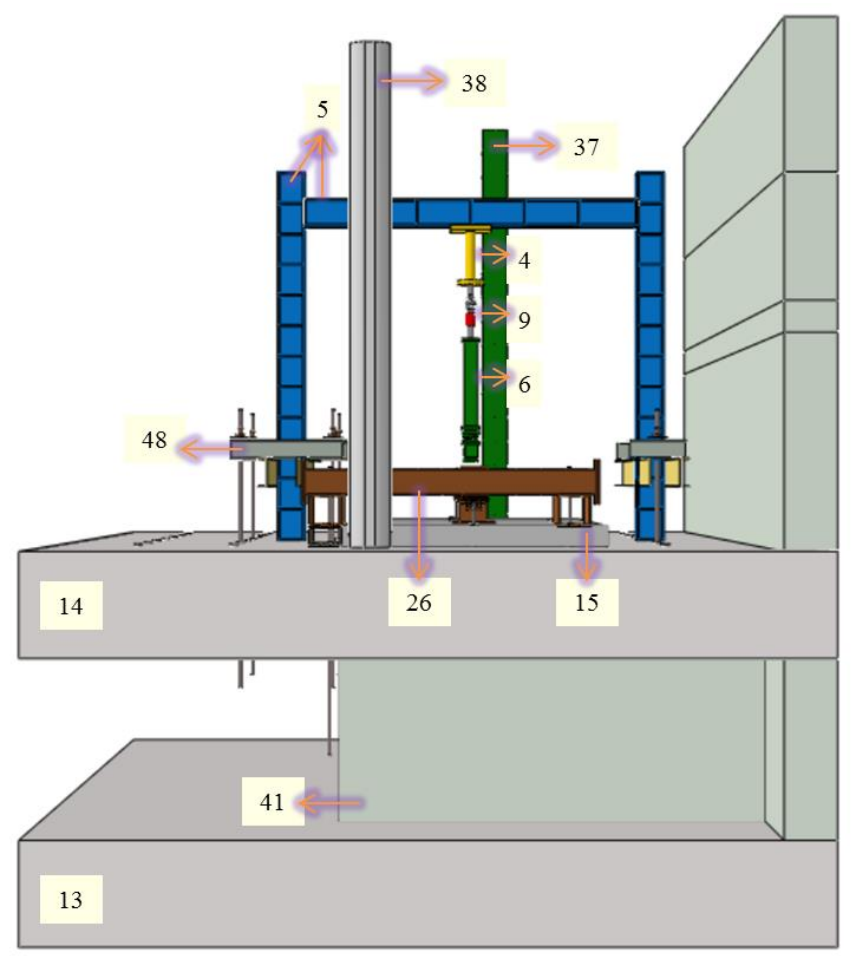

Figura B.4 - Esquemas com vistas laterais do sistema para ensaios de vigas com restrições axiais e rotacionais em situação de incêndio (LAÍM, 2013; adaptado). 


\section{APÊNDICE C - CRITÉRIOS DO PROJETO DE EDIFÍCIOS HIPOTÉTICOS}

Em relação ao lançamento dos modelos de edifícios de concreto armado no programa de computador CAD/TQS ${ }^{\circledR}$ Estudante v.17.1.72 (TQS INFORMÁTICA, 2012), estipulou-se que eles seriam representativos de edifícios de escritórios. Com base nessa hipótese, aplicaram-se os carregamentos descritos a seguir, nos quais " $\mathrm{g}_{\mathrm{k}}$ " representa as forças características permanentes e " $\mathrm{q}_{\mathrm{k}}$ " as características acidentais. Esses valores foram adotados mediante as simulações de forças fornecidas no default do programa e, ainda, à luz da ABNT NBR 6120:2000, que indica as forças para o cálculo de estruturas de edificações. O peso próprio dos elementos, em contrapartida, é admitido automaticamente nos cálculos do programa e, por conta disso, não foi atribuído como dado de entrada.

1) Lajes dos pavimentos tipo;

$\circ \mathrm{g}_{\mathrm{k}}=$ contra piso + revestimento cerâmico $=1 \mathrm{kN} / \mathrm{m}^{2}$;

$\circ \mathrm{q}_{\mathrm{k}}=$ sobrecarga de escritórios $=2 \mathrm{kN} / \mathrm{m}^{2}$;

○ Correspondem à força "serviço1" do CAD/TQS ${ }^{\circledR}$ (áreas de serviço e escritórios).

2) Lajes da cobertura;

○ $\mathrm{g}_{\mathrm{k}}=$ peso do telhado + revestimento de teto $=1,5 \mathrm{kN} / \mathrm{m}^{2}$;

$\circ \mathrm{q}_{\mathrm{k}}=$ sobrecarga de forro $=1 \mathrm{kN} / \mathrm{m}^{2}$;

○ Força "cobert1" (terraço descoberto impermeabilizado).

3) Vigas dos pavimentos tipo.

$\circ g_{\mathrm{k}}=$ alvenaria de bloco de concreto com largura de $14 \mathrm{~cm}=5,67 \mathrm{kN} / \mathrm{m}$;

- Força "TJVAZ14".

Ainda foram adotados como dados de entrada: concreto com resistência característica à compressão $\left(\mathrm{f}_{\mathrm{ck}}\right)$ igual a $25 \mathrm{MPa}$, aço com resistência característica à tração $\left(\mathrm{f}_{\mathrm{yk}}\right)$ igual a 500 
MPa e classe de agressividade ambiental fraca (tipo I), que implica cobrimentos iguais a 1,5 $\mathrm{cm}$ para lajes e iguais a $2,5 \mathrm{~cm}$ para vigas e pilares.

Como adiantado no Capítulo 3 - Análises experimentais, alguns parâmetros adotados foram comparados ao que se prescreve nas normas europeias, para que as dimensões e mesmo as armaduras resultantes fossem também condizentes aos critérios de projeto pertinentes ao âmbito internacional. As forças aplicadas consistiram em um deles.

De modo geral, os valores de sobrecargas indicados no Eurocode 1 parte 1-1 (2002), não diferiam de forma significativa daqueles utilizados no Brasil. Para a sobrecarga de escritórios, por exemplo, que corresponde à categoria B europeia, recomenda-se 2 a $3 \mathrm{kN} / \mathrm{m}^{2}$. Logo, o valor da norma brasileira, $2 \mathrm{kN} / \mathrm{m}^{2}$, encontra-se nesse limite. Já para forros sem acesso a pessoas, categoria $\mathrm{H}$ europeia, recomenda-se $0,5 \mathrm{kN} / \mathrm{m}^{2}$, contra $0,4 \mathrm{kN} / \mathrm{m}^{2}$ da ABNT NBR 6120:2000. Por isso, a favor da segurança, adotou-se a força estipulada no default do CAD/TQS ${ }^{\circledR}$, maior e correspondente a um terraço impermeabilizado.

Outro aspecto a qual se dedicou cuidado consistiu na análise dos coeficientes de ponderação admitidos pelas normas para a determinação dos valores de cálculo das forças, relevantes, por exemplo, na definição das armaduras. Nas fórmulas para combinações de ações, o coeficiente de ponderação das permanentes $\left(\gamma_{\mathrm{g}}\right)$ é igual a 1,4 pela norma brasileira e 1,35 pela europeia. Aquele para ações acidentais $\left(\gamma_{\mathrm{q}}\right)$ é 1,4 na brasileira e 1,5 na europeia. Tais diferenças não se mostraram significativas nos carregamentos estudados. 


\section{APÊNDICE D - ESTUDO DA SIMULAÇÃO DE VIGAS SOB LAJES}

\section{D1 Modelo pretendido para os ensaios experimentais}

Antes da apresentação das análises térmicas ${ }^{1}$ dos materiais isolantes citados no Capítulo 3 Análises Experimentais, é oportuno esclarecer qual foi o modelo de viga ideal escolhido, ou seja, qual foi a situação estipulada como a pretendida para os ensaios experimentais, para a qual se comparariam todas as outras soluções com materiais isolantes, com o propósito de obter o resultado mais próximo a ela. Analisaram-se, num primeiro instante, três modelos de vigas: seção retangular (sem laje); seção T com laje de largura igual a $60 \mathrm{~cm}$ e espessura igual a $7 \mathrm{~cm}$; seção T com laje de largura igual a $60 \mathrm{~cm}$ e espessura igual a $12 \mathrm{~cm}$. Em todas eles, considerou-se fogo nas faces laterais e inferior da viga e sob a laje (quando existente). Compararam-se as temperaturas em determinados pontos relevantes dessas seções, i.e., aqueles representativos do centro geométrico das armaduras positivas e negativas e de outras regiões do concreto, como mostram as Figuras D.1 e D.2.

Em determinados pontos, a seção sem laje conduziu a temperaturas muito mais elevadas do que aquelas que poderiam ser encontradas na prática (vigas sob lajes), fato que torna esse modelo extremamente a favor da segurança ou, em outras palavras, "muito conservador". Em contrapartida, a seção sob laje de $12 \mathrm{~cm}$, para determinados casos, apresentou resultados de temperaturas um tanto quanto brandos para aqueles que podem realmente ocorrer na realidade. Diante desses aspectos, a seção sob laje de $7 \mathrm{~cm}$ se mostrou mais adequada e foi estipulada como a situação pretendida, pois, ao mesmo tempo em que está favor da segurança quando comparada à seção sob laje de $12 \mathrm{~cm}$, porque vigas sob lajes menos espessas se

\footnotetext{
${ }^{1}$ Essas análises foram realizadas com o auxílio do Super Tempcalc (FSD, 2007), programa de computador sueco que realiza análise termestrutural bidimensional transiente por meio do método dos elementos finitos.
} 
APÊNDICE D - ESTUDO DA SIMULAÇÃO DE VIGAS SOB LAJES
Análise numérico-experimental de vigas de concreto armado com restrições axial e rotacional em situação de incêndio

encontram em condições mais críticas (menor massa de concreto a absorver calor), elas não chegam ao ponto de serem tão conservadoras, quando comparadas às seções retangulares.
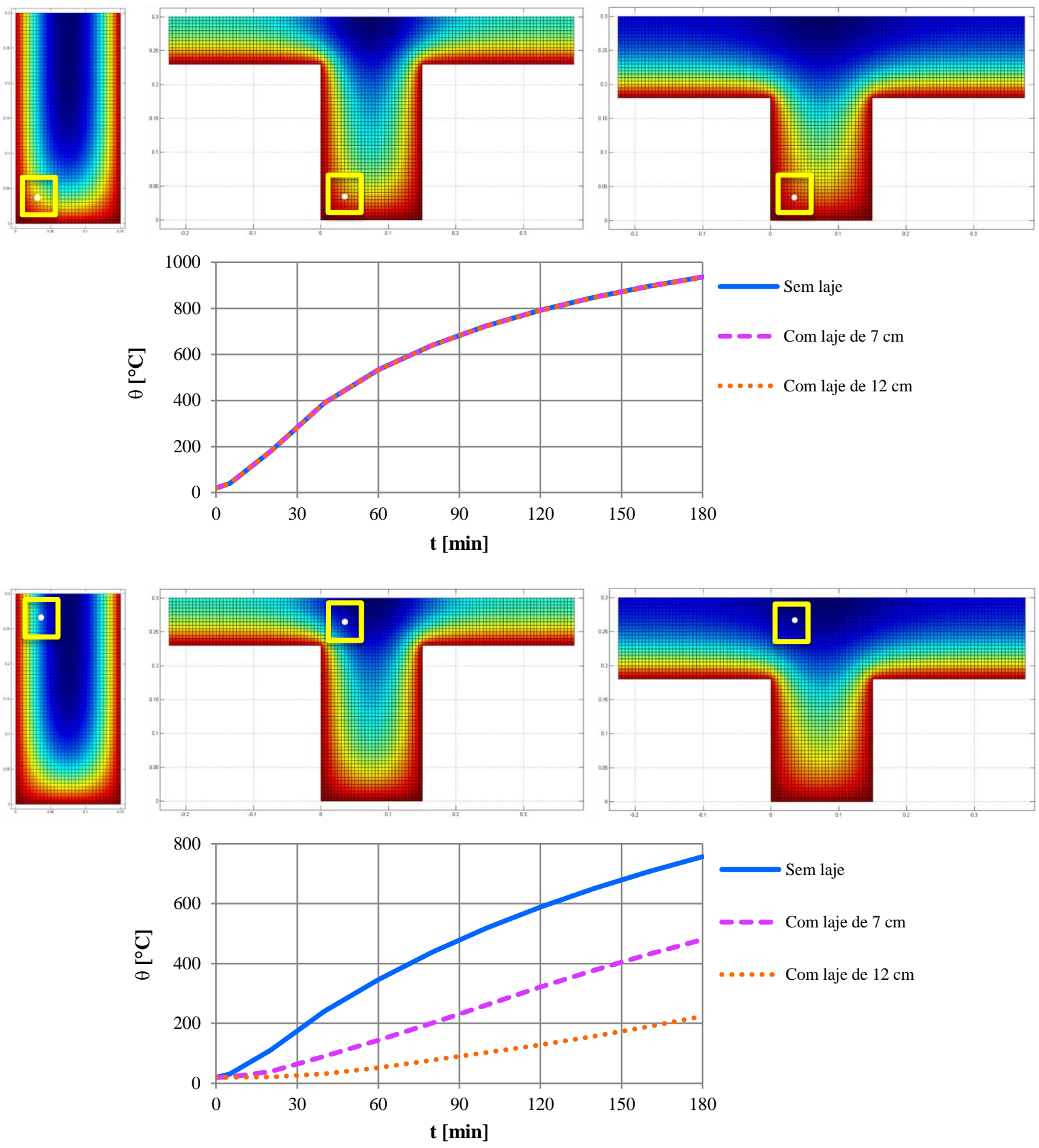

Figura D.1 - Comparação das curvas de temperaturas em pontos representativos do centro geométrico de determinada barra presente em armaduras inferiores e superiores, respectivamente, para seções do tipo retangular e sob lajes. 

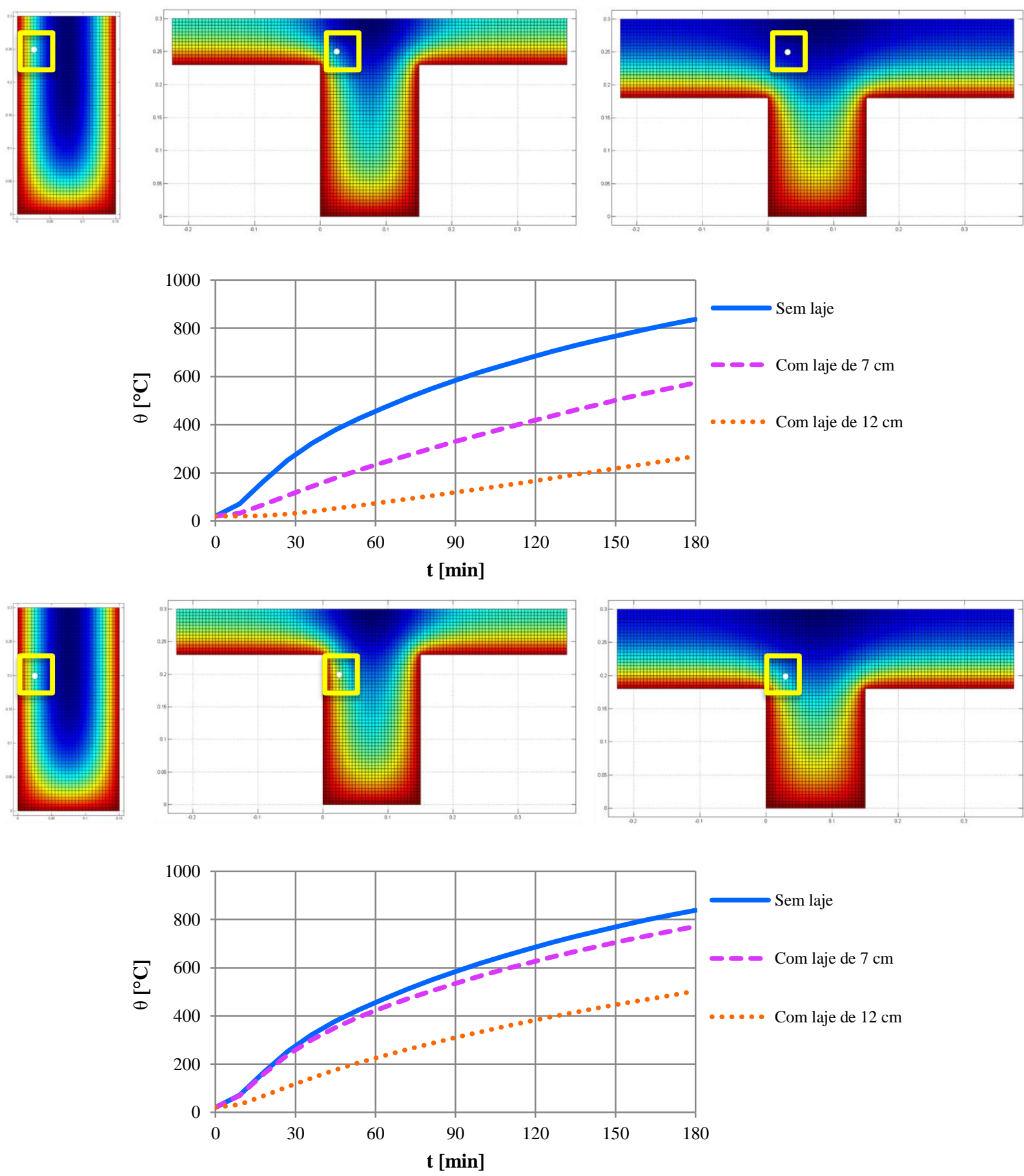

Figura D.2 - Comparação das curvas de temperaturas em pontos representativos de determinadas regiões de concreto, para seções do tipo retangular e sob lajes (continua). 

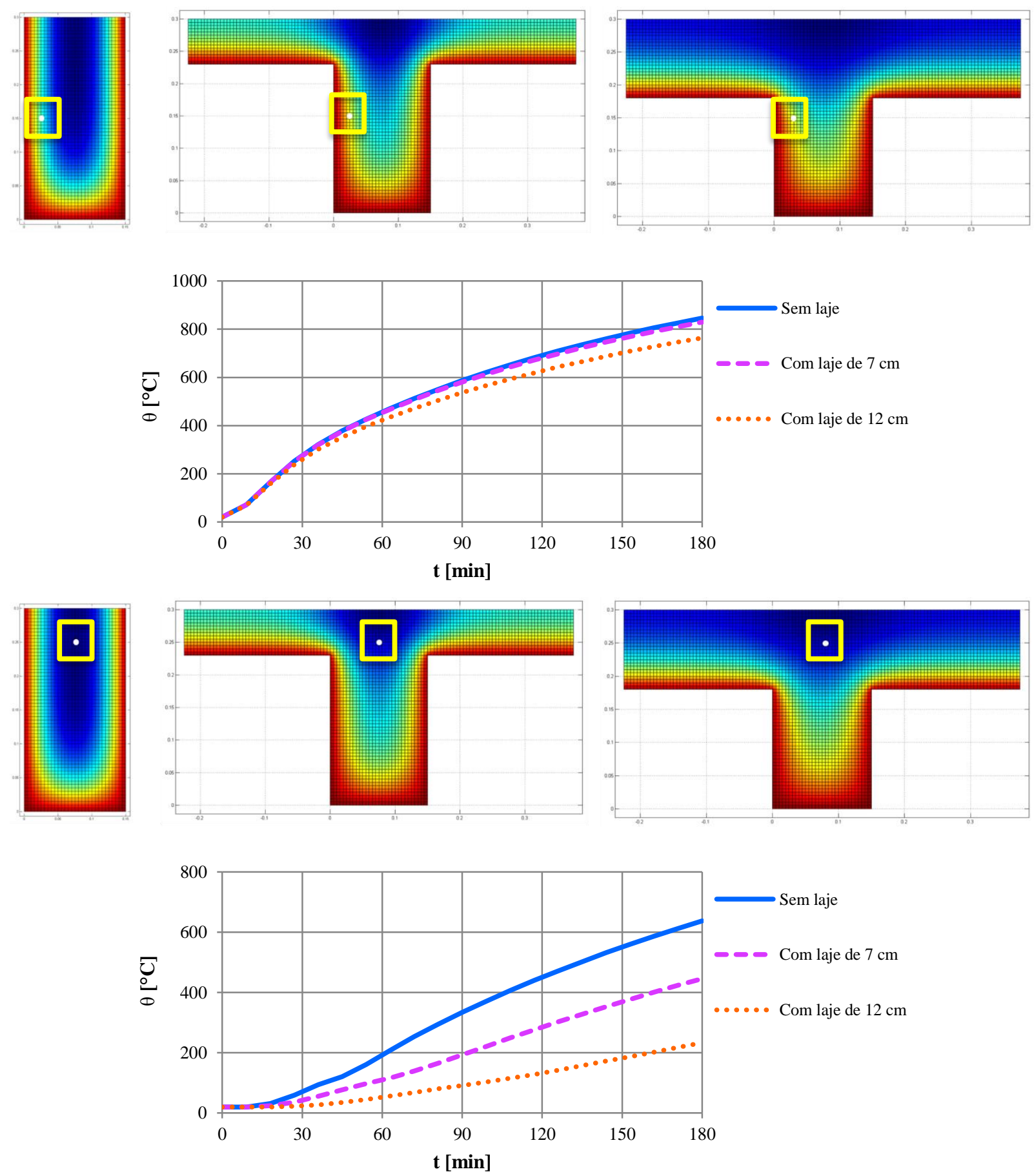

Figura D.2 - Comparação das curvas de temperaturas em pontos representativos de determinadas regiões de concreto, para seções do tipo retangular e sob lajes (continua). 

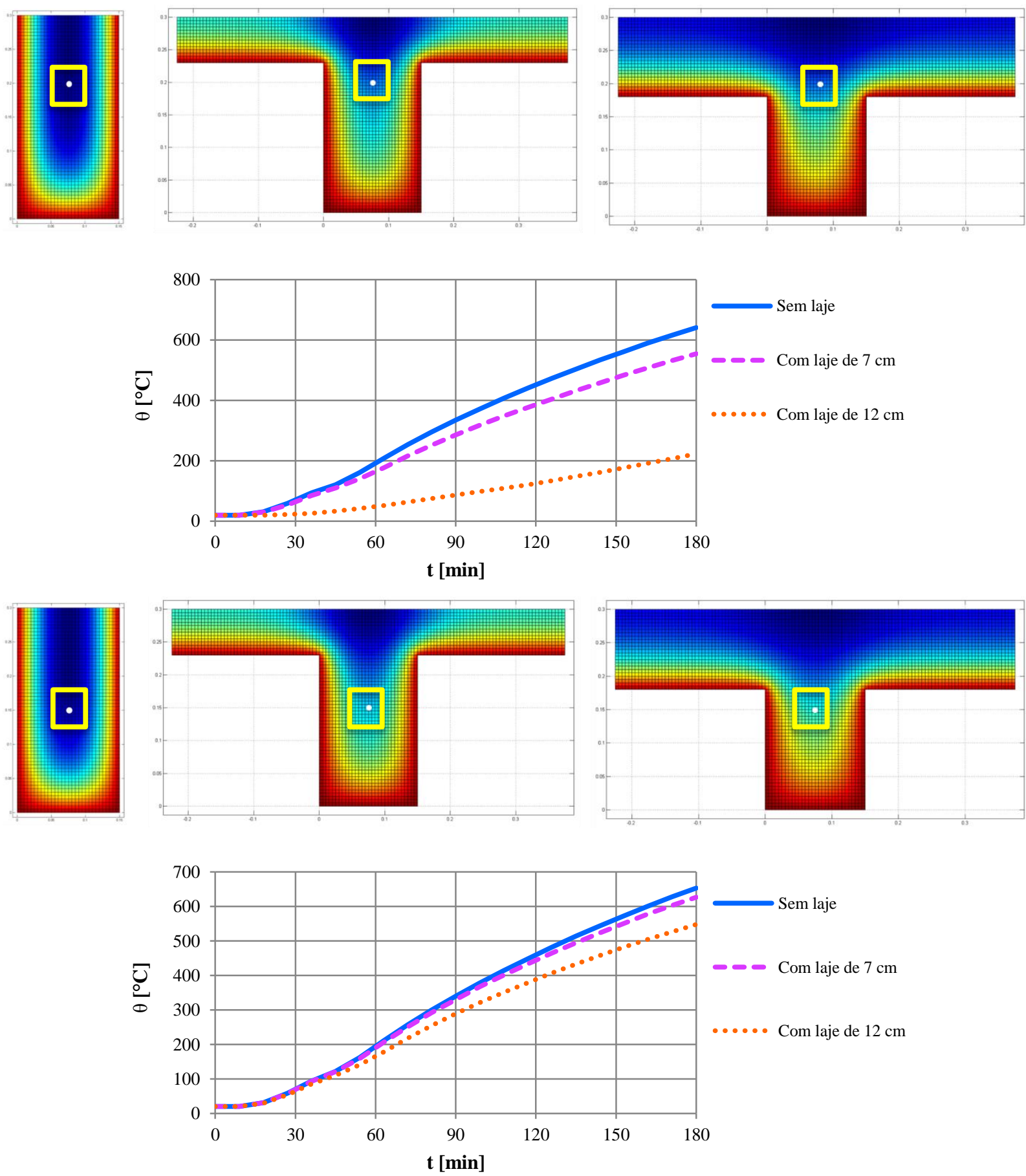

Figura D.2 - Comparação das curvas de temperaturas em pontos representativos de determinadas regiões de concreto, para seções do tipo retangular e sob lajes (conclusão).

Nos primeiros modelos apresentados anteriormente, a face superior da viga (ou das lajes) foi considerada como adiabática, também a favor da segurança, haja vista que assim se admite 
que o calor não é perdido através dela. Porém, na prática, essa superfície não é perfeitamente adiabática e se encontra sujeita à absorção de determinado fluxo de calor.

Com base nas informações fornecidas no Eurocode 1 parte 1-2 (2002), os autores Pierin; Silva e La Rovere (2015) explicaram que uma face não exposta diretamente ao fogo pode ser caracterizada mediante uma combinação de convecção e radiação, simulada por um coeficiente de transferência de calor por convecção $\left(\alpha_{c}\right)$ igual a $9 \mathrm{~W} / \mathrm{m}^{2}{ }^{\circ} \mathrm{C}$. Ademais, deve-se adotar para tal face um valor de temperatura ambiente, igual a $20{ }^{\circ} \mathrm{C}$, e emissividade resultante $\left(\varepsilon_{\text {res }}\right)$ nula.

A partir disso, realizou-se uma nova comparação, agora entre uma viga sob laje de $7 \mathrm{~cm}$ com face superior adiabática e uma viga sob laje também de $7 \mathrm{~cm}$, mas com face superior modelada com as propriedades indicadas por Pierin; Silva e La Rovere (2015). Novamente, os pontos cujas respectivas temperaturas em função do tempo foram confrontadas correspondem àqueles representativos dos centros geométricos das armaduras e de determinadas regiões do concreto, sobretudo as localizadas mais ao centro, no "núcleo frio" da seção transversal, porque conforme pode ser visto nas Figuras D.3 e D.4, os campos térmicos se apresentavam mais distintos nessa zona.

Contudo, à exceção das curvas equivalentes ao ponto localizado na face superior de cada seção, para a qual o regime de aquecimento era diferente, os demais pontos analisados resultaram em curvas bastante próximas. Logo, permaneceu-se com a consideração inicialmente adotada, admitindo-se uma viga sob laje de $7 \mathrm{~cm}$ de espessura e com face superior adiabática como o modelo pretendido para as análises experimentais. 

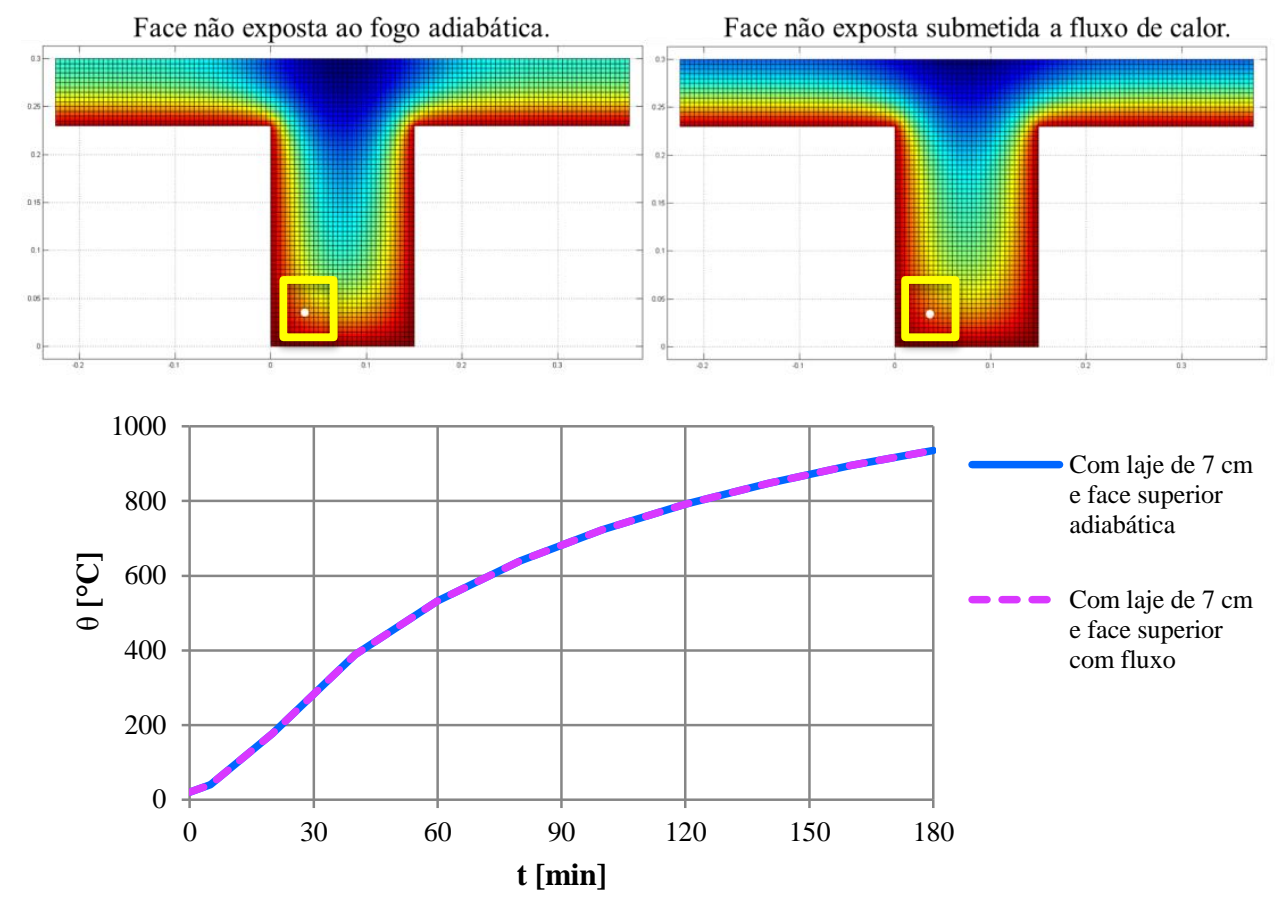

Face não exposta ao fogo adiabática. Face não exposta submetida a fluxo de calor.
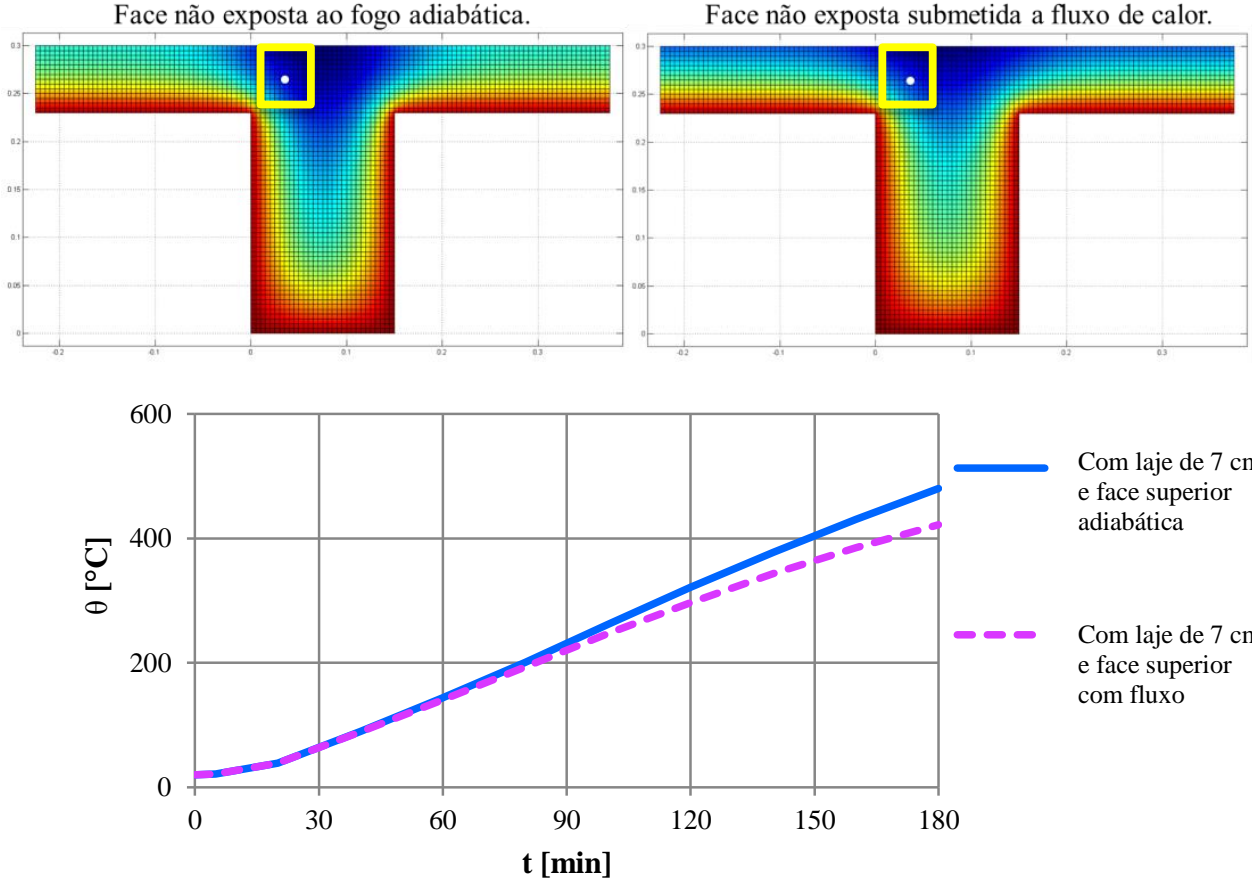

Com laje de $7 \mathrm{~cm}$ e face superior adiabática

Com laje de $7 \mathrm{~cm}$ e face superior com fluxo

Figura D.3 - Comparação das curvas de temperaturas em pontos representativos do centro geométrico de determinada barra presente em armaduras inferiores e superiores, respectivamente, para seções sob lajes com face superior ou adiabática ou submetida a fluxo de calor. 

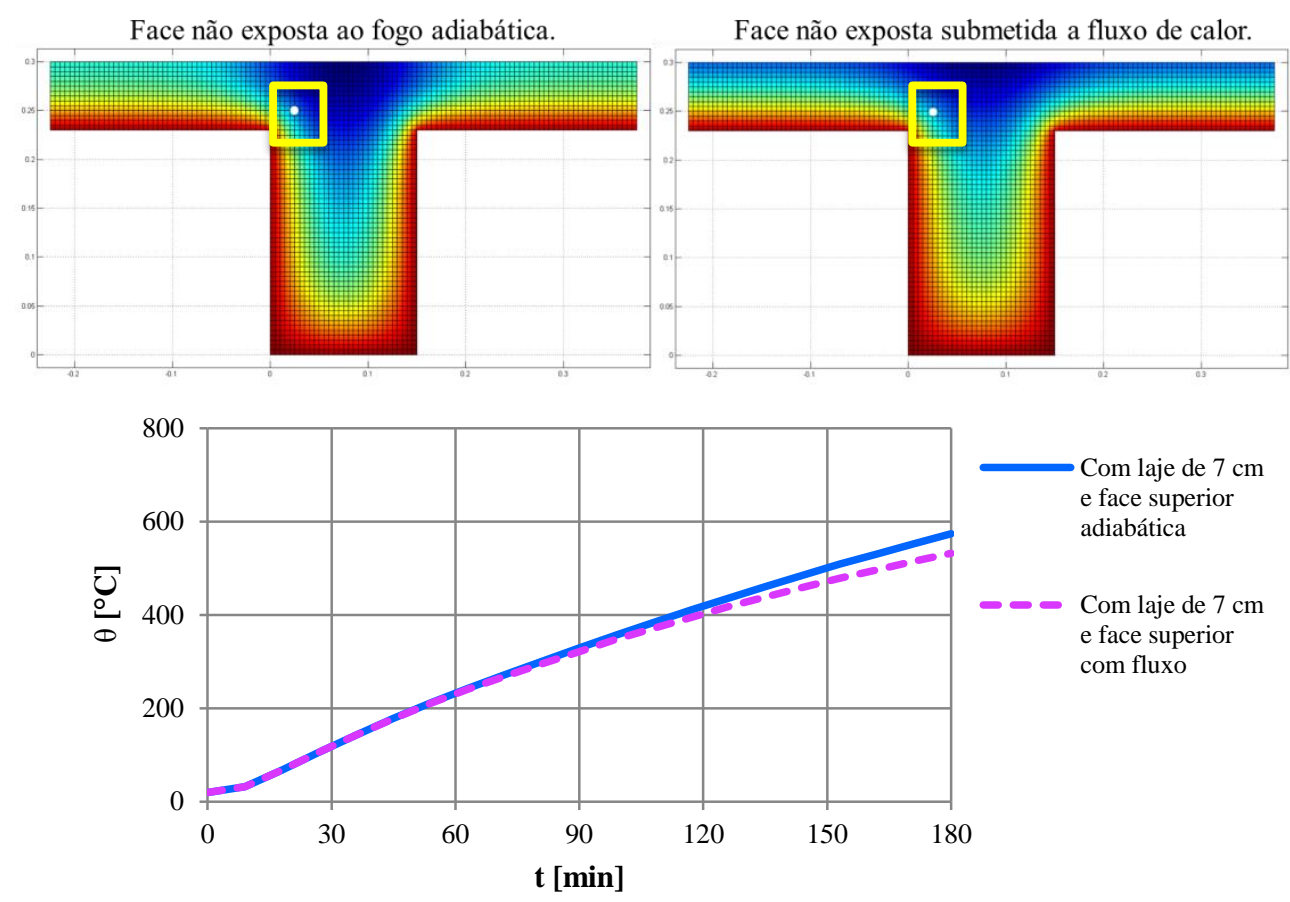

Face não exposta ao fogo adiabática.

Face não exposta submetida a fluxo de calor.
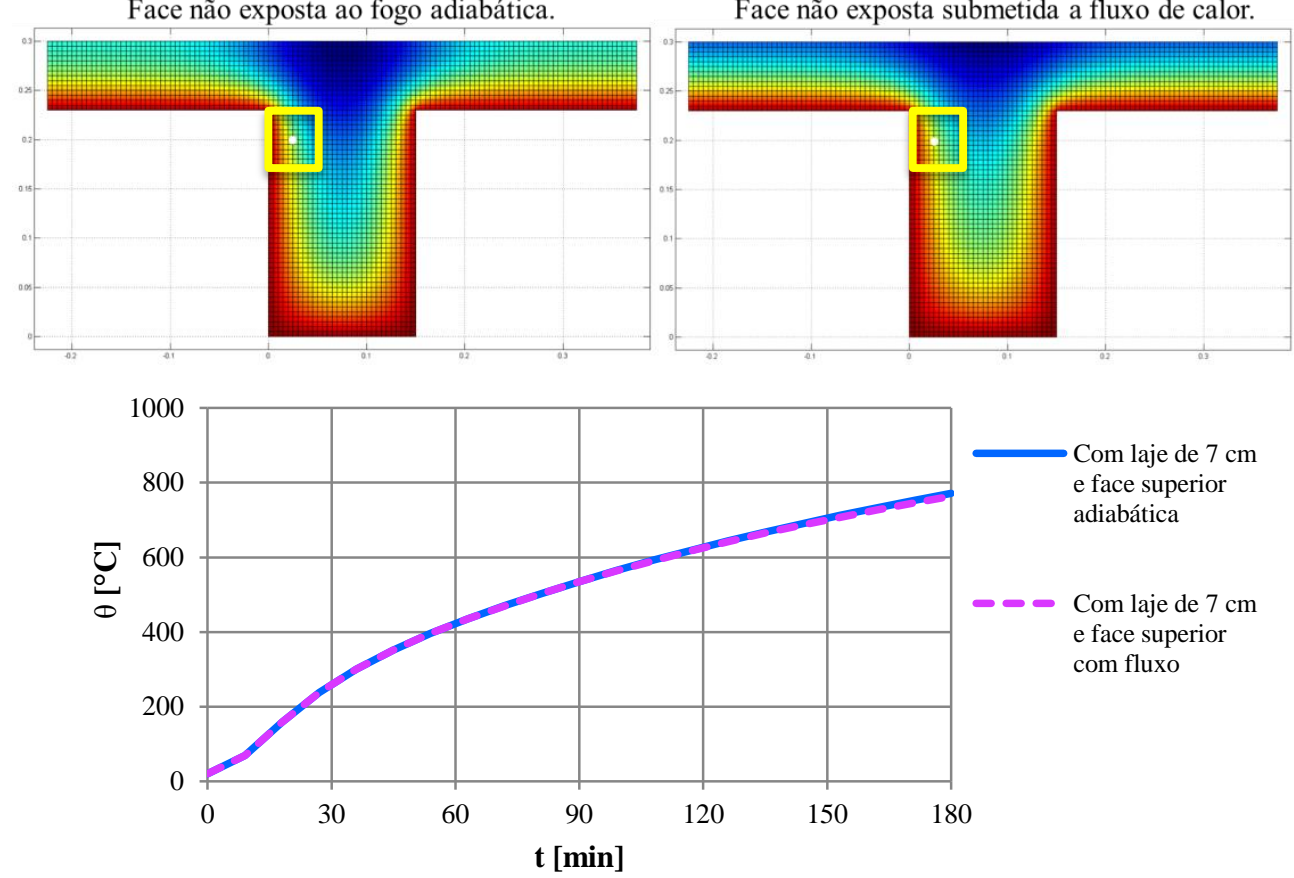

Figura D.4 - Comparação das curvas de temperaturas em pontos representativos de determinadas regiões de concreto, para seções sob lajes com face superior ou adiabática ou submetida a fluxo de calor (continua). 

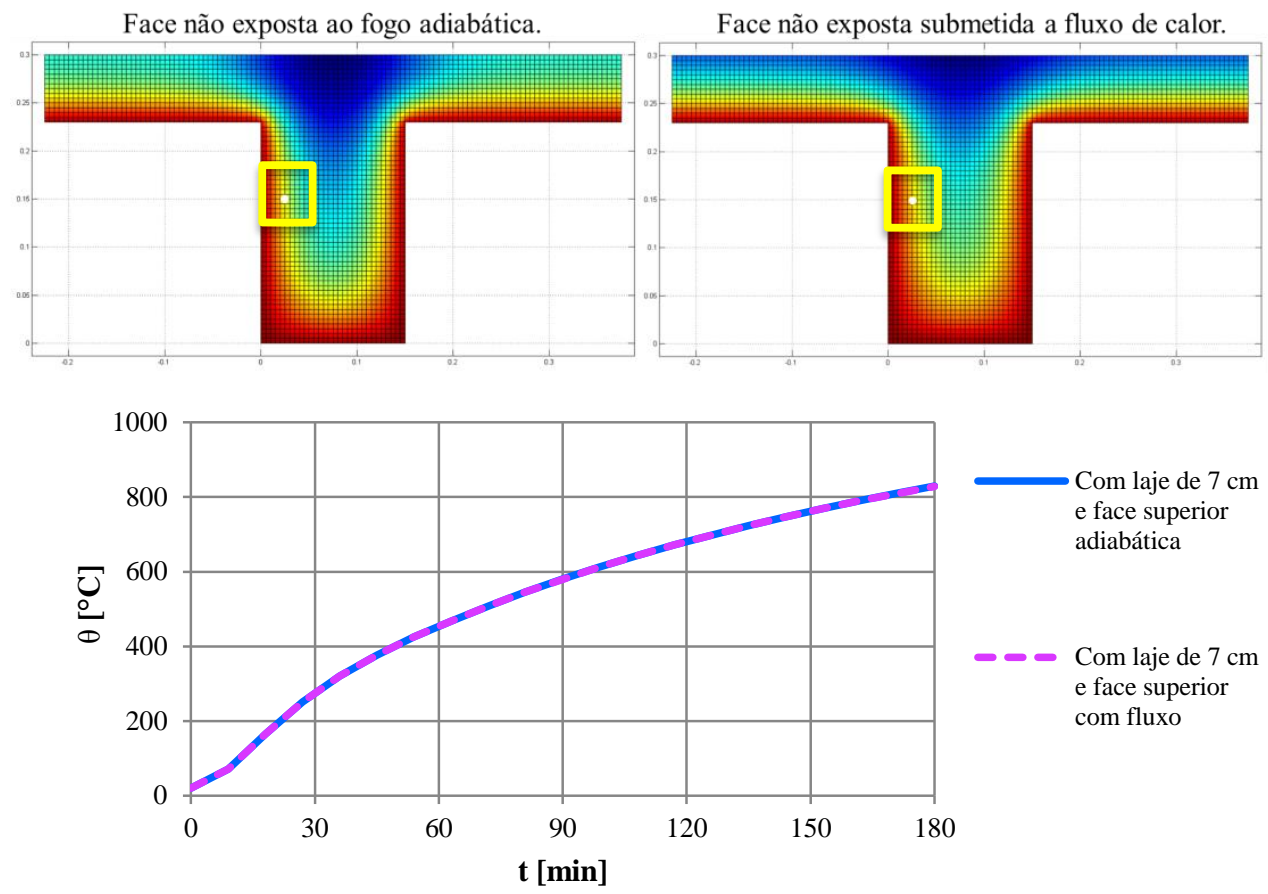

Face não exposta ao fogo adiabática.

Face não exposta submetida a fluxo de calor.
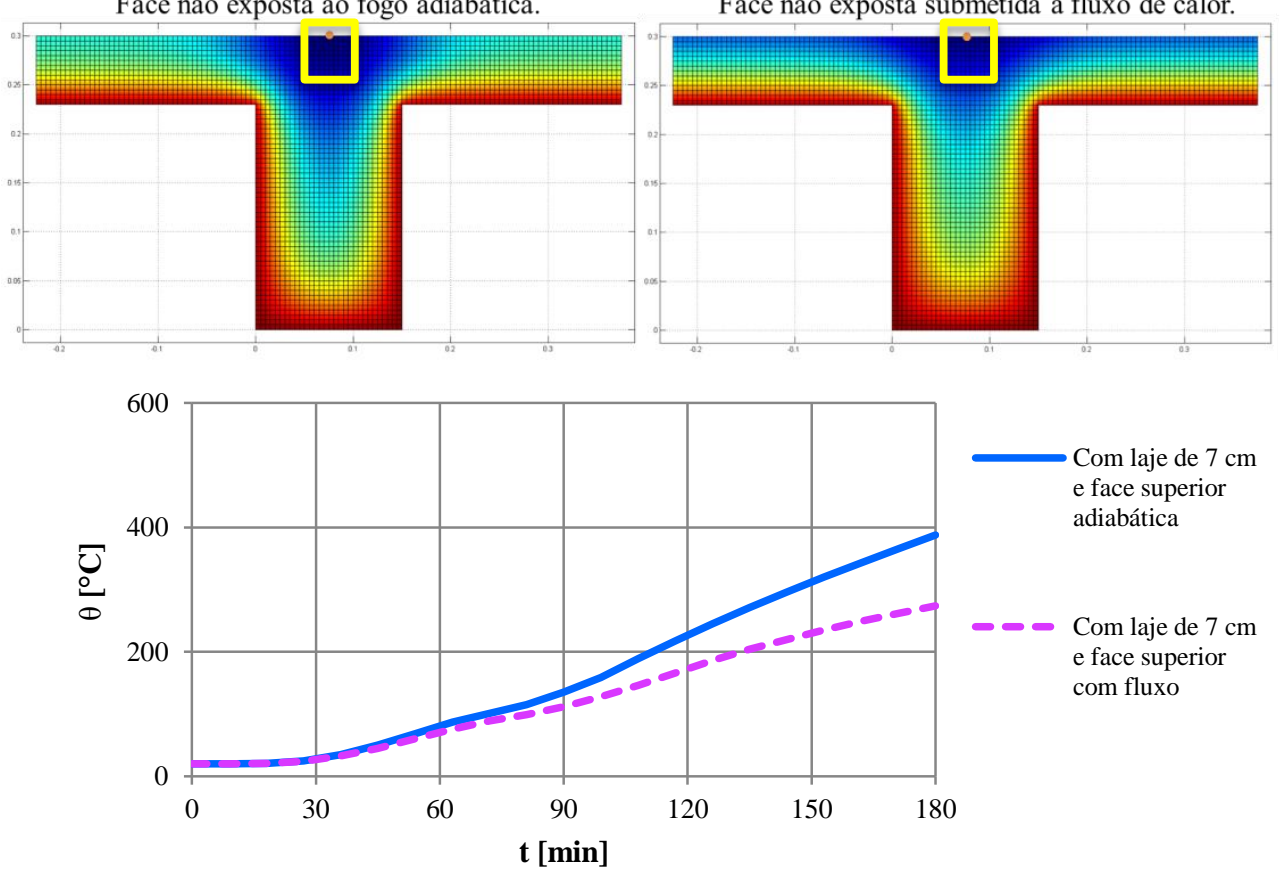

- Com laje de $7 \mathrm{~cm}$ e face superior com fluxo

Figura D.4 - Comparação das curvas de temperaturas em pontos representativos de determinadas regiões de concreto, para seções sob lajes com face superior ou adiabática ou submetida a fluxo de calor (continua). 

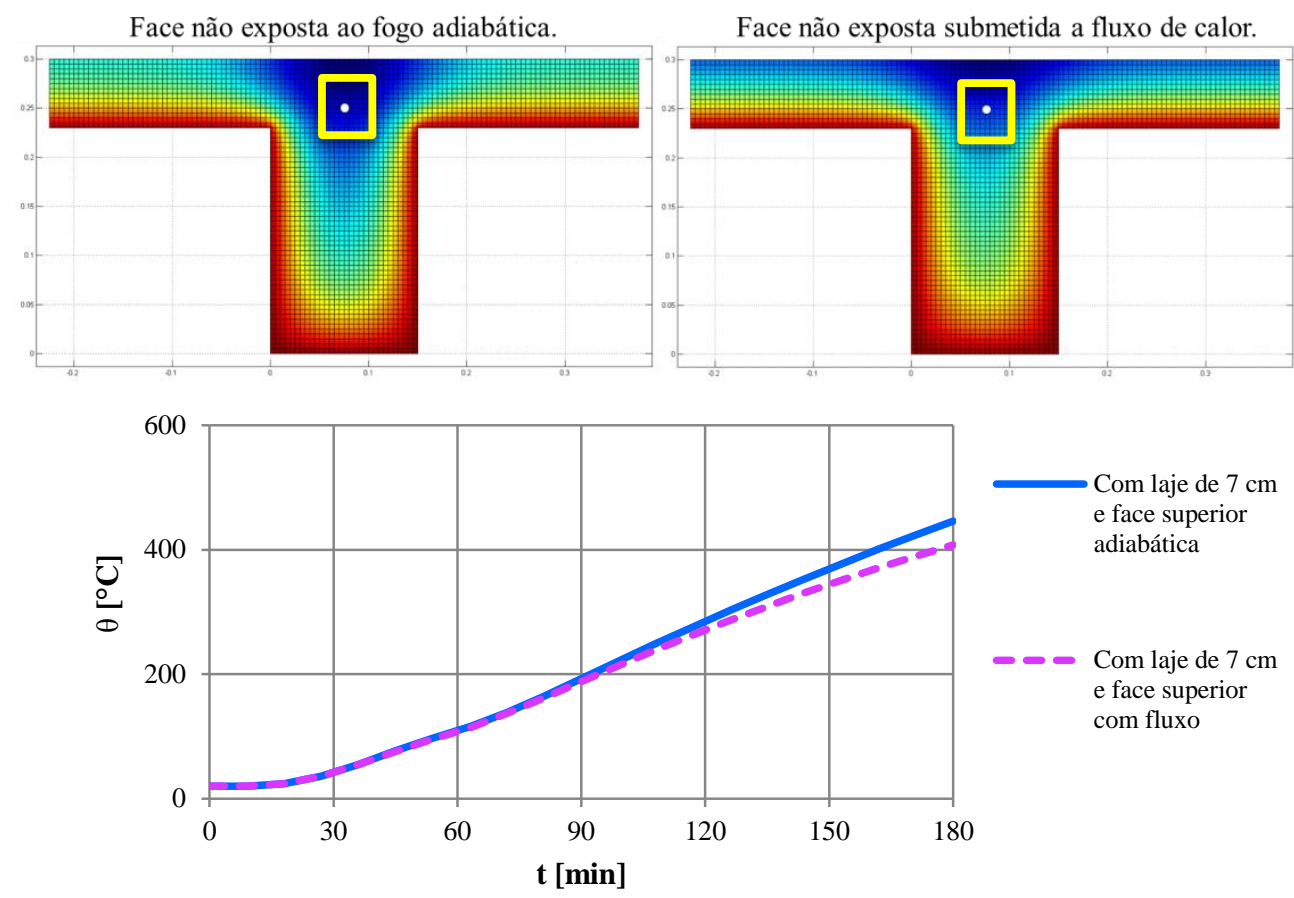

Face não exposta ao fogo adiabática.
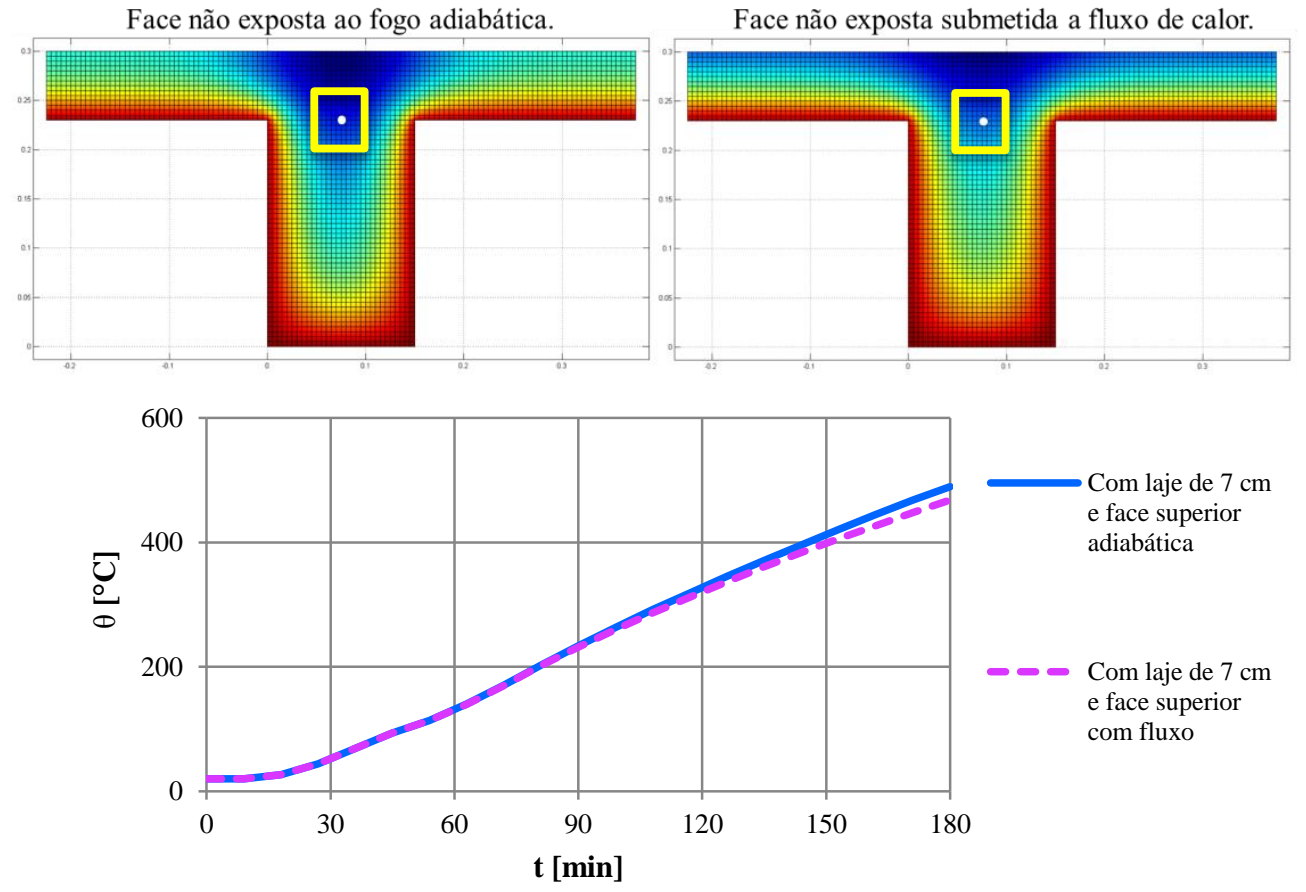

Figura D.4 - Comparação das curvas de temperaturas em pontos representativos de determinadas regiões de concreto, para seções sob lajes com face superior ou adiabática ou submetida a fluxo de calor (continua). 

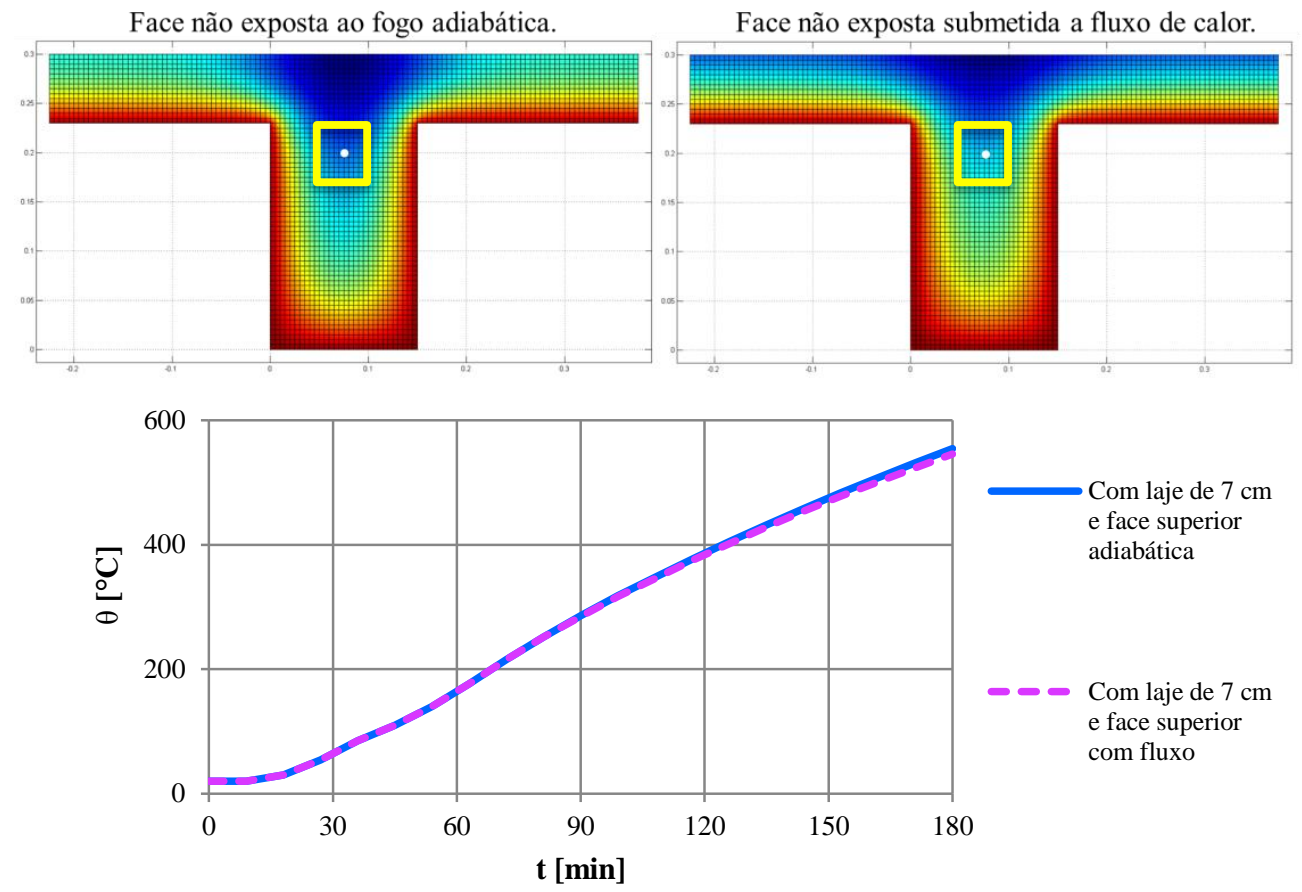

Face não exposta ao fogo adiabática.

Face não exposta submetida a fluxo de calor.
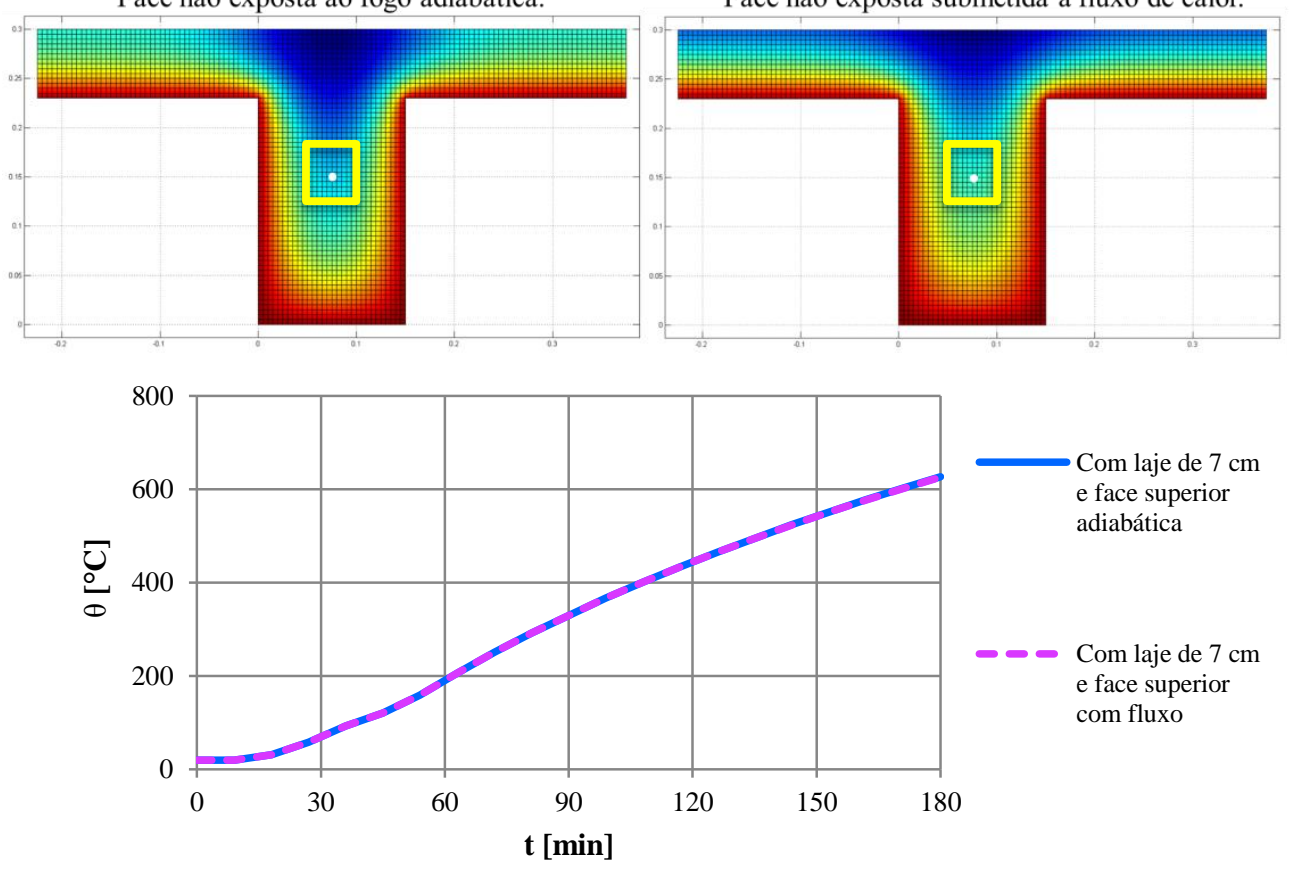

Com laje de $7 \mathrm{~cm}$

e face superior

adiabática

- Com laje de $7 \mathrm{~cm}$

e face superior

com fluxo

Figura D.4 - Comparação das curvas de temperaturas em pontos representativos de determinadas regiões de concreto, para seções sob lajes com face superior ou adiabática ou submetida a fluxo de calor (continua). 

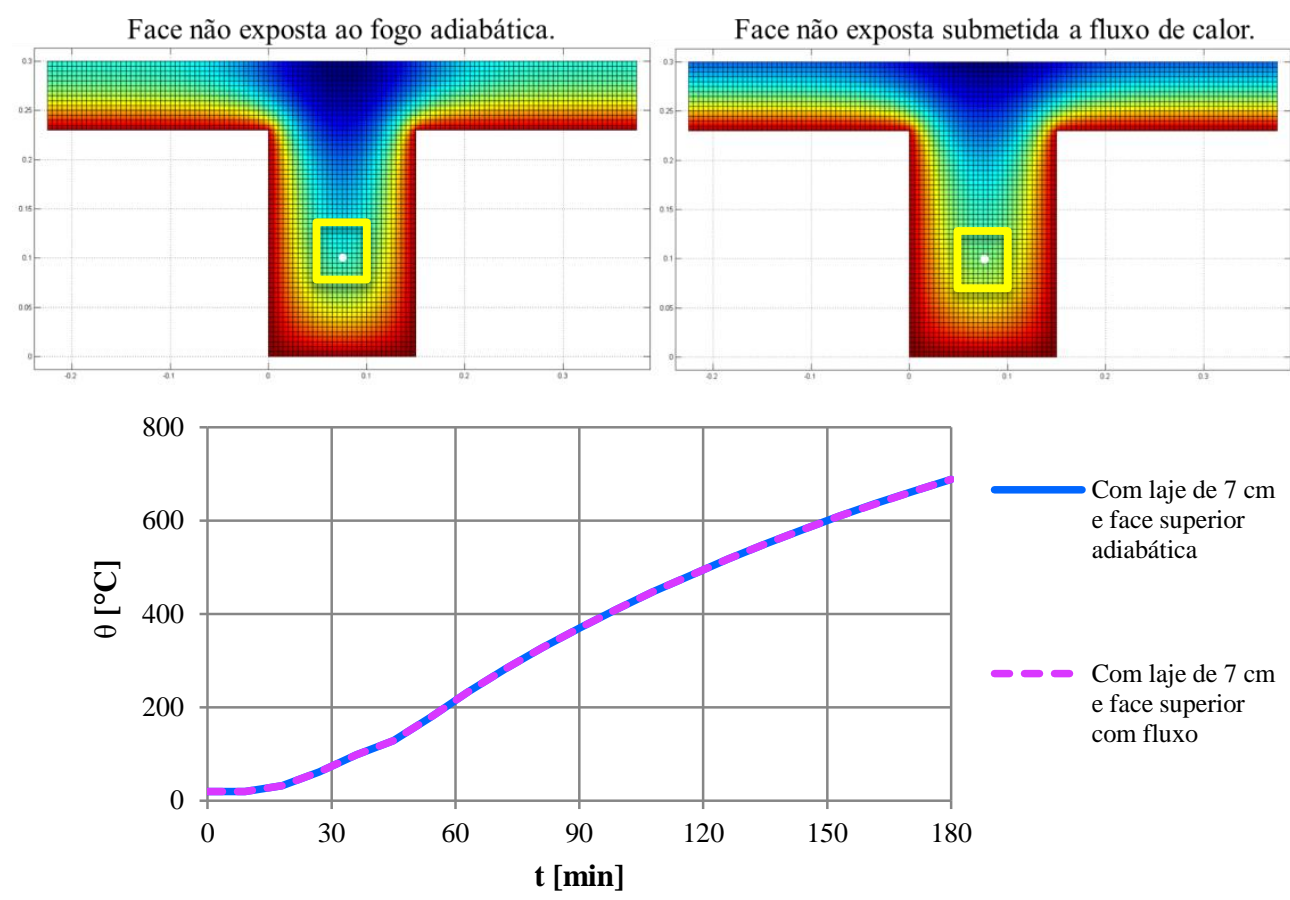

Figura D.4 - Comparação das curvas de temperaturas em pontos representativos de determinadas regiões de concreto, para seções sob lajes com face superior ou adiabática ou submetida a fluxo de calor (conclusão).

\section{D2 Análise dos materiais isolantes}

De posse da "condição ideal", as vigas superpostas por materiais isolantes começaram a ser estudadas. Na Tabela D.1, apresentam-se as propriedades físico-térmicas tomadas como dados de entrada para cada um dos materiais. Apenas para as condutividades térmicas foram admitidos valores sensíveis à elevação das temperaturas, uma vez que, para as demais (massa específica e calor específico), os fabricantes possuíam apenas dados representativos da condição de temperatura ambiente. Dessa forma, considerou-se que essas duas últimas propriedades permaneciam constantes frente à ação do fogo. Ainda se pode verificar por meio dessa tabela que para determinados materiais (tijolos refratários, por exemplo), analisaram-se opções de produtos mais e menos densos, para avaliar se apresentavam melhores soluções 
aqueles mais leves e com condutividades térmicas menores ou aqueles que, apesar de conduzirem mais calor, eram mais densos.

Tabela D.1 - Propriedades físico-térmicas dos materiais isolantes estudados.

\begin{tabular}{|c|c|c|c|c|}
\hline Material & $\begin{array}{c}\text { Temperatura } \\
\left({ }^{\circ} \mathrm{C}\right)\end{array}$ & $\begin{array}{c}\text { Condutividade } \\
\text { térmica } \\
\left(\mathrm{W} / \mathrm{m}^{\circ} \mathrm{C}\right)\end{array}$ & $\begin{array}{c}\text { Massa específica } \\
\left(\mathrm{kg} / \mathrm{m}^{3}\right)\end{array}$ & $\begin{array}{c}\text { Calor específico } \\
\left(\mathrm{J} / \mathrm{kg}{ }^{\circ} \mathrm{C}\right)\end{array}$ \\
\hline \multirow{4}{*}{$\begin{array}{l}\text { Placa de } \\
\text { silicato } \\
\text { de cálcio* }\end{array}$} & 400 & 0,099 & \multirow{4}{*}{285} & \multirow{4}{*}{800} \\
\hline & 600 & 0,116 & & \\
\hline & 700 & 0,138 & & \\
\hline & 800 & 0,154 & & \\
\hline \multirow{3}{*}{$\begin{array}{l}\text { Tijolo } \\
\text { refratário* }^{* *} \\
\text { menos denso }\end{array}$} & 300 & 0,44 & \multirow{3}{*}{1750} & \multirow{3}{*}{1100} \\
\hline & 700 & 0,55 & & \\
\hline & 1100 & 0,59 & & \\
\hline \multirow{3}{*}{$\begin{array}{c}\text { Tijolo } \\
\text { refratário mais } \\
\text { denso } 1\end{array}$} & 300 & 1,20 & \multirow{3}{*}{2050} & \multirow{3}{*}{1100} \\
\hline & 700 & 1,30 & & \\
\hline & 1100 & 1,40 & & \\
\hline \multirow{3}{*}{$\begin{array}{c}\text { Tijolo } \\
\text { refratário mais } \\
\text { denso } 2\end{array}$} & 300 & 1,36 & \multirow{3}{*}{2270} & \multirow{3}{*}{1100} \\
\hline & 700 & 1,66 & & \\
\hline & 1100 & 1,88 & & \\
\hline \multirow{3}{*}{$\begin{array}{l}\text { Manta de fibra } \\
\text { cerâmica } * * *\end{array}$} & 204 & 0,045 & \multirow{3}{*}{128} & \multirow{3}{*}{1130} \\
\hline & 427 & 0,087 & & \\
\hline & 982 & 0,257 & & \\
\hline \multirow{4}{*}{$\begin{array}{l}\text { Manta de lã de } \\
\text { silicato } \\
\text { alcalino } \\
\text { mais densa }\end{array}$} & 400 & 0,11 & \multirow{4}{*}{160} & \multirow{4}{*}{1172} \\
\hline & 600 & 0,17 & & \\
\hline & 800 & 0,26 & & \\
\hline & 1000 & 0,36 & & \\
\hline \multirow{4}{*}{$\begin{array}{c}\text { Manta de lã de } \\
\text { silicato alcalino } \\
\text { menos densa }\end{array}$} & 400 & 0,10 & \multirow{4}{*}{128} & \multirow{4}{*}{1172} \\
\hline & 600 & 0,16 & & \\
\hline & 800 & 0,23 & & \\
\hline & 1000 & 0,31 & & \\
\hline
\end{tabular}

Fontes: " Disponível em: <wWw.calvosealing.com $>$; ${ }^{* *}\langle\underline{w W w . a b r i g a d a . c o m}>$;

*** Silva (2004); ${ }^{* * * * *}$ Ficha técnica enviada pelo fornecedor (via e-mail). 
Nas seções modeladas para as análises térmicas, ainda se admitiram camadas de $0,5 \mathrm{~cm}$ de massa refratária nas interfaces concreto/isolante ou entre camadas isolante/isolante (nos casos de aplicação de mais de uma camada do material isolante). Essa espessura foi indicada no catálogo do fabricante desse material e na falta de dados de suas propriedades físico-térmicas, considerou-se que elas eram iguais às do material isolante analisado em cada uma das seções. Por fim, ressalta-se que as quatro faces de cada uma das seções sobrepostas por isolantes foi submetida a aquecimento conforme a curva de incêndio-padrão ISO 834 (1999), com o propósito de caracterizar as condições de contorno provenientes do forno presente no LEME.

Com base nessas hipóteses, foram aferidas as temperaturas em alguns pontos críticos dessas seções transversais e, sobretudo, aquele localizado na borda da face superior, que representa a interface entre a viga de concreto e o material isolante. Na Figura D.5, ilustra-se o referido ponto tanto para as seções com materiais isolantes quanto a sua localização no que concerne aos outros dois modelos: seção retangular aquecida nas quatro faces (situação provida pelo forno) e seção sob laje de $7 \mathrm{~cm}$ com face superior adiabática (situação pretendida).

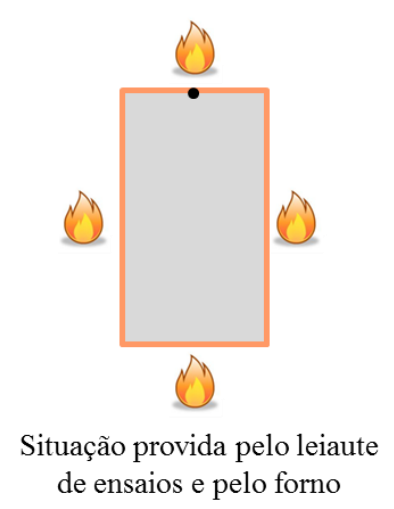

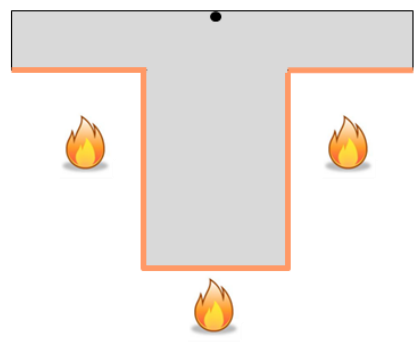

Situação pretendida

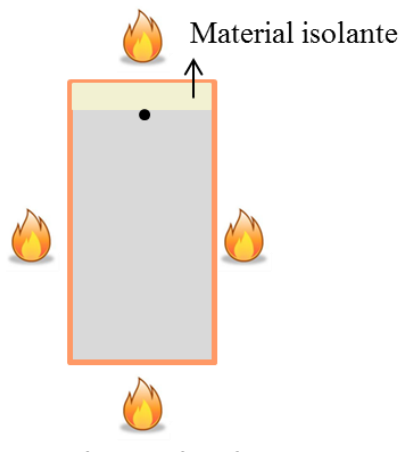

Solução adotada

Figura D.5 - Esquemas das seções transversais e dos regimes de aquecimento que compuseram o estudo da simulação de vigas sob lajes.

Na Figura D.6, apresentam-se os gráficos que fornecem as curvas de temperaturas em função do tempo, para o referido ponto, em relação à situação provida pelo forno, à situação pretendida e a todas as soluções com materiais isolantes estudadas (como indicado, analisaram-se, em determinados casos, materiais com diferentes espessuras e, ainda, a aplicação de múltiplas camadas). 
Subsequentemente, essas curvas foram analisadas uma a uma e, dentre elas, foram selecionadas apenas as que representavam a melhor solução de cada material, i.e., aquelas mais próximas à curva designada como viga sob laje com face superior adiabática, vide gráfico da Figura D.7. A partir dele, pode-se verificar que um determinado tijolo refratário se mostrou mais próximo da condição pretendida, seguido de uma placa de silicato de cálcio. Entretanto, como discutido no Capítulo 3, os materiais mais rígidos poderiam não acompanhar as deformações por flexão que as vigas de concreto armado iriam sofrer durante os ensaios experimentais, comprometendo o isolamento e também impossibilitando a aplicação direta das forças sobre elas. Perante essas questões, viu-se necessário descartar os materiais mais densos. A partir disso, restaram as mantas que, apesar de serem menos isolantes, quando comparadas aos outros materiais, se mostraram mais apropriadas nesse sentido, por serem mais flexíveis. Assim, nos ensaios ao fogo, as faces superiores das vigas de concreto armado foram revestidas pelas mantas denominadas nos gráficos como mantas de lã de silicato menos densas, com espessura igual a $50 \mathrm{~mm}$, aproveitando que esse tipo de manta se encontrava disponível no LEME para uso em projetos.

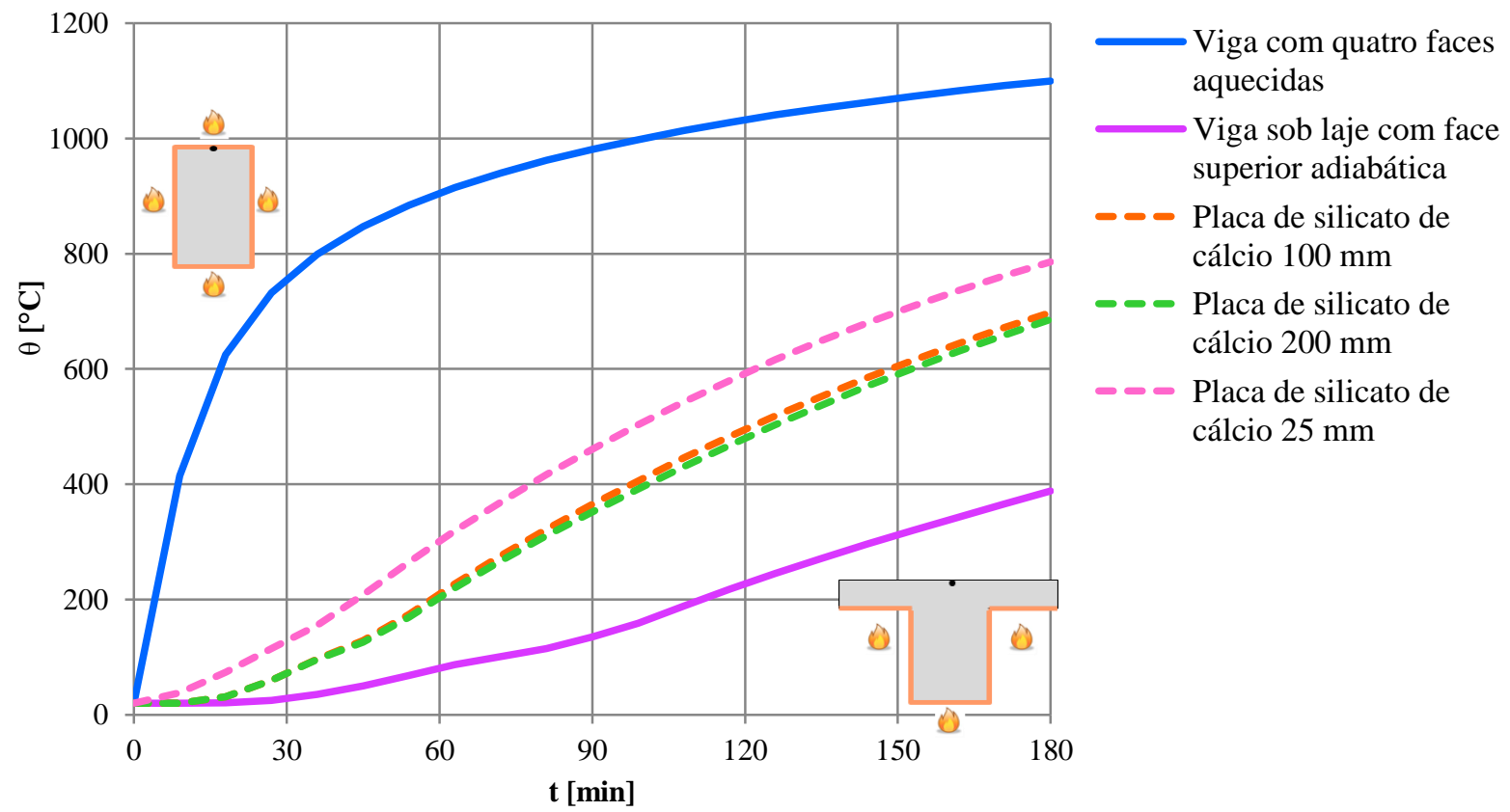

Figura D.6 - Evolução de temperaturas para cada um dos materiais isolantes analisados (continua). 


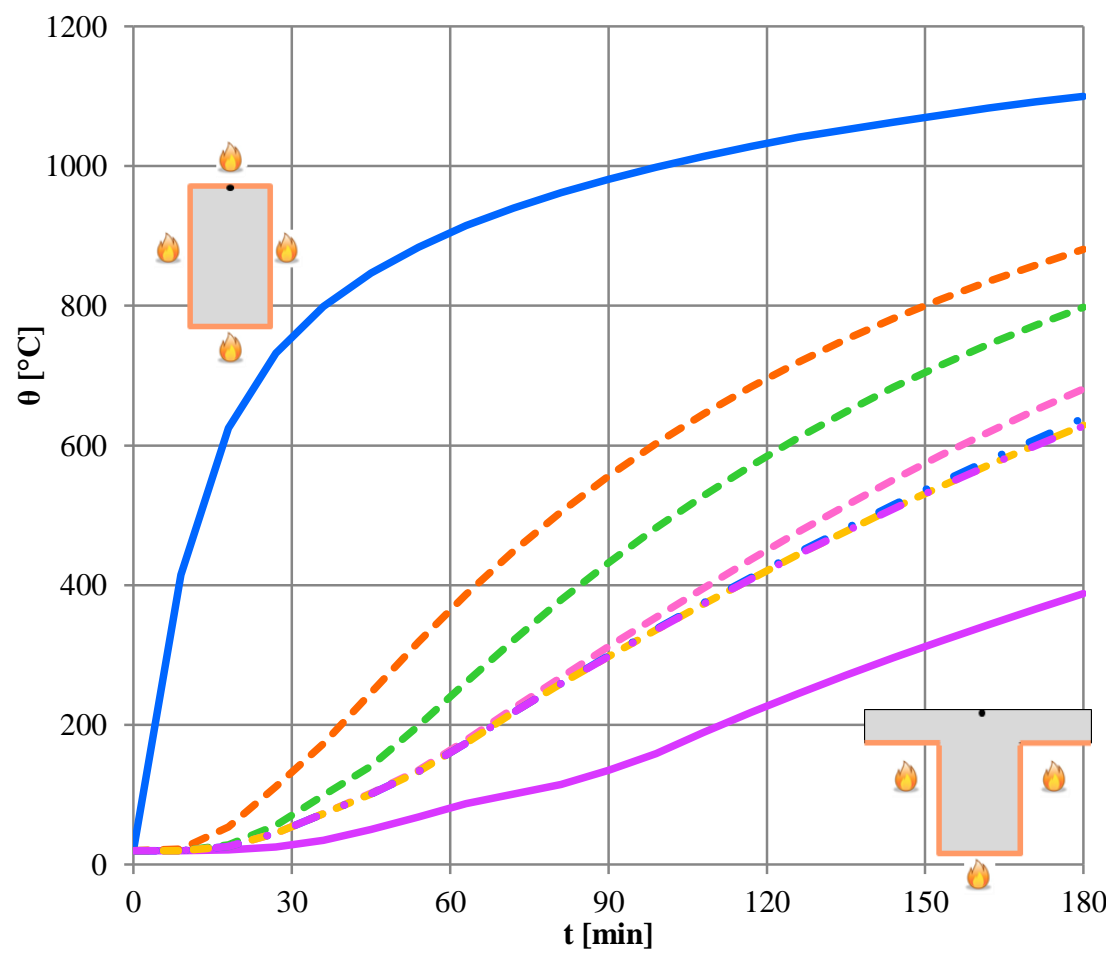

Viga com quatro faces aquecidas

- Viga sob laje com face superior adiabática

- - Tijolo refratário menos denso de $30 \mathrm{~mm}$

- - Tijolo refratário menos denso de $50 \mathrm{~mm}$

- Tijolo refratário menos denso de $100 \mathrm{~mm}$

- Tijolo refratário menos denso de $200 \mathrm{~mm}$

- - Tijolo refratário menos denso de $150 \mathrm{~mm}$

- Tijolo refratário menos denso de $300 \mathrm{~mm}$

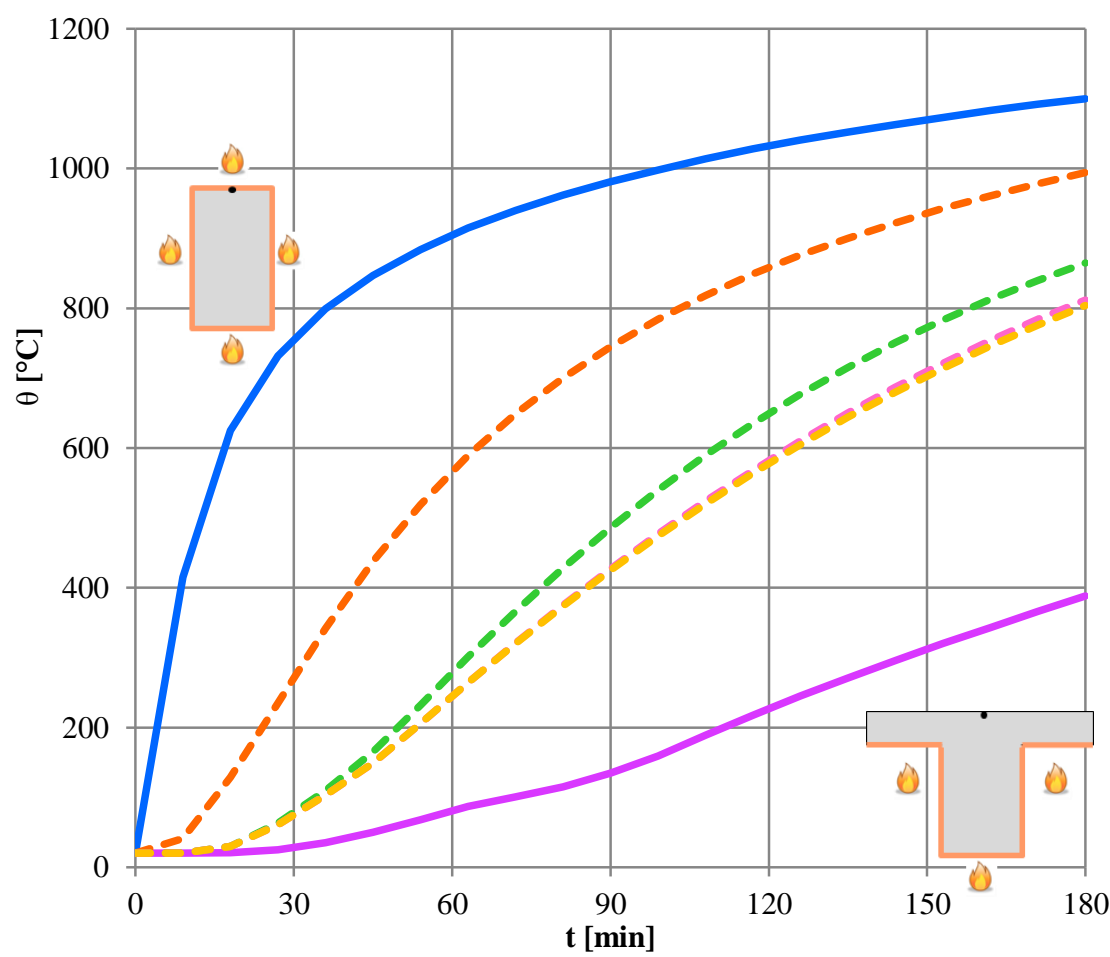

Viga com quatro faces aquecidas

Viga sob laje com face superior adiabática

- Tijolo refratário mais denso 1 de $30 \mathrm{~mm}$

- - Tijolo refratário mais denso 1 de $100 \mathrm{~mm}$

- - Tijolo refratário mais denso 1 de $200 \mathrm{~mm}$

- Tijolo refratário mais denso 1 de $400 \mathrm{~mm}$

Figura D.6 - Evolução de temperaturas para cada um dos materiais isolantes analisados (continua). 


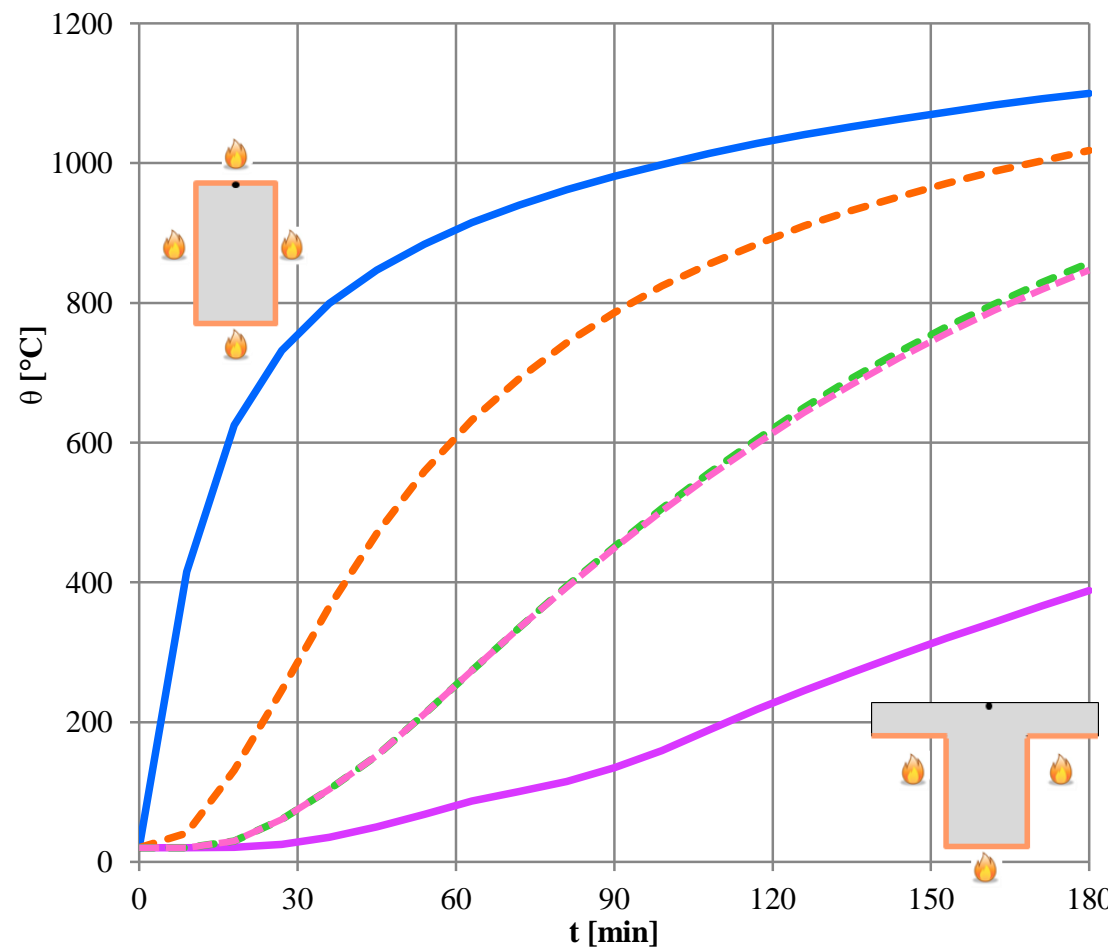

Viga com quatro faces aquecidas

- Viga sob laje com face superior adiabática

- Tijolo refratário mais denso 2 de $30 \mathrm{~mm}$

Tijolo refratário mais denso 2 de $200 \mathrm{~mm}$

- $=$ " Tijolo refratário mais denso 2 de $400 \mathrm{~mm}$

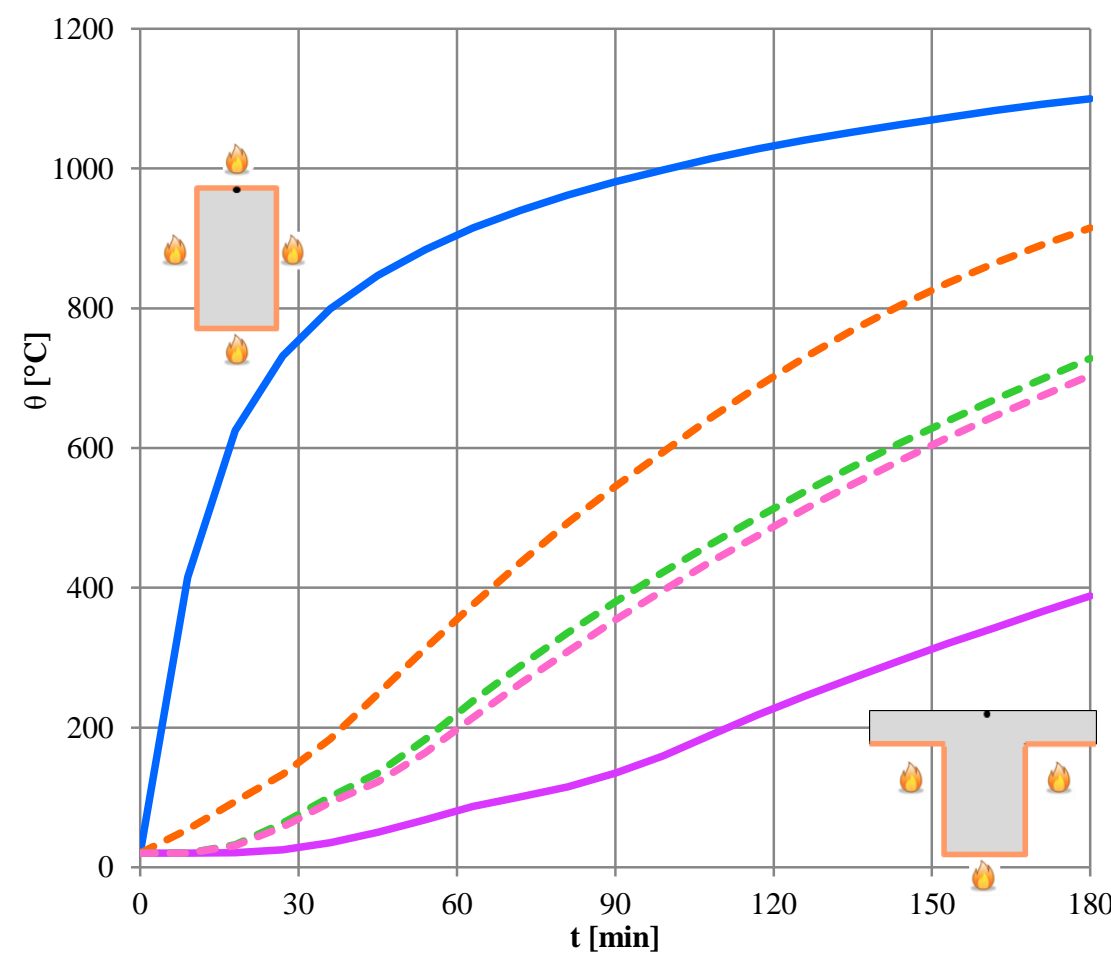

Viga com quatro faces aquecidas

Viga sob laje com face superior adiabática

Manta de fibra cerâmica de $6 \mathrm{~mm}$

- Manta de fibra cerâmica de $51 \mathrm{~mm}$

- Manta de fibra cerâmica de $102 \mathrm{~mm}$

Figura D.6 - Evolução de temperaturas para cada um dos materiais isolantes analisados (continua). 
APÊNDICE D - ESTUDO DA SIMULAÇÃO DE VIGAS SOB LAJES
Análise numérico-experimental de vigas de concreto armado com restrições axial e rotacional em situação de incêndio
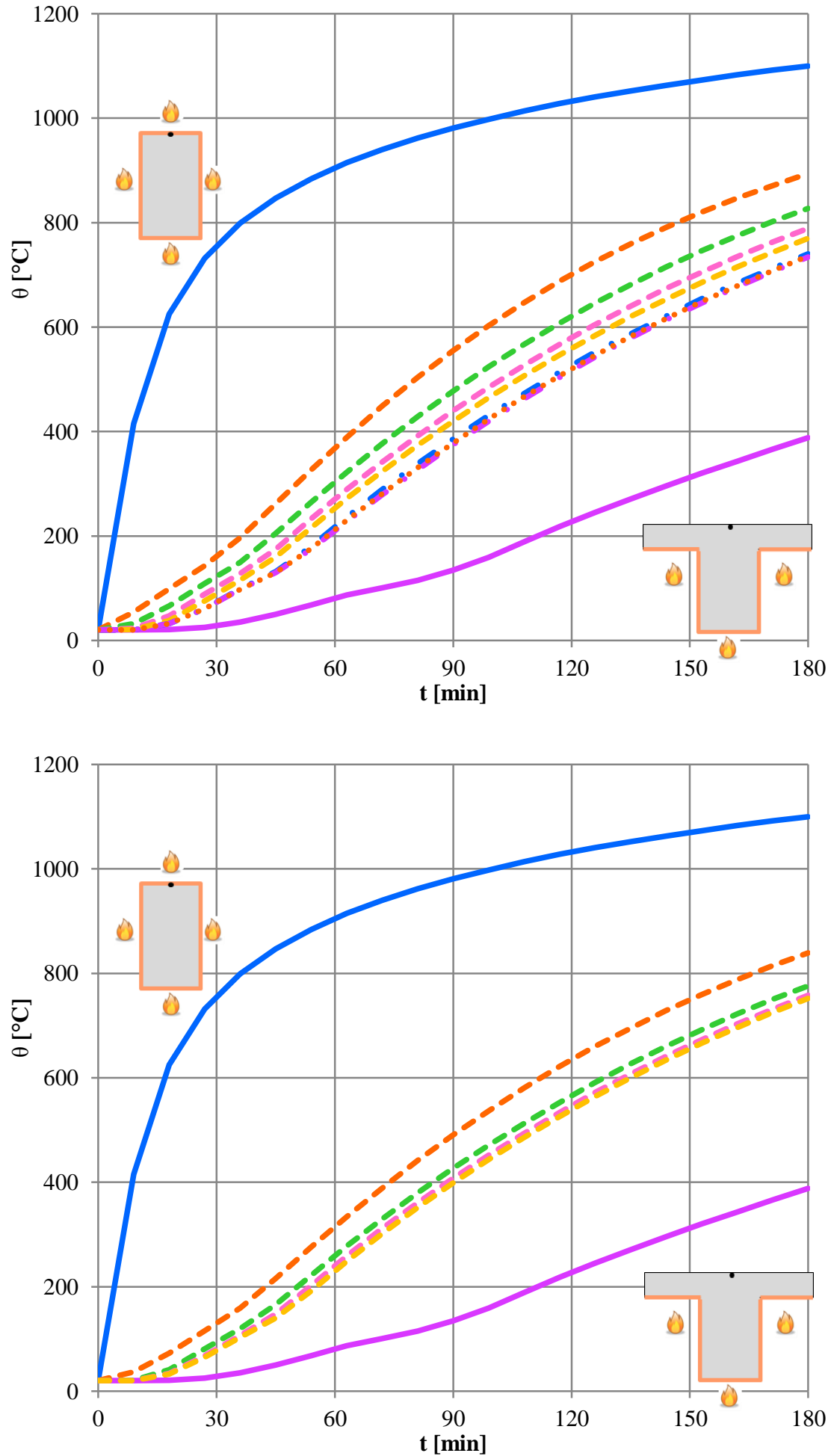

Viga com quatro faces aquecidas

_ Viga sob laje com face superior adiabática

- - Manta de lã de silicato mais densa de $13 \mathrm{~mm}$

- Manta de lã de silicato mais densa de $25 \mathrm{~mm}$

- - Manta de lã de silicato mais densa de $38 \mathrm{~mm}$

- Manta de lã de silicato mais densa de $50 \mathrm{~mm}$

- Manta de lã de silicato mais densa de $100 \mathrm{~mm}$

- Manta de lã de silicato mais densa de $150 \mathrm{~mm}$

..... Manta de lã de silicato mais densa de $125 \mathrm{~mm}$

Viga com quatro faces aquecidas

— Viga sob laje com face superior adiabática

- Manta de lã de silicato menos densa de $25 \mathrm{~mm}$

- Manta de lã de silicato menos densa de $50 \mathrm{~mm}$

- c Manta de lã de silicato menos densa de $75 \mathrm{~mm}$

- Manta de lã de silicato menos densa de $100 \mathrm{~mm}$

Figura D.6 - Evolução de temperaturas para cada um dos materiais isolantes analisados (conclusão). 


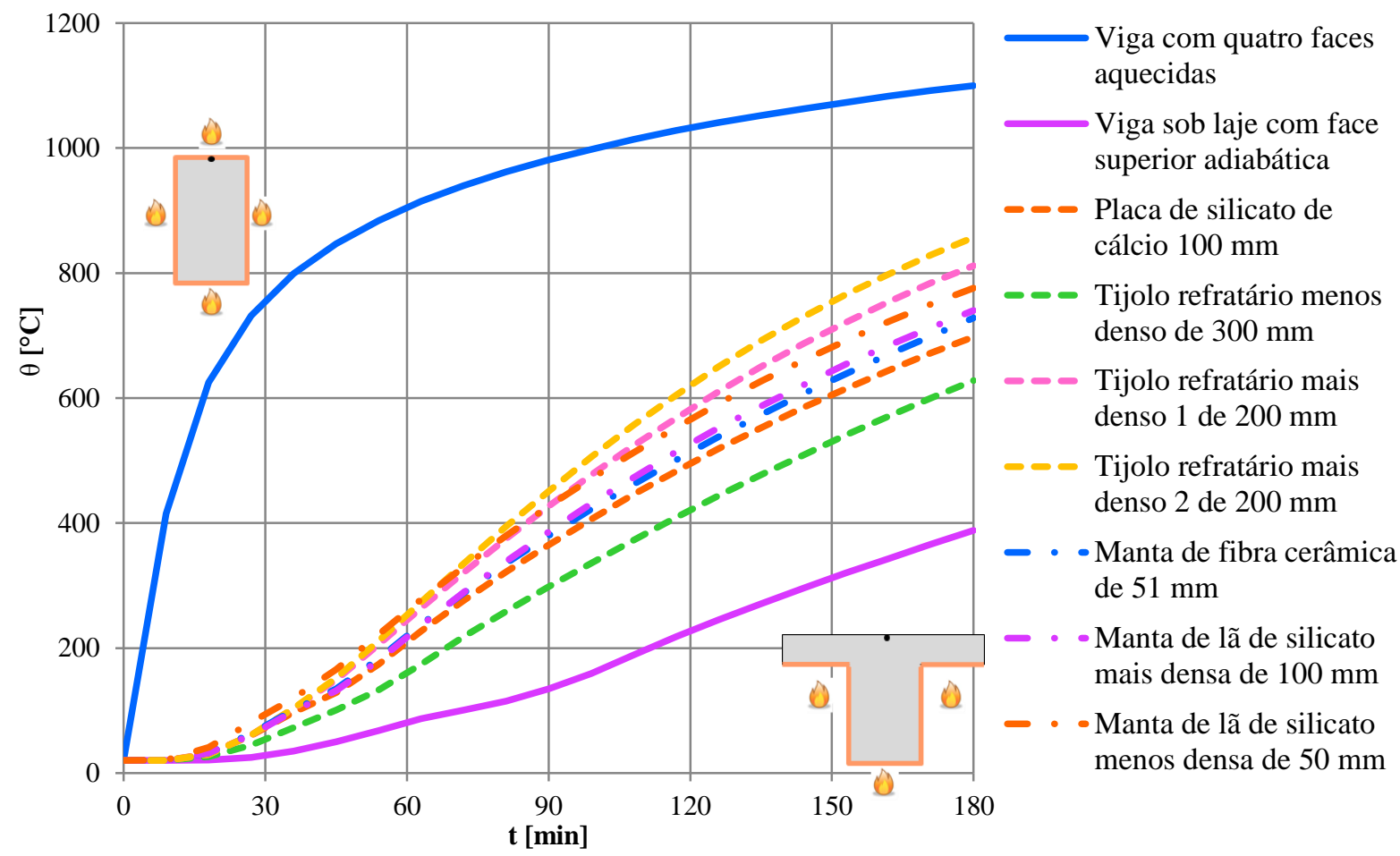

Figura D.7 - Evoluções de temperaturas representativas da melhor solução encontrada para cada um dos materiais isolantes analisados. 



\section{APÊNDICE E - DADOS DOS ENSAIOS EXPERIMENTAIS DE VIGAS AO FOGO}

\section{E.1 Vigas simplesmente apoiadas}

\section{E1.1 T_ka0_kr0}

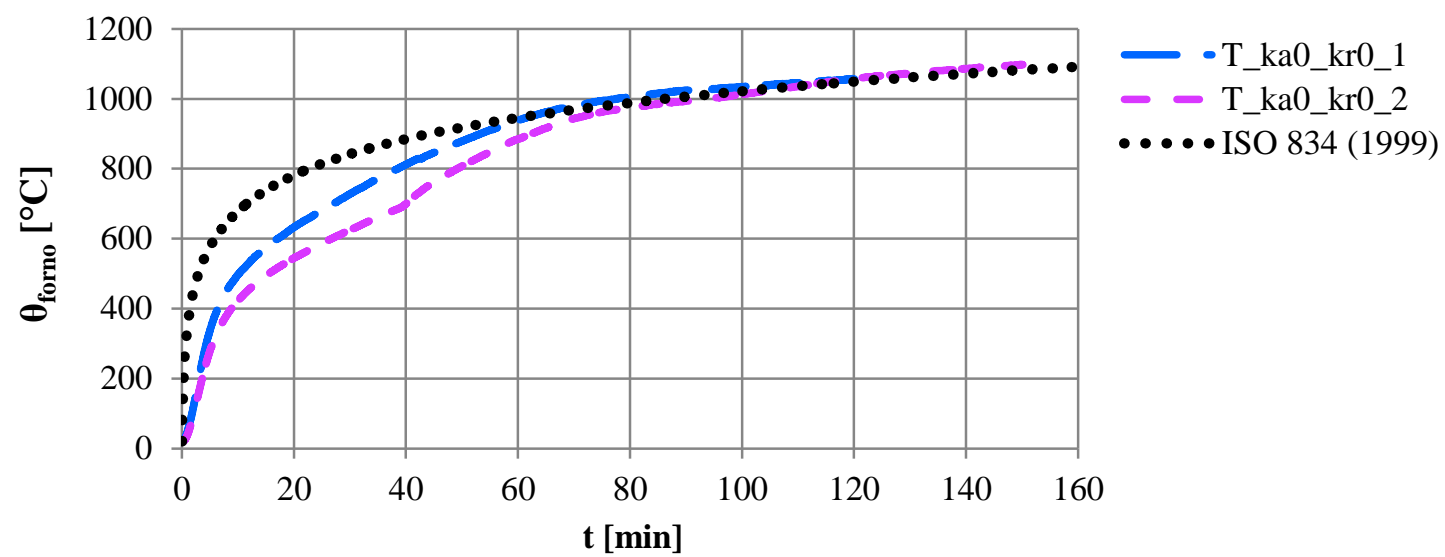

Figura E.1 - Evoluções das temperaturas do forno em função do tempo nos ensaios T_ka0_kr0.
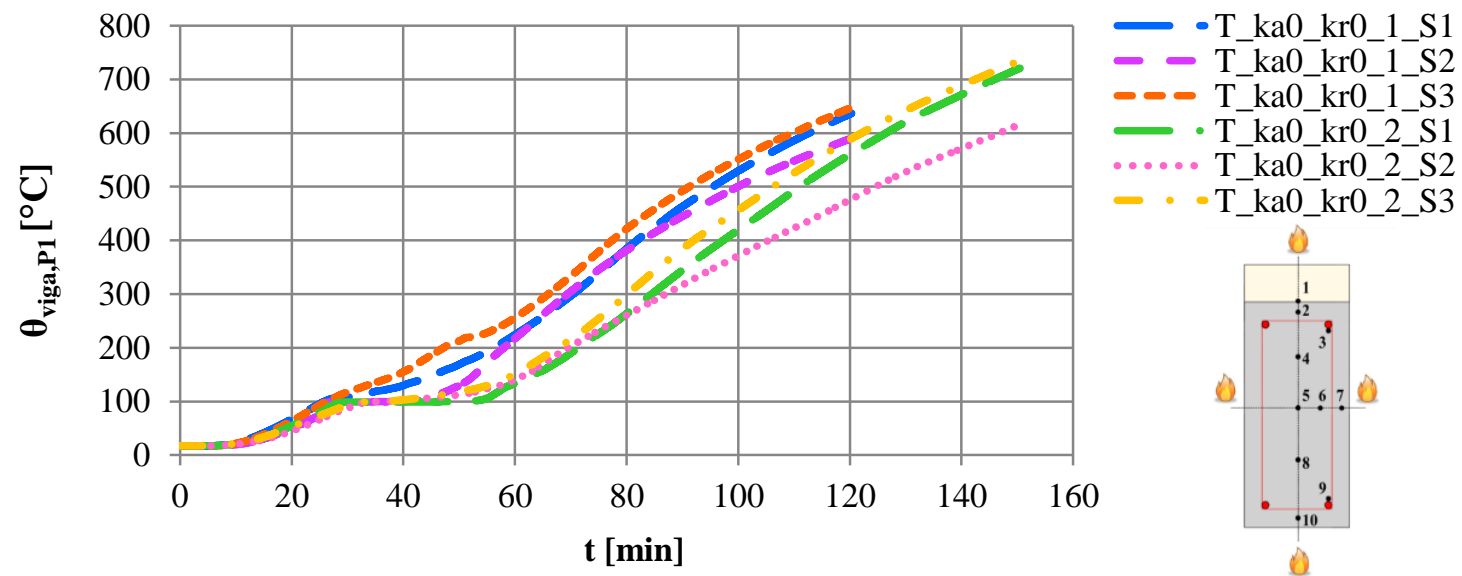

Figura E.2 - Evoluções das temperaturas da interface concreto/manta (ponto 1) em função do tempo nos ensaios T_ka0_kr0. 
APÊNDICE E - DADOS DOS ENSAIOS EXPERIMENTAIS DE VIGAS AO FOGO
Análise numérico-experimental de vigas de concreto armado com restrições axial e rotacional em situação de incêndio
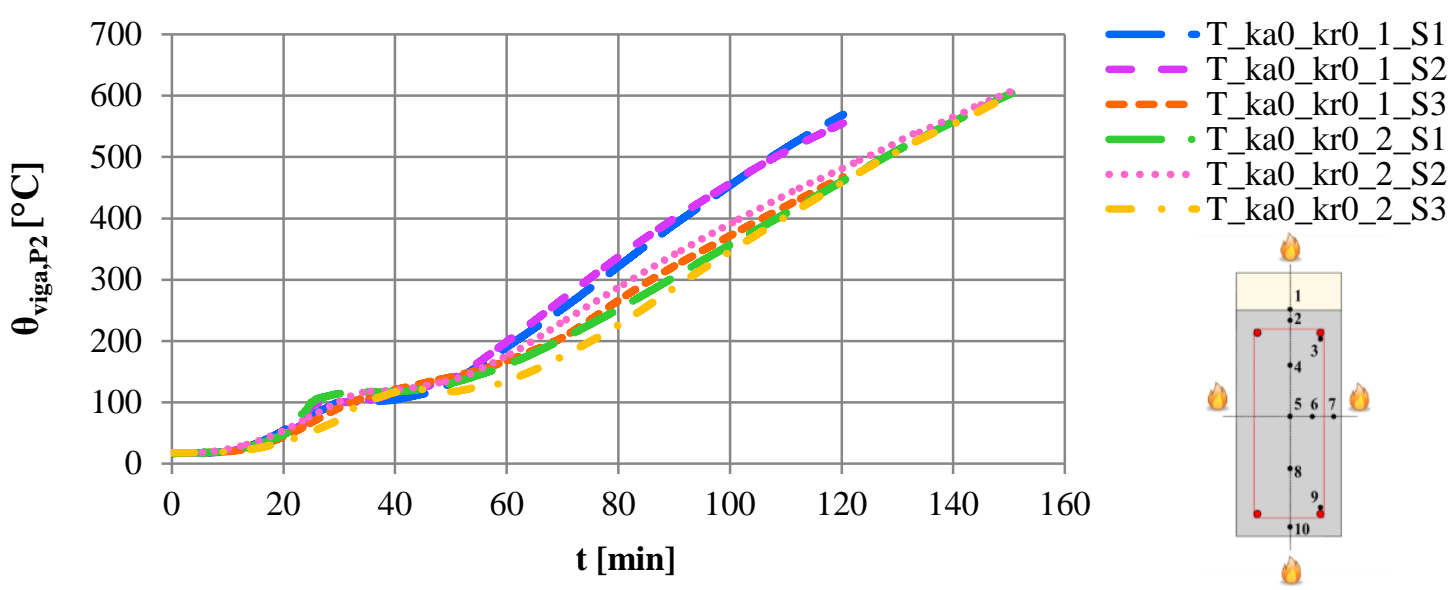

Figura E.3 - Evoluções das temperaturas do concreto (ponto 2) em função do tempo nos ensaios T_ka0_kr0.
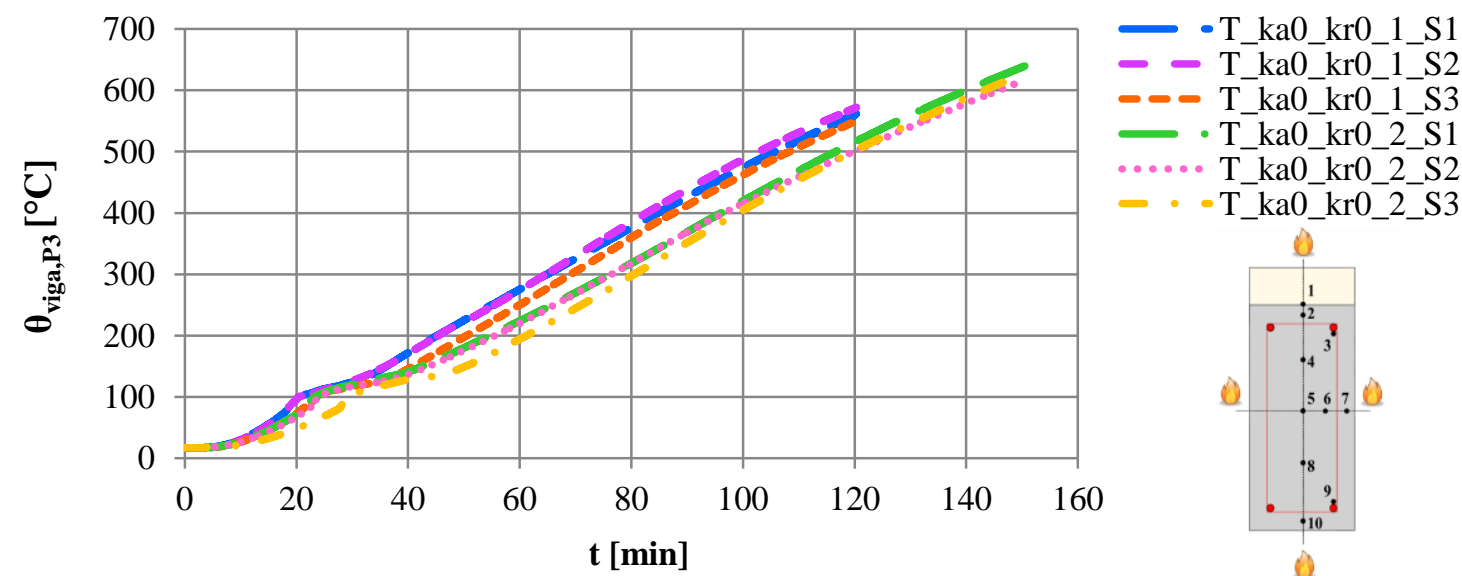

Figura E.4 - Evoluções das temperaturas da armadura (ponto 3) em função do tempo nos ensaios T_ka0_kr0.
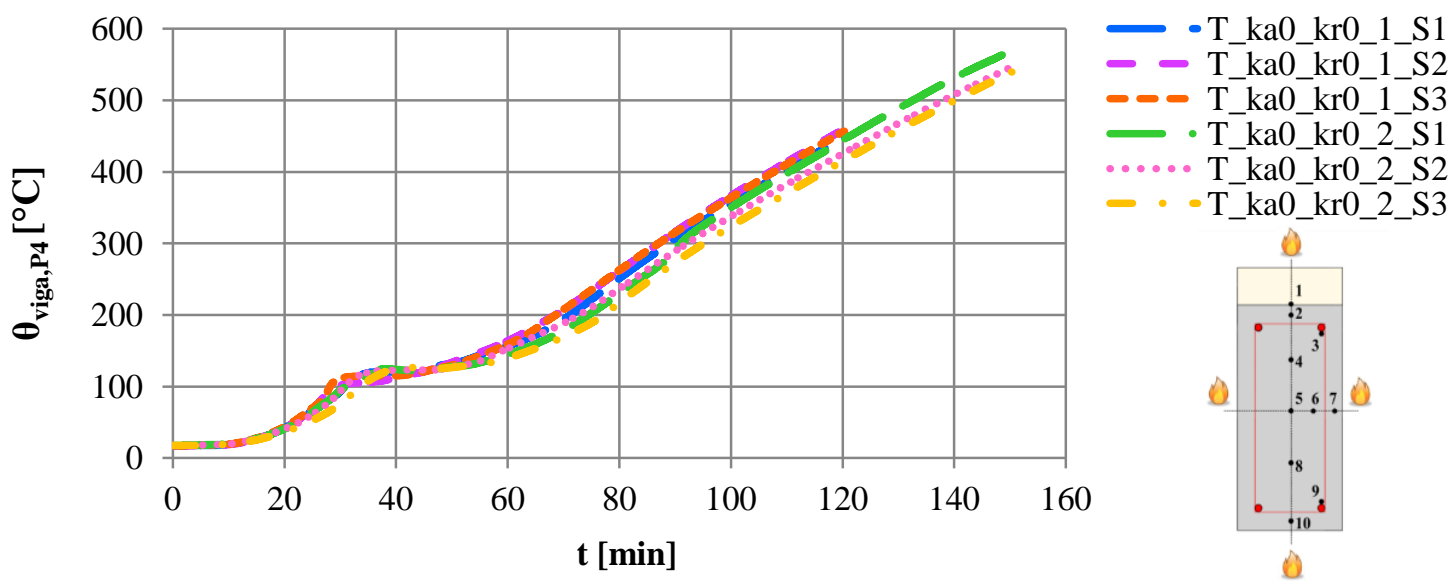

Figura E.5 - Evoluções das temperaturas do concreto (ponto 4) em função do tempo nos ensaios T_ka0_kr0. 

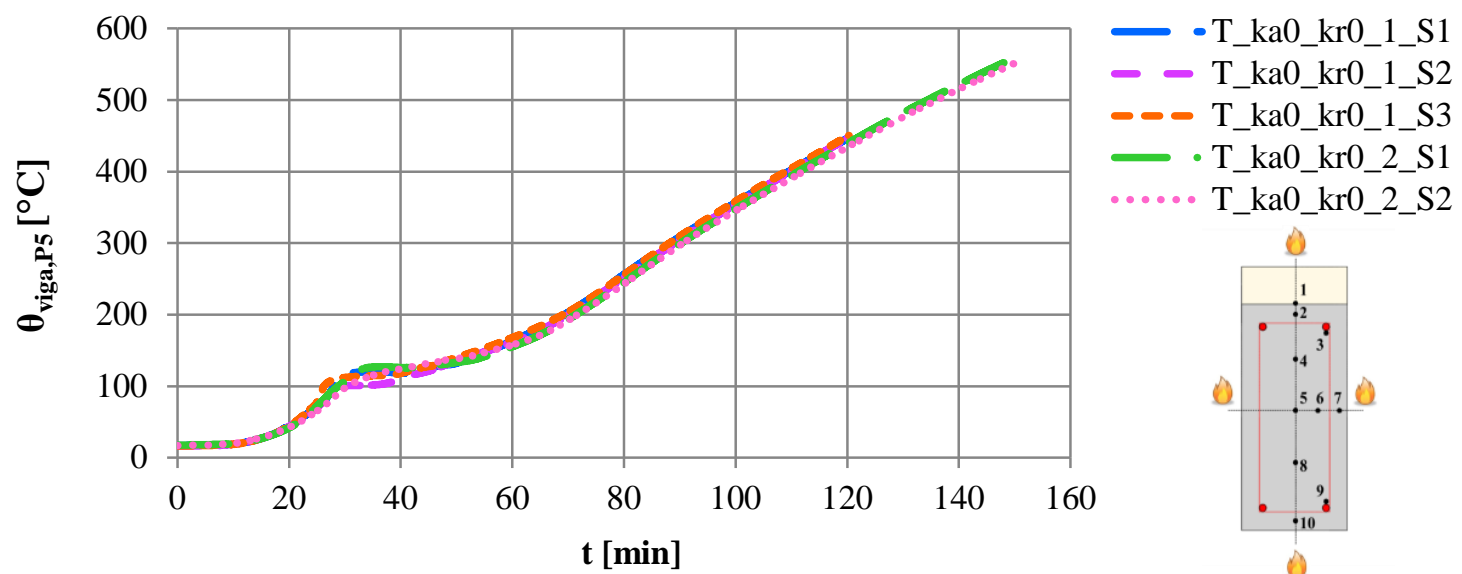

Figura E.6 - Evoluções das temperaturas do concreto (ponto 5) em função do tempo nos ensaios T_ka0_kr0.
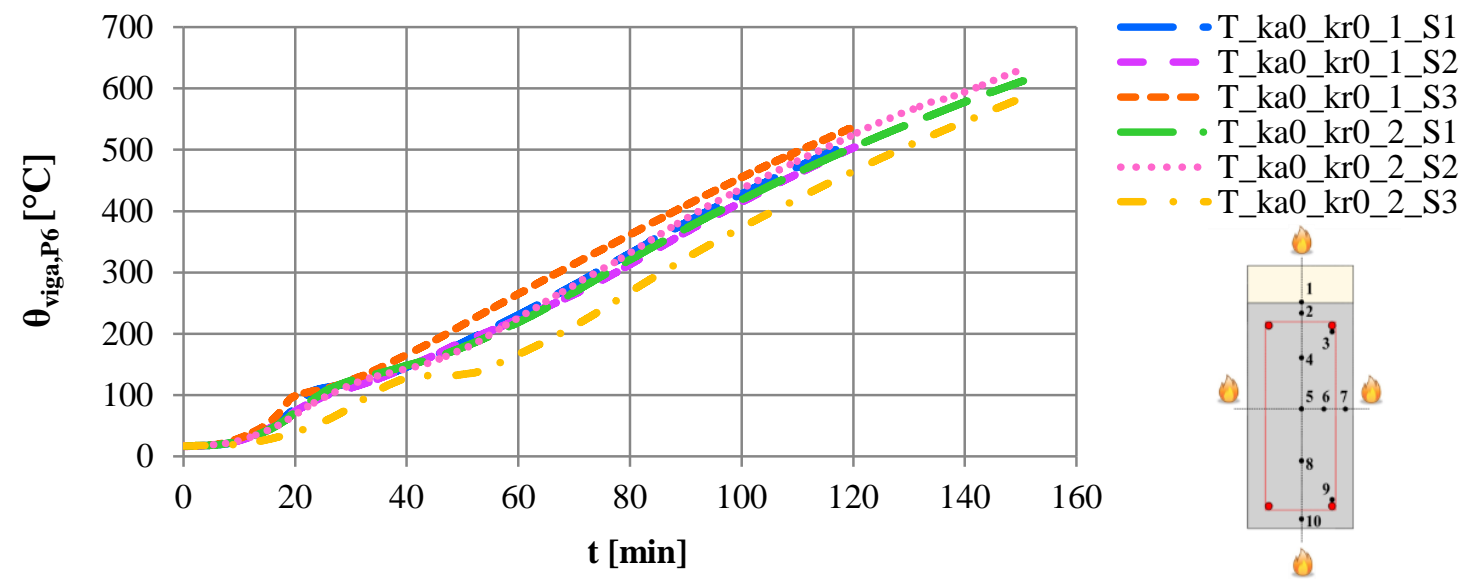

Figura E.7 - Evoluções das temperaturas do concreto (ponto 6) em função do tempo nos ensaios T_ka0_kr0.
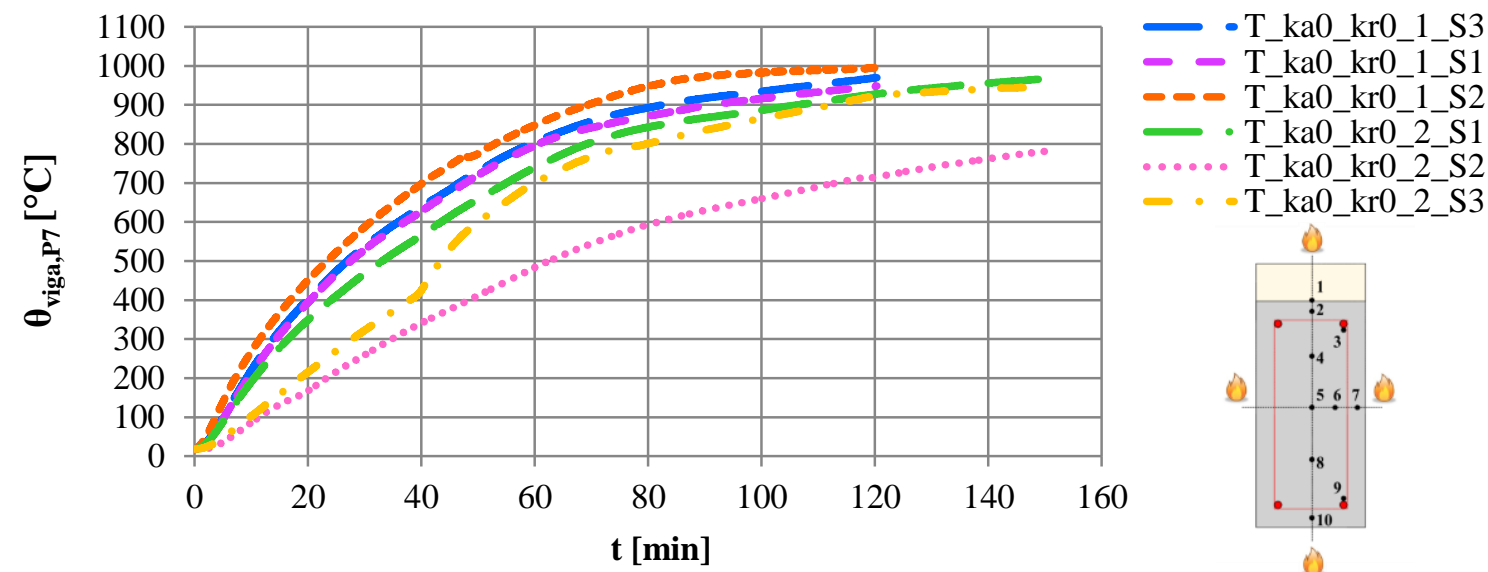

Figura E.8 - Evoluções das temperaturas do concreto (ponto 7) em função do tempo nos ensaios T_ka0_kr0. 
APÊNDICE E - DADOS DOS ENSAIOS EXPERIMENTAIS DE VIGAS AO FOGO
Análise numérico-experimental de vigas de concreto armado com restrições axial e rotacional em situação de incêndio
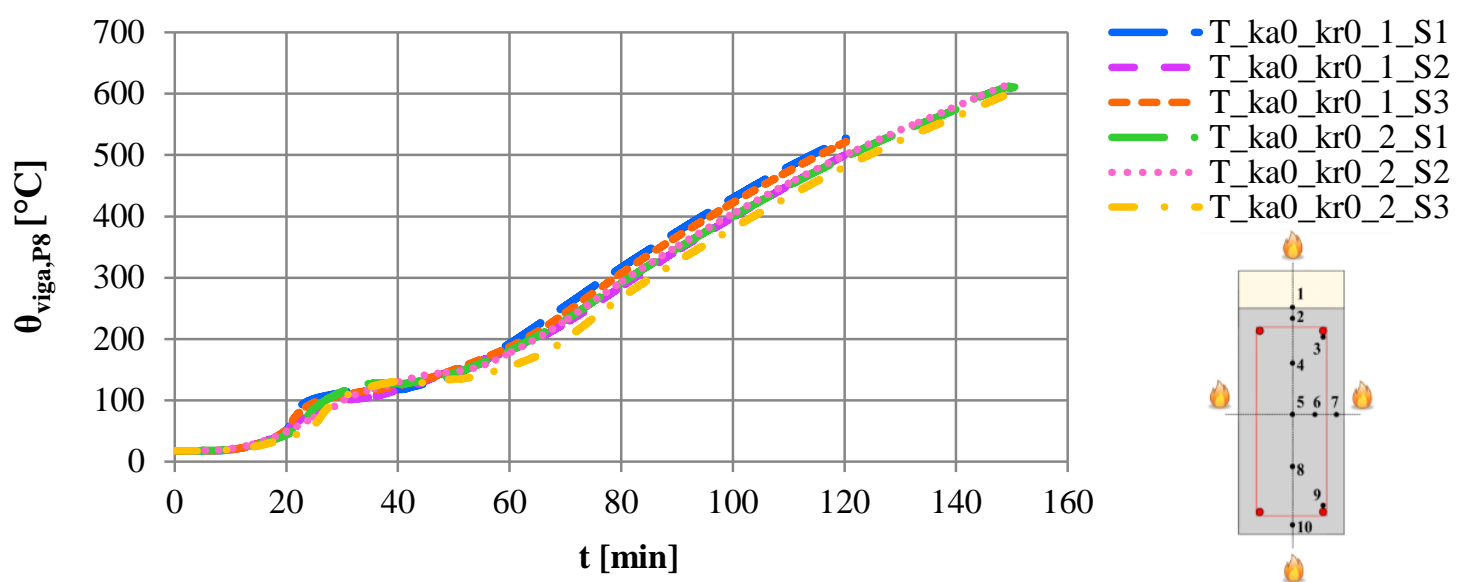

Figura E.9 - Evoluções das temperaturas do concreto (ponto 8) em função do tempo nos ensaios T_ka0_kr0.
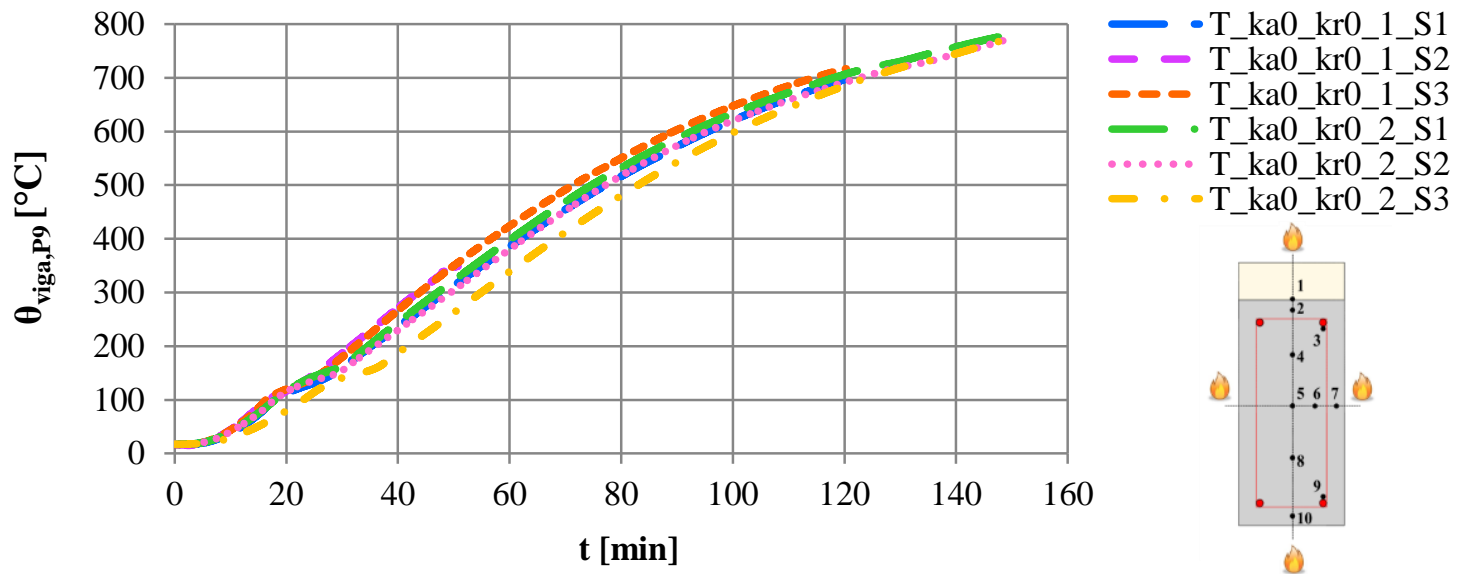

Figura E.10 - Evoluções das temperaturas da armadura (ponto 9) em função do tempo nos ensaios T_ka0_kr0.
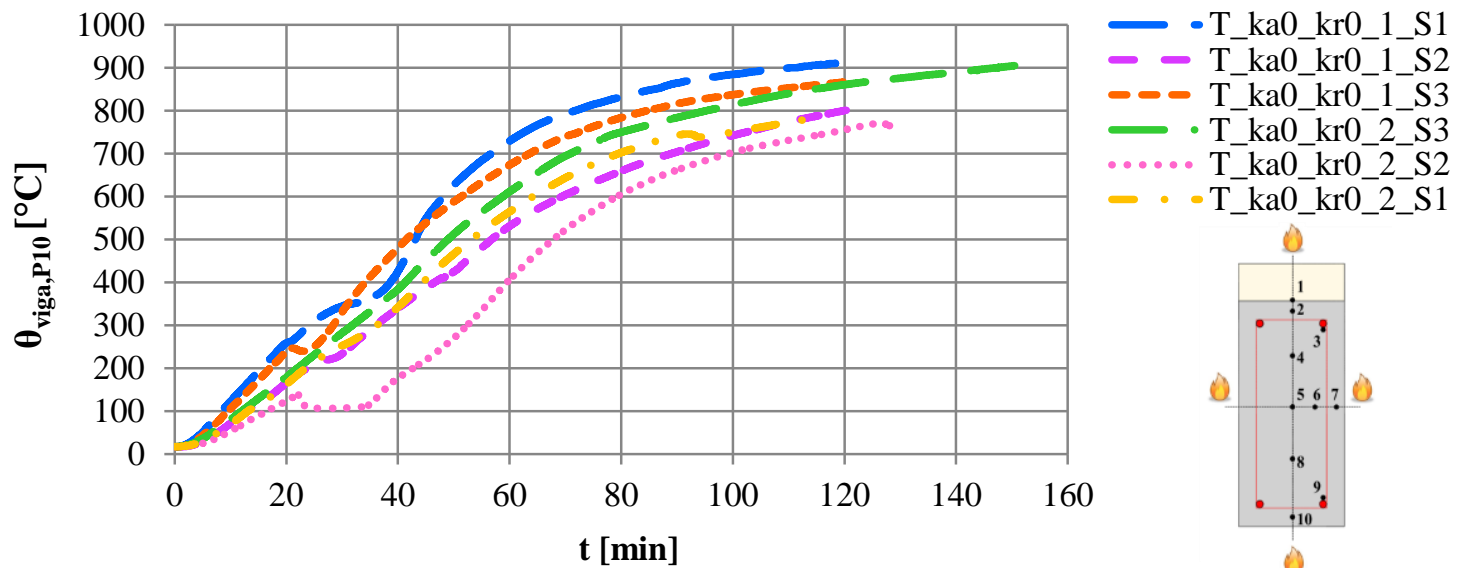

Figura E.11 - Evoluções das temperaturas do concreto (ponto 10) em função do tempo nos ensaios T_ka0_kr0. 


\section{E1.2 ka0_kr0*}

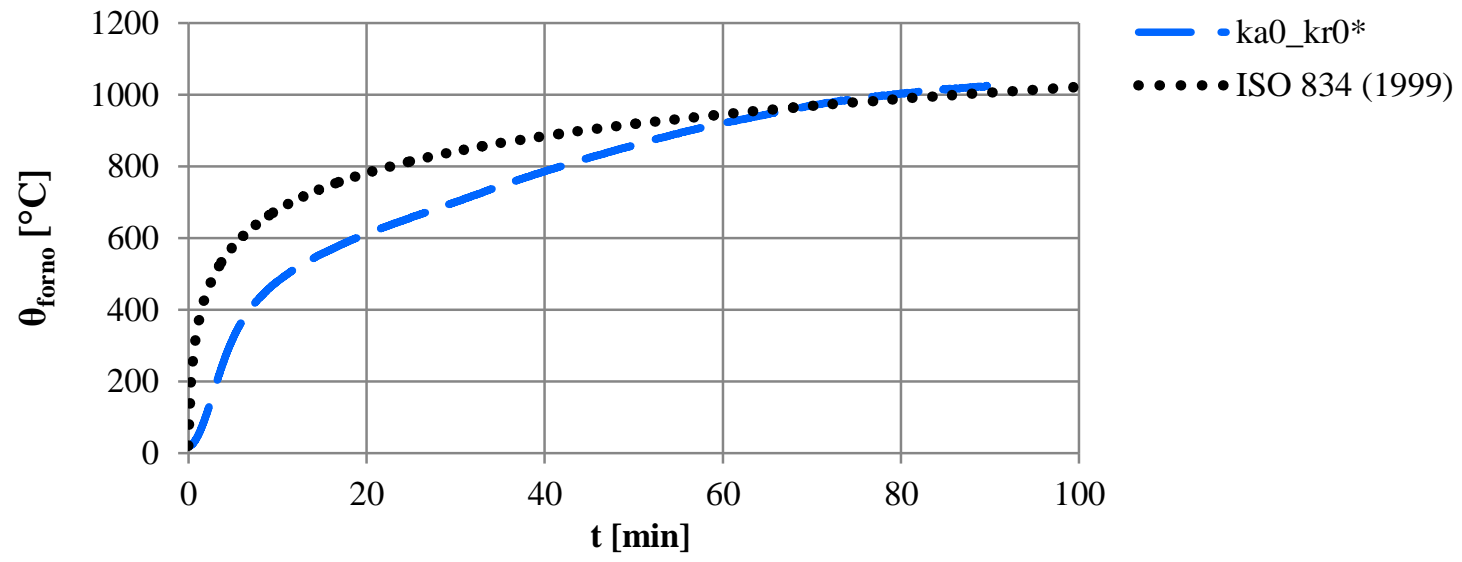

Figura E.12 - Evoluções das temperaturas do forno em função do tempo no ensaio ka0_kr0*.
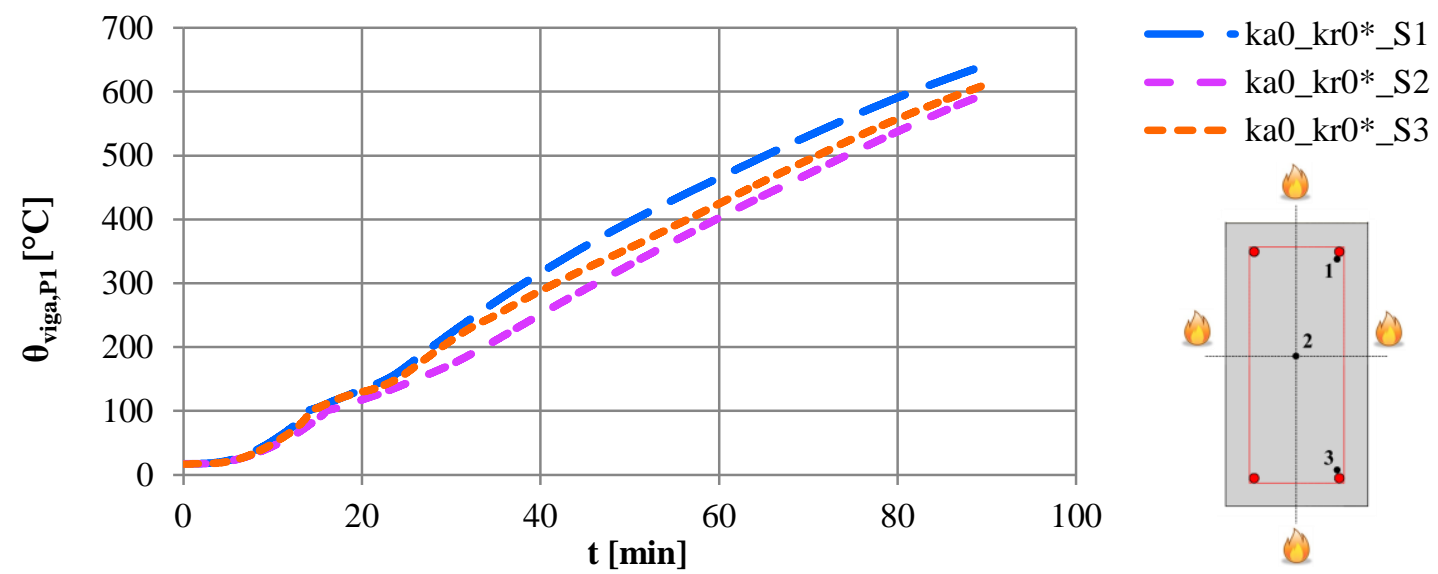

Figura E.13 - Evoluções das temperaturas da armadura (ponto 1) em função do tempo no ensaio ka0_kr0*.
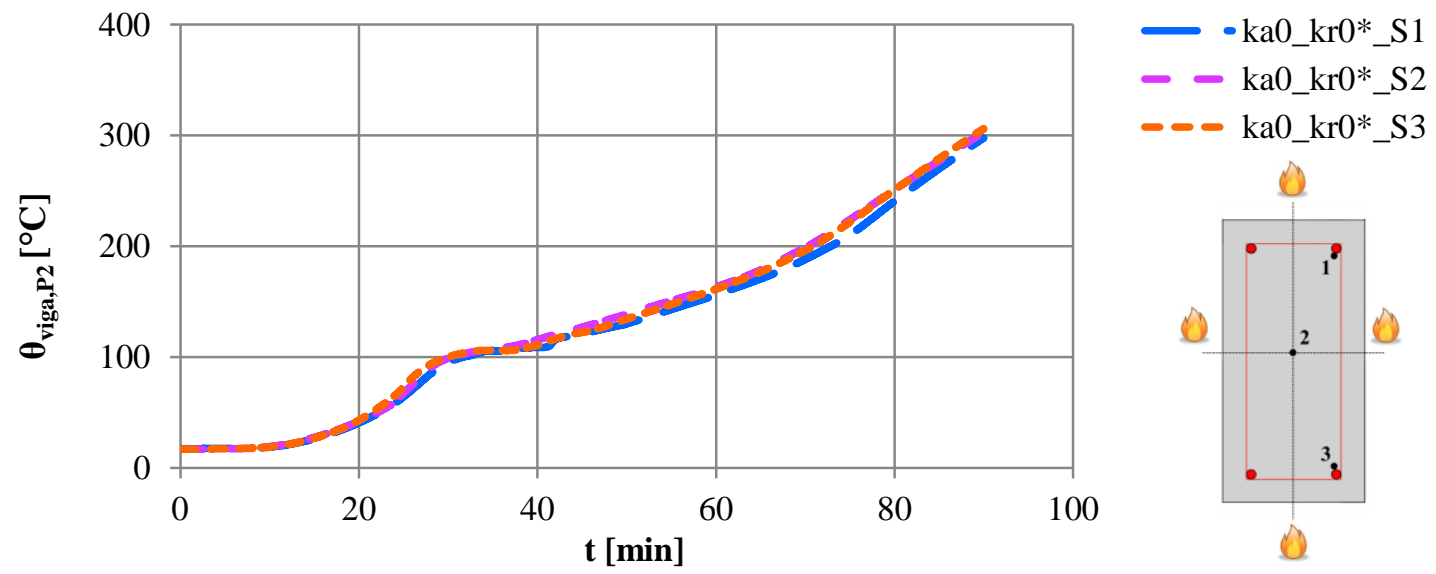

Figura E.14 - Evoluções das temperaturas do concreto (ponto 2) em função do tempo no ensaio ka0_kr0*. 
APÊNDICE E - DADOS DOS ENSAIOS EXPERIMENTAIS DE VIGAS AO FOGO
Análise numérico-experimental de vigas de concreto armado com restrições axial e rotacional em situação de incêndio
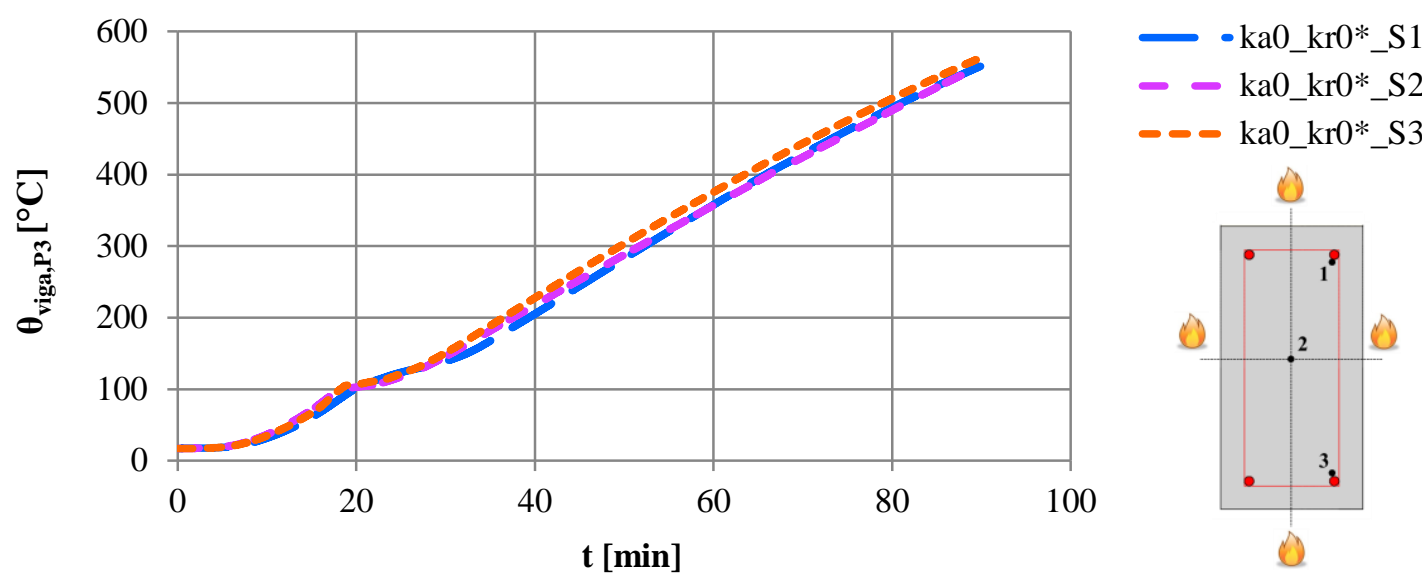

Figura E.15 - Evoluções das temperaturas da armadura (ponto 3) em função do tempo no ensaio ka0_kr0*.

\section{E1.3 ka0_kr0}

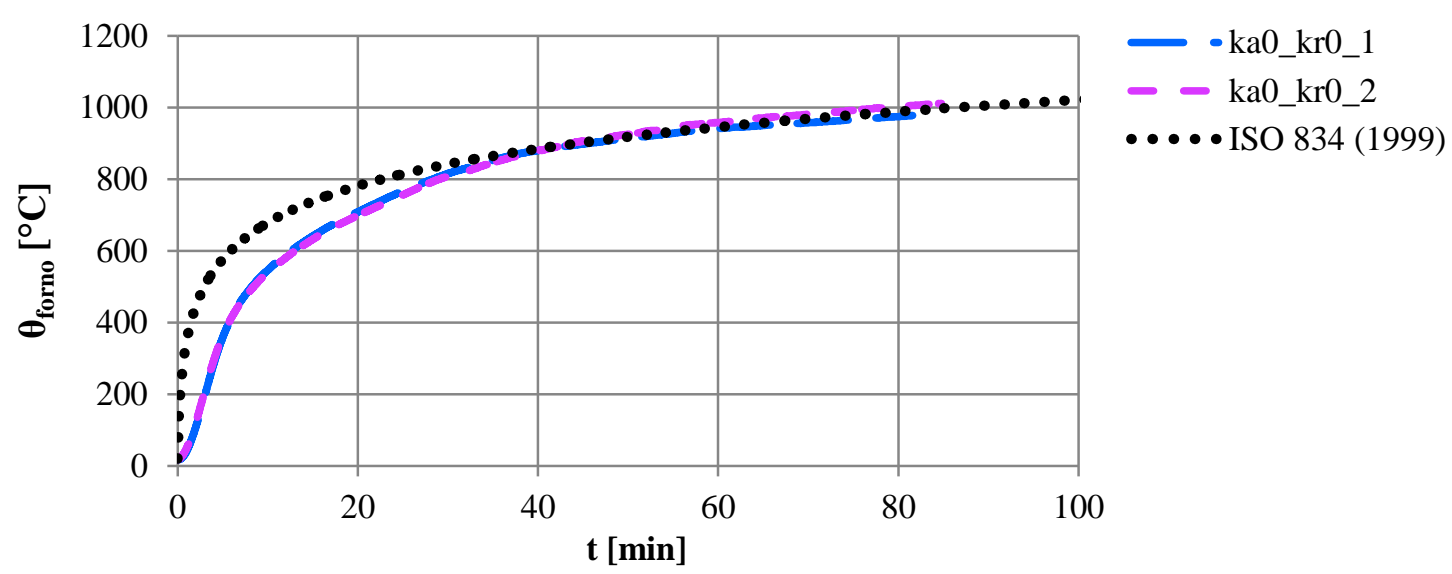

Figura E.16 - Evoluções das temperaturas do forno em função do tempo nos ensaios ka0_kr0.
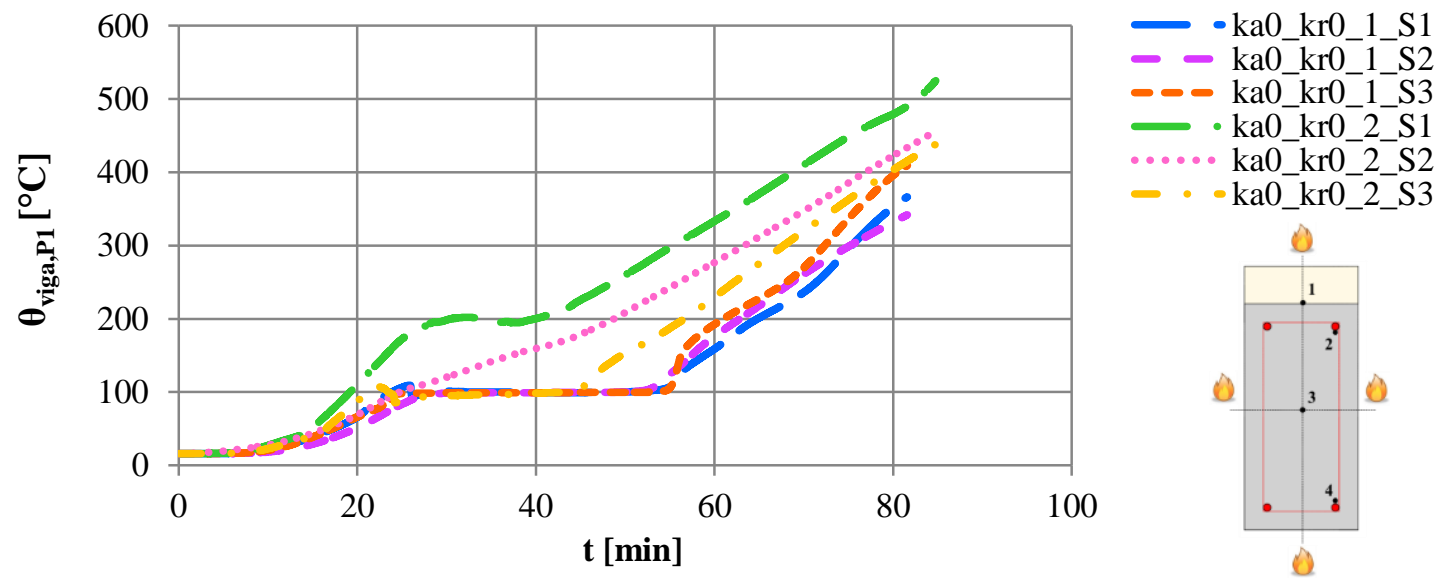

Figura E.17 - Evoluções das temperaturas da interface concreto/manta (ponto 1) em função do tempo nos ensaios ka0_kr0. 

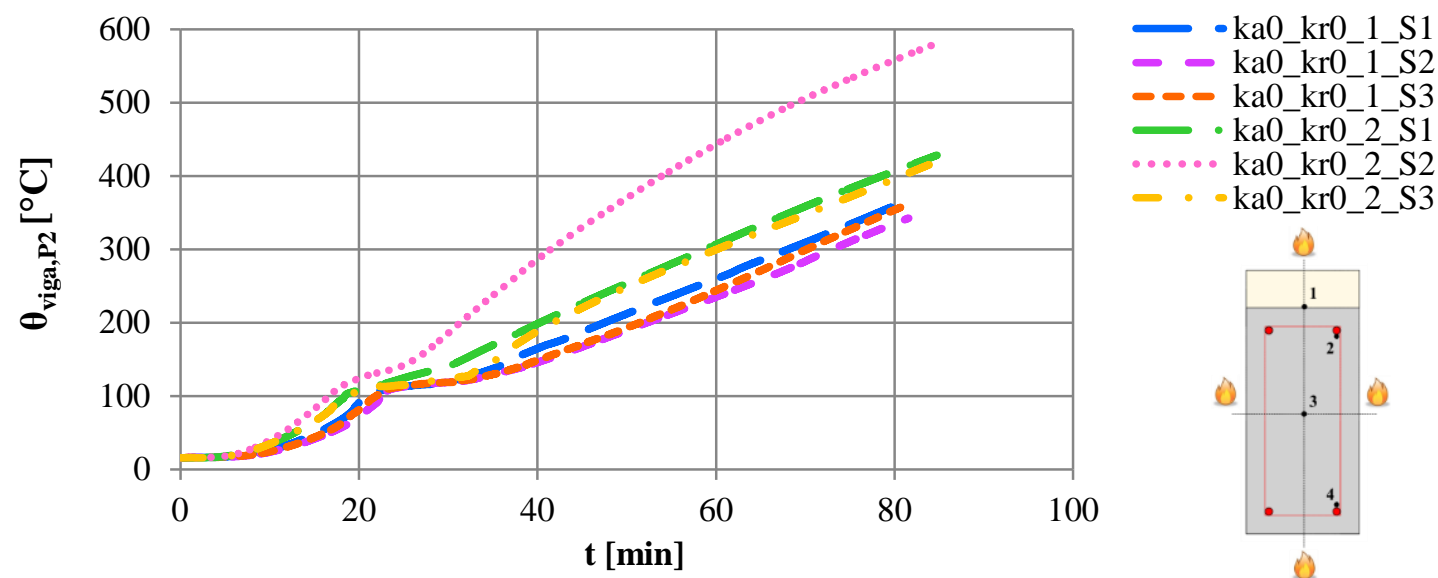

Figura E.18 - Evoluções das temperaturas da armadura (ponto 2) em função do tempo nos ensaios ka0_kr0.
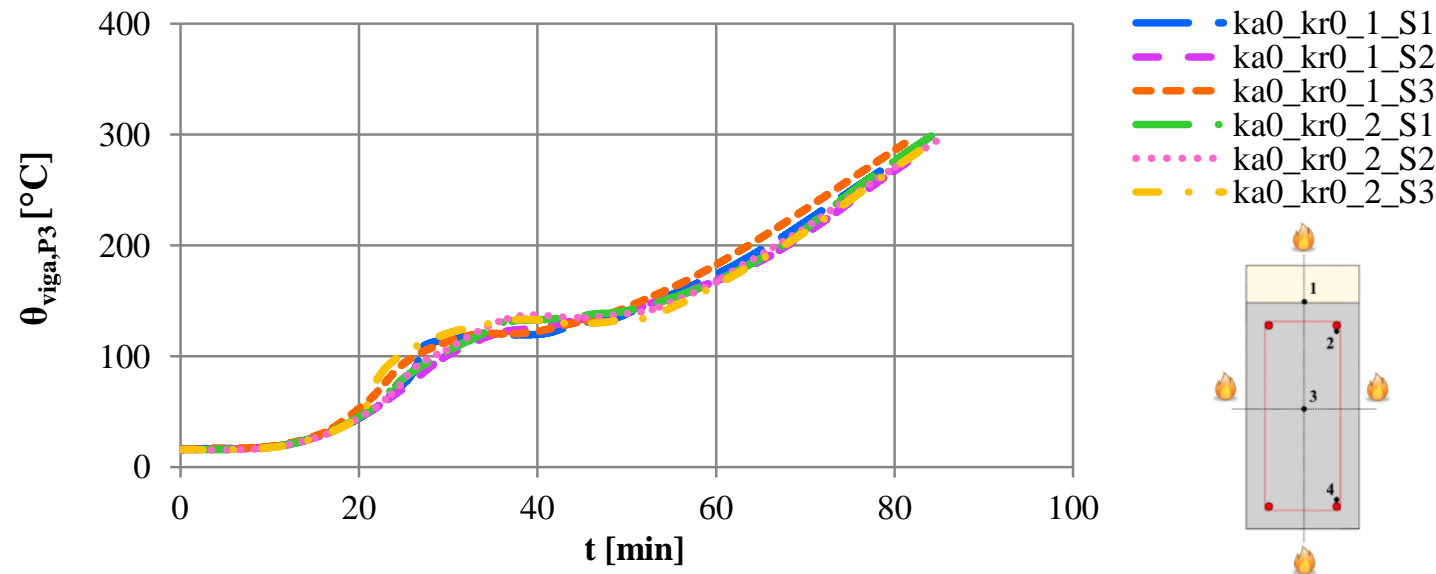

Figura E.19 - Evoluções das temperaturas do concreto (ponto 3) em função do tempo nos ensaios ka0_kr0.
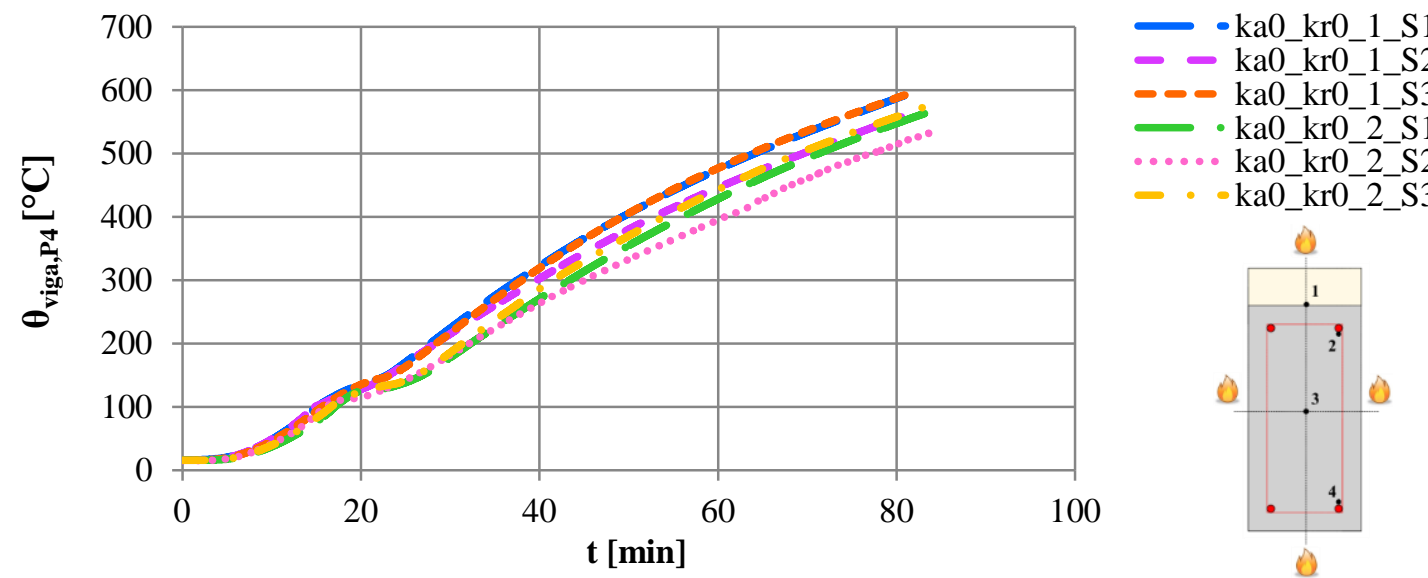

Figura E.20 - Evoluções das temperaturas da armadura (ponto 4) em função do tempo nos ensaios ka0_kr0. 
APÊNDICE E - DADOS DOS ENSAIOS EXPERIMENTAIS DE VIGAS AO FOGO
Análise numérico-experimental de vigas de concreto armado com restrições axial e rotacional em situação de incêndio

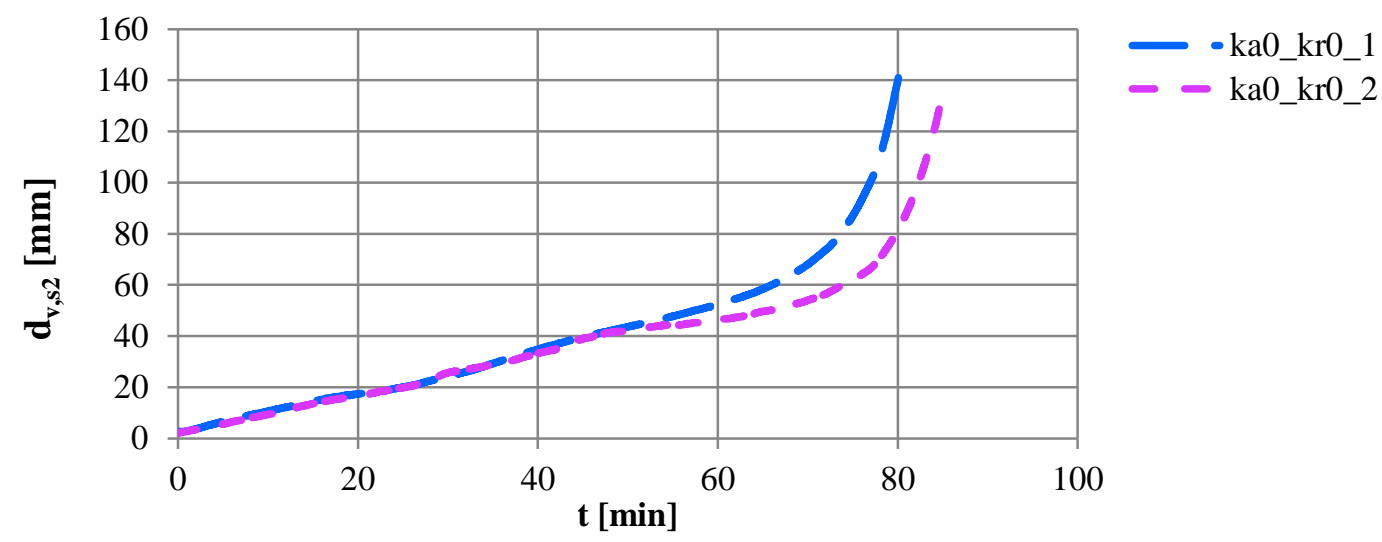

Figura E.21 - Evoluções das flechas em função do tempo nos ensaios ka0_kr0.

\section{E.2 Vigas com restrição axial}

\section{E2.1 ka1_kr0}

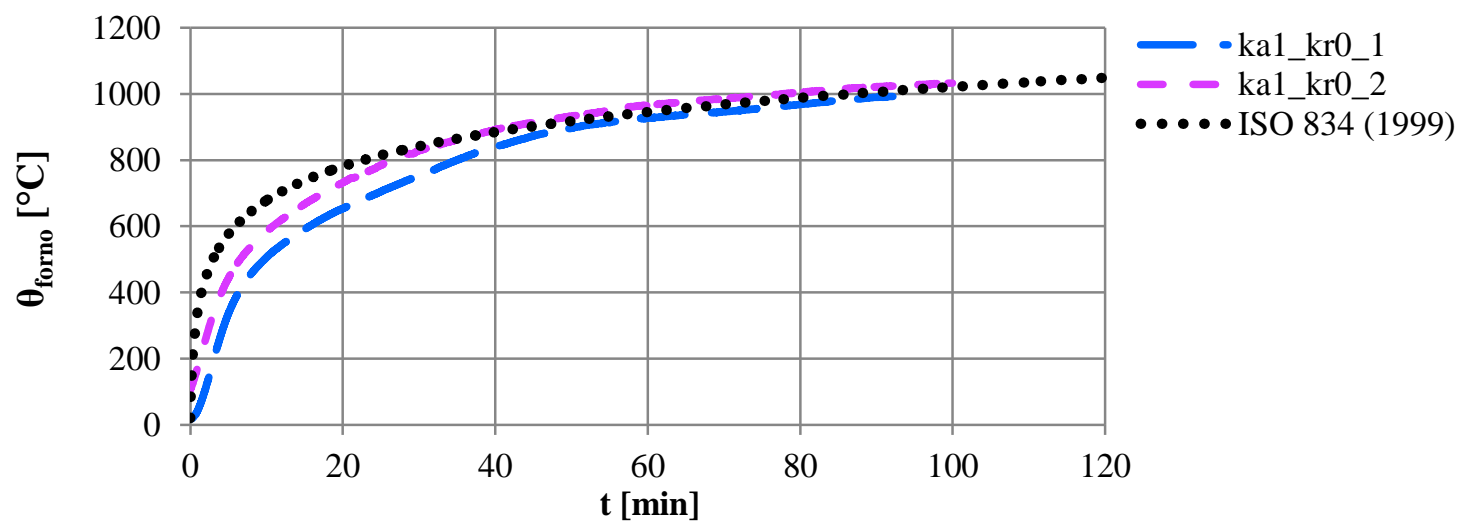

Figura E.22 - Evoluções das temperaturas do forno em função do tempo nos ensaios ka1_kr0.
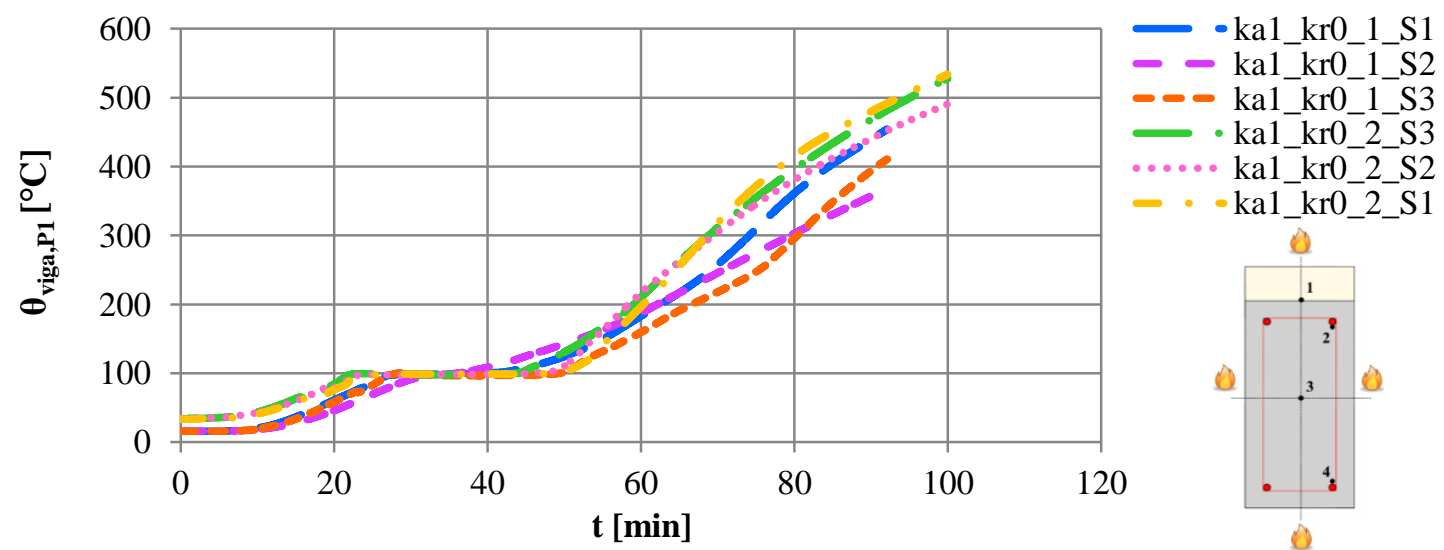

Figura E.23 - Evoluções das temperaturas da interface concreto/manta (ponto 1) em função do tempo nos ensaios ka1_kr0. 

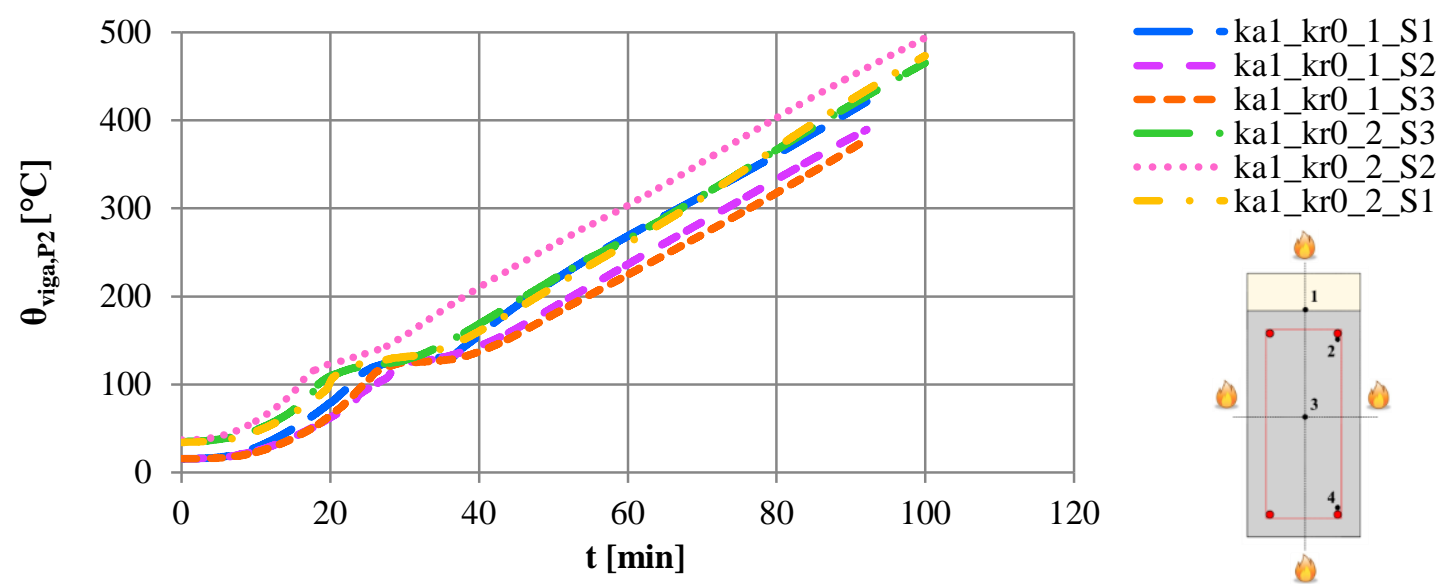

Figura E.24 - Evoluções das temperaturas da armadura (ponto 2) em função do tempo nos ensaios ka1_kr0.
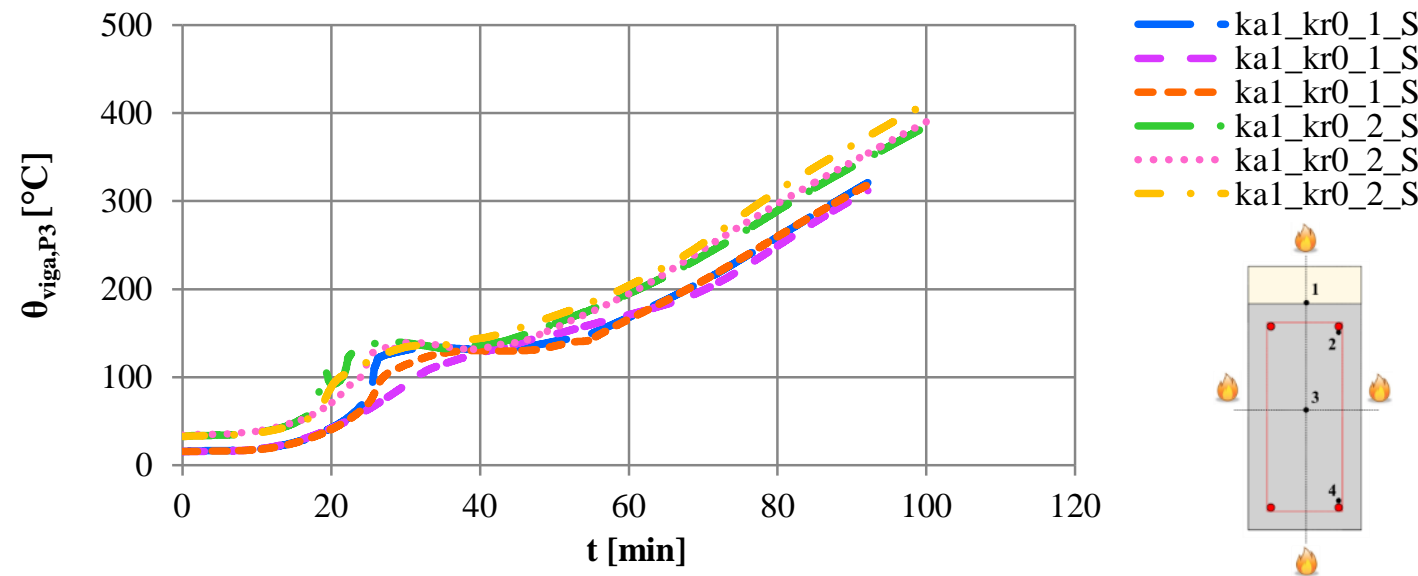

Figura E.25 - Evoluções das temperaturas do concreto (ponto 3) em função do tempo nos ensaios ka1_kr0.
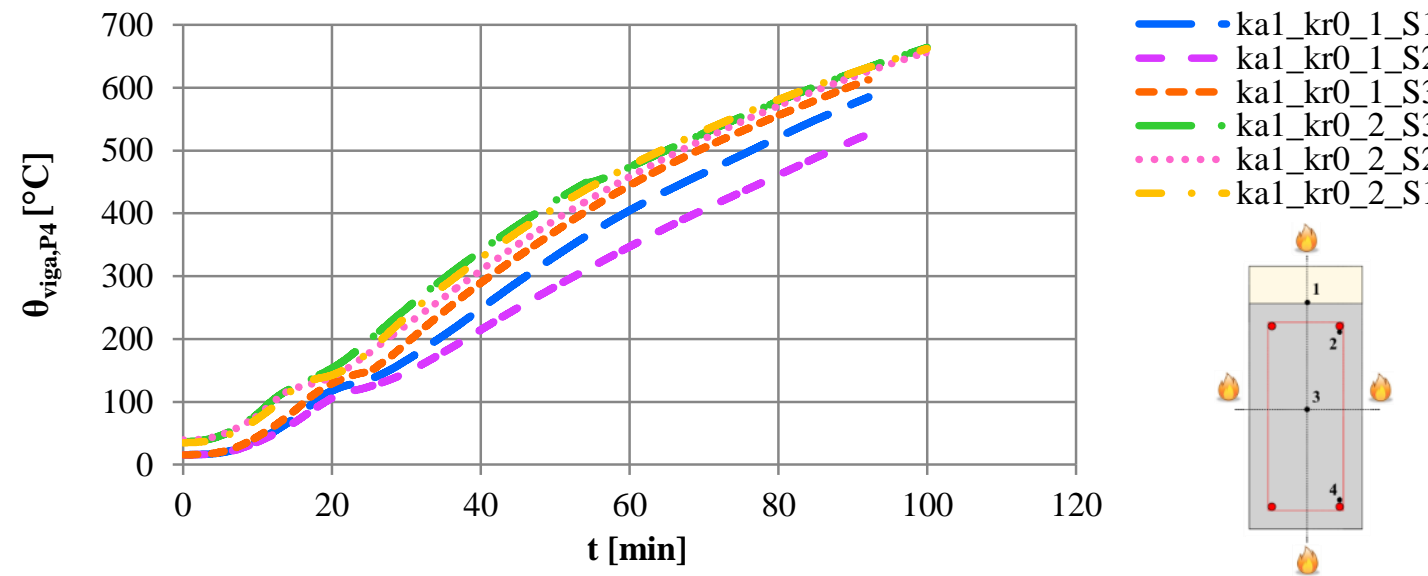

Figura E.26 - Evoluções das temperaturas da armadura (ponto 4) em função do tempo nos ensaios ka1_kr0. 
APÊNDICE E - DADOS DOS ENSAIOS EXPERIMENTAIS DE VIGAS AO FOGO
Análise numérico-experimental de vigas de concreto armado com restrições axial e rotacional em situação de incêndio

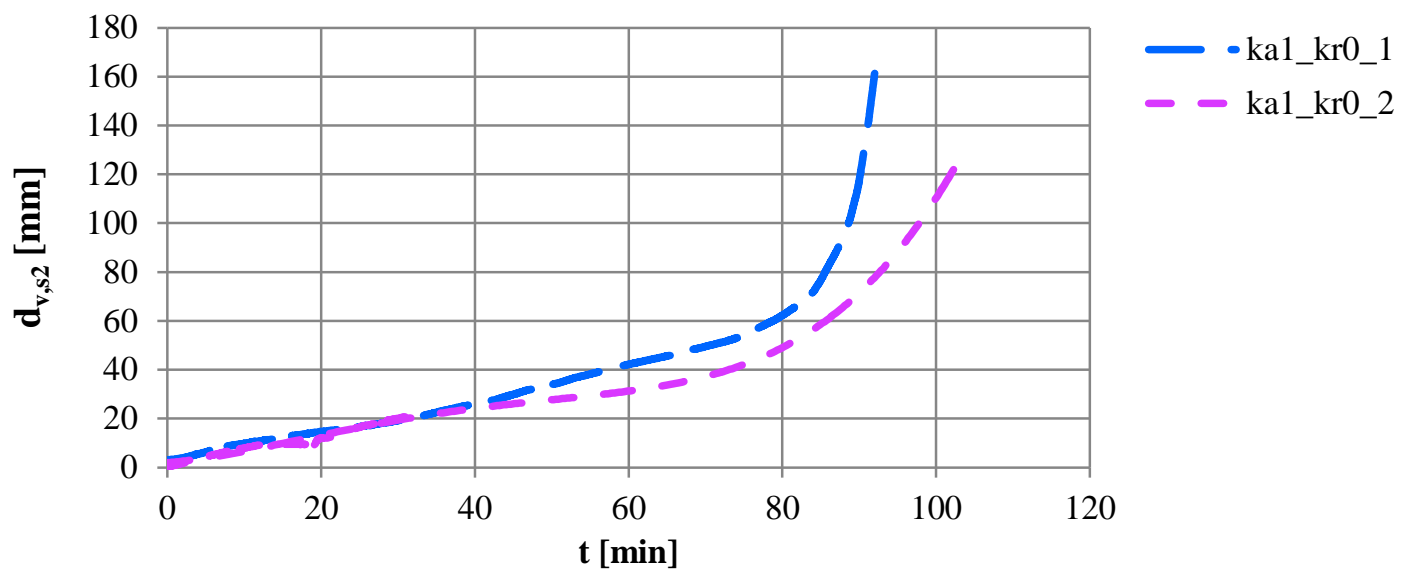

Figura E.27 - Evoluções das flechas em função do tempo nos ensaios ka1_kr0.

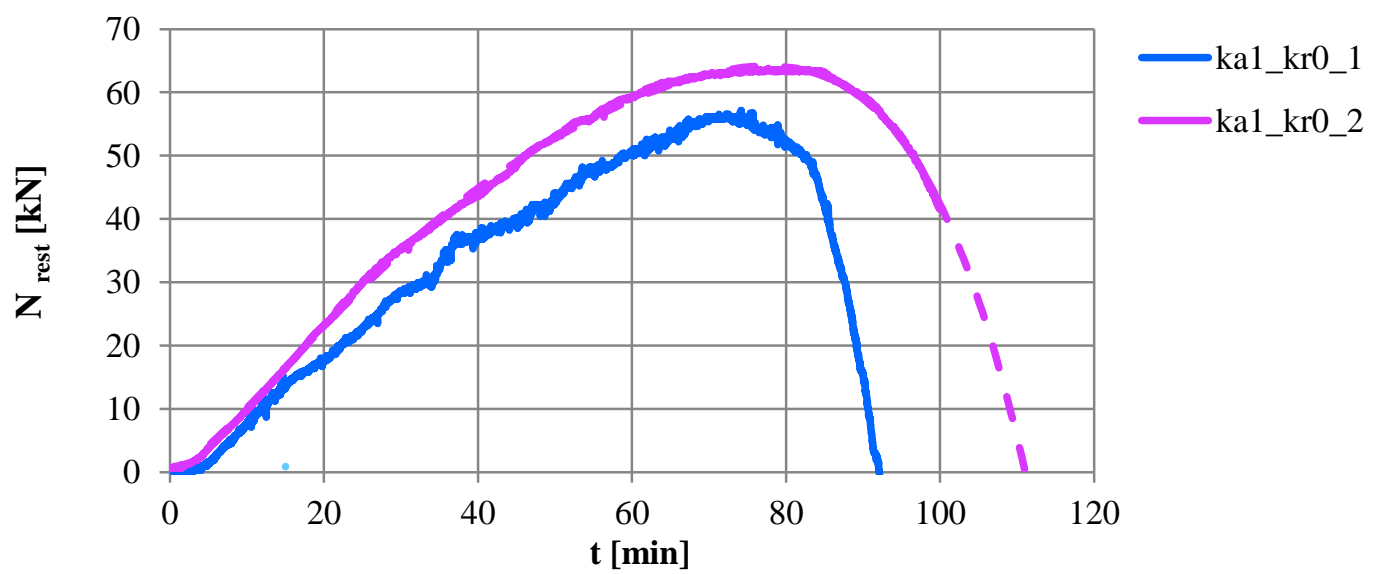

Figura E.28 - Evoluções das forças de restrição axiais em função do tempo nos ensaios ka1_kr0.

\section{E2.2 ka2_kr0}

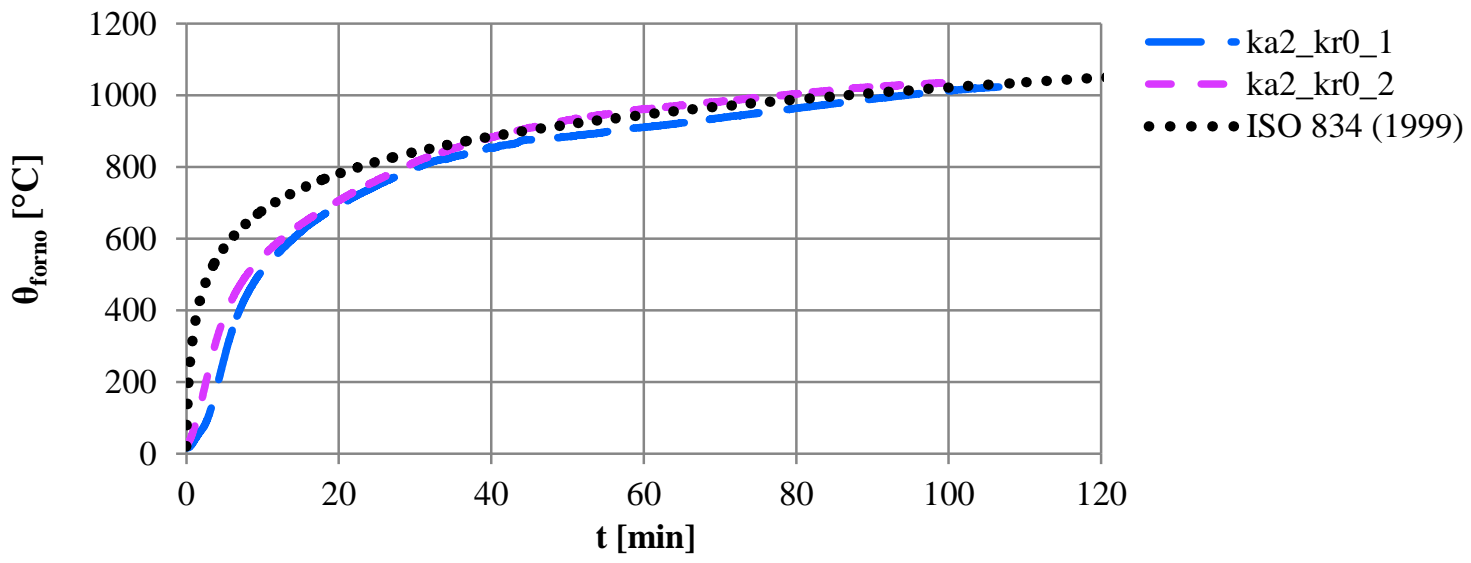

Figura E.29 - Evoluções das temperaturas do forno em função do tempo nos ensaios ka2_kr0. 

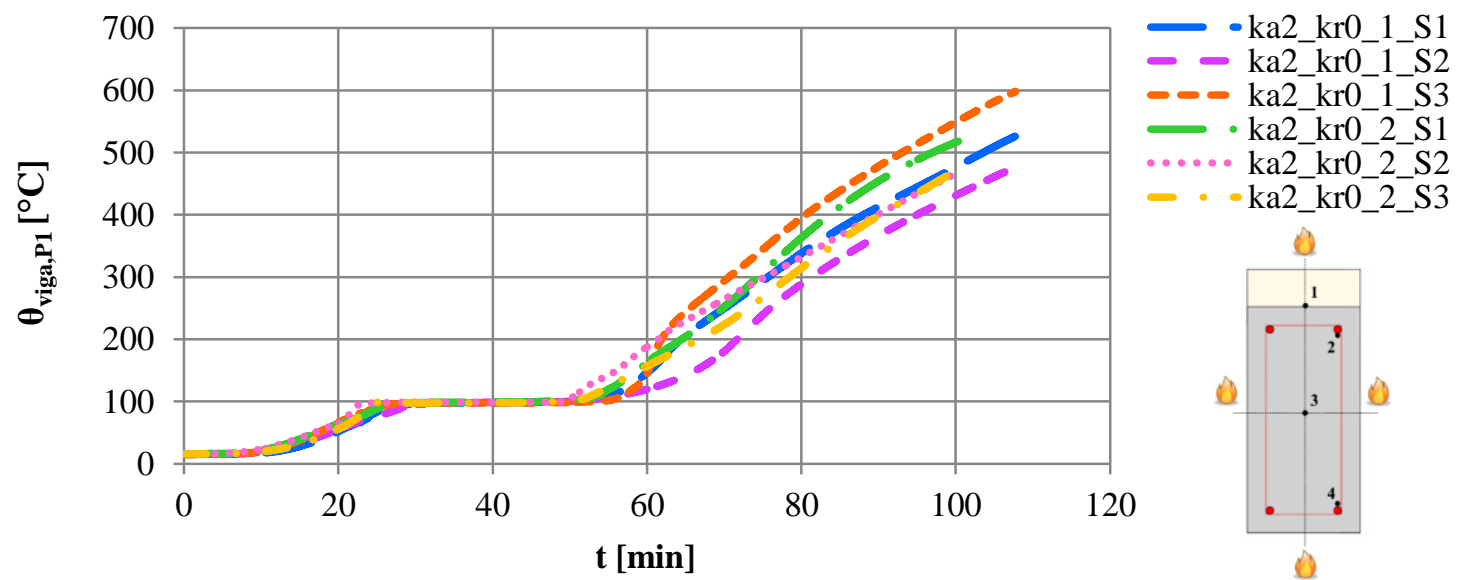

Figura E.30 - Evoluções das temperaturas da interface concreto/manta (ponto 1) em função do tempo nos ensaios ka2_kr0.
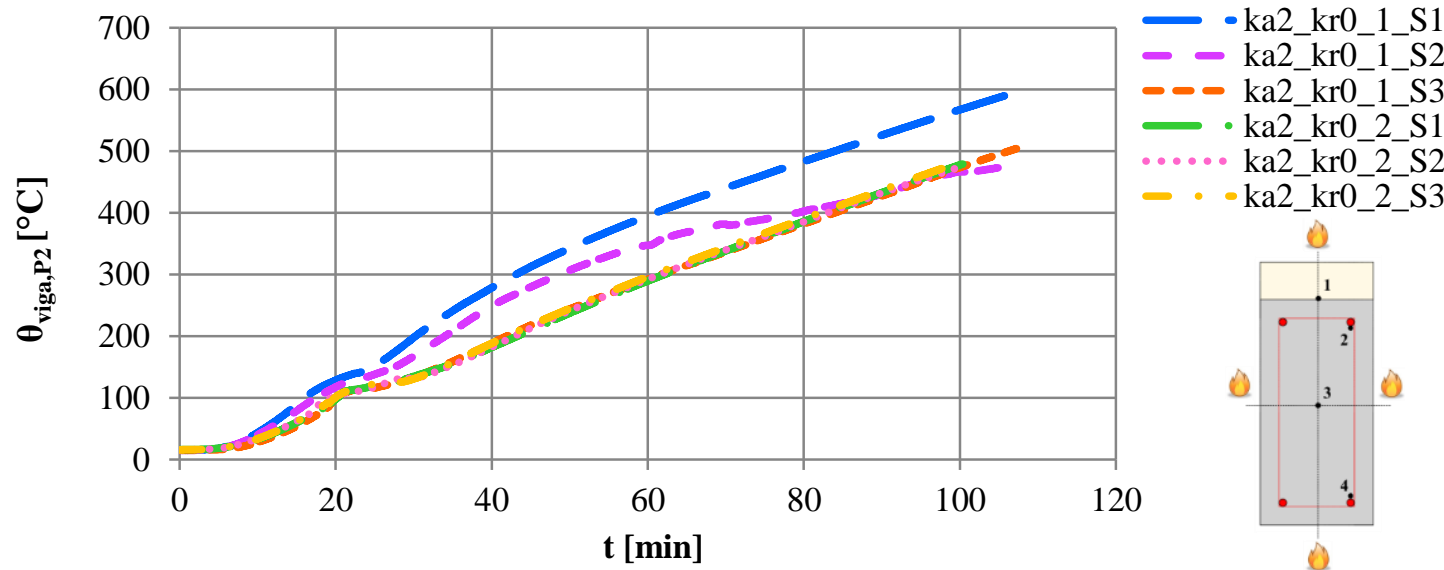

Figura E.31 - Evoluções das temperaturas da armadura (ponto 2) em função do tempo nos ensaios ka2_kr0.
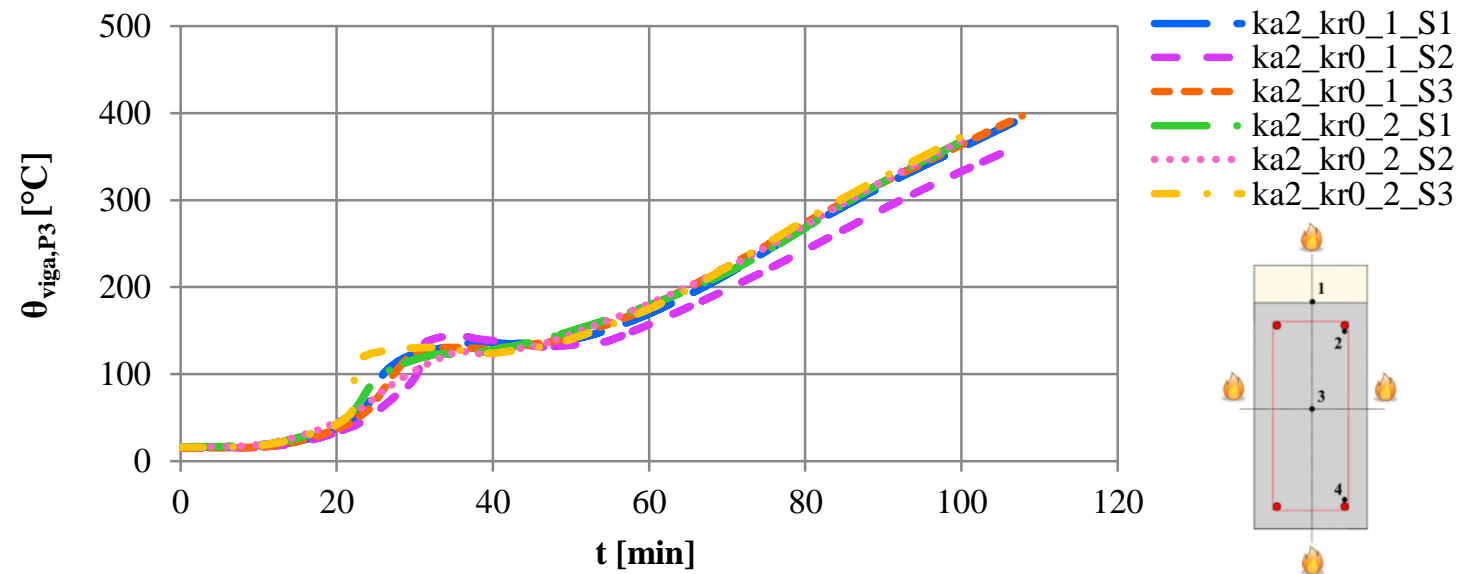

Figura E.32 - Evoluções das temperaturas do concreto (ponto 3) em função do tempo nos ensaios ka2_kr0. 
APÊNDICE E - DADOS DOS ENSAIOS EXPERIMENTAIS DE VIGAS AO FOGO
Análise numérico-experimental de vigas de concreto armado com restrições axial e rotacional em situação de incêndio
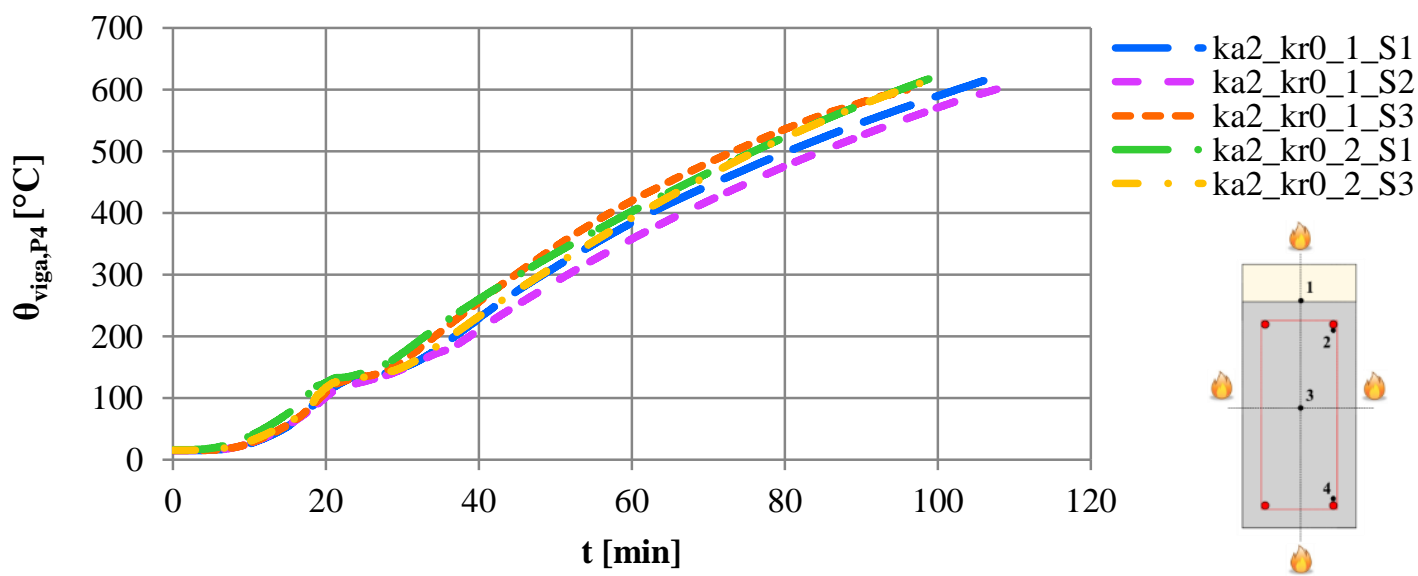

Figura E.33 - Evoluções das temperaturas da armadura (ponto 4) em função do tempo nos ensaios ka2_kr0.

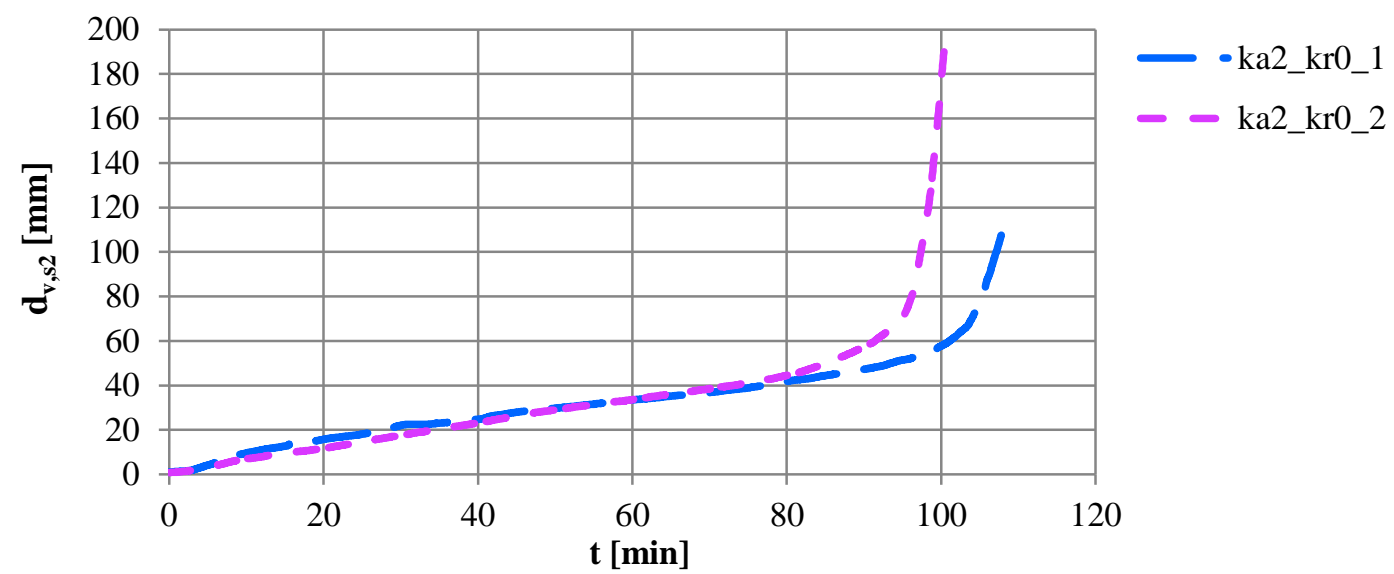

Figura E.34 - Evoluções das flechas em função do tempo nos ensaios ka2_kr0.

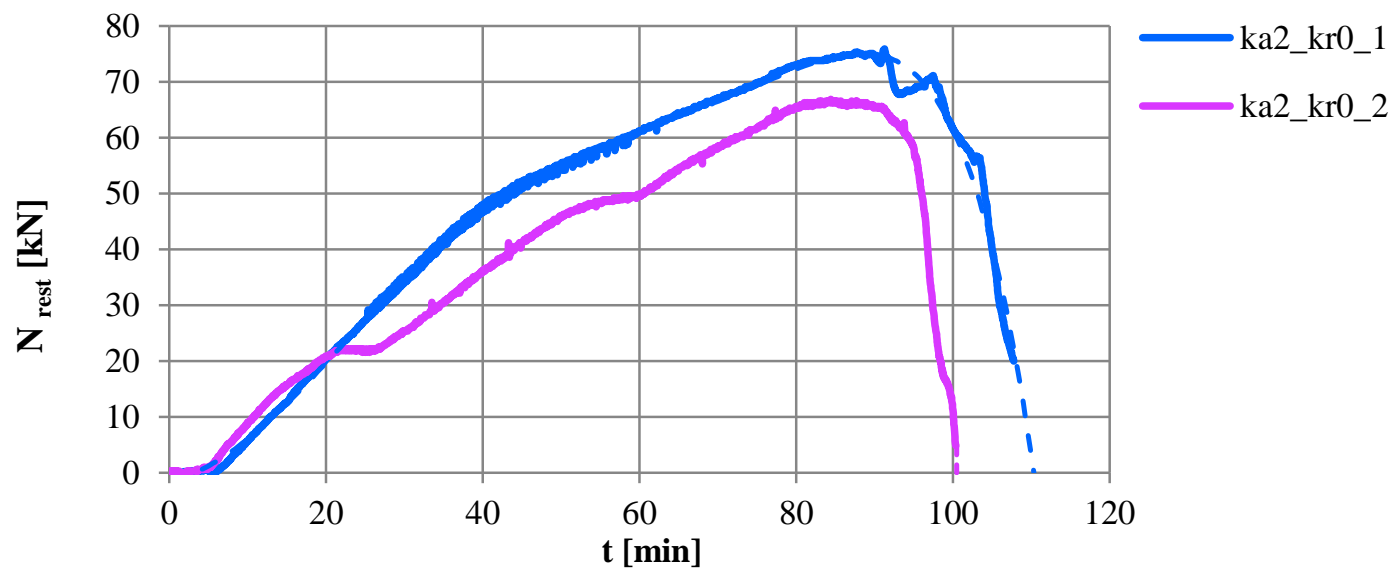

Figura E.35 - Evoluções das forças de restrição axiais em função do tempo nos ensaios ka2_kr0. 


\section{E.3 Vigas com restrições axial e rotacional}

E3.1 ka1_kr1

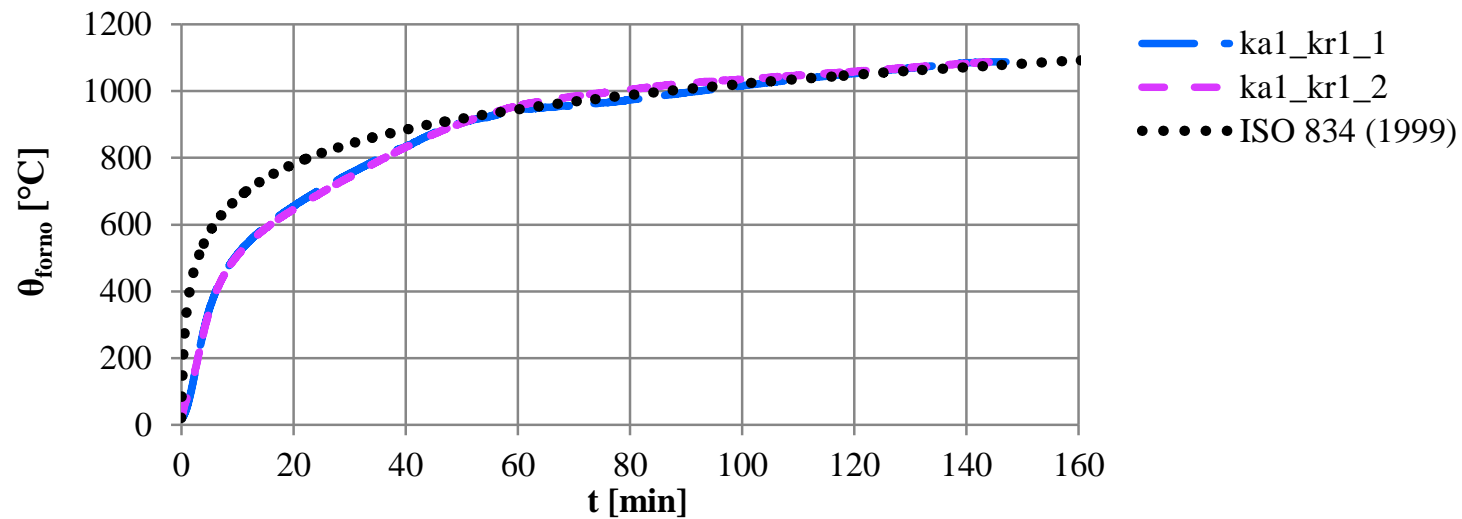

Figura E.36 - Evoluções das temperaturas do forno em função do tempo nos ensaios ka1_kr1.
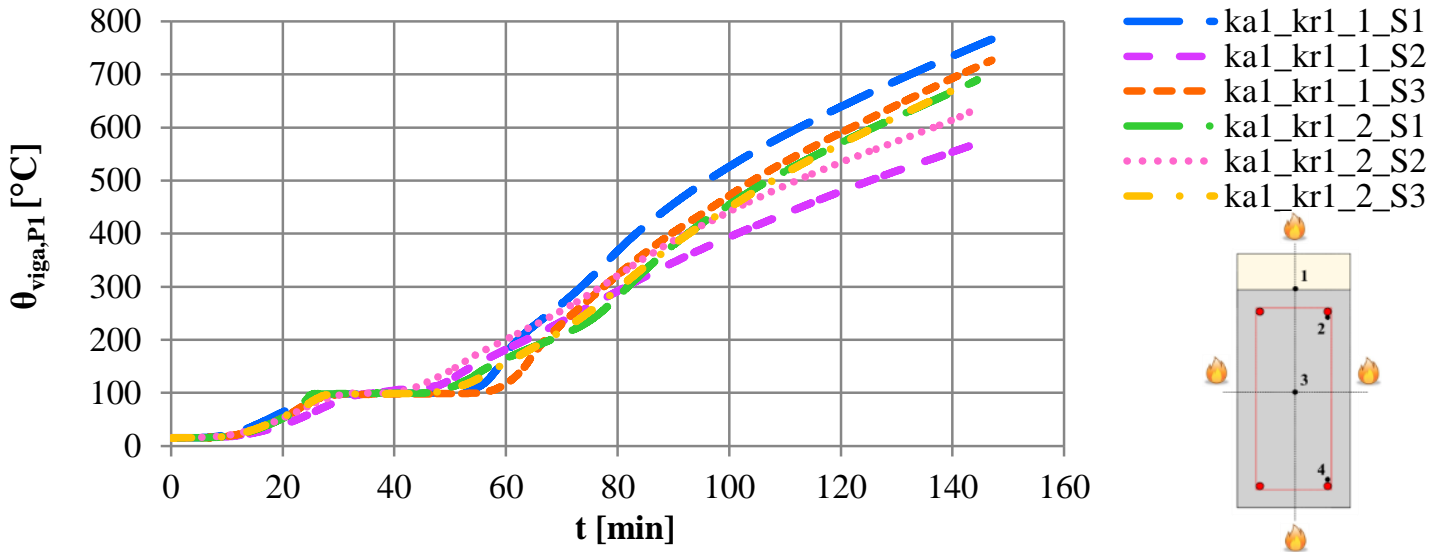

Figura E.37 - Evoluções das temperaturas da interface concreto/manta (ponto 1) em função do tempo nos ensaios ka1_kr1.
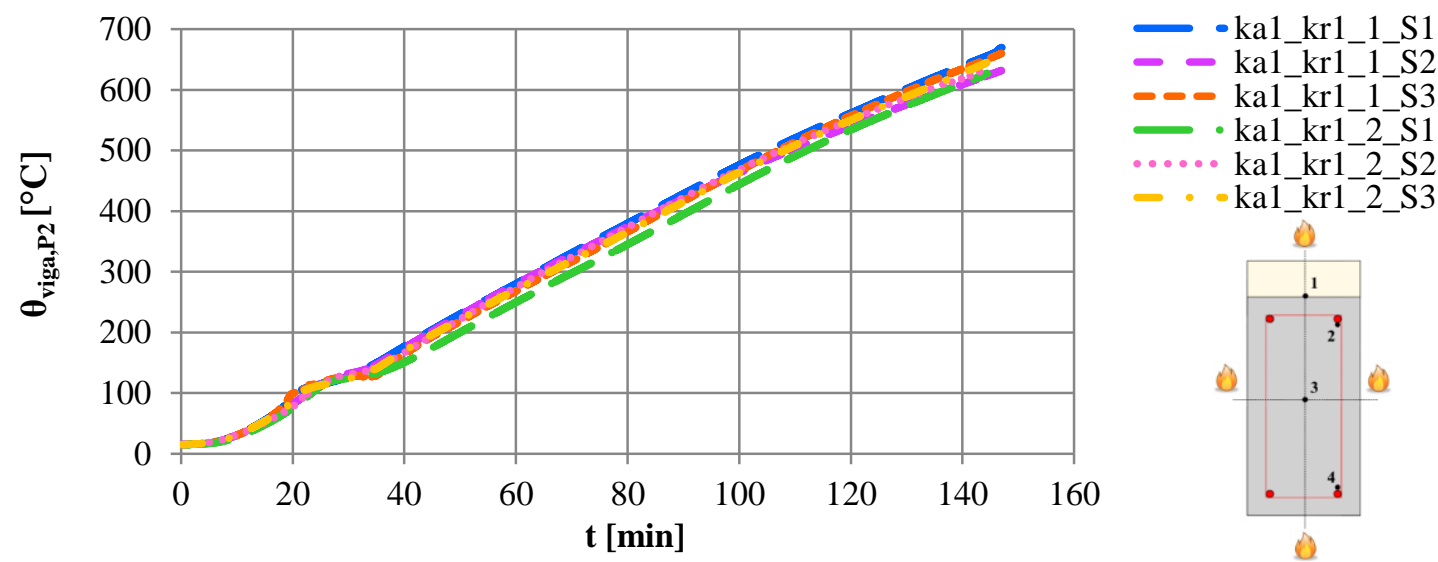

Figura E.38 - Evoluções das temperaturas da armadura (ponto 2) em função do tempo nos ensaios ka1_kr1. 
APÊNDICE E - DADOS DOS ENSAIOS EXPERIMENTAIS DE VIGAS AO FOGO
Análise numérico-experimental de vigas de concreto armado com restrições axial e rotacional em situação de incêndio

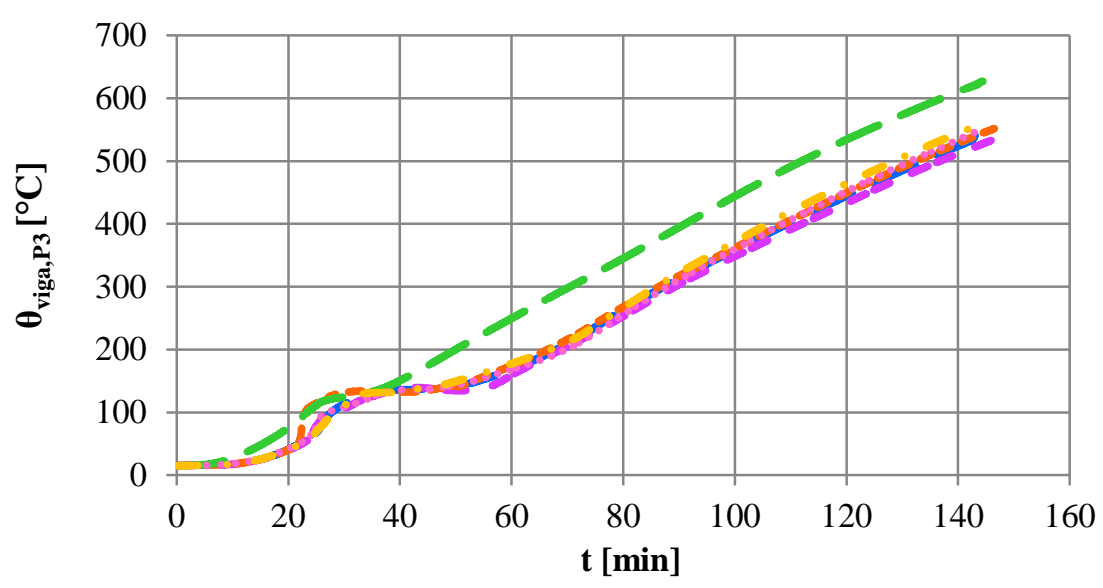

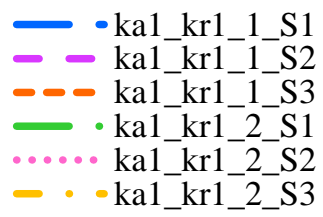

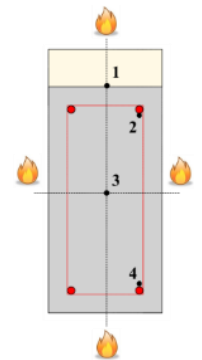

Figura E.39 - Evoluções das temperaturas do concreto (ponto 3) em função do tempo nos ensaios ka1_kr1.
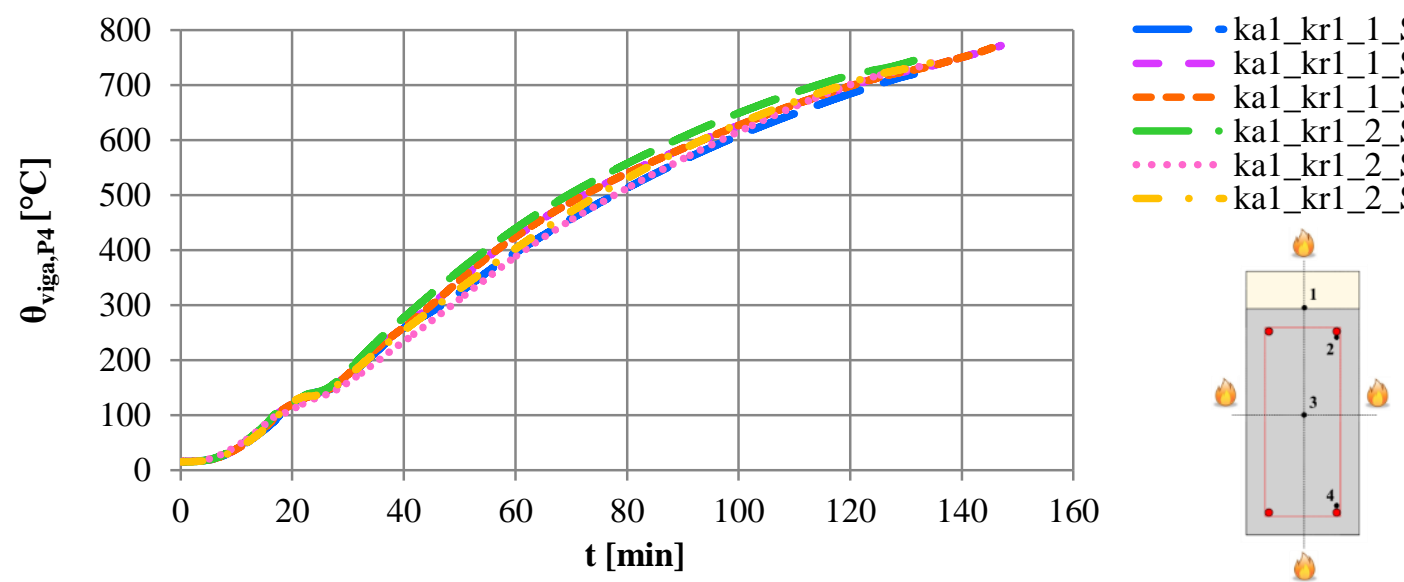

Figura E.40 - Evoluções das temperaturas da armadura (ponto 4) em função do tempo nos ensaios ka1_kr1.

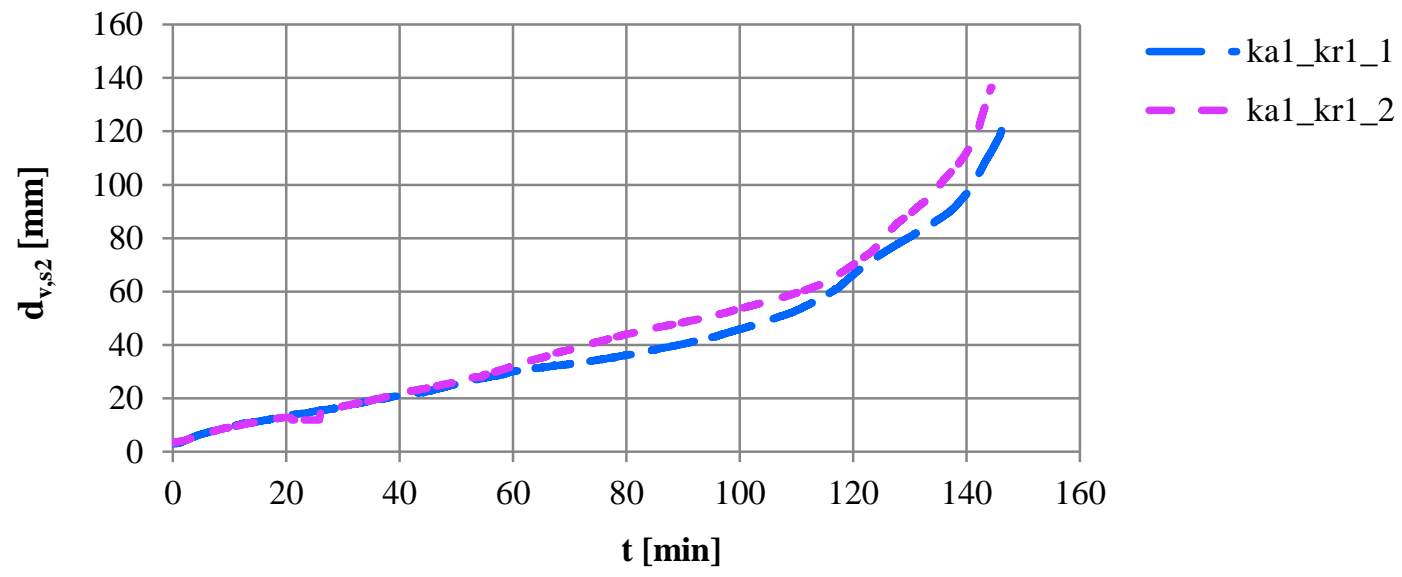

Figura E.41 - Evoluções das flechas em função do tempo nos ensaios ka1_kr1. 


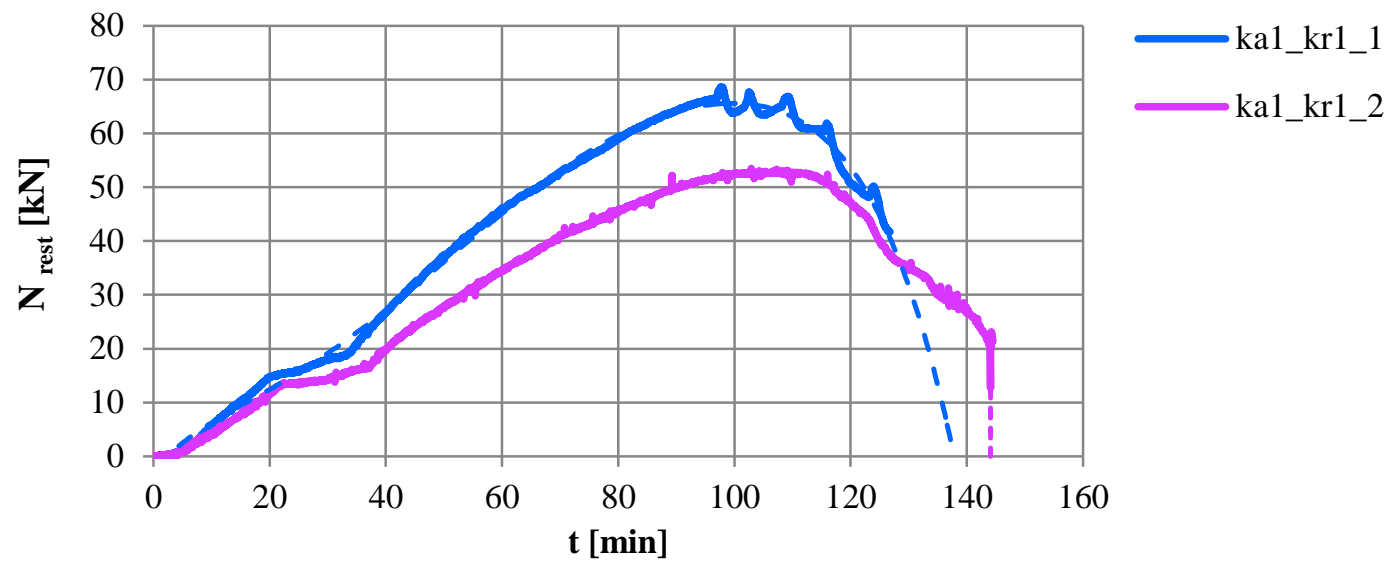

Figura E.42 - Evoluções das forças de restrição axiais em função do tempo nos ensaios ka1_kr1.

\section{E3.2 ka2 kr1}

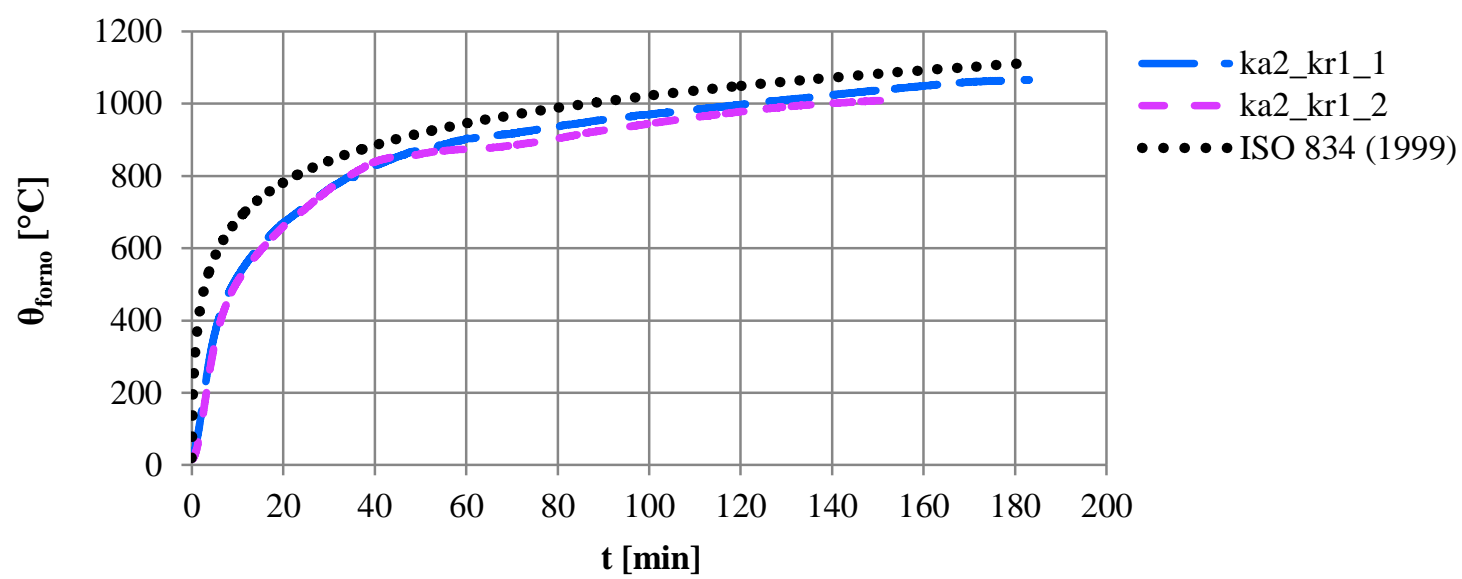

Figura E.43 - Evoluções das temperaturas do forno em função do tempo nos ensaios ka2_kr1.
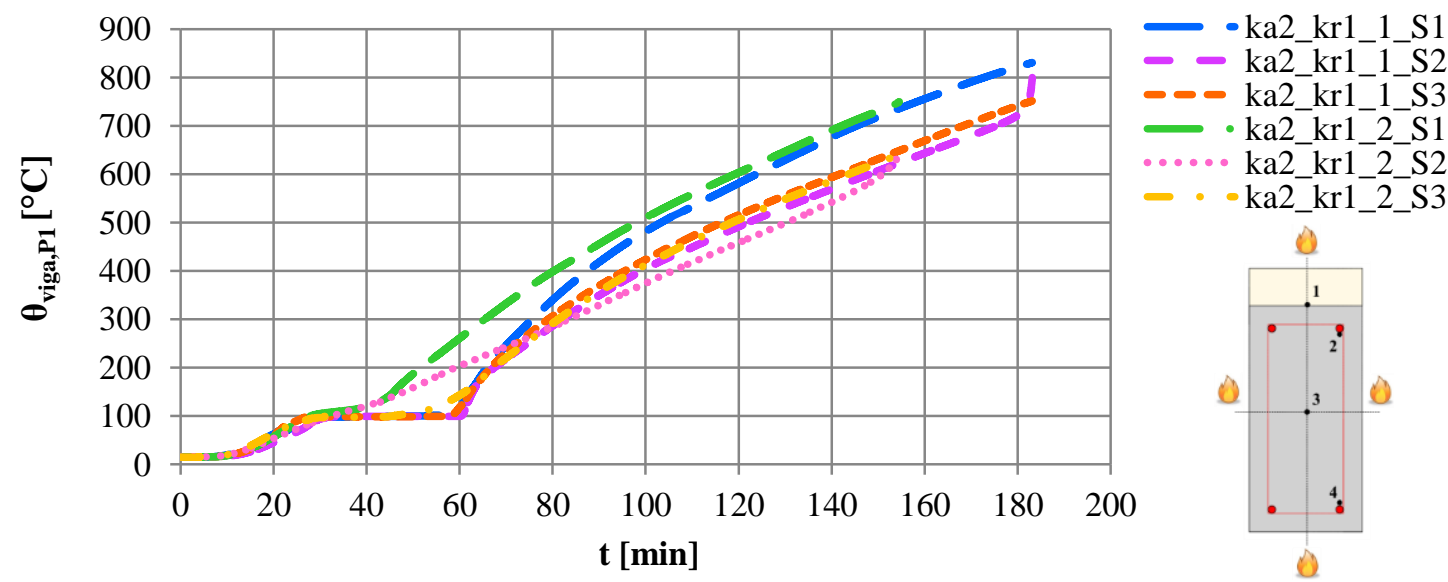

Figura E.44 - Evoluções das temperaturas da interface concreto/manta (ponto 1) em função do tempo nos ensaios ka2_kr1. 
APÊNDICE E - DADOS DOS ENSAIOS EXPERIMENTAIS DE VIGAS AO FOGO
Análise numérico-experimental de vigas de concreto armado com restrições axial e rotacional em situação de incêndio
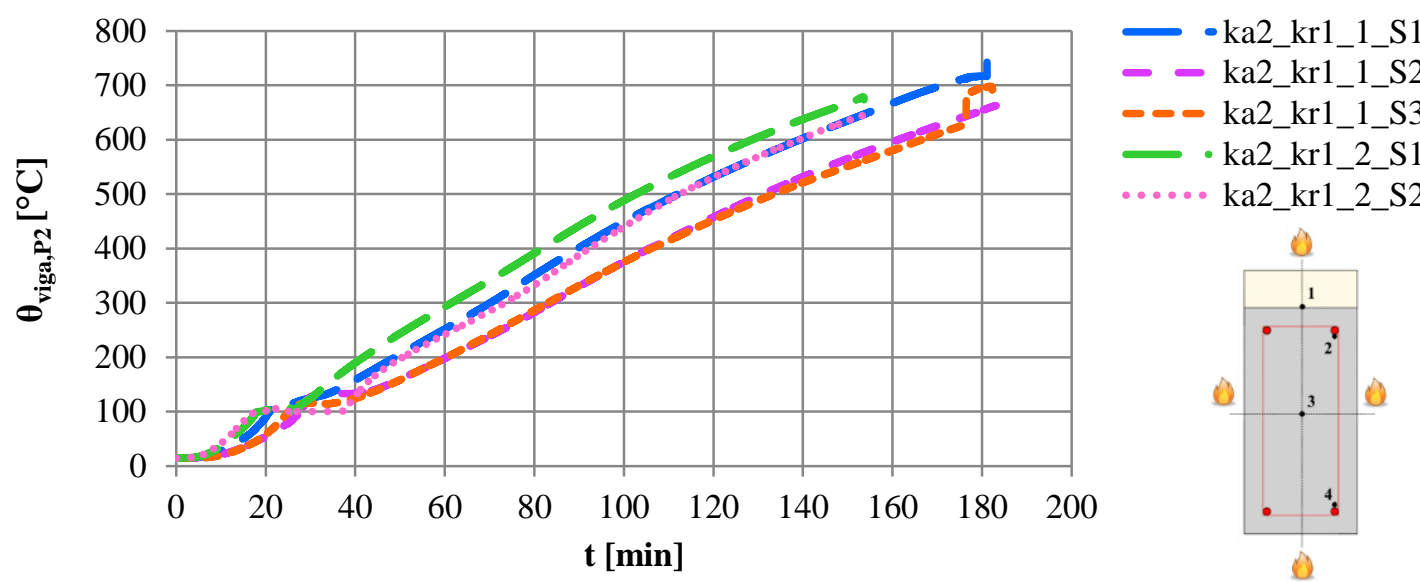

Figura E.45 - Evoluções das temperaturas da armadura (ponto 2) em função do tempo nos ensaios ka2_kr1.
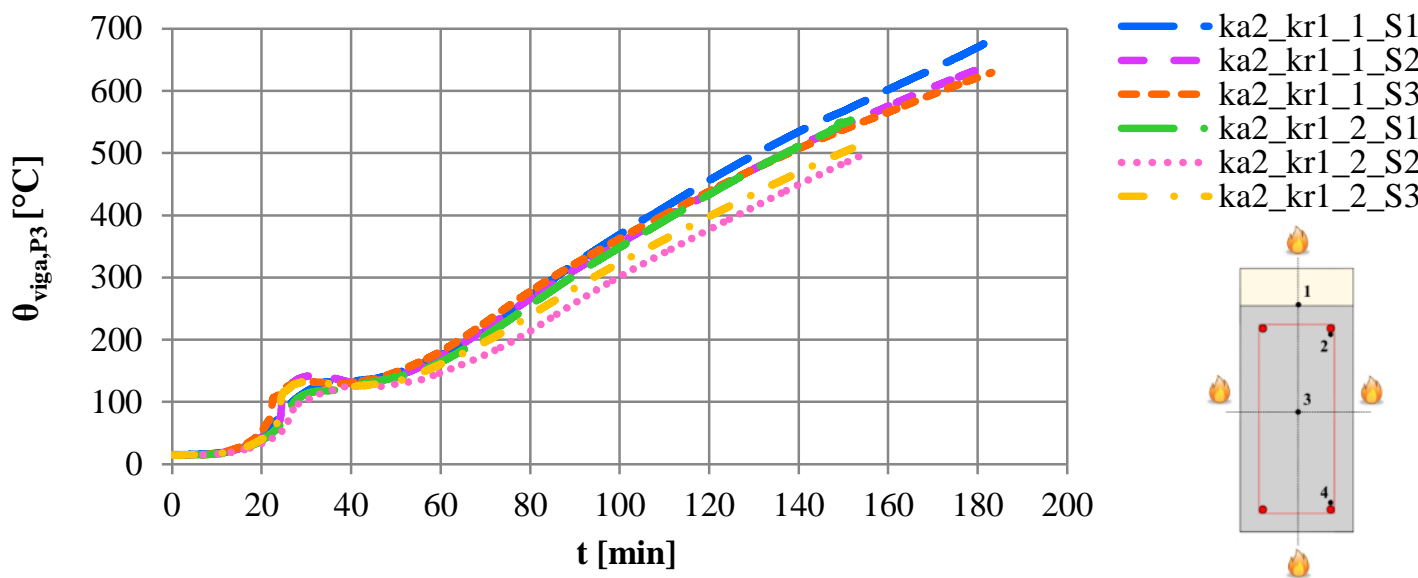

Figura E.46 - Evoluções das temperaturas do concreto (ponto 3) em função do tempo nos ensaios ka2_kr1.
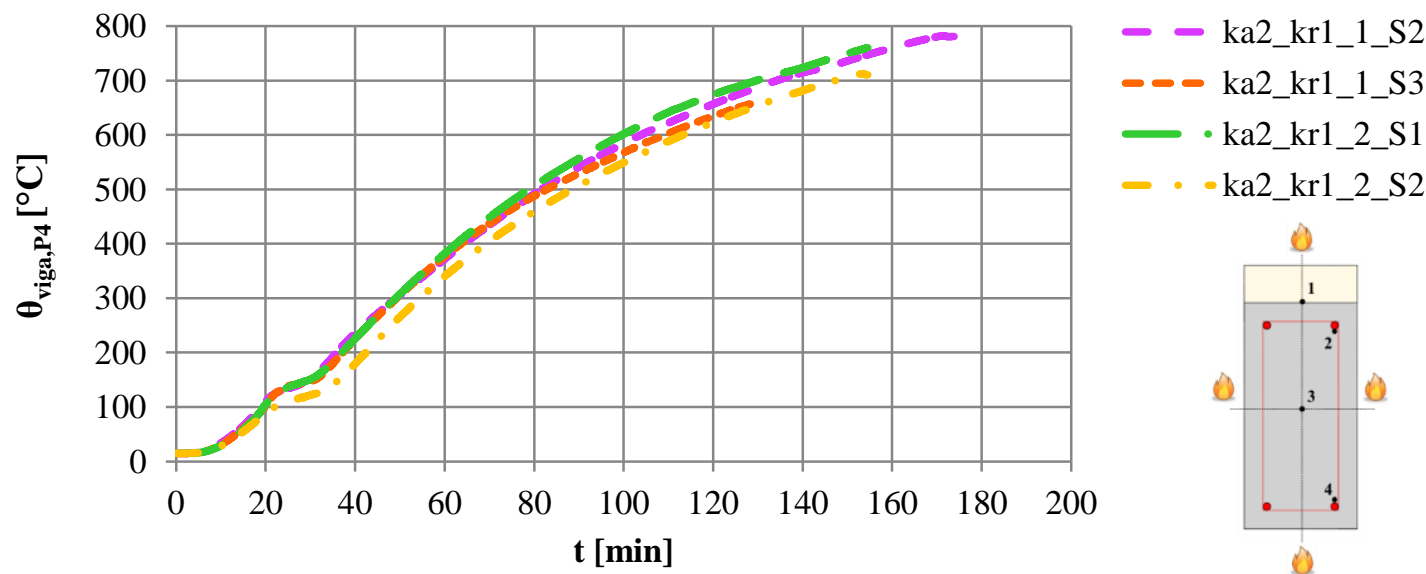

Figura E.47 - Evoluções das temperaturas da armadura (ponto 4) em função do tempo nos ensaios ka2_kr1. 


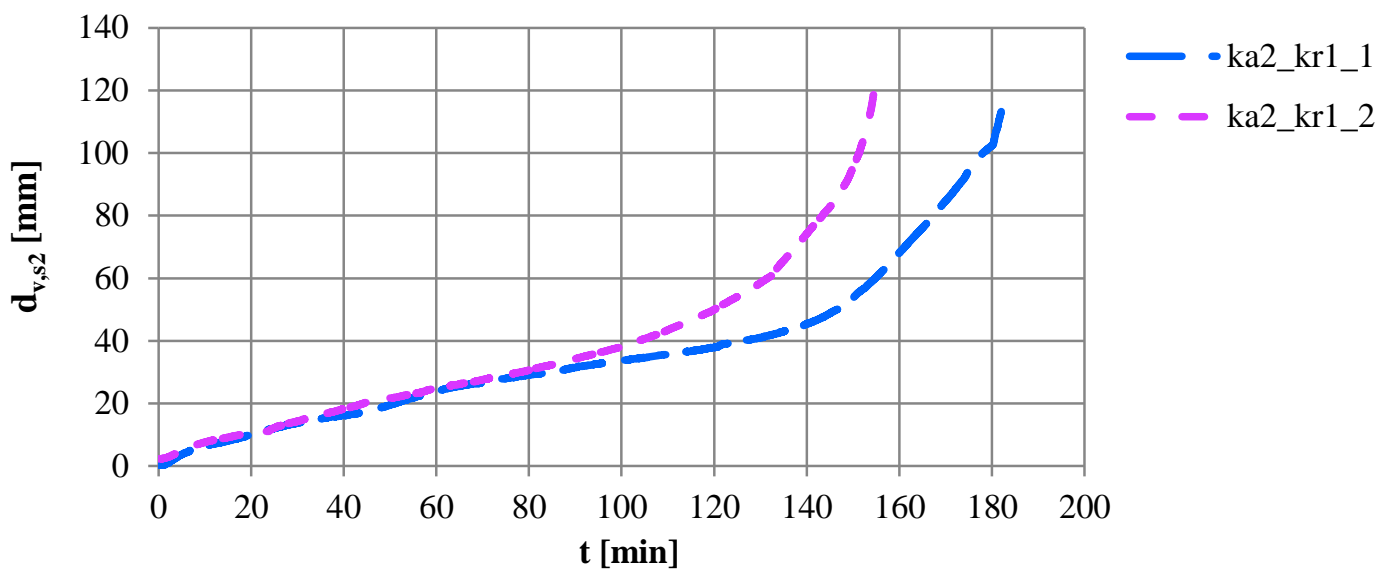

Figura E.48 - Evoluções das flechas em função do tempo nos ensaios ka2_kr1.

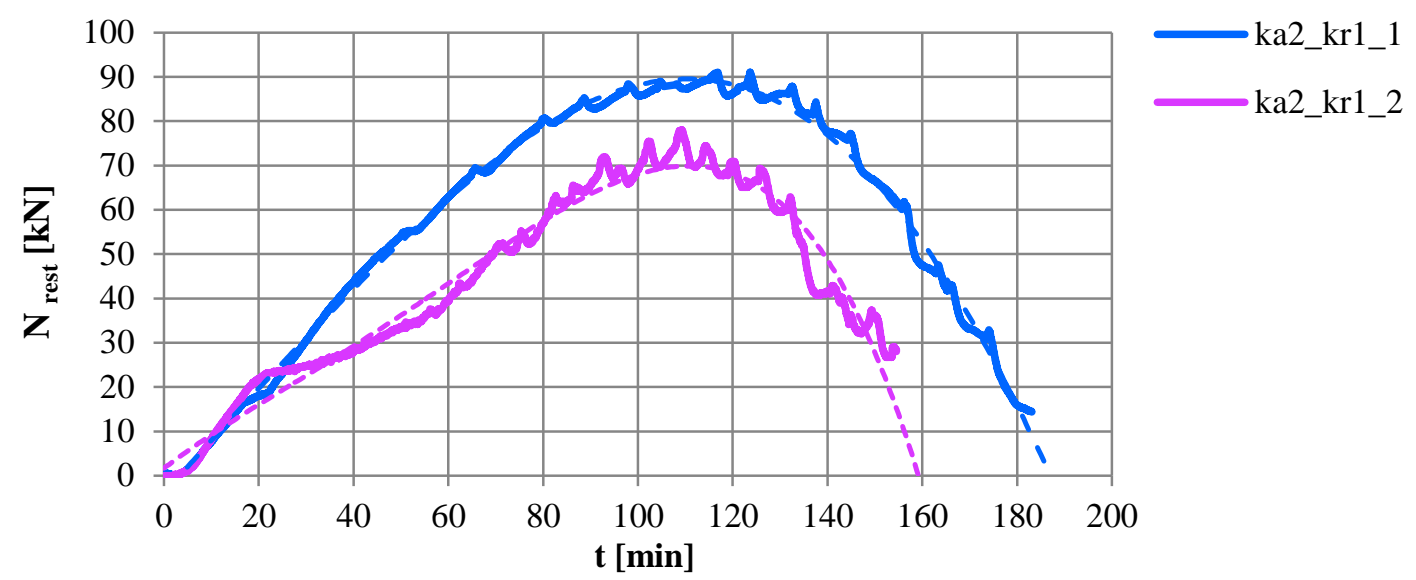

Figura E.49 - Evoluções das forças de restrição axiais em função do tempo nos ensaios ka2_kr1.

\section{E3.3 ka1_kr2}

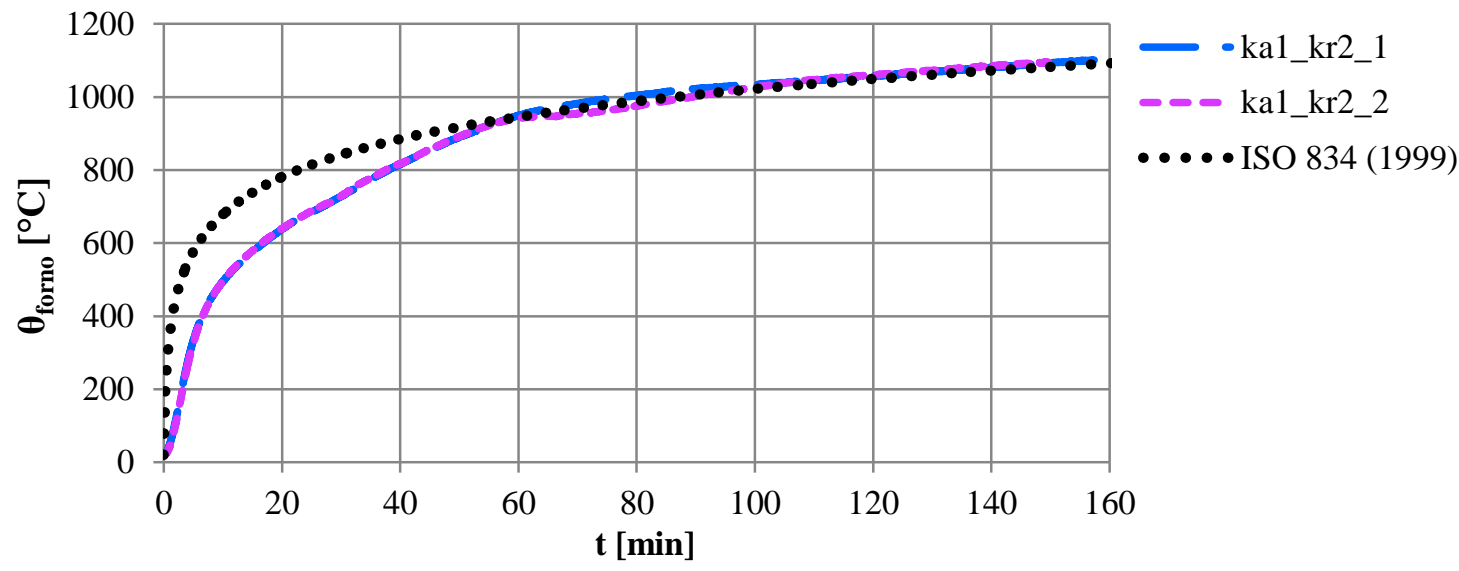

Figura E.50 - Evoluções das temperaturas do forno em função do tempo nos ensaios ka1_kr2. 
APÊNDICE E - DADOS DOS ENSAIOS EXPERIMENTAIS DE VIGAS AO FOGO
Análise numérico-experimental de vigas de concreto armado com restrições axial e rotacional em situação de incêndio
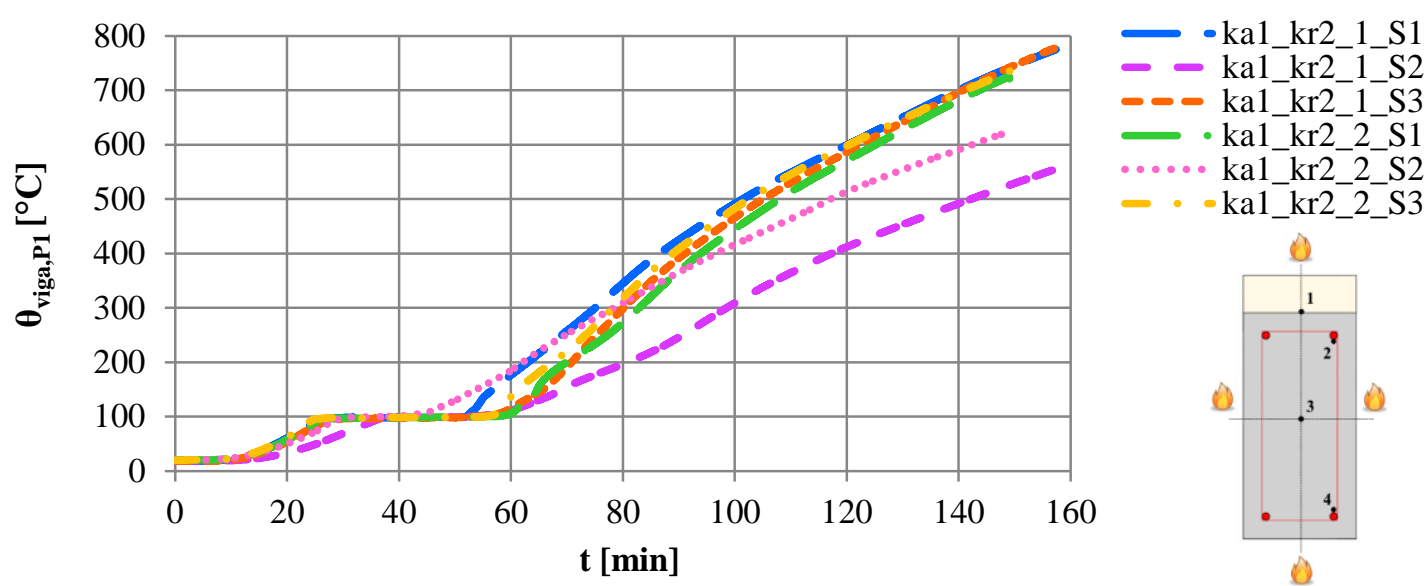

Figura E.51 - Evoluções das temperaturas da interface concreto/manta (ponto 1) em função do tempo nos ensaios ka1_kr2.
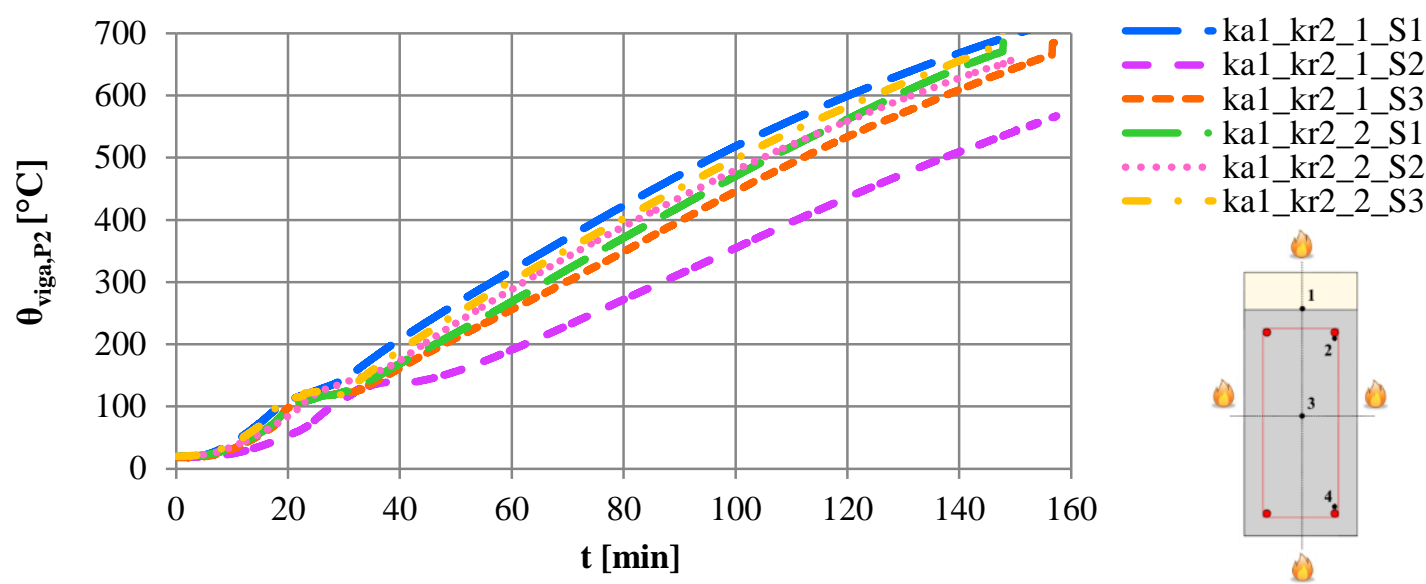

Figura E.52 - Evoluções das temperaturas da armadura (ponto 2) em função do tempo nos ensaios ka1_kr2.
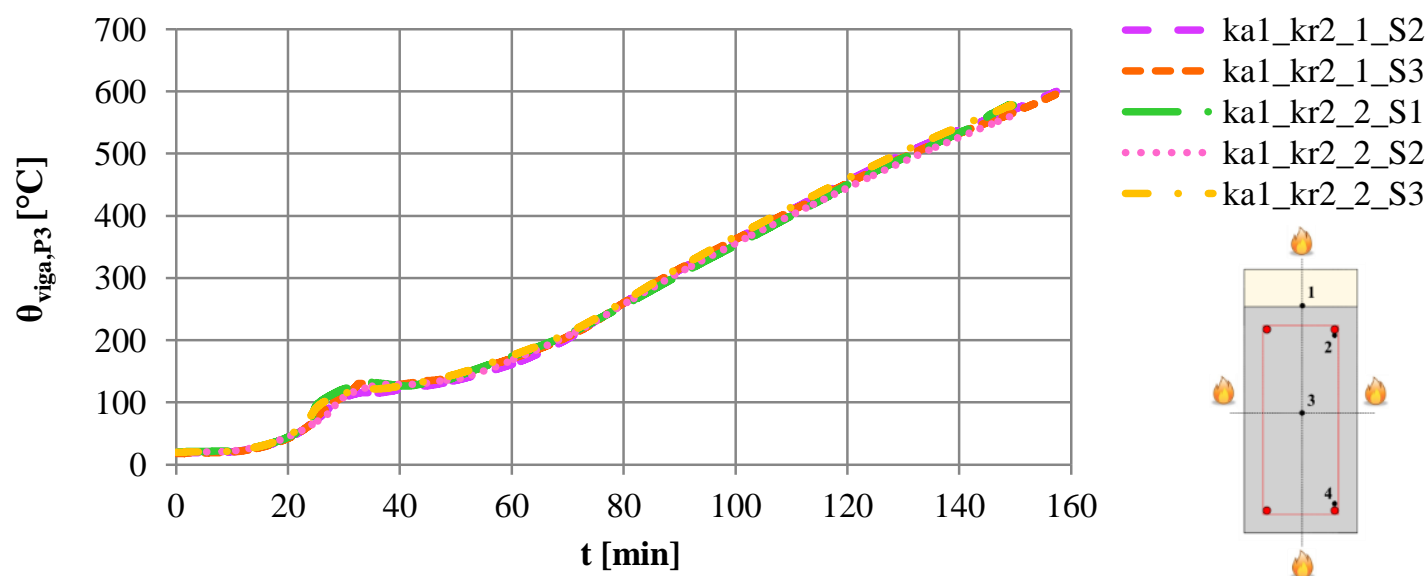

Figura E.53 - Evoluções das temperaturas do concreto (ponto 3) em função do tempo nos ensaios ka1_kr2. 

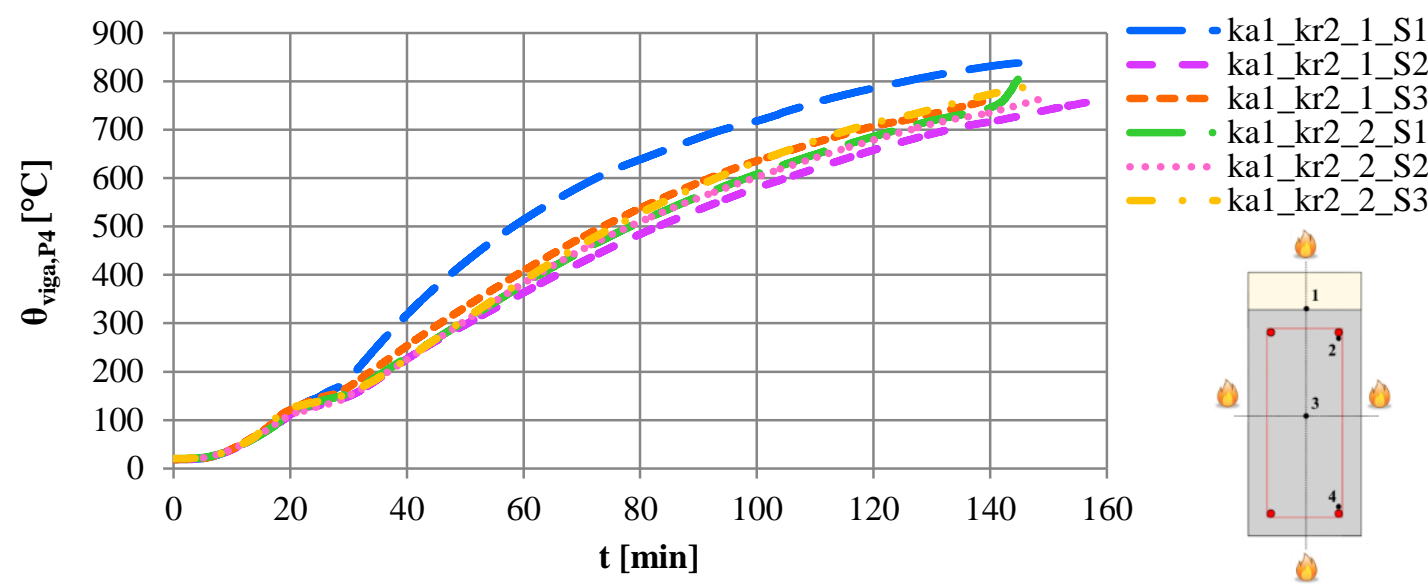

Figura E.54 - Evoluções das temperaturas da armadura (ponto 4) em função do tempo nos ensaios ka1_kr2.

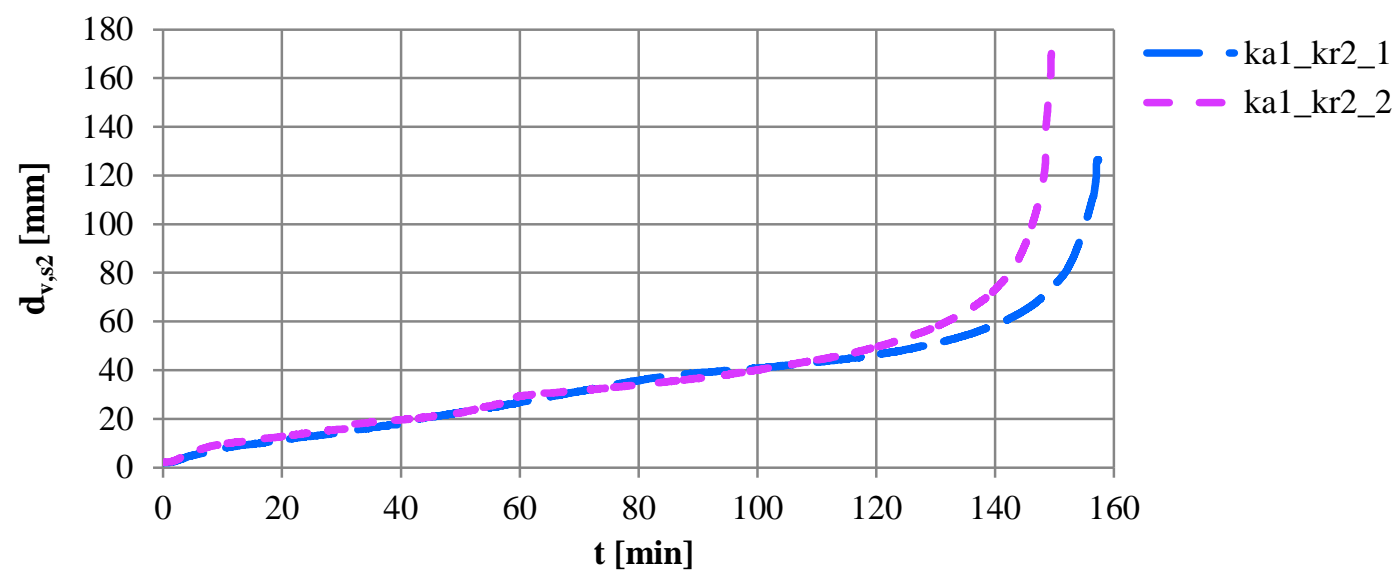

Figura E.55 - Evoluções das flechas em função do tempo nos ensaios ka1_kr2.

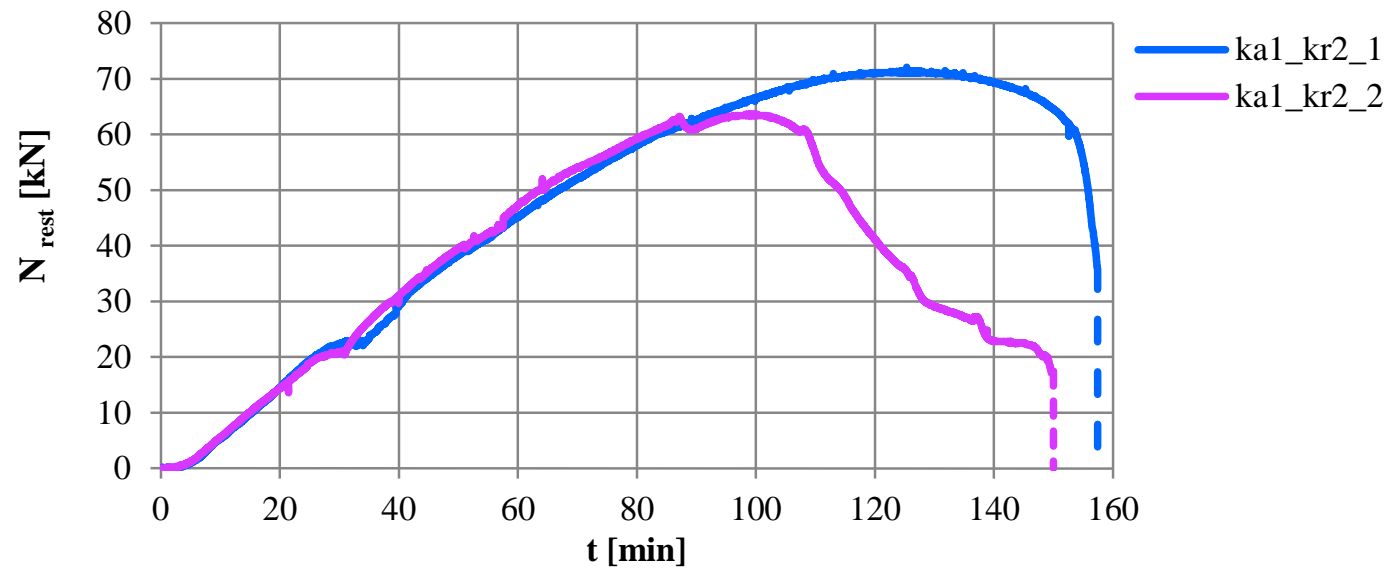

Figura E.56 - Evoluções das forças de restrição axiais em função do tempo nos ensaios ka1_kr2. 



\section{APÊNDICE F - FOTOS DOS ENSAIOS EXPERIMENTAIS DE VIGAS AO FOGO}

\section{F.1 Vigas simplesmente apoiadas}

\section{F1.1 T_ka0_kr0}
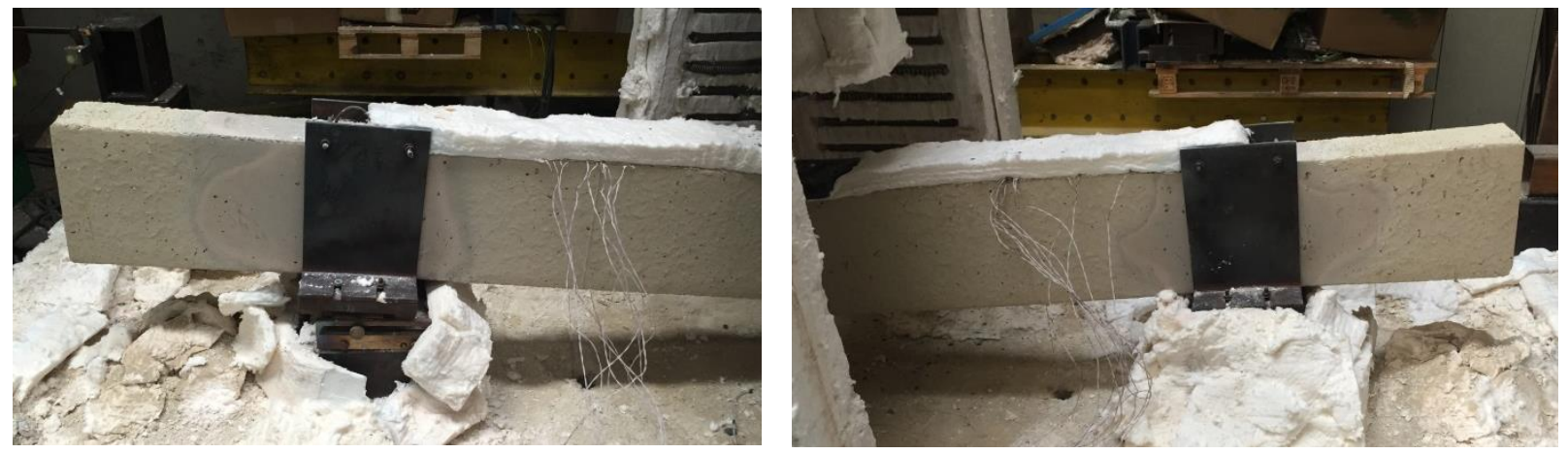

Figura F.1 - Vistas frontais da configuração deformada da viga nas regiões próximas aos apoios simples e duplo, respectivamente, após ensaio T_ka0_kr0_1.

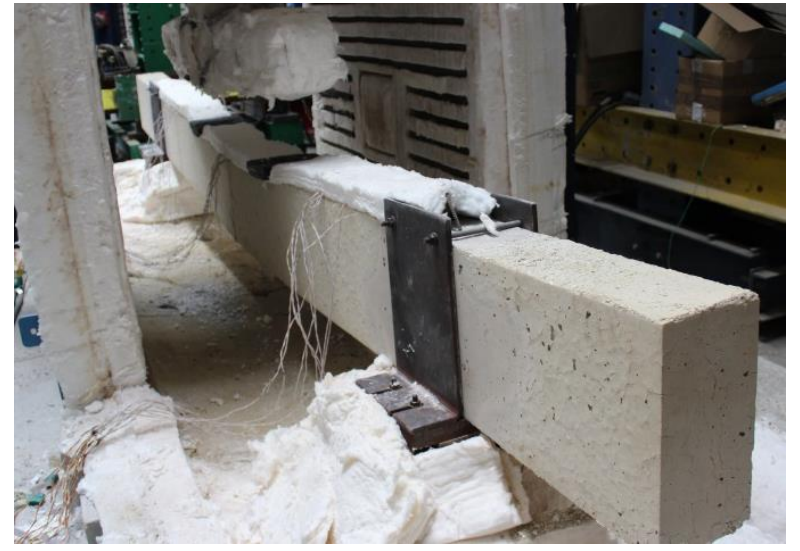

Figura F.2 - Vista lateral da configuração deformada da viga após ensaio T_ka0_kr0_1.

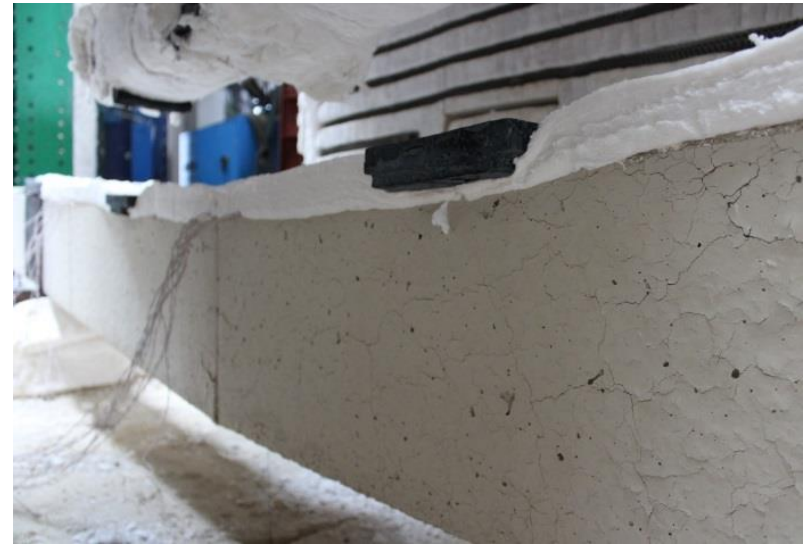

Figura F.3 - Detalhe da aparência "craquelada" da superfície de concreto após ensaio T_ka0_kr0_1. 
Análise numérico-experimental de vigas de concreto armado com restrições axial e rotacional em situação de incêndio
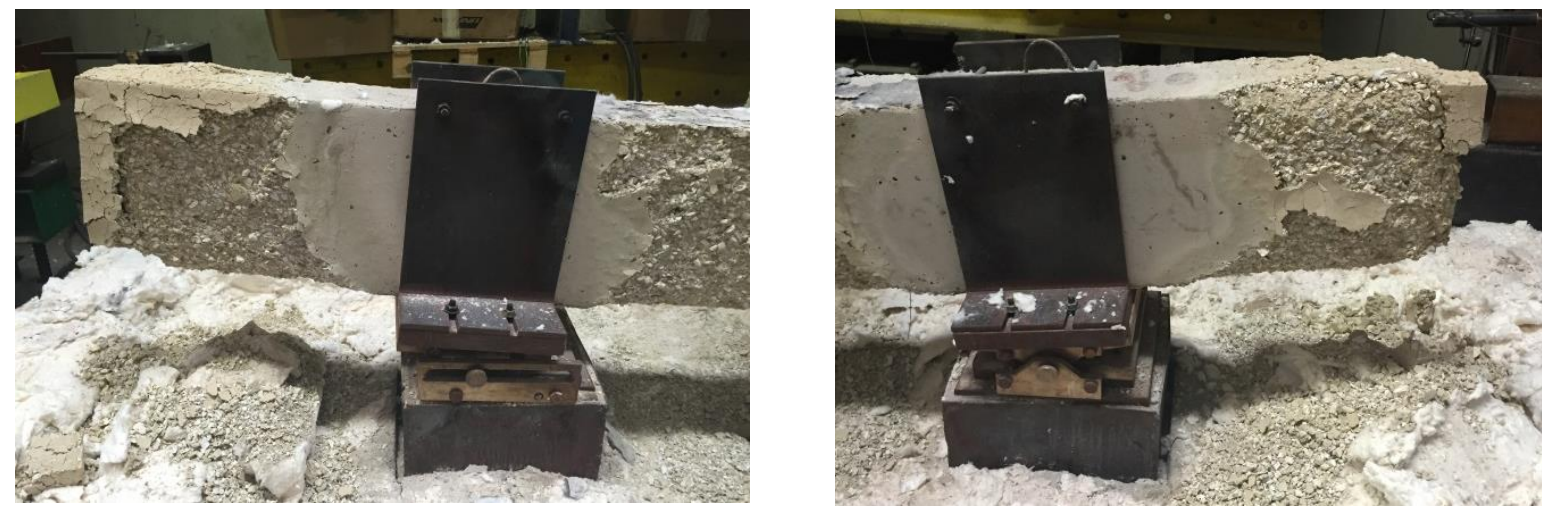

Figura F.4 - Vistas frontais da configuração deformada da viga nas regiões próximas aos apoios simples e duplo, respectivamente, após ensaio T_ka0_kr0_2.

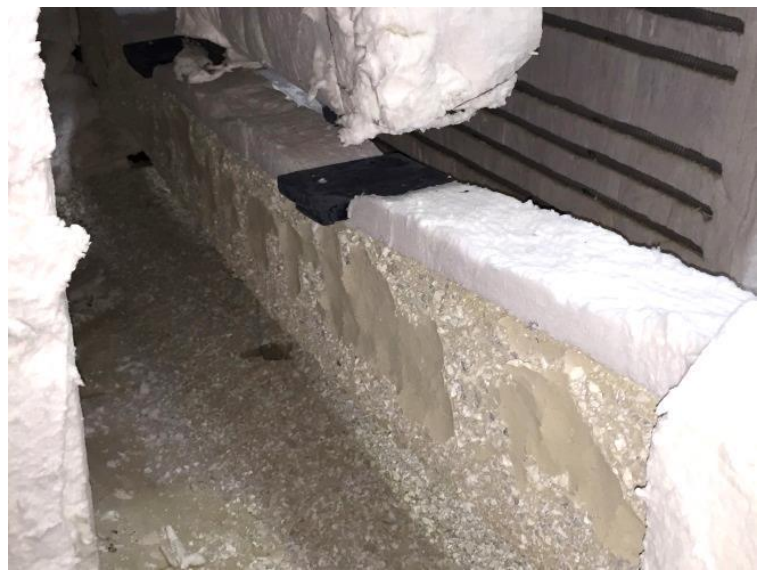

Figura F.5 - Vista lateral da configuração deformada da viga após ensaio T_ka0_kr0_2.

\section{F1.2 ka0_kr0*}
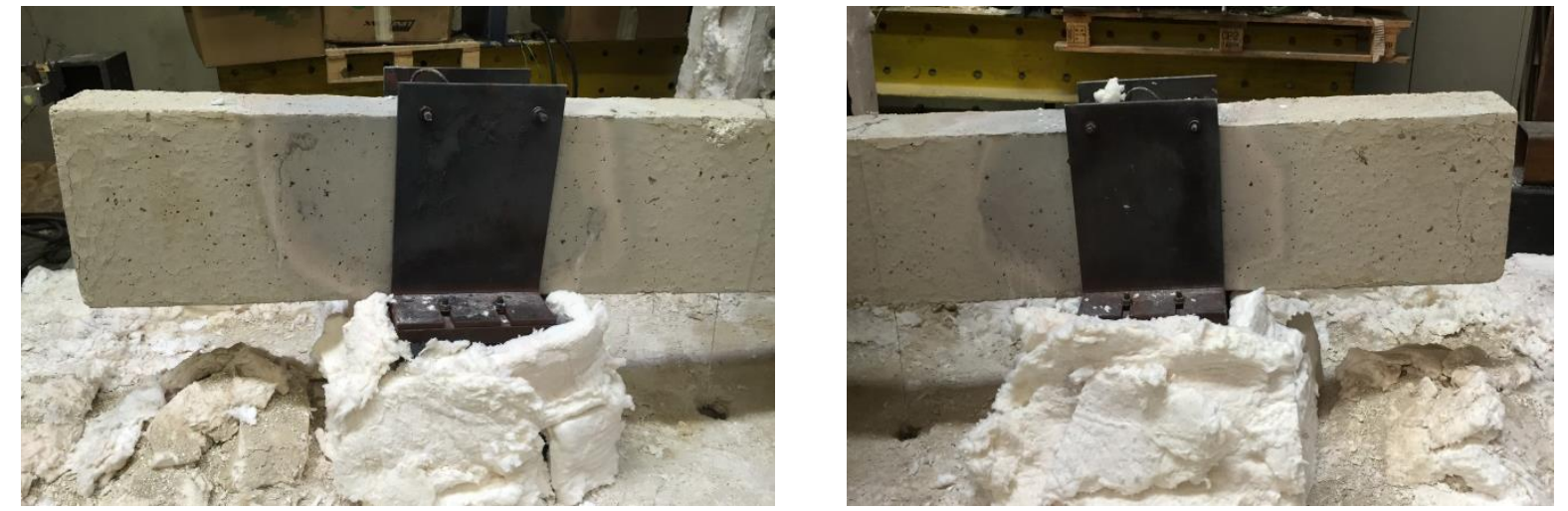

Figura F.7 - Vistas frontais da configuração deformada da viga nas regiões próximas aos apoios simples e duplo, respectivamente, após ensaio ka0_kr0* (sem manta na face superior). 

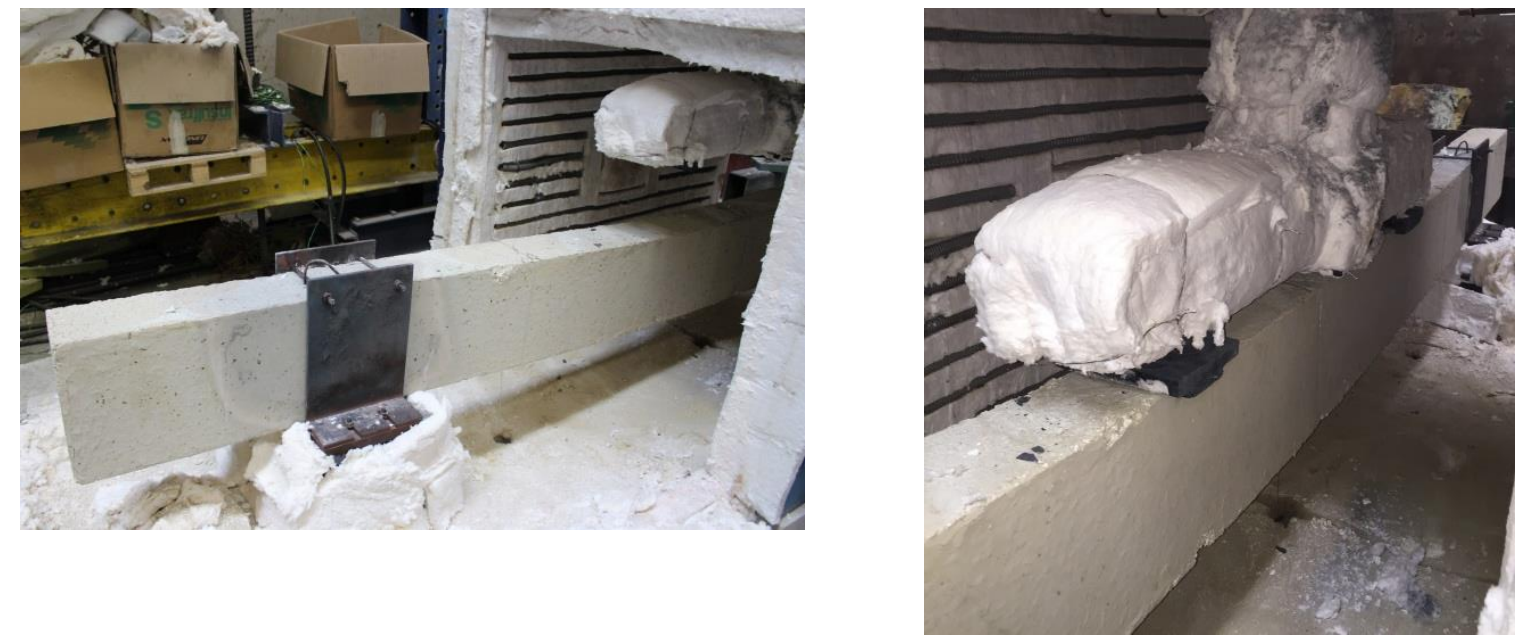

Figura F.8 - Vistas laterais da configuração deformada da viga após ensaio ka0_kr0* (sem manta).

\section{F1.3 ka0_kr0}
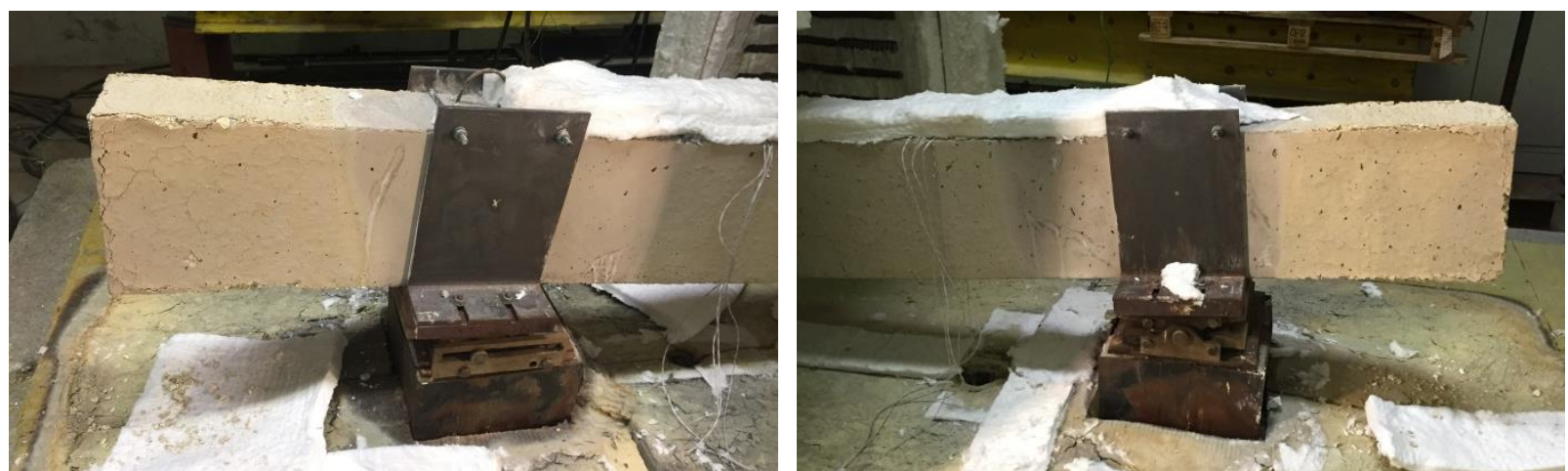

Figura F.9 - Vistas frontais da configuração deformada da viga nas regiões próximas aos apoios simples e duplo, respectivamente, após ensaio ka0_kr0_1.

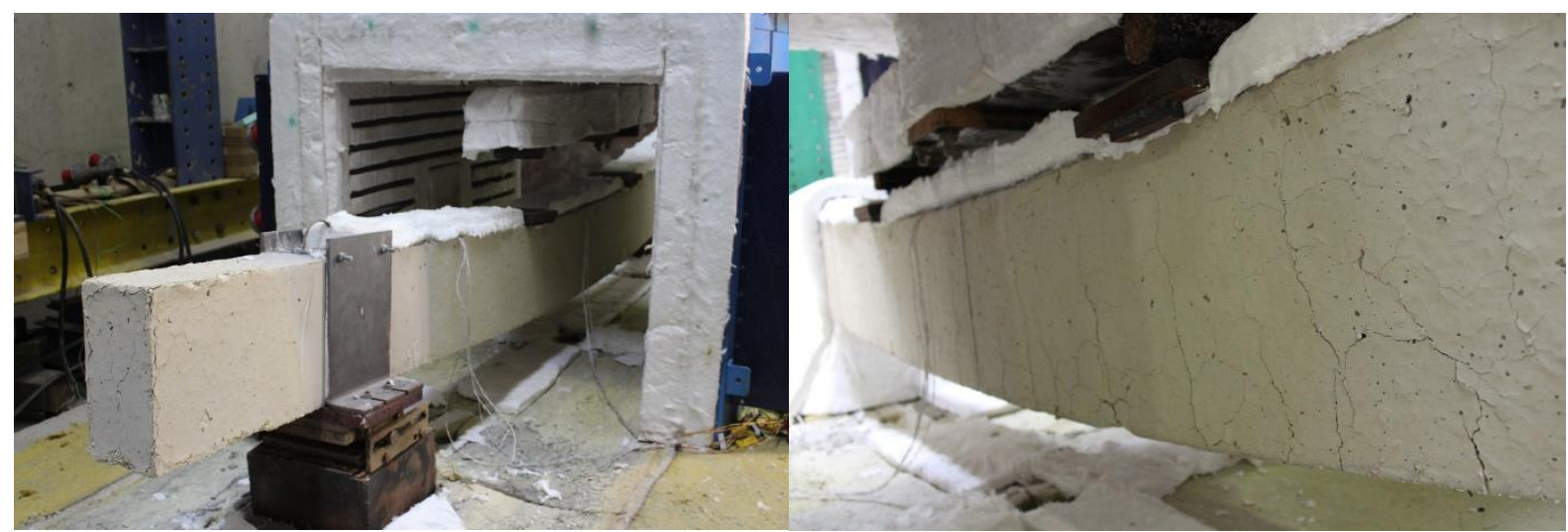

Figura F.10 - Vista lateral da configuração deformada Figura F.11 - Detalhe da aparência "craquelada" da da viga após ensaio ka0_kr0_1. superfície de concreto e das fissuras de flexão após ensaio ka0_kr0_1. 

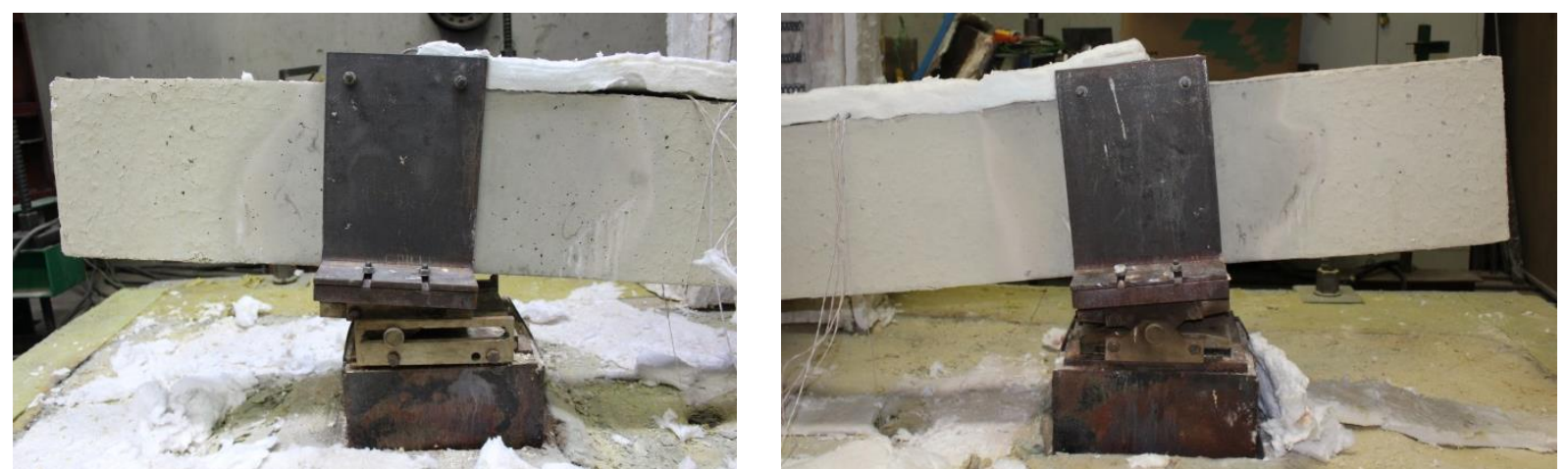

Figura F.12 - Vistas frontais da configuração deformada da viga nas regiões próximas aos apoios simples e duplo, respectivamente, após ensaio ka0_kr0_2.
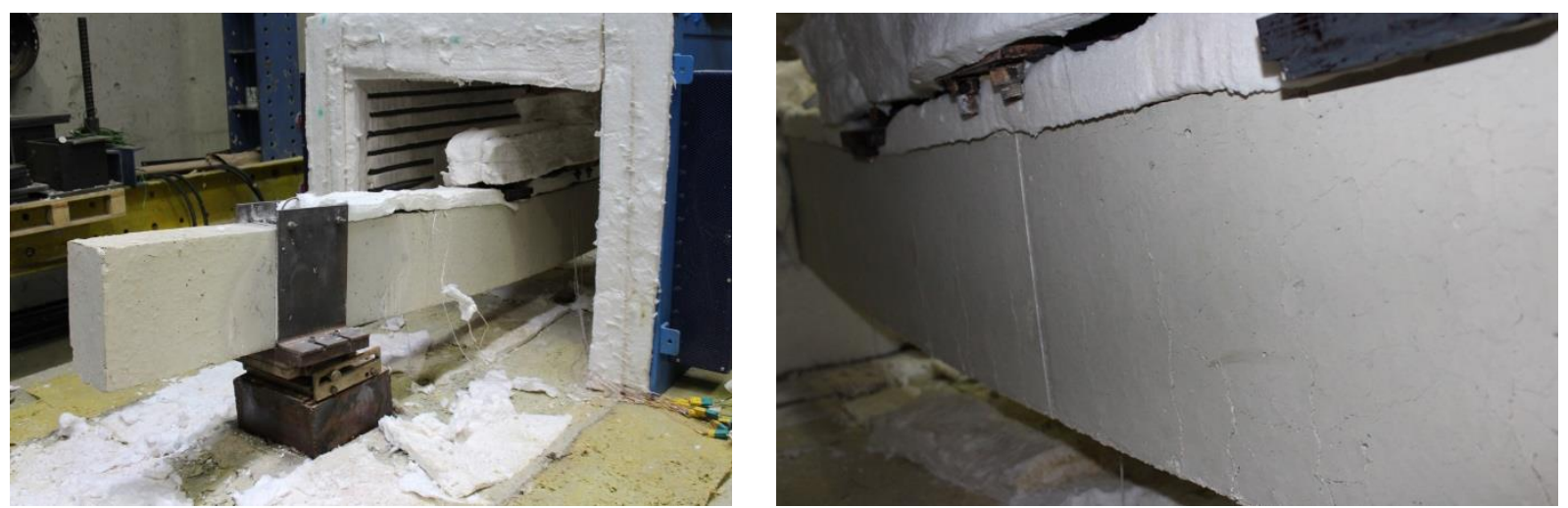

Figura F.13 - Vista lateral da configuração deformada Figura F.14 - Detalhe da aparência "craquelada" da da viga após ensaio ka0_kr0_2.

\section{F.2 Vigas com restrição axial}

\section{F2.1 ka1_kr0}
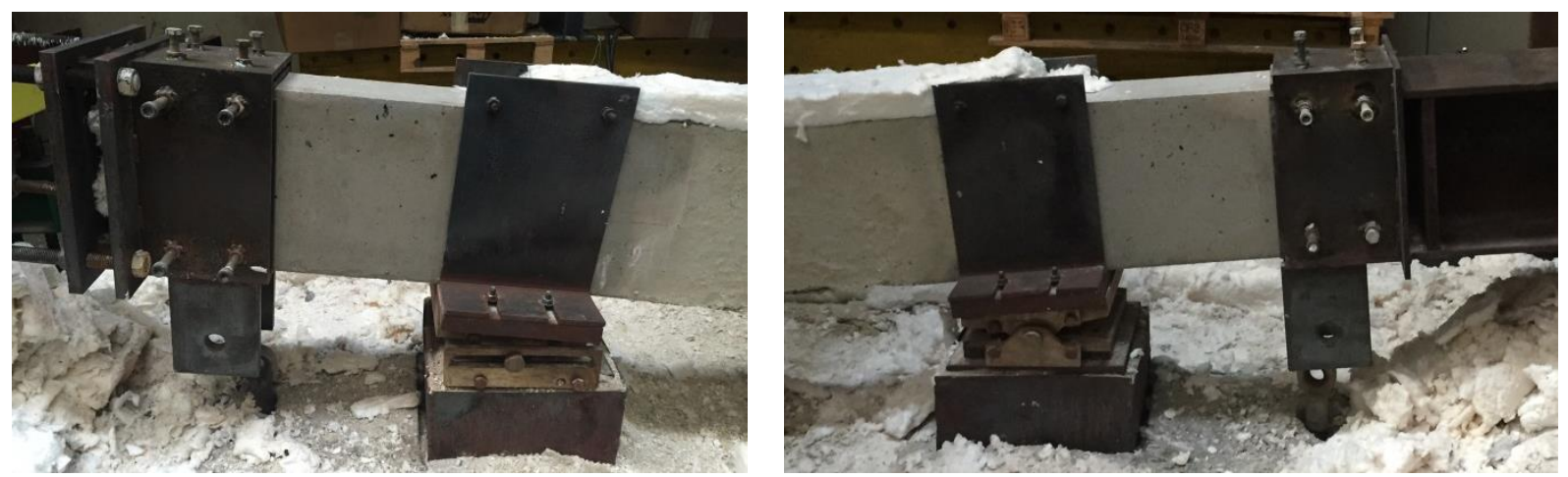

Figura F.15 - Vistas frontais da configuração deformada da viga nas regiões próximas aos apoios simples e duplo, respectivamente, após ensaio ka1_kr0_1. 


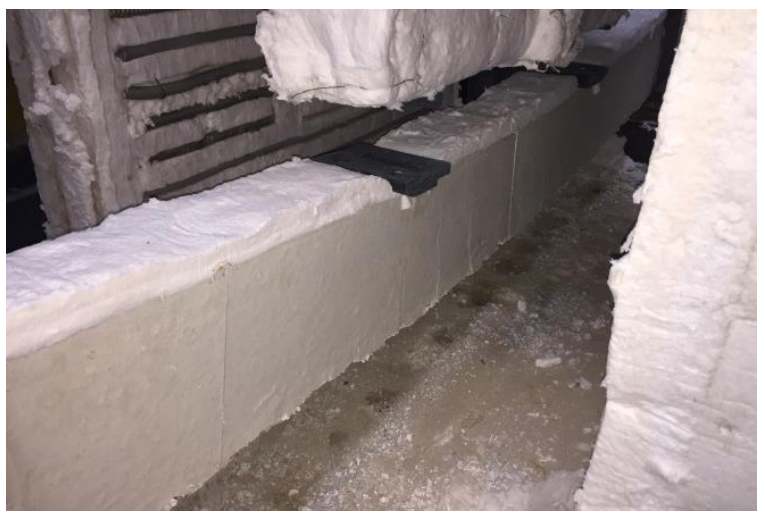

Figura F.16 - Vista lateral da configuração deformada da viga após ensaio ka1_kr0_1.
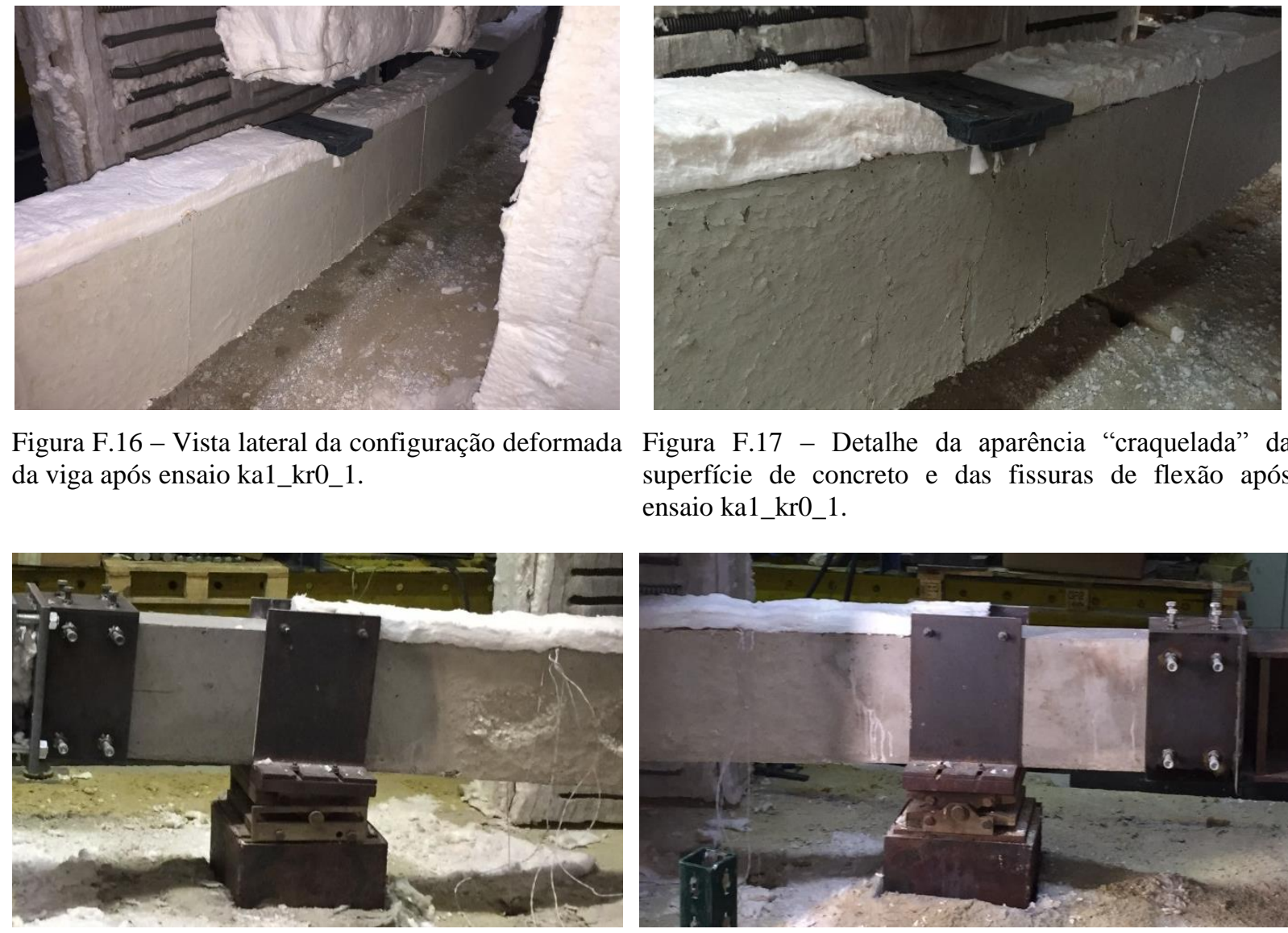

Figura F.17 - Detalhe da aparência "craquelada" da superfície de concreto e das fissuras de flexão após ensaio ka1 kr0 1.

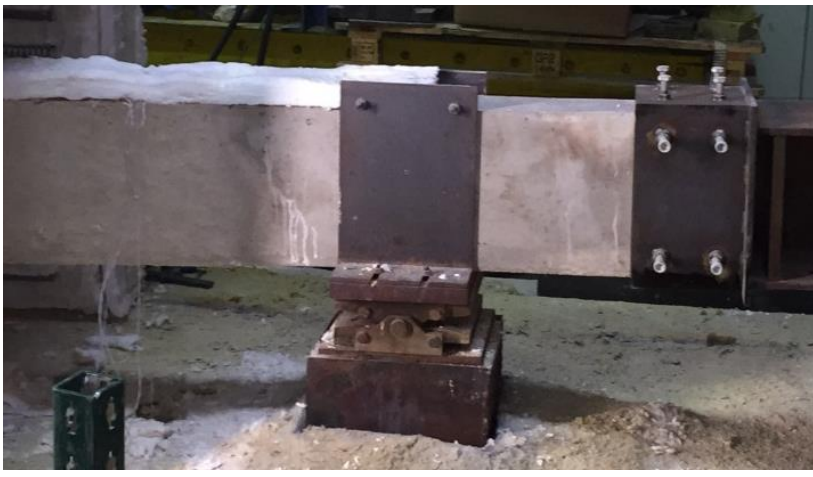

Figura F.18 - Vistas frontais da configuração deformada da viga nas regiões próximas aos apoios simples e duplo, respectivamente, após ensaio ka1_kr0_2.
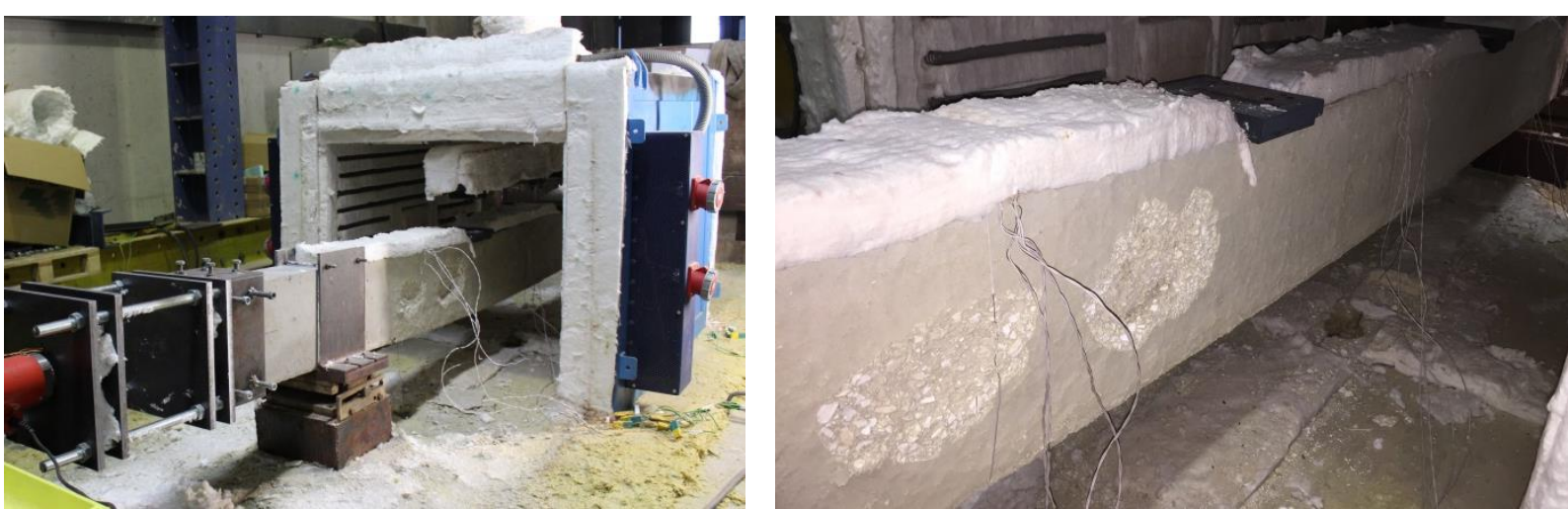

Figura F.19 - Vista lateral da configuração deformada da viga após ensaio ka1_kr0_2.
Figura F.20 - Detalhe do destacamento de dois pedaços de concreto após ensaio ka1_kr0_2. 
APÊNDICE F - FOTOS DOS ENSAIOS EXPERIMENTAIS DE VIGAS AO FOGO
Análise numérico-experimental de vigas de concreto armado com restrições axial e rotacional em situação de incêndio

\section{F2.2 ka2_kr0}
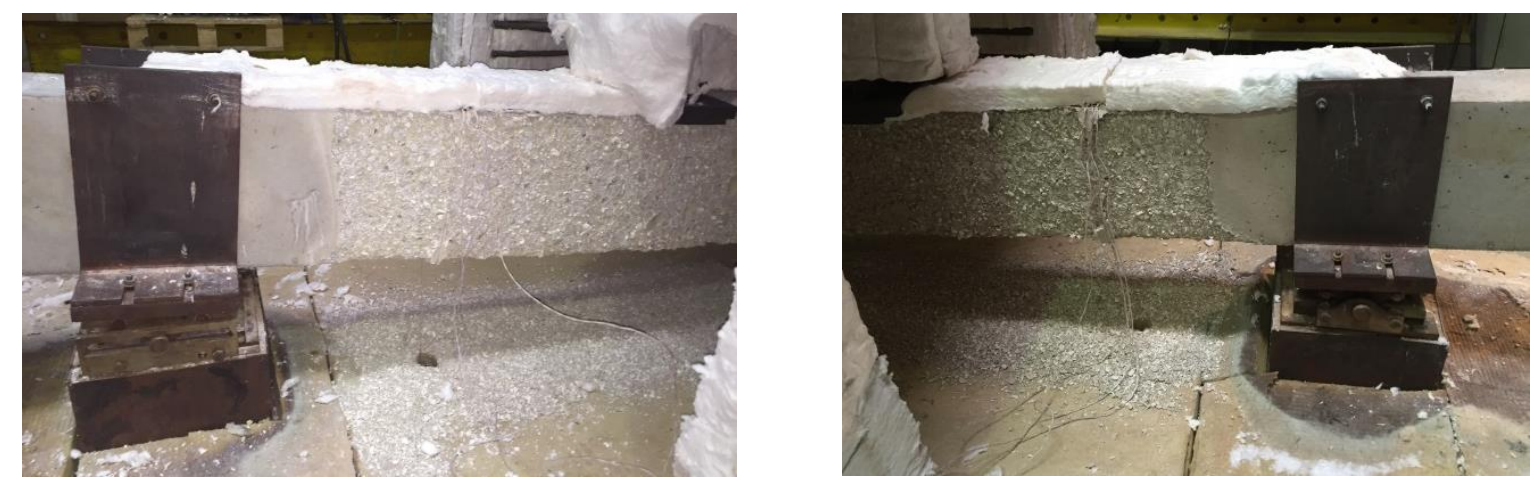

Figura F.21 - Vistas frontais da configuração deformada da viga nas regiões próximas aos apoios simples e duplo, respectivamente, após ensaio ka2_kr0_1.

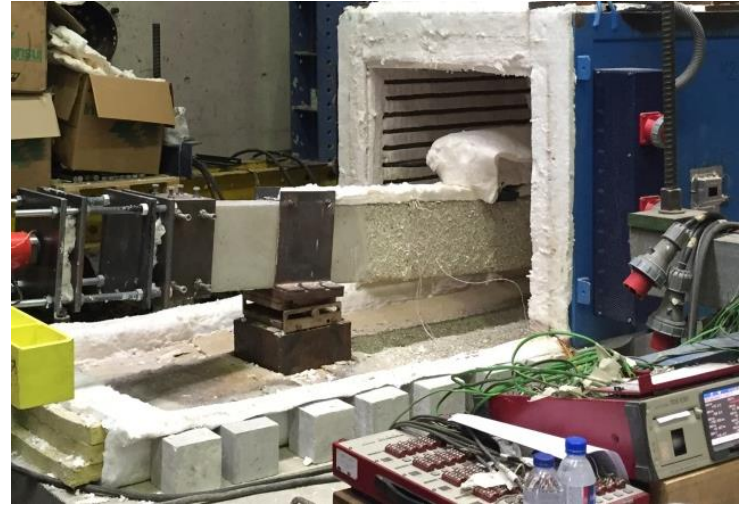

Figura F.22 - Vista lateral da configuração deformada da viga após ensaio ka2_kr0_1.

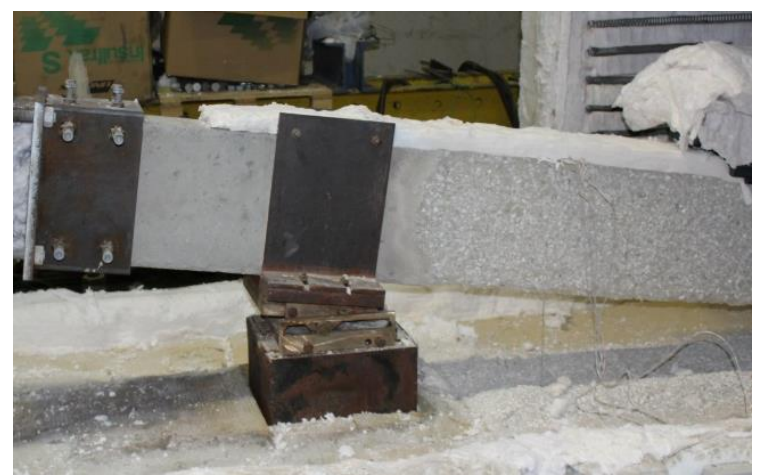

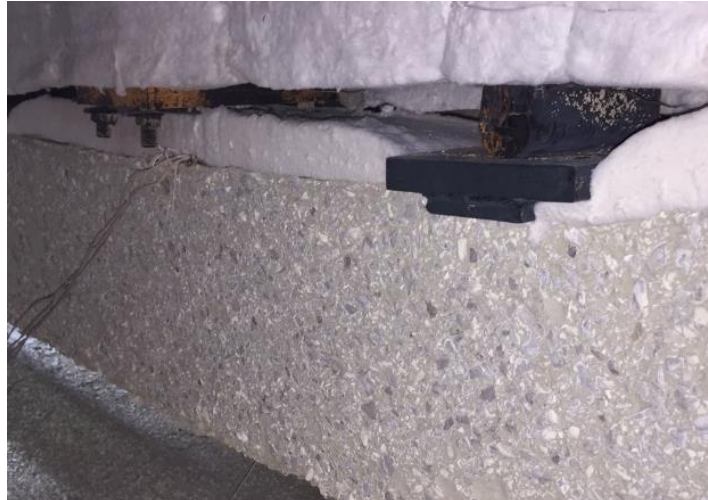

Figura F.23 - Detalhe da esfoliação do concreto da superfície, já com agregados à mostra, pelo fato de não ter sido possível abrir o forno no dia seguinte ao ensaio ka2_kr0_1.

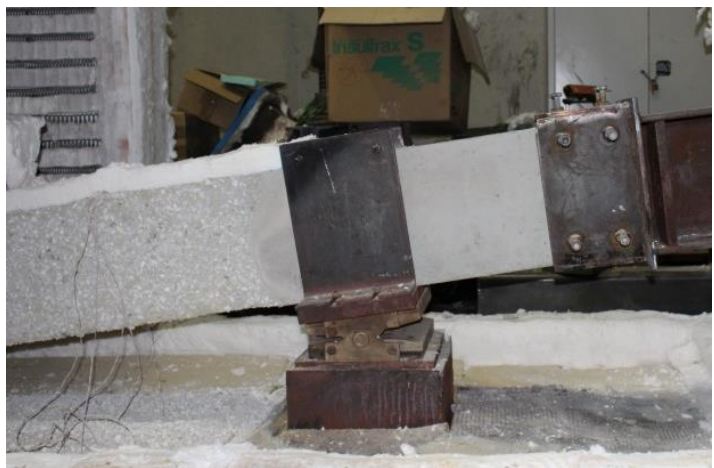

Figura F.24 - Vistas frontais da configuração deformada da viga nas regiões próximas aos apoios simples e duplo, respectivamente, após ensaio ka2_kr0_2. 

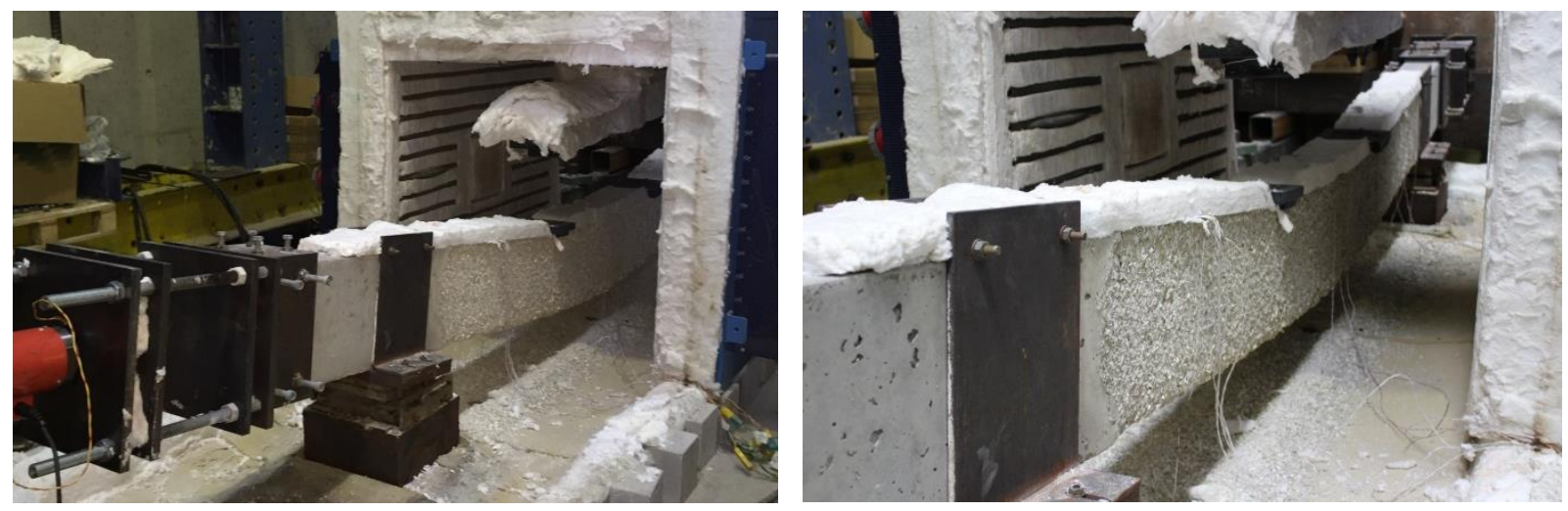

Figura F.25 - Vista lateral da configuração deformada da viga após ensaio ka2_kr0_2.

Figura F.26 - Detalhe da esfoliação do concreto da superfície, já com agregados à mostra, pelo fato de não ter sido possível abrir o forno no dia seguinte ao ensaio ka2_kr0_2.

\section{F.3 Vigas com restrições axial e rotacional}

\section{F3.1 ka1_kr1}
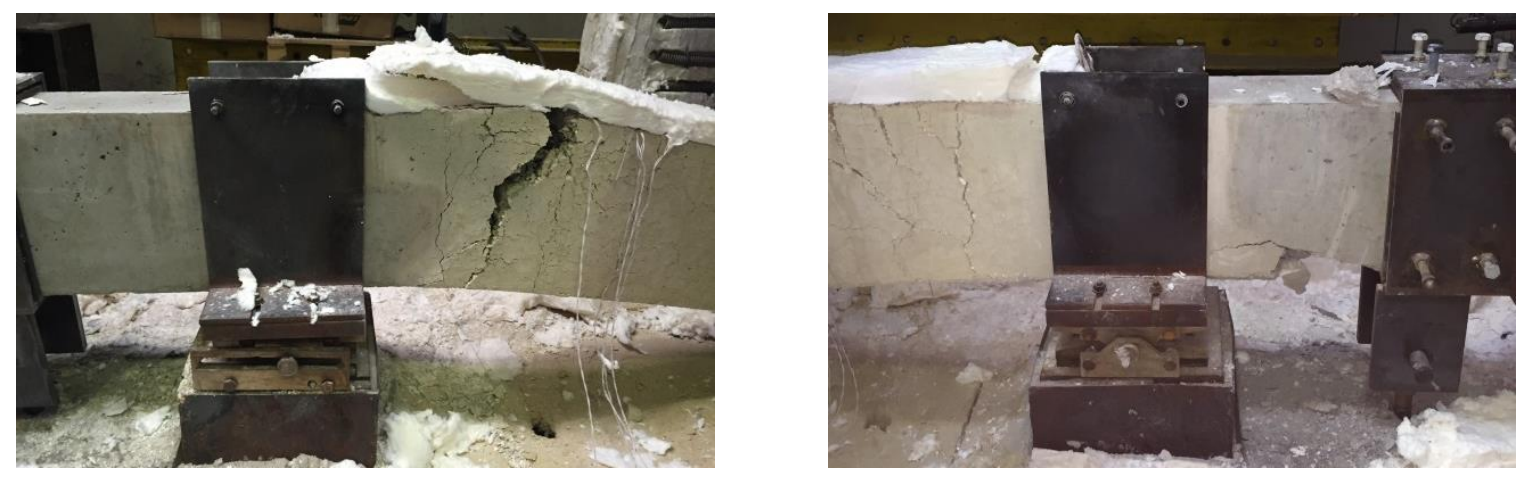

Figura F.27 - Vistas frontais da configuração deformada da viga nas regiões próximas aos apoios simples e duplo, respectivamente, após ensaio ka1_kr1_1.
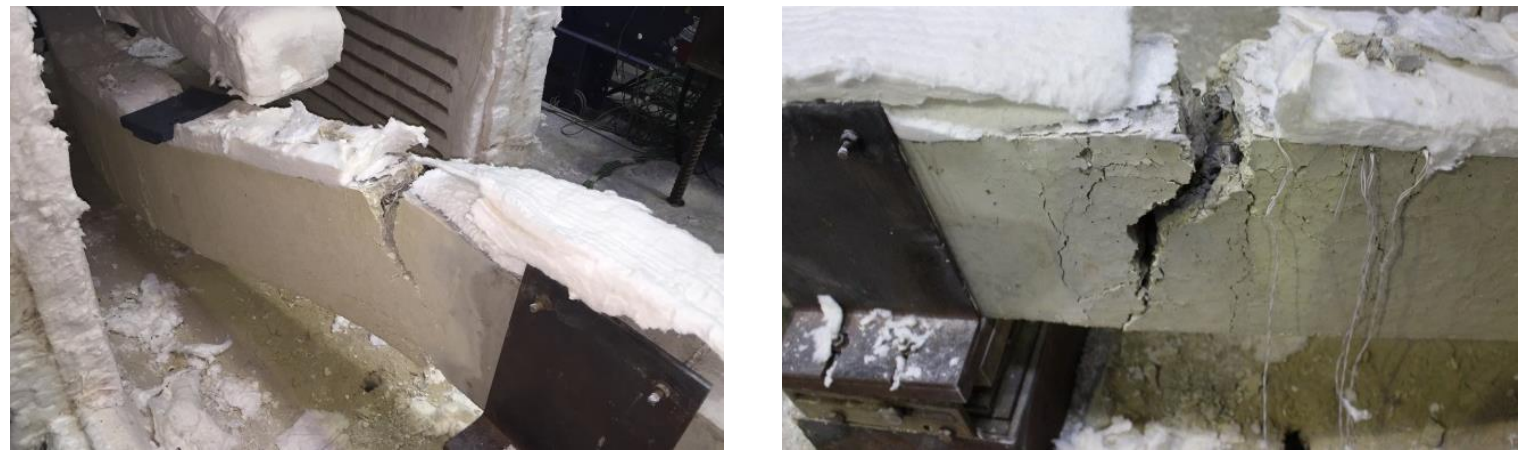

Figura F.28 - Instabilidade lateral com torção da viga Figura F.29 - Detalhe da ruptura das armaduras após ensaio ka1_kr1_1. longitudinais superiores na região próxima ao apoio simples após ensaio ka1_kr1_1. 

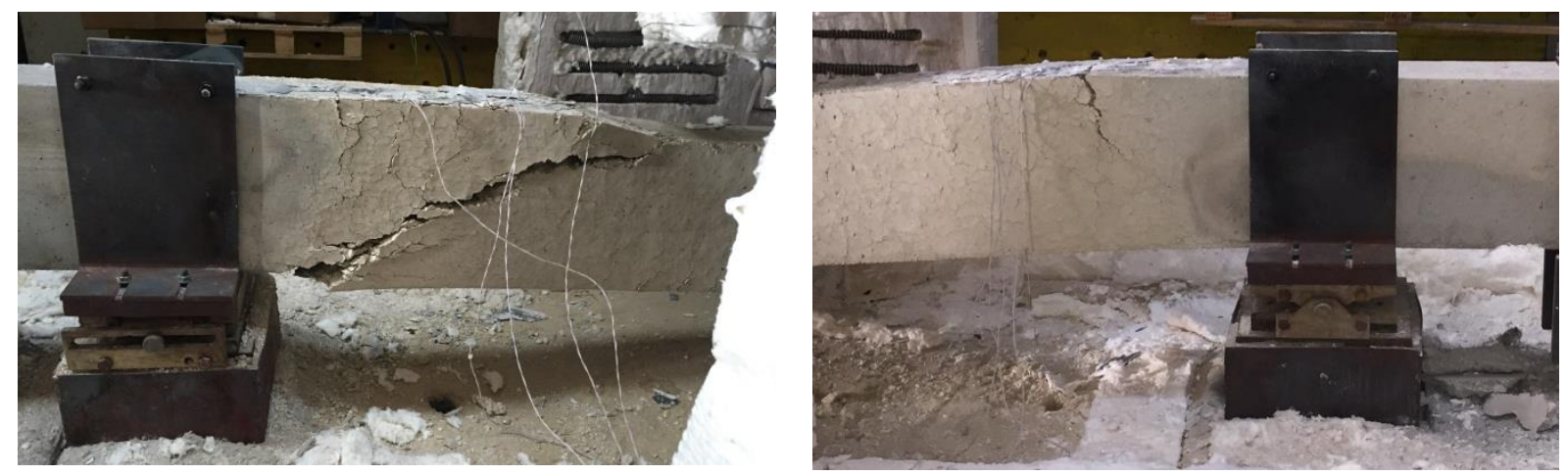

Figura F.30 - Vistas frontais da configuração deformada da viga nas regiões próximas aos apoios simples e duplo, respectivamente, após ensaio ka1_kr1_2.

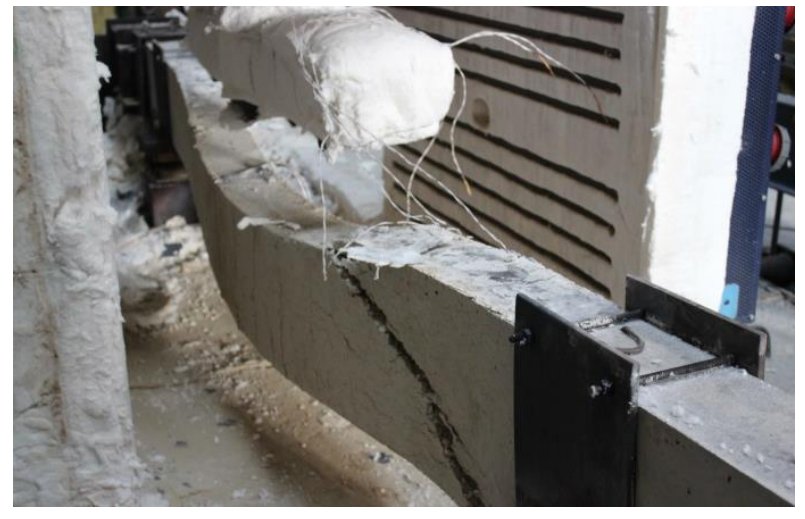

Figura F.31 - Instabilidade lateral com torção da viga após ensaio ka1_kr1_2.

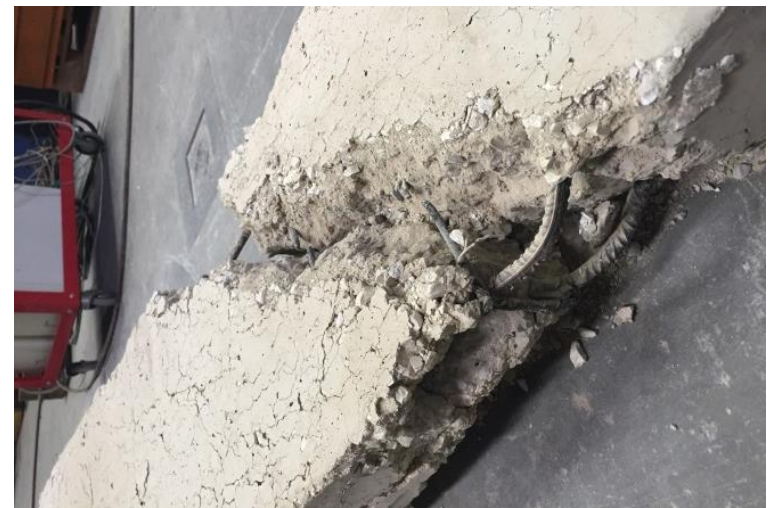

Figura F.32 - Detalhe da ruptura de dois estribos na região próxima ao apoio simples após ensaio ka1_kr1_2.

\section{F3.2 ka2 kr1}
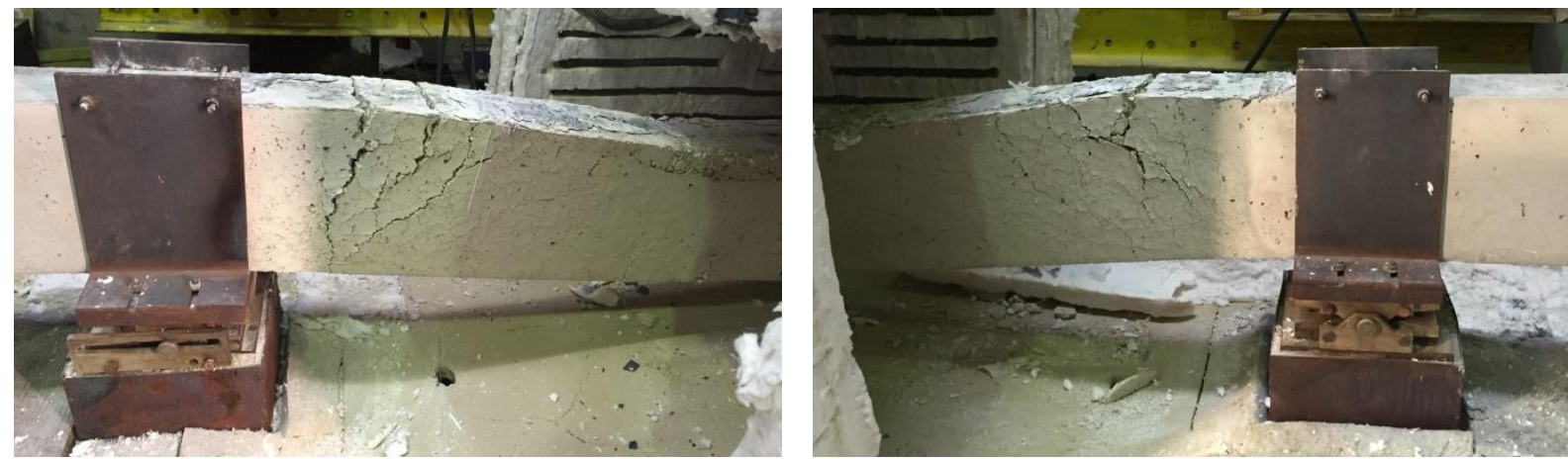

Figura F.33 - Vistas frontais da configuração deformada da viga nas regiões próximas aos apoios simples e duplo, respectivamente, após ensaio ka2_kr1_1. 


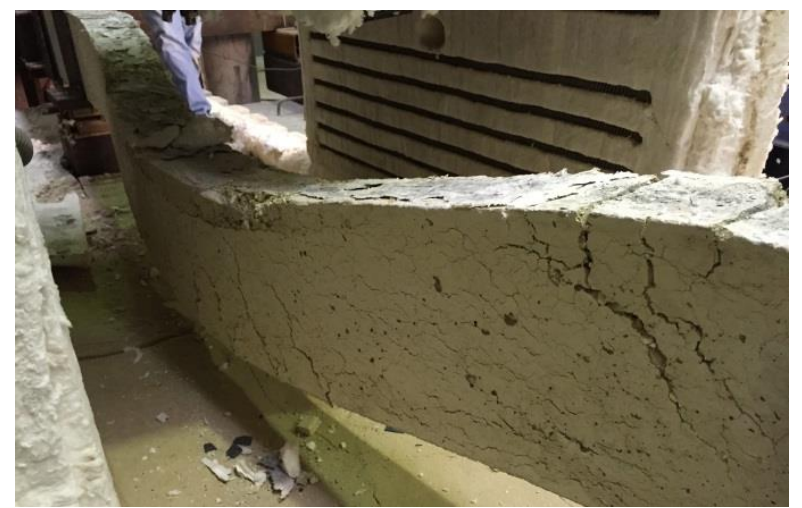

Figura F.34 - Instabilidade lateral com torção da viga após ensaio ka2_kr1_1.
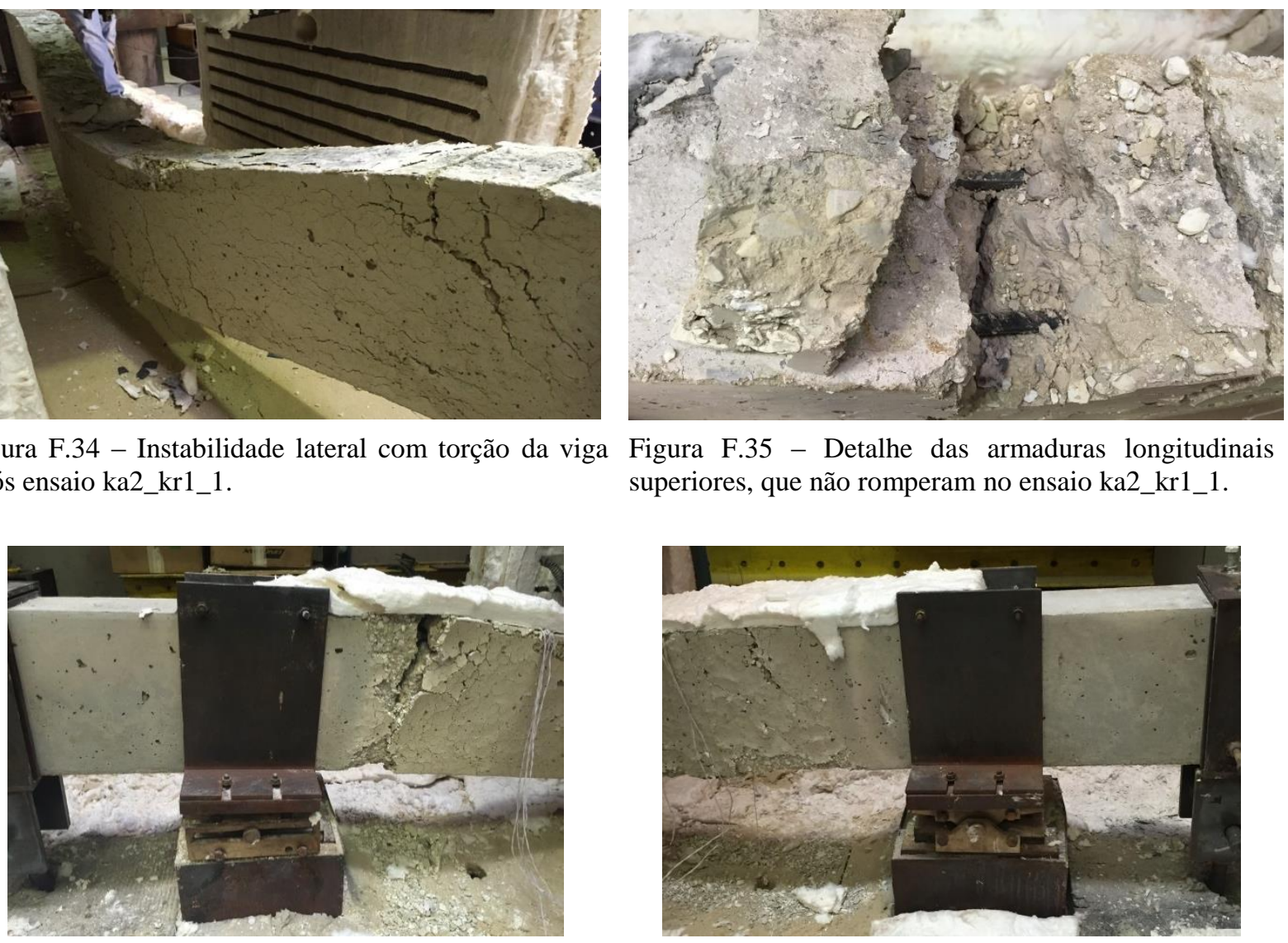

Figura F.35 - Detalhe das armaduras longitudinais superiores, que não romperam no ensaio ka2_kr1_1.

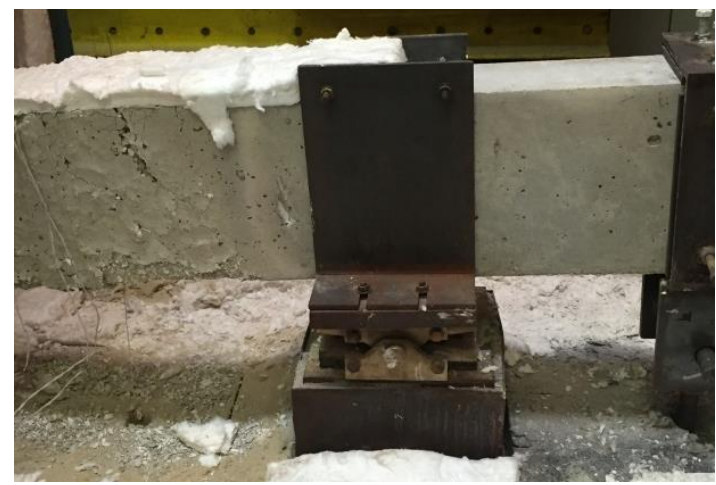

Figura F.36 - Vistas frontais da configuração deformada da viga nas regiões próximas aos apoios simples e duplo, respectivamente, após ensaio ka2_kr1_2.
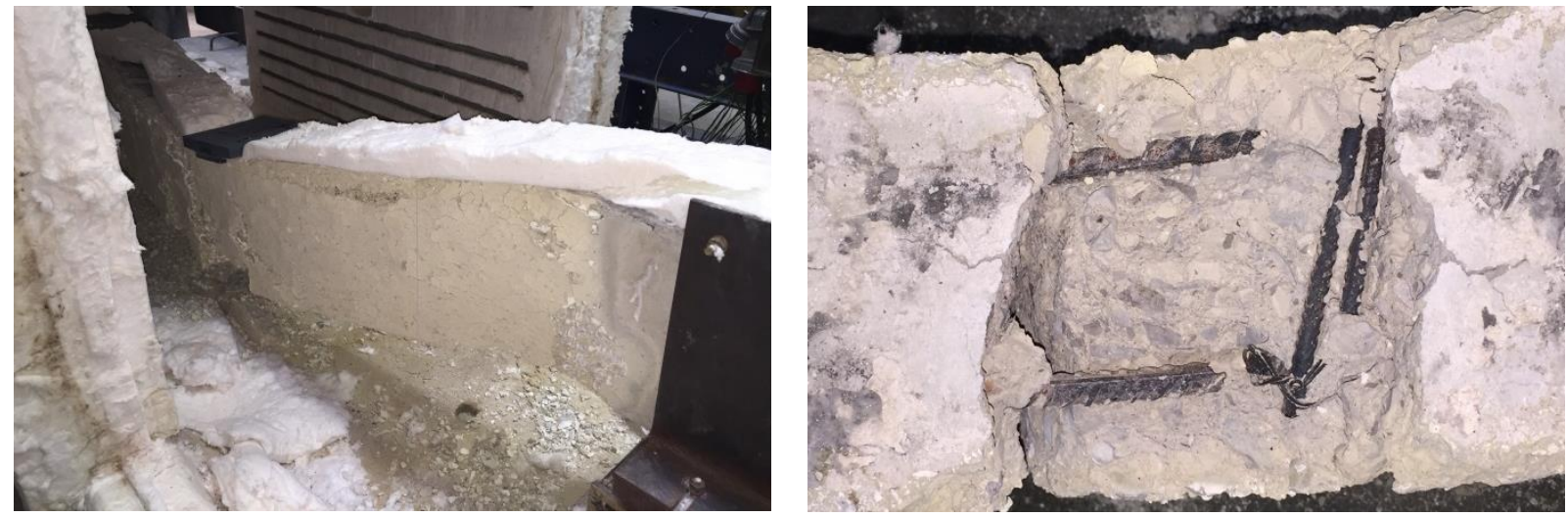

Figura F.37 - Instabilidade lateral com torção da viga após ensaio ka2_kr1_2.

Figura F.38 - Detalhe da ruptura de uma armadura longitudinal superior na região próxima ao apoio simples, após ensaio ka2_kr1_2. 
APÊNDICE F - FOTOS DOS ENSAIOS EXPERIMENTAIS DE VIGAS AO FOGO
Análise numérico-experimental de vigas de concreto armado com restrições axial e rotacional em situação de incêndio

\section{F3.3 ka1_kr2}
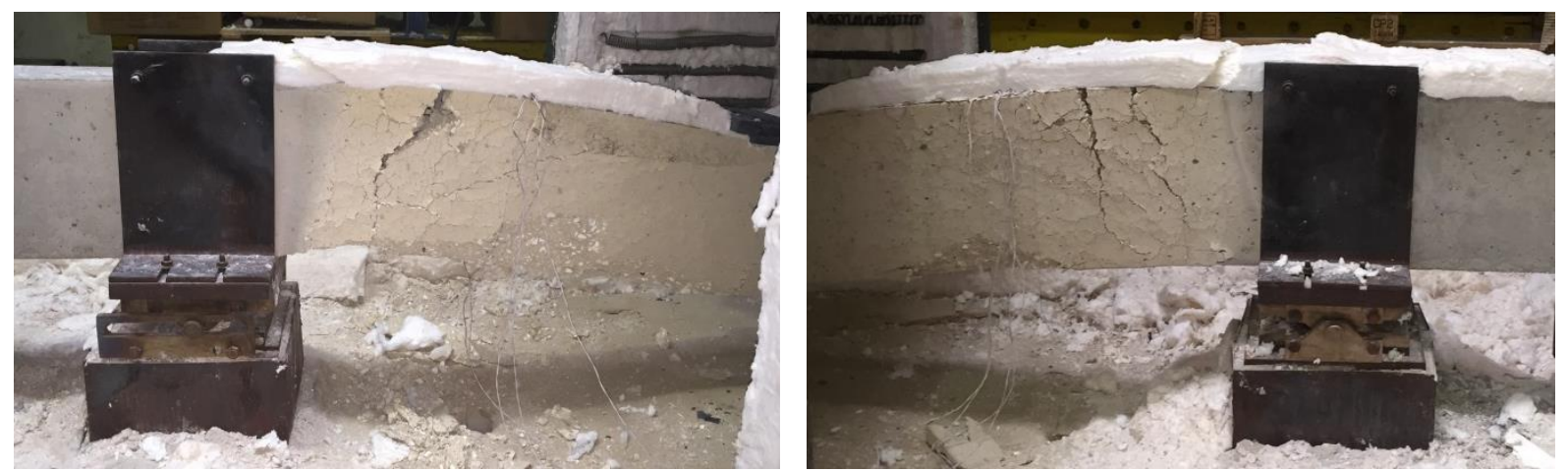

Figura F.39 - Vistas frontais da configuração deformada da viga nas regiões próximas aos apoios simples e duplo, respectivamente, após ensaio ka1_kr2_1.

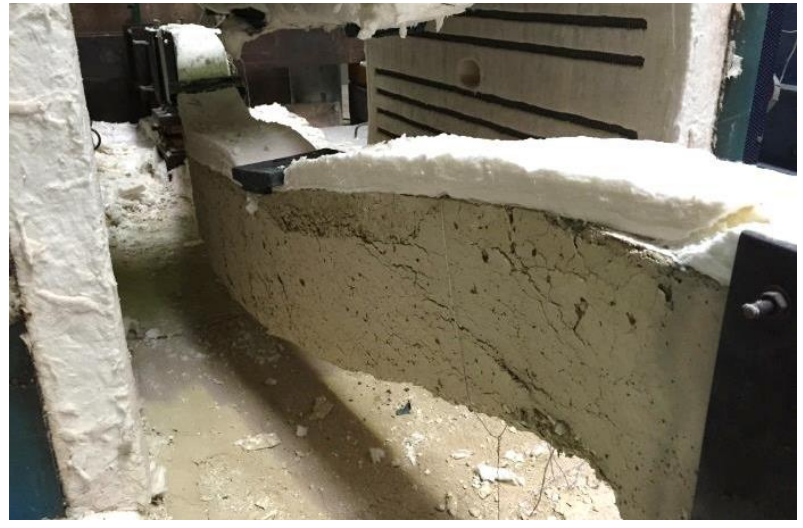

Figura F.40 - Instabilidade lateral com torção da viga após ensaio ka1_kr2_1.
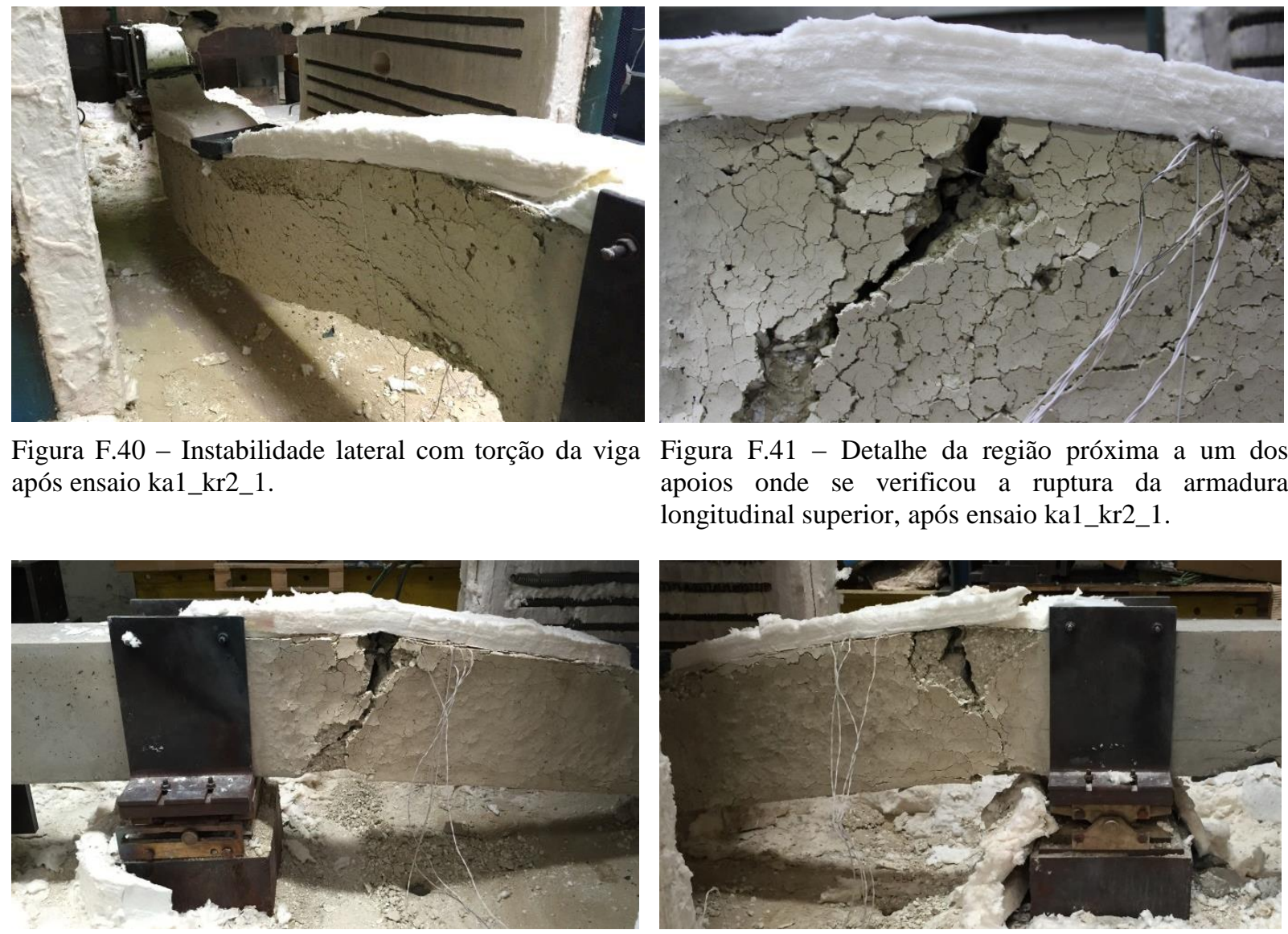

Figura F.41 - Detalhe da região próxima a um dos apoios onde se verificou a ruptura da armadura longitudinal superior, após ensaio ka1_kr2_1.

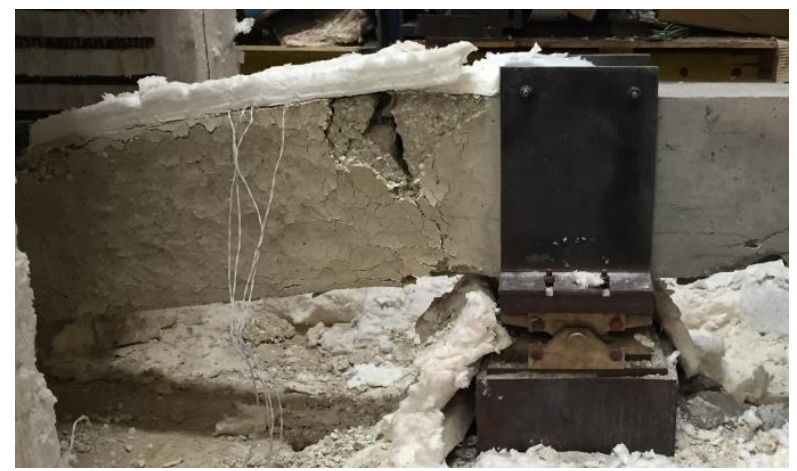

Figura F.42 - Vistas frontais da configuração deformada da viga nas regiões próximas aos apoios simples e duplo, respectivamente, após ensaio ka1_kr2_2. 

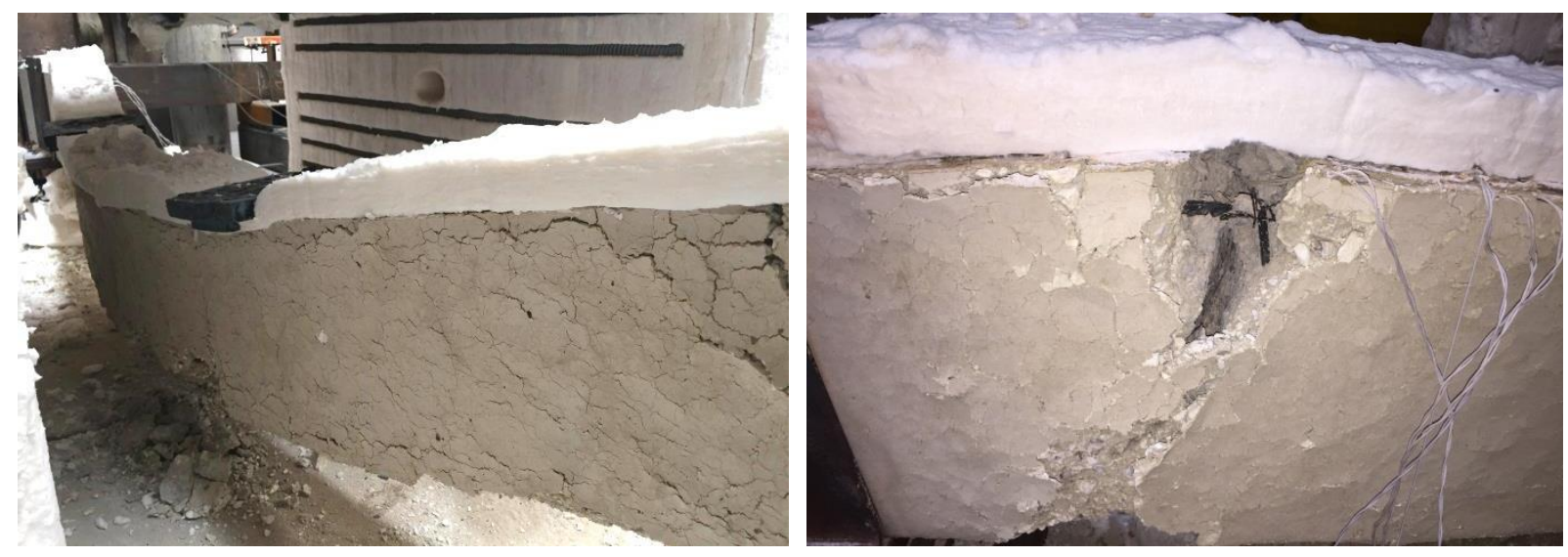

Figura F.43 - Instabilidade lateral com torção da viga Figura F.44 - Detalhe da região próxima a um dos após ensaio ka1_kr2_2. apoios onde se verificou a ruptura da armadura longitudinal superior, após ensaio ka1_kr2_2. 
